$\mathrm{ROٌ̊M}$

Royal Ontario Museum
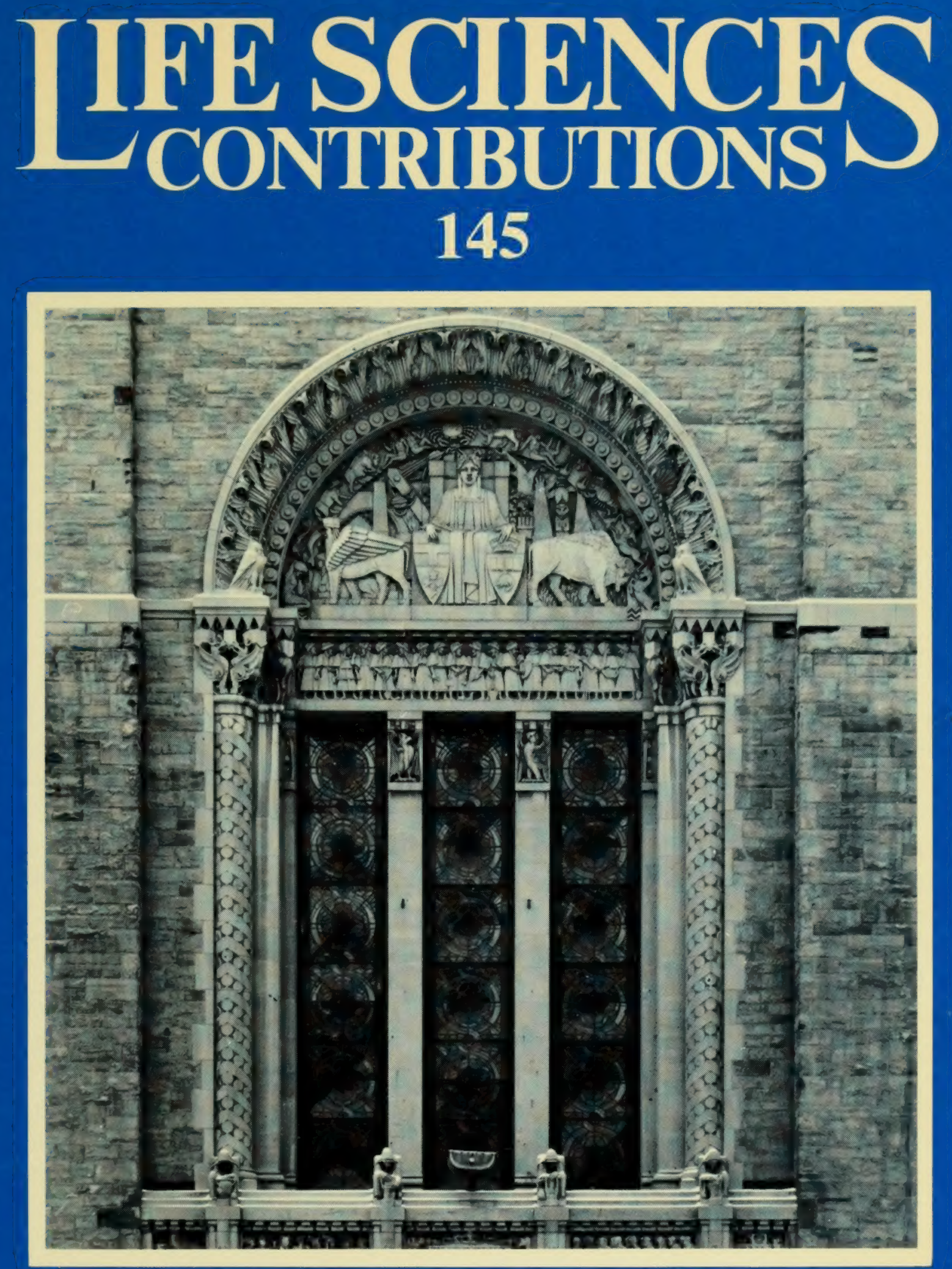

An Annotated Checklist of the Fishes

of the Chagos Archipelago Central Indian Ocean

Richard Winterbottom, Alan R. Emery and Erling Holm 


\section{ROYAL ONTARIO MUSEUM LIFE SCIENCES PUBLICATIONS INSTRUCTIONS TO AUTHORS}

Authors should prepare their manuscripts carefully according to the following instructions; failure to do so will result in the manuscript's being returned to the author for revision. All manuscripts are considered on the understanding that they are not currently offered for publication elsewhere.

1. General Papers for publication are accepted from ROM staff members and research associates, and from researchers reporting on work done with ROM collections. Monographs on the flora and/or fauna of Ontario may be considered for publication by authors not affiliated with the ROM. Financial contributions towards publication will be welcome. Authors are expected to write clearly and concisely and to omit any material not essential for an understanding of the main theme of the paper.

2. Format Manuscripts (including captions, synonymies, literature cited, and tables) should be typed with double space on 11 " $\times 8 \frac{1}{2}$ " " paper with a $1 \frac{1}{2}$ ", margin on all sides. Three xerox copies should be submitted to the Senior Editor of the Editorial Board: the original should be retained by the author(s). The submission should include a separate sheet giving the author(s) names and affiliations, the title of the publication, the series for which it is submitted, the number of typed pages, the number of tables, and the number of plates or figures. Manuscripts should normally be organized in the following order: Contents, Abstract, Introduction, Materials and Methods, Results, Discussion, Conclusions, Summary (if manuscript is long), Acknowledgements, Appendices, and Literature Cited. Authors are encouraged to include foreign-language translations of the Summary, if appropriate. Main headings should be centred; subheadings should be left-justified to the text margin. The first line of the first paragraph in each new section should not be indented. Literature citations in the text should be in the form "Jones (1972)", or "(Jones, 1972)" or "(Smith, 1960:71-79, fig. 17)" .

3. Standard Sources The primary authority on questions of format and style is Guide to Authors, available from ROM Publication Services. For matters not covered in the Guide, consult CBE Style Manual (Fifth Edition). Other standard sources are as follows: for
English spelling, The Concise Oxford Dictionary; for Canadian place names and coordinates, Canada Gazetteer Atlas; for the spelling of geographic names, The Times Atlas.

4. Abstract All papers must be preceded by a short, factual abstract, about one per cent of the text in length. The abstract may be followed by four to six key words in parentheses.

5. Taxonomy The name of a taxon should be given in full in headings, at the beginnings of paragraphs, and at its first occurrence in the text. Give the authority and date, if appropriate, with the first mention of each taxon, but not thereafter. Taxonomic papers, particularly synonymies, should follow the layout in Life Sciences Contributions beginning with No. 136. International Codes of Biological Nomenclature must be followed.

6. Literature Cited A complete list of references, in alphabetical order of authors, must be given at the end of the paper. When two or more works of one author are cited, they should be listed chronologically. The names of journals should not be abbreviated. For correct bibliographic form, see Life Sciences Contributions beginning with No. 136.

7. Tables All tables should be typed on separate sheets and numbered consecutively in arabic numerals in the order of their first mention in the text. Mark the location of each table in the margin of the text.

8. Plates, Figures, and Text-figures Illustrations may be designated according to the conventions of the author's discipline; in some disciplines grouped photographs of scientific subject matter are commonly termed Plates, while line drawings and locality and other illustrations that occupy a full page or less are Text-figures. Usage must be consistent throughout the paper. A full-page illustration for a Contribution, with its caption, should be sized to fit an area of $17.3 \times$ $22.75 \mathrm{~cm}$; for Occasional Papers, the area is $14.1 \times$ $21.2 \mathrm{~cm}$. If captions are lengthy, they may be placed on the facing page. A scale or magnification factor should be included. Authors are reminded that when illustrations are reduced magnification factors will change, and that they are responsible for the conversion. For details, see Guide to Authors. 
An Annotated Checklist of the Fishes of the Chagos Archipelago, Central Indian Ocean 
Digitized by the Internet Archive in 2011 with funding from University of Toronto 
LIFE SCIENCES CONTRIBUTIONS 145

\title{
An Annotated Checklist of the Fishes of the Chagos Archipelago, Central Indian Ocean
}

\author{
Richard Winterbottom, Alan R. Emery \\ and Erling Holm
}

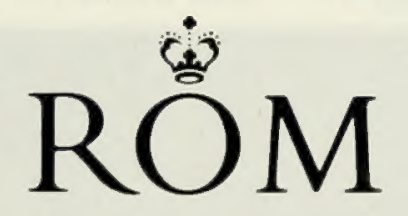

THE ROYAL ONTARIO MUSEUM 


\title{
ROYAL ONTARIO MUSEUM \\ PUBLICATIONS IN LIFE SCIENCES
}

The Royal Ontario Museum publishes three series in the Life Sciences.

Contributions: a numbered series of original scientific publications.

Occasional Papers: a numbered series of original scientific publications, primarily short and of taxonomic significance.

Miscellaneous Publications: an unnumbered series on a variety of subjects.

All manuscripts considered for publication are subject to the scrutiny and editorial policies of the Life Sciences Editorial Board, and to independent refereeing by two or more persons, other than Museum staff, who are authorities in the particular field involved.

\section{LIFE SCIENCES EDITORIAL BOARD}

Senior editor: E. J. Crossman

Editor: J. L. Eger

Editor: C. Darling

External editor: C. S. Churcher

Manuscript editor: J. C. Barlow

Richard Winterbottom is Curator, Department of Ichthyology and Herpetology, Royal Ontario Museum.

Alan R. Emery is Director, National Museum of Natural Sciences, Ottawa.

Erling Holm is Curatorial Assistant, Department of Ichthyology and Herpetology, Royal Ontario Museum, Toronto.

\author{
Canadian Cataloguing in Publication Data \\ Winterbottom, Richard, 1944- \\ An annotated checklist of the fishes of the \\ Chagos Archipelago, Central Indian Ocean \\ (Life sciences contributions, ISSN 0384-8159; 145) \\ Bibliography: $p$. \\ ISBN 0-88854-329-8 \\ 1. Fishes - Chagos Islands. I. Emery, Alan, \\ 1939- . II. Holm, Erling, 1950 \\ III. Royal Ontario Museum. IV. Title. V. Series.
}

QL636.7.C43W55 $1987 \quad 597.0969^{\prime} 7 \quad$ C86-095096-4

Publication date: 23 January 1989

ISBN 0-88854-329-8

ISSN 0384-8159

(C) Royal Ontario Museum, 1989

100 Queen's Park, Toronto, Canada, M5S 2 C6

PRINTED AND BOUND IN CANADA BY UNIVERSITY OF TORONTO PRESS 


\title{
Contents
}

\author{
Abstract 1 \\ Introduction 1 \\ Materials and Methods 2 \\ Checklist of Chagos Fishes 4
}

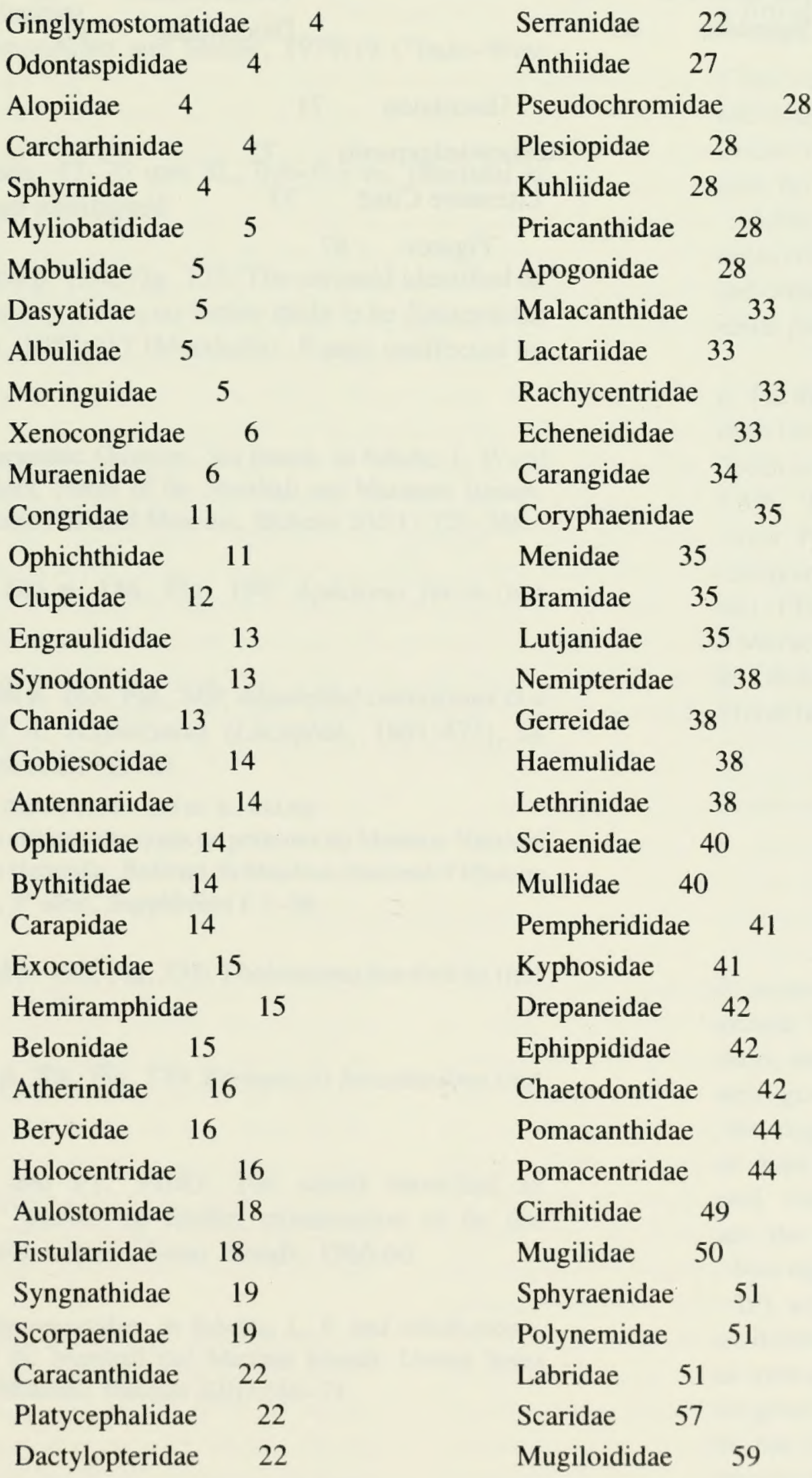




\begin{tabular}{|c|c|c|}
\hline Creediidae & 59 & Scombridae \\
\hline Blenniidae & 59 & Xiphiidae \\
\hline Tripterygiidae & 62 & Istiophoridae \\
\hline Ammodytidae & 62 & Nomeidae \\
\hline Callionymidae & 62 & Bothidae \\
\hline Gobiidae 6 & 62 & Soleidae \\
\hline Eleotrididae & 62 & Balistidae \\
\hline Kraemeriidae & 62 & Ostraciidae \\
\hline Microdesmidae & 62 & Triodontidae \\
\hline Acanthuridae & 63 & Tetraodontidae \\
\hline \multirow[t]{5}{*}{ Siganidae } & 65 & Diodontidae \\
\hline & Discussion & 71 \\
\hline & Acknowledgements & 72 \\
\hline & Literature Cited & 73 \\
\hline & Figures 8 & \\
\hline
\end{tabular}




\section{ERRATA AND ADDENDA}

P. 20, left column, preceding Parascorpaena aurita: A small intertidal collection made for us by L. Taborsky in June 1987 contains the following scorpaenid previously unrecorded from the islands.

Dendrochirus zebra (Cuvier)

Pterois zebra Cuvier in Cuvier and Valenciennes, 1829b:367 (Mauritius and Moluccas)

Dendrochirus zebra-Allen and Steene, 1979:19 ("Indo-West Pacific")

\section{MATERIAI}

One lot, 3 specimens, $47-75 \mathrm{~mm} \mathrm{SL}, 0.6-0.9 \mathrm{~m}$, intertidal at Diego Garcia. Range unassigned.

P. 24 , right column, and p. 128, Fig. 135: The serranid identified as Epinephelus hexagonatus proves on further study to be Epinephelus spilotoceps Schultz, 1953:357 (Marshalls). Range unaffected by reidentification.

SCHULTZ, L. P.

1953 Family Serranidae: Groupers, Sea Basses. In Schultz, L. P. and collaborators, Fishes of the Marshall and Marianas Islands. United States National Museum, Bulletin 202(1):328-388.

P. 35, right column, and p. 146, Fig. 194: Aphareus furca (not furcatus).

P. 44, right column, and p. 163, Fig. 249: Abudefduf coelestinus is a junior synonym of A. sexfasciatus (Lacepède, 1801:477), as reported by Bauchot et al. (1978).

BAUCHOT, M.-L., M. DESOUTTER, and G. R. ALLEN

1978 Catalogue critique des types de poissons du Muséum National d'Histoire Naturelle. Bulletin du Muséum National d'Histoire Naturelle, $3^{\mathrm{e}}$ série, Supplément I:1-56.

P. 56, right column, and p. 193, Fig. 338: Thalassoma hardwicke (not hardwicki).

P. 59, left column, and p. 204, Fig. 370: Parapercis hexophtalma (not hexophthalma).

P. 67, left column, and P1. VIIIG: The soleid identified as "?Monochirus sp." proves on further examination to be the pleuronectid Samariscus triocellatus Woods, 1966:66.

wOODS, L. P.

1966 Family Pleuronectidae. In Schultz, L. P. and collaborators, Fishes of the Marshall and Mariana Islands. United States National Museum, Bulletin 202(3):66-74. 


\section{(15)}

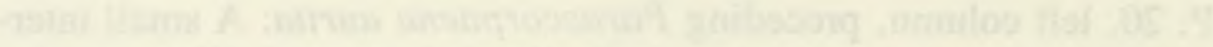

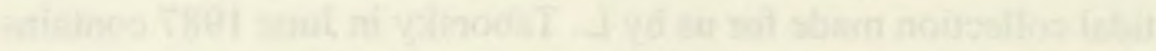

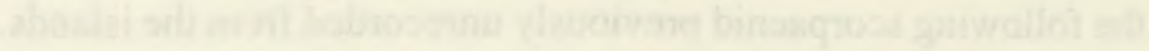

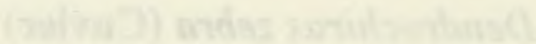

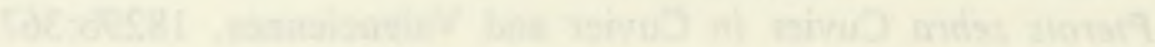

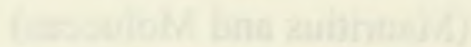

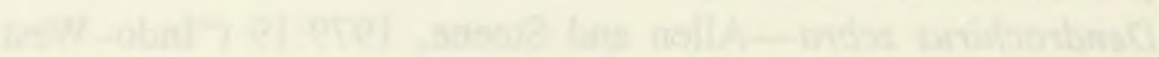

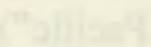

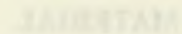

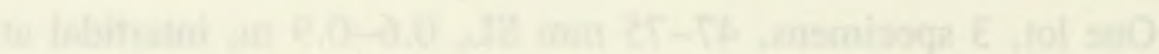

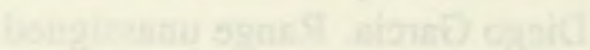

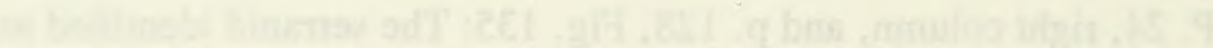

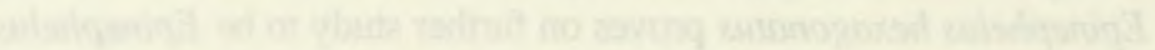

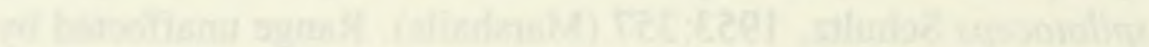

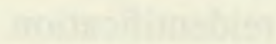
(3)

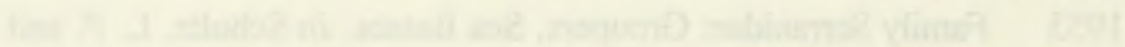

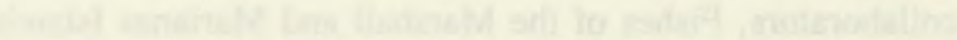

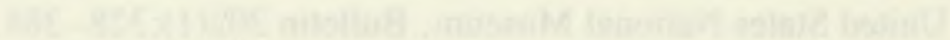

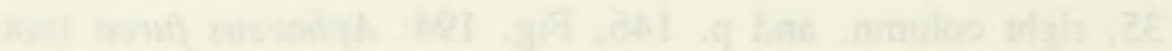

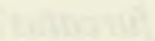

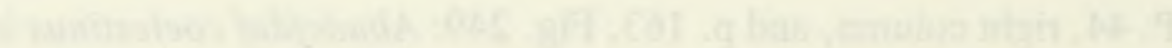

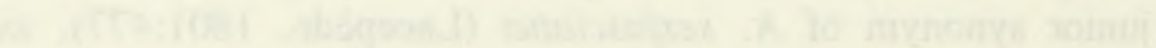

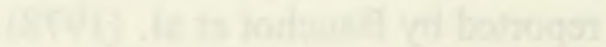
(

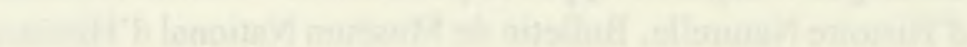




\title{
An Annotated Checklist of the Fishes of the Chagos Archipelago, Central Indian Ocean
}

\begin{abstract}
A two-and-a-half month collecting expedition to the Chagos Archipelago, central Indian Ocean $\left(4^{\circ} 40^{\prime}-7^{\circ} 30^{\prime} \mathrm{S}\right.$ and $\left.71^{\circ} 00^{\prime}-72^{\circ} 45^{\prime} \mathrm{E}\right)$, plus two other smaller collections made in 1980 and 1985 , yielded specimens of 585 species of fishes, with an additional 16 species seen but not collected. A further 100 species are recorded from the literature, and 2 additional species from Chagos were discovered in the collections of the British Museum (Natural History).

For species that we collected, we provide information on the number of lots, number and size range of specimens, range of depth of capture, major habitat, atoll/islands where collected, and standard lengths of specimens for which colour transparencies taken soon after death are available. A breakdown of habitat and depth associations for the more common species is provided, as well as a discussion of systematic problems where encountered. Black-and-white photographs of preserved specimens of species collected but not photographed in colour in the field are included, together with black-and-white prints of colour transparencies of species we did photograph in the field. Eight habitat photographs and 56 fish portraits are illustrated in 8 colour plates.

Faunal affinities were as follows: Indo-Pacific 50.4\%, Indo-west Pacific 12.1\%, Indo-west Pacific and marginally on the Pacific plate $8.4 \%$, western Indian Ocean $6.0 \%$, cosmopolitan 2.6\%, Indian Ocean 2.3\%, circumtropical 2.3\%, Indian Ocean and western extremity of west Pacific $0.8 \%$, endemic $0.4 \%$, central Indian Ocean $0.3 \%$, "Indo-west Pacific" $0.3 \%$, Indo-Pacific and western Atlantic $0.1 \%$, and Indo-west Pacific and Mediterranean $0.1 \%$. Approximately half of the $13.9 \%$ of the fauna not assigned a faunal affinity (for a variety of reasons) consisted of gobiids (7.5\% total fauna). Five families dominate the fauna (Gobiidae, Labridae, Pomacentridae, Serranidae, and Muraenidae) and together constitute $38 \%$ of the total fauna. The 100 species of the Gobioidei known from the archipelago (Gobiidae, Eleotrididae, Microdesmidae, and Kraemeriidae) have been treated in detail previously in this series, and are not included here.
\end{abstract}

\section{Introduction}

The Chagos Archipelago is a fragmented southerly portion of the Maldive/Laccadive ridge and consists of a complex system of low atolls and submerged banks bounded by $4^{\circ} 40^{\prime}-7^{\circ} 30^{\prime} \mathrm{S}$ and $71^{\circ} 00^{\prime}-72^{\circ} 45^{\prime} \mathrm{E}$ (Fig. 1). To the east lies the 5-km-deep Chagos Trench; to the west is the mid-Indian Ocean ridge, the sea-floor spreading centre separating the African and Indo-Australian plates. In some cases, very deep water ( $>2000 \mathrm{~m}$ ) separates the atolls and banks; in other cases, they are separated by water less than $500 \mathrm{~m}$ deep (Fig. 1).

The structure of the outer reefs at Chagos is generally as follows (Fig. 2): the spur-and-groove formation gives way to a gently sloping reef-top, usually $20-50 \mathrm{~m}$ in width, dominated by tabular forms of Acropora (PI. IA,B). The lip of the drop-off occurs at $8-15 \mathrm{~m}$ (PI. IC); the drop-off slope is initially very steep and, in some cases, vertical (Fig. 2A; Pl. ID). The more dendritic forms of hard corals are interspersed with gorgonians, and the sea-fans may occur in large numbers on the more gently sloping drop-offs (Pl. IE). At about 25-30 m, the slope of the drop-off becomes sandier, with outcrops of dead coral, limestonelike rock, and patches of living coral. On the eastern side of Peros Banhos, off Isle Fouquet, the sandy slope gives way at about $40 \mathrm{~m}$ to a vertical, 8 -m-high cliff (Fig. 2B). The cliff is riddled with caves (PI. IF), some of which extend at least $10 \mathrm{~m}$ into the island base. Below the cliff, the sandy slope continues for as far as we were able to see (to about $75 \mathrm{~m}$ ). In the lagoons, the bottom generally slopes gently from the intertidal region towards the centre of the lagoon, with occasional knolls and bommies (Fig. 2C; Pl. IG, H). On the 
southern and southwestern sides of Peros Banhos, however, a rich, coral-covered drop-off begins at about $5 \mathrm{~m}$ and ends on the sandy floor of the lagoon at about $20-25 \mathrm{~m}$ (Fig. 2D). Sea-grass beds are absent at Chagos except at the southern end of the lagoon at Diego Garcia, an area in which we did not collect.

There are five atolls-Diego Garcia, Egmont, the Great Chagos Bank (with only a few islands, such as Eagle Island and Three Brothers, remaining on the western side and one island on the northern side), Peros Banhos, and Salomon (Fig. 1). The approximate distances to the nearest land are as follows: $500 \mathrm{~km}$ to the north (Addu Atoll, Maldives); $1800 \mathrm{~km}$ to the west (Seychelles); and $3500 \mathrm{~km}$ to the east (Sumatra). The islands are bathed by the northern limits of the South Equatorial Current (westward flowing) during July, and by the Easterly Counter Current during January. Thus, recruitment of those organisms with pelagic larvae could come from the western Indian Ocean or from the western Pacific, although the large distances involved could be expected to filter out a fair proportion of those organisms with short pelagic stages.

The FAO Species Identification Sheets for the western Indian Ocean (1984) record a total of 168 species of fishes from the Chagos Archipelago, 75 of which were not obtained by us (although 15 of the latter had been recorded from Chagos by other authors prior to the publication of the FAO sheets). In certain cases we have reservations about the distribution maps including Chagos as a locality, but we have listed the species as present with reference to the source. In 1967 Adair Fehlmann from the Smithsonian Oceanographic Sorting Center spent six weeks on Diego Garcia and made 27 collections of fishes and other organisms to a maximum depth of about $3 \mathrm{~m}$. These collections have been sorted and shelved at the Smithsonian Institution, and it is at present impossible to determine what species were taken without searching the major portion of the fish collection. Some records are available as a result of specialized studies. A fisheries feasibility study was conducted in the Indian Ocean (including Chagos) by the Japanese from 1971 to 1975 . The published results (Kyushin et al., 1977) list 78 species from Chagos taken primarily by longline (mainly lethrinids, lutjanids, and serranids), the majority of which were not taken by us. Regan (1908) recorded 32 shore fish from the islands (some of which we examined), but part of this collection has been lost (Wheeler, pers. comm.) and the identities of a number of the species he recorded are suspect.

\section{Materials and Methods}

During 1978/79, the Joint Services Trust of the British Armed Forces supported a nine-month scientific and training expedition to the Chagos Archipelago. Two of the authors (R. Winterbottom and A. R. Emery) joined the expedition for two-and-a-half months to survey the ichthyofauna, from the intertidal to a maximum depth of $48 \mathrm{~m}$. A total of 124 collections was made, of which 80 were in the lagoons, 21 on the drop-offs, and 23 on the reef-tops and reef-flats. Seventy-one of the stations were made using rotenone ( 37 in lagoons, 14 on reef-tops and reef-flats, and 20 on drop-offs), and in many cases these stations were supplemented by spearing. A total of $193 \mathrm{~L}$ of rotenone was used. Collections were also made with gill nets, trap nets, seines, and baited traps, by angling, and by hand. The first collection was made at Diego Garcia on 4 February 1979; the last at Peros Banhos on 1 April 1979. Fishes were thus collected for 57 days, with an average of 2.2 collections/day, resulting in approximately 1.5 tonnes of fish specimens. With the assistance of other expedition members, a total of 460 man-hours was spent collecting fishes. The single small collection from Diego Garcia was supplemented by seven rotenone collections made at the atoll by J. Ryther and P. C. Menzie in May 1980 (which were forwarded to us for identification by the Museum of Comparative Zoology, Harvard University) and one seine and two rotenone collections made by L. Taborsky in 1985.

Wherever possible, an attempt was made to check the original descriptions of the species listed here. Cases in which we were unable to do so are marked with an asterisk at the end of the first mention of the species. We have also attempted to provide current geographical names for type localities. Species or subspecies that were positively identified are assigned a geographic range in one of the following categories: Indo-Pacific (western/central Indian Ocean to central Pacific plate, may include the eastern Pacific); Indo-west Pacific and marginally on the Pacific plate (may include the Caroline Islands, Marshall Islands, Gilbert Islands, and Samoa, as well as Palau, Yap, and the Marianas on the Philippine plate); Indo-west Pacific (western/central Indian Ocean to the Andesite line); western Indian Ocean (southern tip of India westwards); Indian Ocean (including the Andaman Islands, Cocos [Keeling] Island, and Christmas Island); central Indian Ocean (Chagos Archipelago, Maldives/Laccadive Islands, Sri Lanka); Indian Ocean and western extremity of west Pacific (eastwards to Gulf of Thailand); cosmopolitan (tropical and temperate waters worldwide); circumtropical (tropical waters worldwide); Indo-Pacific and western Atlantic (including the Caribbean); Indo-west Pacific and Mediterranean; endemic to Chagos Archipelago; and un- 
assigned. Most authors (e.g., Allen and Steene, 1979; Russell, 1983) have used "west Pacific" or "Indo-west Pacific" to denote an area extending as far east as Hawaii and French Polynesia. In cases where we could not find specific localities for a species, these terms are given in quotation marks to indicate that the range may, in fact, include Pacific plate localities. Usually we have been reluctant to categorize species that are at present known only from Chagos as "endemics". The number of such species from small island groups has been shrinking rapidly in recent years, as more scuba collections are made, and will no doubt continue to do so in the future. We feel that Springer's (1982) delimitation of the west Pacific is likely to prove more useful in studies of fish distribution. However, distributions of Indo-west Pacific fishes are in many cases complicated by what Springer (op. cit.) refers to as the Caroline conduit, and the Kuroshio extension, through which many Indo-west Pacific fishes appear to have invaded the Pacific plate. Thus the actual ranges of many species were difficult to determine, because there are few reliable checklists of Pacific-plate fishes and those that exist usually cover island groups on the western rim of the plate within the Caroline conduit (e.g., Guam, Marianas, Marshall Islands) or the Kuroshio extension (Hawaii).

The ranges reported here are primarily from the literature, with an emphasis on establishing the easternmost record for each species. For the FAO sheets (1984), we refer to the author of the relevant account. These accounts consist of unnumbered pages - the page number given is from the original FAO sheets and is derived by simply counting the number of pages until the reference referred to is reached. The inclusion in this checklist of species from the FAO sheets that we neither saw nor collected is usually based on the range map and is listed as an occurrence rather than a record. If the species referred to has been previously recorded from the Chagos Archipelago, we have cited that paper. If the title of a paper on the title page is not in agreement with the title heading in the text (e.g., Bleeker, 1856e, f, Smith, 1962a), the former is cited.

The parenthetical addition of photo or photos at the end of many of the Material sections, for example, (photos: 44 and $110 \mathrm{~mm}$ ), indicates that one or more $35-\mathrm{mm}$ colour slides of freshly dead specimens of that species are available in the Department of Ichthyology and Herpetology, ROM. Standard length of the photographed specimen is given, except where otherwise indicated or where only a single specimen of that species was collected. The majority of the specimens listed under Material are housed in the Royal Ontario Museum. Some lots of common species have been sent to the following institutions: Australian Museum, Sydney; British Museum (Natural History), London; Bernice P. Bishop Museum, Honolulu; Museum of Comparative Zoology, Cambridge; National Museum of Natural History, Washington; National Museum of Natural Sciences, Ottawa; Northern Territories Museum, Darwin; Smith Institute, Grahamstown; and The Western Australian Museum, Perth.

In the text, "SL" refers to standard length, "TL" to total length, "BL" to body length (used by Kyushin et al., 1977 , as a synonym for standard length), "FL" to fork length, and "DW" to disc width (batoids only). The colour plates are biased towards depicting undescribed species, species for which the description is based in whole or in part on Chagos material; species we did not collect, in underwater views; rare species; and finally those species that previously have not (or have seldom) been illustrated in colour. 


\section{Checklist of Chagos Fishes}

\section{Ginglymostomatidae}

Nebrius ferrugineus (Lesson)

Fig. 3

Scyllium ferrugineum Lesson, 1830:95 (New Ireland;

Waigeo)

Nebrius ferrugineus-Compagno, 1984c:5 (Indo-Pacific east to Tahiti)

\section{MATERIAL}

One lot, 1 specimen, $1100 \mathrm{~mm}$ TL, $0.5 \mathrm{~m}$ in lagoon at Peros Banhos (photo). Although only a single specimen was collected, this species was occasionally seen in the lagoons (and once cruising the drop-off). A school of 20 to 30 adults (estimated to be up to $3 \mathrm{~m} \mathrm{TL}$ ) occupied the lagoon at the northeast tip of Eagle Island while we were there, usually lying on the bottom $(2-5 \mathrm{~m})$ in small compact groups. Identified by Dr L. J. V. Compagno. Indo-Pacific.

\section{Odontaspididae}

A large (ca $2.5 \mathrm{~m}$ ) odontaspid shark (possibly Eugomphodus taurus) escaped from a trap net during our efforts to secure it. We were unable to identify it positively.

\section{Alopiidae}

\section{Alopias vulpinus (Bonnaterre)}

Squalus vulpinus Bonnaterre, 1788:9 (Mediterranean) Alopias vulpinus-Compagno, 1984a:7 (cosmopolitan, including Chagos)

No specimens collected; record based on Compagno (1984a). Cosmopolitan.

\section{Carcharhinidae}

\section{Carcharhinus albimarginatus (Rüppell)}

Pl. IIA

Carcharias albimarginatus Rüppell, 1837:64 (Red Sea)

Carcharhinus albimarginatus-Garrick, 1982:116 (Indo-

Pacific, including Chagos, east to Mexico)

\section{MATERIAL}

One lot, 4 specimens, $1325-1910 \mathrm{~mm}$ TL, $20 \mathrm{~m}$, drop-off at Peros Banhos. This shark was observed only along the drop-offs and on the reef-tops at all the islands (except Three Brothers). It was the most common carcharhinid observed, being seen on almost every dive made in this habitat. Indo-Pacific.

\section{Carcharhinus melanopterus (Quoy and Gaimard)}

Fig. 4 Carcharias melanopterus Quoy and Gaimard, 1824:194 (Waigeo; Marianas)

Carcharhinus melanopterus-Garrick, 1982:96 (IndoPacific east to Tuamotu Islands)

\section{MATERIAL}

Five lots, 10 specimens, $405-1100 \mathrm{~mm}$ TL, $0-2.5 \mathrm{~m}$, lagoons at Peros Banhos and Salomon (photos: 440 and $1100 \mathrm{~mm}$ TL). The blacktip reef shark was the most abundant shark in the lagoons and was also common on the reef-tops. It was seldom seen on the drop-off. Juveniles were frequently seen patrolling the shoreline in less than $30 \mathrm{~cm}$ of water, and three individuals were observed feeding on a school of the atherinid Atherinomorus lacunosus. Indo-Pacific.

\section{Carcharhinus wheeleri Garrick}

PI. IIB

Carcharhinus wheeleri Garrick, 1982:111 (Red Sea; also Gulf of Aden; Kenya; and Réunion)

Carcharhinus amblyrhynchos-Kyushin et al., 1977:22 (four specimens from Chagos Archipelago) (non Bleeker, 1856)

\section{MATERIAL}

Two lots, 3 specimens, 700-910 mm TL, 17-20 m, lagoon and drop-off at Peros Banhos. The blacktail reef shark was the second most abundant shark, most commonly seen outside the lagoons. It was somewhat more inquisitive and aggressive than $C$. albimarginatus and $C$. melanopterus, sometimes coming within $1 \mathrm{~m}$ of divers. This was especially true when fishes were being speared on the reef-top in the late afternoon; individuals less than $1 \mathrm{~m}$ in length would frequently escort the divers to the boats at this time. Western Indian Ocean.

\section{Prionace glauca (Linnaeus)}

Squalus glaucus Linnaeus, 1758:235 (“Oceano Europaeo")

Prionace glauca-Compagno, 1984b:65 (cosmopolitan, including Chagos)

No specimens seen or collected; occurrence based on Compagno (1984b). Cosmopolitan.

\section{Sphyrnidae}

\section{Sphyrna sp.}

We did not see or collect any hammerhead sharks, but other members of the expedition reported seeing very large 
hammerheads (ca $5 \mathrm{~m}$ ) on two occasions. These may have been $S$. mokarran (Rüppell, 1837).

\section{Myliobatididae}

Eagle rays were seen in the lagoon at Peros Banhos on two occasions, but we were unable to approach them closely enough to identify them even to genus.

\section{Mobulidae}

\section{Manta birostris (Donndorf)*}

Raja birostris Donndorf, 1798:876 (no type locality)

Manta birostris-Fowler, 1941:483 (circumtropical)

No specimens of this species were collected. Solitary manta rays were seen cruising along the edge of the drop-off at Peros Banhos on three occasions. Circumtropical.

\section{Dasyatidae}

Dasyatis purpureus (Müller and Henle)*

Fig. 5

Trygon purpurea Müller and Henle, 1841:160 (probably South Africa)

Dasyatis purpureus-Wallace, 1967:50 (western Indian Ocean)

\section{MATERIAL}

One lot, 1 specimen, $565 \mathrm{~mm}$ DW, $0.5 \mathrm{~m}$, lagoon at Peros Banhos (photo). This species was occasionally seen cruising in shallow water in the lagoon at Peros Banhos. Western Indian Ocean.

\section{Hypolophus sephen (Forsskål)}

Raja sephen Forsskål, 1775:17 (Red Sea)

Dasyatis sephen -Fowler, 1941:415 (Indo-west Pacific)

No material of this species was obtained. It was observed in the lagoons at Peros Banhos and Salomon. Identification was based on coloration and the well-developed ventral fin fold on the tail. Generic placement follows Compagno and Heemstra (1984). Indo-west Pacific.

Urogymnus asperrimus (Bloch and Schneider) Fig. 6 Raja asperrima Bloch and Schneider, 1801:367 (Bombay, Indian Ocean)

Urogymnus africanus - Fowler, 1941:438(Indo-west Pacific) (non Bloch and Schneider, 1801)

\section{MATERIAL}

One lot, 1 specimen, $540 \mathrm{DW}, 0.3 \mathrm{~m}$, lagoon at Eagle Island (photo). No other specimens of this species were seen or collected. Identification as $U$. asperrimus rather than $U$. africanus follows Compagno and Heemstra (1984). Indo-west Pacific.

\section{Albulidae}

\section{Albula glossodonta (Forsskål)}

Argentina glossodonta Forsskål, 1775:68 (Red Sea)

Albula glossodonta-Shaklee, 1984:5 (Indo-Pacific, including Chagos, east to Marquesas Islands)

We did not collect this species, but specimens from Diego Garcia are housed in the National Museum of Natural History, Washington, and have been identified and reported on by Shaklee (1984). We saw schools of Albula at both Diego Garcia and Salomon that were probably this species, but we were unable to catch any. Indo-Pacific.

\section{Moringuidae}

Species of Moringua are difficult to identify, and the separation of three species is based on a list of vertebral count differences supplied by Dr P. H. J. Castle. Virtually nothing is known of the biology of these eels, and they were seen only when they emerged from the sand in rotenone stations. The geographic ranges given are uncertain.

Moringua ferruginea Bliss*

Fig. 7

Moringua ferruginea Bliss, 1883:57 (Mauritius); Randall and McCosker, 1975:4 (Easter Island)

\section{MATERIAL}

Seven lots, 32 specimens, 119-296 mm SL, 0-10 m, intertidal, reef-flat, and reef-top at Diego Garcia, Eagle Island, Peros Banhos, and Salomon (photos: 126 and $182 \mathrm{~mm}$ ). Vertebrae $120-130$. Only a single specimen was taken in water deeper than $1 \mathrm{~m}$. Indo-Pacific.

Moringua javanica (Kaup)

Fig. 8

Aphthalmichthys javanicus Kaup, 1856a:105 (Java)

Moringua javanica-Randall, 1955c:24 (Gilbert Islands)

\section{MATERIAL}

Three lots, 3 specimens, 414-675 mm SL, 0-7 m, lagoon and intertidal at Eagle Island and Peros Banhos (photo: $675 \mathrm{~mm}$ ). Vertebrae 150-170. Indo-west Pacific and marginally on the Pacific plate.

Moringua microchir Bleeker

Fig. 9

Moringua microchir Bleeker, 1853a:124 (Ambon; Kauer); Russell, 1983:18 (“Indo-west Pacific")

MATERIAL

Six lots, 12 specimens, $121-309 \mathrm{~mm} \mathrm{SL}, 0-1 \mathrm{~m}$, intertidal and reef-flat at Diego Garcia, Eagle Island, Peros Banhos, 
and Salomon (photo: $257 \mathrm{~mm}$ ). Vertebrae 100-115. "Indowest Pacific."

\section{Xenocongridae}

The following identifications were provided by Dr D. G. Smith.

\section{Kaupichthys atronasus Schultz}

Fig. 10

Kaupichthys atronasus Schultz, 1953b:65 (Marshall Islands); Allen and Steene, 1979:10 (Christmas Island)

\section{MATERIAL}

One lot, 1 specimen, $54 \mathrm{~mm}$ SL, $7 \mathrm{~m}$, lagoon at Peros Banhos. Indo-west Pacific and marginally on the Pacific plate.

\section{Kaupichthys hyoproroides (Strömmann)* Fig. 11} Leptocephalus hyoproroides Strömmann, 1896:39 (north of Bahamas)

Kaupichthys hyoproroides-Böhlke and Smith, 1968:28 (Indo-west Pacific and west Atlantic); Randall, 1973:174 (Tahiti)

\section{MATERIAL}

Sixteen lots, 24 specimens, 62-183 mm SL, 6-43 m, lagoon, reef-top, and drop-off at Peros Banhos and Salomon (photos: 136, 159, and $183 \mathrm{~mm}$ ). Circumtropical.

\section{Kaupichthys nuchalis Böhlke}

Fig. 12 Kaupichthys nuchalis Böhlke, 1967:95 (Grand Bahama Island; also other Caribbean islands)

\section{MATERIAL}

Two lots, 3 specimens, $58-200 \mathrm{~mm} \mathrm{SL}, 18-43 \mathrm{~m}$, drop-off at Peros Banhos and Salomon (photo: $58 \mathrm{~mm}$ ). Circumtropical.

\section{Kaupichthys sp.}

Fig. 13

\section{MATERIAL}

Two lots, 2 specimens, 107-144 mm SL, 13-25 m, lagoon and drop-off at Peros Banhos and Salomon. Range unassigned.

\section{Powellichthys sp.}

Fig. 14

\section{MATERIAL}

One lot, 1 specimen, $155 \mathrm{~mm} \mathrm{SL}, 18-24 \mathrm{~m}$, drop-off at Salomon. Range unassigned.

\section{Muraenidae}

Since vertebral numbers and formulas are often important in muraenid systematics, this information is given for the 22 species for which it was gathered (Table 1).
Anarchias allardicei Jordan and Starks

Fig. 15 Anarchias allardicei Jordan and Starks, in Jordan and Seale, 1906:204 (Samoa)

\section{MATERIAL}

Four lots, 19 specimens, 43-128 mm SL, 0-1 m, intertidal and reef-flat at Eagle Island, Peros Banhos, and Salomon. It is probable that $A$. fuscus Smith, 1962a, is a junior synonym of $A$. allardicei. Further studies (as part of a revision of the genus by $\mathrm{E}$. Holm) are in progress to determine variation in these two nominal species. IndoPacific east to the Tuamotu Islands.

Anarchias seychellensis Smith

Fig. 16 Anarchias seychellensis Smith, 1962a:429 (Assumption Island; also Mahé)

Anarchias leucurus-Schultz, 1953c:144 (Marshall Islands) (non Snyder, 1902)

\section{MATERIAL}

Eight lots, 19 specimens, $74-157 \mathrm{~mm} \mathrm{SL}, 0.5-25 \mathrm{~m}$, lagoon, reef-top, and drop-off at Peros Banhos and Salomon (photo: $130 \mathrm{~mm}$ ). This species is very close to A. leucurus Schultz, 1953c, but apparently differs in having higher dorsal-fin ray counts $(>35$ vs $<35)$ and vertebral counts $(>120$ vs $<118)$. Indo-Pacific east to Pitcairn Island.

\section{Echidna leucotaenia Schultz}

Fig. 17

Echidna leucotaenia Schultz, 1943:22 (Phoenix Islands; also Samoa); Randall, 1973:175 (Tahiti)

\section{MATERIAI}

Six lots, 6 specimens, 49-298 mm SL, 0-24 m, reef-flat, reef-top, and drop-off at Eagle Island, Peros Banhos, and Salomon. Indo-Pacific.

Echidna nebulosa (Ahl)

Fig. 18

Muraena nebulosa Ahl, 1789:7 (East Indies); Regan, 1908:220 (Chagos Archipelago)

Echidna nebulosa-Randall, 1973:175 (Tahiti)

\section{MATERIAL}

Seven lots, 43 specimens, $35-421 \mathrm{~mm} \mathrm{SL}, 0-1 \mathrm{~m}$, intertidal and reef-flat at Eagle Island, Peros Banhos, and Salomon (photo: $123 \mathrm{~mm}$ ). This series of specimens exhibits a gradual transition in colour pattern from uniform brown with a white snout in juveniles to the typical adult pattern of two rows of about 23 large blotches on the body. The transition occurs between 40-75 mm SL. Indo-Pacific.

\section{Echidna polyzona (Richardson)*}

Fig. 19

Muraena polyzona Richardson, 1844:112 (no type locality); Regan, 1908:220 (Chagos Archipelago)

Echidna polyzona-Randall, 1973:175 (Tahiti) 
TABLE 1. Vertebral counts for some Chagos muraenids, with comparative information from E. Böhlke (1982 - column headings suffixed with B) and McCleneghan (1976 - column heading suffixed with M).

Column headings: $\mathrm{n}$-number of specimens examined by us; $\mathrm{T}$ - total vertebrae; $\mathrm{PD}$ - predorsal vertebrae; PA - preanal vertebrae; PC - precaudal vertebrae. T, PD, and PA were counted following the method outlined by E. Böhlke (1982). Precaudal vertebrae are the anterior vertebrae up to, and including, the first vertebra with a posteriorly directed haemal spine.

\begin{tabular}{|c|c|c|c|c|c|c|c|c|c|}
\hline Taxon & $n$ & $\mathrm{~T}$ & TB & $\mathrm{TM}$ & PD & PDB & PA & PAB & $\mathrm{PC}$ \\
\hline Anarchias allardicei & 13 & $97-102$ & 97 & - & $86-92$ & 85 & 89-92 & 87 & $55-59$ \\
\hline A. seychellensis & 19 & $121-128$ & - & - & $109-116$ & 一 & $113-119$ & - & $57-63^{*}$ \\
\hline Echidna leucotaenia & 2 & $121-122$ & $128-130$ & - & $6-7$ & $6-7$ & 50 & $50-52$ & $55-56$ \\
\hline E. nebulosa & 4 & $122-125$ & - & $120-128$ & $5-6$ & - & $55-59$ & - & $65-69(n=2)$ \\
\hline Gymnothorax buroensis & 5 & $109-116$ & 114 & $110-119$ & $4-6$ & 5 & $46-48$ & 46 & $53-55$ \\
\hline G. chilospilus & 3 & $126-131$ & 127 & - & $5-6$ & 5 & $50-52$ & 50 & $56-58$ \\
\hline G. enigmaticus & 3 & $126-130$ & 一 & - & $4-5$ & - & $51-52$ & - & $61-63$ \\
\hline G. fimbriatus & 3 & $128-133$ & - & - & $5-6$ & - & $52-53$ & - & $62-63$ \\
\hline G. flavimarginatus & 6 & $133-135$ & 134 & $134-138$ & $4-6$ & 6 & $55-58$ & 54 & $66-67$ \\
\hline G. fuscomaculatus & 4 & $117-123$ & $118-122$ & - & $37-39$ & $34-42$ & $48-50$ & $48-51$ & $54-58$ \\
\hline G. margaritophorus & 3 & $131-133$ & - & - & $4-6$ & - & $50-51$ & - & $56-58$ \\
\hline G. melatremus & 6 & $133-139$ & 137 & - & $3-4$ & - & $49-53$ & 52 & $60-65$ \\
\hline G. pictus & 5 & $129-135$ & - & $127-133$ & $9-10$ & - & $57-59$ & - & $67-68$ \\
\hline G. pindae & 3 & $122-124$ & - & - & $5-7$ & - & $41-44$ & - & 53 \\
\hline G. rueppelliae & 8 & $128-134$ & $125-126$ & - & $4-6$ & $4-5$ & $51-54$ & 50 & $60-65$ \\
\hline G. undulatus & 6 & $131-133$ & - & $125-130$ & $4-6$ & - & $53-55$ & - & $62-63$ \\
\hline Uropterygius fuscoguttatus & 1 & 120 & $113-120$ & - & 100 & $93-101$ & 106 & $100-107$ & 63 \\
\hline U. kamar & 2 & $135-143$ & $134-139$ & - & $113-117$ & $109-116$ & $124-128$ & $120-126$ & $66-69$ \\
\hline U.polyspilus & 1 & 134 & - & - & 125 & - & 126 & - & $75 ?$ \\
\hline$U$. supraforatus & 1 & 124 & - & - & 103 & - & 108 & - & 66 \\
\hline$U$. xanthopterus & 1 & 125 & - & - & 111 & - & 115 & - & 66 \\
\hline
\end{tabular}

$*_{\mathrm{n}}=9$, last precaudal vertebra could not be determined with confidence in 10 of the $\mathrm{X}$-rayed specimens.

\section{MATERIAL}

One lot, 2 specimens, 244-338 mm SL, 0-1 m, reef-flat, Peros Banhos. Indo-Pacific.

\section{Echidna unicolor Schultz}

Fig. 20

Echidna unicolor Schultz, 1953c:106 (Marshall Islands); Smith, 1962a:424 (east Africa); Randall, 1973:175 (Tahiti)

\section{MATERIAL}

One lot, 1 specimen, $95 \mathrm{~mm} \mathrm{SL}, 23-25 \mathrm{~m}$, drop-off at Salomon. Indo-Pacific.

\section{Enchelycore bayeri (Schultz)}

Fig. 21

Gymnothorax bayeri Schultz, 1953c:124 (Marshall Islands)

Enchelycore bayeri-Randall, 1973:175 (Tahiti)

\section{MATERIAL}

Two lots, 3 specimens, 318-645 mm SL, 7-20 m, lagoon and drop-off at Peros Banhos and Salomon (photos: 318 and $645 \mathrm{~mm}$ ). Indo-Pacific.

\section{Enchelycore pardalis (Temminck and Schlegel)}

Pl. IIC Muraena pardalis Temminck and Schlegel, 1842:268 (Japan); Allen and Steene, 1979:12 (Christmas Island); Randall, 1973:176 (Tahiti)

\section{MATERIAL}

Two lots, 3 specimens, $109-173 \mathrm{~mm} \mathrm{SL}, 0-3 \mathrm{~m}$, reef-flat and reef-top at Peros Banhos and Salomon (photos: 109 and $173 \mathrm{~mm}$ ). The tooth pattern and red colour of the Chagos material are identical to that described by Schultz (1943), but our specimens have many vertical light bands on the body, rather than "white spots" (which appear to form the typical colour pattern of the Pacific variety). This species is included in Enchelycore on the advice of $\operatorname{Dr} \mathrm{J}$. E. McCosker. Indo-Pacific.

Enchelycore schismatorhynchus (Bleeker)

Fig. 22

Muraena schismatorhynchus Bleeker, 1853b:301 (Sumatra) Enchelycore schismatorhynchus-Randall, 1973:175(Tahiti) 
MATERIAL

Three lots, 4 specimens, 91-238 $\mathrm{mm} \mathrm{SL,} \mathrm{0-7} \mathrm{m,} \mathrm{lagoon} \mathrm{at}$ Peros Banhos and Salomon (photos: 151 and $238 \mathrm{~mm}$ ). Indo-Pacific

Enchelynassa canina (Quoy and Gaimard) Fig. 23 Muraena canina Quoy and Gaimard, 1824:247 (Waigeo and Rawak)

Enchelynassa canina-Randall, 1973:175 (Tahiti)

MATERIAL

One lot, 1 specimen, $630 \mathrm{~mm} \mathrm{SL,} 0-0.75 \mathrm{~m}$, reef-flat at Salomon. Indo-Pacific.

Gymnomuraena zebra (Shaw and Nodder)* Fig. 24 Gymnothorax zebra Shaw and Nodder, 1797:pl. 322 (Pacific)

Echidna zebra-Smith, 1962a:423 (western Indian Ocean); McCosker and Rosenblatt, 1975:420 (Galápagos Islands)

\section{MATERIAL}

Five lots, 6 specimens, $272-810 \mathrm{~mm} \mathrm{SL}, 0-10 \mathrm{~m}$, lagoon, intertidal, reef-flat, and reef-top at Diego Garcia, Eagle Island, Peros Banhos, and Salomon (photos: 600 and $810 \mathrm{~mm}$ ). Generic placement is on the advice of $\mathrm{Dr}$ McCosker. Indo-Pacific.

\section{Gymnothorax buroensis (Bleeker)}

Fig. 25

Muraena buroensis Bleeker, $1857 \mathrm{~b}: 79$ (Kayeli, Indonesia) Gymnothorax buroensis-McCosker and Rosenblatt, 1975:420 (Indo-Pacific to off Costa Rica and Panama)

\section{MATERIAL}

Twenty-one lots, 94 specimens, $63-274 \mathrm{~mm} \mathrm{SL}, 0-25 \mathrm{~m}$, lagoon, intertidal, reef-top, and drop-off at Eagle Island, Peros Banhos, and Salomon (photo: $112 \mathrm{~mm}$ ). This species appeared in more collections than any other moray, although it was the second most abundant muraenid numerically. The largest collection contains 36 specimens and was made in the surf over the spur-and-groove formation on the south coast of Isle Boddam, Salomon. Three other collections contain 5-10 specimens; all other collections contain fewer than this. Indo-Pacific.

\section{Gymnothorax chilospilus (Bleeker) Fig. 26} Gymnothorax chilospilus Bleeker, 1865:52 (Benkulen, Sumatra); Randall and Sinoto, 1978:296 (Rapa)

Lycodontis chilospilus - Smith, 1962a:438 (Malindi, Kenya)

\section{MATERIAL}

Four lots, 10 specimens, $88-186 \mathrm{~mm}$ SL, $0-1 \mathrm{~m}$, intertidal and reef-flat at Diego Garcia and Eagle Island. The only area in which we collected this species was at Eagle Island, the Diego Garcia specimens being taken by Ryther and by Taborsky. It is surprising that specimens were not obtained from the two atolls where most of the collecting took place (Peros Banhos and Salomon). Indo-Pacific.

\section{Gymnothorax enigmaticus McCosker and Randall}

Gymnothorax enigmaticus McCosker and Randall, 1982:18 (Palau; range: Indo-Pacific)

\section{MATERIAL}

Five lots, 21 specimens, $47-340 \mathrm{~mm} \mathrm{SL}, 0-1 \mathrm{~m}$, intertidal and reef-flat at Eagle Island and Peros Banhos (photo: $298 \mathrm{~mm}$ ). Juveniles of this species may be separated from $G$. rueppelliae (which has a similar banded pattern) by the lack of pigment on the snout (vs a brown snout). Indo-Pacific.

Gymnothorax fimbriatus (Bennett)

Fig. 28

Muraena fimbriatus Bennett, 1831:168 (Mauritius)

Gymnothorax fimbriatus - Randall, 1973:175 (Tahiti)

\section{MATERIAL}

Three lots, 11 specimens, 49-337 mm SL, 0-1 m, intertidal and reef-flat at Eagle Island and Peros Banhos (photo: $314 \mathrm{~mm}$ ). Indo-Pacific.

Gymnothorax flavimarginatus (Rüppell)

Fig. 29

Muraena flavimarginata Rüppell, 1830b:119 (Red Sea)

Gymnothorax flavimarginatus-Randall, 1973:175 (Tahiti)

\section{MATERIAL}

Fifteen lots, 129 specimens, 38-903 mm SL, 0-20 m, lagoon, intertidal, reef-flat, reef-top, and drop-off at Diego Garcia, Eagle Island, Peros Banhos, and Salomon (photos: 172 and $903 \mathrm{~mm}$ ). This was numerically the most abundant species of moray, although appearing in fewer collections than $G$. buroensis. Only two specimens were taken in water more than $2 \mathrm{~m}$ in depth. The characteristic dark blotch surrounding the gill opening does not appear until specimens reach at least $80-100 \mathrm{~mm} \mathrm{SL}$. The smaller specimens were identified using the large developmental series represented in our collections, and by vertebral counts (132-134 total, vertebrae at anal-fin origin $54-57 ; n=6$ adult specimens). Indo-Pacific.

\section{Gymnothorax fuscomaculatus (Schultz)}

Fig. 30

Rabula fuscomaculatus Schultz, 1953c:147 (Marshall Islands, also Johnston Island)

Gymnothorax fuscomaculatus-Winterbottom, 1978:43 (Indo-Pacific)

MATERIAL

Eight lots, 11 specimens, 103-198 mm SL, 1-25 m, 
lagoon, reef-top, and drop-off at Diego Garcia, Peros Banhos, and Salomon (photo: $157 \mathrm{~mm}$ ). Indo-Pacific.

\section{Gymnothorax griseus (Lacepède)}

Fig. 31

Muraenophis grisea Lacepède, 1803:629 (Madagascar)

Siderea grisea-Smith, 1962a:441 (western Indian Ocean and Red Sea)

\section{MATERIAL}

Three lots, 3 specimens, $342-408 \mathrm{~mm}$ SL, 0-1 m, lagoon, intertidal, and reef-flat at Diego Garcia and Peros Banhos (photos: 365 and $468 \mathrm{~mm}$ ). This species is frequently cited as Siderea grisea. It is apparently confined to the western Indian Ocean and the Red Sea (Randall, 1983b). Western Indian Ocean.

\section{Gymnothorax javanicus (Bleeker)}

Muraena javanica Bleeker, 1859:347 (Java)

Gymnothorax javanicus - Randall, 1973:175 (Tahiti)

\section{MATERIAL}

Nine lots, 11 specimens, 78-1600 mm SL, lagoon, intertidal, reef-flat, and drop-off at Eagle Island, Peros Banhos, and Salomon (photos: 274,755 , and $1300 \mathrm{~mm}$ ). The two largest specimens (1350 and $1600 \mathrm{~mm}$ ) were both taken on an overnight setline baited with fish. Only the head of the larger specimen was preserved. Indo-Pacific.

\section{Gymnothorax margaritophorus Bleeker}

Fig. 33 Gymnothorax margaritophorus Bleeker, 1865:53 (Ambon); Randall, 1973:175 (Tahiti)

\section{MATERIAL}

Nine lots, 12 specimens, 50-315 mm SL, 0-10 m, lagoon, intertidal, and reef-top at Eagle Island, Peros Banhos, and Salomon (photos: 118, 292, and $315 \mathrm{~mm}$ ). Indo-Pacific.

\section{Gymnothorax melatremus Schultz}

Pl. IID

Gymnothorax melatremus Schultz, 1953c:120 (Marshall Islands); Kailola, 1974:40 (Madang, Papua New Guinea); Allen and Steene, 1979:12 (Christmas Island, Indian Ocean); Randall, 1985:466 (Marquesas Islands)

\section{MATERIAL}

Ten lots, 25 specimens, $60-195 \mathrm{~mm} \mathrm{SL}, 18-43 \mathrm{~m}$, dropoff only at Peros Banhos and Salomon (photo: $119 \mathrm{~mm}$ ). Schultz (1953c) does not mention the network of dark, fine lines on the body that are apparent in most of our specimens, although the rest of his description fits the Chagos material. These lines were mentioned in the subsequent description given by Kailola (1974). Our photographed specimen has a yellow anterior nostril; the black pigment around the eye is best developed along the posterior rim; a vertical, pupil-width bar passes through the eye; and the posterior regions of the dorsal and anal fins, as well as the caudal fin, are yellow. Indo-Pacific.

Gymnothorax pictus (Ahl)

Fig. 34

Muraena picta Ahl, 1789:8 (East Indies)

Gymnothorax pseudothyrsoides-Regan, 1908:220 (Peros

Banhos) (non Bleeker, 1852b)

Gymnothorax pictus-McCosker and Rosenblatt, 1975:420 (eastern Pacific)

Siderea picta - Smith, 1962a:440 (western Indian Ocean)

\section{MATERIAL}

Six lots, 21 specimens, $47-753 \mathrm{~mm} \mathrm{SL}, 0-1 \mathrm{~m}$, intertidal and reef-flat at Eagle Island, Peros Banhos, and Salomon (photos: 60, 101, 181, and $486 \mathrm{~mm}$ ). The specimen identified as $G$. pseudothyrsoides by Regan (1908) from Peros Banhos was examined and proved to be this species.

The colour pattern of juveniles has been described by Smith (1962a). All but two of the specimens are from reef-flats. Specimens were observed during the day, and on one occasion an individual $40-50 \mathrm{~cm}$ long attacked, within a foot of us, a grapsoid crab that had been frightened into the water by our approach. Indo-Pacific.

\section{Gymnothorax pindae Smith}

Fig. 35

Gymnothorax pindae Smith, 1962a:430 (Pinda, Mozambique); Randall and McCosker, 1975:18 (Indo-Pacific, including Chagos, east to Tahiti)

\section{MATERIAL}

Eleven lots, 13 specimens, 49-280 mm SL, 3-43 m, lagoon, reef-top, and drop-off at Peros Banhos and Salomon (photos: 182-189 mm). Indo-Pacific.

Gymnothorax rueppelliae (McClelland)* Fig. 36 Dalophis rueppelliae McClelland, 1845:213 (Red Sea) Gymnothorax rueppelliae-McCosker and Randall, 1982:20 (Indo-Pacific east to Hawaii)

\section{MATERIAL}

Seven lots, 31 specimens, 53-537 mm SL, 0-1 m, intertidal and reef-flat at Diego Garcia, Eagle Island, Peros Banhos, and Salomon (photos: 69, 76, and $537 \mathrm{~mm}$ ). Juveniles of this species have brown snouts; snouts are unpigmented in the closely related $G$. enigmaticus. Indo-Pacific.

Gymnothorax undulatus (Lacepède)

Fig. 37

Muraenophis undulata Lacepède, 1803:629 (no type locality)

Gymnothorax undulatus - Randall, 1973:176 (Tahiti)

Lycodontis undulatus - Smith, 1962a:439 (western Indian Ocean) 
MATERIAL

Seven lots, 74 specimens, 46-424 mm SL, 0-3 m, lagoon, intertidal, and reef-flat at Diego Garcia, Peros Banhos, and Salomon (photos: 135 and $255 \mathrm{~mm}$ ). The colour pattern of our specimens varies from dark brown with fine white reticulations to large dark blotches on a white background, with continuous variation in between. Indo-Pacific.

Gymnothorax zonipectis Seale*

Fig. 38

Gymnothorax zonipectis Seale, 1906:7 (Tahiti); Allen and Steene, 1979:12 (Christmas Island)

\section{MATERIAL}

Seven lots, 9 specimens, 51-360 mm SL, 0.5-43 m, lagoon, reef-top, and drop-off at Peros Banhos and Salomon (photos: 138 and $195 \mathrm{~mm}$ ). Indo-Pacific.

The following four records apparently represent discrete species, but we were unable to assign names to them and are reluctant to describe them as new in view of the limited material available.

\section{Gymnothorax sp. 1}

Pl. IIE

\section{MATERIAL}

One lot, 1 specimen, $148 \mathrm{~mm}$ SL, 23-25 m, drop-off at Salomon (photo). A pale, dusky-snouted moray with the tail 1.56 times in the snout-to-anus distance and with 10 predorsal, 40 preanal, 51 precaudal, and 126 total vertebrae (see Table 1 for definitions). Vomerine teeth biserial, maxillary teeth triserial; all teeth sharp and conical, the largest being the posterior median premaxillary tooth. We have examined one other specimen of this type, from Ponape, Caroline Islands, which has the following vertebral counts: 9, 43, 53, and 132, respectively. Distribution insufficiently known to categorize confidently, but, based on the above material, at least Indo-west Pacific and marginally on the Pacific plate.

\section{Gymnothorax sp. 2}

Pl. IIF

MATERIAL

One lot, 1 specimen, $50 \mathrm{~mm} \mathrm{SL,} 42 \mathrm{~m}$, drop-off at Peros Banhos (photo). A pattern of chainlike dark brown markings on a white background; gill opening in a black blotch; iris yellow, as is basal portion of posterior region of dorsal and anal fins; 3 predorsal, 40 preanal, 51 precaudal, and 106 total vertebrae. Range unassigned.

\section{Gymnothorax sp. 3}

Pl. IIG

MATERIAL

One lot, 1 specimen, $118 \mathrm{~mm} \mathrm{SL,} \mathrm{18-24} \mathrm{m,} \mathrm{drop-off} \mathrm{at}$ Peros Banhos (photo). Brown background peppered from head to tail with darker brown spots about one-third of eye diameter in size; two rows of maxillary teeth with six teeth in inner row; 5 predorsal, 54 preanal, 70 precaudal, and 132 total vertebrae. We have examined two other specimens of this type from the Marianas, which had the following respective vertebral counts: 5-6, 57-59, 67-69, and 134-136. Distribution insufficiently known to categorize confidently, but at least Indo-west Pacific and marginally on the Pacific plate.

Gymnothorax sp. 4

Fig. 39

MATERIAL

One lot, 1 specimen, $47 \mathrm{~mm}$ SL, 0-0.5 m, intertidal at Eagle Island. A rich chocolate brown moray; 55 precaudal and 124 total vertebrae; the entire lower jaw and the lower part of the upper jaw immaculately white (similar to juvenile G. margaritophorus, but lacking the dorsal light streak of that species). Range unassigned.

In addition to the above, we have 7 lots, 29 specimens of small morays ( $<70 \mathrm{~mm} \mathrm{SL}$ ) that we could not identify, but which may represent a combination of $G$. undulatus, $G$. flavimarginatus, G. fimbriatus, and at least one other unknown.

Uropterygius concolor Rüppell

Fig. 40

Uropterygius concolor Rüppell, 1838:83 (Red Sea); Gosline, 1958:226 (central Pacific)

\section{MATERIAL}

Two lots, 5 specimens, 108-147 mm SL, 7-13 m, lagoon at Salomon and Three Brothers. Three of our specimens are females with eggs. Indo-Pacific.

\section{Uropterygius fuscoguttatus Schultz}

Fig. 41

Uropterygius fuscoguttatus Schultz, 1953c:156 (Marshall Islands); Gosline, 1958:224 (Johnston Island)

\section{MATERIAL}

Seven lots, 10 specimens, 77-180 mm SL, 3-25 m, lagoon, reef-top, and drop-off at Peros Banhos and Salomon (photo: $161 \mathrm{~mm}$ ). The darker mottlings that appear on the posterior part of the body may be faint or absent in small specimens $(<100 \mathrm{~mm} \mathrm{SL})$. This species differs from $U$. supraforatus in colour; in having 3-4 rows of maxillary teeth (vs 5-6); and in vertebral (117-119 vs 123 total), dorsal-fin ray ( $37-48$ vs 67 ), and anal-fin ray (33-37 vs 48) counts. Our specimens appear to represent the first record of this species from the Indian Ocean. Indo-Pacific.

Uropterygius inornatus Gosline

Fig. 42

Uropterygius inornatus Gosline, 1958:225 (Hawaii)

\section{MATERIAL}

One lot, 1 specimen, 105 mm SL, 9 m, reef-top at Salomon. 
This appears to be the first record of this species from the Indian Ocean. Indo-Pacific.

Uropterygius kamar McCosker and Randall Fig. 43 Uropterygius kamar McCosker and Randall, 1977:164 (Comoro Islands; also Indo-Pacific to Pitcaim Island)

\section{MATERIAL}

Four lots, 5 specimens, 56-200 mm SL, 10-25 m, reef-top and drop-off at Peros Banhos and Salomon. The only difference from the original description observed in the above material was that, based on X-rays of two specimens, the dorsal fin originates more than a head length away from the tail tip (as opposed to half a head length away). Indo-Pacific.

\section{Uropterygius polyspilus (Regan)}

Fig. 44

Gymnomuraena polyspila Regan, 1909:438 (Tahiti; also Zanzibar)

\section{MATERIAL}

Two lots, 4 specimens, $58-271 \mathrm{~mm} \mathrm{SL}, 0-1 \mathrm{~m}$, intertidal at Eagle Island only (photo: $211 \mathrm{~mm}$ ). Indo-Pacific.

Uropterygius supraforatus (Regan)

Fig. 45

Gymnomuraena supraforata Regan, 1909:439 (Savaii, Western Samoa)

Uropterygius supraforatus—Randall, 1973:176 (Tahiti)

\section{MATERIAL}

One lot, 1 specimen, $269 \mathrm{~mm} \mathrm{SL}, 3-7 \mathrm{~m}$, lagoon at Peros Banhos. This appears to be the first record of this species from the Indian Ocean. Indo-Pacific.

\section{Uropterygius xanthopterus Bleeker}

Fig. 46

Uropterygius xanthopterus Bleeker, 1859:350 (Pajitan); Randall, 1973:176 (Tahiti)

Uropterygius alboguttatus Smith, 1962a:427 (Assumption Island; also widespread in western Indian Ocean)

\section{MATERIAL}

Eight lots, 12 specimens, 68-343 mm SL, 5-36 m, lagoon, reef-top, and drop-off at Peros Banhos and Salomon (photos: 180 and $343 \mathrm{~mm}$ ). Indo-Pacific.

\section{Uropterygius sp. 1}

PI. IIH MATERIAL

One lot, 1 specimen, $180 \mathrm{~mm} \mathrm{SL}, 40-43 \mathrm{~m}$, drop-off at Peros Banhos (photo). This specimen could not be identified. It is plain brown; the tail 1.4 times in the snout-to-anus distance; depth at anus 35 times in total length; 4 rows of maxillary teeth; 50 dorsal-fin rays; 123 precaudal, 131 preanal, 75 predorsal, and 142 total vertebrae. Range unassigned.

\section{Congridae}

Conger cinereus Rüppell

Fig. 47

Conger cinereus Rüppell, 1830a:115 (Red Sea); Randall, 1973:176 (Tahiti)

\section{MATERIAL}

Nine lots, 34 specimens, 54-748 mm SL, 0-26 m, lagoon, intertidal, reef-flat, and drop-off at Diego Garcia, Eagle Island, Peros Banhos, and Salomon (photos: 65, 157, and $183 \mathrm{~mm}$ ). Only two of our specimens (in two lots) were collected in water deeper than $1 \mathrm{~m}$ and in habitats other than the reef-flats and intertidal region. Indo-Pacific.

\section{Gorgasia maculata Klausewitz} and Eibl-Eibesfeldt

Fig. 48

Gorgasia maculata Klausewitz and Eibl-Eibesfeldt, 1959:147 (Nicobar Islands)

\section{MATERIAL}

One lot, 3 specimens, 281-368 mm SL, 15-17 m, lagoon at Peros Banhos (photo: $283 \mathrm{~mm}$ ). The only place in which we observed this and the following species of garden eel was on a sandy bottom adjacent to a patch reef approximately $500 \mathrm{~m}$ south of the pass between Isle Poule and Petite Sœur, Peros Banhos. Gorgasia maculata is apparently confined to the Indian Ocean east to Cocos (Keeling) Island (Smith-Vaniz, pers. comm.).

\section{Heteroconger hassi (Klausewitz \\ and Eibl-Eibesfeldt)}

Fig. 49

Xarifana hassi Klausewitz and Eibl-Eibesfeldt, 1959:138 (Maldives)

Heteroconger hassi-Myers and Sheppard, 1980:312 (Marianas)

\section{MATERIAL}

One lot, 5 specimens, $140-320 \mathrm{~mm} \mathrm{SL}, 15-17 \mathrm{~m}$, lagoon at Peros Banhos (photo: $139 \mathrm{~mm}$ ). We follow Böhlke and Randall (1981) in recognizing only two genera of garden eels (Gorgasia and Heteroconger). Indo-west Pacific and marginally on the Pacific plate.

\section{Ophichthidae}

Brachysomophis crocodilinus (Bennett)

Fig. 50 Ophisurus crocodilinus Bennett, 1833:32 (Mauritius) Brachysomophis crocodilinus-Randall, 1973:176 (Tahiti)

MATERIAL

Two lots, 2 specimens, 172-230 mm SL, 0-7 m, lagoon and intertidal at Eagle Island and Peros Banhos (photos: both). Identified by Dr J. E. McCosker. Indo-Pacific. 


\section{Callechelys marmoratus (Bleeker)}

Fig. 51

Dalophis marmorata Bleeker, $1853 \mathrm{f}: 37$ (Sibolga, Sumatra)

Callechelys marmoratus-Randall, 1973:177 (Tahiti)

MATERIAL

One lot, 1 specimen, $767 \mathrm{~mm} \mathrm{SL}, 0.5 \mathrm{~m}$, lagoon at Peros Banhos (photo). Indo-Pacific.

Lamnostoma orientalis (McClelland)*

Dalophis orientalis McClelland, 1845:213 (Coromandel Coast)

Lamnostoma orientalis-Castle, 1984:9 (Indian Ocean including Chagos); Randall, 1973:177 (Tahiti)

No specimens seen or collected. Castle's (1984) distribution map for this species includes Chagos, and he states that its distribution is "southern Africa to India, and probably most other parts of the Indian Ocean." However, he lists the habitat as being "estuaries and inshore areas of turbid waters"- conditions that do not occur at Chagos. Doubtful literature record, but assigned to the Indo-Pacific.

Leiuranus semicinctus (Lay and Bennett) Fig. 52 Ophisurus semicinctus Lay and Bennett, 1839:66 (Hawaii) Leiuranus semicinctus-Smith, $1962 \mathrm{~b}: 455$ (Indo-Pacific)

MATERIAL

Eight lots, 96 specimens, 114-471 mm SL, 0-1 m, lagoon, intertidal, and reef-flat at Diego Garcia, Eagle Island, and Peros Banhos (photo: $194 \mathrm{~mm}$ ). Indo-Pacific.

\section{Muraenichthys laticaudata (Ogilby)*}

Fig. 53

Myopterura laticaudata Ogilby, 1897:247 (Fiji)

Muraenichthys laticaudata-Smith, 1962 b:462 (western Indian Ocean); Randall, 1973:177 (Tahiti)

\section{MATERIAL}

Six lots, 6 specimens, 53-184 mm SL, 0-26 m, lagoon, reef-flat, reef-top, and drop-off at Peros Banhos and Salomon (photo: $180 \mathrm{~mm}$ ). Indo-Pacific.

\section{Muraenichthys schultzei Bleeker}

Fig. 54

Muraenichthys schultzei Bleeker, $1857 \mathrm{c}: 366$ (south Java); Gosline, 1955:444 (Johnston Island); Smith, 1962b:461 (Red Sea and western Indian Ocean)

\section{MATERIAL}

Five lots, 7 specimens, $75-100 \mathrm{~mm}$ SL, 0-13 m, lagoon, intertidal, and reef-flat at Eagle Island, Peros Banhos, and Salomon. Indo-Pacific.

\section{Myrichthys colubrinus (Boddaert)*}

Muraena colubrina Boddaert, 1781:56 (Ambon)

Ophisurus colubrinus var. semicincta-Regan, 1908:220
(Chagos Archipelago)

Myrichthys colubrinus-McCosker, 1977:78 (Indo-Pacific)

\section{MATERIAL}

Five lots, 7 specimens, 172-645 mm SL, 0-3 m, lagoon, intertidal, and reef-flat at Eagle Island, Peros Banhos, and Salomon (photos: 395 and $565 \mathrm{~mm}$ ). Indo-Pacific.

Myrichthys maculosus (Cuvier)

Fig. 56

Muraena maculosa Cuvier, 1817:232 (no locality given) Myrichthys maculosus-McCosker, 1977:78 (Indo-Pacific)

\section{MATERIAI}

Nine lots, 27 specimens, 89-342 mm SL, 0-7 m, lagoon, intertidal, reef-flat, and reef-top at Diego Garcia, Eagle Island, and Peros Banhos (photos: 230, 276, and $342 \mathrm{~mm}$ ). Indo-Pacific.

Ophisurus serpens (Linnaeus)

Fig. 57

Muraena serpens Linnaeus, 1758:244 (Atlantic)

Ophisurus serpens-McCosker, 1977:82 (Indo-west Pacific; eastern Atlantic and Mediterranean)

\section{MATERIAL}

Two lots, 2 specimens, 83-233 mm SL, 3-36 m, lagoon and drop-off at Peros Banhos (photo: $233 \mathrm{~mm}$ ). Distribution anomalous, eastern Atlantic to Indo-west Pacific.

\section{Schismorhynchus labialis (Seale)}

Fig. 58

Muraenichthys labialis Seale, 1917:79 (Marshall Islands) Schismorhynchus labialis-McCosker, 1977:61 (IndoPacific)

\section{MATERIAL}

One lot, 4 specimens, 63-72 mm SL, 0-0.5 m, lagoon at Eagle Island (photo: $65 \mathrm{~mm}$ ). Indo-Pacific.

Schultzidia johnstonensis (Schultz and Woods) Fig. 59 Muraenichthys johnstonensis Schultz and Woods, 1949:172 (Johnston Island)

Schultzidia johnstonensis-McCosker, 1977:62 (central and west Pacific)

\section{MATERIAL}

One lot, 1 specimen, $73 \mathrm{~mm} \mathrm{SL}, 7 \mathrm{~m}$, lagoon at Three Brothers. This is apparently the first record of this species from the Indian Ocean. Indo-Pacific.

\section{Clupeidae}

Spratelloides delicatulus (Bennett) Fig. 60 Clupea delicatulus Bennett, 1831:168 (Mauritius) Spratelloides delicatulus - Whitehead and Wongratana, 1984a:51 (Indo-west Pacific east to Samoa) 


\section{MATERIAL}

Nineteen lots, 1134 specimens, 16-48 mm SL, 0-13 m, lagoon and reef-flat at Diego Garcia, Peros Banhos, and Salomon (photo: $39 \mathrm{~mm}$ ). Identified by Dr P. J. P. Whitehead. Indo-west Pacific.

\section{Engraulididae}

\section{Thryssa setirostris (Broussonet)}

Clupea setirostris Broussonet, 1782:unpaginated (Vanuatu) Thryssa setirostris-Whitehead and Wongratana, 1984b:26 (Indo-west Pacific, including Chagos)

No specimens seen or collected; occurrence is based on the range map given by Whitehead and Wongratana (1984b). Indo-west Pacific.

\section{Synodontidae}

\section{Saurida gracilis (Quoy and Gaimard)}

Fig. 61

Saurus gracilis Quoy and Gaimard, 1824:224 (Hawaii)

Saurida gracilis-Cressey and Waples, 1984:7 (IndoPacific, including Chagos)

\section{MATERIAL}

Twenty-four lots, 59 specimens, $50-180 \mathrm{~mm} \mathrm{SL}, 0-32 \mathrm{~m}$, primarily lagoon (4 lots from drop-off, 1 from reef-top) at Peros Banhos, Salomon, and Three Brothers (photos: 85, 115 , and $149 \mathrm{~mm}$ ). Only five specimens were collected in areas other than the lagoons. Within the lagoons, there were 4.2 specimens/lot in $0-5 \mathrm{~m}, 2.3$ specimens/lot in both $6-15 \mathrm{~m}$ and $16-25 \mathrm{~m}$, and one specimen from deeper water. Indo-Pacific.

\section{Saurida undosquamis (Richardson)}

Saurus undosquamis Richardson, 1844-48:138 (northwest Australia)

Saurida undosquamis-Kyushin et al., 1977 (Chagos Archipelago); Cressey and Waples, 1984:3 (Indo-west Pacific, including Chagos)

No specimens seen or collected; the record is based on the above citations. Indo-west Pacific.

\section{Synodus binotatus Schultz}

PI. IIIA

Synodus binotatus Schultz, 1953a:35 (Marshall Islands); Cressey and Waples, 1984:13 (Indo-Pacific, including Chagos)

\section{MATERIAL}

Six lots, 10 specimens, 29-119 mm SL, 3-15 m, lagoon and reef-top (once) at Peros Banhos and Salomon (photo:
$53 \mathrm{~mm}$ ). Specimens of this genus were identified by $\mathrm{Dr} R$ Cressey. Indo-Pacific.

Synodus englemani Schultz

Pl. IIIB

Synodus englemani Schultz, 1953a:41 (Marshall Islands); Cressey and Waples, 1984:15 (Indo-Pacific, including Chagos)

\section{MATERIAL}

Ten lots, 21 specimens, 35-126 mm SL, 0-40 m, mainly lagoon (1 reef-top, 1 drop-off) at Eagle Island, Peros Banhos, Salomon, and Three Brothers (photos: 35, 50, and $117 \mathrm{~mm})$. Indo-Pacific.

Synodus jaculum Russell and Cressey Pl. IIIC Synodus jaculum Russell and Cressey, 1979:169 (Great Barrier Reef); Cressey and Waples, 1984:21 (Indo-Pacific, including Chagos)

\section{MATERIAL}

Five lots, 6 specimens, 49-75 mm SL, 0-20 m, lagoon only at Eagle Island and Peros Banhos (photos: 49 and $51 \mathrm{~mm})$. Indo-Pacific.

Synodus variegatus (Lacepède)

Fig. 62

Salmo variegatus Lacepède, 1803:157, 224 (Mauritius)

Synodus variegatus-Cressey and Waples, 1984:27 (IndoPacific, including Chagos)

\section{MATERIAL}

Nine lots, 45 specimens, $31-125 \mathrm{~mm}$ SL, 0-10 m, lagoon only at Eagle Island, Peros Banhos, Salomon, and Three Brothers (photos: 48, 65, 96, and $106 \mathrm{~mm}$ ).

The specimen of $S$. variegatus recorded from Chagos by Kyushin et al. (1977:24) appears, from the photograph, to be $S$. englemani. This is a shallow-water species; $66 \%$ of the specimens were taken in $0-5 \mathrm{~m}$ with a mean of 7.5 specimens/lot. Indo-Pacific.

\section{Chanidae}

\section{Chanos chanos (Forsskål)}

Mugil chanos Forsskål, 1775:74 (Jiddah, Red Sea)

Chanos salmoneus - Regan, 1908:219 (Diego Garcia)

Chanos chanos-Whitehead, 1984:1 (Indo-Pacific)

No specimens collected, but we saw a number of them on several occasions. At Eagle Island, a small school of large (ca $1 \mathrm{~m}$ ) Chanos regularly fed by filtering the surface waters of the lagoon at about dusk. Approximately six similarly sized specimens were observed in a 50 -m-diameter pool, separated from the sea by a vegetated sand-bar about $20 \mathrm{~m}$ wide and $2 \mathrm{~m}$ above the high-spring-tide mark, on the southeast end of Petite Sœur. Peros Banhos. 


\section{Gobiesocidae}

Material of this family was identified by Dr J. C. Briggs.

Aspasmodes sp.

MATERIAL

One lot, 1 specimen, $7 \mathrm{~mm} \mathrm{SL}, 0-3 \mathrm{~m}$, spur-and-groove formation at Salomon. Range unassigned.

\section{Lepadichthys bolini Briggs}

Fig. 63

Lepadichthys bolini Briggs, 1962:424 (Vanuatu); Briggs, 1969:464 (Seychelles)

\section{MATERIAL}

Two lots, 4 specimens, 11-16 mm SL, 3-13 m, lagoon at Peros Banhos and Salomon (photo: $15 \mathrm{~mm}$ ). Indo-west Pacific.

\section{Antennariidae}

Antennarius coccineus (Cuvier)

Fig. 64 Chironectes coccineus Cuvier in Lesson, 1830:143 (Mauritius)

Antennarius coccineus-Regan, 1908:250 (Peros Banhos); Schultz, 1957:97 (Indo-Pacific)

\section{MATERIAL}

Fourteen lots, 20 specimens, 7-65 mm SL, 3-25 m, lagoon, reef-top, and drop-off at Peros Banhos, Salomon, and Three Brothers (photos: 10, 18, 20, 21 [ $\times 2$ ] , 22, 32 [ $\times$ 2], 35, 44, and $65 \mathrm{~mm}$ ). The specimens were identified by Dr T. W. Pietsch. Indo-Pacific.

\section{Ophidiidae}

Brotula multibarbata Temminck and Schlegel Fig. 65 Brotula multibarbata Temminck and Schlegel, 1842:251 (Japan); Springer, 1982:66 (Indo-Pacific)

\section{MATERIAL}

Seven lots, 8 specimens, 47-245 mm SL, 0-36 m, reef-top and drop-off at Peros Banhos and Salomon (photos: 39, 86, and $105 \mathrm{~mm}$ ). Indo-Pacific.

\section{Bythitidae}

\section{Brosmophyciops pautzkei Schultz}

Fig. 66 Brosmophyciops pautzkei Schultz, 1960b:386 (Marshall Islands); Cohen and Nielsen, 1978:53 (Indo-Pacific)

\section{MATERIAL}

Fifteen lots, 26 specimens, 7-53 mm SL, 4-43 m, lagoon, reef-top, and drop-off at Eagle Island, Peros Banhos, and Salomon (photos: 32, 34, 39, and $53 \mathrm{~mm}$ ). Indo-Pacific.
Dinematichthys iluocoeteoides Bleeker

MATERIAL

Thirty-three lots, 150 specimens, 5-97 mm SL, 0-43 m, lagoon, intertidal, reef-top, and drop-off at Diego Garcia, Eagle Island, Peros Banhos, Salomon, and Three Brothers (photo: $91 \mathrm{~mm}$ )

Identification of this species is tentative since the genus is badly in need of revision. As a result, a statement of recorded range may well be inaccurate and is not attempted. The species was most abundant in the lagoons, where the 20 collections had a mean of 6.5 specimens/collection. The four reef-top collections had a mean of 2.3 specimens $/ \mathrm{col}$ lection; the other habitats had means of fewer than 2 specimens/lot. Most specimens (91\%) were collected at a depth of $0-15 \mathrm{~m}$, with a mean of 6 specimens/lot. The above analyses are dependent on there being only a single species in our material. Range unassigned.

\section{Carapidae}

Specimens of this family were identified by Dr D. F. Markle.

Carapus homei (Richardson)

Fig. 68

Oxybelas homei Richardson, 1844-48:74 ("Seas of Australia?")

Fierasfer homei-Regan, 1908:220 (Diego Garcia)

Fierasfer neglectus-Regan, 1908:220 (Salomon)

Carapus homei-Arnold, 1956:273 (Indo-Pacific)

\section{MATERIAL}

One lot, 3 specimens, $75-125 \mathrm{~mm}$ TL, $7 \mathrm{~m}$, lagoon at Peros Banhos (photo: $125 \mathrm{~mm}$ ). The three specimens were taken from large (ca $40 \mathrm{~cm}$ body length) sand-dwelling holothurians, which were a dirty white colour, sprinkled with dark specks (= Stichopus variegatus?).

Arnold (1956) synonymized Fierasfer neglectus Peters, and, with less certainty, Oxybelus lumbricoides Bleeker with $C$. homei. Specimens of these two nominal species were recorded from Salomon by Regan (1908). The Gardiner collection contains two lots of carapids from Salomon at present identified as $C$. homei. One lot is correctly identified; the other represents the species below, to which we tentatively assign Regan's (1908) record of Fierasfer lumbricoides. Indo-Pacific.

Encheliophis gracilis (Bleeker)

Fig. 69

Oxybeles gracilis Bleeker, 1856c:105 (Banda)

?Fierasfer lumbricoides-Regan, 1908:220 (Salomon) Encheliophis gracilis-Arnold, 1956:299 (Indo-Pacific east to Tahiti) 
MATERIAL

Three lots, 4 specimens, $73-136 \mathrm{~mm}$ TL, 0-1 m, intertidal at Eagle Island and Peros Banhos (photos: 73 and $136 \mathrm{~mm}$ ). We follow Williams (1984) in regarding Jordanicus as a synonym of Encheliophis. Indo-Pacific.

\section{Exocoetidae}

No flyingfishes were collected during our expedition, and the following occurrences are based on the area shaded on the distribution maps in Parin (1984).

Regan (1908:220) recorded "Exocoetus nigripinnis Valenciennes" from Salomon. The specimen appears to be a juvenile Hirundichthys with two unbranched pectoral-fin rays. The only species listed by Parin (1984) with this condition is $H$. rondeletii (Valenciennes), which has not been recorded north of $35^{\circ} \mathrm{S}$ in the Indian Ocean. Status and range have, therefore, not been assigned.

\section{Cheilopogon cyanopterus (Valenciennes)}

Exocoetus cyanopterus Valenciennes in Cuvier and Valenciennes, 1846b:97 (Bahia)

Cheilopogon cyanopterus-Parin, 1984:7 (circumtropical, including Chagos)

\section{Cheilopogon furcatus (Mitchill)}

Exocoetus furcatus Mitchill, 1815:449 (New York)

Cheilopogon furcatus-Parin, 1984:9 (circumtropical, including Chagos)

\section{Cheilopogon nigricans (Bennett)}

Exocoetus nigricans Bennett, 1840:287 (Atlantic and Pacific oceans)

Cheilopogon nigricans-Parin, 1984:11 (circumtropical, including Chagos)

\section{Cypselurus naresii (Günther)}

Exocoetus naresii Günther, 1889:36 (between Fiji and Vanuatu)

Cypselurus naresii-Parin, 1984:15 (Indo-Pacific, including Chagos)

\section{Cypselurus poecilopterus (Valenciennes)}

Exocoetus poecilopterus Valenciennes in Cuvier and Valenciennes, 1846b:112 (New Britain)

Cypselurus poecilopterus-Parin, 1984:19 (Indo-Pacific, including Chagos)

\section{Exocoetus monocirrhus Richardson}

Exocoetus monocirrhus Richardson, 1846:265 (Sea of China); Parin, 1984:23 (Indo-Pacific, including Chagos)

\section{Exocoetus volitans Linnaeus}

Exocoetus volitans Linnaeus, 1758:316 (Atlantic Ocean);
Parin, 1984:21 (Indo-Pacific, including Chagos)

\section{Hirundichthys speculiger (Valenciennes)}

Exocoetus speculiger Valenciennes in Cuvier and Valenciennes, 1846b:94 (Indian Ocean)

Hirundichthys speculiger-Parin, 1984:27 (circumtropical, including Chagos)

\section{Parexocoetus brachypterus (Richardson)}

Exocoetus brachypterus Richardson, 1846:265 (Tahiti)

Parexocoetus brachypterus-Parin, 1984:33 (Indo-Pacific, including Chagos)

\section{Prognichthys sealei Abe}

Prognichthys sealei Abe, 1955:185 (Miyako Island); Parin, 1984 (Indo-Pacific, including Chagos)

\section{Hemiramphidae}

Hyporhamphus affinis (Günther)

Fig. 70

Hemirhamphus affinis Günther, 1866b:267 (South Seas)

Hyporhamphus affinis-Parin et al., 1980:73 (Indo-Pacific)

\section{MATERIAL}

One lot, 1 specimen, $77 \mathrm{~mm} \mathrm{SL}, 3-5 \mathrm{~m}$, lagoon at Peros Banhos (photo). Identified by Dr B. B. Collette. IndoPacific.

\section{Belonidae}

No material of the first three species listed was obtained; occurrences are based on the literature cited.

\section{Ablennes hians (Valenciennes)}

Belone hians Valenciennes in Cuvier and Valenciennes, 1846a:432 (Cuba)

Ablennes hians-Collette, 1984a:3 (cosmopolitan, including Chagos)

\section{Platybelone argalus platyura (Bennett)}

Belone platyura Bennett, 1831:168 (Mauritius)

Platybelone argalus platyura-Collette, 1984a:5 (IndoPacific, including Chagos)

Tylosurus acus melanotus (Bleeker)

Belone melanotus Bleeker, $1851 \mathrm{a}: 94$ (Java)

Tylosurus acus melanotus-Collette, 1984a:11 (IndoPacific, including Chagos)

Tylosurus crocodilus crocodilus (Peron and Le Sueur)*

Belone crocodilus Peron and Le Sueur in Le Sueur, 1821:129 (Mauritius) 
Tylosurus crocodilus crocodilus-Collette, 1984a:13 (cosmopolitan)

\section{MATERIAL}

Five lots, 6 specimens, $303-700 \mathrm{~mm}$ SL, 0-2 m, lagoon and reef-flat at Eagle Island, Peros Banhos, and Salomon (photos: 303, 404, and $700 \mathrm{~mm}$ ). The identity of the above material was confirmed by Dr B. B. Collette.

\section{Atherinidae}

The atherinids collected were identified by Dr W. Ivantsoff.

\section{Atherinomorus lacunosus (Schneider)}

Fig. 72

Atherina lacunosus Schneider in Bloch and Schneider, 1801:112 (New Caledonia)

Atherinomorus lacunosus - Ivantsoff, 1984:9 (Indo-Pacific)

\section{MATERIAL}

Five lots, 108 specimens, 49-93 mm SL, $0.5-2.5 \mathrm{~m}$, lagoon and reef-flat at Diego Garcia and Peros Banhos, (photo: $85 \mathrm{~mm}$ ). A large school of this species was frequently observed in very shallow water $(20-30 \mathrm{~cm})$ between the jetty and the northwest shore of Isle du Coin, Peros Banhos. Indo-Pacific.

\section{Hypoatherina barnesi Schultz}

Fig. 73

Hypoatherina barnesi Schultz, 1953d:304 (Marshall Islands); Ivantsoff, 1984:13 (Indo-Pacific, including Chagos)

\section{MATERIAL}

Four lots, 66 specimens, 15-45 mm SL, 3-15 m, lagoon and reef-top at Peros Banhos and Salomon. Indo-Pacific.

\section{Berycidae}

No specimens of this family were collected; occurrences are based on the literature cited.

\section{Beryx decadactylus Cuvier}

Beryx decadactylus Cuvier in Cuvier and Valenciennes, 1829a:222 (locality unknown); Shimizu, 1984:3 (Chagos Archipelago); Woods and Sonoda, 1973:282 (cosmopolitan)

\section{Beryx splendens Lowe}

Beryx splendens Lowe, 1833:142 (Madeira); Shimizu, 1984:5 (Chagos Archipelago); Woods and Sonoda, 1973:286 (cosmopolitan)

\section{Holocentridae}

Myripristis adustus Bleeker

Fig. 74

Myripristis adustus Bleeker, 1853a:108 (Ambon); Ran- dall, 1984d:5 (Indo-Pacific, including Chagos)

\section{MATERIAL}

Seven lots, 7 specimens, 39-225 mm SL, 0-43 m, lagoon, reef-top, and reef-flat at Diego Garcia, Peros Banhos, and Salomon (photo: $171 \mathrm{~mm}$ ). Indo-Pacific.

Myripristis berndti Jordan and Evermann Fig. 75 Myripristis berndti Jordan and Evermann, 1903:170 (Hawaii); Randall, 1984d:7 (Indo-Pacific, including Chagos)

\section{MATERIAL}

Fifteen lots, 42 specimens, 41-168 mm SL, 0-43 m, lagoon, intertidal, reef-flat, reef-top, and drop-off at Diego Garcia, Peros Banhos, and Salomon (photos: 78 and $146 \mathrm{~mm})$. This species was most abundant in depths of 6-25 m (74\% of specimens collected). The breakdown by habitat showed $46 \%$ of the total number of specimens were taken in lagoons, $18 \%$ from reef-tops, and $28 \%$ from drop-offs. Indo-Pacific.

\section{Myripristis kuntee Valenciennes}

Fig. 76

Myripristis kuntee Valenciennes in Cuvier and Valenciennes, 1831a:487 (Mauritius); Randall, 1984d:9 (IndoPacific)

\section{MATERIAL}

Four lots, 11 specimens, $81-135 \mathrm{~mm} \mathrm{SL}, 14-25 \mathrm{~m}$, reeftop and drop-off at Eagle Island, Peros Banhos, and Salomon. Indo-Pacific.

\section{Myripristis murdjan (Forsskål)}

Fig. 77

Sciaena murdjan Forsskål, 1775:48 (Jiddah, Red Sea) Myripristis murdjan Randall, 1984d:13 (Indo-Pacific, including Chagos)

\section{MATERIAL}

Twenty-three lots, 213 specimens, 38-178 mm SL, 0$43 \mathrm{~m}$, intertidal, lagoon, reef-top, and drop-off at Diego Garcia, Peros Banhos, and Salomon (photos: 98 and $158 \mathrm{~mm}$ ). This species was collected primarily on the drop-offs $(78 \%, \overline{\mathrm{x}} /$ lot $=24$ specimens $)$ in depths of $16-35 \mathrm{~m}$ ( $70 \%$ of total specimens, $\overline{\mathrm{x}} / \mathrm{lot}=49$ specimens). Indo-Pacific.

\section{Myripristis pralinius Cuvier}

Fig. 78

Myripristis pralinius Cuvier in Cuvier and Valenciennes, 1829a:170 (New Ireland); Greenfield, 1974:22 (Indo-Pacific)

\section{MATERIAL}

Fourteen lots, 90 specimens, 51-149 mm SL, 3-43 m, lagoon, reef-top (1), and drop-off at Peros Banhos and Salomon (photo: $51 \mathrm{~mm}$ ). This species was virtually confined to the lagoons and drop-offs ( 1 specimen from reef- 
top), but with little apparent depth zonation $(\overline{\mathrm{x}} /$ collection $=8.0$ in $0-5 \mathrm{~m}, 3.7$ in $6-15 \mathrm{~m}, 8.5$ in $16-25 \mathrm{~m}$, and 4.0 in deeper depths). Indo-Pacific.

\section{Myripristis violaceus Bleeker}

Fig. 79 Myripristis violaceus Bleeker, 1851 b:234 (Banda); Randall, 1984d:15 (Indo-Pacific)

\section{MATERIAL}

Seventeen lots, 79 specimens, 31-145 mm SL, 0-25 m, lagoon, reef-top, and drop-off at Diego Garcia, Peros Banhos, and Salomon (photos: 98 and $130 \mathrm{~mm}$ ). In collections in which it was taken, this species was fairly evenly distributed with respect to both habitat and depth $(\bar{x} /$ collection $=4.8$ in lagoons, 7.5 on reef-tops, 3.2 on drop-offs, 5.2 in $0-5 \mathrm{~m}, 5.3$ in $6-15 \mathrm{~m}$, and 3.2 in $16-25 \mathrm{~m}$ ). No specimens were collected deeper than $25 \mathrm{~m}$. Indo-Pacific.

\section{Myripristis vittatus Valenciennes}

PI. IIID Myripristis vittatus Valenciennes in Cuvier and Valenciennes, 1831a:492 (Mauritius); Greenfield, 1974:18 (Indo-Pacific)

\section{MATERIAL}

Twelve lots, 218 specimens, 55-146 mm SL, 15-48 m, drop-off only at Peros Banhos and Salomon (photos: 91 and $105 \mathrm{~mm}$ ). The greatest numbers of this species were collected in caves on the drop-offs; it was somewhat more abundant at deeper depths $(\overline{\mathrm{x}} / \mathrm{lot}=15.7$ at $16-25 \mathrm{~m}, 20.7$ at greater depths). Indo-Pacific.

\section{Neoniphon argenteus (Valenciennes)}

Fig. 80

Holocentrum argenteum Valenciennes in Cuvier and Valenciennes, 1831a:502 (New Guinea)

Neoniphon argenteus-Randall and Heemstra, 1985:3 (Indo-Pacific, including Chagos, east to Society Islands)

\section{MATERIAL}

Three lots, 12 specimens, 29-125 mm SL, 0-10 m, lagoon at Diego Garcia and Salomon. Indo-Pacific.

\section{Neoniphon opercularis (Valenciennes)}

Fig. 81

Holocentrum opercularis Valenciennes in Cuvier and Valenciennes, 1831a:501 (New Ireland)

Neoniphon opercularis-Randall, 1984d:17 (Indo-Pacific, including Chagos)

\section{MATERIAL}

Seven lots, 7 specimens, 89-231 mm SL, 0-43 m, lagoon and drop-off at Diego Garcia, Peros Banhos, and Salomon (photos: 161 and $212 \mathrm{~mm}$ ). Indo-Pacific.
Neoniphon sammara-Randall, 1984d:19 (Indo-Pacific, including Chagos)

\section{MATERIAL}

Ten lots, 29 specimens, 30-164 mm SL, 0-48 m, lagoon and drop-off at Diego Garcia, Peros Banhos, and Salomon (photos: 49, 70, 75, $92[\times 2], 144$, and $164 \mathrm{~mm}$ ). This species was taken primarily in shallow lagoonal habitats ( $93 \%$ of specimens from lagoons, $90 \%$ in $0-5 \mathrm{~m}$ ). IndoPacific.

\section{Plectrypops lima (Valenciennes)}

Fig. 83

Myripristis lima Valenciennes in Cuvier and Valenciennes, 1831a:493 (Mauritius)

Holotrachys lima-Gosline and Brock, 1965:144 (Hawaii); Randall, 1973:181 (Tahiti)

\section{MATERIAL}

Three lots, 3 specimens, 98-113 mm SL, 15-43 m, dropoff only at Peros Banhos and Salomon (photo: $113 \mathrm{~mm}$ ). Indo-Pacific.

Sargocentron caudimaculatum (Rüppell)

Fig. 84

Holocentrus caudimaculatum Rüppell, 1838:97 (Red Sea) Sargocentron caudimaculatum -Randall, 1984d:23 (IndoPacific, including Chagos)

\section{MATERIAL}

Nineteen lots, 50 specimens, 43-151 mm SL, 3-25 m, lagoon, reef-top, and drop-off at Diego Garcia, Eagle Island, Peros Banhos, and Salomon (photo: $130 \mathrm{~mm}$ ). This species was most abundant on the reef-tops and drop-offs ( $83 \%$ of specimens collected), in 6-25 m (92\% of specimens collected). Indo-Pacific.

Sargocentron diadema (Lacepède) Fig. 85 Holocentrus diadema Lacepède, 1802b:335 (South Seas) Adioryx diadema - Kyushin et al., 1977:54 (Chagos Archipelago)

Sargocentron diadema-Randall and Heemstra, 1985:8 (Indo-Pacific east to Society Islands)

\section{MATERIAL}

Nineteen lots, 110 specimens, 39-123 mm SL, 0-32 m, lagoon (except 2 reef-top, 2 reef-flat, 1 drop-off) at Diego Garcia, Eagle Island, Peros Banhos, and Salomon (photos: 50 and $54 \mathrm{~mm}$ ). This is primarily a shallow-water species $(80 \%$ of specimens collected in $0-5 \mathrm{~m}$ ) and was more concentrated on the reef-flats $(23.5$ specimens/lot $)$ than in the lagoons (4.2 specimens/lot). Indo-Pacific.

\section{Sargocentron inaequalis Randall}

and Heemstra PI. IIIE

Sargocentron inaequalis Randall and Heemstra, 1985:8 
(Chagos Archipelago; also Seychelles and Comoro Islands)

MATERIAL

One lot, 1 specimen (holotype), $72 \mathrm{~mm} \mathrm{SL}, 6-10 \mathrm{~m}$, reeftop at Salomon (photo). Western Indian Ocean.

Sargocentron macrosquamis Golani

Fig. 86

Sargocentron macrosquamis Golani, 1984:40 (Amirante Islands; also Red Sea); Randall and Heemstra, 1985:11 (western Indian Ocean, including Chagos)

MATERIAL

One lot, 1 specimen, $65 \mathrm{~mm} \mathrm{SL,} \mathrm{7-10} \mathrm{m,} \mathrm{reef-top} \mathrm{at}$ Salomon. Western Indian Ocean.

\section{Sargocentron microstoma (Günther)}

Fig. 87

Holocentrum microstoma Günther, 1859:34 (Ambon)

Adioryx microstoma-Randall and Heemstra, 1985:13

(Indo-Pacific, including Chagos)

MATERIAL

Four lots, 4 specimens, 92-147 mm SL, 3-17 m, lagoon and reef-top at Eagle Island and Peros Banhos (photos: 109 and $147 \mathrm{~mm}$ ). Indo-Pacific.

\section{Sargocentron punctatissimum (Cuvier) Fig. 88}

Holocentrum punctatissimum Cuvier in Cuvier and Valenciennes, 1829a:215 (Caroline Islands)

Sargocentron punctatissimum-Randall and Heemstra, 1985:15 (Indo-Pacific east to Easter Island)

\section{MATERIAL}

Ten lots, 78 specimens, 45-103 mm SL, 0-20 m, lagoon, reef-flat, and reef-top at Eagle Island, Peros Banhos, and Salomon (photo: $93 \mathrm{~mm}$ ). Only a single collection was made in the spur-and-groove formation, and this would seem to be the preferred habitat of this species $(55$ specimens, $71 \%$ of total, the next largest collection containing 6 specimens). Indo-Pacific.

Sargocentron seychellense (Smith and Smith) Fig. 89 Holocentrus seychellensis Smith and Smith, 1963:9 (Seychelles)

Sargocentron seychellense-Randall and Heemstra, 1985:18 (western Indian Ocean, including Chagos)

\section{MATERIAL}

One lot, 1 specimen, $166 \mathrm{~mm} \mathrm{SL,} \mathrm{1-3} \mathrm{m,} \mathrm{reef-top} \mathrm{at} \mathrm{Diego}$ Garcia. Western Indian Ocean.

\section{MATERIAL}

Twelve lots, 16 specimens, 41-319 mm SL, 0-25 m, lagoon and reef-top at Diego Garcia, Eagle Island, Peros Banhos, and Salomon (photos: 135 and $295 \mathrm{~mm}$ ). IndoPacific.

Sargocentron tiere (Cuvier)

Fig. 91

Holocentrum tiere Cuvier in Cuvier and Valenciennes, 1829a:202 (Tahiti)

Sargocentron tiere - Randall and Heemstra, 1985:20 (IndoPacific, including Chagos, east to Pitcairn Island)

\section{MATERIAL}

Three lots, 3 specimens, 200-222 mm SL, 7-25 m, reeftop and drop-off at Peros Banhos (photo: $222 \mathrm{~mm}$ ). IndoPacific.

Sargocentron tiereoides (Bleeker)

Pl. IIIF

Holocentrum tiereoides Bleeker, 1853e:334 (Ambon)

Sargocentron tiereoides-Randall and Heemstra, 1985:20

(Indo-Pacific, including Chagos, east to Tahiti)

MATERIAL

Six lots, 8 specimens, 29-129 mm SL, 0-25 m, lagoon and drop-off at Peros Banhos and Salomon (photos: 38 and $111 \mathrm{~mm})$. Indo-Pacific.

\section{Sargocentron violaceum (Bleeker)}

Fig. 92

Holocentrum violaceum Bleeker, 1853e:335 (Ambon)

Sargocentron violaceum - Randall and Heemstra, 1985:21

(Indo-Pacific, including Chagos, east to Tahiti)

\section{MATERIAL}

Three lots, 4 specimens, $82-147 \mathrm{~mm} \mathrm{SL}, 0-15 \mathrm{~m}$, lagoon at Salomon (photo: $132 \mathrm{~mm}$ ). Indo-Pacific.

\section{Aulostomidae}

Aulostomus chinensis (Linnaeus)

Fig. 93

Fistularia chinensis Linnaeus, 1766:515 (India)

Aulostomus chinensis-Fritzsche, 1984a:3 (Indo-Pacific, including Chagos)

MATERIAL

Two lots, 2 specimens, 158-179 mm SL, 18-43 m, dropoff at Salomon (photo: $158 \mathrm{~mm}$ ). Indo-Pacific.

\section{Fistulariidae}

Fistularia commersonii Rüppell

Fig. 94

Fistularia commersonii Rüppell, 1838:142 (Red Sea); Fritzsche, 1984b:5 (Indo-Pacific, including Chagos) 
MATERIAL

Four lots, 4 specimens, 137-254 mm SL, 0-1 m, lagoon at Peros Banhos and Salomon (photo: $137 \mathrm{~mm}$ ). Indo-Pacific.

\section{Fistularia petimba Lacepède}

Fistularia petimba Lacepède, 1803:349 (New Britain; Réunion; equatorial Pacific); Fritzsche, 1984b:3 (IndoPacific, including Chagos)

No specimens seen or collected; occurrence based on Fritzsche (1984b). Indo-Pacific.

\section{Syngnathidae}

The pipefishes were identified by Dr C. E. Dawson.

\section{Choeroichthys brachysoma (Bleeker)}

Fig. 95

Syngnathus brachysoma Bleeker, 1855a:327 (Batui)

Choeroichthys brachysoma-Dawson, 1985:32 (IndoPacific, east to Society Islands)

\section{MATERIAL}

Four lots, 4 specimens, $22-39 \mathrm{~mm} \mathrm{SL}, 0-7 \mathrm{~m}$, lagoon and reef-top at Peros Banhos (photos: 22, 37, and $39 \mathrm{~mm}$ ). Indo-Pacific.

\section{Choeroichthys sculptus (Günther)}

Fig. 96

Doryichthys sculptus Günther, 1870:185 (Fiji)

Choeroichthys sculptus-Dawson, 1985:34 (Indo-Pacific, including Chagos, east to Tuamotu Islands)

\section{MATERIAL}

Three lots, 9 specimens, $33-56 \mathrm{~mm} \mathrm{SL}, 0-1 \mathrm{~m}$, reef-flat at Diego Garcia and Salomon. Indo-Pacific.

\section{Corythoichthys flavofasciatus (Rüppell)}

Fig. 97

Syngnathus flavofasciatus Rüppell, 1838: 144 (Jiddah, Red Sea)

Corythoichthys flavofasciatus-Dawson, 1985:396 (IndoPacific, including Chagos, east to Tuamotu Islands)

\section{MATERIAL}

Eleven lots, 45 specimens, 50-121 mm SL, 0-13 m, lagoon at Eagle Island, Peros Banhos, and Salomon (photos: 57,108 , and $115 \mathrm{~mm}$ ). This shallow-water species was often observed on corals. The mean number of specimens/ lot was 5.2 in $0-5 \mathrm{~m}$ and 3.3 in $5-15 \mathrm{~m}$. Indo-Pacific.

\section{Corythoichthys schultzi Herald}

Fig. 98

Corythoichthys schultzi Herald, 1953:271 (Marshall Islands); Dawson, 1985:46 (Indo-Pacific east to Marshall Islands)

\section{MATERIAL}

Two lots, 2 specimens, $80-128 \mathrm{~mm} \mathrm{SL}, 3-20 \mathrm{~m}$, lagoon at Peros Banhos (photo: $128 \mathrm{~mm}$ ). Indo-west Pacific and marginally on the Pacific plate.

Cosmocampus banneri (Herald and Randall) Fig. 99 Syngnathus banneri Herald and Randall, 1972:135 (Ryukyus; also Marshall Islands)

Cosmocampus banneri-Dawson, 1985:51 (Indo-Pacific, including Chagos, east to Marshall Islands)

\section{MATERIAL}

Four lots, 4 specimens, $30-39 \mathrm{~mm} \mathrm{SL}, 10-25 \mathrm{~m}$, lagoon, reef-top, and drop-off at Eagle Island and Peros Banhos. Indo-west Pacific and marginally on the Pacific plate.

Doryrhamphus excisus excisus Kaup

Fig. 100

Doryrhamphus excisus Kaup, 1856b:54 (no locality)

Doryrhamphus excisus excisus-Dawson, 1985:61 (IndoPacific, including Chagos, east to Galápagos Islands)

\section{MATERIAL}

One lot, 2 specimens, $44-49 \mathrm{~mm}$ SL, lagoon at Diego Garcia. Indo-Pacific.

Doryrhamphus multiannulatus (Regan) Pl. IIIG Doryichthys multiannulatus Regan, 1903:413 (Mauritius) Doryrhamphus multiannulatus-Dawson, 1985:67 (western Indian Ocean, including Chagos)

MATERIAL

Four lots, 4 specimens, 119-126 mm SL, 10-25 m, lagoon and drop-off at Peros Banhos and Salomon (photo: $119 \mathrm{~mm})$. Western Indian Ocean.

Halicampus mataafae (Jordan and Seale) Fig. 101 Corythoichthys mataafae Jordan and Seale, 1906:213 (Samoa)

Halicampus mataafae-Dawson, 1985:89 (Indo-Pacific, including Chagos, east to Marshall Islands)

\section{MATERIAL}

One lot, 1 specimen, $47 \mathrm{~mm} \mathrm{SL}, 0-3 \mathrm{~m}$, reef-flat at Salomon. Indo-west Pacific and marginally on the Pacific plate.

\section{Scorpaenidae}

Dr W. N. Eschmeyer identified most of the scorpaenids and provided the geographic ranges. In addition to the following list of species, there are 13 lots, 34 specimens of small (14-26 mm SL) scorpaenids that we were unable to identify. 
Parascorpaena aurita (Rüppell)

Fig. 102

Scorpaena aurita Rüppell, 1838:106 (Red Sea)

Material

One lot, 1 specimen, $80 \mathrm{~mm} \mathrm{SL}, 3-5 \mathrm{~m}$, lagoon at Peros Banhos. The specimen collected agrees generally with the description of this species, but has 16, rather than the more usual 17-18, pectoral-fin rays. Indo-west Pacific.

\section{Pontinus sp.}

Pontinus macrocephalus-Kyushin et al., 1977:328 (Chagos Archipelago) (non Sauvage, 1882)

No specimens collected. The record of Kyushin et al. (1977) is based on a single specimen, $228 \mathrm{~mm} \mathrm{SL}$, taken by vertical longline in $80-160 \mathrm{~m}$. Eschmeyer (1983) recognized three valid described forms of Pontinus from the Indo-Pacific, as well as several undescribed species. We were unable to place the specimen figured and described by Kyushin et al. (1977), but it is most unlikely to be $P$. macrocephalus which is apparently confined to the Hawaiian Islands (Eschmeyer, 1983). Range unassigned.

Pterois antennata (Bloch)

Fig. 103

Scorpaena antennata Bloch, 1787:21 (Ambon)

Pterois antennata-Randall, 1973:184 (Tahiti)

\section{MATERIAL}

Eight lots, 10 specimens, $28-107 \mathrm{~mm} \mathrm{SL}, 3-25 \mathrm{~m}$, lagoon, reef-top, and drop-off at Peros Banhos and Salomon (photos: 66 and $105 \mathrm{~mm}$ ). Indo-Pacific.

\section{Pterois miles (Bennett)}

Scorpaena miles Bennett, 1828:30 (Sri Lanka)

Fig. 104

\section{MATERIAL}

Two lots, 2 specimens, $147-173 \mathrm{~mm}$ SL, 0-4 m, lagoon at Salomon (photo: $147 \mathrm{~mm}$ ). This species is generally referred to as $P$. volitans. However, Schultz (pers. comm.) separates the Indian Ocean form from that of the westcentral Pacific, based on the shape of the spots in the median fins and on certain meristic differences. It is confined to the Indian Ocean, but reaches eastwards to the west coast of Sumatra. Indian Ocean and western extremity of west Pacific

\section{Scorpaenodes albaiensis (Evermann}

and Seale)

Fig. 105

Hypomacrus albaiensis Evermann and Seale, 1907:102 (Philippines)

\section{MATERIAL}

Seventeen lots, 35 specimens, 19-73 mm SL, 5-43 m, primarily drop-off ( 3 lots, 4 specimens from lagoon) at
Peros Banhos and Salomon (photos: 64, 66, and $73 \mathrm{~mm}$ ). The majority of our specimens $(86 \%)$ were collected on the drop-offs, with $84 \%$ of the total being collected in water $16 \mathrm{~m}$ or more in depth. Indo-west Pacific.

\section{Scorpaenodes guamensis (Quoy}

and Gaimard)

Fig. 106

Scorpaena guamensis Quoy and Gaimard, 1824:326 (Guam)

Scorpaenodes guamensis-Randall, 1973:184 (Tahiti)

\section{MATERIAL}

Five lots, 15 specimens, 7-37 mm SL, 5-25 m, reef-top and drop-off at Peros Banhos and Salomon (photo: $26 \mathrm{~mm}$ ).

This species differs from $S$. scaber in having a slimmer body and shorter dorsal spines (length of fourth spine equals snout length or less vs to mid-pupil, and fourth spine extends from coronal spine above mid-pupil to lower one-third of orbit vs to suborbital ridge); in having no spine on the posteroventral margin of the first suborbital vs such a spine being present at sizes $>30 \mathrm{~mm} \mathrm{SL}$, or an acute margin being present at lesser lengths; and in having a more blotchy colour pattern vs being speckled (especially on the caudal fin). Scorpaenodes guamensis was collected only in depths greater than $5 \mathrm{~m}$ on the outer reefs, whereas $S$. scaber was taken only in less than $5 \mathrm{~m}$, usually (92\%) in the lagoons. Indo-Pacific.

Scorpaenodes hirsutus (Smith)

Fig. 107

Parascorpaena hirsutus Smith, 1957a:63 (Islo do Bazaruto) Scorpaenodes hirsutus - Eschmeyer and Randall, 1975:277 (Indo-Pacific, including Chagos)

\section{MATERIAL}

Five lots, 8 specimens, $18-25 \mathrm{~mm} \mathrm{SL}, 0-25 \mathrm{~m}$, lagoon, reef-top, and drop-off at Peros Banhos and Salomon. Indo-Pacific.

\section{Scorpaenodes kelloggi (Jenkins)}

Fig. 108

Sebastopsis kelloggi Jenkins, 1904:492 (Hawaii)

Scorpaenodes kelloggi-Eschmeyer and Randall, 1975:279 (Indo-Pacific)

\section{MATERIAL}

Eight lots, 31 specimens, $8-26 \mathrm{~mm} \mathrm{SL}$, lagoon, intertidal, reef-top, and drop-off at Eagle Island, Peros Banhos, and Salomon. Most of our specimens ( $72 \%$ ) were collected on reef-tops in depths of 5-10 m. Indo-Pacific.

Scorpaenodes parvipinnis (Garrett)

Fig. 109 Scorpaena parvipinnis Garrett, 1863:105 (Hawaii)

Scorpaenodes parvipinnis-Eschmeyer and Randall, 1975:280 (Indo-Pacific) 
MATERIAL

One lot, 1 specimen, $78 \mathrm{~mm} \mathrm{SL}, 10-15 \mathrm{~m}$, reef-top at Peros Banhos (photo). Indo-Pacific.

Scorpaenodes scaber (Ramsey and Ogilby) Fig. 110 Sebastes scaber Ramsey and Ogilby, 1885:577 (Shark Reef, Australia)

\section{MATERIAL}

Nine lots, 62 specimens, 14-67 mm SL, 0-5 m, lagoon, intertidal, and reef-top at Diego Garcia, Eagle Island, Peros Banhos, and Salomon (photos: 25, 57, and $67 \mathrm{~mm}$ ). The geographic range of this species is not clear from the literature since it is frequently confused with $S$. guamensis. Range unassigned.

\section{Scorpaenopsis diabolus (Cuvier)}

Fig. 111

Scorpaena diabolus Cuvier in Cuvier and Valenciennes, 1829b:312 (New Guinea)

Scorpaenopsis diabolus - Eschmeyer and Randall, 1975:305 (Indo-Pacific)

\section{MATERIAL}

Five lots, 6 specimens, 45-150 mm SL, 0-15 m, lagoon, intertidal, and reef-top at Eagle Island and Peros Banhos (photos: 45, 59, and $150 \mathrm{~mm}$ ). Indo-Pacific.

\section{Scorpaenopsis fowleri (Pietschmann)}

Scorpaenodes fowleri Pietschmann, 1934:99 (Hawaii)

Scorpaenopsis fowleri-Eschmeyer and Randall, 1975:297 (central Pacific)

\section{MATERIAL}

One lot, 1 specimen, $17 \mathrm{~mm}$ SL, 33-43 m, drop-off at Salomon. This species has now been found in the western Indian Ocean and eastwards to Pitcairn Island (Eschmeyer, pers. comm.). Indo-Pacific.

\section{Scorpaenopsis gibbosa (Schneider)}

Fig. 112

Scorpaena gibbosa Schneider in Bloch and Schneider, 1801:192 (America)

Scorpaenopsis gibbosa-Eschmeyer and Randall, 1975:305 (Indian Ocean)

\section{MATERIAL}

One lot, 1 specimen, $67 \mathrm{~mm}$ SL, $0.5-1 \mathrm{~m}$, reef-flat at Diego Garcia. Western Indian Ocean.

Scorpaenopsis oxycephala (Bleeker)

Fig. 113

Scorpaena oxycephalus Bleeker, 1849:7 (Java)

\section{MATERIAL}

Two lots, 2 specimens, 27-38 mm SL, 8-25 m, drop-off at Salomon (photo: $38 \mathrm{~mm}$ ). Indo-west Pacific and marginally on the Pacific plate.

Scorpaenopsis sp. 1

PI. IIIH MATERIAL

Eight lots, 9 specimens, 33-123 mm SL, 3-43 m, lagoon, reef-top, and drop-off at Peros Banhos and Salomon (photos: 44, 66, 88, 93, and $123 \mathrm{~mm}$ ). The material represents an undescribed species that will be described by Eschmeyer and Rama-Rao. Range unassigned.

Scorpaenopsis sp. 2

Pl. IVA MATERIAL

Two lots, 2 specimens, 250-270 mm SL, 10-24 m, dropoff at Peros Banhos and Salomon (photo: $270 \mathrm{~mm}$ ). The material represents an undescribed species that will be described by Eschmeyer and Rama-Rao. Range unassigned.

\section{Sebastapistes cyanostigma (Bleeker)}

Fig. 114

Scorpaena cyanostigma Bleeker, 1856g:385 (Indonesia)

Sebastes strongensis-Regan, 1908:235 (Salomon and Egmont, Chagos Archipelago) (non Cuvier in Cuvier and Valenciennes, 1829b)

Sebastapistes albobrunnea-Schultz, 1966a:27 (Marshall Islands)

\section{MATERIAL}

Twelve lots, 45 specimens, 17-59 mm SL, 0-24 m, lagoon, reef-flat, reef-top, and drop-off at Eagle Island, Peros Banhos, and Salomon (photos: 21 and $50 \mathrm{~mm}$ ). Indo-west Pacific and marginally on the Pacific plate. This species is usually referred to as $S$. albobrunnea (Günther, 1873).

Sebastapistes strongia (Cuvier)

Fig. 115

Scorpaena strongia Cuvier in Cuvier and Valenciennes, 1829b:323 (Caroline Islands)

Sebastapistes strongia-Poss and Rama-Rao, 1984:13 (western Indian Ocean)

\section{MATERIAL}

One lot, 1 specimen, $28 \mathrm{~mm}$ SL, 1-2 m, lagoon at Diego Garcia. Indo-west Pacific and marginally on the Pacific plate.

Synanceia verrucosa Bloch and Schneider Fig. 116 Synanceia verrucosa Bloch and Schneider, 1801:195 (India); Eschmeyer and Rama-Rao, 1973:357 (Indo-Pacific)

\section{MATERIAL}

One lot, 1 specimen, $132 \mathrm{~mm} \mathrm{SL}, 0.5 \mathrm{~m}$, lagoon at Salomon (photo). Indo-Pacific.

Taenianotus triacanthus Lacepède Fig. 117 Taenianotus triacanthus Lacepède, 1802b:303 (no type 
locality); Regan, 1908:236 (Salomon); Randall, 1973:185 (Tahiti)

\section{MATERIAL}

Two lots, 2 specimens, 57-62 mm SL, 3-24 m, lagoon and drop-off at Peros Banhos and Salomon (photos: both). Indo-Pacific.

\section{Caracanthidae}

Caracanthus madagascariensis (Guichenot) Fig. 118 Crossoderma madagascariensis Guichenot, 1869:195 (Madagascar)

Caracanthus maculatus-Regan, 1908:237 (Chagos Archipelago)

\section{MATERIAL}

Eleven lots, 32 specimens, $16-38 \mathrm{~mm} \mathrm{SL}, 0-24 \mathrm{~m}$, lagoon, reef-flat, reef-top, and drop-off at Eagle Island, Peros Banhos, and Salomon (photos: 27 and $38 \mathrm{~mm}$ ). The species is confined to the western and central Indian Ocean (Eschmeyer, pers. comm.).

\section{Caracanthus unipinna (Gray)}

Micropus unipinnus Gray, 1831:20 (Pacific Seas)

Fig. 119

Caracanthus unipinna-Regan, 1908:237 (Chagos Archipelago)

\section{MATERIAL}

Sixteen lots, 46 specimens, 13-32 mm SL, 0-25 m, lagoon, reef-flat, reef-top, and drop-off at Eagle Island, Peros Banhos, and Salomon (photo: $28 \mathrm{~mm}$ ). The majority of our specimens (9 lots, 38 specimens) were collected on the reef-top $(\overline{\mathrm{x}} /$ collection $=4.2)$; the other habitats had a mean of less than 1.3 specimens/collection in which this species was taken. Indo-Pacific.

\section{Platycephalidae}

The flatheads were identified by Dr L. W. Knapp, who also provided the geographic ranges.

\section{Rogadius serratus (Cuvier)}

Fig. 120

Platycephalus serratus Cuvier in Cuvier and Valenciennes, 1829b:259 (Sri Lanka)

\section{MATERIAL}

One lot, 1 specimen, $76 \mathrm{~mm}$ SL, $7 \mathrm{~m}$, lagoon at Peros Banhos (photo). Indo-west Pacific (Pakistan to northern Queensland).

Thysanophrys arenicola Schultz

Fig. 121

Thysanophrys arenicola Schultz, 1966b:60 (Marshall Islands)

\section{MATERIAL}

One lot, 1 specimen, $53 \mathrm{~mm} \mathrm{SL}, 4-7 \mathrm{~m}$, reef-top at Salomon. Indo-west Pacific and marginally on the Pacific plate.

\section{Thysanophrys otaitensis (Cuvier)}

Fig. 122

Platycephalus otaitensis Cuvier, 1829:242 (Tahiti)

Thysanophrys otaitensis-Knapp, 1984:4 (western Indian Ocean)

\section{MATERIAL}

Twelve lots, 30 specimens, 29-244 mm SL, 0-10 m, lagoon and reef-top (1) at Eagle Island, Peros Banhos, and Salomon (photos: 122 and $144 \mathrm{~mm}$ ). Indo-Pacific.

\section{Dactylopteridae}

\section{Dactyloptena orientalis (Cuvier)}

Dactylopterus orientalis Cuvier in Cuvier and Valenciennes, 1829b:134 (Mauritius; also Waigeo, Vizagapatam) Dactyloptena orientalis-Gosline and Brock, 1965:290 (Hawaii); Poss, 1984:5 (Indo-west Pacific, including Chagos, east to Japan)

No specimens seen or collected; occurrence is based on the range map given by Poss (1984). Indo-Pacific.

\section{Serranidae}

We here follow Johnson (1983) in including the Grammistidae and Pseudogrammidae in this family, but we retain (for the present) the Anthiidae, Pseudochromidae (which includes the Pseudoplesiopidae), and Plesiopidae as distinct families.

\section{Aethaloperca rogaa (Forsskål)}

Fig. 123

Perca rogaa Forsskål, 1775:38 (Jiddah, Red Sea)

Aethaloperca rogaa-Heemstra and Randall, 1984:9 (Indowest Pacific, including Chagos)

\section{MATERIAL}

Four lots, 5 specimens, $215-338 \mathrm{~mm} \mathrm{SL}, 3-15 \mathrm{~m}$, lagoon only at Peros Banhos (photo: $291 \mathrm{~mm}$ ). This species was seen only on rare occasions and was never sighted or collected outside the lagoons. Indo-west Pacific.

Anyperodon leucogrammicus (Valenciennes) Fig. 124 Serranus leucogrammicus Valenciennes in Cuvier and Valenciennes, 1828:347 (Moluccas and Seychelles) Anyperodon leucogrammicus-Heemstra and Randall, 1984:11 (Indo-west Pacific, including Chagos)

\section{MATERIAL}

One lot, 1 specimen, $205 \mathrm{~mm} \mathrm{SL}, 3-7 \mathrm{~m}$, lagoon at Peros 
Banhos (photo). The species appears to be rare at Chagos, as the above specimen was the only one seen during the entire expedition. However, Kyushin et al. (1977) report obtaining two specimens from Chagos by vertical longline in a depth of $28 \mathrm{~m}$. Indo-west Pacific.

\section{Aporops allfreei Smith}

Pl. IVB

Aporops allfreei Smith, 1953:553 (Kisiti Island and Pemba Island)

\section{MATERIAL}

Four lots, 10 specimens, $16-59 \mathrm{~mm} \mathrm{SL}, 0-7 \mathrm{~m}$, primarily reef-top $(\mathrm{n}=9)$ and lagoon, Peros Banhos and Salomon (photos: 15, 19, 48, and $59 \mathrm{~mm}$ ). This species appears to be confined to the western and central Indian Ocean: it is replaced by A bilinearis from Taiwan (Shen, 1984) to the Great Barrier Reef (Russell, 1983) and on the western portion of the Pacific plate (Schultz, 1943), and by $A$. japonicus in Japan (Schultz, 1966c). Western Indian Ocean.

\section{Belonoperca chabanaudi Fowler and Bean Fig. 125} Belonoperca chabanaudi Fowler and Bean, 1930:182 (Sulawesi; Borneo); Randall, Smith, and Aida, 1980:2 (Indo-Pacific, east to Samoa and Marshall Islands)

\section{MATERIAL}

One lot, 1 specimen, $67 \mathrm{~mm} \mathrm{SL}, 20-25 \mathrm{~m}$, drop-off at Salomon (photo). This species was sighted on three occasions, usually at the interface of the reef-top and drop-off. The specimen collected was taken about $3 \mathrm{~m}$ below the lip of the drop-off. Indo-west Pacific and marginally on the Pacific plate.

\section{Cephalopholis analis (Valenciennes)}

Fig. 126

Serranus analis Valenciennes in Cuvier and Valenciennes, 1828:307 (New Ireland)

Cephalopholis analis-Heemstra and Randall, 1984:17 (Indo-Pacific, including Chagos, east to Pitcairn Island)

\section{MATERIAL}

Fifteen lots, 42 specimens, 31-145 mm SL, 18-48 m, drop-off only at Peros Banhos and Salomon (photo: $128 \mathrm{~mm}$ ). Randall (1985), in an addendum, states that the name for French Polynesian specimens reported as $C$. analis should be $C$. spiloparaea (Valenciennes in Cuvier and Valenciennes, 1828:338). Since $C$. analis has page priority over $C$. spiloparaea, it seems better to await the publication of Randall's results in more detail, and the name $C$. analis is tentatively used here. Indo-Pacific. 1801:311 (East Indies); Heemstra and Randall, 1984:19
(Indo-Pacific, including Chagos, east to Pitcairn Island)

\section{MATERIAL}

Twenty-two lots, 57 specimens, $41-282 \mathrm{~mm} \mathrm{SL}, 0-43 \mathrm{~m}$, lagoon, intertidal, reef-flat, reef-top, and drop-off at Diego Garcia, Eagle Island, Peros Banhos, and Salomon (photo: $239 \mathrm{~mm}$ ).

An earlier name for this species, C. guttata (Bloch), is currently under review by the International Commission for Zoological Nomenclature, and we follow Randall and Ben-Tuvia (1983) in using $C$. argus. The majority of the specimens $(61 \% ; \overline{\mathrm{x}}=8.8$ specimens/lot) were collected in the intertidal region, with $77 \%$ of the total from less than $5 \mathrm{~m}$, and $89 \%$ from less than $15 \mathrm{~m}$. Indo-Pacific.

Cephalopholis leopardus (Lacepède)

Fig. 128

Labrus leopardus Lacepède, 1802a:450 (Indo-Pacific)

Cephalopholis leopardus-Heemstra and Randall, 1984:29 (Indo-Pacific, including Chagos, east to French Polynesia)

\section{MATERIAL}

Twenty-five lots, 159 specimens, 31-107 mm SL, 3-43 m, lagoon, reef-top, and drop-off at Peros Banhos and Salomon (photo: $61 \mathrm{~mm}$ ). This species is primarily an inhabitant of the drop-offs $(68 \%$ of specimens, $\bar{x} /$ lot $=10.8)$, with $85 \%$ of the total number of specimens being collected in depths of 6-25 m. Indo-Pacific.

\section{Cephalopholis miniata (Forsskål)}

Fig. 129

Perca miniata Forsskål, 1775:41 (Jiddah, Red Sea)

Cephalopholis miniata-Heemstra and Randall, 1984:13 (Indo-Pacific, including Chagos)

\section{MATERIAL}

Five lots, 6 specimens, $68-290 \mathrm{~mm} \mathrm{SL}, 6-25 \mathrm{~m}$, lagoon, reef-top, and drop-off at Peros Banhos and Salomon (photos: 68, 245, and $290 \mathrm{~mm}$ ). Indo-Pacific.

\section{Cephalopholis nigripinnis (Valenciennes)}

Fig. 130 Serranus nigripinnis Valenciennes in Cuvier and Valenciennes, 1828:339 (no locality)

Cephalopholis nigripinnis-Kailola, 1975:92 (New Guinea)

\section{MATERIAL}

Eighteen lots, 86 specimens, 36-193 mm SL, 4-26 m, lagoon, reef-top, and drop-off at Peros Banhos and Salomon (photos: 66 and $146 \mathrm{~mm}$ ).

Most of our specimens $(76 \% ; \bar{x} /$ lot $=7.1)$ were collected from the reef-tops, with $77 \%$ of the total in $6-15 \mathrm{~m}$. Heemstra and Randall (1984:31) imply that this species is confined to the Indian Ocean. We note Kailola's record (1975) from New Guinea, although we have not verified the identification of her single specimen. Distribution insuffi- 
ciently known to categorize; range unassigned.

Cephalopholis sexmaculata Rüppell

Fig. 131

Cephalopholis sexmaculatus Rüppell, 1830a:107 (Red Sea);

Randall, 1973:186 (Tahiti)

MATERIAL

Four lots, 6 specimens, 82-283 mm SL, 18-43 m, drop-off only at Peros Banhos and Salomon (photos: 97 and $283 \mathrm{~mm}$ ). Indo-Pacific.

\section{Cephalopholis sp.}

Pl. IVC

MATERIAL

One lot, 1 specimen, $37 \mathrm{~mm} \mathrm{SL}, 0-0.75 \mathrm{~m}$, reef-flat at Salomon (photo). Neither we, nor Dr Heemstra, nor Dr Randall were able to identify this specimen. Dr Randall suggested (in litt.) that it could possibly be a juvenile of $C$. boenack or $C$. pachycentron-neither of which has yet been found at Chagos. Range unassigned.

\section{Epinephelus caeruleopunctatus (Bloch)}

Fig. 132

Holocentrus caeruleopunctatus Bloch, 1790:94 (no locality) Epinephelus caeruleopunctatus-Heemstra and Randall, 1984:59 (Indo-west Pacific, including Chagos, east to Japan and Australia)

\section{MATERIAL}

Three lots, 3 specimens, $184-315 \mathrm{~mm} \mathrm{SL}, 0-25 \mathrm{~m}$, intertidal, reef-flat, and drop-off at Peros Banhos (photos: 184, 223, and $315 \mathrm{~mm}$ ). Indo-west Pacific.

\section{Epinephelus chlorostigma (Valenciennes)}

Serranus chlorostigma Valenciennes in Cuvier and Valenciennes, 1828:352 (Seychelles)

Epinephelus chlorostigma-Kyushin et al., 1977:206 (Chagos Archipelago); Heemstra and Randall, 1984:61 (Indo-Pacific east to Caroline Islands)

No specimens seen or collected, based on record by Kyushin et al. (1977) of a specimen (or specimens) taken by vertical longline from Chagos in depths of $32-150 \mathrm{~m}$. Indo-west Pacific and marginally on the Pacific plate.

\section{Epinephelus fasciatus (Forsskål)}

Fig. 133 Perca fasciata Forsskål, 1775:40 (Râs Muhammad, Red Sea)

Epinephelus fasciatus-Heemstra and Randall, 1984:47 (Indo-Pacific, including Chagos, east to Pitcairn Island)

\section{MATERIAL}

One lot, 1 specimen, $98 \mathrm{~mm} \mathrm{SL,} \mathrm{0-0.5} \mathrm{m,} \mathrm{reef-flat} \mathrm{at} \mathrm{Peros}$ Banhos (photo). This species was only seen on a search-andrecovery dive in the pass between Petite Sœur and Isle Poule at Peros Banhos and on another dive off the pass at the north tip of Eagle Island in $10 \mathrm{~m}$. On the latter occasion, numerous specimens were observed at the beginning of the dive $(1300 \mathrm{~h})$, but none was observed one hour later. Indo-Pacific.

Epinephelus faveatus (Valenciennes)

Fig. 134 Serranus faveatus Valenciennes in Cuvier and Valenciennes, 1828:329 (Mauritius and Sri Lanka)

Epinephelus faveatus-Heemstra and Randall, 1984:67 (Indo-Pacific, including Chagos, east to Marshall Islands)

\section{MATERIAL}

Five lots, 14 specimens, 55-197 mm SL, 0-1 m, intertidal and reef-flat at Diego Garcia, Eagle Island, and Peros Banhos (photo: $73 \mathrm{~mm}$ ). This species is frequently referred to in the literature as $E$. megachir or $E$. macrospilos. Indo-west Pacific and marginally on the Pacific plate.

\section{Epinephelus flavocaeruleus (Lacepède)}

Holocentrus flavocaeruleus Lacepède, 1802b:331 (Mauritius)

Epinephelus flavocaeruleus-Kyushin et al., 1977:194 (Chagos Archipelago); Heemstra and Randall, 1984:69 (Indo-Pacific east to Marshall Islands and Gilbert Islands)

This record is based on the report by Kyushin et al. (1977) of four specimens taken at Chagos, Andaman Islands, and the East Burma Sea by vertical longline in depths of $60-110 \mathrm{~m}$. Indo-west Pacific and marginally on the Pacific plate.

Epinephelus hexagonatus (Schneider)

Fig. 135

Holocentrus hexagonatus Schneider in Bloch and Schneider, 1801:323 (Tahiti)

Epinephelus hexagonatus-Kyushin et al., 1977:212 (Chagos Archipelago); Heemstra and Randall, 1984:71 (Indo-Pacific east to Marshall Islands)

\section{MATERIAL}

Twenty-one lots, 172 specimens, 45-224 mm SL, 0-25 m, lagoon, reef-flat, intertidal, reef-top, and drop-off at Diego Garcia, Eagle Island, Peros Banhos, and Salomon (photos: 112 and $162 \mathrm{~mm})$. Most specimens were taken in the intertidal $(20 \%)$ and reef-flat $(67 \%)$ regions $(\bar{x} /$ lot $=8.5$ and 18.5 specimens, respectively), with $92 \%$ of the total number of specimens collected in $0-5 \mathrm{~m}$. Indo-west Pacific and marginally on the Pacific plate.

\section{Epinephelus longispinis (Kner)}

Serranus longispinis Kner, 1865:27 (Madras)

Epinephelus gaimardi-Kyushin et al., 1977:210 (non Valenciennes in Cuvier and Valenciennes, 1830b; Chagos Archipelago) 
Epinephelus longispinis-Heemstra and Randall, 1984:75 (western Indian Ocean)

This record is from the figure and description of $E$. gaimardi given by Kyushin et al. (1977) based on 12 specimens obtained at five localities (one of which was Chagos). Their specimens were taken by vertical longline in $32-65 \mathrm{~m}$. As pointed out by Heemstra and Randall (1984), E. longispinis is frequently misidentified as $E$. gaimardi, which itself is a junior synonym of $E$. miliaris (Valenciennes). The colour figures given by Kyushin et al. (1977) leave little doubt that their specimens are $E$. longispinis. Western Indian Ocean.

\section{Epinephelus merra Bloch}

Fig. 136 Epinephelus merra Bloch, 1793:17 (Japan); Kyushin et al., 1977:214 (Chagos Archipelago); Heemstra and Randall, 1984:83 (Indo-Pacific east to French Polynesia)

\section{MATERIAL}

Ten lots, 459 specimens, $43-157 \mathrm{~mm} \mathrm{SL}, 0-7 \mathrm{~m}$, lagoon, intertidal, and reef-flat at Eagle Island, Three Brothers, and Peros Banhos (photo: $63 \mathrm{~mm}$ ). This species was the dominant small serranid in very shallow water. Ninety-nine per cent of the specimens were taken in less than $1 \mathrm{~m}$, with $73 \%$ from the intertidal zone and $26 \%$ from the reef-flat. Indo-Pacific.

\section{Epinephelus microdon (Bleeker)}

Fig. 137

Serranus microdon Bleeker, 1856b:86 (Java)

Epinephelus microdon-Kyushin et al., 1977:230 (Chagos

Archipelago); Randall, 1973:186 (Tahiti)

MATERIAL

Seven lots, 7 specimens, $170-417 \mathrm{~mm}$ SL, 0-43 m, lagoon, reef-flat, reef-top, and drop-off at Diego Garcia, Peros Banhos, and Salomon (photos: 201 and $353 \mathrm{~mm}$ ). Indo-Pacific.

\section{Epinephelus miliaris (Valenciennes)}

Serranus miliaris Valenciennes in Cuvier and Valenciennes, 1830b:520 (New Guinea)

Epinephelus fuscus-Kyushin et al., 1977:216 (Chagos Archipelago)

Epinephelus miliaris-Heemstra and Randall, 1984:87 (Indo-west Pacific)

No specimens seen or collected. Kyushin et al. (1977) record $E$. fuscus Fourmanoir, 1963, from Chagos, and their photograph of this species corresponds to E. miliaris. Heemstra and Randall (1984) point out that both E. fuscus and $E$. dictiophorus (Bleeker, 1856e) are synonyms of $E$. miliaris. Indo-west Pacific
Epinephelus morrhua (Valenciennes)

Serranus morrhua Valenciennes in Cuvier and Valenciennes, 1833:434 (Mauritius)

Epinephelus cometae-Kyushin et al., 1977:198 (Chagos Archipelago)

Epinephelus morrhua-Kyushin et al., 1977:200 (Chagos Archipelago); Heemstra and Randall, 1984:91 (Indo-west Pacific, including Chagos)

No specimens seen or collected; the record is based on the reports of Kyushin et al. (1977) and Heemstra and Randall (1984). The latter authors synonymize $E$. cometae Tanaka, 1927, in E. morrhua. Indo-west Pacific.

\section{Epinephelus multinotatus (Peters)}

Serranus multinotatus Peters, 1876:435 (Mauritius/Seychelles)

Epinephelus leprosus-Kyushin et al., 1977:226 (Chagos Archipelago)

Epinephelus multinotatus-Heemstra and Randall, 1984:93 (western Indian Ocean)

No specimens seen or collected; the record is based on the report of Kyushin et al. (1977) of a specimen taken by vertical longline in $40-100 \mathrm{~m}$ (as E. leprosus Smith, 1955a, which Heemstra and Randall [1984] treat as a synonym of E. multinotatus). Western Indian Ocean.

\section{Epinephelus poecilonotus (Temminck and Schlegel)}

Serranus poecilonotus Temminck and Schlegel, 1842:6 (Japan)

Epinephelus poecilonotus-Kyushin et al., 1977:202 (Chagos Archipelago); Heemstra and Randall, 1984:97 (Indo-west Pacific, including Chagos)

No specimens seen or collected; the record is based on the above literature sources. Indo-west Pacific.

\section{Epinephelus radiatus (Day)}

Serranus radiatus Day, 1867:699 (India)

Epinephelus radiatus-Heemstra and Randall, 1984:103 (Indo-west Pacific, including Chagos)

No specimens seen or collected; the record is based on Heemstra and Randall (1984). Indo-west Pacific.

\section{Epinephelus retouti Bleeker}

Epinephelus retouti Bleeker, 1868b:339 (Réunion); Heemstra and Randall, 1984:105 (southwestern Indian Ocean, including Chagos)

?Epinephelus truncatus-Kyushin et al., 1977:220 (Chagos Archipelago)

No specimens seen or collected. Kyushin et al. (1977) 
obtained two specimens of what they identified as $E$. truncatus Katayama, 1957, from Chagos (vertical longline, $25-90 \mathrm{~m}$ ). This species has been tentatively regarded as a synonym of $E$. retouti by Heemstra and Randall (1984). Western Indian Ocean.

\section{Epinephelus septemfasciatus (Thunberg)*}

Perca septemfasciata Thunberg, 1793:56 (Japan)

?Epinephelus compressus -Kyushin et al., 1977:224 (Chagos Archipelago)

Epinephelus septemfasciatus-Heemstra and Randall, 1984:109 (southwestern Indian Ocean, including Chagos)

No specimens seen or collected. Heemstra and Randall (1984) report it from Mauritius, Réunion, and Chagos, in addition to the type locality in Japan. Indo-west Pacific.

Epinephelus tauvina (Forsskål)

Perca tauvina Forsskål, 1775:39 (Jiddah, Red Sea)

Epinephelus tauvina-Heemstra and Randall, 1984:53 (Indo-Pacific)

MATERIAL

Ten lots, 26 specimens, 45-245 mm SL, 0-7 m, lagoon, intertidal, reef-flat, reef-top, and pass at Eagle Island, Peros Banhos, and Salomon (photos: 114, 128, 158, and $245 \mathrm{~mm})$. Indo-Pacific.

Gracila albomarginata (Fowler and Bean) Fig. 139 Cephalopholis albomarginatus Fowler and Bean, 1930:235 (Borneo)

Gracila albomarginata-Randall, 1973:186 (Tahiti); Heemstra and Randall, 1984:119 (Indo-west Pacific, including Chagos)

\section{MATERIAL}

One lot, 1 specimen, $287 \mathrm{~mm} \mathrm{SL}, 5-7 \mathrm{~m}$, reef-top at Salomon (photo). This species was occasionally seen on the edges of the reef-tops near the drop-off in 5-12 m. In natural light at these depths, the fish appears dark, with white vertical bars beneath the soft dorsal fin. The peduncle is white with a large, round black spot centred midlaterally. Indo-Pacific.

\section{Gracila polleni (Bleeker)}

Fig. 140

Epinephelus polleni Bleeker, 1868b:336 (Réunion)

Gracila polleni-Heemstra and Randall, 1984:121 (Indowest Pacific, including Chagos); Myers and Sheppard, 1980:317 (Marianas)

\section{MATERIAL}

One lot, 1 specimen, $168 \mathrm{~mm} \mathrm{SL}, 42 \mathrm{~m}$, drop-off at Peros Banhos (photo).
Grammistes sexlineatus (Thunberg)*

Fig. 141

Perca sexlineatus Thunberg, 1792:142 (Japan)

Grammistes sexlineatus-Regan, 1908:224 (Chagos Archipelago); Randall, 1984c:5(Indo-Pacific, including Chagos)

\section{MATERIAL}

Five lots, 22 specimens, $17-90 \mathrm{~mm} \mathrm{SL}, 0-3 \mathrm{~m}$, lagoon and reef-flat at Peros Banhos and Salomon (photo: $77 \mathrm{~mm}$ ). Indo-Pacific.

\section{Liopropoma africana (Smith)}

Fig. 142

Chorististium africanum Smith, 1954b:866 (Tekomaji Island, Mozambique)

\section{MATERIAL}

Eight lots, 9 specimens, $27-56 \mathrm{~mm} \mathrm{SL}, 18-48 \mathrm{~m}$, dropoffs only at Peros Banhos and Salomon (photos: 36 and $56 \mathrm{~mm}$ ). The genus is under revision by Randall and Taylor, to whom we have sent our specimens. The identification given above is tentative. Range unassigned.

Liopropoma susumi (Jordan and Seale)

Fig. 143

Chorististium susumi Jordan and Seale, 1906:256 (Samoa); Smith, 1954b:862 (East Africa)

\section{MATERIAL}

Four lots, 4 specimens, $36-46 \mathrm{~mm} \mathrm{SL}, 6-25 \mathrm{~m}$, lagoon, reef-top, and drop-off at Peros Banhos, Salomon, and Three Brothers (photos: $44 \mathrm{~mm}[\times 2]$ ). The remarks made under $L$. africana also apply to this species. Range unassigned.

\section{Plectropomus areolatus Rüppell \\ Plectropoma areolatum Rüppell, 1830b:index footnote (Red Sea)}

\section{MATERIAL}

Two lots, 2 specimens, $308-373 \mathrm{~mm} \mathrm{SL}, 3-7 \mathrm{~m}$, lagoon at Peros Banhos. This species is distributed from the Red Sea east to Samoa and the Phoenix Islands (Randall, pers. comm.). Indo-west Pacific and marginally on the Pacific plate.

\section{Plectropomus laevis (Lacepède)}

Figs. 144, 145 and Pl. IVD

Labrus laevis Lacepède, 1802a:431 ("grande golfe de l'Inde")

Plectropomus melanoleucas-Randall, 1973:186 (Tahiti) Plectropomus laevis-Heemstra and Randall, 1984:127 (Indo-Pacific, including Chagos)

Plectropomus truncatus-Kyushin et al., 1977:186 (Chagos Archipelago) 
Plate I

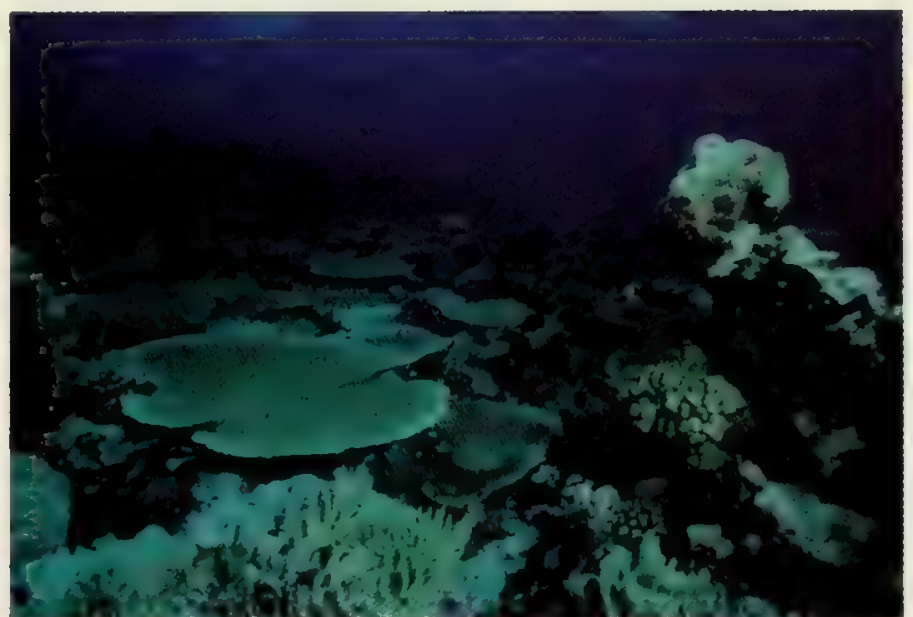

A. Reef-top, west coast of Salomon.

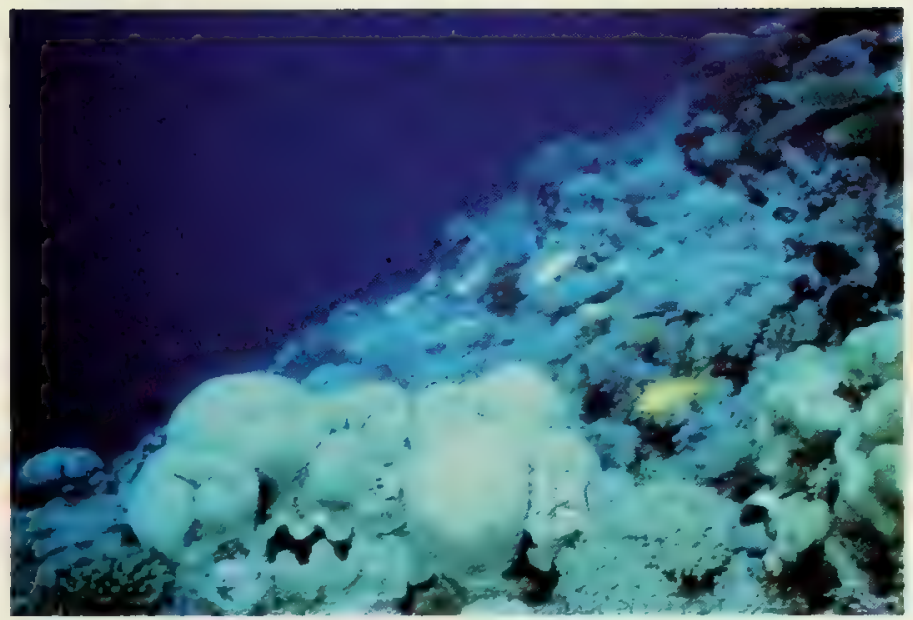

C. Lip of drop-off, Salomon.

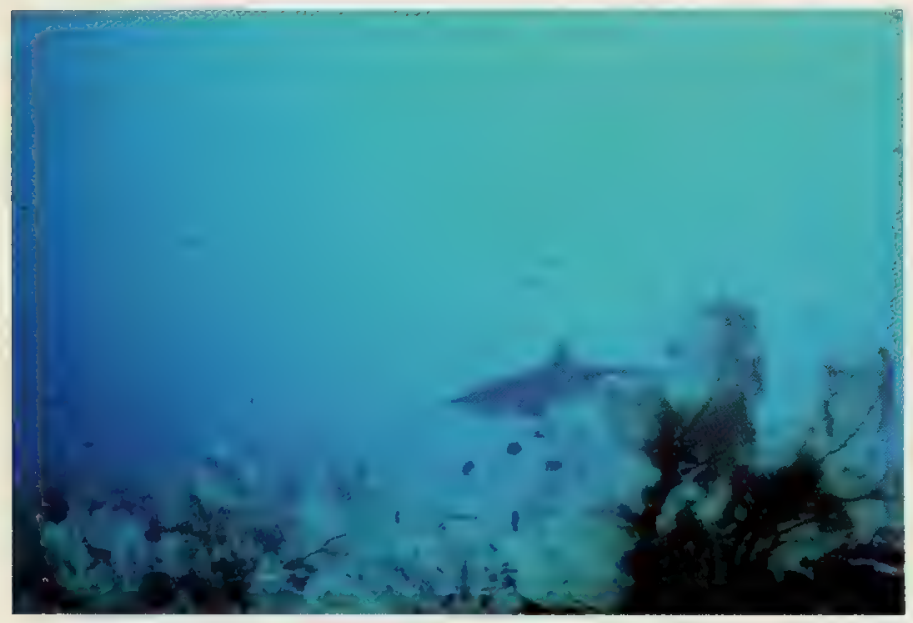

E. Reef-top near drop-off, Salomon.

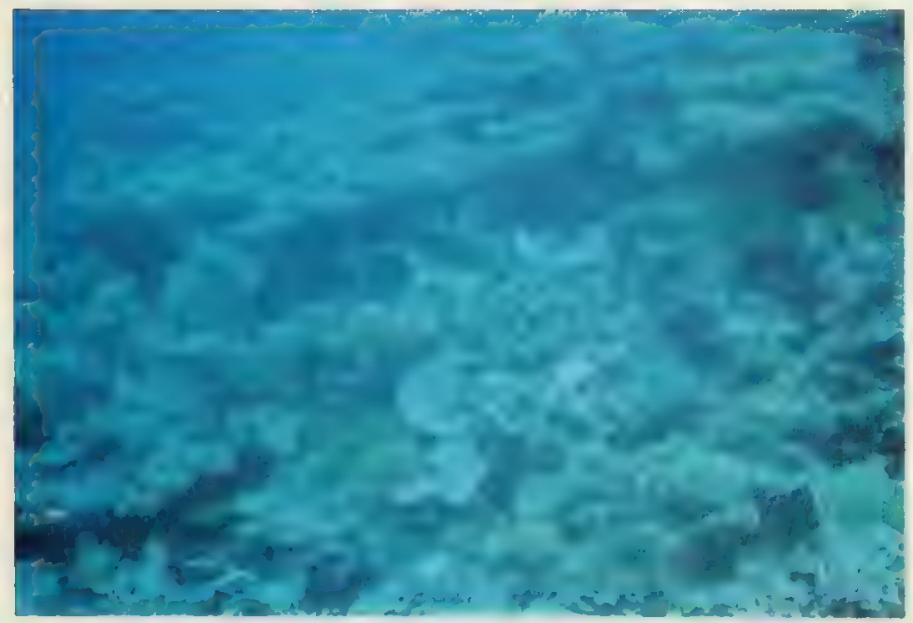

G. Lagoon floor at Peros Banhos.

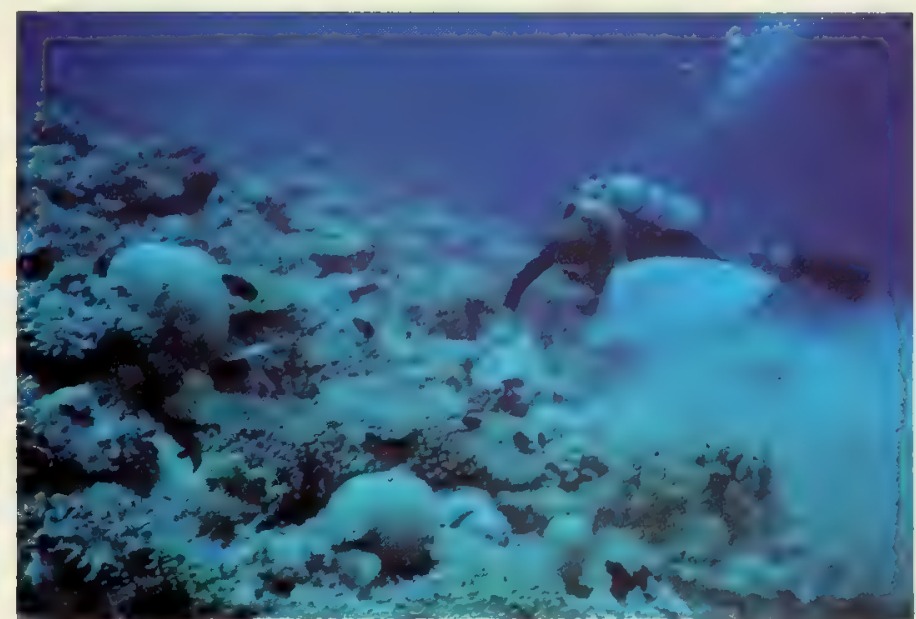

B. Reef-top, south coast of Salomon.

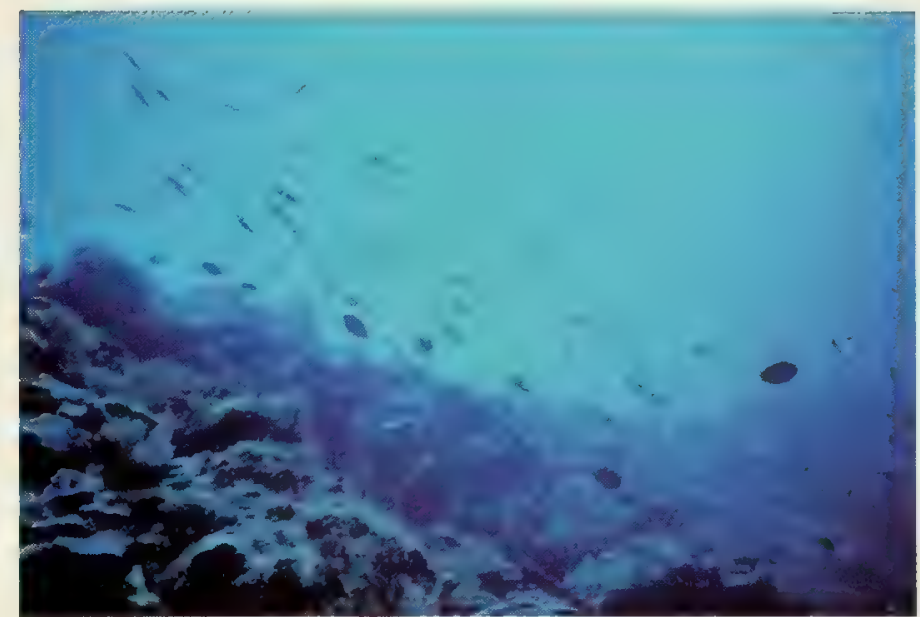

D. Drop-off, north coast of Salomon.

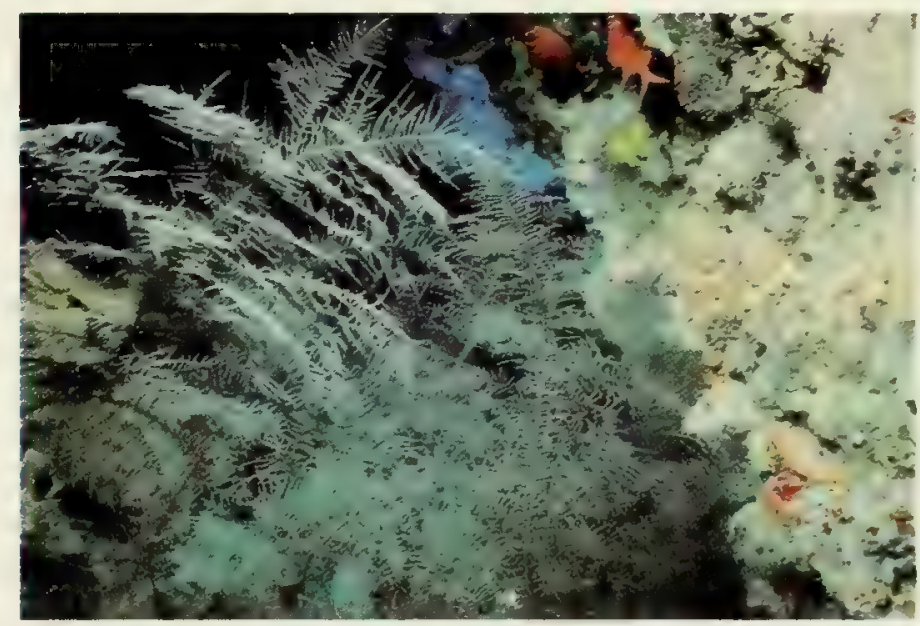

F. Inside cave, $40 \mathrm{~m}$, Peros Banhos.

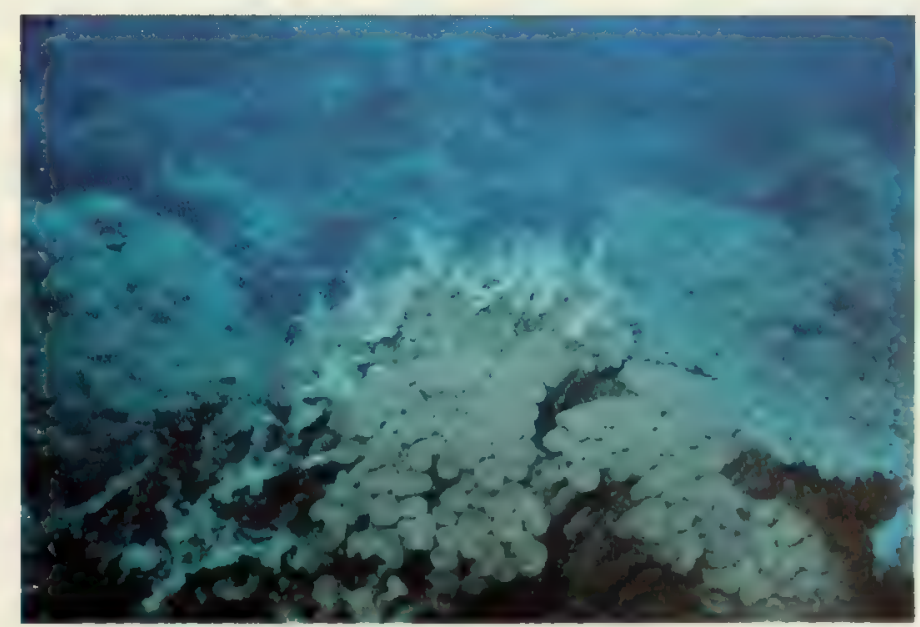

H. Lagoon floor at Salomon. 
Plate II
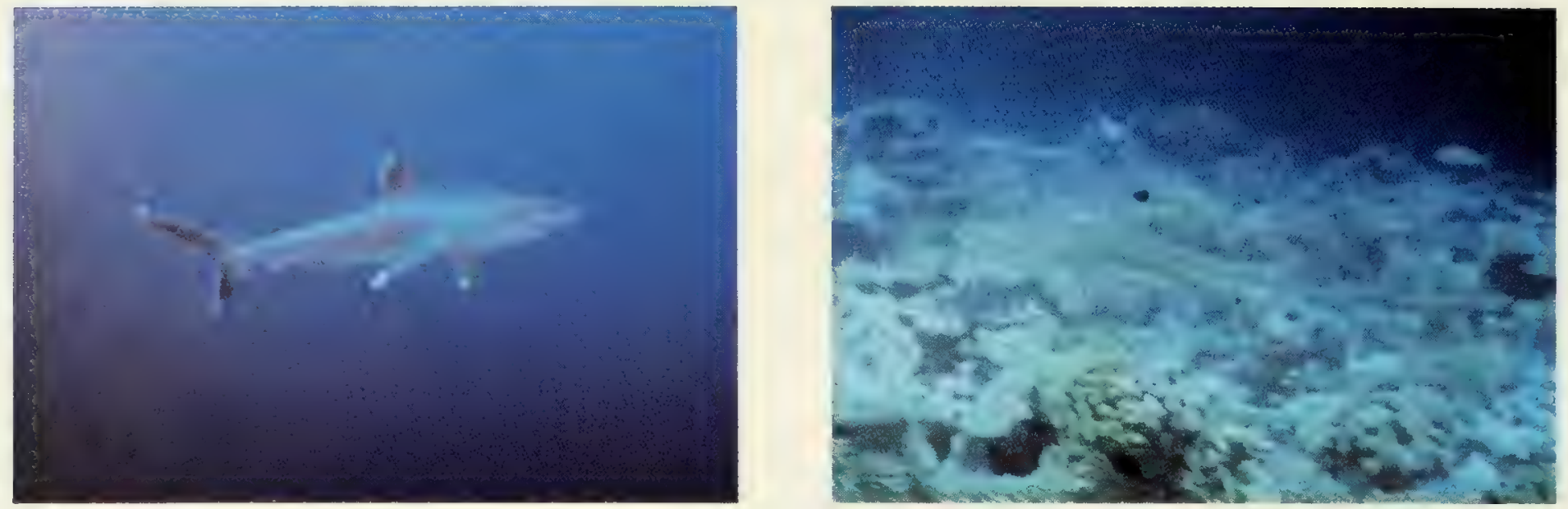

A. Carcharhinus albimarginatus.

B. Carcharhinus wheeleri.
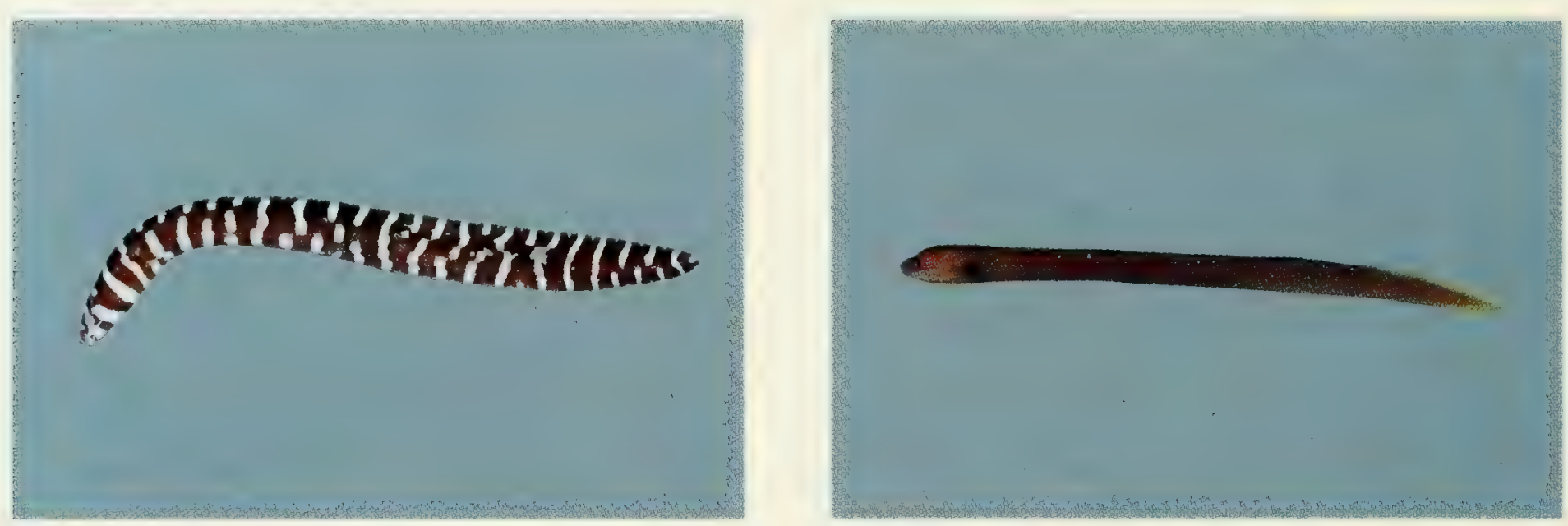

C. Enchelycore pardalis, $109 \mathrm{~mm}$ SL.

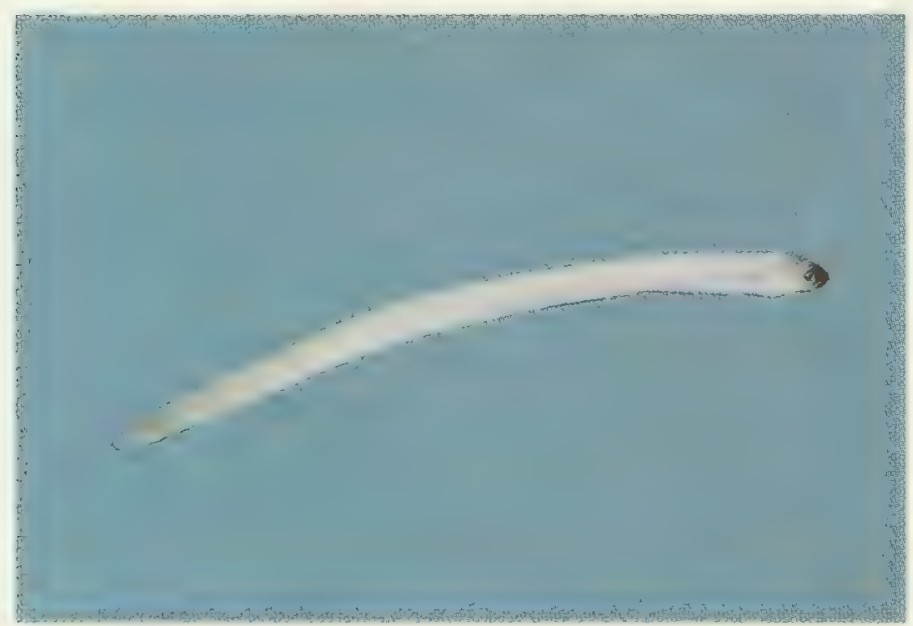

D. Gymnothorax melatremus, $119 \mathrm{~mm} \mathrm{SL}$.

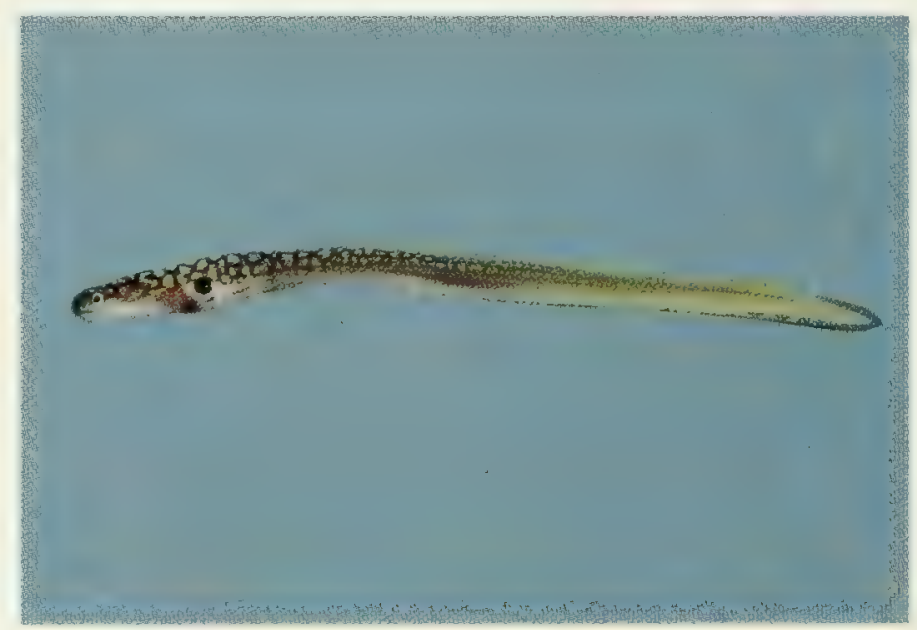

E. Gymnothorax sp. 1, $148 \mathrm{~mm} \mathrm{SL.}$

F. Gymnothorax sp. 2, $50 \mathrm{~mm} \mathrm{SL}$.

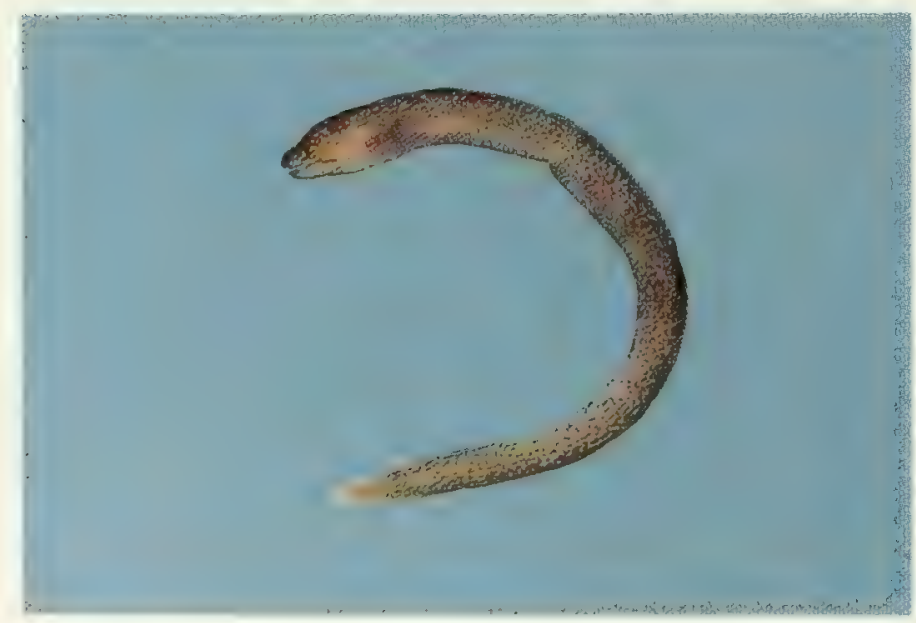

G. Gymnothorax sp. 3, $118 \mathrm{~mm} \mathrm{SL.}$

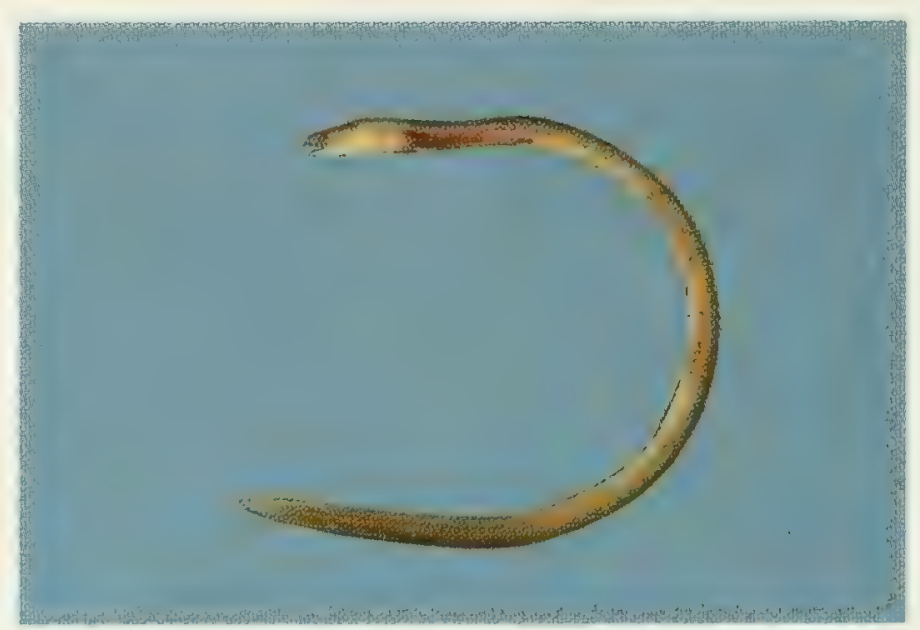

H. Uropterygius sp. 1, $180 \mathrm{~mm}$ SL. 
Plate III

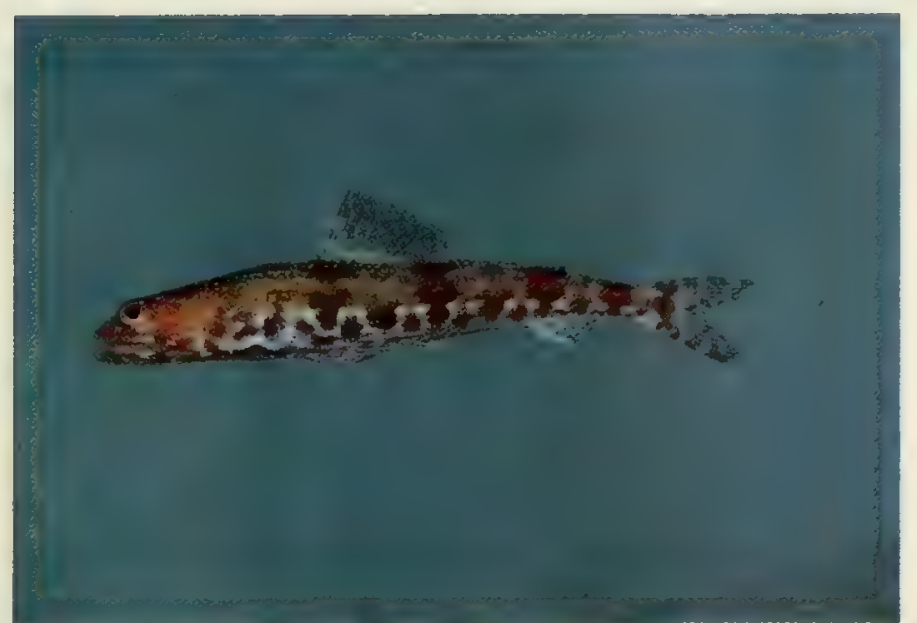

A. Synodus binotatus, $53 \mathrm{~mm} \mathrm{SL}$.

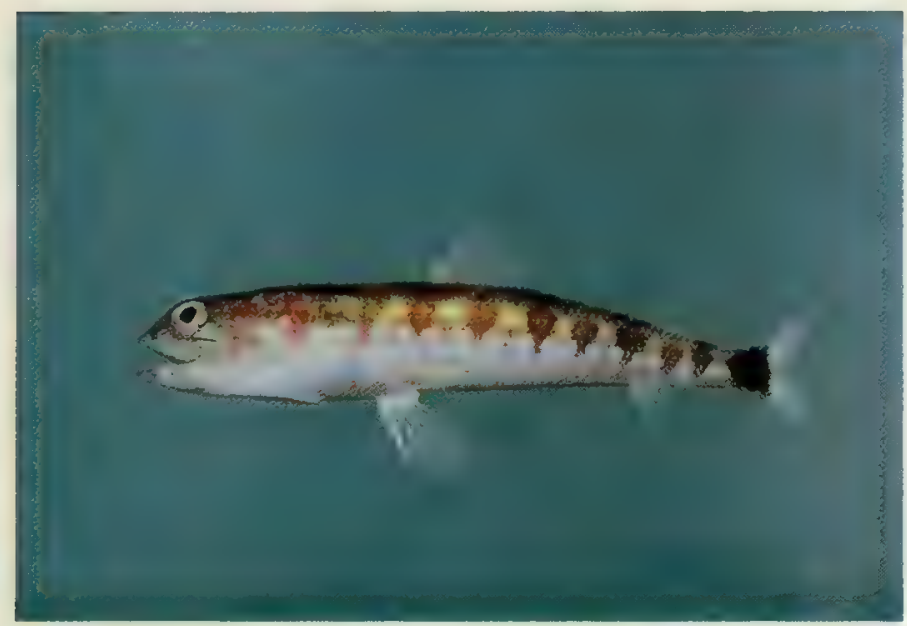

C. Synodus jaculum, $51 \mathrm{~mm} \mathrm{SL}$.

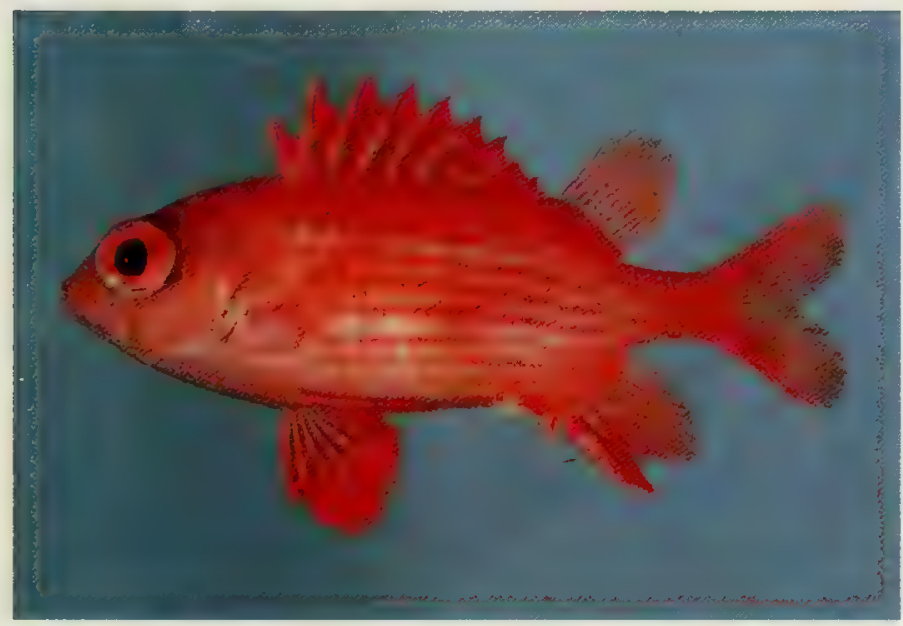

E. Sargocentron inaequalis, $72 \mathrm{~mm} \mathrm{SL}$.

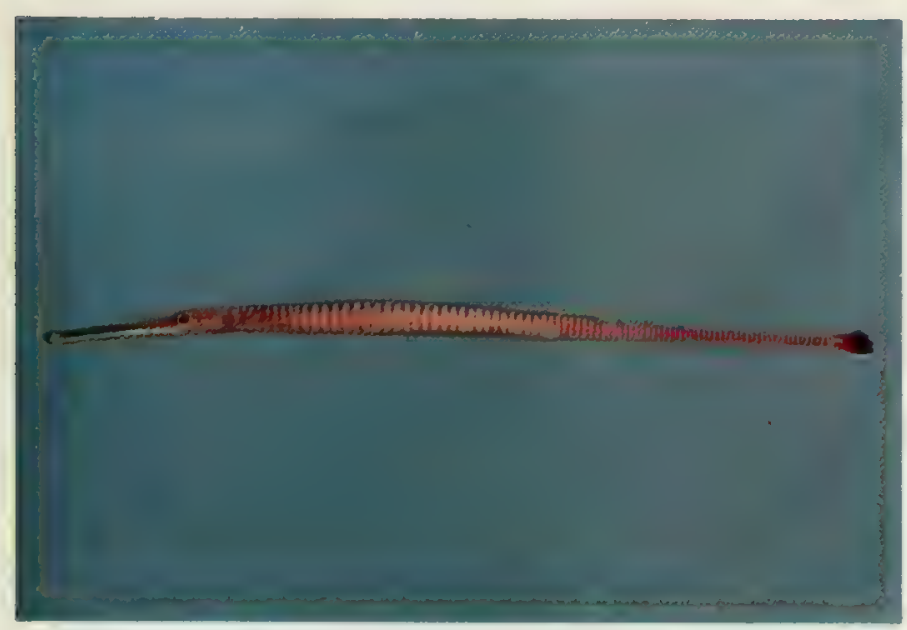

G. Doryrhamphus multiannulatus, $119 \mathrm{~mm} \mathrm{SL}$.

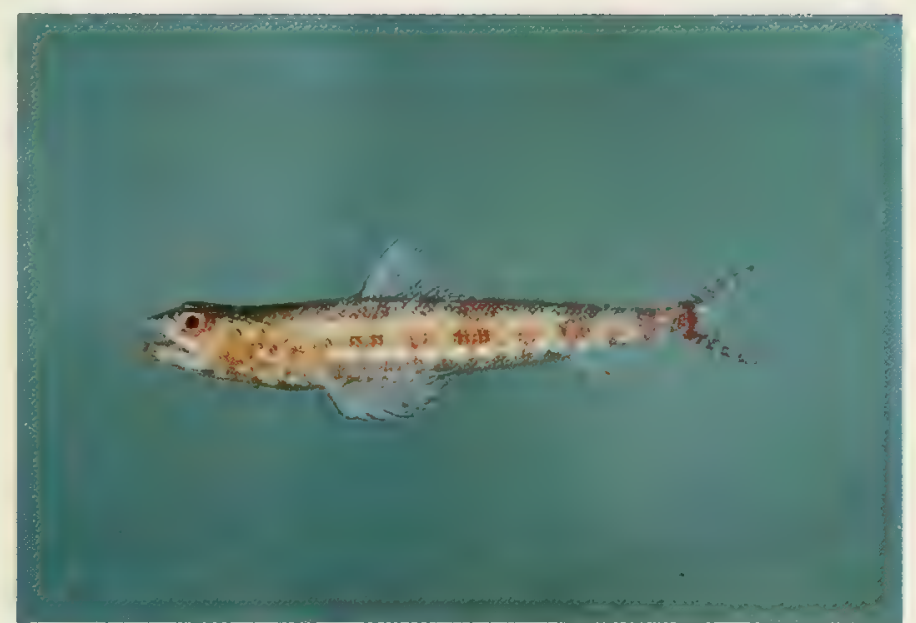

B. Synodus englemani, $117 \mathrm{~mm} \mathrm{SL}$.

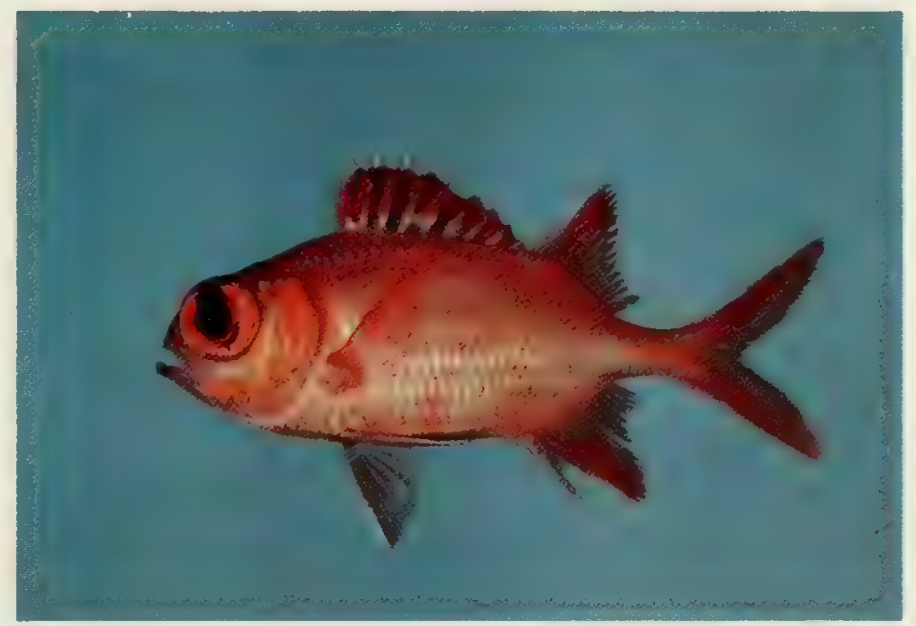

D. Myripristis vittatus, $91 \mathrm{~mm} \mathrm{SL}$.

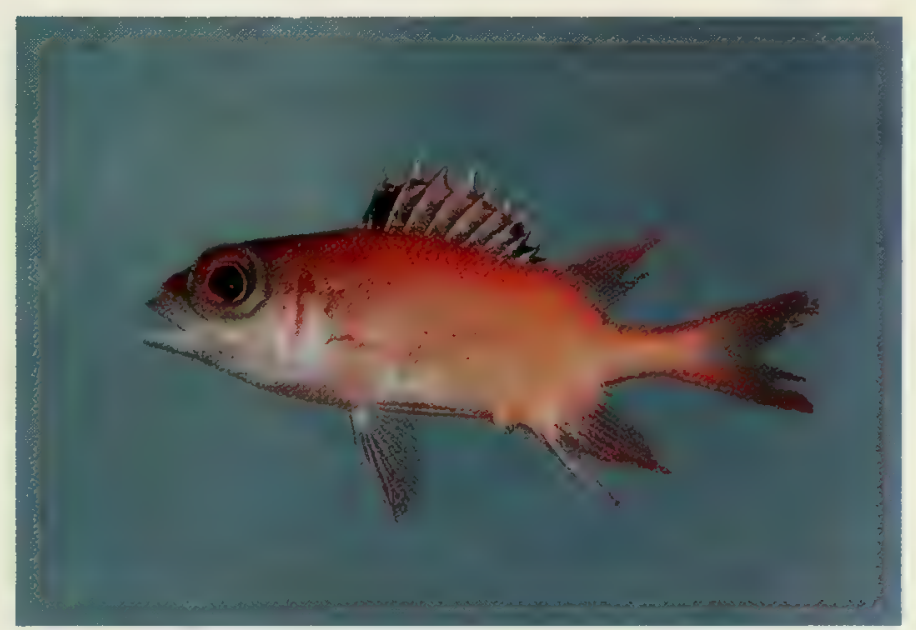

F. Sargocentron tiereoides, $38 \mathrm{~mm} \mathrm{SL}$.

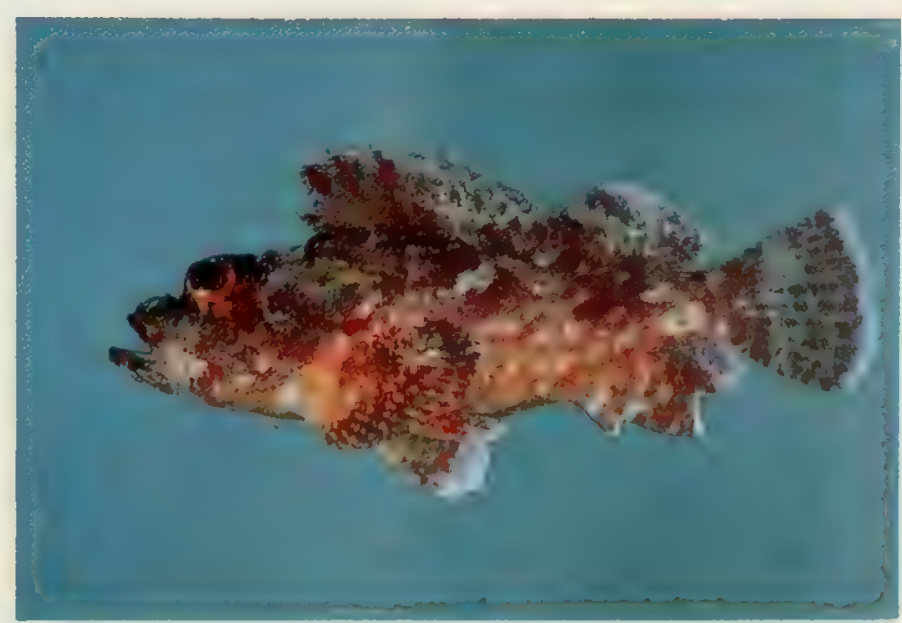

H. Scorpaenopsis sp. 1, 123 mm SL. 


\section{Plate IV}

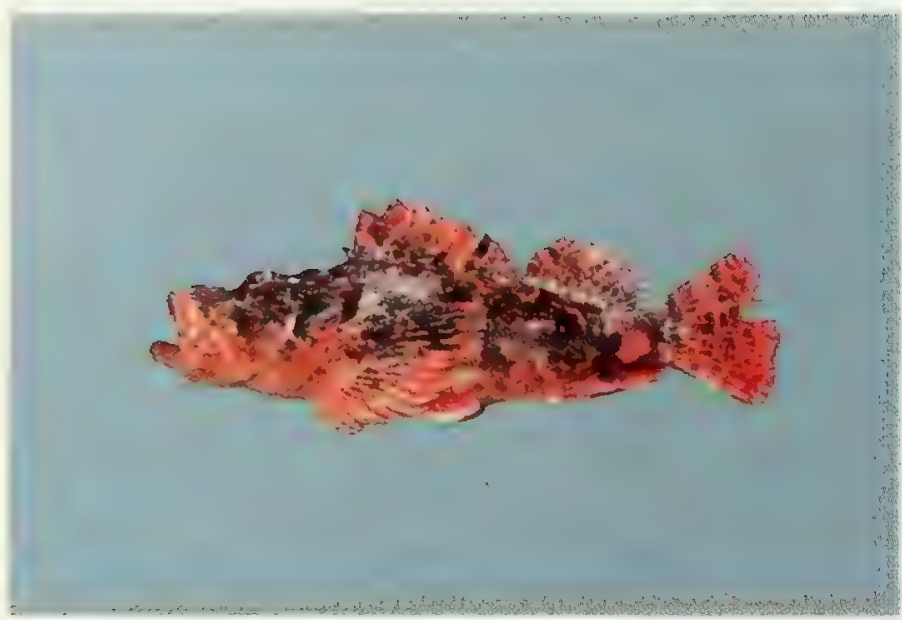

A. Scorpaenopsis sp. $2,270 \mathrm{~mm}$ SL.

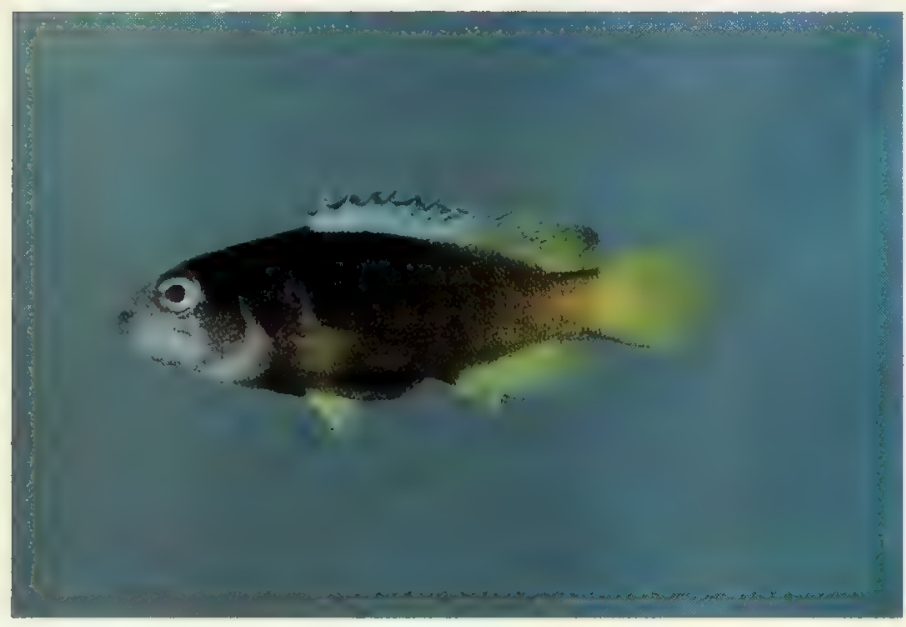

C. Cephalopholis sp., $37 \mathrm{~mm} \mathrm{SL}$.

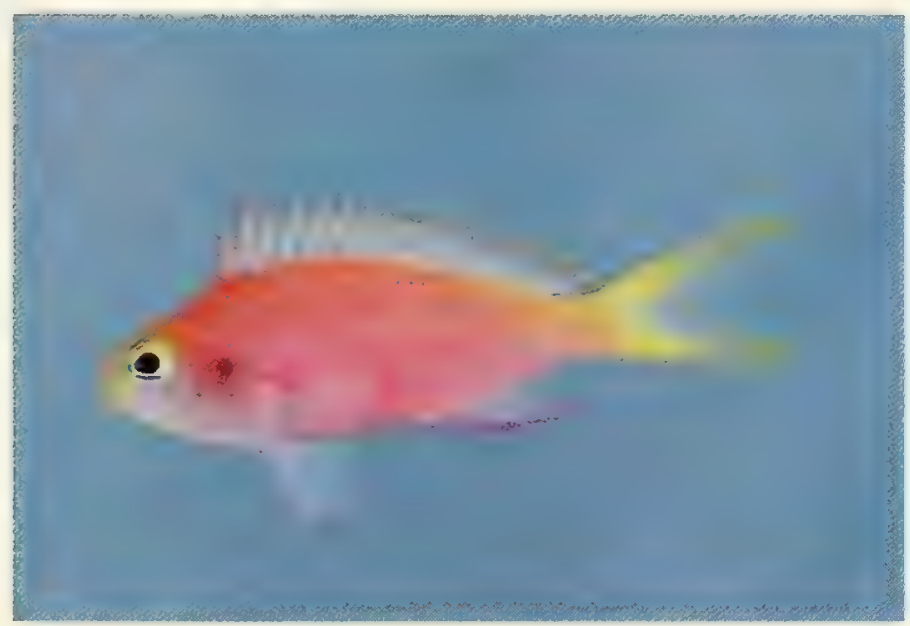

E. Anthias sp., female.

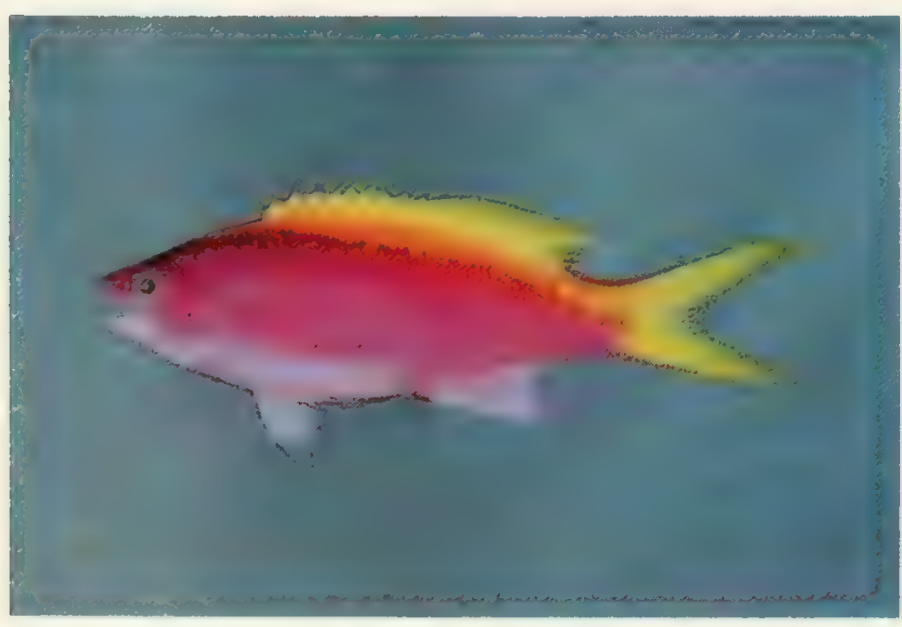

G. Mirolabrichthys evansi.

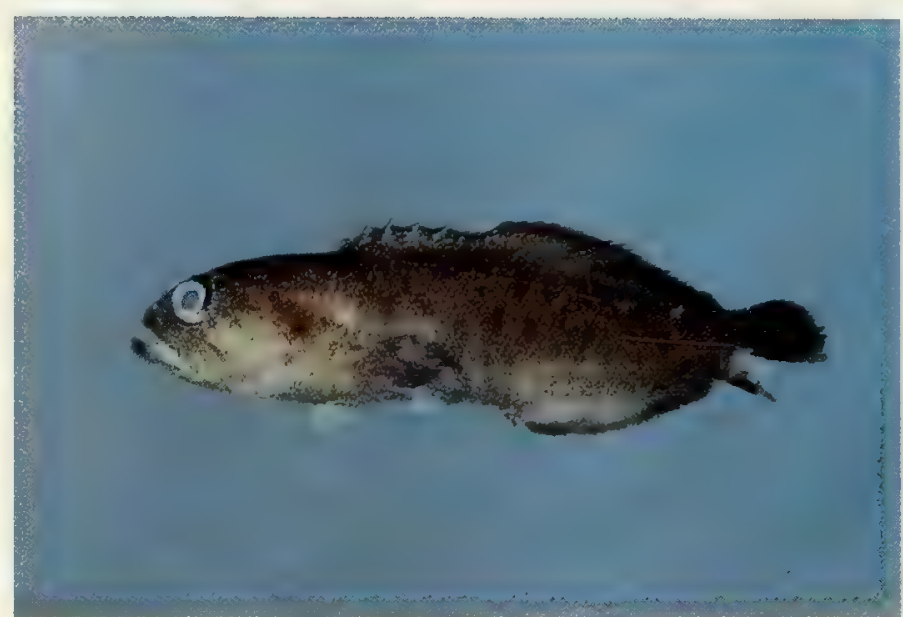

B. Aporops allfreei, $48 \mathrm{~mm} \mathrm{SL}$.

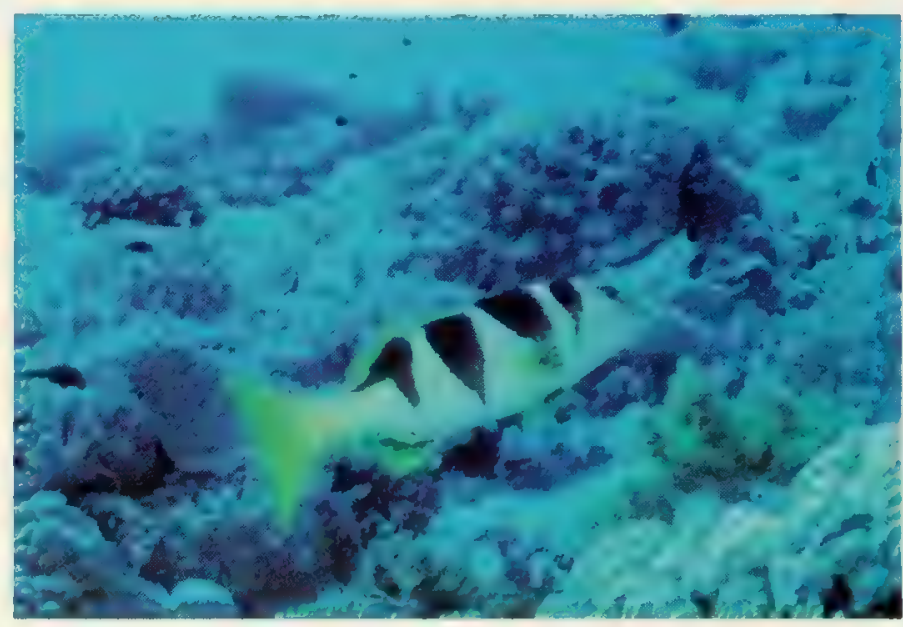

D. Plectropomus laevis.

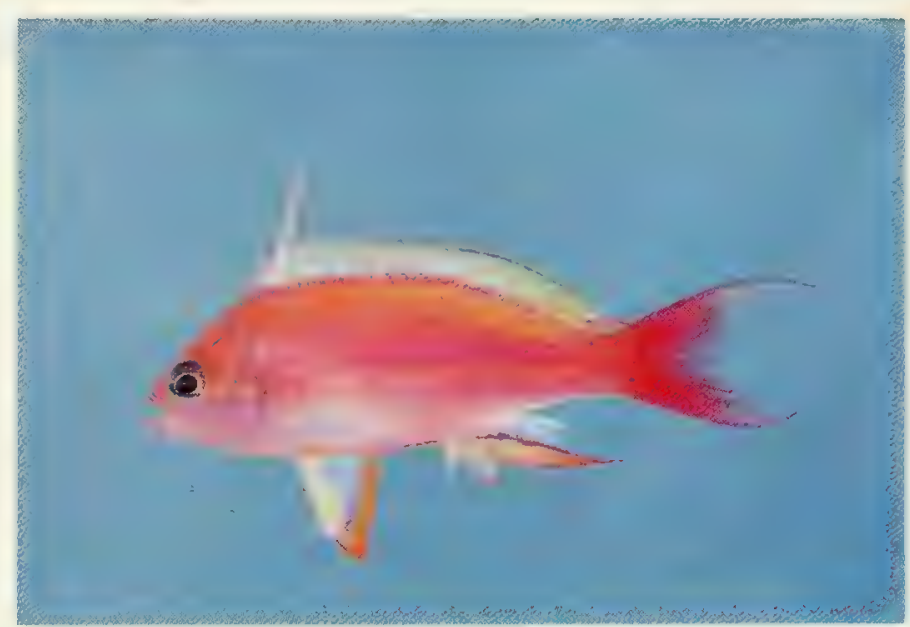

F. Anthias sp., male.

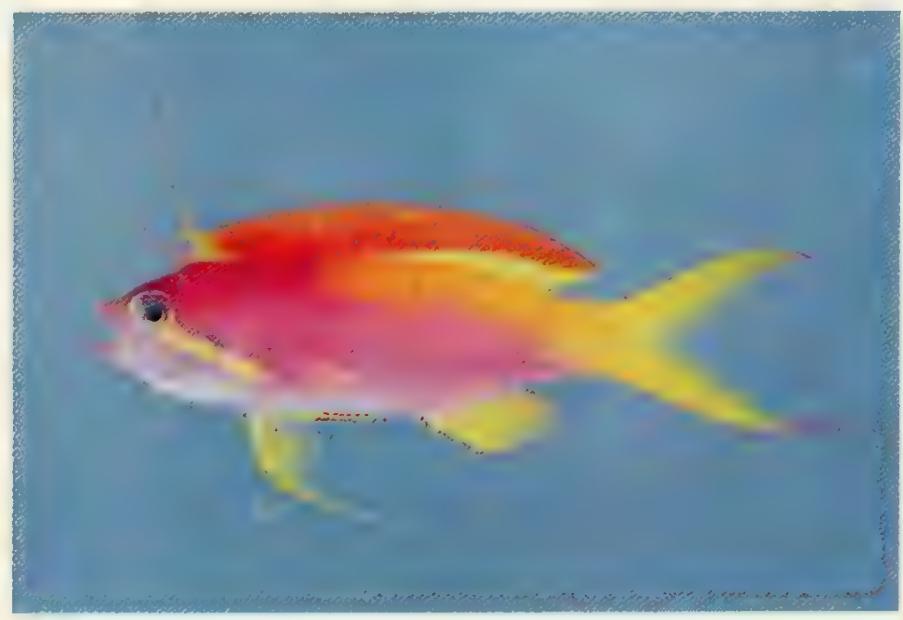

H. Nemanthias carberryi. 


\section{Plate V}

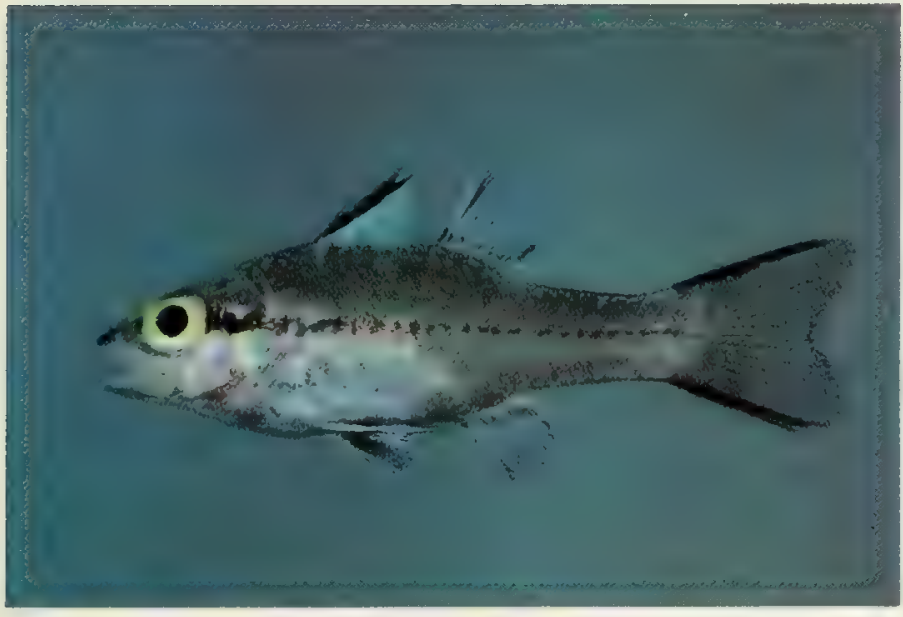

A. Apogon abrogramma?, $93 \mathrm{~mm}$ SL.

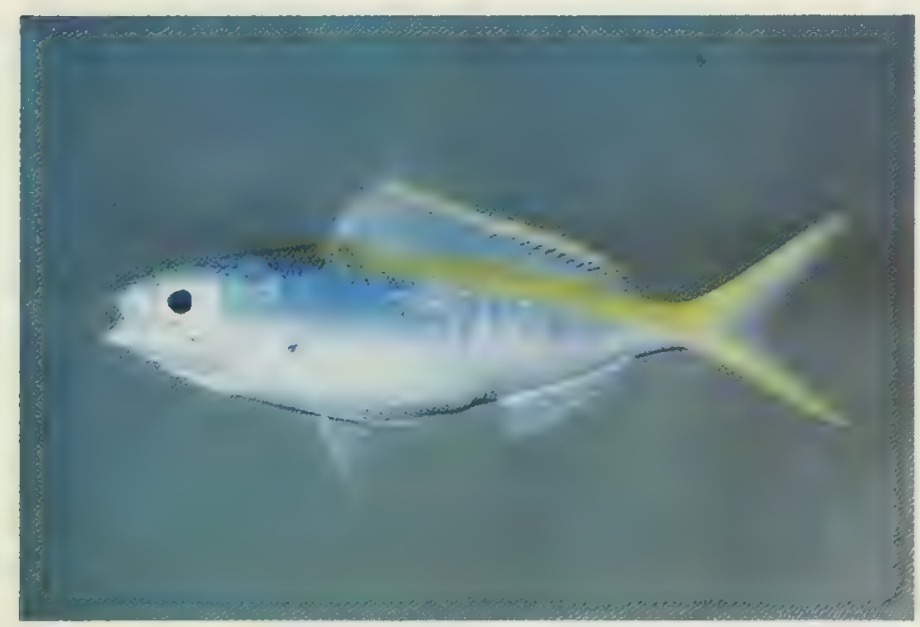

C. Caesio teres, $95 \mathrm{~mm} \mathrm{SL}$.

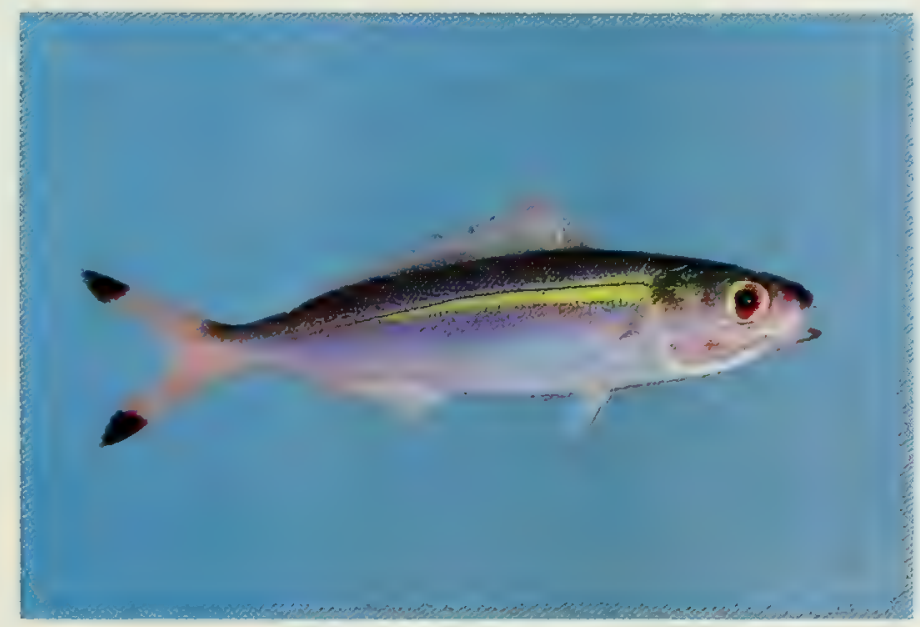

E. Pterocaesio sp., $99 \mathrm{~mm}$ SL.

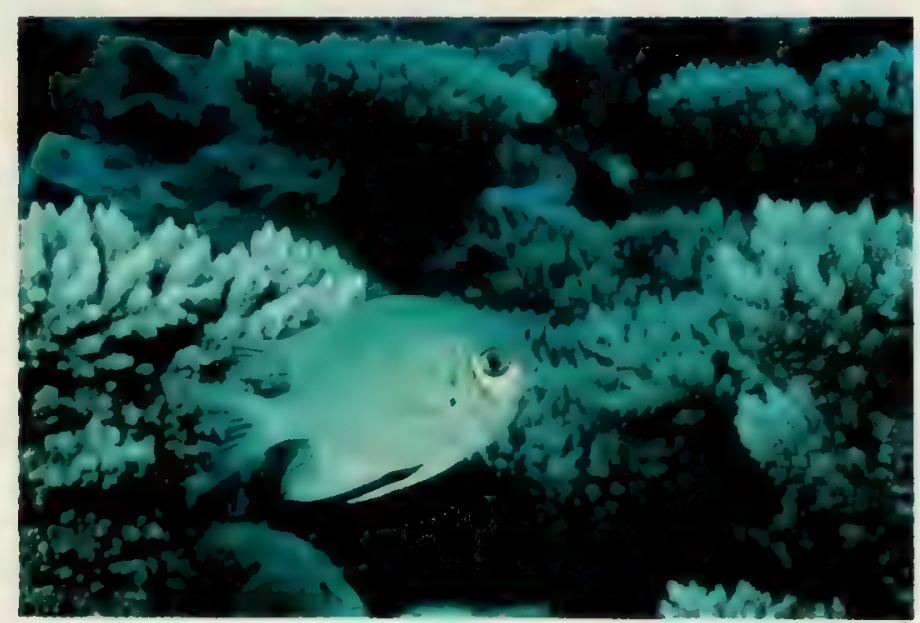

G. Amblyglyphidodon sp.

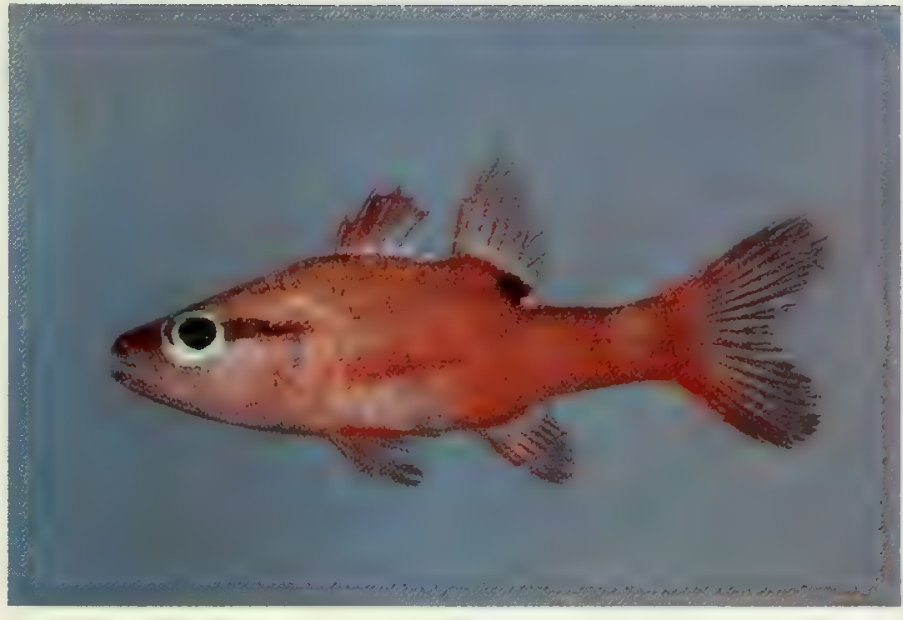

B. Apogon evermanni, $64 \mathrm{~mm}$ SL.

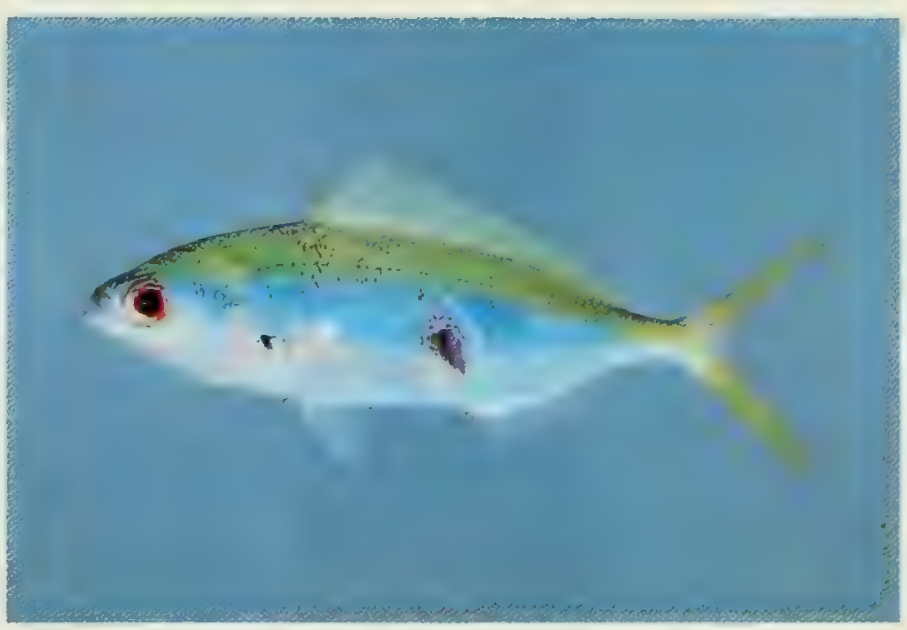

D. Caesio xanthonota, $166 \mathrm{~mm} \mathrm{SL}$.

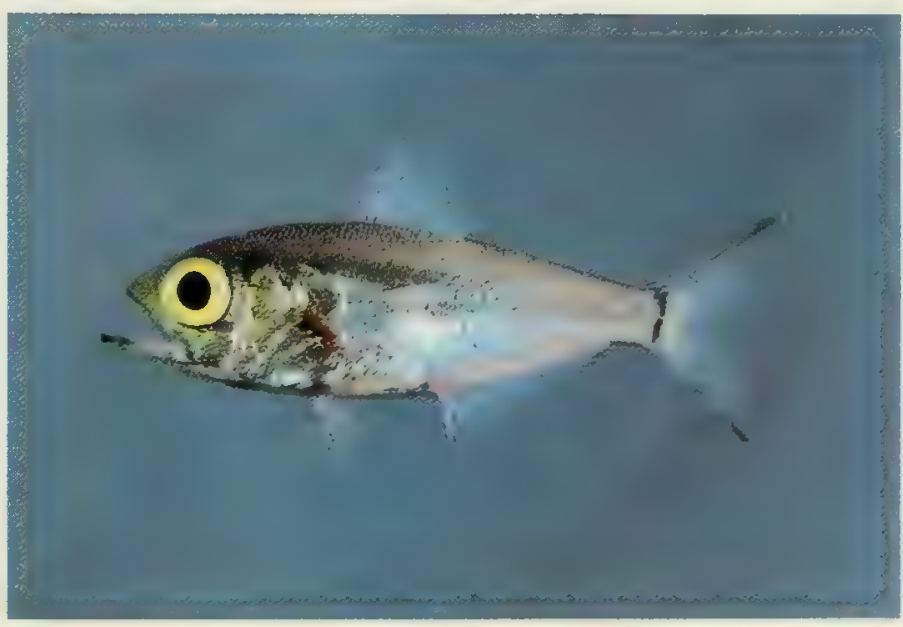

F. Parapriacanthus ransonneti.

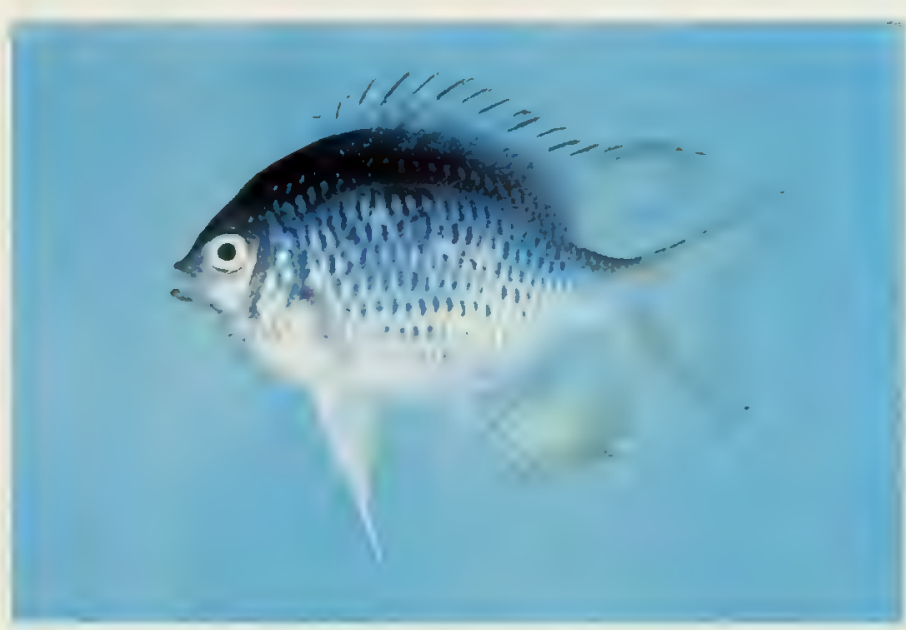

H. Amblyglyphidodon sp., $85 \mathrm{~mm}$. 


\section{Plate VI}

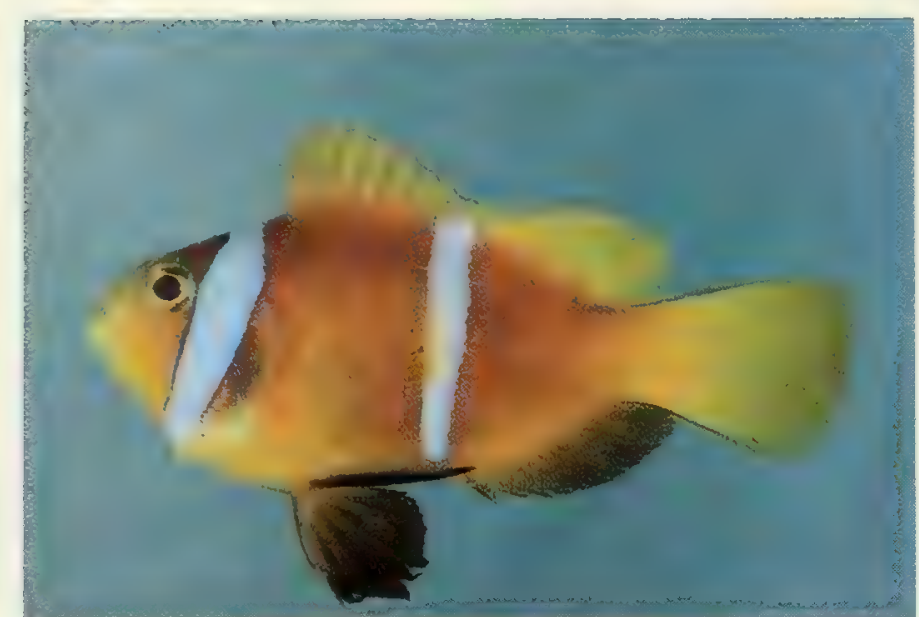

A. Amphiprion chagosensis, $41 \mathrm{~mm} \mathrm{SL}$.

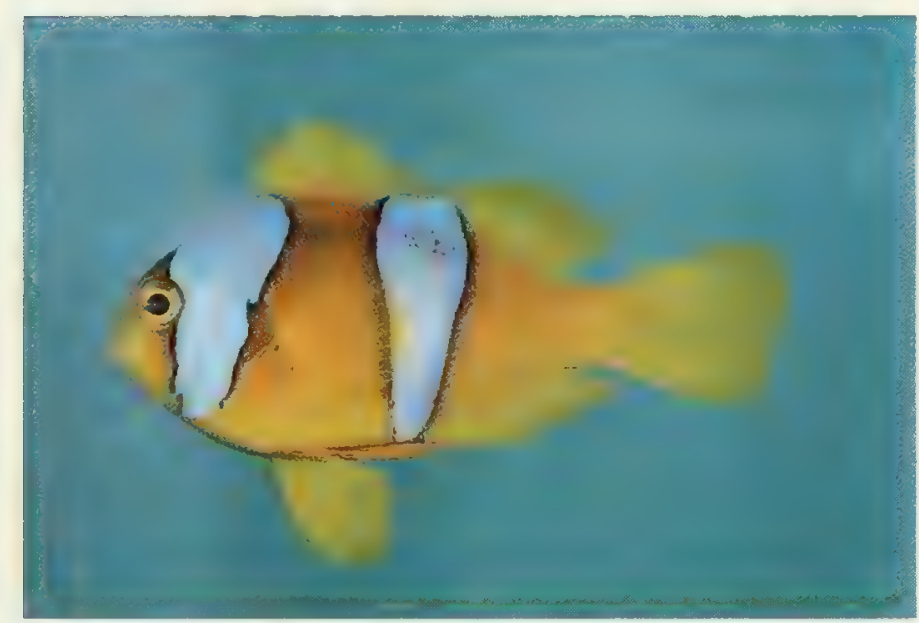

C. Amphiprion sp., $53 \mathrm{~mm}$ SL.

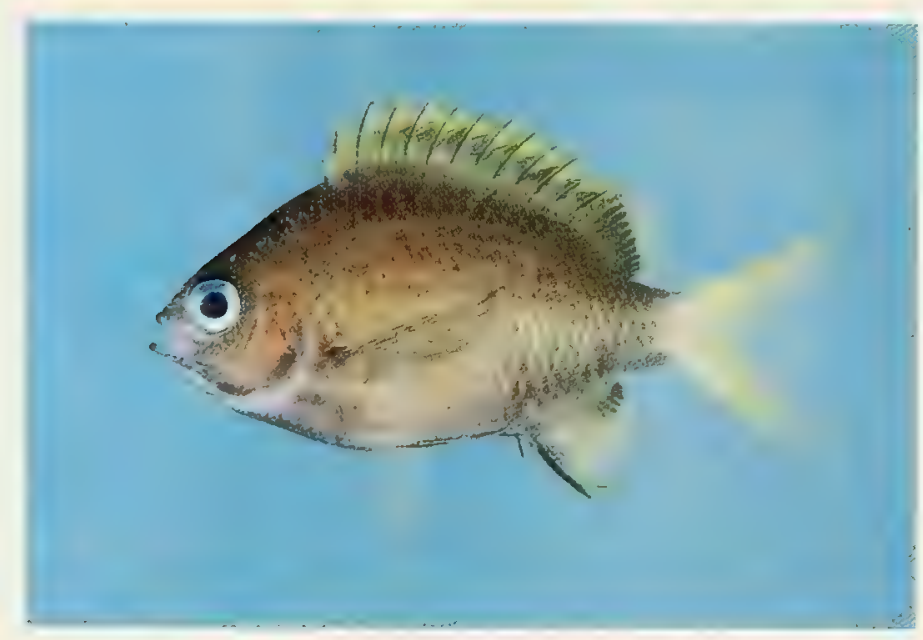

E. Chromis pembae, $77 \mathrm{~mm} \mathrm{SL}$.

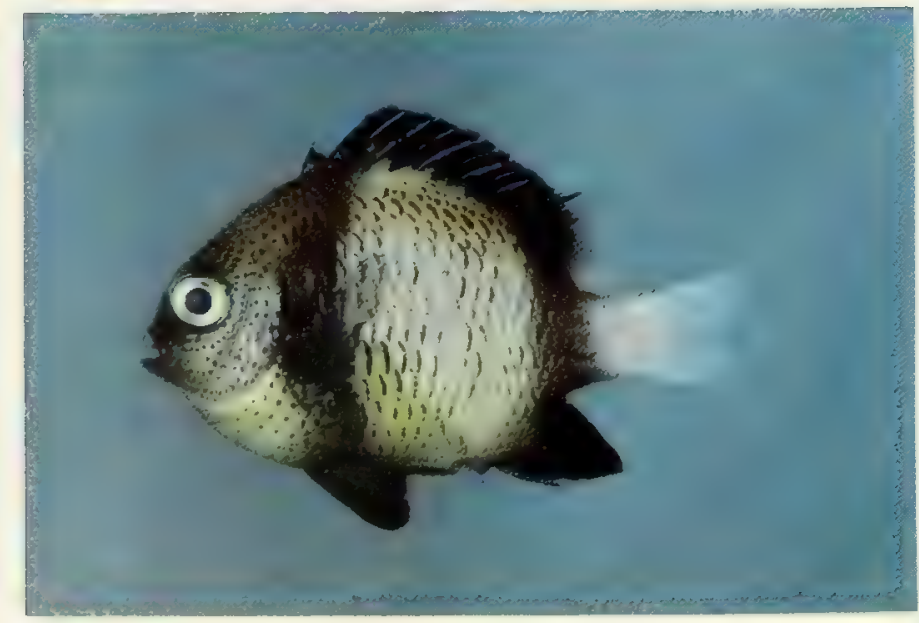

G. Dascyllus carneus, $43 \mathrm{~mm}$ SL.

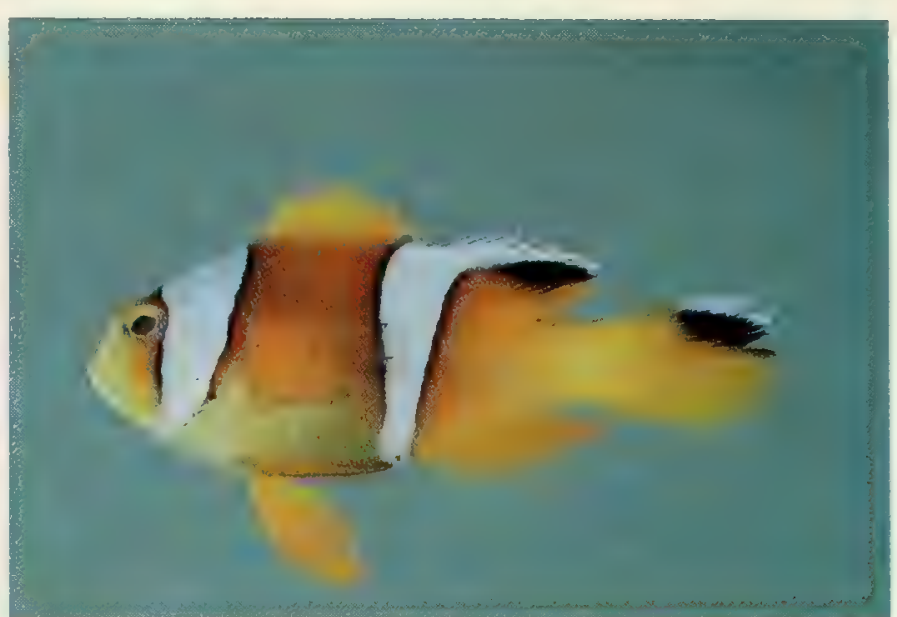

B. Amphiprion sp., $22 \mathrm{~mm}$ SL.

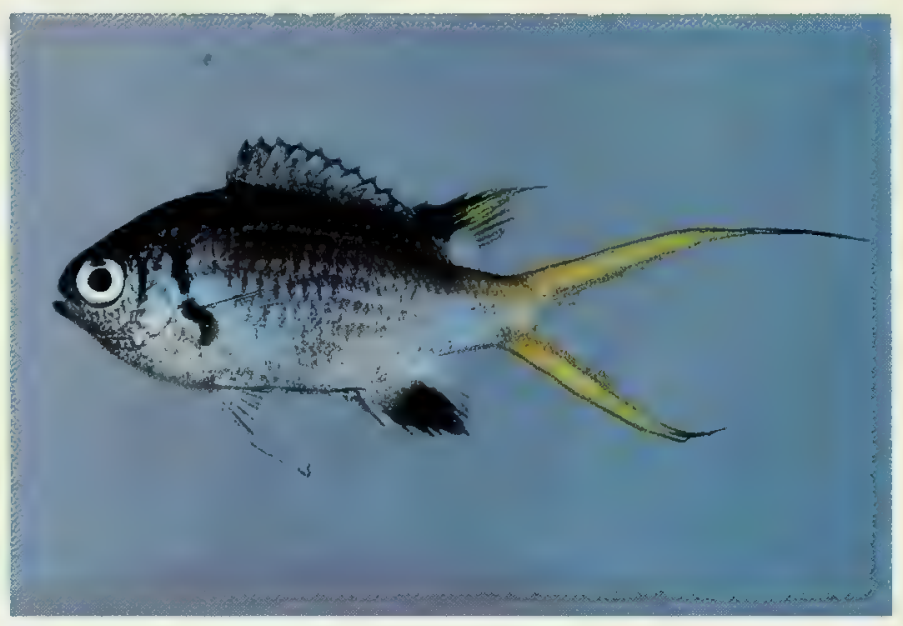

D. Chromis opercularis, $41 \mathrm{~mm} \mathrm{SL.}$

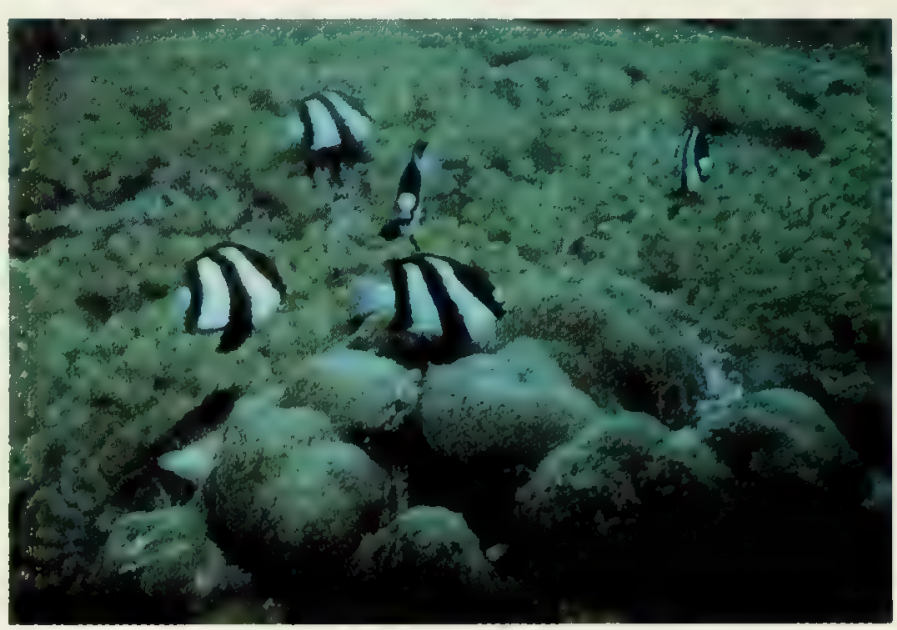

F. Dascyllus aruanus.

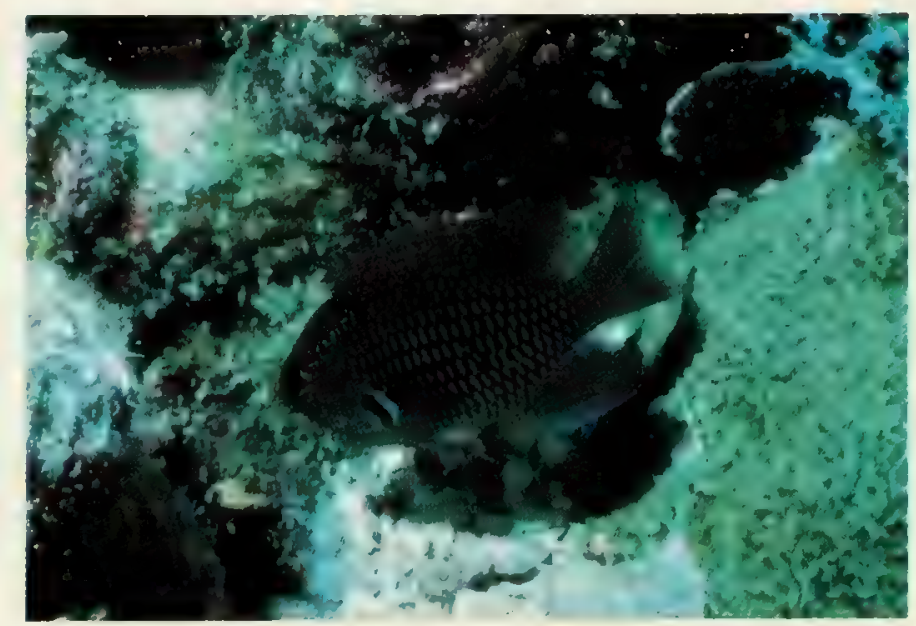

H. Pomacentrus sp. 1. 


\section{Plate VII}

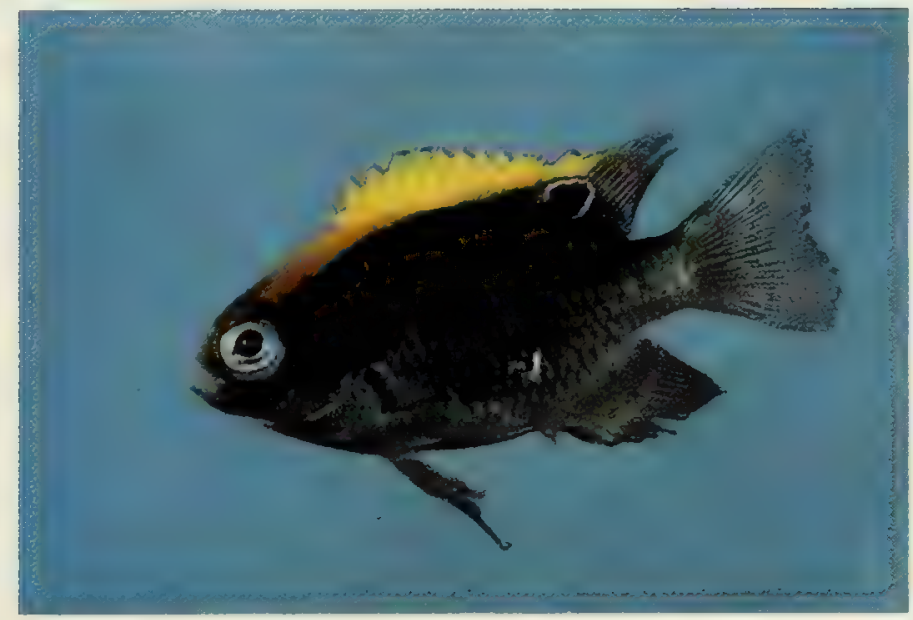

A. Pomacentrus sp. 1, juvenile.

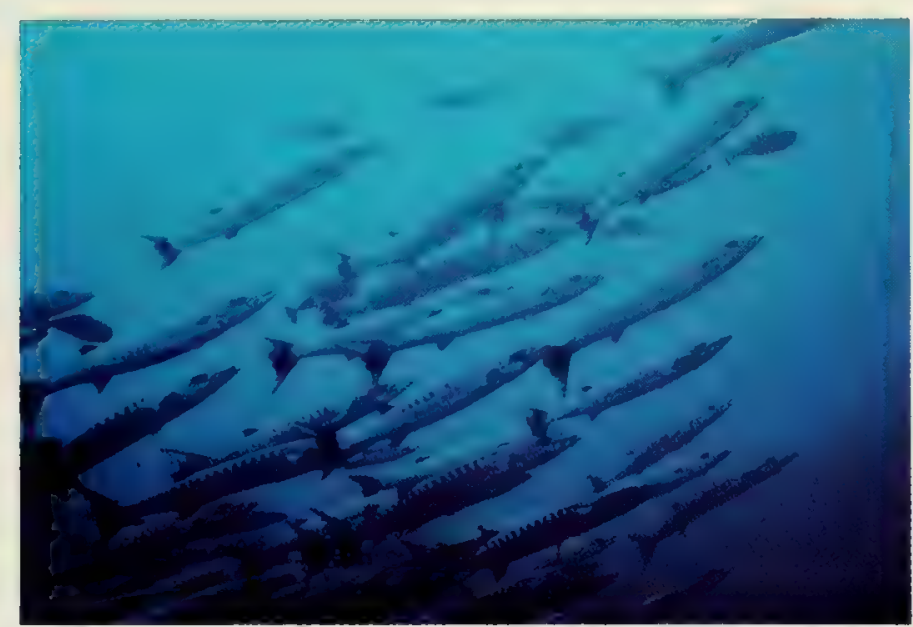

C. Sphyraena nigripinnis, Salomon.

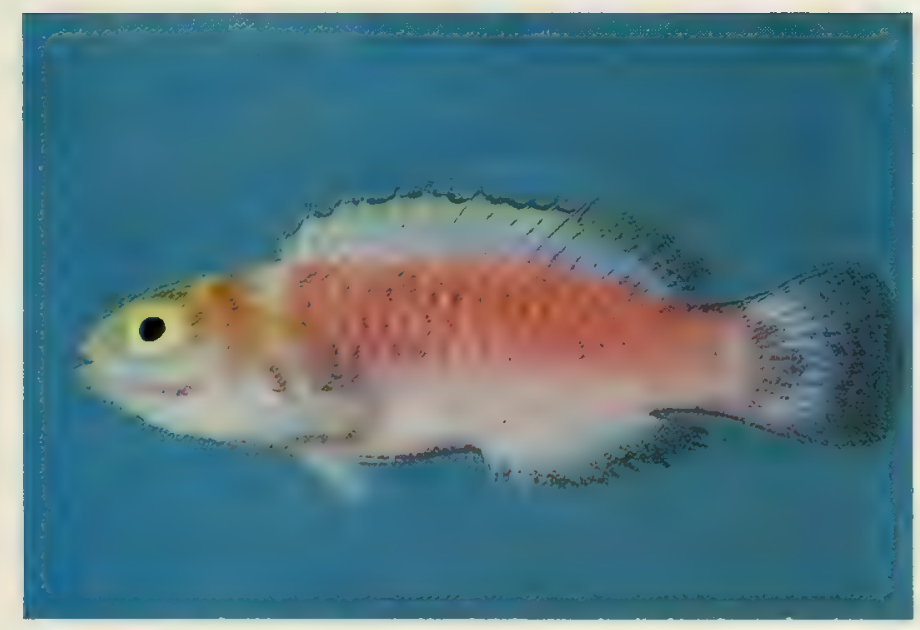

E. Cirrhilabrus rubrisquamis, $41 \mathrm{~mm} \mathrm{SL}$.

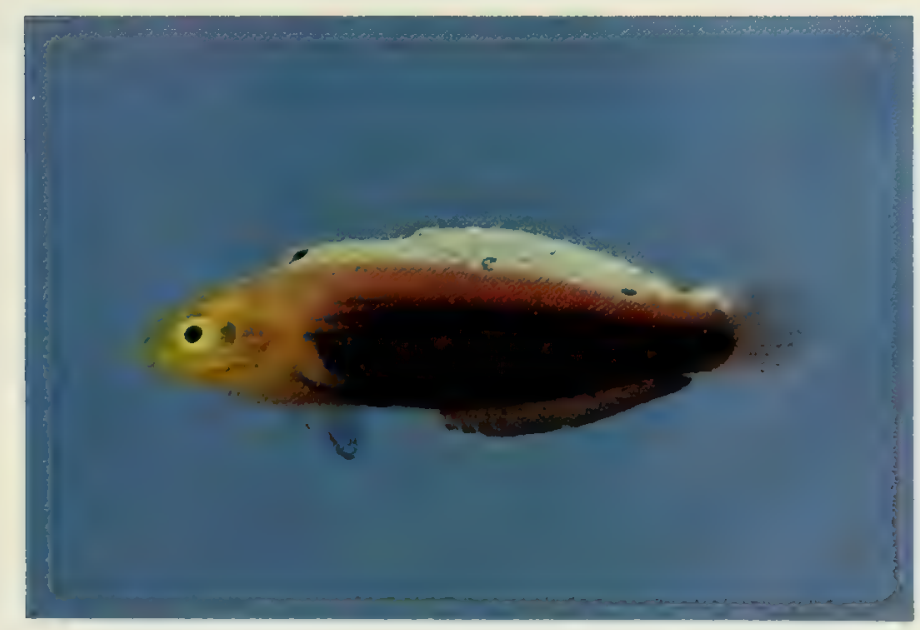

G. Halichoeres iridis, $45 \mathrm{~mm}$ SL.

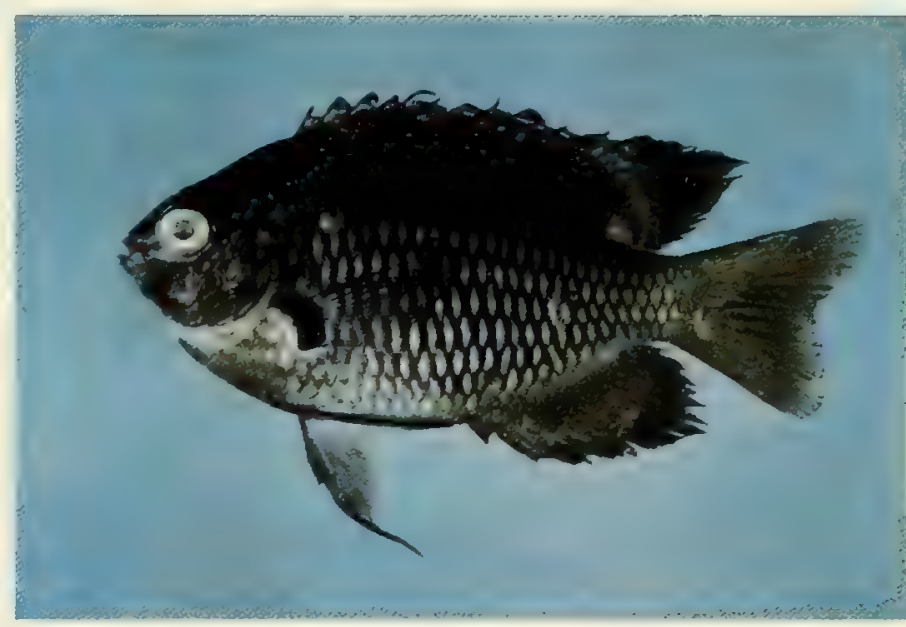

B. Pomacentrus sp. 1, adult.

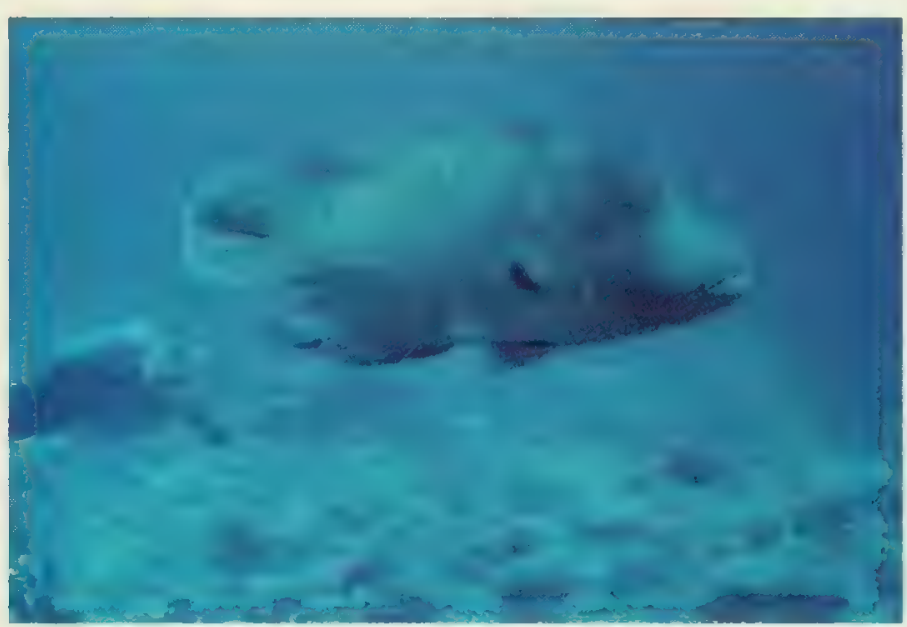

D. Cheilinus undulatus, Salomon.

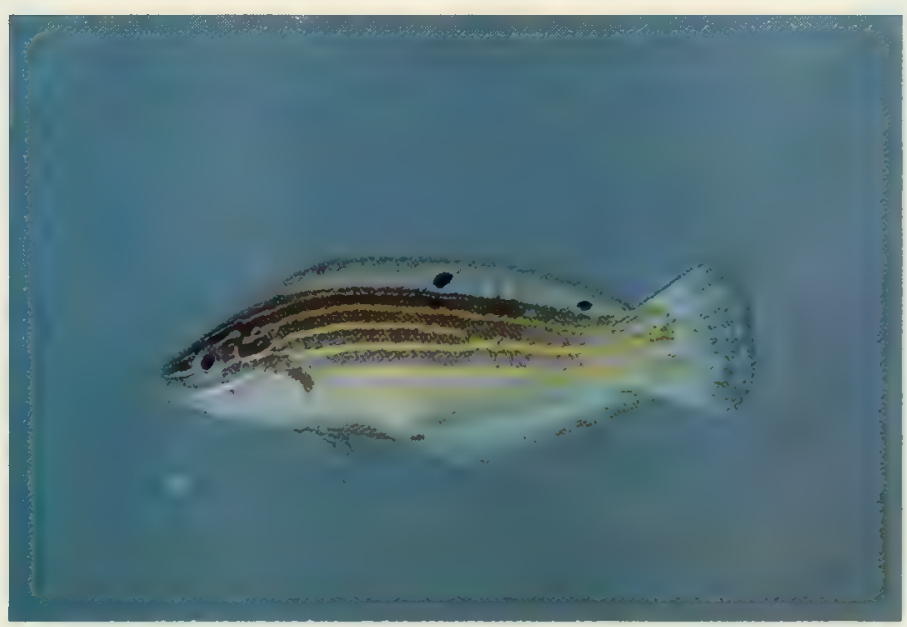

F. Halichoeres cosmetus, $62 \mathrm{~mm} \mathrm{SL}$.

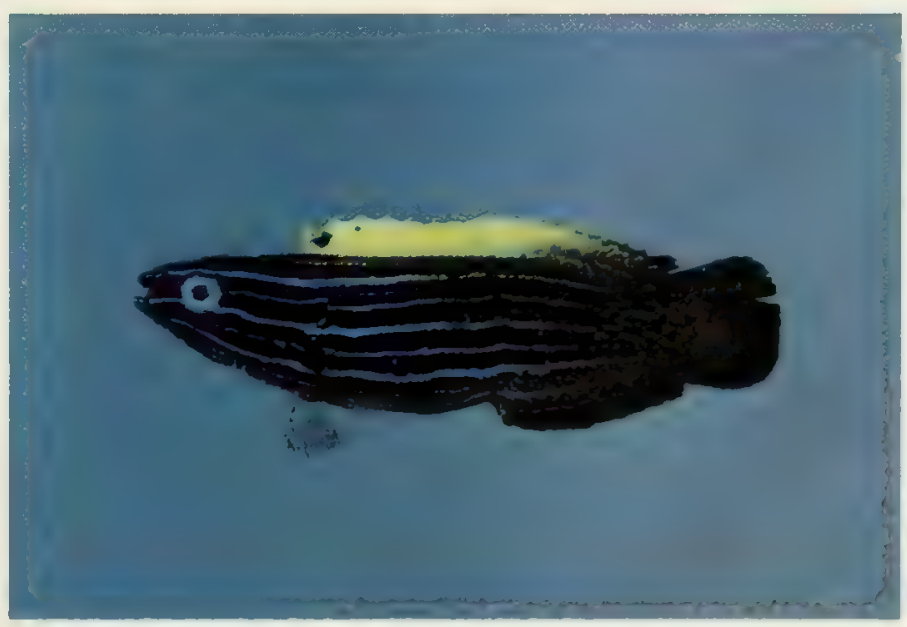

H. Labropsis xanthonota, $40 \mathrm{~mm} \mathrm{SL}$. 


\section{Plate VIII}

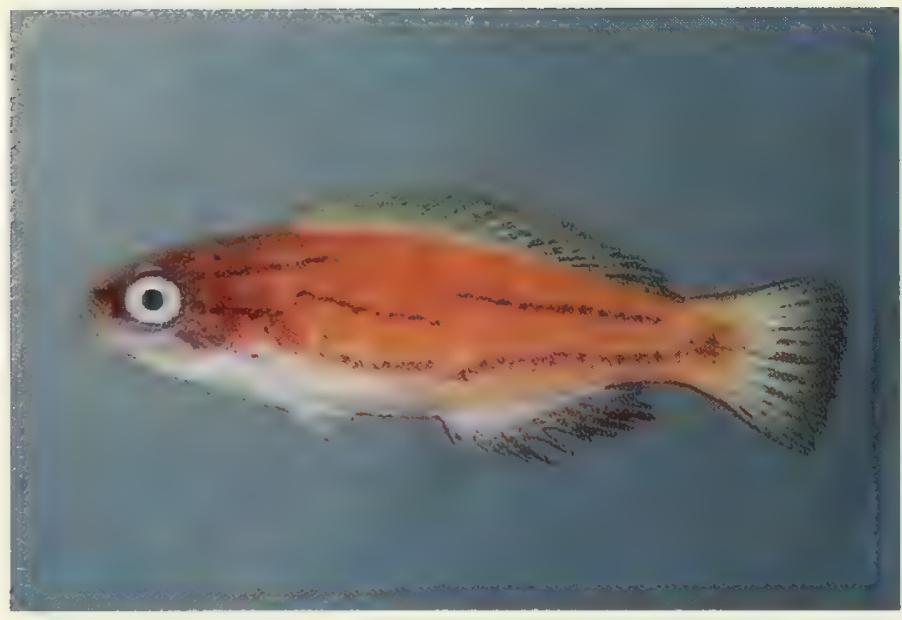

A. Paracheilinus mccoskeri, $40 \mathrm{~mm}$ SL.

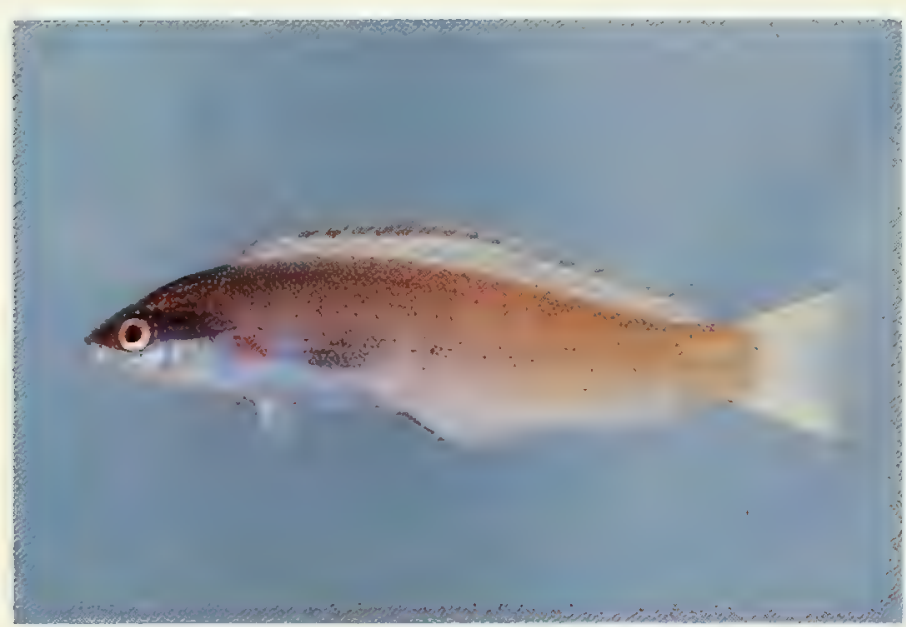

C. Pseudocoris yamashiroi, $61 \mathrm{~mm} \mathrm{SL}$.

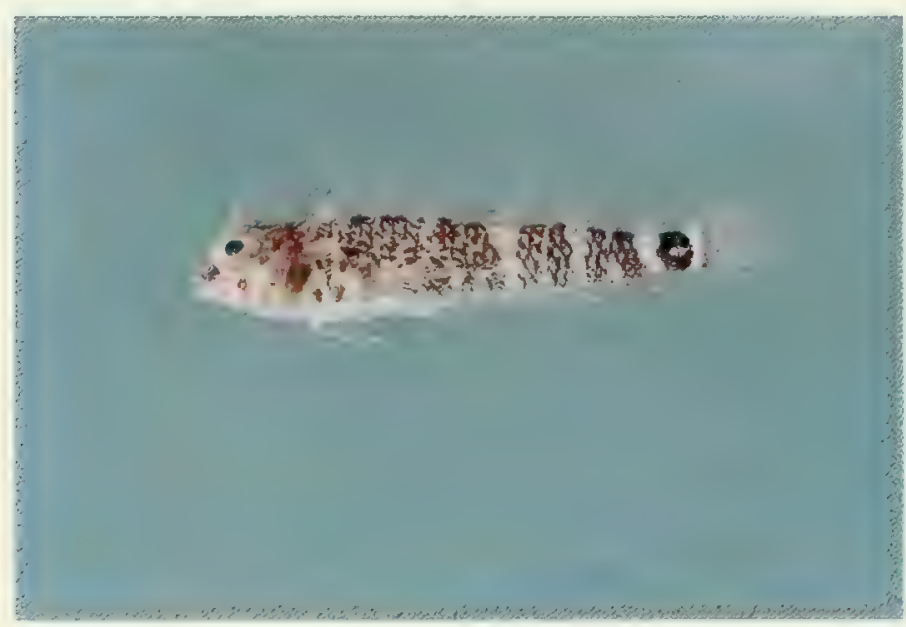

E. Enneapterygius sp., Peros Banhos.

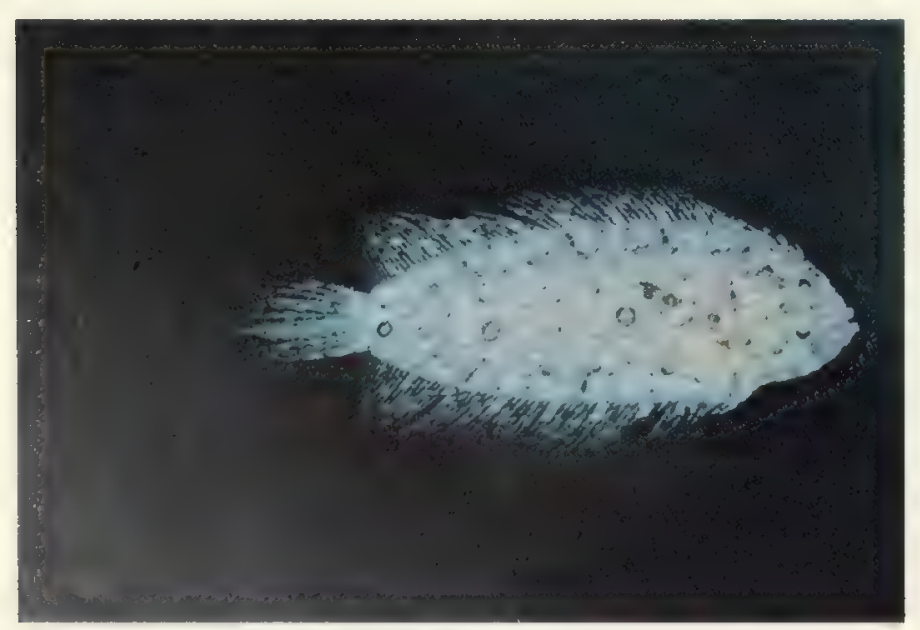

G. ?Monochirus sp., $19 \mathrm{~mm}$ SL.

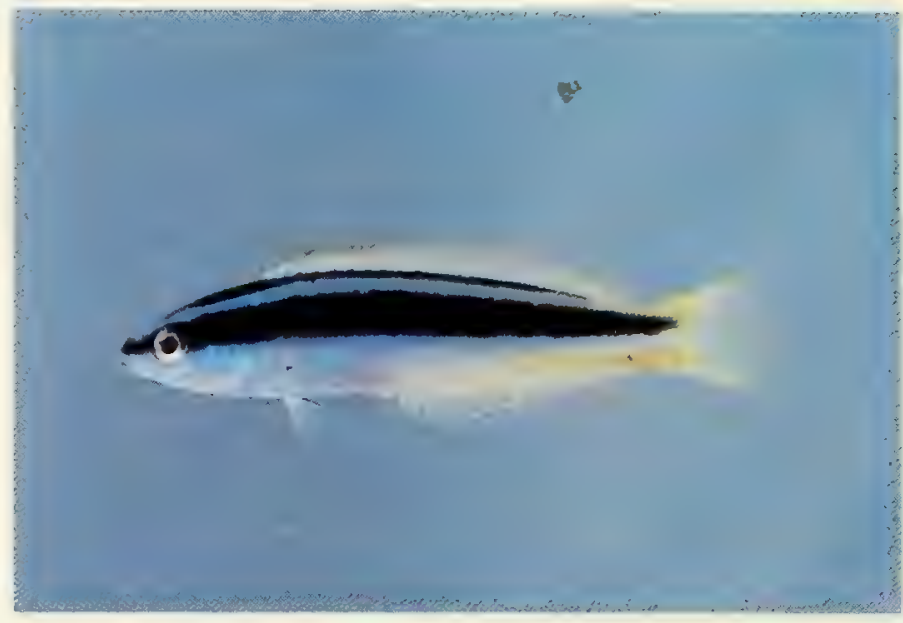

B. Pseudocoris heteroptera, $39 \mathrm{~mm}$ SL.

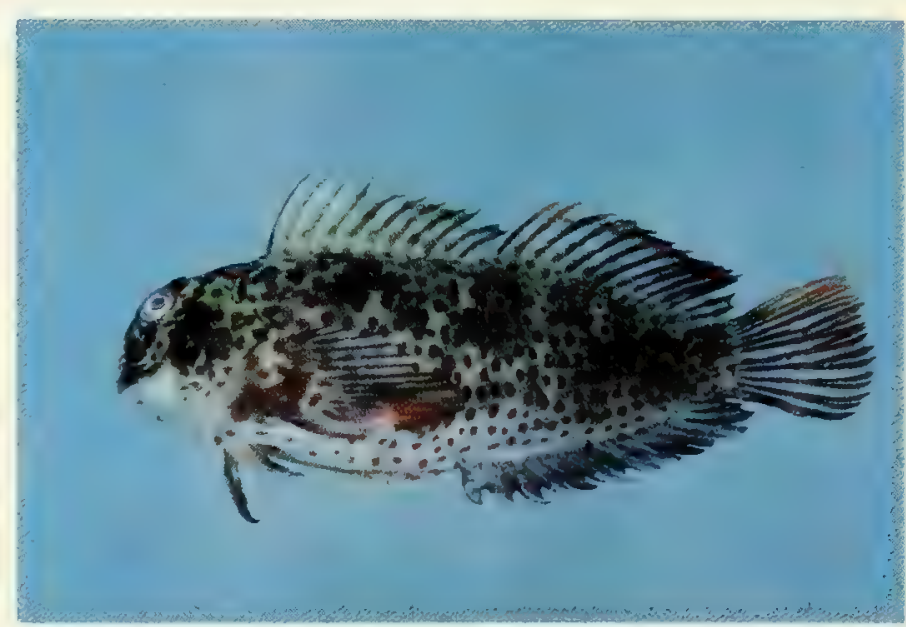

D. Cirripectes sp., Salomon.

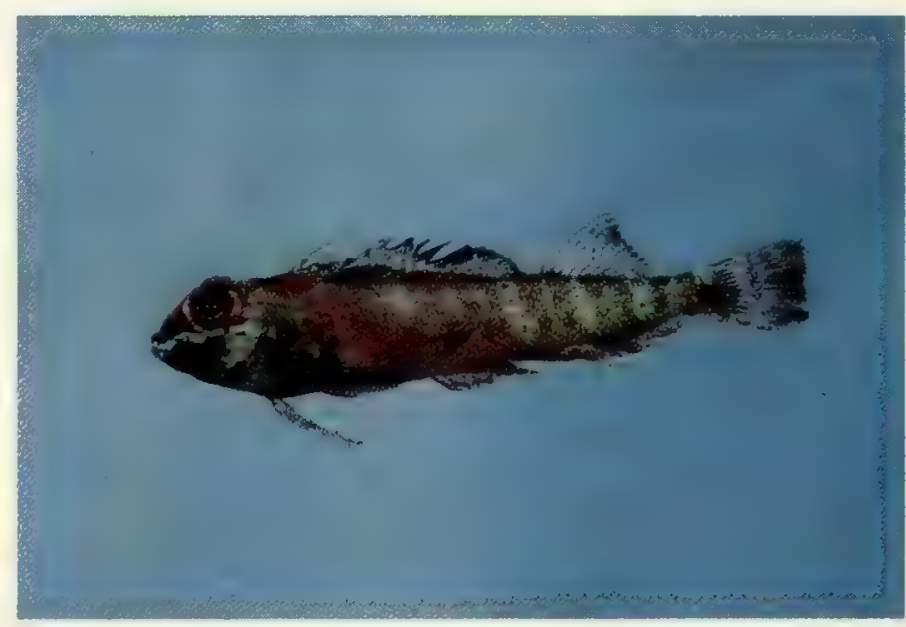

F. Helcogramma fuscopinna, $32 \mathrm{~mm} \mathrm{SL}$.

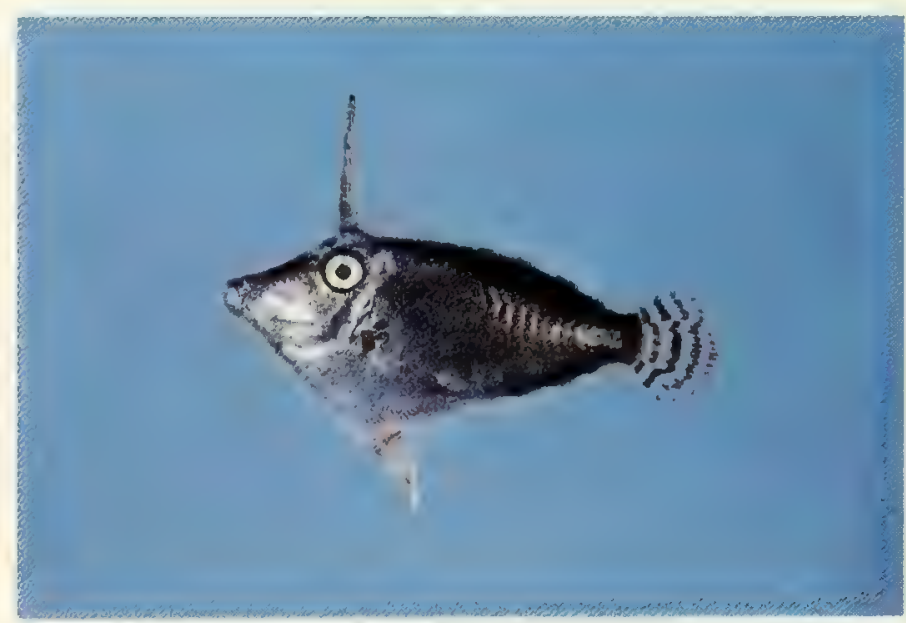

H. Pervagor janthinosoma, $38 \mathrm{~mm}$ SL. 
MATERIAL

Three lots, 3 specimens, 230-567 mm SL, 0.75-42 m, lagoon and drop-off at Peros Banhos (photos: 230, 304, and $567 \mathrm{~mm}$ ). The specimen of $P$. truncatus from Chagos reported on by Kyushin et al. (1977) apparently belongs to this species (Randall, pers. comm.). Indo-Pacific.

\section{Plectropomus pessuliferus Fowler}

Plectropoma pessuliferus Fowler, 1904:520 (Padang) Plectropomus maculatus-Kyushin et al., 1977:184 (Chagos Archipelago); Heemstra and Randall, 1984:129 (Indo-west Pacific)

No specimens seen or collected; the record is based on Kyushin et al. (1977). Indo-west Pacific.

\section{Plectropomus punctatus Quoy and Gaimard}

Plectropoma punctata Quoy and Gaimard, 1824:318 (Mauritius)

Plectropomus punctatus-Heemstra and Randall, 1984:131 (western Indian Ocean, including Chagos)

No specimens seen or collected; the record is based on Heemstra and Randall (1984). Western Indian Ocean.

\section{Promicrops lanceolatus (Bloch)}

Fig. 146

Holocentrus lanceolatus Bloch, 1790:92 (East Indies)

Promicrops lanceolatus-Randall, 1985:470(Society Islands)

\section{MATERIAL}

One lot, 1 specimen, ca $900 \mathrm{~mm}$ SL (head only kept), $25 \mathrm{~m}$, lagoon at Salomon (photo). Indo-Pacific.

\section{Pseudogramma polyacantha (Bleeker)}

Fig. 147

Pseudochromis polyacanthus Bleeker, 1856a:375 (Ternate, Indonesia)

Pseudogramma polyacantha-Randall, 1973:187 (Tahiti)

MATERIAL

Thirty-five lots, 245 specimens, 7-49 mm SL, 0-26 m, lagoon, intertidal, reef-flat, reef-top, and drop-off at Eagle Island, Peros Banhos, and Salomon (photos: 12, 13, and $37 \mathrm{~mm}$ ). This species was collected primarily on the reef-tops $(\overline{\mathrm{x}} /$ lot $=10.6)$ and drop-off $(\overline{\mathrm{x}} / \mathrm{lot}=7.8)$, which combined represented $86 \%$ of the specimens collected. It preferred a depth range of $6-25 \mathrm{~m}(\overline{\mathrm{x}} / \mathrm{lot}=7.8 ; 92 \%$ specimens collected). Indo-Pacific.

\section{Variola albimarginata Baissac}

Fig. 148

Variola albimarginata Baissac, 1953:214 (Mauritius); Heemstra and Randall, 1984:141 (Indo-west Pacific)

\section{MATERIAL}

One lot, 2 specimens, 210-222 mm SL, $20 \mathrm{~m}$, drop-off at Peros Banhos (photo: $210 \mathrm{~mm}$ ). Indo-west Pacific.

Variola louti (Forsskål)

Fig. 149

Perca louti Forsskål, 1775:40 (Red Sea)

Variola louti-Randall, 1973:186 (Tahiti); Kyushin et al., 1977:178 (Chagos Archipelago)

\section{MATERIAL}

Two lots, 2 specimens, 357-370 mm SL, 15-20 m, lagoon and drop-off at Peros Banhos (photo: $370 \mathrm{~mm}$ ). IndoPacific.

\section{Anthiidae}

Anthias squamipinnis (Peters)*

Fig. 150 Serranus squamipinnis Peters, 1855b:429 (Mozambique) Anthias squamipinnis-Randall, 1983b:52 (Indo-west Pacific)

\section{MATERIAL}

Nineteen lots, 187 specimens, 19-74 mm SL, 6-48 m, drop-off, reef-top, and lagoon at Eagle Island, Peros Banhos, and Salomon (photos: 3 specimens). Most of our specimens $(68 \% ; \overline{\mathrm{x}} /$ lot $=10.7$ specimens $)$ were collected on the drop-offs; $61 \%$ of the total $(\overline{\mathrm{x}} / \mathrm{lot}=12.7$ specimens $)$ were taken in depths of 6-15 m. Indo-west Pacific.

\section{Anthias sp. \\ PI. IVE,F MATERIAL}

Four lots, 16 specimens, 16-53 mm SL, 33-48 m, drop-off only at Peros Banhos and Salomon (photos: 5 specimens). The material has been sent to Dr Heemstra, who suspects that it represents an undescribed species. Distribution insufficiently known to categorize. Range unassigned.

\section{Mirolabrichthys evansi (Smith)}

Pl. IVG

Anthias evansi Smith, 1954a:1 (Shimoni, Kenya)

Anthias (Mirolabrichthys) evansi-Randall and Lubbock, 1981a:4 (Indian Ocean, including Cocos[Keeling] Island)

\section{MATERIAL}

Seven lots, 16 specimens, 18-79 mm SL, 15-43 m, drop-off and lagoon (near pass) at Peros Banhos and Salomon (photos: 3 specimens). Indian Ocean.

Nemanthias carberryi Smith

PI. IVH

Nemanthias carberryi Smith, $1954 a: 4$ (Malindi, Kenya)

\section{MATERIAL}

Ten lots, 461 specimens, 19-65 mm SL, 15-43 m, dropoff and lagoon (near pass) at Peros Banhos and Salomon (photos: 3 specimens). Indian Ocean. 
Plectranthias longimanus (Weber)*

Fig. 151

Pteranthias longimanus Weber, 1913:209 (Paternoster Island, Indonesia)

Plectranthias longimanus-Randall, 1980:148 (Indowest Pacific; Caroline Islands)

MATERIAL

One lot, 1 specimen, $12 \mathrm{~mm} \mathrm{SL}, 33-43 \mathrm{~m}$, drop-off at Salomon. The above specimen was identified using Randall's key (1980). However, Randall states (op. cit., p. 151), "... this species seems more likely to be found on coral reefs of continental areas or large islands. By contrast, the closely related $P$. nanus, the color pattern of which is almost identical to $P$. longimanus, is more apt to be found around small oceanic islands." Indo-west Pacific and marginally on the Pacific plate.

\section{Pseudochromidae}

\section{Chlidichthys inornatus Lubbock}

Fig. 152

Chlidichthys inornatus Lubbock, 1976:169 (Sri Lanka; also Chagos Archipelago)

Pseudoplesiops typus-Regan, 1908:228 (Peros Banhos, Chagos Archipelago) (non Bleeker, 1858)

\section{MATERIAL}

Fifty-five lots, 635 specimens, $10-34 \mathrm{~mm} \mathrm{SL}, 0-43 \mathrm{~m}$, lagoon, drop-off, reef-top, reef-flat, and intertidal at Diego Garcia, Eagle Island, Peros Banhos, Salomon, and Three Brothers (photos: 19 and $23 \mathrm{~mm}$ ). The only pseudochromid collected at Chagos, $C$. inornatus was very common. There were, however, certain patterns discernible in its distribution. The main habitats were the lagoons $(\bar{x} / l o t=12.7)$ and drop-offs $(\bar{x} /$ lot $=14.5)$, together accounting for $87 \%$ of the specimens collected. The preferred depth range was the same as that for Pseudogramma polyacantha: $84 \%$ of the specimens were collected between $6-25 \mathrm{~m}$. The species is recorded only from Sri Lanka, the Maldives, and Chagos (Lubbock, 1976). Central Indian Ocean.

\section{Plesiopidae}

Calloplesiops altivelis (Steindachner)

Plesiops altivelis Steindachner, 1903:17 (Sumatra)

Calloplesiops altivelis-Springer, 1982:72 (Indo-west

Pacific and marginally on the Pacific plate)

\section{MATERIAL}

Four lots, 5 specimens, 49-69 mm SL, 3-25 m, lagoon and drop-off at Peros Banhos and Salomon (photo: $62 \mathrm{~mm}$ ). Although this species has been recorded from the Tuamotu Islands, Springer (1982) remains sceptical of this record and regards the species as being Indo-west Pacific in distribution with subsequent dispersal via the Caroline conduit onto the Pacific plate. Indo-west Pacific and marginally on the Pacific plate.

\section{Kuhliidae}

Kuhlia mugil (Schneider)

Fig. 154

Sciaena mugil Schneider in Bloch and Schneider, 1801:541 (Tahiti)

Kuhlia mugil-Heemstra, 1984a:3 (Indo-Pacific, including Chagos)

\section{MATERIAL}

Two lots, 24 specimens, $21-87 \mathrm{~mm} \mathrm{SL}, 0-1 \mathrm{~m}$, reef-flat at Peros Banhos and Salomon (photo: $87 \mathrm{~mm}$ ). Indo-Pacific.

\section{Priacanthidae}

Priacanthus cruentatus (Lacepède)

Fig. 155

Labrus cruentatus Lacepède, 1802a:452 (America)

Priacanthus cruentatus-Starnes, 1984:5 (circumtropical, including Chagos)

\section{MATERIAL}

Three lots, 3 specimens, $88-173 \mathrm{~mm} \mathrm{SL}, 3-25 \mathrm{~m}$, lagoon and drop-off (photo: $172 \mathrm{~mm}$ ). Circumtropical.

\section{Apogonidae}

Apogon abrogramma Fraser and Lachner Pl. VA Apogon abrogramma Fraser and Lachner, 1985:5 (Indian Ocean, including Chagos, east to Philippines)

\section{MATERIAL}

Nineteen lots, 171 specimens, $22-86 \mathrm{~mm} \mathrm{SL}, 0-32 \mathrm{~m}$, lagoon, intertidal, reef-top, and drop-off at Eagle Island, Peros Banhos, Salomon, and Three Brothers (photos: 24, $57,66,72[\times 2], 76$, and $85 \mathrm{~mm})$. This species was most abundant in $0-10 \mathrm{~m}$ in the lagoons, where $91 \%$ of our specimens were caught. It is similar to A. exostigma, but lacks a well-developed caudal spot.

Two specimens, 85 and $93 \mathrm{~mm} \mathrm{SL}$, are intermediate in several characters between A. abrogramma and A. kallopterus. The specimens are generally pale in colour (see $\mathrm{Pl}$. VA). One of these two specimens has an obvious dark spot above the end of the lateral line; the other has a faint spot in this region. The leading edges of the caudal fin are black, more prominently so in the specimen with the faint caudal spot, and in both cases more prominently than in $A$. abrogramma. Dr T. H. Fraser examined a colour slide of 
one of the specimens and suggested that it could be a pale $A$. kallopterus. However, the interorbital width of the two specimens is narrower $(6.5-7.1 \%$ of SL vs $7.5-8.2 \%$ of SL in A. kallopterus), and the body is less deep (34.9$36.0 \%$ of SL vs $35.7-38.0 \%$ of SL; $n=7$ ). The lengths of the first and second dorsal spines in the two specimens are intermediate between A. abrogramma and A. kallopterus, being $4.0-4.1 \%, 2.6-3.0 \%$, and $4.2-5.0 \%$ SL for the first spine and $10.6 \%, 7.4-7.9 \%$, and $11.8-12.1 \%$ SL for the second spine, respectively. Predorsal scale counts are 4-5 for the two specimens, with a mean of 5.6 in A. abrogramma and 5.0 in A. kallopterus. The above data, coupled with the abundance of $A$. abrogramma and $A$. kallopterus at Chagos, suggest that these two specimens could be hybrids. Indo-west Pacific.

Apogon angustatus (Smith and Radcliffe) Fig. 156 Amia angustata Smith and Radcliffe in Radcliffe, 1912a:253 (Malanipa, Philippines)

Apogon angustatus - Randall, 1973:183 (Tahiti)

\section{MATERIAL}

Fourteen lots, 39 specimens, 15-60 mm SL, 5-25 m, lagoon, reef-top, and drop-off at Eagle Island, Peros Banhos, and Salomon (photos: 28, 41, and $58 \mathrm{~mm}$ ). Sixty-seven per cent of our specimens were collected on the reef-tops, and $87 \%$ of the total were taken in $15-25 \mathrm{~m}$. Indo-Pacific.

\section{Apogon apogonides (Bleeker)}

Fig. 157

Cheilodipterus apogonides Bleeker, 1856e:37 (Manado, Celebes)

Apogon apogonides_Randall, 1973:183 (Tahiti)

\section{MATERIAL}

One lot, 49 specimens, 29-54 mm SL, 10-15 m, reef-top at Peros Banhos (photos: 30 and $54 \mathrm{~mm}$ ). Indo-Pacific.

\section{Apogon coccineus Rüppell}

Fig. 158

Apogon coccineus Rüppell, 1838:88 (Red Sea); Randall, 1973:183 (Tahiti)

Amia doryssa Jordan and Seale, 1906:245 (Samoa)

\section{MATERIAL}

Forty lots, 150 specimens, 10-38 mm SL, 0-43 m, lagoon, intertidal, reef-flat, reef-top, and drop-off at Diego Garcia, Eagle Island, Peros Banhos, Salomon, and Three Brothers (photo: $32 \mathrm{~mm}$ ). Apogon coccineus was fairly evenly distributed in four major habitats (lagoon $30 \%$, intertidal $28 \%$, reef-top $21 \%$, and drop-off $18 \%$ ). However, $82 \%$ of the specimens were collected in less than $15 \mathrm{~m}$ of water depth, and $97 \%$ in less than $25 \mathrm{~m}$.

We tentatively regard $A$. doryssa as a synonym of $A$. coccineus, but feel that $A$. erythrinus is a distinct species.
The above specimens have 12 pectoral rays (vs 13-14 in $A$. erythrinus). The shape of the head in Rüppell's figure (1838, p1. 22, fig. 5) matches the more pointed head of our specimens (more blunt in $A$. erythrinus). The single photographed specimen was pale with red scale margins on the nape and anterodorsal half of the body. Gill rakers 7-12 developed, with a total of $13-18(n=14)$. IndoPacific.

Apogon crassiceps Garman

Fig. 159 Apogon crassiceps Garman, 1903:230 (Fiji); Schultz, 1943:96 (Samoa)

\section{MATERIAL}

Two lots, 2 specimens, 45-81 mm SL, 3-10 m, lagoon at Peros Banhos and Three Brothers (photo: $45 \mathrm{~mm}$ ). Indowest Pacific.

Apogon erythrinus Snyder

Fig. 160 Apogon erythrinus Snyder, 1904:526 (Hawaii); Randall, 1955c:69 (Gilbert Islands)

\section{MATERIAL}

Two lots, 7 specimens, $16-30 \mathrm{~mm}$ SL, 0-3 m, lagoon and reef-top at Diego Garcia and Salomon. This species is very similar to $A$. coccineus, but differs from it in the following ways: $A$. erythrinus has a shorter second dorsal spine (3.9-4.7 in SL vs 5.7-6.6 in SL); its melanophores on the predorsal extend onto the lateral body surface, cheeks, and opercles; and it possesses a vague dusky bar which passes posteroventrally from the posteroventral corner of the eye. Indo-Pacific.

Apogon evermanni Jordan and Snyder Pl. VB Apogon evermanni Jordan and Snyder, 1904:123 (Hawaii); Randall and Böhlke, 1981:131 (Indo-Pacific, including Chagos; Caribbean)

\section{MATERIAL}

Two lots, 5 specimens, 41-69 mm SL, 18-43 m, drop-off at Peros Banhos and Salomon (photos: 64 and $68 \mathrm{~mm}$ ). Indo-Pacific and western Atlantic.

\section{Apogon frenatus Valenciennes}

Fig. 161

Apogon fraenatus Valenciennes, 1832:57 (New Guinea and Guam); Fraser and Lachner, 1985:24 (Indo-Pacific, east to Tuamotu Islands)

\section{MATERIAL}

Two lots, 8 specimens, 24-51 mm SL, 4-13 m, lagoon at Peros Banhos. Indo-Pacific.

Apogon kallopterus Bleeker

Fig. 162 Apogon kallopterus Bleeker, 1856e:33 (Manado, Celebes); 
Fraser and Lachner, 1985:8 (Indo-Pacific, including Chagos, east to Pitcairn Island)

\section{MATERIAL}

Thirty-two lots, 193 specimens, 23-92 mm SL, 0-43 m, lagoon, intertidal, reef-flat, reef-top, and drop-off at Diego Garcia, Eagle Island, Peros Banhos, Salomon, and Three Brothers (photos: 26, 36, 46, 61, 76, 84, and $91 \mathrm{~mm}$ ). No major patterns of habitat or depth associations were found. The mean numbers of specimens/lot for the habitats listed above were $5.3,6.5,13.5,4.0$, and 6.5, respectively. Although the reef-flat seems significantly higher than other habitats $(\overline{\mathrm{x}} / \mathrm{lot}=13.5)$, only two reef-flat stations (of a total of five) yielded specimens. Indo-Pacific.

\section{Apogon leptacanthus Bleeker}

Fig. 163

Apogon leptacanthus Bleeker, 1856f:204 (Ternate, Indonesia); Fraser and Lachner, 1985:34 (Indo-Pacific, including Chagos, east to Marshall Islands and Samoa)

\section{MATERIAL}

Two lots, 288 specimens, $15-36 \mathrm{~mm} \mathrm{SL,} \mathrm{1-15} \mathrm{m} \mathrm{lagoon}$ and reef-top at Diego Garcia and Peros Banhos. The vast majority of the specimens $(n=280)$ were collected by Ryther in the lagoon at Diego Garcia. Indo-west Pacific and marginally on the Pacific plate.

\section{Apogon savayensis Günther}

Fig. 164 Apogon savayensis Günther, 1871:656 (Samoa and Celebes); Randall, 1973:18 (Tahiti)

\section{MATERIAL}

Twenty-seven lots, 146 specimens, 12-75 mm SL, 0$33 \mathrm{~m}$, lagoon, intertidal, reef-top, and drop-off at Diego Garcia, Eagle Island, Peros Banhos, Salomon, and Three Brothers (photos: 63 and $75 \mathrm{~mm}$ ). A. savayensis is a quiet, shallow-water inhabitant. The lagoon and fringing intertidal region yielded $95.2 \%$ of our specimens, and $93.2 \%$ of our material was collected in water less than $15 \mathrm{~m}$ in depth. Indo-Pacific.

\section{Apogon semiornatus Peters}

Fig. 165

Apogon semiornatus Peters, 1876:436 (Mauritius); Allen and Steene, 1979:29 ("Indo-west Pacific")

\section{MATERIAL}

Seven lots, 11 specimens, $11-23$ mm SL, 5-26 m, reef-top and drop-off at Peros Banhos and Salomon (photo: $23 \mathrm{~mm}$ ). "Indo-west Pacific."

\section{Apogon taeniophorus Regan}

Fig. 166

Apogon taeniophorus Regan, 1908:226 (Maldives); Allen and Steene, 1979:29 (Indian Ocean to Christmas Island)

\section{MATERIAL}

Ten lots, 84 specimens, $18-73 \mathrm{~mm} \mathrm{SL,} \mathrm{0-7} \mathrm{m,} \mathrm{lagoon,}$ intertidal, reef-flat, and reef-top at Diego Garcia, Eagle Island, Peros Banhos, and Salomon (photos: 46 and $67 \mathrm{~mm}$ ). The species was most abundant on the reef-flats where $68 \%$ of the specimens were collected, with a mean of 11.4 specimens/lot. Indian Ocean.

Apogon talboti Smith

Fig. 167

Apogon talboti Smith, 1961:387 (Zanzibar); Russell, 1983:50 (Great Barrier Reef)

\section{MATERIAL}

Three lots, 3 specimens, 38-53 mm SL, 18-43 m, dropoffs at Peros Banhos and Salomon. Indo-west Pacific.

\section{Apogon sp. 1}

Fig. 168

MATERIAL

One lot, 1 specimen, $48 \mathrm{~mm} \mathrm{SL}, 40-43 \mathrm{~m}$, drop-off at Peros Banhos.

This specimen has the following characteristics: D VI I 9; A 10 (sic); P 13 (first ray rudimentary and unbranched); 3 + 13 developed gill rakers on the first arch with two undeveloped rakers both dorsally and ventrally; preopercular ridge entire, edge of preopercle serrated; about 24 lateral-line scales; a midlateral and a dorsolateral dark stripe; a thin horizontal stripe of melanophores in the soft dorsal and anal fins just distal to their bases; and a dark eye-diameter-sized spot covering the hypural region of the caudal peduncle. The presence of 10 anal rays and no anal spines is most unusual and may indicate that this specimen is aberrant. It may, in addition, represent a new species. If we ignore the anal-fin ray count and lack of anal spines, it keys out to Apogon (Nectamia) using Fraser's (1972) key. It could represent the same species as $A$. sp. of Burgess and Axelrod (1975:1440) and of Hayashi and Kishimoto (1983:34), and A. sp. 1 of Masuda et al. (1984:146, pl. 130-M) from Japan. Range unassigned.

\section{Apogonichthys perdix Bleeker}

Fig. 169 Apogonichthys perdix Bleeker, 1854b:321 (Flores Island, Indonesia); Smith, 1961:391 (east Africa and Red Sea); Randall, 1985:471 (Rapa)

?Apogon variegatus_Regan, 1908:224 (Diego Garcia, Chagos Archipelago_- part)

\section{MATERIAL}

Five lots, 9 specimens, 15-26 mm SL, 0-7 m, lagoon, intertidal, and reef-flat at Diego Garcia and Peros Banhos. One of the three specimens from Diego Garcia identified as Apogon variegatus by Regan (1908) appears to be an Apogonichthys. We were unable to identify it to species since the specimen is faded, but it seems likely to be $A$. perdix. Indo-Pacific. 
Archamia fucata (Cantor)

Fig. 170

Apogon fucatus Cantor, 1849:986 ("Sea of Pinang")

Archamia fucata - Lachner, 1953:477 (Marshall Islands)

\section{MATERIAL}

Four lots, 251 specimens, $25-51 \mathrm{~mm} \mathrm{SL}, 1-25 \mathrm{~m}$, lagoon only at Diego Garcia, Peros Banhos, and Salomon (photos: $32,49$, and $50 \mathrm{~mm})$. Most of the above specimens $(\mathrm{n}=$ 240) were taken from a cave in a large (ca 7-m diameter) hollowed-out bommie that rose about $4 \mathrm{~m}$ from a sandy bottom in $7 \mathrm{~m}$ at the east end of Isle du Coin, Peros Banhos. According to Lachner (1953), this species frequents the deeper waters of the lagoon, although we do have six specimens from 1-3m in the lagoon at Diego Garcia. Indo-west Pacific and marginally on the Pacific plate.

\section{Cheilodipterus lachneri Klausewitz}

Fig. 171

Cheilodipterus lachneri Klausewitz, 1959:260 (Al Ghardaqua, Red Sea); Allen and Steene, 1979:29 (Indian Ocean, including Christmas Island)

\section{MATERIAL}

Eighteen lots, 95 specimens, 22-95 mm SL, 0-43 m, lagoon and drop-off at Peros Banhos, Salomon, and Three Brothers (photos: 57 and $68 \mathrm{~mm}$ ). Cheilodipterus lachneri was collected only in the lagoons and on the drop-offs, with $50 \%$ of specimens being taken in $6-15 \mathrm{~m}$, and $90 \%$ in a water depth of $6-35 \mathrm{~m}$.

This species is often difficult to separate from $C$. macrodon, but possesses more formed gill rakers (11-17 vs $8-11$, the number decreasing with age). Indian Ocean.

\section{Cheilodipterus macrodon (Lacepède)}

Fig. 172

Centropomus macrodon Lacepède, 1802b:252 (Mauritius and Réunion)

Cheilodipterus macrodon-Lachner, 1953:484 (IndoPacific east to Gambier Islands)

\section{MATERIAL}

Eleven lots, 63 specimens, 15-141 mm SL, 0-24 m, lagoon, intertidal, reef-top, and drop-off at Diego Garcia, Eagle Island, Peros Banhos, Salomon, and Three Brothers (photos: 32, 47, 65, and $141 \mathrm{~mm}$ ). This species appears to prefer shallow lagoonal waters less than $10 \mathrm{~m}$ deep, where $89 \%$ of our specimens were collected. Indo-Pacific

\section{Cheilodipterus quinquelineatus Cuvier}

Fig. 173

Cheilodipterus quinquelineatus Cuvier in Cuvier and Valenciennes, 1828:167 (Society Islands)

Chilodipterus quinquelineatus - Regan, 1908:224 (Diego

Garcia, Chagos Archipelago)

\section{MATERIAL}

Twenty lots, 102 specimens, $12-77 \mathrm{~mm} \mathrm{SL}, 0-40 \mathrm{~m}$, lagoon and reef-top (1) at Diego Garcia, Peros Banhos, Salomon, and Three Brothers (photos: 2 missing specimens). Thirty-nine per cent of the above specimens are from less than $10 \mathrm{~m}$, and $85 \%$ from less than $20 \mathrm{~m}$. Indo-Pacific.

\section{Foa sp.}

Apogon variegatus-Regan, 1908:224 (Diego Garcia, Chagos Archipelago-part)

\section{MATERIAL}

One lot, 2 specimens, 24-29 mm SL, 18 m, Diego Garcia, $\mathrm{BM}(\mathrm{NH})$ 1908.3.23.81-83. Two of the three specimens identified by Regan (1908) as Apogon variegatus (currently placed in Fowleria) had an incomplete lateral line, palatine teeth, and a smooth preopercular edge. These characters are diagnostic for Foa in Fraser's (1972) key. The specimens could not be identified to species since the colour pattern has faded. Range unassigned.

\section{Fowleria abocellata Goren and Karplus}

Fig. 174

Fowleria abocellata Goren and Karplus, 1980:232 (Gulf of Elat, Red Sea)

Foa abocellata-Hayashi and Kishimoto, 1983:19 (Ryukyu Islands)

\section{MATERIAL}

Two lots, 2 specimens, $26(\times 2) \mathrm{mm} \mathrm{SL}, 0-1 \mathrm{~m}$, intertidal at Eagle Island (photo).

Like most apogonid genera, Foa and Fowleria are in need of revision. Lachner (1953) recognized four species in this complex, while Smith (1961) recognized only Fowleria aurita and remarked that a "few [specimens] lack the opercular ocellus" (p. 383). The above specimens differ from the original description in lacking the dark spot at the tips of the third to fifth dorsal spines (both in the photograph of the freshly dead and in the preserved specimens). In addition, the median fins lack any pigmentation other than iridocytes and scattered melanophores and are pale in the preserved material. The record by Hayashi and Kishimoto (1983) from the Ryukyu Islands may represent a different species. The Chagos specimens, and specimens from Fiji, lack palatine teeth and would, therefore, fall into Fowleria rather than Foa in Fraser's (1972) key. However, Masuda et al. (1984) include this species in Foa because it retains the first suspensory infrapharyngobranchial. Since Fraser's character, lack of palatine teeth, is apparently an apomorphy, whereas Masuda et al.'s character, retention of the first pharyngobranchial, is a plesiomorphic one, we place this species in Fowleria rather than Foa, with the hint that it may be the plesiomorphic sister group of the other species of that genus. Indo-west Pacific. 
Fowleria aurita (Valenciennes)

Fig. 175

Apogon auritus Valenciennes in Cuvier and Valenciennes, 1831a:443 (Mauritius); Kami, Ikehara, and DeLeon, 1968:106 (Guam)

\section{MATERIAL}

Fourteen lots, 37 specimens, 16-92 mm SL, 0-32 m, lagoon, intertidal (1), and reef-top (1) at Diego Garcia, Peros Banhos, Salomon, and Three Brothers (photos: 24 [ $\times 2$ ] $, 29,44,68$, and $92 \mathrm{~mm}$ ).

Within this material, there are two main colour patternsplain and barred. The latter colour pattern is identified as $F$. marmorata in Masuda et al. (1984, pl. 29-D), and other of our specimens are similar to what Masuda et al. (1984, pl. 29-C) identify as $F$. isostigma. No attempt has been made to separate the above specimens on the basis of colour pattern because of the intermediates which suggest that they are all one species. Randall (1985) records both species from French Polynesia. Whatever the resolution of the systematic problem turns out to be, it would appear that the distribution is Indo-Pacific.

\section{Fowleria variegata (Valenciennes)}

Fig. 176 Apogon variegatus Valenciennes, 1832:55 (Mauritius); Lachner, 1953:475 (Guam)

\section{MATERIAL}

Six lots, 26 specimens, $20-75 \mathrm{~mm} \mathrm{SL}, 0-15 \mathrm{~m}$, lagoon at Diego Garcia and Salomon (photos: 70 and $75 \mathrm{~mm}$ ).

This species was confined to the lagoons and was collected only in the two most sheltered lagoons sampled. A total of six rotenone stations was made in each of the lagoons, with 11 specimens collected from Salomon and 15 from Diego Garcia. The lagoon at Diego Garcia has openings to the sea only at its northern end, whereas Salomon, in addition to the main pass at the northwest corner of the atoll, has another 10 shallow, inter-island channels subject to tidal flow.

The opercular blotch is sometimes obscured by a patch of silvery pigment and may be absent in juveniles. Indo-west Pacific and marginally on the Pacific plate.

\section{Gymnapogon sp.}

Fig. 177

\section{MATERIAL}

Four lots, 4 specimens, 21-34 mm SL, 0-9 m, lagoon, reef-flat, and reef-top at Diego Garcia, Salomon, and Three Brothers.

Fraser (1972) tentatively recognizes six species of Gymnapogon. Smith (1961) records $G$. africanus as the only member of the genus present in the western Indian Ocean and Red Sea. His description is very similar to that of Henichthys philippinus Herre, and the two nominal species may well be synonymous. In addition, Smith (1954c) felt that his series of specimens showed that the caudal fin changes from emarginate to forked with growth, and he cautioned against placing much emphasis on the degree of papillae development. Should these remarks prove valid, it would imply that the two above names would become synonyms of $G$. vanderbilti (Fowler). Range unassigned.

Neamia octospina Smith and Radcliffe

Fig. 178 Neamia octospina Smith and Radcliffe in Radcliffe, 1912b:441 (Philippines)

\section{MATERIAL}

One lot, 3 specimens, $15-31 \mathrm{~mm} \mathrm{SL}, 7 \mathrm{~m}$, lagoon at Three Brothers. Indo-west Pacific.

Pseudamia gelatinosa Smith

Fig. 179

Pseudamia gelatinosa Smith, 1955b:690 (Aldabra Islands); Randall, Lachner, and Fraser, 1985:9 (Indo-Pacific east to Austral Island)

\section{MATERIAL}

Twenty lots, 54 specimens, $13-80 \mathrm{~mm}$ SL, 0-32 m, lagoon, intertidal (1), reef-flat (1), and reef-top (2) at Diego Garcia, Peros Banhos, Salomon, and Three Brothers (photos: 24 and $57 \mathrm{~mm}$ ). The majority of the above specimens $(70 \%)$ are from $6-15 \mathrm{~m}$ in the lagoons, with $89 \%$ collected in lagoons (all depths combined). IndoPacific.

Pseudamiops gracilicauda (Lachner)

Fig. 180

Gymnapogon gracilicauda Lachner, 1953:497 (Marshall Islands)

Pseudamiops pellucidus Smith, 1954c:785 (Malindi, Kenya)

\section{MATERIAL}

Seven lots, 9 specimens, 22-29 mm SL, 0.5-15 m, lagoon and reef-top at Peros Banhos and Salomon (photo: $23 \mathrm{~mm}$ ).

There are several apparent differences between $P$. gracilicauda and $P$. pellucida (see table in Smith, 1954c:785, and Fraser, 1972:31). All but one of these differences fall away on our examination of the above material and six specimens (16-39 mm SL) from Fiji. Lachner (1953) mentioned that $P$. gracilicauda lacked scales on the head and body, whereas all our material possesses scales, as does $P$. pellucida. Ms Jewett reexamined Lachner's type material at our request and found no scales, but did find evidence of scale pockets, particularly on the belly (in litt.). Fraser (1972) reported that $P$. pellucida has five suborbital bones and $P$. gracilicauda has six. Our material was not examined for this character. Fraser also stated that the two 
species differed in the position of the first dorsal pterygiophore, which lies anterior to the third neural spine in $P$. pellucida and posterior to that spine in $P$. gracilicauda. In the Chagos material the pterygiophore lies behind the third neural spine in all specimens, as it does in two of the six Fiji specimens. In the holotype of $P$. gracilicauda the first pterygiophore is inserted anterior to the third neural spine, but in four paratypes $(15-19 \mathrm{~mm} \mathrm{SL})$ the pterygiophore is inserted posterior to the third neural spine. There appears to be some correlation between the position of insertion of the pterygiophore and size-in most specimens less than $29 \mathrm{~mm} \mathrm{SL}$ the insertion is posterior to the neural spine, while in most larger specimens it is anterior to this spine. Pseudamiops pellucida is supposed to have a single enlarged canine on the vomer, versus a single row of small vomerine teeth in $P$. gracilicauda (Fraser, 1972). Our material exhibits the latter condition, except for the largest of the Fiji specimens, which has two large canines on the vomer. $P$. pellucida has 14 pectoral-fins rays, a simple first dorsal-fin ray, 9 anal rays, and 5 lower gill rakers (Smith, $1954 \mathrm{c}$ ), whereas corresponding data for $P$. gracilicauda is 15-16, branched, 8 , and 7 , respectively. Corresponding data for the Chagos material is $13-14$, simple (but branched in largest specimen), 8 (once 7), and 6, respectively; and for the Fiji specimens, 13-16, branched, 8, and 6 or 7 . We tentatively conclude that $P$. pellucida is a synonym of $P$. gracilicauda until a more detailed examination and additional material make a reevaluation possible. Indo-west Pacific.

\section{Pseudamiops sp.}

Fig. 181

\section{MATERIAL}

Nine lots, 16 specimens, 14-21 mm SL, 3-36 m, lagoon and drop-off at Peros Banhos and Salomon.

This is a small species, with gravid females $17-18 \mathrm{~mm}$ $\mathrm{SL}$, that apparently is undescribed. It is unique among apogonids in possessing only a single anal spine. It has many fine teeth on the vomer, palatines, and pterygoids; a rounded caudal fin; and a darkly pigmented peritoneum. It apparently lacks scales. We were unable to ascertain the position of the first dorsal-fin pterygiophore from radiographs, but it lies posterior to the third neural spine in our three cleared and stained specimens. Range unassigned.

\section{Rhabdamia cypselurus Weber}

Fig. 182

Rhabdamia cypselurus Weber, 1909:167 (Seram)

Apogon cypselurus-Lachner, 1953:450 (Marshall Islands)

\section{MATERIAL}

Two lots, 353 specimens, $25-44 \mathrm{~mm} \mathrm{SL}, 5-7 \mathrm{~m}$, lagoon at Peros Banhos (photo: $38 \mathrm{~mm}$ ). Indo-west Pacific and marginally on the Pacific plate.

\section{Malacanthidae}

Malacanthus brevirostris Guichenot

Fig. 183

Malacanthus brevirostris Guichenot, 1848:14 (Madagascar; Réunion); Dooley, 1978:58 (Indo-Pacific)

\section{MATERIAL}

One lot, 1 specimen, $168 \mathrm{~mm} \mathrm{SL}, 13 \mathrm{~m}$, lagoon at Peros Banhos (photo). Indo-Pacific.

\section{Malacanthus latovittatus (Lacepède)}

Labrus latovittatus Lacepède, 1802a:455 ("Great Equatorial Ocean")

Malacanthus latovittatus—Dooley, 1978:60 (Indo-Pacific)

No specimens collected; record based on a sighting of two specimens on the reef-top, west coast of Salomon. IndoPacific.

\section{Lactariidae}

\section{Lactarius lactarius (Bloch and Schneider)}

Scomber lactarius Bloch and Schneider, 1801:31 (Tranquebar)

Lactarius lactarius-Kumaran, 1984:3 (Indo-west Pacific, including Chagos)

No specimens seen or collected; occurrence is based on Kumaran (1984). Doubtful literature record, range unassigned.

\section{Rachycentridae}

\section{Rachycentron canadum (Linnaeus)}

Gasterosteus canadum Linnaeus, 1766:491 (Carolina, U.S.A.)

Rachycentron canadum-Collette, 1984c:3 (cosmopolitan, including Chagos)

No specimens seen or collected; occurrence is based on Coliette (1984c). Cosmopolitan.

\section{Echeneididae}

Echeneis naucrates Linnaeus

Fig. 184

Echeneis naucrates Linnaeus, 1758:261 (Indian Ocean); Lachner and Collette, 1984:4 (cosmopolitan, including Chagos)

MATERIAL

Two lots, 4 specimens, $108-270 \mathrm{~mm}$ SL, $1.5-10 \mathrm{~m}$, 
lagoon and reef-top at Eagle Island and Peros Banhos (photo: $248 \mathrm{~mm}$ ). Cosmopolitan.

\section{Carangidae}

Most of the carangids were identified by Dr W. F. Smith-Vaniz.

\section{Carangoides orthogrammus (Jordan} and Gilbert)

Fig. 185

Caranx orthogrammus Jordan and Gilbert, 1882:226 (Clarión Island)

Caranx ferdua-Kyushin et al., 1977:266 (Chagos Archipelago) (non Forsskål, 1775)

Carangoides orthogrammus-Smith-Vaniz, 1984:63 (Indo-

Pacific, including Chagos)

\section{MATERIAL}

Two lots, 2 specimens, 329-533 FL, 5-7 m, reef-top at Salomon (photo: $533 \mathrm{~mm}$ ). Indo-Pacific.

\section{Carangoides plagiotaenia (Bleeker)}

Caranx plagiotaenia Bleeker, 1857a:59 (Ambon)

Caranx compressus-Kyushin et al., 1977:272 (Chagos Archipelago) (non Day, 1870)

Carangoides plagiotaenia-Smith-Vaniz, 1984:65 (IndoPacific)

No specimens seen or collected; the record is based on the report of $C$. compressus by Kyushin et al. (1977) from Chagos. Their specimens were taken by vertical longline in 22-120 m. Indo-Pacific.

\section{Caranx ignobilis (Forsskål)}

Fig. 186

Scomber ignobilis Forsskål, 1775:55 (Jiddah, Red Sea)

Caranx ignobilis-Smith-Vaniz, 1984:73 (Indo-Pacific, including Chagos)

\section{MATERIAL}

One lot, 1 specimen, $56 \mathrm{~mm}$ SL, 0-0.5 m, lagoon at Diego Garcia. Indo-Pacific.

\section{Caranx lugubris Poey}

Caranx lugubris Poey, 1858:222 (Cuba); Kyushin et al., 1977:264 (Chagos Archipelago); Smith-Vaniz, 1984:83 (circumtropical)

No specimens seen or collected; the record is based on the report and photograph of two specimens taken by vertical longline by Kyushin et al. (1977). Circumtropical.

\section{Caranx melampygus Cuvier}

Fig. 187 Caranx melampygus Cuvier in Cuvier and Valenciennes, 1833:116 (Waigeo; Rawak; Vanicolo; Buru; Mauritius);
Smith-Vaniz, 1984:75 (Indo-Pacific, including Chagos)

\section{MATERIAL}

Four lots, 4 specimens, 70-519 mm FL, 0-17 m, lagoon and reef-flat at Peros Banhos (photo: $519 \mathrm{~mm}$ ). Indo-Pacific.

Caranx sexfasciatus Quoy and Gaimard Fig. 188 Caranx sexfasciatus Quoy and Gaimard, 1824:358 ("Iles des Papous"); Smith-Vaniz, 1984:77 (Indo-Pacific, including Chagos)

\section{MATERIAL}

Six lots, 8 specimens, 60-594 mm FL, 0-25 m, lagoon, intertidal, and drop-off at Peros Banhos and Salomon (photos: 70, 119, and $594 \mathrm{~mm}$ ). Indo-Pacific.

Elagatis bipinnulata (Quoy and Gaimard) Fig. 189 Seriola bipinnulata Quoy and Gaimard, 1824:363 ("Iles des Papous")

Elagatis bipinnulata-Smith-Vaniz, $1984: 99$ (circumtropical, including Chagos)

\section{MATERIAL}

Two lots, 2 specimens, 494-510 mm FL, 0-15 m, lagoon and reef-top at Peros Banhos (photo: $510 \mathrm{~mm}$ ). Circumtropical.

\section{Gnathanodon speciosus (Forsskål)}

Fig. 190

Scomber speciosus Forsskål, 1775:54 (Jiddah, Red Sea) Gnathanodon speciosus_-Smith-Vaniz, 1984:101 (IndoPacific)

\section{MATERIAL}

Two lots, 2 specimens, 30-173 mm FL, 0.5-2 m, lagoon and intertidal at Peros Banhos (photos: both). Indo-Pacific.

\section{Naucrates ductor (Linnaeus)}

Gasterosteus ductor Linnaeus, 1758:295 ("in Pelago") Naucrates ductor-Smith-Vaniz, 1984:107 (circumtropical, including Chagos)

No specimens seen or collected; occurrence is based on Smith-Vaniz (1984). Circumtropical.

Scomberoides lysan (Forsskål)

Fig. 191 Scomber lysan Forsskål, 1775:54 (Jiddah and Lohaja, Red Sea)

Scomberoides lysan-Smith-Vaniz, 1984:115 (Indo-Pacific, including Chagos)

\section{MATERIAL}

Five lots, 8 specimens, $27-465 \mathrm{~mm}$ FL, $0-2 \mathrm{~m}$, lagoon at Diego Garcia, Peros Banhos, and Salomon (photo: $83 \mathrm{~mm}$ ). Indo-Pacific. 
Selar crumenophthalmus (Bloch)

Scomber crumenophthalmus Bloch, 1793:77 (Guinea, West Africa)

Selar crumenophthalmus-Smith-Vaniz, 1984:121 (circumtropical)

\section{MATERIAL}

Two lots, 4 specimens, $77-123 \mathrm{~mm}$ FL, 0-1 m, intertidal and reef-flat at Diego Garcia and Salomon. Circumtropical.

\section{Seriola rivoliana Valenciennes}

Seriola rivoliana Valenciennes in Cuvier and Valenciennes, 1833:207 (uncertain); Smith-Vaniz, 1984:127 (circumtropical)

Seriola songoro-Kyushin et al., 1977:278 (Chagos Archipelago)

No specimens seen or collected; the record is based on the report in Kyushin et al. (1977) of S. songoro (Smith, 1959 a) captured in $30-160 \mathrm{~m}$ by vertical longline. Circumtropical.

\section{Trachinotus baillonii (Lacepède)}

Fig. 193

Caesiomorus baillonii Lacepède, 1802a:92 (Madagascar)

Trachinotus baillonii-Smith-Vaniz, 1984:135 (Indo-Pacific, including Chagos)

\section{MATERIAL}

Five lots, 30 specimens, $63-337 \mathrm{FL}, 0-4 \mathrm{~m}$, pass, lagoon, intertidal, and reef-flat at Eagle Island, Peros Banhos, and Salomon (photos: 194 and $224 \mathrm{~mm}$ ). Indo-Pacific.

\section{Coryphaenidae}

\section{Coryphaena equiselis Linnaeus}

Coryphaena equiselis Linnaeus, 1758:261 ("in alto Pelago"); Collette, 1984b:5 (cosmopolitan, including Chagos)

\section{MATERIAL}

One lot, 1 specimen, $15 \mathrm{~mm} \mathrm{SL}, 0.5 \mathrm{~m}$, lagoon at Peros Banhos. Cosmopolitan.

\section{Coryphaena hippurus Linnaeus}

Coryphaena hippurus Linnaeus, 1758:261 ("in Pelago"); Collette, 1984b:3 (cosmopolitan, including Chagos)

No specimens seen or collected; occurrence is based on Collette (1984b). Cosmopolitan.

\section{Menidae}

\section{Mene maculata (Bloch and Schneider)}

Zeus maculata Bloch and Schneider, 1801:95 (Tranquebar)
Mene maculata-Heemstra, 1984b:3 (Indo-Pacific, including Chagos)

No specimens seen or collected; occurrence is based on Heemstra (1984b). Indo-Pacific.

\section{Bramidae}

\section{Brama dussumieri Cuvier}

Brama dussumieri Cuvier in Cuvier and Valenciennes, 1831a:294 (Indian Ocean); Haedrich and Nzioka, 1984a:5 (circumtropical, including Chagos)

No specimens seen or collected; occurrence is based on the report of Haedrich and Nzioka (1984a). Circumtropical.

\section{Lutjanidae}

\section{Aphareus furcatus (Lacepède)}

Fig. 194 Labrus furcatus Lacepède, 1802a:429 (Indian and Pacific oceans)

Aphareus furcatus - Allen, 1984:15 (Indo-Pacific, including Chagos)

\section{MATERIAL}

Two lots, 2 specimens, 261-262 mm SL, 0-20 m, lagoon at Peros Banhos (photo: $261 \mathrm{~mm}$ ). Indo-Pacific.

Aprion virescens Valenciennes

Fig. 195 Aprion virescens Valenciennes in Cuvier and Valenciennes, 1830b:544 (Seychelles); Allen, 1984:17 (IndoPacific, including Chagos)

\section{MATERIAL}

Three lots, 3 specimens, 425-445 mm SL, 0-20 m, lagoon and drop-off at Peros Banhos (photo: $445 \mathrm{~mm}$ ). Indo-Pacific.

Caesio caerulaureus Lacepède

Fig. 196

Caesio caerulaureus Lacepède, 1802a:85 (Moluccas)

\section{MATERIAL}

Two lots, 25 specimens, $34-101 \mathrm{~mm} \mathrm{SL}, 3-7 \mathrm{~m}$, lagoon at Peros Banhos (photos: 89 and $101 \mathrm{~mm}$ ). The caesionin material was identified by $\mathrm{K}$. Carpenter, who also provided the information on geographic ranges. Caesio caerulaurea is known from east Africa to Tahiti. Indo-Pacific.

\section{Caesio lunaris Cuvier}

Caesio lunaris Cuvier in Cuvier and Valenciennes, 1830b:441 (Indian Ocean; Red Sea; New Ireland)

MATERIAL

Three lots, 6 specimens, $32-171 \mathrm{~mm} \mathrm{SL}, 3-10 \mathrm{~m}$, lagoon 
at Peros Banhos (photos: 32, 153, and $166 \mathrm{~mm}$ ). Indo-west Pacific east to Solomons.

Caesio teres Seale

Pl. VC

Caesio teres Seale, 1906:44 (Shortland Island, Solomon Islands)

MATERIAL

Three lots, 4 specimens, 41-169 mm SL, 1-20 m, lagoon at Peros Banhos and Salomon (photo: $95 \mathrm{~mm}$ ). Indo-west Pacific and marginally on the Pacific plate (Gilbert Islands).

Caesio xanthonota Bleeker

Pl. VD

Caesio xanthonotus Bleeker, 1853c:466 (Jakarta)

\section{MATERIAL}

Two lots, 4 specimens, 129-169 mm SL, 1-20 m, lagoon and drop-off at Peros Banhos and Salomon (photo: $166 \mathrm{~mm}$ ). Indo-west Pacific (east to Philippines and Great Barrier Reef.

\section{Etelis carbunculus Cuvier}

Etelis carbunculus Cuvier in Cuvier and Valenciennes, 1828:127 (Seychelles); Kyushin et al., 1977:116 (Chagos Archipelago); Randall, 1973:190 (Tahiti).

No specimens seen or collected; the record is based on the illustration and report of three specimens taken by vertical longline in 12-160 m by Kyushin et al. (1977). Indo-Pacific.

\section{Lutjanus bohar (Forsskål)}

Fig. 198

Sciaena bohar Forsskål, 1775:46 (Red Sea)

Lutjanus bohar-Allen, 1984:27 (Indo-Pacific, including Chagos)

\section{MATERIAL}

Five lots, 7 specimens, $48-359 \mathrm{~mm} \mathrm{SL}, 0-18 \mathrm{~m}$, lagoon, reef-top, and drop-off at Peros Banhos and Salomon (photos: 45 and $144 \mathrm{~mm}$ ). This species was second in abundance to $L$. gibbus at Chagos and frequently appeared at rotenone stations picking up stunned fish. It was also reported from Chagos by Kyushin et al. (1977). Indo-Pacific.

\section{Lutjanus erythropterus Bloch}

Lutjanus erythropterus Bloch, 1790:115 (Japan); Allen, 1984:39 (Indo-Pacific, including Chagos)

No specimens seen or collected; occurrence is based on Allen (1984). Indo-Pacific.

\section{Lutjanus fulviflammus (Forsskål)}

Sciaena fulviflamma Forsskål, 1775:45 (Red Sea)

Lutjanus fulviflammus - Allen, 1984:29 (Indo-Pacific, including Chagos)
No specimens seen or collected; occurrence is based on Allen (1984). Indo-Pacific.

Lutjanus fulvus (Schneider)

Fig. 199 Holocentrus fulvus Schneider in Bloch and Schneider, 1801:318 (Tahiti)

Lutjanus fulvus-Allen, 1984:61 (Indo-Pacific, including Chagos)

\section{MATERIAL}

Two lots, 5 specimens, $126-168 \mathrm{~mm} \mathrm{SL}, 1-2 \mathrm{~m}$, lagoon and reef-flat at Diego Garcia. Indo-Pacific.

Lutjanus gibbus (Forsskål)

Fig. 200

Sciaena gibbus Forsskål, 1775:46 (Red Sea)

Lutjanus gibbus-Allen, 1984:31 (Indo-Pacific, including Chagos)

\section{MATERIAL}

Nine lots, 12 specimens, 96-289 mm SL, 0-33 m, lagoon, intertidal, and drop-off at Diego Garcia, Peros Banhos, and Salomon (photos: 96, 126, 260, and $285 \mathrm{~mm}$ ). This was the most abundant species of Lutjanus at Chagos and was frequently seen in huge schools on the reef-top at the edge of the drop-off. Indo-Pacific.

\section{Lutjanus kasmira (Forsskål)}

Fig. 201

Sciaena kasmira Forsskål, 1775:46 (Red Sea)

Lutjanus kasmira-Allen, 1984:63 (Indo-Pacific, including Chagos)

\section{MATERIAL}

Five lots, 66 specimens, 32-190 mm SL, 0-42 m, lagoon, reef-flat, reef-top, and drop-off at Diego Garcia and Peros Banhos (photo: $151 \mathrm{~mm}$ ). The main lot of this species $(\mathrm{n}=$ 57) was taken from a large, hollowed-out bommie near a shallow inter-island pass in $7 \mathrm{~m}$ at the south end of Isle du Coin, Peros Banhos. Indo-Pacific.

\section{Lutjanus lutjanus Bloch}

Lutjanus lutjanus Bloch, 1790:107 (Japan); Allen, 1984:37

(Indo-west Pacific, including Chagos)

No specimens seen or collected; occurrence is based on Allen (1984). Indo-west Pacific.

\section{Lutjanus malabaricus (Bloch and Schneider)}

Holocentrus malabaricus Bloch and Schneider, 1801:39 (Tranquebar)

Lutjanus malabaricus-Allen, 1984:43 (Indo-Pacific, including Chagos)

No specimens seen or collected; occurrence is based on Allen (1984). Indo-Pacific. 


\section{Lutjanus monostigmus (Cuvier)}

Fig. 202 Mesoprion monostigmus Cuvier in Cuvier and Valenciennes, 1828:446 (Seychelles)

Lutjanus monostigmus - Allen, 1984:69 (Indo-Pacific, including Chagos)

\section{MATERIAL}

Nine lots, 22 specimens, 18-350 mm SL, 0-20 m, lagoon, intertidal, pass, reef-flat, and drop-off at Diego Garcia, Eagle Island, Peros Banhos, and Salomon (photos: 134, 202, and $350 \mathrm{~mm}$ ).

The largest specimen ( $350 \mathrm{~mm} \mathrm{SL}$ ), which was identified by Dr G. R. Allen, is apparently anomalous in lacking vomerine and palatine teeth. When freshly dead, the head was red, grading posteriorly into light yellow on the body. There was no trace of the dark spot on the lateral line, and all fins were bright yellow. Indo-Pacific.

\section{Lutjanus rivulatus (Cuvier)}

Diacope rivulata Cuvier in Cuvier and Valenciennes, 1828:414 (Coromandel Coast; Java; Red Sea; Malabar Coast)

Lutjanus rivulatus - Allen, 1984:73 (Indo-Pacific, including Chagos)

No specimens seen or collected; occurrence is based on Allen (1984). Indo-Pacific.

\section{Lutjanus sebae (Cuvier)}

Diacope sebae Cuvier in Cuvier and Valenciennes, 1828:411 (no locality given)

Lutjanus sebae-Kyushin et al., 1977:86 (Chagos Archipelago)

No specimens seen or collected; the record is based on the photographs and report by Kyushin et al. (1977) of specimens taken in 10-160 m by vertical longline and squid handline. Indo-west Pacific and marginally on the Pacific plate.

\section{Macolor niger (Forsskål)}

Fig. 203

Sciaena niger Forsskål, 1775:47 (Jiddah, Red Sea)

Macolor niger-Allen, 1984:77 (Indo-Pacific, including Chagos)

\section{MATERIAL}

Three lots, 3 specimens, 180-452 mm SL, 3-26 m, lagoon and drop-off at Peros Banhos and Salomon (photos: 180 , 432 , and $452 \mathrm{~mm}$ ). This species was frequently observed in large schools high in the water column over the edge of the reef-top/drop-off interface and appeared to be feeding on plankton. Indo-Pacific.

\section{Paracaesio sordidus Abe and Shinohara}

Paracaesio sordidus Abe and Shinohara, 1962:163 (Okinawa, Japan); Kyushin et al., 1977:102 (Indo-west Pacific, including Chagos)

No specimens seen or collected; the record is based on the report by Kyushin et al. of specimens taken at Chagos by vertical longline in $26-120 \mathrm{~m}$. Indo-west Pacific.

\section{Paracaesio xanthurus (Bleeker)}

Caesio xanthurus Bleeker, 1869:78 (Madagascar)

Paracaesio xanthurus-Allen, 1984:79 (Indo-Pacific, including Chagos)

No specimens seen or collected; occurrence is based on Allen (1984). Indo-Pacific.

Pristipomoides auricilla (Jordan, Evermann, and Tanaka) Arnillo auricilla Jordan, Evermann, and Tanaka, 1927:668 (Hawaii)

Pristipomoides auricilla-Kyushin et al., 1977:112 (Chagos Archipelago); Kami, Ikehara, and DeLeon, 1968:108 (Guam)

No specimens seen or collected; the record is based on six specimens (295-321 mm BL) collected by vertical longline in 25-90 $\mathrm{m}$ at Chagos, as reported and figured by Kyushin et al. (1977). Indo-Pacific.

\section{Pristipomoides filamentosus (Valenciennes)}

Serranus filamentosus Valenciennes in Cuvier and Valenciennes, 1830b:508 (Réunion; Mauritius)

Pristipomoides filamentosus-Kyushin et al., 1977:106 (Chagos Archipelago); Kami, 1973:107 (Indo-Pacific)

No specimens seen or collected; the record is based on a photograph and report in Kyushin et al. (1977) of specimens from Chagos taken by vertical longline in $24-130 \mathrm{~m}$. Indo-Pacific.

\section{Pristipomoides multidens (Day)}

Mesoprion multidens Day, 1870:680 (Andaman Islands) Pristipomoides multidens-Kyushin et al., 1977:110(Chagos Archipelago); Allen, 1984:87 (Indo-west Pacific)

No specimens seen or collected; the record is based on the photograph and report in Kyushin et al. (1977) of this species taken by vertical longline in $10-169 \mathrm{~m}$. Indo-west Pacific.

Pterocaesio chrysozonus (Cuvier)

Fig. 204 Caesio chrysozona Cuvier in Cuvier and Valenciennes, 1830b:440 (East Indies) 
Pterocaesio chrysozona-Carpenter, 1984:19 (Indo-west Pacific)

\section{MATERIAL}

Two lots, 93 specimens, 32-76 mm SL, 5-10 m, lagoon at Peros Banhos. The material of this genus was identified by K. Carpenter, who also supplied information on the geographic ranges of the species. Indo-west Pacific (east to Solomons).

\section{Pterocaesio marri Schultz}

Fig. 205

Pterocaesio marri Schultz, 1953e:545 (Marshall Islands)

\section{MATERIAL}

Two lots, 12 specimens, 46-74 mm SL, $10 \mathrm{~m}$, lagoon at Peros Banhos (photo: $74 \mathrm{~mm}$ ). Indo-west Pacific and marginally on the Pacific plate (to Marshall Islands).

Pterocaesio tile (Cuvier)

Fig. 206

Caesio tile Cuvier in Cuvier and Valenciennes, 1830b:428

(Caroline Islands)

\section{MATERIAL}

Two lots, 3 specimens, 108-166 mm SL, 10-43 m, lagoon and drop-off at Salomon (photos: 108 and $166 \mathrm{~mm}$ ). Indo-Pacific (to Tahiti).

\section{Pterocaesio sp. \\ Pl. VE}

MATERIAL

Two lots, 2 specimens, 89-99 mm SL, 10-25 m, reef-top and drop-off at Peros Banhos and Salomon (photos: both). This new species will be described by $K$. Carpenter. Indo-west Pacific (east to Papua New Guinea).

\section{Tropidinius zonatus (Valenciennes)}

Serranus zonatus Valenciennes in Cuvier and Valenciennes, 1830b:509 (Mauritius)

Tropidinius zonatus-Allen, 1984:93 (Indo-Pacific, including Chagos)

No specimens seen or collected; occurrence is based on Allen (1984). Indo-Pacific.

\section{Nemipteridae}

\section{Scolopsis frenatus (Cuvier)}

Scolopsides frenatus Cuvier in Cuvier and Valenciennes, 1830a:343 (Seychelles; Mauritius)

Scolopsis frenatus-Russell and Allen, 1984:33 (western Indian Ocean, including Chagos)

No specimens seen or collected; the record is based on Russell and Allen (1984). Western Indian Ocean.

\section{Gerreidae}

The material of this family was identified by $\operatorname{Dr} D$. Woodland.

Gerres acinaces Bleeker

Fig. 207

Gerres acinaces Bleeker, 1854a:194 (Java); Woodland, 1984:11 (Indo-west Pacific)

\section{MATERIAL}

Nine lots, 44 specimens, 29-245 mm SL, 0-2 m, lagoon and reef-flat (1) at Diego Garcia, Eagle Island, Peros Banhos, and Salomon (photo: $245 \mathrm{~mm}$ ). Indo-west Pacific.

\section{Gerres oblongus Cuvier}

Fig. 208

Gerres oblongus Cuvier in Cuvier and Valenciennes, 1830b:479 (Trincomalee, Sri Lanka); Woodland, 1984:15 (Indo-west Pacific)

\section{MATERIAI}

Two lots, 40 specimens, $47-107 \mathrm{~mm} \mathrm{SL}, 0-0.5 \mathrm{~m}$, lagoon at Peros Banhos (photo: $50 \mathrm{~mm}$ ). Indo-west Pacific.

Gerres oyena (Forsskål)

Labrus oyena Forsskål, 1775:35 (Jiddah, Red Sea)

Fig. 209

Gerres oyena-Woodland, 1984:9 (Indo-Pacific)

\section{MATERIAL}

Seven lots, 24 specimens, 25-148 mm SL, 0-5 m, lagoon and intertidal at Diego Garcia, Peros Banhos, and Salomon (photos: 46 and $148 \mathrm{~mm}$ ). Indo-Pacific.

\section{Haemulidae}

Plectorhinchus orientalis (Bloch)

Figs. 210, 211 Anthias orientalis Bloch, 1793:10 (Japan)

Plectorhinchus orientalis-McKay, 1984:29 (Indo-Pacific)

\section{MATERIAL}

Three lots, 4 specimens, $158-370 \mathrm{~mm}$ SL, 0-7 m, lagoon at Peros Banhos (photos: 158 and $315 \mathrm{~mm}$ ). Indo-Pacific.

\section{Lethrinidae}

Gnathodentex aureolineatus (Lacepède)

Fig. 212

Sparus aureolineatus Lacepède, 1802b:42 (no locality) Gnathodentex aurolineatus-Sato and Walker, 1984:11 (Indo-Pacific)

\section{MATERIAL}

Three lots, 3 specimens, $129-187 \mathrm{~mm} \mathrm{SL}, 3-17 \mathrm{~m}$, lagoon at Peros Banhos (photos: 129 and $187 \mathrm{~mm}$ ). Indo-Pacific. 
Gymnocranius griseus (Temminck and Schlegel)

Dentex griseus Temminck and Schlegel, 1842:72 (Japan) Gymnocranius griseus - Kyushin et al., 1977:124 (Chagos Archipelago); Myers and Sheppard, 1980:319 (Marianas)

No specimens seen or collected; the record is based on the report of Kyushin et al. (1977) of specimens taken by vertical longline in $10-100 \mathrm{~m}$. Indo-west Pacific and marginally on the Pacific plate.

\section{Gymnocranius robinsoni (Gilchrist and Thompson)}

Dentex robinsoni Gilchrist and Thompson, 1909:226 (Natal, South Africa)

Gymnocranius robinsoni-Kyushin et al., 1977:126 (Indowest Pacific, including Chagos)

No specimens seen or collected; the record is based on the photograph and description by Kyushin et al. (1977) of specimens collected by vertical longline in $15-160 \mathrm{~m}$. Indo-west Pacific.

\section{Lethrinus conchyliatus (Smith)}

Lethrinella conchyliata Smith, 1959c:292 (Pinda)

Lethrinus conchyliatus-Sato and Walker, 1984:27 (Indian Ocean, including Chagos)

No specimens seen or obtained; the record is based on Sato and Walker (1984). Indian Ocean.

\section{Lethrinus elongatus Valenciennes}

Lethrinus elongatus Valenciennes in Cuvier and Valenciennes, 1830b:289 (Suez); Sato and Walker, 1984:23 (Indo-Pacific, including Chagos)

Lethrinus miniatus-Kyushin et al., 1977:150 (Chagos Archipelago); (non Bloch and Schneider, 1801)

Two specimens, tentatively identified as this species, were seen chasing each other in the late afternoon on the reef-top at Salomon. No specimens were collected; the record is based on Sato and Walker (1984) and Kyushin et al . (1977). Indo-Pacific.

\section{Lethrinus hypselopterus Bleeker}

Fig. 213

Lethrinus hypselopterus Bleeker, 1873:326 (Sumatra; Java; Solor; Waigeo); Sato, 1978:22 (Indo-west Pacific, including Truk Islands, Caroline Islands)

\section{MATERIAL}

Four lots, 4 specimens, $157-406 \mathrm{~mm} \mathrm{SL}, 10-20 \mathrm{~m}$, lagoon and drop-off at Peros Banhos and Salomon (photos: 157, 256, 302, and $406 \mathrm{~mm}$ ). Indo-west Pacific and marginally on the Pacific plate

\section{Lethrinus kallopterus Bleeker}

Lethrinus kallopterus Bleeker, 1856e:47 (Sulawesi); Sato 1978:20 (Indo-Pacific to Marshall Islands and Marianas, including Chagos)

No specimens seen or collected; the record is based on Sato (1978). Indo-west Pacific and marginally on the Pacific plate.

Lethrinus mahsena (Forsskål)

Fig. 214

Sciaena mahsena Forsskål, 1775:52 (Red Sea)

Lethrinus caeruleus-Kyushin et al., 1977:158 (Chagos Archipelago) (non Valenciennes)

Lethrinus enigmaticus - Kyushin et al., 1977:160 (Chagos Archipelago) (non Smith)

Lethrinus mahsena-Sato and Walker, 1984:35 (IndoPacific to Tuamotu Islands, including Chagos)

\section{MATERIAL}

Two lots, 2 specimens, 190-264 mm SL, 1-10 m, lagoon at Diego Garcia and Eagle Island (photo: $264 \mathrm{~mm}$ ). The smaller specimen, from Diego Garcia, was keyed out to $L$. sanguineus in Sato (1978). That species was relegated to the synonymy of L. mahsena by Sato and Walker (1984). Indo-Pacific.

\section{Lethrinus microdon Valenciennes}

Lethrinus microdon Valenciennes in Cuvier and Valenciennes, 1830b:295 (Buru); Sato and Walker, 1984:37 (Indo-west Pacific)

Lethrinella microdon-Kyushin et al., 1977:152 (Chagos Archipelago)

No specimens seen or collected; the record is based on the reports of Kyushin et al. (1977) and Sato and Walker (1984). Indo-west Pacific.

\section{Lethrinus nebulosus (Forsskål)}

Sciaena nebulosa Forsskål, 1775:52 (Red Sea)

Lethrinella choerorhychus-Kyushin et al., 1977:154 (Chagos Archipelago) (non Bloch and Schneider, 1801)

Lethrinus nebulosus-Sato and Walker, 1984:39 (Indowest Pacific, including Samoa)

No specimens seen or collected; the record is based on a report by Kyushin et al. (1977) of specimens caught by vertical longline in $10-90 \mathrm{~m}$. Indo-west Pacific.

\section{Lethrinus reticulatus Valenciennes}

Lethrinus reticulatus Valenciennes in Cuvier and Valenciennes, 1830b:298 (New Guinea); Sato, 1978:53 (Indowest Pacific)

Lethrinella sp. Kyushin et al., 1977:148 (Chagos Archipelago) 
No specimens seen or collected; the record is based on Kyushin et al. (1977). Sato (1978) records this species from the western Pacific, and from the Indian Ocean on the basis of the record of Kyushin et al. (1977). Sato and Walker (1984:9) list the species as being present in the area, but are dubious of its validity, feeling that it is "probably the young of some other species of the genus". However, the Chagos specimen (caught by vertical longline in $23 \mathrm{~m}$ ) is $306 \mathrm{~mm}$ BL, and other material examined by Sato (1978) includes specimens up to $263 \mathrm{~mm} \mathrm{SL}$; so the validity of the species is provisionally accepted here. Indo-west Pacific.

\section{Lethrinus rubrioperculatus Sato}

Lethrinus rubrioperculatus Sato, 1978:58 (Okinawa, Japan); Sato and Walker, 1984:43 (Indo-west Pacific, including Chagos)

?Lethrinella variegatus-Kyushin et al., 1977:144 (Chagos Archipelago) (non Valenciennes)

No specimens seen or collected; the record is based on Sato and Walker (1984). The specimen of $L$. variegatus figured by Kyushin et al. (1977) is of this species, but since they report collecting specimens at three localities in the Indian Ocean, and since their material apparently consists of more than one species, it is not possible to decide whether the figured specimen is from Chagos or one of the other two localities in the Indian Ocean that they mention. Indo-west Pacific.

\section{Lethrinus variegatus Valenciennes}

Lethrinus variegatus Valenciennes in Cuvier and Valenciennes, 1830b:287 (Massawa and Suez, Red Sea); Sato and Walker, 1984:47 (Indo-Pacific, including Chagos)

No specimens seen or collected; the record is based on Sato and Walker (1984). Indo-Pacific.

\section{Lethrinus xanthochilus Klunzinger}

Lethrinus xanthochilus Klunzinger, 1870:753 (Red Sea); Sato and Walker, 1984:49 (Indo-Pacific, including Chagos)

No specimens seen or collected; the record is based on Sato and Walker (1984). Indo-Pacific.

\section{Monotaxis grandoculis (Forsskål)}

Fig. 215

Sciaena grandoculis Forsskål, 1775:53 (Jiddah, Red Sea) Monotaxis grandoculis - Kyushin et al., 1977:168 (Chagos Archipelago); Sato and Walker, 1984:51 (Indo-Pacific to Hawaii)

\section{MATERIAL}

Nine lots, 23 specimens, $28-196 \mathrm{~mm} \mathrm{SL}, 0.5-15 \mathrm{~m}$, primarily lagoon (one reef-top) at Diego Garcia, Peros
Banhos, Salomon, and Three Brothers (photos: 38, 42, 115 , and $166 \mathrm{~mm}$ ). Indo-Pacific.

\section{Sciaenidae}

\section{Otolithes ruber (Schneider)}

Sciaena ruber Schneider in Bloch and Schneider, 1801:82 (America)

Otolithes ruber-Mohan, 1984:63 (Indo-west Pacific, including Chagos)

No specimens seen or collected; occurrence is based on Mohan (1984). Indo-west Pacific.

\section{Mullidae}

Mulloides flavolineatus (Lacepède)

Fig. 216 Mullus flavolineatus Lacepède, 1802a:384 (no locality) Mulloides flavolineatus-Kumaran and Randall, 1984:5 (Indo-Pacific, including Chagos)

\section{MATERIAL}

Fourteen lots, 47 specimens, 58-192 mm SL, 0-10 m, lagoon and reef-flat at Diego Garcia, Peros Banhos, and Salomon (photos: 81, 90, and $151 \mathrm{~mm}$ ). Indo-Pacific.

\section{Mulloides vanicolensis (Valenciennes)}

Upeneus vanicolensis Valenciennes in Cuvier and Valenciennes, 1831a:521 (Vanicolo)

Mulloides vanicolensis-Kumaran and Randall, 1984:7 (Indo-Pacific, including Chagos)

No specimens seen or collected; occurrence is based on Kumaran and Randall (1984). Indo-Pacific.

Parupeneus barberinus (Lacepède) Mullus barberinus Lacepède, 1802a:406 (near Moluccas) Parupeneus barberinus - Kumaran and Randall, 1984:11 (Chagos Archipelago); Lachner, 1960:16 (Indo-Pacific to the Low Archipelago and Hawaii)

\section{MATERIAL}

Three lots, 8 specimens, $80-160 \mathrm{~mm}$ SL, 0-1 m, lagoon only at Eagle Island and Peros Banhos. Indo-Pacific.

\section{Parupeneus bifasciatus (Lacepède)}

Fig. 218

Mullus bifasciatus Lacepède, 1802a:383 (no locality) Parupeneus bifasciatus-Kumaran and Randall, 1984:9 (Indo-Pacific to Pitcairn Island)

\section{MATERIAI}

Two lots, 2 specimens, $130-131 \mathrm{~mm} \mathrm{SL}, 1-10 \mathrm{~m}$, reef-top and lagoon at Diego Garcia and Peros Banhos (photo: 
$130 \mathrm{~mm}$ ). Although only two specimens were collected, this species was frequently seen on the reef-tops, either singly or in small groups. Indo-Pacific.

\section{Parupeneus cinnabarinus (Cuvier)}

Upeneus cinnabarinus Cuvier in Cuvier and Valenciennes, 1829a:475 (Trincomalee, Sri Lanka)

Parupeneus cinnabarinus-Kumaran and Randall, 1984:17 (Indo-west Pacific, including Chagos, to Marshall Islands)

No specimens seen or collected; occurrence is based on Kumaran and Randall (1984). Indo-west Pacific and marginally on the Pacific plate.

\section{Parupeneus cyclostomus (Lacepède)}

Fig. 219

Mullus cyclostomus Lacepède, 1802a:383 (no locality)

Parupeneus cyclostomus - Kumaran and Randall, 1984:21 (Indo-Pacific, including Chagos, to Hawaii and French Polynesia)

\section{MATERIAL}

Three lots, 3 specimens, $79-159 \mathrm{~mm} \mathrm{SL}, 3-17 \mathrm{~m}$, lagoon and reef-top at Eagle Island and Peros Banhos (photo: $79 \mathrm{~mm}$ ). Indo-Pacific.

Parupeneus macronemus (Lacepède)

Fig. 220

Mullus macronema Lacepède, 1802a:383 (no locality)

Parupeneus macronema - Kumaran and Randall, 1984:13 (Indo-west Pacific to Philippines)

MATERIAL

Ten lots, 38 specimens, 34-126 mm SL, 0-20 m, lagoon and reef-top (1) at Diego Garcia, Peros Banhos, Salomon, and Three Brothers (photos: 49, 52, 84, and $86 \mathrm{~mm}$ ). Indo-west Pacific.

\section{Parupeneus pleurostigmus (Bennett)}

Fig. 221

Upeneus pleurostigma Bennett, 1831:59 (Mauritius)

Parupeneus pleurostigma-Kumaran and Randall, 1984:25 (Indo-Pacific, including Chagos, to Hawaii and French Polynesia)

\section{MATERIAL}

One lot, 2 specimens, $61-98 \mathrm{~mm} \mathrm{SL}, 13 \mathrm{~m}$, lagoon at Peros Banhos (photo: $61 \mathrm{~mm}$ ). Indo-Pacific.

\section{Upeneus taeniopterus Cuvier}

Fig. 222

Upeneus taeniopterus Cuvier in Cuvier and Valenciennes, 1829a:454 (Sri Lanka); Kumaran and Randall, 1984:39 (Indo-Pacific to Hawaii)

\section{MATERIAL}

Two lots, 2 specimens, 184-196 mm SL, 1-3 m, lagoon and reef-flat at Diego Garcia and Peros Banhos. Indo-Pacific.

\section{Upeneus tragulus Richardson}

Upeneus tragula Richardson, 1846:220 (Phoenix Islands); Kumaran and Randall, 1984:37 (Indo-west Pacific, including Chagos)

No specimens seen or collected; occurrence is based on Kumaran and Randall (1984).

\section{Pempherididae}

The pempheridids were identified by J.-M. Rose, who also provided comments on distribution.

\section{Parapriacanthus ransonneti Steindachner Pl. VF} Parapriacanthus ransonneti Steindachner, 1870:623 (Japan); Tominaga, 1963:271 (west Pacific east to Marshall Islands)

\section{MATERIAL}

Two lots, 412 specimens, $28-52 \mathrm{~mm} \mathrm{SL}, 10-15 \mathrm{~m}$, reeftop (photo: $51 \mathrm{~mm}$ ). This genus is in need of revision, and the identification is tentative. The Chagos specimens have a teardrop-shaped patch of translucent skin just anterior to the anus, but none anterior to the pelvic-fin base. Indo-west Pacific and marginally on the Pacific plate.

Pempheris schwenkii Bleeker

Fig. 223

Pempheris schwenkii Bleeker, 1855a:314 (Batu, Indonesia)

\section{MATERIAL}

Four lots, 236 specimens, 41-99 mm SL, 5-27 m, lagoon and drop-off at Peros Banhos and Salomon (photos: 3 specimens). Indo-Pacific.

Pempheris vanicolensis Cuvier

Fig. 224

Pempheris vanicolensis Cuvier in Cuvier and Valenciennes, 1831a:305 (Vanicolo)

\section{MATERIAL}

Five lots, 38 specimens, $73-136 \mathrm{~mm} \mathrm{SL}, 3-33 \mathrm{~m}$, lagoon and drop-off at Peros Banhos and Salomon (photos: 3 specimens). Indo-Pacific.

\section{Kyphosidae}

\section{Kyphosus cinerascens (Forsskål)}

Fig. 225

Sciaena cinerascens Forsskål, 1775:53 (Arabia)

Kyphosus cinerascens-Maugé, 1984b:5 (Indo-Pacific, including Chagos, to Easter Island)

\section{MATERIAL}

Three lots, 6 specimens, 148-215 mm SL, 0-1 m, lagoon and intertidal at Eagle Island and Peros Banhos (photo: $148 \mathrm{~mm}$ ). Indo-Pacific 


\section{Drepaneidae}

\section{Drepane punctata (Linnaeus)}

Chaetodon punctatus Linnaeus, 1758:273 (Asia)

Drepane punctata-Maugé, 1984a:3 (Indo-west Pacific, including Chagos, to Japan and Samoa)

No specimens seen or collected; occurrence is based on Maugé (1984a). Indo-west Pacific.

\section{Ephippididae}

\section{Platax orbicularis (Forsskål)}

Fig. 226

Chaetodon orbicularis Forsskål, 1775:59 (Jiddah, Red Sea)

Platax orbicularis-Maugé, 1984c:5 (Indo-west Pacific, including Chagos, to China and Queensland, Australia); Randall, 1973:193 (Tahiti)

MATERIAL

Four lots, 4 specimens, $55-138 \mathrm{~mm} \mathrm{SL}, 0-2 \mathrm{~m}$, lagoons at Peros Banhos and Salomon (photos: 75, 130, and $138 \mathrm{~mm}$ ). Indo-Pacific.

\section{Chaetodontidae}

\section{Chaetodon auriga Forsskål}

Fig. 227

Chaetodon auriga Forsskål, 1775:60 (Jiddah, Red Sea); Allen, 1980:322 (Indo-Pacific)

\section{MATERIAL}

Eleven lots, 60 specimens, 21-149 mm SL, 0-13 m, lagoon, intertidal, reef-flat, and reef-top at Diego Garcia, Eagle Island, Peros Banhos, and Salomon (photo: 130 $\mathrm{mm})$. This species is primarily a very shallow water inhabitant, and all but two specimens were collected in the intertidal and reef-flat habitats. Indo-Pacific.

\section{Chaetodon falcula Bloch}

Fig. 228

Chaetodon falcula Bloch, 1795:102 (no locality); Allen, 1980:322 (Indian Ocean only, east to India)

\section{MATERIAI}

Four lots, 6 specimens, $123-166 \mathrm{~mm} \mathrm{SL}, 0-15 \mathrm{~m}$, lagoons only at Peros Banhos, Salomon, and Three Brothers (photos: 123, 146, and $159 \mathrm{~mm}$ ). Western Indian Ocean.

\section{Chaetodon guttatissimus Bennett}

Fig. 229

Chaetodon guttatissimus Bennett, 1832a:183 (Sri Lanka); Allen, 1980:322 (Indo-west Pacific east to Thailand)

\section{MATERIAL}

Fifteen lots, 23 specimens, $26-86 \mathrm{~mm}$ SL, $0.5-30 \mathrm{~m}$, primarily lagoons, also reef-top (2) and drop-off (5) at Peros Banhos, Salomon, and Three Brothers (photo: $69 \mathrm{~mm})$. Indo-west Pacific.

Chaetodon kleinii Bloch

Fig. 230

Chaetodon kleinii Bloch, 1790:7 (East Indies); Allen, 1980:322 (Indo-Pacific to Hawaii and Society Islands)

\section{MATERIAL}

Six lots, 6 specimens, 51-95 mm SL, 0-26 m, lagoon, reef-top, and drop-off at Eagle Island, Peros Banhos, and Salomon (photos: 77 and $89 \mathrm{~mm}$ ). Indo-Pacific.

\section{Chaetodon lineolatus Cuvier}

Chaetodon lineolatus Cuvier in Cuvier and Valenciennes, 1831a:40 (Mauritius); Allen, 1980:324 (Indo-Pacific to Hawaii and Society Islands)

No specimens collected; occurrence is based on a sight record in $15 \mathrm{~m}$ off the north tip of Eagle Island. IndoPacific.

Chaetodon lunula (Lacepède)

Fig. 231

Pomacentrus lunula Lacepède, 1802b:507 (no locality) Chaetodon lunula-Allen, 1980:324 (Indo-Pacific, to Hawaii and Marquesas Islands)

\section{MATERIAL}

Seven lots, 8 specimens, 68-208 mm SL, 0-24 m, lagoon, reef-flat, and drop-off at Diego Garcia, Eagle Island, Peros Banhos, and Salomon (photo: $165 \mathrm{~mm}$ ). Indo-Pacific.

Chaetodon madagascariensis Ahl

Fig. 232

Chaetodon madagascariensis Ahl, 1923:162 (Madagascar); Allen, 1980:324 (Indian Ocean to Sri Lanka)

\section{MATERIAL}

Two lots, 3 specimens, 51-84 mm SL, 9-18 m, reef-top and drop-off at Eagle Island and Peros Banhos (photo: $51 \mathrm{~mm}$ ). Western Indian Ocean.

\section{Chaetodon melannotus Schneider}

Chaetodon melannotus Schneider in Bloch and Schneider, 1801:224 (Bay of Bengal); Allen, 1980:324 (Indo-Pacific to Hawaii and Society Islands)

No specimens collected; the record is based on an underwater photograph taken by Ryther in the lagoon at Diego Garcia. Indo-Pacific.

\section{Chaetodon meyeri Schneider}

Fig. 233 Chaetodon meyeri Schneider in Bloch and Schneider, 1801:223 (Moluccas); Allen, 1980:324 (Indo-Pacific east to Marshall Islands and Marianas) 
MATERIAL

Six lots, 6 specimens, 94-133 mm SL, 0-15 m, lagoon and reef-top at Peros Banhos and Salomon (photos: 126 and $133 \mathrm{~mm}$ ). Indo-west Pacific and marginally on the Pacific plate.

Chaetodon mitratus Günther

Fig. 234

Chaetodon mitratus Günther, 1860:16 (probably Mauritius); Allen, 1980:324 (Indian Ocean including Cocos[Keeling] Island and Christmas Island)

\section{MATERIAL}

Three lots, 4 specimens, $69-87$ mm SL, 40-48 m, drop-off at Peros Banhos (photo: $87 \mathrm{~mm}$ ). Indian Ocean.

\section{Chaetodon trifascialis Quoy and Gaimard Fig. 235} Chaetodon trifascialis Quoy and Gaimard, 1824:379 (Guam); Allen, 1980:326 (Indo-Pacific east to Hawaii and Rapa)

\section{MATERIAL}

Seven lots, 15 specimens, 42-127 mm SL, 3-20 m, lagoon and reef-top at Peros Banhos and Salomon (photos: 55 and $66 \mathrm{~mm})$. Indo-Pacific.

\section{Chaetodon trifasciatus trifasciatus Park}

Fig. 236

Chaetodon trifasciatus Park, 1797:34 (Sumatra); Allen, 1980:326 (Indo-Pacific to Hawaii and Rapa)

Chaetodon trifasciatus trifasciatus-Burgess, 1978:483

(Indian Ocean to west coasts of Sumatra and Java)

\section{MATERIAL}

Twenty-two lots, 45 specimens, $23-127 \mathrm{~mm} \mathrm{SL}$, lagoon, reef-top, and drop-off at Diego Garcia, Peros Banhos, Salomon, and Three Brothers (photo: $94 \mathrm{~mm}$ ).

Burgess (1978:478-486) recognizes two subspecies based on meristics and colour pattern, the disjunction between the two being the Sumatra/Java chain of islands, with one subspecies on the east and the other on the west coast. The Chagos material belongs to the Indian Ocean population, possessing an orange or yellow caudal peduncle. Indian Ocean and western extremity of west Pacific.

\section{Chaetodon unimaculatus interruptus Ahl}

Fig. 237 Chaetodon unimaculatus Bloch, 1787:75 (East Indies); Allen, 1980:326 (Indo-Pacific to Hawaii and the Marquesas Islands)

Chaetodon unimaculatus interruptus Ahl, 1923:142 (Malay Archipelago to Africa)

\section{MATERIAL}

Three lots, 3 specimens, $31-140 \mathrm{~mm}$ SL, 1-17 m, lagoon and reef-top at Diego Garcia, Eagle Island, and Salomon (photo: $111 \mathrm{~mm}$ ).
Burgess (1978:637-641) recognizes two subspecies, with approximately the same geographic distribution as that outlined for $C$. trifasciatus. Our specimens agree with the Indian Ocean form. Indian Ocean and western extremity of west Pacific.

Chaetodon vagabundus Linnaeus

Fig. 238 Chaetodon vagabundus Linnaeus, 1758:276 ("Indiis"); Allen, 1980:326 (Indo-Pacific east to Tuamotu Islands)

\section{MATERIAL}

One lot, 1 specimen, $48 \mathrm{~mm} \mathrm{SL}, 0-3 \mathrm{~m}$, lagoon at Salomon (photo). Indo-Pacific.

Chaetodon xanthocephalus Bennett

Fig. 239 Chaetodon xanthocephalus Bennett, 1832a:182 (Sri Lanka); Allen, 1980:235 (Indian Ocean east to the Maldives).

\section{MATERIAL}

Four lots, 4 specimens, 149-184 mm SL, 1-25 m, lagoon and drop-off at Diego Garcia, Peros Banhos, Salomon, and Three Brothers (photos: 181 and $184 \mathrm{~mm}$ ). Western Indian Ocean.

Chaetodon zanzibarensis Playfair

Fig. 240

Chaetodon zanzibarensis Playfair, 1866:33 (Zanzibar); 1980:326 (western Indian Ocean)

\section{MATERIAL}

Four lots, 4 specimens, 53-113 mm SL, 2-17 m, lagoon and reef-top at Diego Garcia, Eagle Island, Peros Banhos, and Salomon (photo: $112 \mathrm{~mm}$ ). Western Indian Ocean.

\section{Forcipiger flavissimus (Cuvier)}

Fig. 241

Chaetodon flavissimus Cuvier in Cuvier and Valenciennes, 1831a:89 (Mauritius)

Forcipiger flavissimus-Allen, 1980:326 (Indo-Pacific, including eastern Pacific)

\section{MATERIAL}

Four lots, 4 specimens, 90-116 mm SL, 7-43 m, lagoon, reef-top, and drop-off at Eagle Island, Peros Banhos, and Salomon (photos: 90, 99, and $108 \mathrm{~mm}$ ). Indo-Pacific.

Hemitaurichthys zoster (Bennett) Fig. 242 Chaetodon zoster Bennett, 1831:61 (Mauritius) Hemitaurichthys zoster-Allen, 1980:326 (Indian Ocean to Sri Lanka and India)

\section{MATERIAL}

Two lots, 3 specimens, $75-129$ mm SL, 10-20 m, reef-top and drop-off at Eagle Island and Salomon (photo: $129 \mathrm{~mm}$ ). Western Indian Ocean. 
Heniochus monoceros Cuvier

Fig. 243

Heniochus monoceros Cuvier in Cuvier and Valenciennes, 1831 a:100 (Mauritius); Allen, 1980:326 (Indo-Pacific east to Tuamotu Islands)

MATERIAL

Two lots, 2 specimens, 95-310 mm SL, 0-7 m, lagoon at Salomon (photos: both). Indo-Pacific.

\section{Pomacanthidae}

Apolemichthys trimaculatus (Cuvier)

Fig. 244

Holacanthus trimaculatus Cuvier in Cuvier and Valenciennes, 1831 a:196 (Moluccas)

Apolemichthys trimaculatus-Allen, 1980:328 (Indowest Pacific east to Marshall Islands)

\section{MATERIAL}

Three lots, 3 specimens, 96-150 mm SL, 0-15 m, lagoons at Eagle Island and Peros Banhos (photos: 96 and $150 \mathrm{~mm}$ ). Indo-west Pacific and marginally on the Pacific plate.

\section{Centropyge acanthops (Norman)}

Holacanthus acanthops Norman, 1922:318 (Natal)

Centropyge acanthops-Allen, 1980:328 (western Indian Ocean)

No specimens collected; occurrence is based on a sight record of three specimens in $12 \mathrm{~m}$ on the reef-top off Isle Boddam, Salomon. Western Indian Ocean.

\section{Centropyge bispinosus (Günther)}

Fig. 245

Holacanthus bispinosus Günther, 1860:48 (Ambon)

Centropyge bispinosus-Allen, 1980:328 (Indo-Pacific east to Tuamotu Islands)

\section{MATERIAL}

One lot, 1 specimen, $56 \mathrm{~mm} \mathrm{SL}, 33-43 \mathrm{~m}$, drop-off at Salomon (photo). Indo-Pacific.

\section{Centropyge multispinis (Playfair)}

Fig. 246

Holacanthus multispinis Playfair, 1866:37 (Zanzibar)

Centropyge multispinis-Allen, 1980:328 (Indian Ocean to Thailand)

\section{MATERIAL}

Thirty-one lots, 84 specimens, 21-95 mm SL, 0-30 m, lagoon, intertidal, reef-flat, reef-top, and drop-off at Eagle Island, Peros Banhos, and Salomon (photos: 31, 66, 69, and $78 \mathrm{~mm}$ ). This species was most common in depths between 6 and $25 \mathrm{~m}$, where $81 \%$ of the specimens were collected, and was almost equally abundant in lagoonal and outer-reef habitats. Indo-west Pacific
Pomacanthus imperator (Bloch)

Fig. 247

Chaetodon imperator Bloch, 1787:51 (Japan)

Pomacanthus imperator-Allen, 1980:330 (Indo-Pacific to Pitcairn Island)

MATERIAL

Three lots, 3 specimens, 36-242 mm SL, 10-15 m, lagoon at Peros Banhos (photos: 36 and $240 \mathrm{~mm}$ ). Indo-Pacific.

Pygoplites diacanthus (Boddaert)

Fig. 248

Chaetodon diacanthus Boddaert, 1772, pl. 9 (Ambon; Moluccas)

Pygoplites diacanthus-Allen, 1980:330 (Indo-Pacific east to Tuamotu Islands)

\section{MATERIAL}

Six lots, 8 specimens, 31-176 mm SL, 5-33 m, lagoon and drop-off at Eagle Island, Peros Banhos, and Salomon (photos: $31,61,142$, and $163 \mathrm{~mm}$ ). Indo-Pacific.

\section{Pomacentridae}

Abudefduf coelestinus (Cuvier)

Fig. 249

Glyphisodon coelestinus Cuvier in Cuvier and Valenciennes, 1830a:464 (Indies; Mauritius; Malabar; Ulietea; Society Islands)

Abudefduf coelestinus-Allen, 1975:114 (Indo-Pacific east to Rapa)

\section{MATERIAL}

Three lots, 28 specimens, 13-58 mm SL, 0-3 m, lagoon and reef-top at Peros Banhos and Salomon (photo: $32 \mathrm{~mm}$ ). Indo-Pacific.

Abudefduf septemfasciatus (Cuvier)

Fig. 250 Glyphisodon septemfasciatus Cuvier in Cuvier and Valenciennes, 1830a:463 (Mauritius)

Abudefduf septemfasciatus-Allen, 1975:115 (Indo-Pacific east to Tuamotu Islands)

\section{MATERIAL}

Two lots, 3 specimens, 114-138 mm SL, 1-2 m, lagoon at Peros Banhos. Indo-Pacific.

\section{Abudefduf sordidus (Forsskål)}

Fig. 251

Chaetodon sordidus Forsskål, 1775:62 (Jiddah, Red Sea) Abudefduf sordidus-Allen, 1975:115 (Indo-Pacific east to Pitcairn Island)

\section{MATERIAL}

Five lots, 10 specimens, 16-138 mm SL, 0-1 m, lagoon and reef-flat at Diego Garcia, Peros Banhos, and Salomon (photos: 31,38 , and $119 \mathrm{~mm}$ ). Indo-Pacific. 
Abudefduf vaigiensis (Quoy and Gaimard) Fig. 252 Glyphisodon vaigiensis Quoy and Gaimard, 1824:391 ("Iles des Papous")

Abudefduf vaigiensis - Allen, 1976:33 (Indo-west Pacific)

MATERIAL

One lot, 1 specimen, $32 \mathrm{~mm} \mathrm{SL}, 0-0.75 \mathrm{~m}$, lagoon at Eagle Island. Indo-west Pacific.

\section{Amblyglyphidodon sp. $\quad \mathrm{Pl}$. VG, H MATERIAL}

Fourteen lots, 176 specimens, 7-97 mm SL, 1-24 m, lagoon and drop-off at Diego Garcia, Peros Banhos, Salomon, and Three Brothers (photo: $85 \mathrm{~mm}$ ).

This species is similar to A. leucogaster (Bleeker), originally described from Java. There appear to be at least three forms, one in Oceania, a second in the southwest Pacific Ocean, and a third in the Indian Ocean. Both Pacific forms have black bars on the caudal lobes and a yellow venter. The Oceania form also has a black spot on the pectoral-fin base and a black margin to the dorsal fin. The Indian Ocean form is uniform in colour with a pale belly. Systematics are insufficiently known to categorize distribution. Range unassigned.

Amphiprion chagosensis Allen

Pl. VIA Amphiprion chagosensis Allen, 1972:161 (Chagos Archipelago)

\section{MATERIAL}

Nine lots, 37 specimens, $22-69 \mathrm{~mm} \mathrm{SL}, 10-25 \mathrm{~m}$, primarily drop-off, also reef-top (1) and lagoon (1) at Peros Banhos and Salomon (photos: 41, 62, and $63[\times 2] \mathrm{mm}$ ). The single collection from the reef-top contained seven specimens. The seven drop-off collections had a mean of 4.0 specimens/collection and comprised $76 \%$ of the total number of specimens, of which $81 \%$ were taken in 16 $25 \mathrm{~m}$. Endemic.

\section{Amphiprion sp. 1}

Pl. VIB,C MATERIAL

Six lots, 15 specimens, 19-74 mm SL, 3-20 m, lagoon and reef-top (1) at Peros Banhos and Salomon (photos: 22, 36, 53 , and $74 \mathrm{~mm}$ ).

These specimens could represent an undescribed species, but they are very similar to $A$. chagosensis (possessing two white bands, interorbital scales reaching anteriorly to mid-orbit, 13-15 anal rays, and 19 pectoral rays). They differ from $A$. chagosensis in the following ways: the anterior white bar is wider, the horizontal width of the bar at the lower margin of the eye (B) always being greater than $10 \%$ of SL (vs always less than $11 \%$ of SL); the width of the bar in the midline of the nape (A) usually increases with SL (vs decreasing or absent); the ratio $\mathrm{A} / \mathrm{B}$ is usually greater than $1(0.7-1.4)$ vs usually less than $1(0-1.0)$; and juveniles $(<25 \mathrm{~m} \mathrm{SL})$ have black markings in the soft dorsal and posterodorsal part of caudal fins (vs no dark markings in these fins). A single $30-\mathrm{mm}$ SL specimen (from a depth of 23-25 $\mathrm{m}$ on the drop-off at Salomon) appears to be an intergrade between these two forms. Only one station ( $20 \mathrm{~m}$ in the lagoon at Peros Banhos) contained both forms (one specimen of each). Systematics insufficiently known to categorize distribution. Range unassigned.

Chromis atripectoralis Welander and Schultz Fig. 253 Chromis atripectoralis Welander and Schultz, 1951:107 (central and western tropical Pacific); Allen, 1975:78 (Tuamotu Islands to Dampier Archipelago)

\section{MATERIAL}

Eight lots, 13 specimens, 26-69 mm SL, 4-29 m, lagoon, reef-top, and drop-off at Peros Banhos and Salomon (photos: 45 and $64 \mathrm{~mm}$ ). Indo-Pacific.

\section{Chromis atripes Fowler and Bean}

Fig. 254

Chromis atripes Fowler and Bean, 1928:43 (East Indies; Philippines); Allen, 1975:79 (Gilbert Islands; eastern part of western Pacific)

\section{MATERIAL}

Seventeen lots, 322 specimens, $22-55 \mathrm{~mm} \mathrm{SL}, 15-48 \mathrm{~m}$, drop-off only at Peros Banhos and Salomon (photos: 43, 44 , and $46 \mathrm{~mm}$ ). Sixty-nine per cent of our specimens were taken in $16-25 \mathrm{~m}$, with a further $26 \%$ in water deeper than $36 \mathrm{~m}$. Chromis atripes was recorded from the Indian Ocean for the first time by Allen and Steene (1979) at Christmas Island. Indo-west Pacific and marginally on the Pacific plate.

\section{Chromis dimidiata (Klunzinger)}

Fig. 255

Heliases dimidiatus Klunzinger, 1871:529 (Red Sea)

Chromis dimidiatus-Allen, 1975:86 (Red Sea and western Indian Ocean)

\section{MATERIAL}

Thirty-seven lots, 491 specimens, $14-51 \mathrm{~mm} \mathrm{SL}, 0.5-36$ $\mathrm{m}$, lagoon, reef-top, and drop-off at Eagle Island, Peros Banhos, and Salomon (photos: 34 and $37 \mathrm{~mm}$ ). This species was most abundant on the reef-tops $(24 \%)$ and drop-offs $(70 \%)$, which was reflected in the depth distribution ( $31 \%$ in $6-15 \mathrm{~m}, 66 \%$ in $16-25 \mathrm{~m}$ ). It was ubiquitous along the rim of the drop-off, where it formed large associations feeding on plankton in the water column. Western Indian Ocean.

Chromis lepidolepis Bleeker

Fig. 256

Chromis lepidolepis Bleeker, 1876:389 (Timor); Allen, 1975:83 (Indo-Pacific to Line Islands and Fiji) 
MATERIAI

Twelve lots, 32 specimens, 12-53 mm SL, 15-43 m, lagoon (1), reef-top (1), and drop-off at Peros Banhos and Salomon (photos: 43 and $48 \mathrm{~mm}$ ). Seventy-eight per cent of specimens were collected on drop-offs, where they showed a slight preference $(53 \%)$ for depths of $16-25 \mathrm{~m}$. IndoPacific.

\section{Chromis nigrura Smith}

Fig. 257

Chromis nigrurus Smith, 1960:325 (Inhaca)

Chromis nigrura-Allen and Steene, 1979:42 (Indian Ocean to Christmas Island)

MATERIAL

Fourteen lots, 194 specimens, 19-40 mm SL, 0-25 m, lagoon (1), reef-top, and drop-off (1) at Eagle Island, Peros Banhos, and Salomon (photo: $37 \mathrm{~mm}$ ). Eighty-four per cent of our specimens were collected on the reef-top in 6-15 m $(\overline{\mathrm{x}} /$ lot $=15$ specimens). The single collection from $16-25 \mathrm{~m}$ on the drop-off contained 18 specimens. Indian Ocean.

Chromis opercularis (Günther)

PI. VID

Heliases opercularis Günther, 1866a:84 (Zanzibar)

Chromis opercularis-Smith, 1960:325 (western Indian Ocean)

MATERIAL

Nine lots, 10 specimens, 41-103 mm SL, 5-25 m, lagoon, reef-top, and drop-off at Peros Banhos and Salomon (photos: 41, 80, and $103 \mathrm{~mm}$ ). Western Indian Ocean.

\section{Chromis pembae Smith}

Pl. VIE

Chromis pembae Smith, 1960:323 (Pemba, Mozambique); Allen and Randall, 1980:29 (Gulf of Elat, Red Sea)

\section{MATERIAI}

Two lots, 10 specimens, 77-96 mm SL, 40-48 m, drop-off at Peros Banhos and Salomon (photo: $77 \mathrm{~mm}$ ). At Chagos, this species was confined to deep water, where it formed small schools close to the substrate. Western Indian Ocean and Red Sea.

\section{Chromis simulans Smith}

Fig. 258

Chromis simulans Smith, 1960:326 (Mozambique Island)

\section{MATERIAL}

Seven lots, 10 specimens, 65-80 m SL, 4-25 m, reef-top and drop-off at Eagle Island, Peros Banhos, and Salomon. Western Indian Ocean.

Chromis ternatensis (Bleeker)

Fig. 259

Heliases ternatensis Bleeker, 1856a:377 (Ternate, Indonesia)
Chromis ternatensis-Allen and Randall, 1980:31 (IndoPacific east to Marshall Islands and Gilbert Islands)

\section{MATERIAL}

Eleven lots, 50 specimens, 24-84 mm SL, 3-36 m, lagoon, reef-top, and drop-off at Peros Banhos and Salomon (photos: 58 and $75 \mathrm{~mm}$ ). This species was most abundant in the lagoons and on the drop-offs, and it was evenly distributed in a depth range of 6-36 m. Although the correct name for this species is $C$. caerulea, we retain $C$. ternatensis pending a request for suppression of the former name (see Randall, Bauchot, and Desoutter, 1985). Indowest Pacific and marginally on the Pacific plate.

\section{Chromis viridis (Cuvier)}

Fig. 260

Pomacentrus viridis Cuvier in Cuvier and Valenciennes, 1830a:420 (Massawa, Red Sea)

Chromis viridis - Randall, Bauchot, and Desoutter, 1985:411 (Indo-Pacific to French Polynesia)

\section{MATERIAL}

Twenty-two lots, 590 specimens, 7-54 mm SL, 0-20 m, lagoon and drop-off (1) at Diego Garcia, Peros Banhos, Salomon, and Three Brothers (photos: 40 and $42 \mathrm{~mm}$ ). This species occurred primarily in the lagoons (97\% of specimens collected), where it showed a slight preference for water $6-15 \mathrm{~m}$ in depth $(68 \%)$, with $28 \%$ being collected in $0-5 \mathrm{~m}$. It is a schooling species whose well-known habit of seeking shelter among the branches of Acropora no doubt accounts for the large number of specimens per lot $(\overline{\mathrm{x}} / \mathrm{lot}=$ 27). Up until the publication by Randall, Bauchot, and Desoutter (1985), this species was widely known as $C$. caerulea. Indo-Pacific.

Chromis weberi Fowler and Bean

Fig. 261

Chromis weberi Fowler and Bean, 1928:41 (Java); Allen, 1975:86 (Indo-Pacific to Pitcairn Island and Line Islands)

\section{MATERIAL}

Five lots, 29 specimens, 16-65 mm SL, 3-15 m, lagoon and reef-top (1) at Peros Banhos (photo: $65 \mathrm{~mm}$ ).

There is some doubt about the geographic range of this species. Although the range given in Allen (1975) is unambiguous, a subsequent publication (Allen and Randall, 1980:39) gives the range as being Indo-west Pacific "at least as far as the Fiji and Marshall Islands". The latter range is followed here. Indo-west Pacific and marginally on the Pacific plate.

Chrysiptera biocellata (Quoy and Gaimard) Fig. 262 Glyphisodon biocellatus Quoy and Gaimard, 1824:389 (Guam)

Glyphidodontops biocellatus-Allen, 1975:150 (IndoPacific to Marshall Islands and Gilbert Islands) 
MATERIAL

Thirteen lots, 957 specimens, $10-77 \mathrm{~mm} \mathrm{SL,} \mathrm{0-2} \mathrm{m,}$ lagoon and reef-flat (1 specimen) at Diego Garcia, Eagle Island, Peros Banhos, and Salomon (photo: $45 \mathrm{~mm}$ ). Indo-west Pacific and marginally on the Pacific plate.

\section{Chrysiptera glauca (Cuvier)}

Fig. 263

Glyphisodon glaucus Cuvier in Cuvier and Valenciennes, 1830a:475 (Guam)

Glyphidodontops glaucus-Allen, 1975:154 (Indo-Pacific to Pitcairn Island)

\section{MATERIAL}

Thirteen lots, 1161 specimens, 12-64 mm SL, 0-2 m, lagoon and reef-flat at Diego Garcia, Eagle Island, Peros Banhos, and Salomon (photos: 36 and $45 \mathrm{~mm}$ ). Seventeen per cent of our specimens came from reef-flats, the remainder from very shallow lagoonal habitats. IndoPacific.

\section{Chrysiptera leucopoma (Lesson)}

Fig. 264

Glyphisodon leucopomus Lesson, 1830:189 (Caroline Islands)

Glyphidodontops leucopomus-Allen and Steene, 1979:43 (Indo-west Pacific); Allen, 1975:155 (East Indies to Marquesas Islands)

\section{MATERIAL}

Eight lots, 81 specimens, 17-50 mm SL, 0-3 m, lagoon and reef-flat at Diego Garcia, Eagle Island, Peros Banhos, and Salomon (photo: $44 \mathrm{~mm}$ ). This species was almost equally divided between the lagoons (55\% of specimens collected, $\overline{\mathrm{x}} /$ lot $=10.3$ specimens $)$ and the reef-flats $(45 \%$ of specimens collected, $\overline{\mathrm{x}} / \mathrm{lot}=11$ specimens). IndoPacific

\section{Chrysiptera xanthozona (Bleeker)}

Fig. 265 Glyphisodon xanthozonus Bleeker, 1853b:283 (Kauer, East Indies)

Abudefduf xanthozonus-Smith, 1960:337 (western Indian Ocean)

\section{MATERIAL}

Three lots, 111 specimens, 19-50 $\mathrm{mm} \mathrm{SL,} \mathrm{0-3} \mathrm{m,} \mathrm{reef-top}$ and reef-flat at Peros Banhos and Salomon (photo: $44 \mathrm{~mm}$ ). This species was collected only on the ocean side of the island-on the reef-flat and in the spur-and-groove formation. Indo-west Pacific.

\section{Chrysiptera sp. 1}

Fig. 266 MATERIAL

Two lots, 5 specimens, 39-46 mm SL, 0-1 m, lagoon at Eagle Island. This species, which may be new, is a pale-coloured fish, having a white opercle with a black spot on it and having a black spot on the posteriormost dorsal-fin rays. Systematics insufficiently known to categorize distribution. Range unassigned.

Chrysiptera sp. 2

Fig. 267 MATERIAL

Three lots, 174 specimens, 13-48 mm SL, 0-0.5 m, lagoon at Diego Garcia, Eagle Island, and Peros Banhos. This species is characterized by a pale overall coloration, a $\mathrm{V}$-shaped line on the snout extending onto the dorsum, a dark spot in the spinous dorsal fin, and a dark spot on the posteriormost dorsal-fin rays. Systematics insufficiently known to categorize distribution. Range unassigned.

\section{Chrysiptera sp. 3}

Fig. 268 MATERIAL

One lot, 1 specimen, $20 \mathrm{~mm} \mathrm{SL,} \mathrm{0-0.5} \mathrm{m,} \mathrm{reef-flat} \mathrm{at} \mathrm{Peros}$ Banhos. This small juvenile possesses tricuspid teeth and may represent one of the above species. Systematics insufficiently known to categorize distribution. Range unassigned.

Dascyllus aruanus (Linnaeus) Pl. VIF Chaetodon aruanus Linnaeus, 1758:275 ("Indies") Dascyllus aruanus-Regan, 1908:229 (Chagos Archipelago); Allen, 1975:103 (Indo-Pacific to Rapa and the Marquesas Islands)

\section{MATERIAL}

Twenty lots, 994 specimens, 7-54 mm SL, 0-22 m, lagoon, reef-top (1), and reef-flat (1) at Diego Garcia, Peros Banhos, Salomon, and Three Brothers. Ninety-four per cent of the specimens were taken in the lagoons, with $96 \%$ being from water less than $15 \mathrm{~m}$ deep. Indo-Pacific.

\section{Dascyllus carneus Fischer PI. VIG} Dascyllus carneus Fischer, 1885:71 (Mozambique); Randall and Allen, 1977:368 (Indian Ocean, including Chagos, to Jakarta and west Thailand)

\section{MATERIAL}

Ten lots, 95 specimens, 16-48 mm SL, 5-20 m, lagoon, reef-top, and drop-off at Eagle Island, Peros Banhos, and Salomon (photos: 19 and $43 \mathrm{~mm}$ ). Collections of this species from the lagoons had a mean of 15.3 specimens/lot, as opposed to 8.3 for the reef-top and 1.5 for the drop-off. Ninety-seven per cent of the specimens were taken in water less than $15 \mathrm{~m}$ deep.

The distribution of $D$. carneus as reported by Randall and Allen (1977) is unusual, although they record both this species and $D$. reticulatus (Richardson), a closely related (possibly geminate) species, from the Gulf of Thailand. Randall and Allen (1977) report several colour differences between the western Indian Ocean population and those 
from the Maldives, Thailand, and Java. The Chagos specimens fit the description of the former population, and it is possible that the two populations merit taxonomic distinction. Indian Ocean and western extremity of west Pacific.

Dascyllus trimaculatus (Rüppell)

Fig. 269

Pomacentrus trimaculatus Rüppell, 1829a:39 (Massawa, Red Sea)

Dascyllus trimaculatus-Randall and Allen, 1977:360 (Indo-Pacific to Pitcairn Island)

\section{MATERIAL}

Ten lots, 23 specimens, 11-82 mm SL, 5-25 m, lagoon, reef-top, and drop-off at Peros Banhos and Salomon (photos: 80 and $82 \mathrm{~mm}$ ). This species was mainly collected on the drop-offs (78\% of specimens collected), but was nowhere particularly abundant. The largest lot contains six specimens. Indo-Pacific.

\section{Lepidozygus tapeinosoma (Bleeker)}

Fig. 270

Pomacentrus tapeinosoma Bleeker, 1856a:376 (Ternate) Lepidozygus tapeinosoma-Emery, 1983:1326 (Indo-Pacific to Marquesas Islands)

\section{MATERIAL}

Five lots, 27 specimens, 43-77 mm SL, 5-15 m, reef-top only at Peros Banhos and Salomon (photos: 60 and $61 \mathrm{~mm}$ ). Indo-Pacific.

\section{Plectroglyphidodon dickii (Liénard)}

Fig. 271

Glyphisodon dickii Liénard, 1839:35 (Mauritius)

Plectroglyphidodon dickii-Allen, 1975:195 (Indo-Pacific east to Tuamotu Islands)

\section{MATERIAL}

Fifteen lots, 62 specimens, 12-71 mm SL, 0-10 m, lagoon and reef-top at Diego Garcia, Eagle Island, Peros Banhos, and Salomon (photo: $51 \mathrm{~mm}$ ). Specimens of this species were more concentrated in the lagoons than on the reef-top $(\overline{\mathrm{x}} /$ lot $=6.7$ vs 1.8$)$, and evenly distributed between $0-5 \mathrm{~m}$ and $6-15 \mathrm{~m}(\overline{\mathrm{x}} / \mathrm{lot}=4$ specimens at both depth ranges). Indo-Pacific.

Plectroglyphidodon imparipennis (Sauvage) Fig. 272 Glyphisodon imparipennis Sauvage in Vaillant and Sauvage, 1875:279 (Hawaii)

Plectroglyphidodon imparipennis-Allen, 1975:195 (IndoPacific east to Pitcairn Island)

\section{MATERIAL}

Two lots, 26 specimens, $37-43 \mathrm{~mm} \mathrm{SL}, 0-3 \mathrm{~m}$, reef-flat and reef-top at Peros Banhos and Salomon (photo: $42 \mathrm{~mm}$ ). The specimens from the reef-top are from the spur-and- groove formation. Indo-Pacific.

\section{Plectroglyphidodon johnstonianus Fowler and Ball}

Fig. 273

Plectroglyphidodon johnstonianus Fowler and Ball, 1924:271 (Johnston Island); Allen, 1975:195 (Pacific east to Pitcairn Island)

\section{MATERIAL}

Nine lots, 11 specimens, 23-59 mm SL, 5-25 m, lagoon, reef-top, and drop-off at Eagle Island, Peros Banhos, and Salomon (photo: $50 \mathrm{~mm}$ ). Allen (1975) suggests that $P$. nitidus Smith from the western Indian Ocean may be synonymous with $P$. johnstonianus, extending the range of the latter species into the western Indian Ocean. Indo-Pacific.

\section{Plectroglyphidodon lacrymatus (Quoy and Gaimard)}

Fig. 274 Glyphisodon lacrymatus Quoy and Gaimard, 1824:388 (Guam)

Plectroglyphidodon lacrymatus-Allen, 1975:198 (IndoPacific to Society Islands)

\section{MATERIAL}

Twenty lots, 117 specimens, 15-79 mm SL, 0-25 m, lagoon, reef-top (1), and drop-off (1) at Diego Garcia, Eagle Island, Peros Banhos, and Salomon (photos: 31, 50, and $67 \mathrm{~mm}$ ). Ninety-seven per cent of our specimens are from the lagoons, with $43 \%$ of the total from $0-5 \mathrm{~m}$ and $52 \%$ from 6-15 m. Indo-Pacific.

Plectroglyphidodon leucozonus (Bleeker)

Fig. 275

Glyphisodon leucozona Bleeker, 1859:339 (Java)

Plectroglyphidodon leucozona-Allen, 1975:198 (IndoPacific east to Pitcairn Island)

\section{MATERIAL}

Two lots, 32 specimens, $45-68 \mathrm{~mm} \mathrm{SL}, 0-3 \mathrm{~m}$, reef-top at Salomon. All but one specimen were taken in a single collection from the spur-and-groove formation on the south coast of Isle Boddam. Indo-Pacific.

Plectroglyphidodon phoenixensis (Schultz) Fig. 276 Abudefduf phoenixensis Schultz; 1943:190 (Phoenix Islands)

Plectroglyphidodon phoenixensis-Winterbottom, 1978:46 (Transkei and Kwazulu, South Africa); Allen, 1975:198 (Pacific to Marquesas Islands, questionable from Mauritius)

\section{MATERIAL}

One lot, 19 specimens, 38-47 mm SL, reef-top at Salomon (photo: $47 \mathrm{~mm}$ ). The single collection of this species from the spur-and-groove formation of the reef-top was the only collection made in this habitat. Indo-Pacific. 
Pomacentrus coelestis Jordan and Starks

Fig. 277

Pomacentrus coelestis Jordan and Starks, 1901:383 (Japan); Allen, 1975:211 (Pacific east to Tuamotu Islands)

Pomacentrus pulcherrimus Smith, 1960:344 (Bazaruto north over east Africa to Seychelles)

\section{MATERIAL}

Twenty-three lots, 305 specimens, $13-56 \mathrm{~mm} \mathrm{SL}, 0-25 \mathrm{~m}$, lagoon, reef-top (2), and drop-off (1) at Diego Garcia, Eagle Island, Peros Banhos, Salomon, and Three Brothers (photos: 34 and ? mm). Lagoon collections of this species had a mean of 15 specimens/lot and represented $98 \%$ of specimens collected; $84 \%$ of the total number of specimens collected were in $0-15 \mathrm{~m}$. Indo-Pacific.

\section{Pomacentrus sp. 1 \\ Pls. VIH, VIIA,B}

\section{MATERIAL}

Twenty-six lots, 356 specimens, 11-87 mm SL, 0-25 m, lagoon, intertidal (1), reef-top (2), and drop-off (3) at Diego Garcia, Eagle Island, Peros Banhos, Salomon, and Three Brothers. This undescribed species, similar to $P$. opisthostigma Fowler, is being studied by Emery. Systematics insufficiently known to categorize distribution. Range unassigned.

\section{Pomacentrus sp. 2}

Fig. 278 MATERIAL

Three lots, 4 specimens, $28-65 \mathrm{~mm} \mathrm{SL}, 18-25 \mathrm{~m}$, drop-off at Peros Banhos and Salomon. Systematics insufficiently known to categorize distribution. Range unassigned.

Stegastes fasciolatus (Ogilby)

Fig. 279

Pomacentrus fasciolatus Ogilby, 1889:64 (Lord Howe Island)

Eupomacentrus fasciolatus - Allen, 1975:139 (Pacific east to Easter Island)

Stegastes fasciolatus - Allen and Steene, 1979:44 ("Indowest Pacific")

\section{MATERIAL}

One lot, 1 specimen, $73 \mathrm{~mm} \mathrm{SL}, 0-3 \mathrm{~m}$, reef-top at Salomon. Indo-Pacific.

\section{Stegastes nigricans (Lacepède)}

Fig. 280

Holocentrus nigricans Lacepède, 1802b:332 (no locality) Eupomacentrus nigricans-Allen, 1975:142(Indo-Pacific east to Marquesas Islands)

\section{MATERIAL}

Twelve lots, 788 specimens, $17-89 \mathrm{~mm} \mathrm{SL}, 0-7 \mathrm{~m}$, lagoon only at Eagle Island, Peros Banhos, and Salomon (photos: 51,56 , and $83 \mathrm{~mm}$ ).

This species is very similar to $S$. albifasciatus (Schlegel and Müller, 1839-44) from the western and central Pacific. The Chagos specimens agree with Allen's (1975) distinction between $S$. nigricans and $S$. albifasciatus in the following ways: they have 16 (usually)-17 pectoral-fin rays (vs 15 [usually]-16 in S. albifasciatus); they seldom have a broad light bar over the body (vs such a bar being present); and the black spot on the soft dorsal fin lacks a light ocellus (vs at least half an ocellus being present). Indo-Pacific.

\section{Cirrhitidae}

Amblycirrhitus bimaculus (Jenkins)

Fig. 281

Cirrhitoidea bimacula Jenkins, 1904:489 (Hawaii)

Amblycirrhitus bimacula-Randall, 1963:427 (IndoPacific east to Tuamotu Islands)

?Cirrhitichthys oxyrhynchus-Regan, 1908:224 (Salomon, Chagos Archipelago) (non Bleeker, 1858:205)

\section{MATERIAL}

Sixteen lots, 82 specimens, 23-64 mm SL, 0-25 m, lagoon, reef-top, and drop-off at Eagle Island, Peros Banhos, and Salomon (photo: $53 \mathrm{~mm}$ ). The majority of the specimens were taken on the reef-tops $(66 \% ; \overline{\mathrm{x}} / \mathrm{lot}=5.4)$ and lagoons $(28 \% ; \overline{\mathrm{x}} / \mathrm{lot}=5.8)$, most commonly in $6-15 \mathrm{~m}$ $(62 \% ; \overline{\mathrm{x}} / \mathrm{lot}=4.6)$ and in $0-5 \mathrm{~m}(32 \% ; \overline{\mathrm{x}} / \mathrm{lot}=8.7)$.

Regan's (1908) report of $C$. oxyrhynchus appears to represent this species; specimens of $A$. bimaculus collected from Salomon on the Gardiner expedition are present in the British Museum. Indo-Pacific.

Cirrhitichthys oxycephalus (Bleeker)

Fig. 282

Cirrhites oxycephalus Bleeker, 1855b:408 (Ambon)

Cirrhitichthys oxycephalus-Randall, 1963:437 (IndoPacific to Panama)

\section{MATERIAL}

Thirteen lots, 24 specimens, $25-49 \mathrm{~mm} \mathrm{SL}, 0-43 \mathrm{~m}$, lagoon, reef-top, and drop-off at Eagle Island, Peros Banhos, and Salomon (photos: 42 and $48 \mathrm{~mm}$ ). This species was collected primarily on the drop-offs ( $71 \%)$ and in $16-25 \mathrm{~m}(67 \%)$. Indo-Pacific.

\section{Cirrhitus pinnulatus (Schneider)}

Fig. 283

Labrus pinnulatus Schneider in Bloch and Schneider, 1801:264 (Tahiti)

Cirrhitus pinnulatus-Randall, 1984b:5 (Indo-Pacific, including Chagos)

\section{MATERIAI}

Two lots, 26 specimens, 56-126 mm SL, lagoon (1) and reef-top at Eagle Island and Peros Banhos (photo: $88 \mathrm{~mm}$ ). This species appears to prefer areas of surge-and-wave 
action, all but one of the specimens being taken in the single collection from the spur-and-groove formation on Isle Boddam. Indo-Pacific.

\section{Oxycirrhites typus Bleeker}

Fig. 284

Oxycirrhites typus Bleeker, 1857a:40 (Ambon); Randall, 1963:445 (Indo-Pacific to Baja California)

\section{MATERIAL}

Two lots, 2 specimens, 44-54 mm SL, 20-25 m, drop-off at Salomon (photo: $44 \mathrm{~mm}$ ). Indo-Pacific.

\section{Paracirrhites arcatus (Cuvier)}

Fig. 285

Cirrhites arcatus Cuvier in Cuvier and Valenciennes, 1829a:74 (Mauritius; Tahiti)

Paracirrhites arcatus - Randall, 1963:411 (lectotype designation, Mauritius)

\section{MATERIAL}

Twenty-one lots, 122 specimens, 27-84 mm SL, 4-26 m, lagoon, reef-top, and drop-off at Peros Banhos and Salomon (photos: 59, 65, and $66 \mathrm{~mm}$ ). The material includes specimens with and without the white lateral stripe. The species was most abundant on the reef-tops and drop-offs ( $92 \%$ of specimens collected). Indo-Pacific.

\section{Paracirrhites forsteri (Schneider)}

Fig. 286

Grammistes forsteri Schneider in Bloch and Schneider, 1801:191 (Marquesas Islands)

Paracirrhites forsteri-Randall, 1984b:7 (Indo-Pacific, including Chagos)

\section{MATERIAL}

Thirty-two lots, 50 specimens, 14-123 mm SL, 0-43 m, lagoon, reef-top, and drop-off at Eagle Island, Peros Banhos, and Salomon (photos: 29, 39, 67, 75, 83, 95, and $108 \mathrm{~mm}$ ).

The species was fairly evenly distributed among the habitats listed above, but $82 \%$ of the specimens were taken in $6-25 \mathrm{~m}$. Solitary individuals were frequently observed perched on the branches of Acropora corals. The specimens exhibit a tremendous variety of colour pattern, ranging from a red or brown dorsum with a light yellow belly and red spots on the head, to a red dorsum and white venter on a $39 \mathrm{~mm}$ SL specimen, and a red dorsum and black venter on a $29 \mathrm{~mm}$ SL specimen (neither of the latter two specimens possessed any head spots). Indo-Pacific.

\section{Mugilidae}

Identifications of this family were checked by Dr. J. M. Thomson.
Crenimugil crenilabis (Forsskål)

Fig. 287

Mugil crenilabis Forsskål, 1775:73 (Red Sea)

Crenimugil crenilabis-Thomson and Luther, 1984:13 (Indo-Pacific east to Hawaii)

\section{MATERIAL}

Five lots, 37 specimens, $36-342 \mathrm{~mm} \mathrm{SL}, 0-2 \mathrm{~m}$, lagoon at Eagle Island, Peros Banhos, and Salomon (photos: 54 and $309 \mathrm{~mm})$. Indo-Pacific.

Liza macrolepis (Smith)*

Fig. 288

Mugil macrolepis Smith, 1849:none (South Africa)

Liza macrolepis-Thomson and Luther, 1984:27 (IndoPacific to Tuamotu Islands)

\section{MATERIAL}

Three lots, 6 specimens, $20-138 \mathrm{~mm} \mathrm{SL}, 0-1 \mathrm{~m}$, lagoon at Diego Garcia and Eagle Island. The identity of a $27-\mathrm{mm} \mathrm{SL}$ specimen is somewhat doubtful owing to its small size and somewhat damaged condition. Indo-Pacific.

\section{Mugil cephalus Linnaeus}

Mugil cephalus Linnaeus, 1758:316 ("European Ocean"); Thomson and Luther, 1984:41 (cosmopolitan, including Chagos Archipelago)

No specimens seen or collected; occurrence is based on Thomson and Luther (1984). Cosmopolitan.

\section{?Myxus elongatus Günther}

Myxus elongatus Günther, 1861:466 (coasts of Australia)

\section{MATERIAL}

One lot, 1 specimen, $24 \mathrm{~mm} \mathrm{SL}, 0-0.5 \mathrm{~m}$, lagoon at Peros Banhos.

Dr Thomson commented on this specimen as follows: "The conformation of the teeth indicate elongatus, however, as the specimen lacks scales and again head parts are not in adult proportions, it is possible that it may be a local species of Myxus." The only species of this genus recorded from the western Indian Ocean is $M$. capensis (Thomson and Luther, 1984). Range unassigned.

\section{?Valamugil seheli (Forsskål)}

Mugil seheli Forsskål, 1775:73 (Red Sea)

Mugil caeruleomaculatus Lacepède, 1803:385 (no locality); Regan, 1908:221 (Diego Garcia, Chagos Archipelago)

No specimens seen or collected; the record is tentatively included on the basis of Regan's record of $M$. caeruleomaculatus, which Thomson and Luther (1984) regard as a junior synonym of $V$. seheli. There remains the possiblity that Regan's identification is in error, especially in this taxonomically difficult group. Range unassigned. 


\section{Sphyraenidae}

Material of this family was identified by J.-M. Rose, who also provided the geographic ranges.

\section{Sphyraena barracuda (Walbaum)}

Fig. 290

Esox barracuda Walbaum, 1792:94 (West Indies)

Sphyraena barracuda-Allen and Steene, 1979:46 (cosmopolitan)

MATERIAL

Two lots, 2 specimens, 583-616 mm SL, surface waters of lagoon at Peros Banhos (photo: $616 \mathrm{~mm}$ ). Cosmopolitan.

\section{Sphyraena forsteri Cuvier}

Fig. 291

Sphyraena forsteri Cuvier in Cuvier and Valenciennes, 1829a:353 (Tahiti); Kyushin et al., 1977:60 (Chagos Archipelago)

\section{MATERIAL}

One lot, 1 specimen, $433 \mathrm{~mm} \mathrm{SL}$, lagoon at Peros Banhos. Indo-Pacific (east to Hawaii).

\section{Sphyraena nigripinnis Temminck} and Schlegel

Sphyraena nigripinnis Temminck and Schlegel, 1842:34 (Japan)

Sphyraena jello Kyushin et al., 1977:58 (Chagos Archipelago) (non Cuvier, 1829:349)

Rose stated (in litt:) that there is some uncertainty as to the distinction between this species and $S$. putnamiae Jordan and Seale. We have underwater photographs off the northern tip of Salomon of a large school of barracudas which appears to be composed of individuals of $S$. nigripinnis. The photograph identified as $S$. jello in Kyushin et al. (1977) seems to be $S$. putnamiae (Rose, pers. comm.), but since identification is not certain, we do not include that species as definitely present at Chagos. Indo-Pacific.

\section{Polynemidae}

Polydactylus sexfilis (Valenciennes)

Fig. 292

Polynemus sexfilis Valenciennes in Cuvier and Valenciennes, 1831 a:515 (Mauritius)

\section{MATERIAL}

Three lots, 6 specimens, $103-313 \mathrm{~mm} \mathrm{SL}, 0.5-2.5 \mathrm{~m}$, lagoons at Eagle Island and Peros Banhos (photo: $313 \mathrm{~mm}$ ). The material was identified by R. M. Feltes, who also provided the distribution. Indo-Pacific (east to the Marquesas Islands)

\section{Labridae}

Anampses caeruleopunctatus Rüppell

Fig. 293

Anampses caeruleopunctatus Rüppell, 1829a:42 (Tor, Red Sea); Randall, 1972a:160 (Indo-Pacific east to Easter Island)

\section{MATERIAL}

One lot, 1 specimen, $127 \mathrm{~mm} \mathrm{SL}, 1-2 \mathrm{~m}$, pass at Diego Garcia. The single specimen was collected by a gill net set in the pass by J. Ryther. Indo-Pacific.

\section{Anampses meleagrides Valenciennes}

Fig. 294 Anampses meleagrides Valenciennes in Cuvier and Valenciennes, 1839a:12 (Mauritius); Randall, 1972a:166 (IndoPacific, sight record from Caroline Islands)

\section{MATERIAL}

One lot, 1 specimen, $56 \mathrm{~mm} \mathrm{SL}, 4-7 \mathrm{~m}$, lagoon at Peros Banhos (photo). Indo-west Pacific and marginally on the Pacific plate.

\section{Anampses twistii Bleeker}

Fig. 295

Anampses twistii Bleeker, 1856d:56 (Ambon); Randall, 1972a:182 (Indo-Pacific east to Austral Islands)

\section{MATERIAL}

Six lots, 8 specimens, 32-109 mm SL, 3-25 m, lagoon (1) and drop-off at Peros Banhos and Salomon (photos: 59 and $89 \mathrm{~mm})$. Indo-Pacific.

Bodianus anthioides (Bennett)

Fig. 296

Crenilabrus anthioides Bennett, 1831:167 (Mauritius)

\section{MATERIAL}

Two lots, 3 specimens, $88-115$ mm SL, 10-25 m, drop-off at Salomon (photo: $97 \mathrm{~mm}$ ). Indo-Pacific (Gomon, pers. comm.).

\section{Bodianus axillaris (Bennett)}

Figs. 297,298

Labrus axillaris Bennett, 1831:166 (Mauritius)

Bodianus axillaris - Randall, 1973:196 (Tahiti)

\section{MATERIAL}

Ten lots, 12 specimens, 43-118 mm SL, 5-33 m, lagoon (1), reef-top, and drop-off at Peros Banhos and Salomon (photos: 44, 93, and $96 \mathrm{~mm}$ ). Indo-Pacific.

Bodianus bilunulatus bilunulatus (Lacepède) Fig. 299 Labrus bilunulatus Lacepède, 1802a:454 (Pacific Ocean) Bodianus bilunulatus bilunulatus-Gomon, 1984:15 (Indowest Pacific, including Chagos)

Bodianus hirsutus - Kyushin et al., 1977:298 (Chagos Archipelago) (non Lacepède, 1802) 
MATERIAL

Two lots, 4 specimens, 22-201 mm SL, 18-27 m, drop-off at Peros Banhos (photos: 22, 95, and $189 \mathrm{~mm}$ ). Gomon (pers. comm.) divides this species into three subspecies, and the Chagos specimens represent $B$. bilunulatus bilunulatus. Indo-west Pacific.

\section{Bodianus diana (Lacepède)}

Figs. 300, 301

Labrus diana Lacepède, 1802a:450 (Pacific Ocean)

Bodianus diana-Gomon, 1984:17 (Indo-west Pacific, including Chagos)

\section{MATERIAL}

Six lots, 7 specimens, 48-131 mm SL, 18-43 m, drop-off at Peros Banhos and Salomon (photos: 69, 78, 113, and $131 \mathrm{~mm}$ ). Indo-west Pacific.

\section{Cheilinus arenatus Valenciennes}

Fig. 302

Cheilinus arenatus Valenciennes in Cuvier and Valenciennes, 1839b:101 (Réunion)

\section{MATERIAL}

Seven lots, 10 specimens, 39-80 mm SL, 18-43 m, drop-off at Peros Banhos and Salomon (photos: 54 and $56 \mathrm{~mm}$ ). Indo-west Pacific (east to the Philippines).

\section{Cheilinus chlorurus (Bloch)}

Sparus chlorurus Bloch, 1791:24 (Japan)

Cheilinus chlorurus-Gomon, 1984:31 (Indo-Pacific, including Chagos)

No specimens seen or collected; occurrence is based on the distribution map given by Gomon (1984). Indo-Pacific.

\section{Cheilinus digrammus (Lacepède)}

Figs. 303, 304

Labrus digrammus Lacepède, 1802a:448 (Pacific Ocean) Cheilinus digrammus-Gomon, 1984:33 (Indo-west Pacific, including Chagos, east to Samoa)

\section{MATERIAL}

Twenty-two lots, 61 specimens, $17-163 \mathrm{~mm} \mathrm{SL}, 0-40 \mathrm{~m}$, lagoon, reef-top (1), and drop-off at Peros Banhos, Salomon, and Three Brothers (photos: 22, 30, 145, 155, and $157 \mathrm{~mm}$ ). Eighty per cent of our specimens were collected in the lagoons, with $89 \%$ of the total being taken in 6-25 m. Indo-west Pacific.

\section{Cheilinus fasciatus (Bloch)}

Sparus fasciatus Bloch, 1791:18 (Japan)

Fig. 305

Cheilinus fasciatus-Gomon, 1984:35 (Indo-west Pacific, east to Marshall Islands and Samoa)

\section{MATERIAL}

Eight lots, 19 specimens, $12-173 \mathrm{~mm}$ SL, 5-40 m, lagoon and reef-top (1) at Peros Banhos and Salomon (photos: 53 and $150 \mathrm{~mm}$ ). This species was collected primarily in the lagoons (one specimen from the reef-top), with $68 \%$ of the specimens being taken in 6-15 m. Indo-west Pacific.

Cheilinus oxycephalus Bleeker

Fig. 306

Cheilinus oxycephalus Bleeker, 1853e:349 (Ambon); Randall, 1973:196 (Tahiti)

\section{MATERIAL}

Eleven lots, 23 specimens, $27-80 \mathrm{~mm}$ SL, 0-25 m, lagoon only at Peros Banhos and Salomon (photos: 37, 56, 62, 64, and $80 \mathrm{~mm}$ ). Sixty-one per cent of the specimens taken were collected in $6-15 \mathrm{~m}$. Indo-Pacific.

\section{Cheilinus trilobatus Lacepède}

Figs. 307, 308

Cheilinus trilobatus Lacepède, 1802a:529 (Réunion; Mauritius; Madagascar); Gomon, 1984:39 (Indo-Pacific, including Chagos, east to Society Islands)

\section{MATERIAL}

Six lots, 33 specimens, 23-260 mm SL, 0-10 m, lagoon, intertidal, and reef-flat at Diego Garcia, Eagle Island, and Peros Banhos (photos: 50, 178, and $260 \mathrm{~mm}$ ). Eighty-two per cent of the specimens were collected on the reef-flats, with $97 \%$ of the total being taken in less than $5 \mathrm{~m}$. Indo-Pacific.

\section{Cheilinus undulatus Rüppell}

Pl. VIID

Cheilinus undulatus Rüppell, 1835:20 (Jiddah, Red Sea); Gomon, 1984:41 (Indo-Pacific, including Chagos, east to Tuamotu Islands)

No material collected; the record is based on Gomon (1984), as well as on underwater photographs and several sightings of adults in the lagoon, reef-top, and drop-off at Peros Banhos and Salomon. Indo-Pacific.

Cheilo inermis (Forsskål)

Fig. 309

Labrus inermis Forsskål, 1775:34 (Al Mukhā, Red Sea)

Cheilo inermis-Gomon, 1984:43 (Indo-Pacific, including Chagos, east to Tahiti)

\section{MATERIAL}

One lot, 1 specimen, $43 \mathrm{~mm} \mathrm{SL}, 0.5 \mathrm{~m}$, lagoon at Peros Banhos (photo). Indo-Pacific.

Cirrhilabrus exquisitus Smith

Fig. 310

Cirrhilabrus exquisitus Smith, 1957b:109 (Pinda; also Zanzibar and Madagascar); Randall and Shen, 1978:16 (Indo-Pacific east to Tuamotu Islands)

\section{MATERIAL}

Thirteen lots, 65 specimens, $12-56 \mathrm{~mm} \mathrm{SL}, 4-43 \mathrm{~m}$, 
lagoon, reef-top, and drop-off at Peros Banhos and Salomon (photos: 46 and $56 \mathrm{~mm}$ ). With a single exception, all specimens were collected in 6-25 m, with almost equal numbers being taken in the three habitats listed above. Indo-Pacific.

\section{Cirrhilabrus rubrisquamis Randall and Emery}

Pl. VIIE Cirrhilabrus rubrisquamis Randall and Emery, 1983:21 (Peros Banhos, Chagos Archipelago)

\section{MATERIAL}

One lot, 1 specimen (holotype), $41 \mathrm{~mm} \mathrm{SL}, 41-48 \mathrm{~m}$, drop-off at Peros Banhos (photo). Endemic.

\section{Coris aygula Lacepède}

Coris aygula Lacepède, 1802a:96 (no locality); Gomon, 1984:49 (Indo-Pacific, including Chagos, east to Society Islands)

No specimens seen or collected; occurrence is based on the range map given in Gomon (1984). Indo-Pacific.

Coris formosa (Bennett)*

Fig. 311

Labrus formosa Bennett, 1830:16 (Sri Lanka)

Coris formosa-Gomon, 1984:51 (Indo-west Pacific, including Chagos, east to Malay Archipelago)

MATERIAL

One lot, 1 specimen, $206 \mathrm{~mm} \mathrm{SL}, 0-1 \mathrm{~m}$, pass at Peros Banhos (photo). Indo-west Pacific.

\section{Coris gaimard africana Smith}

Fig. 312

Coris gaimard africana Smith, 1957d:119 (Seychelles); Gomon, 1984:53 (western Indian Ocean)

\section{MATERIAL}

One lot, 1 specimen, $190 \mathrm{~mm} \mathrm{SL}, 18-25 \mathrm{~m}$, drop-off at Salomon (photo). Gomon (1984) recognizes two subspecies, our material belonging to the western Indian Ocean form.

\section{Coris variegata (Rüppell)}

Fig. 313

Halichöres variegatus Rüppell, 1835:14 (Jiddah, Red Sea) Coris variegata - Schultz, 1960a: 183 (Marshall Islands)

\section{MATERIAL}

Five lots, 8 specimens, 31-94 mm SL, 7-30 m, lagoon only at Peros Banhos and Salomon (photos: 31, 38, 67, and $87 \mathrm{~mm}$ ). Indo-west Pacific and marginally on the Pacific plate.

\section{Cymolutes lecluse (Quoy and Gaimard) Fig. 314} Xyrichthys lecluse Quoy and Gaimard, 1824:284 (Hawaii)

\section{MATERIAL}

One lot, 1 specimen, $65 \mathrm{~mm} \mathrm{SL}, 0-0.5 \mathrm{~m}$, reef-flat at Peros Banhos (photo). Indo-Pacific.

Epibulus insidiator (Pallas)

Fig. 315

Sparus insidiator Pallas, 1770:41 (Java)

Epibulus insidiator-Gomon, 1984:55 (Indo-Pacific, including Chagos, east to Tuamotu Islands)

\section{MATERIAL}

Twelve lots, 33 specimens, $17-182 \mathrm{~mm} \mathrm{SL}, 0-25 \mathrm{~m}$, lagoon, reef-top, and drop-off at Peros Banhos and Salomon (photos: $47,86,131,146$, and $156 \mathrm{~mm}$ ). This species was most abundant in the lagoons, where $67 \%$ of the specimens obtained were collected, although 18 of these specimens were taken in a single collection made in $0-3 \mathrm{~m}$ on the sides and top of a bommie which had numerous caves. Indo-Pacific.

Gomphosus coeruleus Lacepède

Fig. 316 Gomphosus coeruleus Lacepède, 1802a:100 (no locality); Gomon, 1984:57 (Indian Ocean, including Chagos)

\section{MATERIAL}

Thirty-one lots, 181 specimens, $14-113 \mathrm{~mm} \mathrm{SL}, 0-20 \mathrm{~m}$, lagoon, intertidal, reef-flat, and reef-top at Diego Garcia, Eagle Island, Peros Banhos, Salomon, and Three Brothers (photos: 67, 82, and $109 \mathrm{~mm}$ ) This species was most common in the very shallow water of the intertidal and reef-flat habitats $(\overline{\mathrm{x}} / \mathrm{lot}=26$ and 11 , respectively), and $77 \%$ were collected in $0-5 \mathrm{~m}$. Indian Ocean.

Halichoeres cosmetus Randall and Smith Pl. VIIF Halichoeres cosmetus Randall and Smith, 1982:15 (Maldives, also western Indian Ocean, including Chagos)

\section{MATERIAL}

Six lots, 8 specimens (paratypes), 30-86 mm SL, 13$25 \mathrm{~m}$, lagoon and drop-off at Peros Banhos and Salomon (photos: $30,36,43,62$, and $86 \mathrm{~mm}$ ). Only a single specimen was collected in the lagoons $(13 \mathrm{~m})$, the remainder coming from $16-25 \mathrm{~m}$ on the drop-offs. Western Indian Ocean.

Halichoeres hortulanus (Lacepède) Figs. 317, 318 Labrus hortulanus Lacepède, 1802a:449 (Pacific Ocean) Halichoeres hortulanus-Randall and Smith, 1982:4 (Indo-Pacific)

Halichoeres hortulanus centiquadrus-Gomon, 1984:59 (Indian Ocean, including Chagos)

MATERIAL

Eighteen lots, 35 specimens, 14-183 mm SL, lagoon, intertidal, reef-top, and drop-off at Eagle Island, Peros Banhos, and Salomon (photos: 28, 30, 40, 42, 51, 136, and 
$137 \mathrm{~mm}$ ). This species was most abundant in the lagoon and intertidal habitats $(80 \%)$ in $0-15 \mathrm{~m}(91 \%)$. We tentatively follow Randall and Smith (1982) in not recognizing a western Indian Ocean and a Pacific subspecies, as Gomon (1984) has done. Indo-Pacific.

\section{Halichoeres iridis Randall and Smith Pl. VIIG}

Halichoeres iridis Randall and Smith, 1982:17 (Mauritius, also western Indian Ocean including Chagos)

\section{MATERIAL}

Three lots, 4 specimens (paratypes), 40-79 mm SL, 13-43 m, lagoon and drop-off at Peros Banhos and Salomon (photos: 45 and $79 \mathrm{~mm}$ ). Three of the four specimens are paratypes, the lone exception being the specimen from the lagoon at Peros Banhos. Western Indian Ocean.

\section{Halichoeres marginatus Rüppell}

Figs. 319,320

Halichöres marginatus Rüppell, 1835:16 (Mohila and Massawa, Red Sea); Randall and Smith, 1982:5 (east Africa to French Polynesia)

\section{MATERIAL}

Fourteen lots, 133 specimens, 13-95 mm SL, 0-26 m, lagoon, intertidal, reef-flat, reef-top, and drop-off at Eagle Island, Peros Banhos, and Salomon (photos: 19, 23, 33, $44,60,91$, and $95 \mathrm{~mm}$ ). Only two specimens (in two lots) were collected in water deeper than $5 \mathrm{~m}$, and the majority of specimens came from intertidal (32\%) and reef-flat $(59 \%)$ habitats. Indo-Pacific.

\section{Halichoeres nebulosus (Valenciennes) Fig. 321 Julis nebulosus Valenciennes in Cuvier and Valenciennes, 1839a:461 (Bombay) \\ Halichoeres nebulosus-Randall and Smith, 1982:10 (Indo-west Pacific east to Ryukyus)}

\section{MATERIAL}

Seven lots, 18 specimens, 20-64 mm SL, 0-3 m, lagoon, intertidal, and reef-flat at Diego Garcia, Eagle Island, Peros Banhos, and Three Brothers. Indo-west Pacific.

\section{Halichoeres scapularis (Bennett)}

Fig. 322

Julis scapularis Bennett, 1831:167 (Mauritius)

Halichoeres scapularis-Randall and Smith, 1982:5 (Indo-west Pacific east to Japan)

\section{MATERIAL}

Seventeen lots, 818 specimens, 12-112 mm SL, 0-24 m, lagoon, intertidal, reef-flat, reef-top, and drop-off at Diego Garcia, Eagle Island, Peros Banhos, Salomon, and Three Brothers (photos: 37, 50, 54, 84, and $110 \mathrm{~mm}$ ). This species was extremely abundant in areas subjected to tidal variation, the intertidal and reef-flat habitats accounting for $93 \%$ of the specimens collected, with $99 \%$ taken in $0-5 \mathrm{~m}$. Indo-west Pacific.

Hemigymnus fasciatus (Bloch)

Fig. 323

Labrus fasciatus Bloch, 1792:6 (Japan)

Hemigymnus fasciatus-Gomon, 1984:61 (Indo-Pacific including Chagos, east to Tahiti)

\section{MATERIAL}

Two lots, 2 specimens, 101-202 mm SL, 10-15 m, lagoon at Peros Banhos and Salomon (photos: both). Indo-Pacific.

\section{Hemigymnus melapterus Bloch}

Labrus melapterus Bloch, 1791:137 (Japan)

Hemigymnus melapterus-Gomon, 1984:63 (Indo-Pacific, including Chagos, east to Polynesia)

No specimens seen or collected; occurrence is based on the range map given by Gomon (1984). Indo-Pacific.

\section{Hologymnosus annulatus (Lacepède)}

Fig. 324

Labrus annulatus Lacepède, 1802a:455 (Pacific Ocean)

Hologymnosus annulatus-Gomon, 1984:65 (Indo-Pacific, including Chagos, east to Pitcairn Island)

\section{MATERIAL}

One lot, 1 specimen, $73 \mathrm{~mm} \mathrm{SL,} 13 \mathrm{~m}$, lagoon at Peros Banhos (photo). Indo-Pacific.

Labrichthys unilineatus (Guichenot) Fig. 325

Cossyphus unilineatus Guichenot, 1847:284 (Guam)

Labrichthys unilineatus - Randall and Springer, 1973:284 (Indo-Pacific east to Marshall Islands, Gilbert Islands, and Samoa)

\section{MATERIAL}

Seventeen lots, 33 specimens, 15-118 mm SL, 0-25 m, lagoon and drop-off at Peros Banhos, Salomon, and Three Brothers (photos: 36,64 , and $118 \mathrm{~mm}$ ). The majority of the specimens $(85 \%)$ were taken in the lagoons, with $70 \%$ of the total collected in 6-15 m. Indo-west Pacific and marginally on the Pacific plate.

Labroides bicolor Fowler and Bean

Fig. 326

Labroides bicolor Fowler and Bean, 1928:224 (Philippines); Randall, 1958:334 (Indo-Pacific east to Marquesas Islands)

\section{MATERIAL}

Four lots, 4 specimens, 25-42 mm SL, 0.5-25 m, lagoon and drop-off at Peros Banhos and Salomon (photos: 25, 40, and $42 \mathrm{~mm}$ ). Indo-Pacific. 
Labroides dimidiatus (Valenciennes)

Fig. 327 Cossyphus dimidiatus Valenciennes in Cuvier and Valenciennes, 1839a:136 (Mauritius)

Labroides dimidiatus-Randall, 1958:329 (Indo-Pacific east to Tuamotu Islands)

\section{MATERIAL}

Twenty-four lots, 47 specimens, $12-55 \mathrm{~mm} \mathrm{SL}, 0-43 \mathrm{~m}$, lagoon, intertidal, reef-flat, reef-top, and drop-off at Eagle Island, Peros Banhos, and Salomon (photos: 37 [× 2], 54, and $55 \mathrm{~mm}$ ). This species was fairly evenly distributed among the above listed habitats, although $98 \%$ of our specimens were taken in less than $26 \mathrm{~m}$. Indo-Pacific.

\section{Labropsis xanthonota Randall}

Pl. VIIH

Labropsis xanthonota Randall, 1981:138 (Samoa; also Indo-Pacific, including Chagos, east to the Marshall Islands)

\section{MATERIAL}

Two lots, 2 specimens (paratypes), $38-40 \mathrm{~mm} \mathrm{SL}$, 18-25 m, drop-off at Salomon (photo: $40 \mathrm{~mm}$ ). Indo-west Pacific and marginally on the Pacific plate.

\section{Macropharyngodon bipartitus bipartitus}

Smith

Figs. 328, 329

Macropharyngodon bipartitus Smith, 1957b:104 (Pinda, Mozambique)

Macropharyngodon bipartitus bipartitus - Randall, 1978: 756 (western Indian Ocean)

\section{MATERIAL}

Four lots, 4 specimens, 39-75 mm SL, 7-33 m, lagoon, reef-top, and drop-off at Eagle Island and Peros Banhos (photos: 40, 58, and $75 \mathrm{~mm}$ ). Randall (1978) includes $M$. varialvus Smith in the synonymy of this species (as the female form). Both colour forms were collected and photographed. Western Indian Ocean.

\section{Novaculichthys taeniourus (Lacepède)}

Fig. 330

Labrus taeniourus Lacepède, 1802a:448 (Pacific Ocean)

Novaculichthys taeniourus-Gomon, 1984:69 (IndoPacific, including Chagos, east to Society Islands)

MATERIAL

Two lots, 2 specimens, $40-177 \mathrm{~mm} \mathrm{SL}, 0-0.5 \mathrm{~m}$, reef-flat at Diego Garcia and Peros Banhos (photo: $177 \mathrm{~mm}$ ). Indo-Pacific.

\section{Paracheilinus mccoskeri Randall}

and Harmelin-Vivien Pl. VIIIA

Paracheilinus mccoskeri Randall and Harmelin-Vivien, 1977:332 (Comoro Islands); Randall and Lubbock, 1981b:23 (eastern Andaman Sea)

\section{MATERIAL}

One lot, 9 specimens, $20-40 \mathrm{~mm} \mathrm{SL}, 20 \mathrm{~m}$, lagoon at Peros Banhos (photo: $40 \mathrm{~mm}$ ). Indian Ocean.

\section{Pseudocheilinus evanidus Jordan and Evermann}

Fig. 331

Pseudocheilinus evanidus Jordan and Evermann, 1903:192

(Hawaii); Randall, 1973:197 (Tahiti); Smith, 1957b:108 (western Indian Ocean)

\section{MATERIAL}

Eighteen lots, 46 specimens, 10-56 mm SL, 10-43 m, lagoon and drop-off at Peros Banhos and Salomon (photos: 31 and $49 \mathrm{~mm}$ ). Eighty-nine per cent of the specimens are from the drop-offs, with $83 \%$ collected in $16-25 \mathrm{~m}$ (only a single specimen from shallower water). Indo-Pacific.

Pseudocheilinus hexataenia (Bleeker)

Fig. 332

Cheilinus hexataenia Bleeker, 1857a:84 (Ambon)

Pseudocheilinus hexataenia - Randall, 1973:197 (Tahiti)

\section{MATERIAL}

Fifty lots, 418 specimens, 8-54 mm SL, 0-36 m, lagoon, reef-top, and drop-off at Diego Garcia, Eagle Island, Peros Banhos, and Salomon (photos: 33, 39, and $47 \mathrm{~mm}$ ).

This species was ubiquitous in the above habitats, and was taken in small numbers in virtually all rotenone stations. The mean numbers of specimens/lot were 7.9 , 9.8 , and 7.9 for the lagoon, reef-top, and drop-off, respectively. It seems to prefer depths of $6-15 \mathrm{~m}(\overline{\mathrm{x}} / \mathrm{lot}=$ $11.0)$ and $16-25 \mathrm{~m}(\overline{\mathrm{x}} / \mathrm{lot}=7.7)$; the two depth ranges combined contribute $94 \%$ of the total number of specimens collected. Indo-Pacific.

Pseudocheilinus octotaenia Jenkins

Fig. 333

Pseudocheilinus octotaenia Jenkins, 1901:64 (Hawaii); Randall, 1973:197 (Tahiti)

Pseudocheilinus margaretae-Smith, 1957b:108 (Aldabra Islands)

MATERIAL

Six lots, 7 specimens, 44-82 mm SL, 15-26 m, drop-off at Peros Banhos and Salomon (photos: 44, 45, 62, and $82 \mathrm{~mm})$. Indo-Pacific.

\section{Pseudocoris heteroptera (Bleeker)}

Pl. VIIIB

Julis heteropterus Bleeker, 1857a:78 (Ambon)

Pseudocoris heteroptera-Gomon, 1984:10 (western Indian Ocean)

MATERIAI

Two lots, 3 specimens, 33-39 mm SL, 15-24 m, drop-off at Peros Banhos and Salomon (photos: 33 and $39 \mathrm{~mm}$ ). Indo-west Pacific 
Pseudocoris yamashiroi (Schmidt)

PI. VIIIC

Julis yamashiroi Schmidt, 1930:85 (Japan)

Pseudocoris yamashiroi-Gomon, 1984:10 (western Indian Ocean)

\section{MATERIAL}

Two lots, 3 specimens, $57-61 \mathrm{~mm} \mathrm{SL}, 18-25 \mathrm{~m}$, drop-off at Salomon (photos: 57 and $61 \mathrm{~mm}$ ). Indo-west Pacific.

\section{Pseudodax moluccanus (Valenciennes)}

Fig. 334

Odax moluccanus Valenciennes in Cuvier and Valenciennes, 1839b:305 (Moluccas)

Pseudodax moluccanus-Gomon, 1984:71 (Indo-Pacific, including Chagos, east to Tahiti)

\section{MATERIAL}

One lot, 1 specimen, $127 \mathrm{~mm} \mathrm{SL}, 18-25 \mathrm{~m}$, drop-off at Salomon (photo). Indo-Pacific.

\section{Stethojulis albovittata (Bonnaterre)}

Fig. 335

Labrus albovittatus Bonnaterre, 1788:108 (no locality)

Stethojulis albovittata-Randall and Kay, 1974:103 (Indian Ocean)

\section{MATERIAL}

Fifteen lots, 562 specimens, 16-93 mm SL, 0-10 m, lagoon, intertidal, and reef-flat at Diego Garcia, Eagle Island, Peros Banhos, and Salomon (photos: 59 and $75 \mathrm{~mm}$ ). This species was extremely abundant in the intertidal region $(\overline{\mathrm{x}} / \mathrm{lot}=83.3)$, and somewhat less so on the reef-flats $(\overline{\mathrm{x}} / \mathrm{lot}=21.0)$. All but two of the specimens were collected in less than $5 \mathrm{~m}$ of water. Indian Ocean.

\section{Stethojulis strigiventer (Bennett)}

Julis strigiventer Bennett, 1832b:184 (Mauritius)

Fig. 336

Stethojulis strigiventer-Schultz, 1960a:210 (Guam and Marshall Islands)

\section{MATERIAL}

Two lots, 2 specimens, $45-49 \mathrm{~mm} \mathrm{SL}, 0-3 \mathrm{~m}$, lagoon at Diego Garcia and Salomon (photo: $45 \mathrm{~mm}$ ). Indo-west Pacific and marginally on the Pacific plate.

\section{Thalassoma amblycephalum (Bleeker)}

Fig. 337

Julis amblycephalum Bleeker, 1856b:83 (Malang, southeast Java)

\section{MATERIAL}

Five lots, 17 specimens, $20-60 \mathrm{~mm} \mathrm{SL}, 0-24 \mathrm{~m}$, reef-top and drop-off at Eagle Island, Peros Banhos, and Salomon (photo: $60 \mathrm{~mm}$ ). Indo-Pacific (east to Hawaii-Heiser, pers. comm.)
Thalassoma hardwicki (Bennett)

Fig. 338

Sparus hardwicki Bennett, 1830:12 (Sri Lanka)

\section{MATERIAL}

Seven lots, 33 specimens, $27-113 \mathrm{~mm} \mathrm{SL}, 0-10 \mathrm{~m}$, lagoon and intertidal at Diego Garcia, Eagle Island, and Peros Banhos (photos: 47, 103, and $104 \mathrm{~mm}$ ). Only three specimens (two lots) are from the lagoon, the rest being from the intertidal region in $0-1 \mathrm{~m}$. Indo-Pacific (east to the Tuamotu Islands-Heiser, pers. comm.).

Thalassoma hebraicum (Lacepède)

Fig. 339

Labrus hebraicum Lacepède, 1802a:454 (Pacific Ocean)

\section{MATERIAL}

Ten lots, 80 specimens, $33-127 \mathrm{~mm}$ SL, 0-15 m, lagoon, intertidal, reef-flat, and reef-top at Eagle Island, Peros Banhos, and Salomon (photos: 48, 96, and $127 \mathrm{~mm}$ ). Most specimens (79\%) are from the intertidal region, and $98 \%$ of the total are from less than $5 \mathrm{~m}$. Western Indian Ocean (Heiser, pers. comm.).

Thalassoma lunare (Linnaeus)

Fig. 340

Labrus lunaris Linnaeus, 1758:283 (“Indies")

Thalassoma lunare-Gomon, 1984:75 (Indo-Pacific, including Chagos, east to Tuamotu Islands)

\section{MATERIAL}

Two lots, 2 specimens, $92-93 \mathrm{~mm} \mathrm{SL}, 10-20 \mathrm{~m}$, lagoon at Peros Banhos and Salomon (photos: both). Indo-Pacific.

\section{Thalassoma purpureum (Forsskål)}

Fig. 341

Scarus purpureum Forsskål, 1775:27 (Jiddah, Red Sea)

Thalassoma purpureum -Gomon, 1984:77 (Indo-Pacific, including Chagos, east to Easter Island)

\section{MATERIAL}

Four lots, 10 specimens, $76-218 \mathrm{~mm} \mathrm{SL}, 0-3 \mathrm{~m}$, intertidal, reef-flat, and reef-top at Peros Banhos and Salomon (photos: 149 and $174 \mathrm{~mm}$ ). Indo-Pacific.

\section{Thalassoma quinquevittatum (Lay and Bennett)}

Figs. 342,343 Scarus quinquevittatus Lay and Bennett, 1839:66 (Loo-Choo)

\section{MATERIAL}

Seven lots, 33 specimens, 19-100 mm SL, 0-3 m, lagoon, reef-flat, and reef-top at Eagle Island, Peros Banhos, and Salomon (photos: 42,70 , and $100 \mathrm{~mm}$ ). Most specimens were collected on the reef-flats and reef-top (a single collection of 13 specimens from the spur-and-groove formation at Salomon). Indo-Pacific (east to Easter Island-Heiser, pers. comm.). 
Thalassoma trilobatum (Lacepède)

Fig. 344

Labrus trilobatus Lacepède, 1802a:454 (Pacific Ocean)

Thalassoma fuscum-Gomon, 1984:73 (Indo-Pacific, including Chagos, east to French Polynesia)

\section{MATERIAL}

Two lots, 3 specimens, $24-33 \mathrm{~mm} \mathrm{SL}, 0-1 \mathrm{~m}$, reef-flat at Peros Banhos and Salomon (photo: $31 \mathrm{~mm}$ ). Identifications confirmed by Dr J. E. Randall. Indo-Pacific.

\section{Wetmorella nigropinnata (Seale)}

Fig. 345

Cheilinus nigropinnatus Seale, 1901:86 (Guam)

Wetmorella nigropinnata-Randall, 1983a:879 (Indo-

Pacific, including Chagos, east to Pitcairn Island)

\section{MATERIAL}

Fifteen lots, 38 specimens, $10-52 \mathrm{~mm} \mathrm{SL}, 0-43 \mathrm{~m}$, lagoon, reef-top, and drop-off at Peros Banhos and Salomon (photos: 36 and $39 \mathrm{~mm}$ ). This species was most abundant in the lagoons ( $82 \%$ of specimens, $\overline{\mathrm{x}} / \mathrm{lot}=3.4)$, and preferred depths of $6-15 \mathrm{~m}(71 \%$ of specimens, $\overline{\mathrm{x}} / \mathrm{lot}=5.4)$. IndoPacific.

\section{Xyrichthys pavo Valenciennes}

Figs. 346,347

Xyrichthys pavo Valenciennes in Cuvier and Valenciennes, 1839b:61 (Mauritius); Gomon, 1984:81 (Indo-Pacific, including Chagos, to eastern Pacific)

MATERIAL

Three lots, 3 specimens, $16-139 \mathrm{~mm} \mathrm{SL}, 7-25 \mathrm{~m}$, lagoon and drop-off at Peros Banhos and Salomon (photos: 16 and $102 \mathrm{~mm}$ ). Indo-Pacific.

Xyrichthys pentadactylus (Linnaeus)

Coryphaena pentadactylus Linnaeus, 1758:261 (India)

Xyrichthys pentadactylus - Gomon, 1984:83 (Indo-west Pacific, including Chagos, east to Taiwan)

No specimens seen or collected; occurrence is based on the range map give by Gomon (1984). Indo-west Pacific.

Xyrichthys sp.

Fig. 348

MATERIAL

One lot, 1 specimen, $38 \mathrm{~mm} \mathrm{SL}, 7 \mathrm{~m}$, lagoon at Peros Banhos. Gomon (1984) records the presence of seven species of this genus in the western Indian Ocean. We were unable to identify this small specimen to species. Range unassigned.

\section{Scaridae}

Identification of scarids was provided or confirmed by Dr J. E. Randall. In addition to the species listed below, there are 5 lots, 12 specimens of juvenile Scarus ( $11-35 \mathrm{~mm} \mathrm{SL}$ ) that we were unable to assign to species.

Calotomus carolinus (Valenciennes)

Fig. 349

Callyodon carolinus Valenciennes in Cuvier and Valenciennes, 1839b:291 (Caroline Islands)

Calotomus carolinus - Bruce and Randall, 1984:7 (Indo-

Pacific, including Chagos, to eastern Pacific)

MATERIAL

One lot, 1 specimen, $190 \mathrm{~mm} \mathrm{SL}, 0-5 \mathrm{~mm}$, lagoon at Eagle Island. Indo-Pacific.

\section{Calotomus spinidens (Quoy and Gaimard)}

Scarus spinidens Quoy and Gaimard, 1824:289 (Waigeo) Calotomus spinidens-Schultz, 1969:38 (Indo-Pacific, including Chagos, east to Revilla Gigedo Islands)

Calatomus japonicus - Schultz, 1969:38 (Chagos Archipelago, partim)

No specimens seen or collected, but 12 specimens in 3 lots from Diego Garcia are housed in the National Museum of Natural History, Washington. Indo-Pacific.

Cetoscarus bicolor (Rüppell)

Fig. 350

Scarus bicolor Rüppell, 1829b:82 (Jiddah, Red Sea)

Cetoscarus bicolor-Randall and Bruce, 1983:6 (IndoPacific to French Polynesia); Bruce and Randall, 1984:13 (Indo-Pacific, including Chagos)

MATERIAL

One lot, 1 specimen, $420 \mathrm{~mm} \mathrm{SL}, 7-10 \mathrm{~m}$, reef-top at Salomon (photo). Indo-Pacific.

Hipposcarus harid (Forsskål)

Fig. 351

Scarus harid Forsskål, 1775:30 (Red Sea)

Hipposcarus harid-Bruce and Randall, 1984:15 (Indian Ocean, including Chagos, east to Sri Lanka)

\section{MATERIAL}

Two lots, 2 specimens, 224-370 mm SL, 0.5-7 m, lagoon at Peros Banhos and Salomon (photos: both). Western Indian Ocean.

\section{Leptoscarus vaigiensis (Quoy and Gaimard)}

Scarus vaigiensis Quoy and Gaimard, 1824:288 (Waigeo) Leptoscarus vaigiensis-Bruce and Randall, 1984:17 (Indo-Pacific, including Chagos, east to Easter Island)

No specimens seen or collected; the record is based on the reports of Schultz (1969) and Bruce and Randall (1984). Indo-Pacific. 
Scarus atrilunula Randall and Bruce

Scarus atrilunula Randall and Bruce, 1983:9 (Kenya)

?Scarus rhoduropterus - Schultz, 1969:18 (Chagos Archipelago) (non Bleeker, 1861, partim)

No specimens seen or collected; the record is tentatively based on Schultz's (1969) report of two specimens of $S$. rhoduropterus from Diego Garcia. The latter species does not occur in the Indian Ocean, and specimens from east Africa identified as $S$. rhoduropterus form the bulk of the type material of $S$. atrilunula. Western Indian Ocean.

Scarus enneacanthus Lacepède

Fig. 352

Scarus enneacanthus Lacepède, 1802b:2 (Mauritius); Bruce and Randall, 1984:29 (western Indian Ocean, including Chagos)

\section{MATERIAL}

Six lots, 14 specimens, 161-255 mm SL, 0-5 m, lagoon, intertidal, reef-flat, and reef-top at Eagle Island, Peros Banhos, and Salomon (photos: 190, 221, 250, and $255 \mathrm{~mm}$ ). Western Indian Ocean.

\section{Scarus falcipinnis (Playfair)}

Fig. 353

Pseudoscarus falcipinnis Playfair, 1867:865 (Seychelles) Scarus falcipinnis-Bruce and Randall, 1984:31 (western Indian Ocean)

\section{MATERIAL}

One lot, 1 specimen, $48 \mathrm{~mm} \mathrm{SL}, 15-20 \mathrm{~m}$, drop-off at Salomon (photo). Western Indian Ocean.

\section{Scarus frenatus Lacepède}

Fig. 354

Scarus frenatus Lacepède, 1802b:3 (Mauritius); Bruce and Randall, 1984:37 (Indo-Pacific, including Chagos, east to Pitcairn Island)

\section{MATERIAL}

One lot, 1 specimen, $270 \mathrm{~mm}$ SL, 0.5-4 m, lagoon near pass at Peros Banhos (photo). Indo-Pacific.

\section{Scarus ghobban Forsskål}

Fig. 355

Scarus ghobban Forsskål, 1775:28 (Jiddah, Red Sea); Bruce and Randall, 1984:43 (Indo-Pacific, including Chagos, to eastern Pacific)

MATERIAL

One lot, 1 specimen, $190 \mathrm{~mm} \mathrm{SL}, 0.5-2 \mathrm{~m}$, lagoon at Peros Banhos (photo). Indo-Pacific.

\section{Scarus gibbus Rüppell}

Figs. 356, 357

Scarus gibbus Rüppell, 1829b:81 (Mahila, Red Sea); Bruce and Randall, 1984:45 (Indo-Pacific, including Chagos, east to Pitcairn Island)
MATERIAL

Eight lots, 10 specimens, $32-350 \mathrm{~mm}$ SL, $0.5-20 \mathrm{~m}$, lagoon and reef-top at Peros Banhos and Salomon (photos: $32,47,175,270,275,280$, and $350 \mathrm{~mm}$ ). Indo-Pacific.

\section{Scarus niger Forsskål}

Fig. 358

Scarus niger Forsskål, 1775:28 (Red Sea); Bruce and Randall, 1984:51 (Indo-Pacific, including Chagos, east to Polynesia)

\section{MATERIAL}

Eight lots, 10 specimens, 21-240 mm SL, 0.5-20 m, lagoon at Peros Banhos and Salomon (photos: 45, 108, 185 , and $240 \mathrm{~mm}$ ). Indo-Pacific.

Scarus psittacus Forsskål

Figs. 359, 360

Scarus psittacus Forsskål, 1775:29 (Jiddah, Red Sea); Bruce and Randall, 1984:57 (Indo-Pacific, including Chagos, east to Society Islands)

\section{MATERIAL}

Two lots, 3 specimens, 39-125 mm SL, 2-25 m, lagoon at Peros Banhos and Salomon (photos: 39 and $125 \mathrm{~mm}$ ). Indo-Pacific.

Scarus rubroviolaceus Bleeker

Figs. 361, 362

Scarus rubroviolaceus Bleeker, 1847:162 (Jakarta, Java); Bruce and Randall, 1984:59 (Indo-Pacific, including Chagos, to eastern Pacific)

\section{MATERIAL}

Four lots, 4 specimens, 270-370 mm SL, 0-25 m, lagoon and drop-off at Eagle Island, Peros Banhos, and Salomon (photos: 340,350 , and $370 \mathrm{~mm}$ ). Indo-Pacific.

\section{Scarus scaber Valenciennes}

Fig. 363

Scarus scaber Valenciennes in Cuvier and Valenciennes, 1839b:239 (Mauritius); Bruce and Randall, 1984:63 (western Indian Ocean, including Chagos)

\section{MATERIAL}

One lot, 1 specimen, $117 \mathrm{~mm} \mathrm{SL}, 2-7 \mathrm{~m}$, lagoon at Salomon (photo). Western Indian Ocean.

Scarus sordidus Forsskål Figs. 364, 365, 366 Scarus sordidus Forsskål, 1775:30 (Red Sea); Bruce and Randall, 1984:65 (Indo-Pacific, including Chagos, east to Hawaii)

\section{MATERIAL}

Twenty-three lots, 120 specimens, $16-247 \mathrm{~mm} \mathrm{SL}, 0-22 \mathrm{~m}$, lagoon, intertidal, reef-top (1), and drop-off (1) at Diego Garcia, Eagle Island, Peros Banhos, and Salomon (photos: $30,35,111,149,155[\times 2]$, and $247 \mathrm{~mm}$ ). 
This species was virtually confined to the lagoon and intertidal habitats (only two specimens from elsewhere), with $78 \%$ of the specimens collected in depths of $0-5 \mathrm{~m}$. It should be noted, however, that the majority of the specimens are juveniles of less than $60 \mathrm{~mm} \mathrm{SL}$. Indo-Pacific.

\section{Scarus tricolor Bleeker}

Fig. 367

Scarus tricolor Bleeker, 1847:164 (Jakarta, Java); Bruce and Randall, 1984:67 (Indo-Pacific, including Chagos, east to Pitcairn Island)

\section{MATERIAL}

One lot, 1 specimen, $206 \mathrm{~mm} \mathrm{SL}, 9-13 \mathrm{~m}$, lagoon at Salomon (photo). Indo-Pacific.

\section{Scarus sp.}

Fig. 368

MATERIAL

One lot, 1 specimen, $205 \mathrm{~mm} \mathrm{SL}, 10-20 \mathrm{~m}$, lagoon at Peros Banhos.

This specimen was sent to Dr Randall for identification, but he was unable to do so and commented (in litt.): "It has 6 median predorsal scales, 16 pectoral rays, but only two rows of scales on the cheek. If you look at the tables of counts in Schultz and in Randall and Bruce, you will find all with 6 predorsal scales and 16 pectoral rays must have 3 rows of scales on the cheek. I don't recognize the fish from color either though the line on the chin is naggingly familiar." Range unassigned.

\section{Mugiloididae}

Parapercis cephalopunctata (Seale)

Fig. 369

Percis cephalopunctata Seale, 1901:24 (Marianas)

Parapercis cephalopunctata-Randall, 1973:199 (Tahiti)

\section{MATERIAL}

Eighteen lots, 49 specimens, 33-126 mm SL, 0-24 m, lagoon, reef-flat, reef-top, and drop-off (1) at Eagle Island, Peros Banhos, and Salomon (photos: 63 and $100 \mathrm{~mm}$ ). This species was most abundant in lagoons and on the reef-flats ( $71 \%$ of specimens), and was virtually always ( $92 \%$ of specimens) taken in water less than $15 \mathrm{~m}$ deep. Indo-Pacific.

\section{Parapercis hexophthalma (Ehrenberg)}

Fig. 370

Percis hexophtalma (sic) Ehrenberg in Cuvier and Valenciennes, 1829a:271 (Massawa, Red Sea)

Parapercis hexophthalma - Randall, 1973:199 (Tahiti)

\section{MATERIAL}

Four lots, 4 specimens, $48-168 \mathrm{~mm} \mathrm{SL}, 1-20 \mathrm{~m}$, lagoon at Peros Banhos and Salomon (photos: 63 and $168 \mathrm{~mm}$ ). Indo-Pacific.
Parapercis sp.

Parapercis sp.—Kyushin et al., 1977:294 (Chagos Archipelago)

No specimens seen or collected; the record is based on the colour photograph of Parapercis sp. given by Kyushin et al. (1977). There is some doubt as to the provenance of their specimen, for under "Fishing data" they record "Chagos, 80-160 m, vertical long line", but state "Sri Lanka" under "Distribution". Range unassigned.

\section{Creediidae}

Identification of the material was undertaken by Dr. J. S Nelson.

Chalixodytes chameleontoculis Smith

Fig. 371

Chalixodytes chameleontoculis Smith, 1956:890 (Seychelles); Nelson, 1978:363 (Indian Ocean east to Cocos [Keeling] Island)

\section{MATERIAL}

Five lots, 9 specimens, $17-33 \mathrm{~mm} \mathrm{SL}, 0-10 \mathrm{~m}$, lagoon and intertidal at Eagle Island and Peros Banhos (photo: $31 \mathrm{~mm}$ ). We tentatively retain this species as distinct from $C$. tauensis Schultz on the advice of Dr Nelson (in litt.). Indian Ocean.

Limnichthys nitidus Smith

Fig. 372 Limnichthys nitidus Smith, 1958a:247 (Pinda, Mozambique); Nelson, 1978:360 (western Indian Ocean, possibly extending to Cocos[Keeling] Island)

\section{MATERIAL}

One lot, 1 specimen, $17 \mathrm{~mm} \mathrm{SL}, 7 \mathrm{~m}$, lagoon at Peros Banhos (photo). Tentatively assigned to the Indian Ocean.

\section{Blenniidae}

In addition to those species listed below, there are two species of blenniids recorded by Regan (1908) from Chagos: Salarias quadricornis and $S$. sumatranus (=Istiblennius periophthalmus, q.v.). The former nominal species is currently assigned to the genus Istiblennius (Smith-Vaniz and Springer, 1971), but we have not been able to locate Regan's specimen to establish whether it is conspecific with any of the species of Istiblennius recorded here.

\section{Aspidontus taeniatus tractus Fowler}

Fig. 373 Aspidontus tractus Fowler, 1903:170 (Zanzibar) Aspidontus taeniatus tractus - Smith-Vaniz, 1976:62 (Indian Ocean, including Chagos, east to Thailand and Java) 


\section{MATERIAL}

Four lots, 4 specimens, 47-79 mm SL, 3-25 m, lagoon, reef-top, and drop-off at Peros Banhos and Salomon (photo: $79 \mathrm{~mm}$ ). Indian Ocean and western extremity of west Pacific.

Cirripectes castaneus (Valenciennes) Figs. 374, 375 Salarias castaneus Valenciennes in Cuvier and Valenciennes, 1836:324 (Mauritius)

\section{MATERIAL}

Seven lots, 17 specimens, 26-64 mm SL, 0-7 m, lagoon, intertidal, reef-flat, and reef-top at Eagle Island, Peros Banhos, and Salomon (photos: 42, 48, and $61 \mathrm{~mm}$ ). J. T. Williams identified the material of this genus and of Exallias, and provided the distributions. Indo-west Pacific.

\section{Cirripectes perustus Smith}

Fig. 376

Cirripectes perustus Smith, 1959b:238 (Malindi, Kenya)

\section{MATERIAL}

Ten lots, 42 specimens, 21-62 mm SL, 0-24 m, lagoon, intertidal, and drop-off at Eagle Island, Peros Banhos, Salomon, and Three Brothers (photos: 36, 52, and $60 \mathrm{~mm}$ ). Seventy-one per cent of the specimens collected were taken in two stations made in the intertidal region. Indo-west Pacific and marginally on the Pacific plate (east to the Gilbert Islands).

\section{Cirripectes polyzona (Bleeker)}

Fig. 377

Salarias (Cirripectes) polyzona Bleeker, 1868a:278 (Ambon)

\section{MATERIAL}

Three lots, 117 specimens, 18-58 mm SL, 0-20 m, lagoon, reef-flat, and reef-top at Eagle Island, Peros Banhos, and Salomon (photo: specimen not located). Most of the specimens (101) were taken in the single collection made in the spur-and-groove formation off Isle Boddam, Salomon. Indo-Pacific.

\section{Cirripectes quagga (Fowler and Ball)}

Fig. 378

Rupiscartes quagga Fowler and Ball, 1924:273 (Wake Island)

\section{MATERIAL}

One lot, 6 specimens, 41-55 mm SL, 0-3 m, reef-top at Salomon (photo: $48 \mathrm{~mm}$ ). This species was collected only in the spur-and-groove formation at Salomon. Indo-Pacific (east to Pitcairn Island).

\section{Cirripectes sp.}

PI. VIIID

\section{MATERIAL}

One lot, 6 specimens, 76-93 mm SL, 0-3 m, reef-top at
Salomon (photo: $83 \mathrm{~mm}$ ). The only collection came from the spur-and-groove formation off Isle Boddam, Salomon. The species will be described by J. T. Williams. Indian Ocean.

Ecsenius midas Starck

Fig. 379

Ecsenius midas Starck, 1969:1 (Amirante Islands); McKinney and Springer, 1976:10 (Indo-west Pacific east to Fiji)

MATERIAL

Five lots, 18 specimens, $37-58 \mathrm{~mm}$ SL, $10-26 \mathrm{~m}$, lagoon, reef-top, and drop-off at Peros Banhos and Salomon (photo: $52 \mathrm{~mm}$ ). Indo-west Pacific.

\section{Ecsenius nalolo Smith}

Fig. 380

Ecsenius nalolo Smith, 1959b:245 (Pinda, Mozambique); McKinney and Springer, 1976:11 (Indian Ocean west of $\left.75^{\circ} \mathrm{E}\right)$.

\section{MATERIAL}

Eighteen lots, 63 specimens, 15-47 mm SL, 0.5-25 m, lagoon, reef-top, and drop-off (2) at Eagle Island, Peros Banhos, Salomon, and Three Brothers (photos: 34 and $46 \mathrm{~mm}$ ). Sixty-five per cent of the specimens collected were taken in the lagoons, with $68 \%$ of the total from $6-15 \mathrm{~m}$ water depth. Western Indian Ocean.

\section{Enchelyurus kraussi (Klunzinger)}

Fig. 381

Petroscirtes kraussi Klunzinger, 1871:497 (Koseir, Red Sea)

Enchelyurus kraussi-Springer, 1972:6 (Indo-Pacific east to Marianas)

\section{MATERIAL}

Two lots, 3 specimens, $18-27 \mathrm{~mm} \mathrm{SL}, 0.5-1 \mathrm{~m}$, lagoon at Eagle Island. Indo-west Pacific and marginally on the Pacific plate.

Entomacrodus striatus (Quoy and Gaimard) Fig. 382 Salarias striatus Quoy and Gaimard in Cuvier and Valenciennes, 1836:309 (Mauritius)

Entomacrodus striatus — Springer, 1967:73 (Indo-Pacific east to Tuamotu Islands)

\section{MATERIAL}

Three lots, 75 specimens, $20-53 \mathrm{~mm} \mathrm{SL}, 0-3 \mathrm{~m}$, reef-flat and reef-top at Peros Banhos and Salomon (photos: 30 and $57 \mathrm{~mm}$ ). The single specimen from the reef-top was collected from the spur-and-groove formation. Indo-Pacific.

Exallias brevis (Kner)

Fig. 383 
MATERIAL

Two lots, 7 specimens, 57-78 mm SL, 0-5 m, lagoon and reef-top at Peros Banhos (photos: 71, 73, and $78 \mathrm{~mm}$ ). Indo-Pacific (east to Pitcairn Island).

\section{Glyptoparus delicatulus Smith}

Fig. 384

Glyptoparus delicatulus Smith, 1959b:249 (Malindi, Kenya); Smith-Vaniz and Springer, 1971:24 (Indo-Pacific)

\section{MATERIAL}

Four lots, 34 specimens, $15-25 \mathrm{~mm}$ SL, 0-1 m, lagoon at Eagle Island and Peros Banhos. Indo-Pacific.

\section{Istiblennius edentulus (Schneider)}

Fig. 385

Blennius edentulus Schneider in Bloch and Schneider, 1801:172 (Society Islands)

\section{MATERIAL}

Four lots, 867 specimens, 18-107 mm SL, 0-1 m, reef-flat at Diego Garcia, Peros Banhos, and Salomon (photos: 58 and $65 \mathrm{~mm}$ ). Indo-Pacific.

Istiblennius gibbifrons (Quoy and Gaimard) Fig. 386 Salarias gibbifrons Quoy and Gaimard, 1824:253 (Hawaii) Istiblennius gibbifrons insolitus Smith, 1959b:242 (Assumption)

\section{MATERIAL}

Two lots, 23 specimens, 45-97 mm SL, 0-3 m, reef-flat and reef-top at Salomon (photos: 75, 86, and $97 \mathrm{~mm}$ ).

As with all members of this difficult genus, identification is tentative. Smith (1959b) felt that the subspecies he erected for the Indian Ocean form could merit full specific distinction, echoing Strasburg's (1956) opinion that the Hawaiian form is endemic. Indo-Pacific.

Istiblennius periophthalmus (Valenciennes) Fig. 387 Salarias periophthalmus Valenciennes in Cuvier and Valenciennes, 1836:311 (Santa Cruz)

Salarias sumatranus-Regan, 1908:250 (Salomon, Chagos Archipelago)

Istiblennius periophthalmus - Smith, 1959b:243 (western Indian Ocean)

\section{MATERIAL}

Eleven lots, 539 specimens, 19-97 mm SL, 0-3 m, lagoon and reef-flat at Diego Garcia, Eagle Island, Peros Banhos, and Salomon (photos: 33, 52, 81, 88, and $91 \mathrm{~mm}$ ).

Regan (1908) recorded a single blenniid specimen from Salomon. The only such specimen in the British Museum (Natural History) bears a bottle label identifying it as "Salarias periophthalmus". We assume this specimen formed the basis of Regan's record of $S$. sumatranus. Indo-west Pacific.
Meiacanthus smithi Klausewitz

Fig. 388

Meiacanthus smithi Klausewitz, 1962:17 (Maldives); Smith-

Vaniz, 1976:99 (Maldives east to western Borneo)

\section{MATERIAL}

Six lots, 7 specimens, 28-61 mm SL, 3-22 m, lagoon and reef-top at Peros Banhos and Salomon (photo: $56 \mathrm{~mm}$ ). Indian Ocean and western extremity of west Pacific.

Omobranchus elongatus (Peters)

Fig. 389

Petroscirtes elongatus Peters, 1855a:249 (Mozambique)

Omobranchus elongatus-Springer and Gomon, 1975:28

(Indo-west Pacific, including Chagos, east to Philippines)

MATERIAL

One lot, 1 specimen, $23 \mathrm{~mm} \mathrm{SL}, 0.5-1 \mathrm{~m}$, reef-flat at Diego Garcia. Indo-west Pacific.

Parenchelyurus hepburni (Snyder)

Fig. 390

Enchelyurus hepburni Snyder, 1908:110 (Japan)

Parenchelyurus hepburni-Springer, 1972:12 (Thailand east to Marshall Islands and Samoa); Springer and Gomon, 1975:79 (Indo-Pacific east to Samoa)

MATERIAL

Two lots, 5 specimens, 21-26 mm SL, 0-1 m, reef-flat at Peros Banhos and Salomon. Indo-west Pacific and marginally on the Pacific plate.

\section{Petroscirtes mitratus Rüppell}

Petroscirtes mitratus Rüppell, 1830a:111 (Red Sea); SmithVaniz, 1976:32 (Indo-Pacific, including Chagos, east to the Gilbert Islands and Samoa)

No specimens seen or collected; the record is based on Smith-Vaniz's (1976) report of seven specimens from Diego Garcia. Indo-west Pacific and marginally on the Pacific plate.

Petroscirtes xestus Jordan and Seale

Fig. 391

Petroscirtes xestus Jordan and Seale, 1906:433 (Samoa); Smith-Vaniz, 1976:36 (Indo-Pacific east to Society Islands)

\section{MATERIAL}

Two lots, 2 specimens, 34-47 mm SL, 2-17 m, lagoon at Peros Banhos and Salomon (photo: $47 \mathrm{~mm}$ ). Indo-Pacific.

Plagiotremus rhinorhynchos (Bleeker) Fig. 392 Petroskirtes rhinorhijnchos Bleeker, 1852a:273 (Wahai, Seram)

Plagiotremus rhinorhynchos-Smith-Vaniz, 1976:133 (Indo-Pacific east to Marquesas Islands) 
MATERIAL

Five lots, 7 specimens, 39-63 mm SL, 7-43 m, lagoon, reef-top, and drop-off at Peros Banhos and Salomon (photos: 39, 50, 54, and $63 \mathrm{~mm}$ ). Indo-Pacific.

Plagiotremus tapeinosoma (Bleeker)

Fig. 393

Petroskirtes tapeinosoma Bleeker, 1857a:64 (Ambon)

Plagiotremus tapeinosoma-Smith-Vaniz, 1976:138 (Indo-Pacific, including Chagos, east to Pitcairn Island)

MATERIAL

Eleven lots, 13 specimens, 36-73 mm SL, 3-25 m, lagoon, reef-top, and drop-off at Peros Banhos and Salomon (photos: 39 and $46 \mathrm{~mm}$ ). Indo-Pacific.

\section{Tripterygiidae}

Specimens of this family were identified by W. Holleman.

Enneapterygius abeli (Klausewitz)

Tripterygium abeli Klausewitz, 1960:11 (Red Sea)

\section{MATERIAL}

Five lots, 15 specimens, 14-19 mm SL, 0-7 m, lagoon, intertidal, and reef-top at Eagle Island, Peros Banhos, and Salomon (photo: $17 \mathrm{~mm}$ ). Western Indian Ocean.

\section{Enneapterygius sp.}

Pl. VIIIE

\section{MATERIAL}

Seven lots, 21 specimens, 17-26 mm SL, 3-18 m, lagoon, reef-top, and drop-off at Peros Banhos and Salomon (photo). This species is apparently undescribed. Range unassigned.

\section{Helcogramma fuscopinna Holleman}

PI. VIIIF Helcogramma fuscopinna Holleman, 1982:115 (Zululand, South Africa; also Indo-west Pacific including Chagos, east to Japan)

\section{MATERIAL}

Four lots, 8 specimens (paratypes), 22-33 mm SL, 0-7 m, lagoon and intertidal at Peros Banhos and Salomon (photos: 25, 28, 29, and $32 \mathrm{~mm}$ ). Indo-west Pacific.

\section{Ammodytidae}

\section{?Bleekeria renniei Smith}

Fig. 395

Bleekeria renniei Smith, 1957c:219 (eastern South Africa)

\section{MATERIAL}

One lot, 1 specimen, $61 \mathrm{~mm} \mathrm{SL,} 7 \mathrm{~m}$, lagoon at Peros Banhos (photo).
The single specimen has the following characteristics: D 48, A 24, P 14, tubed lateral-line scales 103(L)-106(R), followed by $7(\mathrm{~L})-10(\mathrm{R})$ untubed scales, dorsal transverse scales 2 , gill rakers $4+22$.

The dorsal and anal ray counts are consistent with $B$. gilli and $B$. vaga, but the former count is low for $B$. renniei (50-51). In $B$. vaga there are vertical tubules on the scales in the row above the posterior part of the lateral line; these tubules are absent on other species of the genus. Bleekeria gilli has $7+8$ gill rakers, whereas $B$. renniei has $10+$ 21-22. In spite of the differences, it seems possible that $B$. gilli (range: California to Hawaii) is conspecific with $B$. renniei. Both of these species, like the Chagos specimen, have numerous small black spots in the membranes of the dorsal and anal fins, and a curved vertical bar on the caudal fin. Range unassigned.

\section{Callionymidae}

Specimens of this family were identified by Dr R. Fricke.

Callionymus delicatulus Smith

Fig. 396

Callionymus delicatulus Smith, 1963:557; Fricke, 1983:335 (Indo-Pacific, including Chagos, east to Palau)

\section{MATERIAL}

Seven lots, 14 specimens, 12-29 mm SL, 0-10 m, lagoon at Peros Banhos, Salomon, and Three Brothers (photos: 16 and $29 \mathrm{~mm}$ ). Indo-west Pacific and marginally on the Pacific plate.

Synchiropus minutulus Fricke

Fig. 397

Synchiropus minutulus Fricke, 1981:119 (Maldives; also Chagos Archipelago)

\section{MATERIAL}

One lot, 1 specimen (paratype), $13 \mathrm{~mm} \mathrm{SL}, 5-7 \mathrm{~m}$, reef-top at Salomon. Central Indian Ocean.

\section{Gobioidei}

The 100 species of gobioid fishes (families Gobiidae, Eleotrididae, Kraemeriidae, and Microdesmidae) from the Chagos Archipelago have been treated in some detail earlier in this series (Winterbottom and Emery, 1986) and will not be considered further. The ranges of 43 of these species could be established with some degree of confidence and are included in the zoogeographic analysis here. The ranges and the number of species in each range area as follows: Indo-Pacific, 23; Indo-Pacific and marginally on the Pacific plate, 3; Indo-west Pacific, 13; western Indian Ocean, 2; and Indian Ocean, 2. In addition, the 
microdesmid Paragunnellichthys fehlmani is known from a single collection from Diego Garcia and is considered an endemic.

\section{Acanthuridae}

Acanthurus bleekeri Günther

Fig. 398

Acanthurus bleekeri Günther, 1861:335 (east Indian Archipelago); Randall, 1984a:5 (Indo-Pacific, including Chagos, east to French Polynesia)

MATERIAL

One lot, 1 specimen, $300 \mathrm{~mm}$ SL, 9-18 m, drop-off at Peros Banhos (photo). Indo-Pacific.

\section{Acanthurus guttatus Schneider}

Fig. 399

Acanthurus guttatus Schneider in Bloch and Schneider, 1801:215 (Tahiti); Randall, 1956:184 (Indo-Pacific east to Tuamotu Islands)

MATERIAL

One lot, 8 specimens, $131-198 \mathrm{~mm} \mathrm{SL}, 0-3 \mathrm{~m}$, reef-top to Salomon (photo: $173 \mathrm{~mm}$ ). The only collection of this species was made in the spur-and-groove formation. Indo-Pacific.

Acanthurus leucosternon Bennett

Fig. 400

Acanthurus leucosternon Bennett, 1832a:183 (Sri Lanka); Randall, 1984a:9 (Indian Ocean east to Sumatra)

\section{MATERIAL}

Nineteen lots, 67 specimens, $61-168 \mathrm{~mm} \mathrm{SL}, 0.5-36 \mathrm{~m}$, lagoon, reef-top, and drop-ofi at Peros Banhos and Salomon (photos: 132 and $160 \mathrm{~mm}$ ). This species was most frequently collected in the lagoons $(61 \%)$ and in a depth range of $6-15 \mathrm{~m}(66 \%)$. Indian Ocean and western extremity of west Pacific.

\section{Acanthurus lineatus (Linnaeus)}

Fig. 401

Chaetodon lineatus Linnaeus, 1758:274 ("Indies")

Acanthurus lineatus - Randall, 1956:193 (Indo-Pacific east to Tuamotu Islands); Randall, 1984a:11 (Indo-Pacific, including Chagos)

\section{MATERIAL}

Eight lots, 56 specimens, 36-207 mm SL, 0-10 m, lagoon, reef-flat, and reef-top at Eagle Island, Peros Banhos, and Salomon (photo: $198 \mathrm{~mm}$ ). The single reef-top collection containing this species was made in the spur-and-groove formation and contained 43 specimens. Indo-Pacific.

\section{Acanthurus mata (Cuvier)*}

Fig. 402

Chaetodon meta (sic) Cuvier, 1829:224 (no locality)
Acanthurus mata-Randall, 1956:218 (Indo-Pacific east to Tuamotu Islands)

MATERIAL

Two lots, 4 specimens, $45-59 \mathrm{~mm} \mathrm{SL}, 0-0.5 \mathrm{~m}$, intertidal and reef-flat at Peros Banhos (photo: $30 \mathrm{~mm}$ ). Indo-Pacific.

Acanthurus nigricaudus Duncker and Mohr Fig. 403 Acanthurus gahm nigricauda Duncker and Mohr, 1931:75 (South Seas)

Acanthurus gahm-Randall, 1956:207 (Indo-Pacific east to Tuamotu Islands)

\section{MATERIAL}

One lot, 1 specimen, $122 \mathrm{~mm} \mathrm{SL}, 0-0.5 \mathrm{~m}$, intertidal at Peros Banhos (photo). Indo-Pacific.

\section{Acanthurus nigrofuscus (Forsskål)}

Fig. 404

Chaetodon nigrofuscus Forsskål, 1775:64 (Jiddah, Red Sea)

Acanthurus nigrofuscus — Randall, 1956:190(Indo-Pacific east to Tuamotu Islands)

\section{MATERIAL}

Fourteen lots, 58 specimens, 35-107 mm SL, 0-10 m, lagoon, intertidal, reef-flat, reef-top, and drop-off at Eagle Island, Peros Banhos, and Salomon (photo: $63 \mathrm{~mm}$ ). Indo-Pacific.

Acanthurus pyroferus Kittlitz

Fig. 405 Acanthurus pyroferus Kittlitz, 1834:191 (Caroline Islands); Randall, 1956:196 (Indo-Pacific east to Tahiti)

\section{MATERIAL}

Two lots, 2 specimens, $67-102 \mathrm{~mm} \mathrm{SL}, 10-20 \mathrm{~m}$, lagoon and reef-top at Eagle Island and Peros Banhos (photo: $67 \mathrm{~mm}$ ). Indo-Pacific

Acanthurus tennenti Günther

Fig. 406 Acanthurus tennenti Günther, 1861:337 (Sri Lanka); Randall, 1984a:13 (Indian Ocean, including Chagos, east to Sri Lanka)

\section{MATERIAL}

Three lots, 3 specimens, 28-148 mm SL, 0-10 m, lagoon and pass at Peros Banhos (photo: $148 \mathrm{~mm}$ ). Western Indian Ocean.

Acanthurus thompsoni (Fowler)

Fig. 407

Hepatus thompsoni Fowler, 1923:386 (Hawaii)

Acanthurus thompsoni-Randall, 1973:205 (Tahiti); Allen and Steene, 1979:63 (Christmas Island) 
MATERIAL

Six lots, 7 specimens, 82-118 mm SL, 5-25 m, reef-top and drop-off at Eagle Island and Salomon (photos: 115 and $117 \mathrm{~mm}$ ). This species was frequently observed in large, loose aggregations above the lip of the drop-off, apparently foraging for plankton in the water column. Indo-Pacific.

\section{Acanthurus triostegus (Linnaeus)}

Fig. 408

Chaetodon triostegus Linnaeus, 1758:274 ("Indies")

Acanthurus triostegus-Randall, 1984a:15 (Indo-Pacific, including Chagos, east to Mexico)

\section{MATERIAL}

Fourteen lots, 606 specimens, 21-132 mm SL, 0-3 m, lagoon (1), intertidal, reef-flat, and reef-top (1) at Diego Garcia, Eagle Island, Peros Banhos, and Salomon (photo: $87 \mathrm{~mm}$ ). Indo-Pacific.

\section{Acanthurus xanthopterus Valenciennes}

Fig. 409 Acanthurus xanthopterus Valenciennes in Cuvier and Valenciennes, 1835:215 (Seychelles); Randall, 1984a:17 (Indo-Pacific, including Chagos, east to Mexico)

\section{MATERIAL}

Two lots, 3 specimens, 154-421 mm SL, lagoon at Eagle Island and Peros Banhos (photo: $421 \mathrm{~mm}$ ). Indo-Pacific.

Ctenochaetus striatus (Quoy and Gaimard) Fig. 410 Acanthurus striatus Quoy and Gaimard, 1824:373 (Guam) Ctenochaetus striatus - Randall, 1955a:155 (Indo-Pacific east to Tuamotu Islands)

\section{MATERIAL}

Twenty-two lots, 133 specimens, 27-169 mm SL, 0-25 m, lagoon, intertidal, reef-flat, reef-top, and drop-off (1) at Diego Garcia, Eagle Island, Peros Banhos, Salomon, and Three Brothers (photo: $30 \mathrm{~mm}$ ). This species was most abundant in the lagoons, where $72 \%$ of our specimens were obtained. It was collected deeper than $15 \mathrm{~m}$ on only two occasions $(n=7)$. Indo-Pacific.

\section{Ctenochaetus strigosus (Bennett)}

Fig. 411

Acanthurus strigosus Bennett, 1828:41 (Hawaii)

Ctenochaetus strigosus-Randall, 1955a:159 (Indo-Pacific east to Tuamotu Islands)

\section{MATERIAL}

Twenty-four lots, 71 specimens, 25-141 mm SL, 3-32 m, lagoon, reef-top, and drop-off at Peros Banhos, Salomon, and Three Brothers (photos: 27, 35, and $101 \mathrm{~mm}$ ). This species was fairly evenly distributed among the three habitats, although rather more abundant in the lagoons, with $61 \%(\overline{\mathrm{x}} / \mathrm{lot}=3.3)$ in lagoon, $15 \%(\overline{\mathrm{x}} / \mathrm{lot}=2.8)$ on reef-top, and $21 \%(\overline{\mathrm{x}} / \mathrm{lot}=2.5)$ on drop-off, and two specimens without data. Indo-Pacific.

Naso brachycentron (Valenciennes)

Fig. 412

Naseus brachycentron Valenciennes in Cuvier and Valenciennes, 1835:275 (Waigeo)

Naso brachycentron-Randall, 1973:205 (Tahiti)

MATERIAL

One lot, 1 specimen, $464 \mathrm{~mm}$ SL, $5 \mathrm{~m}$, lagoon at Eagle Island (photo). Indo-Pacific.

Naso brevirostris (Valenciennes)

Fig. 413

Naseus brevirostris Valenciennes in Cuvier and Valenciennes, 1835:277 (Mauritius; Moluccas; New Guinea) Naso brevirostris_Randall, 1973:206 (Tahiti)

\section{MATERIAL}

Five lots, 6 specimens, 230-277 mm SL, 7-25 m, lagoon, reef-top, and drop-off at Peros Banhos and Salomon (photo: $277 \mathrm{~mm}$ ). Indo-Pacific.

Naso hexacanthus (Bleeker)

Priodon hexacanthus Bleeker, 1855b:421 (Ambon)

Naso hexacanthus - Randall, 1973:206 (Tahiti); Randall, 1984a:21 (Indo-Pacific, including Chagos)

\section{MATERIAL}

One lot, 2 specimens, 457-484 mm SL, 10-20 m, drop-off at Salomon (photo: $484 \mathrm{~mm}$ ). Indo-Pacific.

Naso lituratus (Schneider)

Fig. 415

Acanthurus lituratus Schneider in Bloch and Schneider, 1801:216 (no locality)

Naso lituratus-Randall, 1973:206 (Tahiti); 1984a:23 (Indo-Pacific, including Chagos)

\section{MATERIAL}

Three lots, 5 specimens, 148-252 mm SL, 0-7 m, lagoon and reef-flat at Eagle Island, Peros Banhos, and Salomon (photos: 236 and $252 \mathrm{~mm}$ ). Indo-Pacific.

\section{Naso unicornis (Forsskål)}

Fig. 416 Chaetodon unicornis Forsskål, 1775:63 (Jiddah, Red Sea) Naso unicornis-Randall, 1973:206 (Tahiti); 1984a:25 (Indo-Pacific, including Chagos)

\section{MATERIAL}

One lot, 1 specimen, $165 \mathrm{~mm} \mathrm{SL}, 0-0.5 \mathrm{~m}$, reef-flat at Peros Banhos (photo). Indo-Pacific.

Naso vlamingi (Valenciennes)

Fig. 417

Naseus vlamingi Valenciennes in Cuvier and Valenciennes, 1835:293 (Moluccas)

Naso vlamingi-Randall, 1973:206 (Tahiti) 
MATERIAL

Two lots, 2 specimens, $242-255 \mathrm{~mm} \mathrm{SL}, 10-25 \mathrm{~m}$, drop off at Salomon (photo: $255 \mathrm{~mm}$ ). Indo-Pacific.

\section{Paracanthurus hepatus (Linnaeus)}

Teuthis hepatus Linnaeus, 1758:507 (“Indies”, partim) Paracanthurus hepatus - Randall, 1955b:408 (Indo-Pacific east to Gilbert Islands)

No specimens collected; the record is based on the underwater sighting of a single individual in $7 \mathrm{~m}$ on the reef-top off Isle Anglaise, Salomon. Indo-west Pacific and marginally on the Pacific plate.

\section{Zanclus cornutus (Linnaeus)}

Fig. 418

Chaetodon cornutus Linnaeus, 1758:273 ("Indies")

Zanclus cornutus — Randall, 1973:204 (Tahiti)

\section{MATERIAL}

Three lots, 3 specimens, $114-150 \mathrm{~mm} \mathrm{SL}, 3-15 \mathrm{~m}$, lagoon and reef-top at Eagle Island and Peros Banhos (photo: $139 \mathrm{~mm}$ ). Randall (1973) pointed out that although $Z$. canescens (Linnaeus) has page priority over $Z$. cornutus, the latter name was selected by Cuvier, the first reviser of the genus (in Cuvier and Valenciennes, 1831a). Indo-Pacific.

Zebrasoma veliferum desjardinii (Bennett) Fig. 419 Acanthurus desjardinii Bennett, 1835:207 (Mauritius) Zebrasoma veliferum desjardinii-Randall, 1984a:27 (Indian Ocean, including Chagos, east to Maldives)

MATERIAL

Six lots, 10 specimens, $26-200 \mathrm{~mm} \mathrm{SL}, 0-15 \mathrm{~m}$, lagoon and reef-top (1) at Peros Banhos, Salomon, and Three Brothers (photos: 21, 29, and $200 \mathrm{~mm}$ ). We follow Randall (1984a) in separating the Indian Ocean form from that in the Pacific. Western Indian Ocean.

Zebrasoma scopas (Valenciennes)

Fig. 420 Acanthurus scopas Valenciennes in Cuvier and Valenciennes, 1835:245 (Banda, Mozambique)

Zebrasoma scopas-Randall, 1955b:405 (Indo-Pacific east to Tuamotu Islands)

MATERIAL

Eight lots, 12 specimens, $83-130 \mathrm{~mm}$ SL, 0.5-22 m, lagoon at Peros Banhos and Salomon (photos: 111 and $114 \mathrm{~mm}$ ). Indo-Pacific

\section{Siganidae}

No specimens of this family were collected, but two individuals were seen on one occasion in the lagoon at Salomon. Positive identification to species was not achieved.
They were dusky in colour, with a white spot just beneath the end of the dorsal fin, and other light spots on the belly. They became an overall silvery colour over sand. They may have been Siganus sutor (Valenciennes in Cuvier and Valenciennes, 1835). Range unassigned.

\section{Scombridae}

\section{Euthynnus affinis (Cantor)}

Fig. 421

Thynnus affinis Cantor, 1849:1088 ("Sea of Penang") Euthynnus affinis-Collette and Nauen, 1983:33 (IndoPacific east to Marquesas Islands)

\section{MATERIAL}

Two lots, 4 specimens, $465-565 \mathrm{~mm} \mathrm{SL}, 12-17 \mathrm{~m}$, lagoon at Peros Banhos (photo: $575 \mathrm{~mm}$ ). Indo-Pacific.

\section{Gymnosarda unicolor (Rüppell)}

Thynnus unicolor Rüppell, 1836:40 (Red Sea)

Gymnosarda unicolor-Collette and Nauen, 1983:40 (Indo-Pacific east to Pitcairn Island)

No specimens collected, but this species was occasionally seen cruising the edge of the drop-off, at $20-30 \mathrm{~m}$, off Peros Banhos and Salomon. Indo-Pacific.

\section{Katsuwonus pelamis (Linnaeus)}

Scomber pelamis Linnaeus, 1758:297 ("in Pelago intertropicas")

Katsuwonus pelamis-Collette and Nauen, 1983:42 (cosmopolitan)

No specimens seen or collected; occurrence is based on the range maps in Collette and Nauen (1983) and Collette (1984d). Cosmopolitan.

\section{Scomberomorus commerson (Lacepède)}

Scomberoides commersonianus Lacepède, 1802a:50 (Madagascar)

Scomberomorus commerson-Collette, 1984d:29 (Indowest Pacific, including Chagos, east to New Caledonia)

No specimens seen or collected; occurrence is based on the range map in Collette (1984d). Indo-west Pacific.

\section{Thunnus alalunga (Bonnaterre)}

Scomber alalunga Bonnaterre, 1788:139 (Mediterranean) Thunnus alalunga - Collette and Nauen, 1983:40 (cosmopolitan, including Chagos)

No specimens seen or collected; occurrence is based on the range maps in Collette and Nauen (1983) and Collette (1984d). Cosmopolitan. 


\section{Thunnus albacares (Bonnaterre)}

Scomber albacares Bonnaterre, 1788:140 (Jamaica)

Thunnus albacares-Collette and Nauen, 1983:83 (worldwide, including Chagos)

A single specimen, approximately $1 \mathrm{~m}$ in length, was hooked in the pass between Petite Sœur and Isle Poule, Peros Banhos. It was brought alongside the inflatable boat before breaking loose, and this afforded a good lateral view. Identification was based on the bright yellow, elongate, soft dorsal and anal fins. Cosmopolitan.

\section{Thunnus obesus (Lowe)}

Thynnus obesus Lowe, 1839:78 (Madeira Islands)

Thunnus obesus-Collette and Nauen, 1983:88 (worldwide, including Chagos)

No specimens seen or collected; occurrence is based on the range maps of Collette and Nauen (1983) and Collette (1984d). Cosmopolitan.

\section{Xiphiidae}

\section{Xiphias gladius Linnaeus}

Xiphias gladius Linnaeus, 1758:248 ("in Oceano Europae"); Nakamura, 1984b:3 (cosmopolitan, including Chagos)

No specimen seen or collected; occurrence is based on the range map given by Nakamura (1984b). Cosmopolitan.

\section{Istiophoridae}

No istiophorids were seen or collected during the expedition; their inclusion here is based on the range maps given by Nakamura (1984a). Ranges as given in the citations below are included in the zoogeographic analysis.

\section{Istiophorus platypterus (Shaw and Nodder)}

Xiphias platypterus Shaw and Nodder, 1791:none (Indian and Pacific oceans)

Istiophorus platypterus-Nakamura, 1984a:5 (Indo-Pacific, including Chagos)

\section{Makaira indica (Cuvier)}

Tetrapterus indicus Cuvier in Cuvier and Valenciennes, 1831b:286 (Sumatra)

Makaira indica-Nakamura, 1984a:7 (Indo-Pacific, including Chagos)

\section{Tetrapterus angustirostris Tanaka}

Tetrapterus angustirostris Tanaka, 1914:324 (Japan);
Nakamura, 1984a:11 (Indo-Pacific, including Chagos)

\section{Tetrapterus audax (Philippi)}

Histiophorus audax Philippi, 1887:568 (Chile)

Tetrapterus audax-Nakamura, 1984a:13 (Indo-Pacific, including Chagos)

\section{Nomeidae}

\section{Psenes squamiceps (Lloyd)}

Mulichthys squamiceps Lloyd, 1909:158 (Arabian Sea)

Psenes squamiceps-Haedrich and Nzioka, 1984b:5 (Indo-west Pacific, including Chagos, east to Japan)

No specimens seen or collected; occurrence is based on the range map given by Haedrich and Nzioka (1984b). Indowest Pacific.

\section{Bothidae}

Arnoglossus intermedius (Bleeker)

Platophrys intermedius Bleeker, 1866:47 (Sulawesi)

Engyprosopon intermedius-Regan, 1908:235 (Diego Garcia, Chagos Archipelago)

Arnoglossus intermedius-Norman, 1934:197 (Indo-west Pacific east to Solomon Islands)

No specimens seen or collected; occurrence is based on Regan's (1908) report of a specimen taken in 10 fathoms $(18.3 \mathrm{~m})$ at Diego Garcia. Indo-west Pacific.

\section{Bothus mancus (Broussonet)}

Fig. 422

Pleuronectes mancus Broussonet, 1782:none (Pacific Ocean)

Platophrys pavo - Regan, 1908:232 (Peros Banhos, Chagos Archipelago)

Bothus mancus-Norman, 1934:230 (Indo-Pacific east to Mexico)

\section{MATERIAL}

Three lots, 9 specimens, $117-189 \mathrm{~mm} \mathrm{SL}, 0-3 \mathrm{~m}$, reef-flat at Peros Banhos and Salomon (photo: $117 \mathrm{~mm}$ ). Indo-Pacific.

Bothus pantherinus (Rüppell)

Fig. 423 Rhombus pantherinus Rüppell, 1830b:121 (Mahila, Red Sea)

Bothus pantherinus-Nielsen, 1984:5 (Indo-Pacific east to Hawaii)

\section{MATERIAL}

One lot, 4 specimens, $32-37 \mathrm{~mm} \mathrm{SL}, 0-0.5 \mathrm{~m}$, lagoon at Peros Banhos (photo: $35 \mathrm{~mm}$ ). Indo-Pacific. 


\section{Soleidae}

Aseraggodes cyaneus (Alcock)*

Fig. 424

Solea cyaneus Alcock, 1890:439 (Bay of Bengal)

\section{MATERIAL}

Two lots, 4 specimens, $12-38 \mathrm{~mm} \mathrm{SL}, 7-25 \mathrm{~m}$, lagoon and drop-off at Peros Banhos and Salomon (photo: $34 \mathrm{~mm}$ ). Indian Ocean.

\section{?Monochirus sp.}

PI. VIIIG

MATERIAL

One lot, 1 specimen, $19 \mathrm{~mm} \mathrm{SL}, 18-25 \mathrm{~m}$, drop-off at Salomon (photo).

This small specimen appears to belong in Monochirus, since the dorsal and anal fins are separate from the caudal fin, the right pectoral is well developed, and the left pectoral fin is absent. It does not seem to be conspecific with the only other Indian Ocean member of the genus, $M$. quadriocellata Bonde. A description of the specimen follows: D 68, originating at the level of the pupil of the left eye; A 55; pelvics subequal with five fin-rays; three darkrimmed ocelli just ventral to the midlateral septum, the first in line with the tip of the pectoral fin, the third on the caudal peduncle, and the second midway between these two; scattered spots and blotches of dark pigment over the rest of the ocular side of the body. Range unassigned.

\section{Balistidae}

\section{Abalistes stellaris (Schneider)}

Balistes stellaris Schneider in Bloch and Schneider, 1801:476 (Indian Ocean)

Abalistes stellaris-Kyushin et al., 1977:344 (Chagos Archipelago)

No specimens seen or collected; the record is based on the report of Kyushin et al. (1977) of a single specimen taken with a vertical longline in $28-100 \mathrm{~m}$ at Chagos. Indo-west Pacific.

\section{Aluterus scriptus (Osbeck)*}

Balistes scriptus Osbeck, 1765:145 (China Sea)

Alutera scripta-Allen and Steene, 1979:66 (circumtropical)

The record is based on the sighting of a single specimen on the reef-top at Isle Boddam, Salomon, in $7 \mathrm{~m}$. The specimen was a light tan ground colour with numerous light blue spots and was approximately $30 \mathrm{~cm} \mathrm{SL}$. Circumtropical.

\section{Balistapus undulatus (Park)}

Fig. 425

Balistes undulatus Park, 1797:37 (Sumatra)

Balistapus undulatus-Randall, 1973:206 (Tahiti); Kyu- shin et al., 1977:350 (Chagos Archipelago)

MATERIAL

Fourteen lots, 16 specimens, $30-223 \mathrm{~mm} \mathrm{SL}, 0-43 \mathrm{~m}$, lagoon, reef-top, and drop-off at Eagle Island, Peros Banhos, and Salomon (photos: 30 and $146 \mathrm{~mm}$ ). Indo-Pacific.

\section{Balistoides conspicillum Schneider}

Fig. 426

Balistes conspicillum Schneider in Bloch and Schneider, 1801:474 (Indian Ocean)

Balistoides conspicillum-Kami, Ikehara, and DeLeon, 1968:127 (Guam)

\section{MATERIAL}

One lot, 1 specimen, $183 \mathrm{~mm} \mathrm{SL}, 18-25 \mathrm{~m}$, drop-off at Salomon (photo). Indo-west Pacific and marginally on the Pacific plate.

\section{Balistoides viridescens (Schneider)}

Balistes viridescens Schneider in Bloch and Schneider, 1801:477 (no locality)

Balistoides viridescens - Randall, 1973:206 (Tahiti)

No specimens collected; the record is based on several sightings of the species on the reef-tops at Peros Banhos and Salomon. We found it impossible to approach these fish (estimated to be $300-400 \mathrm{~mm} \mathrm{SL}$ ) closer than about $10 \mathrm{~m}$ before they took flight. Indo-Pacific.

Cantherhines dumerili (Hollard)

Fig. 427

Monacanthus dumerili Hollard, 1854:361 (Mauritius)

Cantherhines dumerili-Randall and Sinoto, 1978:304

(Rapa); Hutchins, 1984:9 (Indo-Pacific, including Chagos)

\section{MATERIAL}

One lot, 1 specimen, $219 \mathrm{~mm} \mathrm{SL}, 20-25 \mathrm{~m}$, drop-off at Peros Banhos (photo). Indo-Pacific.

Cantherhines fronticinctus (Günther)

Fig. 428

Monacanthus fronticinctus Günther, 1866a:136 (Zanzibar)

Cantherhines fronticinctus-Hutchins, 1984:11 (IndoPacific, including Chagos)

MATERIAL

One lot, 1 specimen, $98 \mathrm{~mm} \mathrm{SL}, 18-25 \mathrm{~m}$, drop-off at Salomon (photo). Indo-west Pacific.

Cantherhines pardalis (Rüppell)

Fig. 429

Monacanthus pardalis Rüppell, 1938:57 (Red Sea)

Cantherhines pardalis-Randall and Sinoto, 1978:304

(Rapa); Hutchins, 1984:13 (Indo-Pacific, including Chagos)

MATERIAL

Three lots, 4 specimens, 57-133 mm SL, 5-24 m, lagoon 
and drop-off at Peros Banhos (photos: 57 and $133 \mathrm{~mm}$ ). Indo-Pacific.

\author{
Melichthys indicus Randall \\ and Klausewitz \\ Figs. 430, 431 \\ Melichthys indicus Randall and Klausewitz, 1973:64 (Thai- \\ land; also west to Seychelles)
}

\section{MATERIAL}

Three lots, 5 specimens, 145-190 mm SL, 5-25 m, reeftop and drop-off at Eagle Island and Salomon (photos: 166, 170 , and $190 \mathrm{~mm}$ ). The $170-\mathrm{mm}$ SL specimen differs from the others in that the second dorsal fin is pure white with an eye-diameter-wide edging of black. This morph was seen on a number of occasions. Indo-west Pacific.

\section{Melichthys niger (Bloch)}

Balistes niger Bloch, 1786:27 (China Sea)

Melichthys niger-Randall and Klausewitz, 1973:60 (circumtropical, including Chagos)

\section{MATERIAL}

Two lots, 2 specimens, 199-217 mm SL, 7-10 m, reef-top at Peros Banhos and Salomon (photos: both). Circumtropical.

Odonus niger (Rüppell)

Xenodon niger Rüppell, 1837:53 (Red Sea)

Fig. 433

Odonus niger-Kyushin et al., 1977:348 (Chagos Archipelago); Randall, 1973:207 (Tahiti)

\section{MATERIAL}

Two lots, 3 specimens, 71-173 mm SL, 9-25 m, drop-off at Peros Banhos (photo: $71 \mathrm{~mm}$ ). Small schools of this species were observed apparently feeding in the water column on the sandy slope of the drop-off on the eastern side of Isle Fouquet. Indo-Pacific.

\section{Oxymonacanthus longirostris (Bloch} and Schneider)

Fig. 434

Balistes hispidus var. longirostris Bloch and Schneider, 1801:464 (no locality)

Oxymonacanthus longirostris - Kami, Ikehara, and De Leon, 1968:126 (Guam)

\section{MATERIAL}

Five lots, 5 specimens, 38-72 mm SL, 3-17 m, lagoon and reef-top at Eagle Island, Peros Banhos, and Salomon (photos: 57 and $60 \mathrm{~mm}$ ). Indo-west Pacific and marginally on the Pacific plate.

\section{Paraluteres prionurus (Bleeker)}

Fig. 435

Alutarius prionurus Bleeker, 1851 b:260 (Banda, Moluccas; Neira)

Paraluteres prionurus —Woods, 1966:98 (Marshall Islands)
MATERIAL

Two lots, 2 specimens, 16-63 mm SL, 5-15 m, lagoon at Peros Banhos and Salomon (photos: both). Indo-west Pacific and marginally on the Pacific plate.

\section{Pervagor janthinosoma (Bleeker)}

Pl. VIIIH

Monacanthus janthinosoma Bleeker, 1854a:504 (Ambon)

\section{MATERIAL}

One lot, 1 specimen, $38 \mathrm{~mm} \mathrm{SL}, 18-24 \mathrm{~m}$, drop-off at Peros Banhos (photo). The single small specimen was tentatively identified as this species by $\mathrm{J}$. B. Hutchins. Indo-west Pacific.

Pervagor melanocephalus (Bleeker)

Fig. 436

Monacanthus melanocephalus Bleeker, 1853d:95 (Solar; Lawajong)

Pervagor melanocephalus-Gosline and Brock, 1965:296 (Hawaii)

\section{MATERIAL}

Six lots, 6 specimens, $61-77 \mathrm{~mm} \mathrm{SL}, 1-43 \mathrm{~m}$, lagoon and drop-off at Diego Garcia, Peros Banhos, and Salomon (photo: $77 \mathrm{~mm}$ ). Gosline and Brock (1965) record a single specimen from Hawaii. Woods (1966:83) divided this species into three subspecies: one found in Indo-west Pacific, one from the Marshall Islands, and the third from Johnston Island. It appears that further work is necessary to clarify the nature of the variation in the Pacific plate populations. Tentatively assigned to the Indo-Pacific.

Note: After this manuscript was typeset, a paper by J. B. Hutchins (1986, Review of the monacanthid fish genus Pervagor, with descriptions of two new species. IndoPacific Fishes 12:1-35) indicated that all our specimens of Pervagor were assignable to $P$. janthinosoma. Range: Indo-west Pacific and marginally on the Pacific plate. This new information is not incorporated into the main body of the text.

Rhinecanthus aculeatus (Linnaeus)

Fig. 437

Balistes aculeatus Linnaeus, 1758:328 (India); Regan, 1908:251 (Chagos Archipelago)

Rhinecanthus aculeatus-Randall and Steene, 1983:45 (Indo-Pacific east to Pitcairn Island)

MATERIAL

Five lots, 37 specimens, 37-176 mm SL, 0-7 m, lagoon and reef-flat at Diego Garcia, Eagle Island, Peros Banhos, and Salomon (photos: 133 and $151 \mathrm{~mm}$ ). Indo-Pacific.

Rhinecanthus rectangulus (Bloch and Schneider)

Fig. 438

Balistes rectangulus Bloch and Schneider, 1801:465 
(Indian Ocean)

Rhinecanthus rectangulus-Randall and Steene, 1983:45 (Indo-Pacific east to Pitcairn Island)

MATERIAL

Two lots, 2 specimens, 101-104 mm SL, 0-1 m, reef-flat at Peros Banhos and Salomon (photo: $104 \mathrm{~mm}$ ). Indo-Pacific.

Sufflamen bursa (Schneider)

Fig. 439

Balistes bursa Schneider in Bloch and Schneider, 1801:476 (Indian Ocean)

Sufflamen bursa-Randall, 1973:207 (Tahiti)

MATERIAL

Three lots, 3 specimens, $129-151 \mathrm{~mm}$ SL, 7-25 m, reeftop and drop-off at Peros Banhos and Salomon (photo: $129 \mathrm{~mm})$. Indo-Pacific

\section{Sufflamen chrysopterum (Bloch} and Schneider)

Fig. 440

Balistes chrysopterus Bloch and Schneider, 1801:466 (India)

Sufflamen chrysopterus - Randall, 1973:207 (Tahiti)

MATERIAL

Four lots, 4 specimens, 31-154 mm SL, 3-24 m, lagoon and drop-off at Peros Banhos (photos: 31 and $134 \mathrm{~mm}$ ). Indo-Pacific.

\section{Sufflamen fraenatum (Latreille)*}

Fig. 441

Balistes fraenatus Latreille, 1804:74 (Madagascar; Polynesia)

MATERIAL

One lot, 1 specimen, $274 \mathrm{~mm} \mathrm{SL}, 20 \mathrm{~m}$, drop-off at Peros Banhos (photo). Indo-Pacific.

\section{Thamnaconus modestoides (Barnard)}

Cantherines (sic) modestoides Barnard, 1927:958 (Algoa Bay, South Africa)

Navodon sp.-Kyushin et al., 1977:354 (Chagos Archipelago)

Thamnoconus modestoides-Hutchins, 1984:19 (Indowest Pacific east to Japan)

No specimens seen or collected, and the record is based on the photograph and report of Kyushin et al. (1977) of Navodon sp. taken with vertical longline in $72-160 \mathrm{~m}$ (305 mm BL). Indo-west Pacific.

\section{Xanthichthys auromarginatus (Bennett)}

Fig. 442

Balistes auromarginatus Bennett, 1831:168 (Mauritius)

Xanthichthys auromarginatus - Randall, Matsuura, and Zama, 1978:696 (Indo-Pacific east to Hawaii)
MATERIAL

One lot, 1 specimen, $102 \mathrm{~mm} \mathrm{SL}, 41-48 \mathrm{~m}$, drop-off at Peros Banhos (photo). Indo-Pacific

\section{Ostraciidae}

Ostracion cubicus Linnaeus

Fig. 443

Ostracion cubicus Linnaeus, 1758:332 (India); Randall, 1972b:761 (Indo-Pacific east to Polynesia)

MATERIAL

Four lots, 11 specimens, 11-295 mm SL, 0-10 m, lagoon at Eagle Island, Peros Banhos, and Salomon (photo: $295 \mathrm{~mm}$ ). Indo-Pacific.

Ostracion meleagris Shaw and Nodder

Fig. 444 Ostracion meleagris Shaw and Nodder, 1796:none ("southern ocean"); Randall, 1972b:765 (Indo-Pacific to eastern tropical Pacific)

\section{MATERIAL}

Three lots, 5 specimens, 93-148 mm SL, 0-30 m, lagoon, reef-top, and drop-off at Eagle Island and Salomon (photo: $132 \mathrm{~mm}$ ). Indo-Pacific.

\section{Triodontidae}

\section{Triodon macropterus Lesson}

Triodon macropterus Lesson, 1829:none (Mauritius); Kyushin et al., 1977:364 (Chagos Archipelago); Tyler, 1967:89 (Indo-west Pacific east to Japan)

No specimens seen or collected; the record is based on the report of 4 specimens taken by vertical longline in 50-160 m (347-395 mm BL) by Kyushin et al. (1977).

Tyler (1967) reported variation in the presence or absence of the dorsal spines: specimens from the Indian Ocean and a specimen from Ambon lack the spines, while specimens from other areas in the Moluccas as well as those from Japan possess them. Kyushin et al. (1977) do not explicitly state whether the Chagos specimens have or lack dorsal spines. Indo-west Pacific.

\section{Tetraodontidae}

Arothron aerostaticus (Jenyns)

Fig. 445

Tetrodon aerostaticus Jenyns, 1842:152 (unknown)

\section{MATERIAL}

One lot, 1 specimen, 46 mm SL. $0.2 \mathrm{~m}$, lagoon at Salomon (photo). This species is very similar to A. stellatus (Bloch 
and Schneider). Possibly only one species is involved, but we tentatively retain $A$. aerostaticus as distinct, based on dark spots on the caudal fin, as suggested by Smith (1958b). Range unassigned.

\section{Arothron meleagris (Lacepède)}

Figs. 446,447

Tetrodon meleagris Lacepède, 1798:476 ("seas of Asia"); Regan, 1908:253 (Chagos Archipelago)

Arothron meleagris—Randall, 1973:207 (Tahiti)

MATERIAL

Six lots, 12 specimens, 181-252 mm SL, 0-3 m, lagoon and reef-flat at Peros Banhos and Salomon (photos: 209 and $243 \mathrm{~mm}$ ). The specimens of this and the following species were identified by Drs J. Su and J. C. Tyler. One photographed specimen represents the yellow colour phase of this species. Indo-Pacific.

\section{Arothron nigropunctatus (Schneider)}

Fig. 448

Tetrodon nigropunctatus Schneider in Bloch and Schneider, 1801:507 (Tranquebar, India)

Arothron nigropunctatus-Kami, Ikehara, and DeLeon, 1968:128 (Guam)

\section{MATERIAL}

Two lots, 2 specimens, 164-200 mm SL, 0-4 m, lagoon and reef-flat at Salomon (photo: $200 \mathrm{~mm}$ ). Indo-west Pacific and marginally on the Pacific plate.

\section{Canthigaster bennetti (Bleeker)}

Fig. 449

Tropidichthys bennetti Bleeker, 1854c:504 (Ambon)

Canthigaster bennetti-Allen and Randall, 1977:488 (Indo-

Pacific east to Tuamotu Islands)

\section{MATERIAL}

One lot, 1 specimen, $63 \mathrm{~mm} \mathrm{SL}, 0-0.5 \mathrm{~m}$, lagoon at Peros Banhos (photo). Indo-Pacific.

\section{Canthigaster janthinoptera (Bleeker)}

Fig. 450

Tropidichthys janthinoptera Bleeker, 1855b:429 (Ambon) Canthigaster janthinoptera-Allen and Randall, 1977:495 (Indo-Pacific, including Chagos, east to Pitcairn Island)

\section{MATERIAL}

Ten lots, 15 specimens, 14-50 mm SL, 0.5-25 m, lagoon, reef-top, and drop-off at Eagle Island, Peros Banhos, and Salomon (photos: 15, 25, and $46 \mathrm{~mm}$ ). Indo-Pacific.

Canthigaster natalensis (Günther)

Fig. 451

Tetrodon amboinensis var. natalensis Günther, 1870:303 (Durban, South Africa)

Canthigaster natalensis-Allen and Randall, 1977:500 (western Indian Ocean)

MATERIAL

One lot, 1 specimen, $67 \mathrm{~mm}$ SL, 0-3 m, reef-top at Salomon (photo). Western Indian Ocean.

Canthigaster tyleri Allen and Randall

Fig. 452

Canthigaster tyleri Allen and Randall, 1977:497 (Mauritius; also Indo-west Pacific east to the Moluccas)

\section{MATERIAL}

Three lots, 3 specimens, 37-39 mm SL, 23-43 m, drop-off at Peros Banhos and Salomon (photos: 37 and $38 \mathrm{~mm}$ ). Indo-Pacific.

Canthigaster valentini (Bleeker) Fig. 453

Tetraodon valentini Bleeker, 1853a:130 (Ambon)

Canthigaster valentini-Allen and Randall, 1977:484 (Indo-Pacific east to Tuamotu Islands)

\section{MATERIAL}

Twelve lots, 26 specimens, 12-49 mm SL, 0-30 m, lagoon at Diego Garcia, Peros Banhos, Salomon, and Three Brothers (photo: $30 \mathrm{~mm}$ ). Indo-Pacific.

\section{Diodontidae}

\section{Diodon hystrix Linnaeus}

Fig. 454

Diodon hystrix Linnaeus, 1758:335 (India); Leis, 1978:545 (cosmopolitan)

MATERIAL

Two lots, 2 specimens, $245-365 \mathrm{~mm} \mathrm{SL}, 0.5-2 \mathrm{~m}$, lagoon at Diego Garcia and Eagle Island (photo: $365 \mathrm{~mm}$ ). Cosmopolitan. 


\section{Discussion}

Collections of Chagos fishes at the ROM contain representatives of 585 species ( 98 of which are gobioids). A further 12 species were identified in the field but not collected, and another 4 field identifications were at the familial or generic level. Two species (Paragobiodon echinocephalus and Foa sp.) not collected by us are represented in the collections of the British Museum (Natural History). One hundred species not encountered by us are included here based on published records, for a total known fish fauna of 703 species belonging to 94 families and 314 genera. The Chagos fish collection at ROM contains a total of 3798 lots consisting of 31408 specimens. In addition, there are 25 lots with 75 specimens of juvenile muraenids, scorpaenids, and scarids that we were unable to identify to species.

In a zoogeographic analysis, $50.4 \%$ of the fishes have an Indo-Pacific distribution, $12.1 \%$ are found in the Indowest Pacific, $8.4 \%$ in the Indo-west Pacific and marginally on the Pacific plate, and $6.0 \%$ are restricted to the western
Indian Ocean. Other categories are as follows: cosmopolitan, 2.6\%; circumtropical, 2.3\%; Indian Ocean, 2.3\%; Indian Ocean and western extremity of the western Pacific, $0.8 \%$; endemic to Chagos, $0.4 \%$; central Indian Ocean, $0.3 \%$; and "Indo-west Pacific", $0.3 \%$. Taxa not assigned a range constituted $13.9 \%$ of the total fauna and fell into the following categories: taxa not assigned to species; those in which systematic or literature problems precluded range assessments; and those for which systematic revisions have just begun or are pending, and distributions have yet to be worked out. Fifty-seven of these unassigned species (7.5\% total fauna) belong to the Gobiidae. The above figures are not readily comparable to other faunal lists because of the different Pacific subdivisions used here, as discussed in Materials and Methods (pp. 2-3).

The Chagos fauna, as is usual in coral-reef environments, is dominated by gobiids, labrids, pomacentrids, serranids, and muraenids, which together account for

TABLE 2. A comparative listing for the 19 most speciose families of fishes at the Chagos Archipelago, and percentages of total fauna represented by each family in other regions-Christmas Island (Allen and Steene, 1979); the Capricorn-Bunker group of the Great Barrier Reef (Russell, 1983); Lizard Island, Great Barrier Reef (Paxton, Hoese, and Larson, 1978); and the Seychelles (Smith and Smith, 1963).

Column headings: $\mathrm{n}$ - number of species in each family that are known from the Chagos Archipelago; $\mathrm{n} \%$ - percentage represented by each family of total fauna at Chagos; $\mathrm{c}$ - number of species in each family seen or collected by us at Chagos; c\%-percentage that "c" represents of total fauna seen or collected by us at Chagos; and percentages represented by each family of total fauna in other regions: Chr\% — Christmas Island; Cap\% - the Capricorn-Bunker group; Liz\% — Lizard Island; Sey\% — the Seychelles.

\begin{tabular}{|c|c|c|c|c|c|c|c|c|}
\hline Family & $\mathrm{n}$ & $\mathrm{n} \%$ & $\mathrm{c}$ & $\mathrm{c} \%$ & Chr\% & Сар\% & $\mathrm{Liz} \%$ & Sey\% \\
\hline Gobiidae & 91 & 13.0 & 90 & 15.0 & 6.8 & 12.1 & 18.6 & 7.1 \\
\hline Labridae & 59 & 8.4 & 57 & 9.5 & 10.7 & 8.0 & 10.2 & 7.2 \\
\hline Pomacentridae & 42 & 5.8 & 42 & 7.0 & 8.5 & 8.0 & 10.2 & 5.2 \\
\hline Serranidae & 41 & 5.8 & 29 & 4.8 & 6.4 & 3.7 & 4.3 & 4.0 \\
\hline Muraenidae & 38 & 5.4 & 38 & 6.3 & 5.6 & 2.7 & 2.7 & 2.7 \\
\hline Apogonidae & 30 & 4.3 & 29 & 4.8 & 3.9 & 3.8 & 5.5 & 4.1 \\
\hline Lutjanidae & 29 & 4.1 & 16 & 2.7 & 1.9 & 1.6 & 2.2 & 4.1 \\
\hline Acanthuridae & 24 & 3.4 & 24 & 4.0 & 4.8 & 2.9 & 2.6 & 3.7 \\
\hline Holocentridae & 22 & 3.1 & 22 & 3.7 & 2.9 & 1.3 & 2.9 & 1.9 \\
\hline Blenniidae & 22 & 3.1 & 21 & 3.5 & 4.5 & 4.7 & 3.9 & 4.2 \\
\hline Balistidae & 22 & 3.1 & 20 & 3.3 & 3.8 & 2.8 & 2.0 & 2.6 \\
\hline Scorpaenidae & 20 & 2.9 & 19 & 3.2 & 2.9 & 2.4 & 1.9 & 2.7 \\
\hline Chaetodontidae & 19 & 2.7 & 19 & 3.2 & 5.4 & 3.7 & 4.6 & 2.3 \\
\hline Scaridae & 18 & 2.6 & 15 & 2.5 & 2.3 & 2.6 & 1.6 & 4.2 \\
\hline Lethrinidae & 15 & 2.1 & 4 & 0.7 & 0.4 & 1.0 & 0.9 & 1.6 \\
\hline Carangidae & 13 & 1.9 & 9 & 1.5 & 1.9 & 2.4 & 0.7 & 3.4 \\
\hline Ophichthidae & 11 & 1.6 & 10 & 1.7 & 0.8 & 1.2 & 0.7 & 1.2 \\
\hline Mullidae & 10 & 1.4 & 7 & 1.2 & 1.2 & 0.8 & 0.7 & 1.9 \\
\hline Exocoetidae & 10 & 1.4 & 0 & 0.0 & 0.2 & 0.3 & 0.1 & 0.7 \\
\hline
\end{tabular}


$38.4 \%$ of the total fish fauna by species (Table 2 ). The most speciose 11 families (each contributing more than $3 \%$ of the total fauna) comprise $60 \%$ of the total fauna known from Chagos, and the top 19 families make up $76 \%$ of that fauna. The blenniids at Chagos were in a tie with two other families for the ninth-most speciose family, whereas they were eighth at Christmas Island, fourth at the CapricornBunker group, seventh at Lizard Island, and tied for fourth at the Seychelles (Table 2). The low percentage of gobiids at Christmas Island and at the Seychelles undoubtedly reflects collecting efforts and techniques, for most species are small and cryptic. The relatively high percentage of the total Chagos fauna made up of lutjanids, lethrinids, and exocoetids is not reflected in the percentage of the fauna seen or collected and is largely the result of fishery surveys using techniques not commonly employed by coral-reef ichthyologists (e.g., vertical longlines); the collected/seen percentage for each of these three groups is, however, comparable to the percentages from the other localities listed in Table 2, where collecting techniques and emphases more nearly parallel those that we employed.

\section{Acknowledgements}

The majority of the specimens reported on here were collected during the 1978-1979 Joint Services Chagos Research Expedition of the British Armed Forces. We would especially like to record our deep appreciation of Major John Griffiths and Dr C. Sheppard, who, as respective military and scientific leaders of the expedition, provided every conceivable type of assistance and equipment; and to Peter Winch, whose ketch made the expedition possible. Special thanks to those who helped with collections or warded off sharks during these activities: $\mathrm{H}$. Arnold, R. Crawford, S. Crellin, R. Crosby, J. Griffiths, J. Liptrot, P. Ormerod, R. Perry, A. Ryan, B. Simm, J. Smith, and S. Syson. Our participation was also made possible by the excellent transportation facilities offered by the British and Canadian Armed Forces. Fieldwork costs were defrayed by a grant from the University of Toronto and by the generous assistance of Benjamin Film Laboratories Ltd., Toronto.

The following colleagues kindly assisted us with identifications in various groups of fishes: G. R. Allen, Western Australian Museum, Perth; J. C. Briggs, University of South Florida, St Petersburg; M. Burridge-Smith and S. J. Campbell, Royal Ontario Museum, Toronto; K. Carpenter, formerly of the East-West Center, Honolulu; P. H. J. Castle, Victoria University, Wellington; B. B. Collette, National Marine Fisheries Service, Washington; L. J. V. Compagno, Smith Institute, Grahamstown; R. Cressey, Smithsonian Institution, Washington; C. E. Dawson, formerly of Gulf Coast Research Laboratory, Ocean Springs; W. N. Eschmeyer, California Academy of Sciences, San Francisco; R. M. Feltes, Ohio State University, Columbus; T. H. Fraser, Environmental Quality Laboratory, Port Charlotte; R. Fricke, Braunschweig; M. F. Gomon, National Museum of Victoria, Melbourne; P. C. Heemstra, Smith Institute, Grahamstown; J. Heiser, Cor- nell University, Ithaca; W. Holleman, Albany Museum, Grahamstown; J. B. Hutchins, Western Australian Museum, Perth; W. Ivantsoff, Macquarie University, North Ryde; L. W. Knapp, Smithsonian Institution Sorting Center, Washington; D. F. Markle, University of Oregon, Eugene; J. E. McCosker, Steinhardt Aquarium, San Francisco; J. S. Nelson, University of Alberta, Edmonton; T. W. Pietsch, University of Washington, Seattle; J. E. Randall, Bernice P. Bishop Museum, Honolulu; J.-M. Rose, Ichthyological Laboratory, Pont de Briques; D. G. Smith, formerly of University of Texas, Galveston; W. F. Smith-Vaniz, Academy of Natural Sciences of Philadelphia, Philadelphia; J. Su, Shanghai Fisheries College, Shanghai; J. M. Thomson, University of Queensland, Brisbane; J. C. Tyler, Smithsonian Institution, Washington; P. J. P. Whitehead, British Museum (Natural History), London; J. T. Williams, Smithsonian Institution, Washington; and D. J. Woodland, University of New England, Armidale.

Thanks to Arthur Strange and Mary Burridge-Smith for photographing the preserved specimens for species of which we failed to take colour slides in the field, and to $J$. Ryther and L. Taborsky for additional collections of Chagos fishes. Special thanks to Jill Hawken for the magnificent job she has done in copy-editing this manuscript, and thus, incidentally, saving us from considerable potential embarassment. Naturally any remaining inconsistencies, omissions, and commissions remain the sole property of the authors. The research leading to this paper was supported in part by NSERC grant No. A 7619 to the senior author. The cost of the colour plates was borne by the above-mentioned grant, by the National Museum of Natural Sciences, and by Publication Services, Royal Ontario Museum. 


\section{Literature Cited}

$\mathrm{ABE}, \mathrm{T}$.

1955 On a new Pacific flyingfish, Prognichthys sealei, retaining five unbranched fin-rays above in the pectoral throughout life. Records of Oceanographic Works in Japan, n.s. 2:185-192.

ABE, T. and S. SHINOHARA

1962 Description of a new lutjanid fish from the Ryukyu Islands. Japanese Journal of Ichthyology 9:163-170.

AHL, E.

1923 Zur Kenntnis der Knochenfischfamilie Chaetodontidae, insbesondere der Unterfamilie Chaetodontinae. Archiv. für Naturgesellschaften, Abtheilung A, 89:1205.

AHL, J, N.

1789 Specimen ichthyologicium de Muraena et Ophichtho. Inaugural Dissertation, Uppsala. 14 pp.

ALCOCK, A. W

1890 On some undescribed shore-fishes from the Bay of Bengal. Annals and Magazine of Natural History, ser. $6,6: 425-443$

ALLEN, G. R.

1972 The anemonefishes; their classification and biology. Neptune City, TFH Publications. 272 pp.

1975 Damselfishes of the south seas. Neptune City, TFH Publications. $240 \mathrm{pp}$.

1976 How many sergeant majors? Marine Aquarist 7(6):3341 .

1980 Butterfly and angelfishes of the world. Vol. 2. Toronto, Wiley-Interscience. $352 \mathrm{pp}$.

1984 Family Lutjanidae. In Fischer, W. and G. Bianchi, eds., FAO Species Identification Sheets for Fishery Purposes; Western Indian Ocean (fishing area 51). Rome, FAO. Vol. 3.

ALLEN, G, R. and J, E. RANDALL

1977 Review of the sharpnose pufferfishes (subfamily Canthigasterinae) of the Indo-Pacific. Records of the Australian Museum 30:475-517.

1980 A review of the damselfishes (Teleostei: Pomacentridae) of the Red Sea. Israel Journal of Zoology 29:1-98

ALLEN, G. R. and R. C. STEENE

1979 The fishes of Christmas Island, Indian Ocean. Australian National Parks and Wildlife Service, Special Publication 2:1-81

ARNOLD, D. C

1956 A systematic revision of the fishes of the Teleost family Carapidae (Percomorphi, Blennioidea), with descriptions of two new species. Bulletin of the British Museum (Natural History), Zoology 4:245-307

BAISSAC, J. de B

1953 Contribution à l'étude des poissons de l'Île Maurice, V Proceedings of the Royal Society of Arts \& Sciences of Mauritius: 185-240 (for 1952).

BARNARD, K. H.

1927 A monograph of the marine fishes of South Africa
Part II. Annals of the South African Museum 21:419-1065.

BENNETT, E. T

1828 Observations on the fishes contained in the collection of the Zoological Society. Zoological Journal 4:3143.

1831 Observations on a collection of fishes from the Mauritius presented by Mr. Telfair, with characters of new genera and species. Proceedings of the Zoological Society of London (1):59-61, 126-128, 147, 165169.

1832a Characters of several new species of fishes, from Ceylon, presented by Dr. Sibbald. Proceedings of the Committee of Science and Correspondence of the Zoological Society of London (2):182-184.

$1832 \mathrm{~b}$ Characters of two new species of fishes, from the Mauritius, presented by Mr. Telfair. Proceedings of the Committee of Science and Correspondence of the Zoological Society of London (2):184.

1833 Characters of new species of fishes from the Mauritius, presented by C. Telfair, Esq. Proceedings of the Zoological Society of London 1833:32.

1835 Characters of several fishes from the Isle de France. Proceedings of the Zoological Society of London 1835:206-208.

BENNETT, F. D.

1840 Narrative of a whaling voyage round the globe from the year 1833 to 1836 comprising sketches of Polynesia, California, the Indian Archipelago, etc. with an account of southern whales, the sperm whale fishery and the natural history of the climates visited. Vol . 2 London, Richard Bentley. 395 pp. (reprint 1970, New York, N. Israel, Amsterdam \& Da Copo Press).

BENNETT, J, W.

1830 A selection of rare and curious fishes found upon the coast of Ceylon. Part 6. London.

BLEEKER, $\mathrm{P}$.

1847 Pharyngognathorum siluroideorumque species novae javanenses. Natuur- en Geneeskundig Archief voor Neerland's Indië, ser. 2, 4:155-169.

1849 Bijdrage tot de kennis der Scleroparei van den SoendaMolukschen Archipel. Verhandelingen van het Bataviaasch Genootschap van Kunsten en Wetenschappen 22(5): $1-10$.

1851a Over eenige nieuwe soorten van Belone en Hemiram phus van Java. Natuurkundig Tijdschrift voor Nederlandsch Indië 1:93-95.

1851b Bijdrage tot de kennis der ichthyologische fauna van de Banda-eilanden. Natuurkundig Tijdschrift voor Nederlandsch Indië 2:225-261.

1852a Bijdrage tot de kennis der ichthyologische fauna van de Moluksche eilanden. Visschen van Amboina en Ceram. Natuurkundig Tijdschrift voor Nederlandsch Indië 3:229-309.

1852b Derde bijdrage tot de kennis der ichthyologische fauna van Celebes. Natuurkundig Tijdschrift voor Nederlandsch Indië 3:739-782. 
1853a Derde bijdrage tot de kennis der ichthyologische fauna van Amboina. Natuurkundig Tijdschrift voor Nederlandsch Indië 4:91-130.

$1853 \mathrm{~b}$ Diagnostische beschrijvingen van nieuwe of weinig bekende vischsoorten van Sumatra. Tiental V-X. Natuurkundig Tijdschrift voor Nederlandsch Indië $4: 243-302$.

1853c Diagnostische beschrijvingen van nieuwe of weinig bekende vischsoorten van Batavia. Tiental I-VI. Natuurkundig Tijdschrift voor Nederlandsch Indië $4: 451-516$.

1853d Bijdrage tot de kennis der ichthyologische fauna van Solor. Natuurkundig Tijdschrift voor Nederlandsch Indië 5:67-96.

1853e Vierde bijdrage tot de kennis der ichthyologische fauna van Amboina. Natuurkundig Tijdschrift voor Nederlandsch Indië 5:317-352.

1853f Bijdrage tot de kennis der Muraenoiden en Symbranchoïden van den Indischen Archipel. Verhandelingen van het Bataviaasch Genootschap van Kunsten en Wetenschappen 25(5): 1-76.

1854a Species piscium Bataviensium novae vel minus cognitae. Natuurkundig Tijdschrift voor Nederlandsch Indië 6:191-202.

1854b Bijdrage tot de kennis der ichthyologische fauna van het eiland Floris. Natuurkundig Tijdschrift voor Nederlandsch Indië 6:311-338

1854c Vijfde bijdrage tot de kennis der ichthyologische fauna van Amboina. Natuurkundig Tijdschrift voor Nederlandsch Indië 6:455-508.

1855a Bijdrage tot de kennis der ichthyologische fauna van de Batoe-eilanden. Natuurkundig Tijdschrift voor Nederlandsch Indië 8:305-328.

1855b Zesde bijdrage tot de kennis der ichthyologische fauna van Amboina. Natuurkundig Tijdschrift voor Nederlandsch Indië 8:391-434.

1856a Zevende bijdrage tot de kennis der ichthyologische fauna van Ternate (1). Natuurkundig Tijdschrift voor Nederlandsch Indië 10:357-386.

1856b Verslag omtrent eenige vischsoorten gevangen aan de Zuidkust van Malang in Oost-Java. Natuurkundig Tidjschrift voor Nederlandsch Indië 11:81-92.

1856c Vijfde bijdrage tot de kennis der ichthyologische fauna van de Banda-eilanden (1). Natuurkundig Tijdschrift voor Nederlandsch Indië 11:93-110.

1856d Beschrijvingen van nieuwe en weinig bekende vischsoorten van Amboina, verzameld op eene reis door den Molukschen Archipel gedaan in het gevolg van den Gouverneur Generaal Duymaer van Twist, in September en Oktober 1855. Acta Societatis Scientiarum Indo-Neerlandicae 1:1-72.

1856e Beschrijvingen van nieuwe en weinig bekende vischsoorten van Manado en Makassar, grootendeels verzameld op eene reis door den Molukschen Archipel, gedaan in het gevolg van den Gouverneur Generaal Duymaer van Twist, in September en Oktober 1855. Acta Societatis Scientiarum Indo-Neerlandicae $1: 1-80$.

1856f Achtste bijdrage tot de kennis der ichthyologische fauna van Ternate (1). Natuurkundig Tijdschrift voor Nederlandsch Indië 12:191-210.

$1856 \mathrm{~g}$ Bijdrage tot de kennis der ichthyologische fauna van het eiland Boero. Natuurkundig Tijdschrift voor Nederlandsch Indië 11:383-414.

1857a Achtste bijdrage tot de kennis der vischfauna van Amboina. Acta Societatis Scientiarum Indo-Neerlandicae 2:1-102.

1857b Tweede bijdrage tot de kennis der ichthyologische fauna van Boero. Natuurkundig Tijdschrift voor Nederlandsch Indië 13:55-82.

1857c Descriptiones specierum piscium javanensium novarum vel minus cognitarum diagnosticae. Natuurkundig Tijdschrift voor Nederlandsch Indië 13:323368.

1858 Bijdrage tot de kennis der vischfauna van den Goramarchipel. Natuurkundig Tijdschrift voor Nederlandsch Indië 15:197-218.

1859 Over eenige vischsoorten van de Zuidkust-wateren van Java. Natuurkundig Tijdschrift voor Nederlandsch Indië 19:329-352.

1865 Poissons inédits indo-archipélagiques de l'orde des Murènes. Nederlandsch Tijdschrift voor de Dierkunde 2:38-54.

1866 Description de quelques espèces inédites des genres Pseudorhombus et Platophrys de l'Inde archipélagique. Nederlandsch Tijdschrift voor de Dierkunde 3:43-50.

1868a Description de deux espèces nouvelles de Blennioids de l'Inde archipélagique. Verslagen en Mededeelingen der Koninklijke Akademie van Wetenschappen, ser. 2, 2:278-280.

1868b Description de deux espèces inédites d'Epinephelus rapportées de l'Île de la Réunion par M. M. Pollen et van Dam. Verslagen en Mededeelingen der Koninklijke Akademie van Wetenschappen, ser. 2, 2:336-341.

1869 Description d'une espèce inédite de Caesio de l'Île de Nossibé. Verslagen en Mededeelingen der Koninklijke Akademie van Wetenschappen, ser. 2, 3:7879.

1873 Révision des espèces indo-archipélagiques du genre Lethrinus. Nederlandsch Tijdschrift voor de Dierkunde 4:318-344.

1876 Description de quelques espèces inédites de Pomacentroïdes de l'Inde archipélagique. Verslagen en Mededeelingen der Koninklijke Akademie van Wetenschappen, ser. 2, 10:384-391.

BLISS, R., Jr

1883 Description of new species of Mauritian fishes. Transactions of the Society of Arts and Sciences of Mauritius:45-63.

BLOCH, M.

1786 Naturgeschichte des ausländischen Fische. Part 2. Berlin, J. Marino. 160 pp.

1787 Naturgeschichte des ausländischen Fische. Part 3. Berlin, J. Marino. $146 \mathrm{pp}$.

1790 Naturgeschichte des ausländischen Fische. Part 4 Berlin, J. Marino. 128 pp.

1791 Naturgeschichte des ausländischen Fische. Part 5. 
Berlin, J. Marino. 152 pp.

1792 Naturgeschichte des ausländischen Fische. Part 6. Berlin, J. Marino. 126 pp.

1793 Naturgeschichte des ausländischen Fische. Part 7. Berlin, J. Marino. 144 pp.

1795 Naturgeschichte des ausländischen Fische. Part 9. Berlin, J. Marino. 192 pp.

BLOCH, M. and J. G. SCHNEIDER

1801 Systema ichthyologiae; iconibus CX illustratum. Berlin. 584 pp. (reprint 1967, Lehre, J. Cramer).

BODDAERT, $\mathrm{P}$.

1772 Epistola... de Chaetodonte diacantho descripto. Amstelodamae.

1781 Beschreibung zweier merkwürdiger Fische (Sparus palpebratus und Muraena colubrina). Neue Nord. Beiträge (Pallas) 2:55-57.

BÖHLKE, E. B.

1982 Vertebal formulae for type specimens of eels (Pisces: Anguilliformes). Proceedings of the Academy of Natural Sciences of Phildelphia 134:31-49.

BÖHLKE, J. E.

1967 The descriptions of three new eels from the tropical west Atlantic. Proceedings of the Academy of Natural Sciences of Philadelphia 118:91-108 (for 1966).

BÖHKLE, J. E. and J. E. RANDALL

1981 Four new garden eels (Congridae, Heterocongrinae) from the Pacific and Indian oceans. Bulletin of Marine Science 31:366-382

BÖHKLE, J. E. and D. G. SMITH

1968 A new xenocongrid eel from the Bahamas, with notes on other species in the family. Proceedings of the Academy of Natural Sciences of Philadelphia 120:2543.

BONNATERRE, J. P.

1788 Tableau encyclopédique et méthodique des trois règnes de la nature, dédié et présenté à $\mathbf{M}$. Necker, ministre d'état, et directeur général des finances. Ichthyologie. Paris, Pankoucke. 215 pp.

BRIGGS, J. C.

1962 A new clingfish of the genus Lepadichthys from the New Hebrides. Copeia 1962:424-425.

1969 A new species of Lepadichthys (Gobiesocidae) from the Seychelles, Indian Ocean. Copeia 1969:464-466.

BROUSSONET, P. M. A.

1782 Ichthyologia sistens piscium descriptiones et icones. Icthyologiae. Decas I. London. 41 pp.

BRUCE, R. W. and J. E. RANDALL

1984 Family Scaridae. In Fischer, W. and G. Bianchi, eds., FAO Species Identification Sheets for Fishery Purposes; Western Indian Ocean (fishing area 51). Rome, FAO. Vol. 3.

BURGESS, W. E.

1978 Butterflyfishes of the world. Neptune City, TFH Publications. $832 \mathrm{pp}$.

BURGESS, W. E. and H. R. AXELROD

1975 Fishes of Melanesia. Pacific Marine Fishes Book 6. Neptune City, TFH Publications, pp. 1387-1654.

CANTOR, T.

1849 Catalogue of Malayan fishes. Journal of the Asiatic
Society of Bengal 18:983-1443.

CARPENTER, $\mathrm{K}$.

1984 Family Caesionidae. In Fischer, W. and G. Bianchi, eds., FAO Species Identification Sheets for Fishery Purposes; Western Indian Ocean (fishing area 51). Rome, FAO. Vol. 1.

CASTLE, P. H. J.

1984 Family Ophichthidae. In Fischer, W. and G. Bianchi, eds., FAO Species Identification Sheets for Fishery Purposes; Western Indian Ocean (fishing area 51). Rome, FAO. Vol. 3.

COHEN, D. M. and J. G. NIELSEN

1978 Guide to the identification of genera of the fish order Ophidiiformes with a tentative classification of the order. NOAA Technical Report NMFS Circular 417: $1-72$.

COLLETTE, B. B.

1984a Family Belonidae. In Fischer, W. and G. Bianchi, eds., FAO Species Identification Sheets for Fishery Purposes; Western Indian Ocean (fishing area 51). Rome, FAO. Vol. 1.

1984b Family Coryphaenidae. In Fischer, W. and G. Bianchi, eds., FAO Species Identification Sheets for Fishery Purposes; Western Indian Ocean (fishing area 51). Rome, FAO. Vol. 2.

1984c Family Rachycentridae. In Fischer, W. and G. Bianchi, eds., FAO Species Identification Sheets for Fishery Purposes; Western Indian Ocean (fishing area 51). Rome, FAO. Vol. 3.

1984d Family Scombridae. In Fischer, W. and G. Bianchi, eds., FAO Species identification Sheets for Fishery Purposes; Western Indian Ocean (fishing area 51). Rome, FAO. Vol. 4.

COLLETTE, B. B. and C. E. NAUEN

1983 FAO species catalogue. Vol. 2. Scombrids of the world; an annotated and illustrated catalogue of tunas, mackerels, bonitos and related species known to date. FAO Fisheries Synopsis 125(2):1-137.

COMPAGNO, L. J. V.

1984a Family Alopiidae. In Fischer, W. and G. Bianchi, eds., FAO Species Identification Sheets for Fishery Purposes; Western Indian Ocean (fishing area 51). Rome, FAO. Vol. 5.

1984b Family Carcharhinidae. In Fischer, W. and G. Bianchi, eds., FAO Species Identification Sheets for Fishery Purposes; Western Indian Ocean (fishing area 51). Rome, FAO. Vol. 5.

1984c Family Ginglystomatidae. In Fischer, W. and G. Bianchi, eds., FAO Species Identification Sheets for Fishery Purposes; Western Indian Ocean (fishing area 51). Rome, FAO. Vol. 5.

COMPAGNO, L. J. V. and P. C. HEEMSTRA

1984 Himantura draco, a new species of stingray (Myliobatiformes: Dasyatidae) and the first record of Dasyatis kuhlii (Müller \& Henle, 1841) from southern Africa. Smith Institute, Special Publication 33:117.

CRESSEY, R, and R. S. WAPLES

1984 Family Synodontidae. In Fischer, W. and G. Bianchi, 
eds., FAO Species Identification Sheets for Fishery Purposes; Western Indian Ocean (fishing area 51). Rome, FAO. Vol. 4.

CUVIER, G.

1817 Le règne animal distribué d'après son organisation, pour servir de base à l'histoire naturelle des animaux et d'introduction à l'anatomie comparée. Tome II. Paris, Déterville. 532 pp.

1829 Le règne animal. Éd. 2, vol. 2. Paris, Déterville. $406 \mathrm{pp}$.

CUVIER, G. and A. VALENCIENNES

1828 Histoire naturelle des poissons. Vol. 2. Paris, Levrault. $490 \mathrm{pp}$

1829a Histoire naturelle des poissons. Vol. 3. Paris, Levrault. 500 pp.

1829b Histoire naturelle des poissons. Vol. 4. Paris, Levrault. 518 pp.

1830a Histoire naturelle des poissons. Vol. 5. Paris, Levrault. $499 \mathrm{pp}$.

$1830 \mathrm{~b}$ Histoire naturelle des poissons. Vol. 6. Paris, Levrault. 559 pp.

1831a Histoire naturelle des poissons. Vol. 7. Paris, Levrault. $531 \mathrm{pp}$.

1831b Histoire naturelle des poissons. Vol. 8. Paris, Levrault. 509 pp.

1833 Histoire naturelle des poissons. Vol. 9. Paris, Levrault. 512 pp.

1835 Histoire naturelle des poissons. Vol. 10. Paris, Levrault. $482 \mathrm{pp}$.

1836 Histoire naturelle des poissons. Vol. 11. Paris, Levrault. 506 pp.

1839a Histoire naturelle des poissons. Vol. 13. Paris, PitoisLevrault. 505 pp.

1839b Histoire naturelle des poissons. Vol. 14. Paris, PitoisLevrault. 464 pp.

1846a Histoire naturelle des poissons. Vol. 18. Paris, Bertrand. 505 pp.

1846b Histoire naturelle des poissons. Vol. 19. Paris, Bertrand. 544 pp.

DAWSON, C. E.

1985 Indo-Pacific pipefishes (Red Sea to the Americas). Ocean Springs, Gulf Coast Research Laboratory. 230 $\mathrm{pp}$

DAY, F.

1867 On some new or imperfectly known fishes of India. Proceedings of the Zoological Society of London 1867:699-707

1870 On the fishes of the Andaman Islands. Proceedings of the Zoological Society of London 1870:677-705.

DONNDORF, J.A

1798 Zoologische Beiträge zur 13ten Ausgobe des Linné'schen Natursystems. Vol. 3. Ichthyologische Beiträge. Leipzig.

DOOLEY, J. K

1978 Systematics and biology of the tilefishes (Perciformes: Branchiostegidae and Malacanthidae) with descriptions of two new species. NOAA Technical Report NMFS Circular 411:1-78
DUNCKER, G. and E. MOHR

1931 Die Fische der Südsee-Expedition der Hamburgischen Wissenschaftlichen Stiftung 1908-1909. Mitteilungen aus dem Zoologischen Staatsinstitut und Zoologischen Museum in Hamburg 44:57-84.

EMERY, A. R

1983 Geographic variation in the Indo-Pacific damselfish genus Lepidozygus (Pisces: Pomacentridae). Canadian Journal of Zoology 61:1326-1338.

ESCHMEYER, W, N.

1983 A new species of the fish genus Pontinus (Scorpaeniformes: Scorpaenidae) from off Natal, South Africa. Smith Institute, Special Publication 28:1-4.

ESCHMEYER, W. N. and K. V. RAMA-RAO

1973 Two new stonefishes (Pisces, Scorpaenidae) from the Indo-west Pacific, with a synopsis of the subfamily Synanceiinae. Proceedings of the California Academy of Sciences, ser. 4, 39:337-382

ESCHMEYER, W. N. and J. E. RANDALL

1975 The scorpaenid fishes of the Hawaiian Islands, including new species and new records (Pisces: Scorpaenidae). Proceedings of the California Academy of Sciences, ser. 4, 40:265-334.

EVERMANN, B. W. and A. SEALE

1907 Fishes of the Philippine Islands. Bulletin of the Bureau of Fisheries 26:49-110

FISCHER, J, G

1885 Über einige afrikanische Fische des Naturhistorischen Museums in Hamburg (2). Jahrbuch der Hamburgischen Wissenschaftlichen Anstalten 2:66-77.

FORSSKÅL, P.

1775 Descriptiones animalium avium, amphibiorum, piscium, insectorum, vermium; quae in itinere orientali observavit. Hauniae, Möller. 164 pp.

FOURMANOIR, $\mathrm{P}$.

1963 Epinephelus fuscus, nouvelle espèce de serranidé trouvée dans les eaux Malgaches. Bulletin du Muséum national d'histoire naturelle, ser. 2, 35:140-142.

FOWLER, H, W.

1903 Descriptions of several fishes from Zanzibar Island, two of which are new. Proceedings of the Academy of Natural Sciences of Philadelphia 55:161-176.

1904 A collection of fishes from Sumatra. Journal of the Academy of Natural Sciences of Philadelphia, ser. 2, 12:495-560

1923 New or little-known Hawaiian fishes. Bernice P. Bishop Museum Occasional Papers 8:375-392

1941 The fishes of the groups Elasmobranchii, Holocephali, Isopondyli and Ostariophysi obtained by the United States Bureau of Fisheries steamer "Albatross" in 1907 to 1910 , chiefly in the Philippine Islands and adjacent seas. United States National Museum, Bulletin 100(13): 1-879.

FOWLER, H. W. and S. W, BALL

1924 Descriptions of new fishes obtained by the Tanager Expedition of 1923 in the Pacific Islands west of Hawaii. Proceedings of the Academy of Natural 
Sciences of Philadephia 76:269-274.

FOWLER, H. W. and B. A. BEAN

1928 The fishes of the families Pomacentridae, Labridae and Callyodontidae, collected by the United States Bureau of Fisheries steamer "Albatross", chiefly in Philippine seas and adjacent waters. United States National Museum, Bulletin 100(7):1-525.

1930 The fishes of the families Amiidae, Chandidae, Duleidae, and Serranidae, obtained by the United States Bureau of Fisheries steamer "Albatross" in 1907 to 1910 , chiefly in the Philippine Islands and adjacent seas. United States National Museum, Bulletin 100(10): 1-334.

FRASER, T. H.

1972 Comparative osteology of the shallow water cardinal fishes (Perciformes: Apogonidae) with reference to the systematics and evolution of the family. Smith Institute, Ichthyological Bulletin 34:1-105.

FRASER, T. H. and E. A. LACHNER

1985 A revision of the cardinalfish subgenera Pristiapogon and Zoramia (genus Apogon) of the Indo-Pacific region (Teleostei: Apogonidae). Smithsonian Contributions to Zoology 412:1-47.

FRICKE, R.

1981 Revision of the genus Synchiropus (Teleostei: Callionymidae). Theses Zoologicae, 1. Braunschweig, J. Cramer. 194 pp.

1983 Revision of the Indo-Pacific genera and species of the dragonet family Callionymidae (Teleostei). Theses Zoologicae, 3. Braunschweig, J. Cramer. 774 pp.

FRITZSCHE, R. A.

1984a Family Aulostomidae. In Fischer, W. and G. Bianchi, eds., FAO Species Identification Sheets for Fishery Purposes; Western Indian Ocean (fishing area 51). Rome, FAO. Vol. 1.

1984b Family Fistulariidae. In Fischer, W. and G. Bianchi, eds., FAO Species Identification Sheets for Fishery Purposes; Western Indian Ocean (fishing area 51). Rome, FAO. Vol. 2.

GARMAN, $\mathrm{S}$.

1903 Some fishes from Australasia. Bulletin of the Museum of Comparative Zoology 39:229-241.

GARRETT, A. J.

1863 Descriptions of new species of fishes. Proceedings of the California Academy of Sciences 3:103-107.

GARRICK, J. A. F.

1982 Sharks of the genus Carcharhinus. NOAA Technical Report NMFS Circular 445:1-194.

GILCHRIST, J. D. F. and W. W. THOMPSON

1909 Description of fishes from the coast of Natal (Part II). Annals of the South African Museum 6:213-279.

GOLANI, D.

1984 Sargocentron macrosquamis, a new squirrelfish from the Amirantes Islands and the Red Sea (Holocentridae. Pisces). Cybium 8:39-43.

GOMON, M. F.

1984 Family Labridae. In Fischer, W. and G. Bianchi, eds., FAO Species Identification Sheets for Fishery Pur- poses; Western Indian Ocean (fishing area 51). Rome, FAO. Vol. 2.

GOREN, M. and I. KARPLUS

1980 Fowleria abocellata, a new cardinal fish from the Gulf of Elat-Red Sea (Pisces, Apogonidae). Zoologische Mededeelingen 55:231-234.

GOSLINE, W. A.

1955 The inshore fish fauna of Johnston Island, a central Pacific Atoll. Pacific Science 9:442-480.

1958 Central Pacific eels of the genus Uropterygius, with descriptions of two new species. Pacific Science 12:221-228

GOSLINE, W. A. and V. E. BROCK

1965 Handbook of Hawaiian fishes. Honolulu, University of Hawaii. 372 pp.

GRAY, J. E.

1831 Description of a new genus of percoid fish, discovered by Mr. Samuel Stutchbury, in the Pacific Sea, and now in the British Museum. In Gray, J. E., Zoological Miscellany 1:20.

GREENFIELD, D. W

1974 A revision of the squirrelfish genus Myripristis Cuvier (Pisces: Holocentridae). Los Angeles County Natural History Museum, Science Bulletin 19:1-54.

GUICHENOT, A.

1847 Description de deux nouvelles espèces de Cossyphes. Revue et magasin de zoologie pure et appliquée 10:282-284

1848 Sur une nouvelle espèce de Malacanthus. Revue et magasin de zoologie pure et appliquée 11:14-15.

1869 Notice sur quelques poissons inédits de Madagascar et de la Chine. Nouvelles archives du Musée d'histoire naturelle, Paris 5:193-206.

GÜNTHER, A.

1859 Catalogue of the acanthopterygian fishes in the collection of the British Museum. Vol. 1. London. 524 pp.

1860 Catalogue of the acanthopterygian fishes in the collection of the British Museum. Vol. 2. London. 548 pp.

1861 Catalogue of the acanthopterygian fishes in the collection of the British Museum. Vol. 3. London. 586 pp.

1866a Pharyngognathie etc. In Playfair, R. L. and A Günther, eds., The fishes of Zanzibar. London, John van Voorst. 153 pp.

1866b Catalogue of the fishes in the British Museum. Vol. 6. London. $368 \mathrm{pp}$.

1870 Catalogue of the fishes in the British Museum. Vol. 8. London. 549 pp.

1871 Report on several collections of fishes recently obtained for the British Museum. Proceedings of the Scientific Meetings of the Zoological Society of London, pp. 652-675.

1873 Andrew Garrett's Fische der Südsee. Band 1. Heft 1 Journal des Museum Godeffroy 2:1-128.

1889 Report on the pelagic fishes collected by H.M.S Challenger during the years 1873-76. Report on the scientific results of the voyage of H.M.S. Challenger... Zoology 32(2):1-47 (reprint 1965, New York Johnson Reprint Corporation). 
HAEDRICH, R. L. and R. NZIOKA

1984a Family Bramidae. In Fischer, W. and G. Bianchi, eds., FAO Species Identification Sheets for Fishery Purposes; Western Indian Ocean (fishing area 51). Rome, FAO. Vol. 1.

1984b Family Nomeidae. In Fischer, W. and G. Bianchi, eds., FAO Species Identification Sheets for Fishery Purposes; Western Indian Ocean (fishing area 51). Rome, FAO. Vol. 3.

HAYASHI, M. and H. KISHIMOTO

1983 Fish fauna of Iriomote-Island, Ryukyu Islands III. Apogonidae (Apogoninae). Scientific Reports of the Yokosuka City Museum 31:15-46.

HEEMSTRA, P. C.

1984a Family Kuhliidae. In Fischer, W. and G. Bianchi, eds., FAO Species Identification Sheets for Fishery Purposes; Western Indian Ocean (fishing area 51). Rome, FAO. Vol. 2.

1984b Family Menidae. In Fischer, W. and G. Bianchi, eds., FAO Species Identification Sheets for Fishery Purposes; Western Indian Ocean (fishing area 51). Rome, FAO. Vol. 3.

HEEMSTRA, P. C. and J. E. RANDALL

1984 Family Serranidae. In Fischer, W. and G. Bianchi, eds., FAO Species Identification Sheets for Fishery Purposes; Western Indian Ocean (fishing area 51). Rome, FAO. Vol. 4.

HERALD, E. S.

1953 Family Syngnathidae: Pipefishes. In Schultz, L. P. and collaborators, Fishes of the Marshall and Marianas Islands. United States National Museum, Bulletin 202(1):231-278.

HERALD, E. S. and J. E. RANDALL

1972 Five new Indo-Pacific pipefishes. Proceedings of the California Academy of Sciences, ser. 4, 39:121-140.

HOLLARD, H.

1854 Monographie des balistides, 3. Genre Monacanthus. Annales des sciences naturelles zoologiques, ser. 4, 2:321-366.

HOLLEMAN, W.

1982 Three new species and a new genus of tripterygiid fishes (Blennioidei) from the Indo-west Pacific Ocean. Annals of the Cape Provincial Museums, Natural History 14:109-137.

HUTCHINS, B.

1984 Family Monacanthidae. In Fischer, W. and G. Bianchi, eds., FAO Species Identification Sheets for Fishery Purposes; Western Indian Ocean (fishing area 51). Rome, FAO. Vol. 3.

IVANTSOFF, W.

1984 Family Atherinidae. In Fischer, W. and G. Bianchi, eds., FAO Species Identification Sheets for Fishery Purposes; Western Indian Ocean (fishing area 51). Rome, FAO. Vol. 1.

JENKINS, O. P.

1901 Descriptions of new species of fishes from the Hawaiian Islands belonging to the families of Labridae and Scaridae. Bulletin of the United States Fish Commission 19:45-65.

1904 Report on collections of fishes made in the Hawaiian Islands, with descriptions of new species. Bulletin of the United States Fish Commission 22:417-511 (for 1902).

JENYNS, L.

1842 Fish. In Darwin, C., ed., The zoology of the voyage of H.M.S. Beagle, under the command of Captain Fitzroy, R.N., during the years 1832-1836. London, Smith, Elder. Part 4. 172 pp.

JOHNSON, G. D.

1983 Niphon spinosus: a primitive epinepheline serranid, with comments on the monophyly and intrarelationships of the Serranidae. Copeia 1983:777-787.

JORDAN, D. S. and B. W. EVERMANN

1903 Descriptions of new genera and species of fishes from the Hawaiian Islands. Bulletin of the United States Fish Commission 22:161-208 (for 1902).

JORDAN, D. S., B. W. EVERMANN, and S. TANAKA

1927 Notes on new or rare fishes from Hawaii. Proceedings of the California Academy of Sciences, ser. 4, $16: 649-680$.

JORDAN, D. S. and C. H. GILBERT

1882 Notes on a collection of fishes, made by Lieut. Henry E. Nichols, U.S.N., on the west coast of Mexico, with descriptions of new species. Proceedings of the United States National Museum 4:225-233 (for 1881).

JORDAN, D. S. and A. SEALE

1906 The fishes of Samoa; description of the species found in the archipelago, with a provisional check-list of the fishes of Oceania. Bulletin of the United States Bureau of Fisheries 25:173-455.

JORDAN, D. S. and J. O. SNYDER

1904 Description of a new species of fish (Apogon evermanni) from the Hawaiian Islands, with notes on other species. Proceedings of the United States National Museum 28:123-126.

JORDAN, D. S. and E. C. STARKS

1901 Descriptions of three new species of fishes from Japan. Proceedings of the California Academy of Sciences, ser. 3, Zoology 2:381-386.

KAILOLA, P. J.

1974 Additions to the fish fauna of Papua New Guinea 2. Eels. Papua New Guinea, Department of Agriculture, Stock and Fisheries, Research Bulletin 12:1-89.

1975 A catalogue of the fish reference collection at the Kanudi Fisheries Research Laboratory, Port Moresby. Papua New Guinea, Department of Agriculture, Stock and Fisheries, Research Bulletin 16:1-277.

KAMI, H. T.

1973 The Pristipomoides (Pisces: Lutjanidae) of Guam with notes on their biology. Micronesica 9:97-117.

KAMI, H. T., I. I. IKEHARA, and F. P. DELEON

1968 Checklist of Guam fishes. Micronesica 4:95-131.

KATAYAMA, J. J.

1957 Four new species of serranid fishes from Japan. Japanese Journal of Ichthyology 6:153-159. 
KAUP, J. J.

1856a Catalogue of apodal fish in the collection of the British Museum. London. $160 \mathrm{pp}$.

$1856 \mathrm{~b}$ Catalogue of the ophobranchiate fishes in the collection of the British Museum. London. $80 \mathrm{pp}$.

KITTLITZ, F. H. von

1834 Beschreibung mehrerer neuer oder wenig gekannter Arten des Geschlechtes Acanthurus, im stillen Ozean beobachtet und nach dem Leben abgebildet. Museum Senckenbergianum 1:189-194.

KLAUSEWITZ, w.

1959 Fische aus dem Roten Meer. II. Knochenfische der Familie Apogonidae (Pisces, Percomorphi). Senckenbergiana Biologica 40:251-262.

1960 Fische aus dem Roten Meer. III. Tripterygion abeli n.sp. (Pisces, Blennioidea, Clinidae). Senckenbergiana Biologica 41:11-13

1962 Meiacanthus smithi n.sp. aus dem Indischen Ozean (Pisces, Percomorphi, Blenniidae). Senckenbergiana Biologica 43:17-19.

KLAUSEWITZ, W. and I. EIBL-EIBESFELDT

1959 Neue Röhrenaale von den Maldiven und Nikobaren (Pisces, Apodes, Heterocongridae). Senckenbergiana Biologica 40:135-153.

KLUNZINGER, C. B.

1870 Synopsis der Fische des Rothen Meeres. I. Theil. Percoiden-Mugiloiden. Verhandlungen der KaiserlichKöniglichen Zoologisch-Botanischen Gesellschaft in Wien 20:699-834 (reprint 1964, Weinheim, J. Cramer).

1871 Synopsis der Fische des Rothen Meeres. II. Theil. Verhandlungen der Kaiserlich-Königlichen Zoologisch-Botanischen Gesellschaft in Wien 21:441688 (reprint 1964, Weinheim, J. Cramer).

KNAPP, L, W.

1984 Family Platycephalidae. In Fischer, W. and G. Bianchi, eds., FAO Species Identification Sheets for Fishery Purposes; Western Indian Ocean (fishing area 51). Rome, FAO. Vol. 3.

KNER, $\mathbf{R}$.

1865 Fische. In Reise der österreichischen Fregate Novara um die Erde in dem Jahren 1857, 1858, 1859, unter den Befehlung des Commador B. von Wüllerstorf-Urbair. Zoologischer Theil. Erste Abtheilung. Wien. 109 pp.

1868 Fische aus dem Museum der Herren Joh. Cäs. Gode ffroy und Sohn in Hamburg. (IV), I Abtheilung Acanthopteri. Sitzungsberichte der Kaiserlichen Akademie der Wissenschaften, Mathematisch-Naturwissenschaftlichen Classe 58:293-356

KUMARAN, M.

1984 Family Lactariidae. In Fischer, W. and G. Bianchi, eds., FAO Species Identification Sheets for Fishery Purposes; Western Indian Ocean (fishing area 51). Rome, FAO. Vol. 3.

KUMARAN, M. and J. E. RANDALL

1984 Family Mullidae. In Fischer, W. and G. Bianchi, eds., FAO Species Identification Sheets for Fishery Purposes; Western Indian Ocean (fishing area 51). Rome, FAO. Vol. 3.
KYUSHIN, K., K. AMAOKA, K. NAKAYA, and H. IDA

1977 Fishes of Indian Ocean. Tokyo, Japan Marine Fishery Resource Center. 392 pp.

LACEPÈDE, B. G. E.

1798 Histoire naturelle des poissons. Vol. 1. Paris, Plassan. $532 \mathrm{pp}$.

1800 Histoire naturelle des poissons. Vol. 2. Paris, Plassan. $632 \mathrm{pp}$.

1802a Histoire naturelle des poissons. Vol. 3. Paris, Plassan. $558 \mathrm{pp}$.

1802b Histoire naturelle des poissons. Vol. 4. Paris, Plassan. $728 \mathrm{pp}$.

1803 Histoire naturelle des poissons. Vol. 5. Paris, Plassan. $803 \mathrm{pp}$.

LACHNER, E. A.

1953 Family Apogonidae: cardinal fishes. In Schultz, L. P. and collaborators, Fishes of the Marshall and Marianas Islands. United States National Museum, Bulletin 202(1):412-498.

1960 Family Mullidae: goatfishes. In Schultz, L. P. and collaborators, Fishes of the Marshall and Marianas Islands. United States National Museum, Bulletin 202(1): 1-46.

LACHNER, E. A. and B. B. COLLETTE

1984 Family Echeneidae. In Fischer, W. and G. Bianchi, eds., FAO Species Identification Sheets for Fishery Purposes; Western Indian Ocean (fishing area 51). Rome, FAO. Vol. 2.

LATREILLE, P. A.

1804 Tableau méthodique. In Nouvelle dictionnaire d'histoire naturelle. XXIV Poissons. Paris, pp. 71, 73, 74, 79 , and 104.

LAY, G. T. and E. T. BENNETT

1839 Fishes. In Richardson, J., N. A. Vigors, G. T. Lay, E. T. Bennett, R. Owen, J. E. Gray, W. Buckland, and G. B. Sowerby, eds., Zoology of Captain Beechey's voyage; compiled from the collections and notes made by Captain Beechey, the officers and naturalist of the expedition during a voyage to the Pacific and Behring's Straits performed in His Majesty's ship "Blossom".... London, Henry G. Bohn, pp. 41-75.

LEIS, J. M.

1978 Systematics and zoogeography of the porcupinefishes (Diodon, Diodontidae, Tetraodontiformes), with comments on egg and larval development. Fishery Bulletin $76: 535-567$.

LESSON, R. P.

1829 Voyage autour de monde, exécuté par ordre du Roi, sur la corvette de S.M. "la Coquille", pendant les années $1822,1823,1824$, et $1825 \ldots$ Atlas. Paris.

1830 Poissons. In Duperry, L. I. Voyage autour de monde sur la corvette de S.M. "la Coquille", pendant les années 1822-1825; Zoologie, vol. 2. Paris, A. Bertrand, pp. 66-238.

LE SUEUR, C. A.

1821 Observations on several genera and species of fish, belonging to the natural family of the Esoces. Joumal 
of the Academy of Natural Sciences of Philadelphia 2:124-138.

LIÉNARD, E.

1839 Poissons. Rapport (annuel) sur les travaux de la Société d'histoire naturelle de l'Île Maurice 10:31-37.

LINNAEUS, $\mathrm{C}$.

1758 Systema Naturae. 10th ed. Holmiae, Laurentii Salvi. Tomus 1. $824 \mathrm{pp}$.

1766 Systema naturae per regna tria naturae, secundum classes, ordines, genera, species, cum characteribus, differentiis, synonymis, locis. Tomus 1. Editio duodecima (12), reformata. Holmiae, Laurentii Salvi. $532 \mathrm{pp}$.

LLOYD, R. E

1909 A description of the deep-sea fish caught by the R.I.M.S. ship "Investigator" since the year 1900, with supposed evidence of mutation in Malthopsis. Memoirs of the Indian Museum 2:139-180.

LOWE, R. T.

1833 Fishes from Madeira; a letter read to the Zoological Society of London, dated November 15, 1833. Proceedings of the Zoological Society of London 1:142144.

1839 A supplement to a synopsis of the fishes of Madeira. Proceedings of the Zoological Society of London 7:76-92.

LUBBOCK, $\mathbf{R}$.

1976 Fishes of the family Pseudochromidae (Perciformes) in the central Indian Ocean. Journal of Natural History $10: 167-177$.

MASUDA, H., K. AMAOKA, C. ARAGA, T. UYENO, and T. YOSHINO, eds.

1984 The fishes of the Japanese Archipelago. Tokyo, Tokai University Press. 437 pp.

MAUGE, A.

1984a Family Drepanidae. In Fischer, W. and G. Bianchi, eds., FAO Species Identification Sheets for Fishery Purposes; Western Indian Ocean (fishing area 51). Rome, FAO. Vol. 2.

1984b Family Kyphosidae. In Fischer, W. and G. Bianchi, eds., FAO Species Identification Sheets for Fishery Purposes; Western Indian Ocean (fishing area 51). Rome, FAO. Vol. 2.

1984c Family Platacidae. In Fischer, W. and G. Bianchi, eds., FAO Species Identification Sheets for Fishery Purposes; Western Indian Ocean (fishing area 51). Rome, FAO. Vol. 3.

MCCLELLAND, J.

1845 Apodal fishes of Bengal. Calcutta Journal of Natural History and Miscellany of the Arts and Sciences in India 5:151-226.

MCCLENEGHAN, $\mathrm{K}$.

1976 Vertebral counts of some Pacific morays (Family Muraenidae). Copeia 1976:207-210.

MCCOSKER, J. E

1977 The osteology, classification, and relationships of the eel family Ophichthidae. Proceedings of the California Academy of Sciences, ser. 4, 41:1-123.
MCCOSKER, J, E. and J. E. RANDALL

1977 Three new species of Indo-Pacific moray eels (Pisces: Muraenidae). Proceedings of the California Academy of Sciences, ser. 4, 41:161-168.

1982 Synonymies of Indian Ocean eels, with the description of Gymnothorax enigmaticus, a moray previously known as $G$. rupelli. Proceedings of the California Academy of Sciences, ser. 4, 43:17-24.

MCCOSKER, J. E. and R. H. ROSENBLATT

1975 The moray eels (Pisces: Muraenidae) of the Galapagos Islands, with new records and synonymies of extralimital species. Proceedings of the California Academy of Sciences, ser. 4, 40:417-427.

MCKAY, R. J.

1984 Family Haemulidae. In Fischer, W. and G. Bianchi, eds., FAO Species Identification Sheets for Fishery Purposes; Western Indian Ocean (fishing area 51). Rome, FAO. Vol. 2.

MCKINNEY, J. F. and V. G. SPRINGER

1976 Four new species of the fish genus Ecsenius with notes on other species of the genus (Blenniidae: Salariini). Smithsonian Contributions to Zoology 236:1-27.

MITCHILL, S. L.

1815 The fishes of New-York, described and arranged. Transactions of the Literary and Philosophical Society of New-York 1:355-492.

MOHAN, R. S.

1984 Family Sciaenidae. In Fischer, W. and G. Bianchi, eds., FAO Species Identification Sheets for Fishery Purposes; Western Indian Ocean (fishing area 51). Rome, FAO. Vol. 4.

MÜLLER, J, and J. HENLE

1841 Systematische Beschreibung der Plagiostomen. Berlin, Von Veit. 200 pp.

MYERS, R. F. and J. W. SHEPPARD

1980 New records of fishes from Guam, with notes on the ichthyofauna of the southern Marianas. Micronesica 16:305-347.

NAKAMURA, I.

1984a Family Istiophoridae. In Fischer, W. and G. Bianchi, eds., FAO Species Identification Sheets for Fishery Purposes; Western Indian Ocean (fishing area 51). Rome, FAO. Vol. 2

1984b Family Xiphiidae. In Fischer, W. and G. Bianchi, eds., FAO Species Identification Sheets for Fishery Purposes; Western Indian Ocean (fishing area 51). Rome, FAO. Vol. 5.

NELSON, J. S.

1978 Limnichthys polyactis, a new species of blennioid fish from New Zealand, with notes on the taxonomy and distribution of other Creediidae (including Limnichthyidae). New Zealand Journal of Zoology 5:351364 .

NIELSEN, 3 .

1984 Family Bothidae. In Fischer, W. and G. Bianchi, eds., FAO Species Identification Sheets for Fishery Purposes; Western Indian Ocean (fishing area 51). Rome, FAO. Vol. 1. 
NORMAN, J, R.

1922 Three new fish from Zululand and Natal, collected by Mr. H. W. Bell Marley; with additions to the fish fauna of Natal. Annals and Magazine of Natural History, ser. 9, 9:318-322.

1934 A systematic monograph of the flatfishes (Heterosomate). Vol. I, Psettodidae, Bothidae, Pleuronectidae. London, Trustees of the British Museum. 459 pp. (Reprint, 1966, Johnson Reprint Corp.)

OGILBY, J. D.

1889 The reptiles and fishes of Lord Howe Island. Memoirs of the Australian Museum 2:51-74.

1897 Some new genera and species of fishes. Proceedings of the Linnean Society of New South Wales 22:245-257.

OSBECK, $\mathbf{P}$.

1765 Reise nach Ostindien und China... Deutsche Übersetzung von G. G. Georgius. Rostock, J. C. Koppe. $552 \mathrm{pp}$.

PALLAS, P. $\mathbf{S}$.

1770 Spicilegia zoologicae, quibus novae imprimis et obscurae animalium species iconibus, descriptionibus atque commentariis illustrantur. Vol. 8. Berlin.

PARIN, N. V.

1984 Family Exocoetidae. In Fischer, W. and G. Bianchi, eds., FAO Species Identification Sheets for Fishery Purposes; Western Indian Ocean (fishing area 51). Rome, FAO. Vol. 2.

PARIN, N. V., B. B. COLLETTE, and Y. N. SHCHERBACHEV

1980 Preliminary review of the marine halfbeaks (Hemiramphidae, Beloniformes) of the tropical Indo-WestPacific. Transactions of the P. P. Shirshov Institute of Oceanology 97:7-173

PARK, M.

1797 Description of eight new fishes from Sumatra. Transactions of the Linnean Society 3:33-38.

PAXTON, J. R., D. F. HOESE, and H. K. LARSON

1978 Preliminary checklist of Lizard Island area fishes. Australian Museum, Mimeograph. 30 pp.

PETERS, $W$.

1855a Uebersicht der in Mossambique beobachten Fische. Archiv für Naturgeschichte 21(1):234-282.

1855b Uebersicht der in Mossambique beobachten Fische. Akademie der Wissenschaften Berlin, Monatsberichte 1855:428-466.

1876 Uebersicht der von Hrn. Prof. Dr. K. Möbius in Mauritius und bei den Seychellen gesammelten Fische. Akademie der Wissenschaften Berlin, Monatsberichte 1876:435-447 (for 1875).

PHILIPPI, R. A.

1887 Sobre los tiburones y algunos otros peces de Chile. Apendice, sobre el peje-espada, peje-agua, peje-perro y vieja negra. Annales de Universidad de Chile $71: 535-574$.

PIETSCHMANN, $v$.

1934 Drei neue Fische aus den hawaiischen Küstenwässern. Anzeiger der Akademie der Wissenschaften in Wien,
Mathematisch-Naturwissenschaftliche Klasse 71:99_ 100.

PLAYFAIR, R. L.

1866 Acanthopterygii. In Playfair, R. L. and A. C. L. G Günther. The fishes of Zanzibar. London, John van Vorst. $153 \mathrm{pp}$.

1867 The fishes of Seychelles. Proceedings of the Scientific Meetings of the Zoological Society of London $1867: 846-872$

POEY, F.

1858 Poissons de Cuba. In Poey, F., Memorias sobre la historia natural de la isla de Cuba, acompañadas de sumarios latinos y extractos en francés. Habana, vol. 2, pp. $115-356$

POSS, S. G.

1984 Family Dactylopteridae. In Fischer, W. and G. Bianchi, eds., FAO Species Identification Sheets for Fishery Purposes; Western Indian Ocean (fishing area 51). Rome, FAO. Vol. 2.

POSS, S. G. and K. V. RAMA-RAO

1984 Family Scorpaenidae. In Fischer, W. and G. Bianchi, eds., FAO Species Identification Sheets for Fishery Purposes; Western Indian Ocean (fishing area 51). Rome, FAO. Vol. 4.

QUOY, J. R. C. and P. GAIMARD

1824 Zoologie. In Freycinet, L. de, Voyage autour de monde, entrepris par ordre du roi. Paris, Pillet Aine, vol. 3, pp. 183-401.

RADCLIFFE, L.

1912a Notes on somes fishes of the genus Amia, family of Cheilodipteridae, with descriptions of four species from the Philippine Islands. Proceedings of the United States National Museum 41:245-261

1912b Descriptions of fifteen new fishes of the family Cheilodipteridae, from the Philippine Islands and contiguous waters. Proceedings of the United States National Museum 41:431-446.

RAMSAY, E. P. and J. D. OGILBY

1885 Descriptions of new or rare Australian fishes. Proceedings of the Linnean Society of New South Wales 10:575-579.

RANDALL, H. A. and G. R. ALLEN

1977 A revision of the damselfish genus Dascyllus (Pomacentridae) with the description of a new species. Records of the Australian Museum 31:349-385

RANDALL, J. E.

1955a A revision of the surgeon fish genus Ctenochaetus, family Acanthuridae, with descriptions of five new species. Zoologica 40:149-166.

1955b A revision of the surgeon fish genera Zebrasoma and Paracanthurus. Pacific Science 9:396-412.

1955c Fishes of the Gilbert Islands. Atoll Research Bulletin $47: 1-243$

1956 A revision of the surgeon fish genus Acanthurus Pacific Science 10:159-235. 
1958 A review of the labrid fish genus Labroides, with descriptions of two new species and notes on ecology. Pacific Science 12:327-347.

1963 Review of the hawkfishes (family Cirrhitidae). Proceedings of the United States National Museum 114:389-451.

1972a A revision of the labrid fish genus Anampses. Micronesica 8:151-190.

1972b The Hawaiian trunkfishes of the genus Ostracion. Copeia 1972:756-768.

1973 Tahitian fish names and a preliminary checklist of the fishes of the Society Islands. Occasional Papers of the Bernice P. Bishop Museum 24:167-214.

1978 A revision of the Indo-Pacific labrid fish genus Macropharyngodon, with descriptions of five new species. Bulletin of Marine Science 28:742-789.

1980 Revision of the fish genus Plectranthias (Serranidae: Anthiinae) with descriptions of 13 new species. Micronesica 16:101-187.

1981 Revision of the labrid fish genus Labropsis with descriptions of five new species. Micronesica 17:125155.

1983a Revision of the Indo-Pacific labrid fish genus Wetmorella. Copeia 1983:875-883.

$1983 \mathrm{~b}$ Red Sea reef fishes. London, Immel Publications. 182 pp.

1984a Family Acanthuridae. In Fischer, W. and G. Bianchi, eds., FAO Species Identification Sheets for Fishery Purposes; Western Indian Ocean (fishing area 51). Rome, FAO. Vol. 1.

1984b Family Cirrhitidae. In Fischer, W. and G. Bianchi, eds., FAO Species Identification Sheets for Fishery Purposes; Western Indian Ocean (fishing area 51). Rome, FAO. Vol. 1.

1984c Family Grammistidae. In Fischer, W. and G. Bianchi, eds., FAO Species Identification Sheets for Fishery Purposes; Western Indian Ocean (fishing area 51). Rome, FAO. Vol. 2.

1984d Family Holocentridae. In Fischer, W. and G. Bianchi, eds., FAO Species Identification Sheets for Fishery Purposes; Western Indian Ocean (fishing area 51). Rome, FAO. Vol. 2.

1985 Fishes. In Delesalle, B., R. Galzin, and B. Salvat, eds., Fifth International Coral Reef Congress, Tahiti, 27 May-1 June, 1985. French Polynesian Coral Reefs. Tahiti, vol. 1, pp. 462-481.

RANDALL, J. E., M.-L. BAUCHOT, and M. DESOUTTER

1985 Chromis viridis (Cuvier, 1830), the correct name for the Indo-Pacific damselfish previously known as $C$. caerulea (Cuvier, 1830) (Pisces, Pomacentridae). Cybium 9:411-413.

RANDALL, J. E. and A. BEN-TUVIA

1983 A review of the groupers (Pisces: Serranidae: Epinephelinae) of the Red Sea, with description of a new species of Cephalopholis. Bulletin of Marine Science 33:373-426.

RANDALL, J. E. and J. E. BÖHKLE

1981 The status of the cardinalfishes Apogon evermanni and A. anisolepis (Perciformes: Apogonidae) with descrip- tion of a related new species from the Red Sea Proceedings of the Academy of Natural Sciences of Philadelphia 133:129-140.

RANDALL, J. E. and R. W. BRUCE

1983 The parrotfishes of the subfamily Scarinae of the western Indian Ocean with descriptions of three new species. Smith Institute, Ichthyological Bulletin 47:139.

RANDALL, J. E. and A. R. EMERY

1983 A new labrid fish of the genus Cirrhilabrus from the Chagos Archipelago, Indian Ocean. Journal of Aquariculture and Aquatic Sciences 3:21-24.

RANDALL, J. E. and M. L. HARMELIN-VIVIEN

1977 A review of the labrid fishes of the genus Paracheilinus with description of two new species from the western Indian Ocean. Bulletin du Museum national d'histoire naturelle, ser. 3, 436:329-342.

RANDALL, J. E. and P. C. HEEMSTRA

1985 A review of the squirrelfishes of the subfamily Holocentrinae from the western Indian Ocean and Red Sea. Smith Institute, Ichthyological Bulletin 49:1-29.

RANDALL, J. E. and J. C. KAY

1974 Stethojulis axillaris, a junior synonym of the Hawaiian labrid fish Stethojulis balteata, with a key to the species of the genus. Pacific Science 28:101-107.

RANDALL, J. E. and W. KLAUSEWITZ

1973 A review of the trigger fish genus Melichthys, with a description of a new species from the Indian Ocean. Senckenbergiana Biologica 54:57-69.

RANDALL, J. E., E. A. LACHNER, and T. H. FRASER

1985 A revision of the Indo-Pacific apogonid fish genus Pseudamia, with descriptions of three new species. Indo-Pacific Fishes 6:1-23.

RANDALL, J. E. and R. LUBBOCK

1981a A revision of the serranid fishes of the subgenus Mirolabrichthys (Anthiinae: Anthias), with descriptions of five new species. Natural History Museum of Los Angeles County, Contributions in Science 333:127.

1981b Labrid fishes of the genus Paracheilinus, with descriptions of three new species from the Philippines. Japanese Journal of Ichthyology 28:19-30.

RANDALL, J. E., K. MATSUURA, and A. ZAMA

1978 A revision of the triggerfish genus Xanthichthys, with description of a new species. Bulletin of Marine Science 28:688-706.

RANDALL, J. E. and J. E. MCCOSKER

1975 The eels of Easter Island with a description of a new moray. Natural History Museum of Los Angeles County, Contributions in Science 264:1-32.

RANDALL, J, E. and S.-C. SHEN

1978 A review of the labrid fishes of the genus Cirrhilabrus from Taiwan, with description of a new species. Bulletin of the Institute of Zoology, Academia Sinica 17:13-24.

RANDALL, J. E. and Y. H. SINOTO

1978 Rapan fish names. Occasional Papers of the Bernice P. Bishop Museum 24:291-306. 
RANDALL, J. E. and M. M. SMITH

1982 A review of the labrid fishes of the genus Halichoeres of the western Indian Ocean, with descriptions of six new species. Smith Institute, Ichthyological Bulletin $45: 1-26$.

RANDALL, J. E., M. M. SMITH, and K. AIDA

1980 Notes on the classification and distribution of the Indo-Pacific soapfish, Belonoperca chabanaudi (Perciformes: Grammistidae). Smith Institute, Special Publication 21:1-8.

RANDALL, J. E. and V. G. SPRINGER

1973 The monotypic Indo-Pacific labrid fish genera Labrichthys and Diproctacanthus with description of a new related genus, Larabicus. Proceedings of the Biological Society of Washington 86:279-298.

RANDALL, J. E. and R. C. STEENE

1983 Rhinecanthus lunula, a new species of triggerfish from the South Pacific. Freshwater and Marine Aquarium $6: 45-51$.

REGAN, C. T.

1903 Descriptions de poissons nouveaux faisant partie de la collection du Musée d'histoire naturelle de Genève. Revue Suisse Zoologie 11:413-418.

1908 Report on the marine fishes collected by Mr. J. Stanley Gardiner in the Indian Ocean. Transactions of the Linnean Society of London, ser. 2, Zoology 12:217-255.

1909 Descriptions of new marine fishes from Australia and the Pacific. Annals and Magazine of Natural History, ser. 8, 4:438-440.

RICHARDSON, J,

1844 Ichthyology. In Hinds, R. B., ed., The zoology of the voyage of H.M.S. "Sulphur", under the command of Captain Sir Edward Belcher, during the years 1836-42. London, pp. 51-150.

1844 Ichthyology. In Richardson, J. and J. E. Gray, eds.,

1848 Zoology of the voyage of H.M.S. "Erebus and Terror", under the command of Captain Sir James Ross Clark, R.N., F.R.S. London. 139 pp.

1846 Report on the ichthyology of the seas of China and Japan. Report of the Fifteenth Meeting of the British Association for the Advancement of Science, Cambridge, June 1845, pp. 187-320.

RÜPPELL, E.

1829a Atlas zu der Reise im nördlichen Afrika. Fische des rothen Meers. Frankfurt, Bronner, pp. 27-50

1829b Atlas zu der Reise im nördlichen Afrika. Fische des rothen Meers. Frankfurt, Bronner, pp. 71-94.

1830a Atlas zu der Reise im nördlichen Afrika. Fische des rothen Meers. Frankfurt, Bronner, pp. 95-118.

1830b Atlas zu der Reise im nördlichen Afrika. Fische des rothen Meers. Frankfurt, Bronner, pp. 119-141.

1835 Neue Wirbelthiere der Fauna von Abyssinien gehörig. Fische des rothen Meeres. Frankfurt am Main, Schmerber, pp. 1-28.

1836 Neue Wirbelthiere der Fauna von Abyssinien gehörig. Fische des rothen Meeres. Frankfurt am Main, Schmerber, pp. 29-52.

1837 Neue Wirbelthiere der Fauna von Abyssinien gehörig
Fische des rothen Meeres. Frankfurt am Main, Schmerber, pp. 53-80.

1838 Neue Wirbelthiere der Fauna von Abyssinien gehörig. Fische des rothen Meeres. Frankfurt am Main, Schmerber, pp. 81-148.

RUSSELL, B. C.

1983 Annotated checklist of the coral reef fishes in the Capricorn-Bunker group, Great Barrier Reef, Australia. Townsville, Queensland, Great Barrier Reef Marine Park Authority. 184 pp.

RUSSELL, B. C. and G. R. ALLEN

1984 Family Nemipteridae. In Fischer, W. and G. Bianchi, eds., FAO Species Identification Sheets for Fishery Purposes; Western Indian Ocean (fishing area 51). Rome, FAO. Vol. 3.

RUSSELL, B. C. and R. F. CRESSEY

1979 Three new species of Indo-west Pacific lizardfish (Synodontidae). Proceedings of the Biological Society of Washington 92:166-175.

SATO, T.

1978 A synopsis of the sparoid fish genus Lethrinus, with the description of a new species. University of Tokyo University Museum, Bulletin 15:1-70.

SATO, T. and M. WALKER

1984 Family Lethrinidae. In Fischer, W. and G. Bianchi, eds., FAO Species Identification Sheets for Fishery Purposes; Western Indian Ocean (fishing area 51) Rome, FAO. Vol. 2.

SCHLEGEL, $\mathrm{H}$. and S. MÜLLER

1839- Overzight den iut de Sunda en Moluksche zeen bekende

1844 visschen, van de geslachten Amphiprion, Premnas, Pomacentrus, Glyphisodon, Dascyllus, en Heliases. Verhandelingen over de Natuurlijke Geschiendenis der Nederlandsche Overzeesche Bezittingen, door de leden der Natuurkundige Commissie in Oost-Indie en andere schrijvers; door Temminck 2:17-26.

SCHMIDT, P. J.

1930 Fishes of the Riu-Kiu Islands. Transactions of the Pacific Commission of the Academy of Sciences of the U.S.S.R. 1:19-208.

SCHULTZ, L. P.

1943 Fishes of the Phoenix and Samoan Islands collected in 1939 during the expedition of the U.S.S. "Bushnell". United States National Museum, Bulletin 180:1-306

1953a Suborder Iniomina. Family Synodontidae: lizardfishes. In Schultz, L. P. and collaborators, Fishes of the Marshall and Marianas Islands. United States National Museum, Bulletin 202(1):30-42.

1953b Family Echelidae: worm eels. In Schultz, L. P. and collaborators, Fishes of the Marshall and Marianas Islands. United States National Museum, Bulletin 202(1):60-83.

1953c Family Muraenidae: moray eels. In Schultz, L. P. and collaborators, Fishes of the Marshall and Marianas Islands. United States National Museum. Bulletin 202(1):98-159. 
1953d Family Atherinidae: silversides. In Schultz, L. P. and collaborators, Fishes of the Marshall and Marianas Islands. United States National Museum, Bulletin 202(1):287-310.

1953e Family Lutjanidae: snappers. In Schultz, L. P. and collaborators, Fishes of the Marshall and Marianas Islands. United States National Museum, Bulletin 202(1):521-556

1957 The frogfishes of the family Antennariidae. Proceedings of the United States National Museum 107: 47-105.

1960a Family Labridae. In Schultz, L. P. and collaborators, Fishes of the Marshall and Marianas Islands. United States National Museum, Bulletin 202(2):121-238.

1960b Suborder Ophidina. Family Brotulidae. In Schultz, L. P. and collaborators, Fishes of the Marshall and Marianas Islands. United States National Museum, Bulletin 202(2):382-396

1966a Family Scorpaenidae: scorpionfishes. In Schultz, L. P. and collaborators, Fishes of the Marshall and Marianas Islands. United States National Museum, Bulletin 202(3):13-43.

1966b Family Platycephalide: flatheads. In Schultz, L. P. and collaborators, Fishes of the Marshall and Marianas Islands. United States National Museum, Bulletin 202(3):45-62.

1966c Pseudorhegma diagramma, a new genus and species of grammistid fish, with a key to genera of the family and to the species of the subfamily Pseudogramminae. Ichthyologica; the Aquarium Journal 37:185-194.

1969 The taxonomic status of the controversial genera and species of parrotfishes with a descriptive list (family Scaridae). Smithsonian Contributions to Zoology $17: 1-49$

SCHULTZ, L. P. and L. P. WOODS

1949 Keys to the genera of echelid eels and the species of Muraenichthys of the Pacific, with two new species. Journal of the Washington Academy of Sciences $39: 169-174$

SEALE, A.

1901 Report of a mission to Guam. Occasional Papers of the Bernice P. Bishop Museum 1:1-124.

1906 Fishes of the South Pacific. Occasional Papers of the Bernice P. Bishop Museum 4(1):1-89.

1917 New species of apodal fishes. Bulletin of the Museum of Comparative Zoology 61:79-94

SHAKLEE, J. B.

1984 Family Albulidae. In Fischer, W. and G. Bianchi, eds., FAO Species Identification Sheets for Fishery Purposes; Western Indian Ocean (fishing area 51). Rome, FAO. Vol. 1.

SHAW, G. and F. P. NODDER

1791 The naturalists' miscellany. Vol. 3. London.

1796 The naturalists' miscellany. Vol. 7. London.

1797 The naturalists' miscellany. Vol. 9. London.

SHEN, S.-C.

1984 Coastal fishes of Taiwan. T'ai-pei, National Taiwan University. $191 \mathrm{pp}$.
SHIMIZU, T.

1984 Family Berycidae. In Fischer, W. and G. Bianchi, eds., FAO Species Identification Sheets for Fishery Purposes; Western Indian Ocean (fishing area 51). Rome, FAO. Vol. 1.

SMITH, A.

1849 Illustrations of the zoology of South Africa... and expedition into the interior of South Africa in 1834-36. Vol. 4. London.

SMITH, J. L. B.

1953 The fishes of the family Pseudogrammidae from east Africa. Annals and Magazine of Natural History, ser. $12,6: 548-560$.

1954a Two interesting new anthiid fishes from east Africa. Annals and Magazine of Natural History, ser. 12, $7: 1-6$

1954b Abberrant serraniform fishes from east Africa. Annals and Magazine of Natural History, ser. 12, 7:861-872.

1954c Apogonid fishes of the subfamily Pseudamiinae from south-east Africa. Annals and Magazine of Natural History, ser. 12, 7:775-795.

1955a The fishes of Aldabra. Part I. Annals and Magazine of Natural History, ser. 12, 8:304-312.

1955b The fishes of Aldabra. Part II. Annals and Magazine of Natural History, ser. 12, 8:689-697.

1956 The fishes of Aldabra. Part VII. Annals and Magazine of Natural History, ser. 12, 9:888-892.

1957 a The fishes of the family Scorpaenidae in the western Indian Ocean; Part I. The subfamily Scorpaeninae. Rhodes University Ichthyological Bulletin 4:49-69.

1957b List of the fishes of the family Labridae in the western Indian Ocean with new records and five new species. Rhodes University, Ichthyological Bulletin 7:99-114.

$1957 \mathrm{c}$ Four interesting new fishes from South Africa. South African Journal of Science 53:219-222.

1957d The labrid fishes of the subgenus Julis Cuvier, 1814 (in Coris Lacepède, 1802) from south and east Africa. Rhodes University, Ichthyological Bulletin $8: 117-120$

1958a The genus Limnichthys Waite, 1904 in African seas. Annals and Magazine of Natural History, ser. 13 $1: 247-269$

1958b Tetraodont fishes from south and east Africa. Annals and Magazine of Natural History, ser. 13, 1:156-160.

1959a Serioline fishes (yellowtails; amberjacks) from the western Indian Ocean. Rhodes University, Ichthyological Bulletin 15:253-261.

$1959 \mathrm{~b}$ Fishes of the families Blenniidae and Salariidae of the western Indian Ocean. Rhodes University, Ichthyological Bulletin 14:227-252.

1959c Fishes of the family Lethrinidae from the western Indian Ocean. Rhodes University, Ichthyological Bulletin 17:283-298.

1960 Coral fishes of the family Pomacentridae from the western Indian Ocean and the Red Sea. Rhodes University, Ichthyological Bulletin 19:315-349.

1961 Fishes of the family Apogonidae of the western Indian Ocean and the Red Sea. Rhodes University, Ichthyological Bulletin 22:373-419. 
1962a The moray eels of the western Indian Ocean and the Red Sea. Rhodes University, Ichthyological Bulletin 23:421-444.

1962b Sand-dwelling eels of the western Indian Ocean and the Red Sea. Rhodes University, Ichthyological Bulletin 24:447-466.

1963 Fishes of the families Draconettidae and Callionymidae from the Red Sea and the western Indian Ocean. Rhodes University, Ichthyological Bulletin 28:545-564

SMITH, J. L. B. and M. M. SMITH

1963 The fishes of Seychelles. Grahamstown, Rhodes University, Department of Ichthyology. 215 pp.

SMITH-VANIZ, W. F,

1976 The saber-toothed blennies, Tribe Nemophini (Pisces: Blenniidae). Academy of Natural Sciences of Philadelphia, Monograph 19:1-196.

1984 Family Carangidae. In Fischer, W. and G. Bianchi, eds., FAO Species Identification Sheets for Fishery Purposes; Western Indian Ocean (fishing area 51). Rome, FAO. Vol. 1.

SMITH-VANIZ, W. F. and V. G. SPRINGER

1971 Synopsis of the tribe Salariini, with description of five new genera and three new species (Pisces: Blenniidae). Smithsonian Contributions to Zoology $73: 1-72$.

SNYDER, J. 0.

1904 A catalogue of the shore fishes collected by the steamer Albatross about the Hawaiian Islands in 1902. Bulletin of the United States Fish Commission 22:513-538 (for 1902).

1908 Descriptions of eighteen new species and two new genera of fishes from Japan and the Riu-Kiu Islands. Proceedings of the United States National Museum 35:93-111.

SPRINGER, V. G.

1967 Revision of the circumtropical shorefish genus Entomacrodus (Blenniidae: Salariinae). Proceedings of the United States National Museum 122:1-150.

1971 Revision of the fish genus Ecsenius (Blenniidae, Blenniinae, Salariini). Smithsonian Contributions to Zoology 72:1-76.

1972 Synopsis of the tribe Omobranchini with descriptions of three new genera and two new species (Pisces: Blenniidae). Smithsonian Contributions to Zoology 130:1-31.

1982 Pacific plate biogeography, with special reference to shorefishes. Smithsonian Contributions to Zoology 367:1-182.

SPRINGER, V. G. and M. F. GOMON

1975 Revision of the blenniid fish genus Omobranchus with descriptions of three new species and notes on other species of the tribe Omobranchini. Smithsonian Contributions to Zoology 177:1-135.

STARCK, W. A. II

1969 Ecsenius (Anthiiblennius) midas a new subgenus and species of mimic blenny from the western Indian Ocean. Notulae Naturae 419:1-9.
STARNES, W. C.

1984 Family Priacanthidae. In Fischer, W. and G. Bianchi, eds., FAO Species Identification Sheets for Fishery Purposes; Western Indian Ocean (fishing area 51). Rome, FAO. Vol. 3.

STEINDACHNER, $F$

1870 Ichthyologische notizen (X). Sitzungsberichte der Kaiserlichen Akademie der Wissenschaften, Mathematisch-Naturwissenschaftliche Classe 61:623-642.

1903 Über einige neue Reptilien- und Fischarten des Hofmuseums in Wien. Sitzungsberichte der Kaiserlichen Akademie der Wissenschaften, Mathematisch-Naturwissenschaftlichen Classe 113:15-22.

STRASBURG, D. W

1956 Notes on the blennioid fishes of Hawaii with descriptions of two new species. Pacific Science 10:241-267.

STRÖMMANN, H.

1896 Leptocephalids in the University Zoological Museum at Uppsala. Inaugural Dissertation Uppsala, Almquist and Wiksell. $53 \mathrm{pp}$.

TANAKA, S

1914 Figures and descriptions of the fishes of Japan. Vols. 16-30. (2nd ed., rev., 1953). Tokyo, Daichi Shain.

1927 Figures and descriptions of the fishes of Japan. Vols. 35-41. Tokyo, Daichi Shain, pp. 645-808.

TEMMINCK, C. J. and H. SCHLEGEL

1842 In Siebold, P. F. von, Fauna Japonica sive descriptio animalium, quae in itinere per Japoniam, jussu et auspiciis superiorum, qui summun in India Batavia imperium tenent suscepto, annis 1823-1830 collegit, notis, observationibus et adumbrationibus illustravit P. F. de Siebold. Batavorum Lugduni. 323 pp. (reprint 1934, Tokyo).

THOMSON, J. M. and G. LUTHER

1984 Family Mugilidae. In Fischer, W. and G. Bianchi, eds., FAO Species Identification Sheets for Fishery Purposes; Western Indian Ocean (fishing area 51). Rome, FAO. Vol. 3.

THUNBERG, C. P.

1792 Atskillige förut okände fiskar af abborslägtet (Perca). Stockholm, Vetenskaps Akademie Nya Handlingar 13:141-143.

1793 Atskillige förut okände fiskar af abborslägtet (Perca) Stockholm, Vetenskaps Akademie Nya Handlingar 14:55-56

TOMINAGA, Y.

1963 A revision of the fishes of the family Pempheridae of Japan. Journal of the Faculty of Science, University of Tokyo, sect. 4 (10):269-290

TYLER, J, C.

1967 A redescription of Triodon macropterus Lesson, a phyletically important plectognath fish. Koninklijke Nederlandsche Akademie van Wetenschappen, ser. c, 70:84-96.

VAILLANT, L. and H. E. SAUVAGE

1875 Note sur quelques espèces nouvelles de poissons des 
Îles Sandwich. Revue et magasin de zoologie pure et appliquée, ser. 3, 3:278-287.

VALENCIENNES, A

1832 Descriptions de plusieurs nouvelles poissons du genre Apogon. Paris, Nouvelles annales de l'île-de-France, Museum d'histoire naturelle, 1:51-60.

WALBAUM, J. J.

1792 Petri Artedi sueci genera Piscium. Grypeswaliae. 723 pp.

WALLACE, J. H.

1967 The batoid fishes of the east coast of southern Africa: Part II: Manta, eagle, duckbill, cownose, butterfly and sting rays. Durban, Oceanographic Research Institute, Investigational Report 16:1-56.

WEBER, M.

1909 Note IV. Diagnosen neuer Fische der Siboga-Expedition. Notes from the Leiden Museum 31:143-169.

1913 Die Fische der Siboga-Expedition. Leiden, E. J. Brill. $710 \mathrm{pp}$.

WELANDER, A. and L. P. SCHULTZ

1951 Chromis atripectoralis, a new damselfish from the tropical Pacific, closely related to $C$. caerulus, family Pomacentridae. Journal of the Washington Academy of Sciences 41:107-110.

WHITEHEAD, P. J. P.

1984 Family Chanidae. In Fischer, W. and G. Bianchi, eds., FAO Species Identification Sheets for Fishery Purposes; Western Indian Ocean (fishing area 51). Rome, FAO. Vol. 1.

WHITEHEAD, P. J. P. and T. WONGRATANA

1984a Family Clupeidae. In Fischer, W. and G. Bianchi, eds., FAO Species Identification Sheets for Fishery
Purposes; Western Indian Ocean (fishing area 51). Rome, FAO. Vol. 1.

1984b Family Engraulidae. In Fischer, W. and G. Bianchi, eds., FAO Species Identification Sheets for Fishery Purposes; Western Indian Ocean (fishing area 51). Rome, FAO. Vol. 2.

WILLIAMS, J. T.

1984 Synopsis and phylogenetic analysis of the pearlfish subfamily Carapinae (Pisces: Carapidae). Bulletin of Marine Science 34:386-397.

WINTERBOTTOM, R.

1978 Range extensions and additions to the South African marine ichthyofauna, with the description of a new species of congrogadid from Kwazulu. Zoologica Africana 13:41-56.

WINTERBOTTOM, R. and A. R. EMERY

1986 Review of the gobioid fishes of the Chagos Archipelago, central Indian Ocean. Royal Ontario Museum, Life Sciences Contributions 142:1-82.

WOODLAND, D. J.

1984 Family Gerreidae. In Fischer, W. and G. Bianchi, eds., FAO Species Identification Sheets for Fishery Purposes; Western Indian Ocean (fishing area 51). Rome, FAO. Vol. 2.

WOODS, L. P.

1966 Family Aluteridae. In Schultz, L. P. and collaborators, Fishes of the Marshall and Marianas Islands. United States National Museum Bulletin 202(2):80-100.

WOODS, L. P. and P. M. SONODA

1973 Order Berycomorphi (Beryciformes). In Fishes of the western North Atlantic. Part Six. Memoirs of the Sears Foundation for Marine Research, Yale University, pp. 263-396. 
Figures 



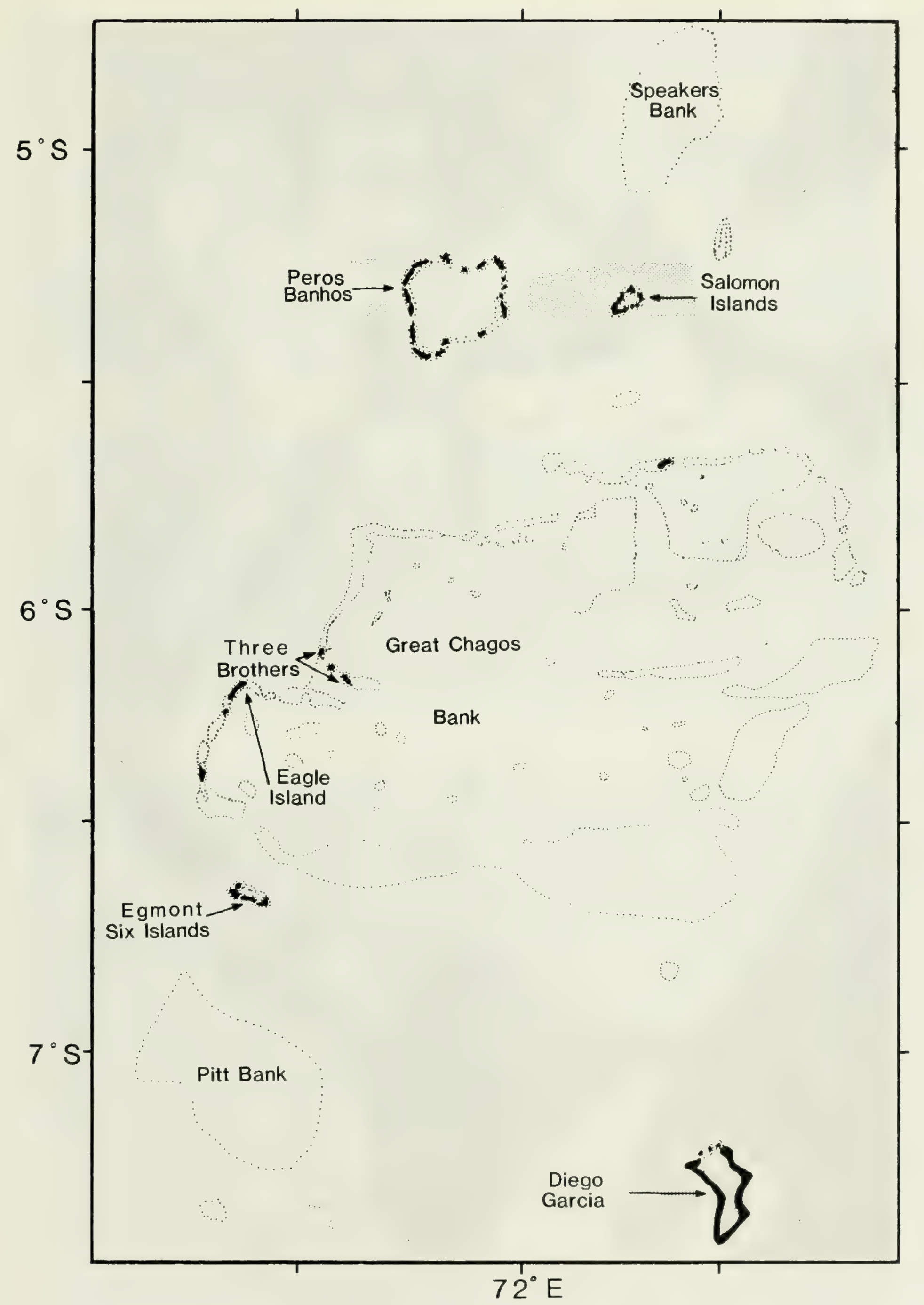

Fig. 1. Map of the Chagos Archipelago. Land black, reef margins with dotted outlines, areas below $500 \mathrm{~m}$ stippled. 

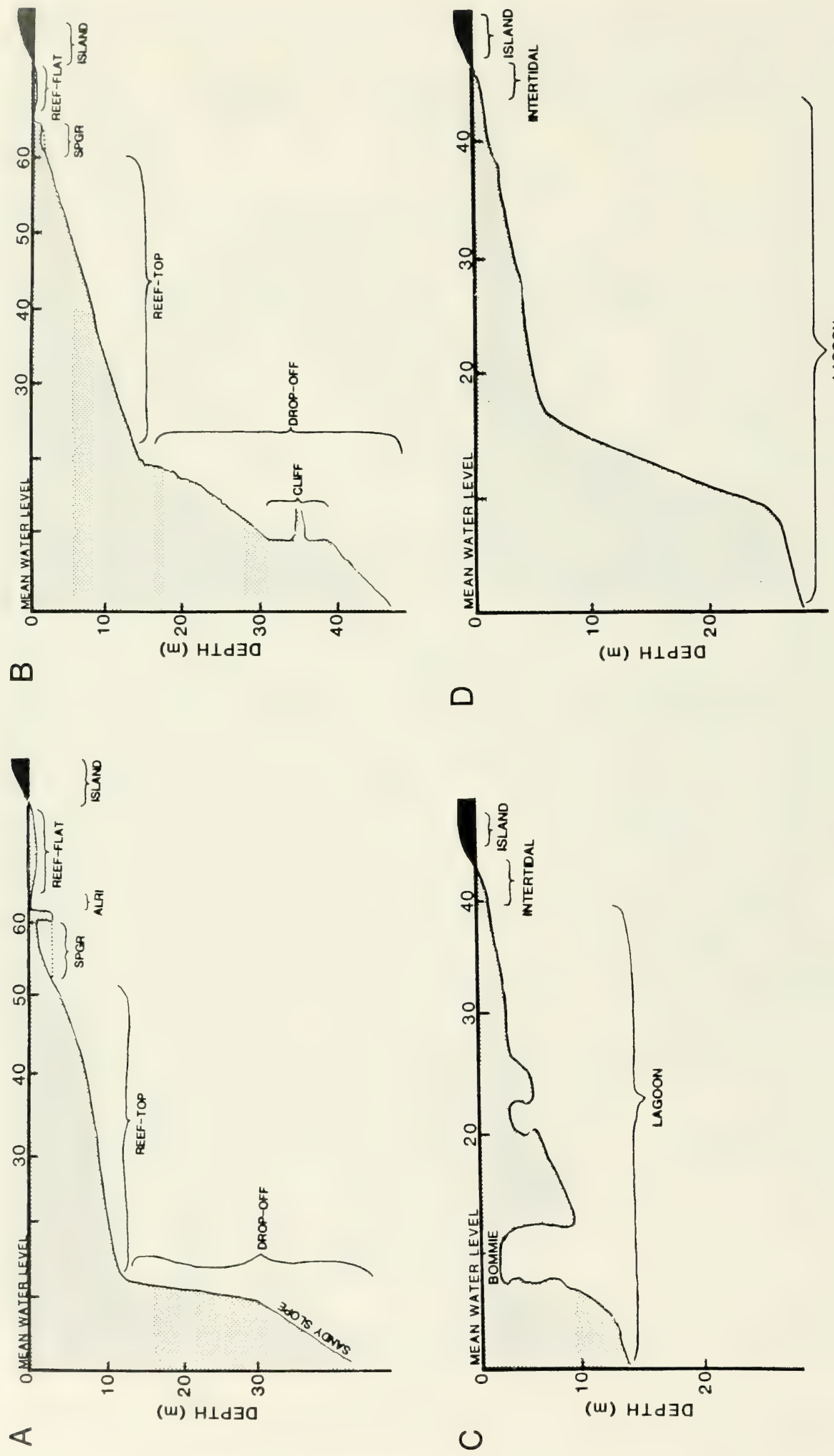

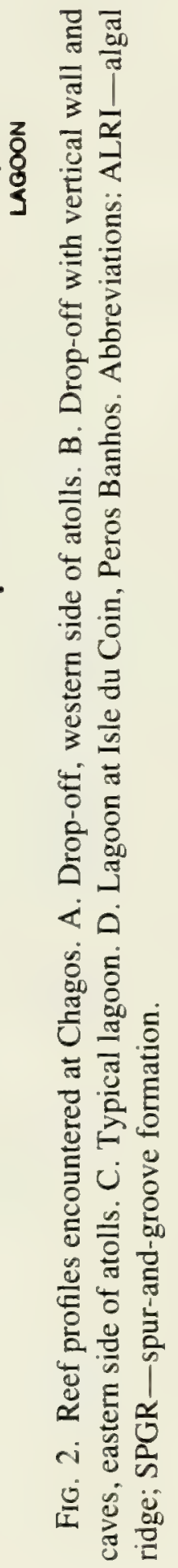




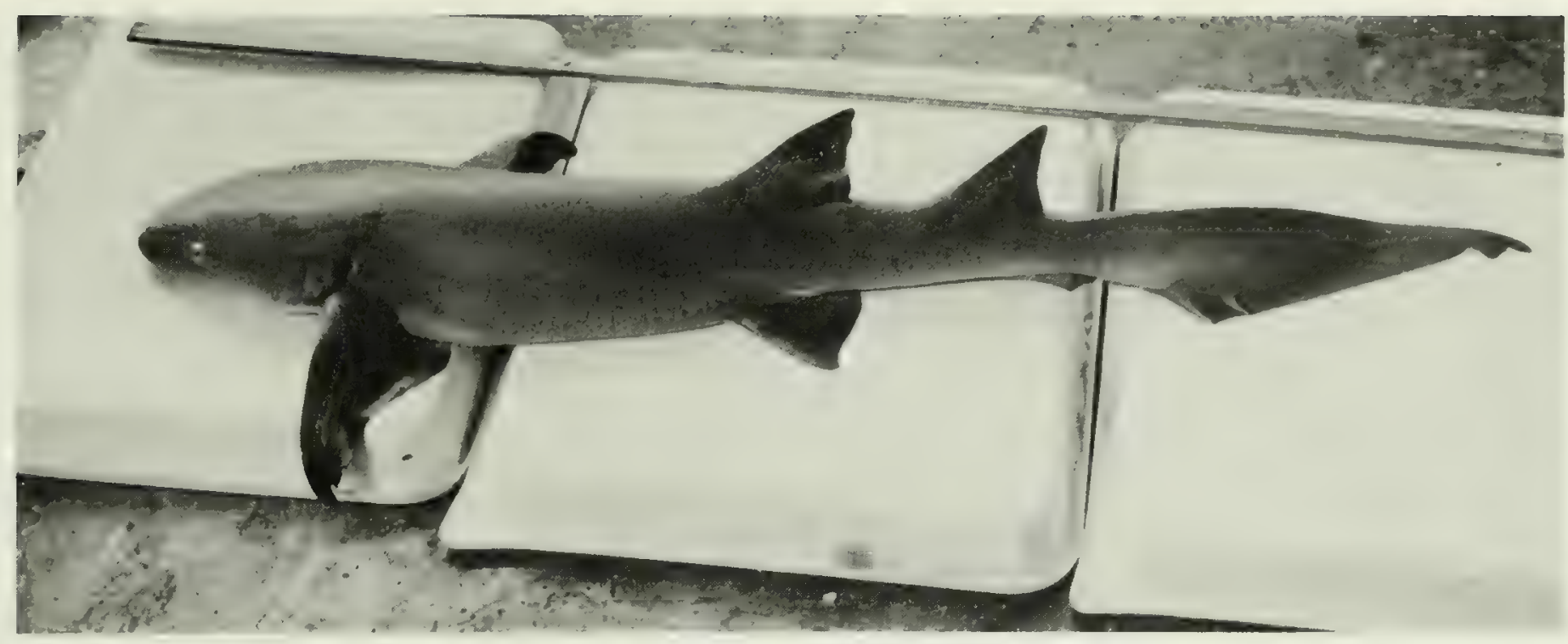

FIG. 3. Nebrius ferrugineus, $1100 \mathrm{~mm}$ TL, Peros Banhos.

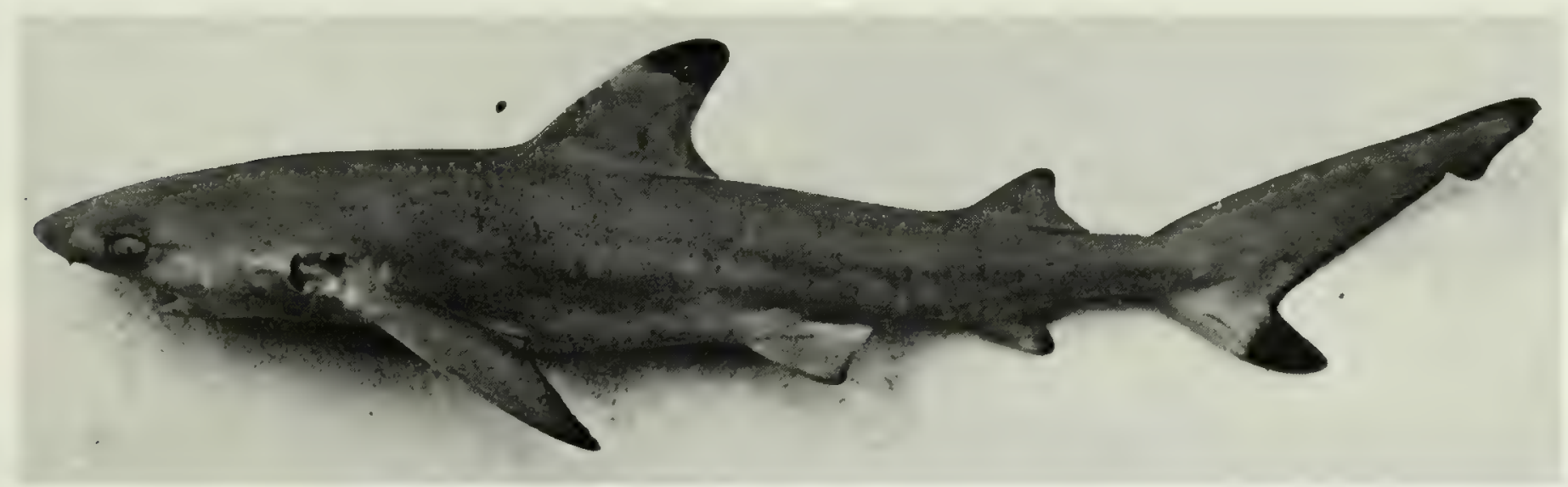

FIG. 4. Carcharhinus melanopterus, $1100 \mathrm{TL}$, Peros Banhos.

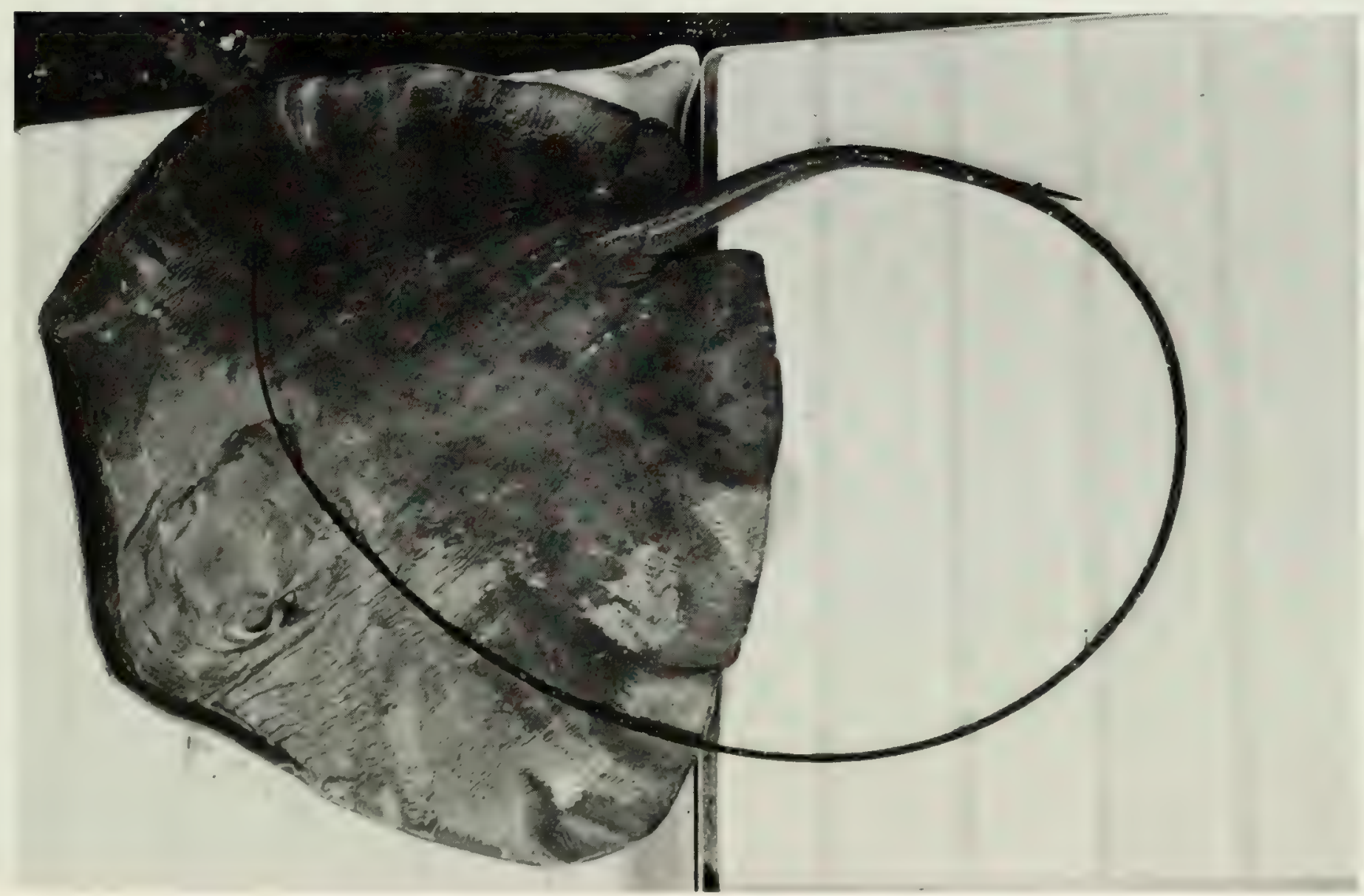

FIG. 5. Dasyatis purpureus, $565 \mathrm{~mm}$ DW, Peros Banhos. 


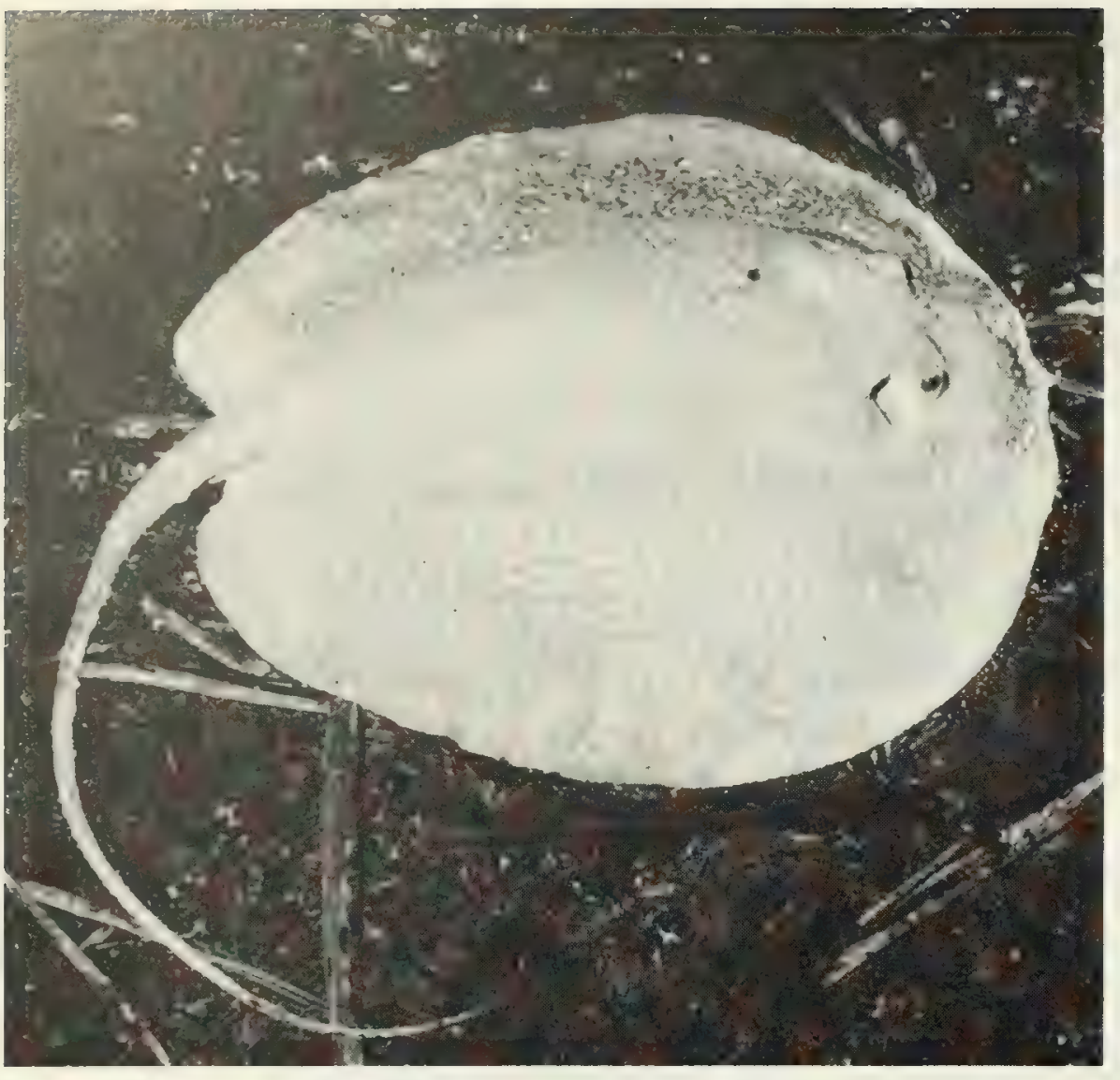

FIG. 6. Urogymnus asperrimus, $540 \mathrm{~mm}$ DW, Eagle Island.

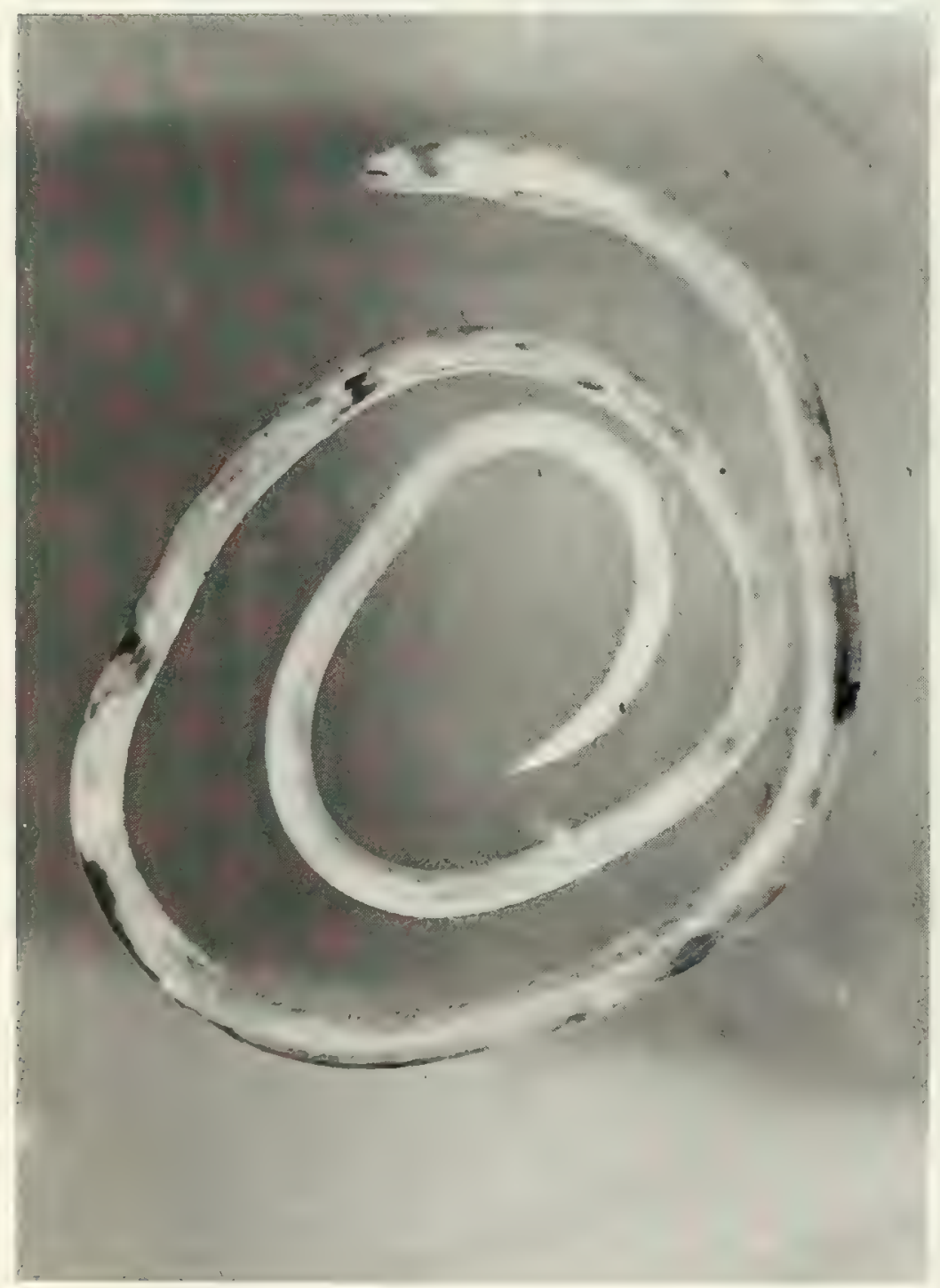

FIG. 8. Moringua javanica, $675 \mathrm{~mm}$ SL, Peros Banhos.

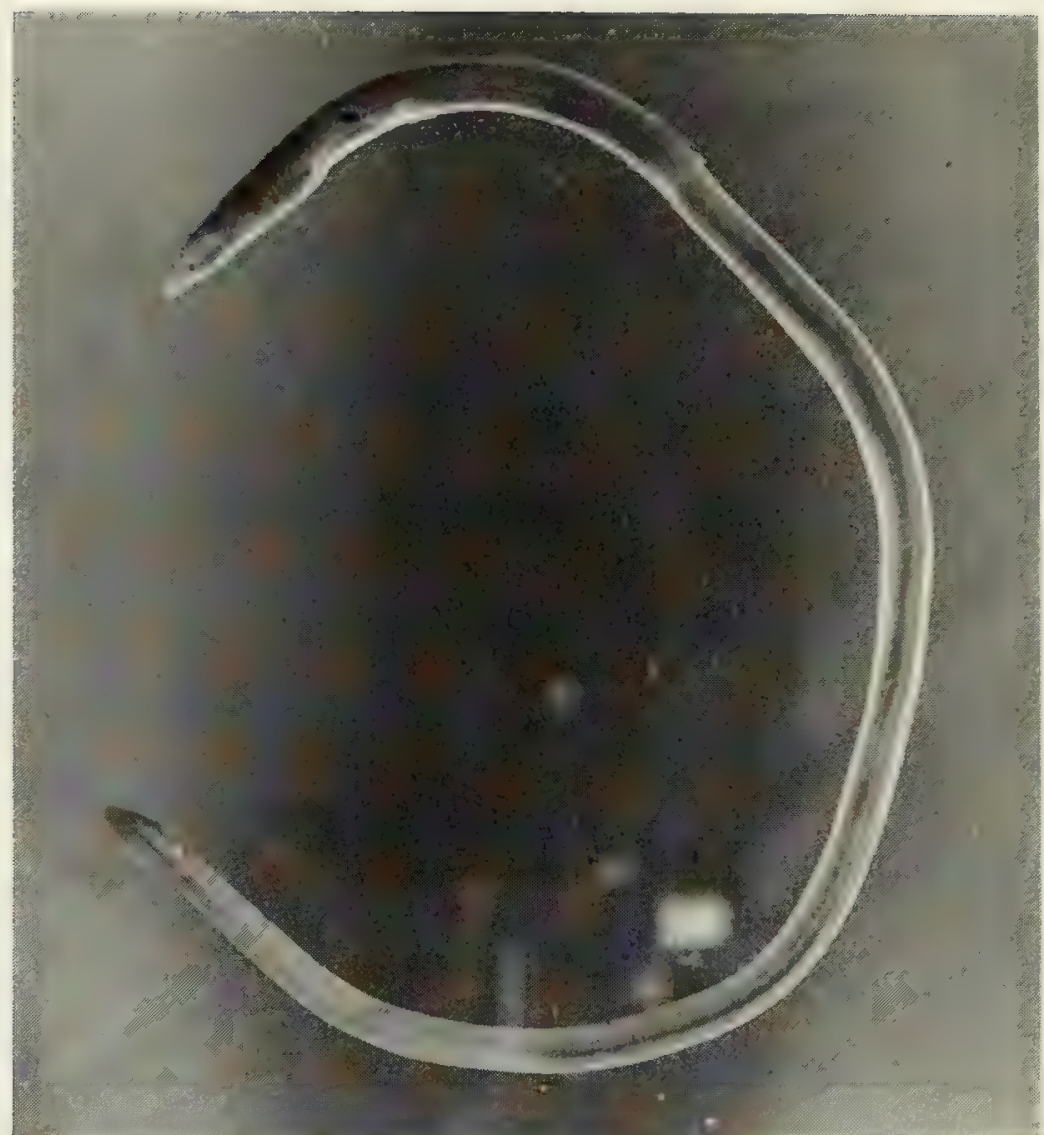

FIG. 7. Moringua ferruginea, $126 \mathrm{~mm}$ SL, Peros Banhos.

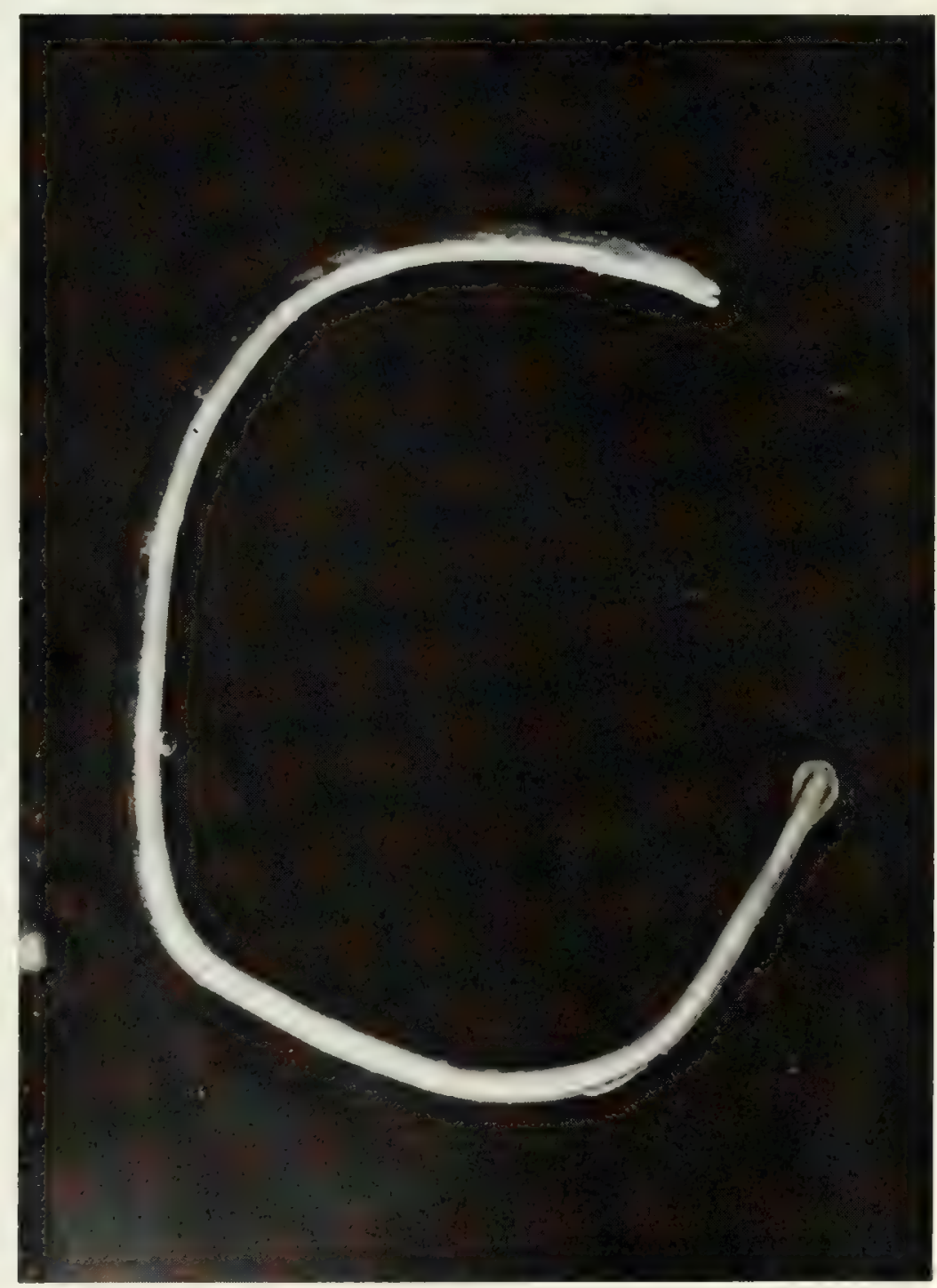

FIG. 9. Moringua microchir, $257 \mathrm{~mm}$ SL, Eagle Island. 


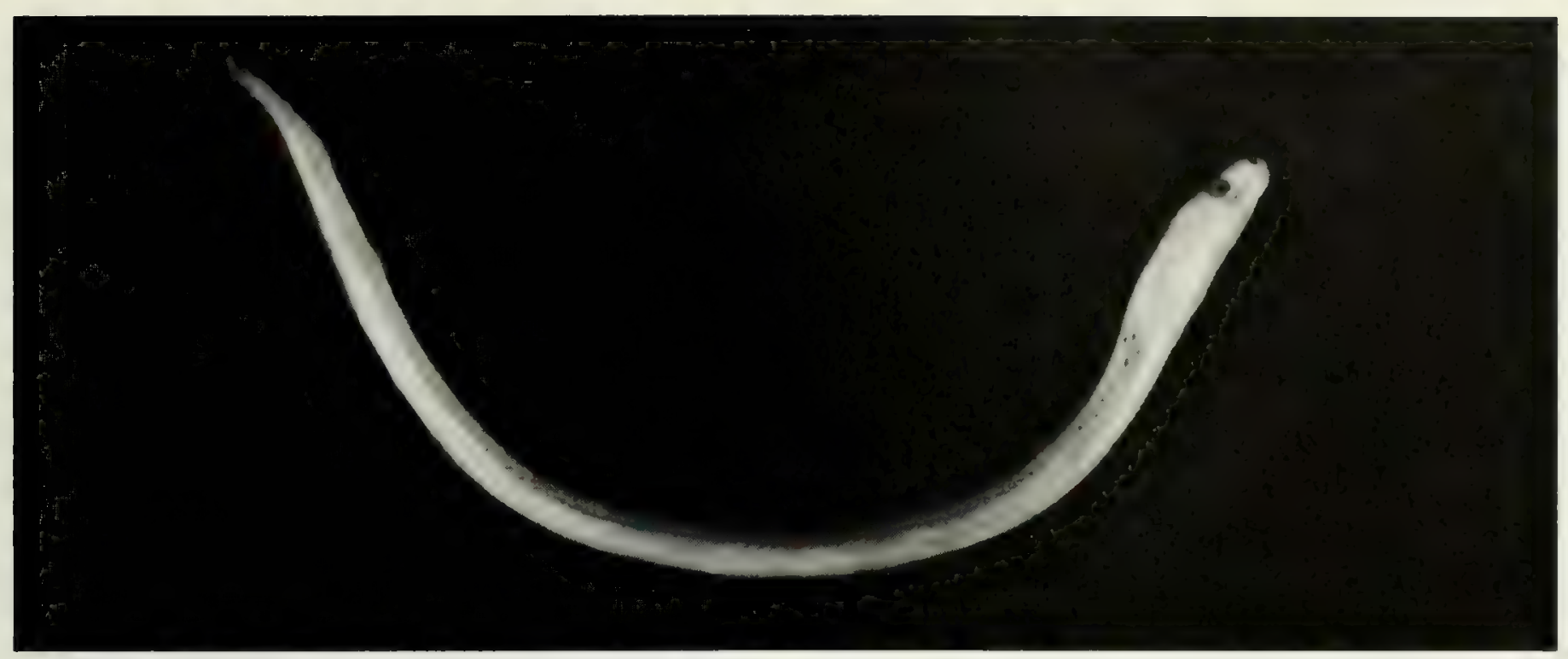

FIG. 10. Kaupichthys atronasus, (preserved) $54 \mathrm{~mm} \mathrm{SL}$, Peros Banhos. Photo by A. Strange.

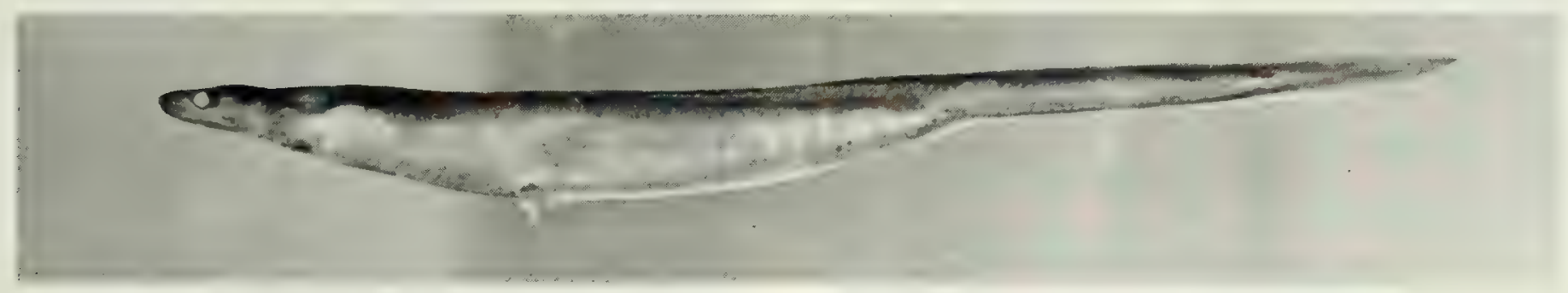

FIG. 11. Kaupichthys hyoproroides, $159 \mathrm{~mm} \mathrm{SL}$, Salomon.

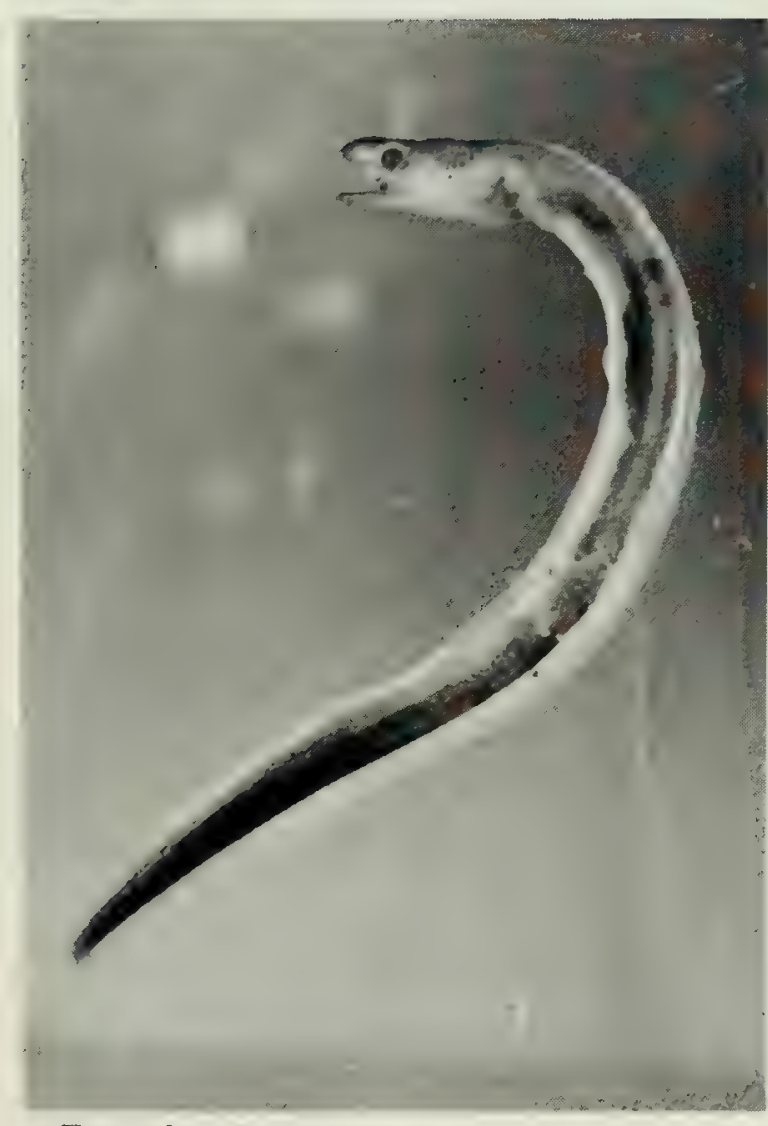

FIG. 12. Kaupichthys nuchalis, $58 \mathrm{~mm} \mathrm{SL}$, Peros Banhos.

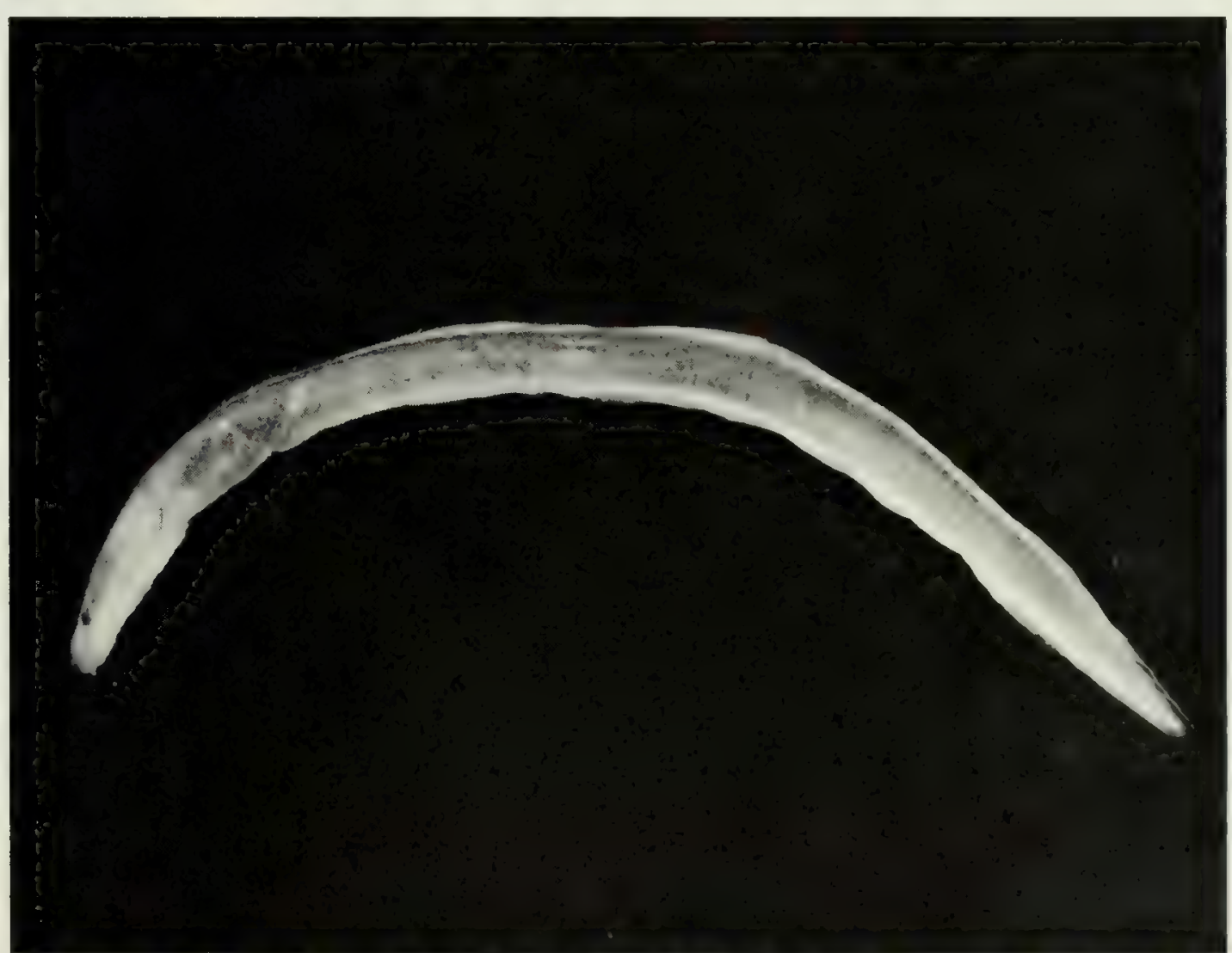

FIG. 13. Kaupichthys sp., (preserved) $107 \mathrm{~mm} \mathrm{SL}$, Salomon. Photo by A. Strange. 


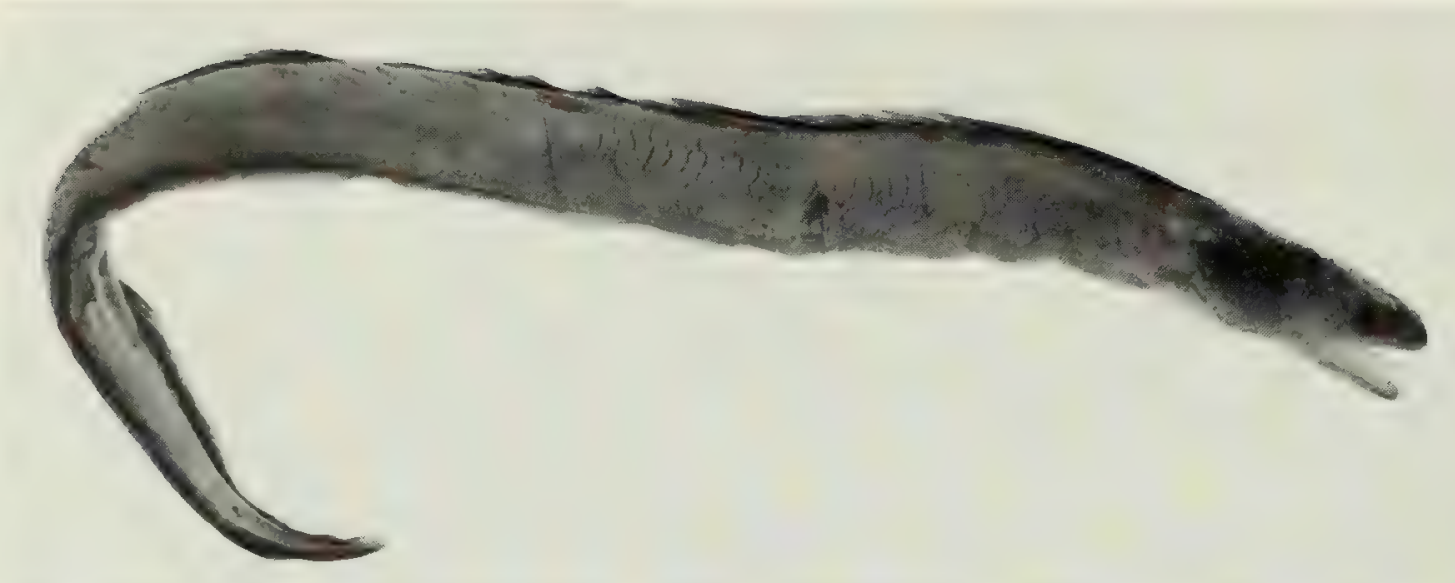

FIG. 14. Powellichthys sp., (preserved) $155 \mathrm{~mm} \mathrm{SL}$, Salomon. Photo by A. Strange.

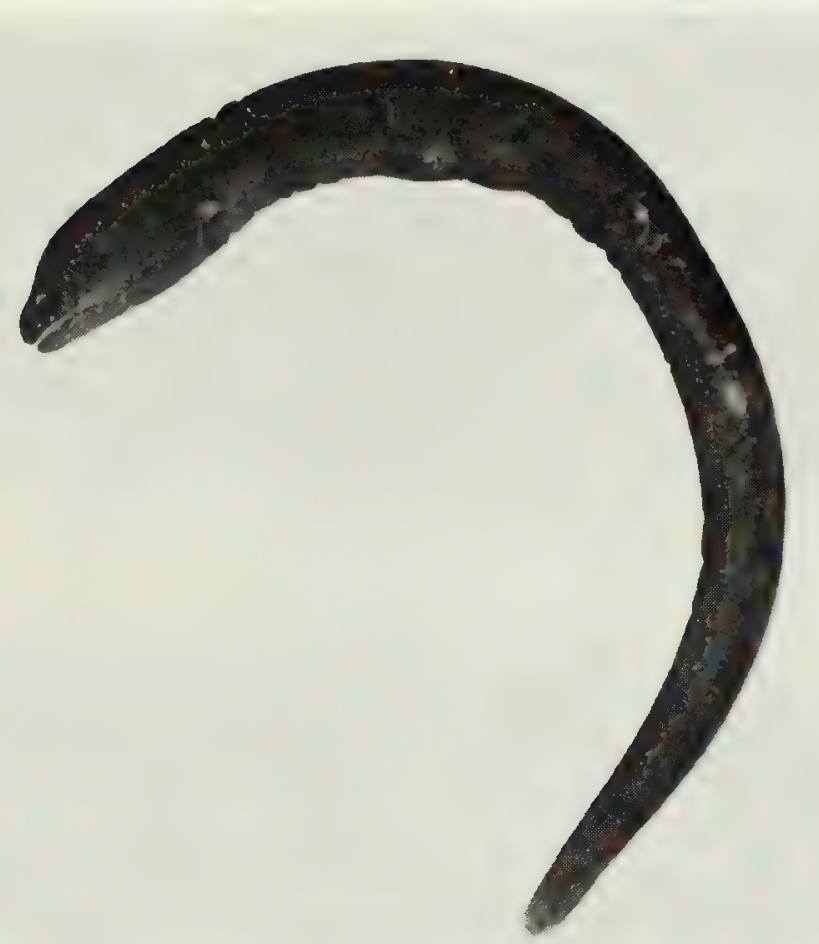

FIG. 15. Anarchias allardicei, (preserved) $97 \mathrm{~mm} \mathrm{SL}$, Eagle Island. Photo by M. Burridge-Smith.

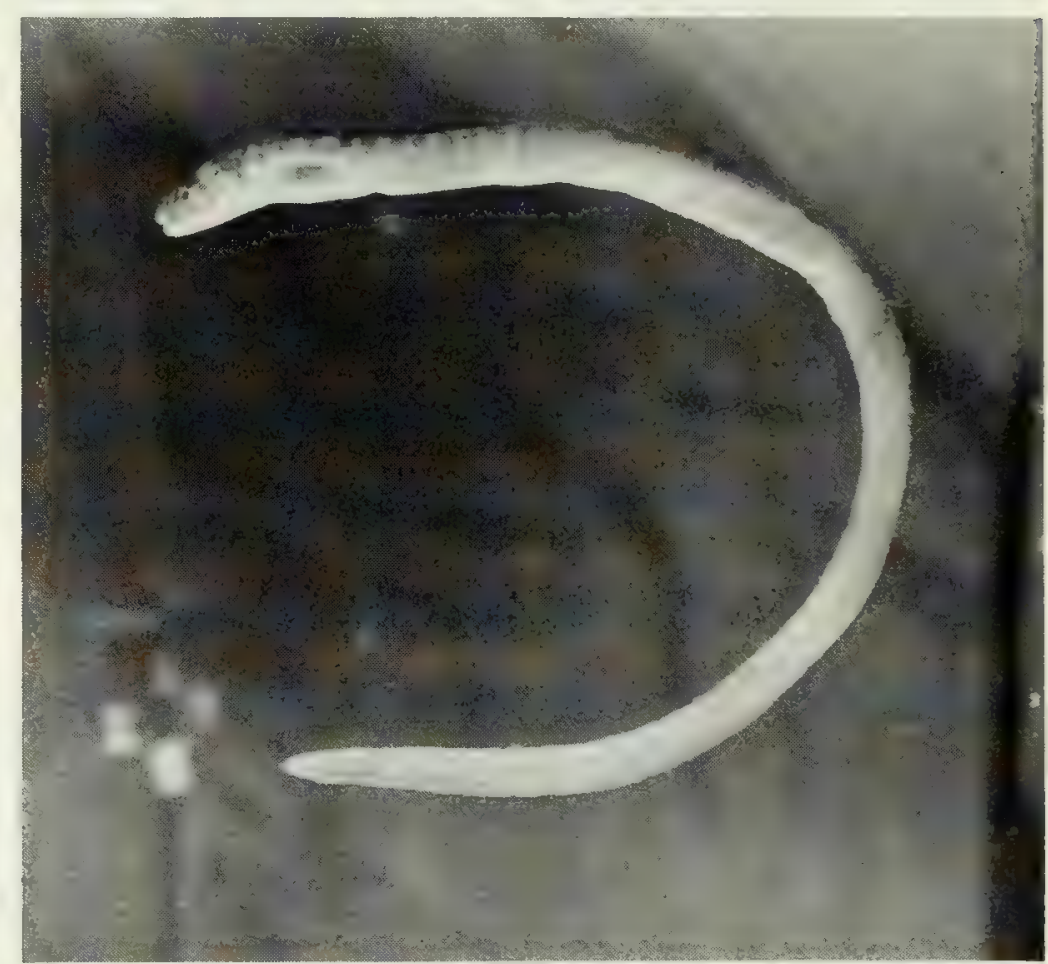

Fig. 16. Anarchias seychellensis, $130 \mathrm{~mm} \mathrm{SL,} \mathrm{Peros} \mathrm{Banhos.}$

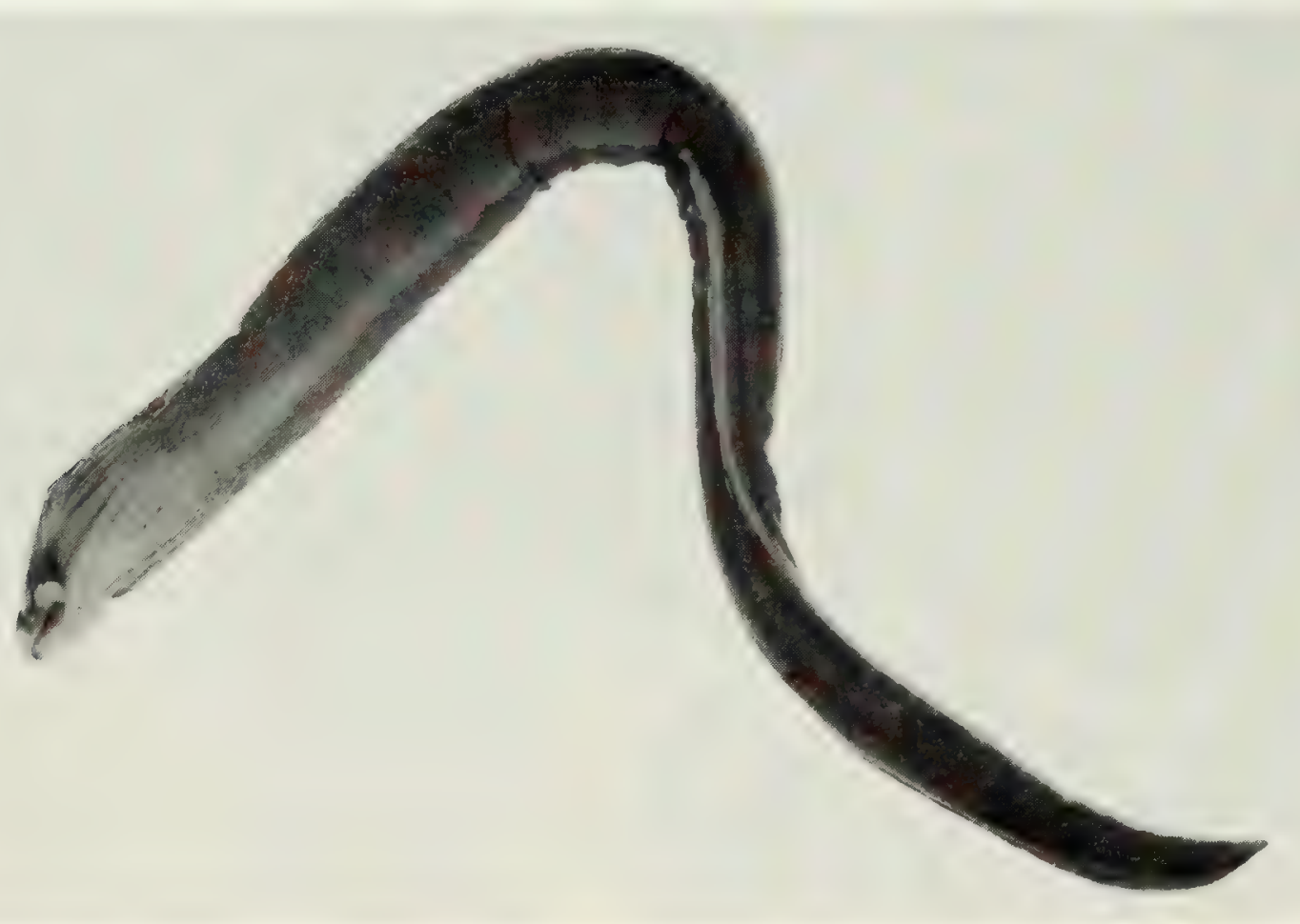

FIG. 17. Echidna leucotaenia, (preserved) $164 \mathrm{~mm} \mathrm{SL}$, Salomon. Photo by A. Strange. 


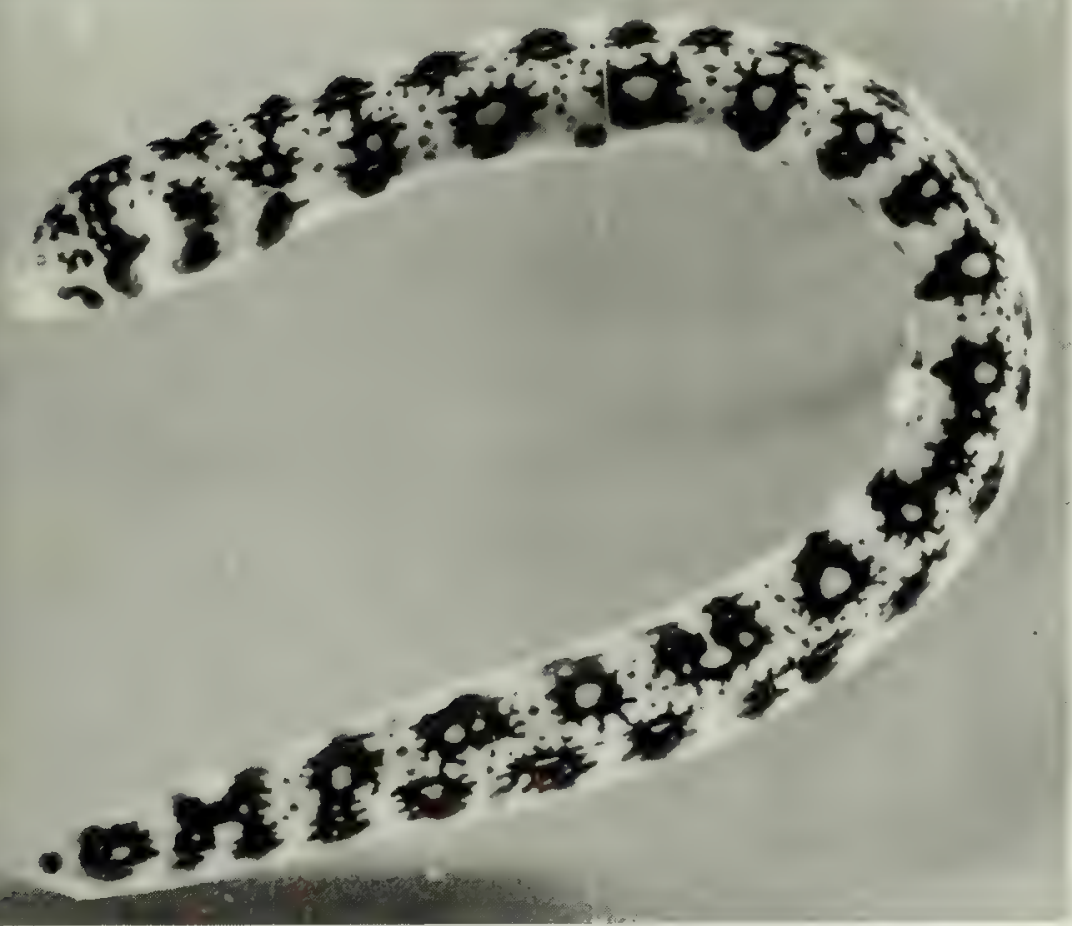

FIG. 18. Echidna nebulosa, $123 \mathrm{~mm}$ SL, Peros Banhos.

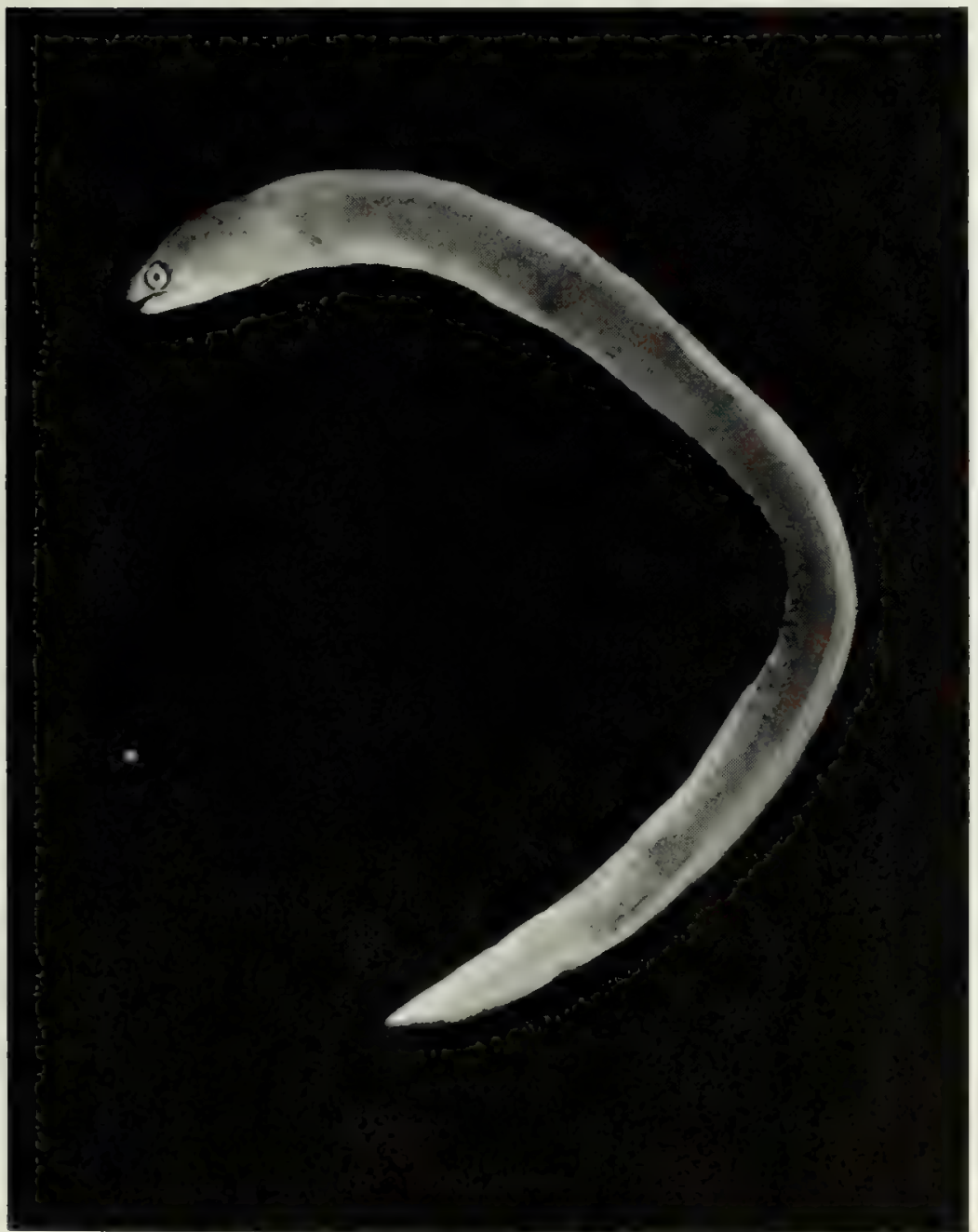

FIG. 20. Echidna unicolor, (preserved) $95 \mathrm{~mm} \mathrm{SL}$, Salomon. Photo by A. Strange.

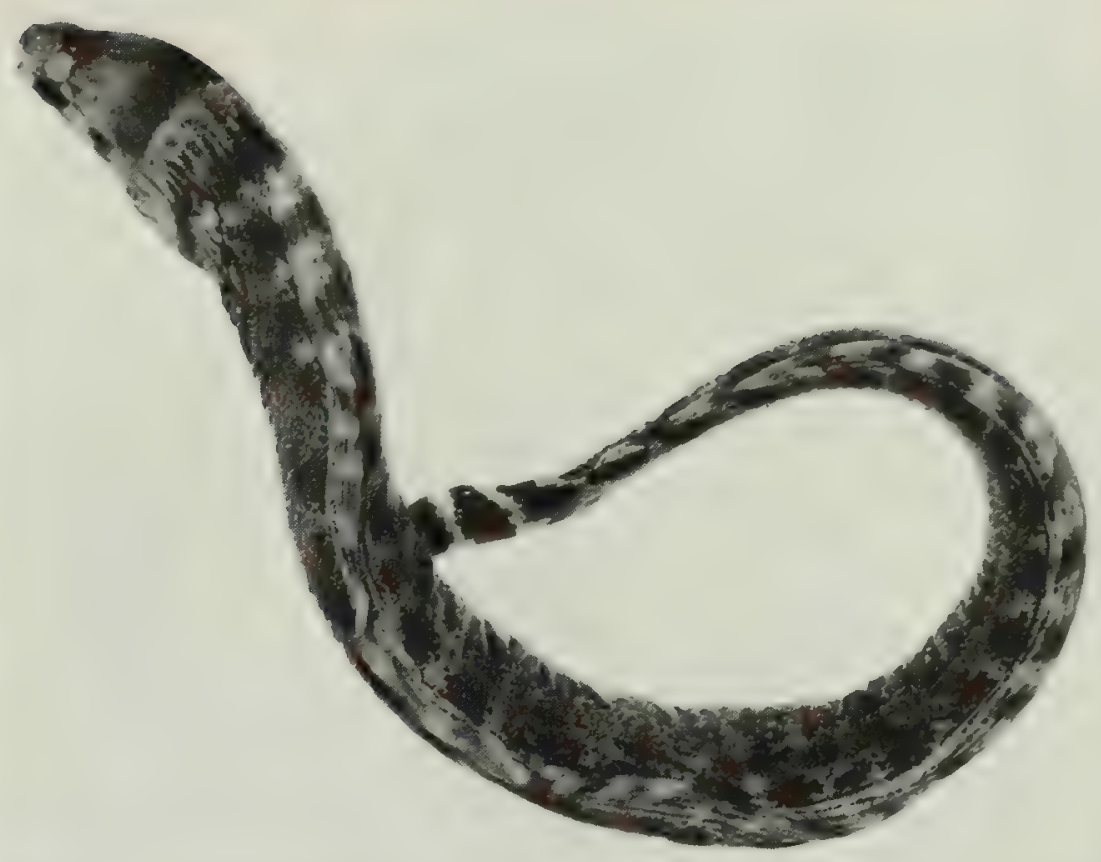

FIG. 19. Echidna polyzona, (preserved) $338 \mathrm{~mm} \mathrm{SL}$, Peros Banhos. Photo by A. Strange

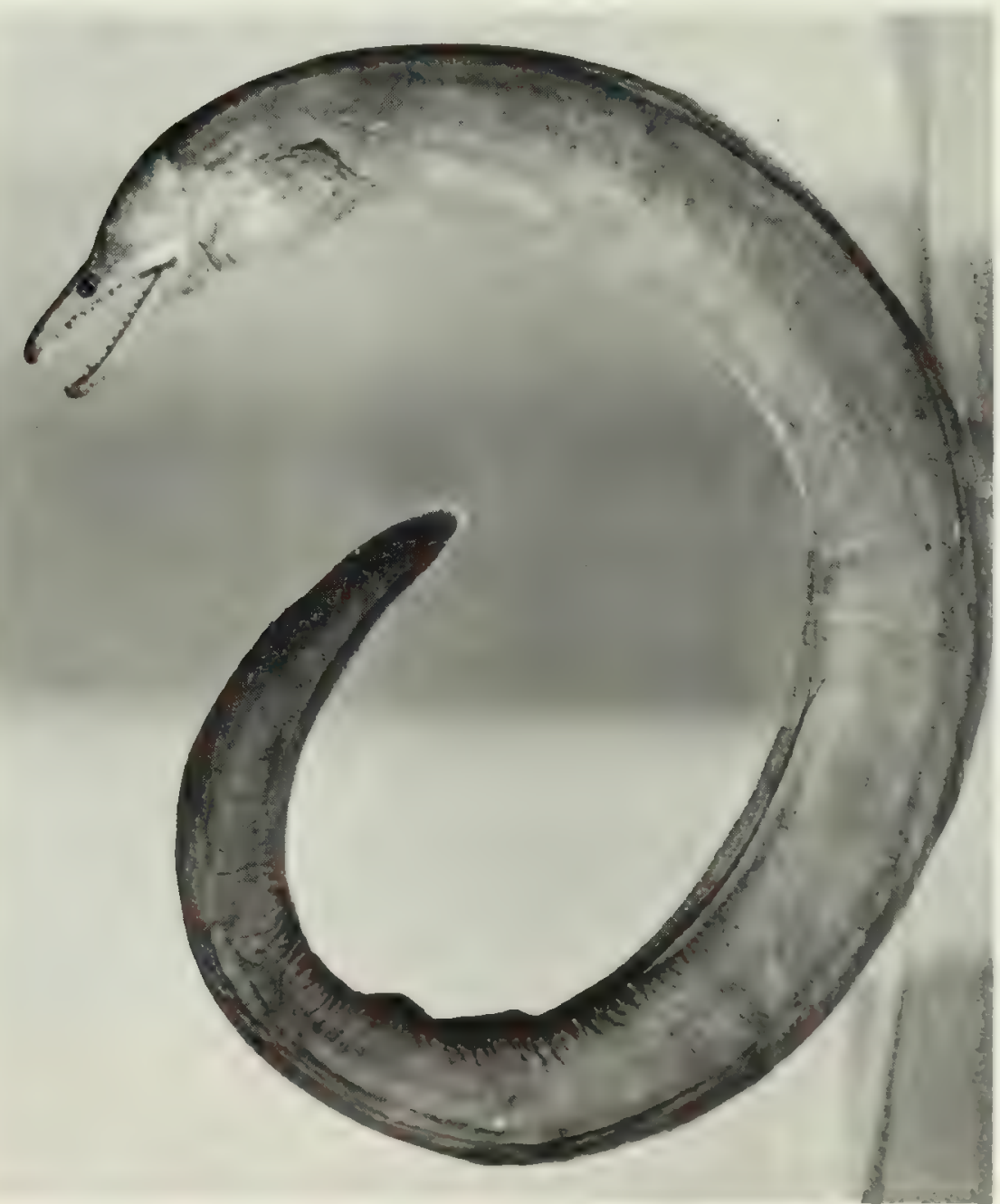

FIG. 21. Enchelycore bayeri, $645 \mathrm{~mm} \mathrm{SL}$, Salomon. 


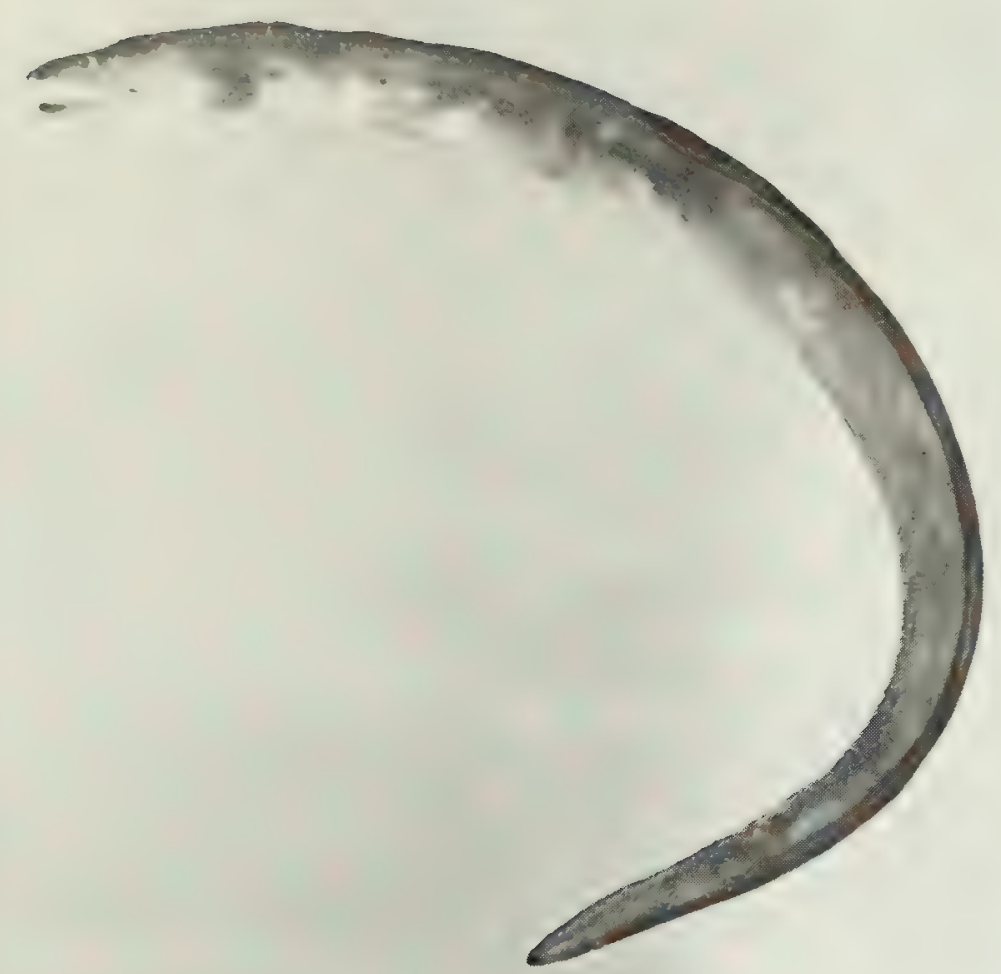

FIG. 22. Enchelycore schismatorhynchus, $238 \mathrm{~mm} \mathrm{SL}$, Peros Banhos.

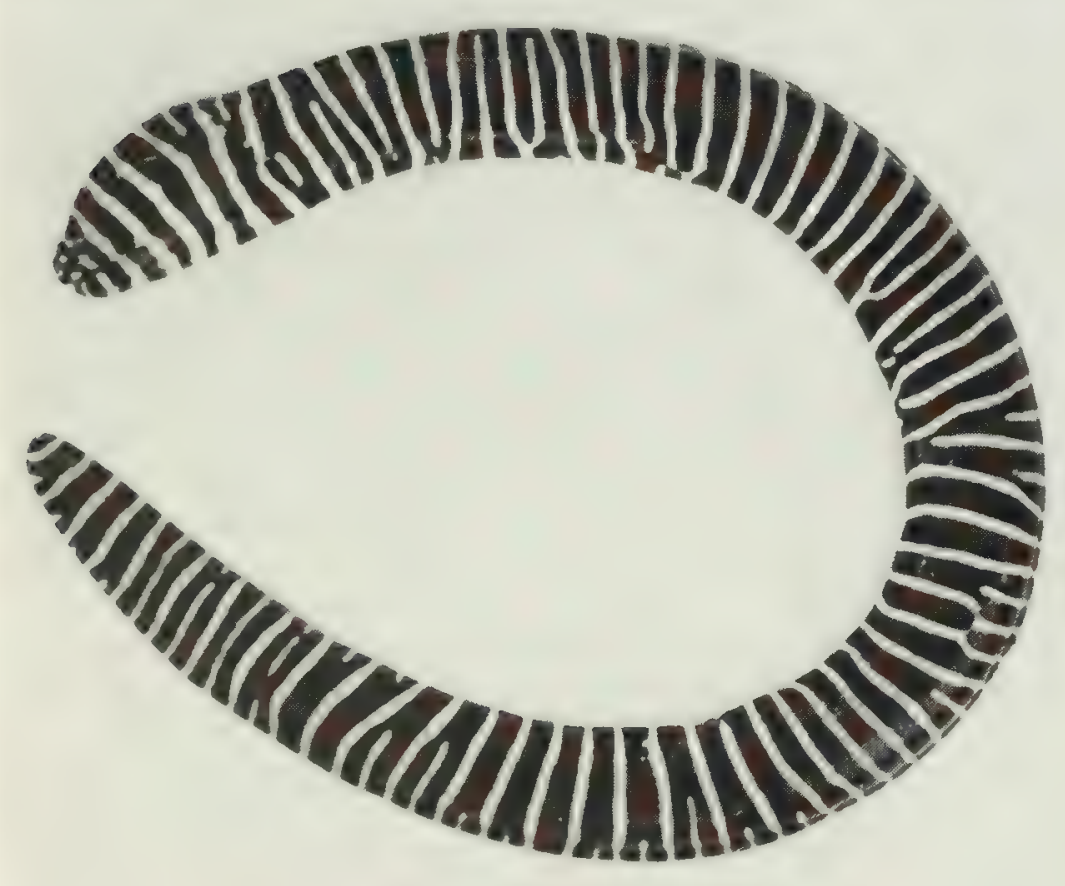

FIG. 24. Gymnomuraena zebra, $600 \mathrm{~mm}$ SL, Eagle Island.

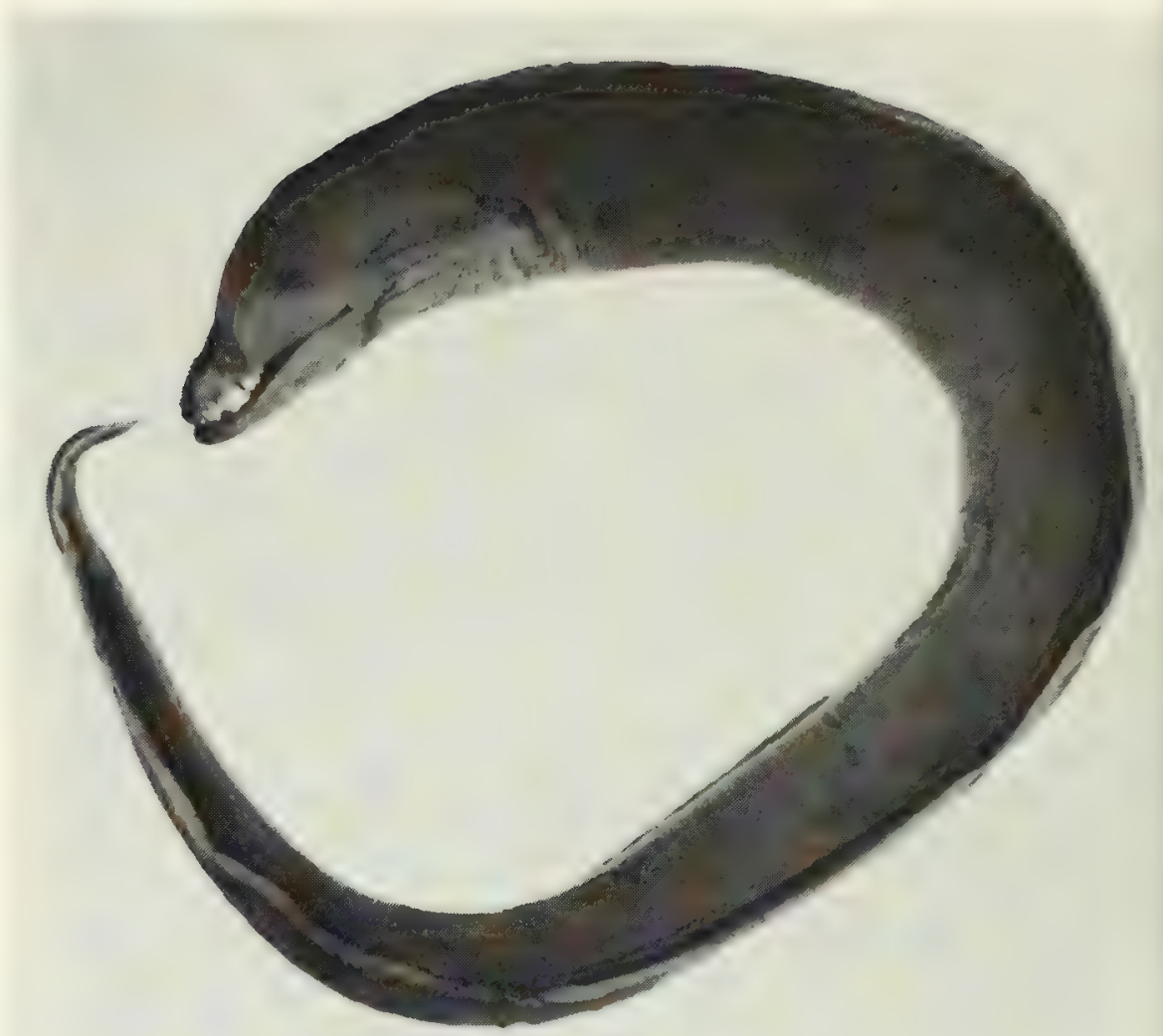

FIG. 23. Enchelynassa canina, (preserved) $630 \mathrm{~mm} \mathrm{SL}$, Salomon. Photo by M. Burridge-Smith.

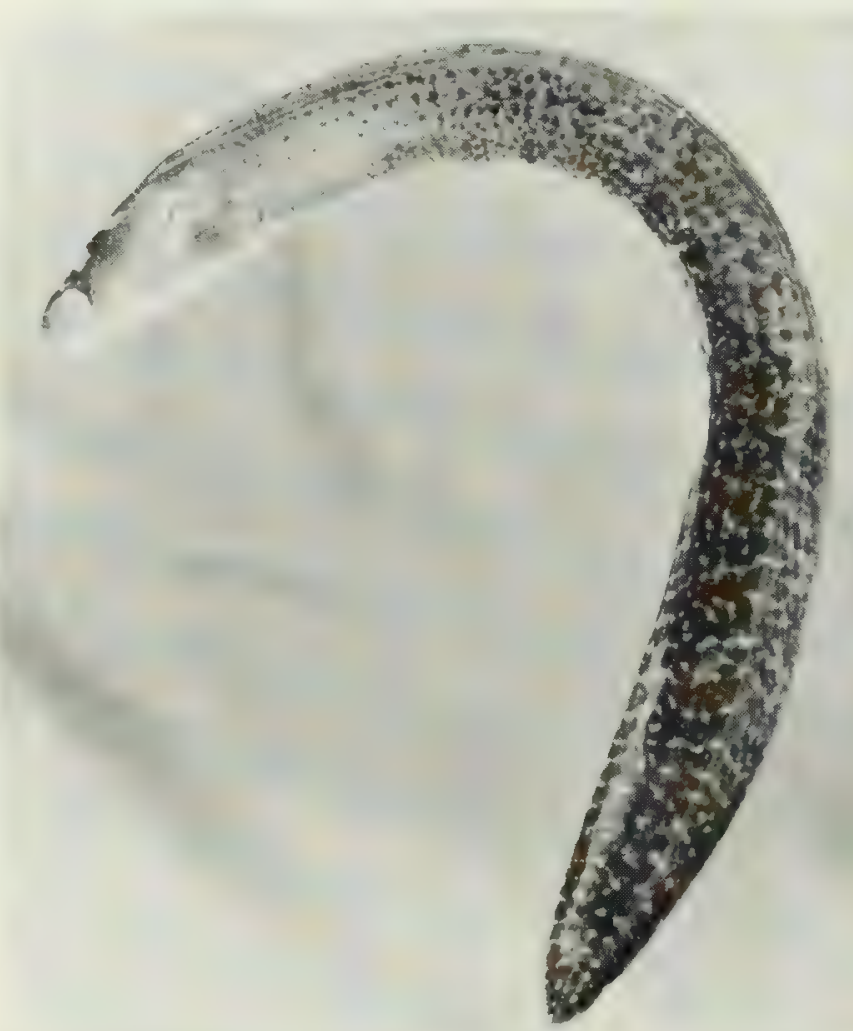

FIG. 25. Gymnothorax buroensis, $112 \mathrm{~mm} \mathrm{SL}$, Peros Banhos. 


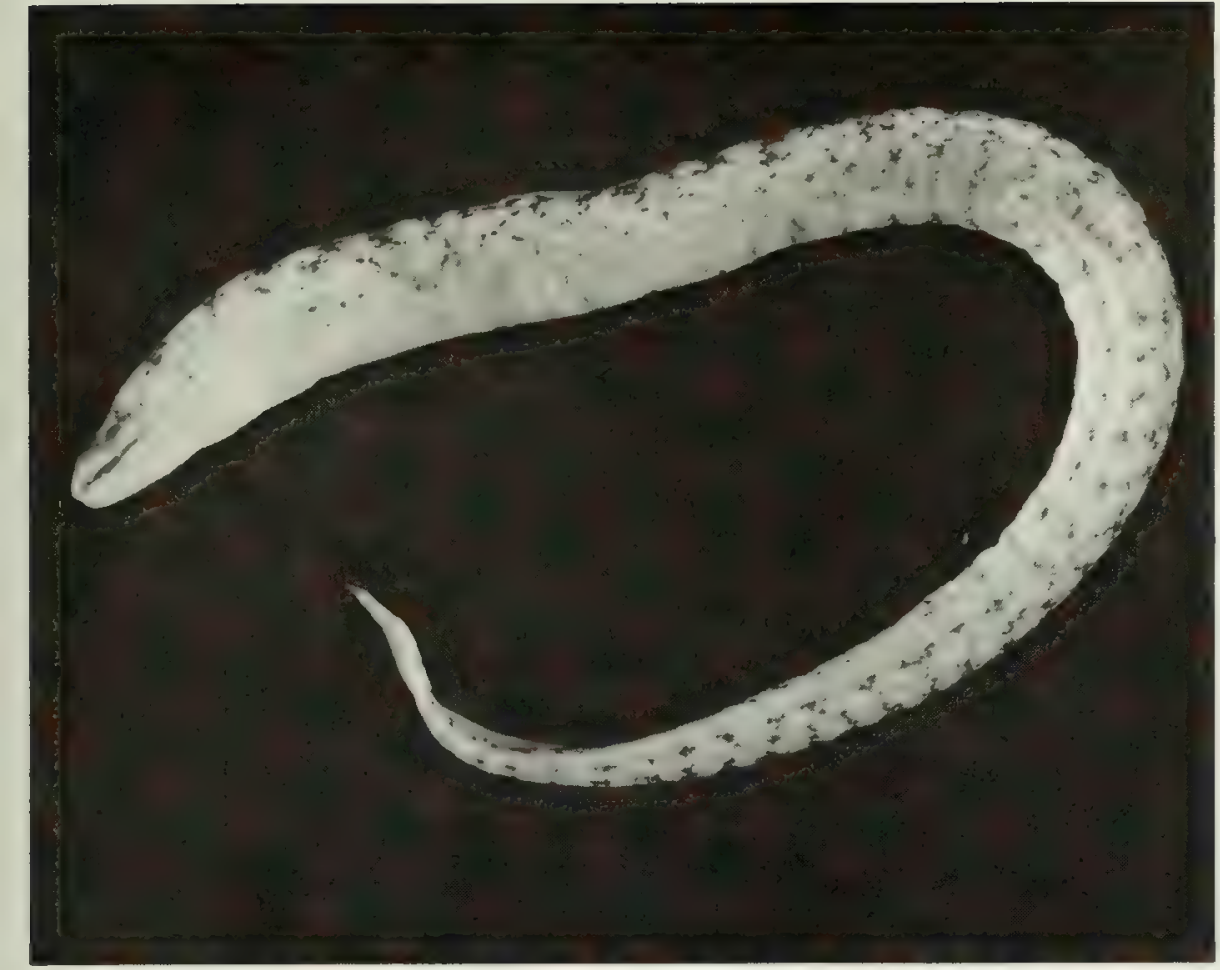

FIG. 26. Gymnothorax chilospilus, (preserved) $186 \mathrm{~mm} \mathrm{SL}$, Diego Garcia. Photo by A. Strange.

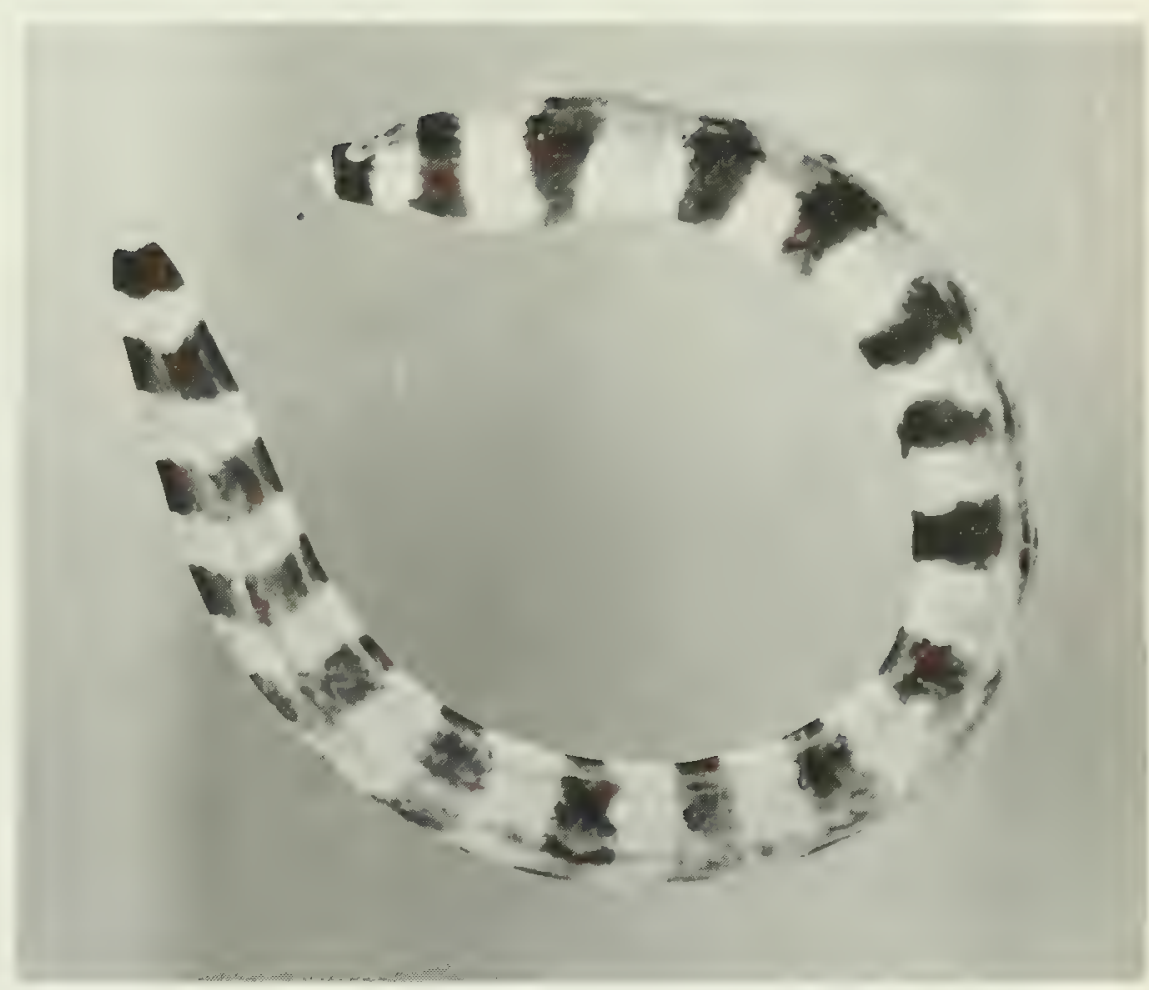

FIG. 27. Gymnothorax enigmaticus, $298 \mathrm{~mm} \mathrm{SL,} \mathrm{Peros}$ Banhos.

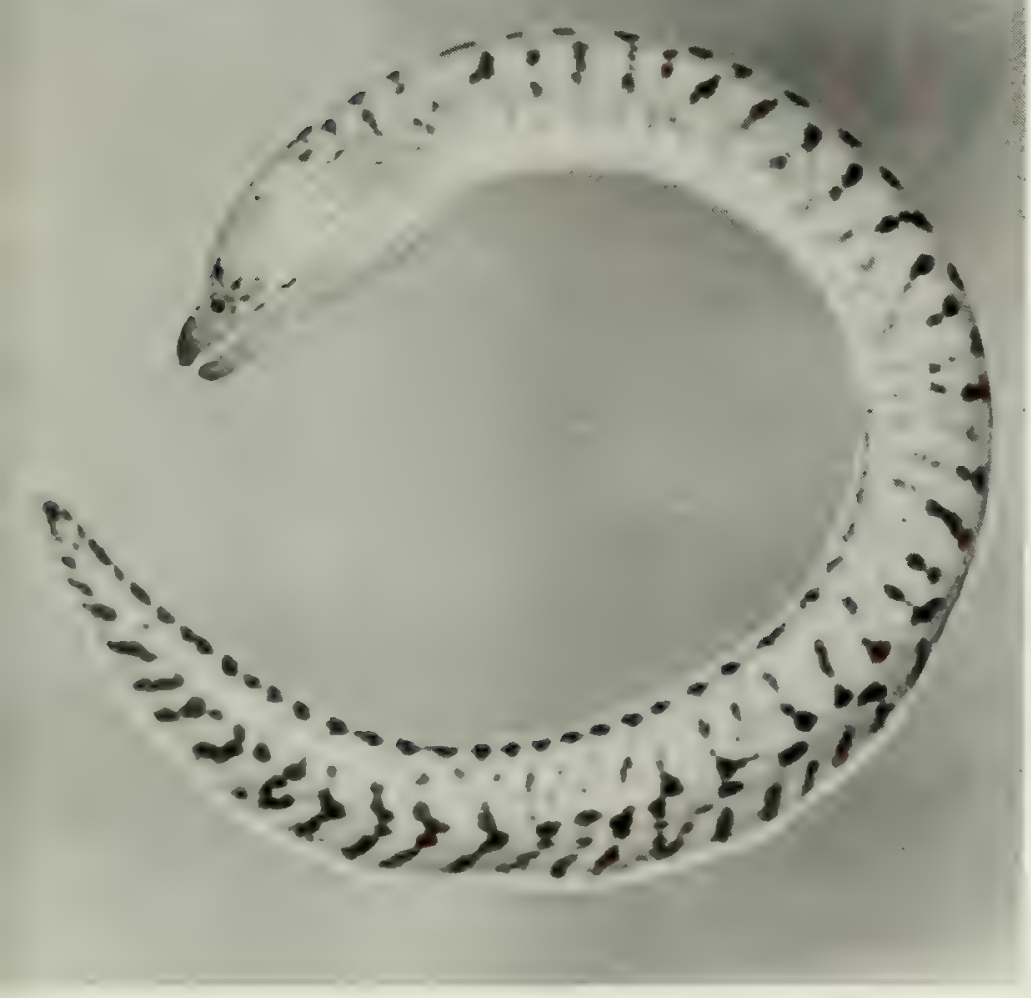

FIG. 28. Gymnothorax fimbriatus, $314 \mathrm{~mm} \mathrm{SL}$, Peros Banhos.

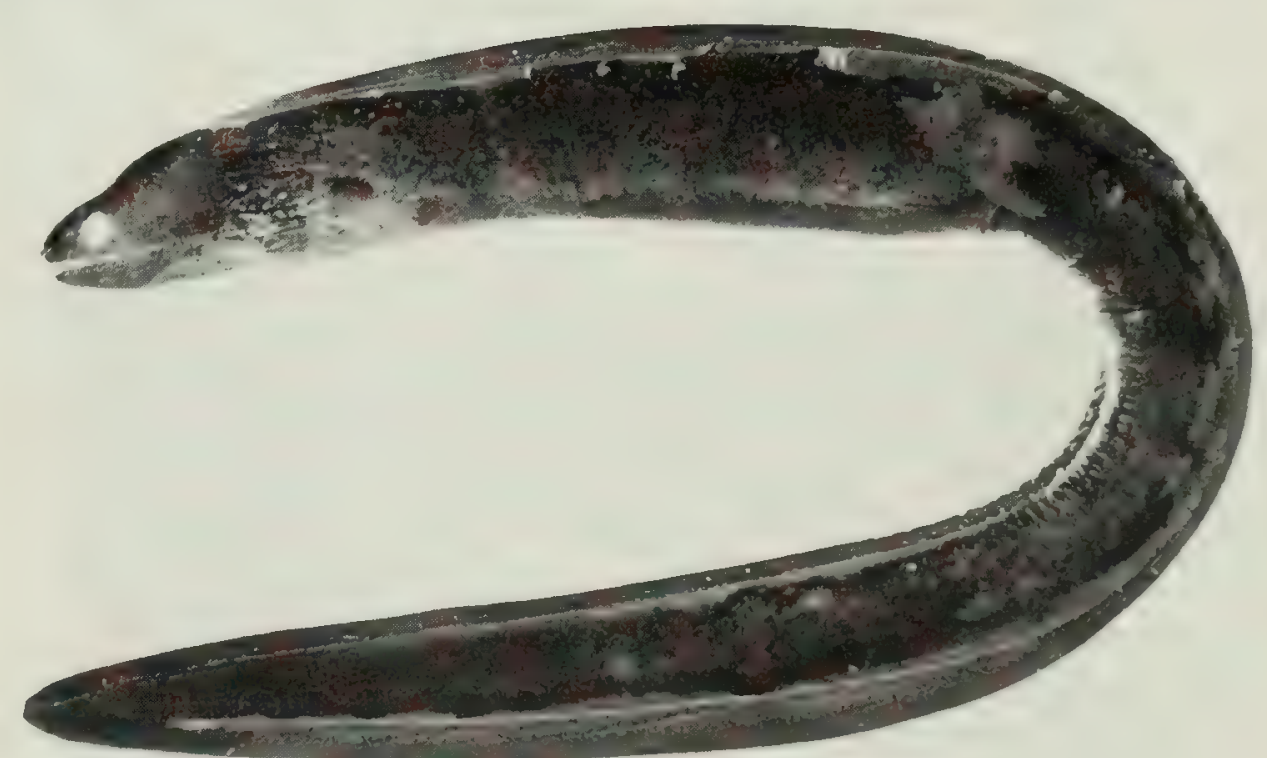

Fig. 29. Gymnothorax flavimarginatus, $172 \mathrm{~mm} \mathrm{SL}$, Peros Banhos. 


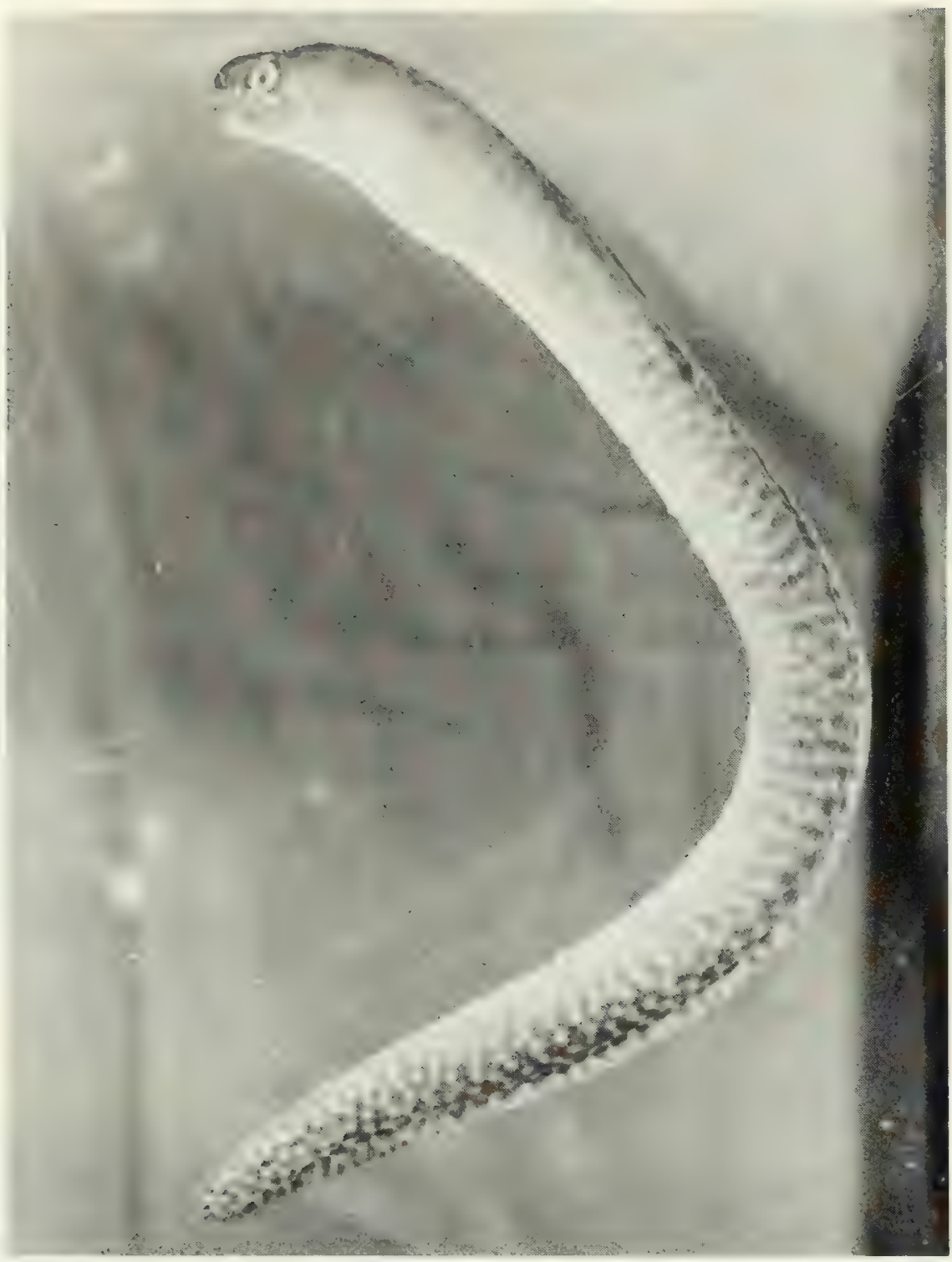

FIG. 30. Gymnothorax fuscomaculatus, $157 \mathrm{~mm}$ SL, Peros Banhos.

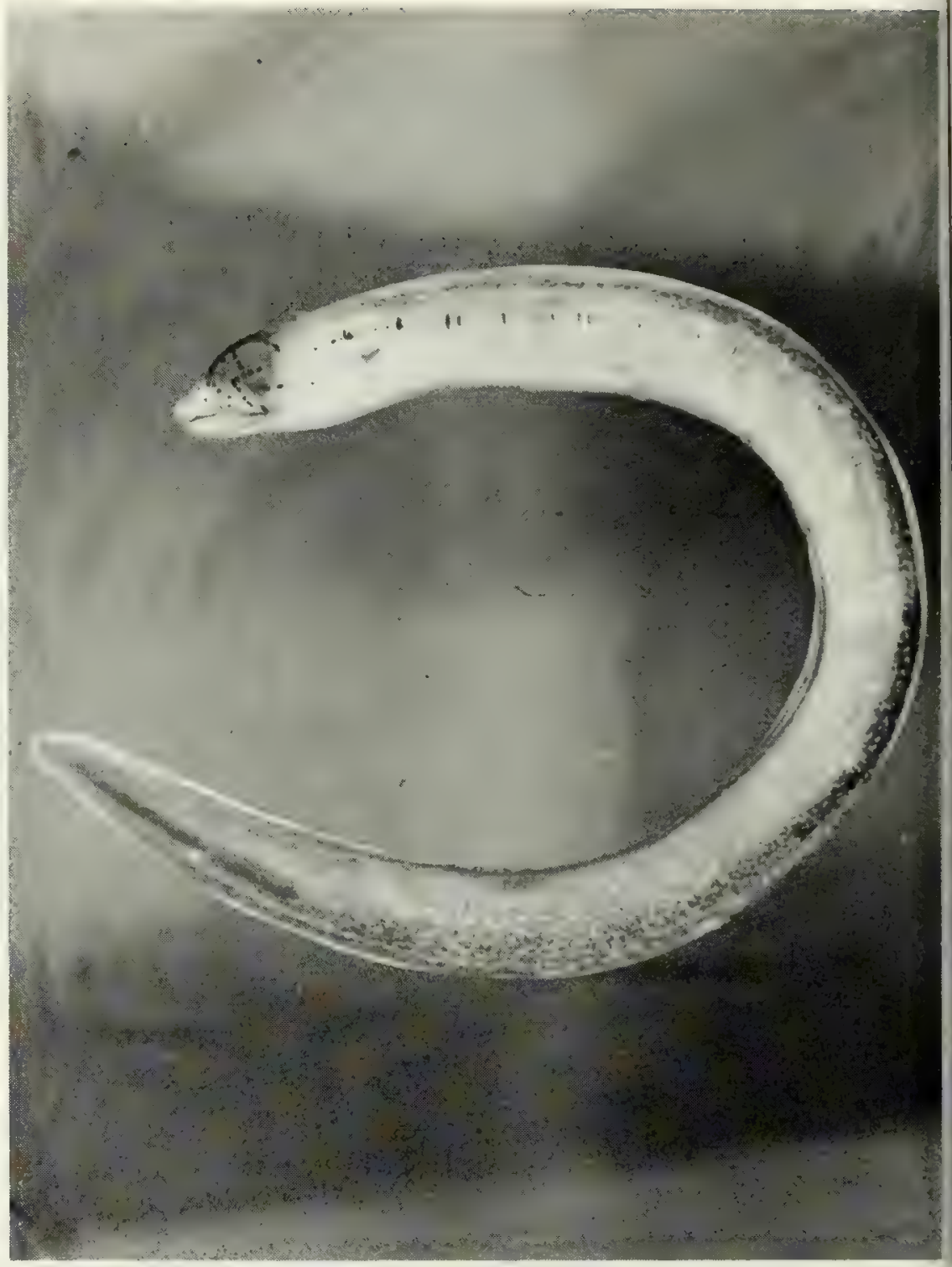

Fig. 31. Gymnothorax griseus, $365 \mathrm{~mm}$ SL, Peros Banhos.

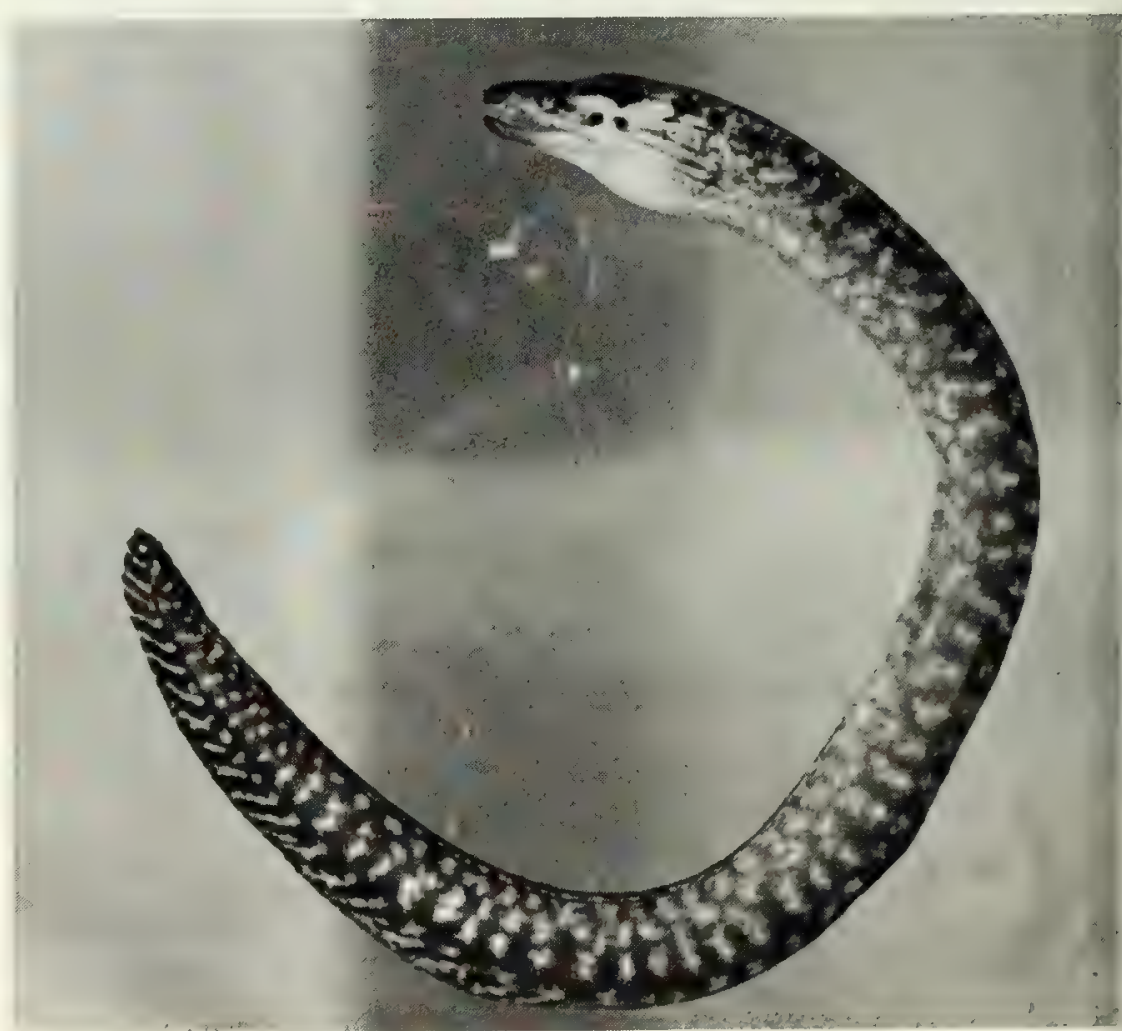

FIG. 33. Gymnothorax margaritophorus, $292 \mathrm{~mm}$ SL, Salomon 


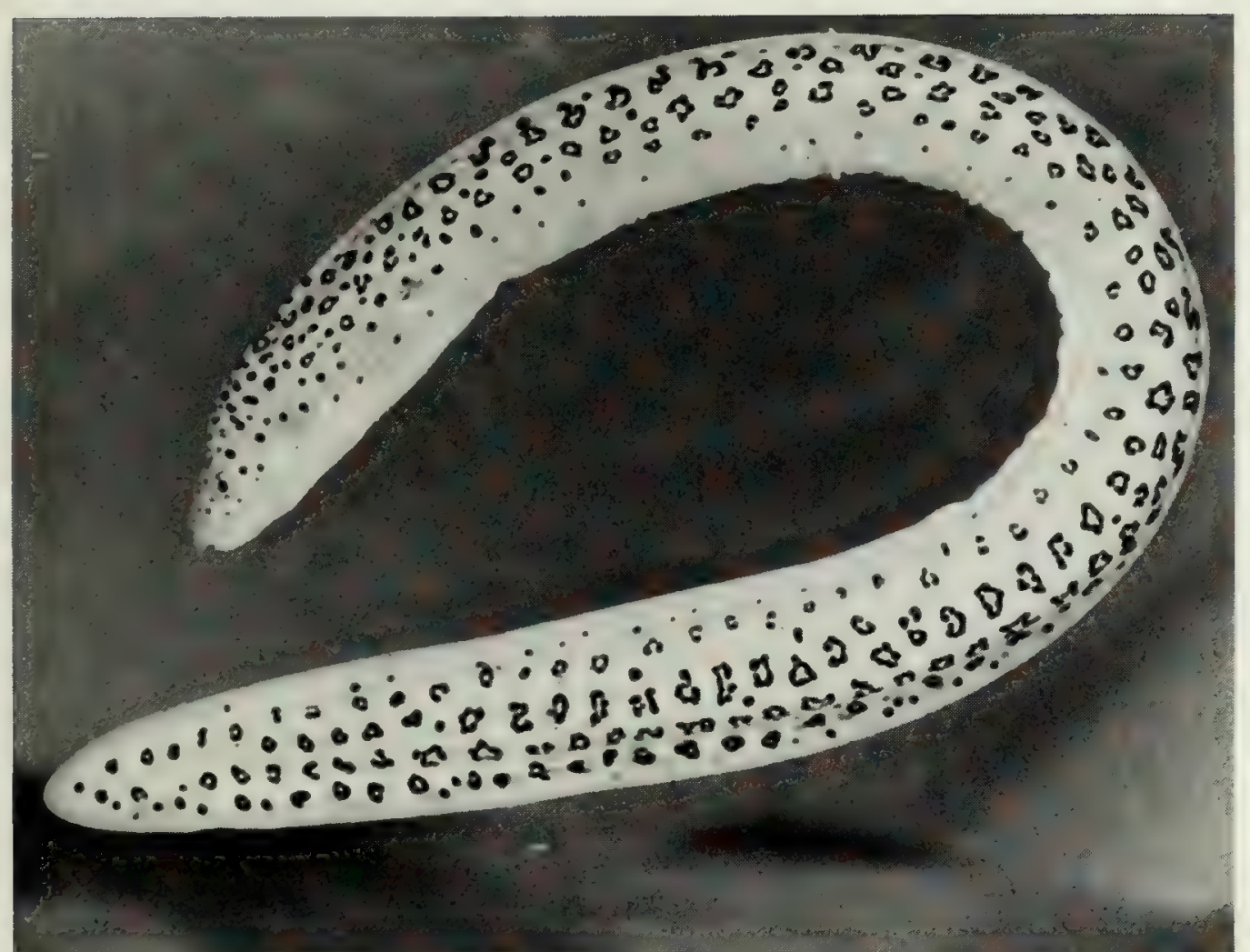

FIG. 34. Gymnothorax pictus, $181 \mathrm{~mm}$ SL, Peros Banhos.

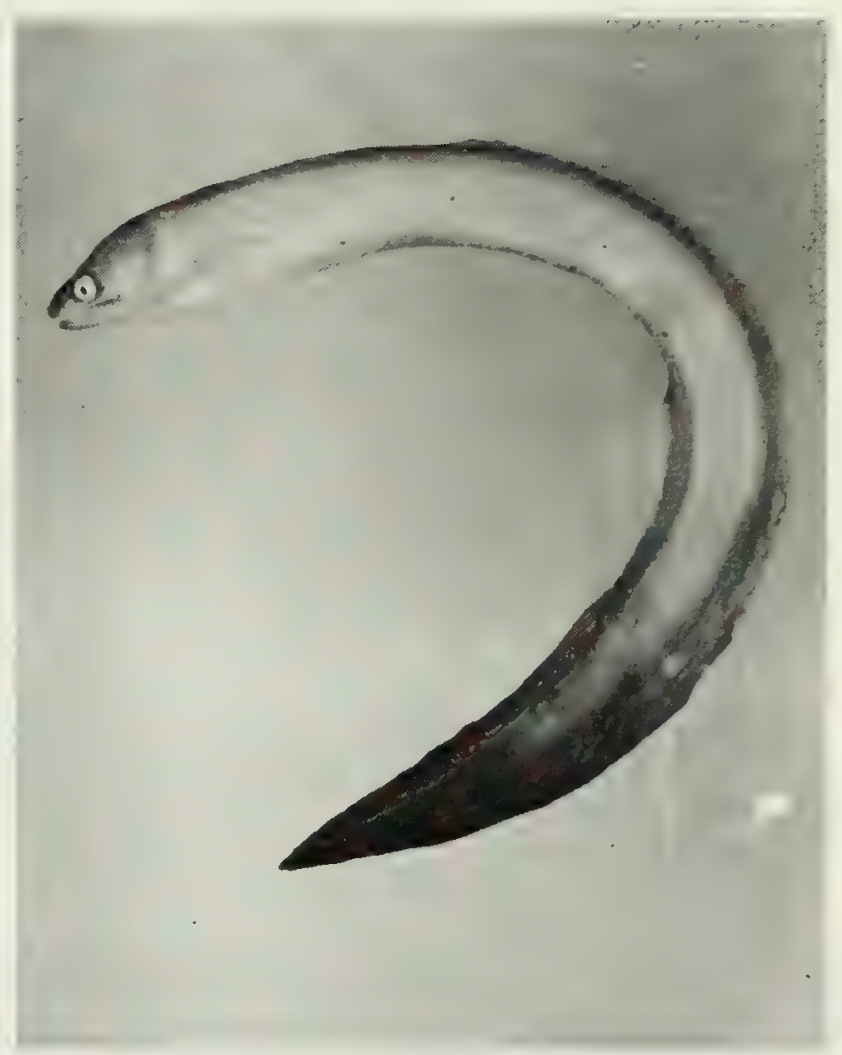

FIG. 35. Gymnothorax pindae, $189 \mathrm{~mm} \mathrm{SL}$, Peros Banhos.

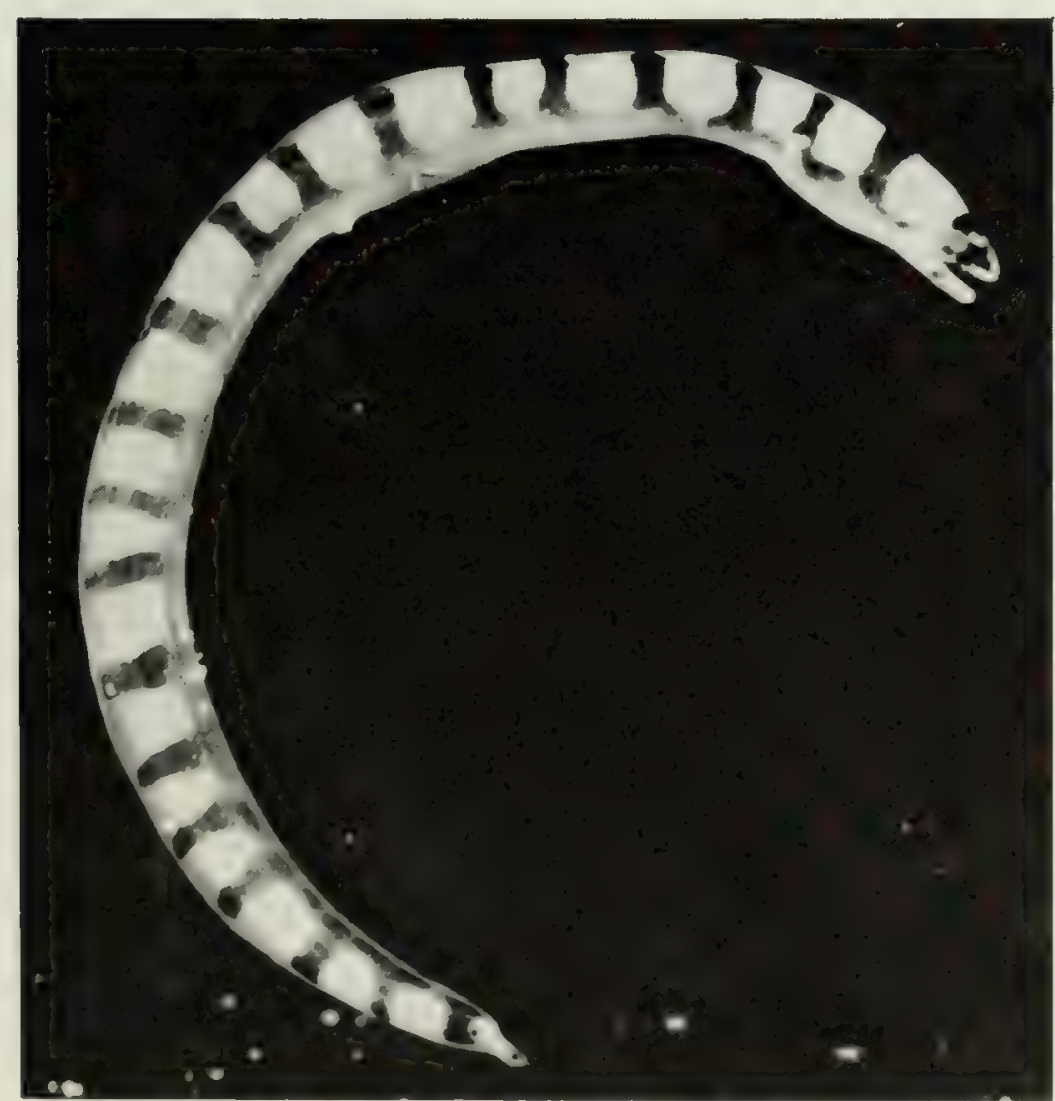

FIG. 36. Gymnothorax rueppelliae, $69 \mathrm{~mm} \mathrm{SL}$, Eagle Island.

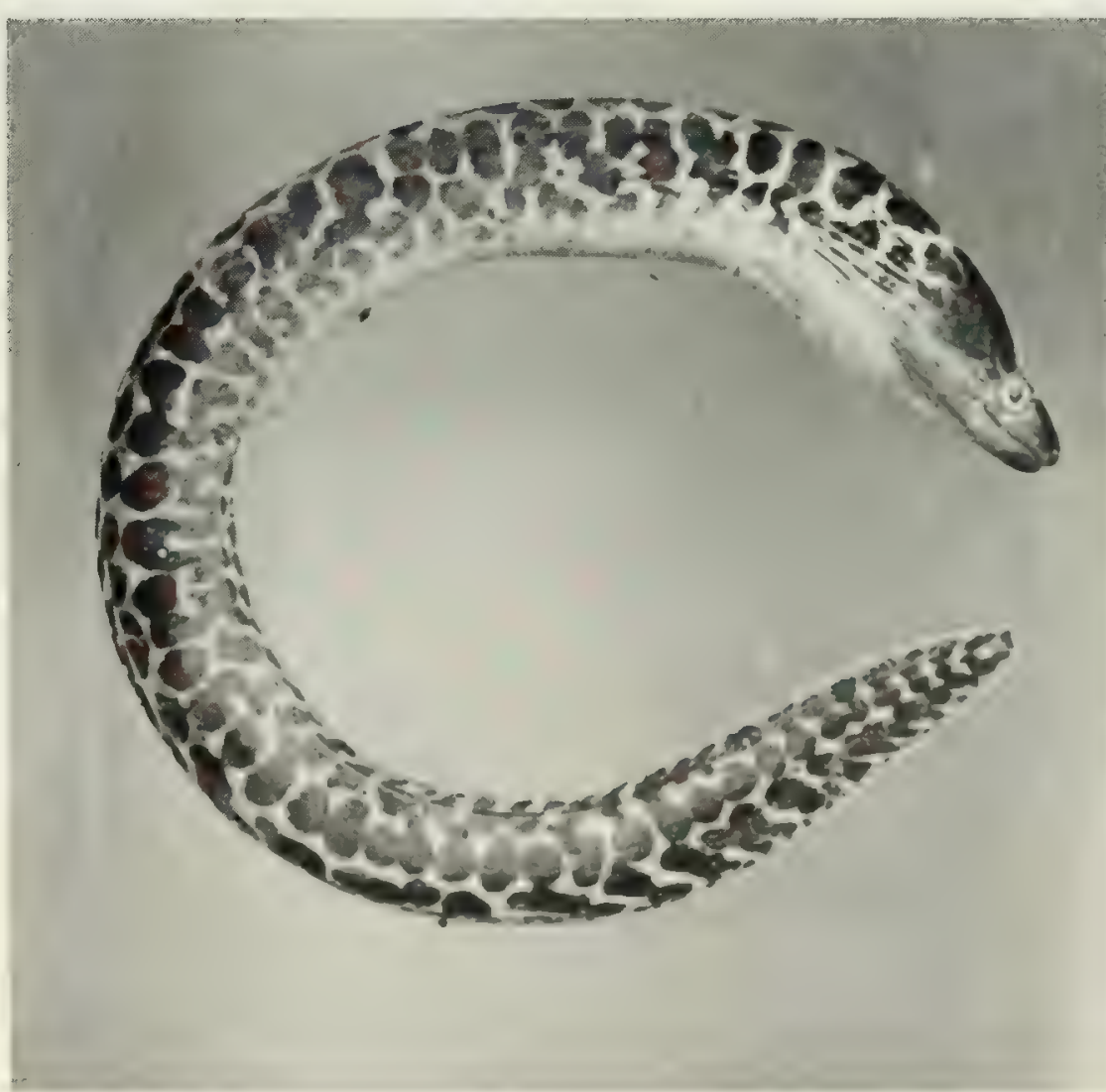

FIG. 37. Gymnothorax undulatus, $255 \mathrm{~mm} \mathrm{SL}$, Peros Banhos. 


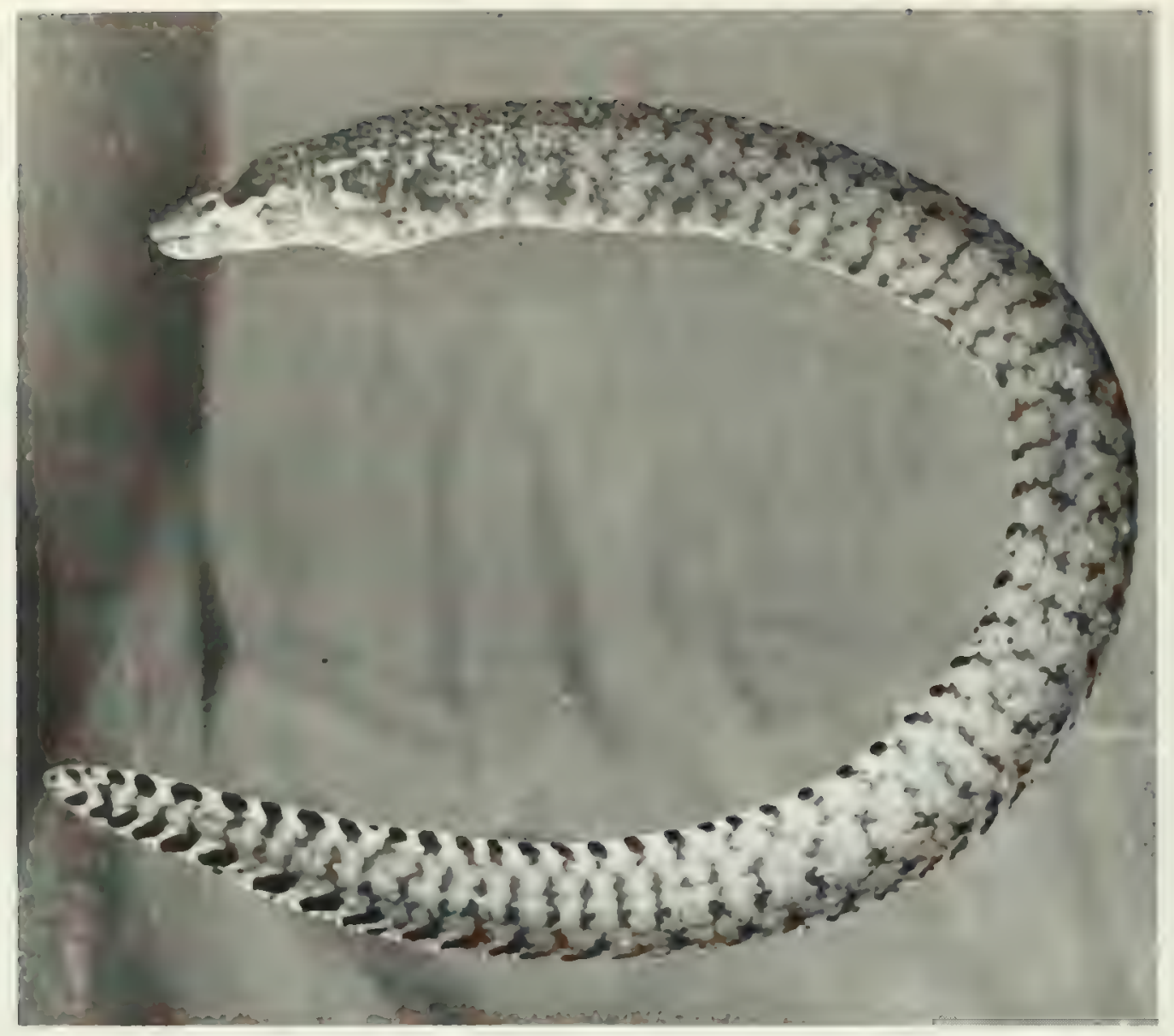

FIG. 38. Gymnothorax zonipectis, $195 \mathrm{~mm}$ SL, Peros Banhos.

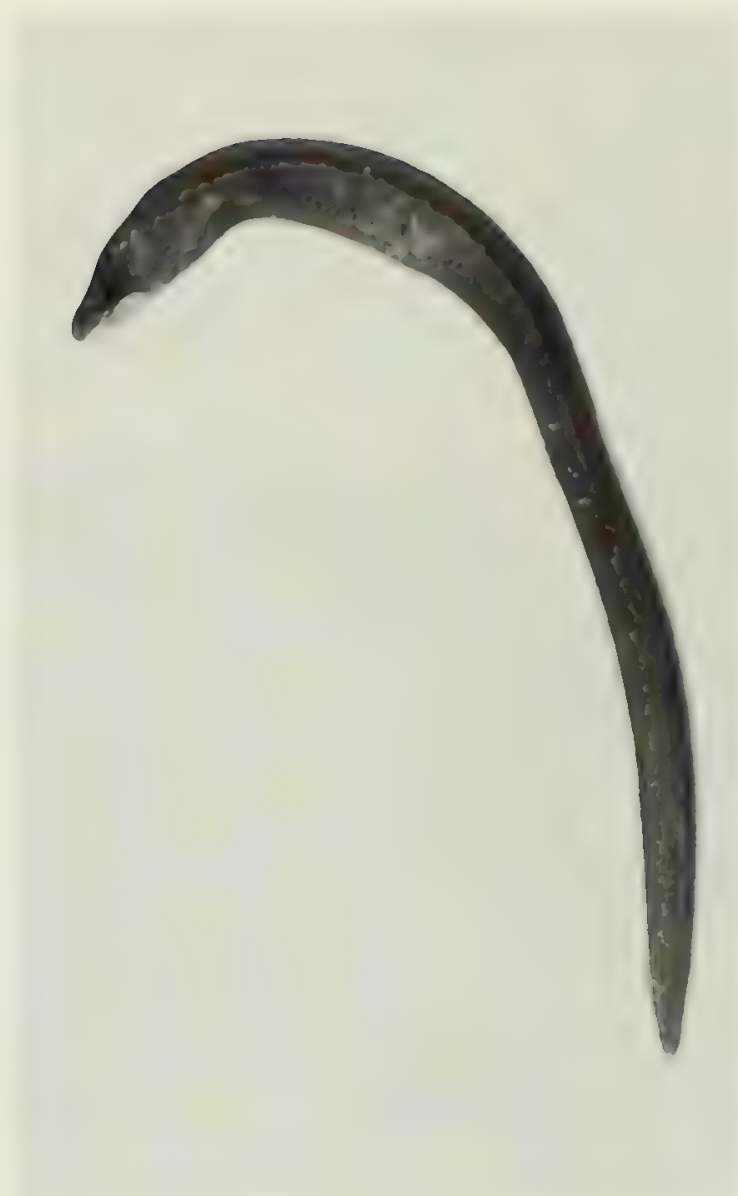

FIG. 39. Gymnothorax sp. 4, (preserved) $47 \mathrm{~mm}$ SL, Eagle Island. Photo by A. Strange.

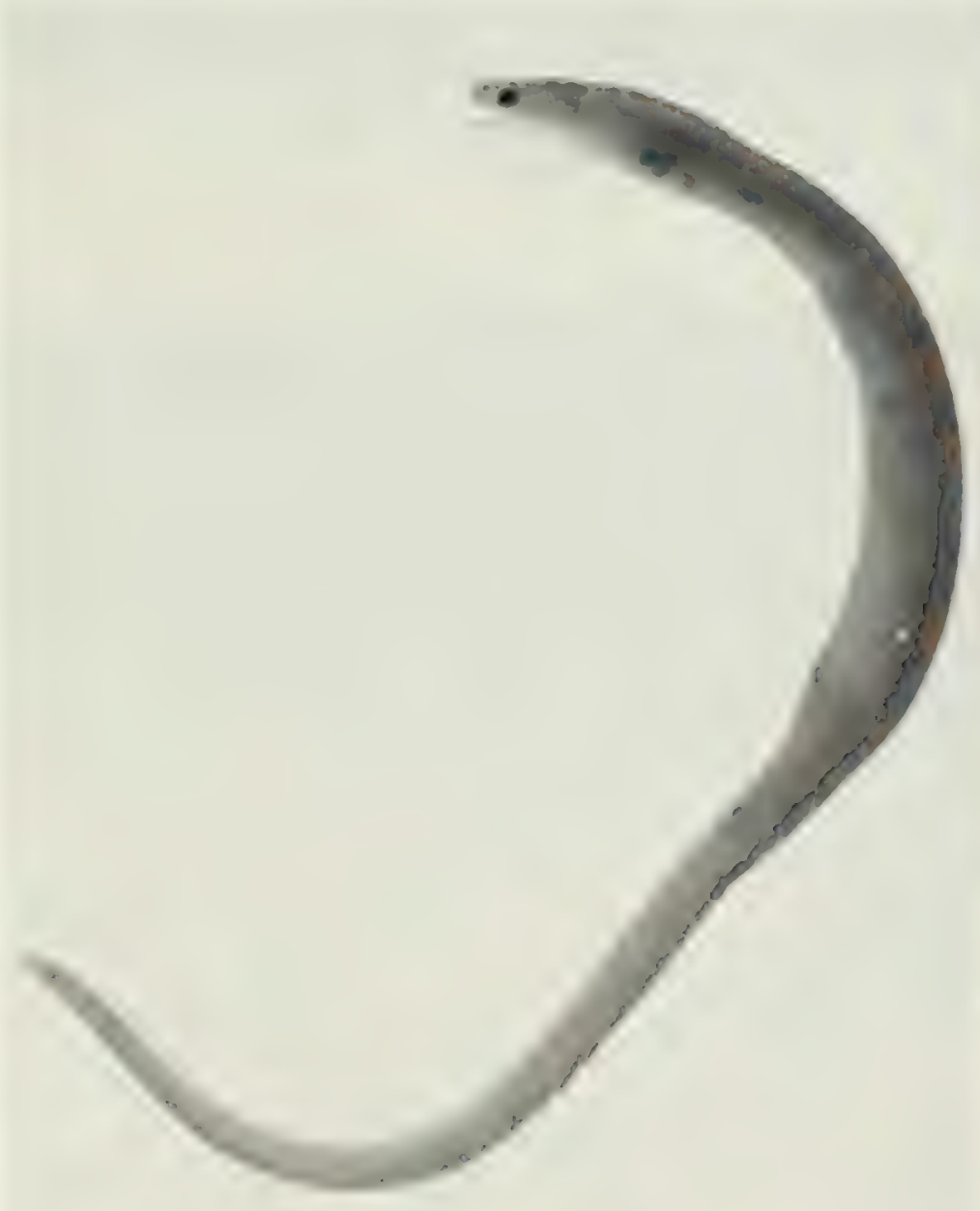

Fig. 40. Uropterygius concolor, (preserved) $136 \mathrm{~mm} \mathrm{SL}$, Salomon. Photo by A. Strange.

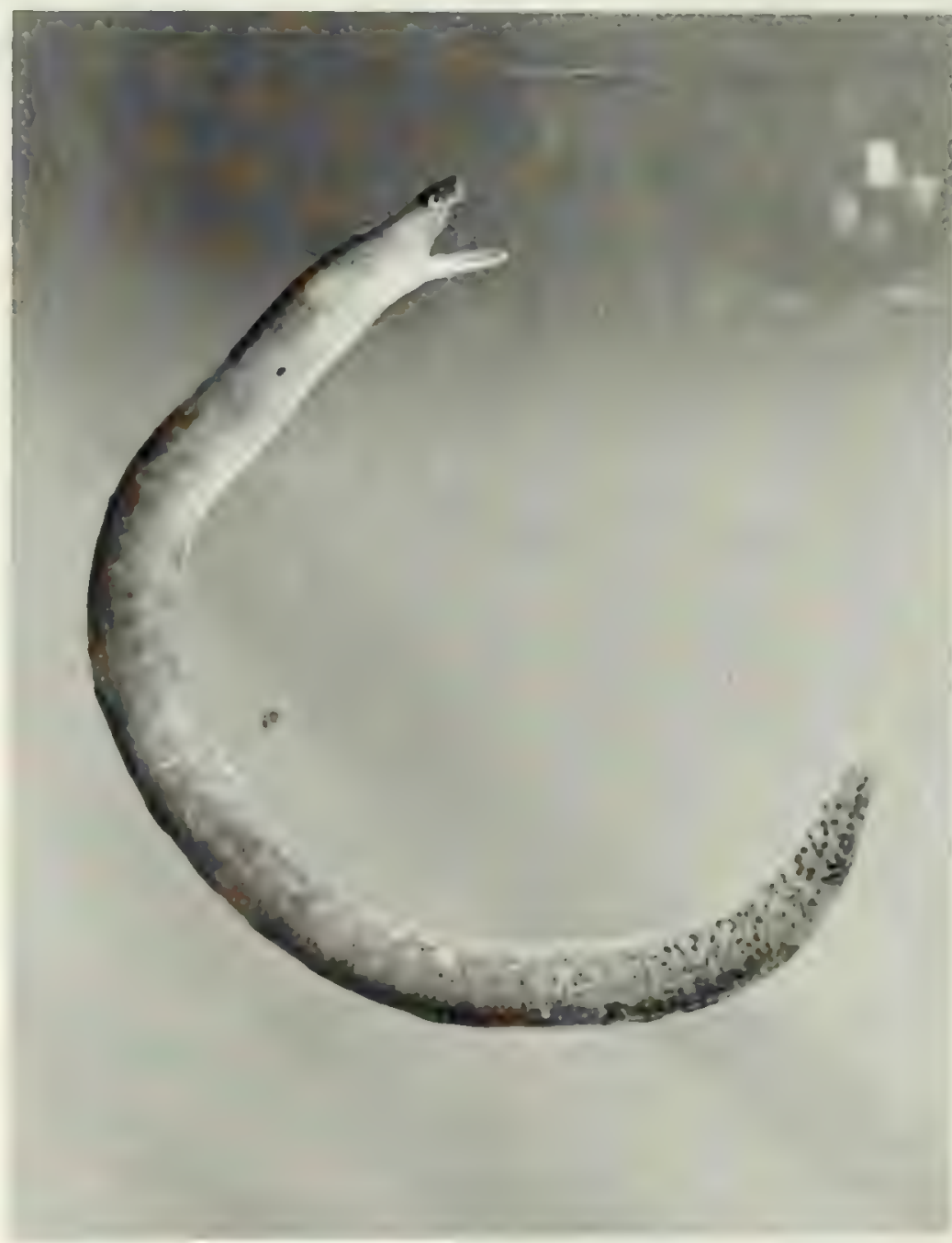

FIG. 41. Uropterygius fuscoguttatus, $161 \mathrm{~mm}$ SL, Salomon. 


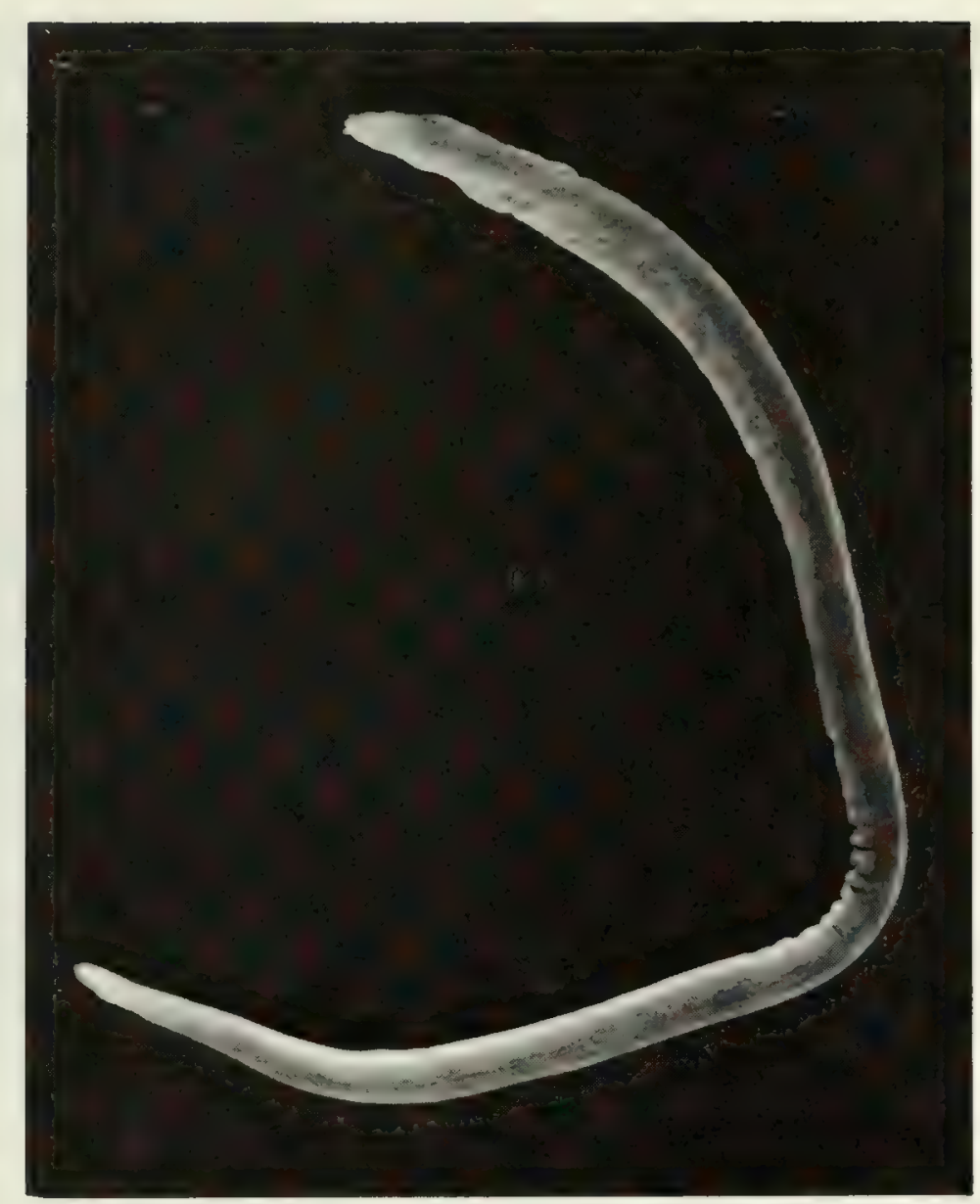

FIG. 42. Uropterygius inornatus, (preserved) $105 \mathrm{~mm}$ SL, Salomon. Photo by A. Strange.

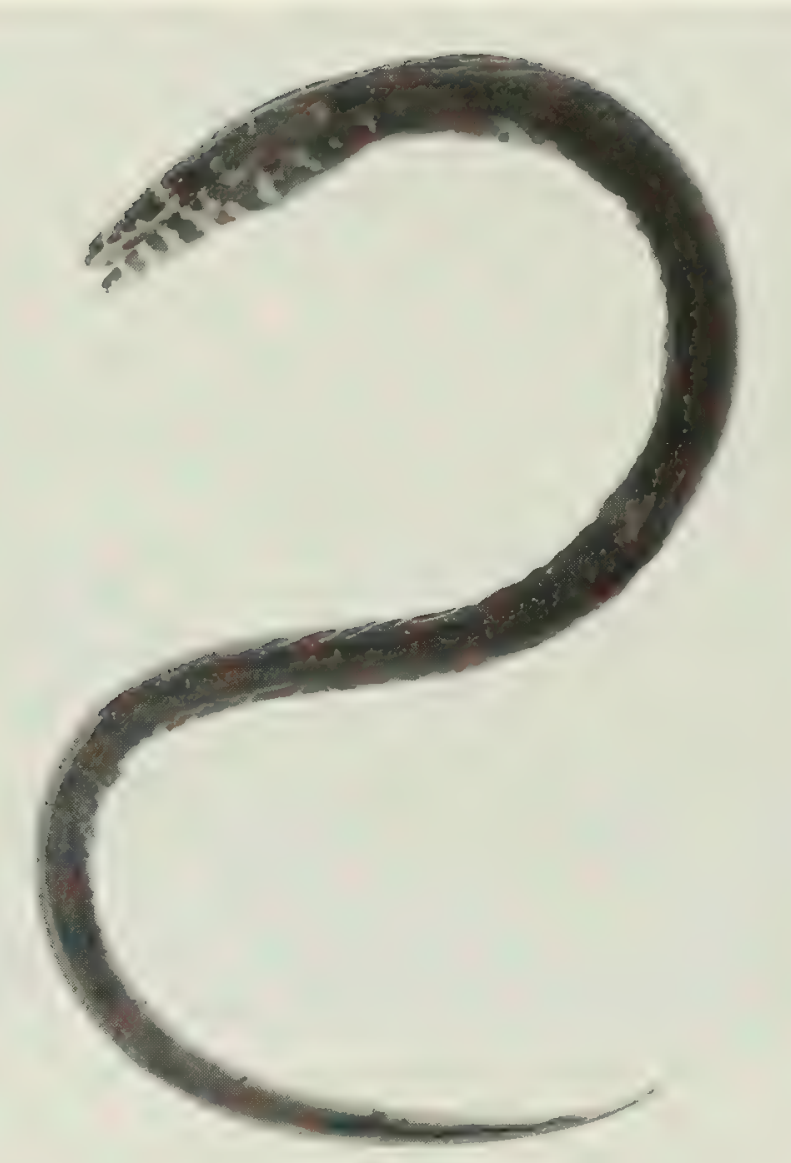

FIG. 43. Uropterygius kamar, (preserved) $168 \mathrm{~mm} \mathrm{SL,}$ Peros Banhos. Photo by A. Strange.

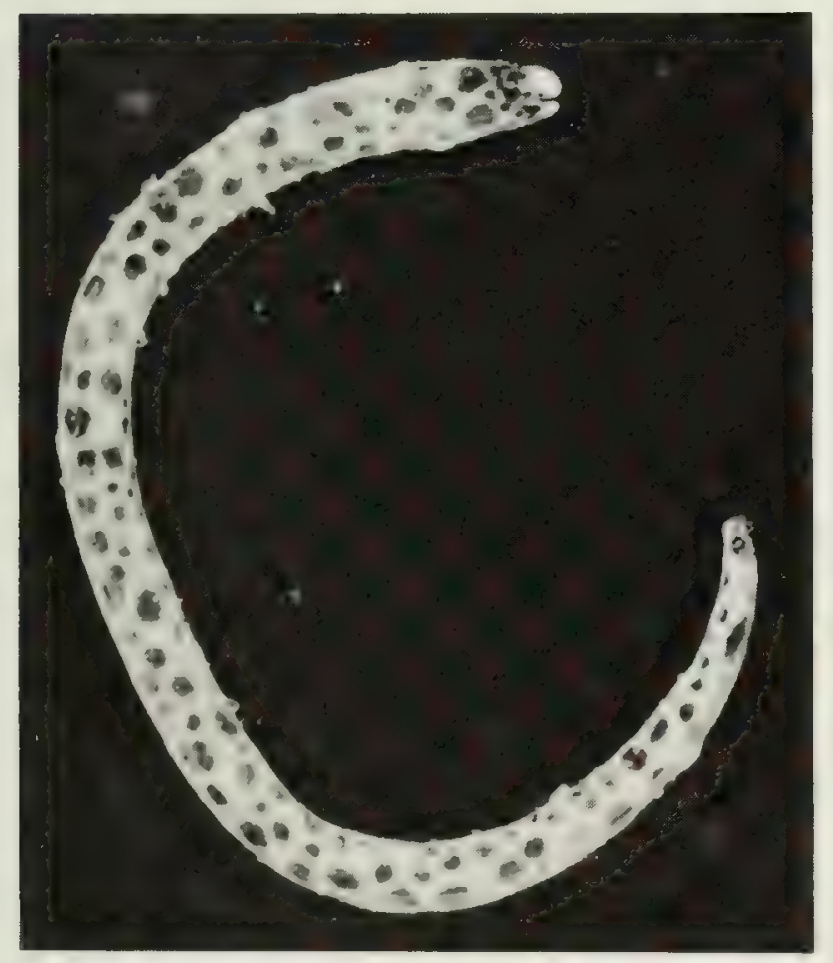

FIG. 44. Uropterygius polyspilus, $211 \mathrm{~mm} \mathrm{SL}$, Eagle Island.

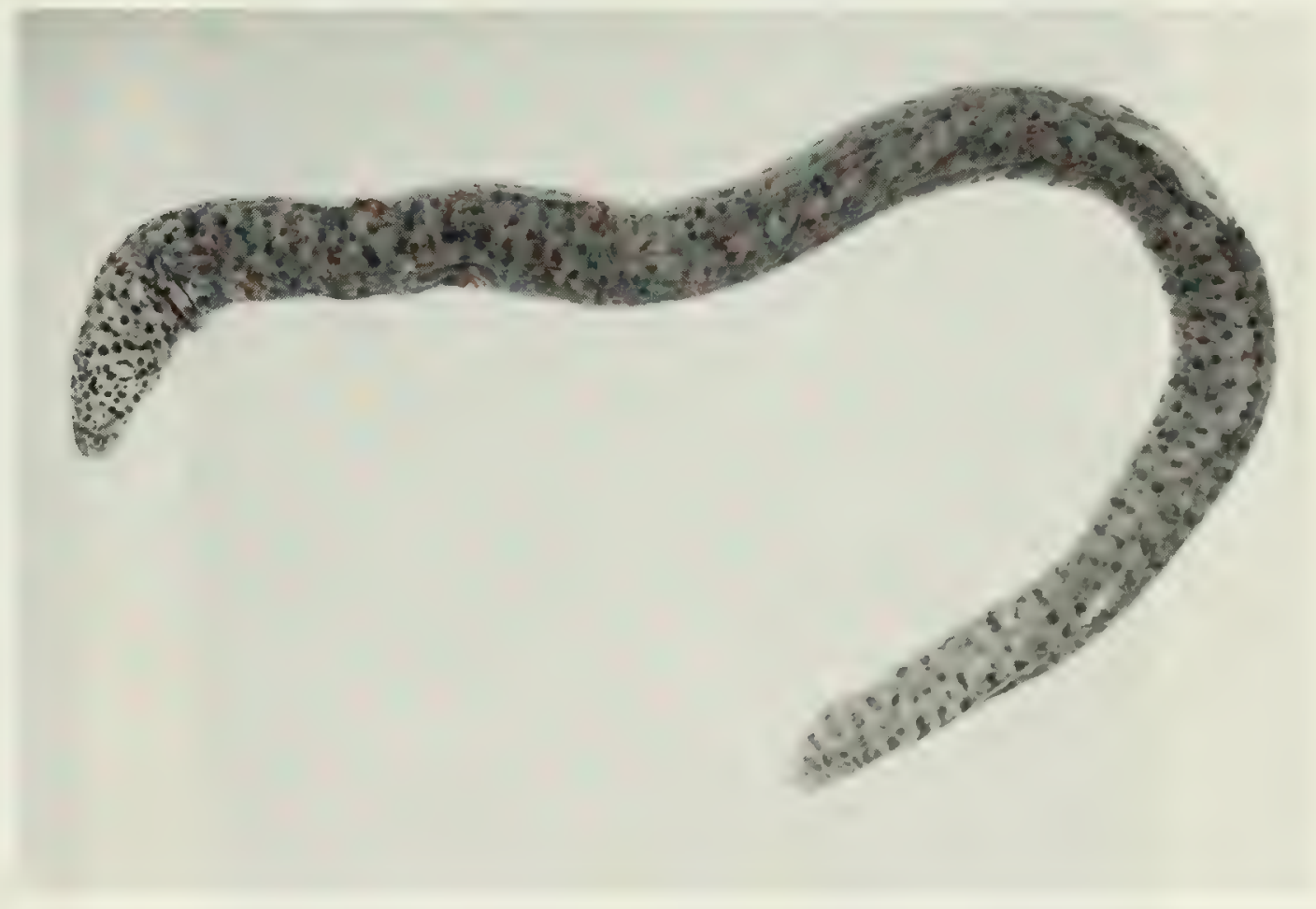

FIG. 45. Uropterygius supraforatus, (preserved) $269 \mathrm{~mm} \mathrm{SL}$, Peros Banhos. Photo by A. Strange. 


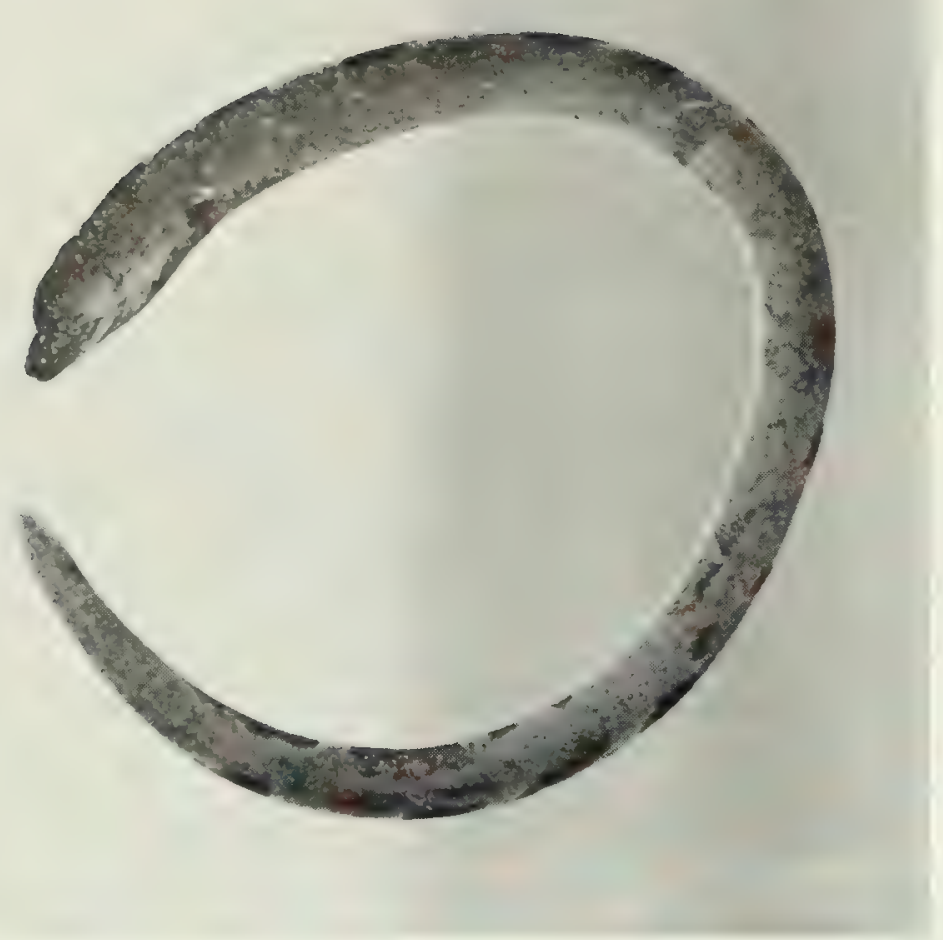

FIG. 46. Uropterygius xanthopterus, $343 \mathrm{~mm}$ SL, Salomon.

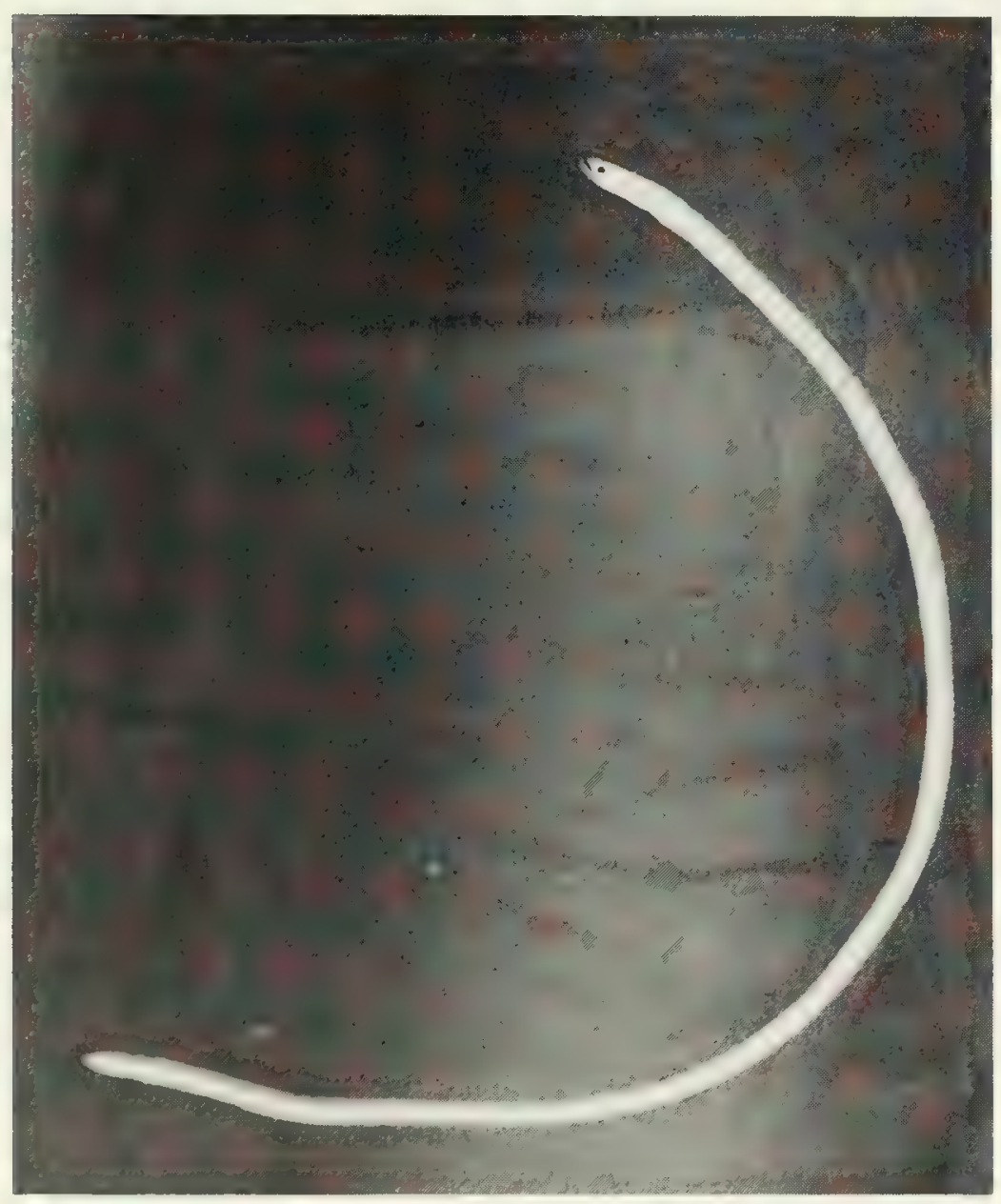

FIG. 48. Gorgasia maculata, 283 mm SL, Peros Banhos.

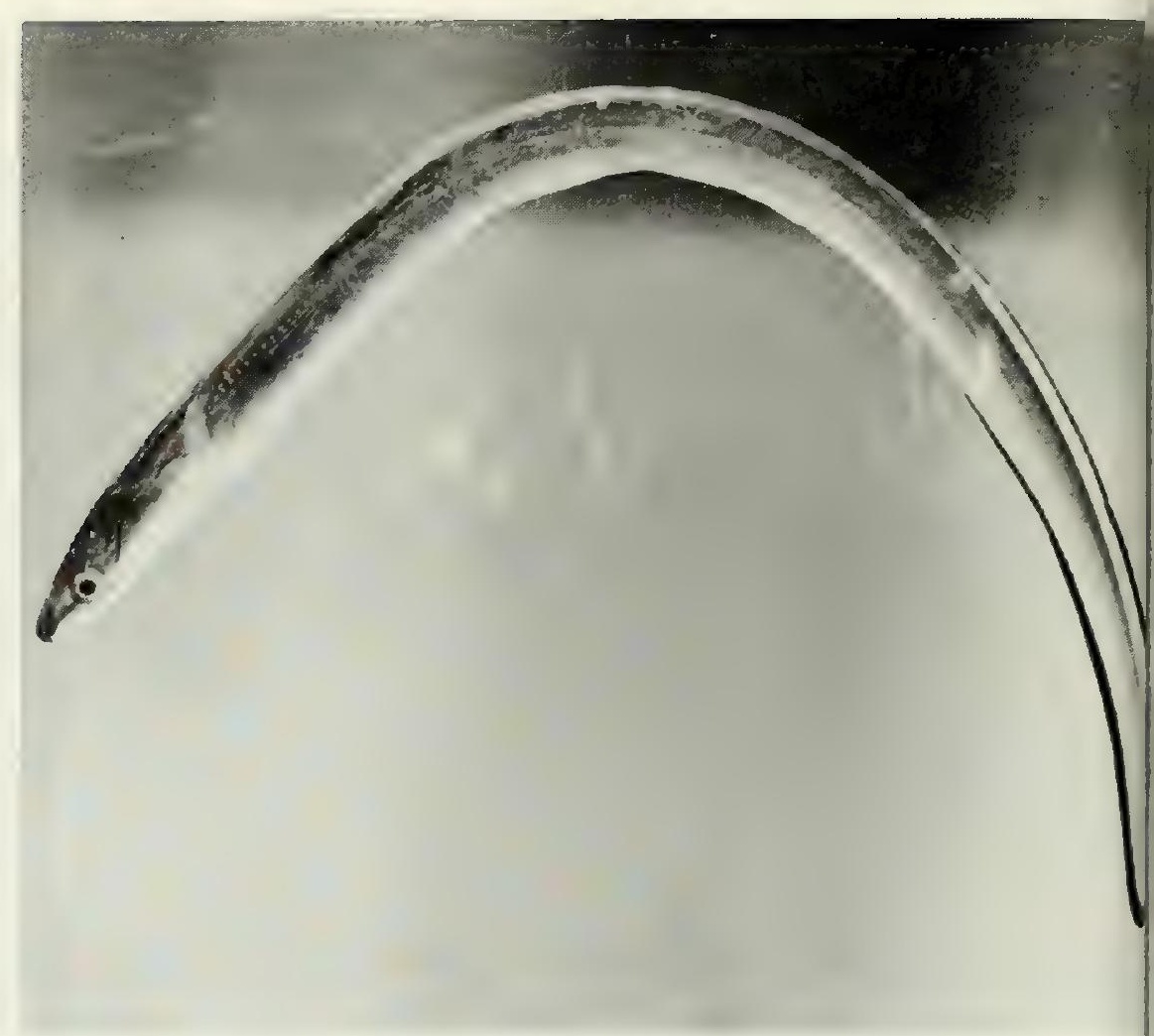

Fig. 47. Conger cinereus, $157 \mathrm{~mm}$ SL, Peros Banhos.

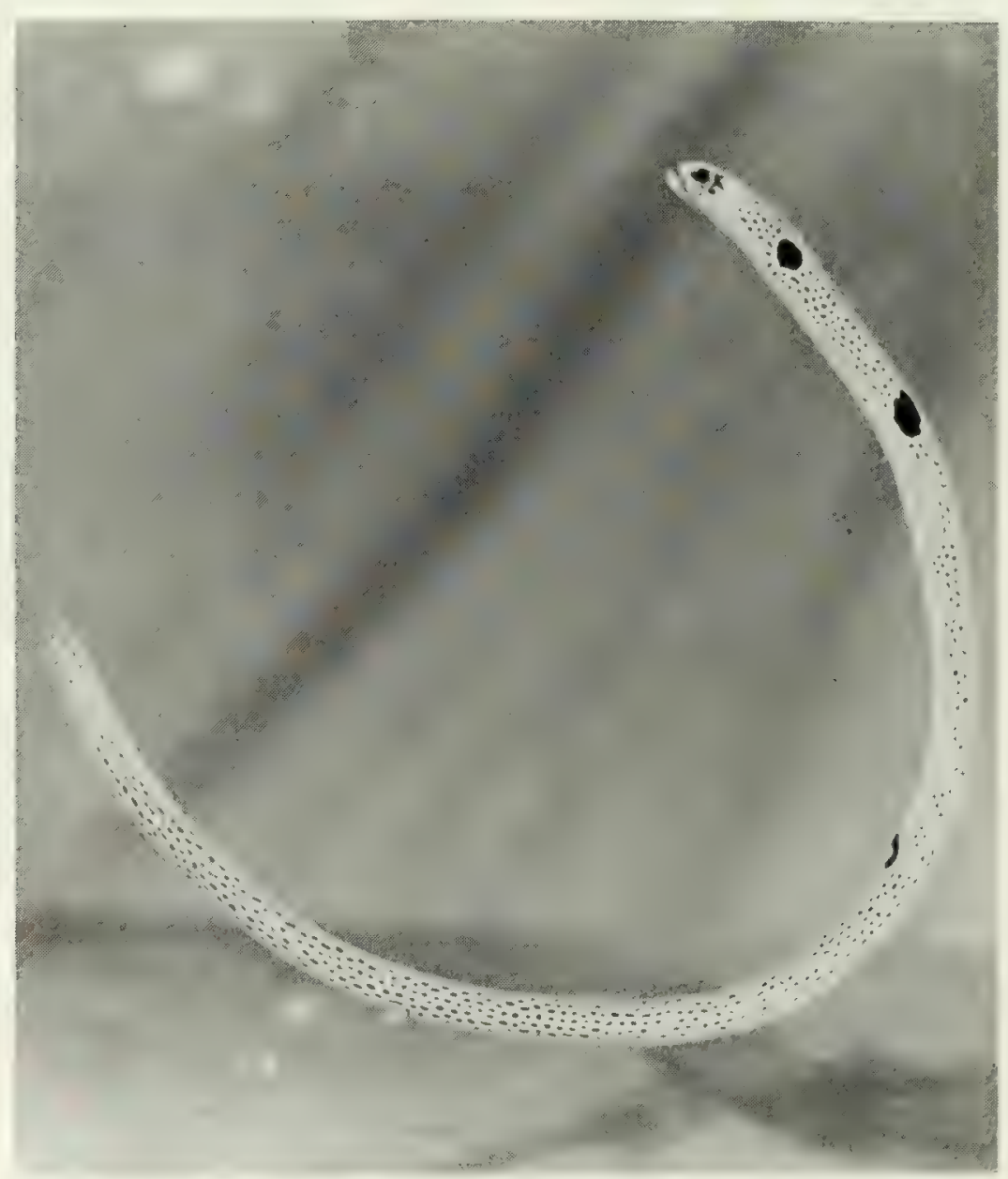

FiG. 49. Heteroconger hassi, $139 \mathrm{~mm}$ SL, Peros Banhos. 


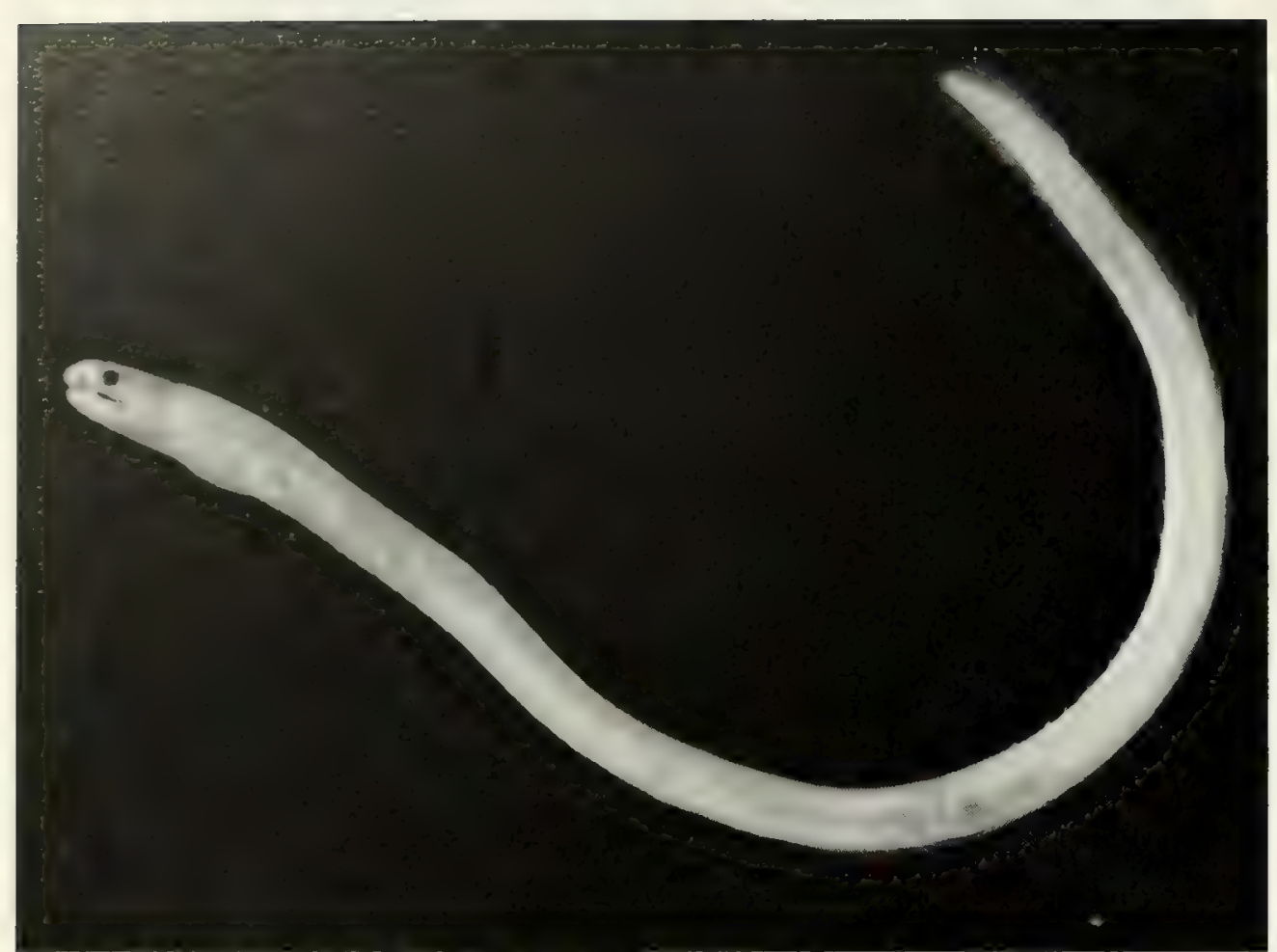

FIG. 54. Muraenichthys schultzei, (preserved) $82 \mathrm{~mm} \mathrm{SL,} \mathrm{Salomon.} \mathrm{Photo}$ by A. Strange.

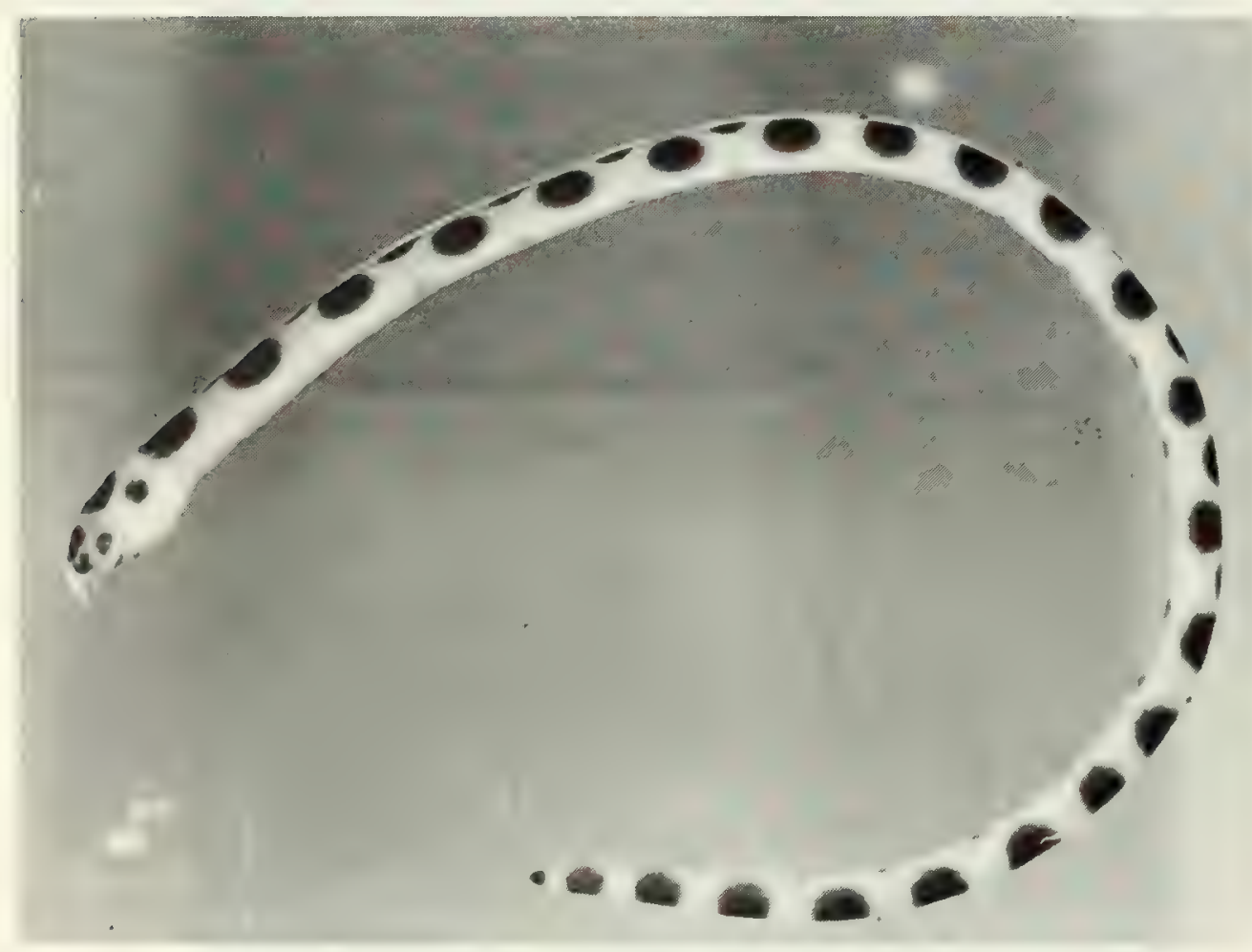

FIG. 56. Myrichthys maculosus, $276 \mathrm{~mm}$ SL, Peros Banhos.

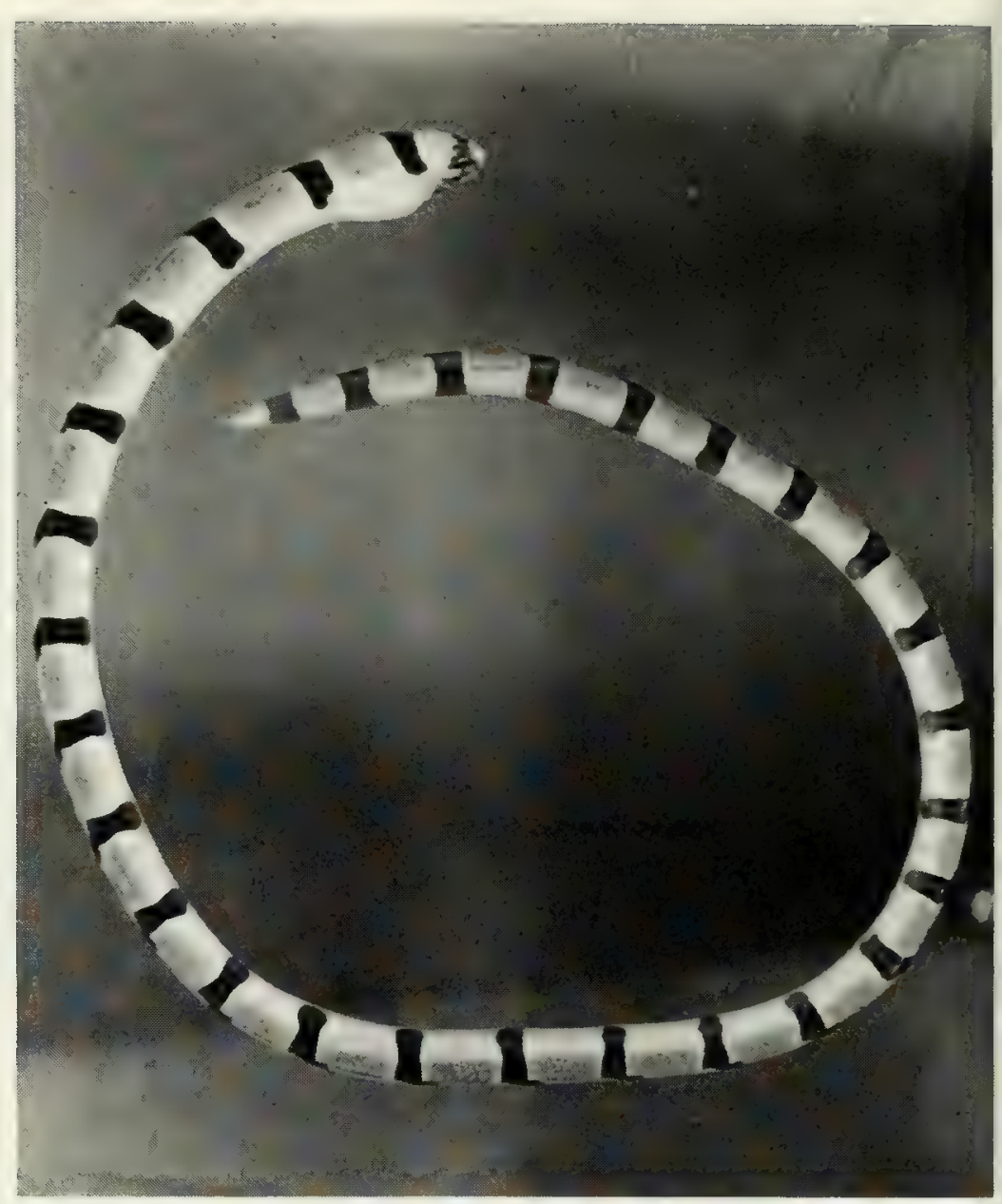

FIG. 55. Myrichthys colubrinus, $565 \mathrm{~mm} \mathrm{SL}$, Peros Banhos.

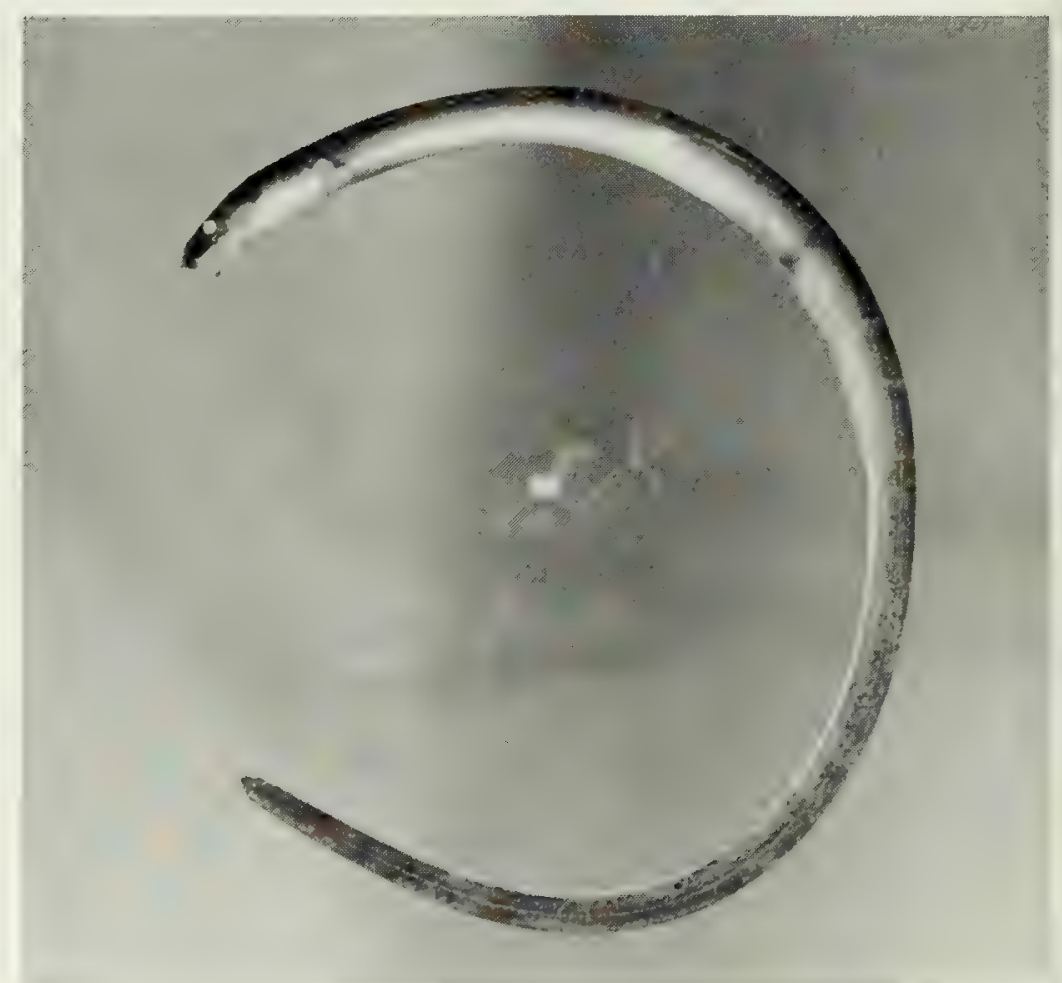

FIG. 57. Ophisurus serpens, $233 \mathrm{~mm} \mathrm{SL}$, Peros Banhos. 


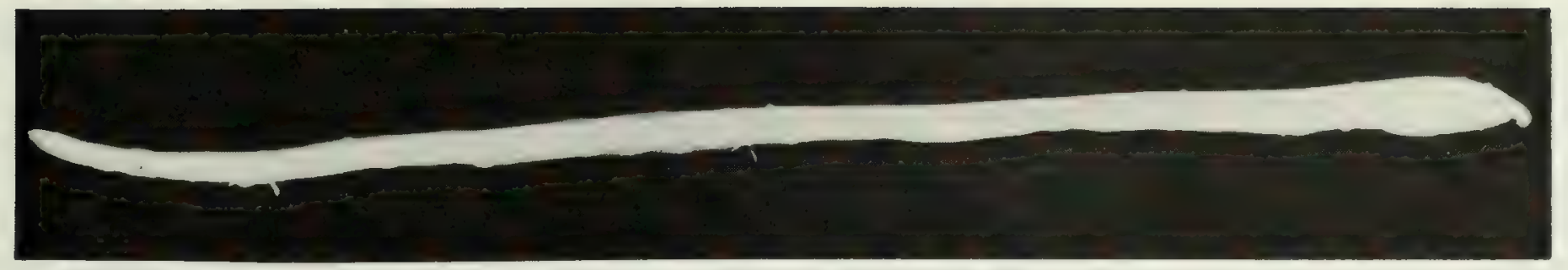

Fig. 58. Schismorhynchus labialis, $65 \mathrm{~mm}$ SL, Eagle Island.

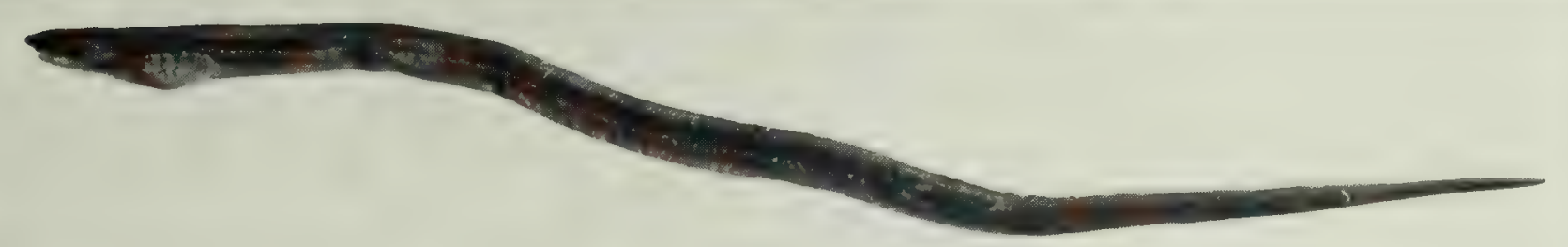

FIG. 59. Schultzidia johnstonensis, (preserved) $73 \mathrm{~mm} \mathrm{SL}$, Three Brothers. Photo by M. Burridge-Smith.

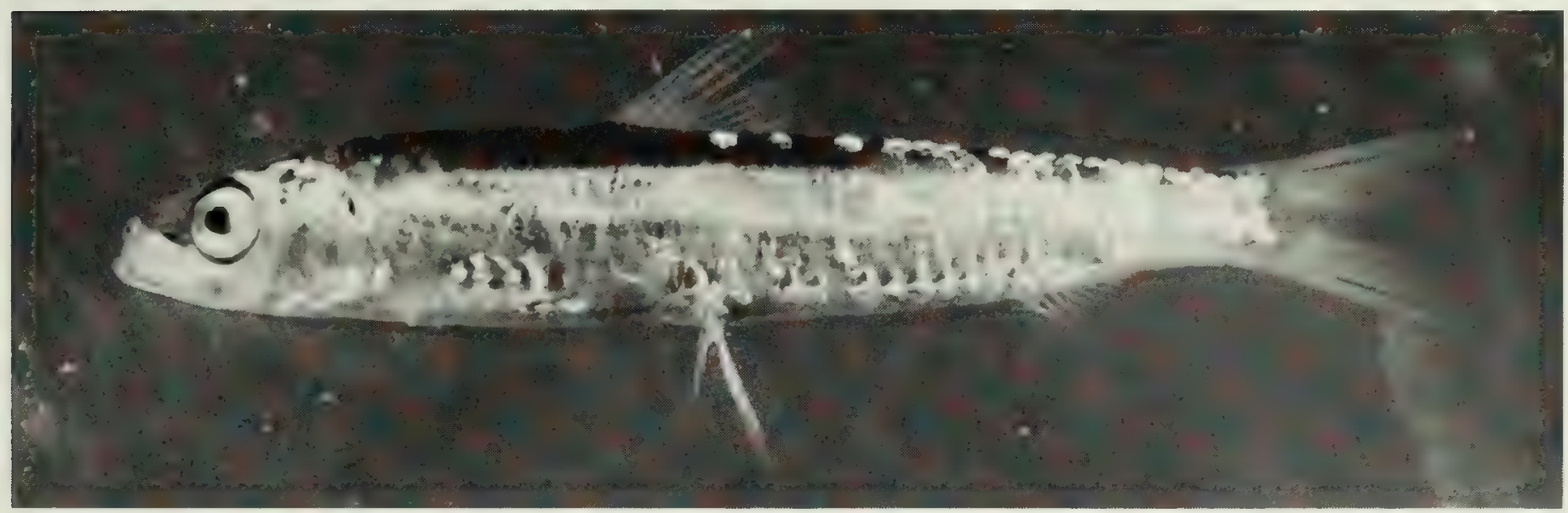

FIG. 60. Spratelloides delicatulus, $39 \mathrm{~mm} \mathrm{SL}$, Peros Banhos.

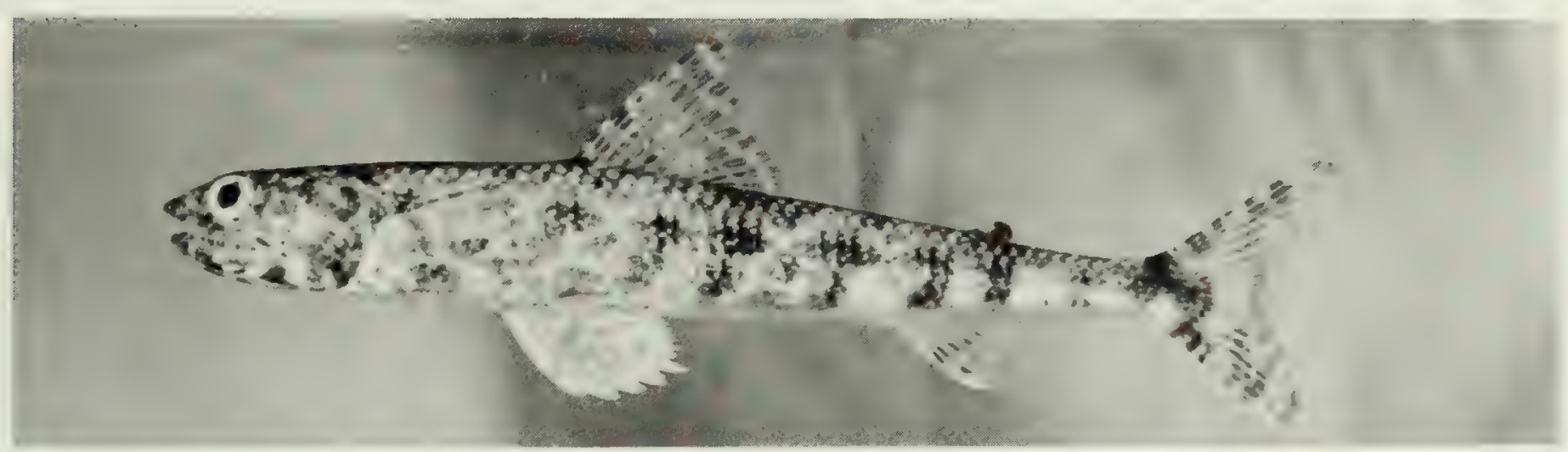

FIG. 61. Saurida gracilis, $115 \mathrm{~mm}$ SL, Peros Banhos.

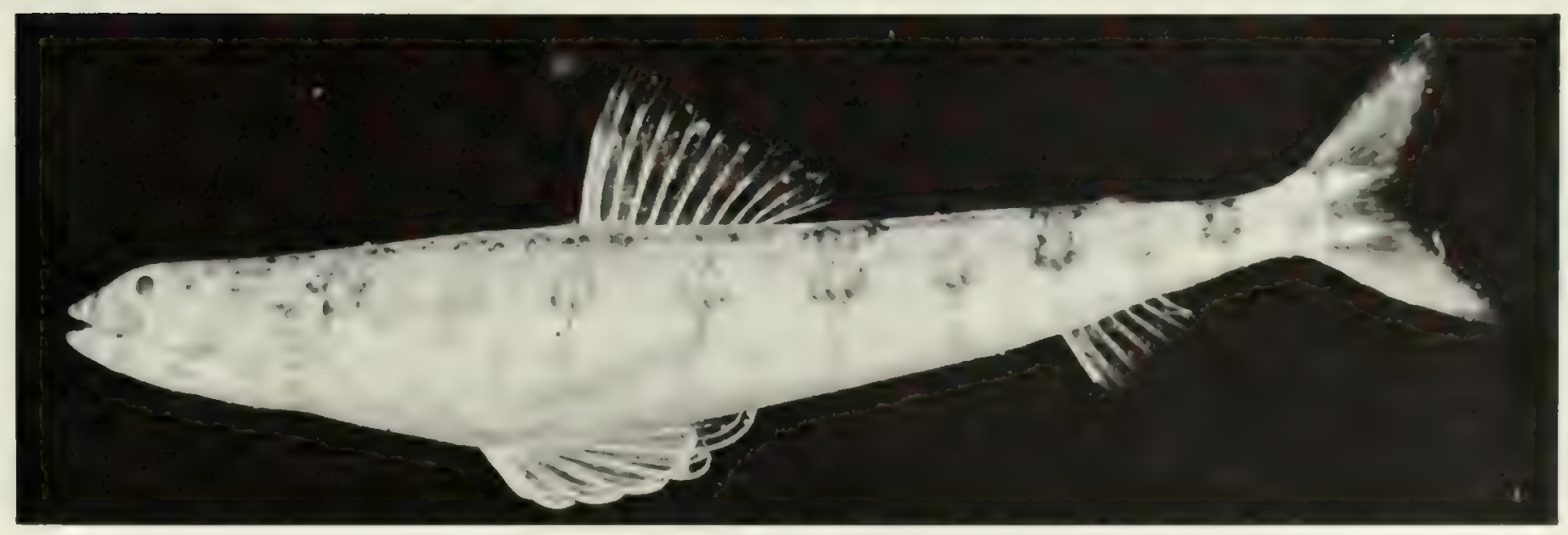

FIG. 62. Synodus variegatus, $96 \mathrm{~mm} \mathrm{SL}$, Eagle Island. 


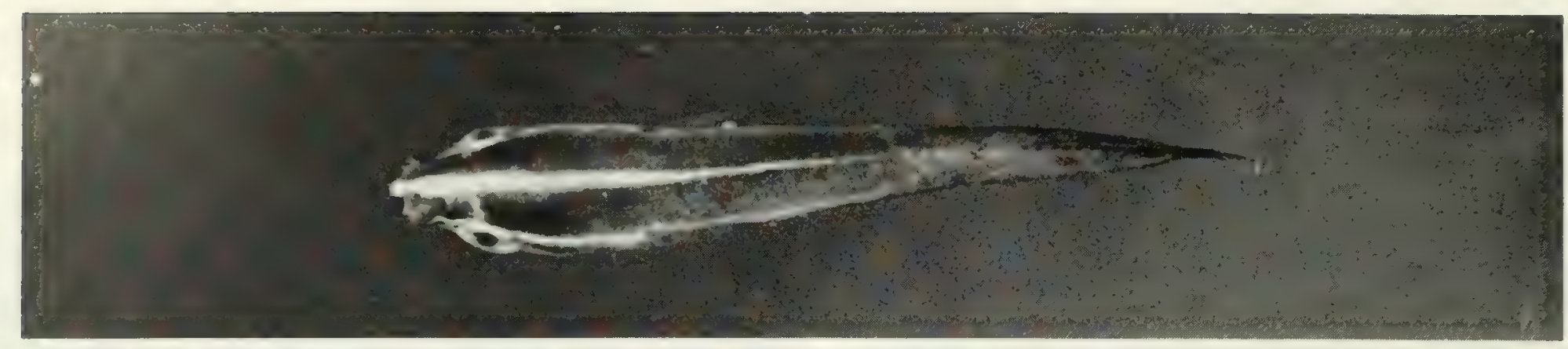

FIG. 63. Lepadichthys bolini, $15 \mathrm{~mm}$ SL, Peros Banhos.

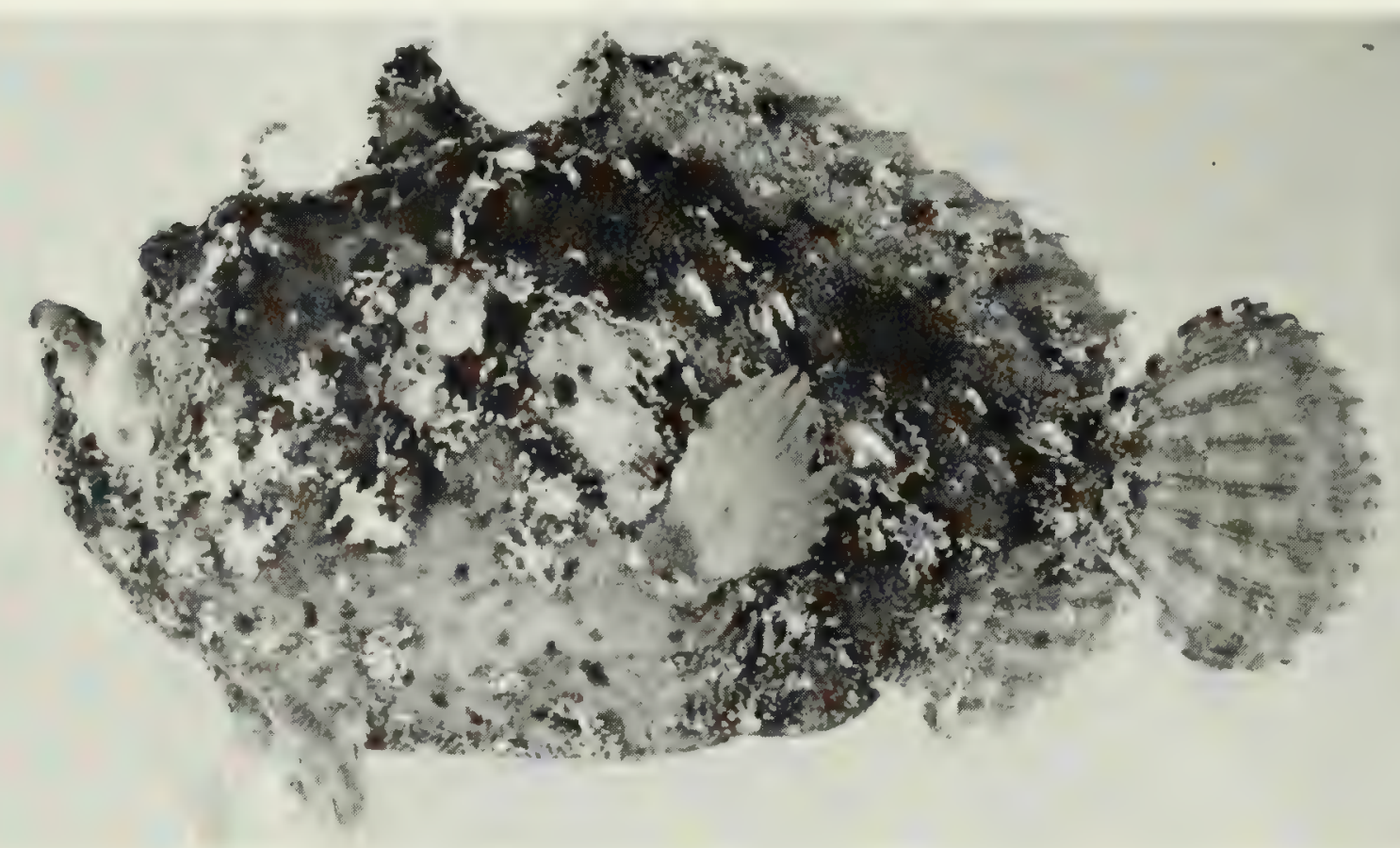

Fig. 64. Antennarius coccineus, $65 \mathrm{~mm} \mathrm{SL}$, Peros Banhos.

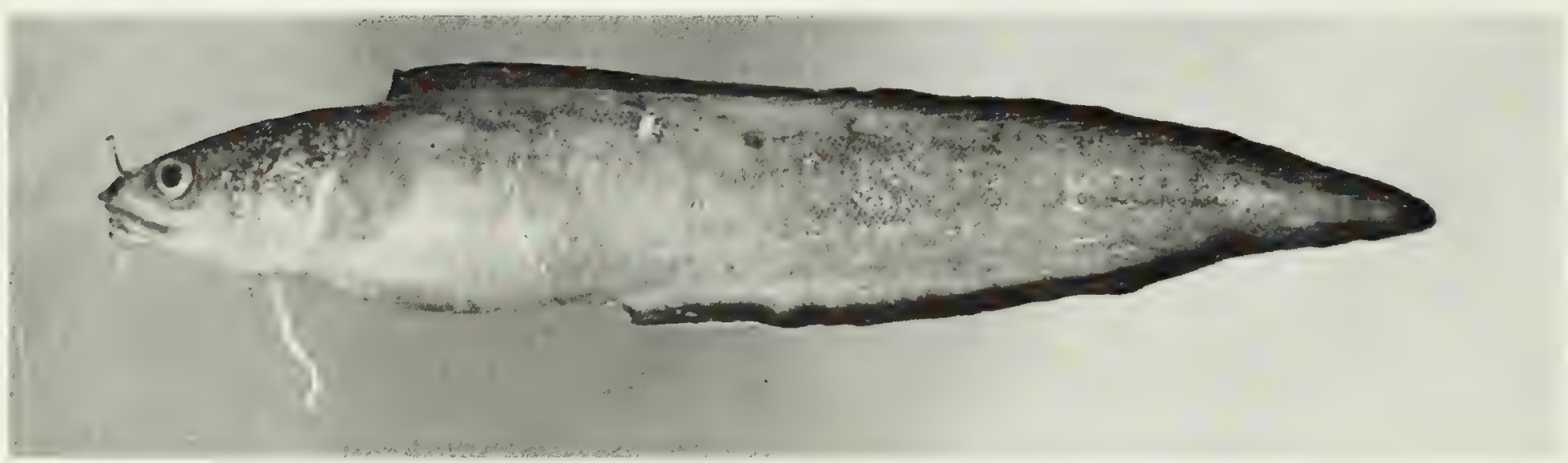

FIG. 65. Brotula multibarbata, $105 \mathrm{~mm}$ SL, Salomon.

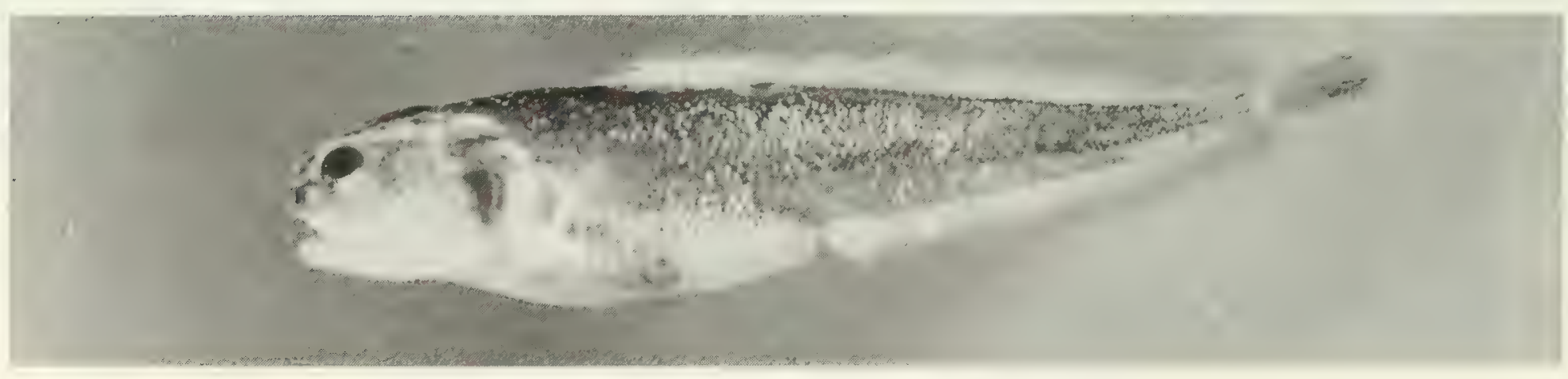

FIG. 66. Brosmophyciops pautzkei, $53 \mathrm{~mm} \mathrm{SL}$, Salomon. 


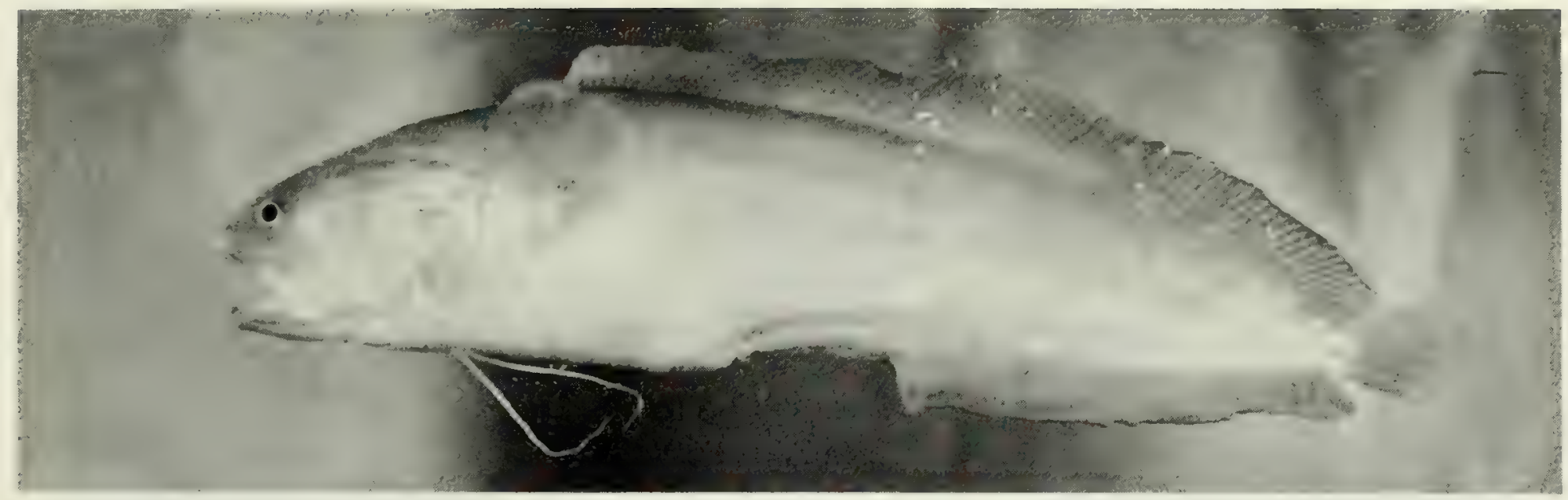

FIG. 67. Dinematichthys iluocoeteoides, $91 \mathrm{~mm} \mathrm{SL}$, Peros Banhos.

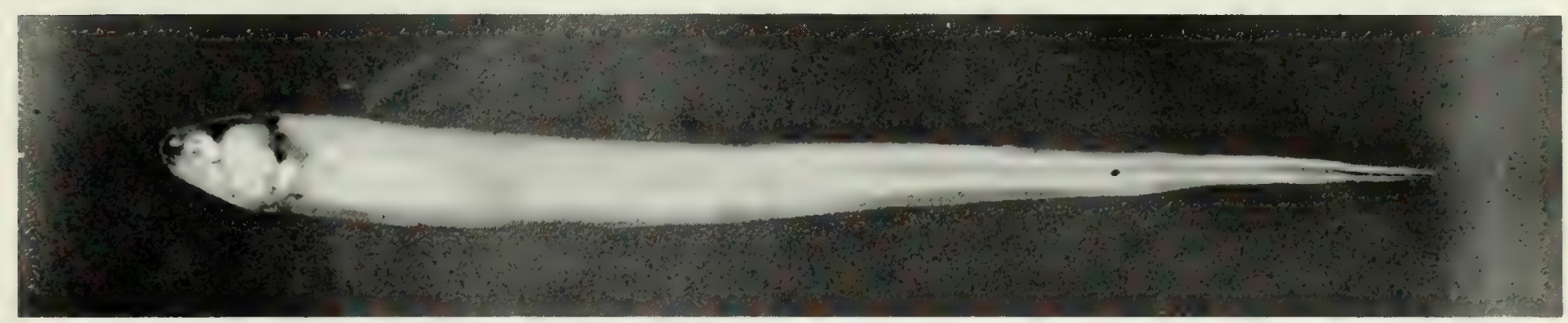

FIG. 68. Carapus homei, $125 \mathrm{~mm} \mathrm{SL}$, Peros Banhos.

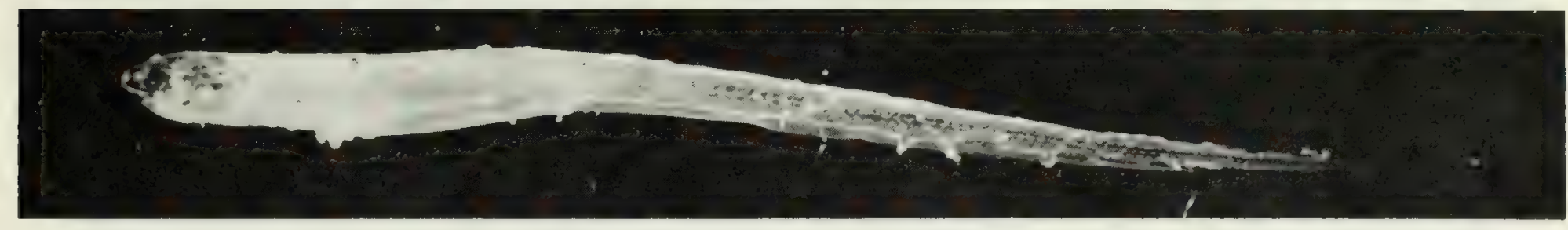

FIG. 69. Encheliophis gracilis, $73 \mathrm{~mm} \mathrm{SL}$, Eagle Island.

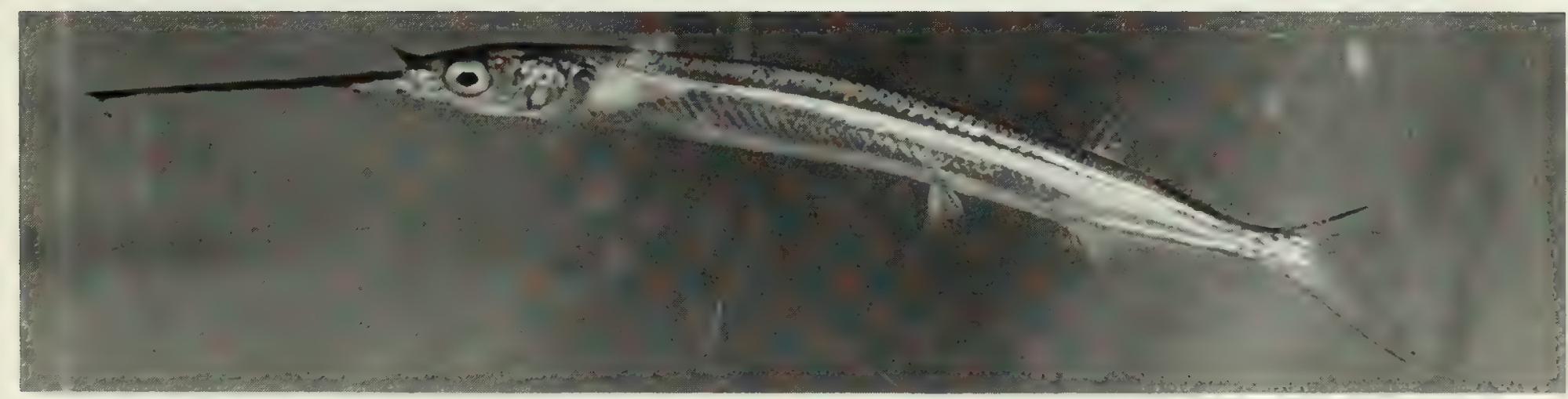

Fig. 70. Hyporhamphus affinis, $77 \mathrm{~mm}$ SL, Peros Banhos.

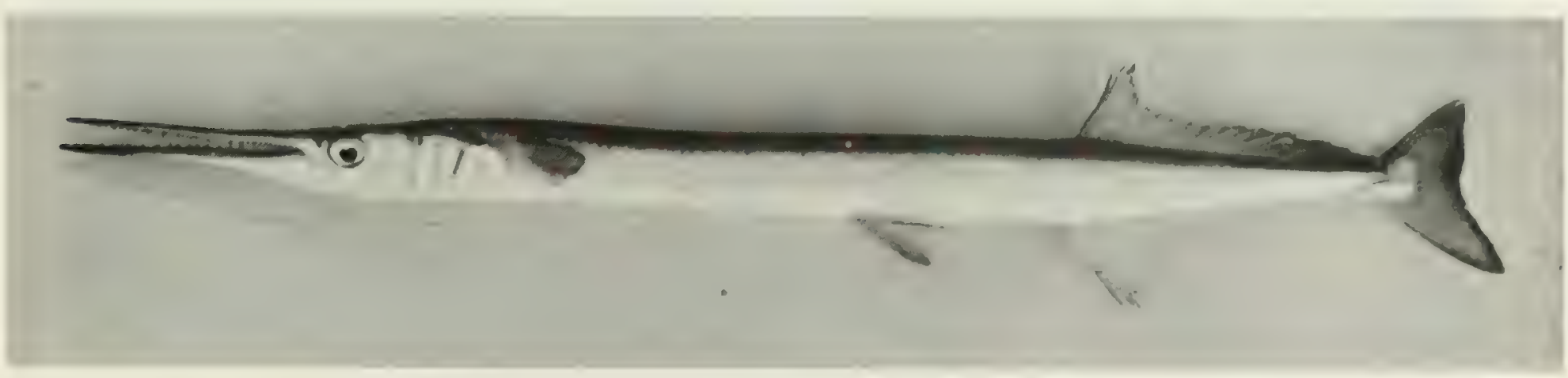

FIG. 71. Tylosurus crocodilus crocodilus, $404 \mathrm{~mm} \mathrm{SL}$, Eagle Island. 


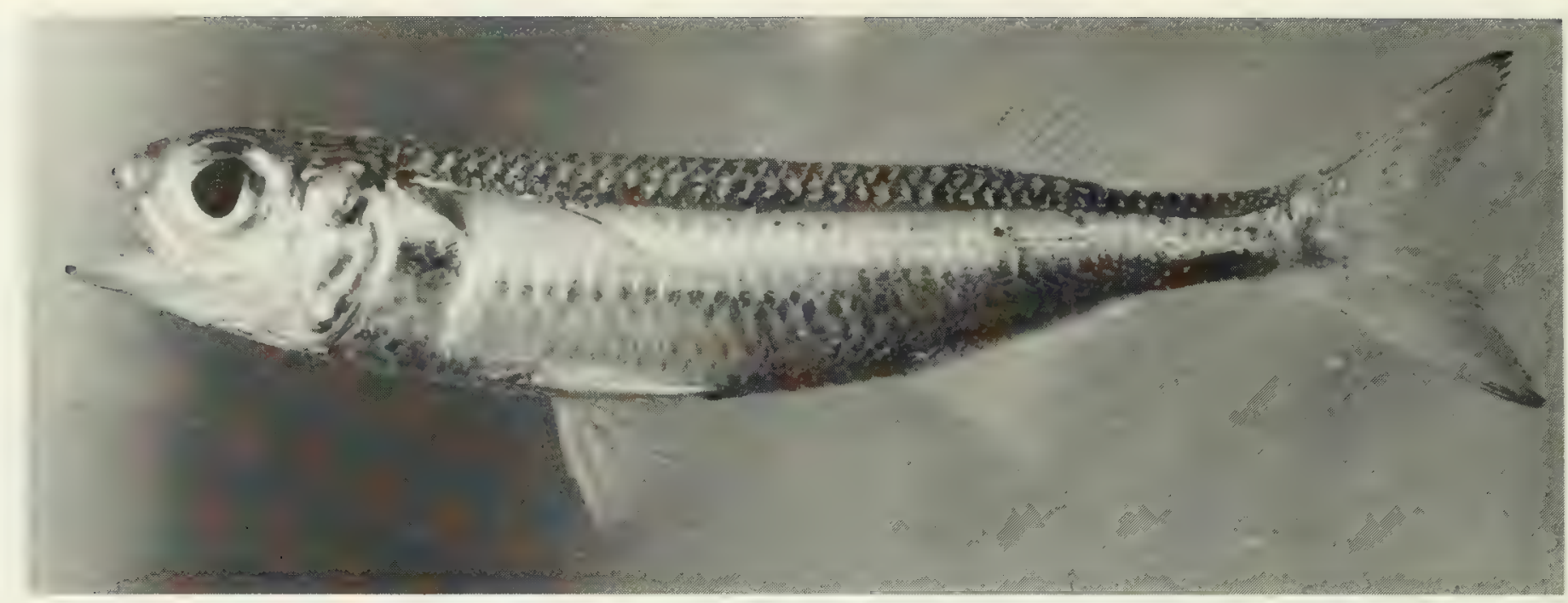

Fig. 72. Atherinomorus lacunosus, $85 \mathrm{~mm} \mathrm{SL}$, Peros Banhos.

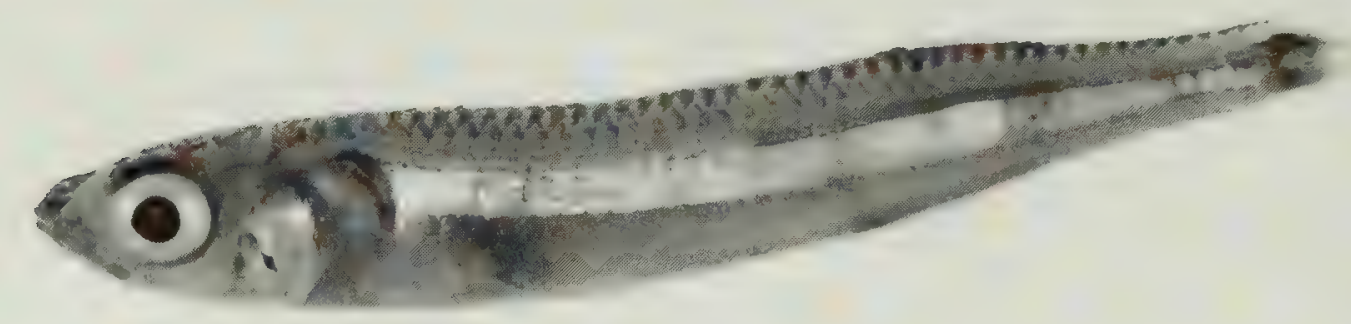

Fig. 73. Hypoatherina barnesi, (preserved) $40 \mathrm{~mm} \mathrm{SL}$, Peros Banhos. Photo by A. Strange.

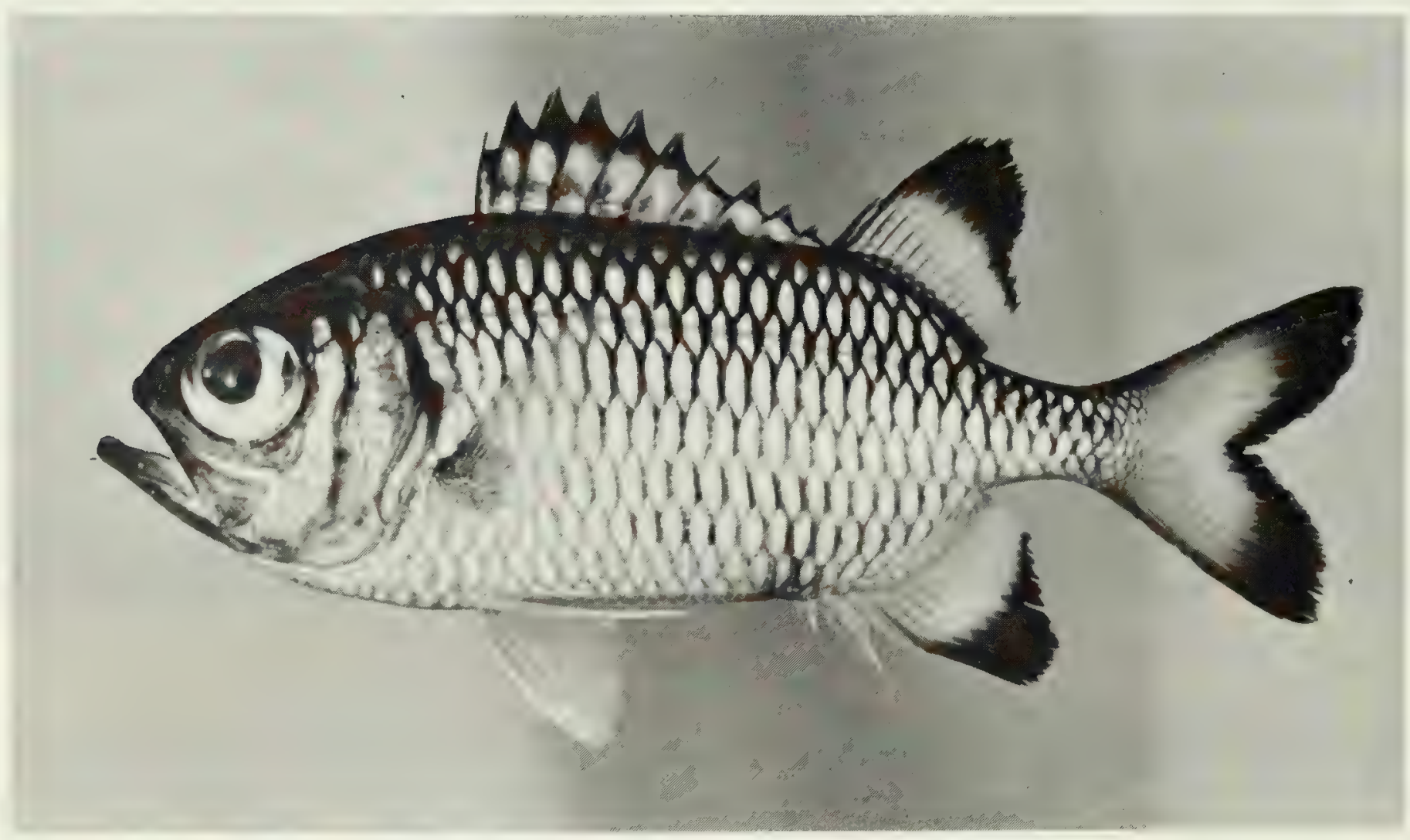

FIG. 74. Myripristis adustus, $171 \mathrm{~mm} \mathrm{SL}$, Salomon. 


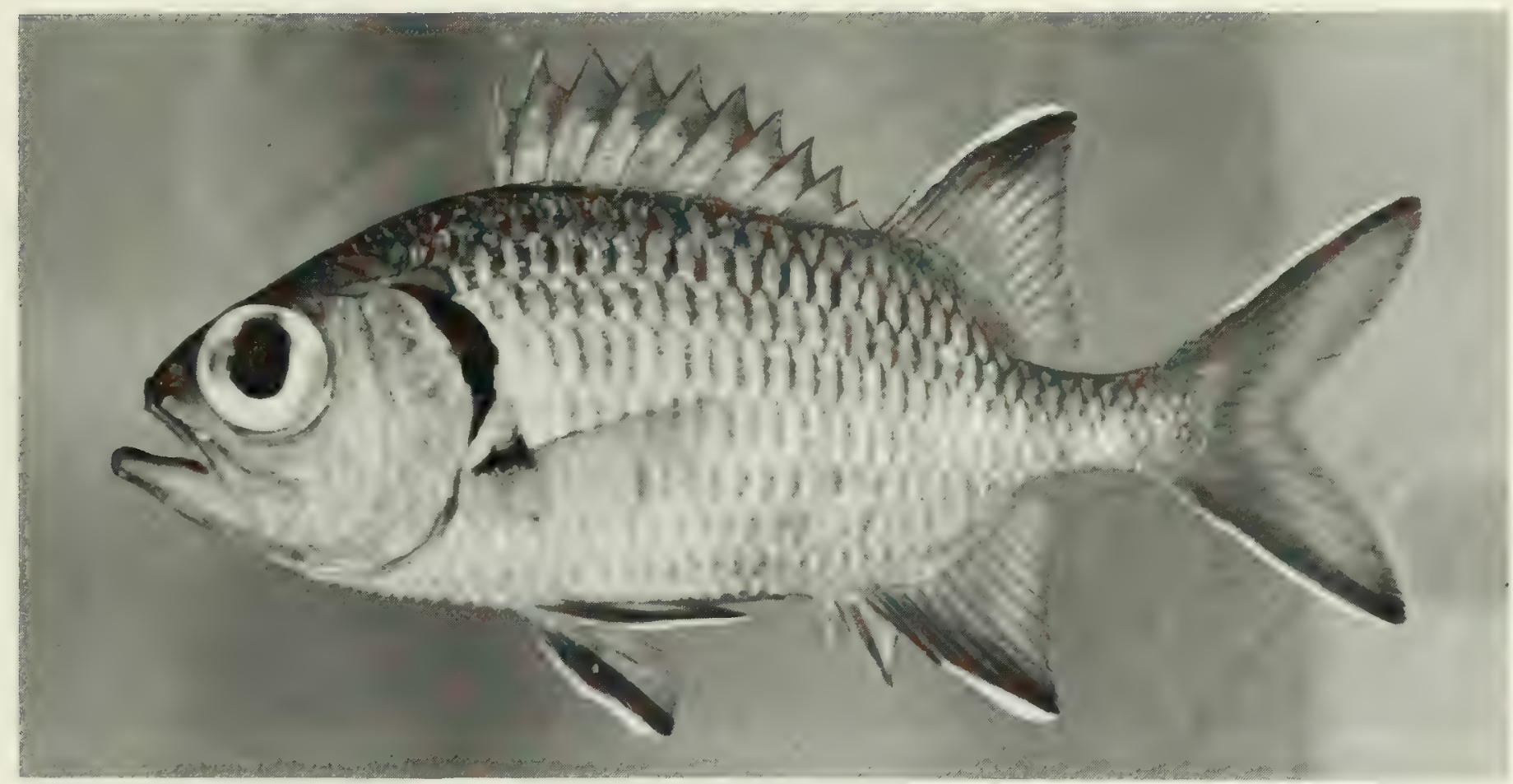

FIG. 75. Myripristis berndti, $146 \mathrm{~mm} \mathrm{SL}$, Peros Banhos.

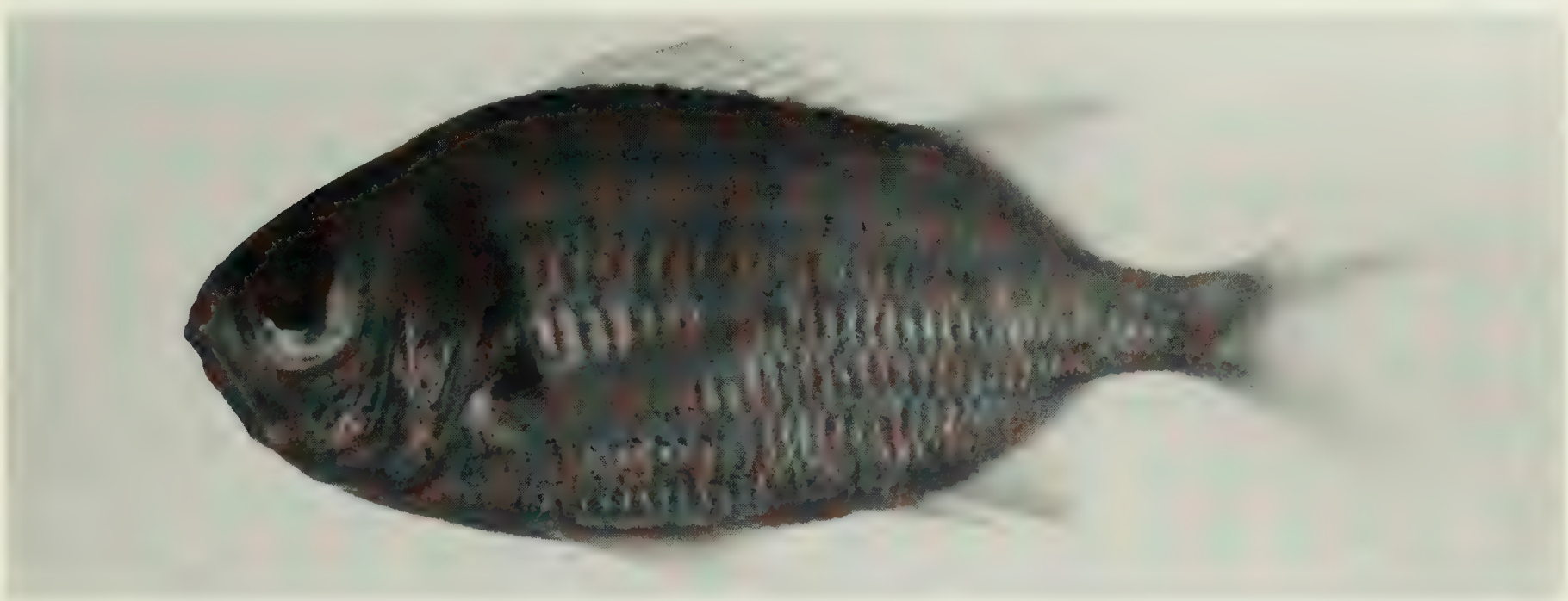

Fig. 76. Myripristis kuntee, (preserved) $127 \mathrm{~mm} \mathrm{SL,} \mathrm{Peros} \mathrm{Banhos.} \mathrm{Photo} \mathrm{by} \mathrm{A.} \mathrm{Strange.}$

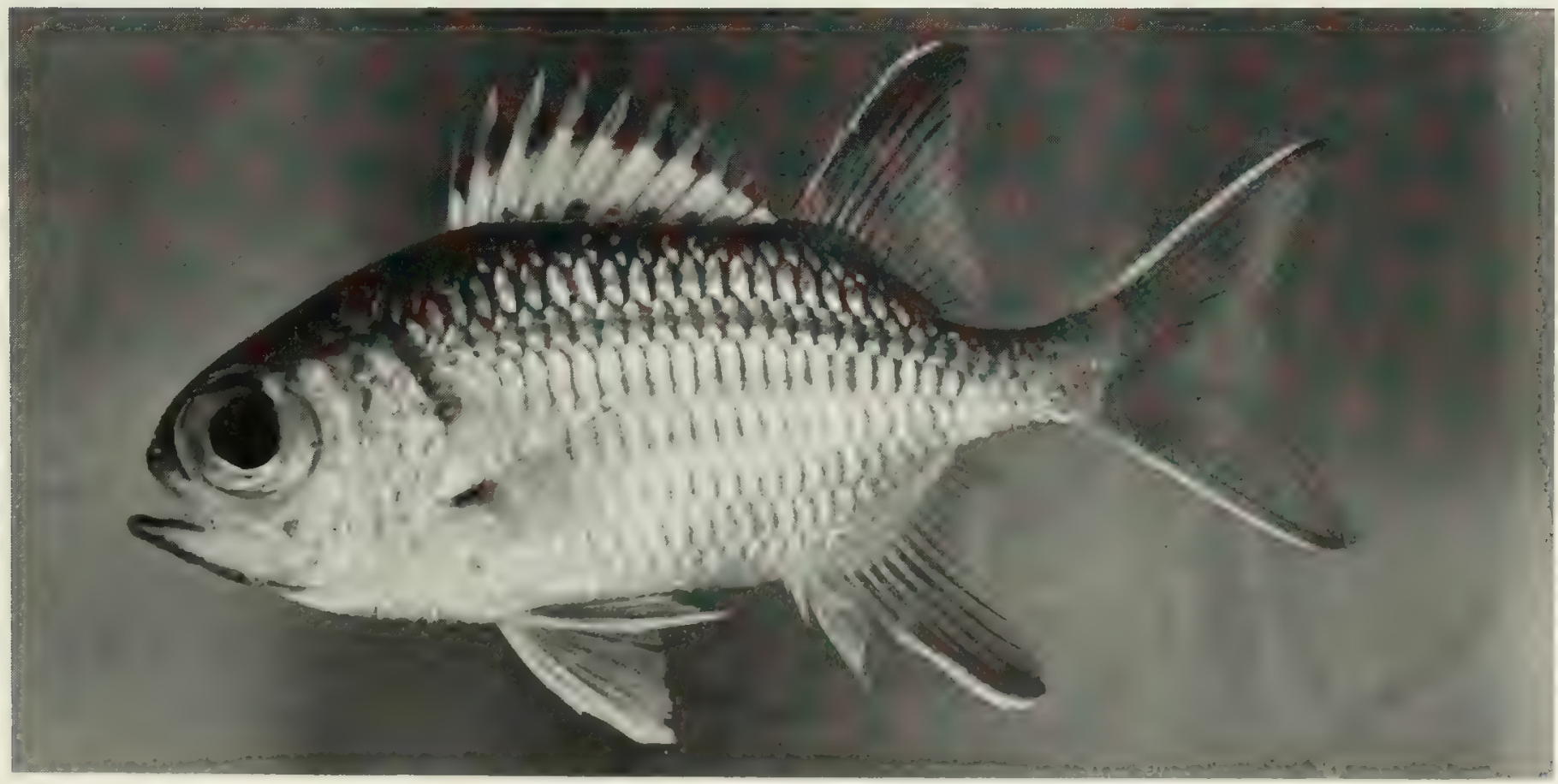

Fig. 77. Myripristis murdjan, $98 \mathrm{~mm}$ SL, Peros Banhos. 


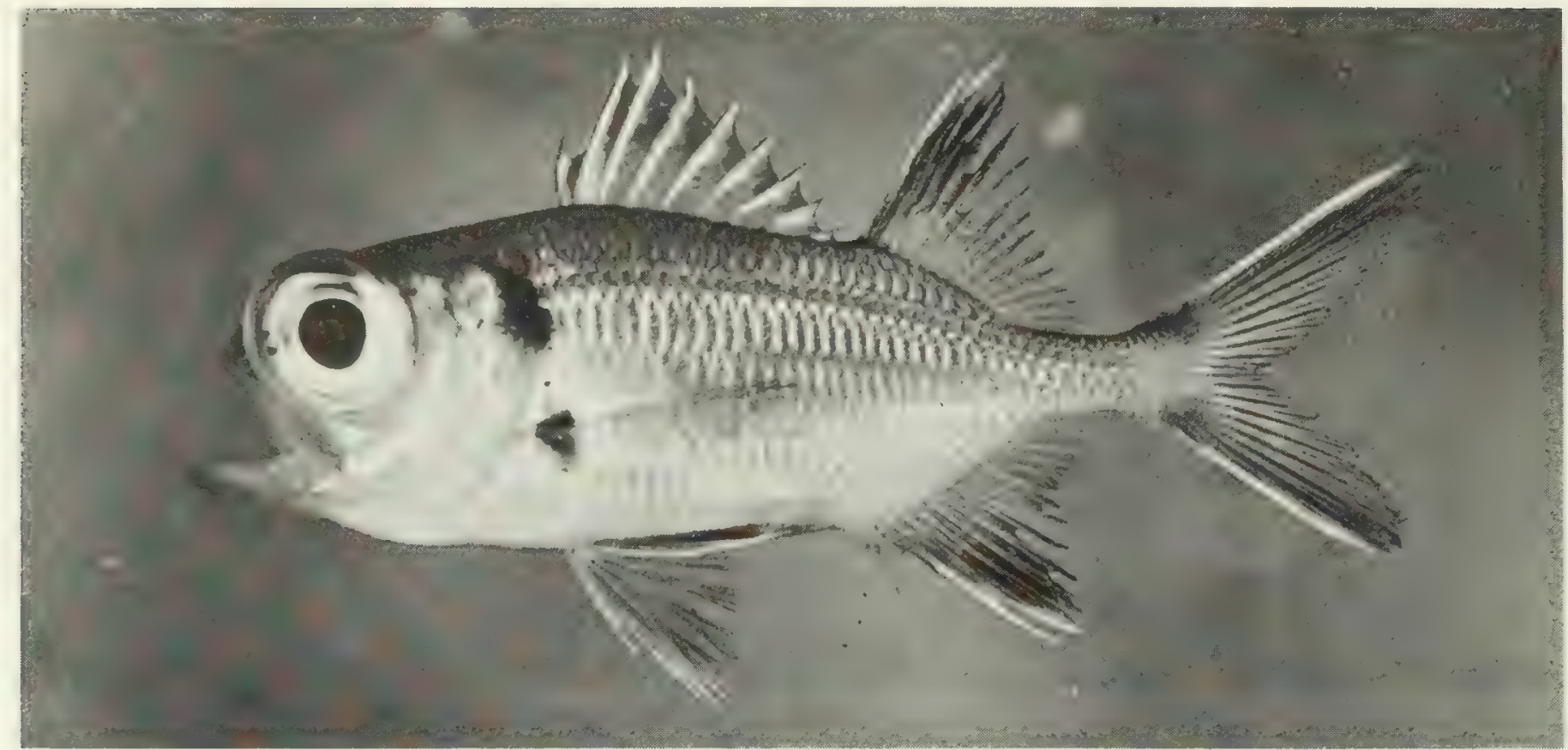

FIG. 78. Myripristis pralinius, $51 \mathrm{~mm}$ SL, Peros Banhos.

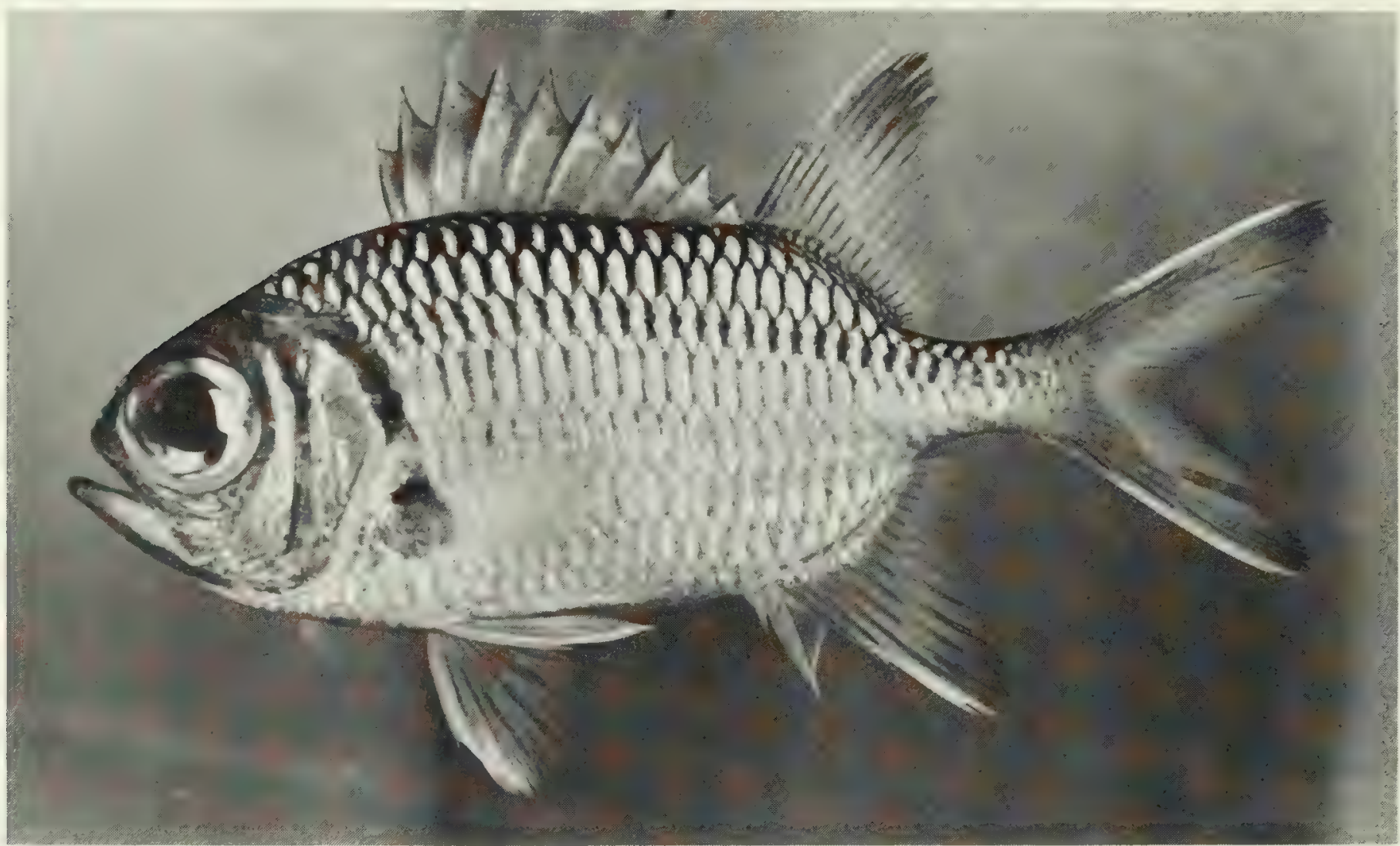

FIG. 79. Myripristis violaceus, $98 \mathrm{~mm}$ SL, Salomon.

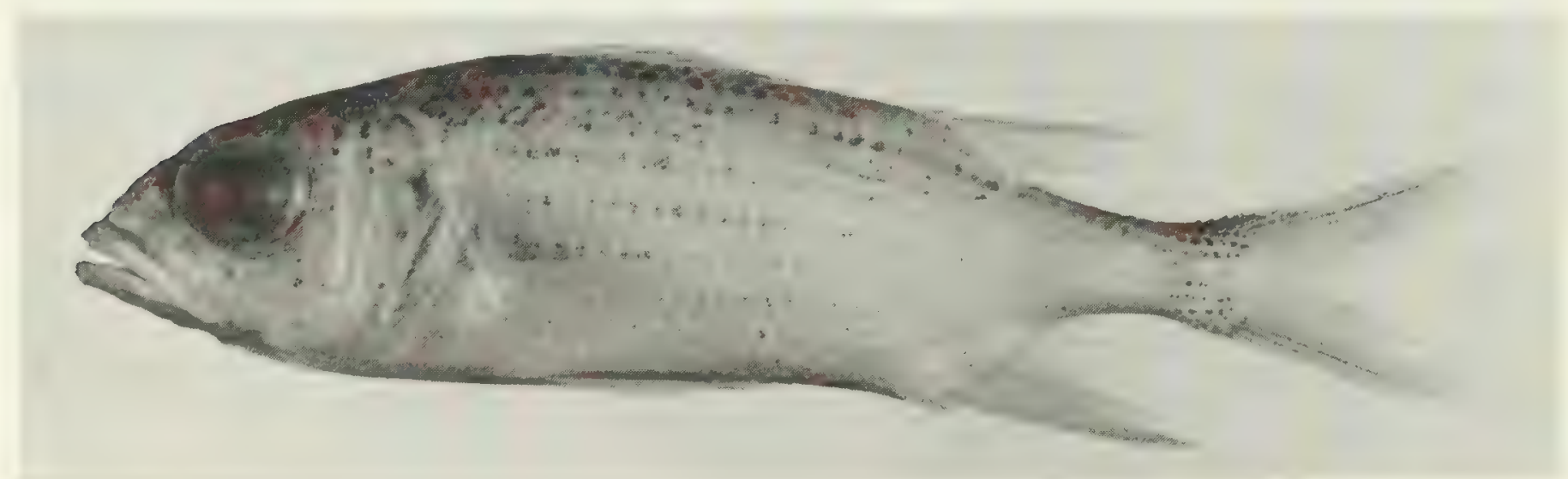

FIG. 80. Neoniphon argenteus, (preserved) $93 \mathrm{~mm} \mathrm{SL}$, Diego Garcia. Photo by M. Burridge-Smith. 


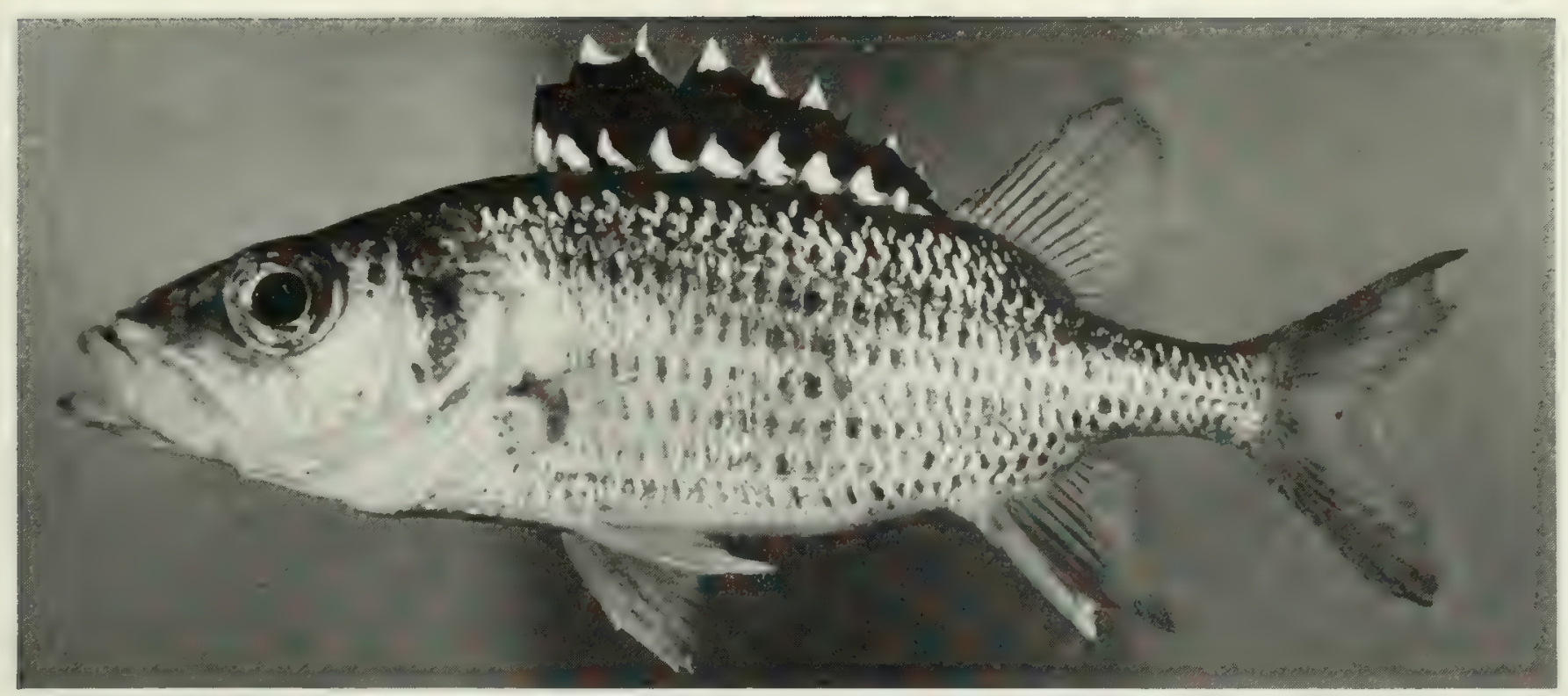

FIG. 81. Neoniphon opercularis, $212 \mathrm{~mm} \mathrm{SL}$, Salomon.

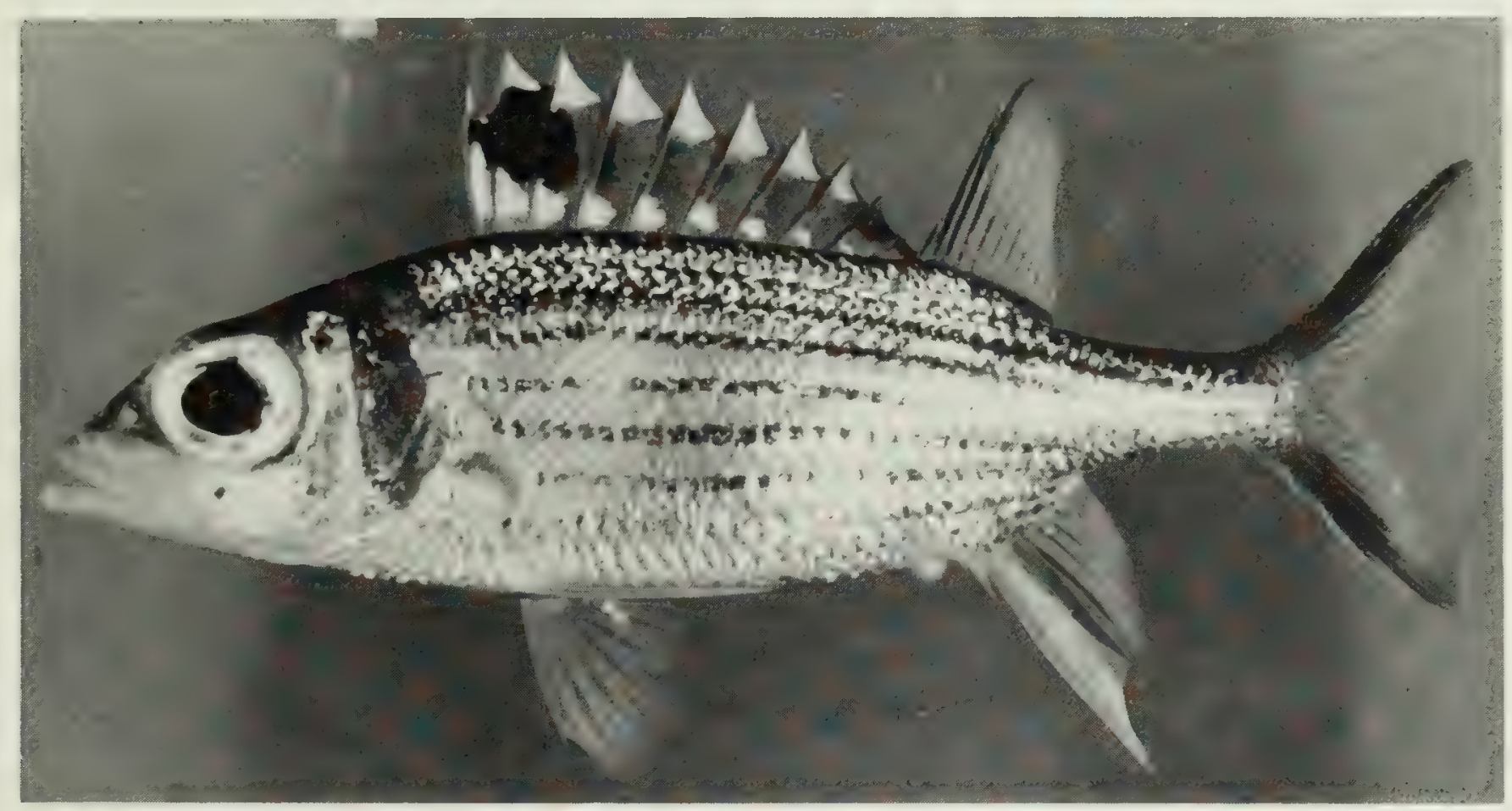

FIG. 82. Neoniphon sammara, $144 \mathrm{~mm} \mathrm{SL}$, Peros Banhos.

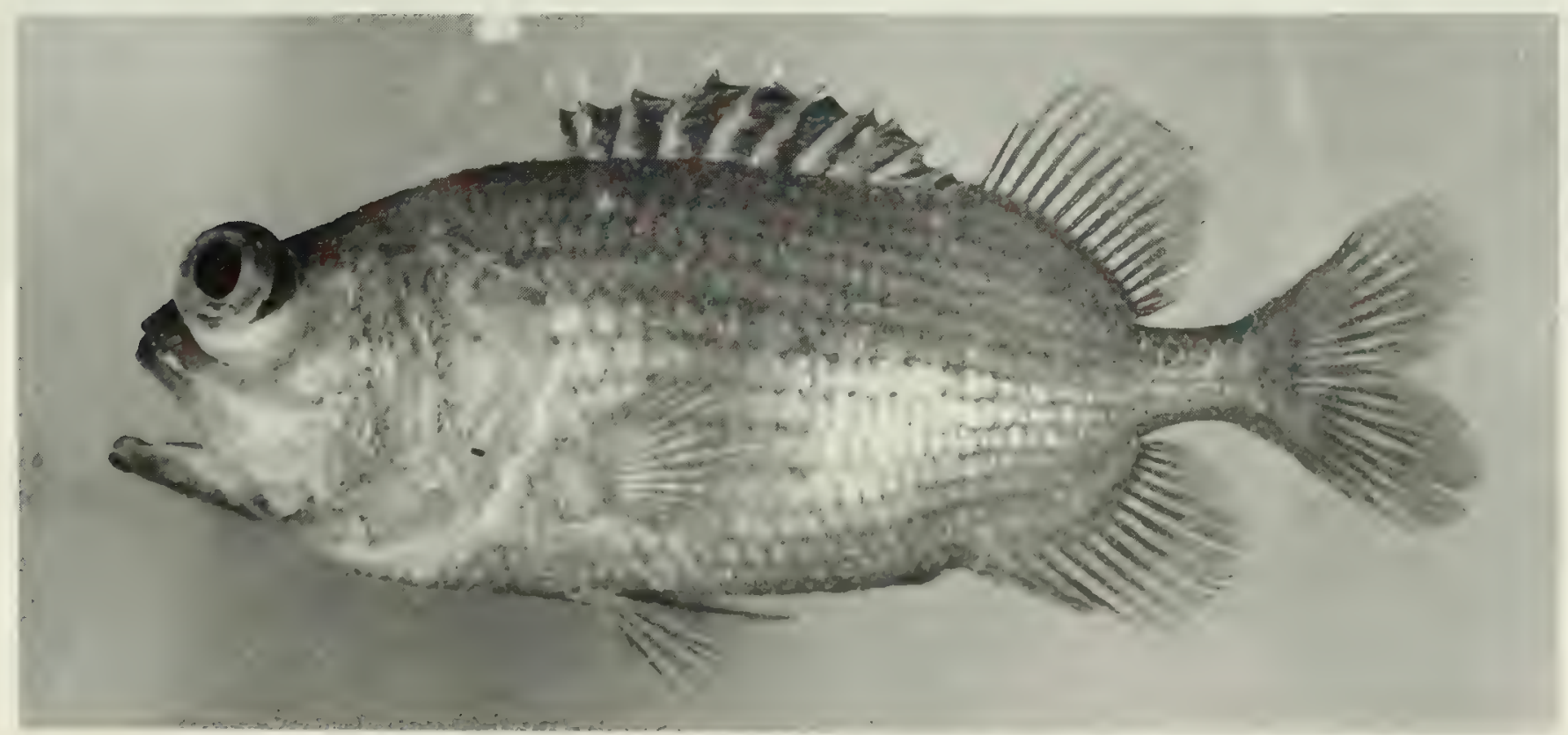

FIG. 83. Plectrypops lima, $113 \mathrm{~mm} \mathrm{SL,} \mathrm{Peros} \mathrm{Banhos.}$ 


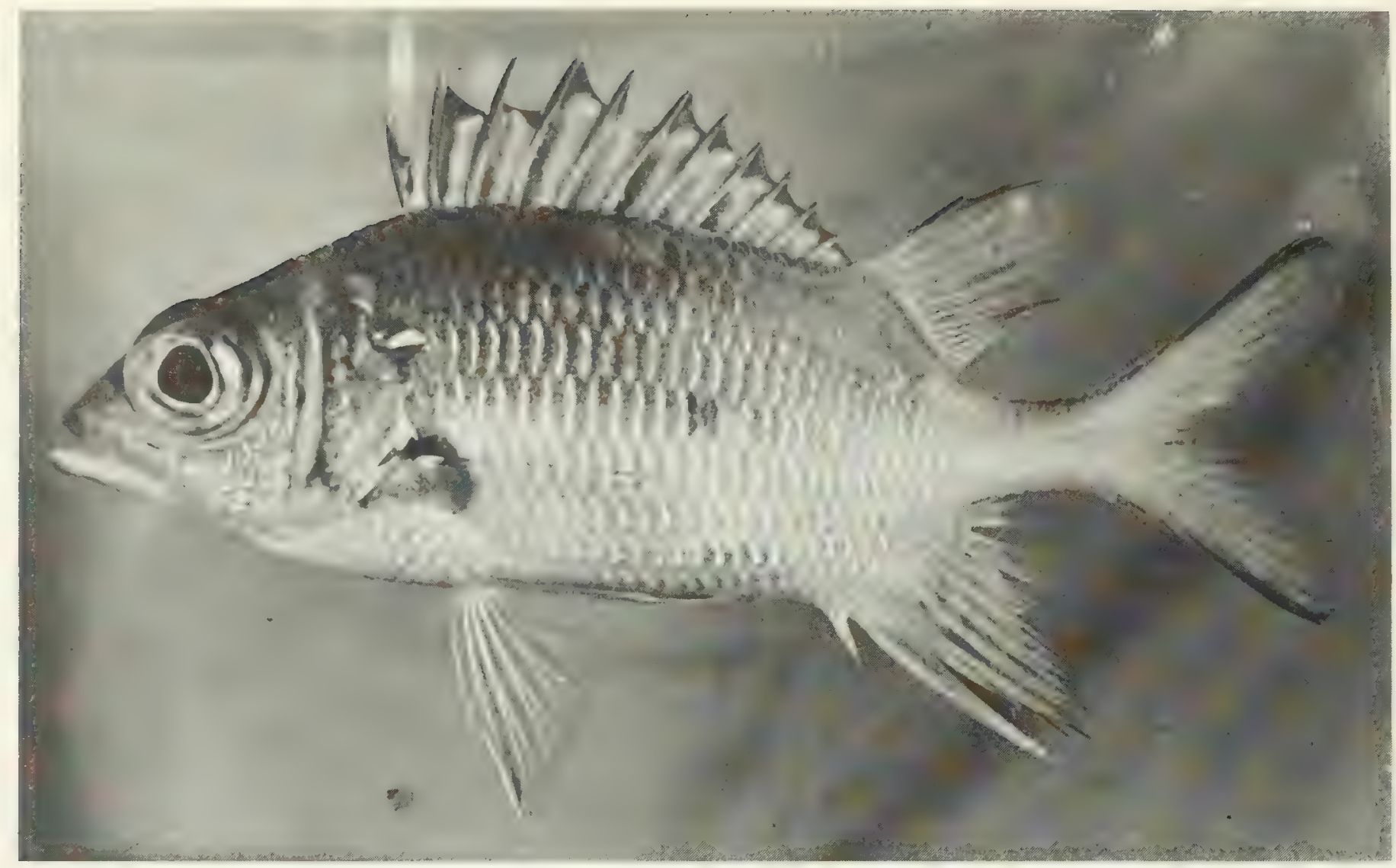

FIG. 84. Sargocentron caudimaculatum, $130 \mathrm{~mm} \mathrm{SL,} \mathrm{Peros} \mathrm{Banhos.}$

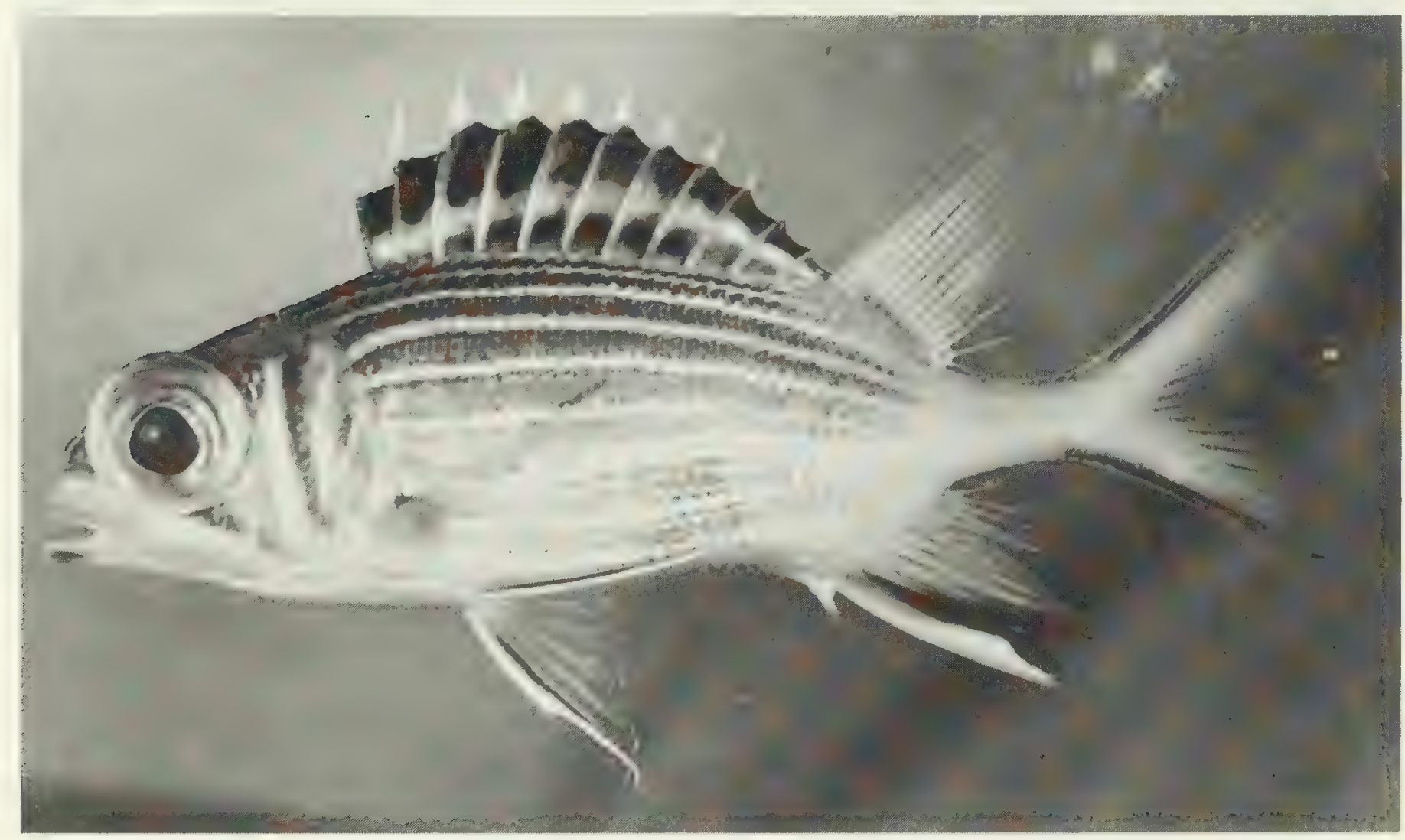

FIG. 85. Sargocentron diadema, $54 \mathrm{~mm} \mathrm{SL}$, Peros Banhos. 


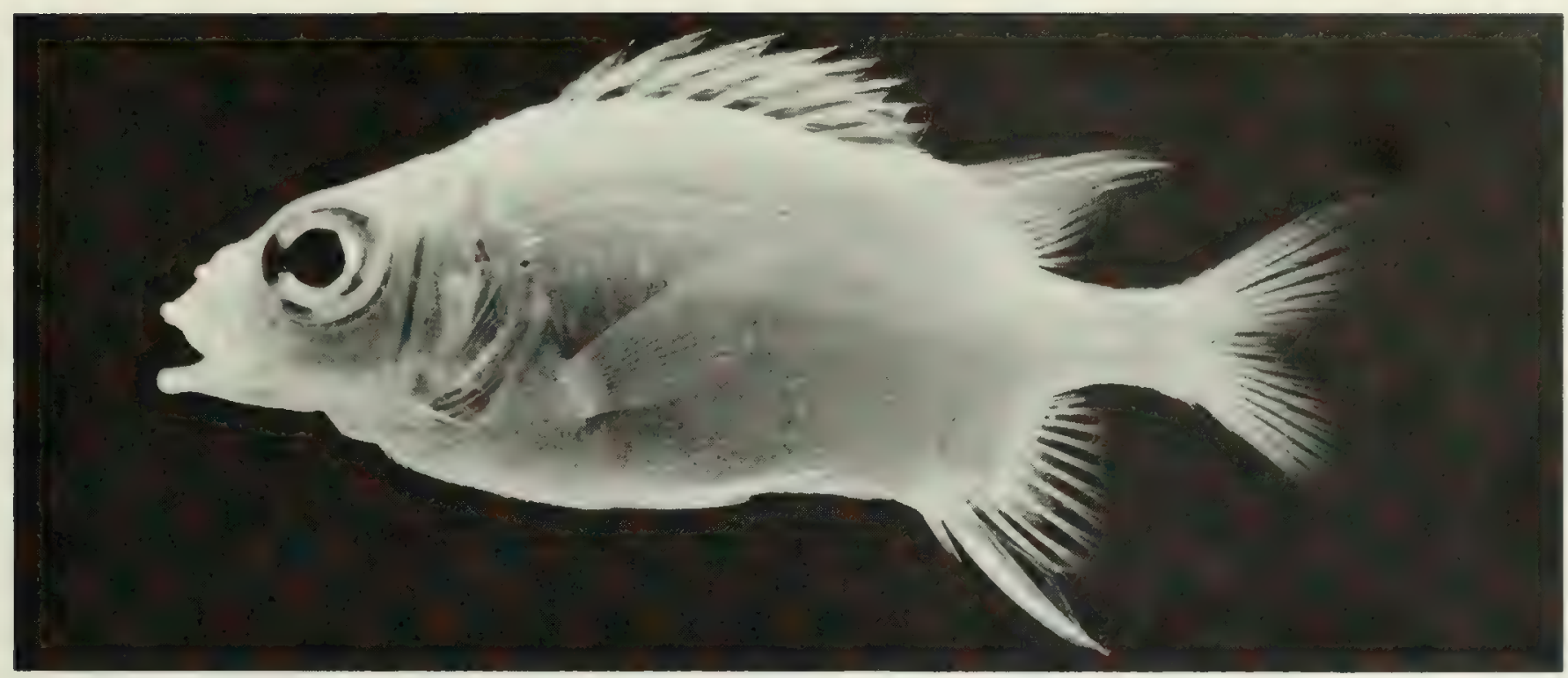

Fig. 86. Sargocentron macrosquamis, (preserved) $65 \mathrm{~mm} \mathrm{SL,} \mathrm{Salomon.} \mathrm{Photo} \mathrm{by} \mathrm{A.} \mathrm{Strange.}$

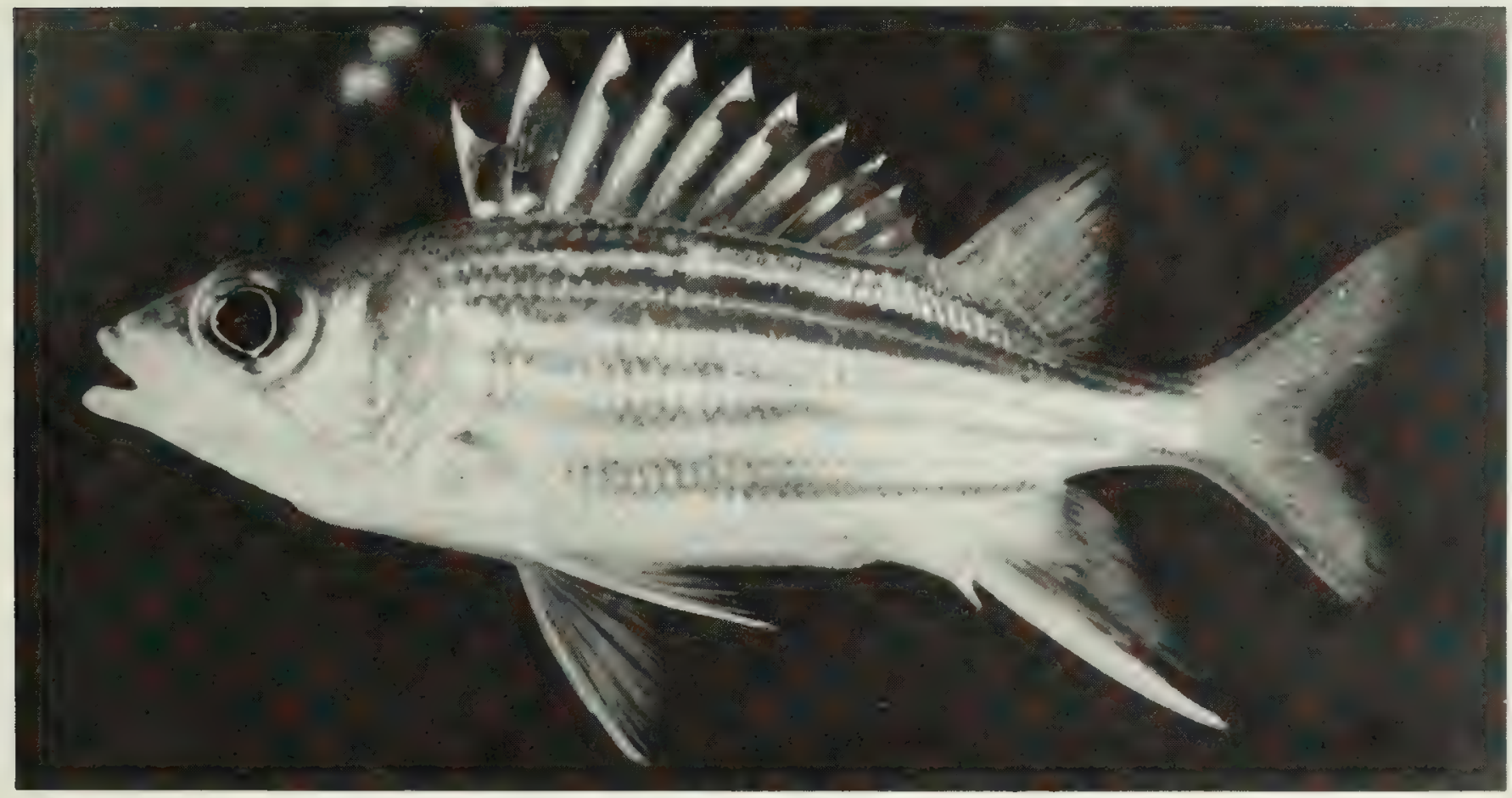

FIG. 87. Sargocentron microstoma, $109 \mathrm{~mm}$ SL, Eagle Island.

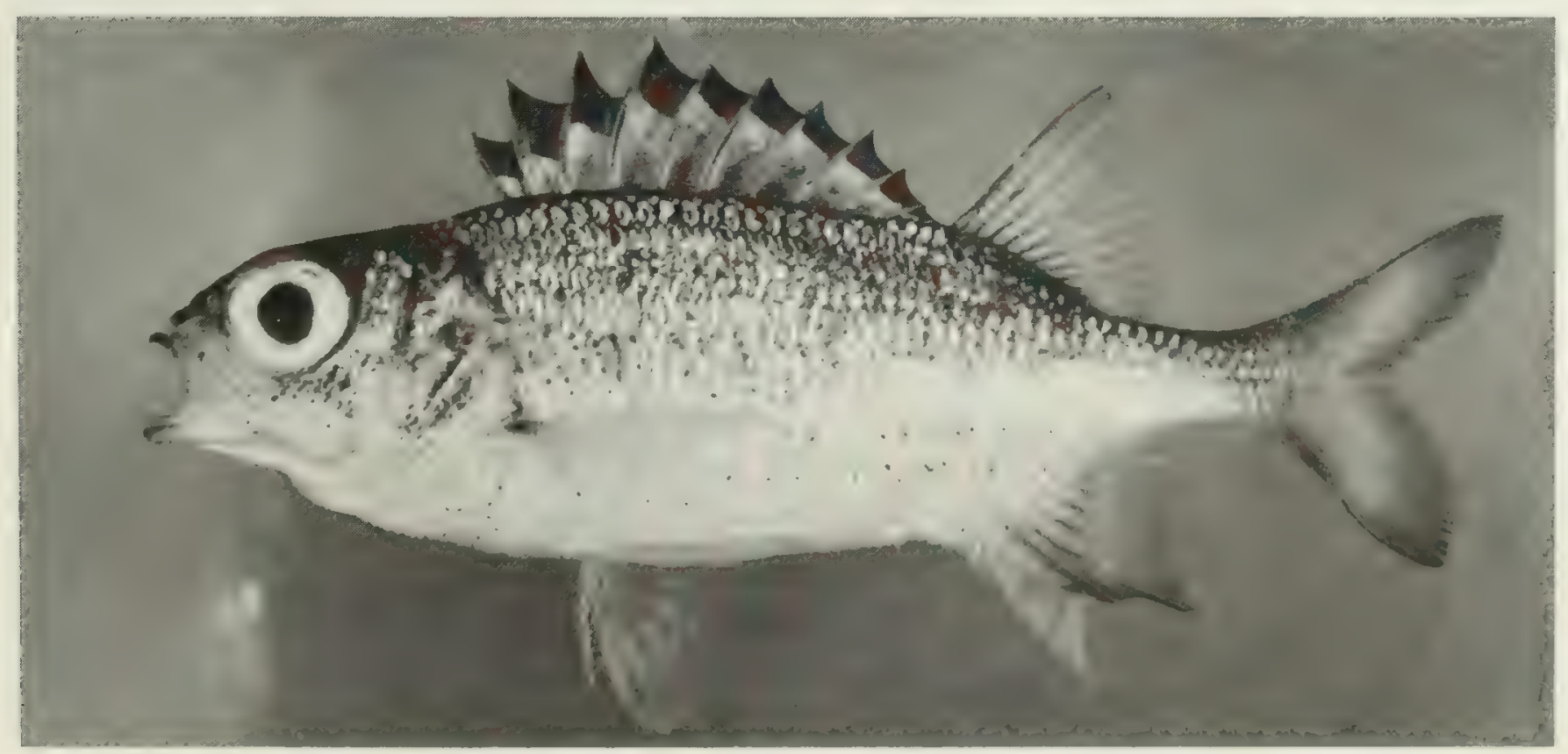

FiG. 88. Sargocentron punctatissimum, $93 \mathrm{~mm} \mathrm{SL}$, Peros Banhos. 


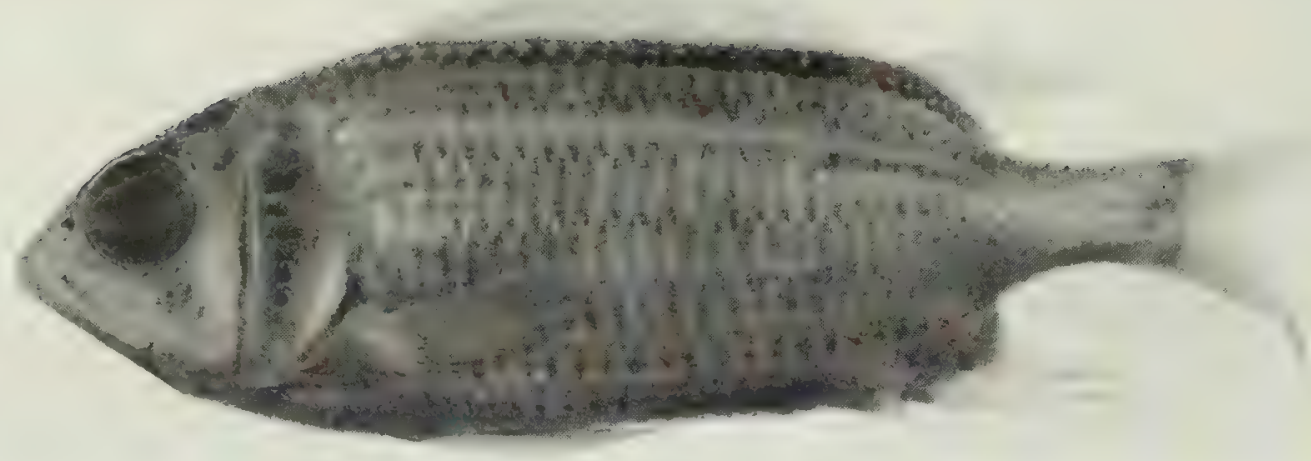

FIG. 89. Sargocentron seychellense, (preserved) $166 \mathrm{~mm} \mathrm{SL}$, Diego Garcia. Photo by A. Strange.

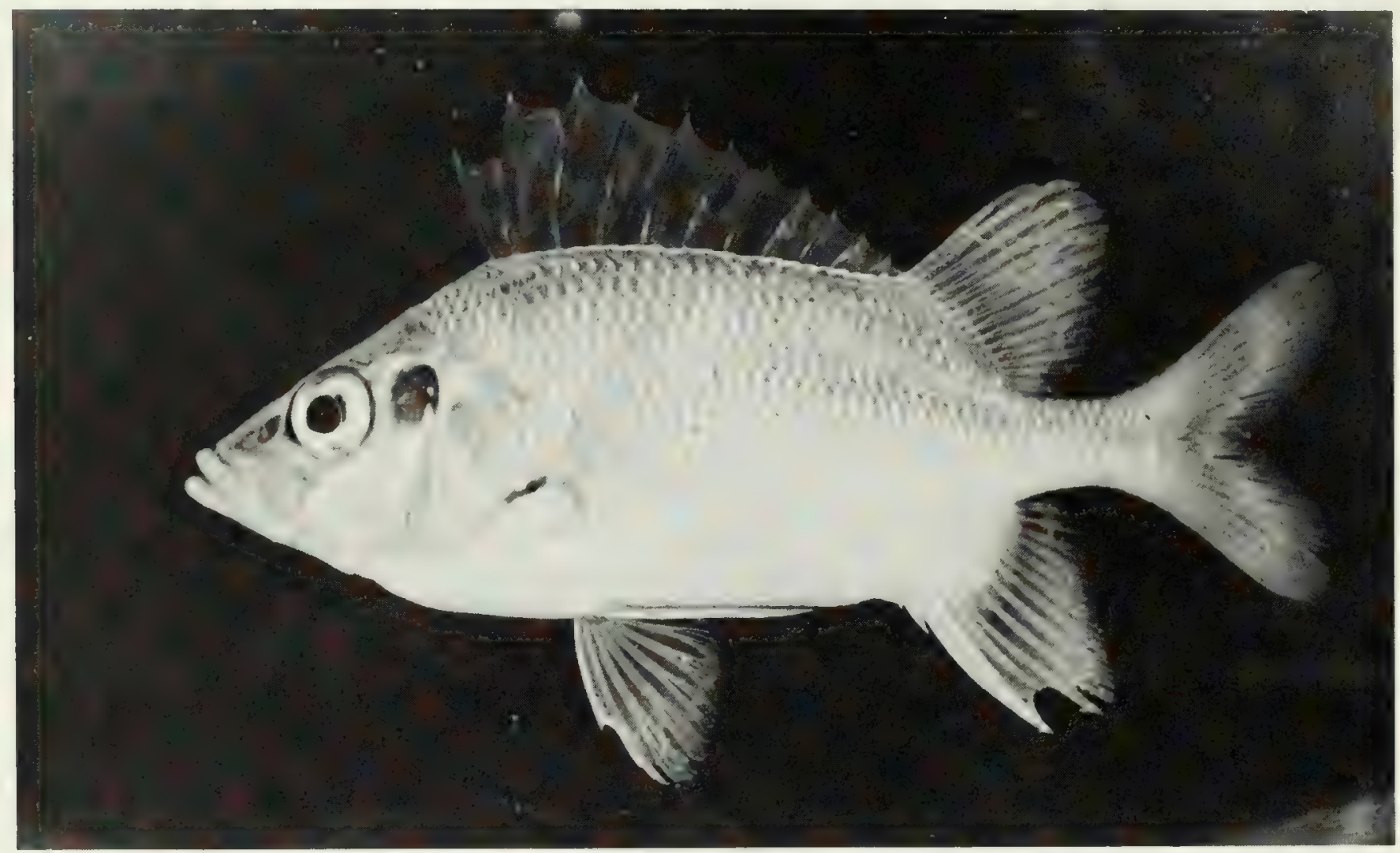

FIG. 90. Sargocentron spiniferum, $135 \mathrm{~mm}$ SL, Eagle Island.

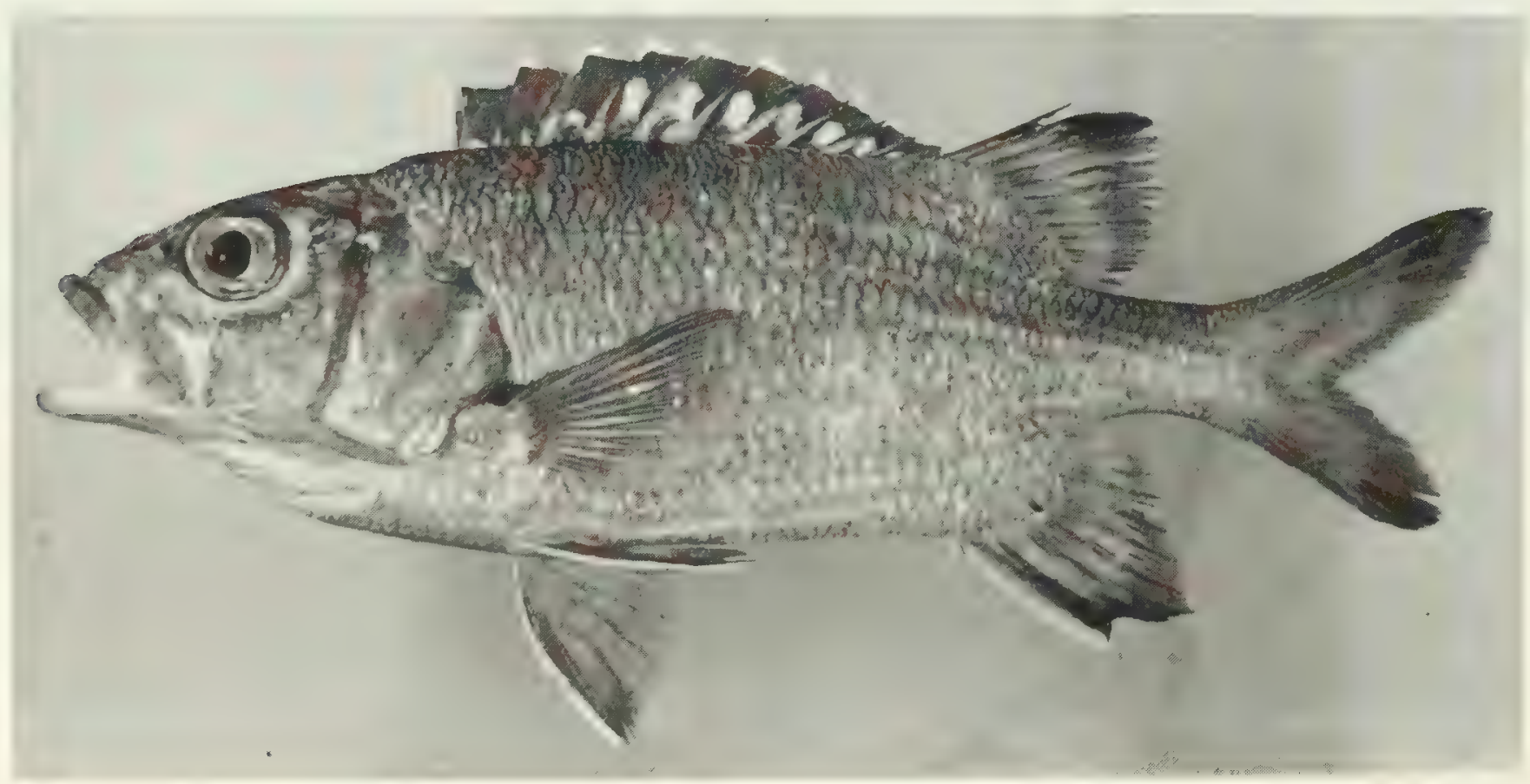

Fig. 91. Sargocentron tiere, $222 \mathrm{~mm} \mathrm{SL,} \mathrm{Peros} \mathrm{Banhos.}$ 


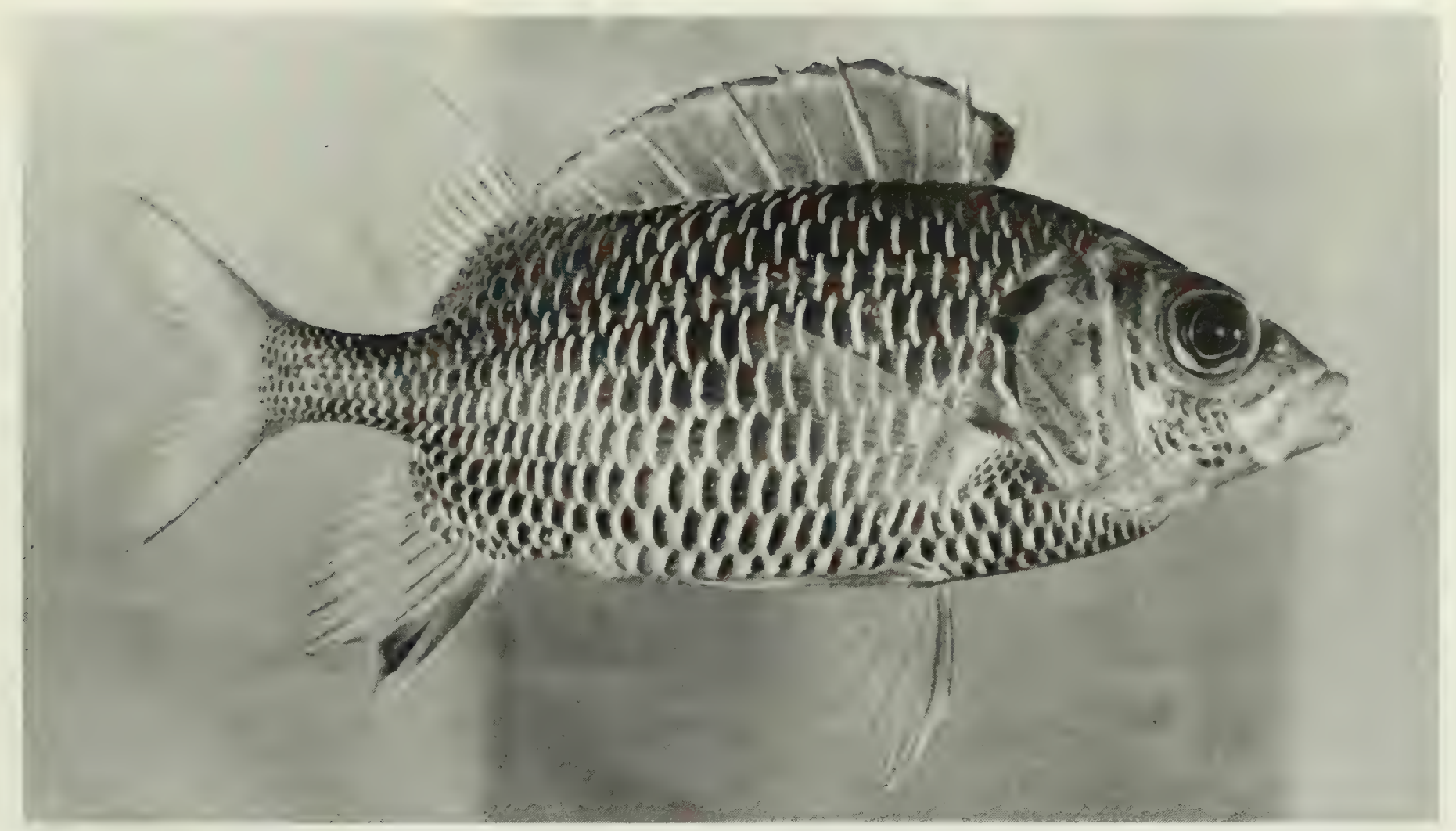

FIG. 92. Sargocentron violaceum, $132 \mathrm{~mm} \mathrm{SL}$, Salomon.

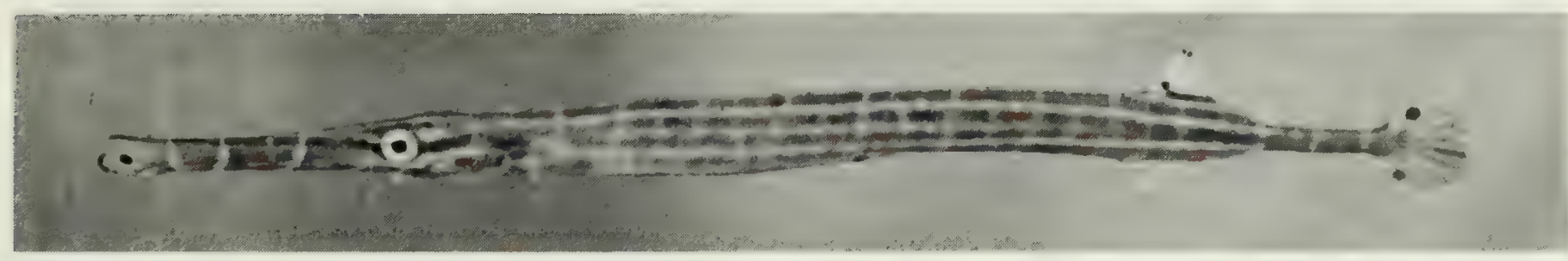

FIG. 93. Aulostomus chinensis, $158 \mathrm{~mm} \mathrm{SL}$, Salomon.

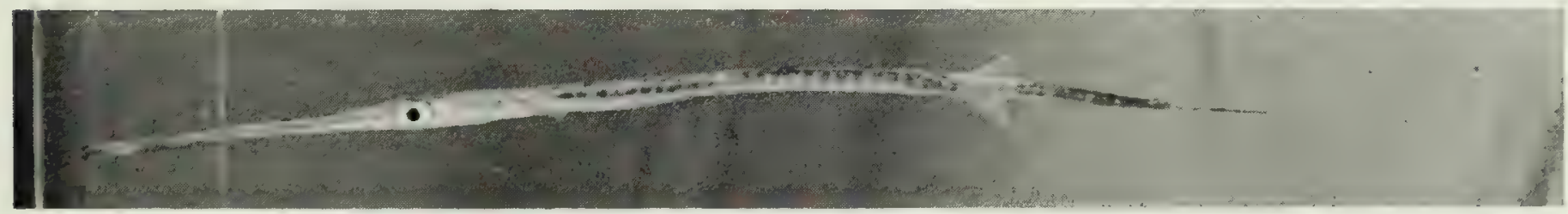

FIG. 94. Fistularia commersonii, $137 \mathrm{~mm} \mathrm{SL}$, Peros Banhos.

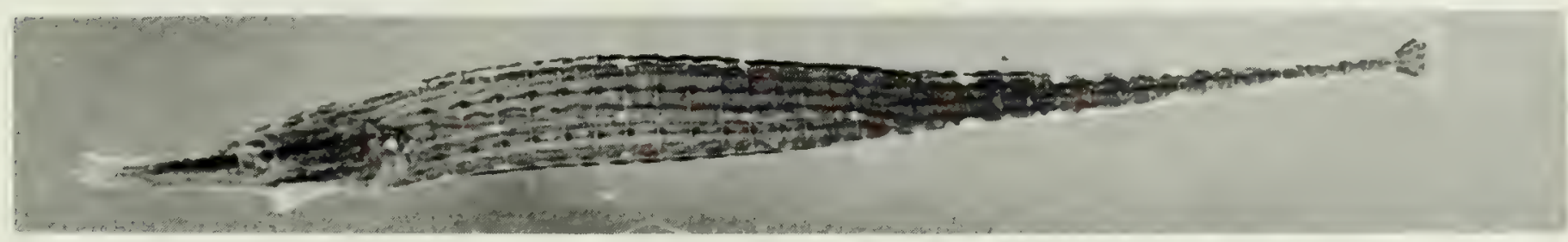

FIG. 95. Choeroichthys brachysoma, $37 \mathrm{~mm} \mathrm{SL}$, Peros Banhos.

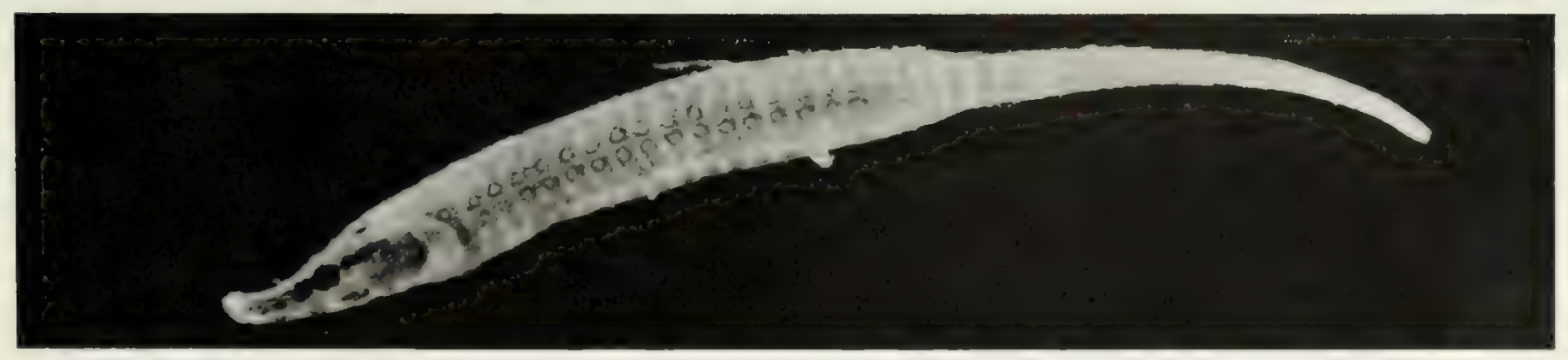

FIG. 96. Choeroichthys sculptus, (preserved) $56 \mathrm{~mm} \mathrm{SL}$, Diego Garcia. Photo by A. Strange. 


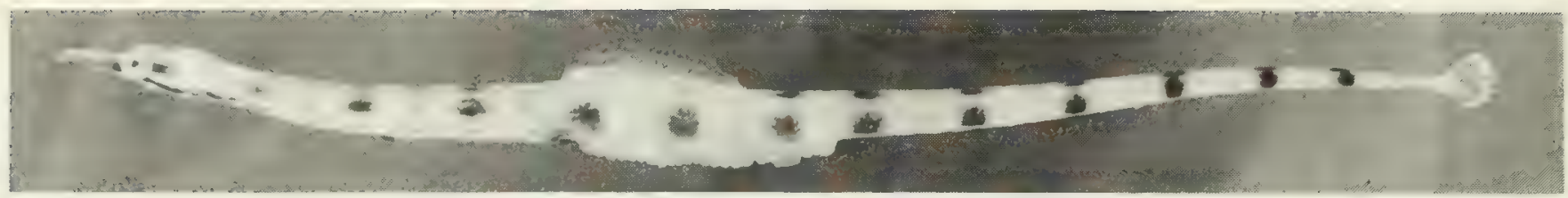

FIG. 97. Corythoichthys flavofasciatus, $115 \mathrm{~mm} \mathrm{SL}$, Peros Banhos.

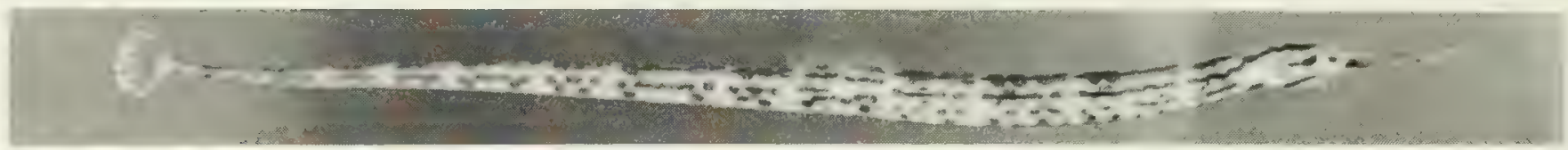

FIG. 98. Corythoichthys schultzi, $128 \mathrm{~mm} \mathrm{SL}$, Peros Banhos.

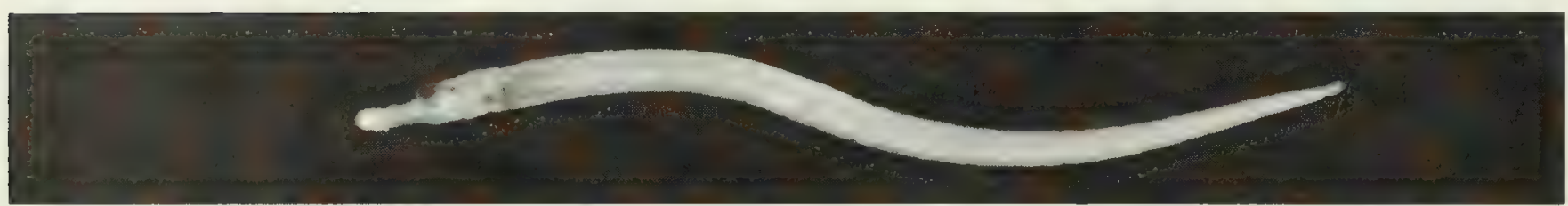

FIG. 99. Cosmocampus banneri, (preserved) $37 \mathrm{~mm} \mathrm{SL}$, Peros Banhos. Photo by A. Strange.

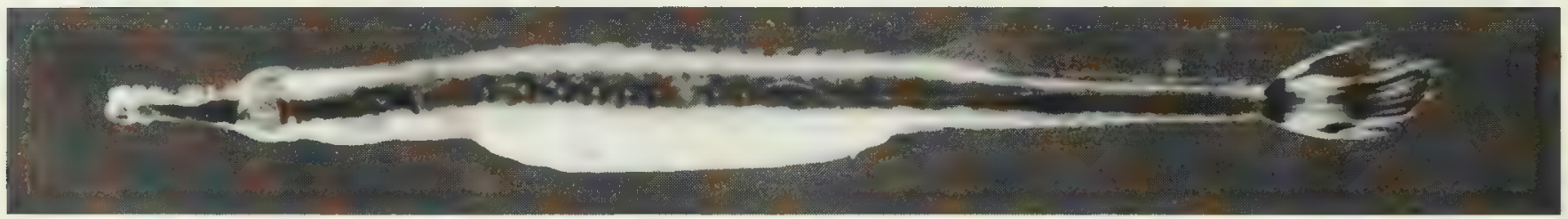

FIG. 100. Doryrhamphus excisus excisus, (preserved) $44 \mathrm{~mm} \mathrm{SL}$, Diego Garcia. Photo by A. Strange.

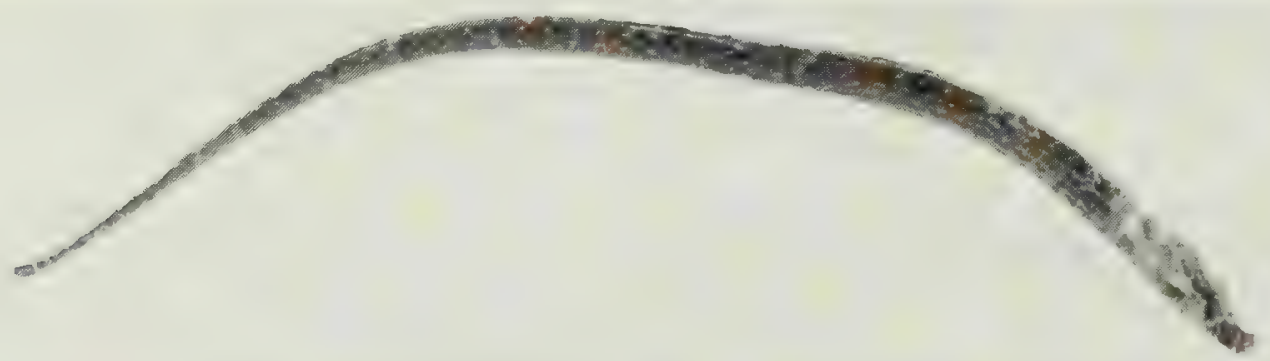

Fig. 101. Halicampus mataafae, (preserved) $47 \mathrm{~mm} \mathrm{SL}$, Salomon. Photo by A. Strange.

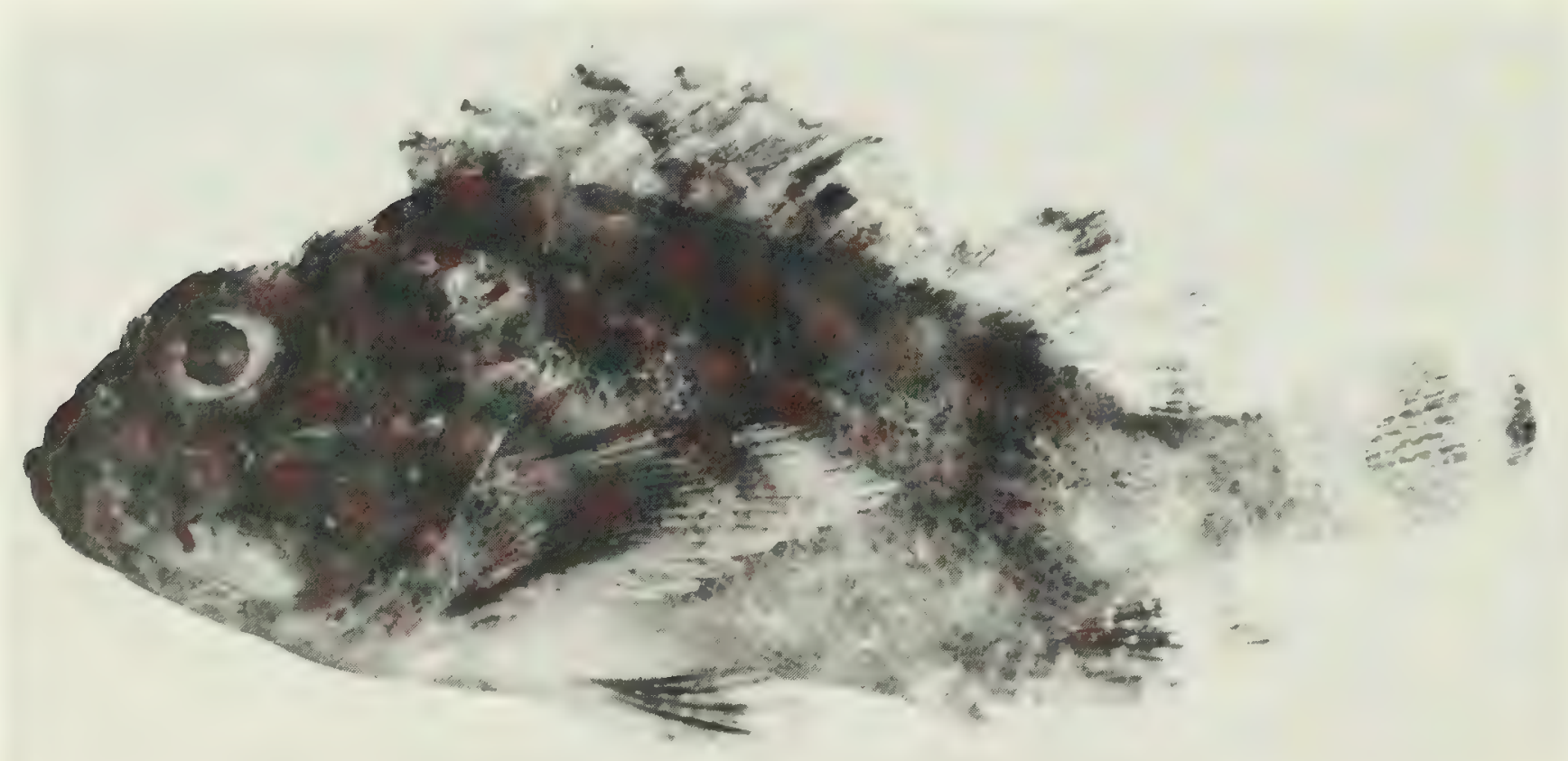

FIG. 102. Parascorpaena aurita, (preserved) $80 \mathrm{~mm} \mathrm{SL}$, Peros Banhos. Photo by M. Burridge-Smith. 


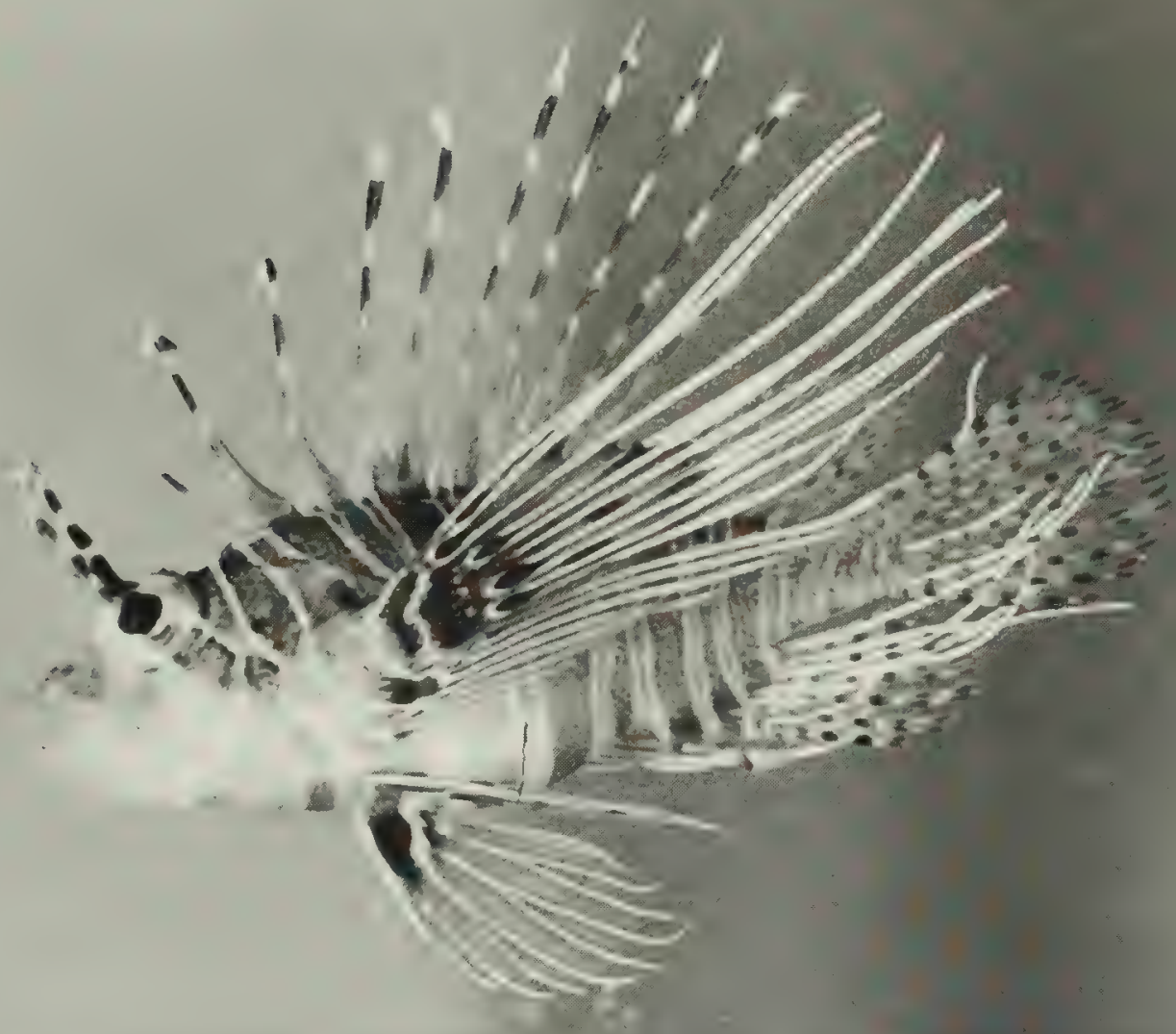

FIG. 103. Pterois antennata, $66 \mathrm{~mm} \mathrm{SL}$, Salomon

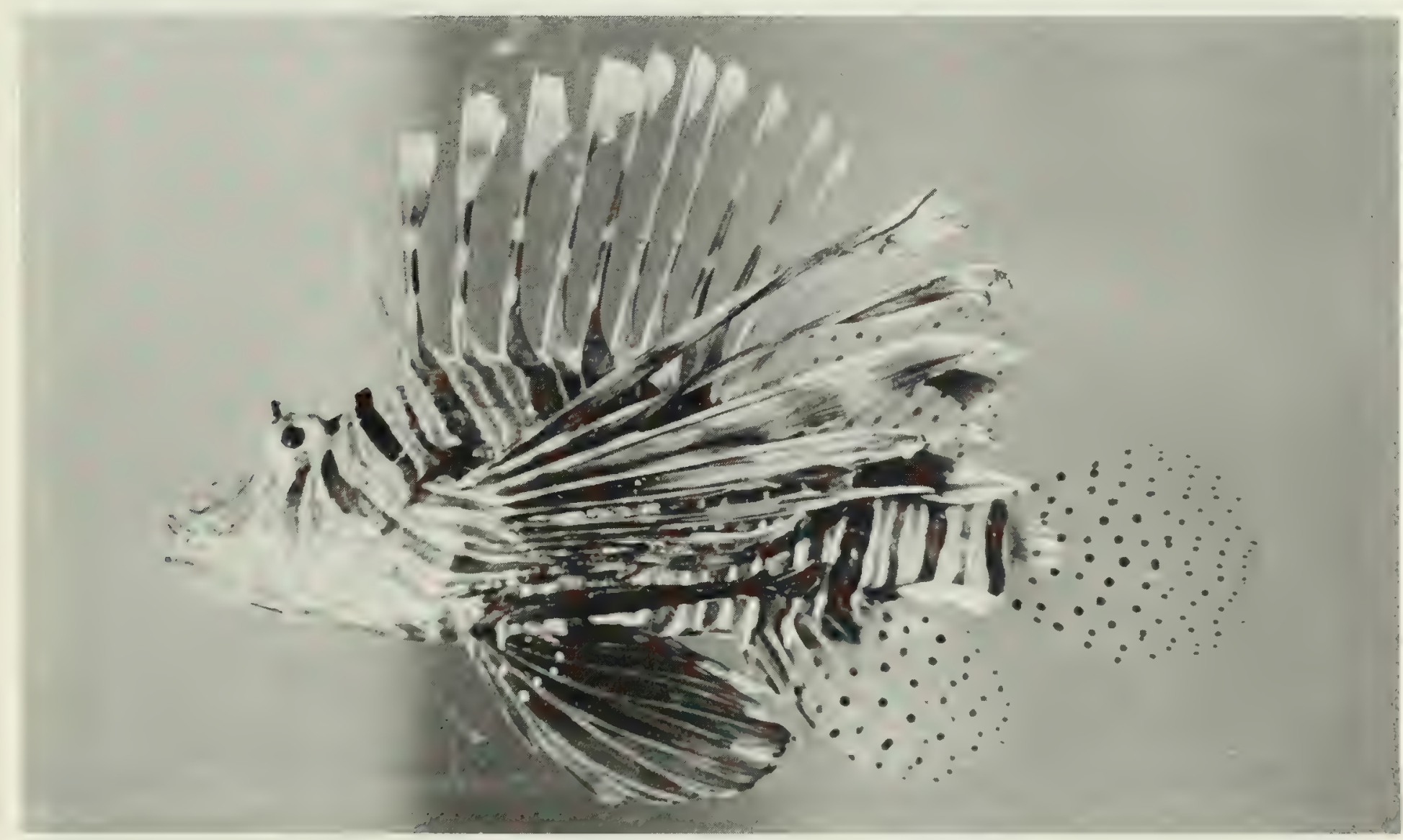

FIG. 104. Pterois miles, $147 \mathrm{~mm} \mathrm{SL}$, Salomon. 


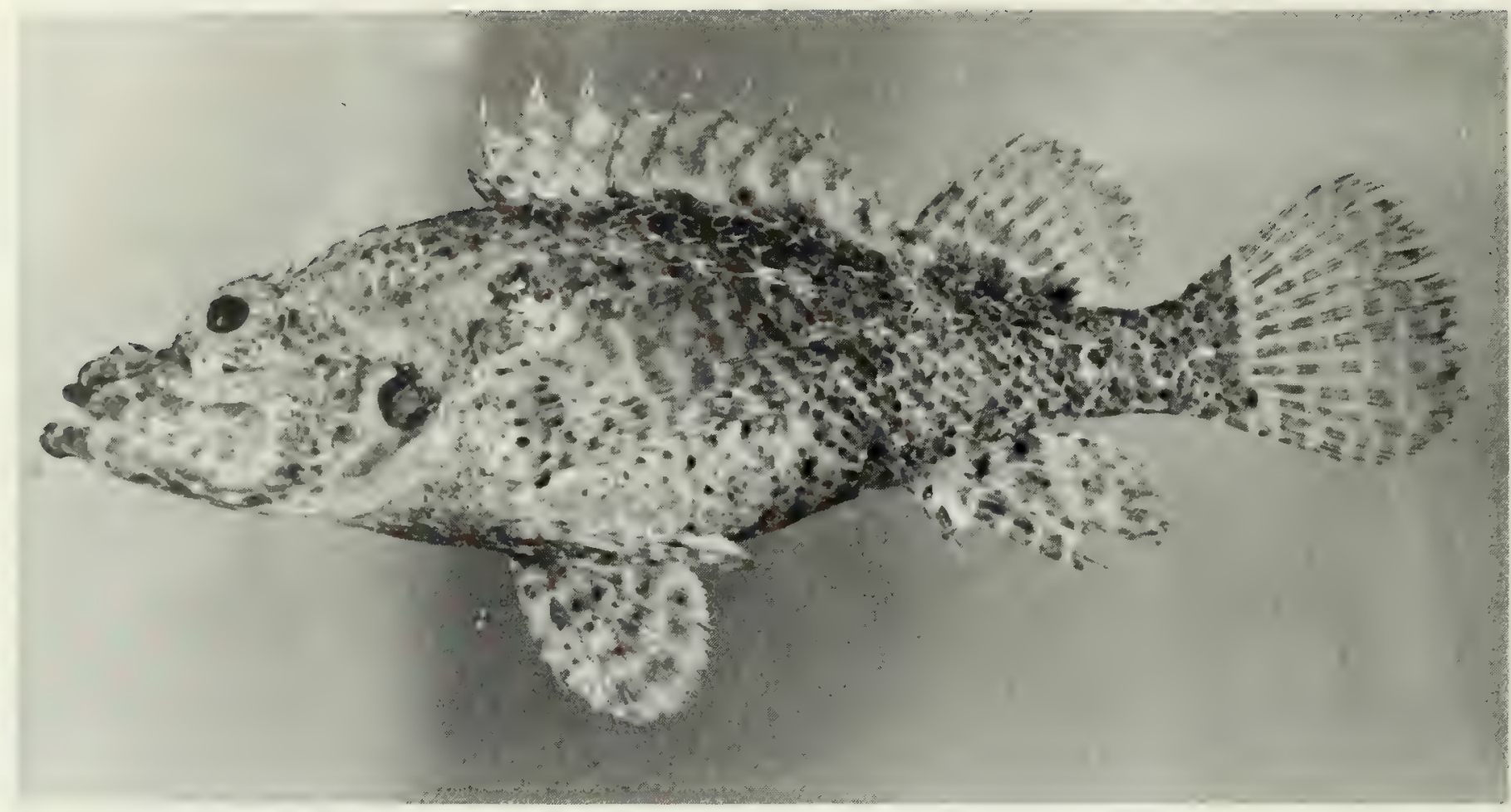

FIG. 105. Scorpaenodes albaiensis, $73 \mathrm{~mm} \mathrm{SL}$, Salomon.

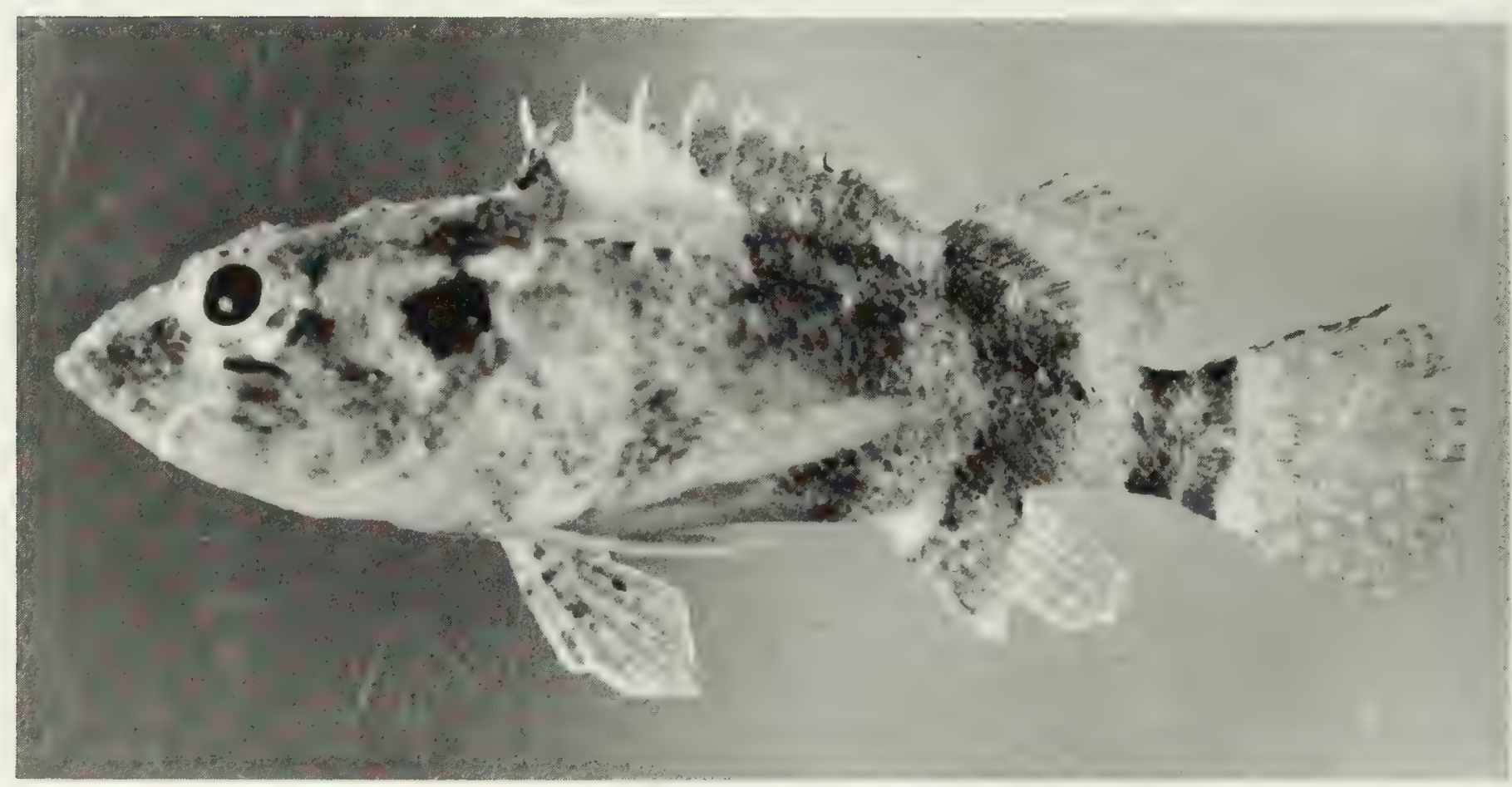

Fig. 106. Scorpaenodes guamensis, $26 \mathrm{~mm} \mathrm{SL,} \mathrm{Salomon.}$

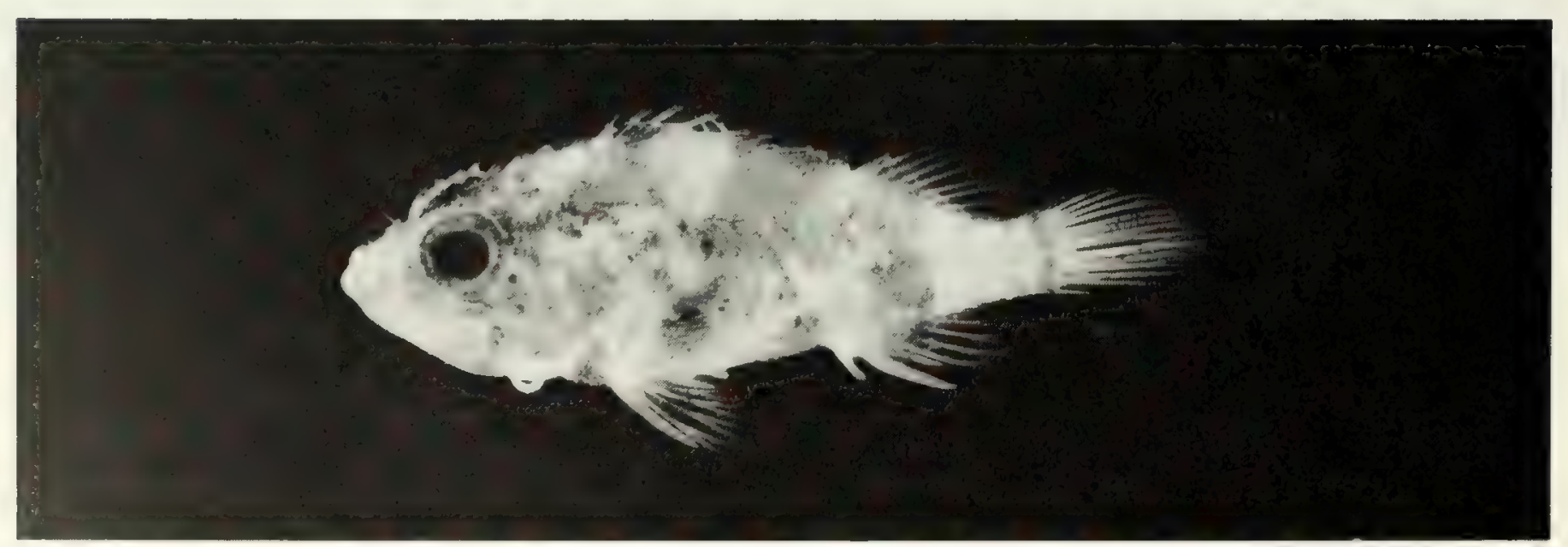

FIG. 107. Scorpaenodes hirsutus, (preserved) $25 \mathrm{~mm} \mathrm{SL}$, Peros Banhos. Photo by A. Strange. 


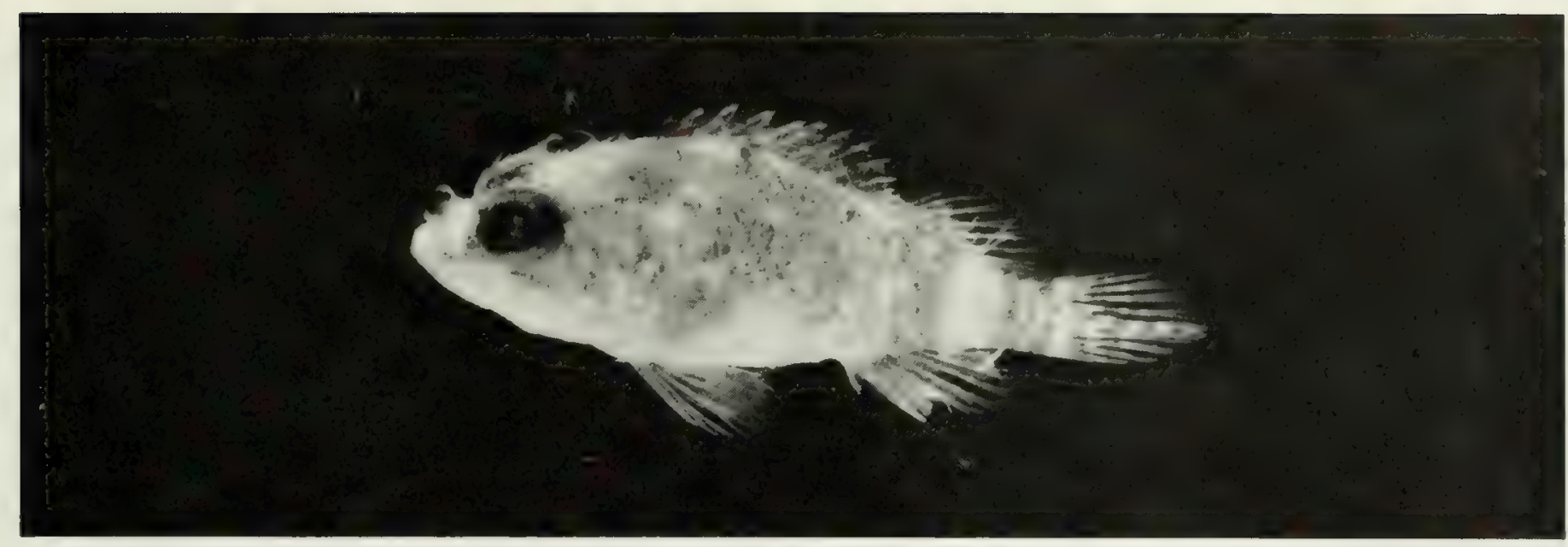

FIG. 108. Scorpaenodes kelloggi, (preserved) $22 \mathrm{~mm} \mathrm{SL}$, Eagle Island. Photo by A. Strange.

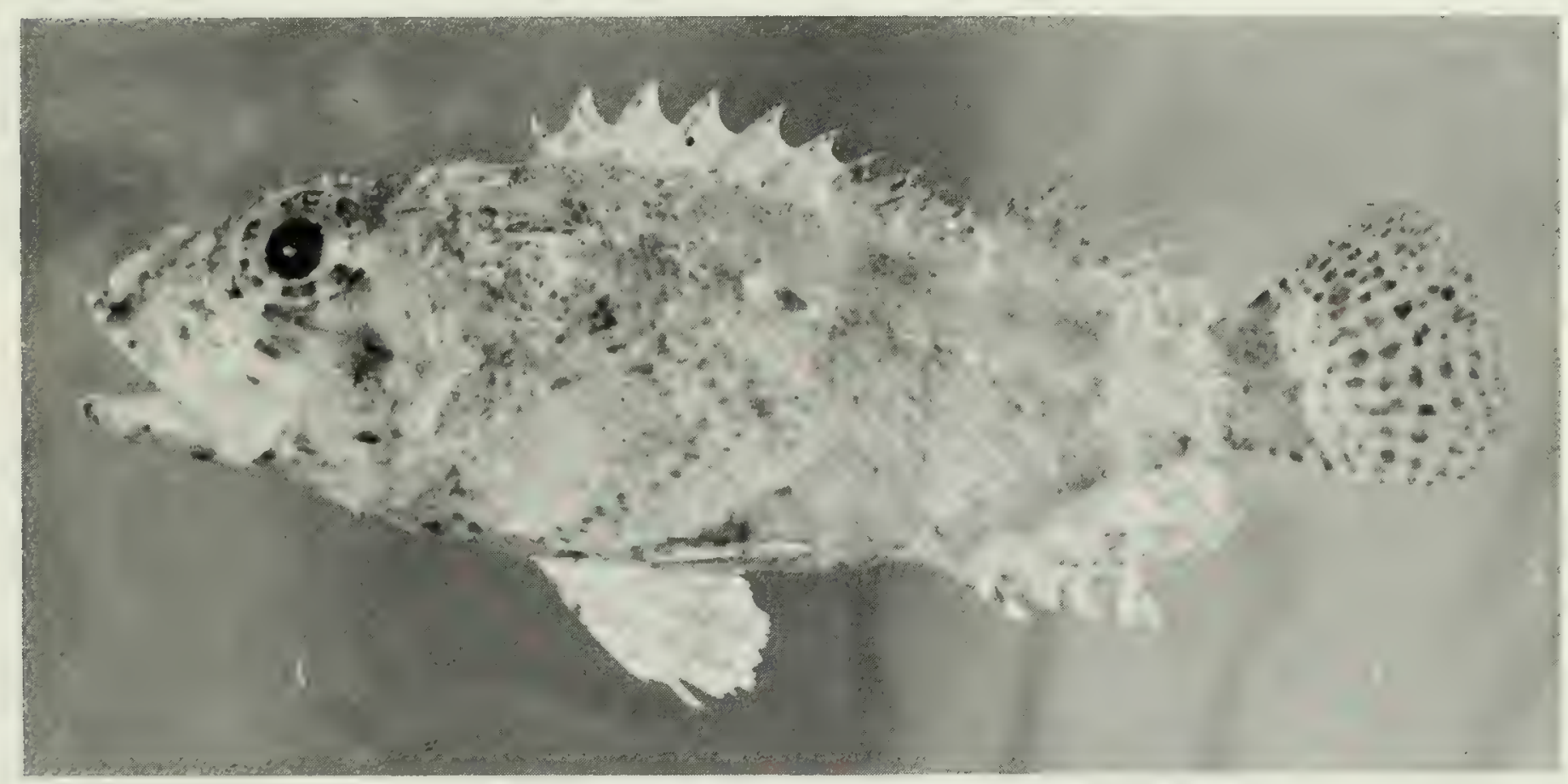

FIG. 109. Scorpaenodes parvipinnis, $78 \mathrm{~mm} \mathrm{SL}$, Peros Banhos.

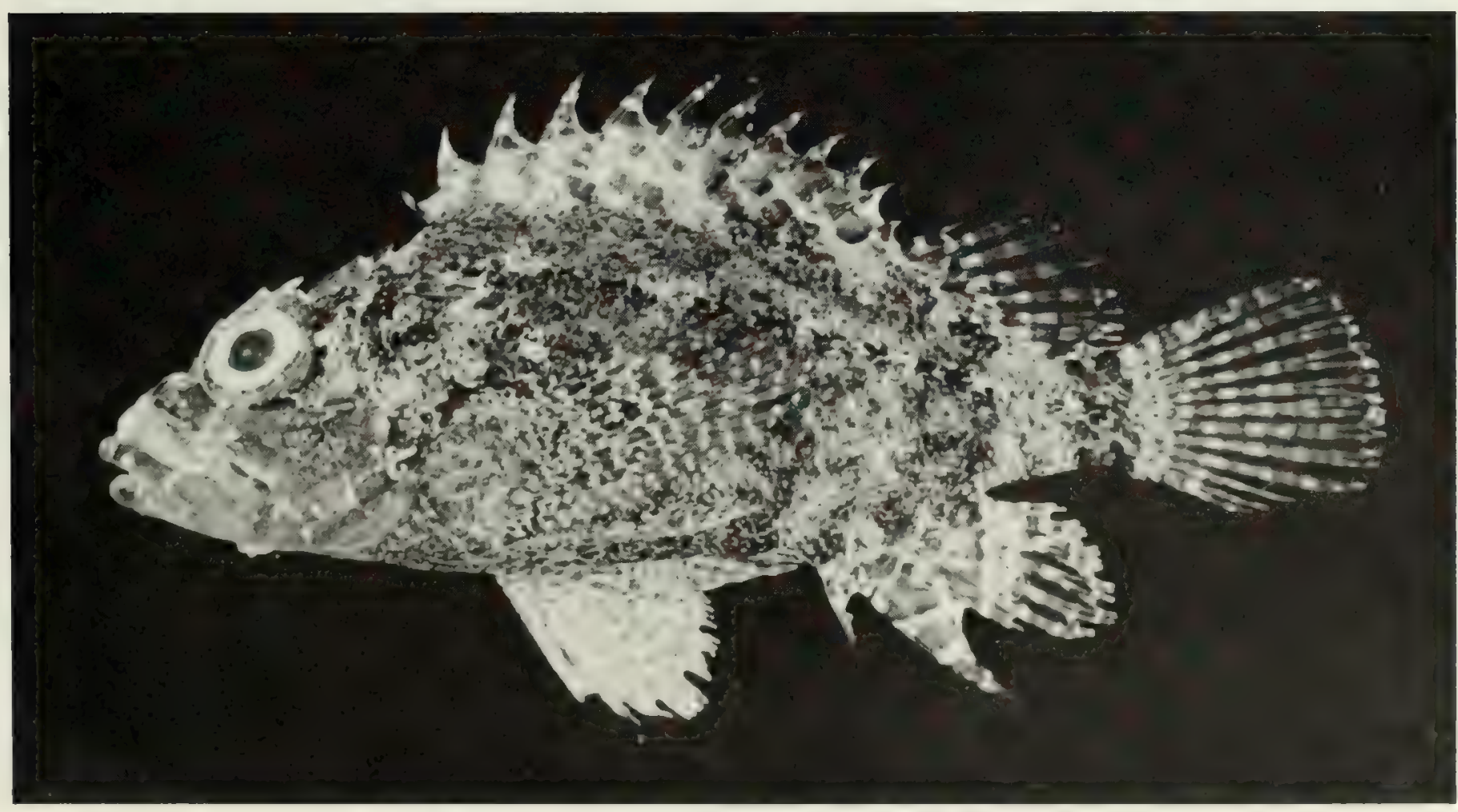

FIG. 110. Scorpaenodes scaber, $25 \mathrm{~mm} \mathrm{SL,} \mathrm{Eagle} \mathrm{Island.}$ 


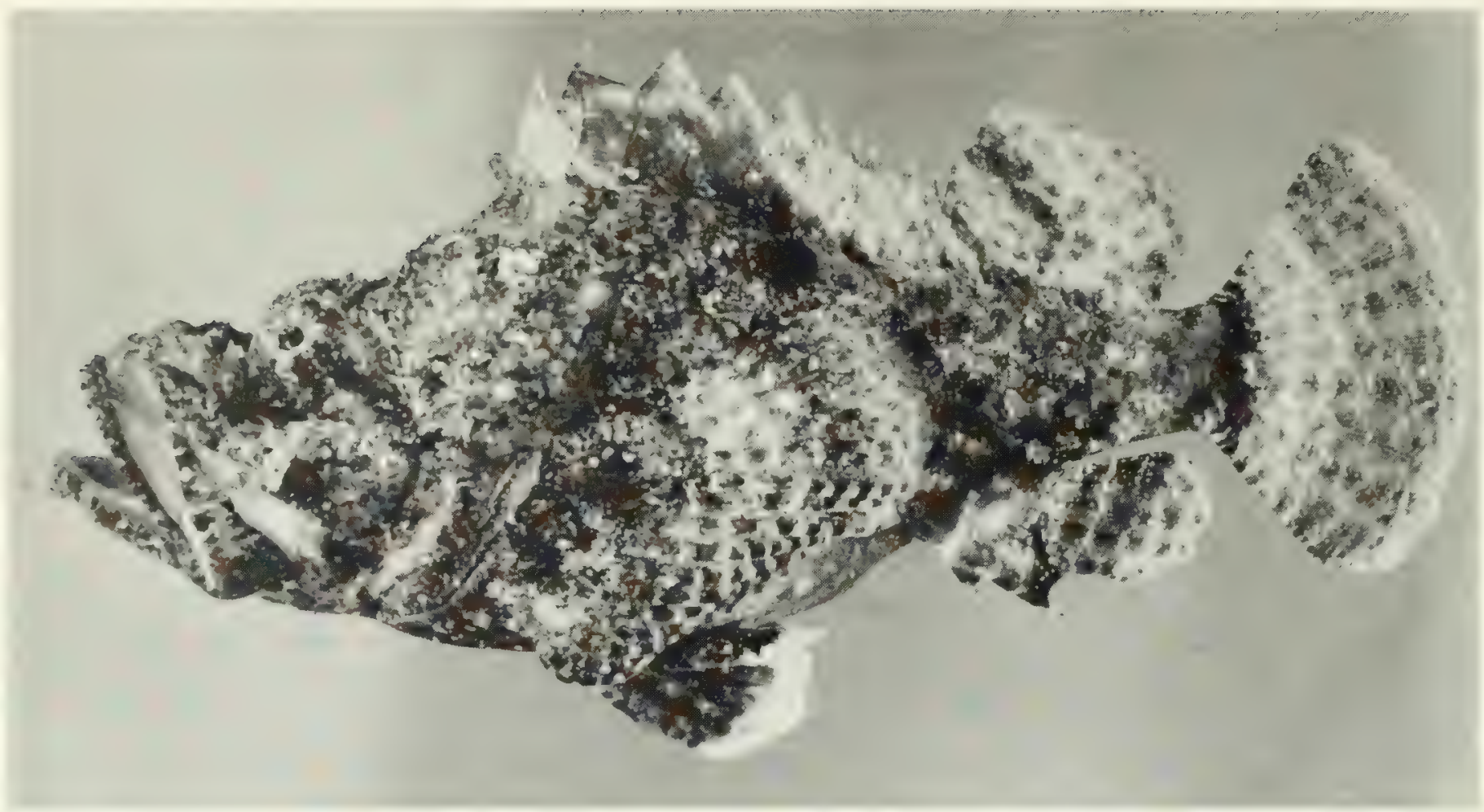

FIG. 111. Scorpaenopsis diabolus, $150 \mathrm{~mm} \mathrm{SL,} \mathrm{Peros} \mathrm{Banhos.}$

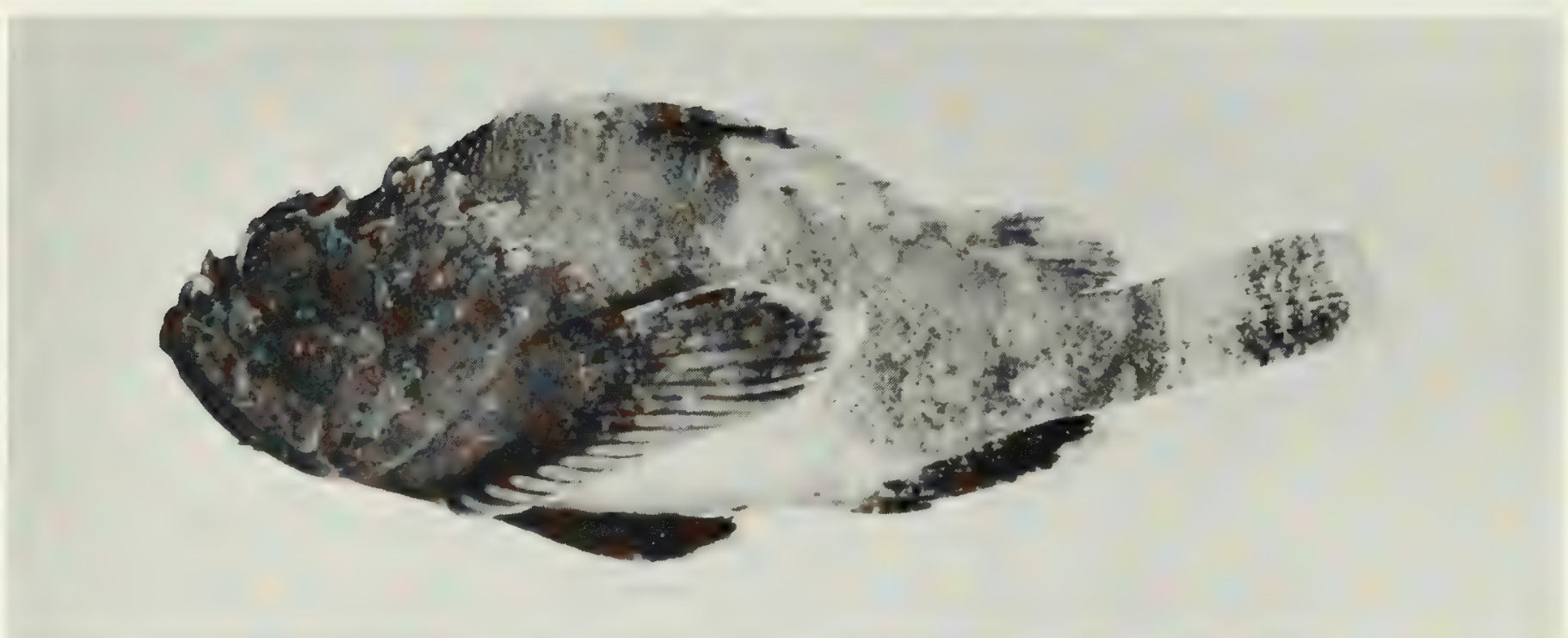

FIG. 112. Scorpaenopsis gibbosa, (preserved) $67 \mathrm{~mm} \mathrm{SL,} \mathrm{Diego} \mathrm{Garcia.} \mathrm{Photo} \mathrm{by} \mathrm{M.} \mathrm{Burridge-Smith.}$

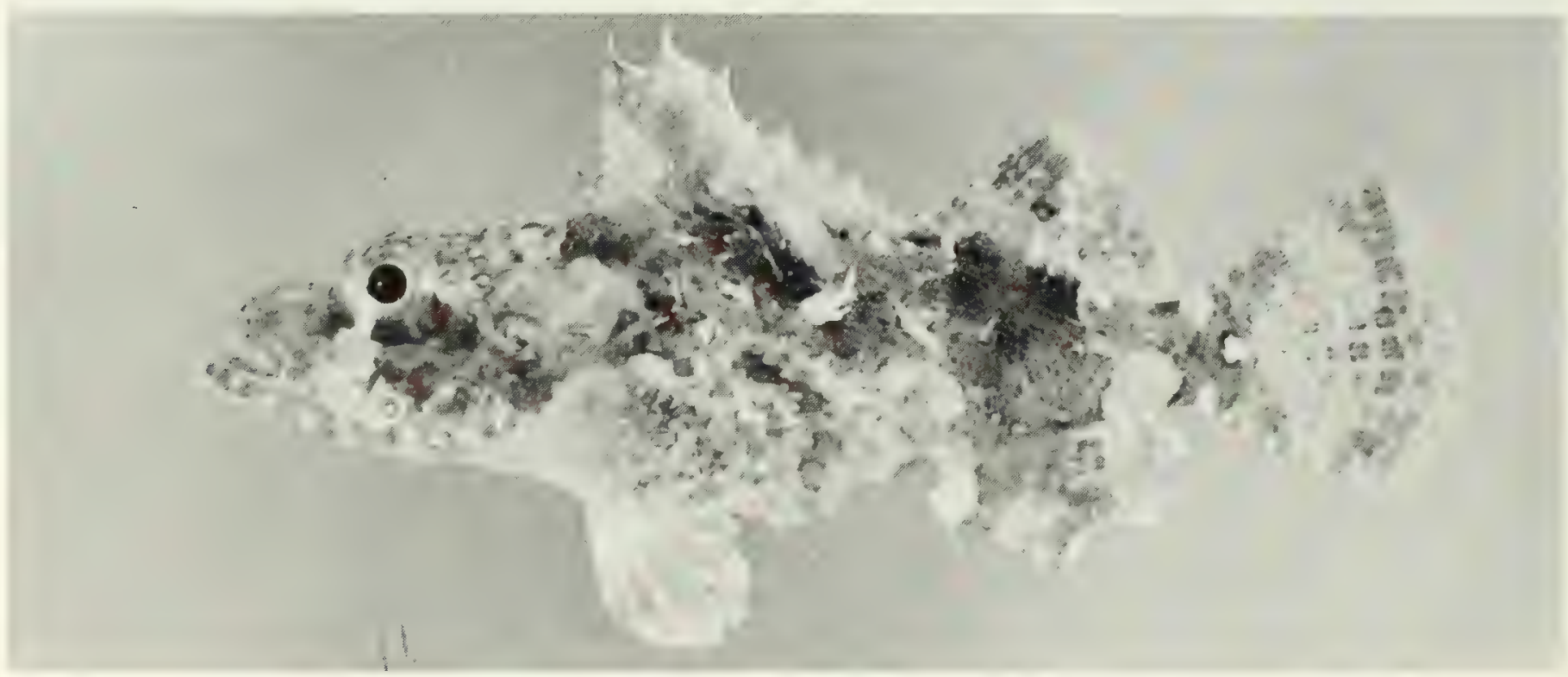

FIG. 113. Scorpaenopsis oxycephala, $38 \mathrm{~mm} \mathrm{SL}$, Salomon. 


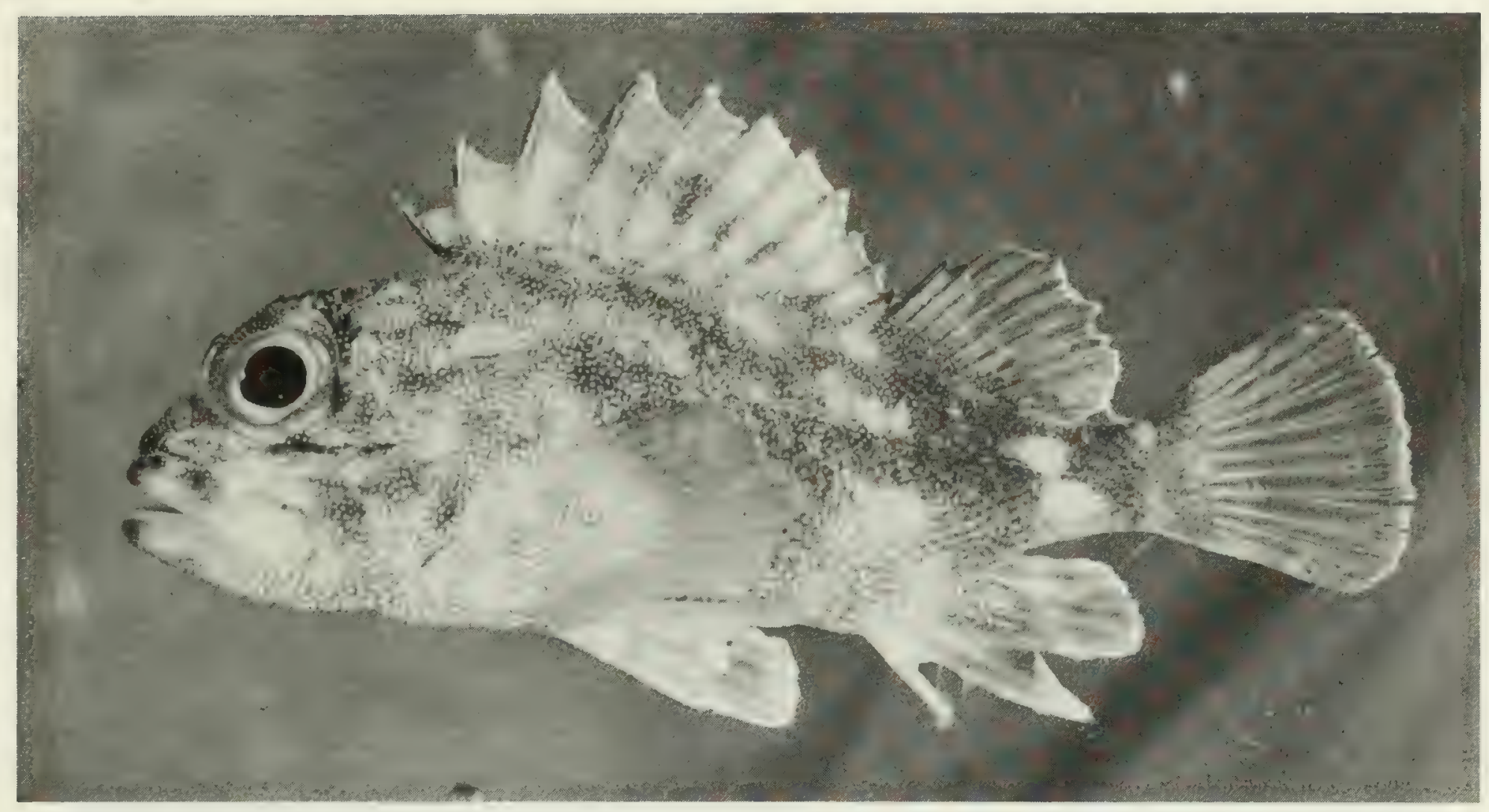

FIG. 114. Sebastapistes cyanostigma, $50 \mathrm{~mm} \mathrm{SL}$, Peros Banhos.

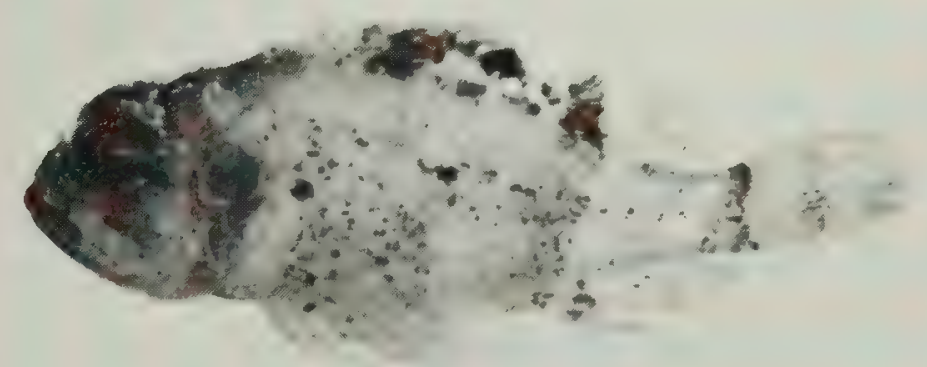

FIG. 115. Sebastapistes strongia, (preserved) $28 \mathrm{~mm} \mathrm{SL,} \mathrm{Diego} \mathrm{Garcia.} \mathrm{Photo} \mathrm{by} \mathrm{M.} \mathrm{Burridge-Smith.}$

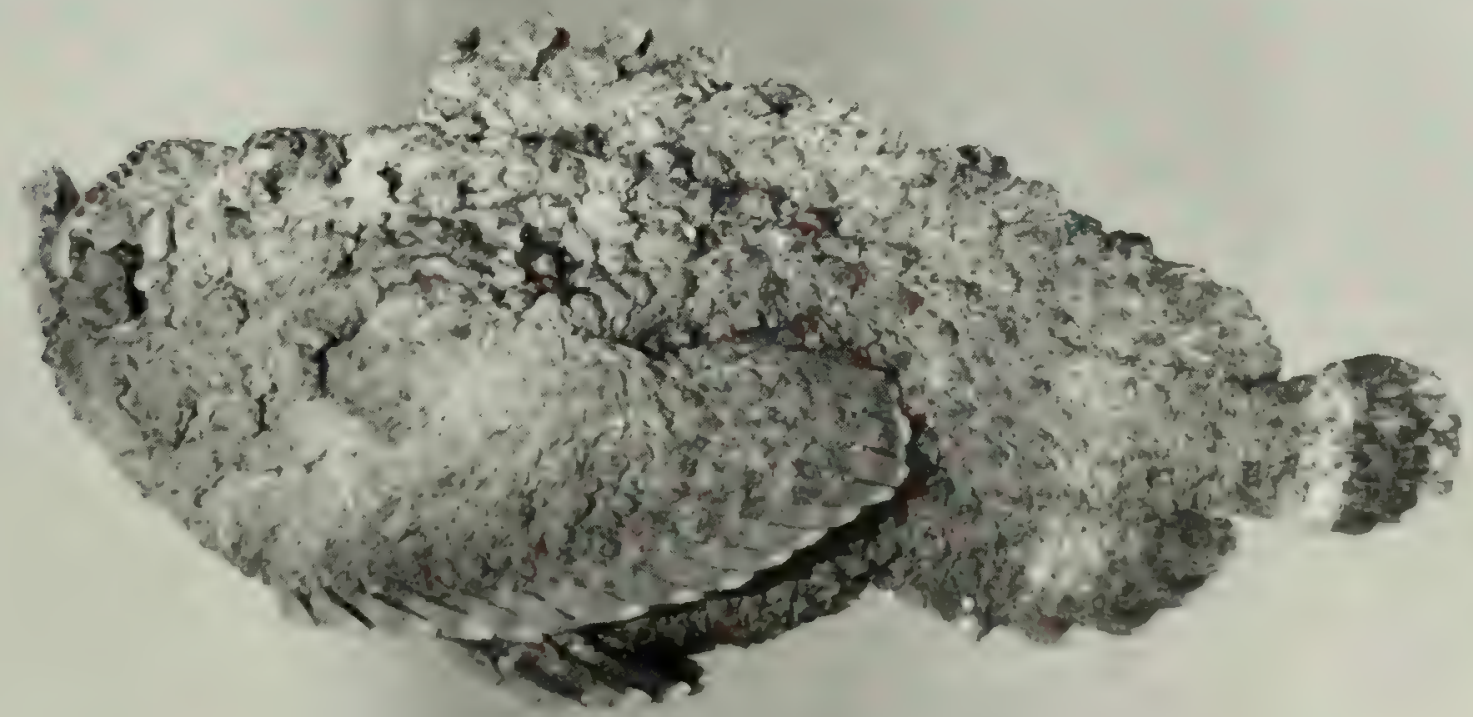

FIG. 116. Synanceia verrucosa, $132 \mathrm{~mm} \mathrm{SL}$, Salomon 


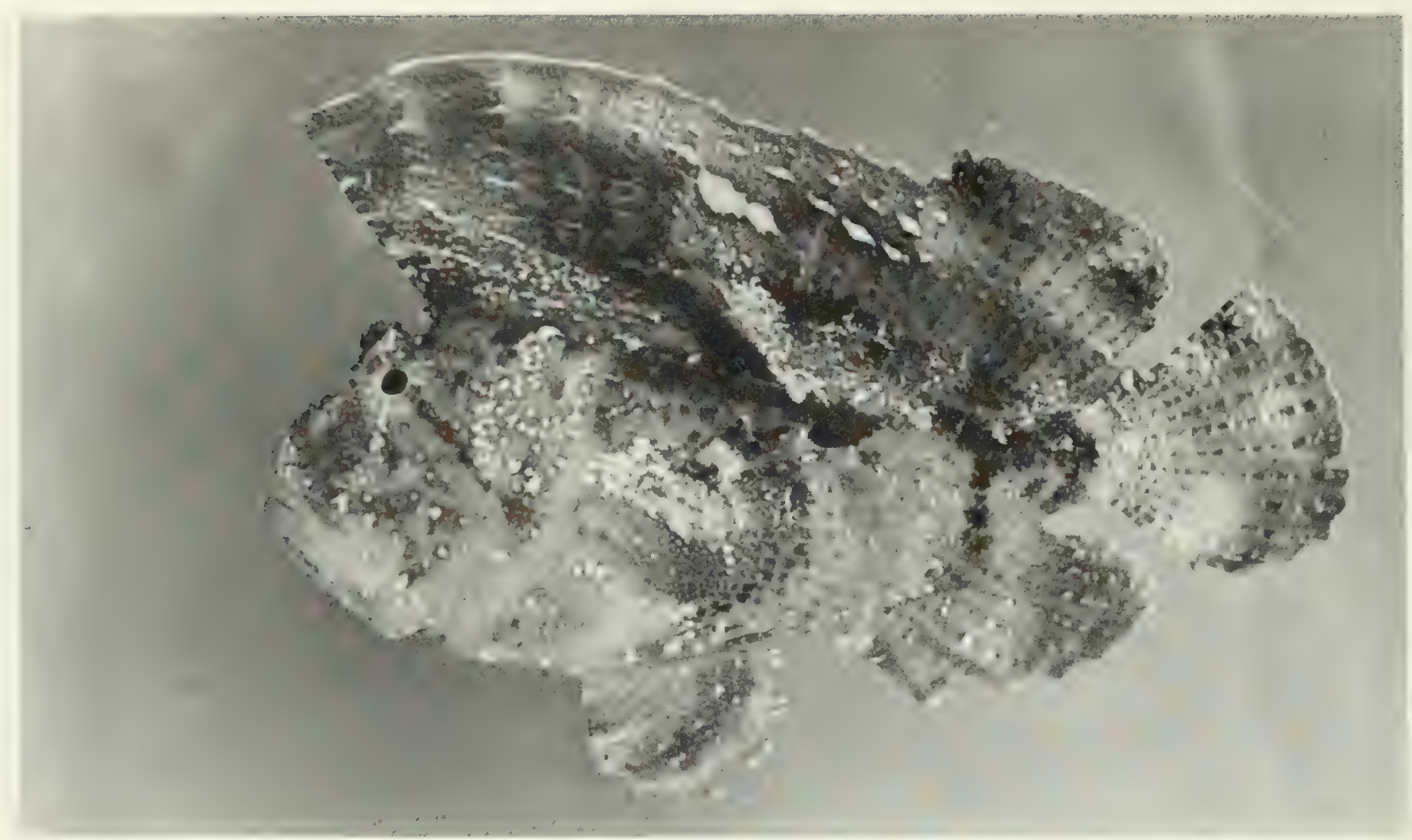

FIG. 117. Taenianotus triacanthus, $62 \mathrm{~mm}$ SL, Peros Banhos.

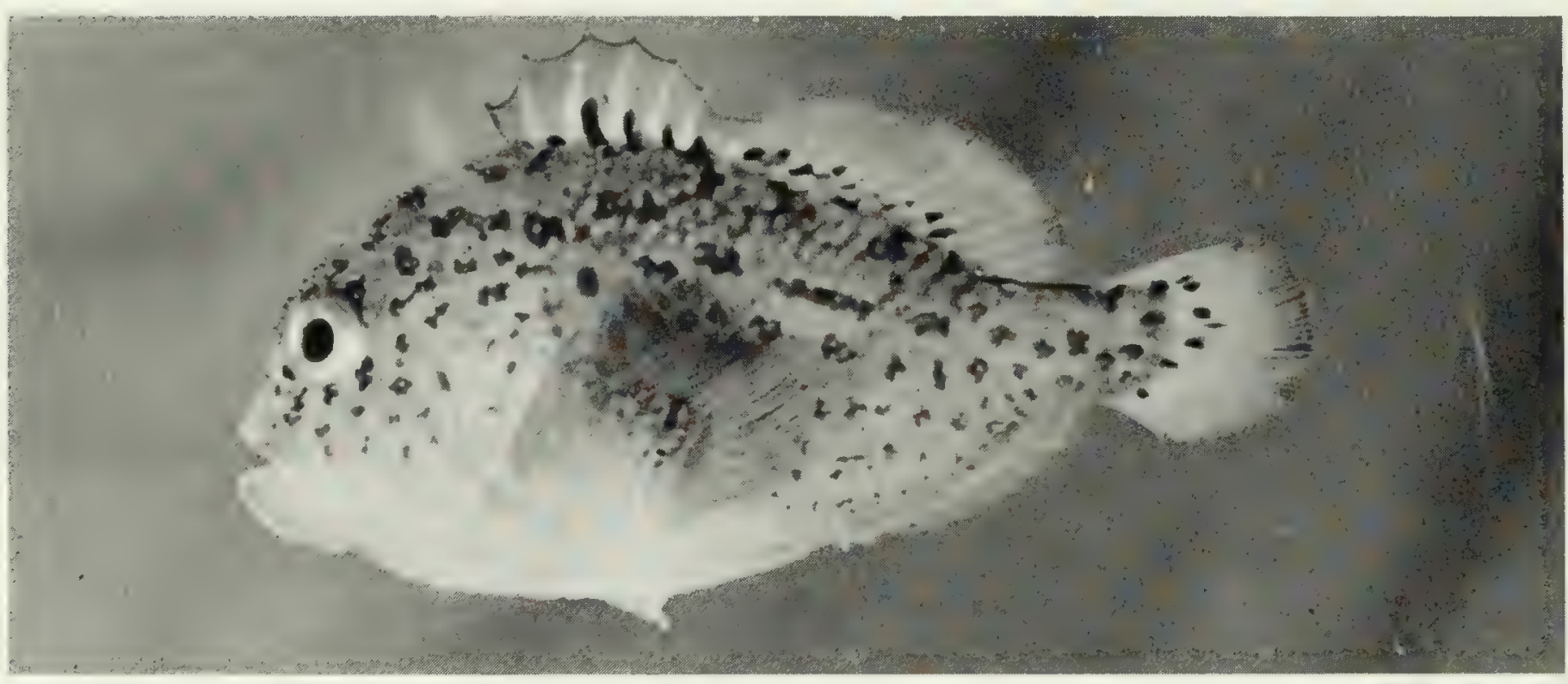

Fig. 118. Caracanthus madagascariensis, $27 \mathrm{~mm} \mathrm{SL,} \mathrm{Peros} \mathrm{Banhos.}$

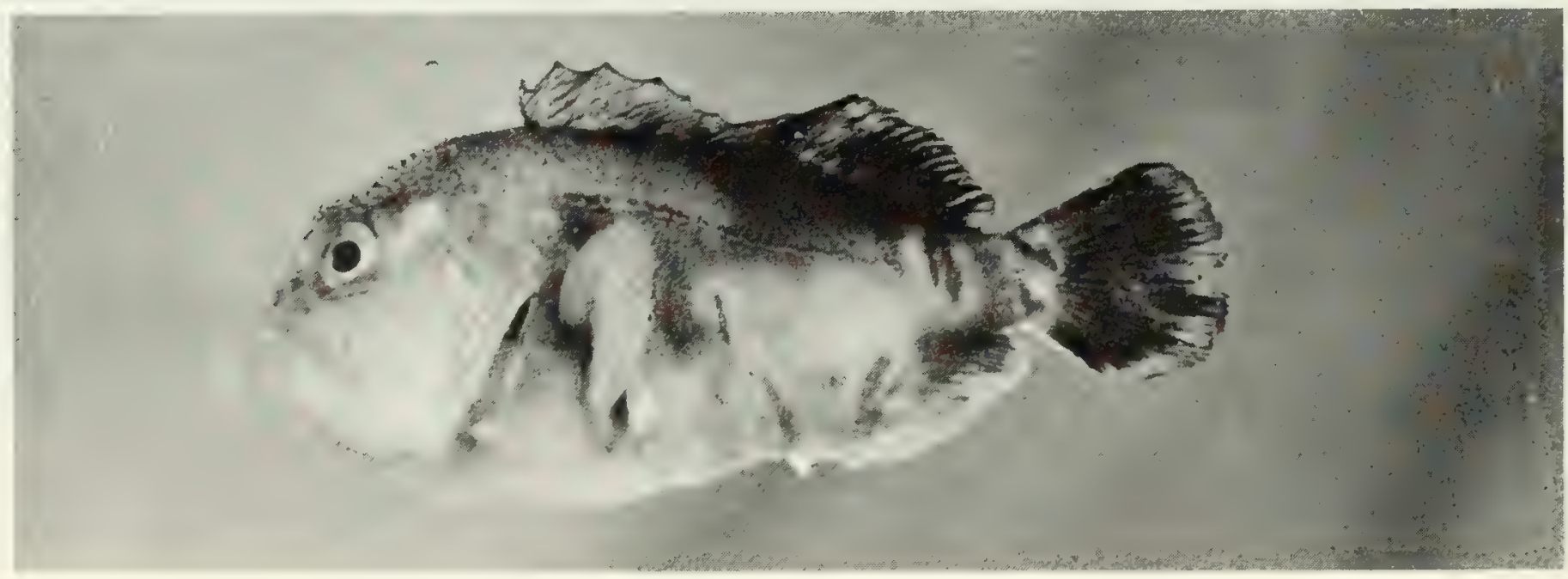

FIG. 119. Caracanthus unipinna, $28 \mathrm{~mm} \mathrm{SL}$, Peros Banhos. 


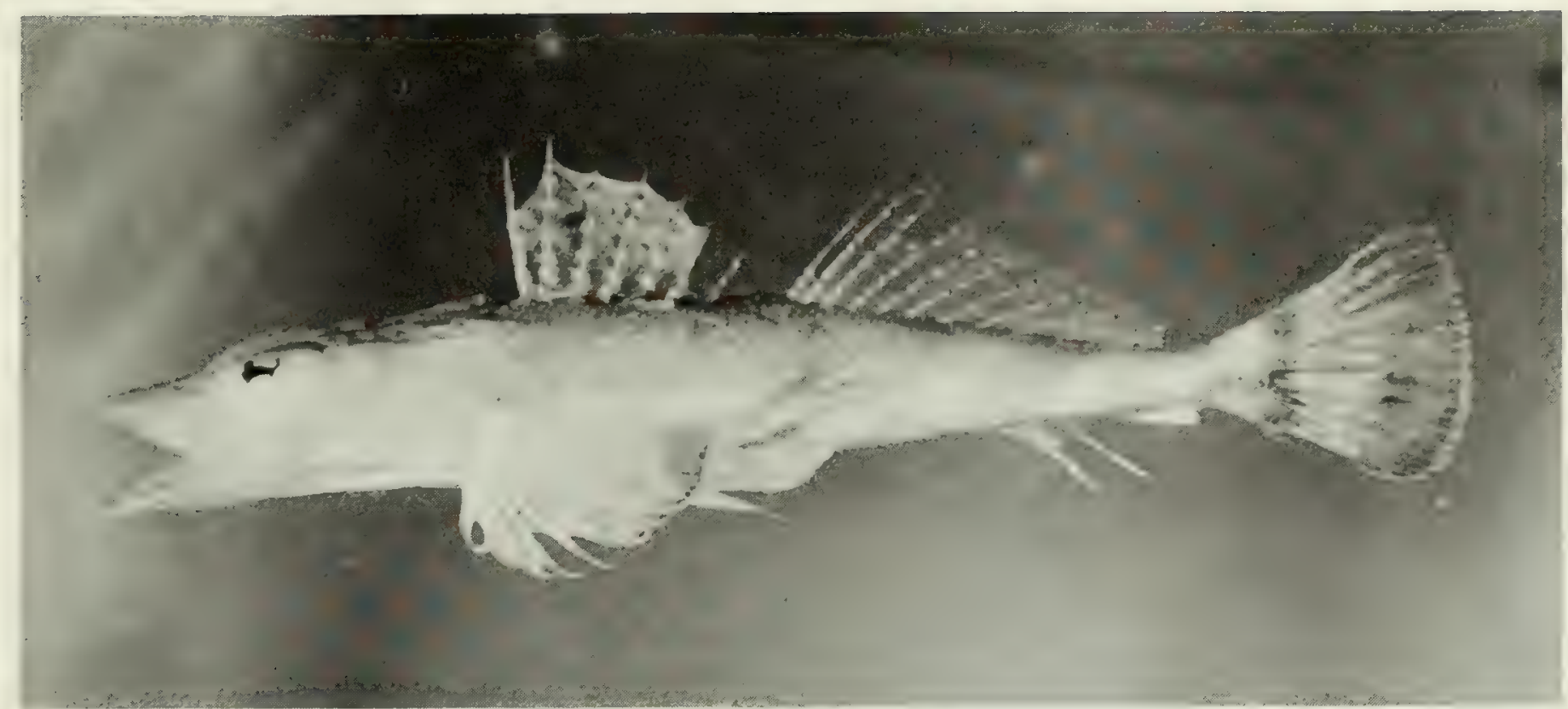

FIG. 120. Rogadius serratus, $76 \mathrm{~mm}$ SL, Peros Banhos.

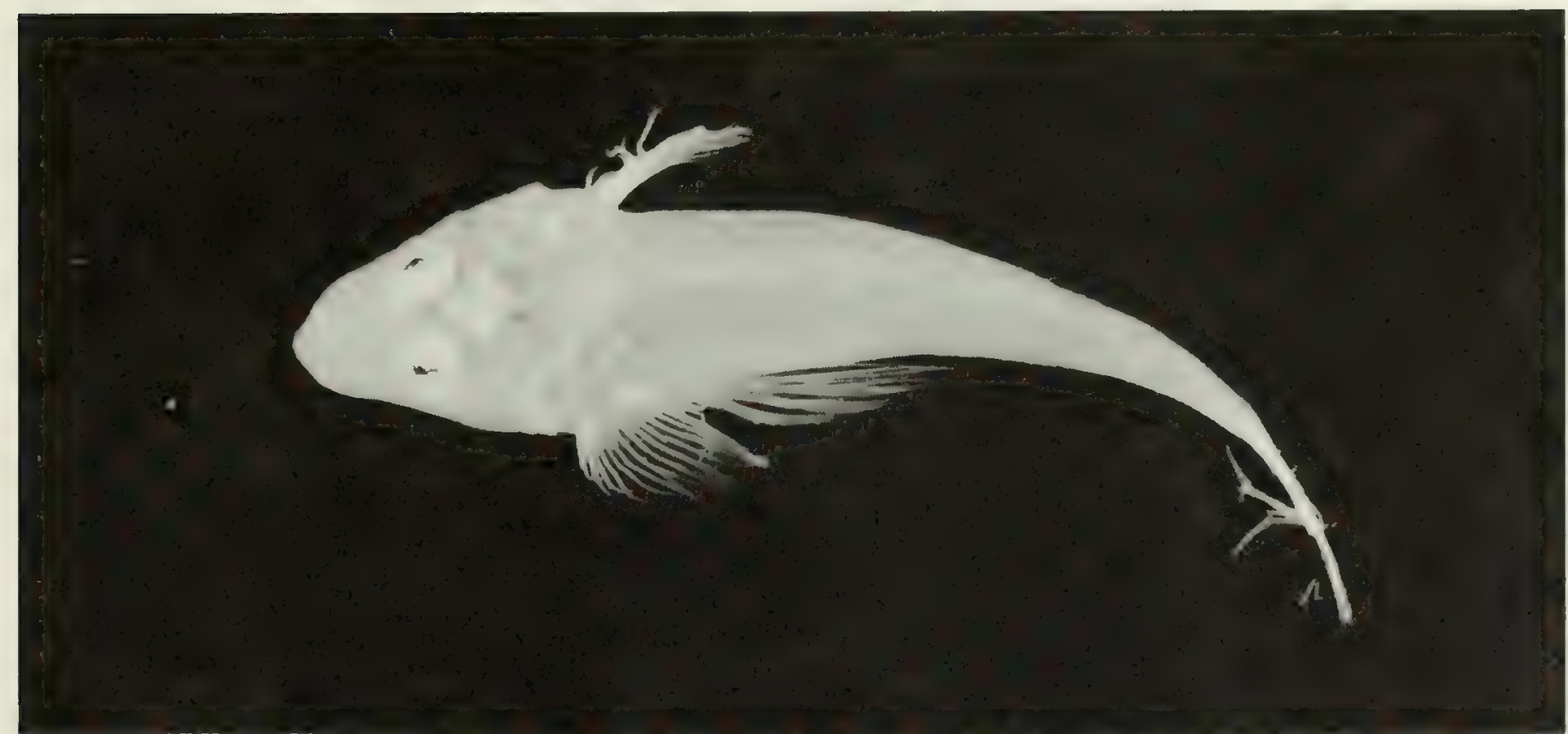

FIG. 121. Thysanophrys arenicola, (preserved) $53 \mathrm{~mm} \mathrm{SL}$, Salomon. Photo by A. Strange.

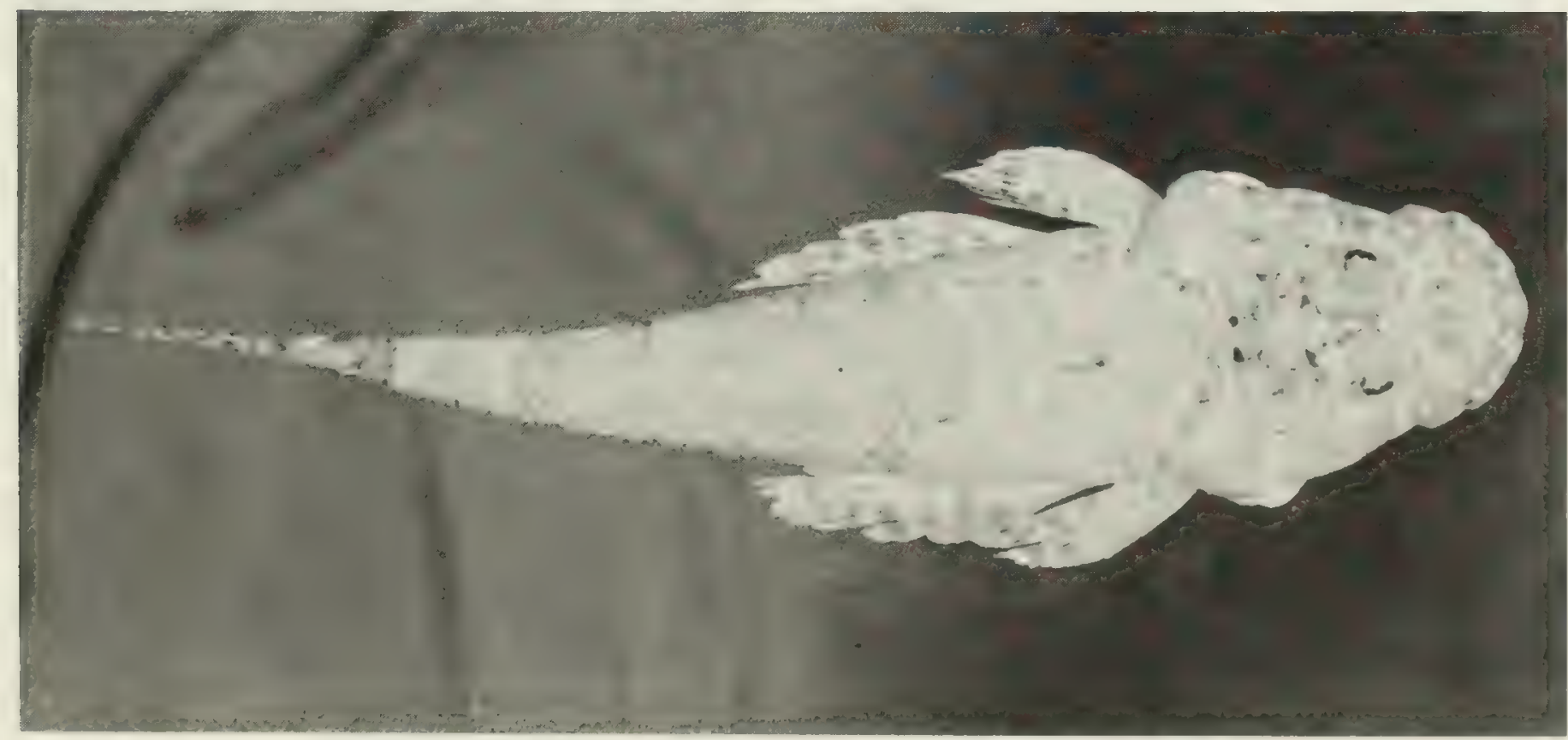

FIG. 122. Thysanophrys otaitensis, $122 \mathrm{~mm} \mathrm{SL}$, Peros Banhos. 


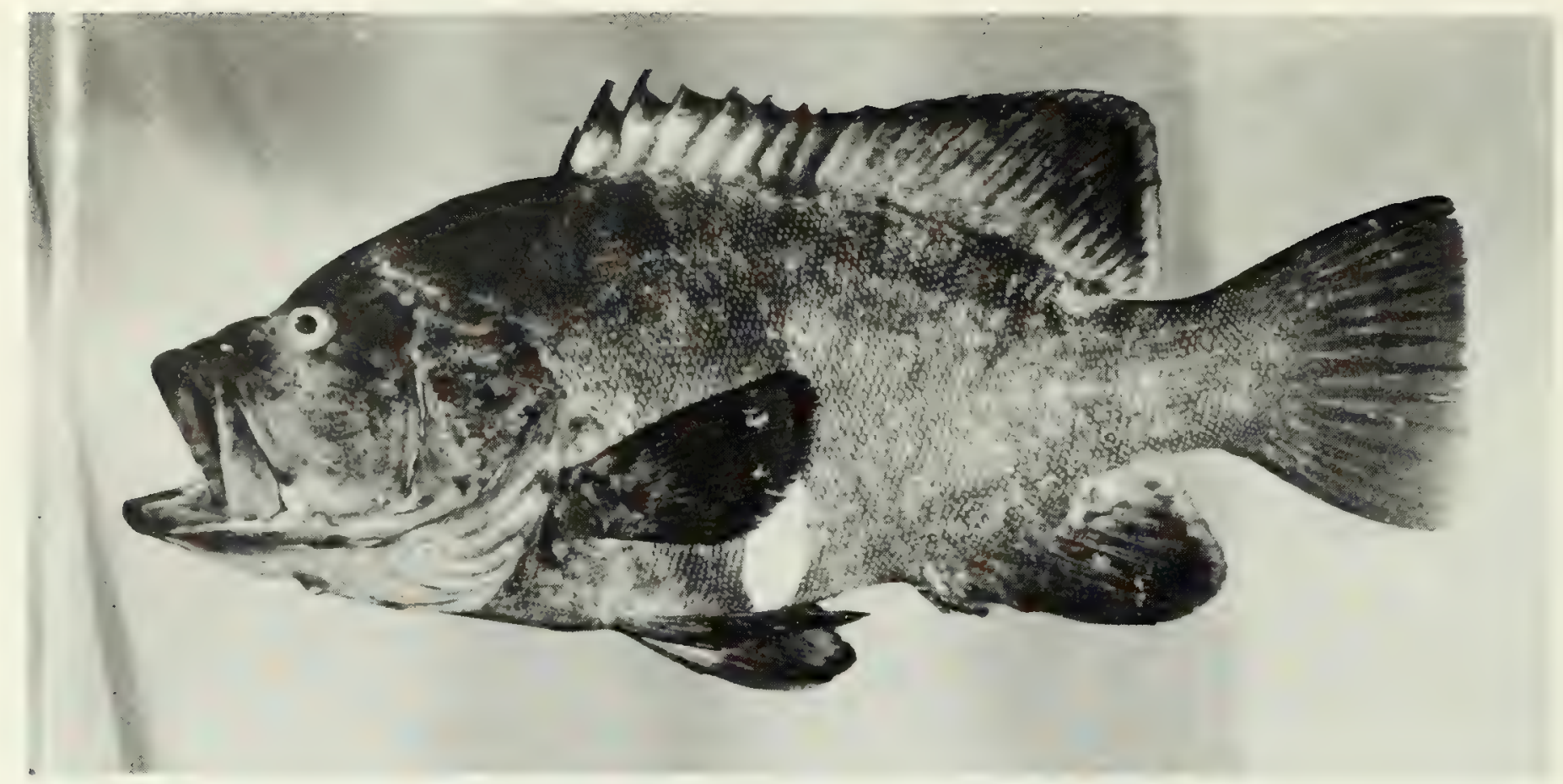

Fig. 123. Aethaloperca rogaa, $291 \mathrm{~mm}$ SL, Peros Banhos.

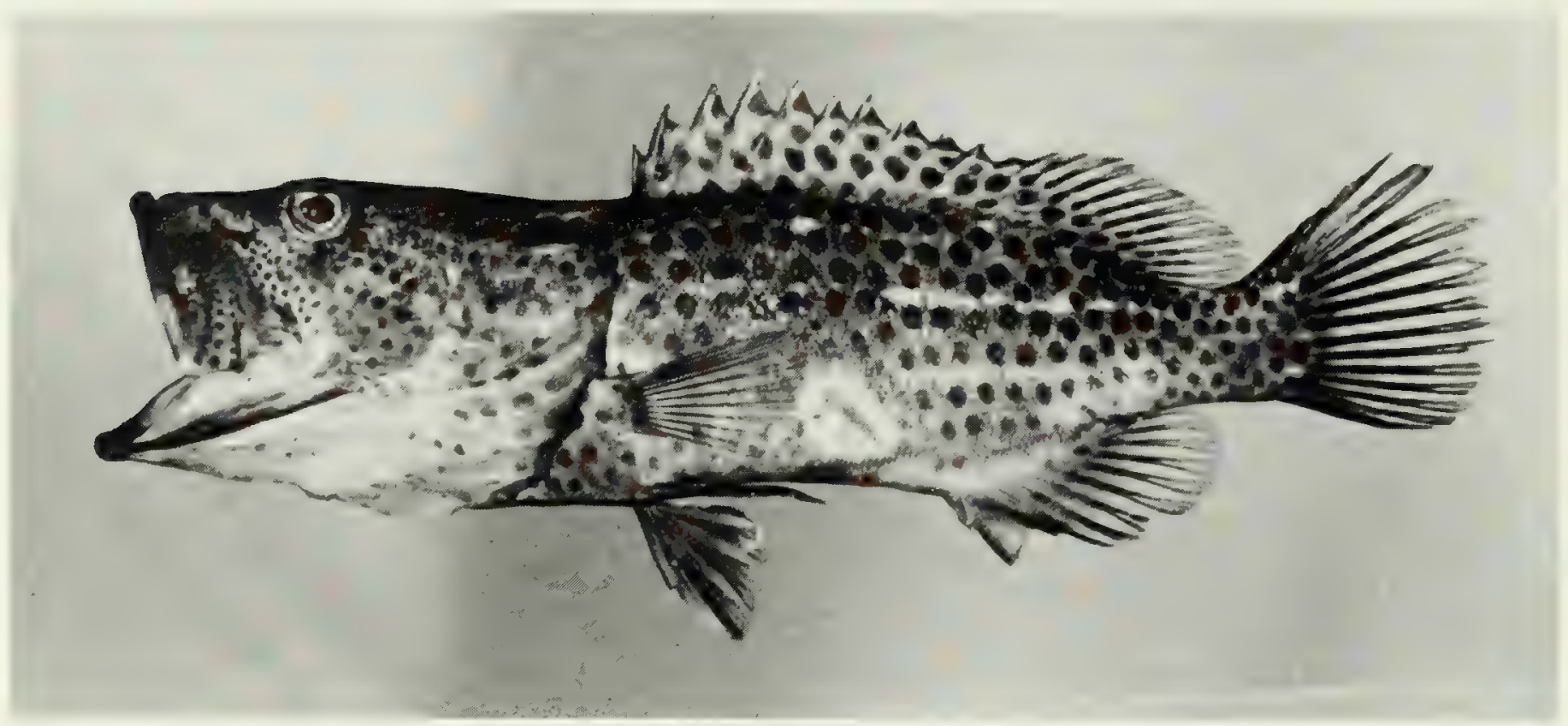

FIG. 124. Anyperodon leucogrammicus, $205 \mathrm{~mm} \mathrm{SL}$, Peros Banhos.

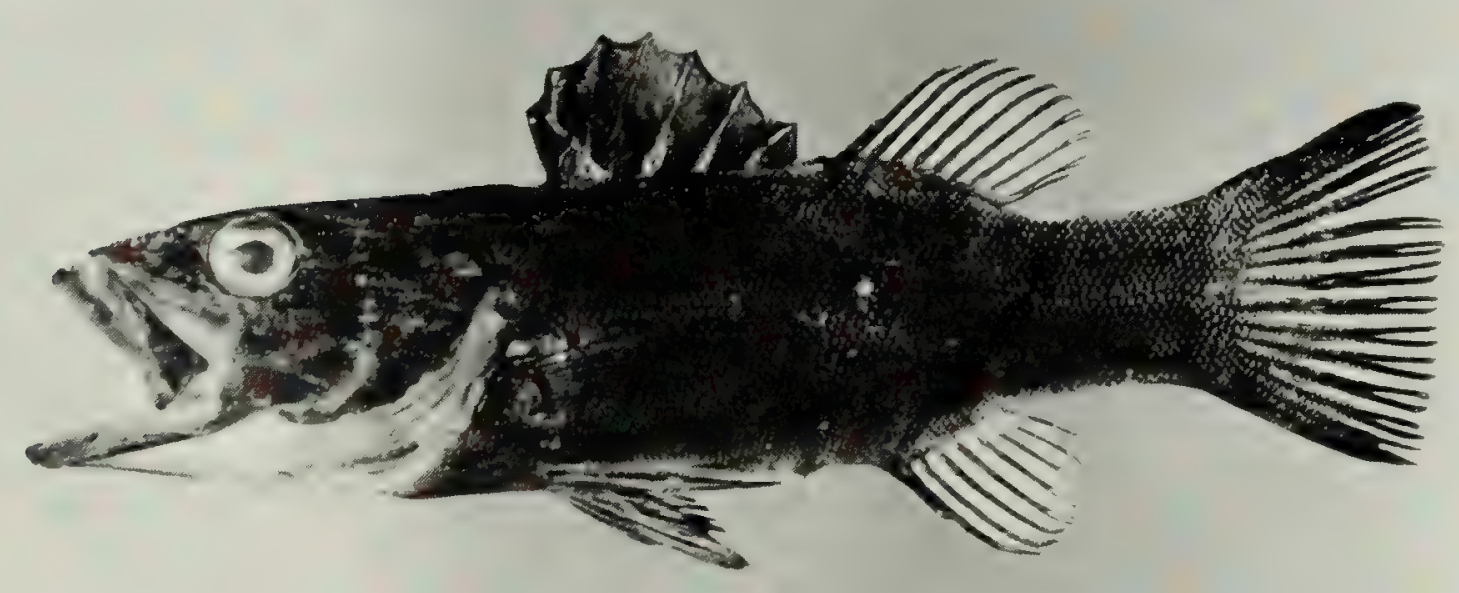

FIG. 125. Belonoperca chabanaudi, $67 \mathrm{~mm} \mathrm{SL}$, Salomon. 


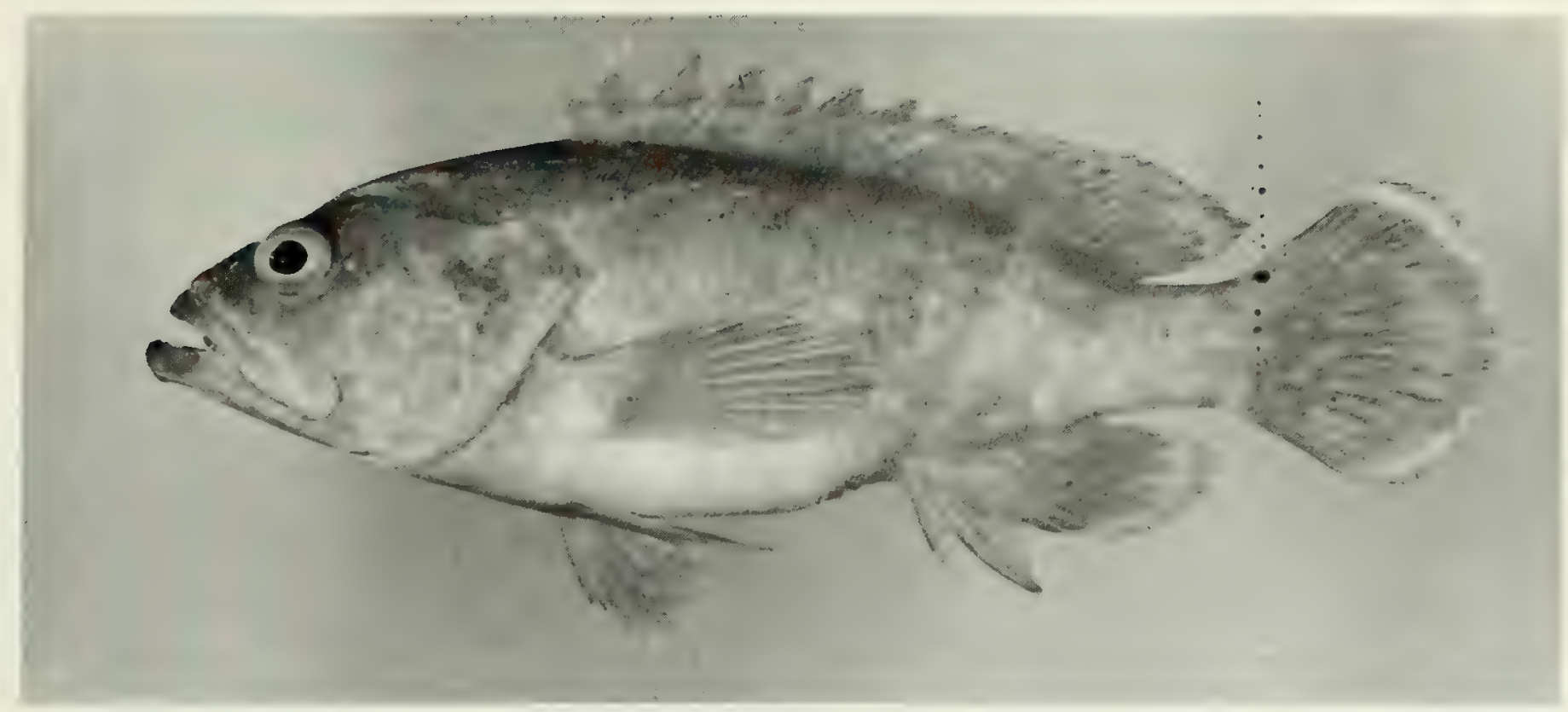

FIG. 126. Cephalopholis analis, $128 \mathrm{~mm} \mathrm{SL}$, Peros Banhos.

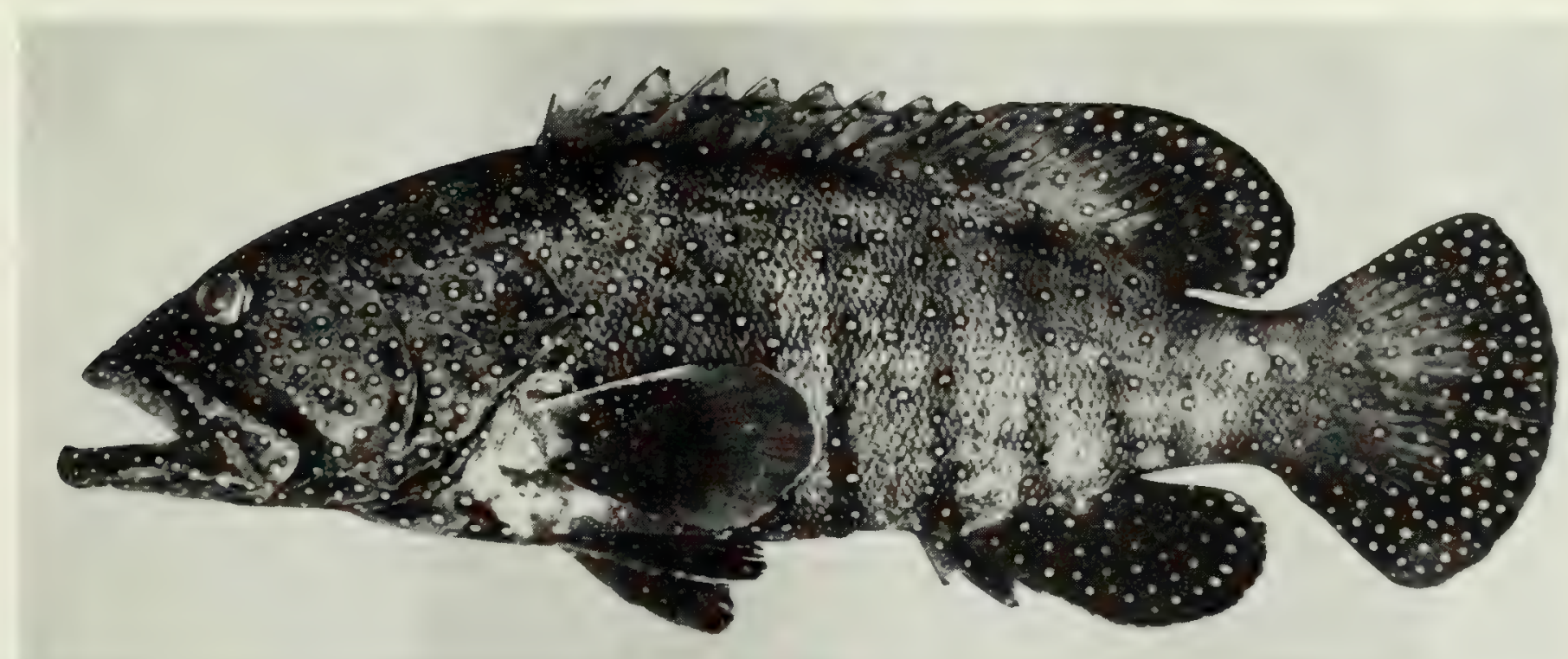

FIG. 127. Cephalopholis argus, $239 \mathrm{~mm} \mathrm{SL}$, Peros Banhos.

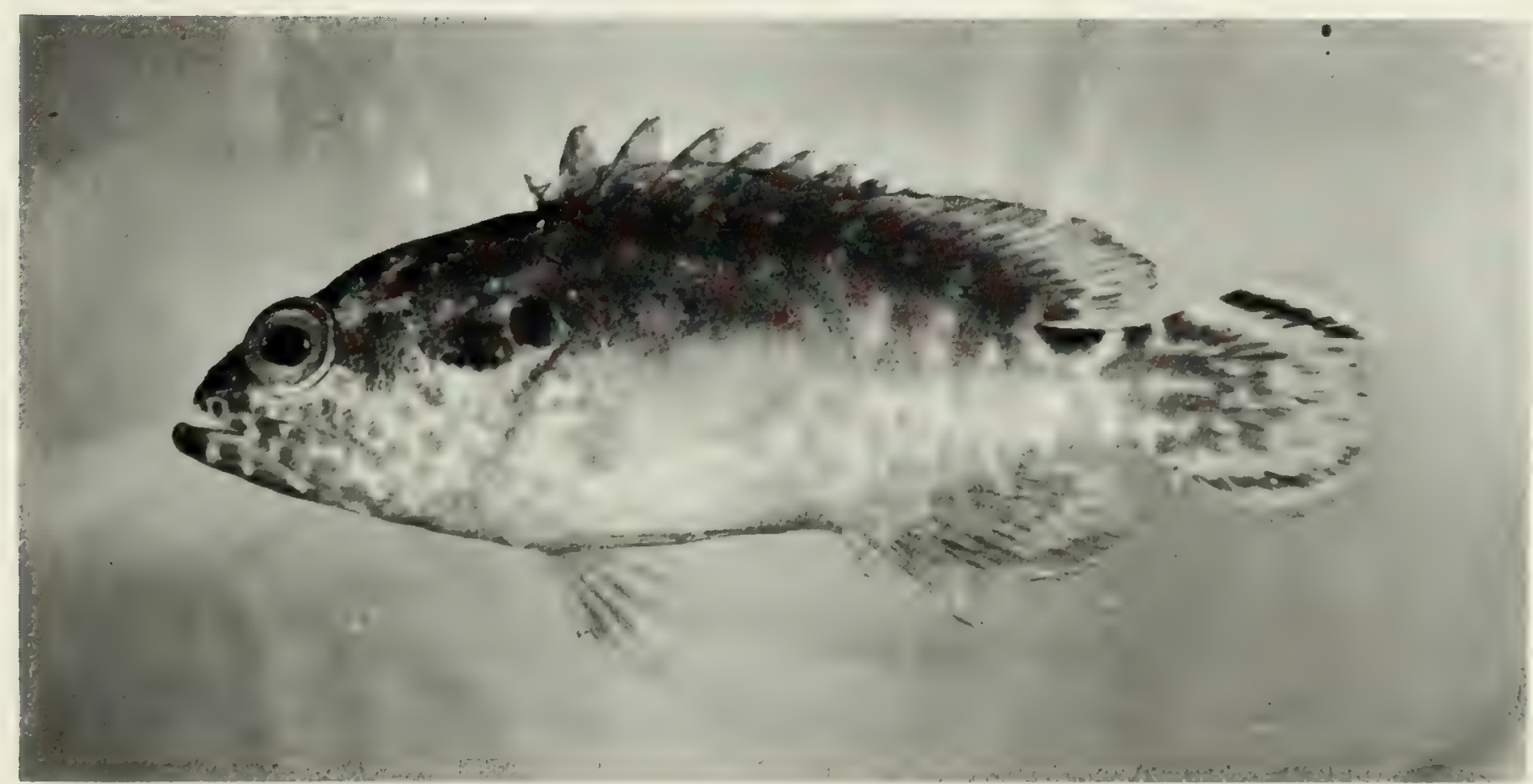

FIG. 128. Cephalopholis leopardus, $61 \mathrm{~mm} \mathrm{SL,} \mathrm{Salomon.}$ 


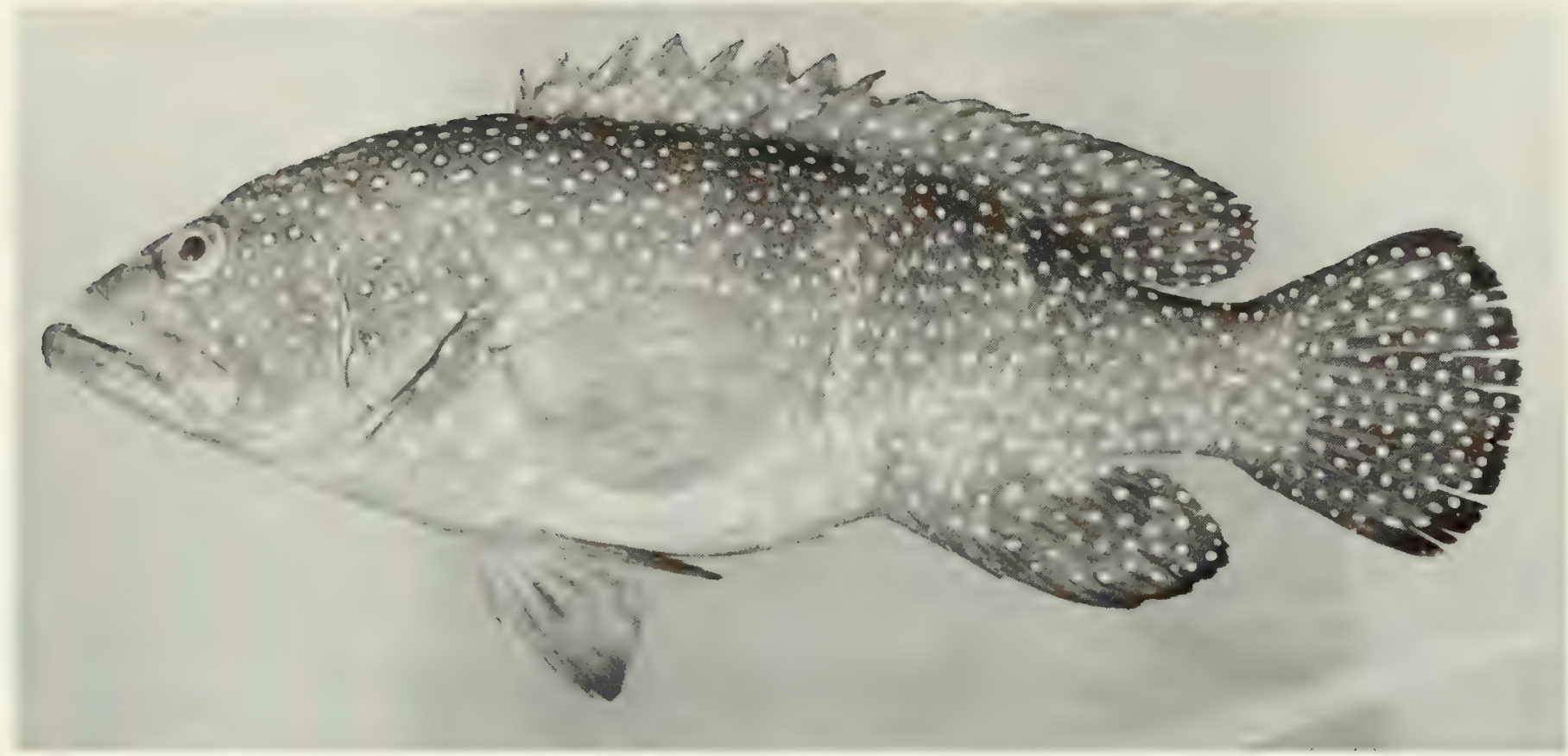

FIG. 129. Cephalopholis miniata, $245 \mathrm{~mm} \mathrm{SL}$, Peros Banhos.

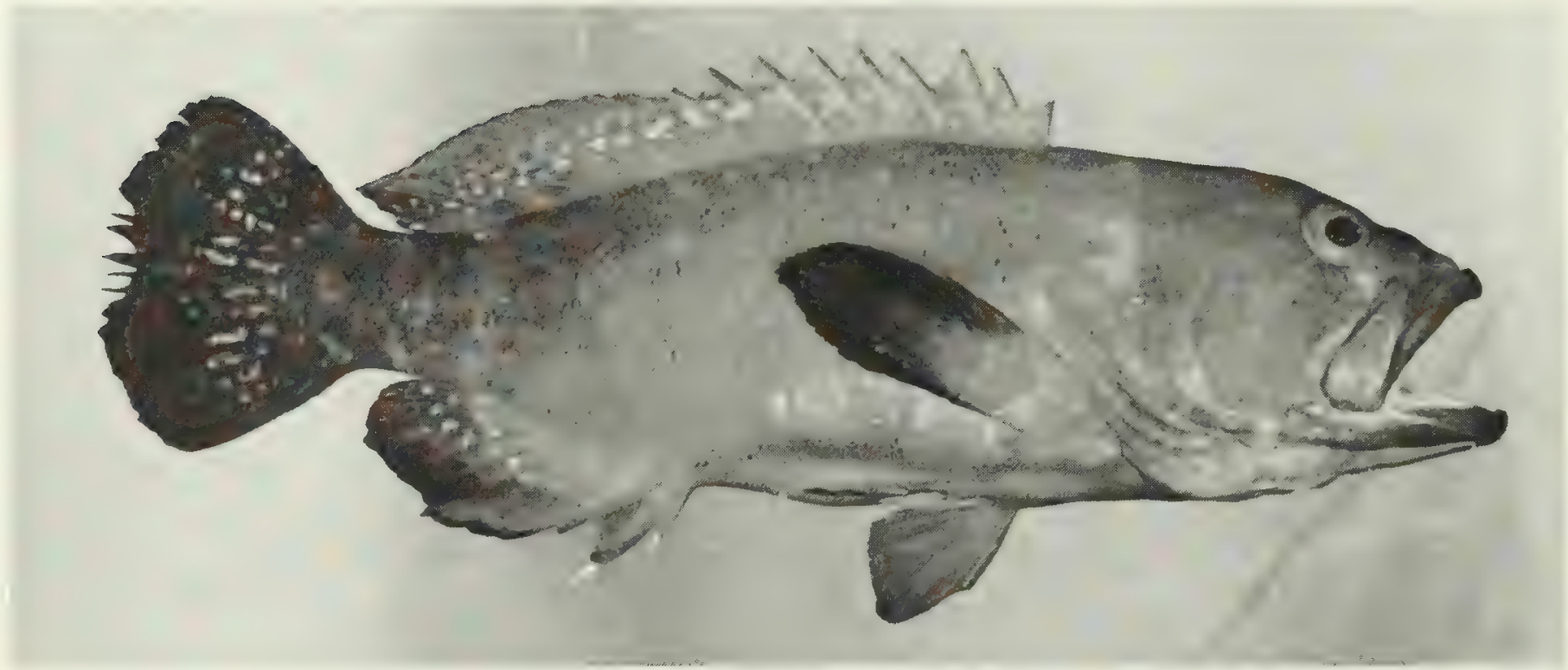

FIG. 130. Cephalopholis nigripinnis, $146 \mathrm{~mm}$ SL, Peros Banhos.

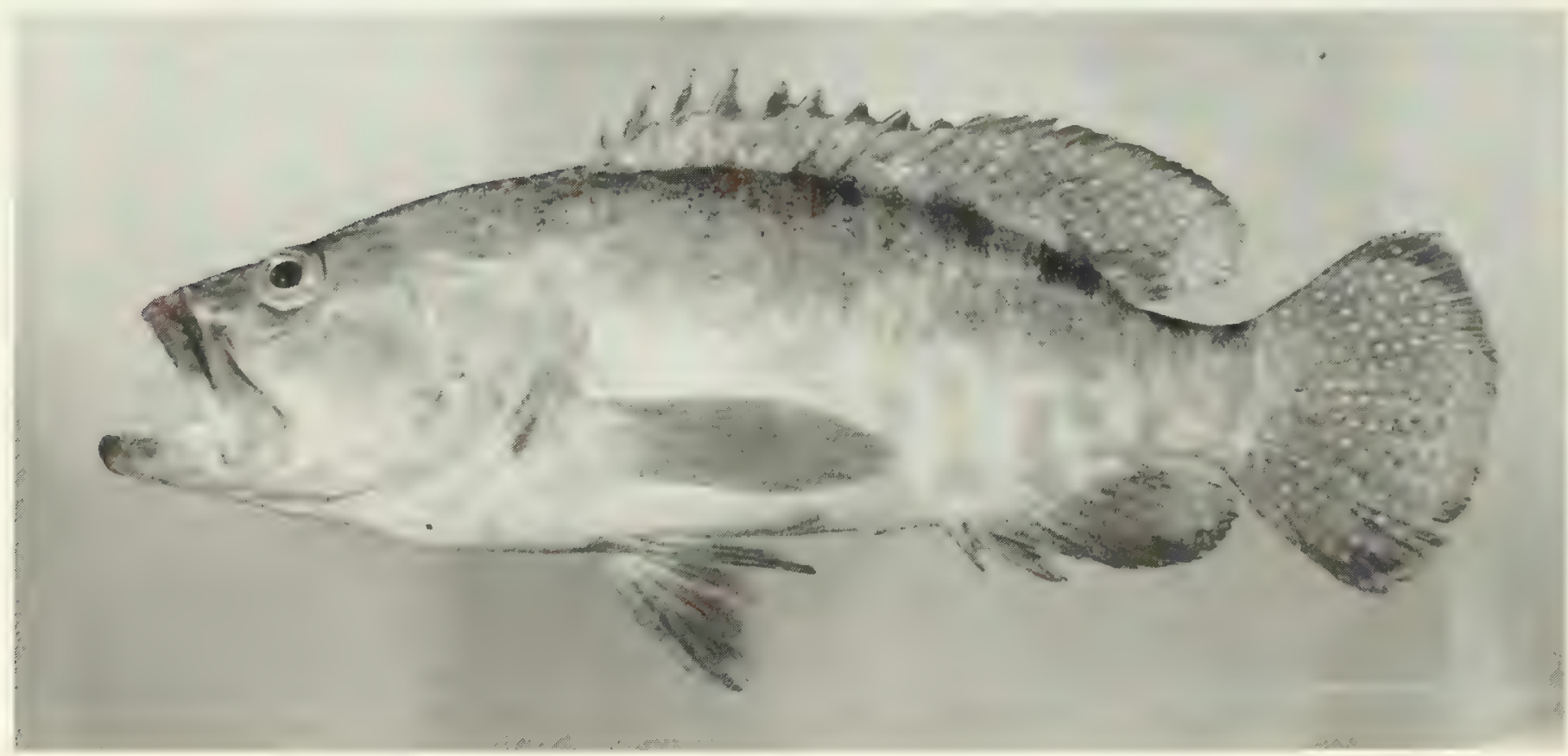

FIG. 131. Cephalopholis sexmaculata, $283 \mathrm{~mm}$ SL, Peros Banhos. 


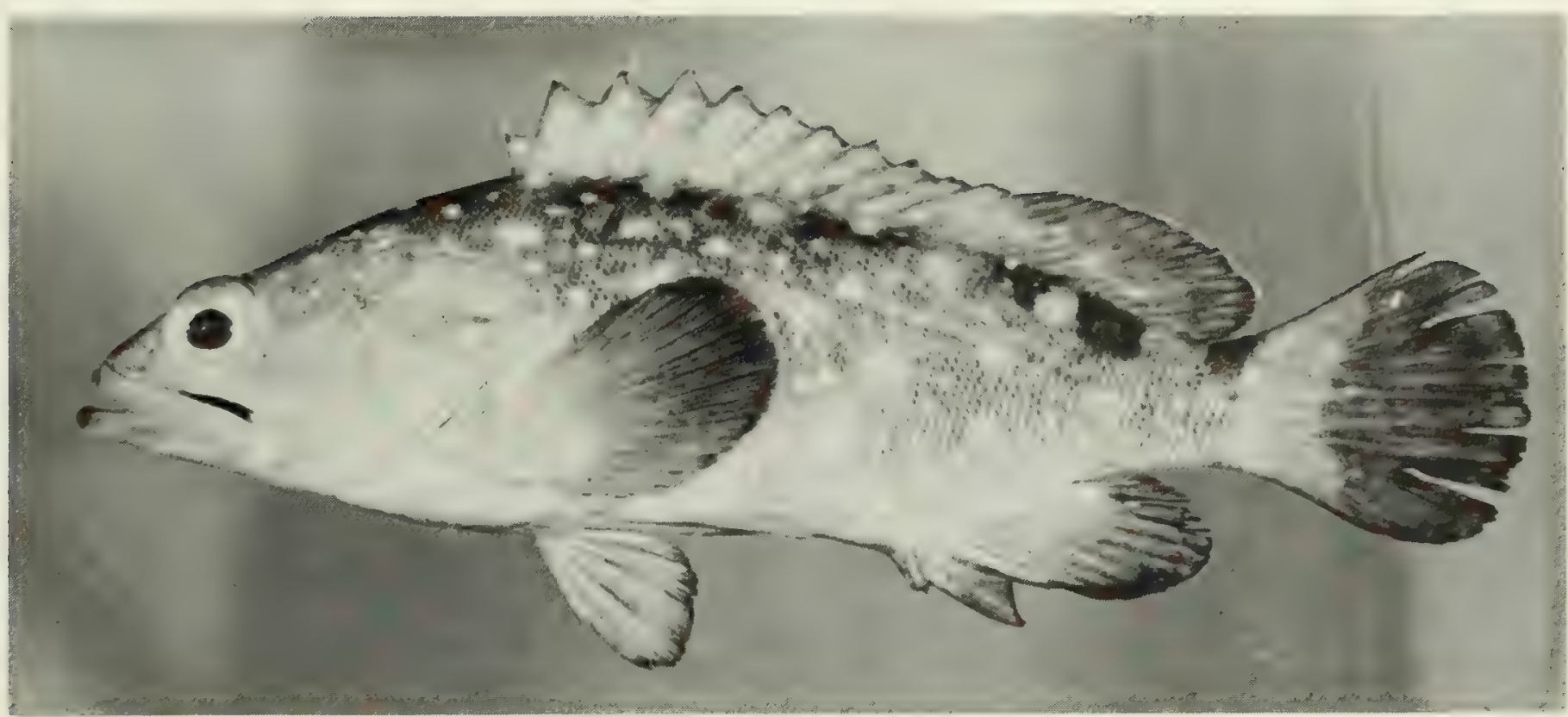

FIG. 132. Epinephelus caeruleopunctatus, $184 \mathrm{~mm} \mathrm{SL}$, Peros Banhos.

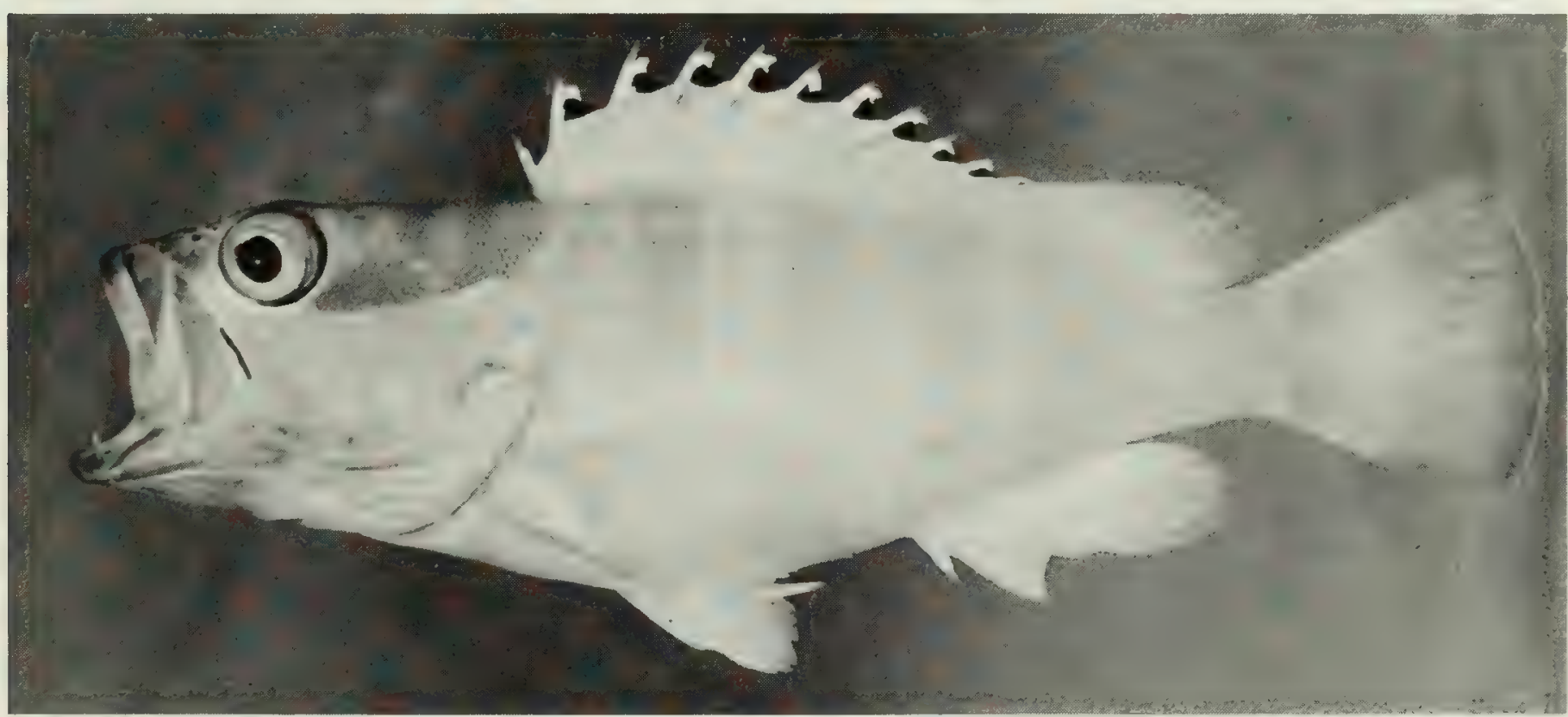

FIG. 133. Epinephelus fasciatus, $98 \mathrm{~mm}$ SL, Peros Banhos.

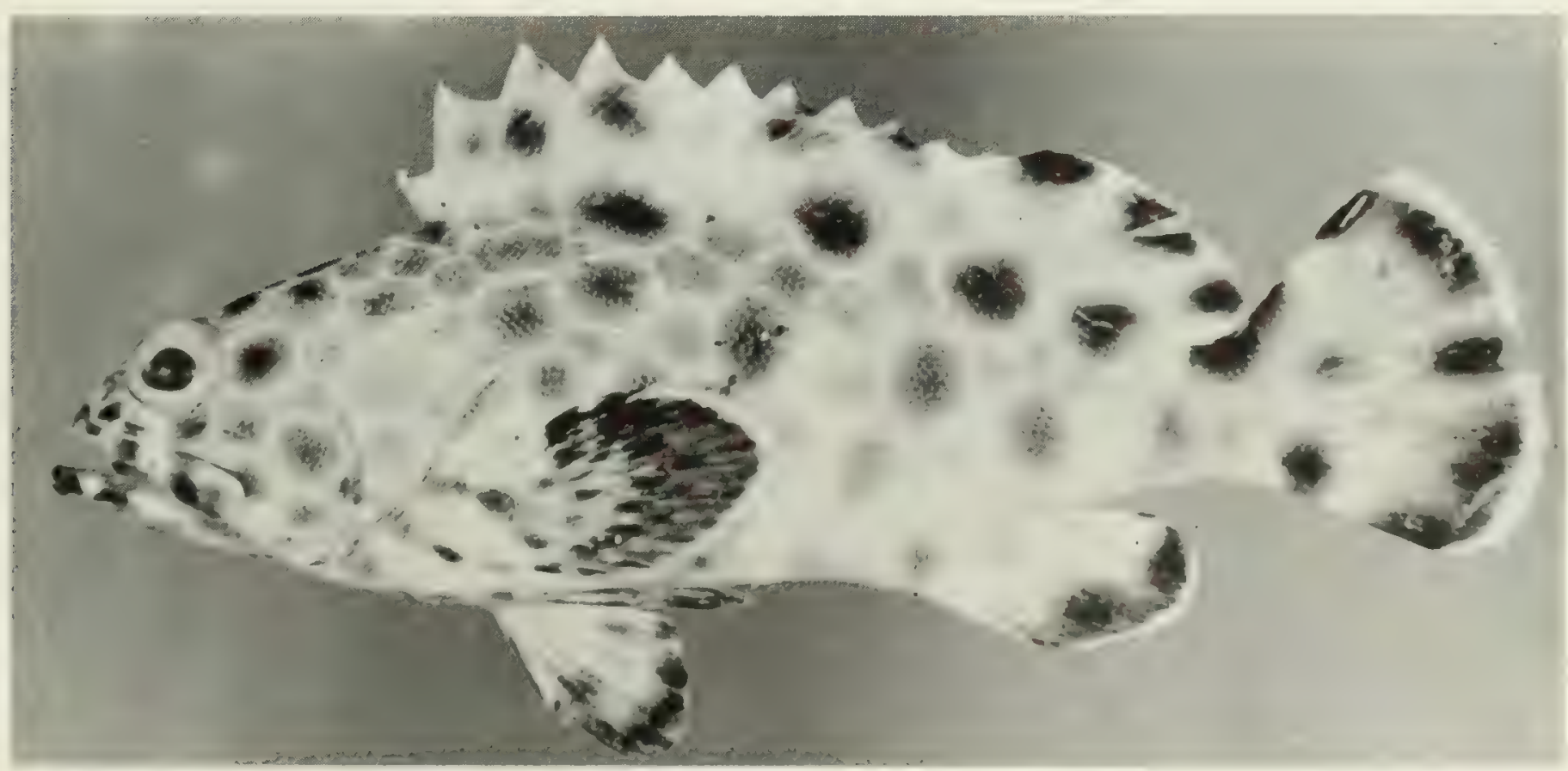

Fig. 134. Epinephelus faveatus, $73 \mathrm{~mm} \mathrm{SL}$, Peros Banhos. 


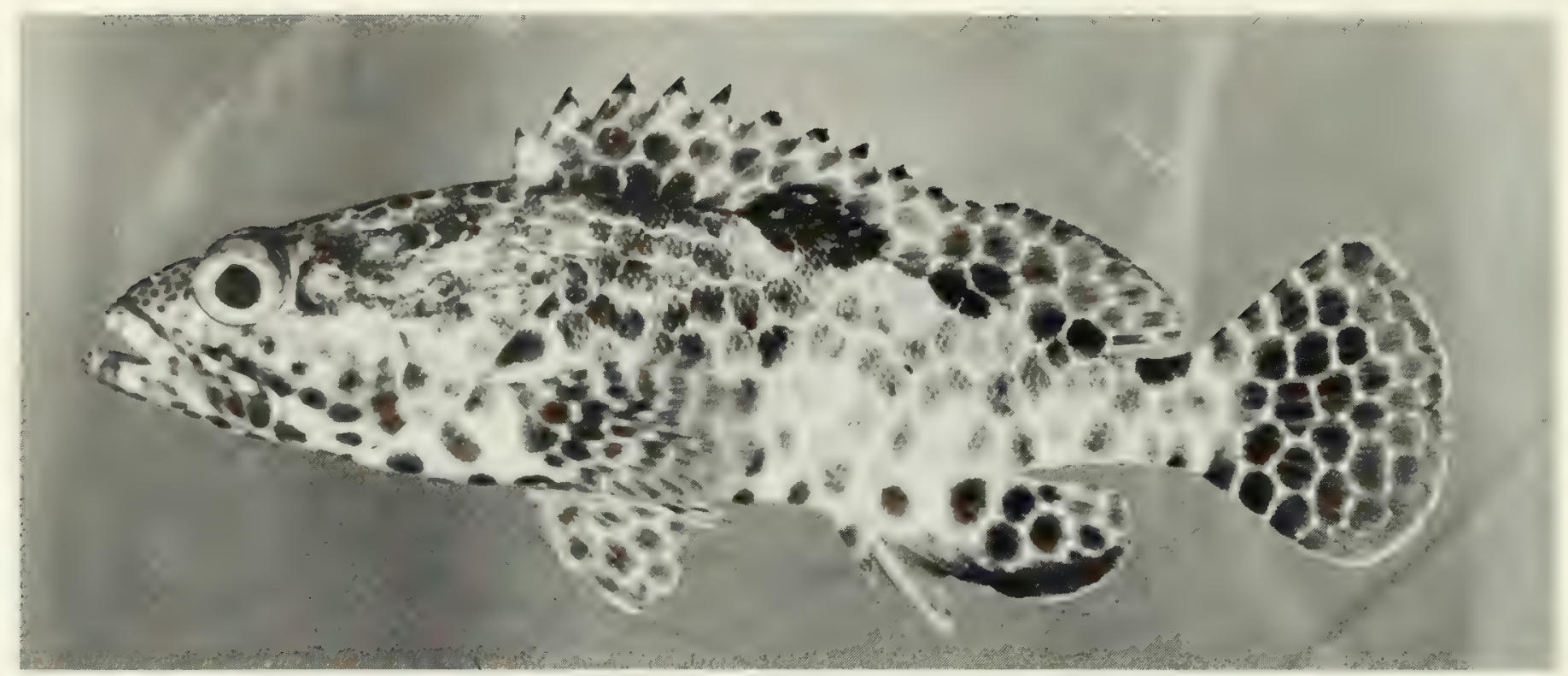

Fig. 135. Epinephelus hexagonatus, $112 \mathrm{~mm} \mathrm{SL}$, Peros Banhos.

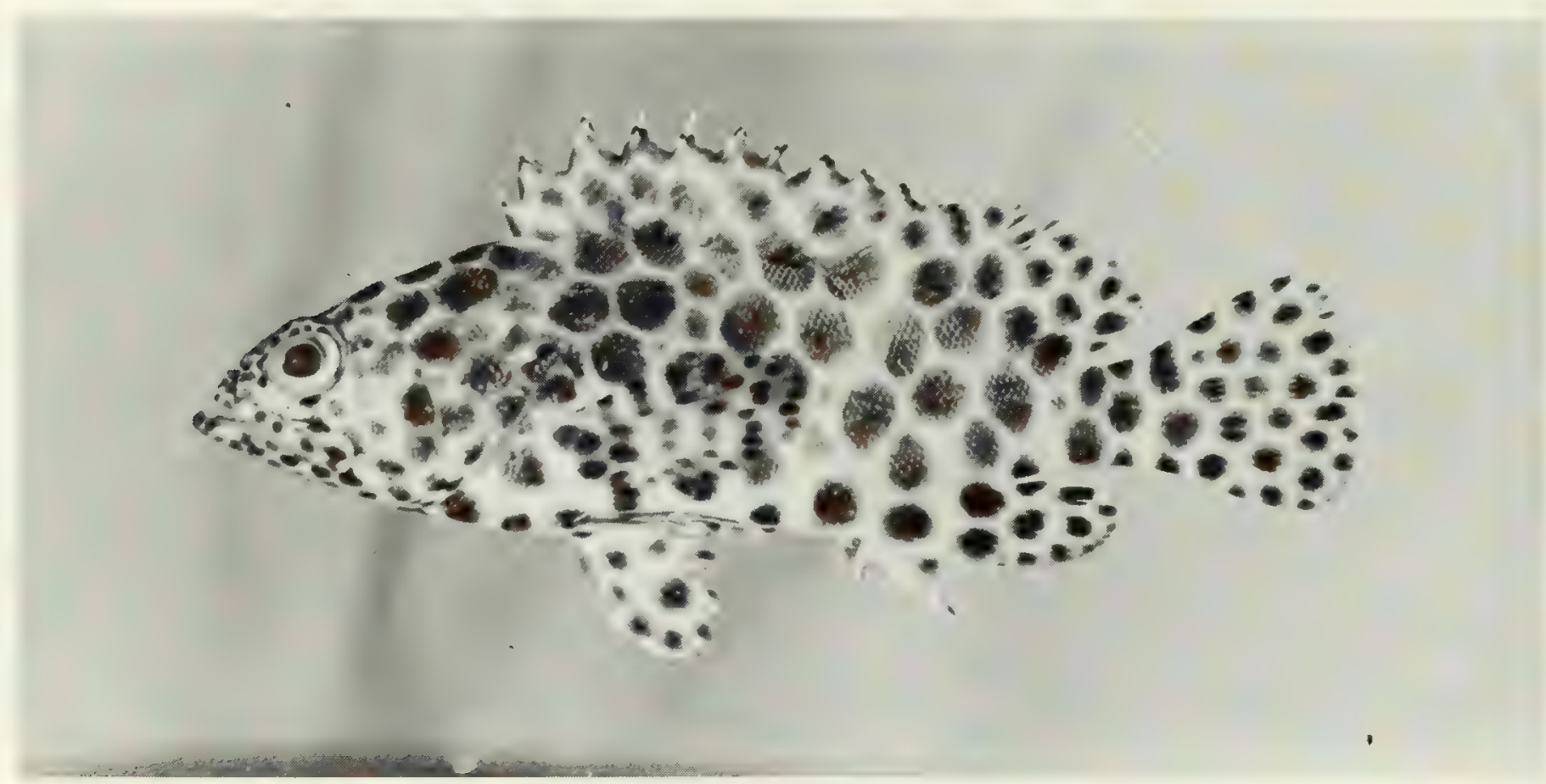

FIG. 136. Epinephelus merra, $63 \mathrm{~mm} \mathrm{SL}$, Peros Banhos.

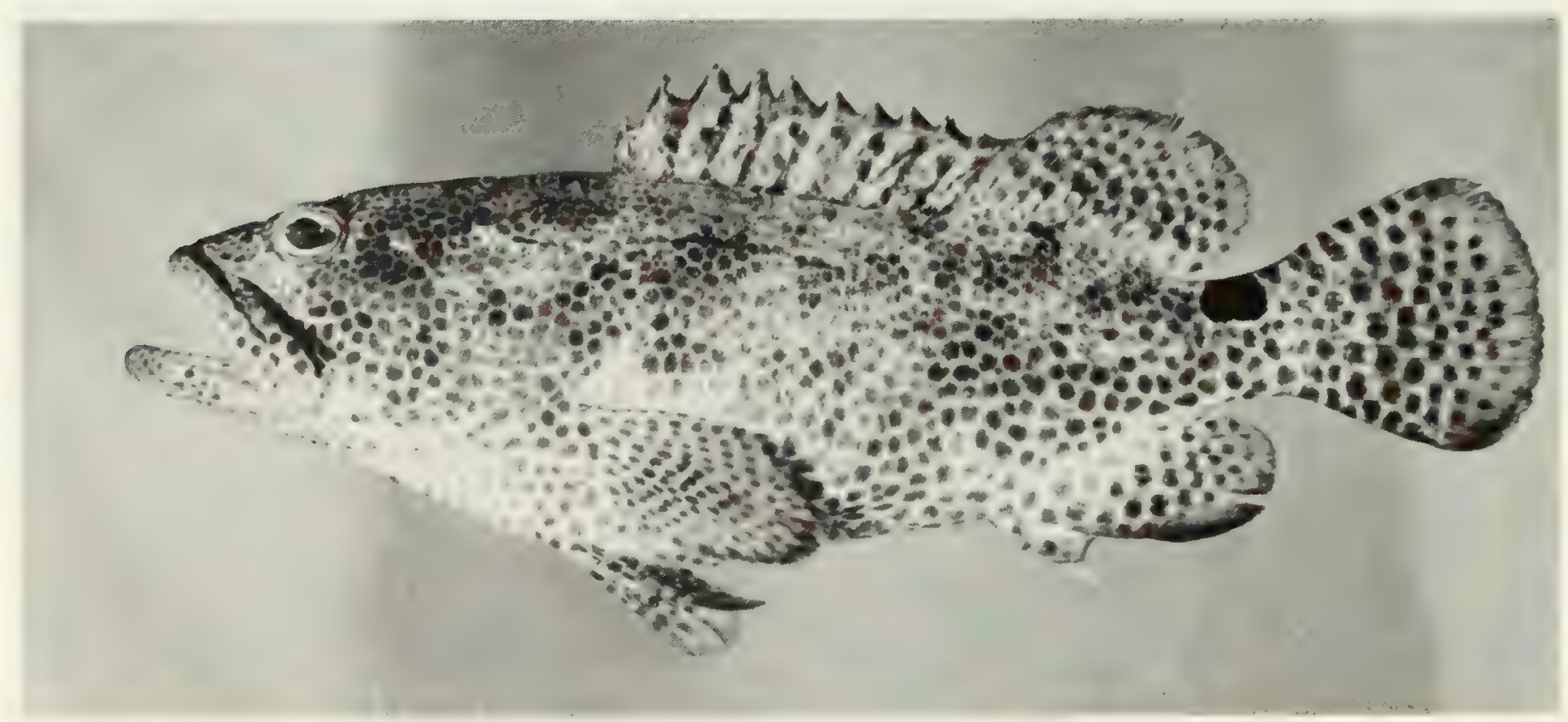

FIG. 137. Epinephelus microdon, $201 \mathrm{~mm}$ SL, Peros Banhos. 


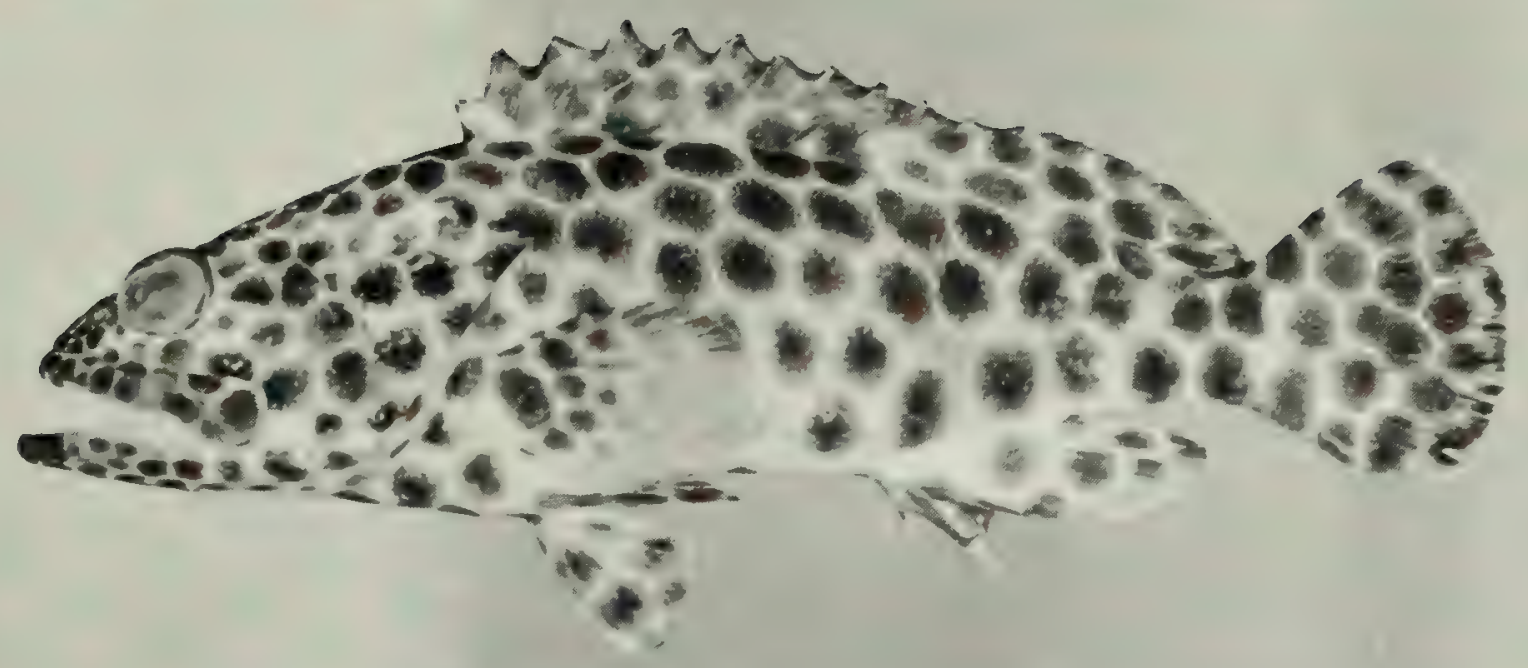

FIG. 138. Epinephelus tauvina, $114 \mathrm{~mm} \mathrm{SL}$, Salomon.

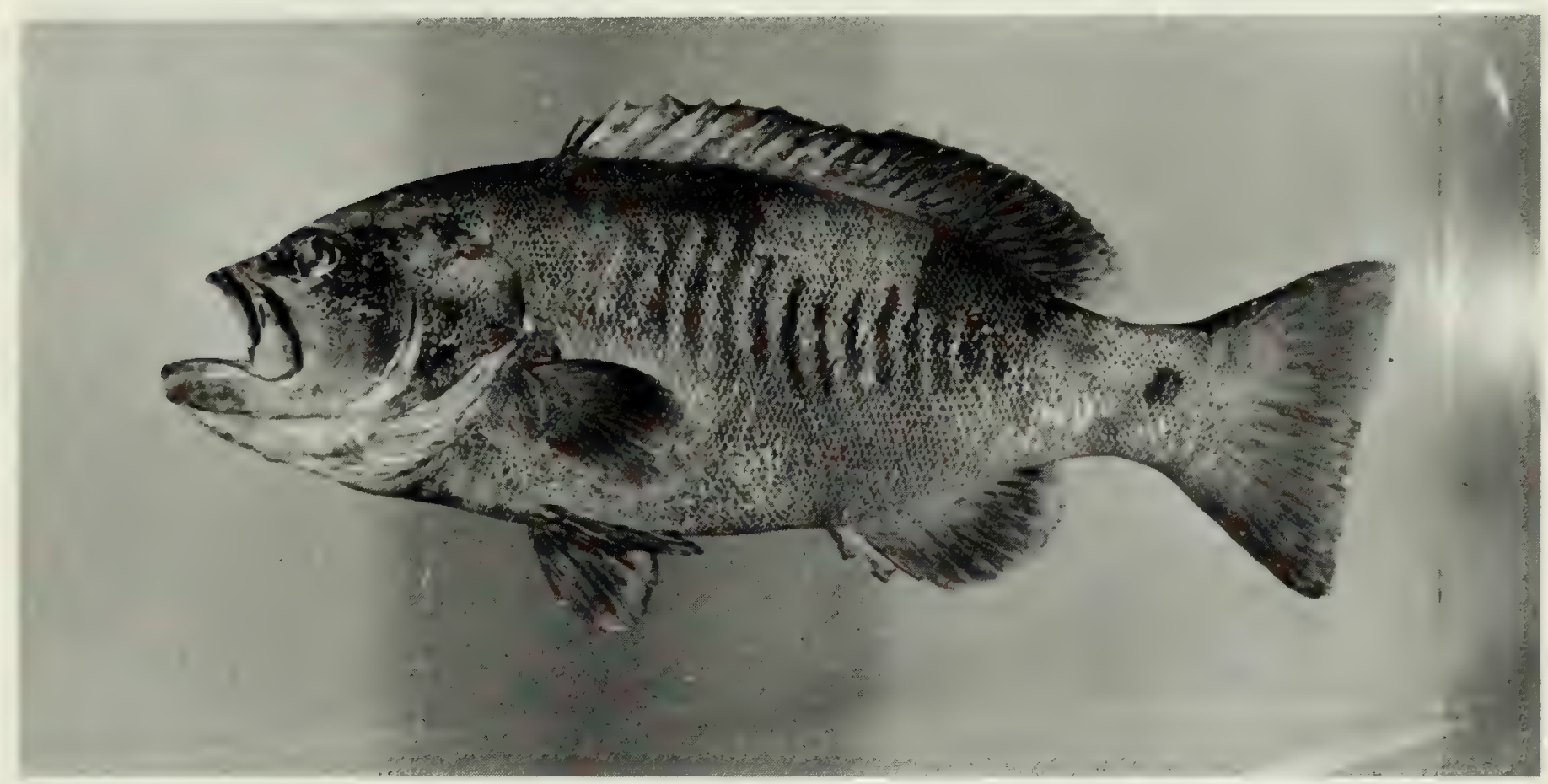

FIG. 139. Gracila albomarginata, $287 \mathrm{~mm} \mathrm{SL}$, Salomon.

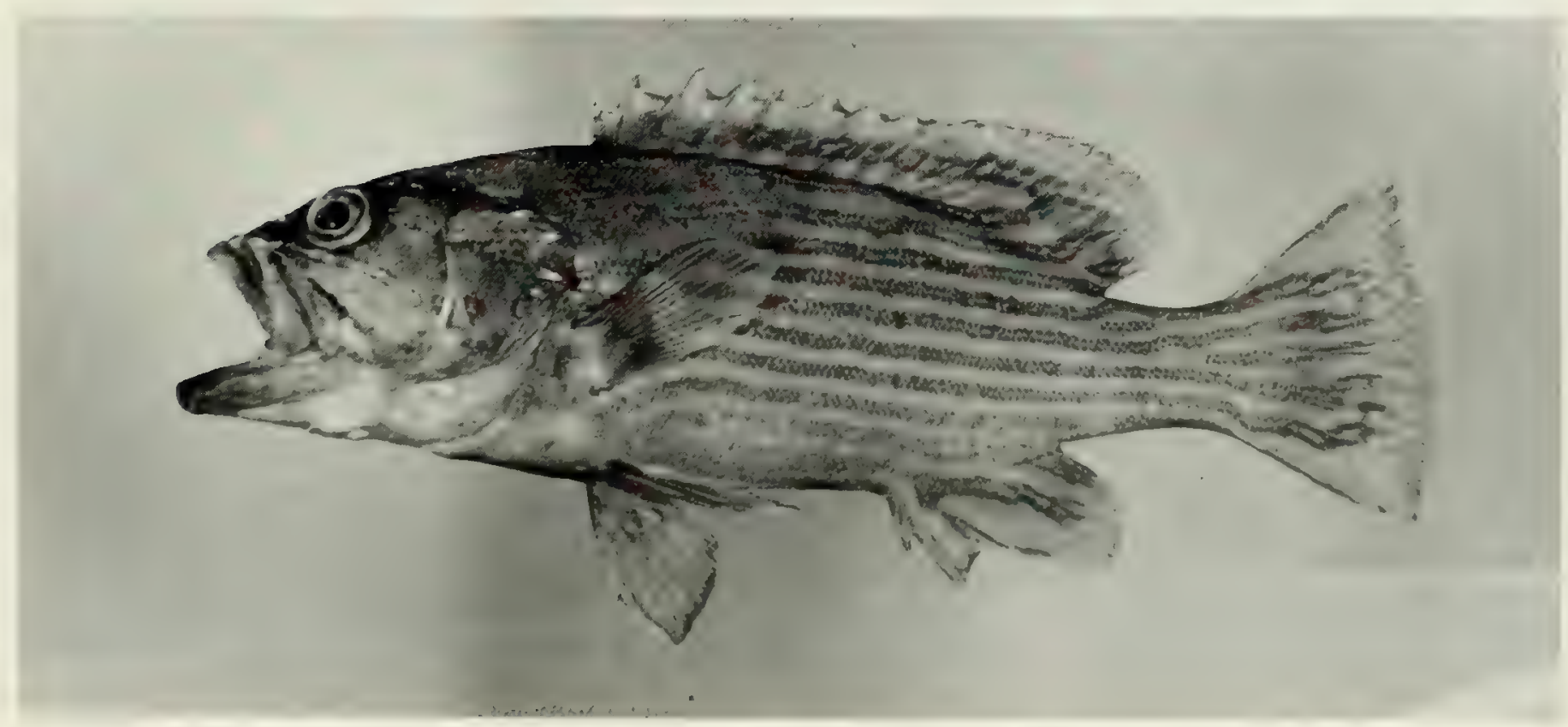

FIG. 140. Gracila polleni, $168 \mathrm{~mm}$ SL, Peros Banhos. 


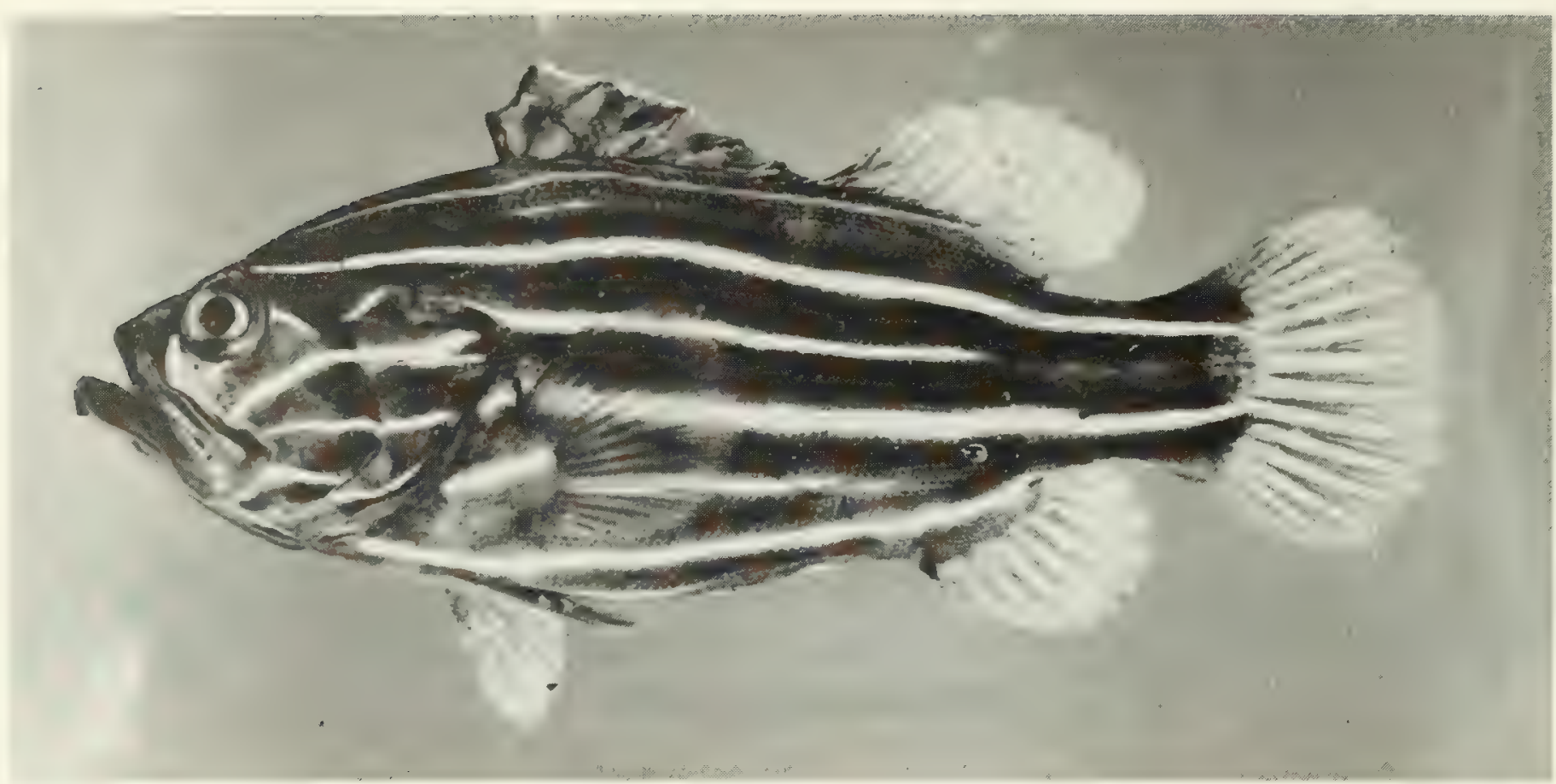

FIG. 141. Grammistes sexlineatus, $77 \mathrm{~mm} \mathrm{SL}$, Peros Banhos.

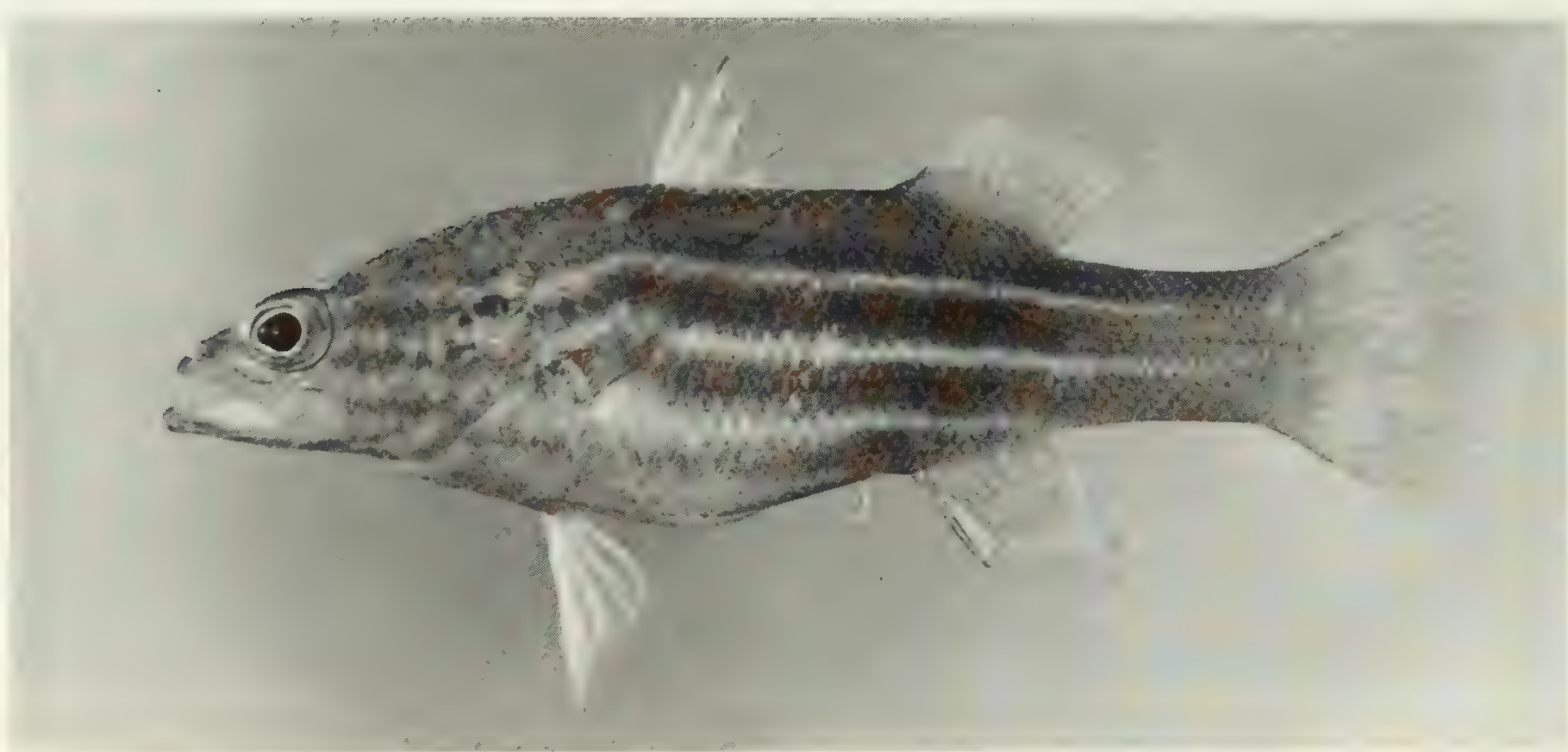

Fig. 142. Liopropoma africana, $56 \mathrm{~mm} \mathrm{SL}$, Salomon.

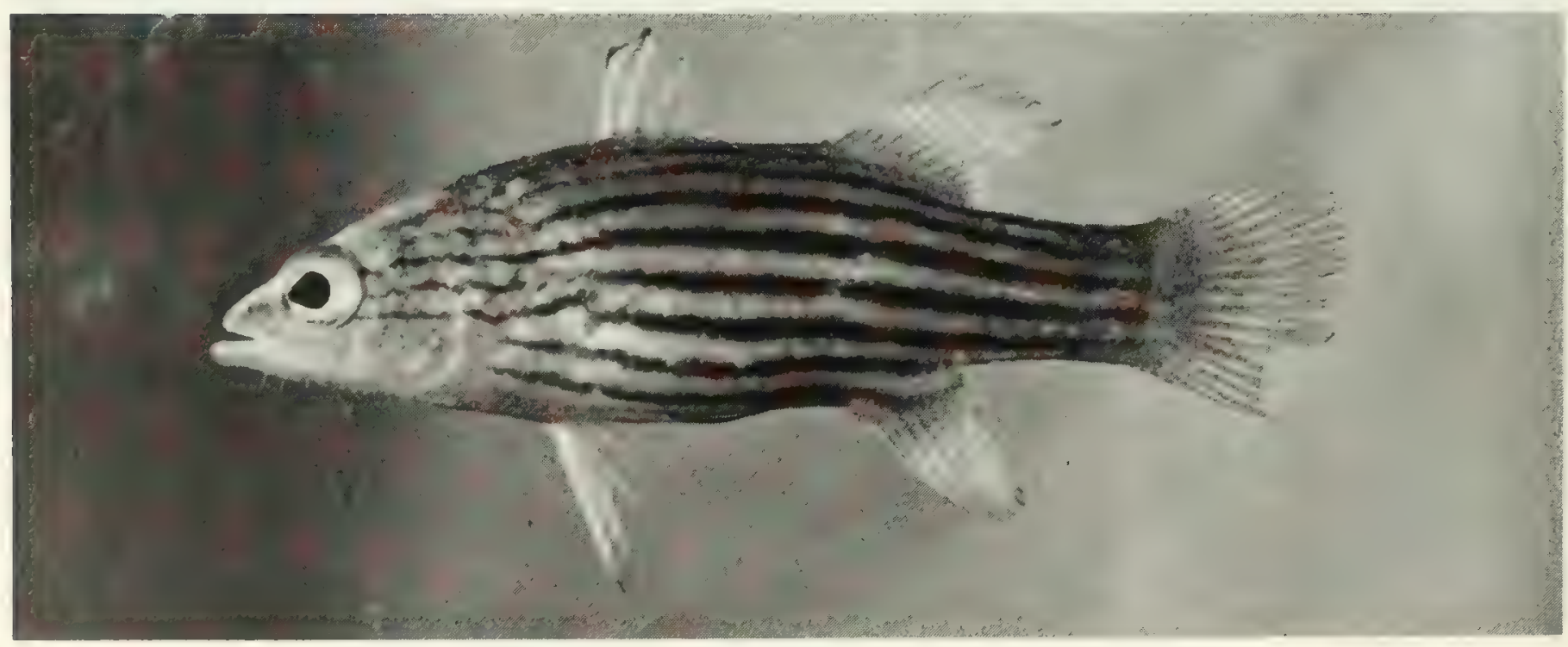

Fig. 143. Liopropoma susumi, 44 mm SL, Salomon. 


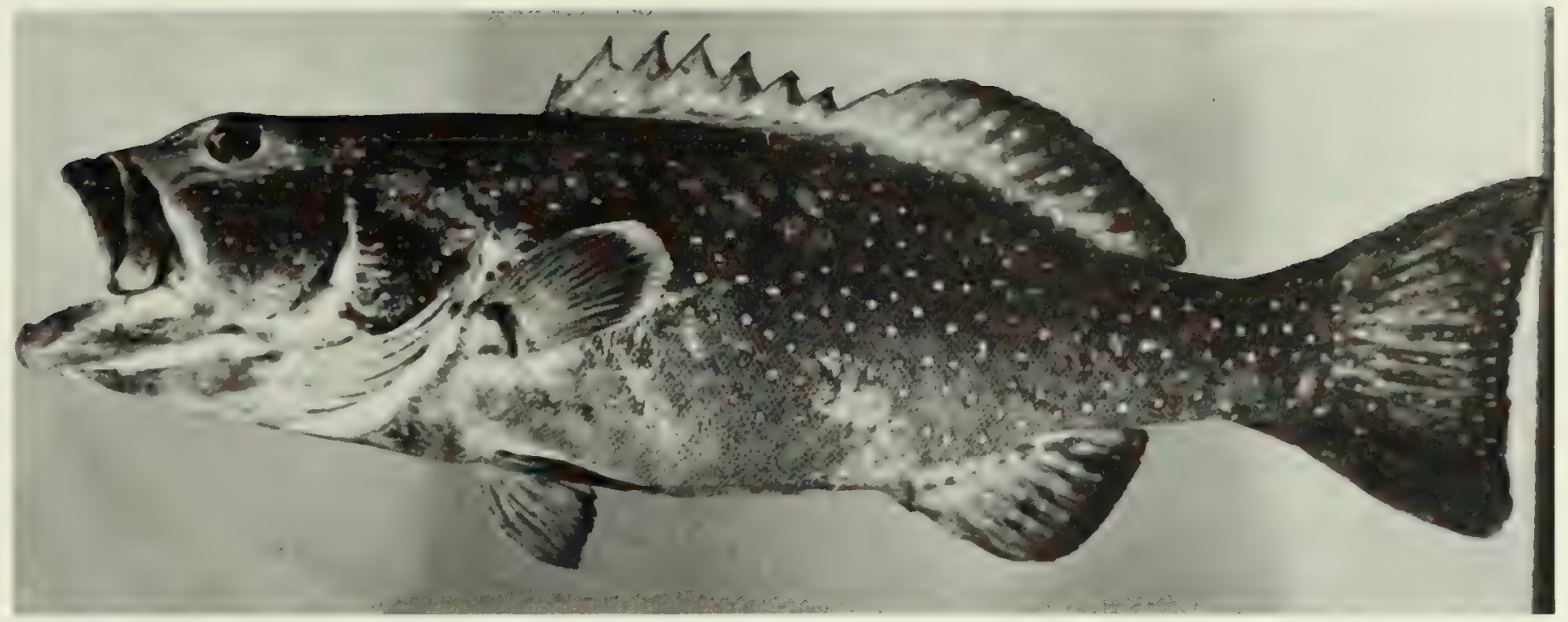

Fig. 144. Plectropomus laevis, $304 \mathrm{~mm} \mathrm{SL}$, Peros Banhos.

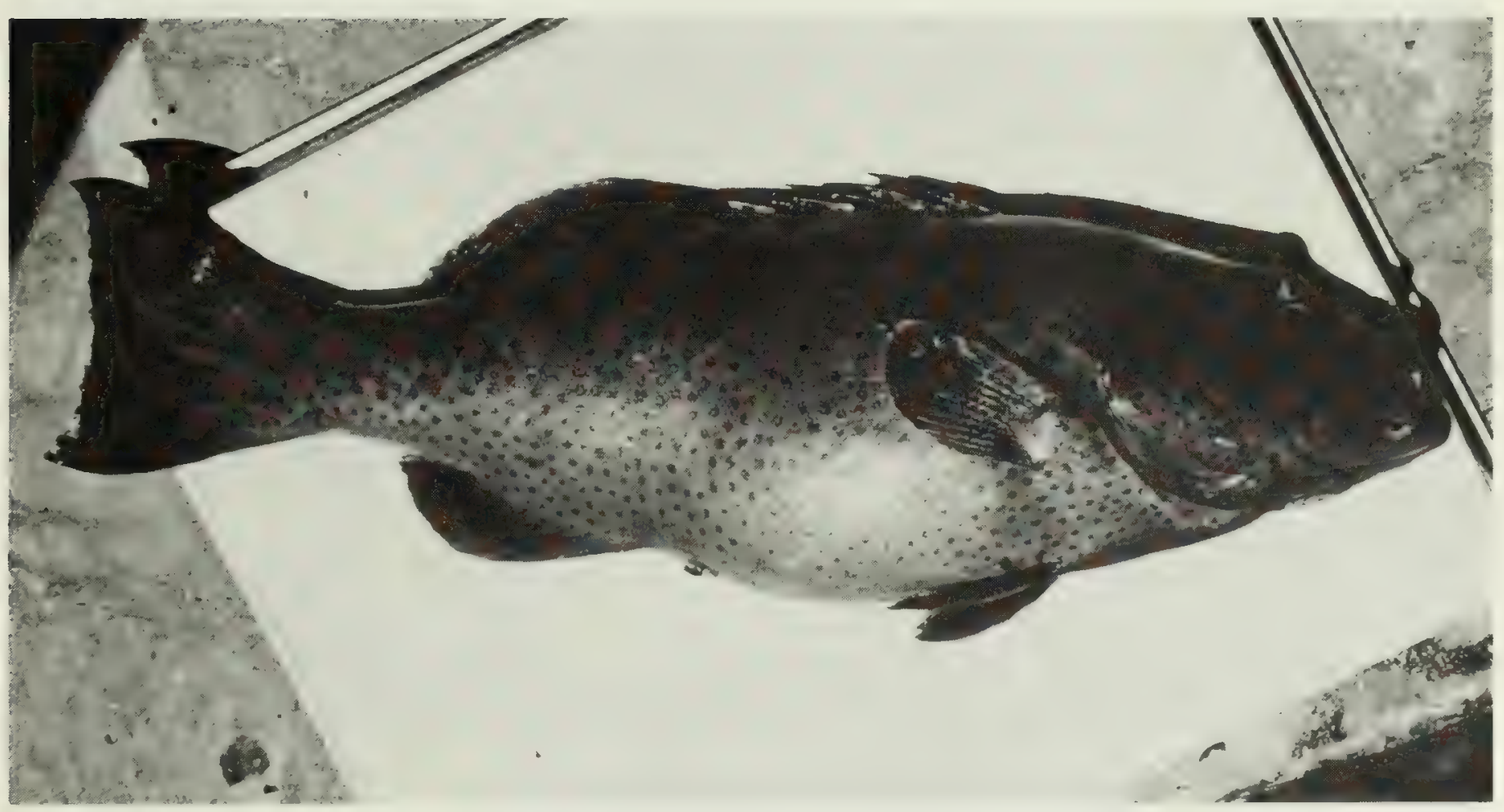

FIG. 145. Plectropomus laevis, $567 \mathrm{~mm} \mathrm{SL}$, Peros Banhos.

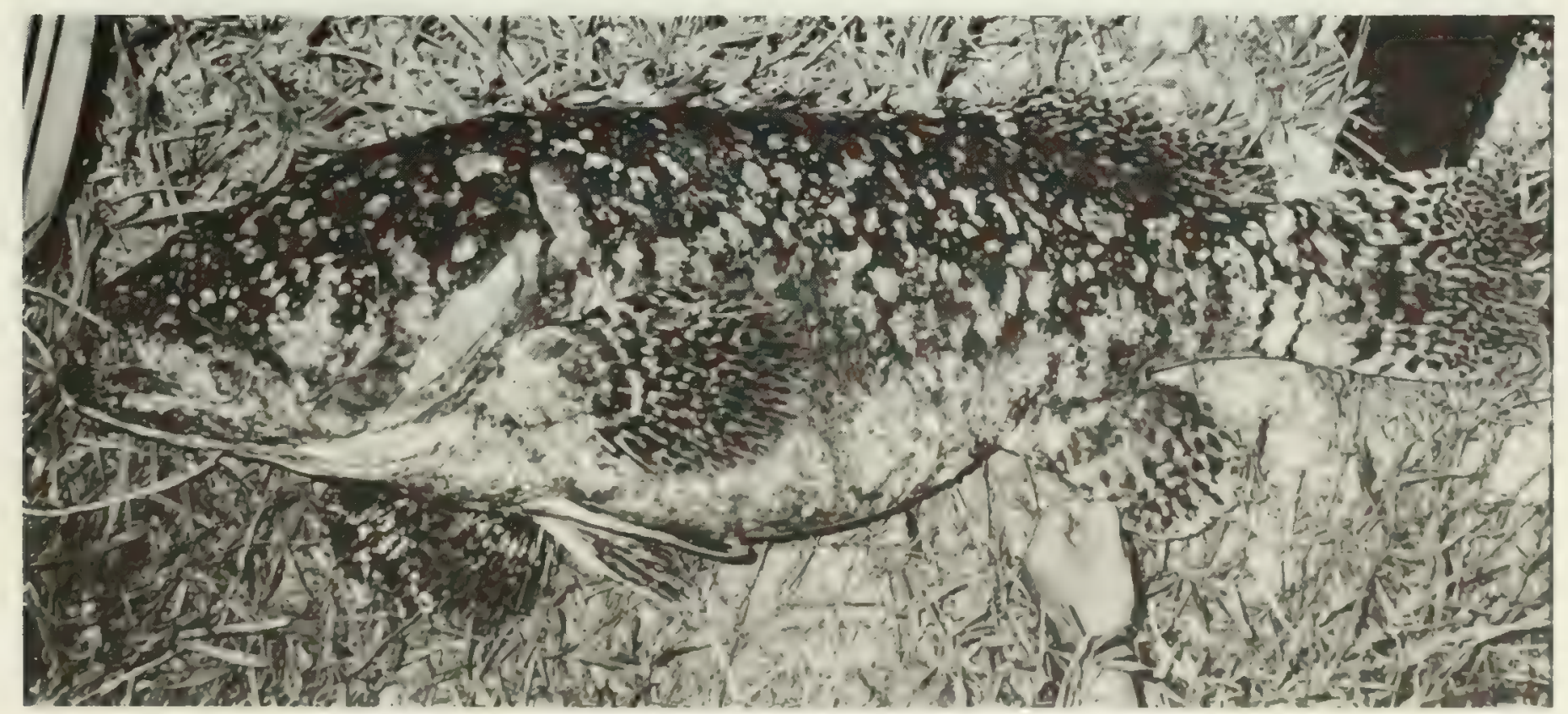

FIG. 146. Promicrops lanceolatus, ca $900 \mathrm{~mm} \mathrm{SL}$. Salomon. 


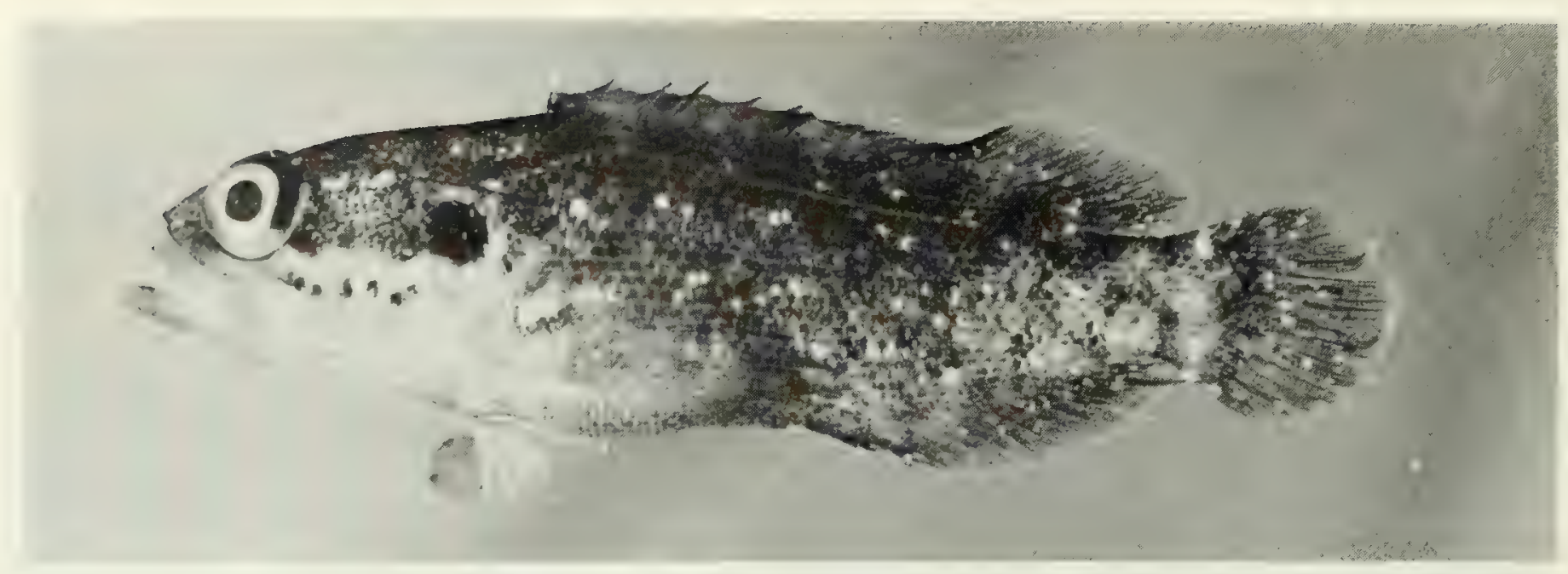

FIG. 147. Pseudogramma polyacantha, $37 \mathrm{~mm} \mathrm{SL}$, Peros Banhos.

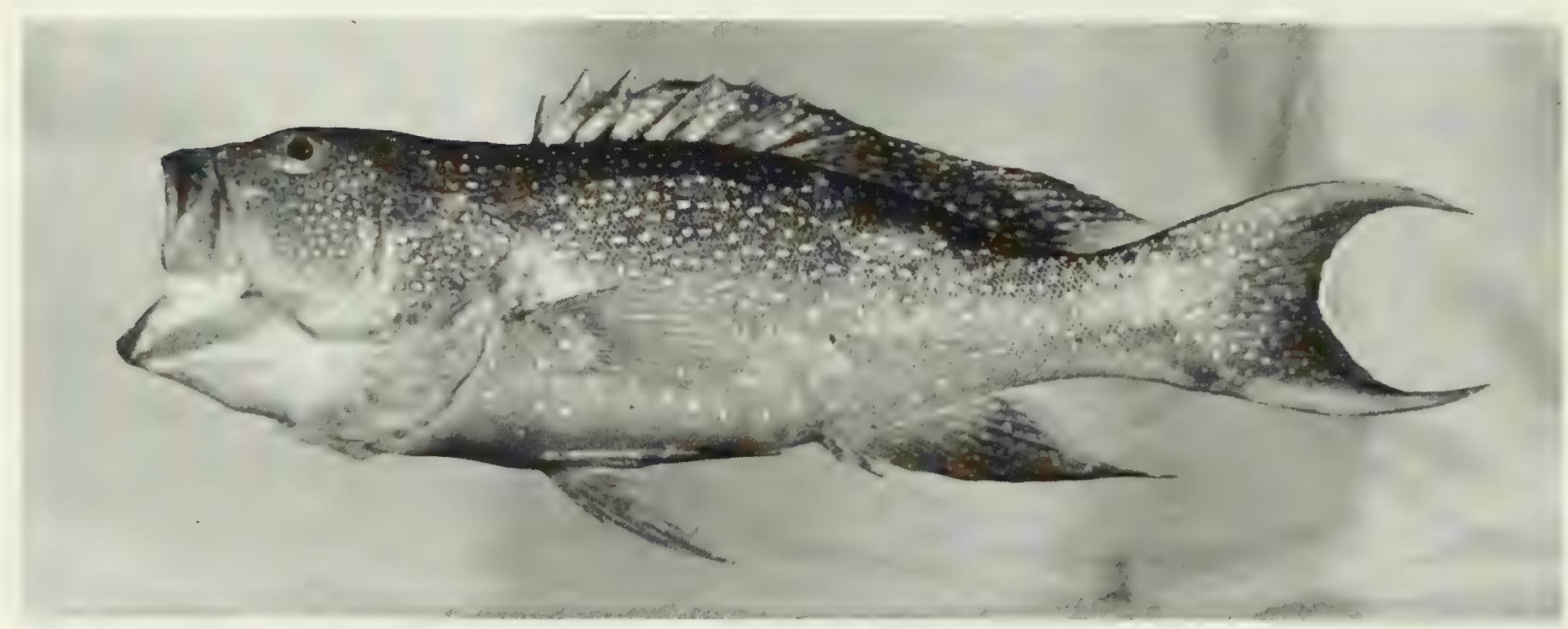

FIG. 148. Variola albimarginata, $210 \mathrm{~mm} \mathrm{SL,} \mathrm{Peros} \mathrm{Banhos.}$

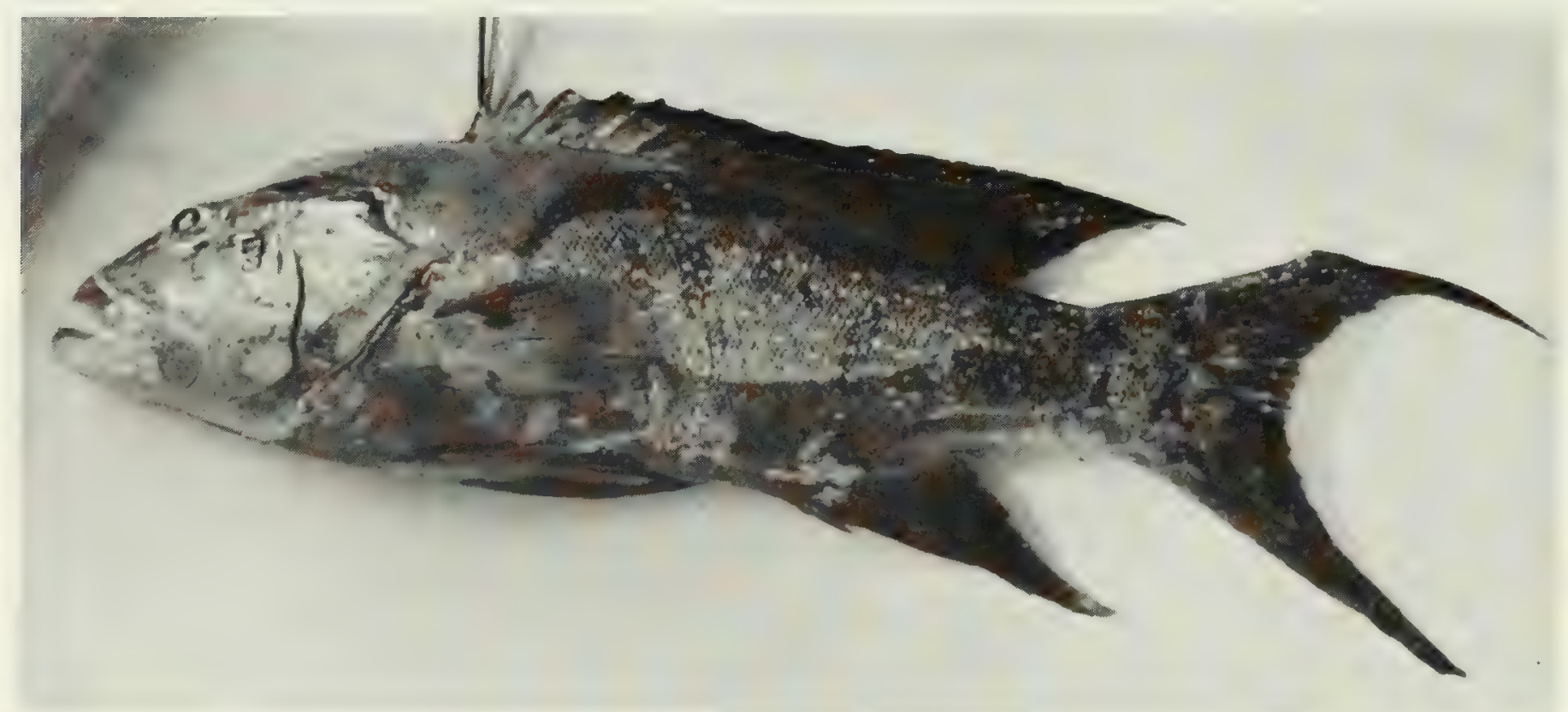

FIG. 149. Variola louti, $370 \mathrm{~mm}$ SL, Peros Banhos. 


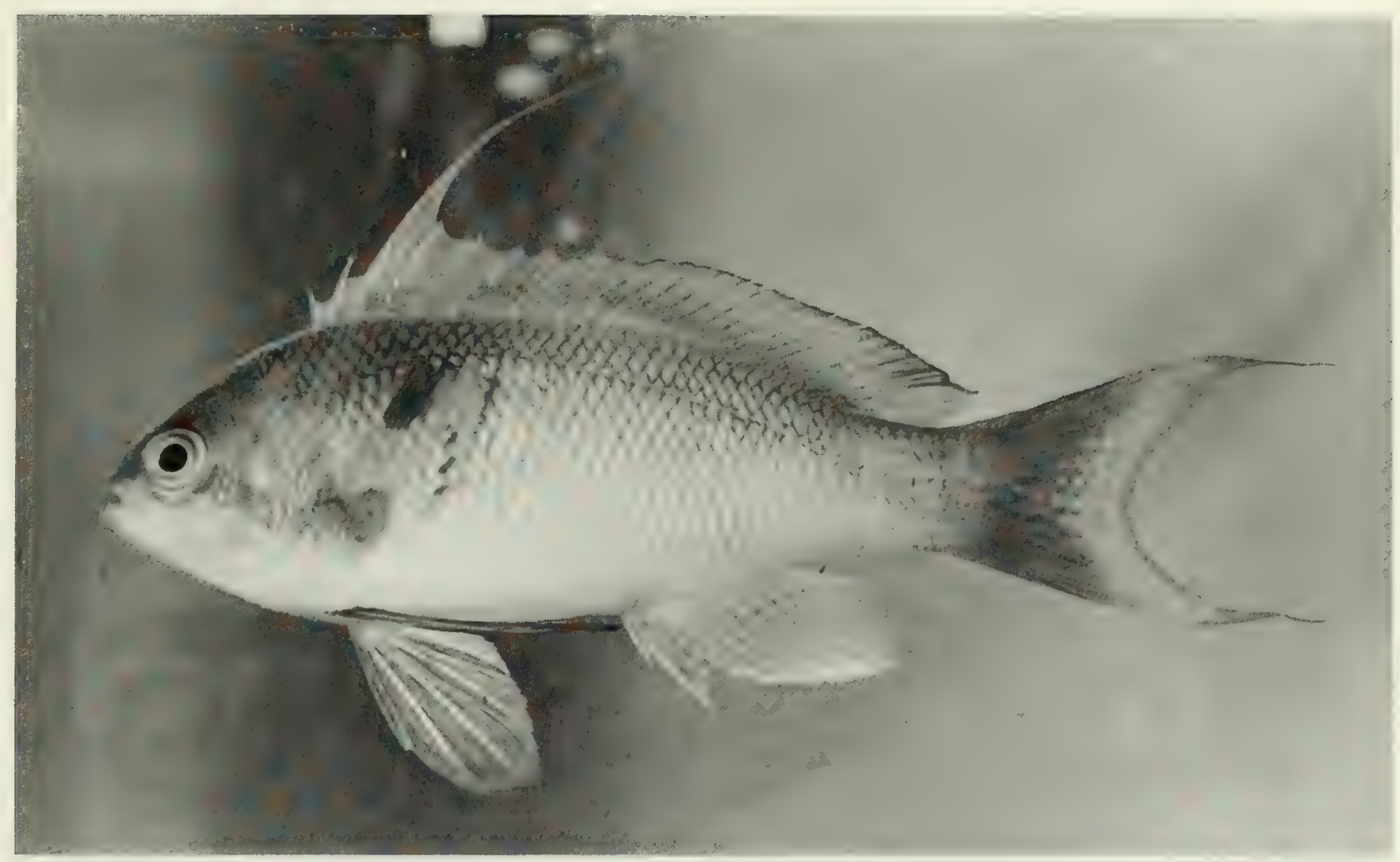

FIG. 150. Anthias squamipinnis, $65 \mathrm{~mm}$ SL, Salomon.

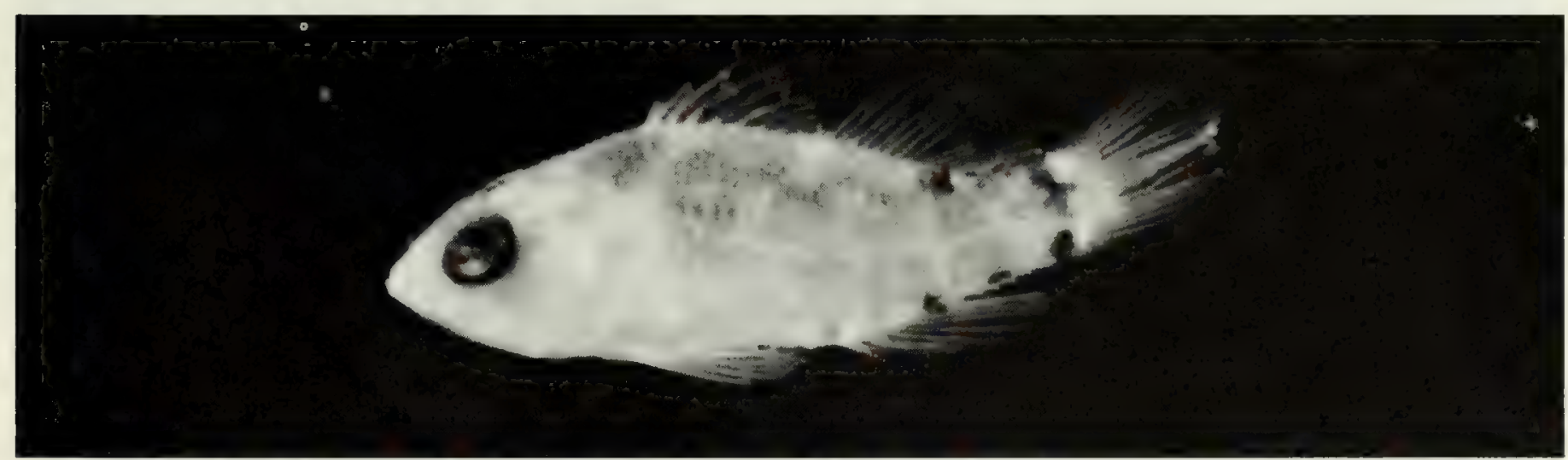

FIG. 151. Plectranthias longimanus, (preserved) $12 \mathrm{~mm} \mathrm{SL}$, Salomon. Photo by A. Strange.

FIG. 152. Chlidichthys inornatus, $23 \mathrm{~mm} \mathrm{SL}$, Peros Banhos. 


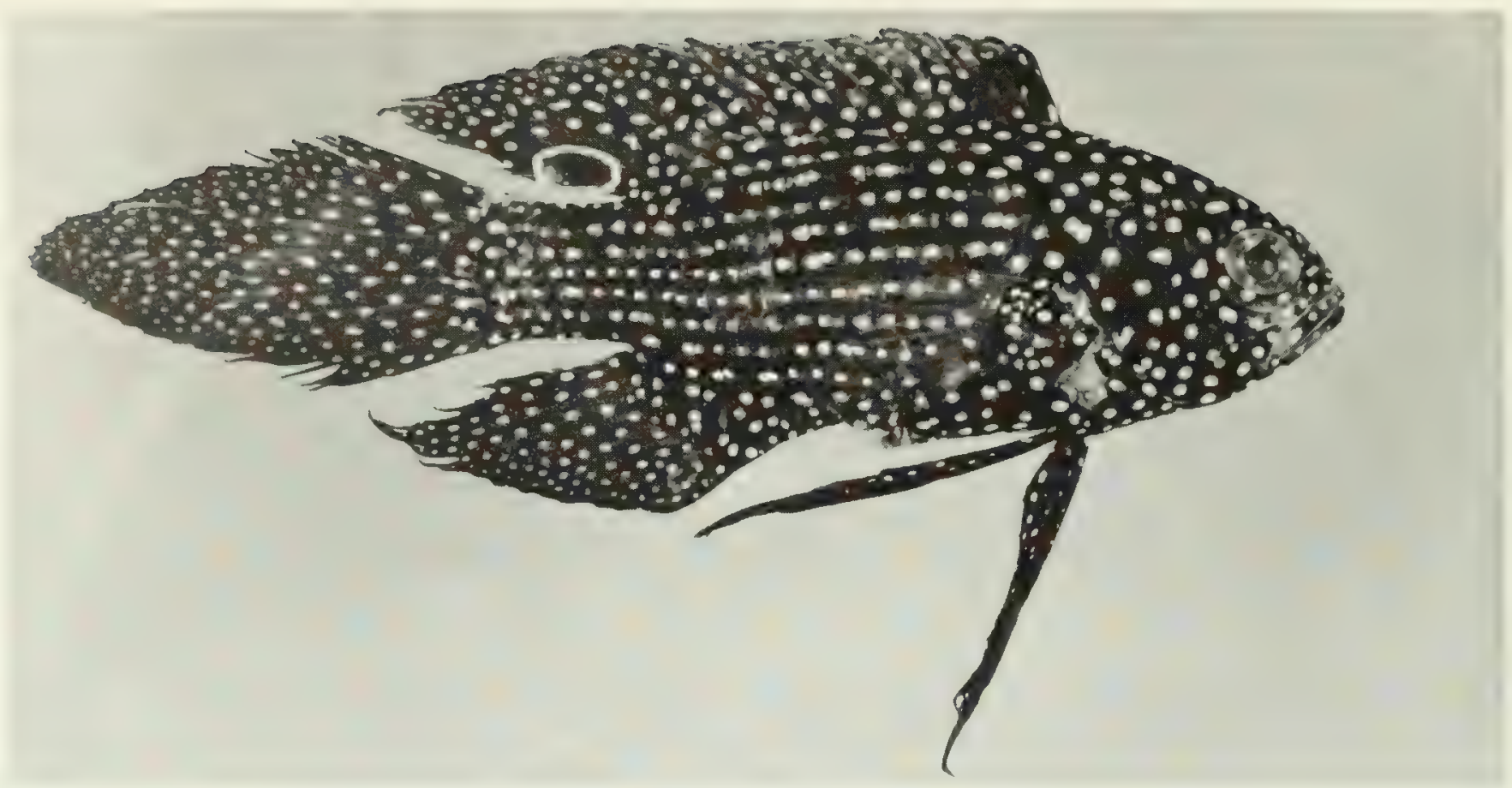

FIG. 153. Calloplesiops altivelis, $62 \mathrm{~mm}$ SL, Peros Banhos.

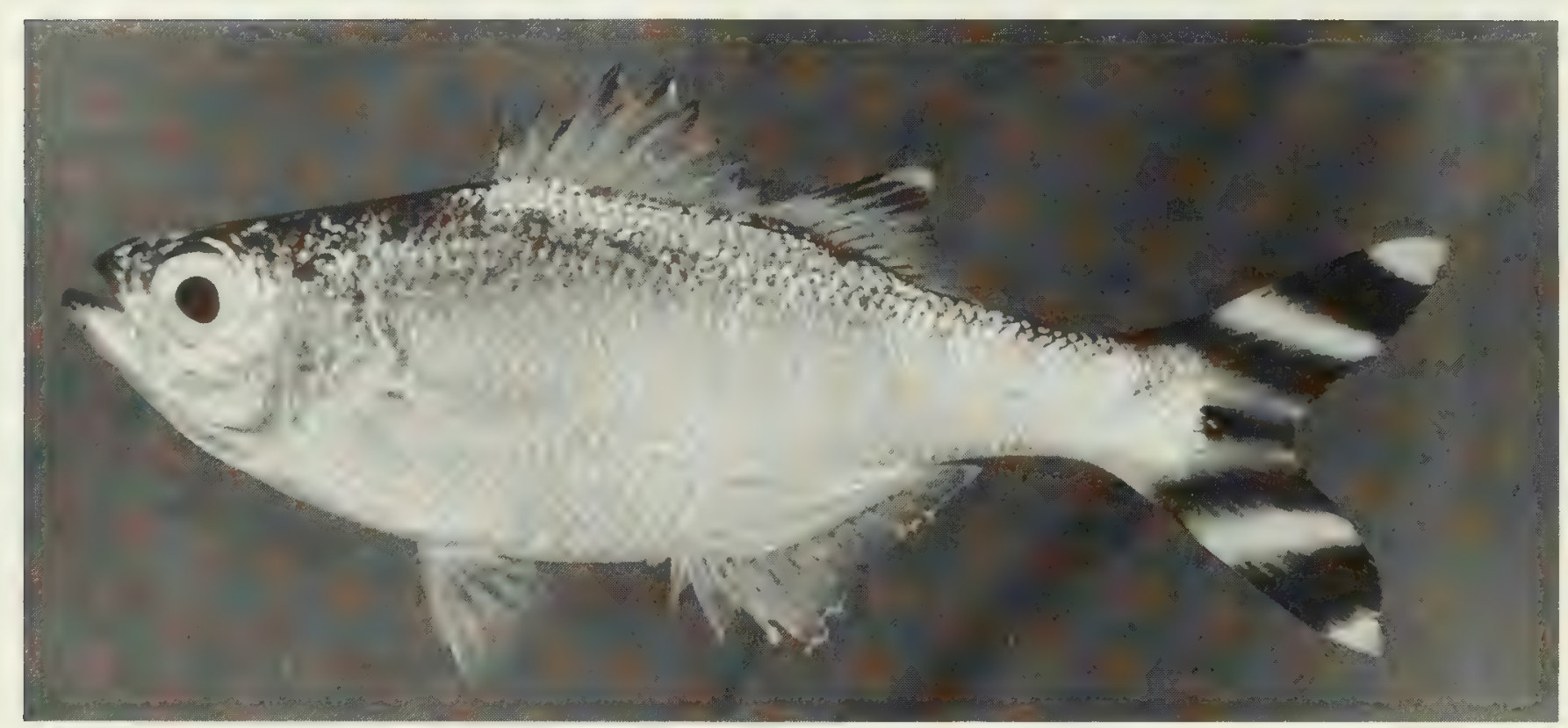

FIG. 154. Kuhlia mugil, $87 \mathrm{~mm} \mathrm{SL,} \mathrm{Peros} \mathrm{Banhos.}$

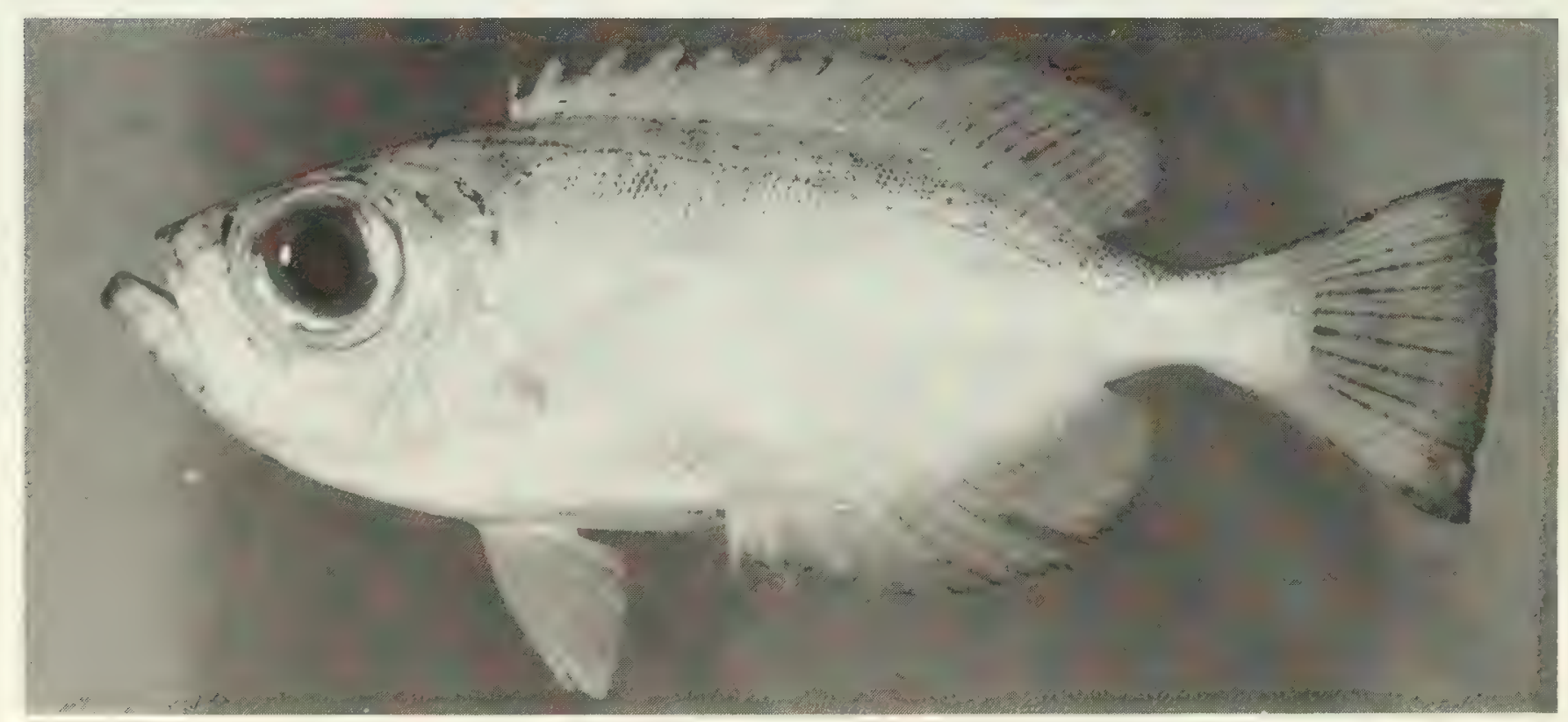

FIG. 155. Priacanthus cruentatus, $172 \mathrm{~mm} \mathrm{SL}$, Peros Banhos. 


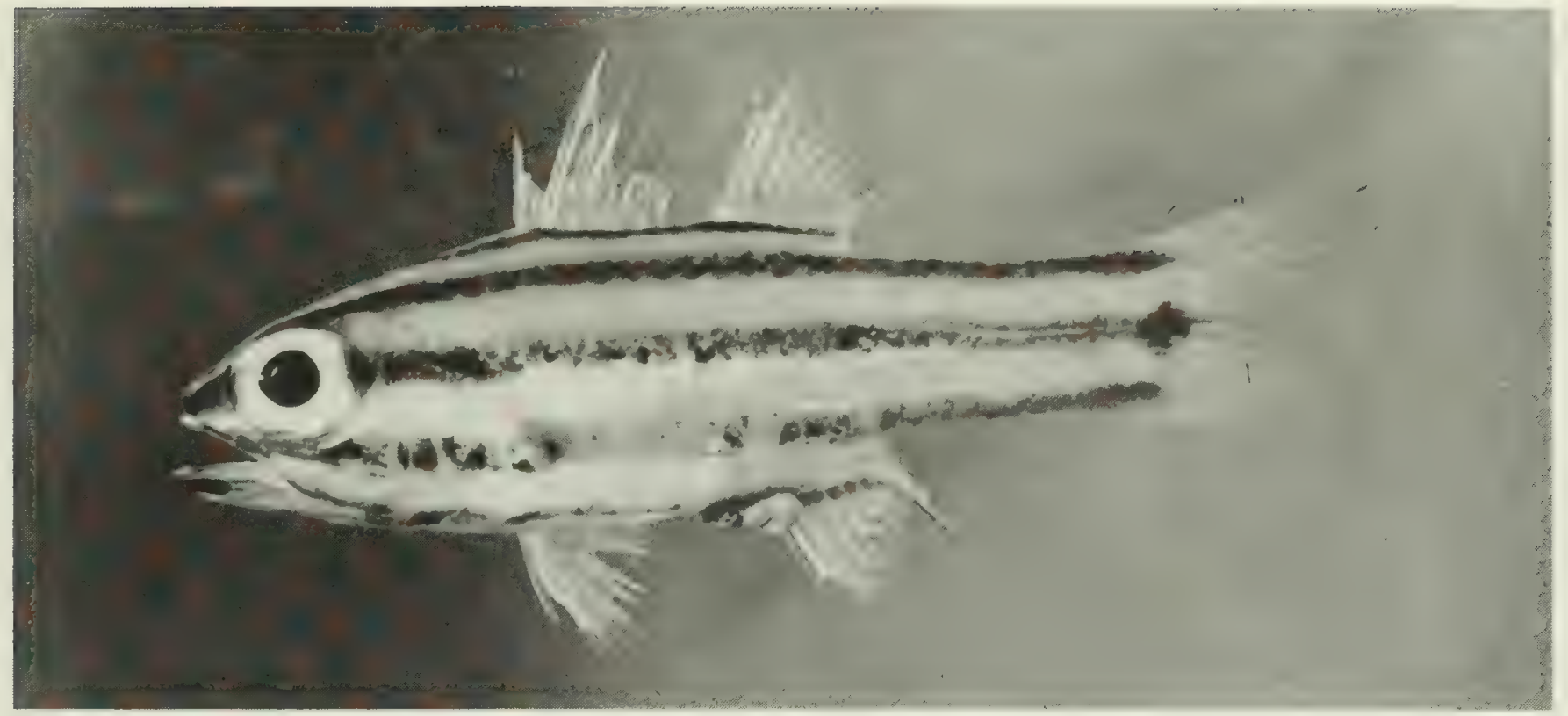

FIG. 156. Apogon angustatus, $58 \mathrm{~mm} \mathrm{SL}$, Salomon.

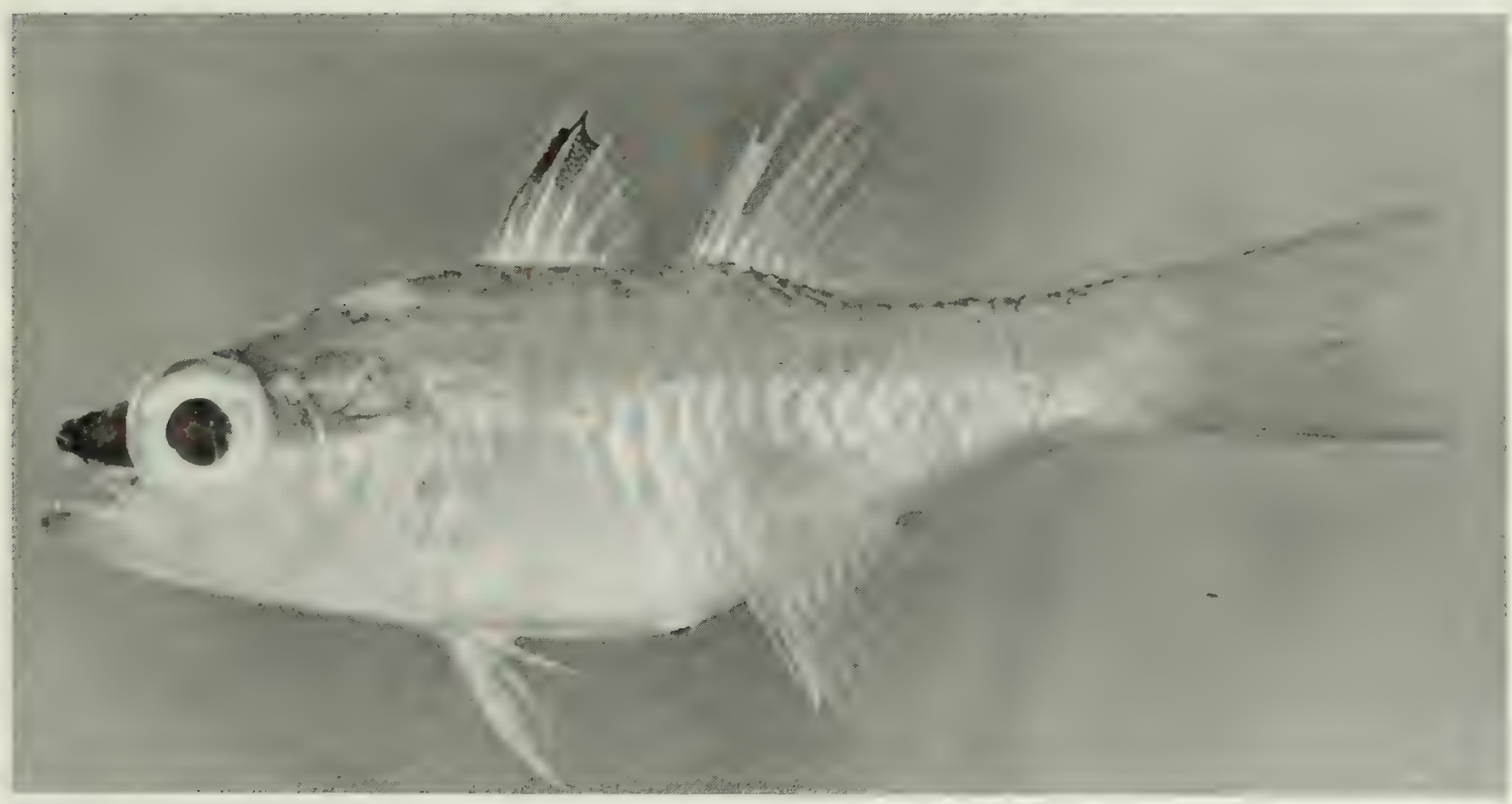

FIG. 157. Apogon apogonides, $54 \mathrm{~mm}$ SL, Peros Banhos.

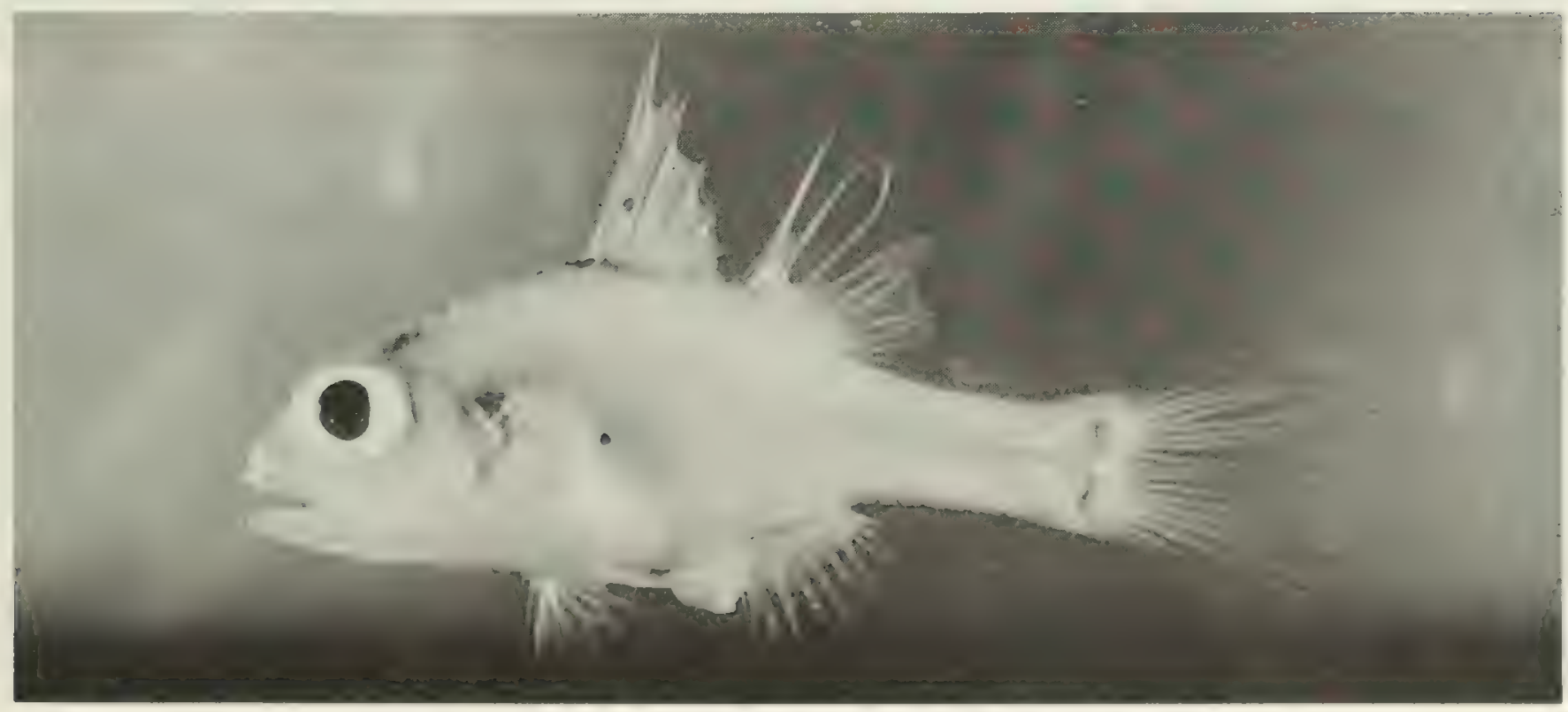

Fig. 158. Apogon coccineus, $32 \mathrm{~mm} \mathrm{SL}$, Peros Banhos. 


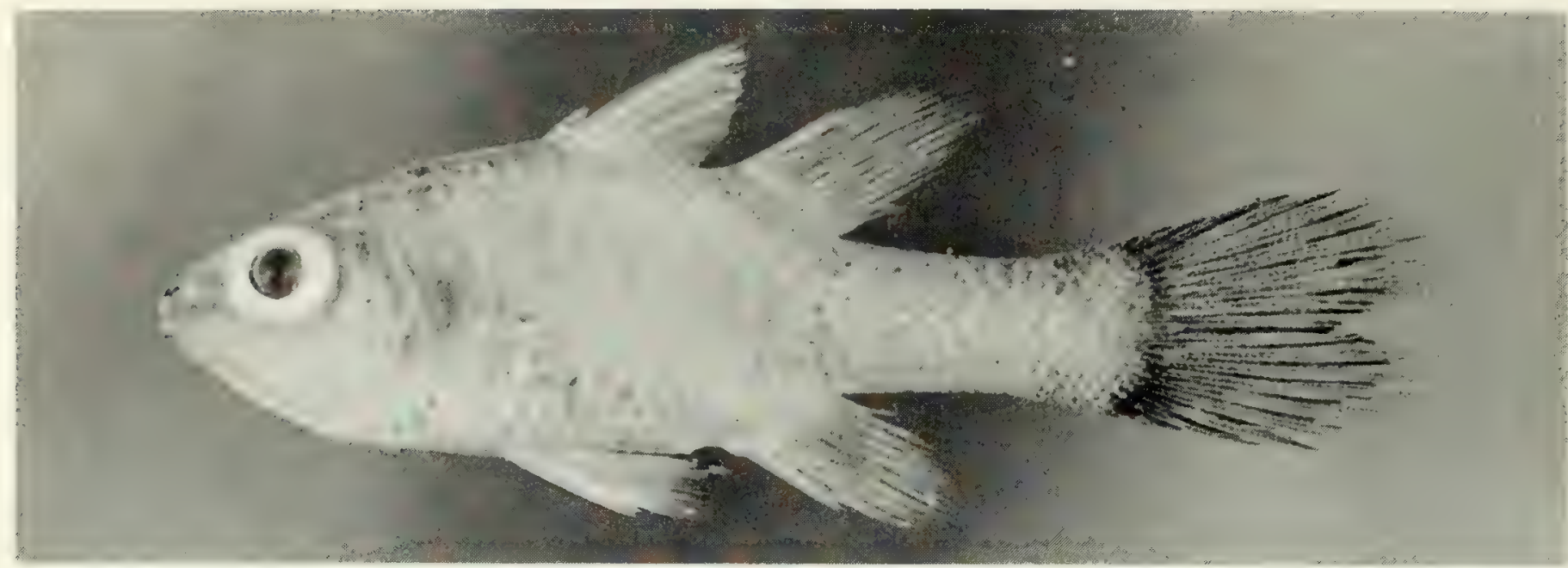

FIG. 159. Apogon crassiceps, $45 \mathrm{~mm}$ SL, Three Brothers.

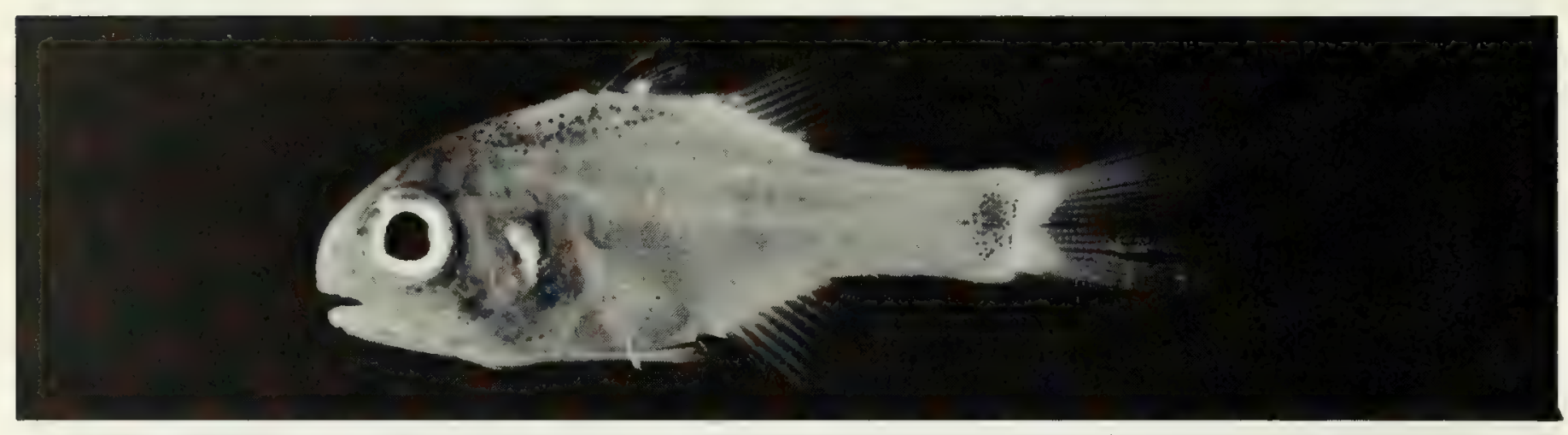

FIG. 160. Apogon erythrinus, (preserved) $27 \mathrm{~mm} \mathrm{SL}$, Salomon. Photo by A. Strange.

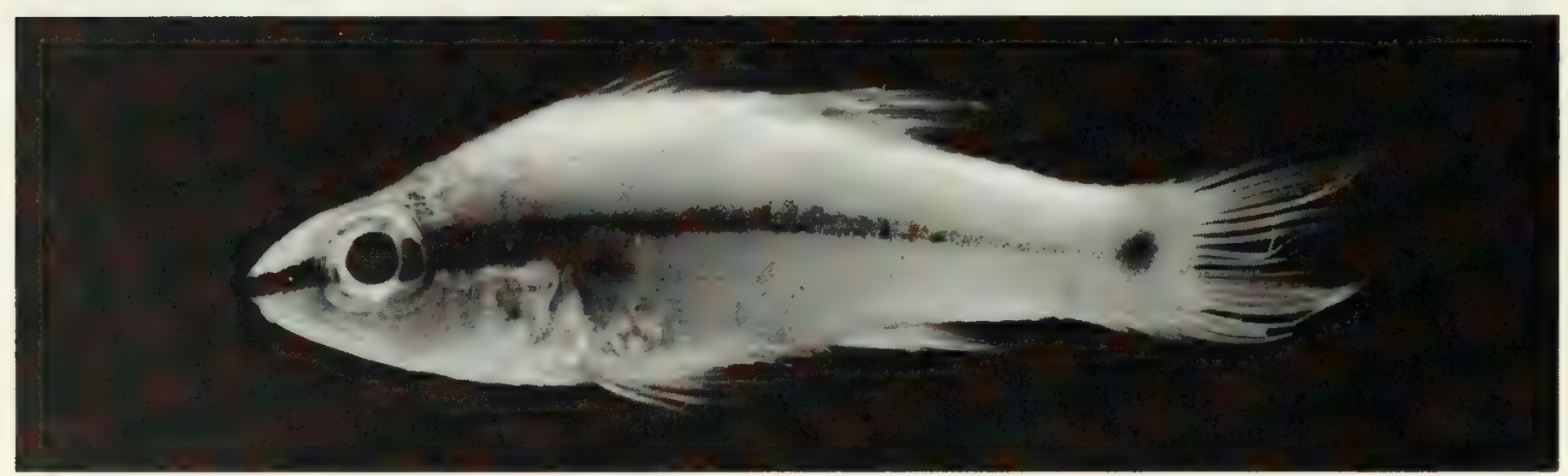

Fig. 161. Apogon frenatus, (preserved) $51 \mathrm{~mm} \mathrm{SL}$, Peros Banhos. Photo by A. Strange.

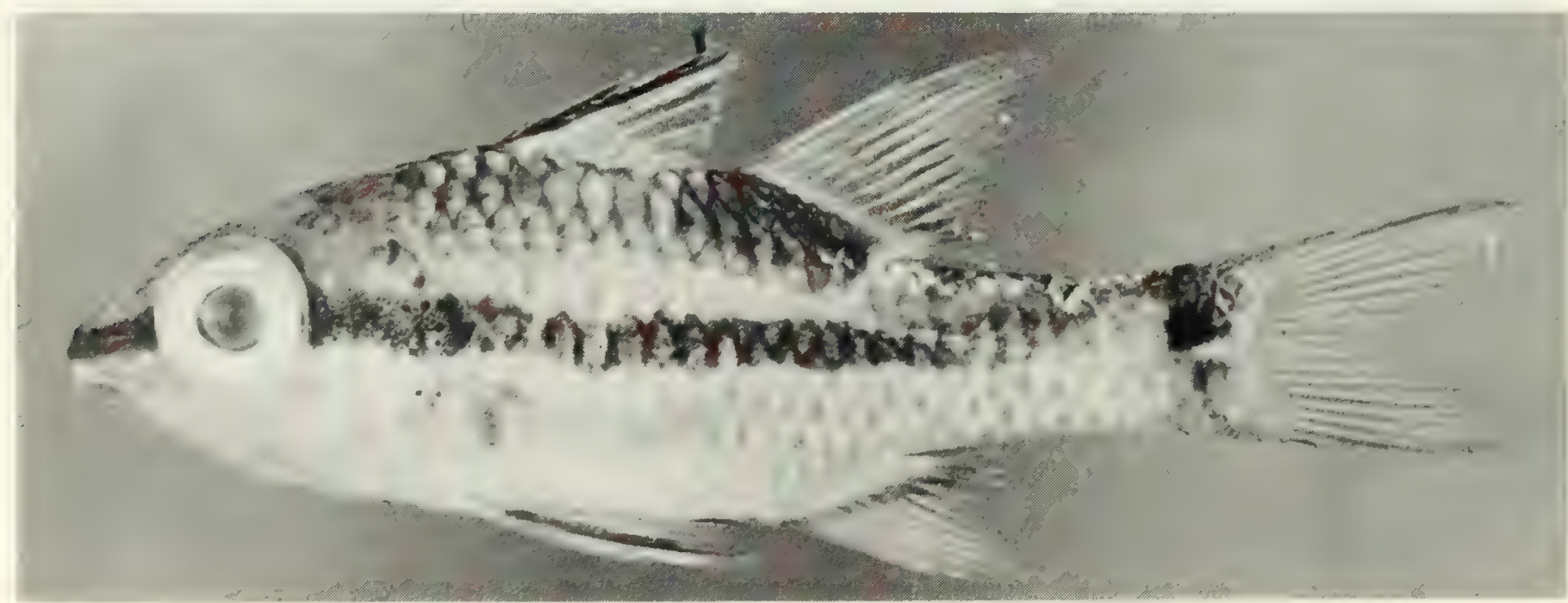

FIG. 162. Apogon kallopterus, $84 \mathrm{~mm}$ SL, Three Brothers. 


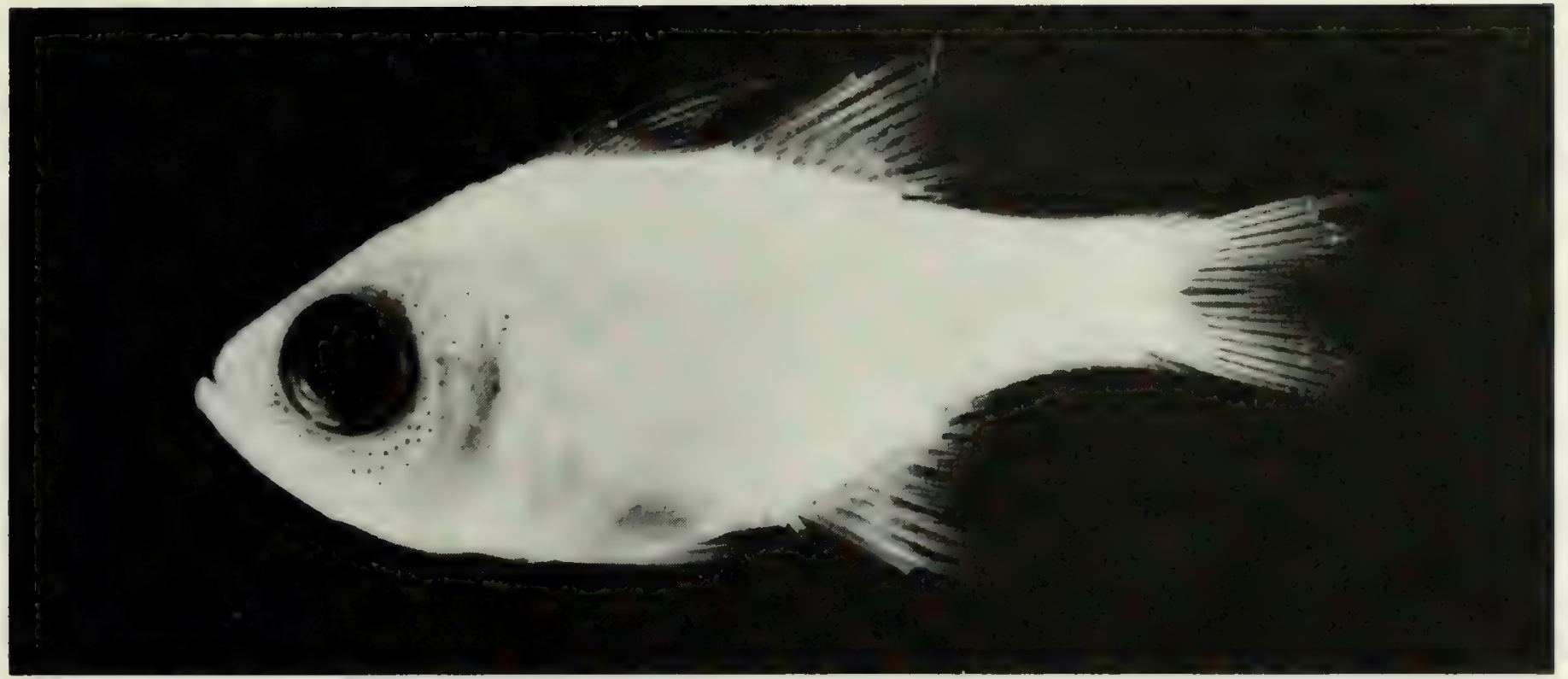

FIG. 163. Apogon leptacanthus, (preserved) $35 \mathrm{~mm} \mathrm{SL}$, Diego Garcia. Photo by A. Strange.

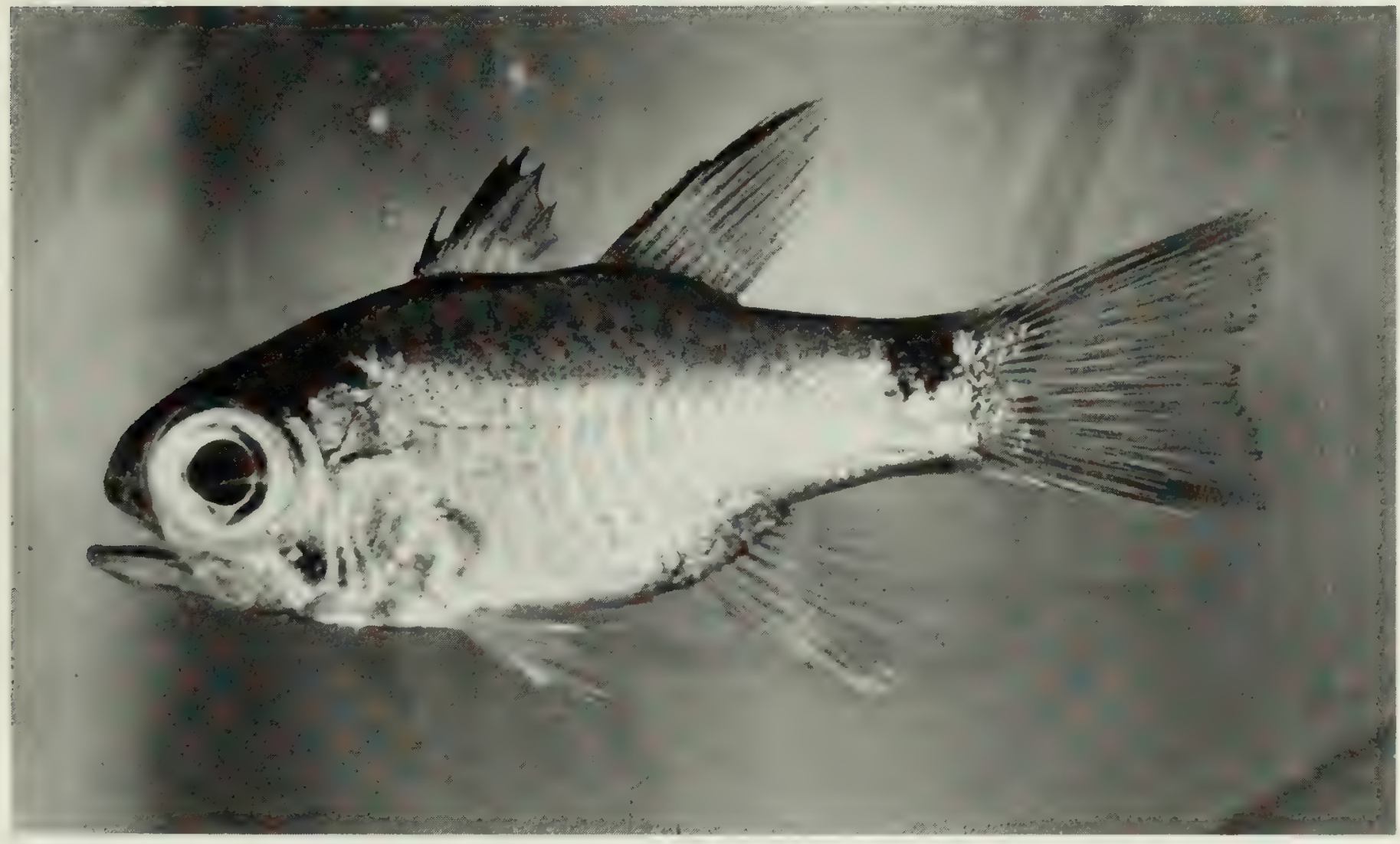

FIG. 164. Apogon savayensis, $63 \mathrm{~mm} \mathrm{SL}$, Peros Banhos.

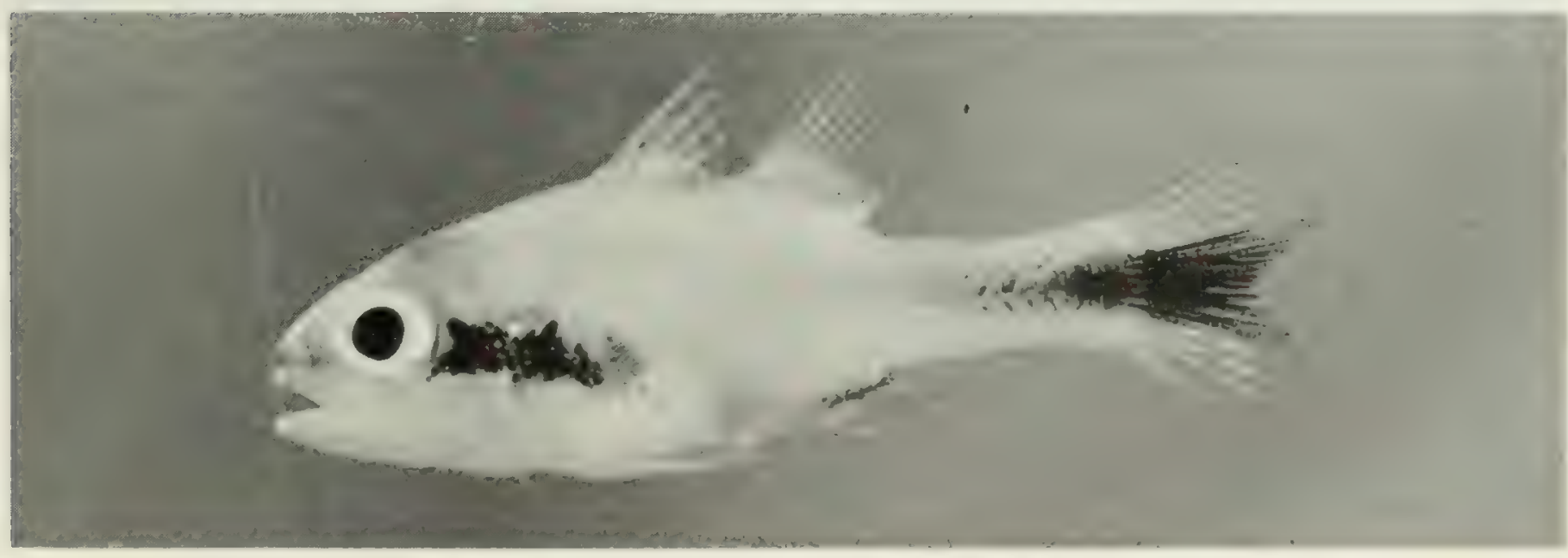

FIG. 165. Apogon semiornatus, $23 \mathrm{~mm} \mathrm{SL,} \mathrm{Salomon.}$ 


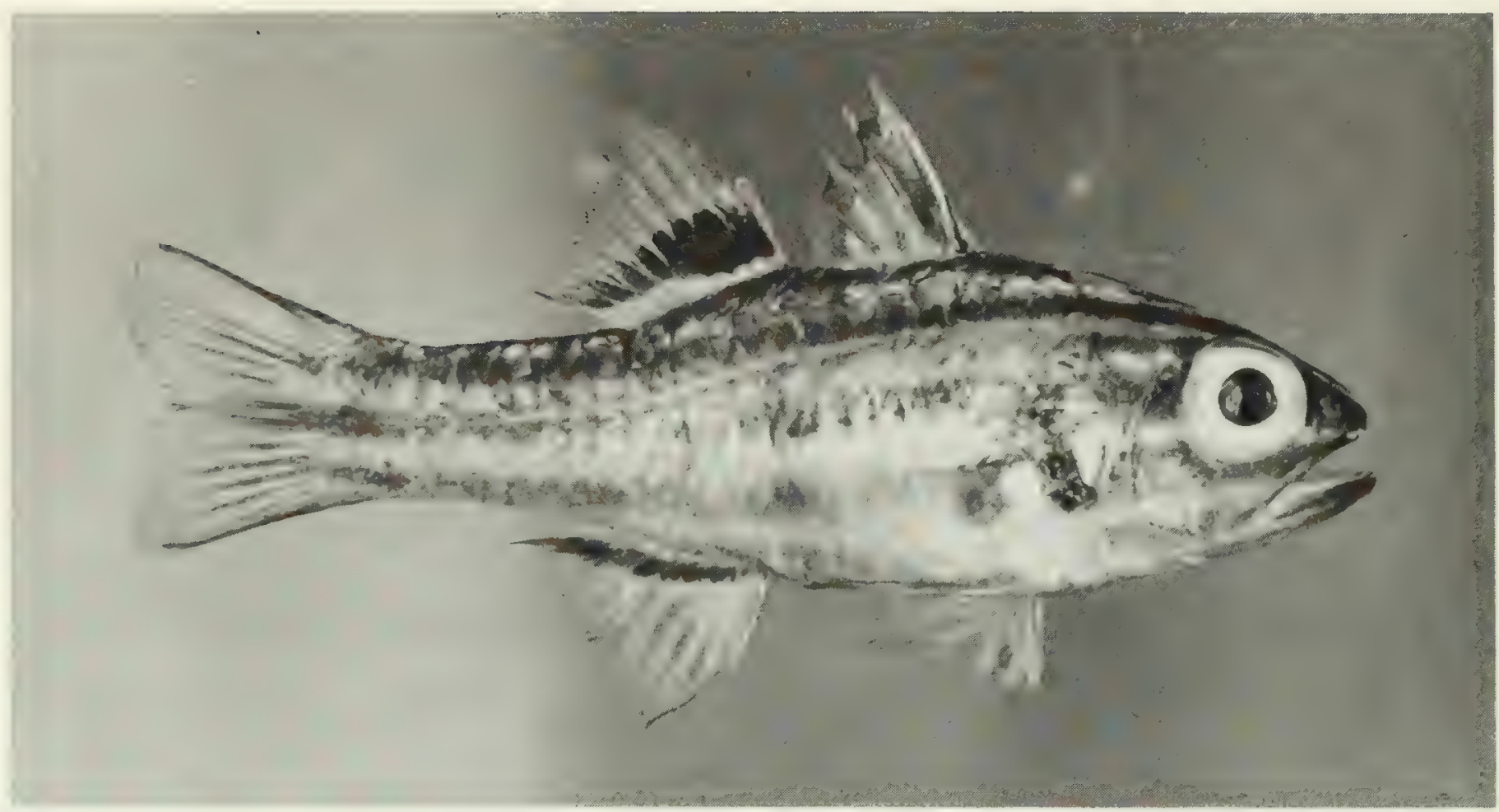

FIG. 166. Apogon taeniophorus, $67 \mathrm{~mm} \mathrm{SL}$, Salomon.

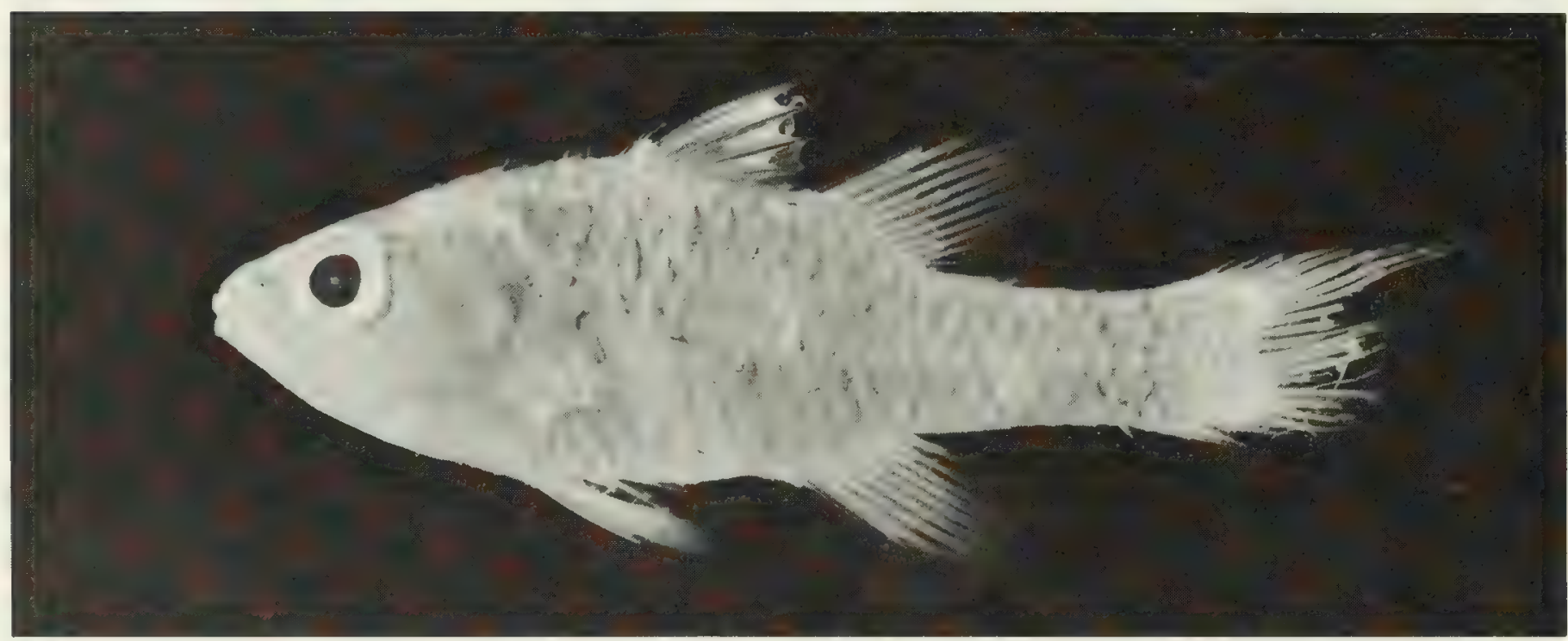

Fig. 167. Apogon talboti, (preserved) $45 \mathrm{~mm} \mathrm{SL,} \mathrm{Peros} \mathrm{Banhos.} \mathrm{Photo} \mathrm{by} \mathrm{A.} \mathrm{Strange.}$

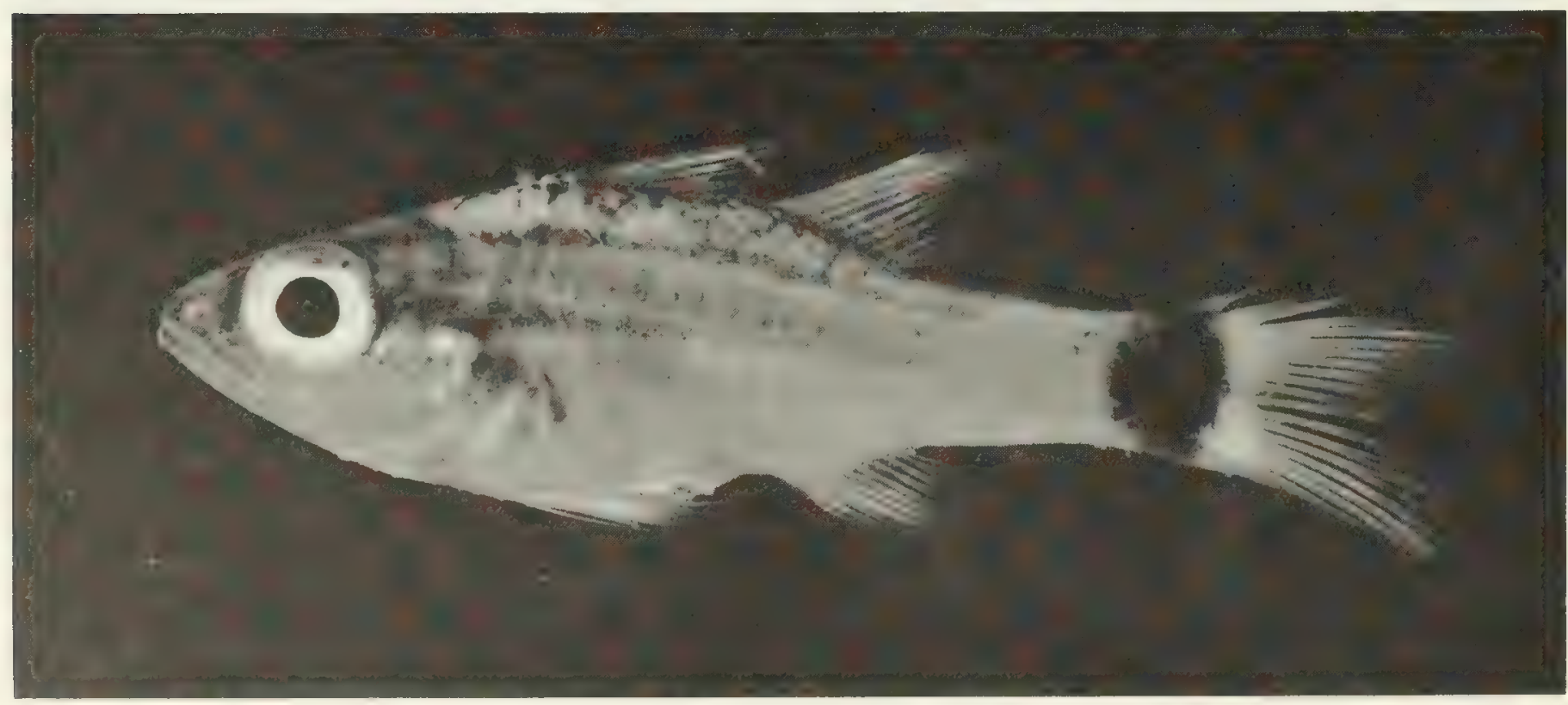

FIG. 168. Apogon sp. 1, (preserved) $48 \mathrm{~mm} \mathrm{SL}$, Peros Banhos. Photo by A. Strange. 


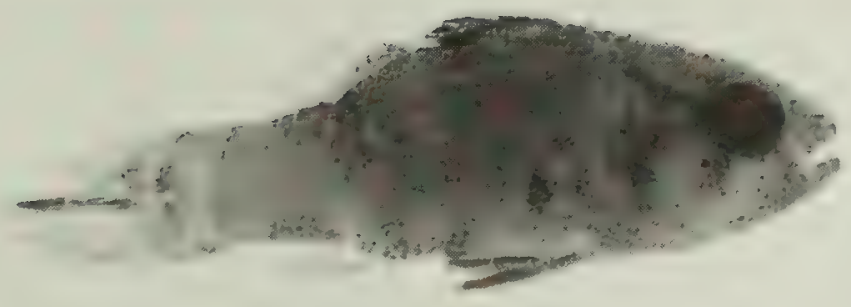

FIG. 169. Apogonichthys perdix, (preserved) $20 \mathrm{~mm} \mathrm{SL,} \mathrm{Peros} \mathrm{Banhos.} \mathrm{Photo} \mathrm{by} \mathrm{A.} \mathrm{Strange.}$

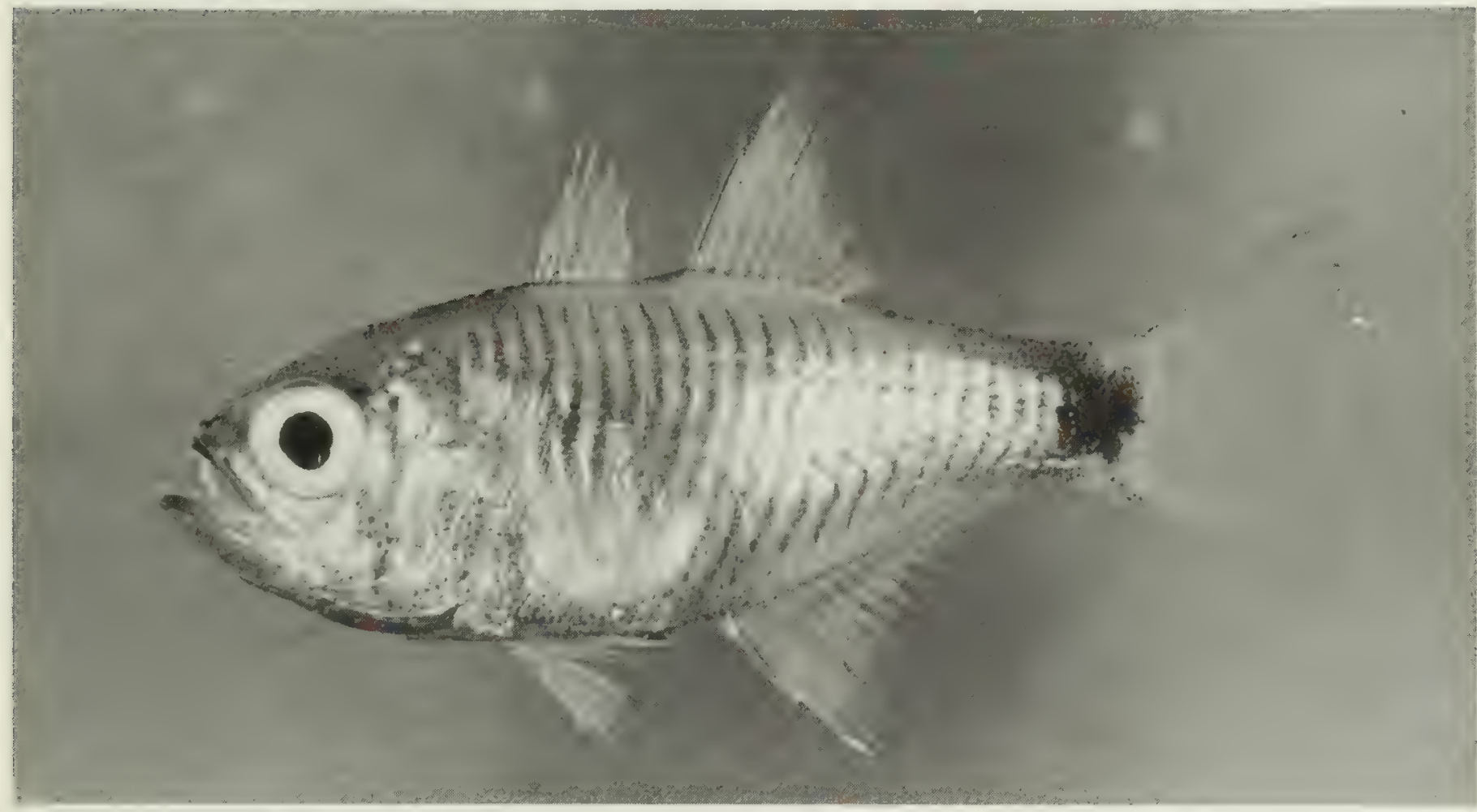

Fig. 170. Archamia fucata, $50 \mathrm{~mm}$ SL, Peros Banhos.

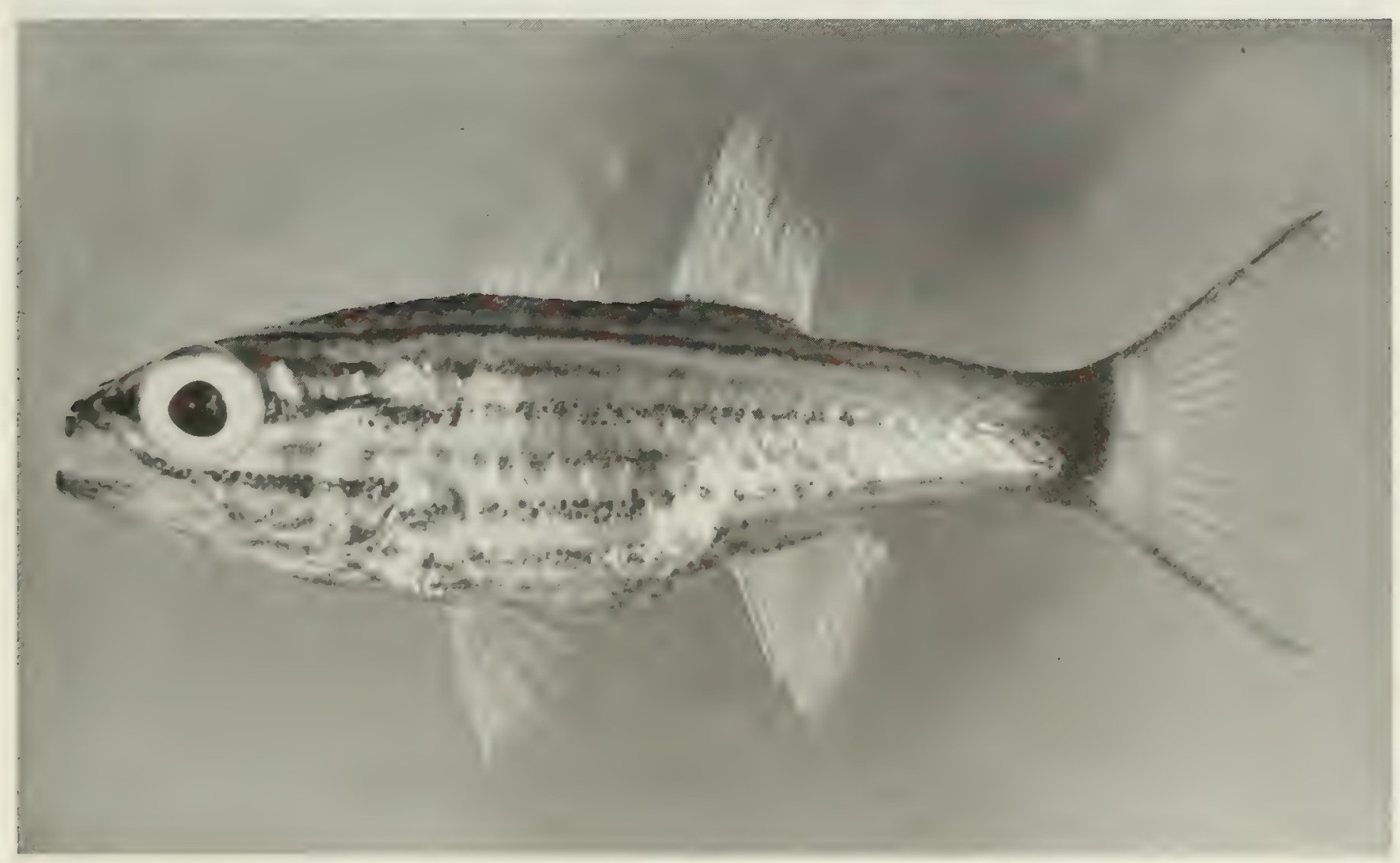

FIG. 171. Cheilodipterus lachneri, $68 \mathrm{~mm}$ SL, Peros Banhos. 


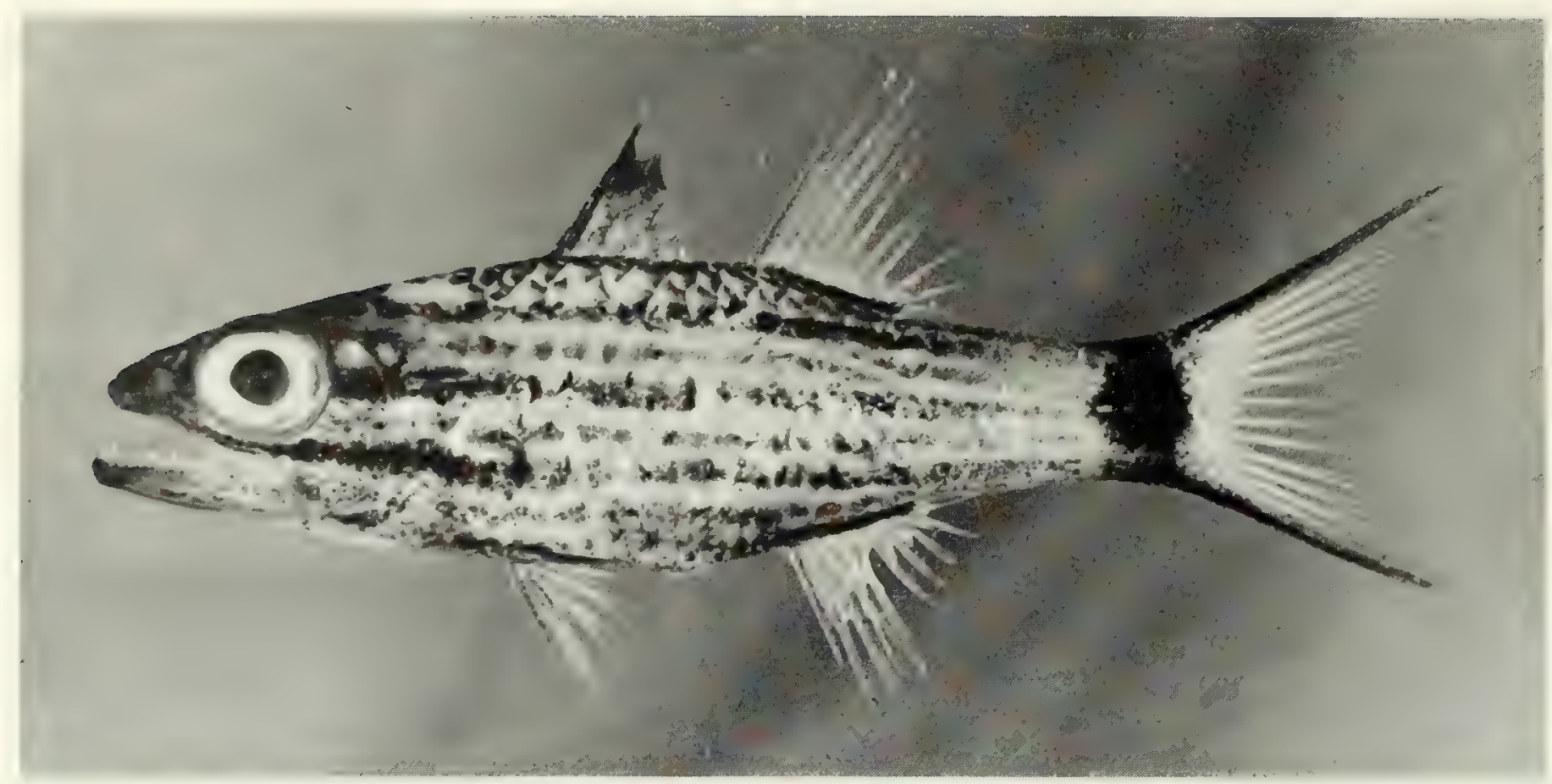

Fig. 172. Cheilodipterus macrodon, $47 \mathrm{~mm} \mathrm{SL}$, Peros Banhos.

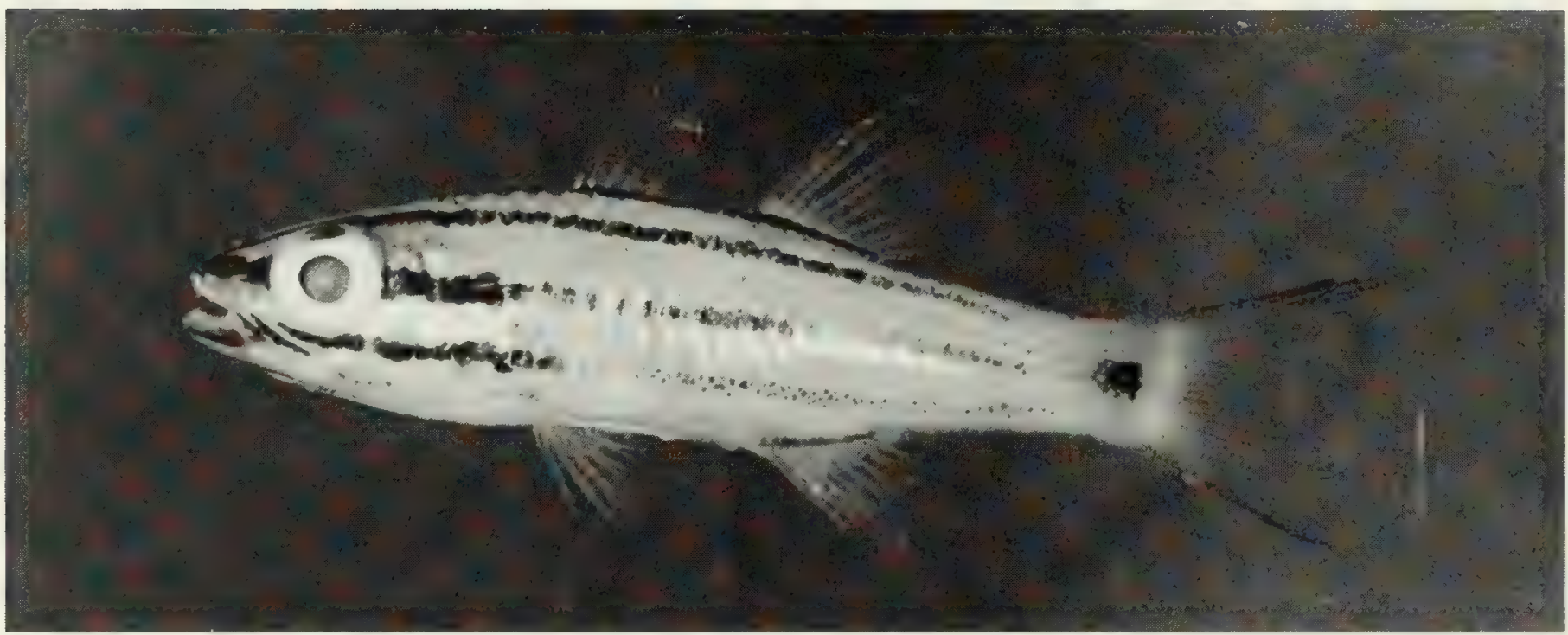

FIG. 173. Cheilodipterus quinquelineatus, specimen not located, Peros Banhos.

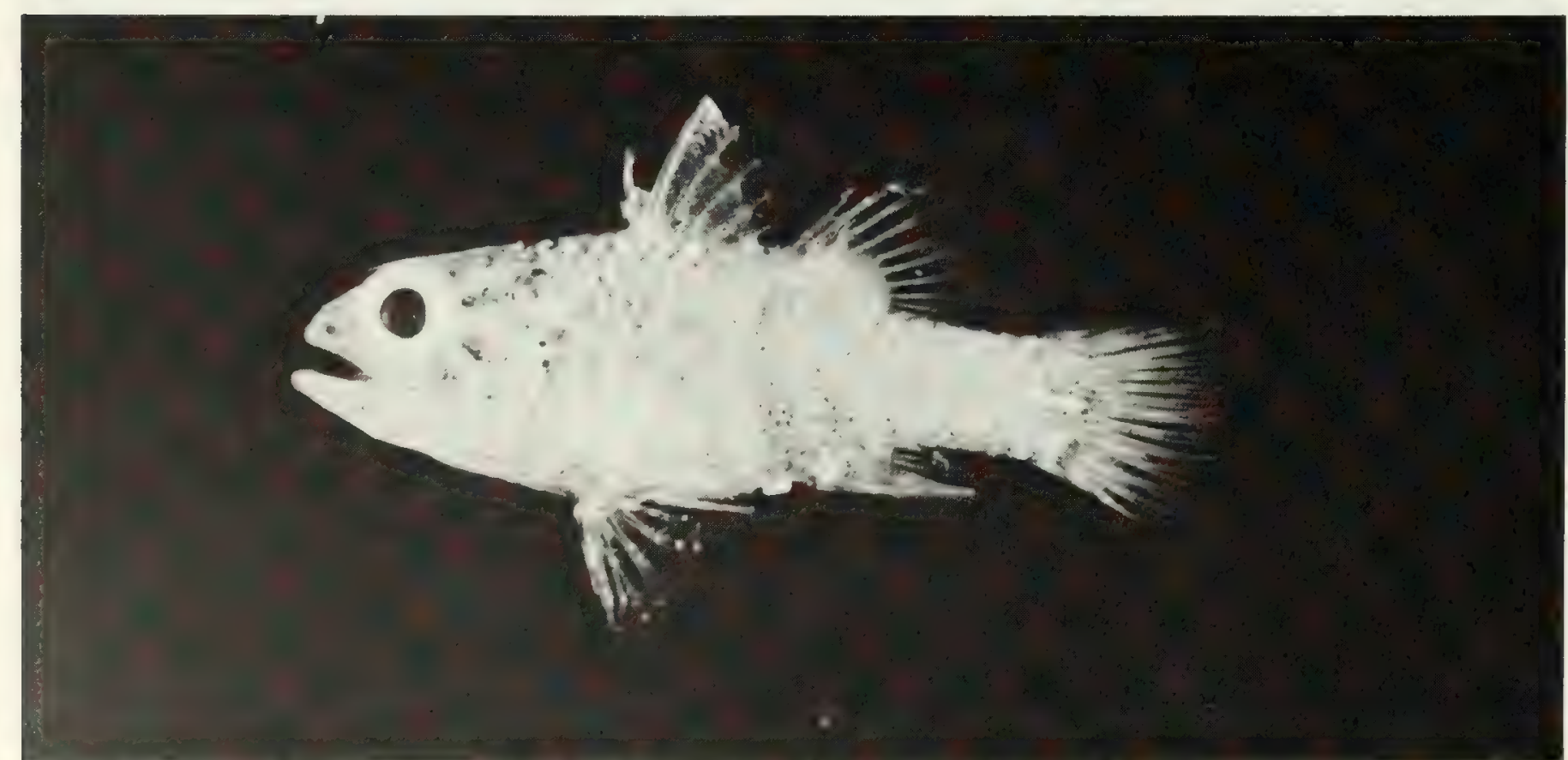

FIG. 174. Fowleria abocellata, $26 \mathrm{~mm} \mathrm{SL}$, Eagle Island. 


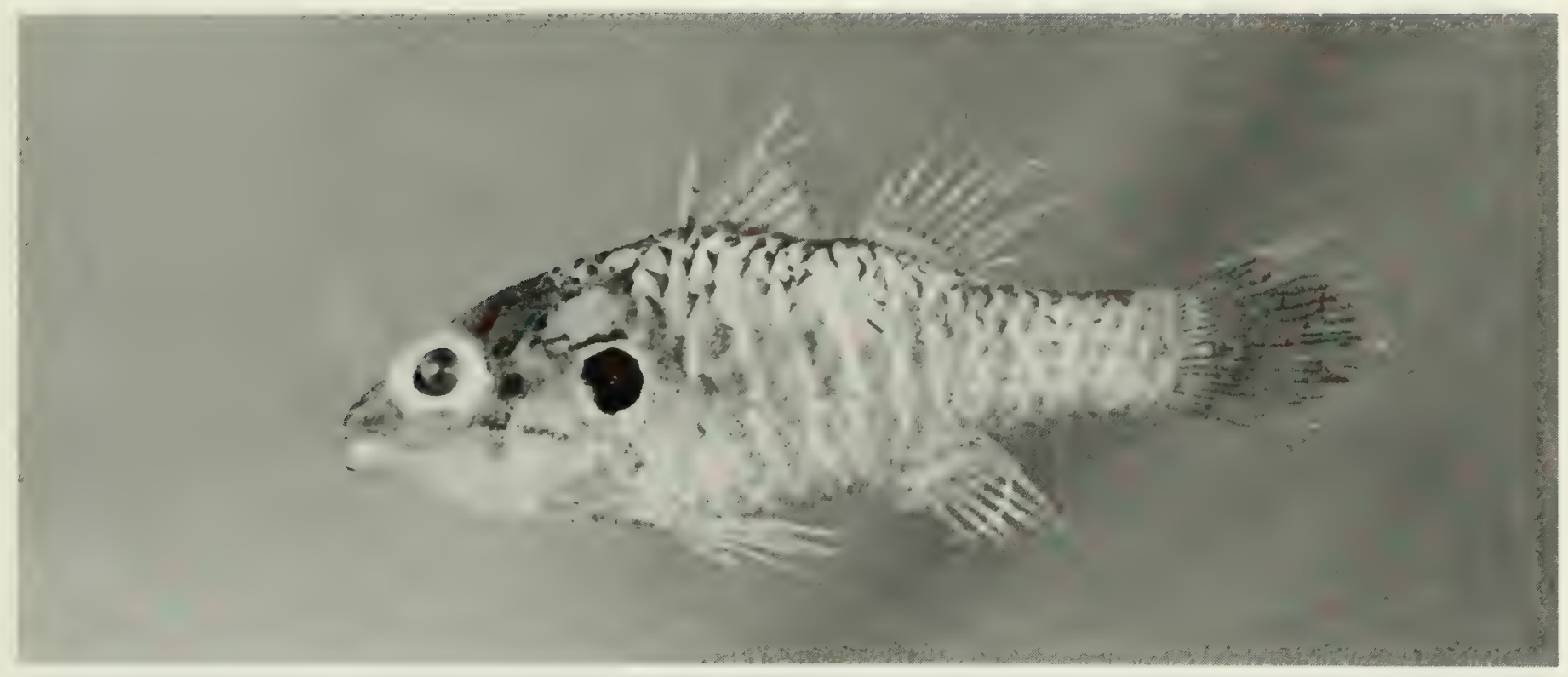

FIG. 175. Fowleria aurita, $24 \mathrm{~mm} \mathrm{SL}$, Peros Banhos.

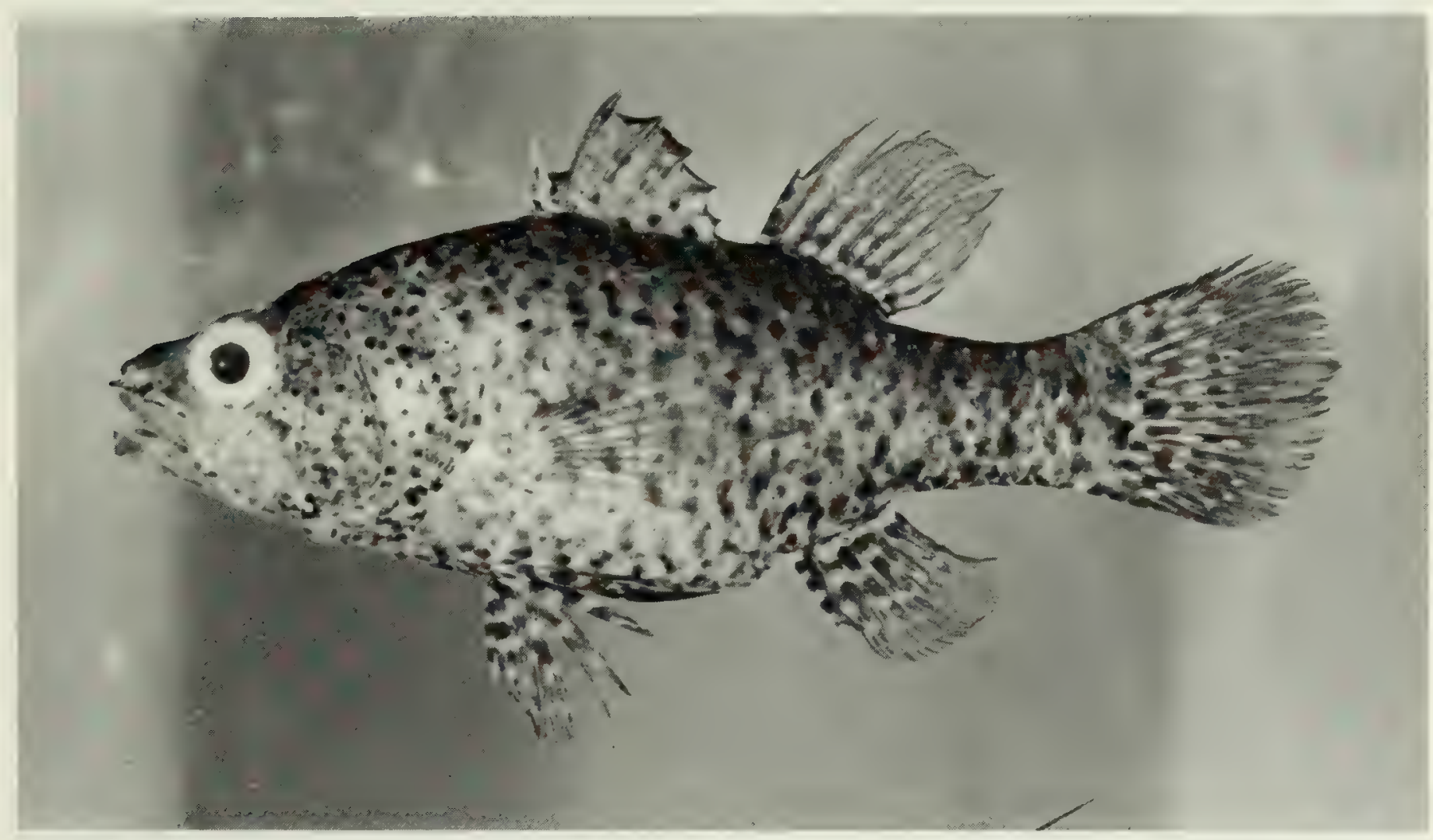

FIG. 176. Fowleria variegata, $75 \mathrm{~mm} \mathrm{SL}$, Salomon.

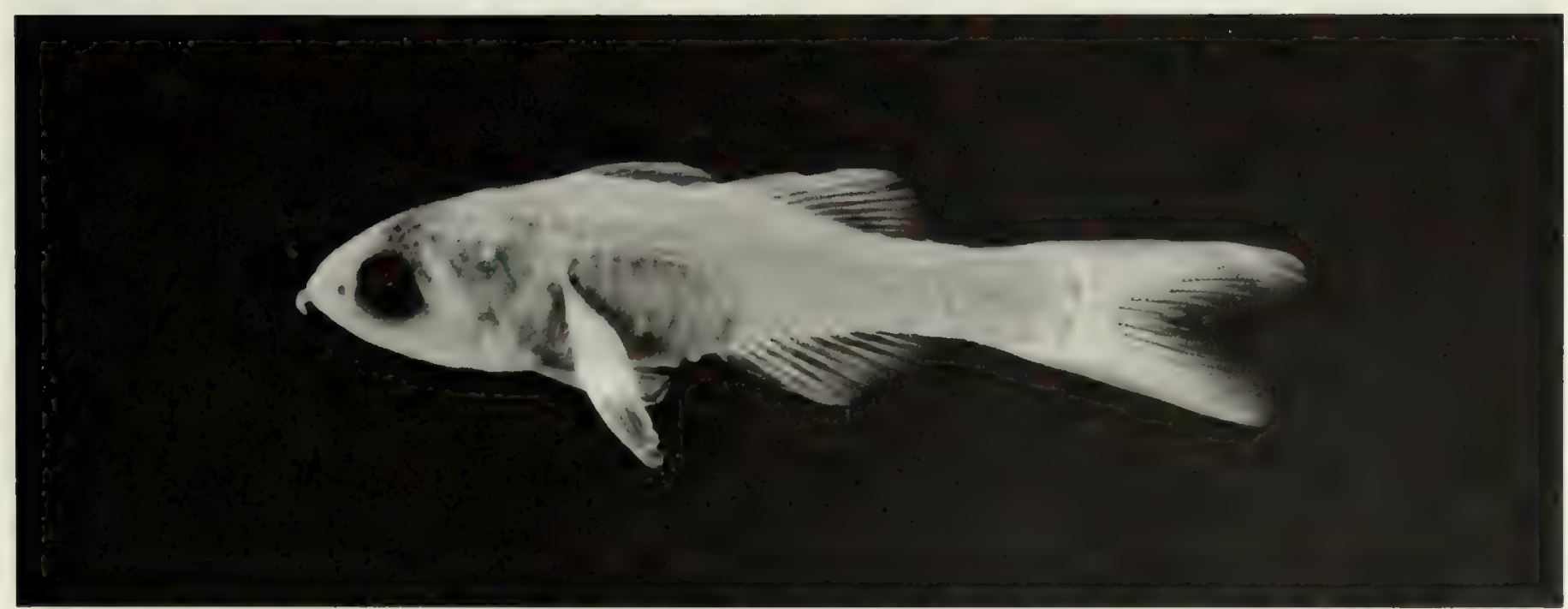

FIG. 177. Gymnapogon sp., (preserved) $33 \mathrm{~mm} \mathrm{SL}$, Diego Garcia. Photo by A. Strange. 


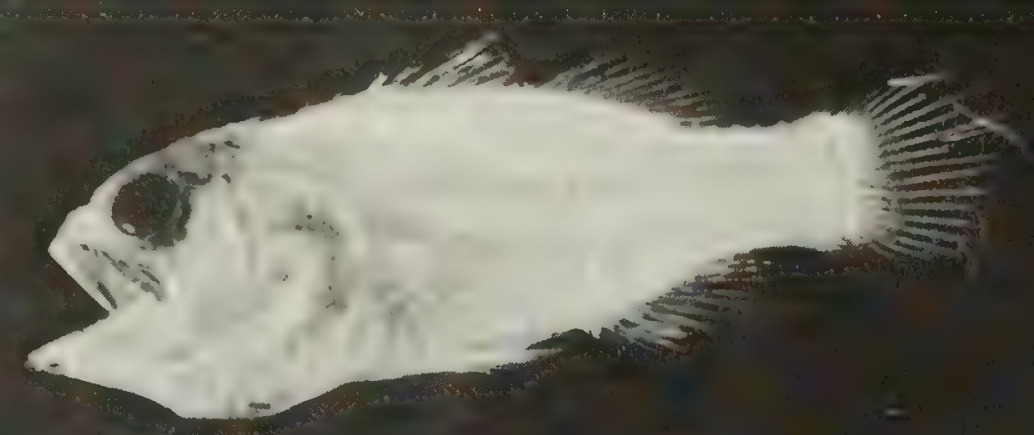

Fig. 178. Neamia octospina, (preserved) $31 \mathrm{~mm} \mathrm{SL}$, Three Brothers. Photo by A. Strange.

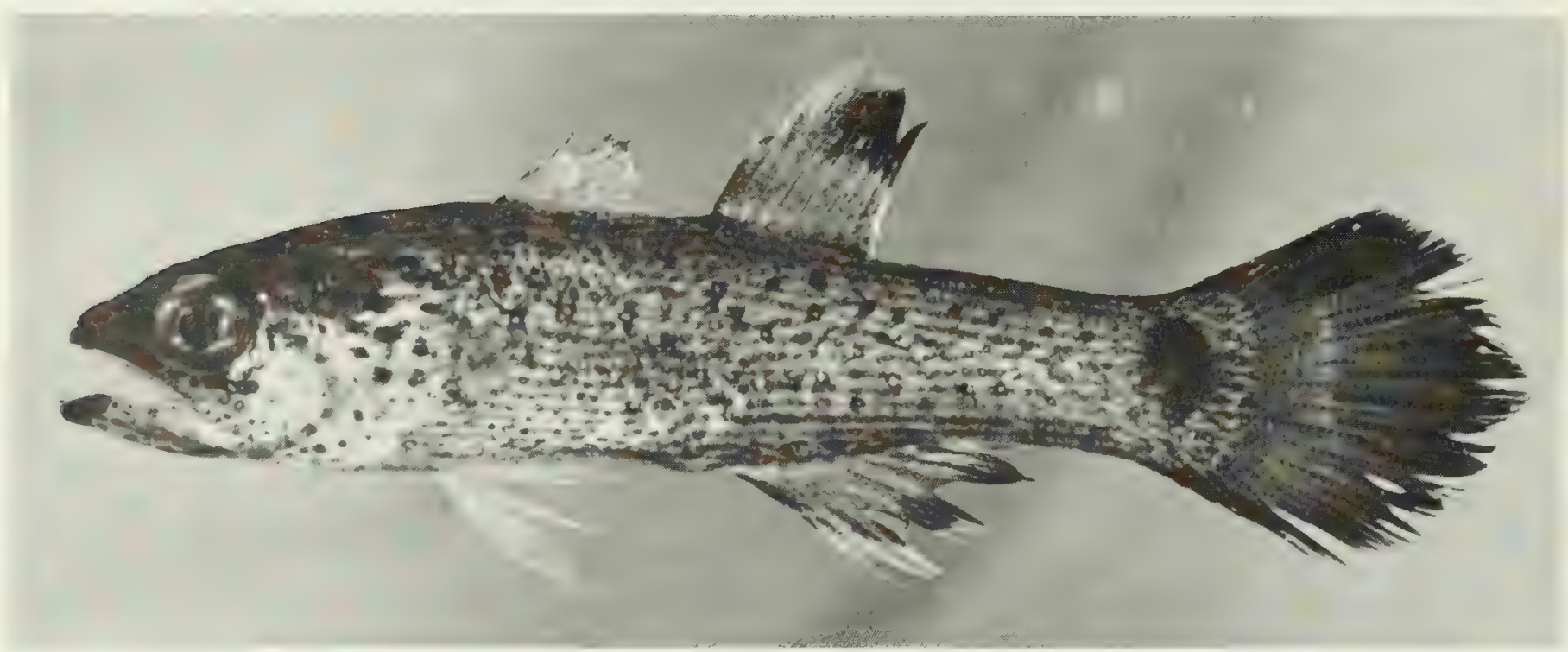

Fig. 179. Pseudamia gelatinosa, $57 \mathrm{~mm}$ SL, Peros Banhos.

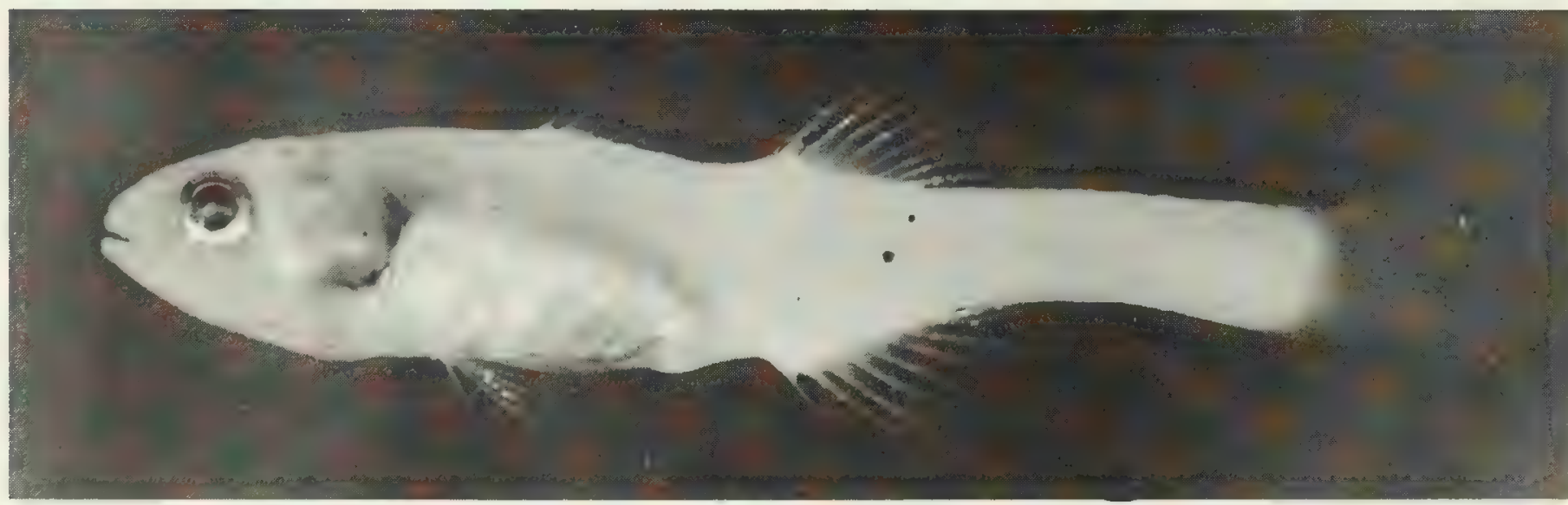

FIG. 180. Pseudamiops gracilicauda, $23 \mathrm{~mm}$ SL, Peros Banhos.

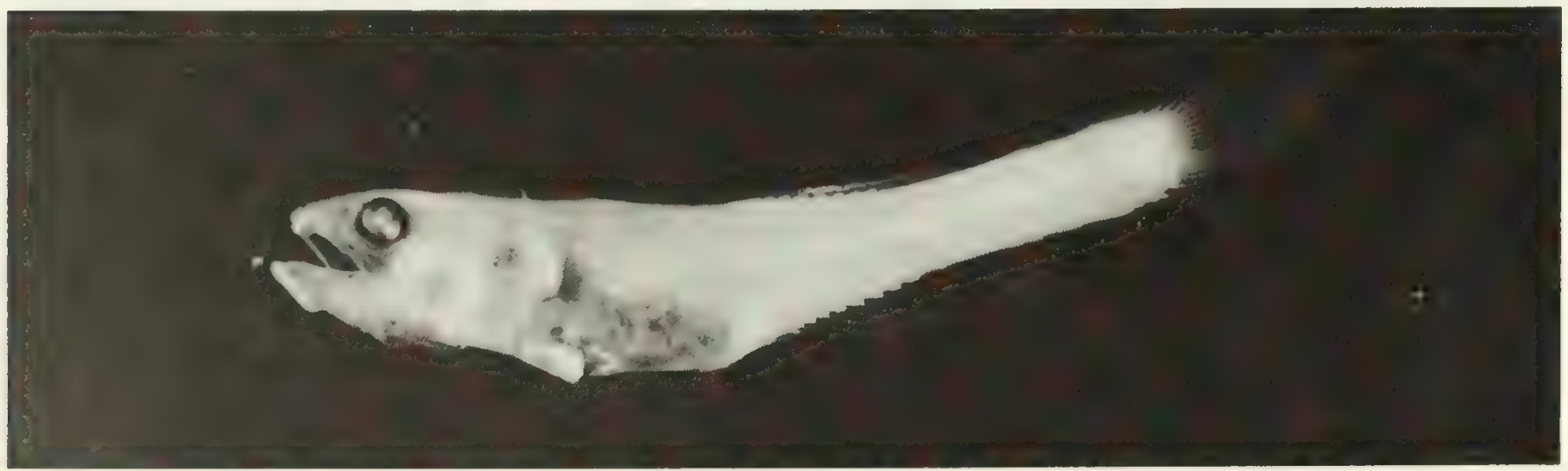

FIG. 181. Pseudamiops sp., (preserved) $21 \mathrm{~mm} \mathrm{SL,} \mathrm{Peros} \mathrm{Banhos.} \mathrm{Photo} \mathrm{by} \mathrm{A.} \mathrm{Strange.}$ 


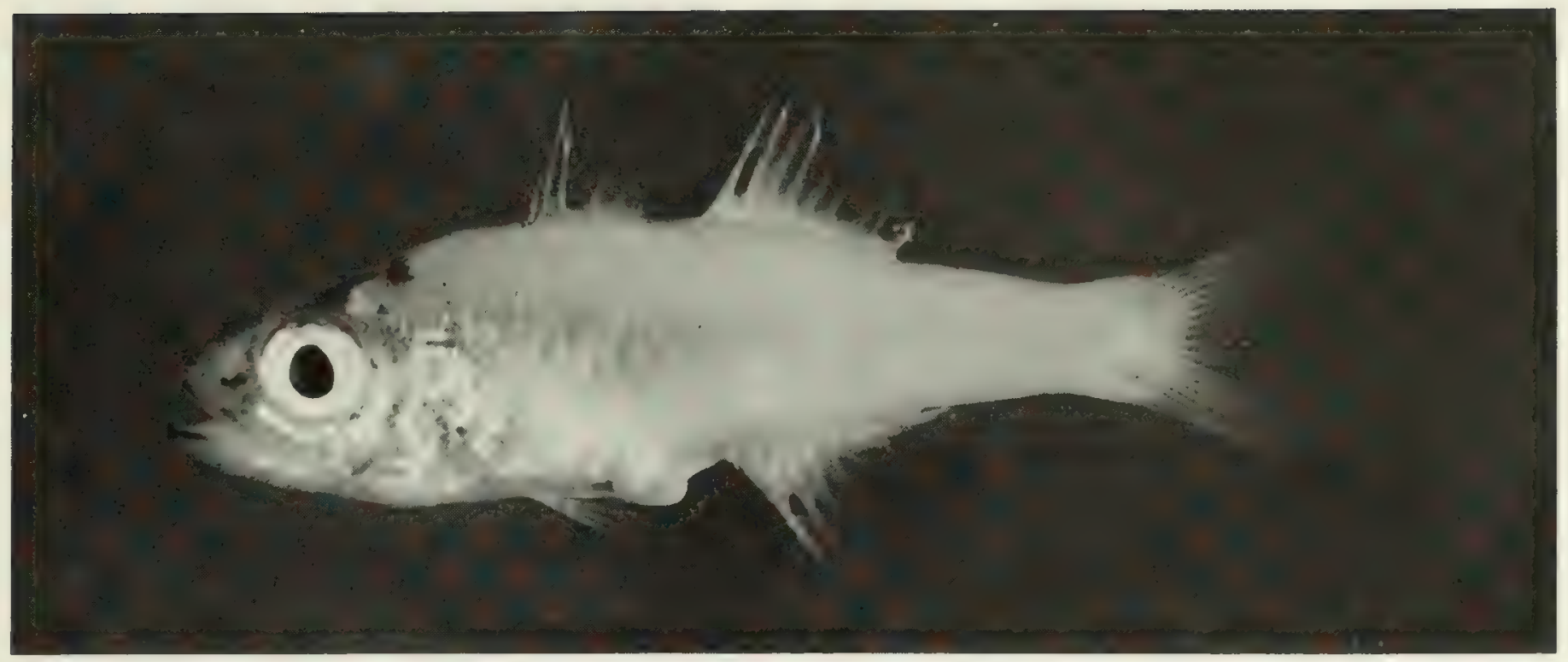

FIG. 182. Rhabdamia cypselurus, $38 \mathrm{~mm} \mathrm{SL}$, Peros Banhos.

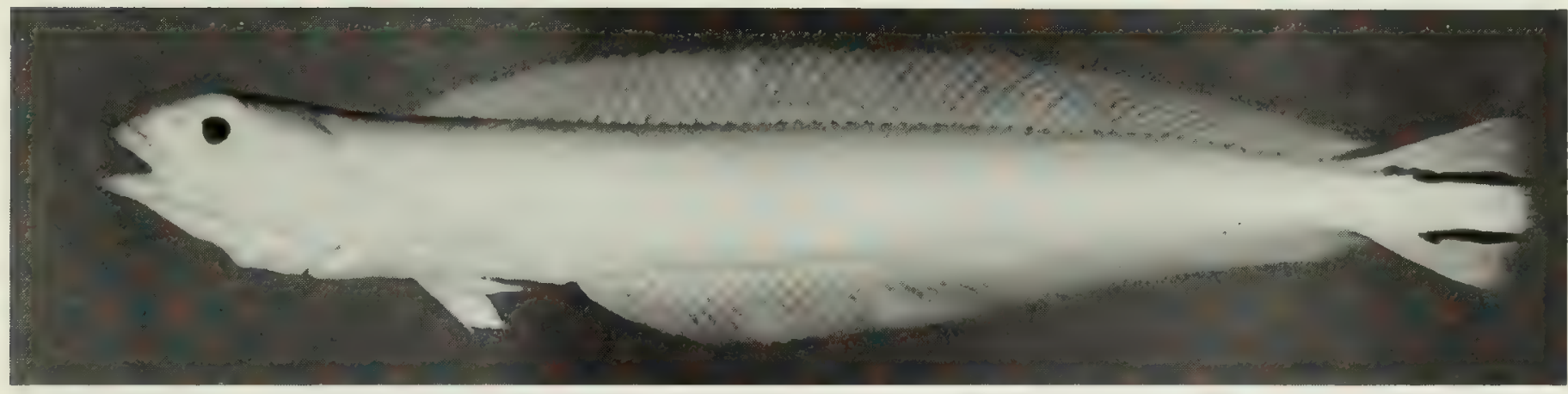

FIG. 183. Malacanthus brevirostris, $168 \mathrm{~mm} \mathrm{SL}$, Peros Banhos.

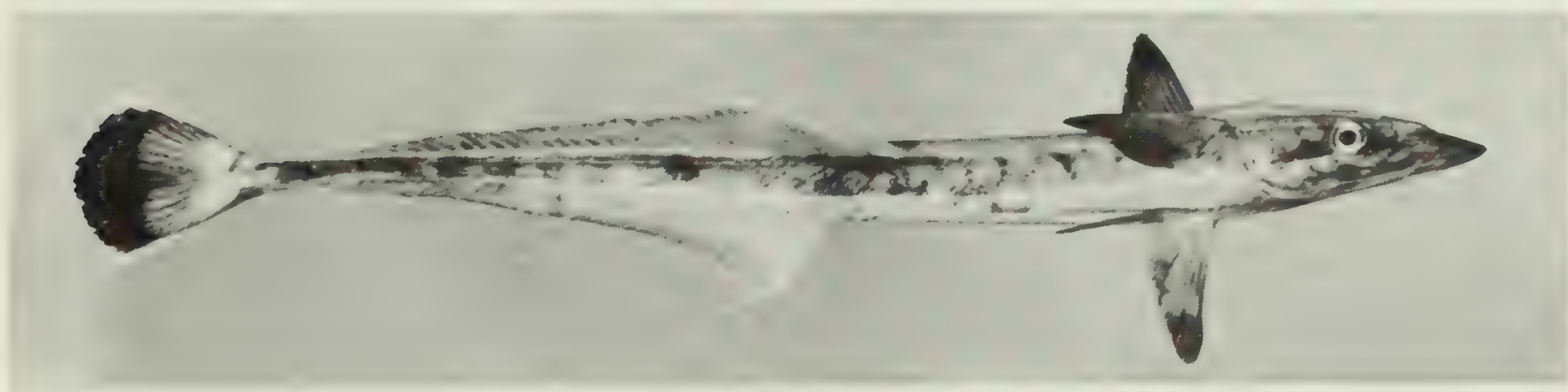

FIG. 184. Echeneis naucrates, $248 \mathrm{~mm} \mathrm{SL}$, Peros Banhos.

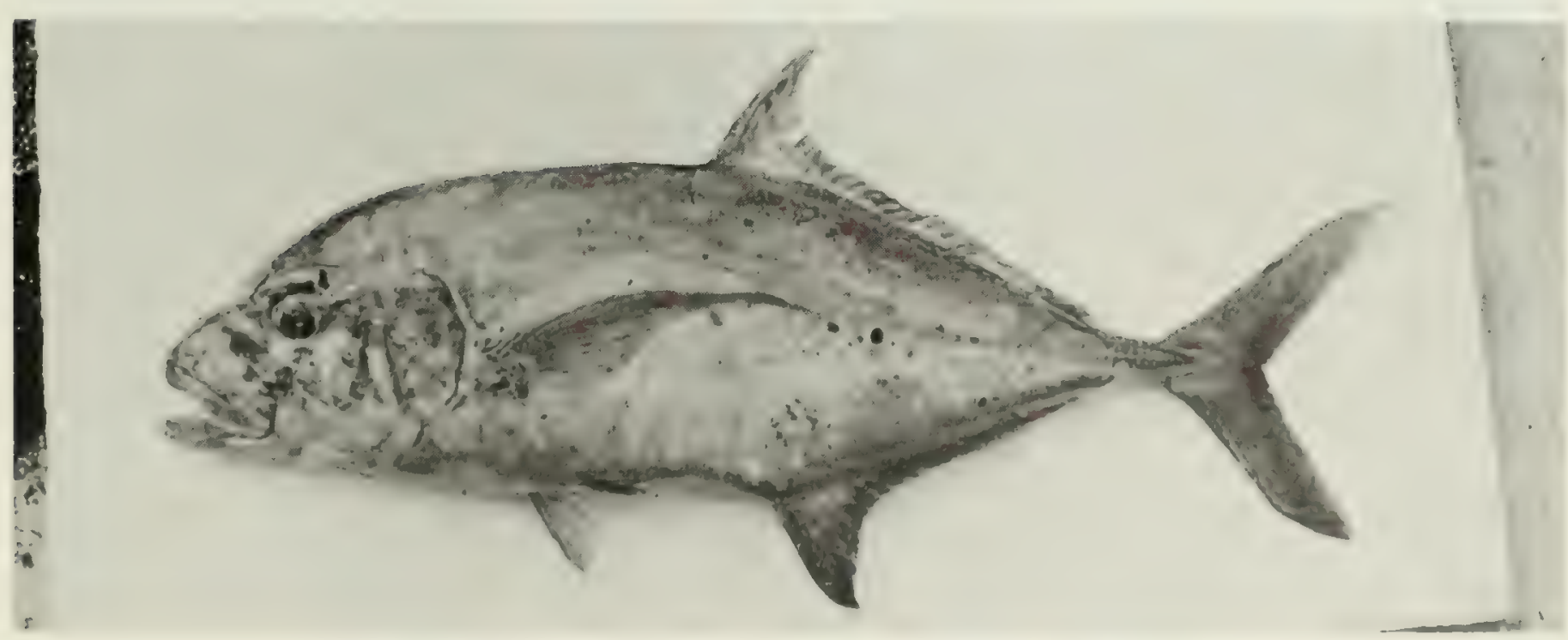

FIG. 185. Carangoides orthogrammus, $533 \mathrm{~mm} \mathrm{SL}$, Salomon. 


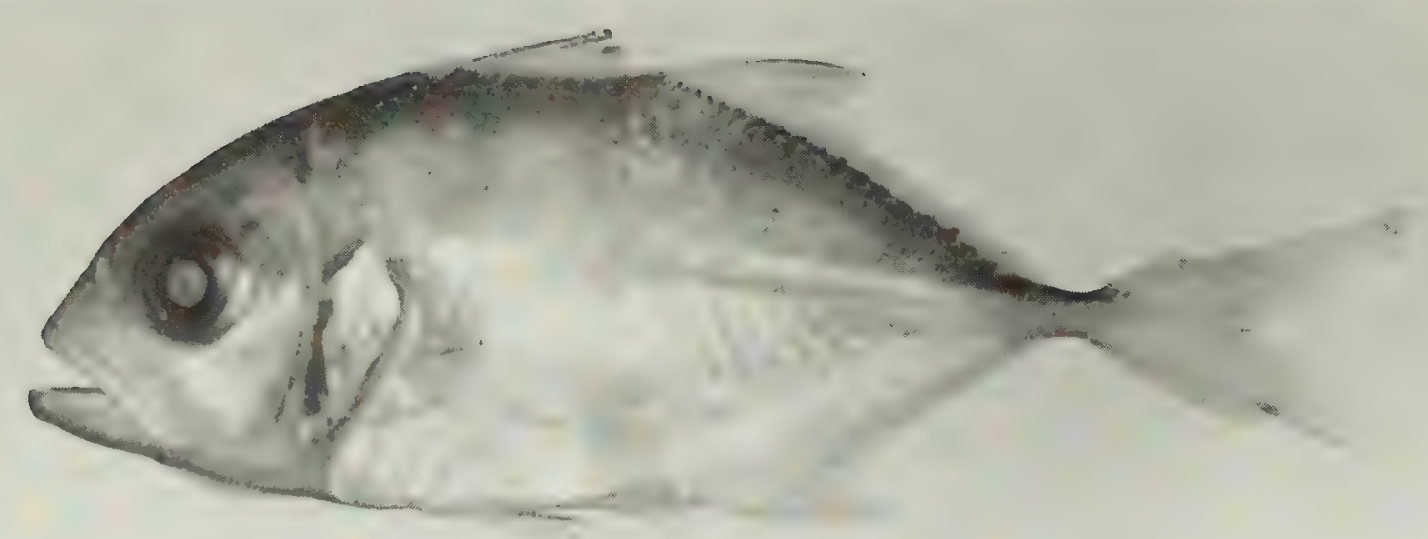

FIG. 186. Caranx ignobilis, (preserved) $56 \mathrm{~mm}$ SL, Diego Garcia. Photo by M. Burridge-Smith.

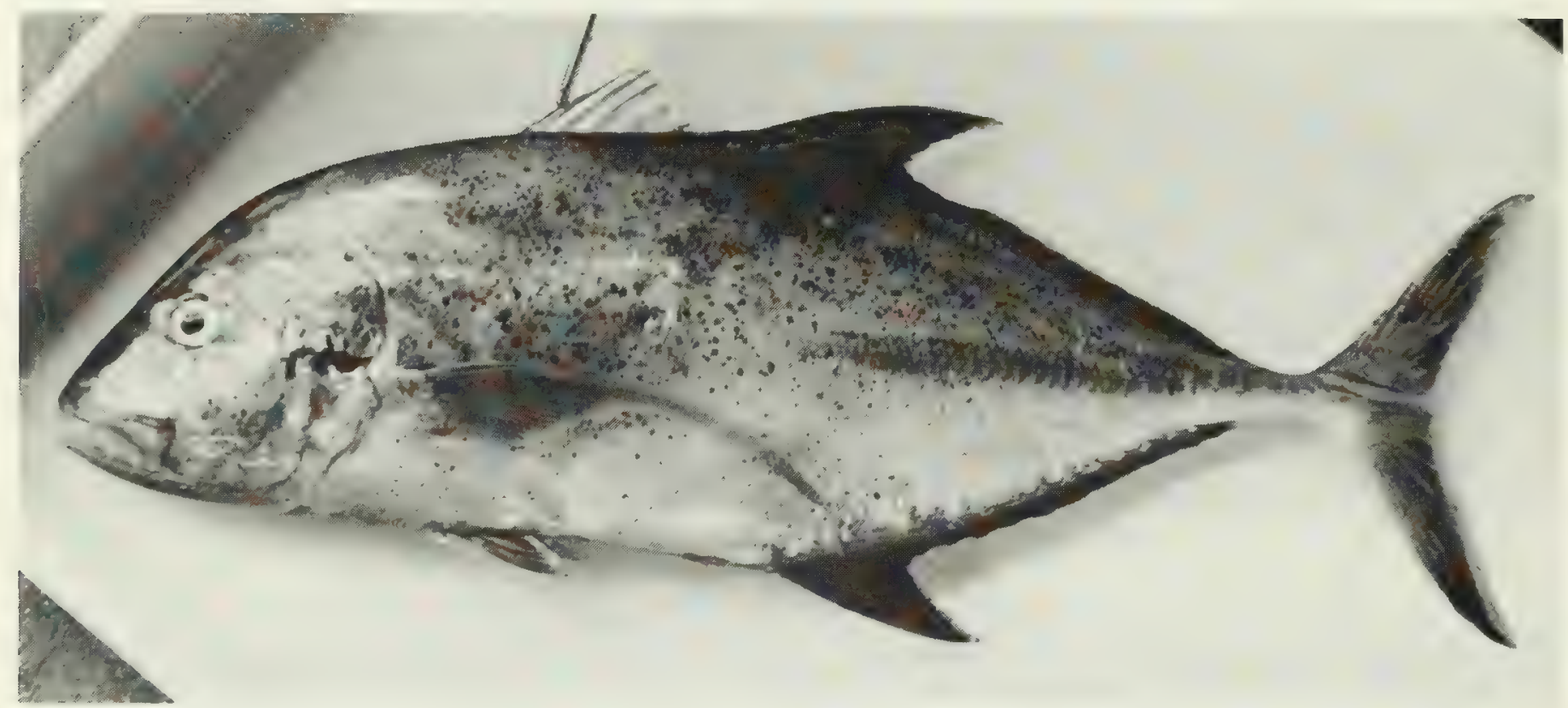

FIG. 187. Caranx melampygus, $519 \mathrm{~mm} \mathrm{SL,} \mathrm{Peros} \mathrm{Banhos.}$

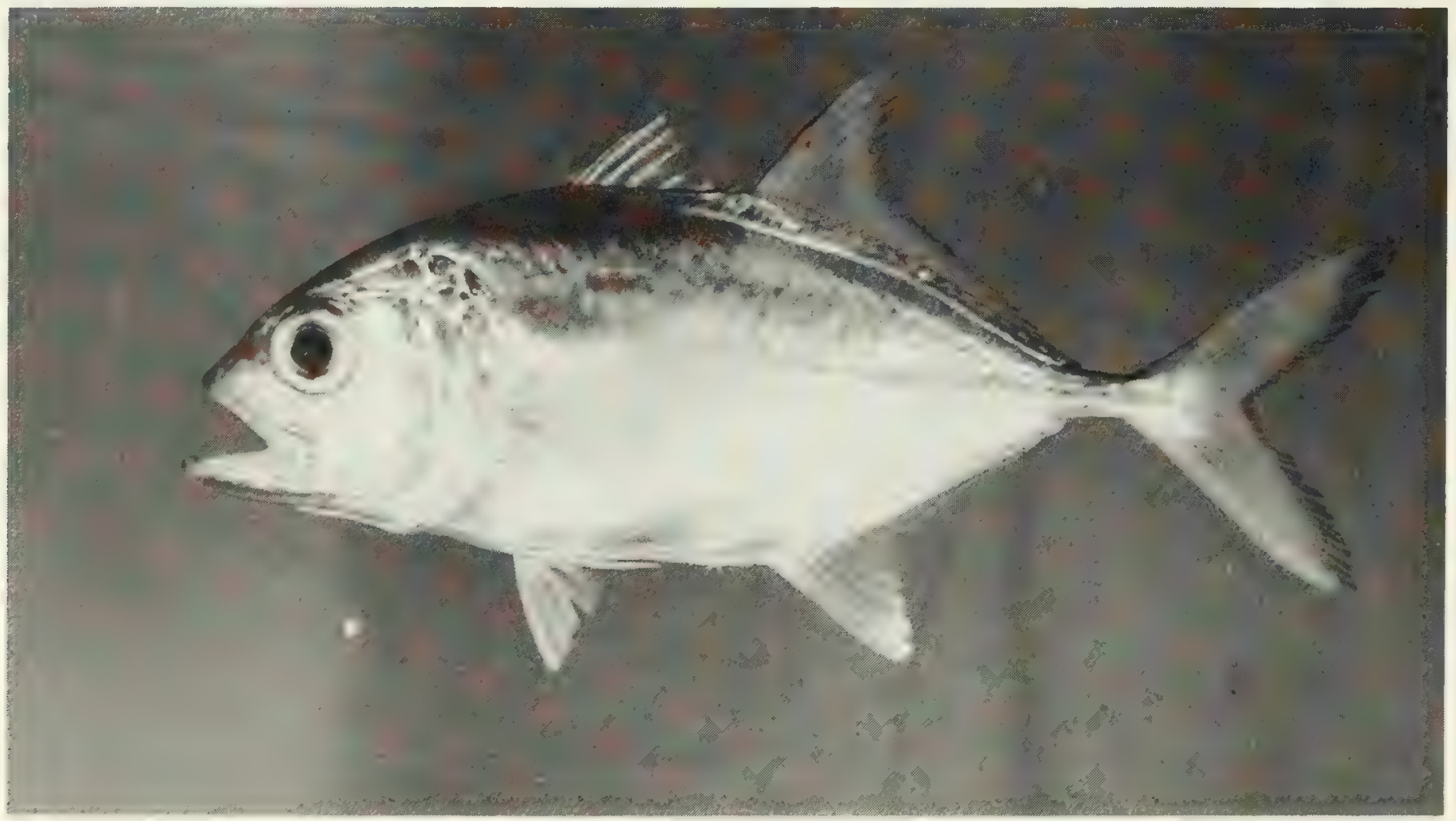

FIG. 188. Caranx sexfasciatus, $119 \mathrm{~mm} \mathrm{SL}$, Peros Banhos. 


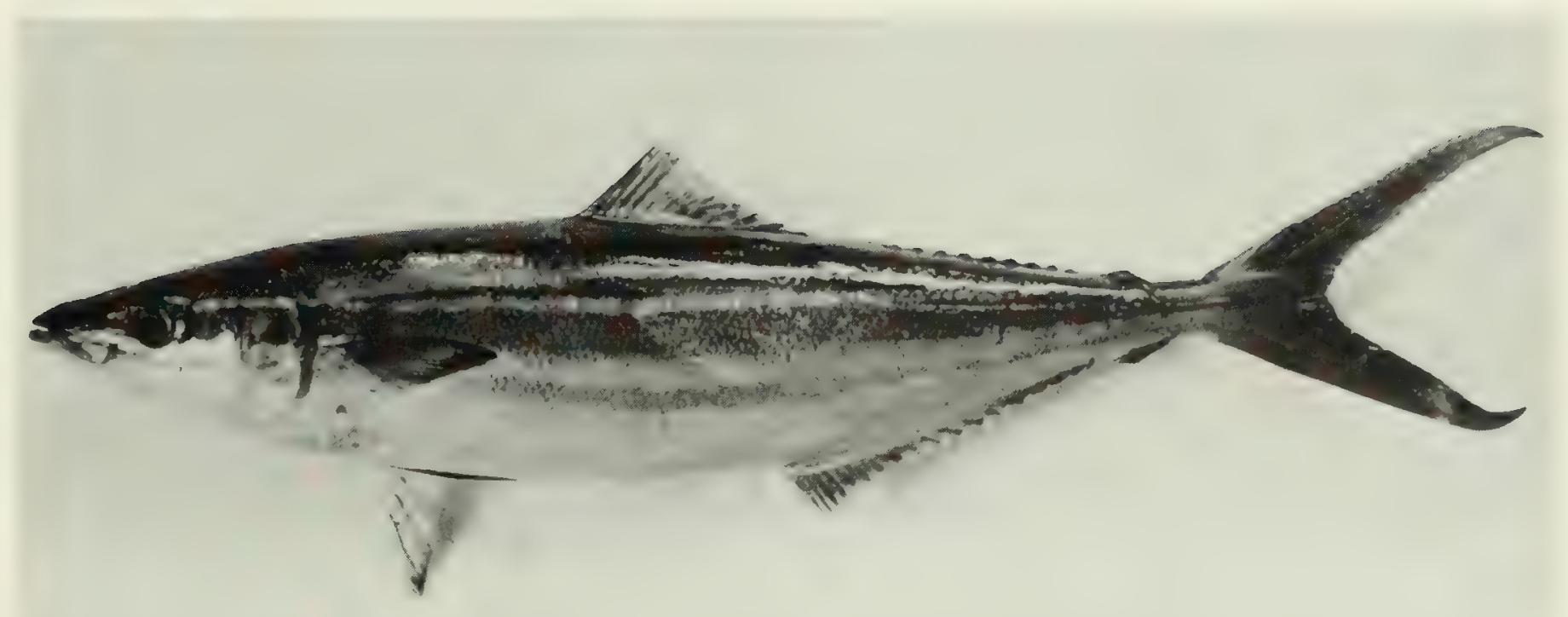

Fig. 189. Elagatis bipinnulata, $510 \mathrm{~mm}$ SL, Peros Banhos.

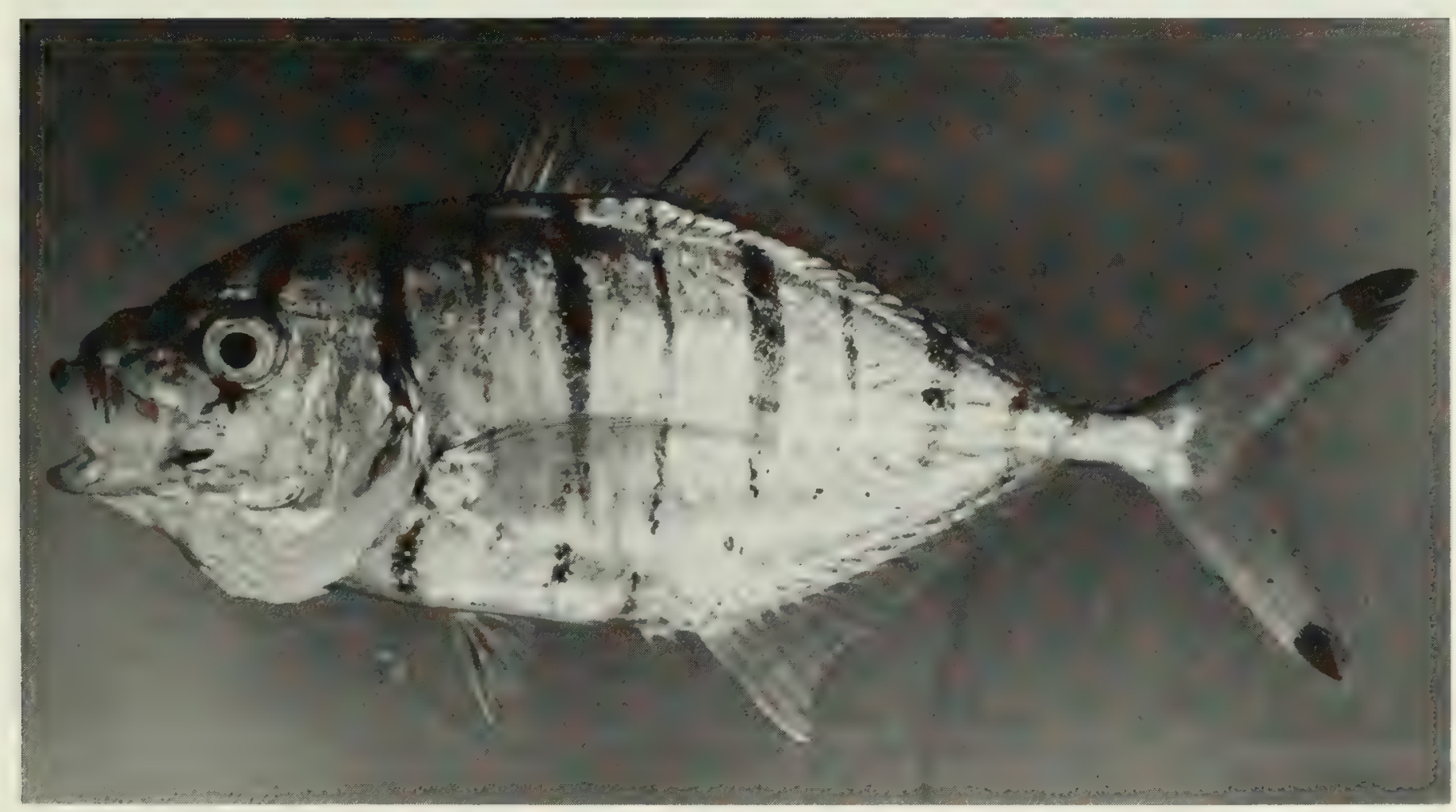

FIG. 190. Gnathanodon speciosus, $173 \mathrm{~mm} \mathrm{SL,} \mathrm{Peros} \mathrm{Banhos.}$

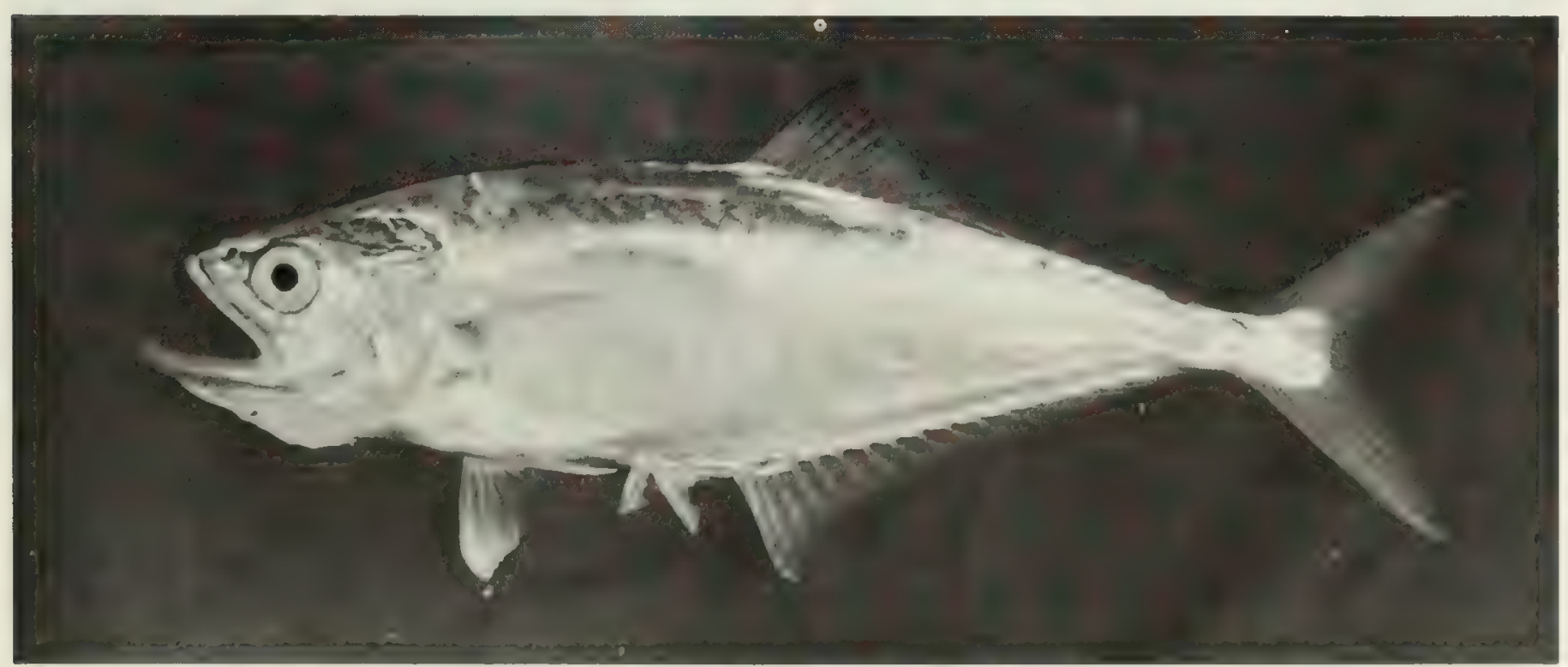

FIG. 191. Scomberoides lysan, $83 \mathrm{~mm}$ SL, Peros Banhos. 


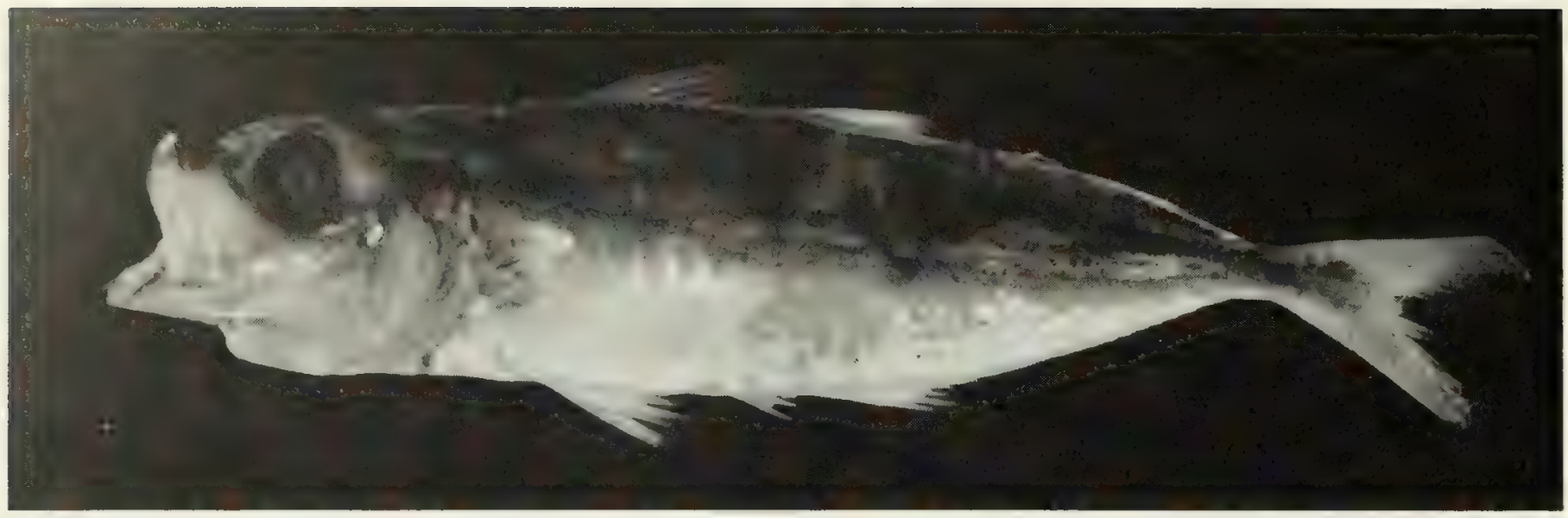

FIG. 192. Selar crumenophthalmus, (preserved) $123 \mathrm{~mm} \mathrm{SL}$, Salomon. Photo by A. Strange.

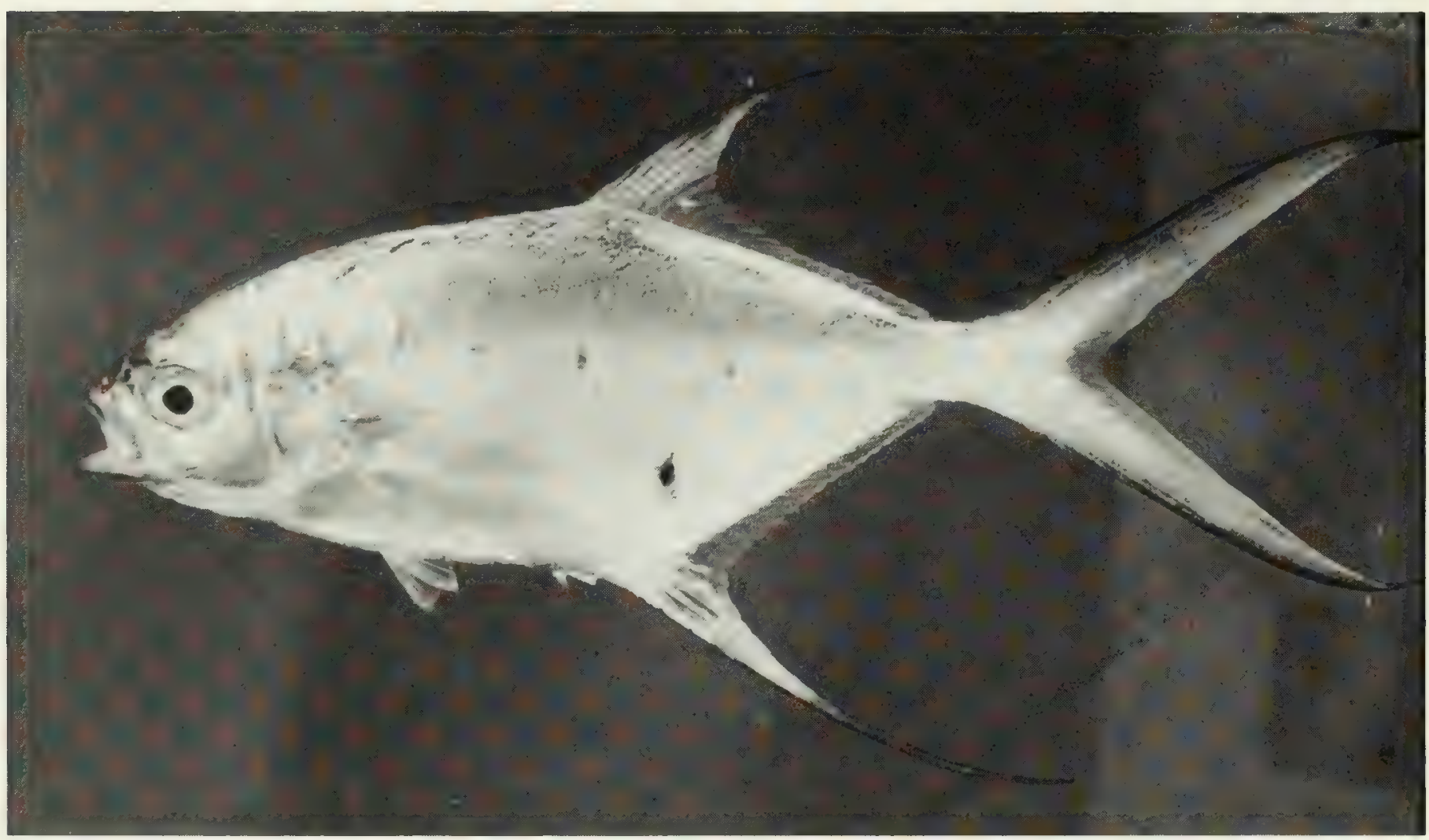

FiG. 193. Trachinotus baillonii, $224 \mathrm{~mm}$ SL, Peros Banhos.

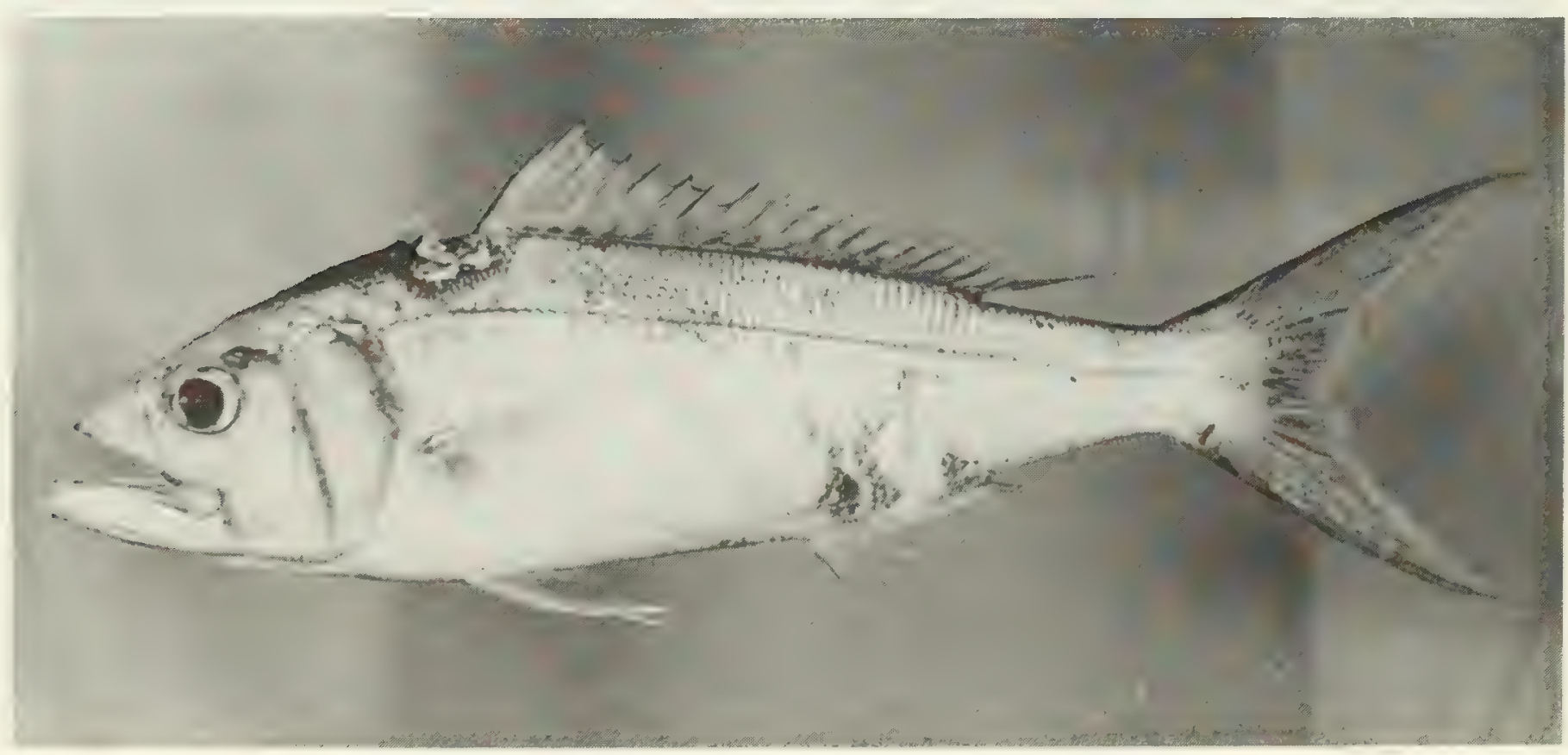

Fig. 194. Aphareus furcatus, $261 \mathrm{~mm}$ SL, Peros Banhos. 


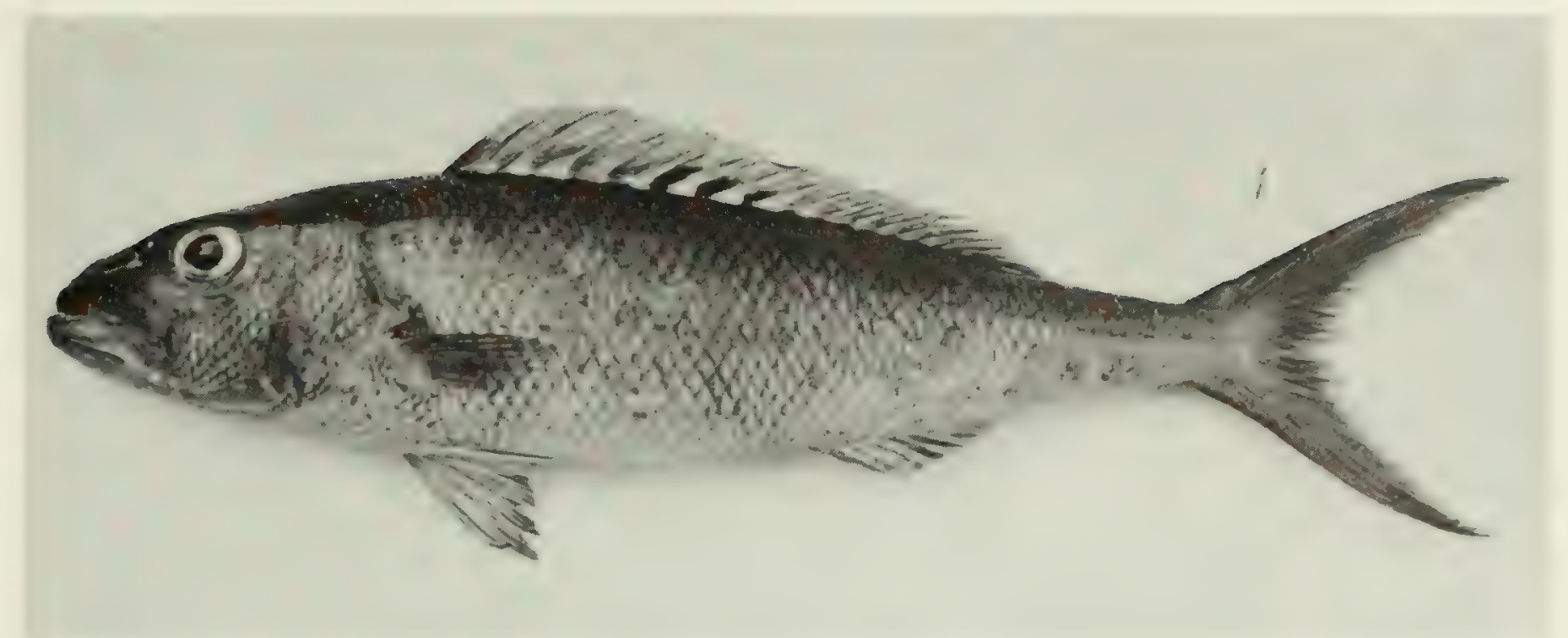

FIG. 195. Aprion virescens, $445 \mathrm{~mm} \mathrm{SL}$, Peros Banhos.

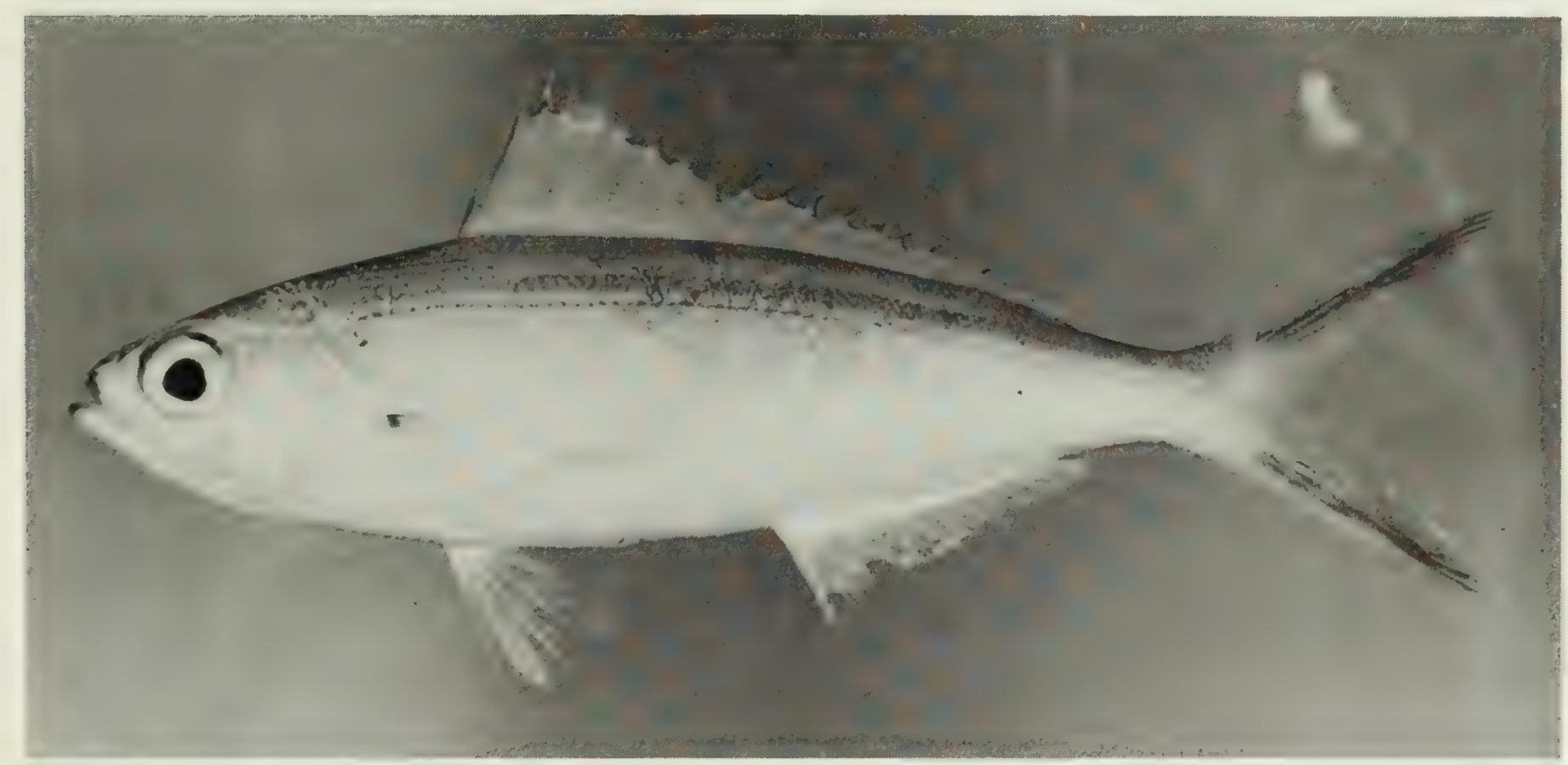

FIG. 196. Caesio caerulaureus, $101 \mathrm{~mm} \mathrm{SL}$, Peros Banhos.

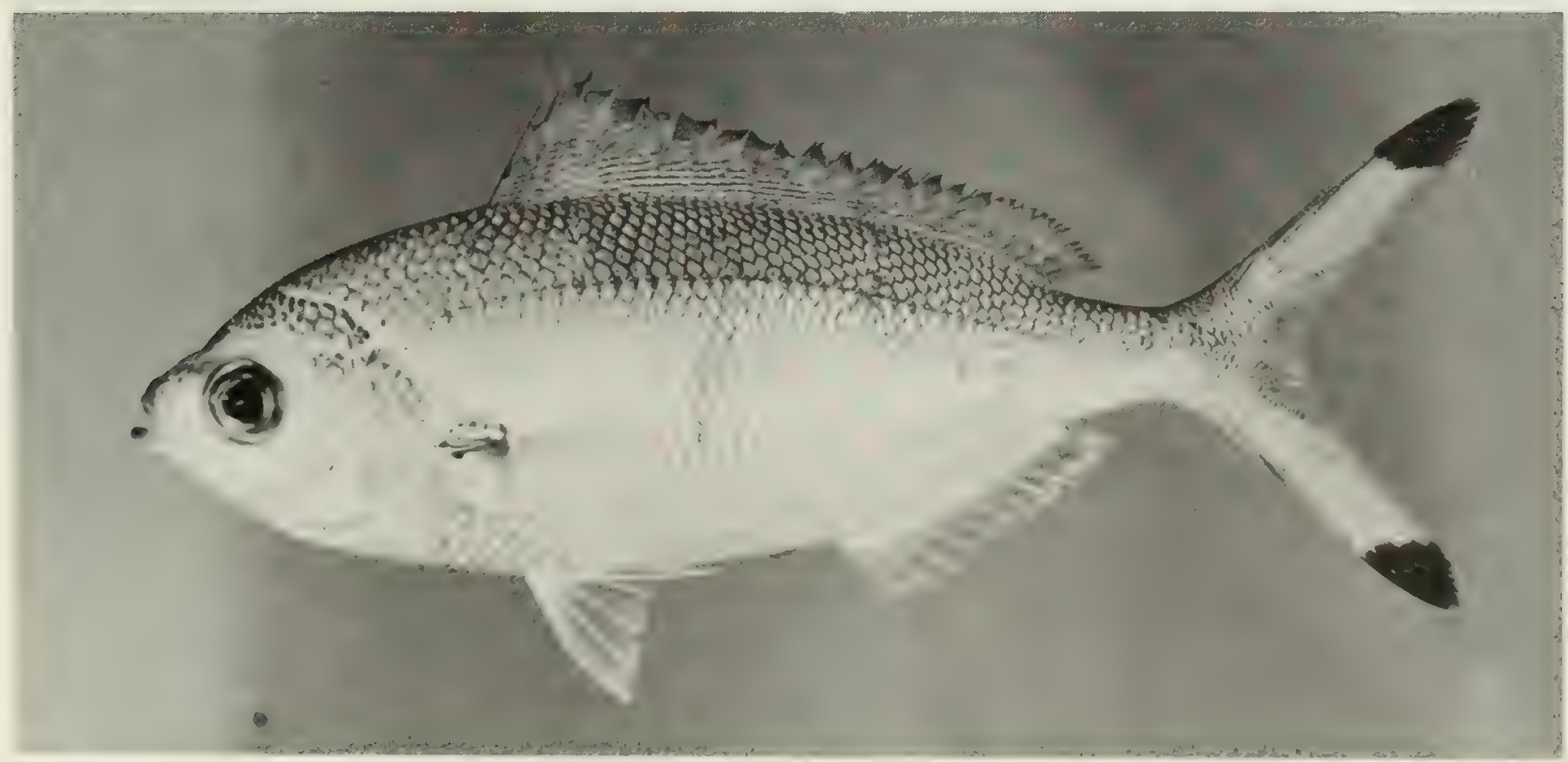

FIG. 197. Caesio lunaris, $166 \mathrm{~mm}$ SL, Peros Banhos. 


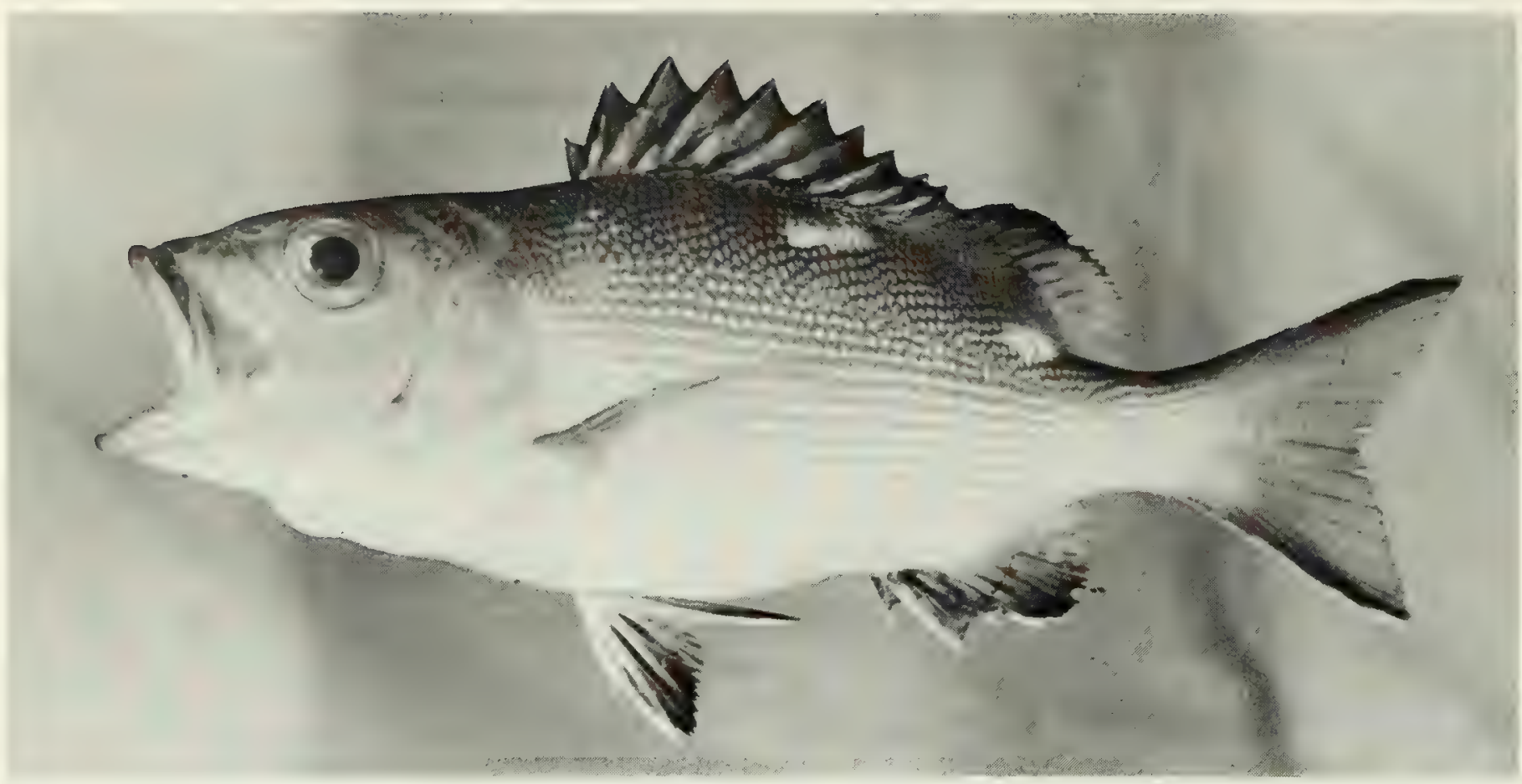

FIG. 198. Lutjanus bohar, $144 \mathrm{~mm}$ SL, Peros Banhos.

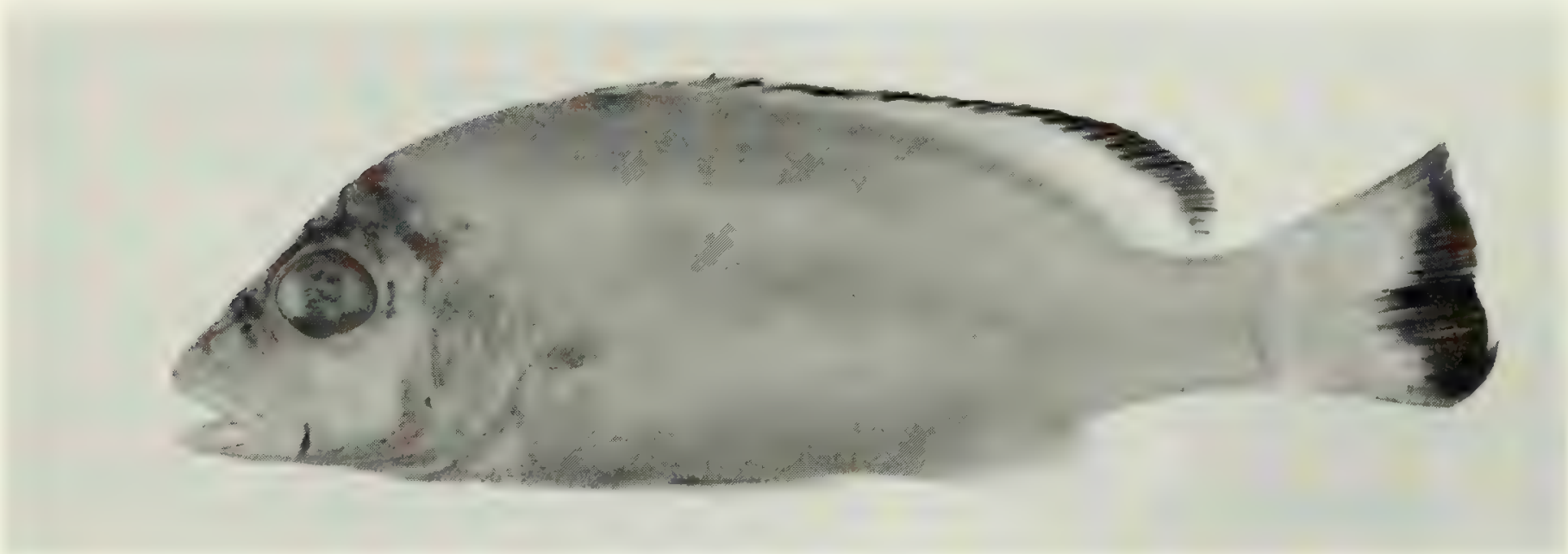

FIG. 199. Lutjanus fulvus, (preserved) $141 \mathrm{~mm} \mathrm{SL}$, Diego Garcia. Photo by A. Strange.

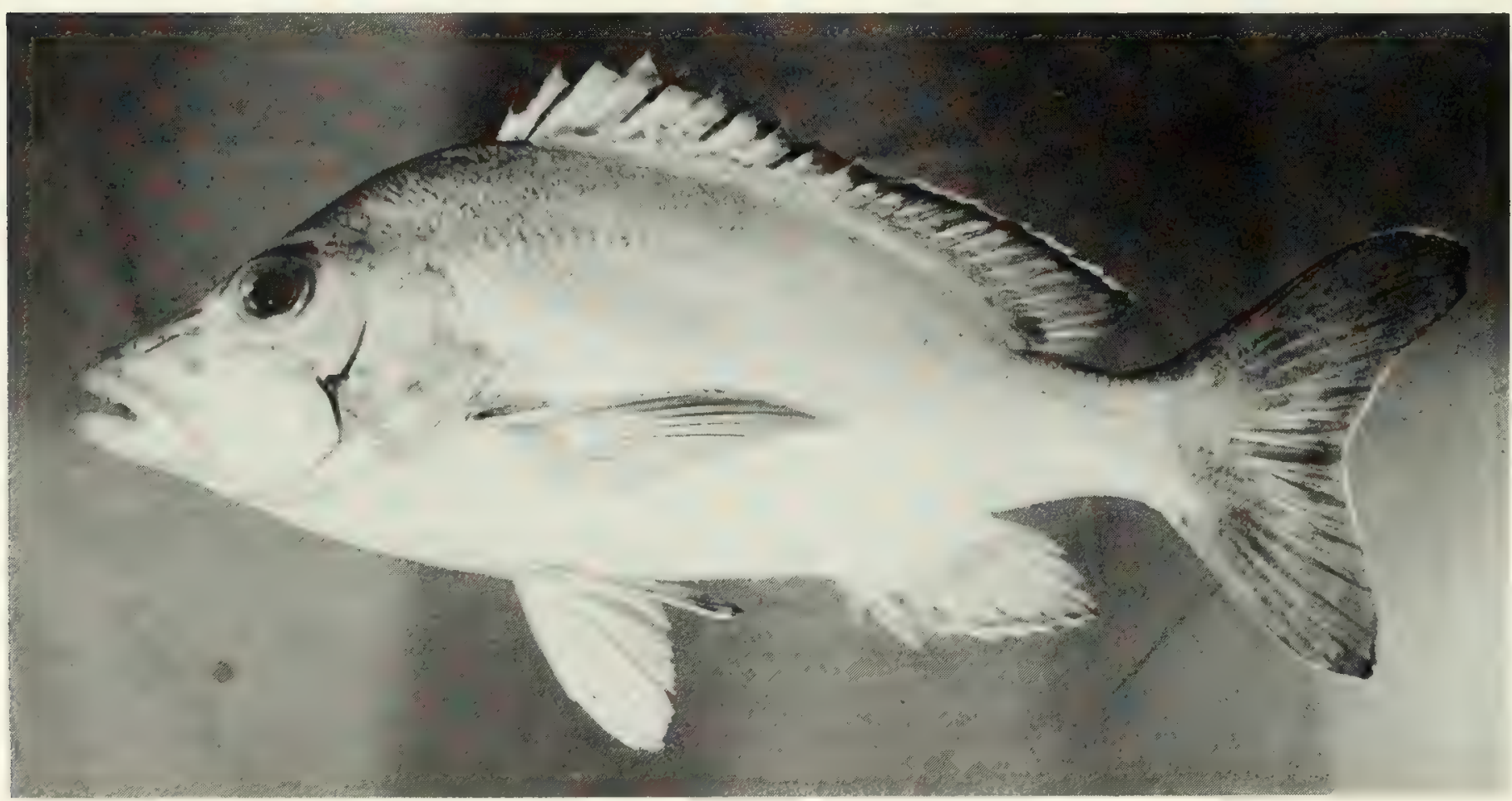

FIG. 200. Lutjanus gibbus, $260 \mathrm{~mm}$ SL, Peros Banhos. 


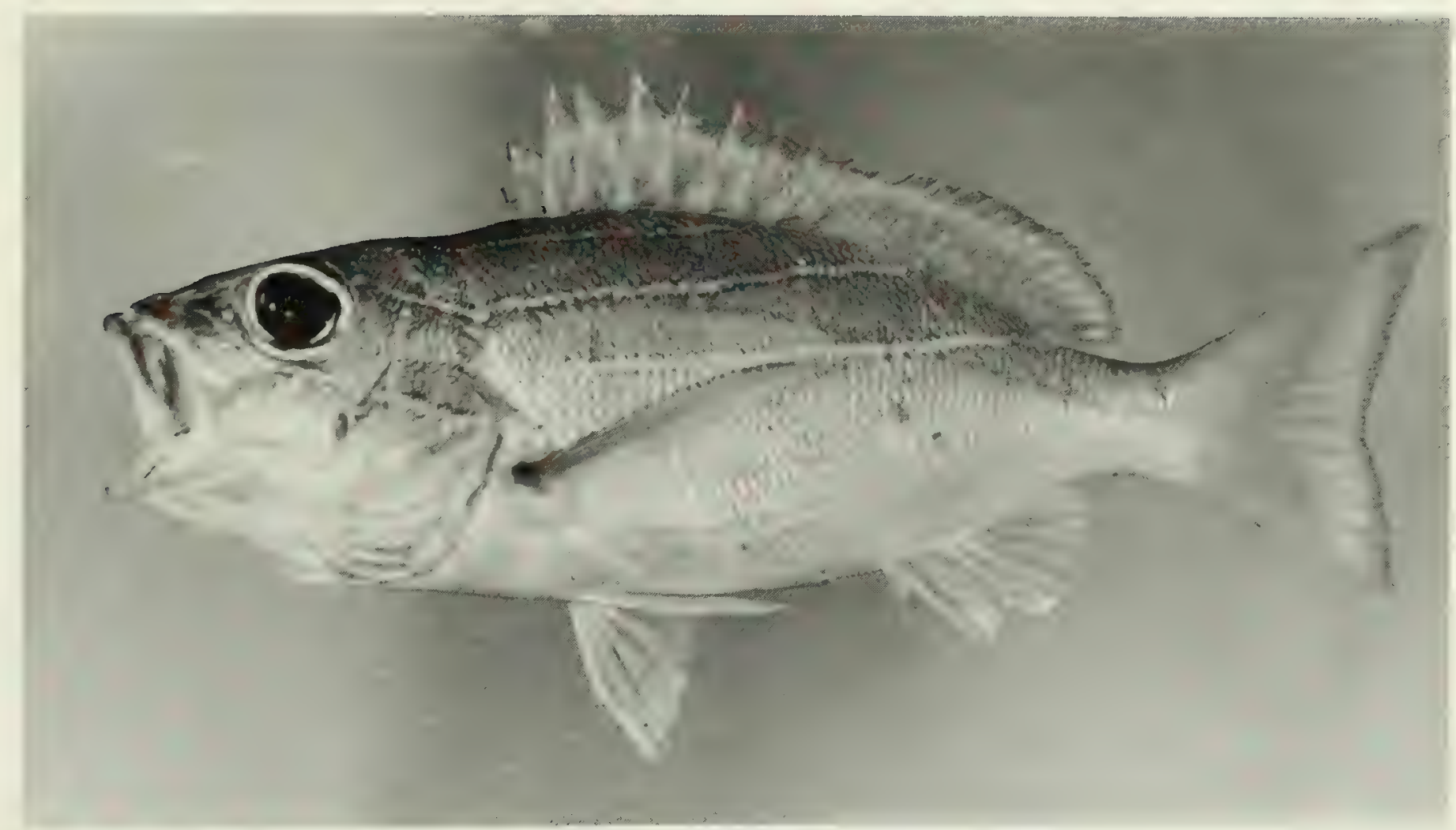

FIG. 201. Lutjanus kasmira, $151 \mathrm{~mm}$ SL, Peros Banhos.

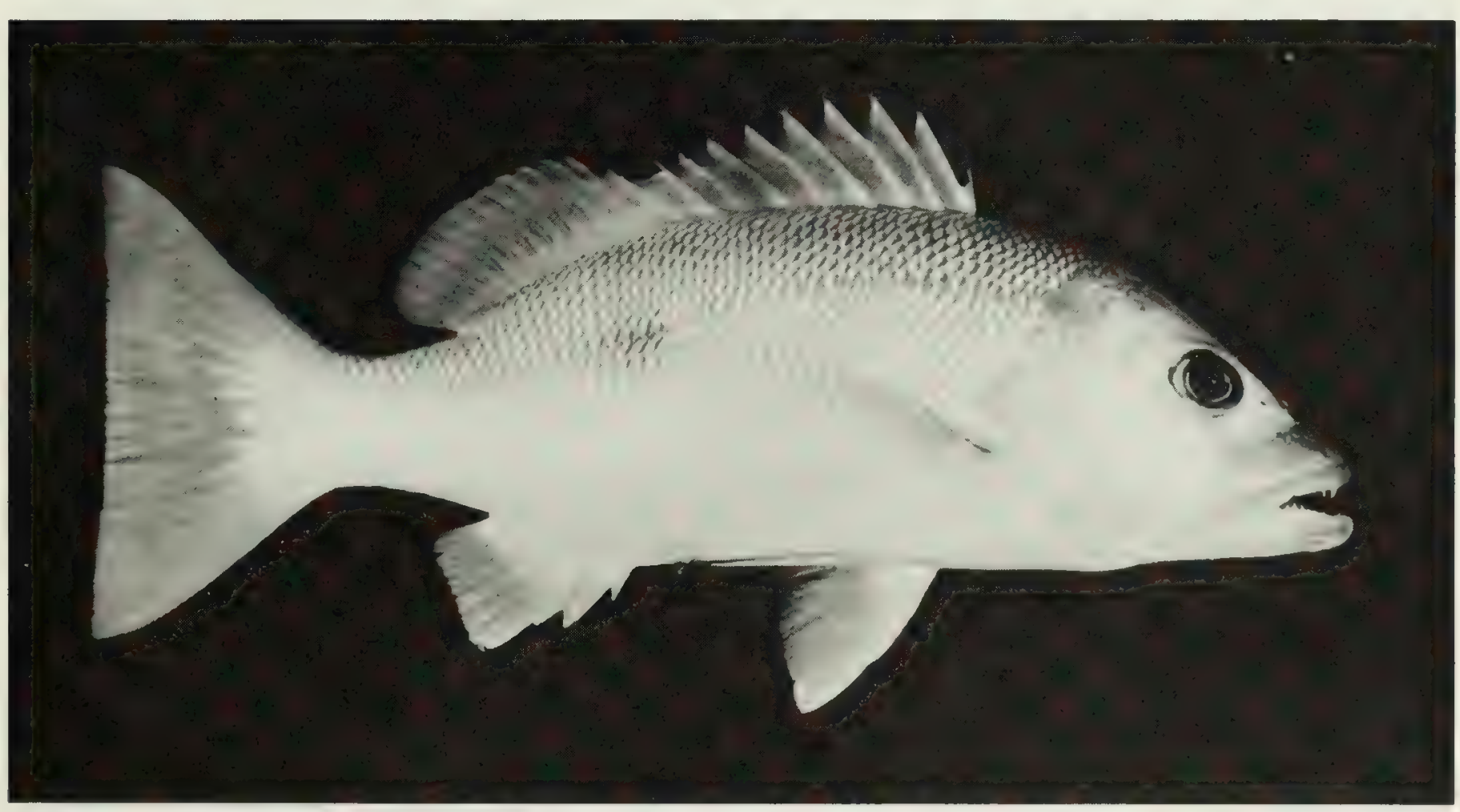

FIG. 202. Lutjanus monostigmus, $202 \mathrm{~mm} \mathrm{SL}$, Eagle Island. 


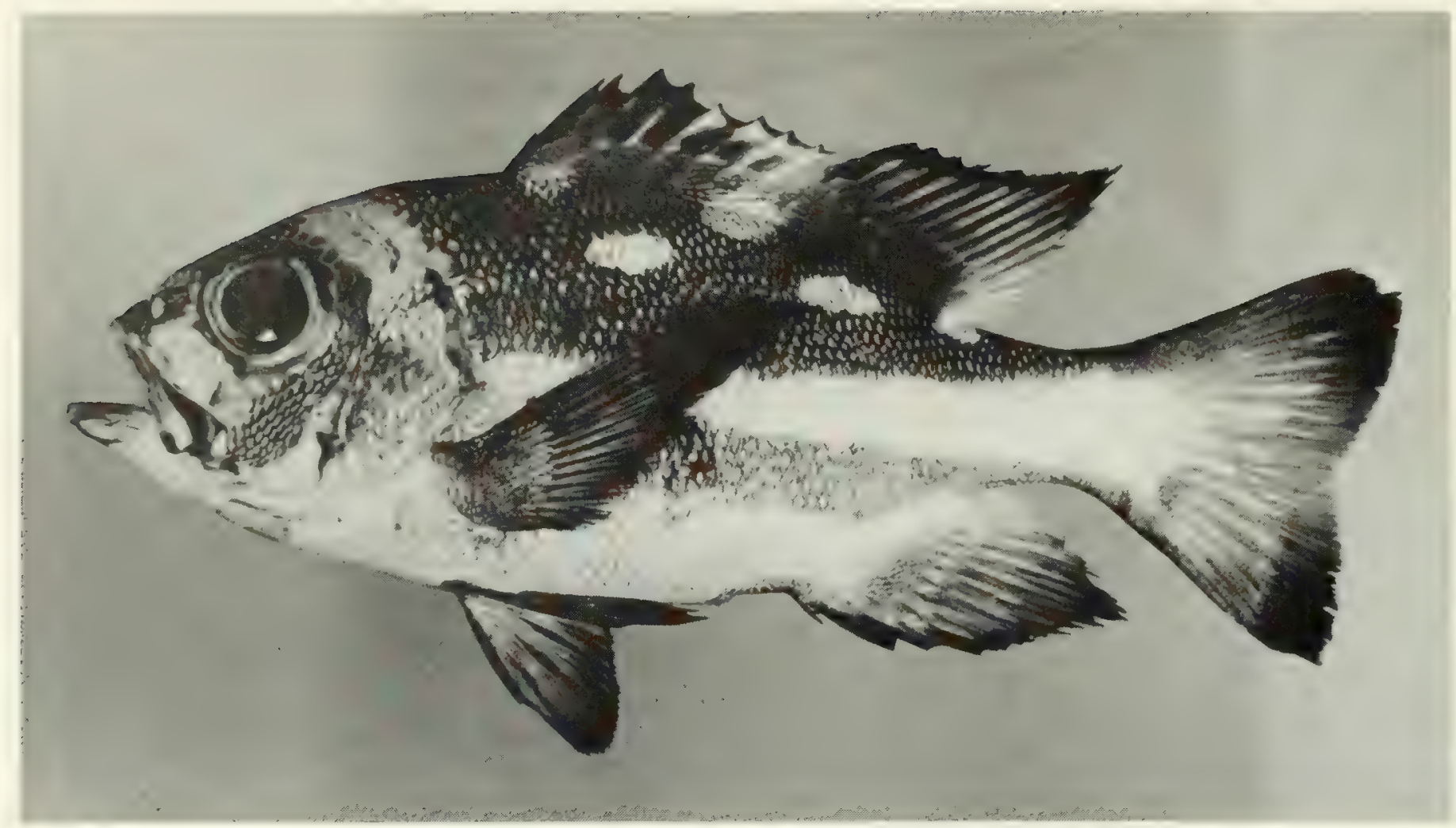

FIG. 203. Macolor niger, $180 \mathrm{~mm} \mathrm{SL}$, Peros Banhos.

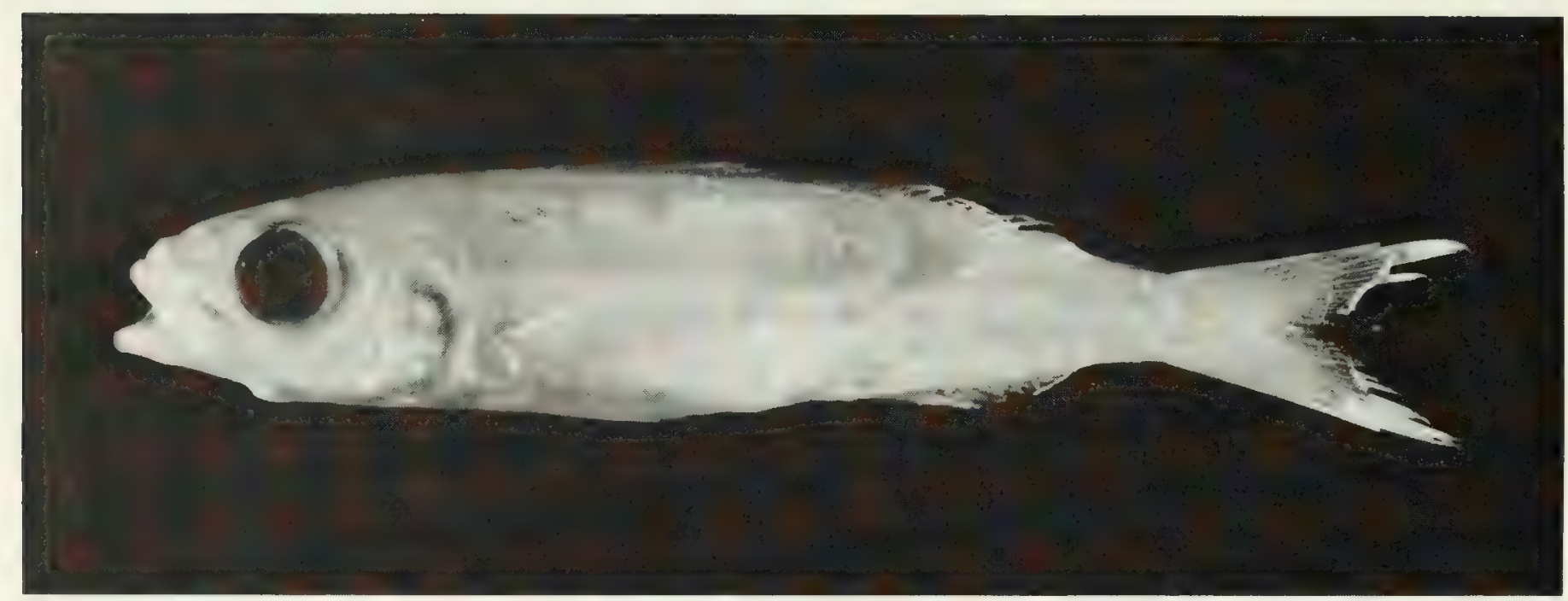

FIG. 204. Pterocaesio chrysozonus, (preserved) $63 \mathrm{~mm} \mathrm{SL}$, Peros Banhos. Photo by B. Boyle.

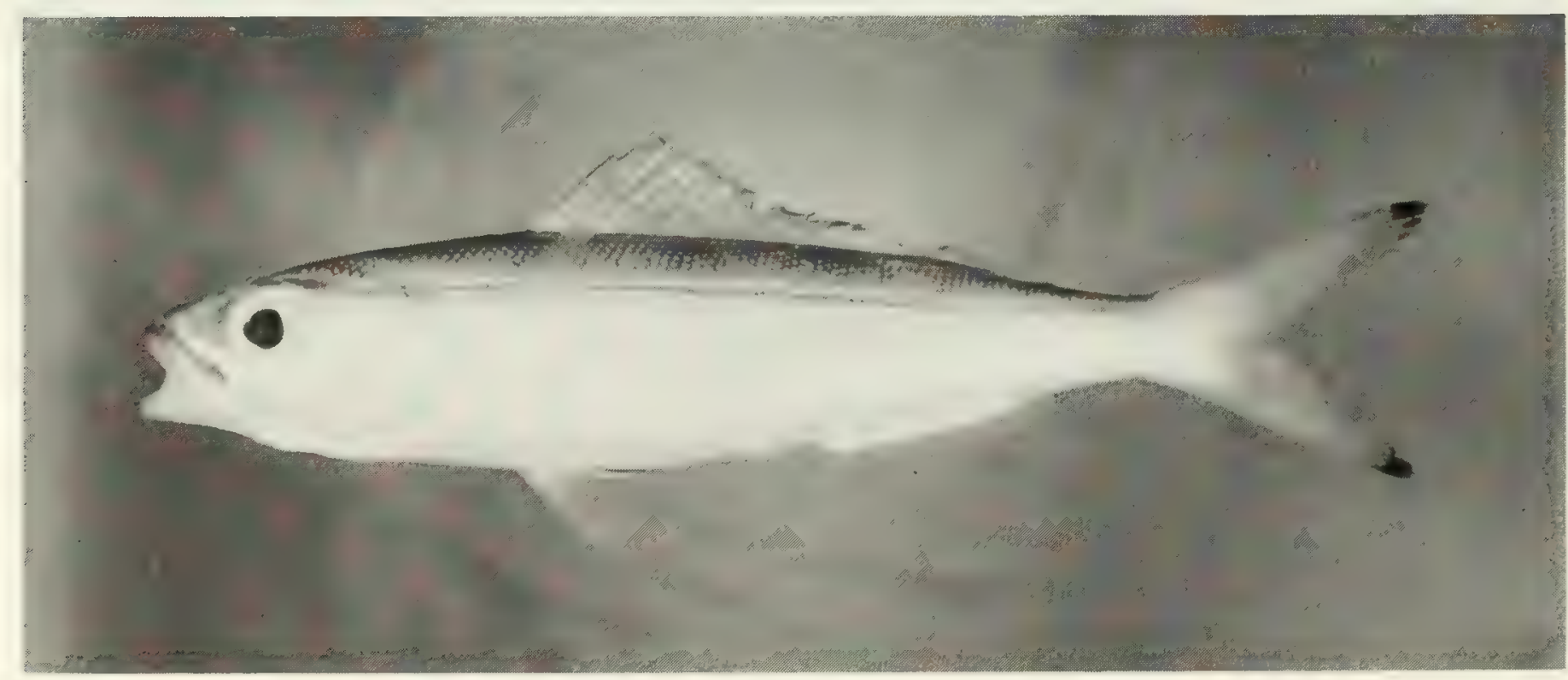

FIG. 205. Pterocaesio marri, $74 \mathrm{~mm}$ SL, Peros Banhos. 


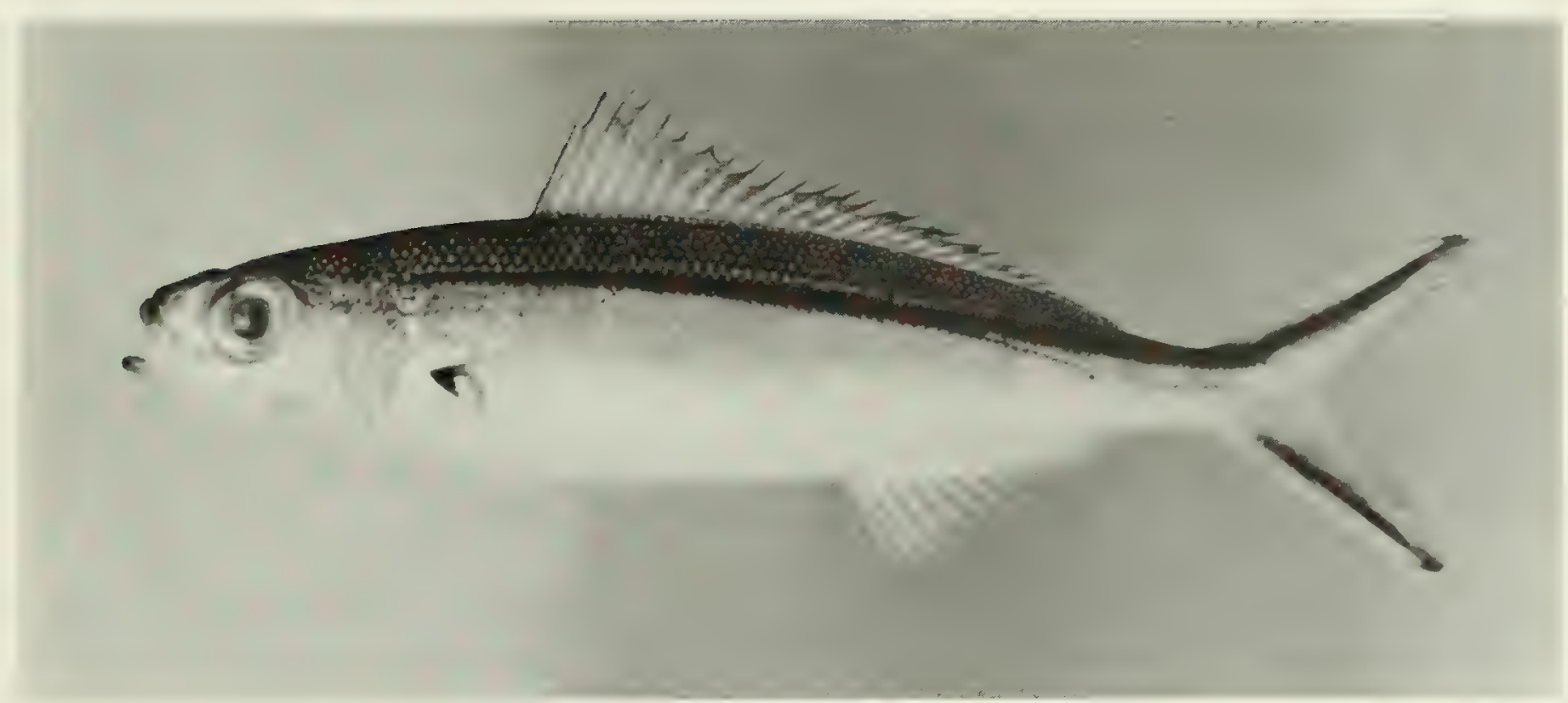

Fig. 206. Pterocaesio tile, $108 \mathrm{~mm} \mathrm{SL}$, Salomon.

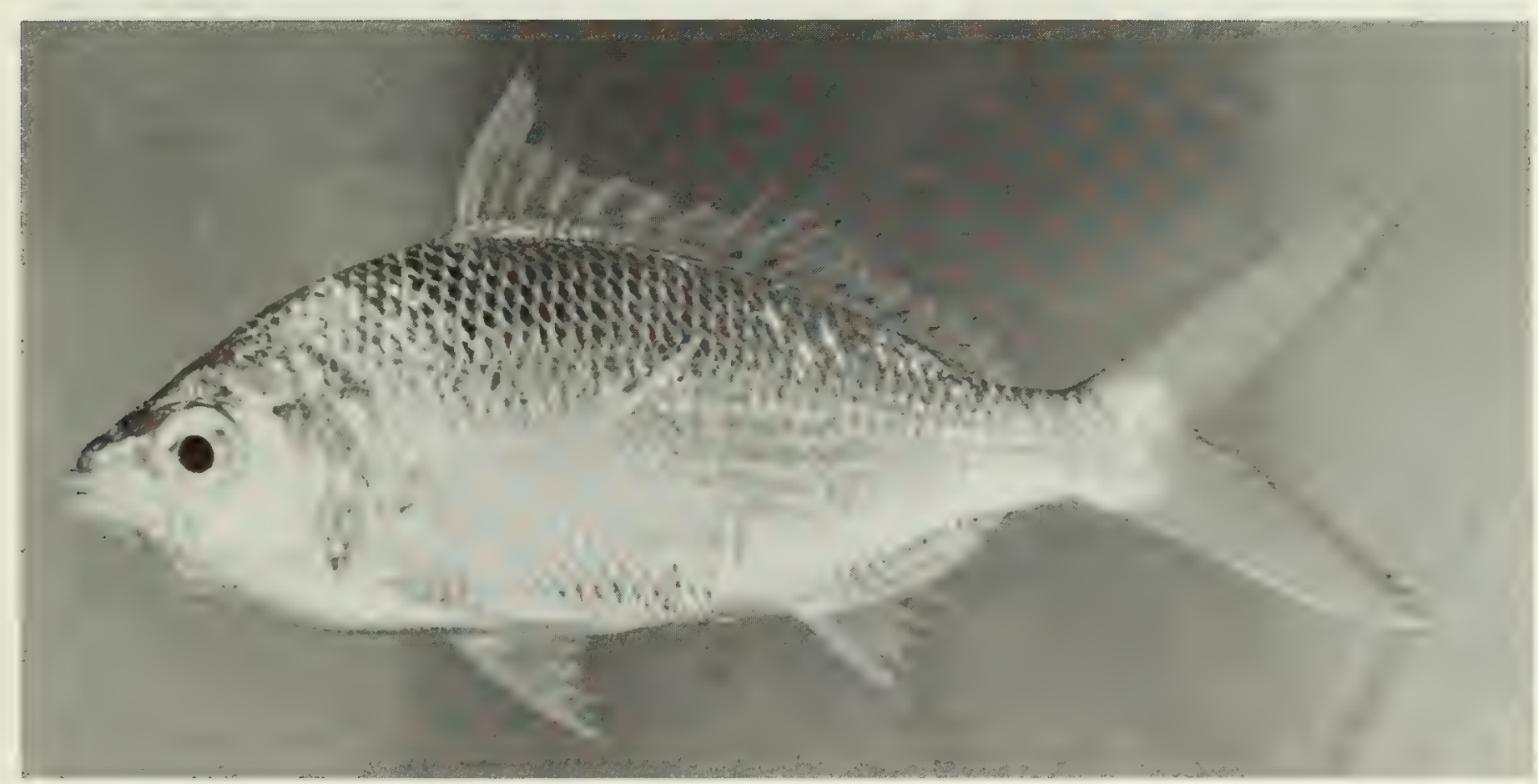

FIG. 207. Gerres acinaces, $245 \mathrm{~mm} \mathrm{SL,} \mathrm{Peros} \mathrm{Banhos.}$

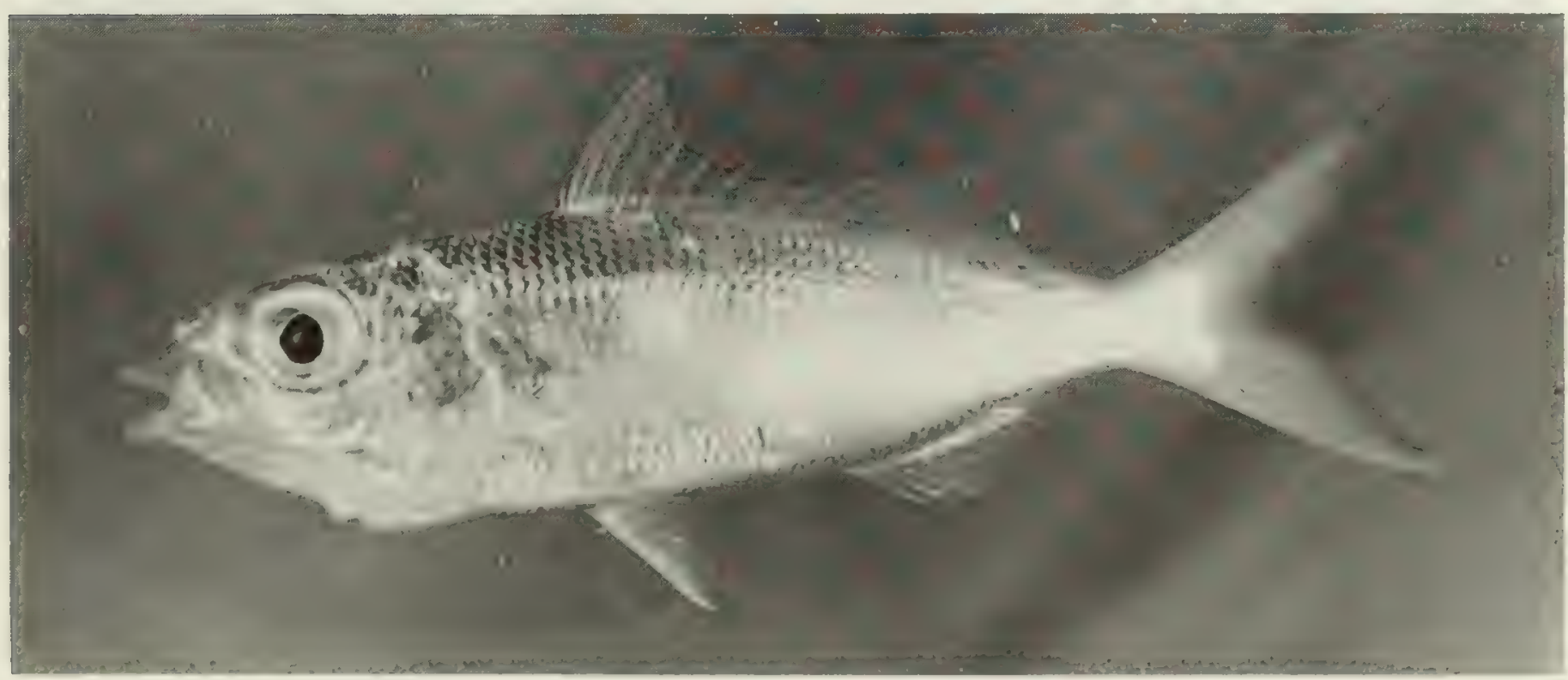

FIG. 208. Gerres oblongus, $50 \mathrm{~mm}$ SL, Peros Banhos. 


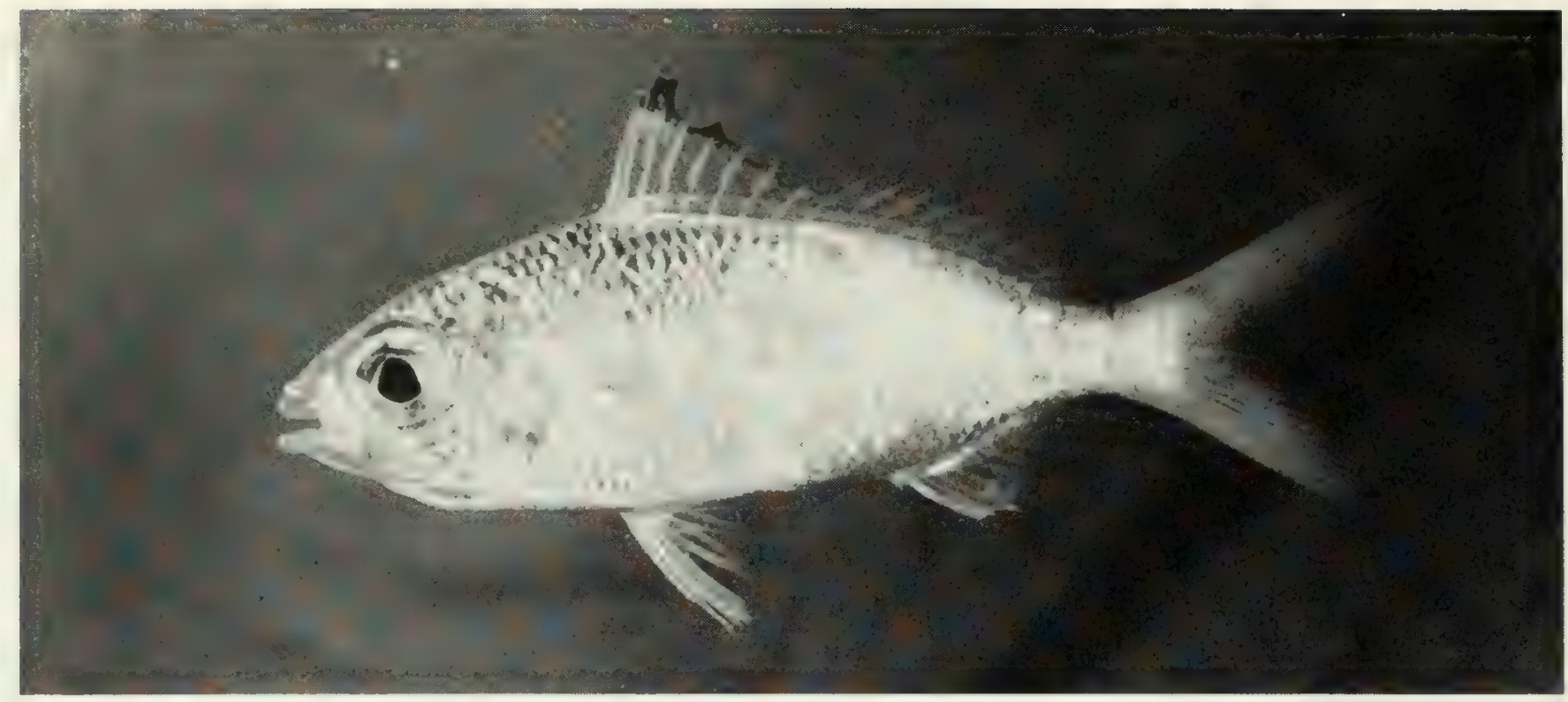

FIG. 209. Gerres oyena, $46 \mathrm{~mm}$ SL, Peros Banhos.

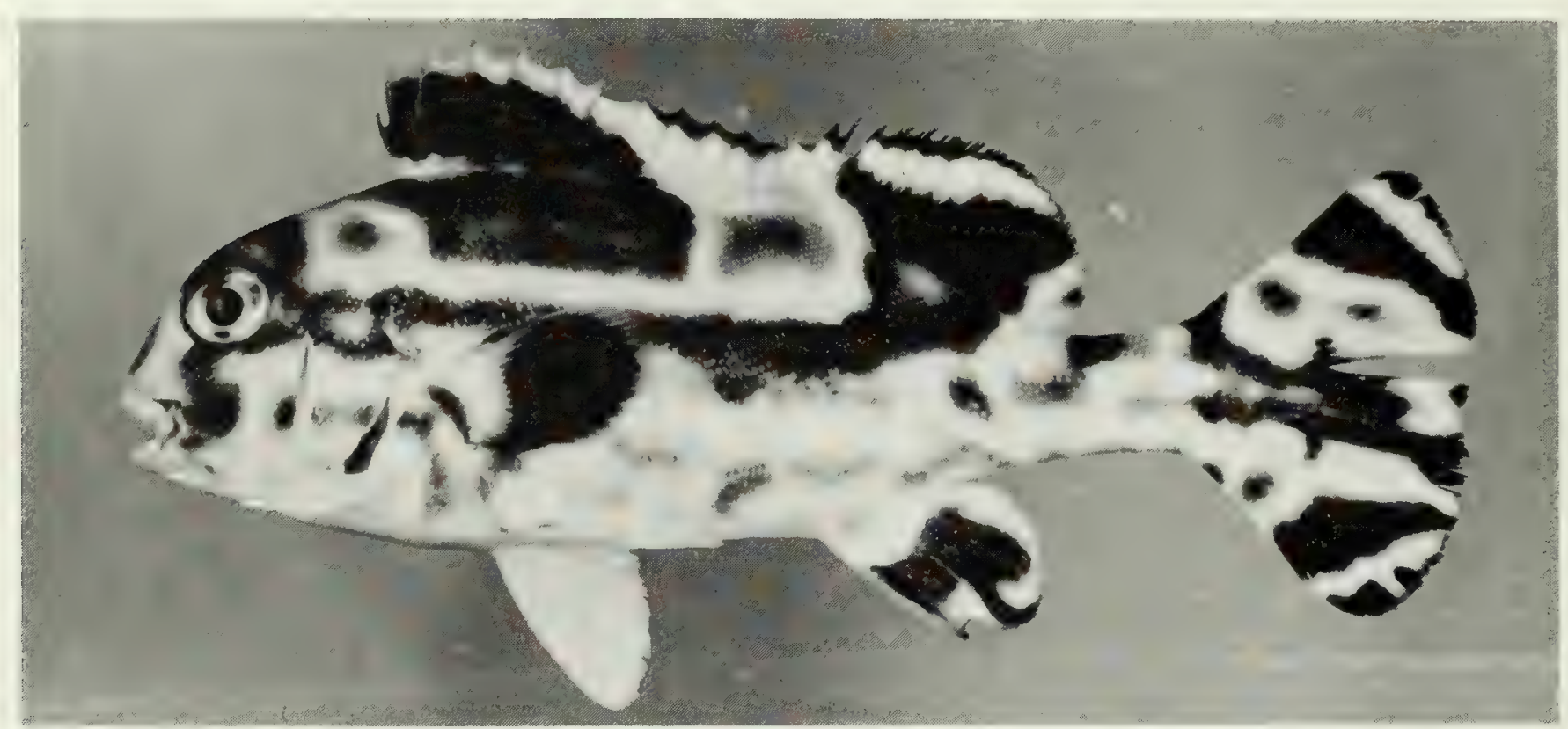

FIG. 210. Plectorhinchus orientalis, $158 \mathrm{~mm} \mathrm{SL}$, Peros Banhos.

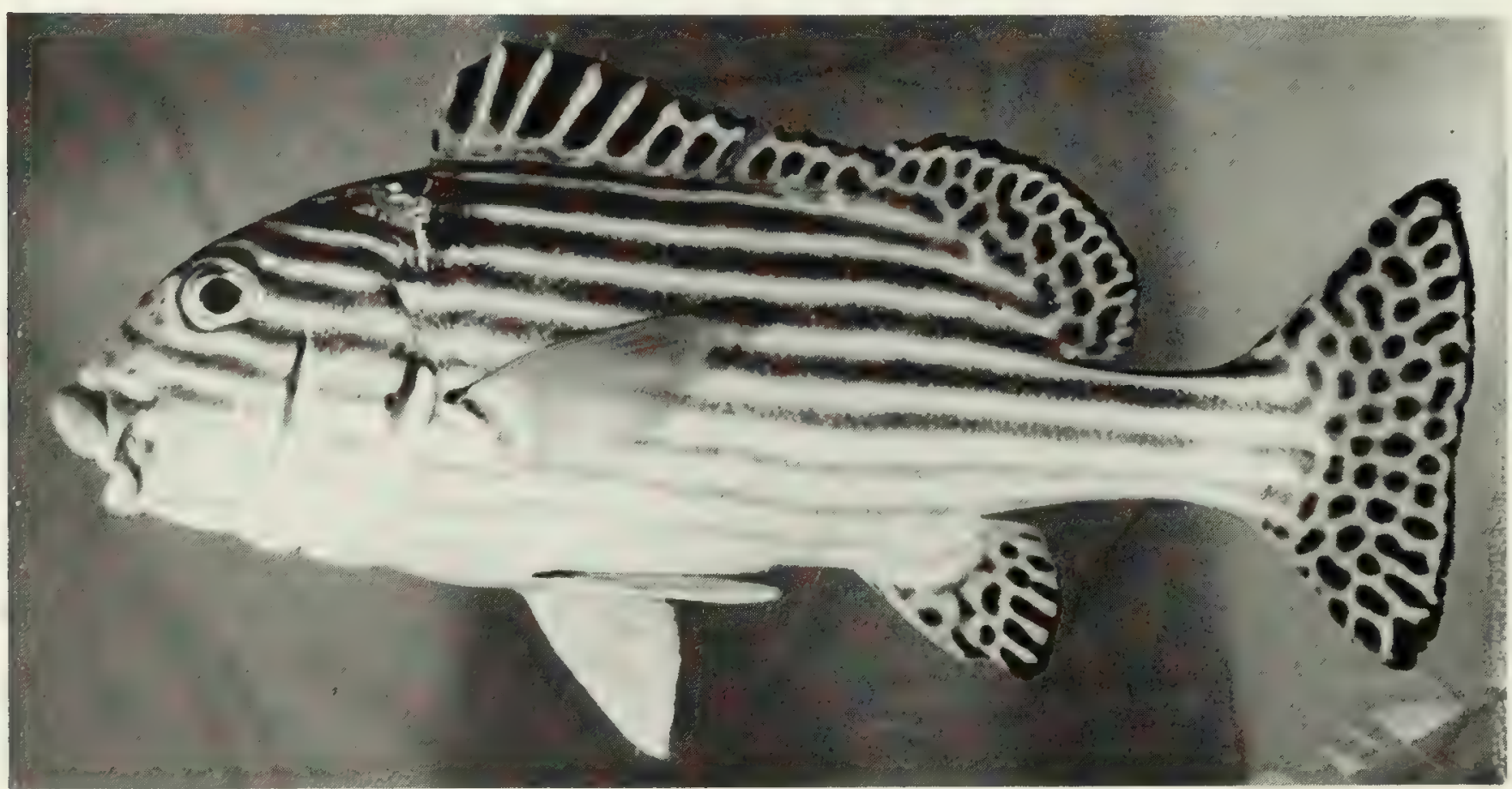

FIG. 211. Plectorhinchus orientalis, $315 \mathrm{~mm} \mathrm{SL}$, Peros Banhos. 


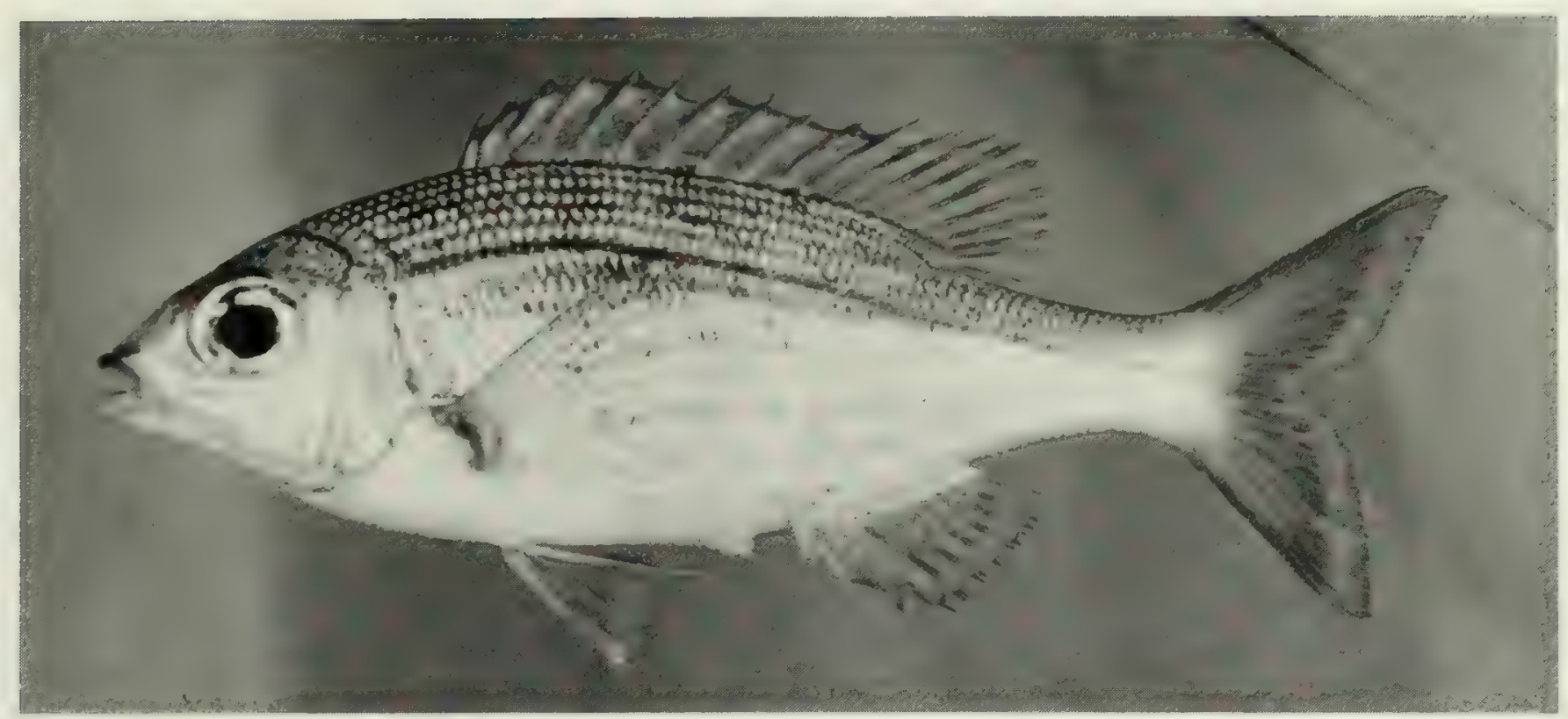

FIG. 212. Gnathodentex aureolineatus, $187 \mathrm{~mm} \mathrm{SL}$, Peros Banhos.

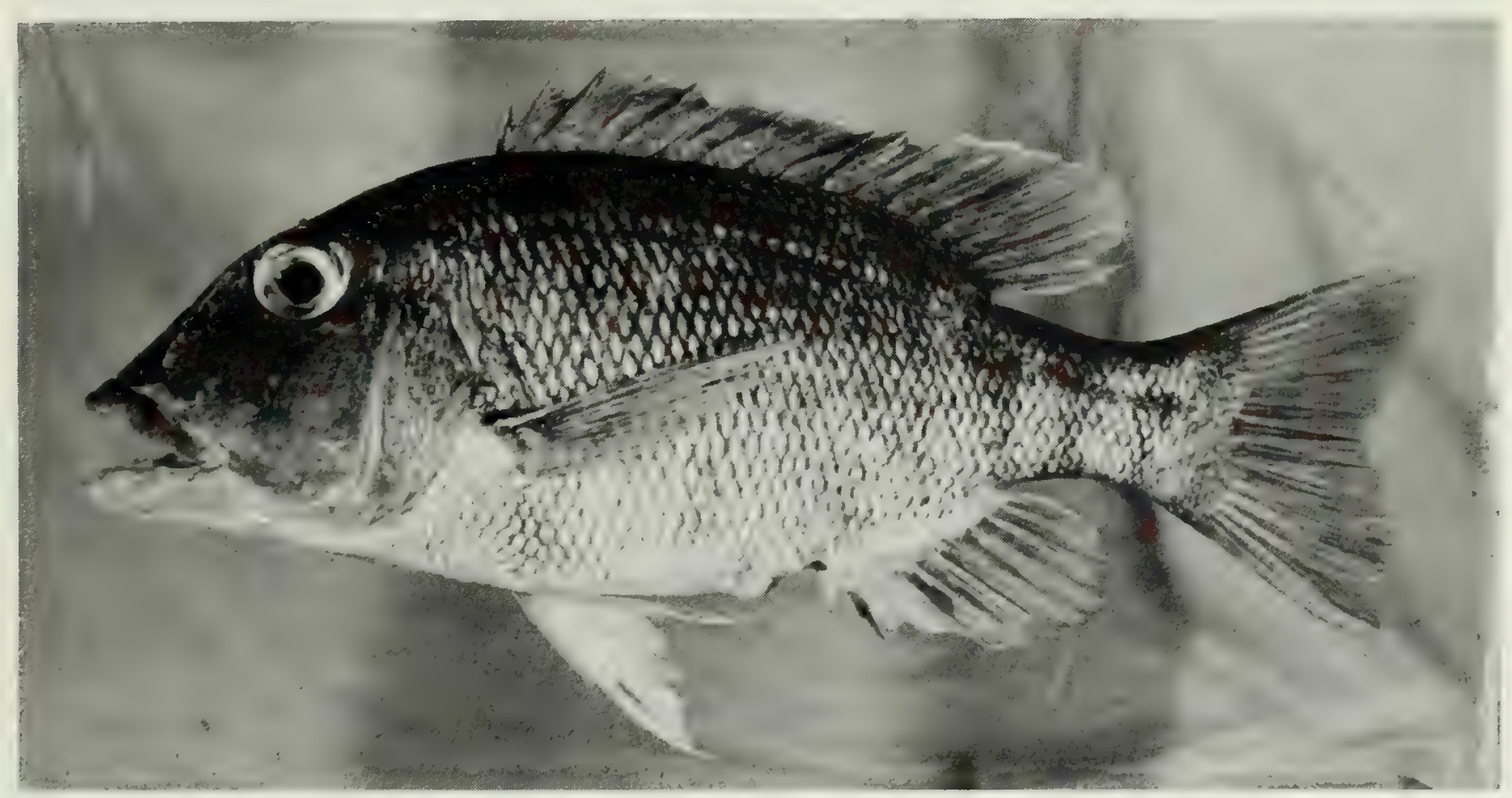

FIG. 213. Lethrinus hypselopterus, $256 \mathrm{~mm}$ SL, Peros Banhos.

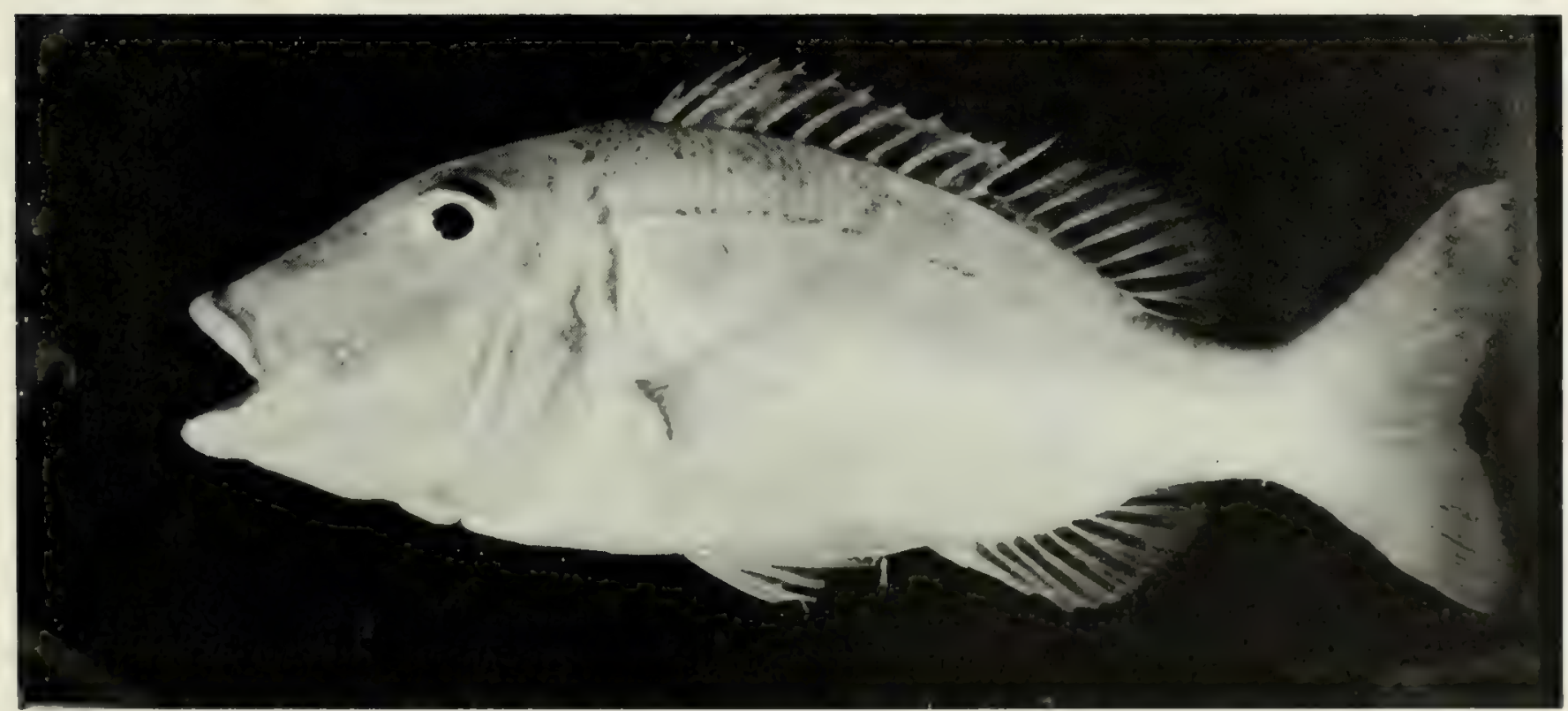

FIG. 214. Lethrinus mahsena, $264 \mathrm{~mm} \mathrm{SL,} \mathrm{Peros} \mathrm{Banhos.}$ 


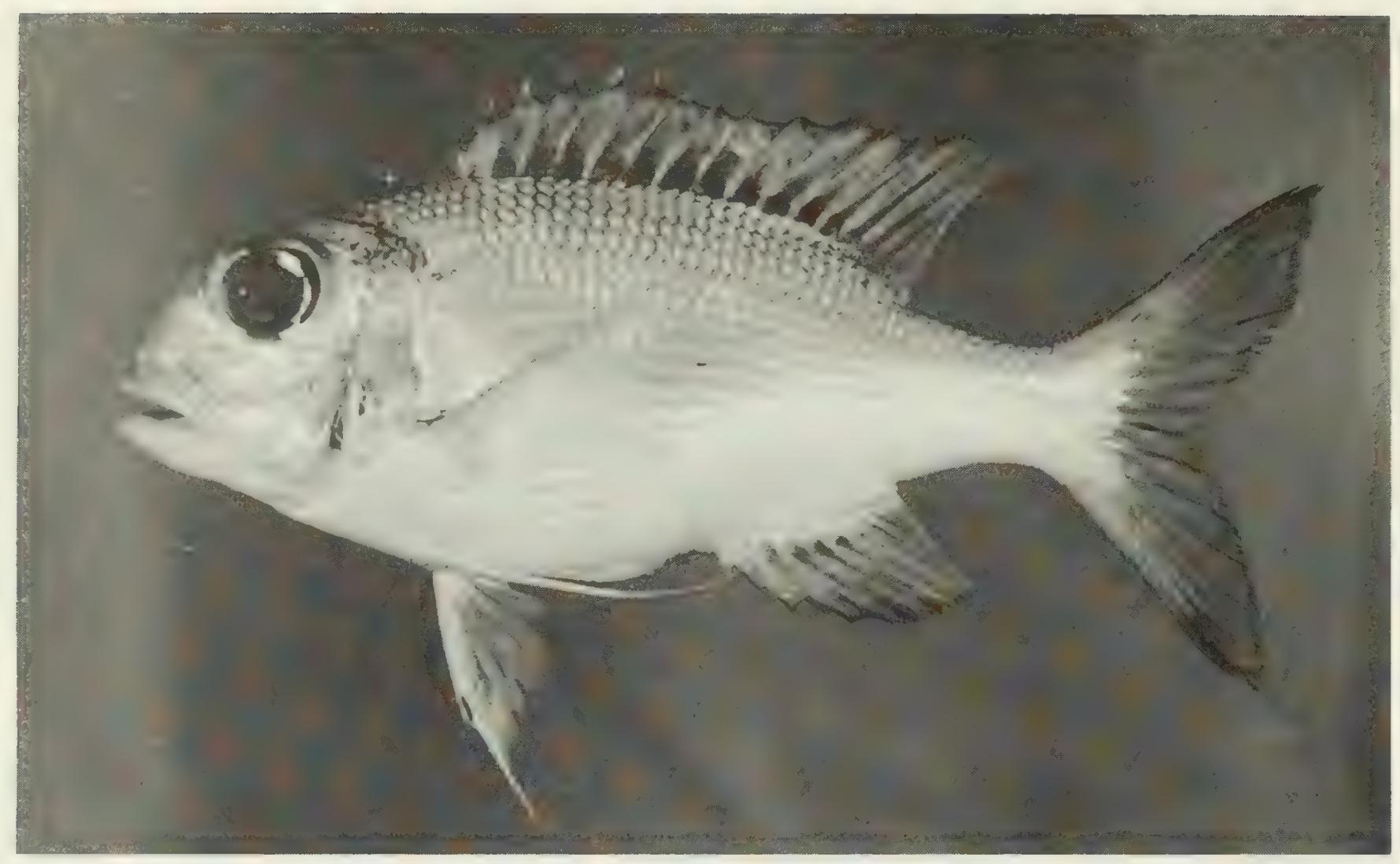

FIG. 215. Monotaxis grandoculis, $166 \mathrm{~mm} \mathrm{SL}$, Peros Banhos.

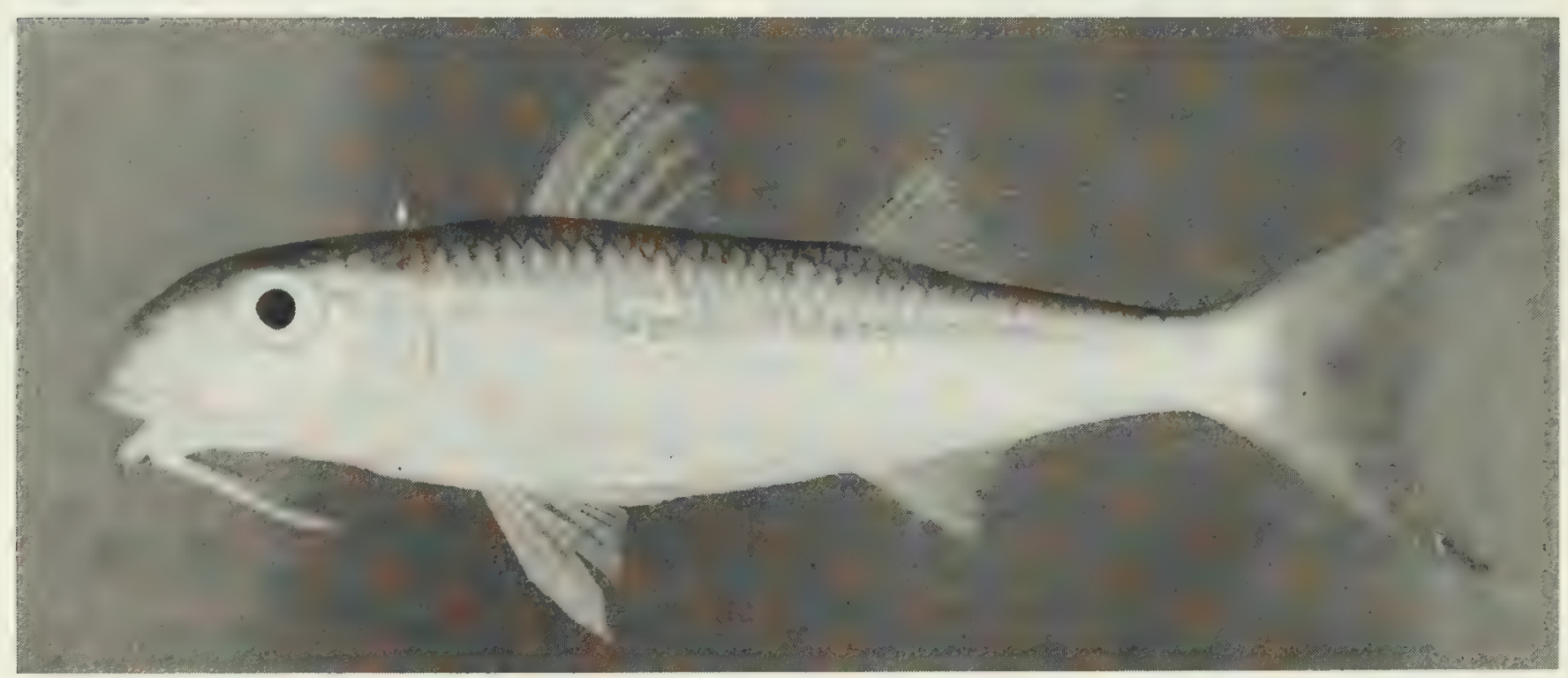

FIG. 216. Mulloides flavolineatus, $151 \mathrm{~mm} \mathrm{SL}$, Peros Banhos.

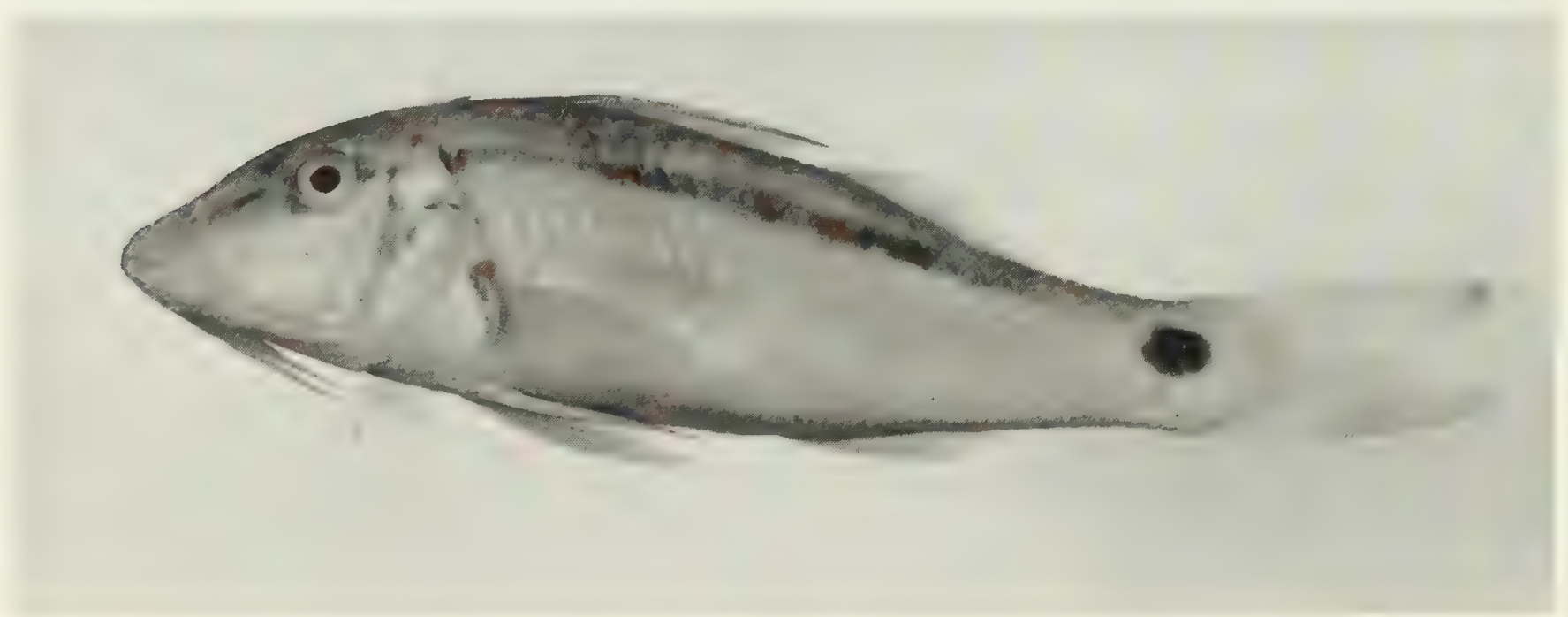

FIG. 217. Parupeneus barberinus, (preserved) $155 \mathrm{~mm} \mathrm{SL,} \mathrm{Peros} \mathrm{Banhos.} \mathrm{Photo} \mathrm{by} \mathrm{A.} \mathrm{Strange.}$ 


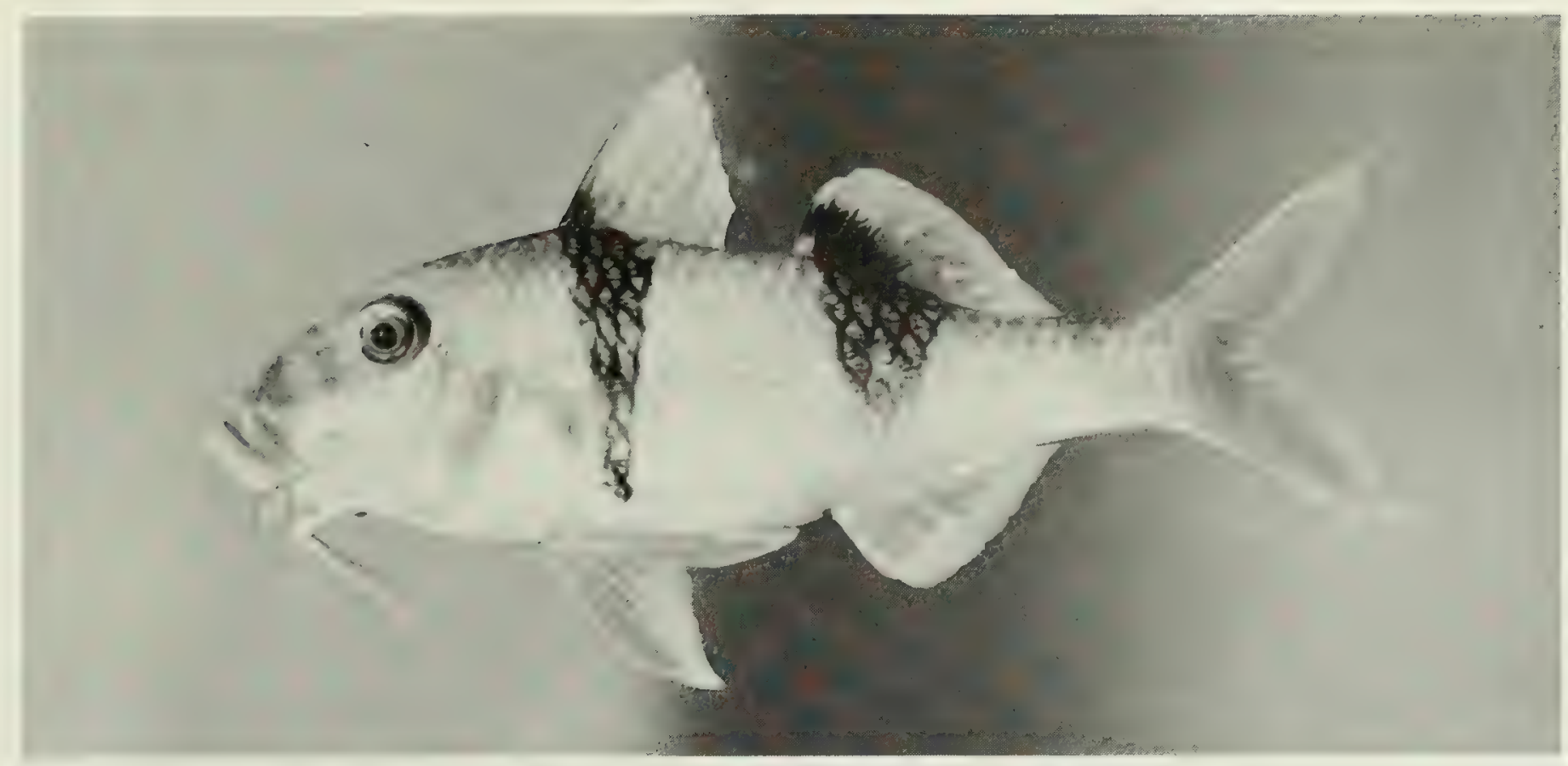

FIG. 218. Parupeneus bifasciatus, $130 \mathrm{~mm} \mathrm{SL}$, Salomon.

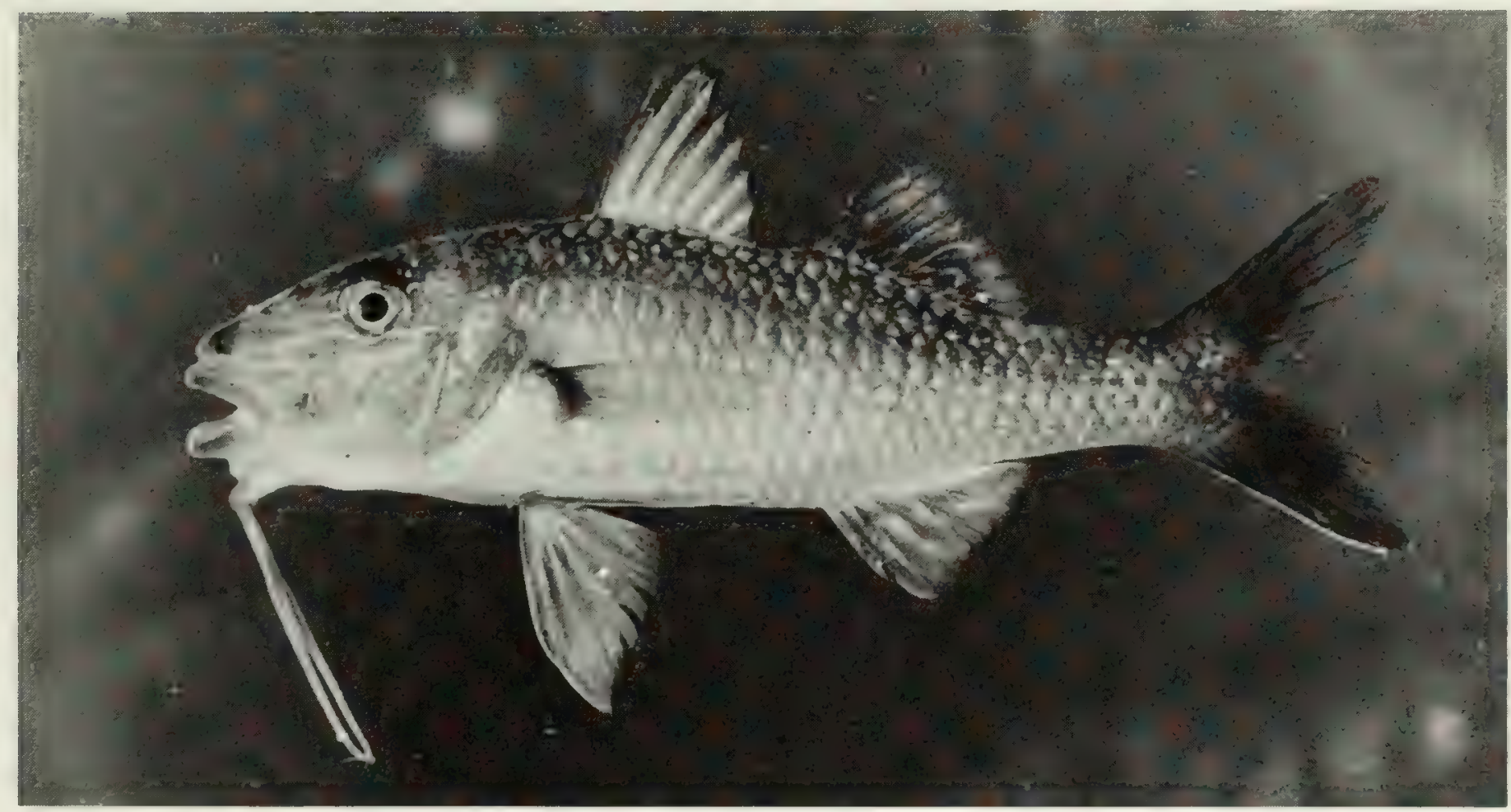

FIG. 219. Parupeneus cyclostomus, $79 \mathrm{~mm} \mathrm{SL}$, Eagle Island. 


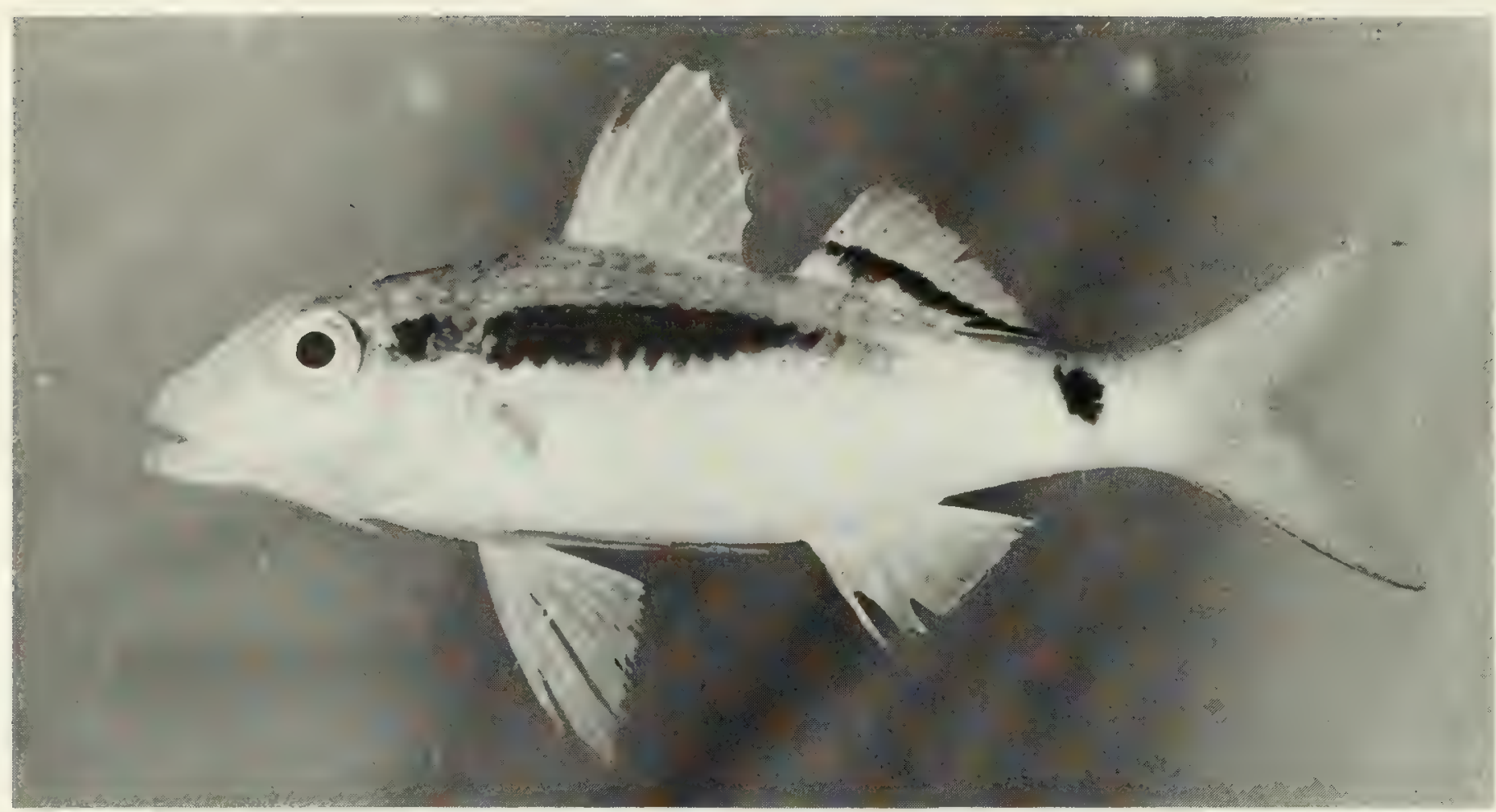

FIG. 220. Parupeneus macronemus, $49 \mathrm{~mm}$ SL, Peros Banhos.

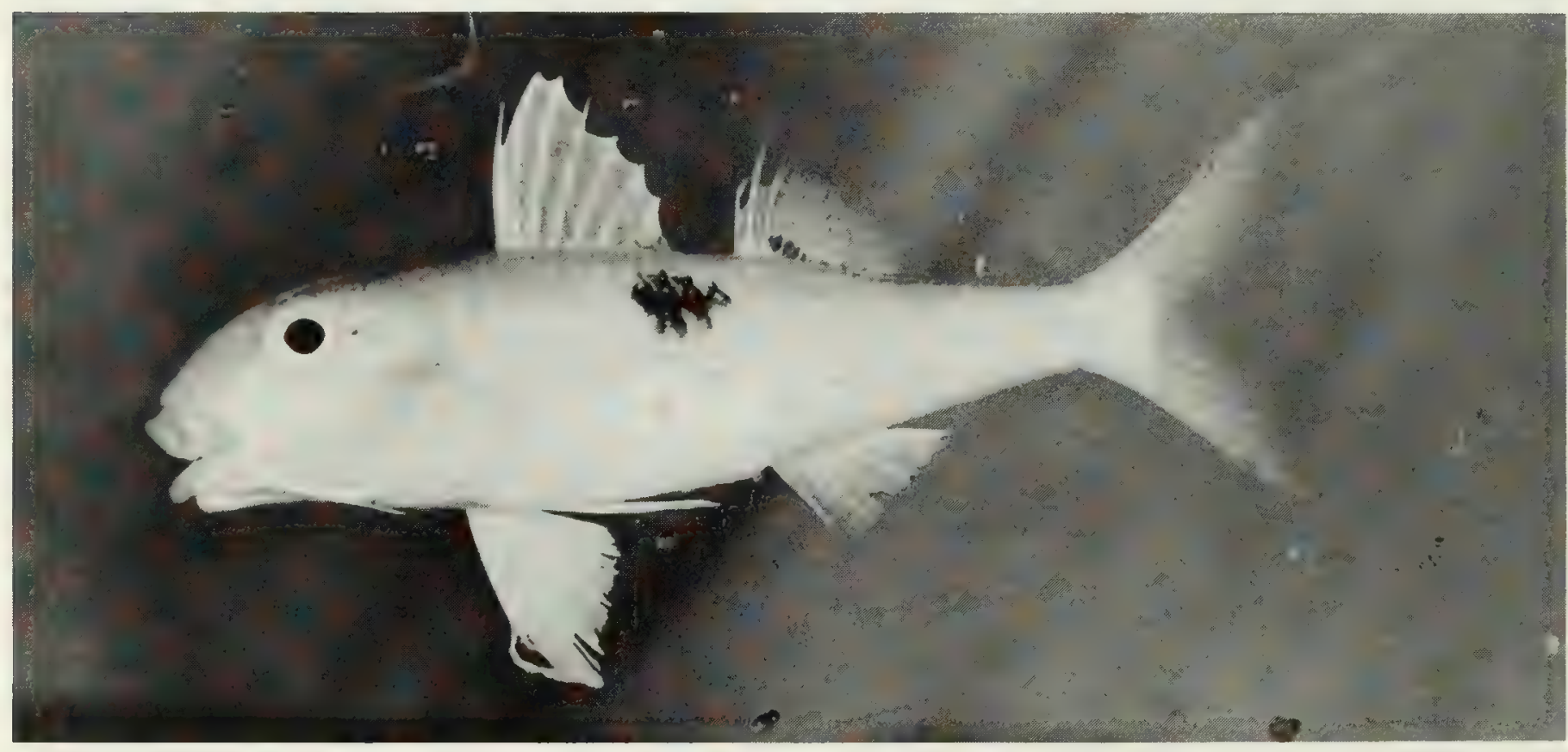

Fig. 221. Parupeneus pleurostigmus, $61 \mathrm{~mm} \mathrm{SL}$, Peros Banhos.

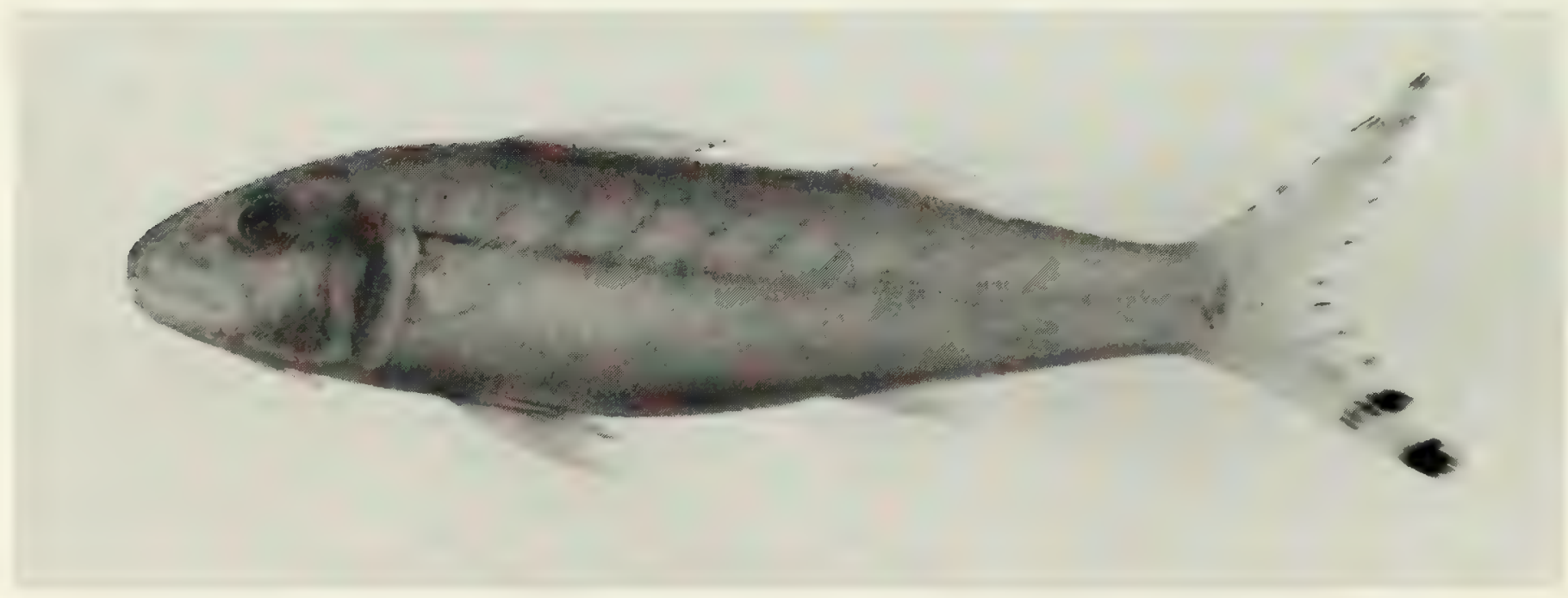

FIG. 222. Upeneus taeniopterus, (preserved) $196 \mathrm{~mm} \mathrm{SL,} \mathrm{Peros} \mathrm{Banhos.} \mathrm{Photo} \mathrm{by} \mathrm{A.} \mathrm{Strange.}$ 


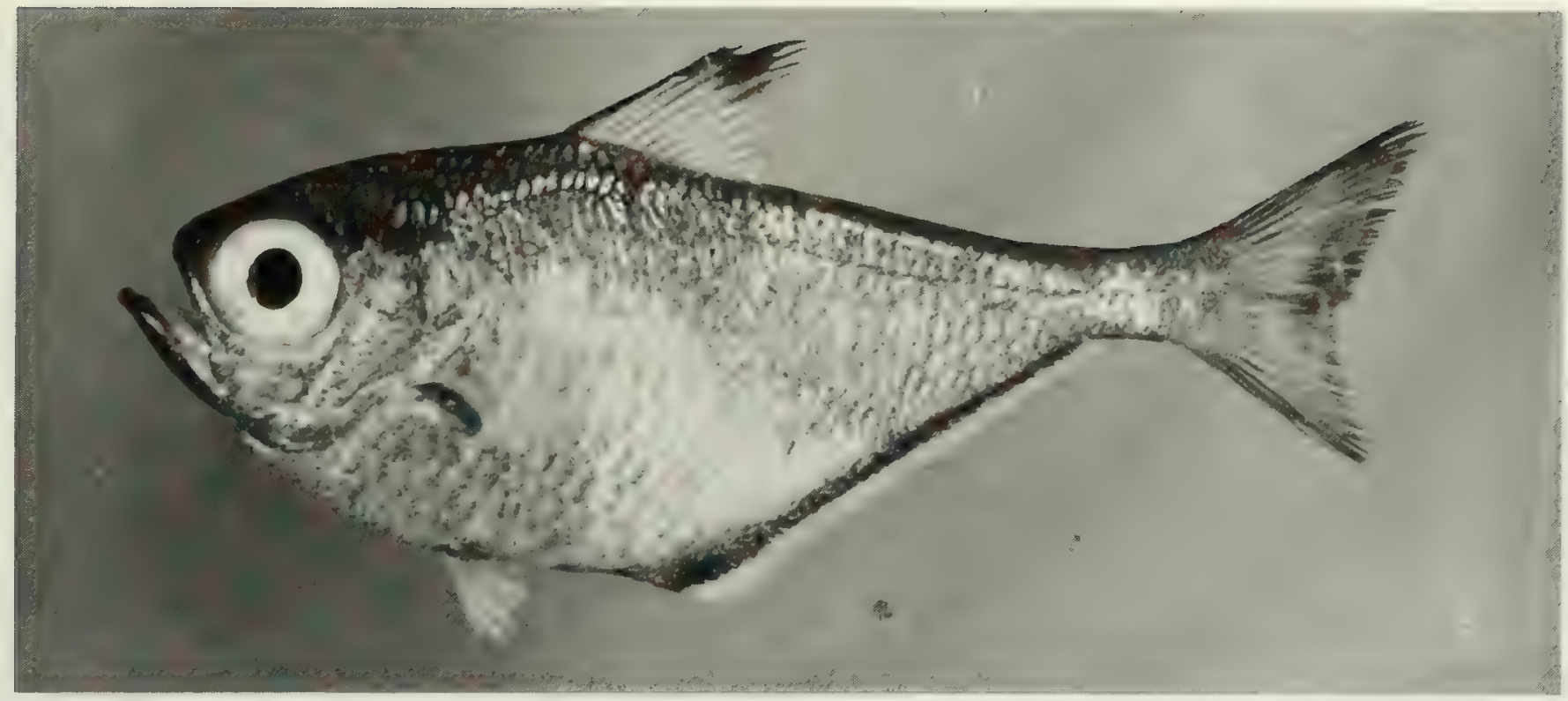

FIG. 223. Pempheris schwenkii, specimen not located, Salomon.

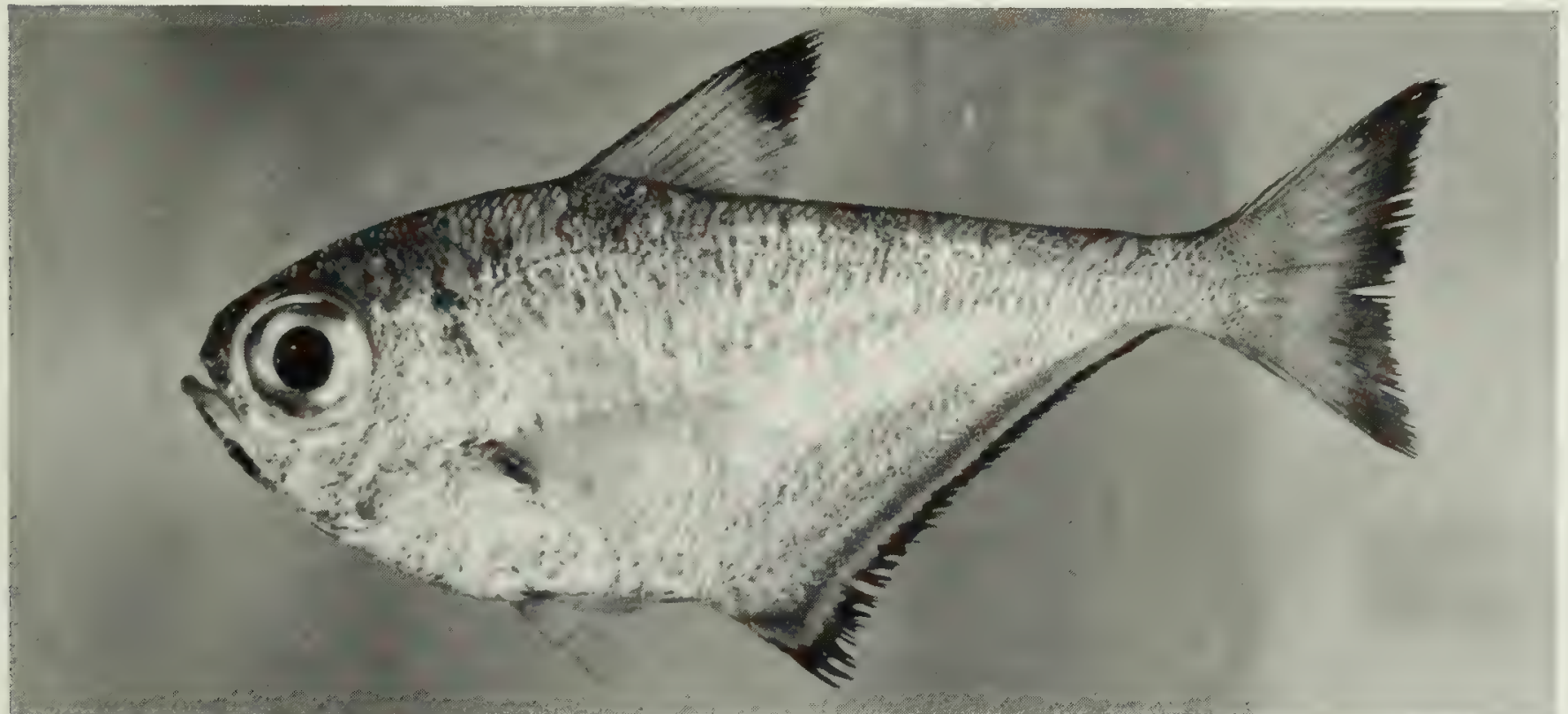

FIG. 224. Pempheris vanicolensis, specimen not located, Peros Banhos.

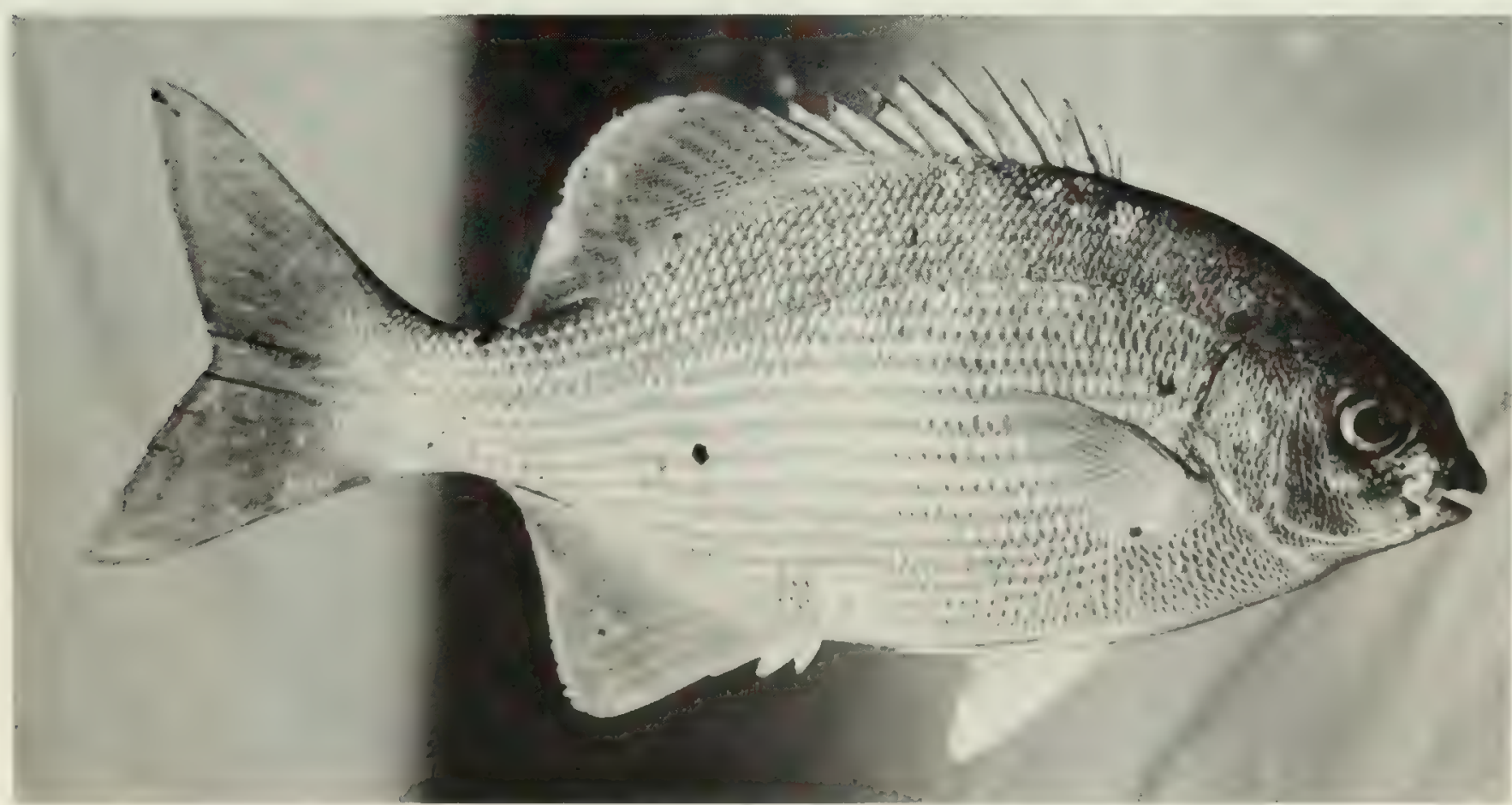

Fig. 225. Kyphosus cinerascens, $148 \mathrm{~mm} \mathrm{SL,} \mathrm{Peros} \mathrm{Banhos.}$ 


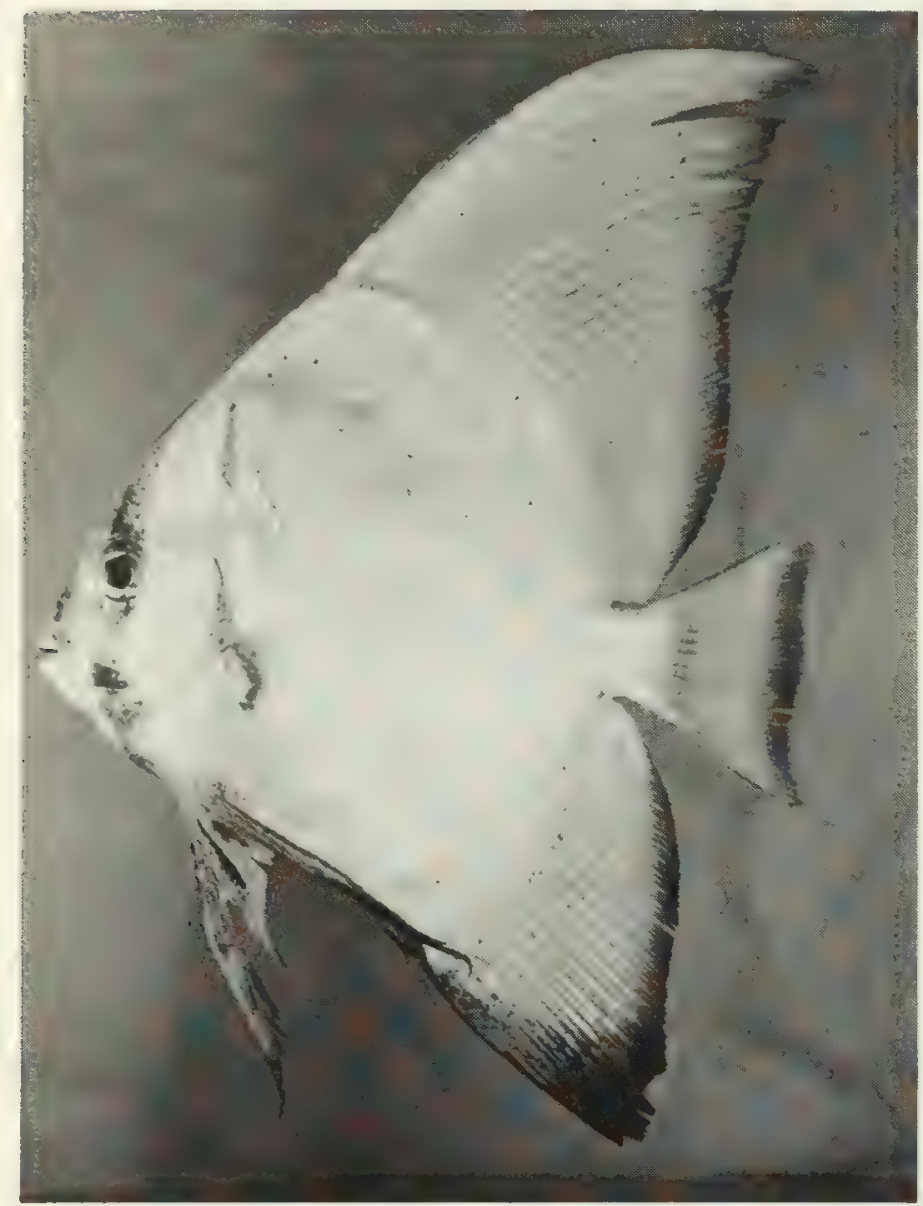

Fig. 226. Platax orbicularis, $138 \mathrm{~mm} \mathrm{SL,} \mathrm{Peros}$ Banhos.

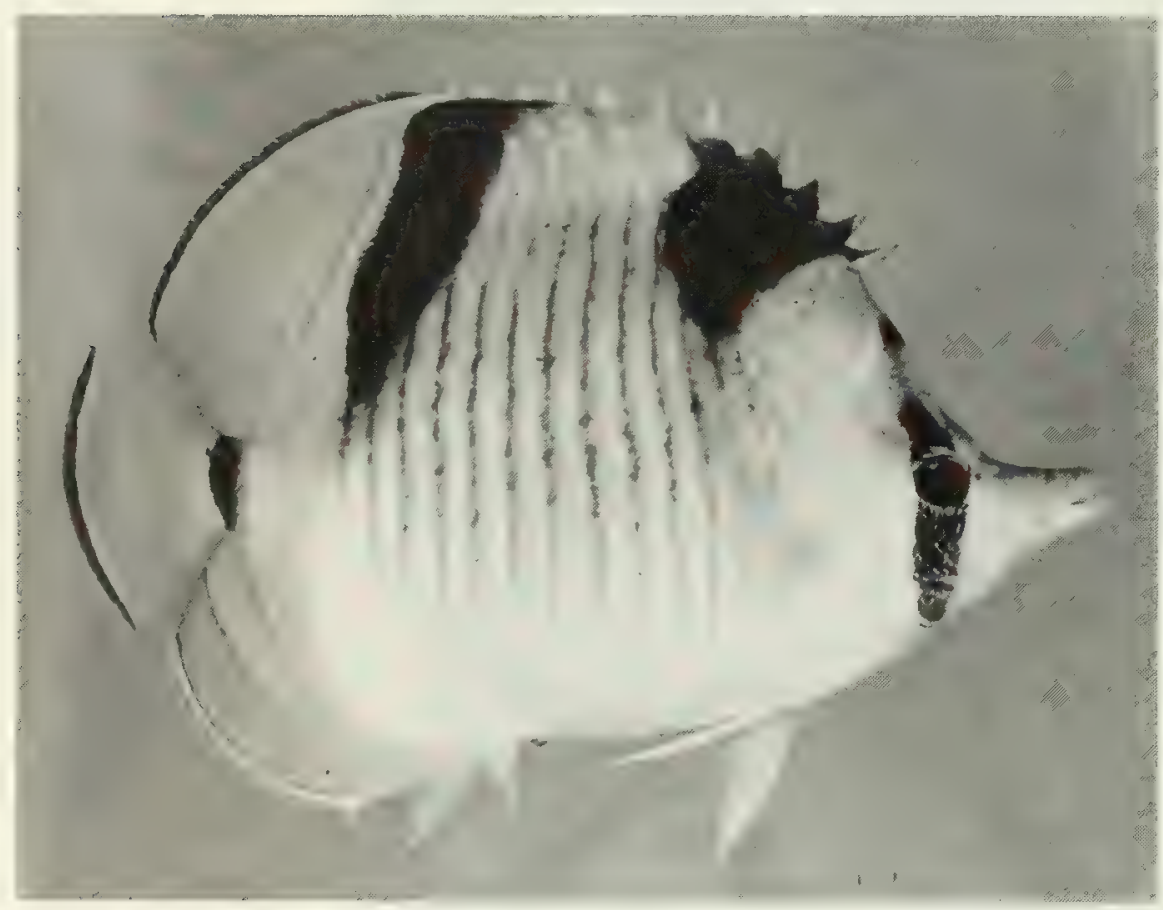

Fig. 228. Chaetodon falcula, $159 \mathrm{~mm}$ SL, Peros Banhos.

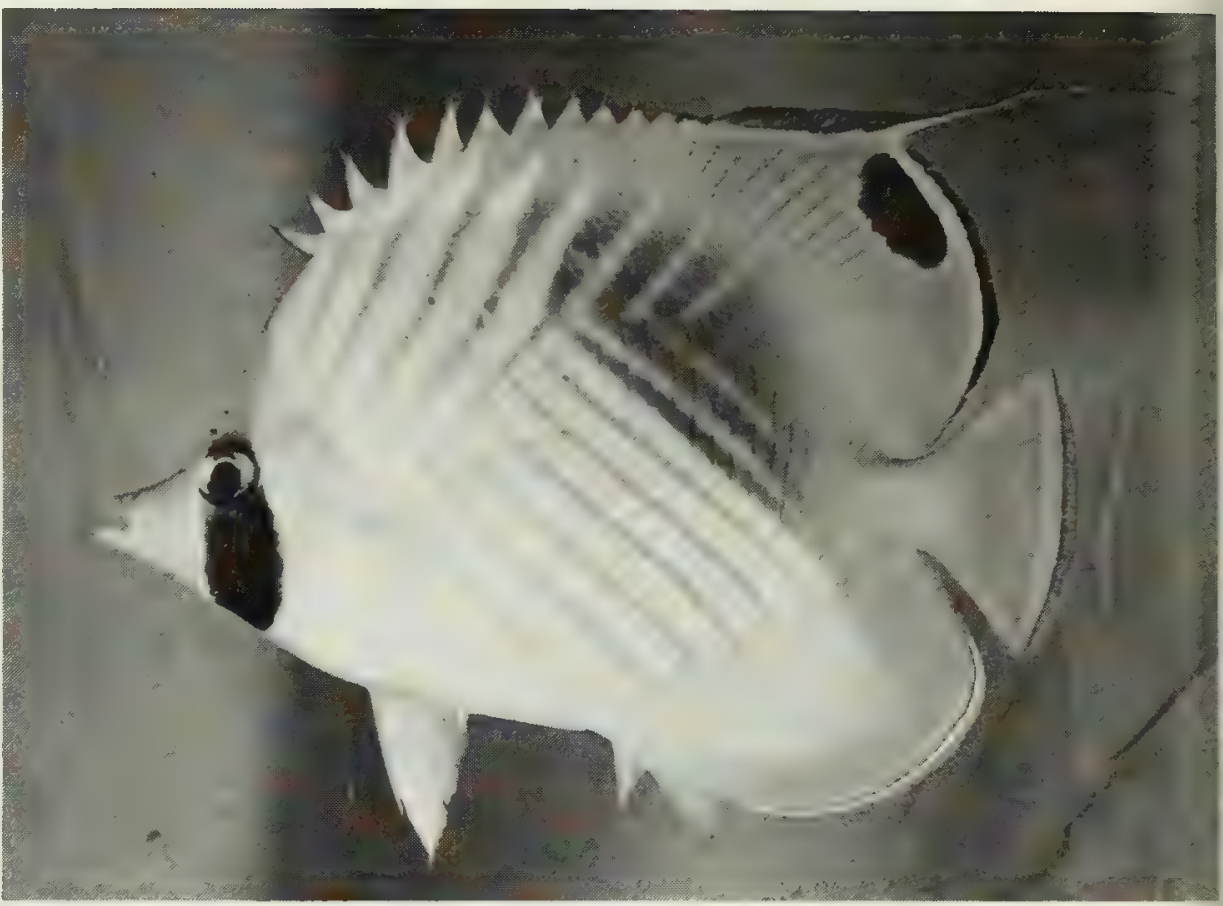

FIG. 227. Chaetodon auriga, $130 \mathrm{~mm} \mathrm{SL,} \mathrm{Peros} \mathrm{Banhos.}$

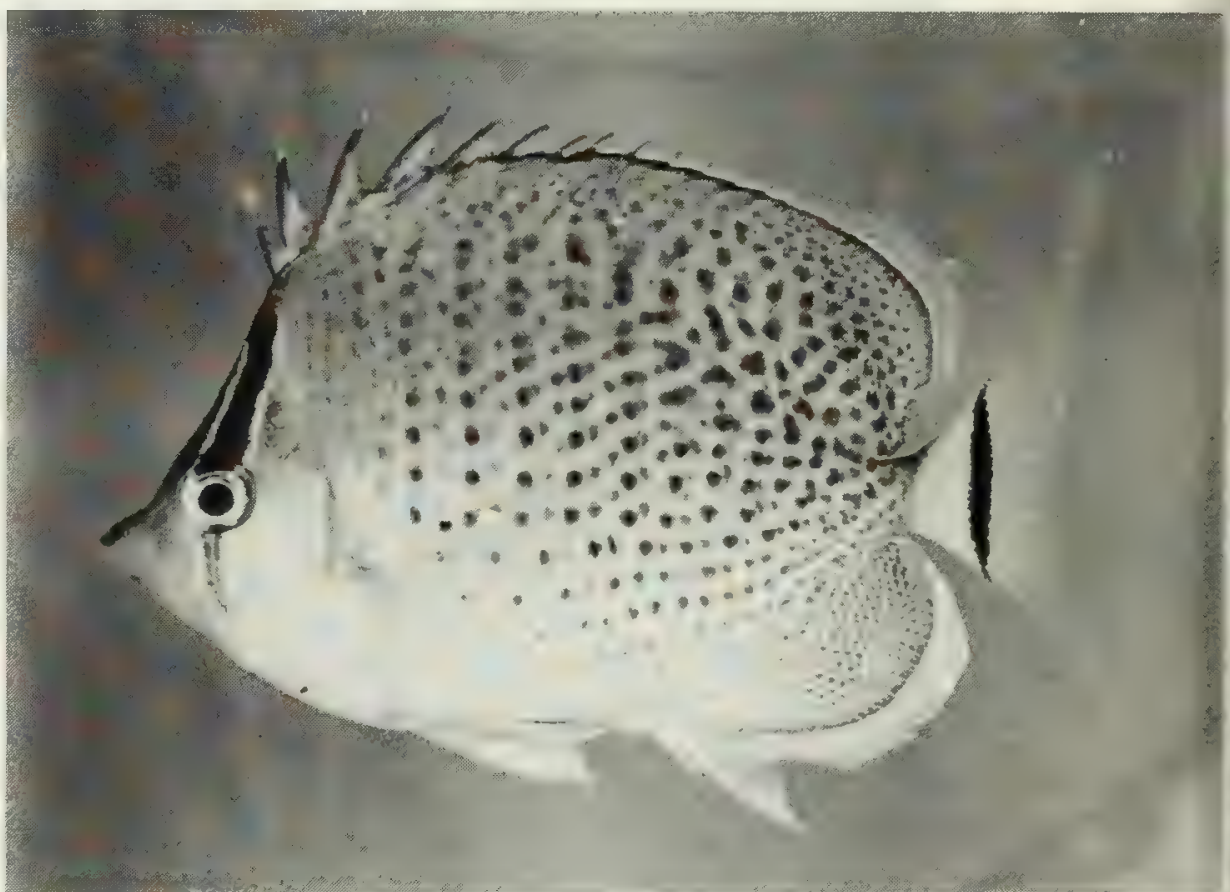

FIG. 229. Chaetodon guttatissimus, $69 \mathrm{~mm} \mathrm{SL}$, Peros Banhos. 


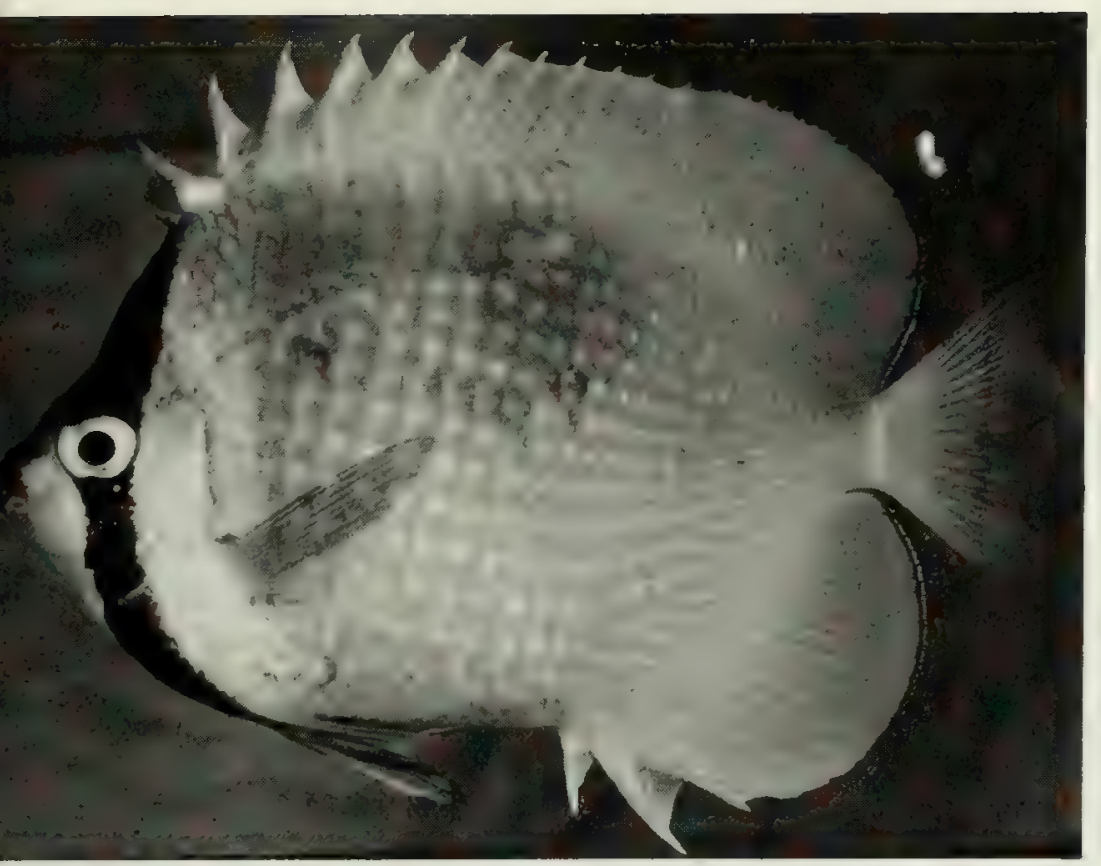

FIG. 230. Chaetodon kleinii, $77 \mathrm{~mm}$ SL, Peros Banhos.

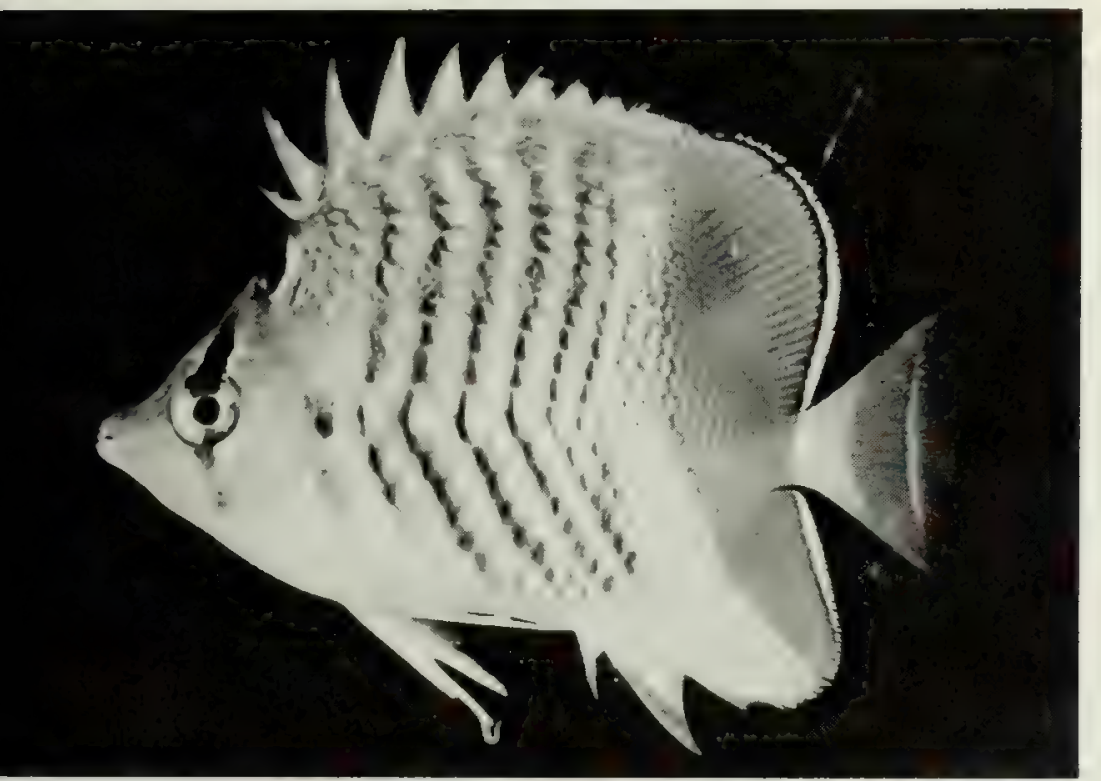

IG. 232. Chaetodon madagascariensis, $51 \mathrm{~mm}$ SL, Eagle Island.

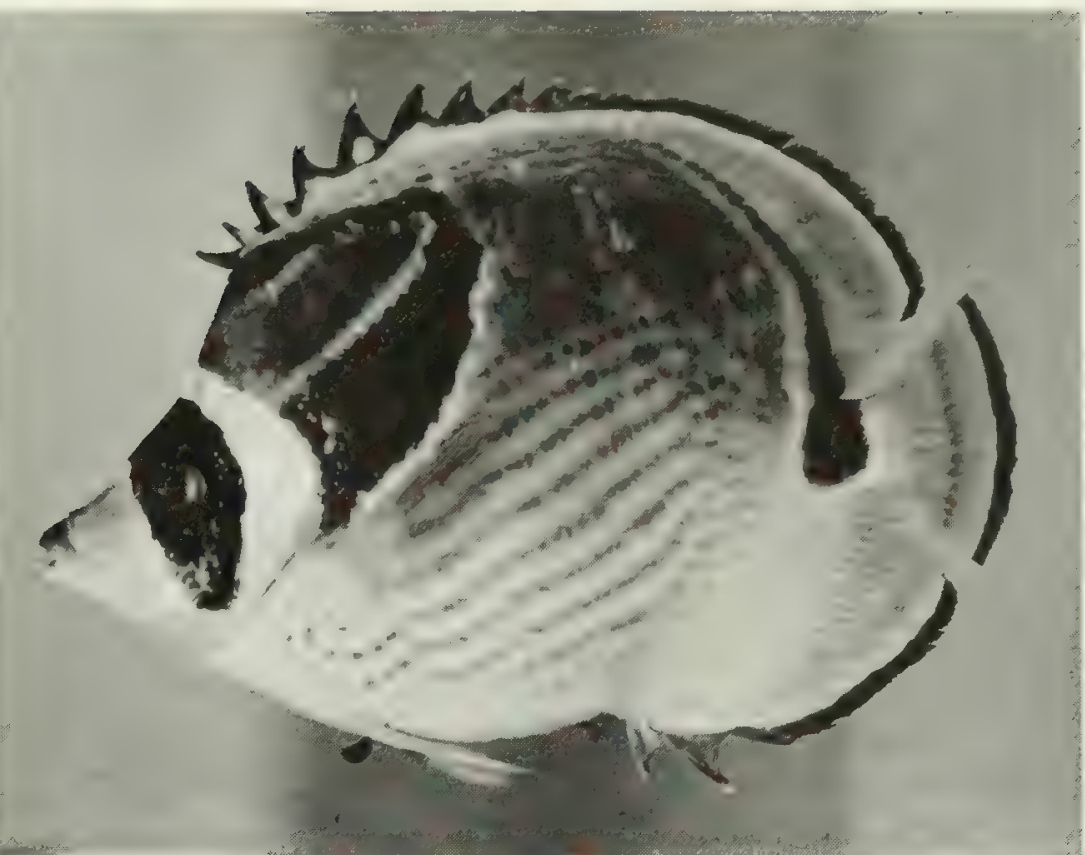

FIG. 231. Chaetodon lunula, $165 \mathrm{~mm} \mathrm{SL}$, Salomon.

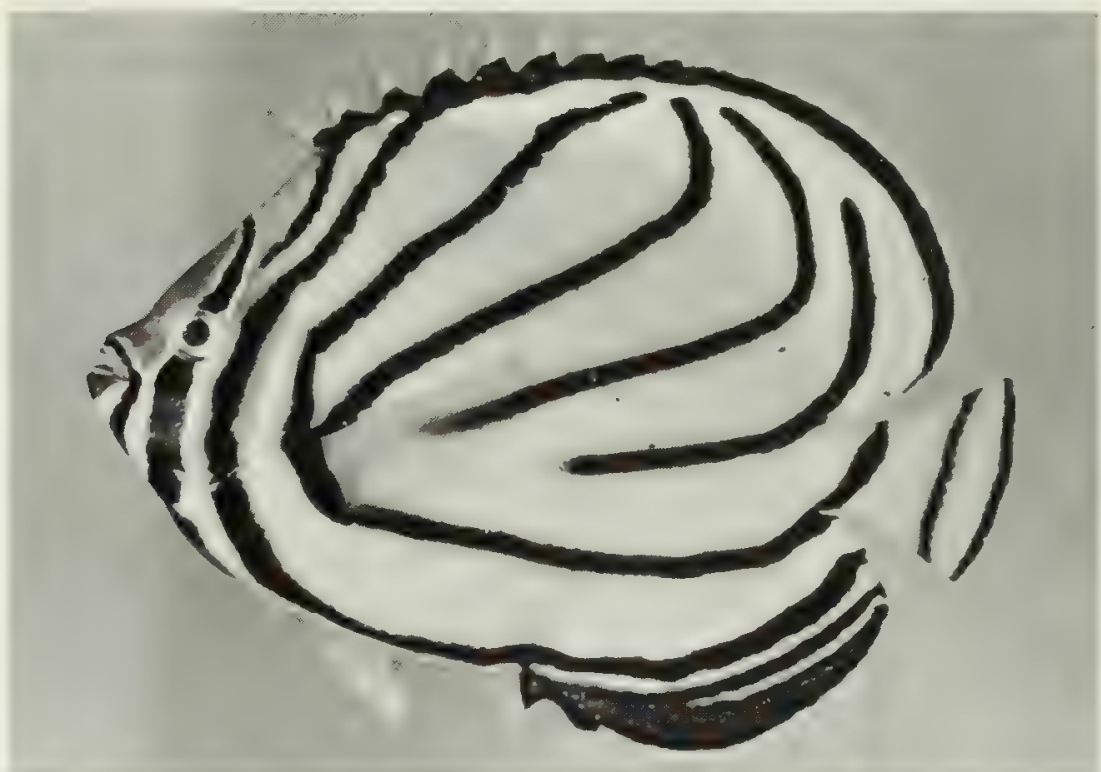

FIG. 233. Chaetodon meyeri, $133 \mathrm{~mm}$ SL, Peros Banhos.

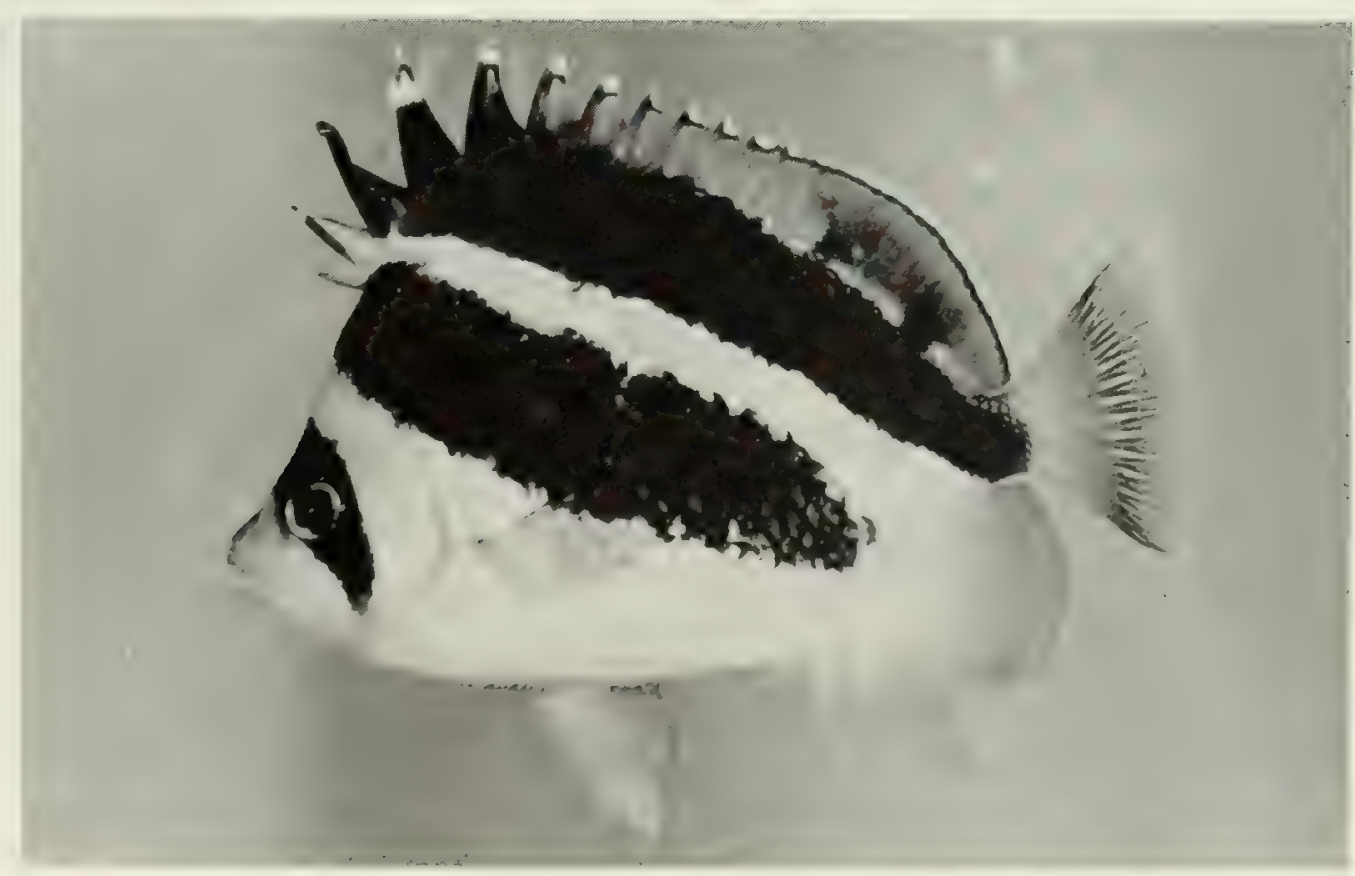

Fig. 234. Chaetodon mitratus, $87 \mathrm{~mm}$ SL, Peros Banhos. 


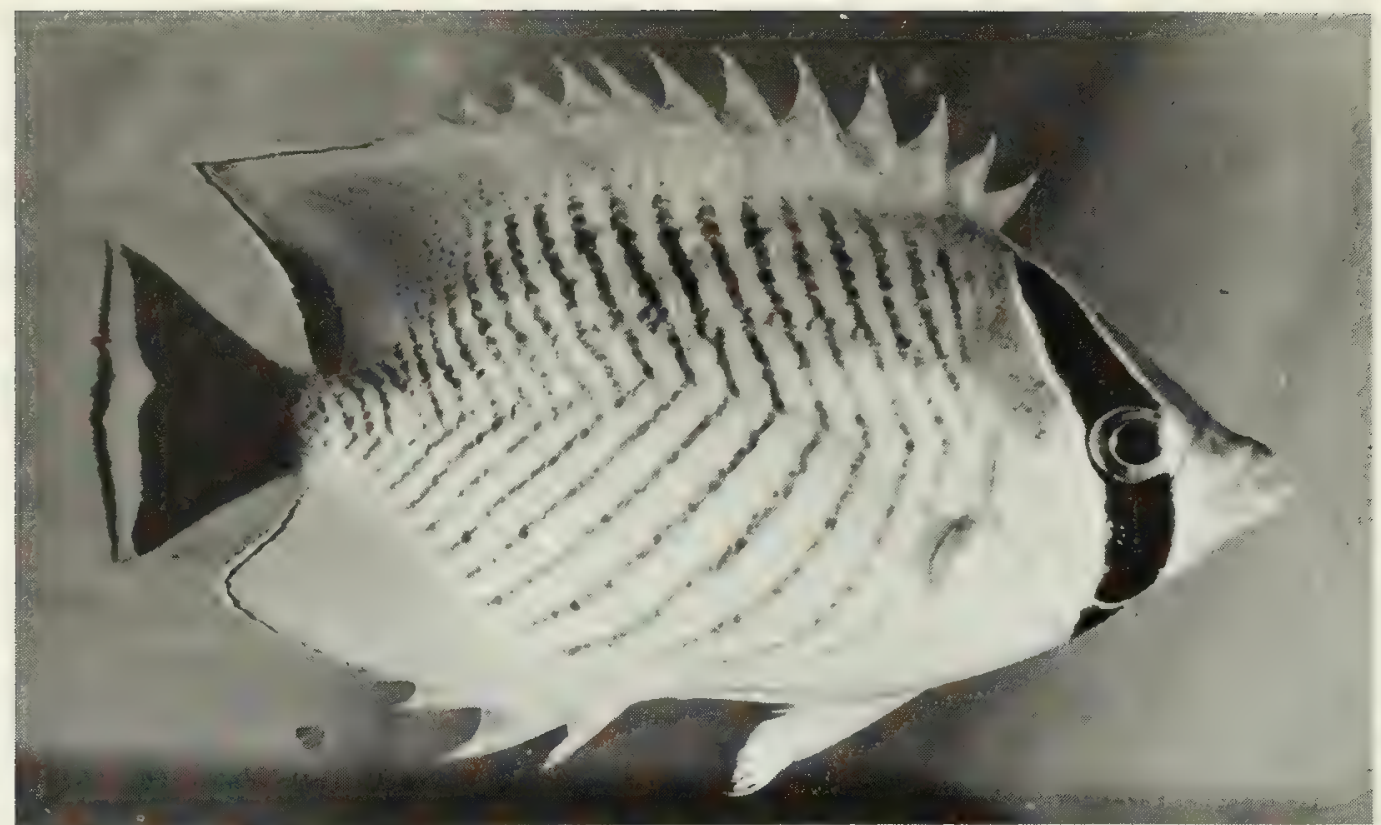

FIG. 235. Chaetodon trifascialis, $66 \mathrm{~mm}$ SL, Peros Banhos.

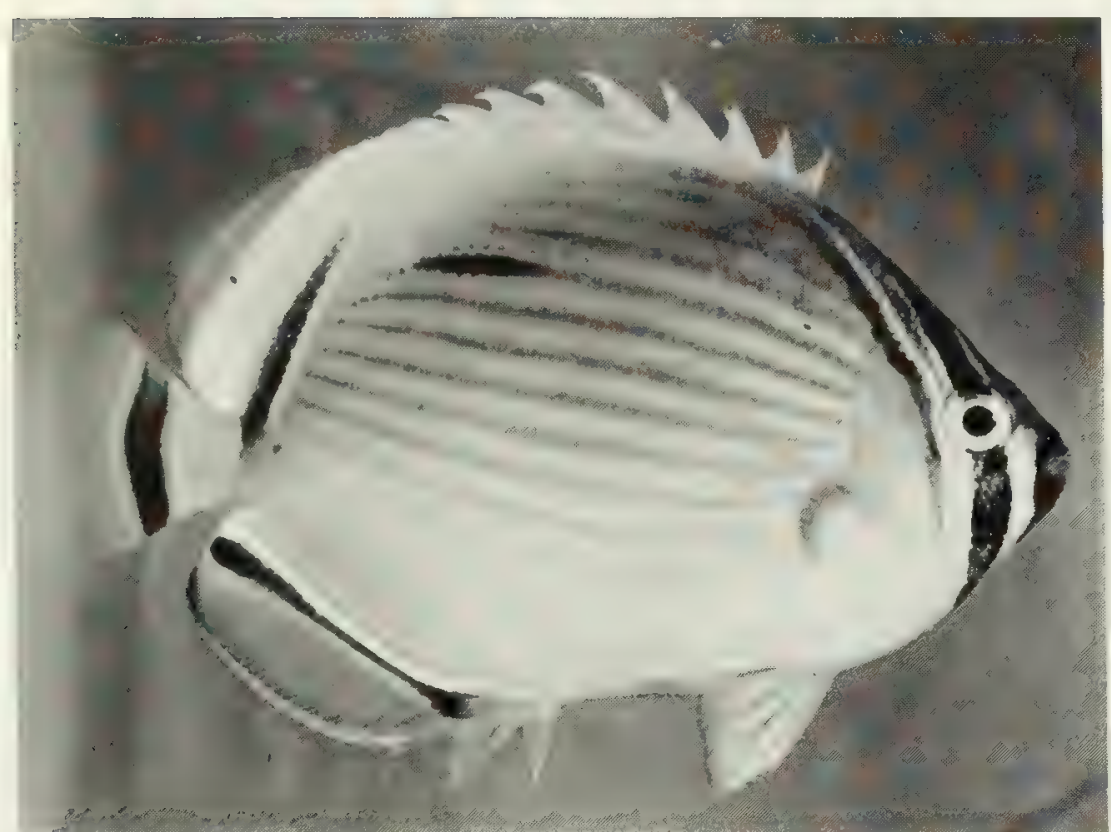

FIG. 236. Chaetodon trifasciatus trifasciatus, $94 \mathrm{~mm}$ SL, Peros Banhos.

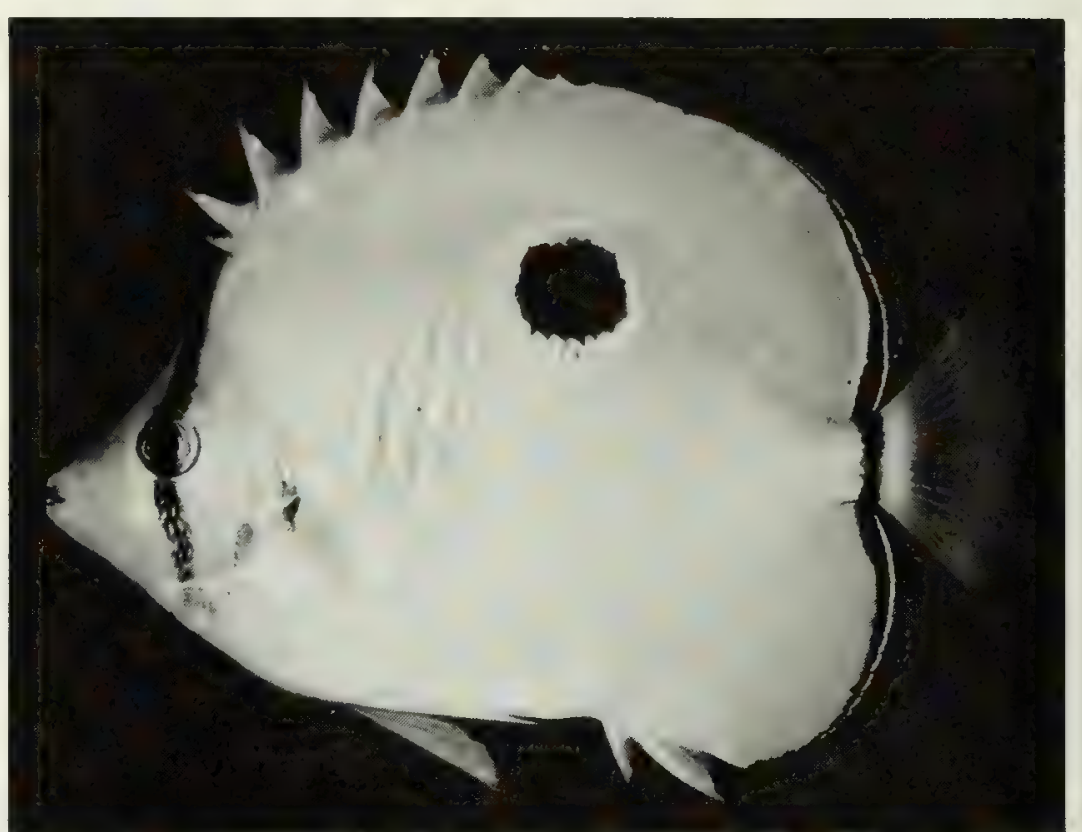

FIG. 237. Chaetodon unimaculatus interruptus, $111 \mathrm{~mm} \mathrm{SL}$, Eagle Island.

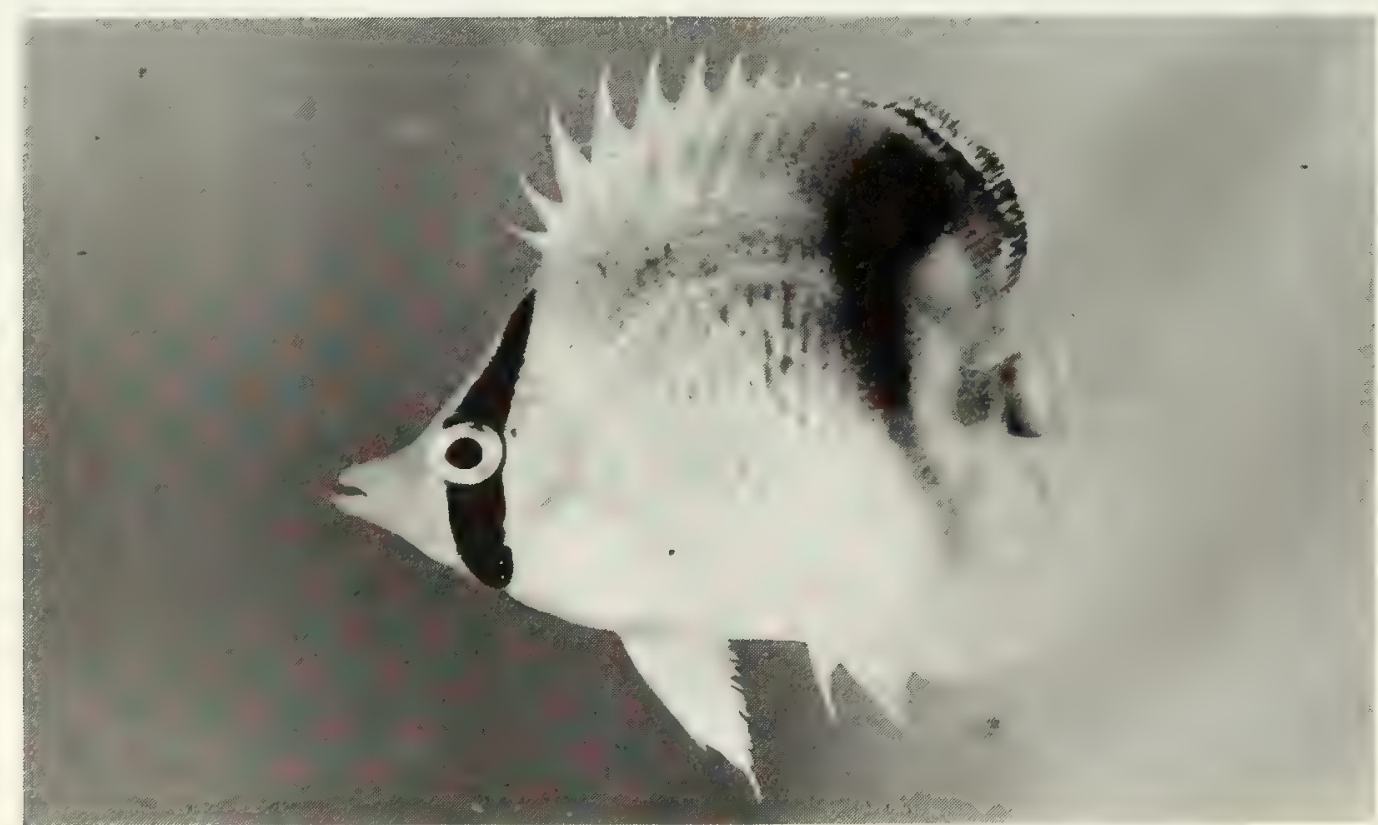

FIG. 238. Chaetodon vagabundus, $48 \mathrm{~mm}$ SL, Salomon. 


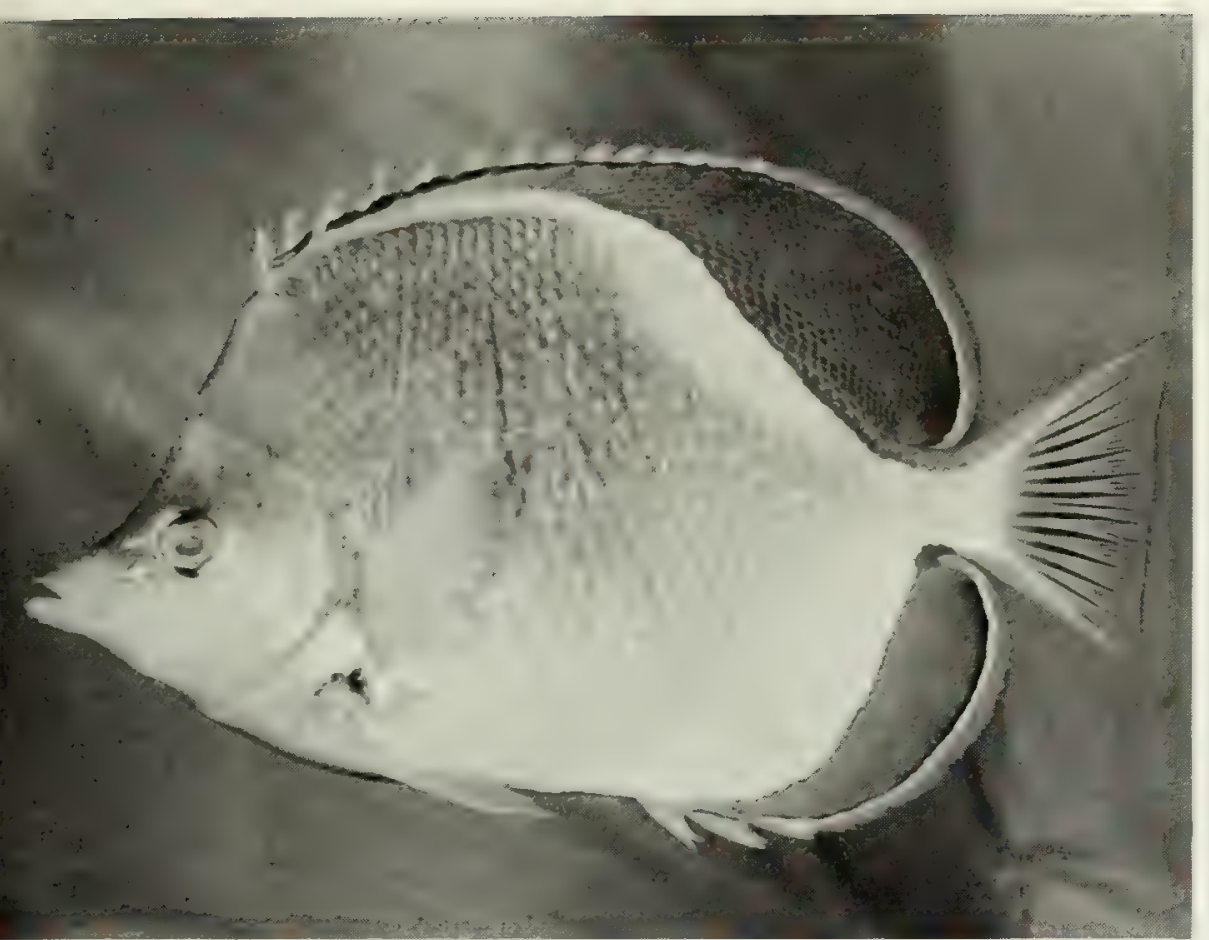

FIG. 239. Chaetodon xanthocephalus, $181 \mathrm{~mm} \mathrm{SL}$, Three Brothers.

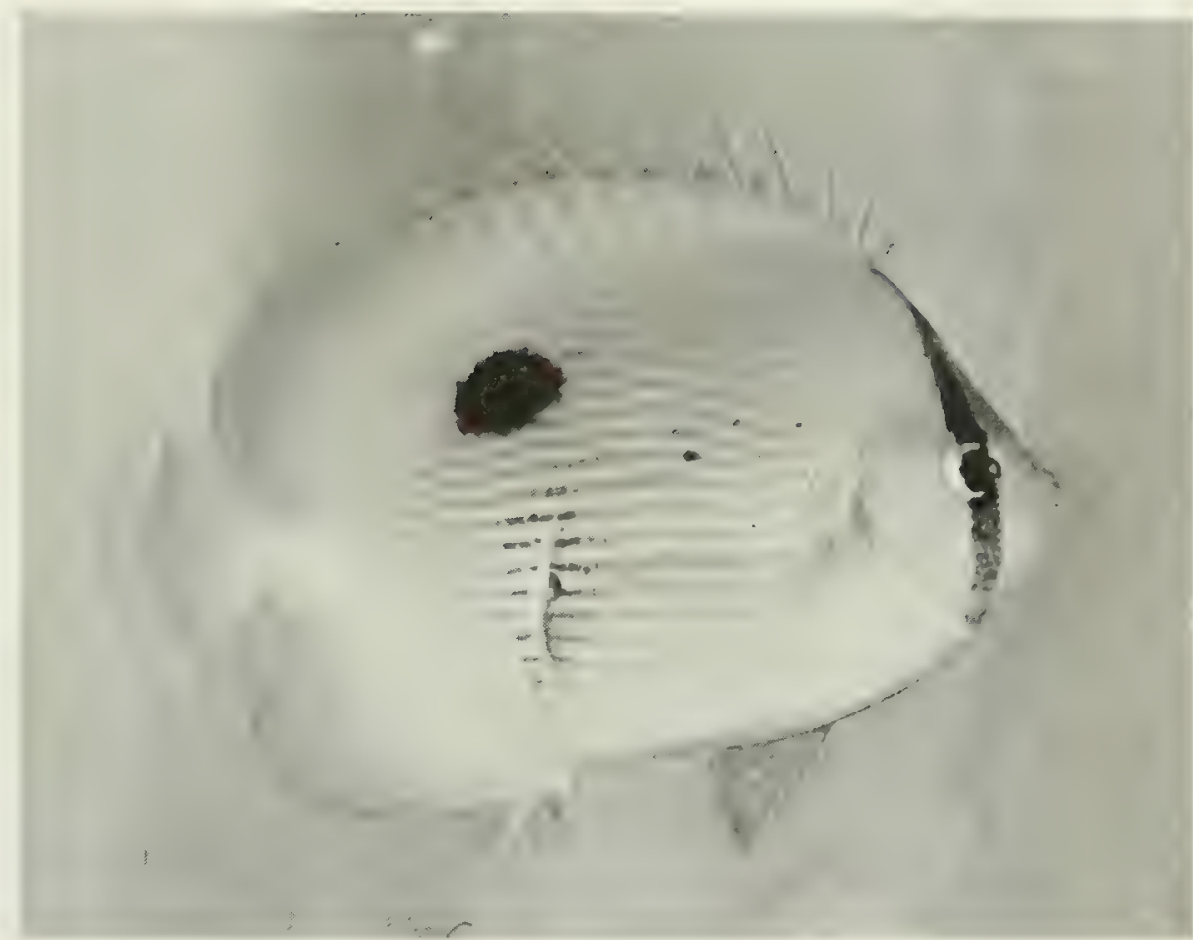

FIG. 240. Chaeotodon zanzibarensis, $112 \mathrm{~mm}$ SL, Peros Banhos.

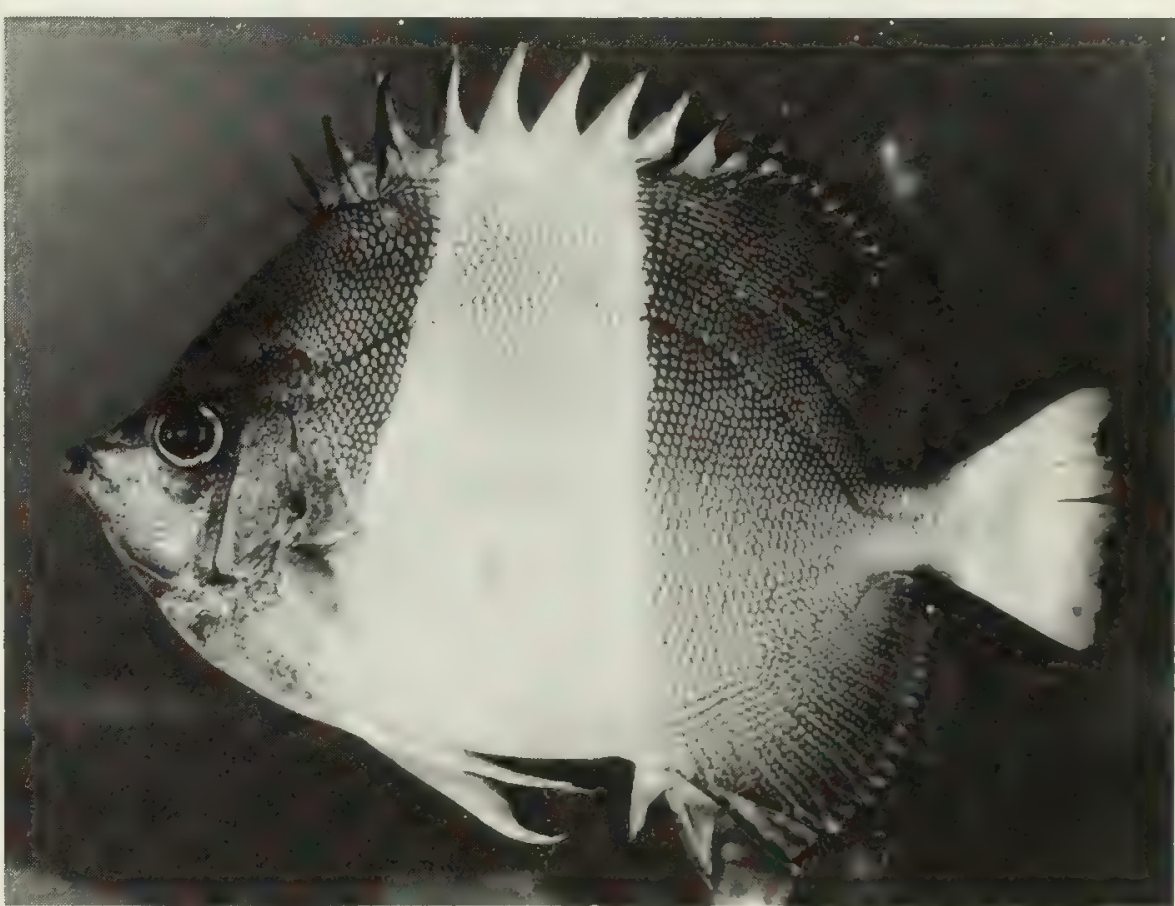

FIG. 242. Hemitaurichthys zoster, $129 \mathrm{~mm} \mathrm{SL}$, Eagle Island.

Fig. 241. Forcipiger flavissimus, $90 \mathrm{~mm} \mathrm{SL}$, Peros Banhos. 


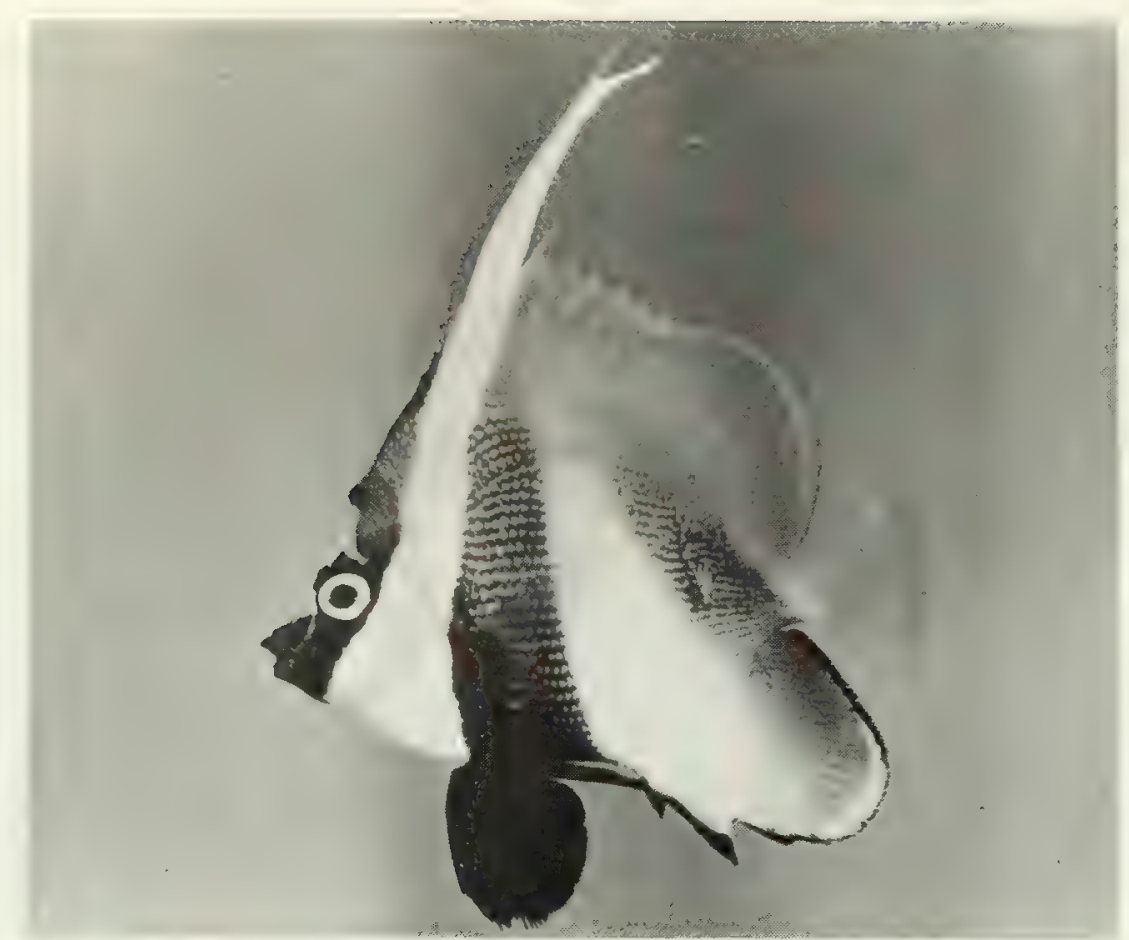

FIG. 243. Heniochus monoceros, $95 \mathrm{~mm}$ SL, Salomon.

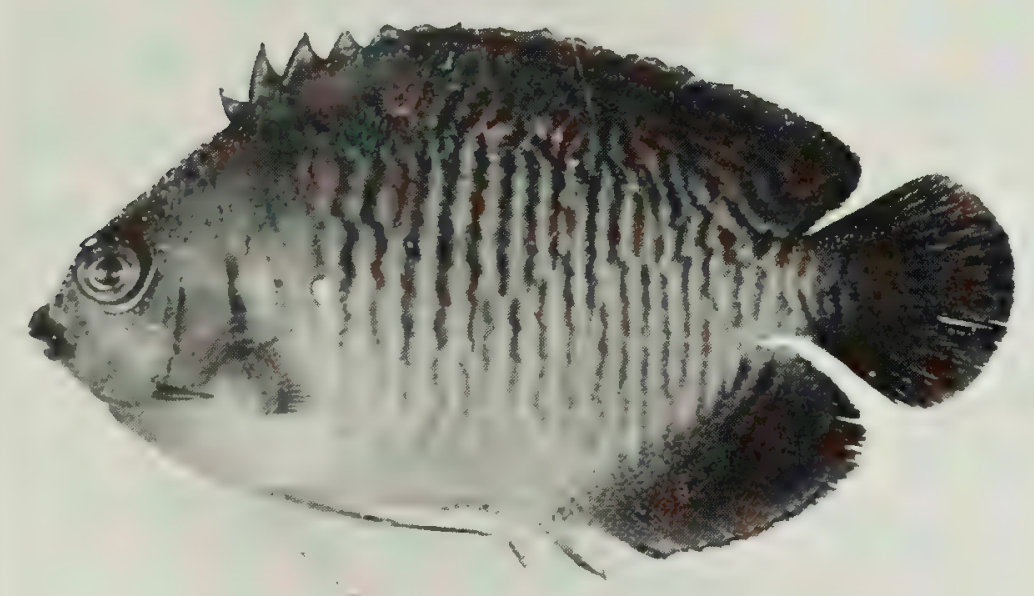

FIG. 245. Centropyge bispinosus, $56 \mathrm{~mm} \mathrm{SL}$, Salomon.

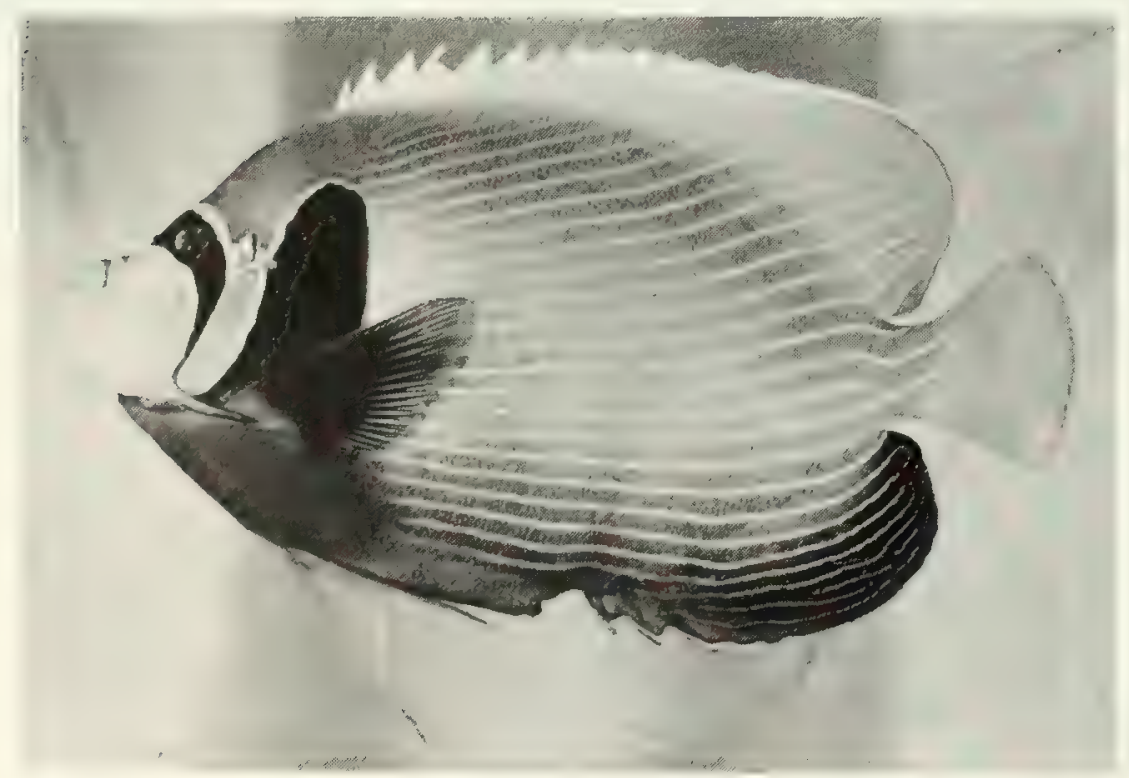

Fig. 247. Pomacanthus imperator, $240 \mathrm{~mm}$ SL, Peros Banhos.

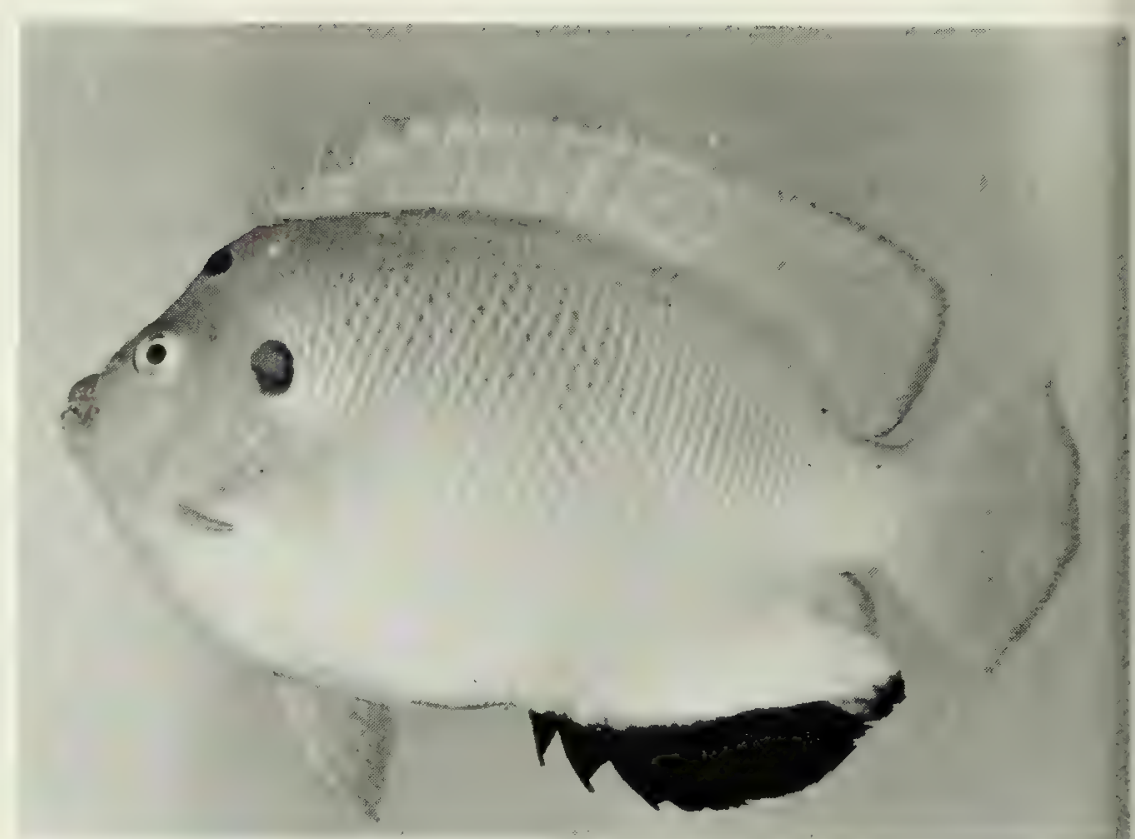

FIG. 244. Apolemichthys trimaculatus, $150 \mathrm{~mm} \mathrm{SL}$, Peros Banhos

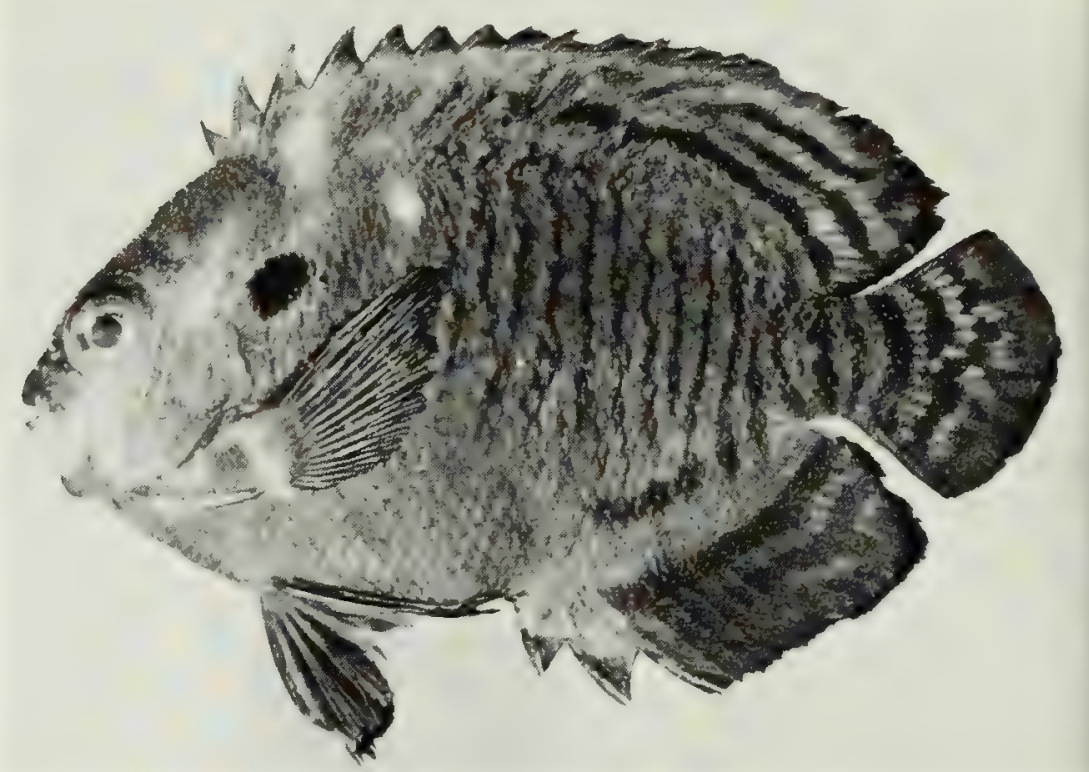

FIG. 246. Centropyge multispinis, $69 \mathrm{~mm}$ SL, Salomon.

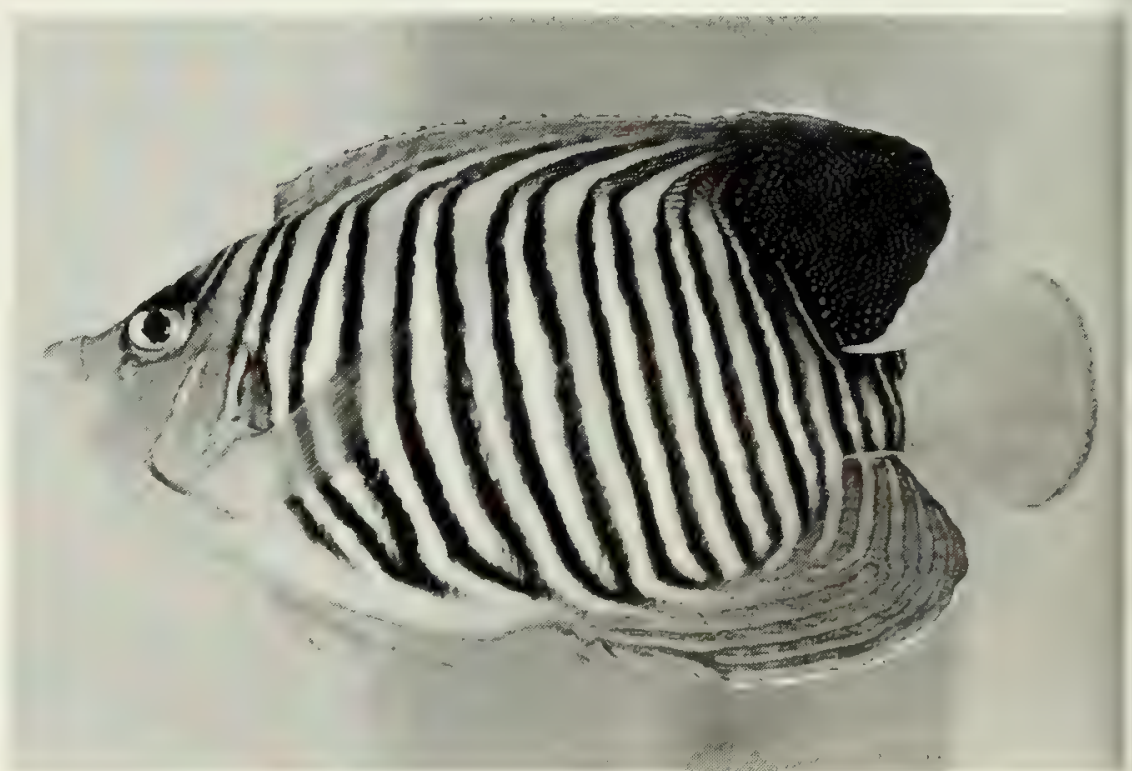

Fig. 248. Pygoplites diacanthus, $142 \mathrm{~mm} \mathrm{SL}$, Salomon. 


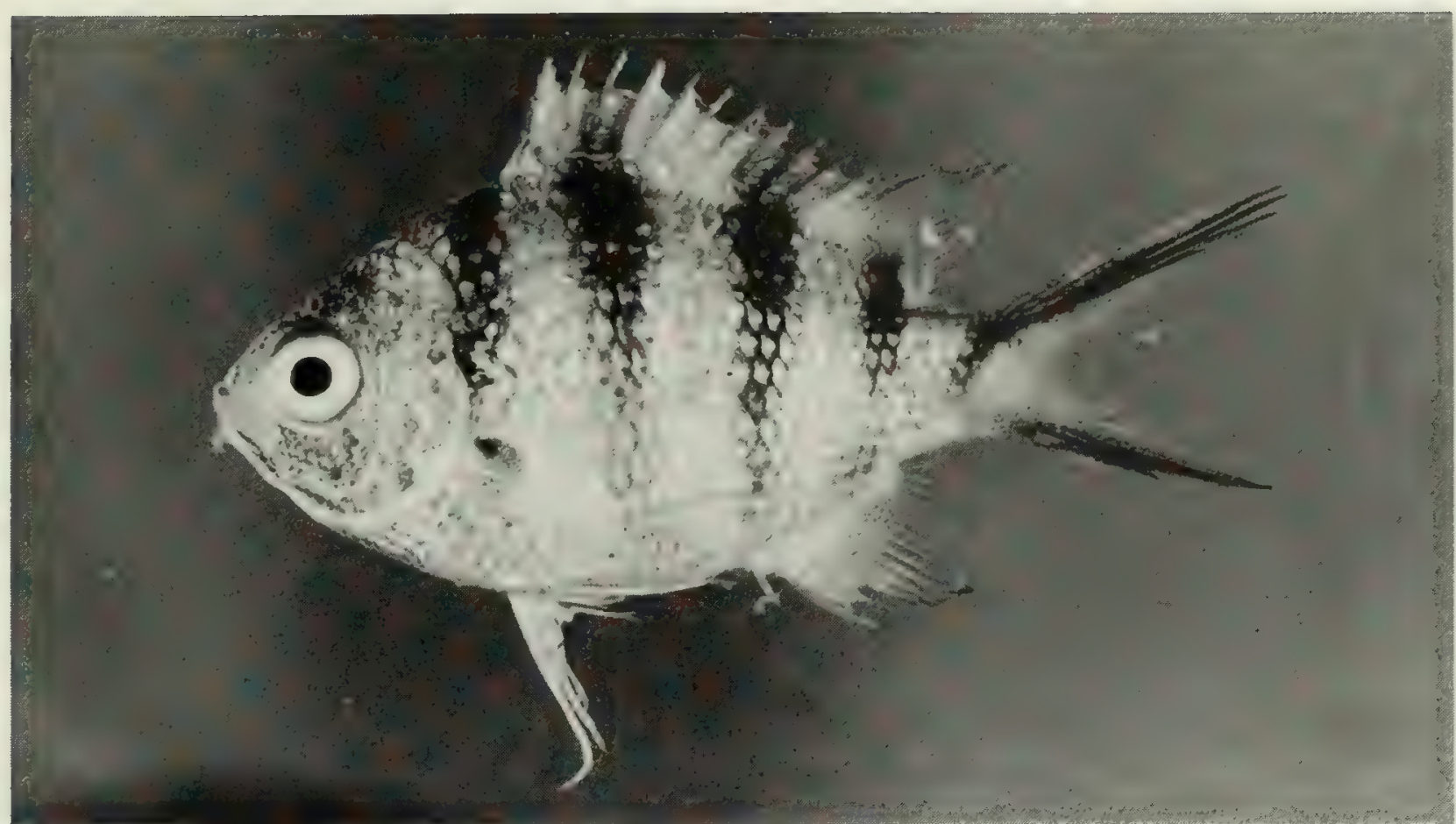

Fig. 249. Abudefduf coelestinus, $32 \mathrm{~mm}$ SL, Peros Banhos.

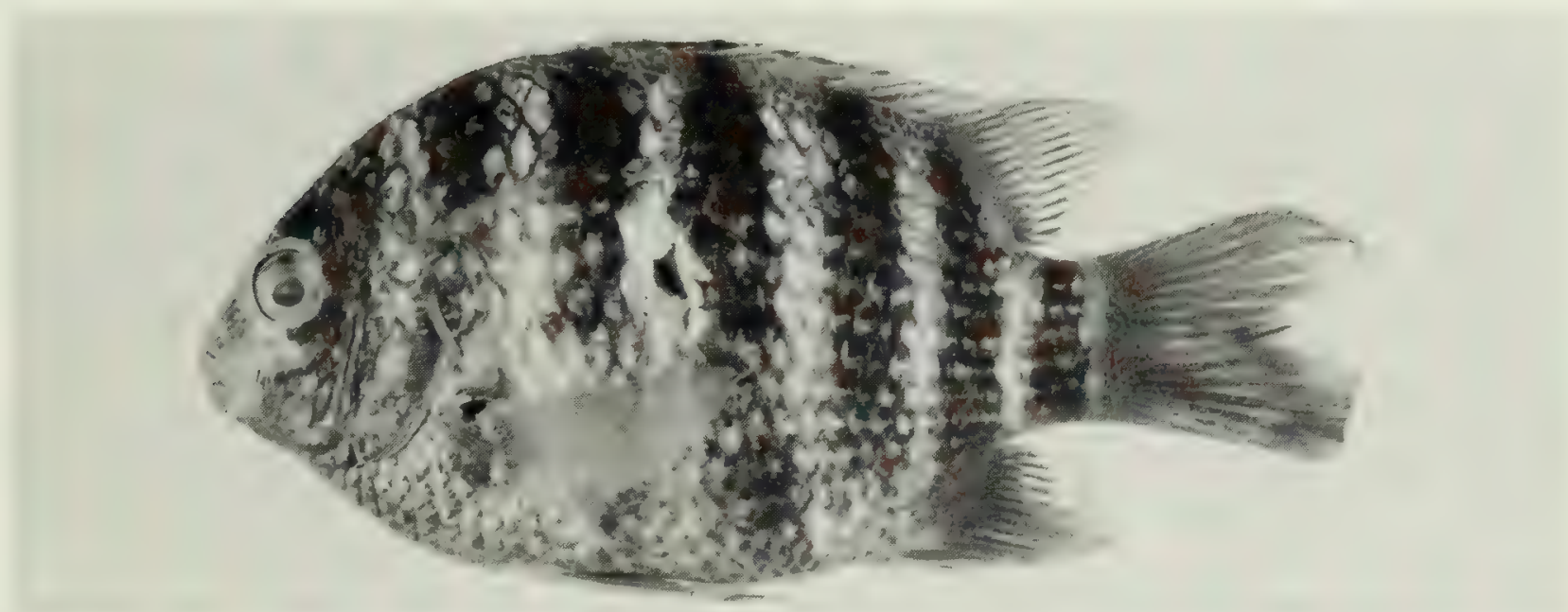

FIG. 250. Abudefduf septemfasciatus, (preserved) $138 \mathrm{~mm} \mathrm{SL}$, Peros Banhos. Photo by A. Strange.

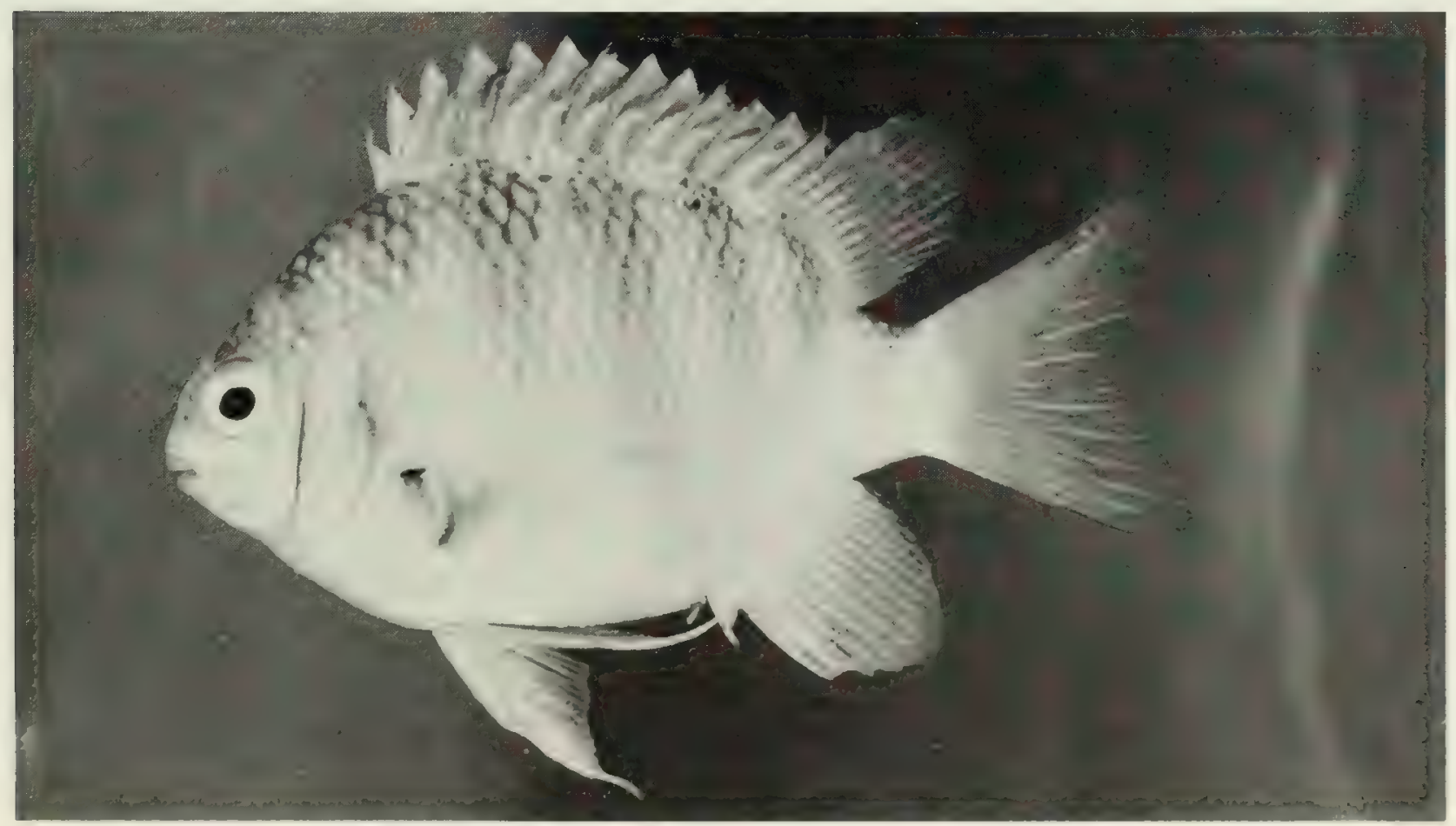

Fig. 251. Abudefduf sordidus, $31 \mathrm{~mm} \mathrm{SL}$, Salomon. 


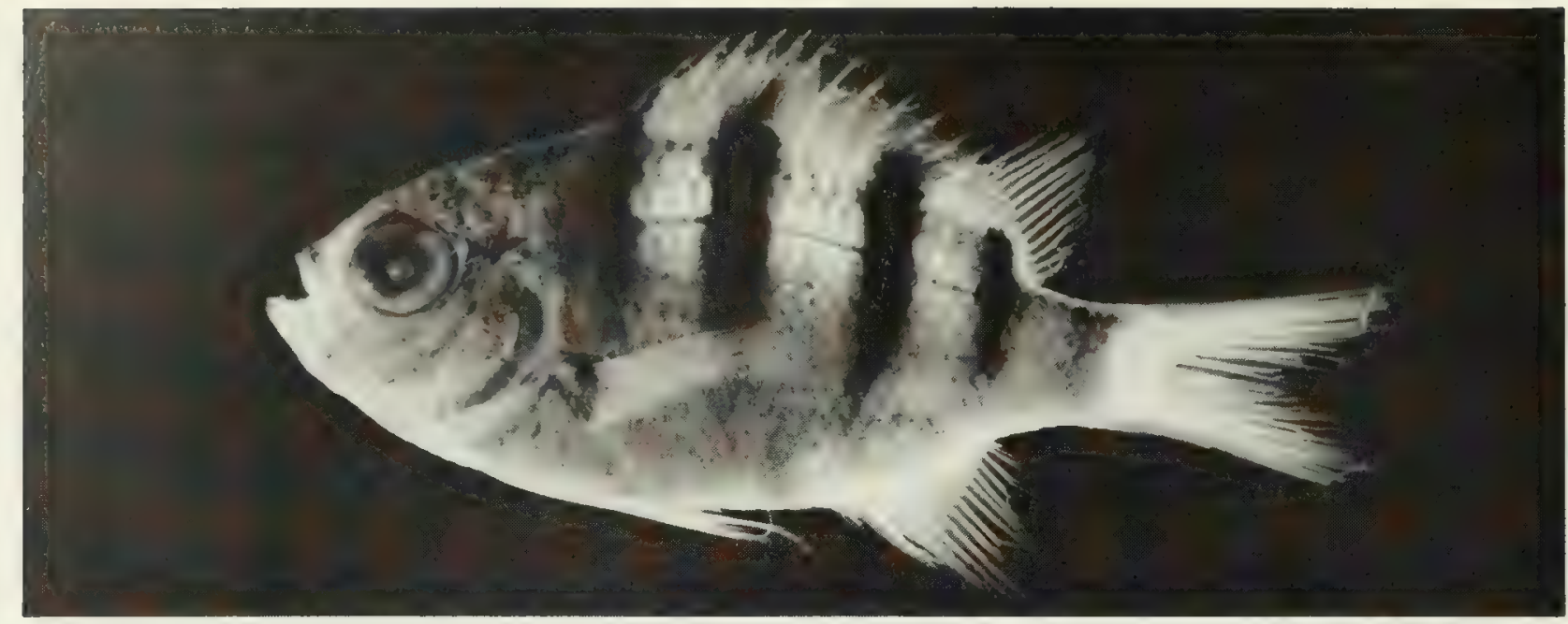

FIG. 252. Abudefduf vaigiensis, (preserved) $32 \mathrm{~mm} \mathrm{SL}$, Eagle Island. Photo by A. Strange.

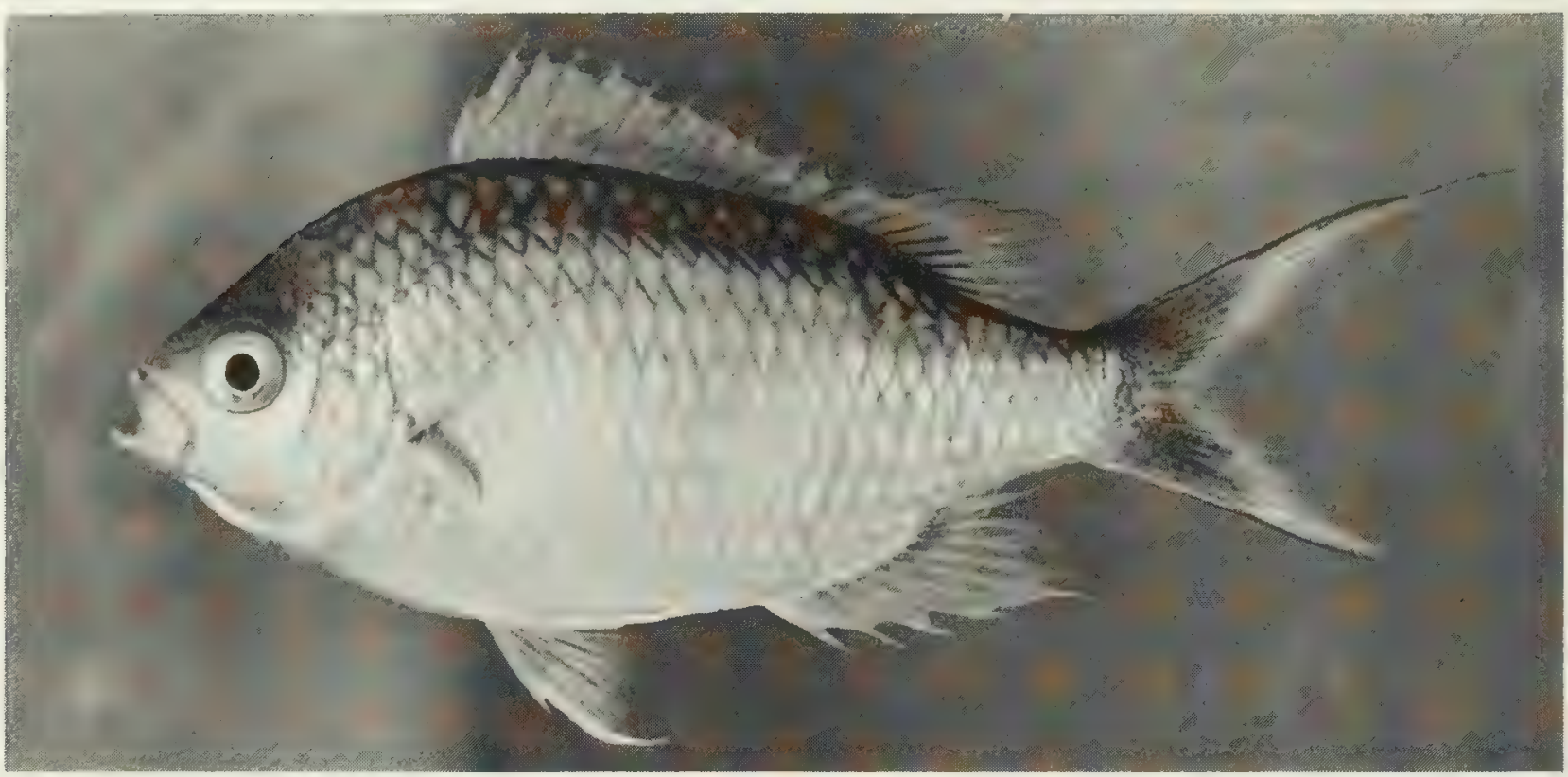

FIG. 253. Chromis atripectoralis, $64 \mathrm{~mm} \mathrm{SL}$, Salomon.

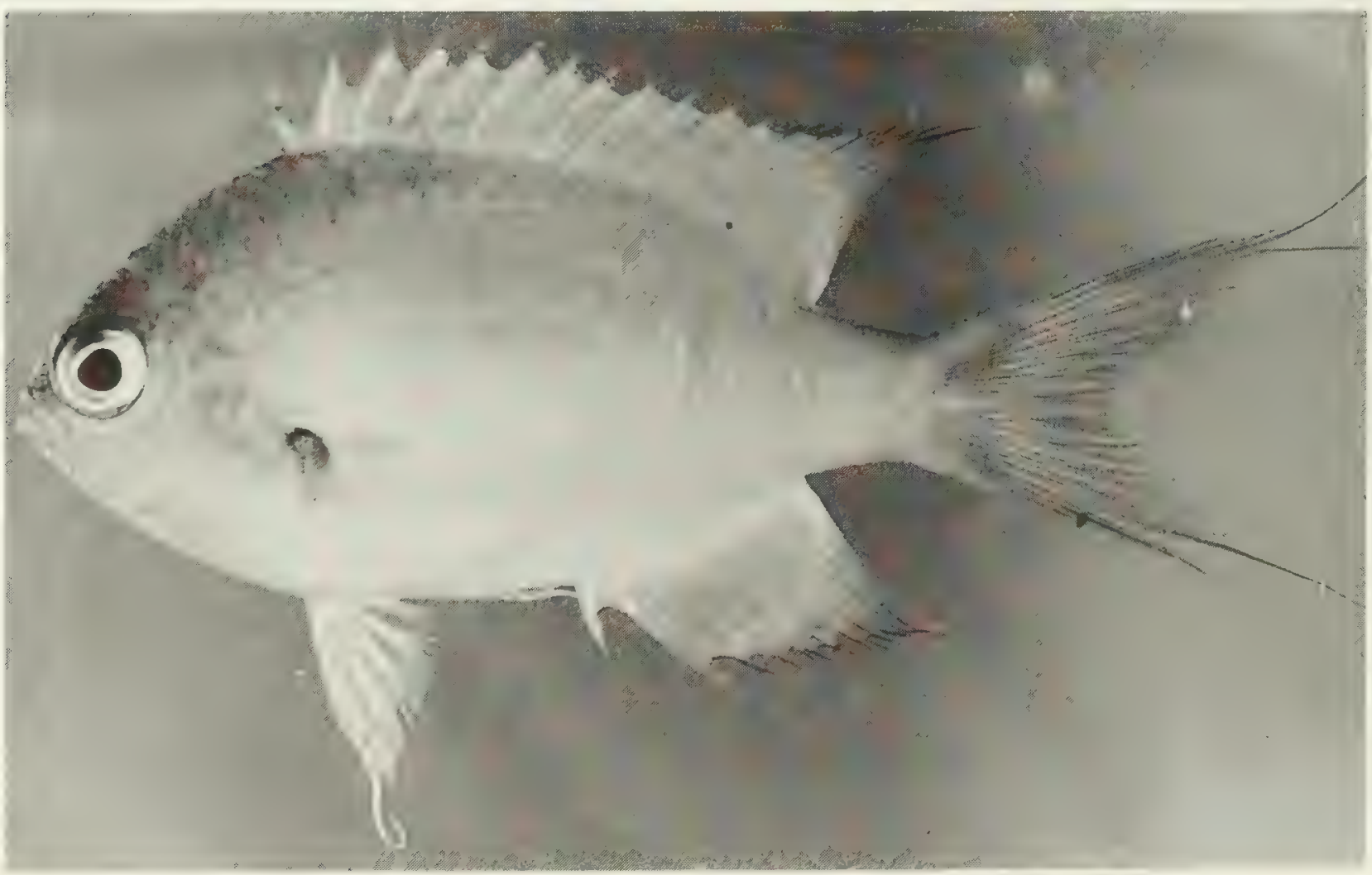

FIG. 254. Chromis atripes, $43 \mathrm{~mm} \mathrm{SL}$, Peros Banhos. 


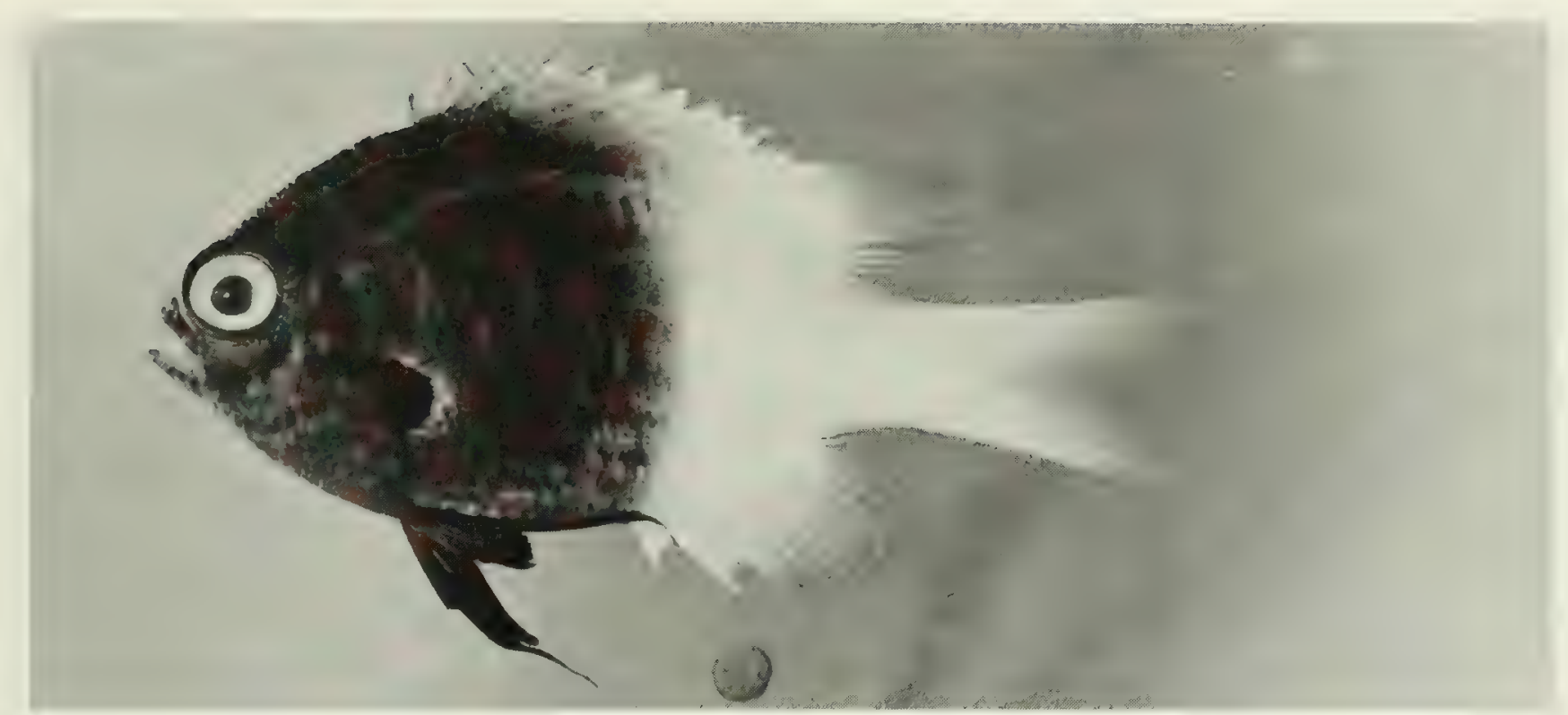

FIG. 255. Chromis dimidiata, $34 \mathrm{~mm} \mathrm{SL,} \mathrm{Peros} \mathrm{Banhos.}$

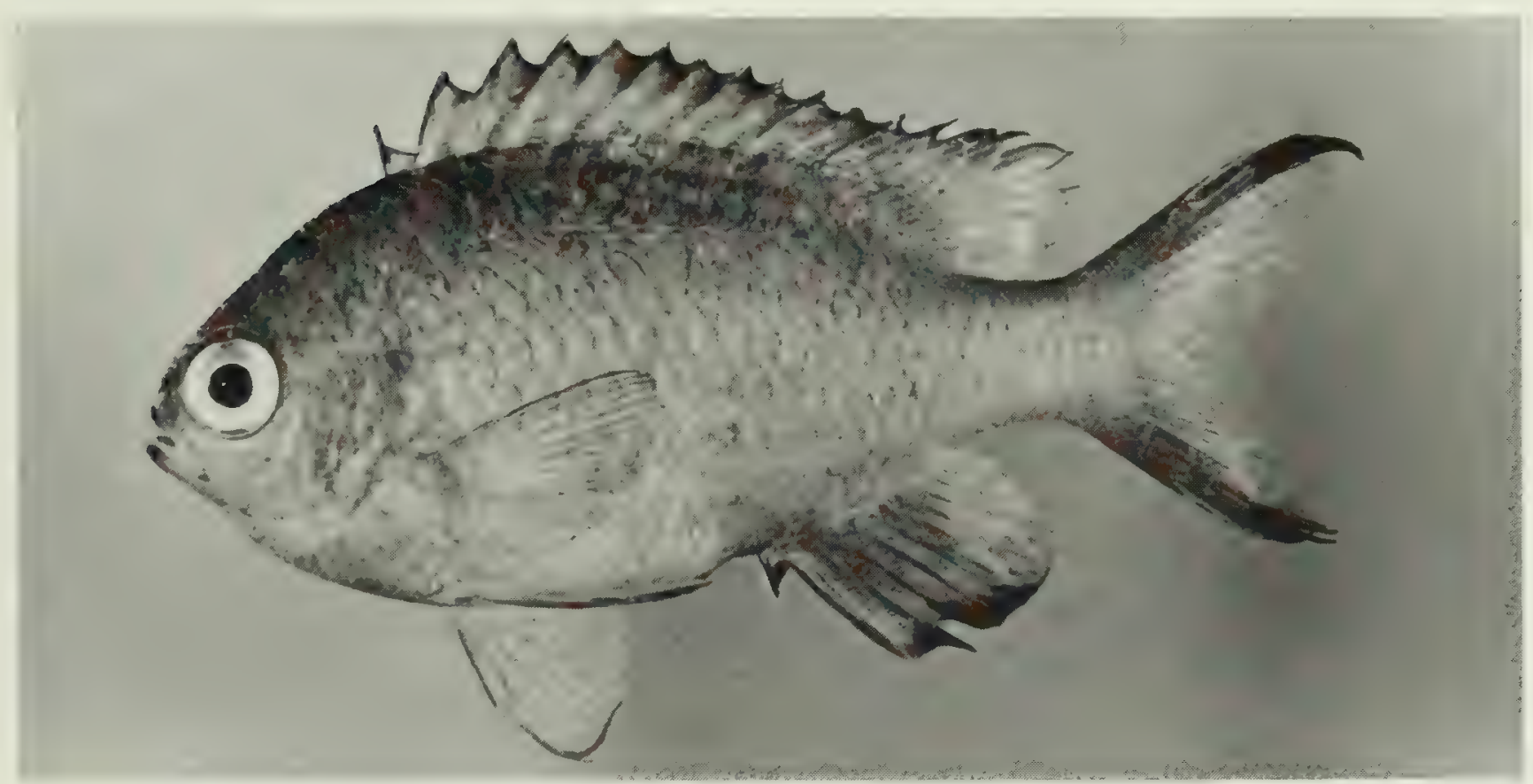

FIG. 256. Chromis lepidolepis, $48 \mathrm{~mm} \mathrm{SL}$, Salomon.

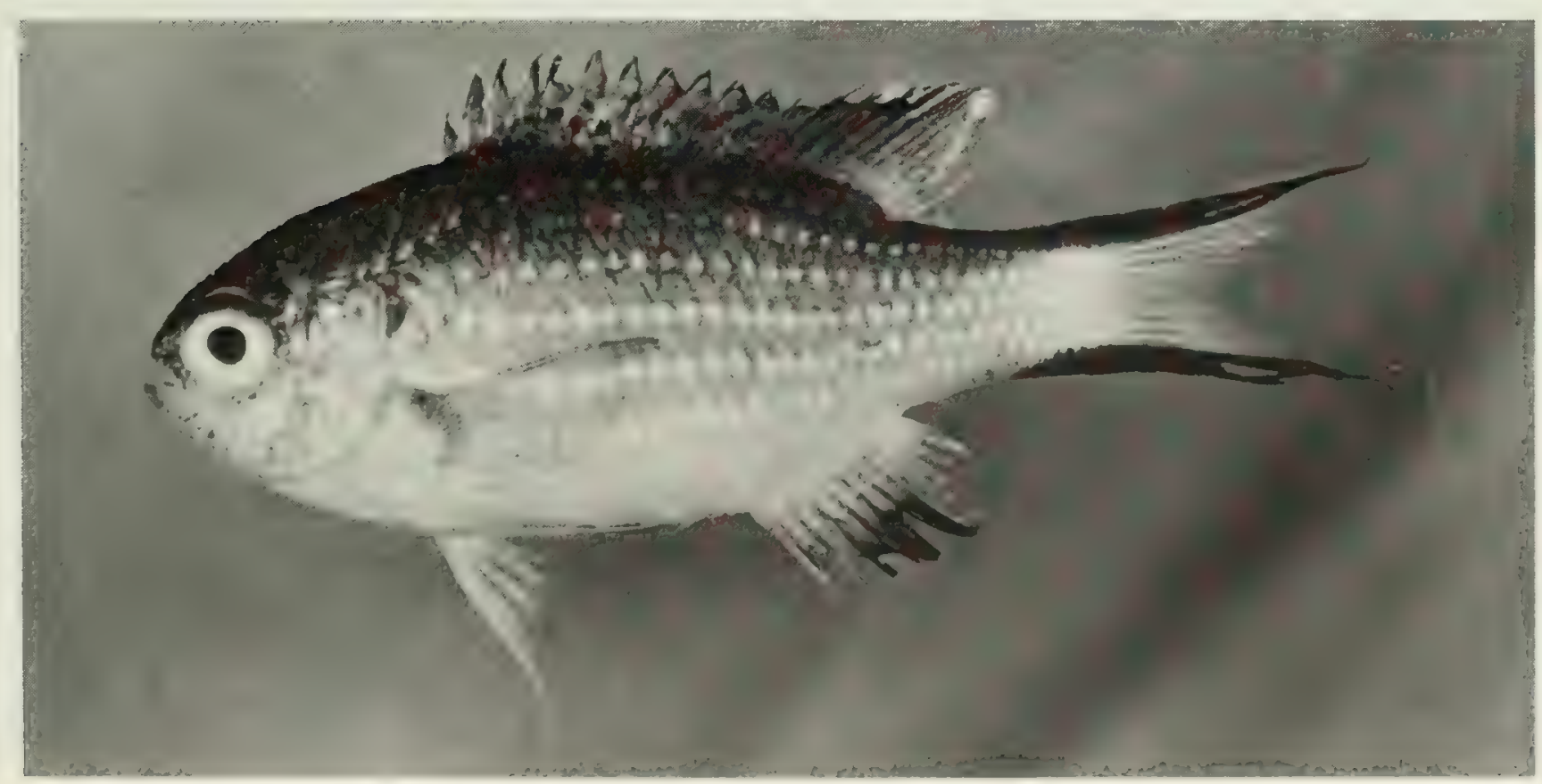

FIG. 257. Chromis nigrura, $37 \mathrm{~mm} \mathrm{SL,} \mathrm{Peros} \mathrm{Banhos}$ 


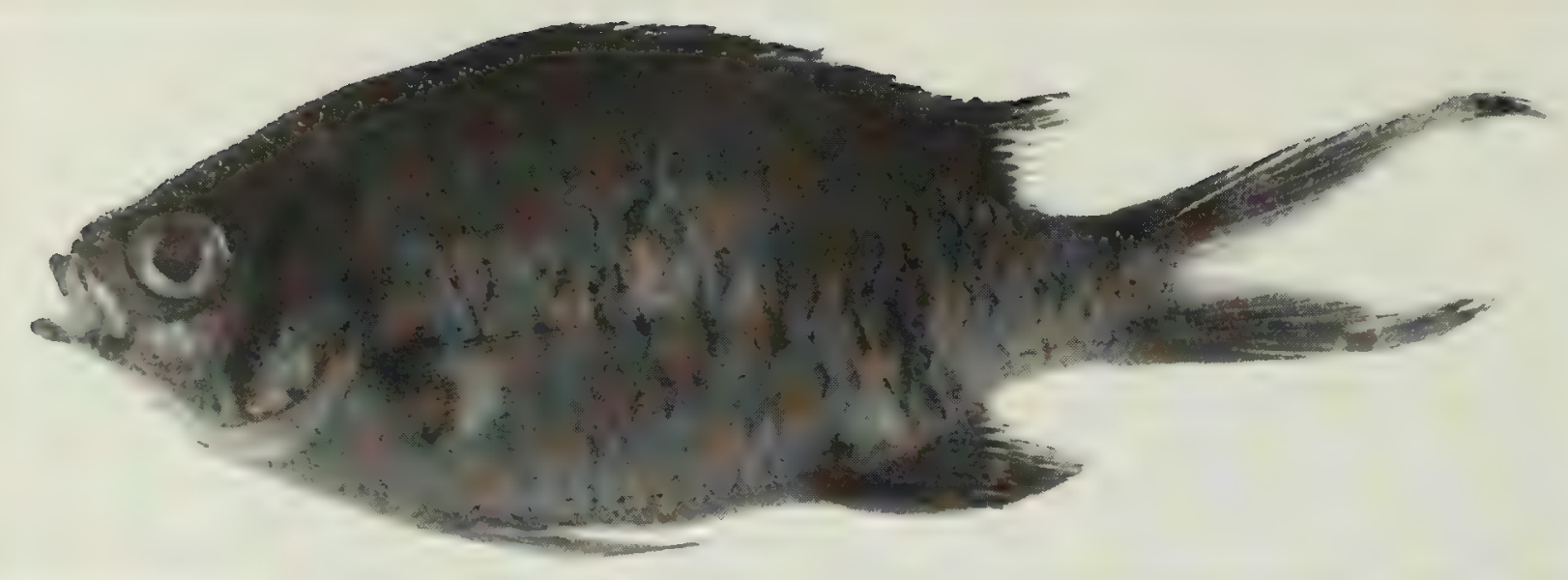

FIG. 258. Chromis simulans, (preserved) $72 \mathrm{~mm} \mathrm{SL}$, Salomon. Photo by A. Strange.

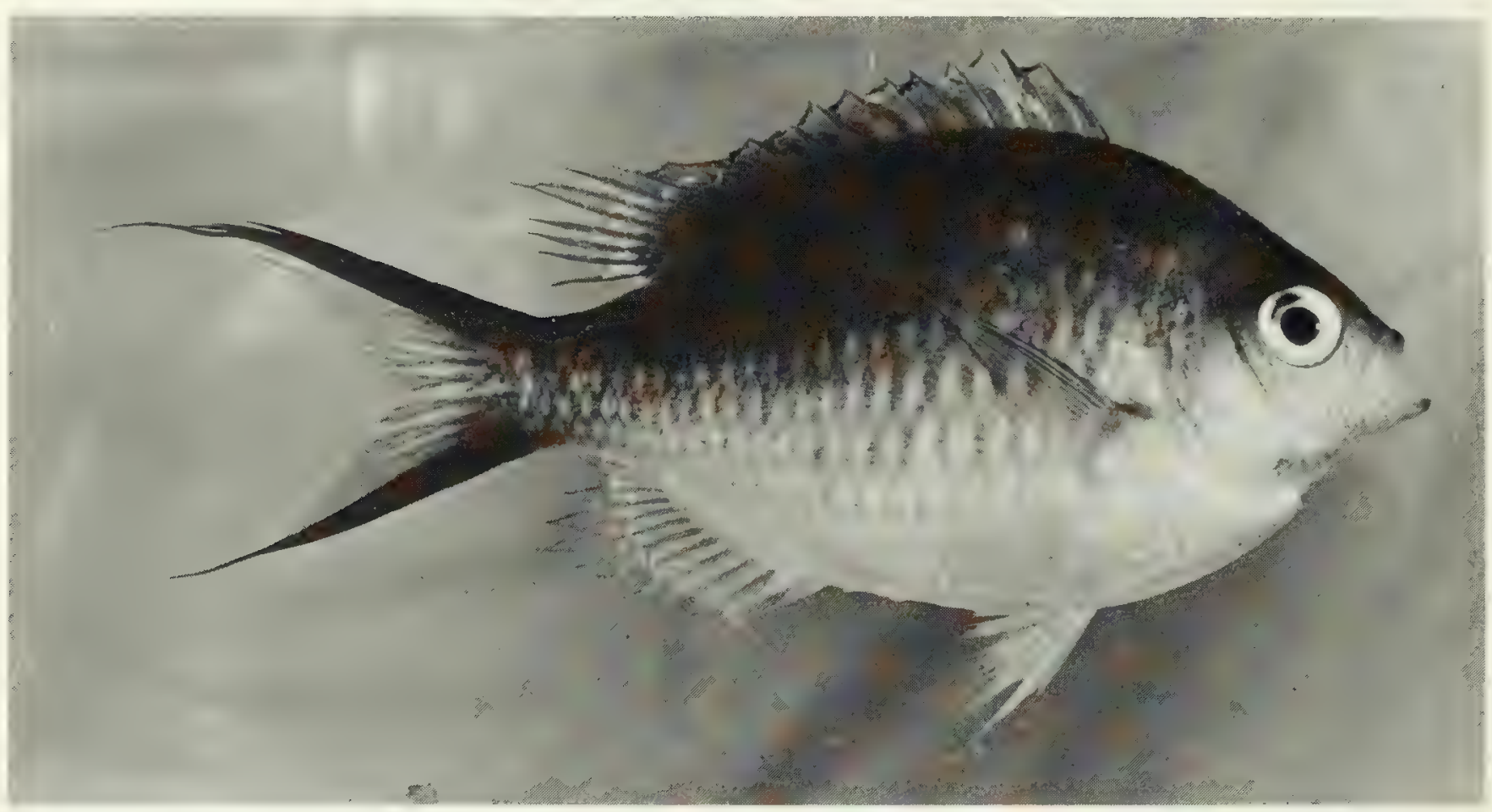

FIG. 259. Chromis ternatensis, $58 \mathrm{~mm} \mathrm{SL,} \mathrm{Peros} \mathrm{Banhos.}$

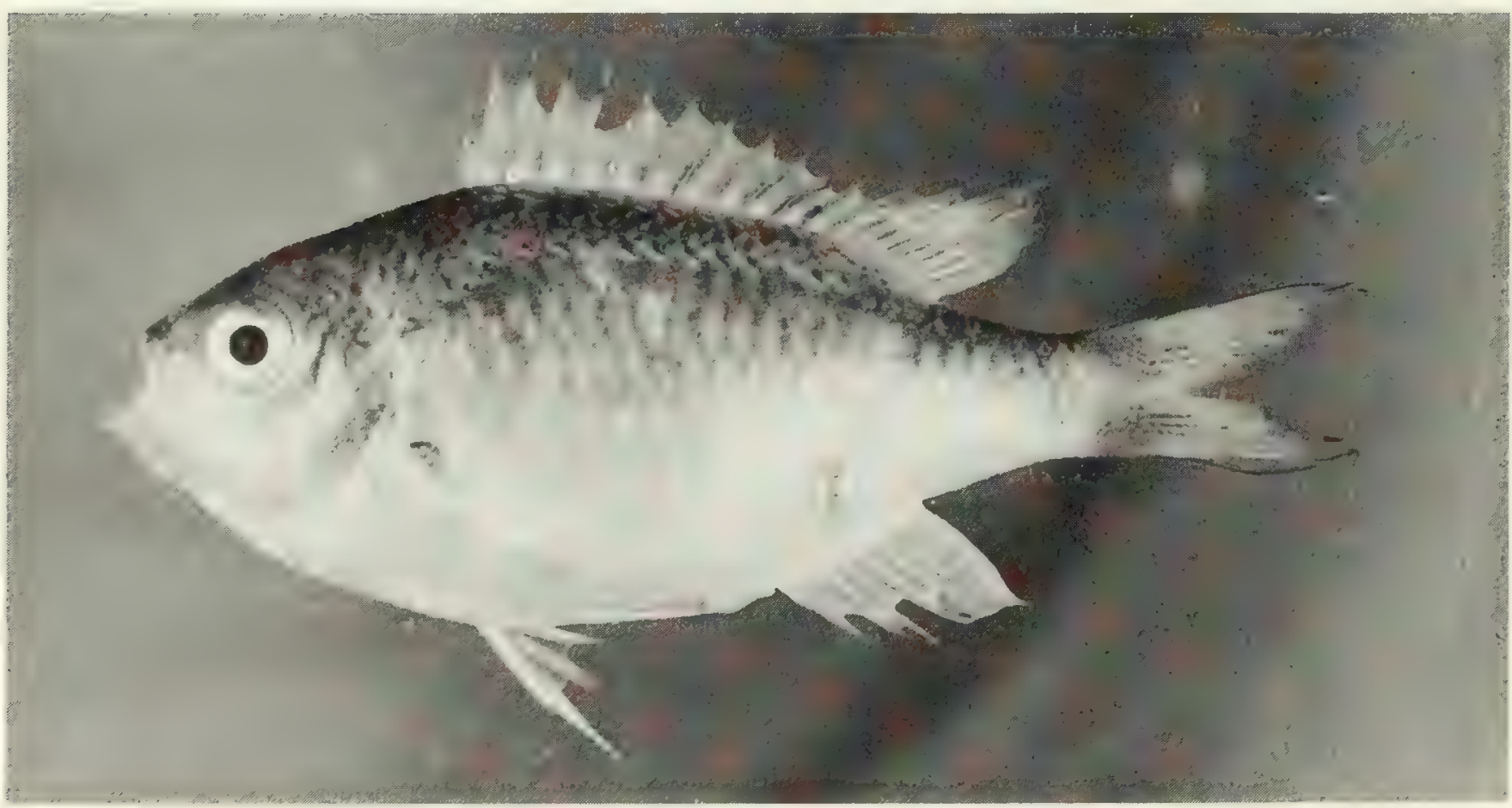

FIG. 260. Chromis viridis, $40 \mathrm{~mm} \mathrm{SL}$, Peros Banhos. 


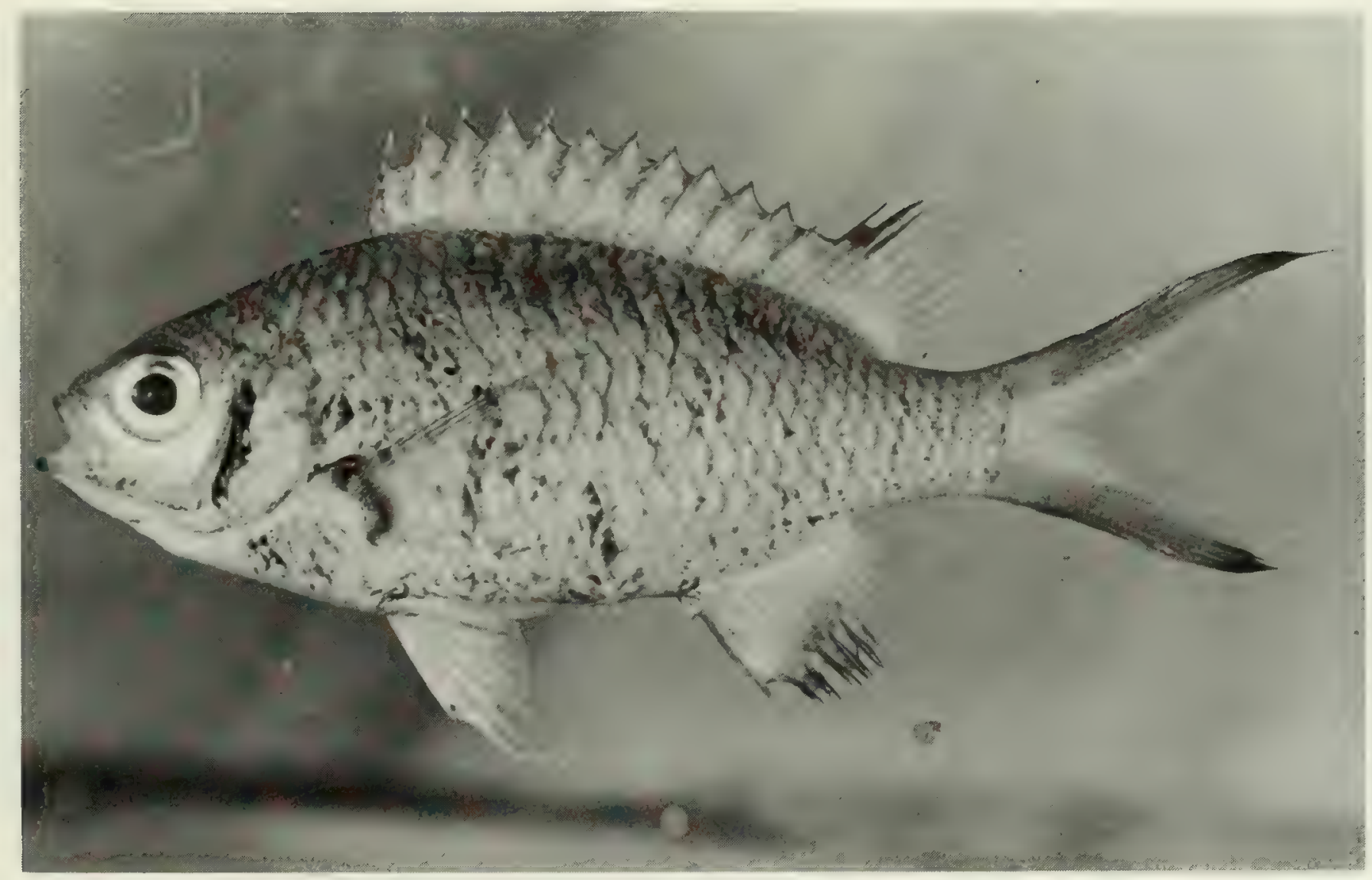

FIG. 261. Chromis weberi, $65 \mathrm{~mm}$ SL, Peros Banhos.

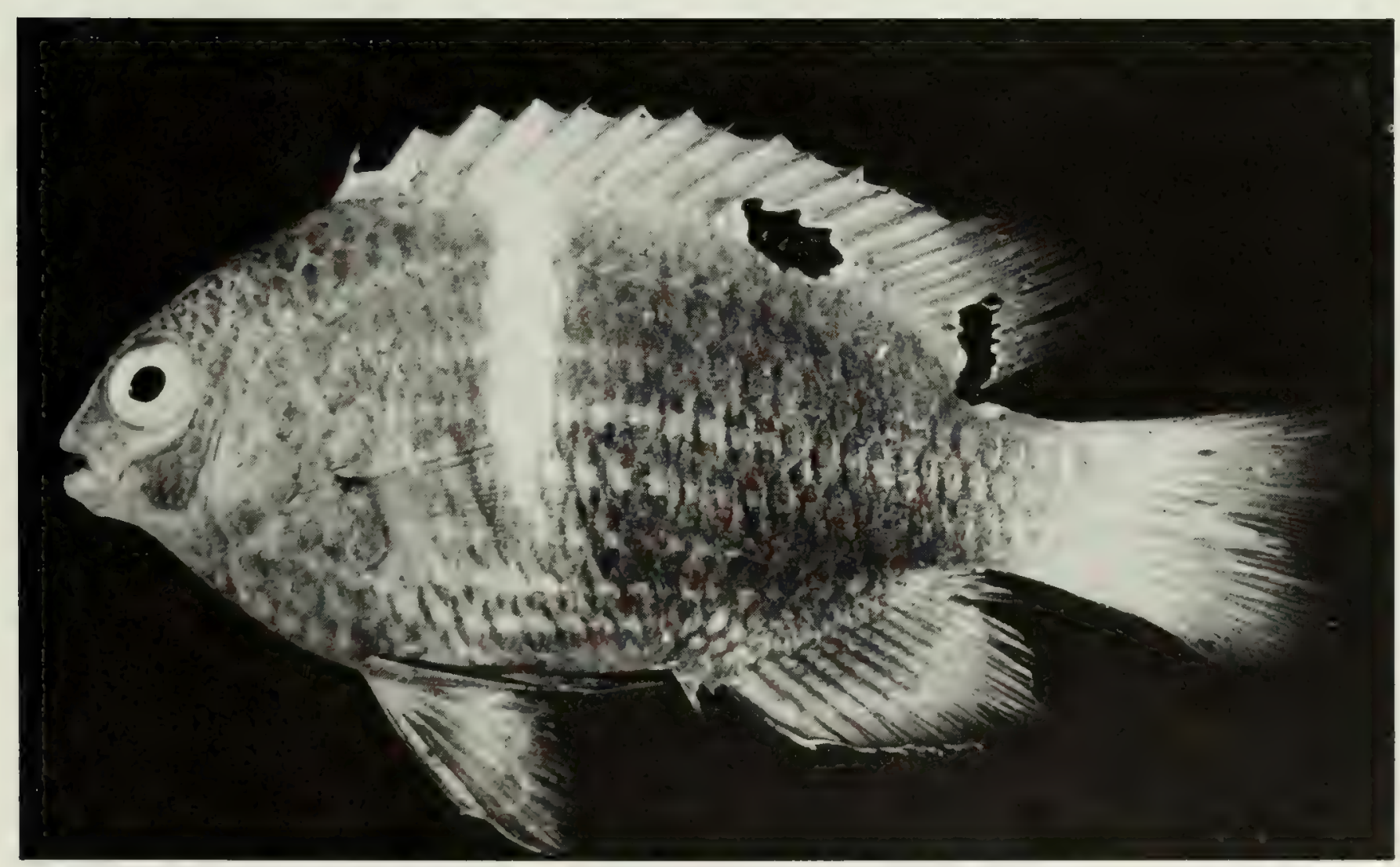

Fig. 262. Chrysiptera biocellata, $45 \mathrm{~mm} \mathrm{SL}$, Eagle Island. 


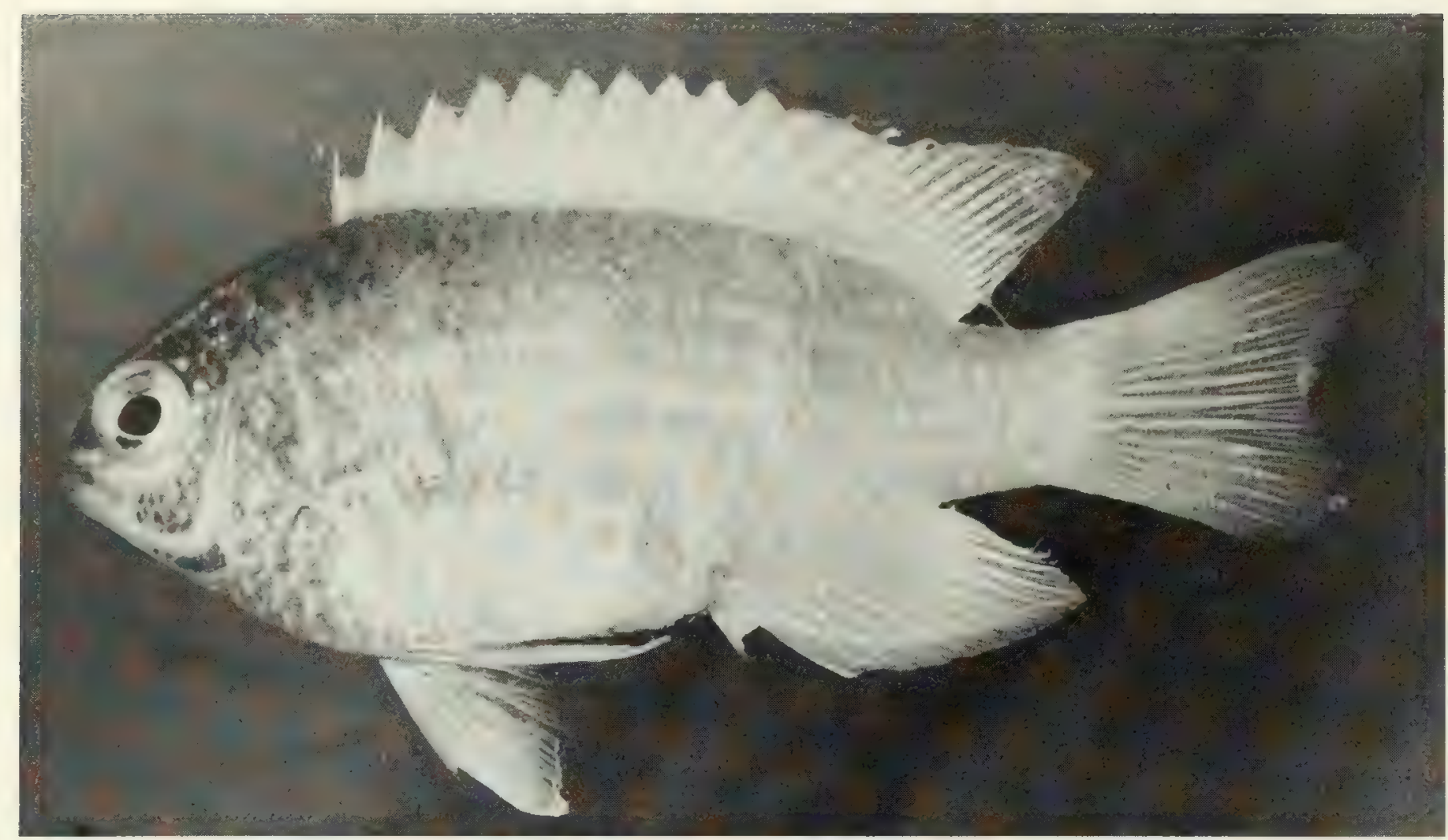

FIG. 263. Chrysiptera glauca, $45 \mathrm{~mm} \mathrm{SL}$, Peros Banhos.

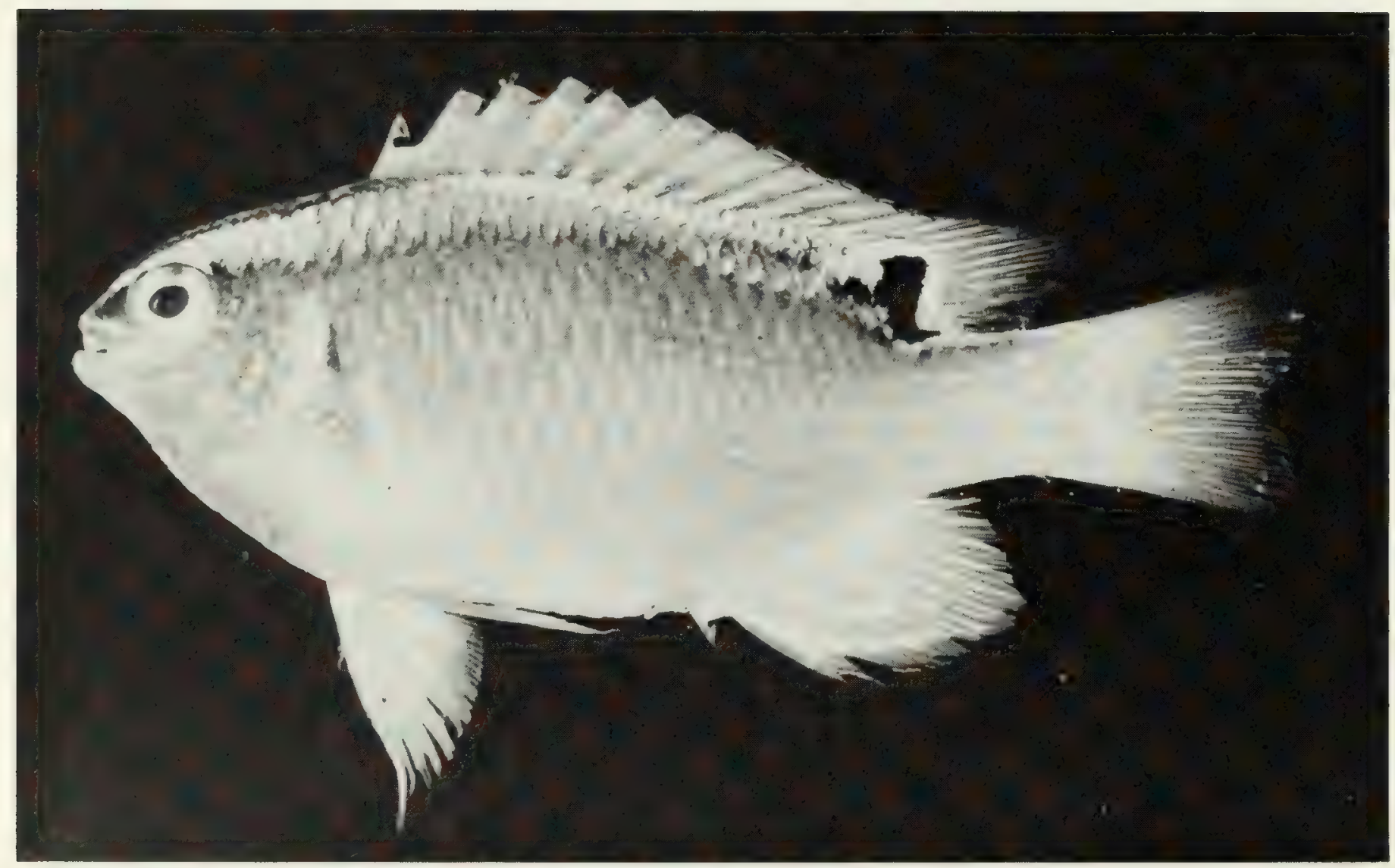

FIG. 264. Chrysiptera leucopoma, $44 \mathrm{~mm} \mathrm{SL}$, Eagle Island. 


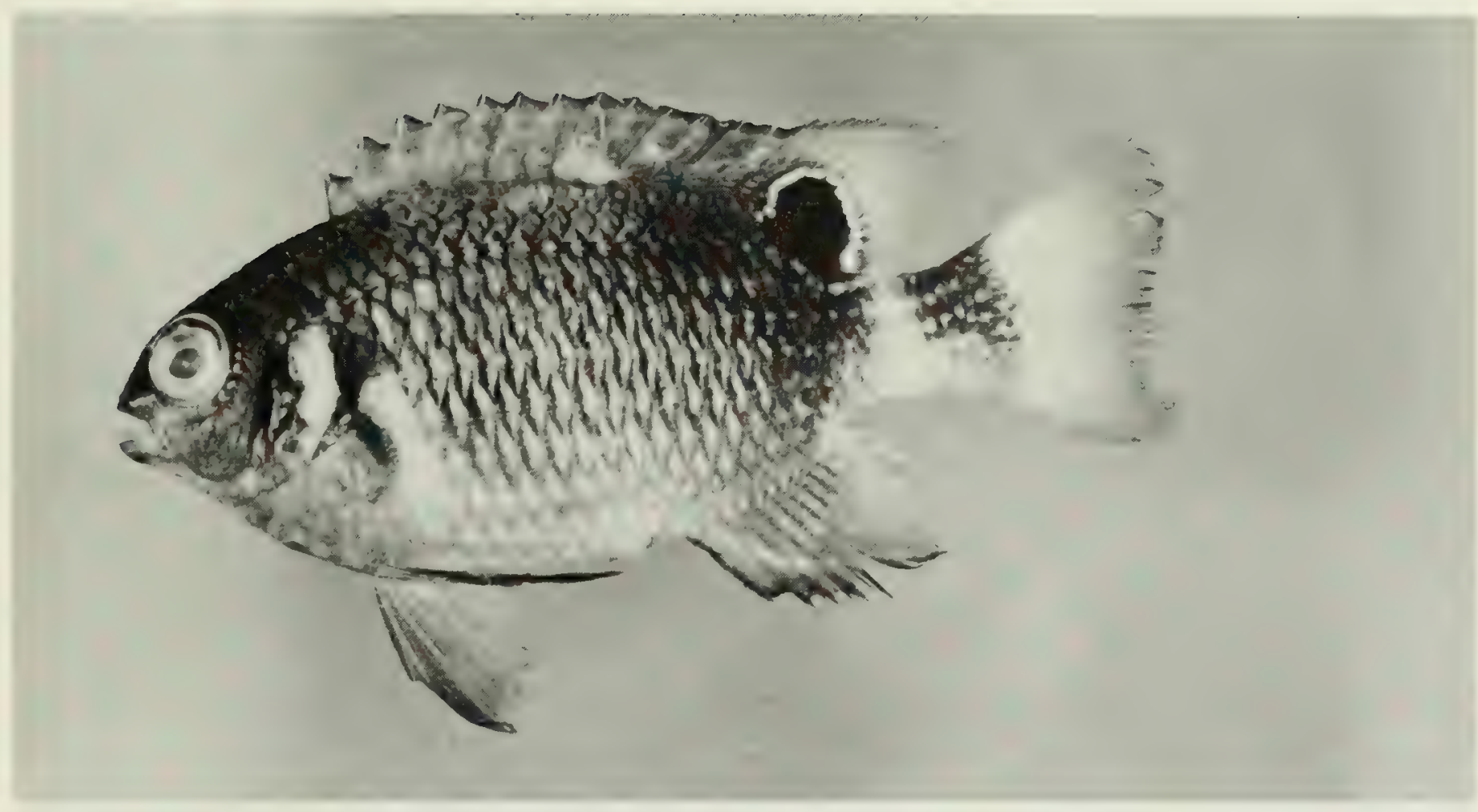

FIG. 265. Chrysiptera xanthozona, $44 \mathrm{~mm} \mathrm{SL}$, Salomon.

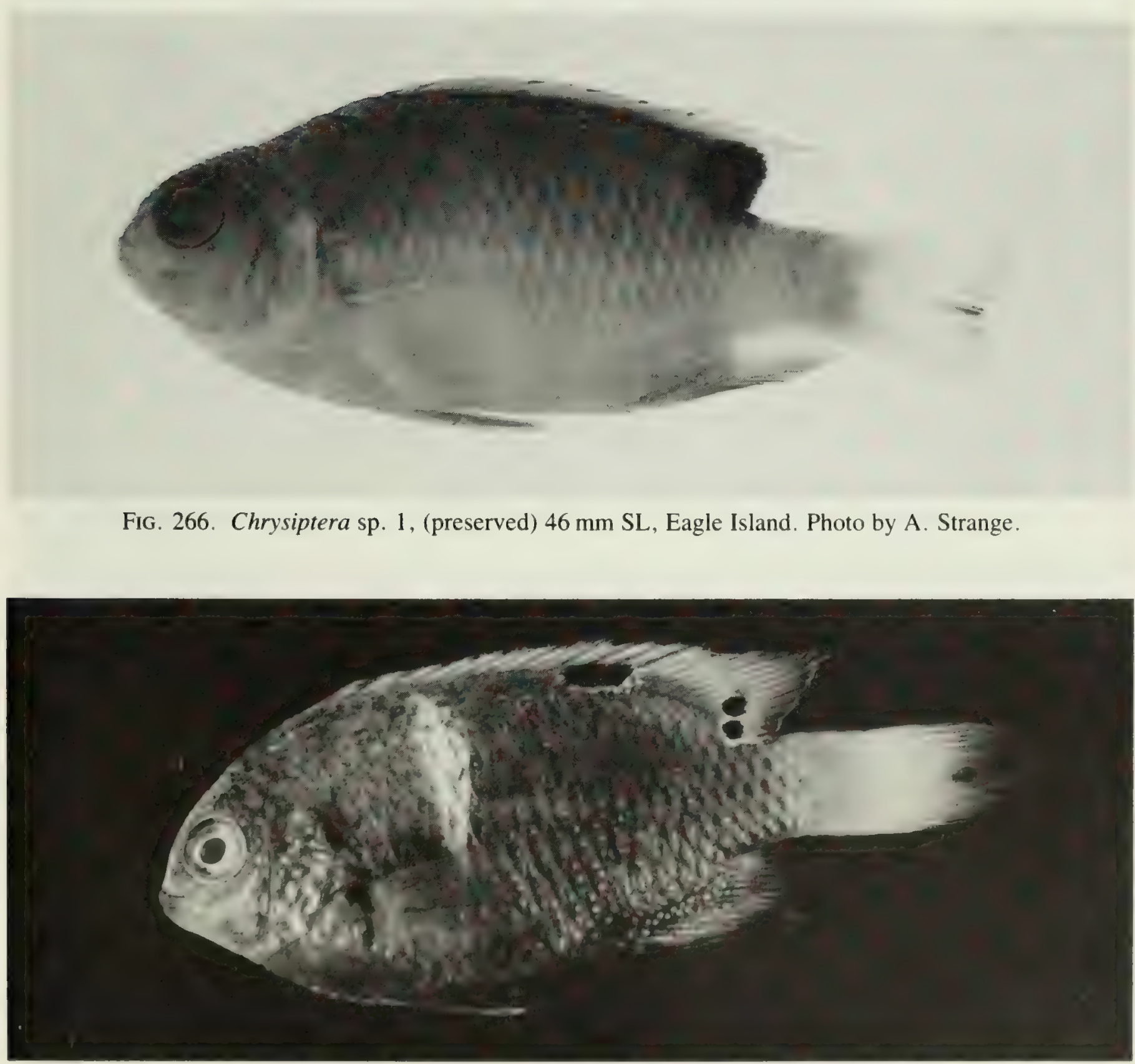

FIG. 267. Chrysiptera sp. 2, (preserved) $48 \mathrm{~mm} \mathrm{SL,} \mathrm{Peros} \mathrm{Banhos.} \mathrm{Photo} \mathrm{by} \mathrm{A.} \mathrm{Strange.}$ 


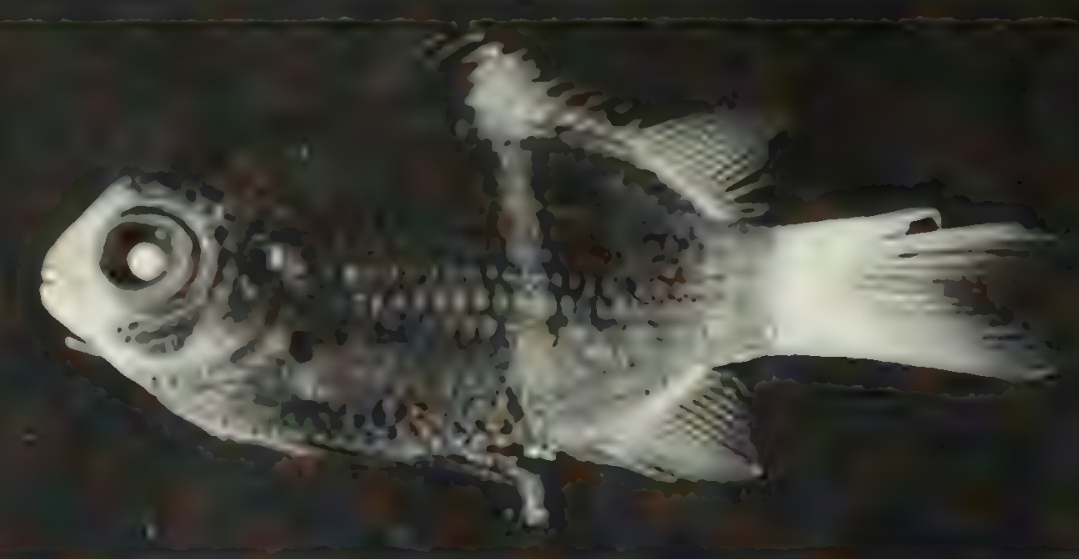

Fic, 268. Chrusiptera sp. 3. (preserved) $20 \mathrm{~mm}$ SL. Peros Banhos Photo by A Strange

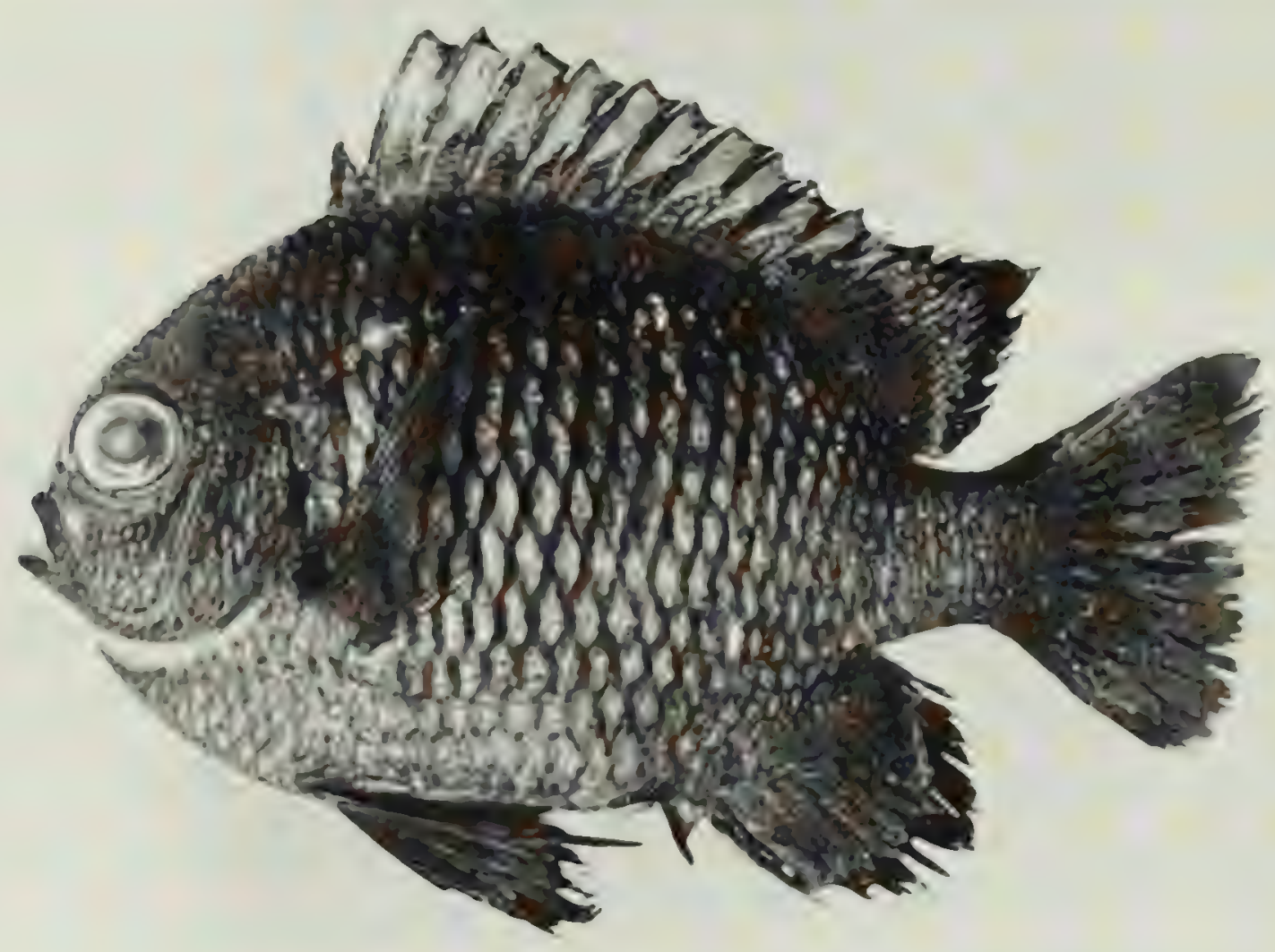

Fic. 269. Dascillus trimaculatus. $82 \mathrm{~mm}$ SL. Salomon

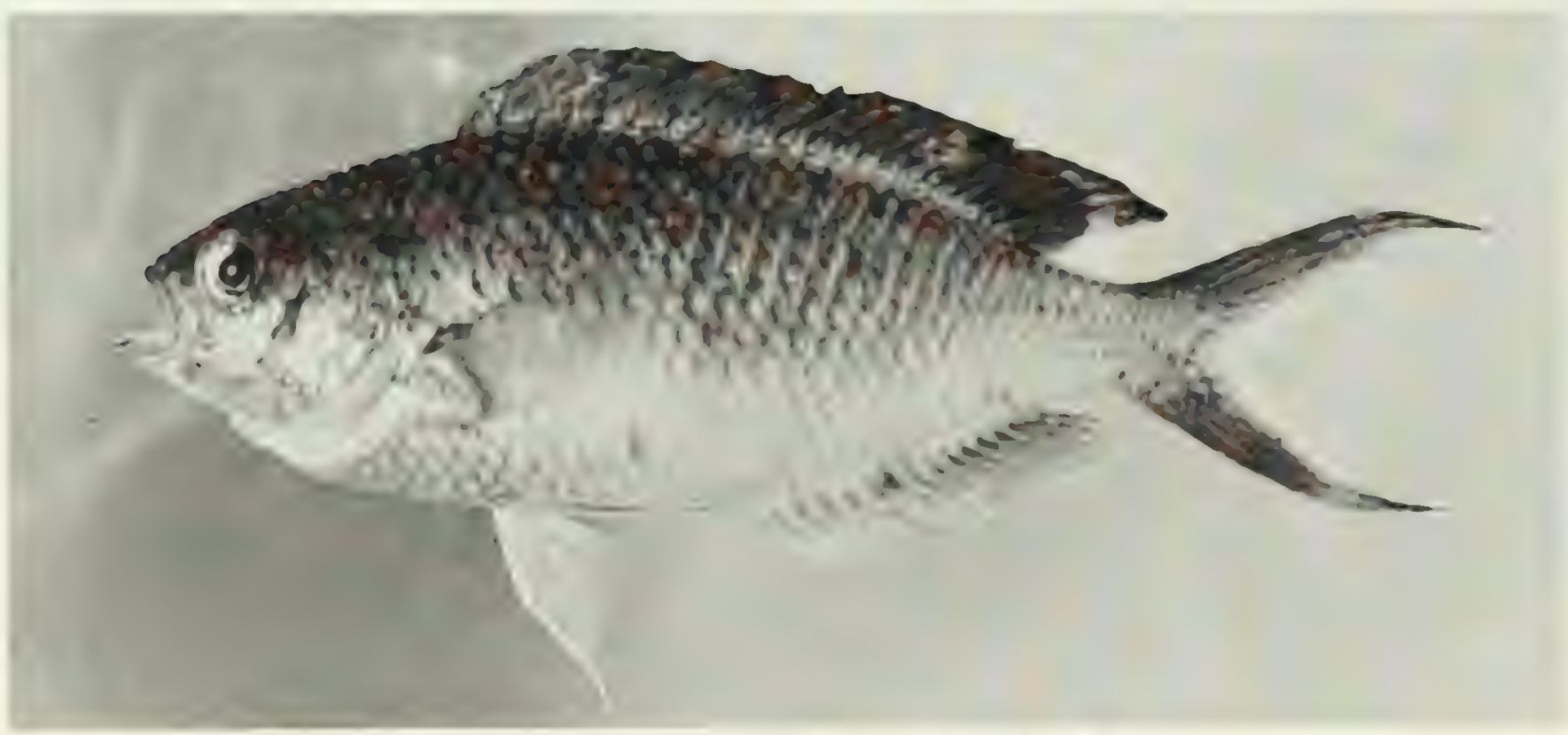

FIC, 270, Lepidazygas tapeinosoma, $61 \mathrm{~mm} \mathrm{SL.,} \mathrm{Salomun}$ 


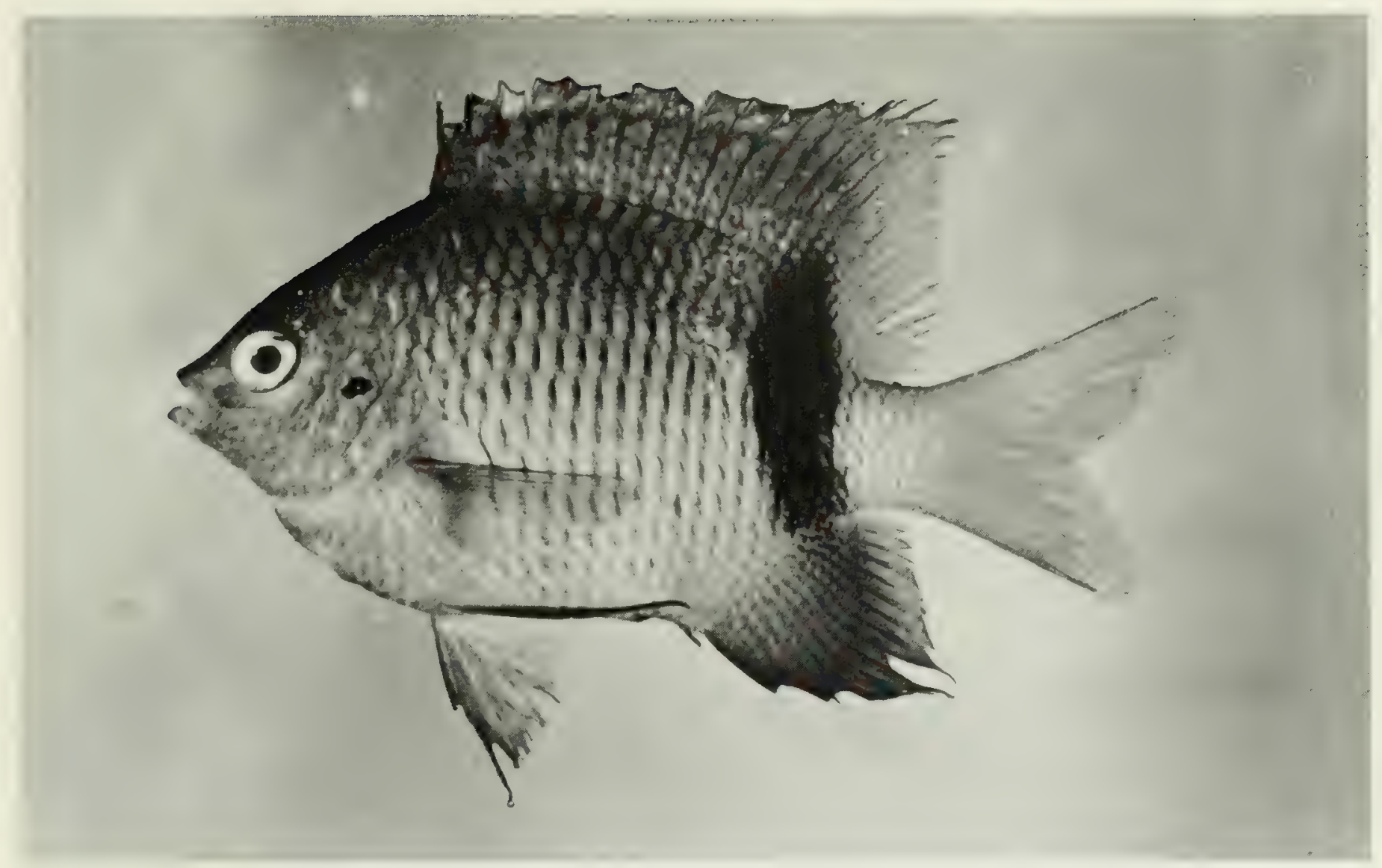

FIG. 271. Plectroglyphidodon dickii, $51 \mathrm{~mm} \mathrm{SL}$, Peros Banhos.

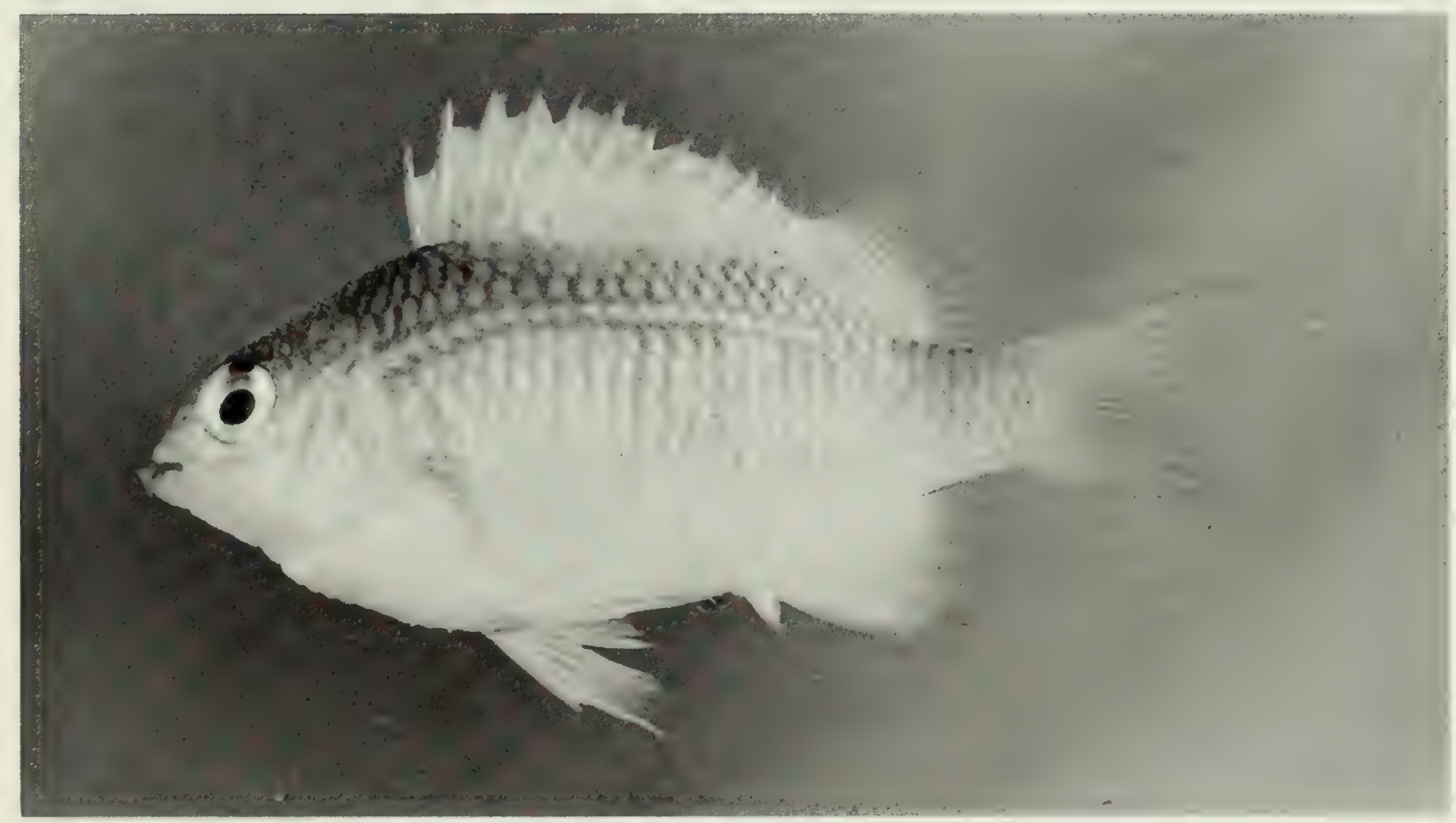

FiG. 272. Plectroglyphidodon imparipennis, $42 \mathrm{~mm}$ SL, Salomon. 


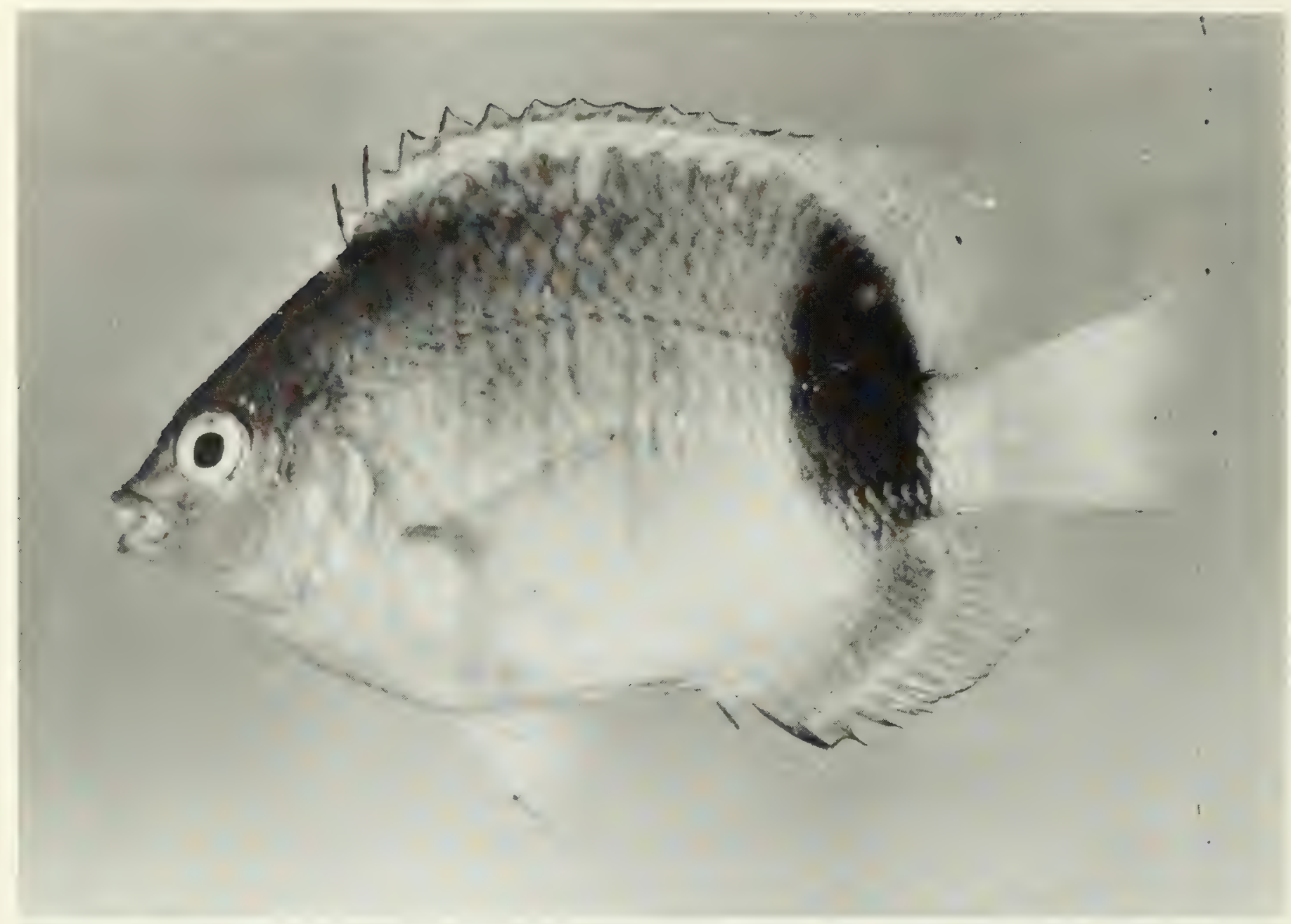

FIG. 273. Plectroglyphidodon johnstonianus, $50 \mathrm{~mm} \mathrm{SL}$, Peros Banhos.

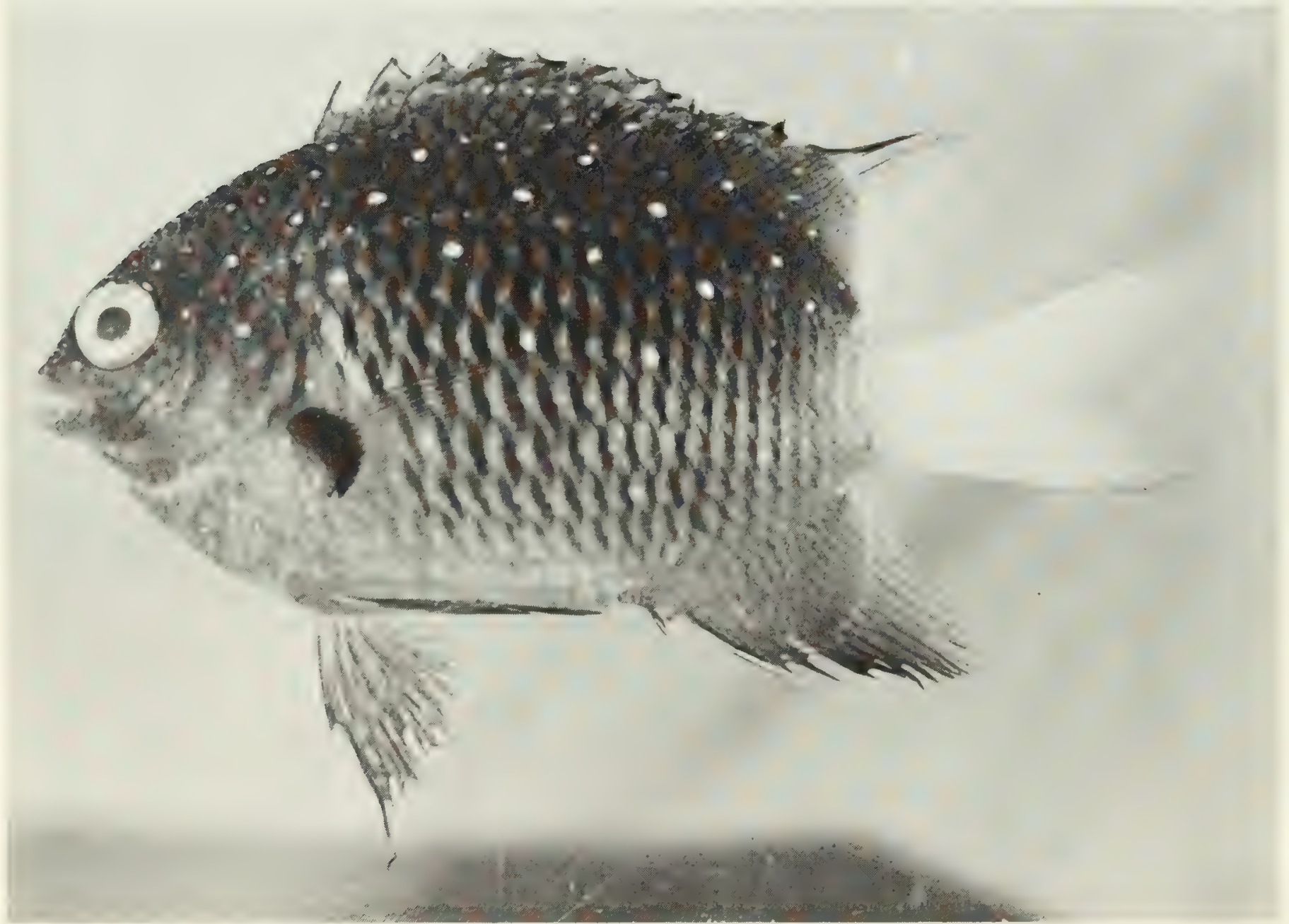

FIG. 274. Plectroglyphidodon lacrymatus, $50 \mathrm{~mm}$ SL, Peros Banhos. 


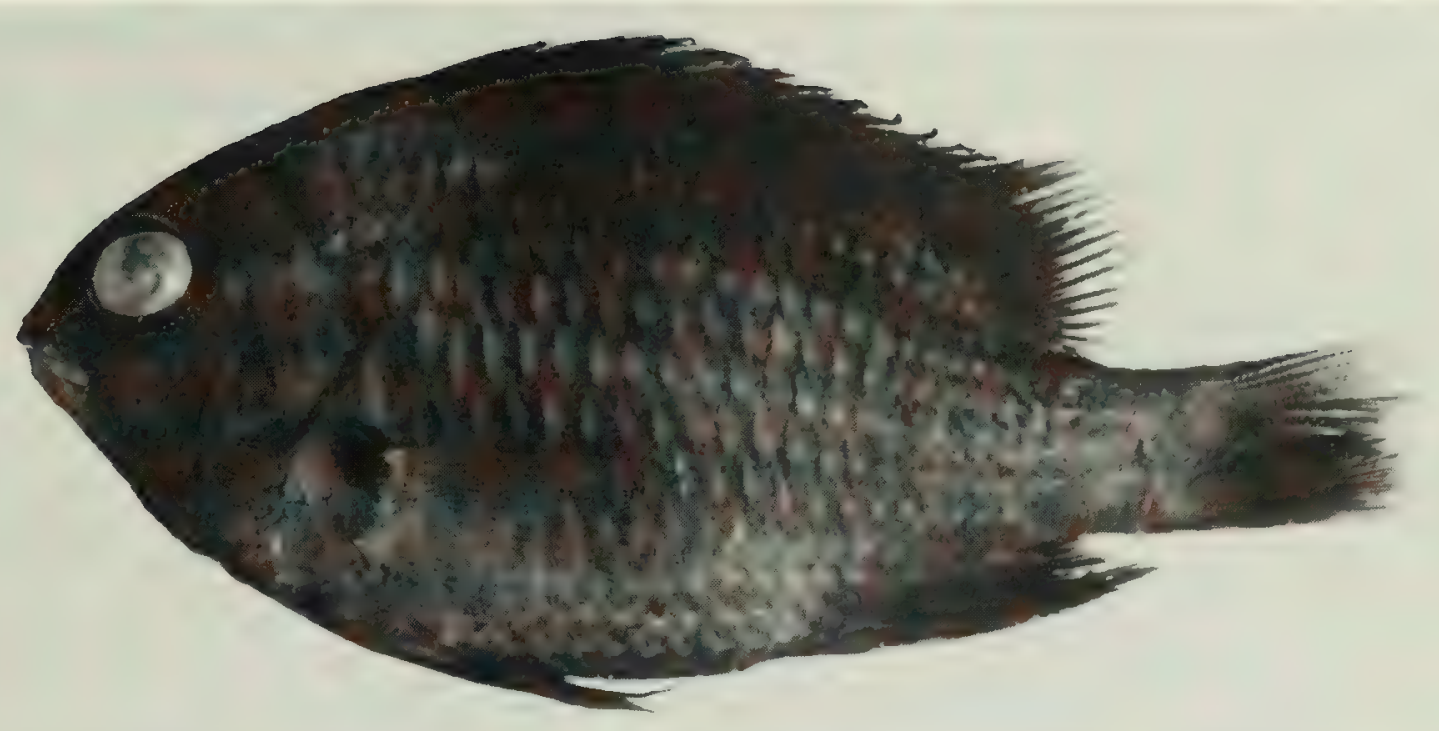

FiG. 275. Plectroglyphidodon leucozonus, (preserved) $59 \mathrm{~mm}$ SL, Salomon. Photo by M. BurridgeSmith.

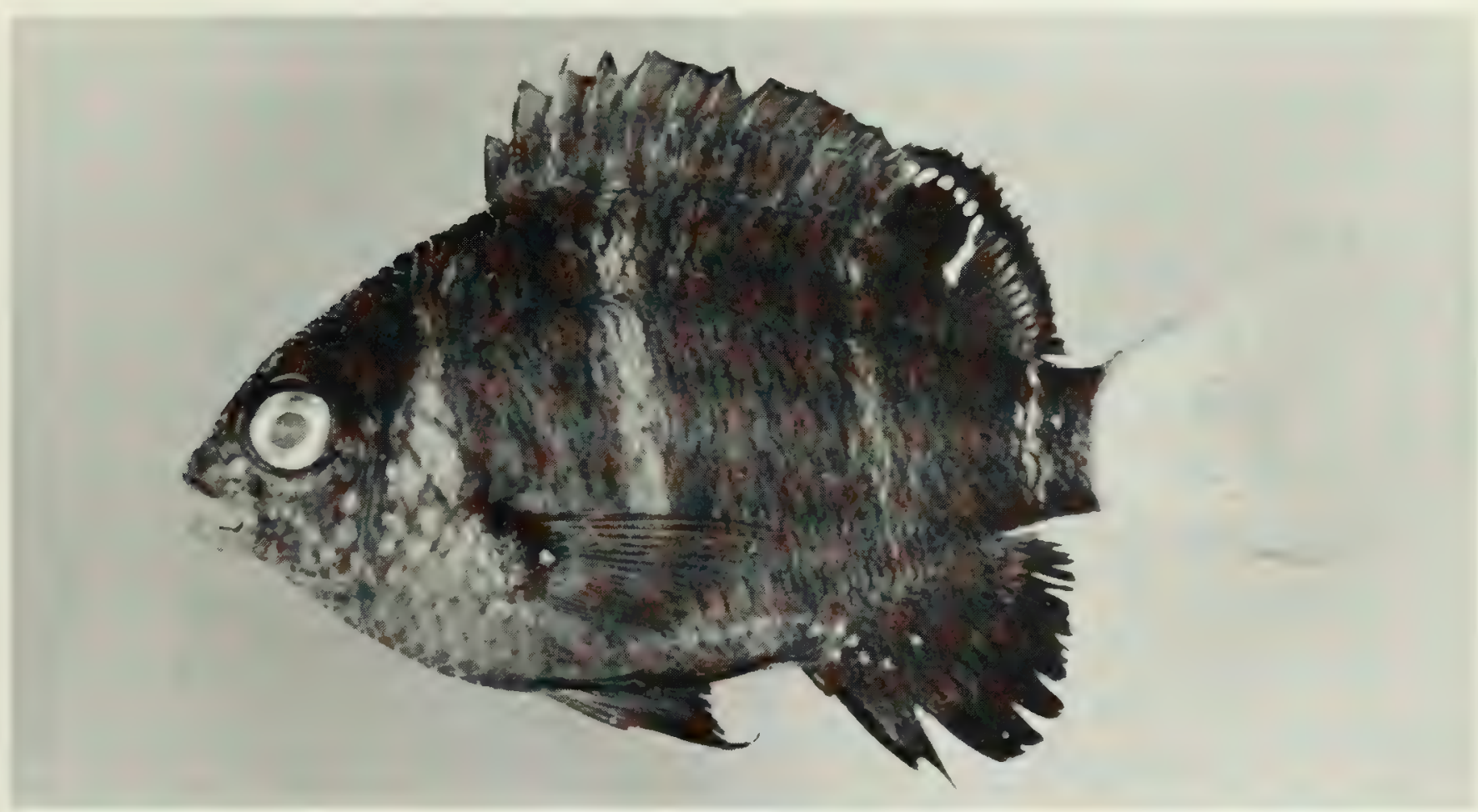

FIG. 276. Plectroglyphidodon phoenixensis, $47 \mathrm{~mm}$ SL, Peros Banhos.

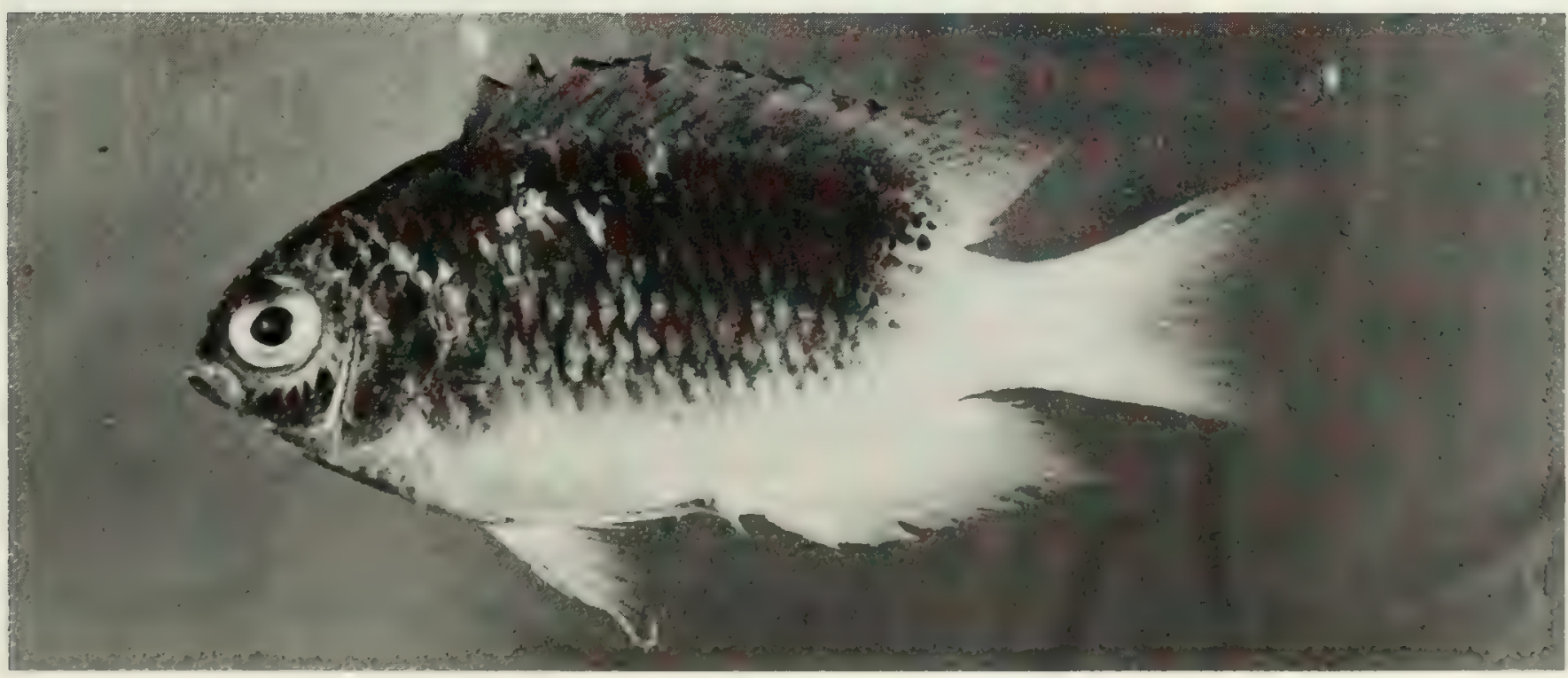

Fig. 277. Pomacentrus coelestis, $34 \mathrm{~mm} \mathrm{SL}$, Peros Banhos. 


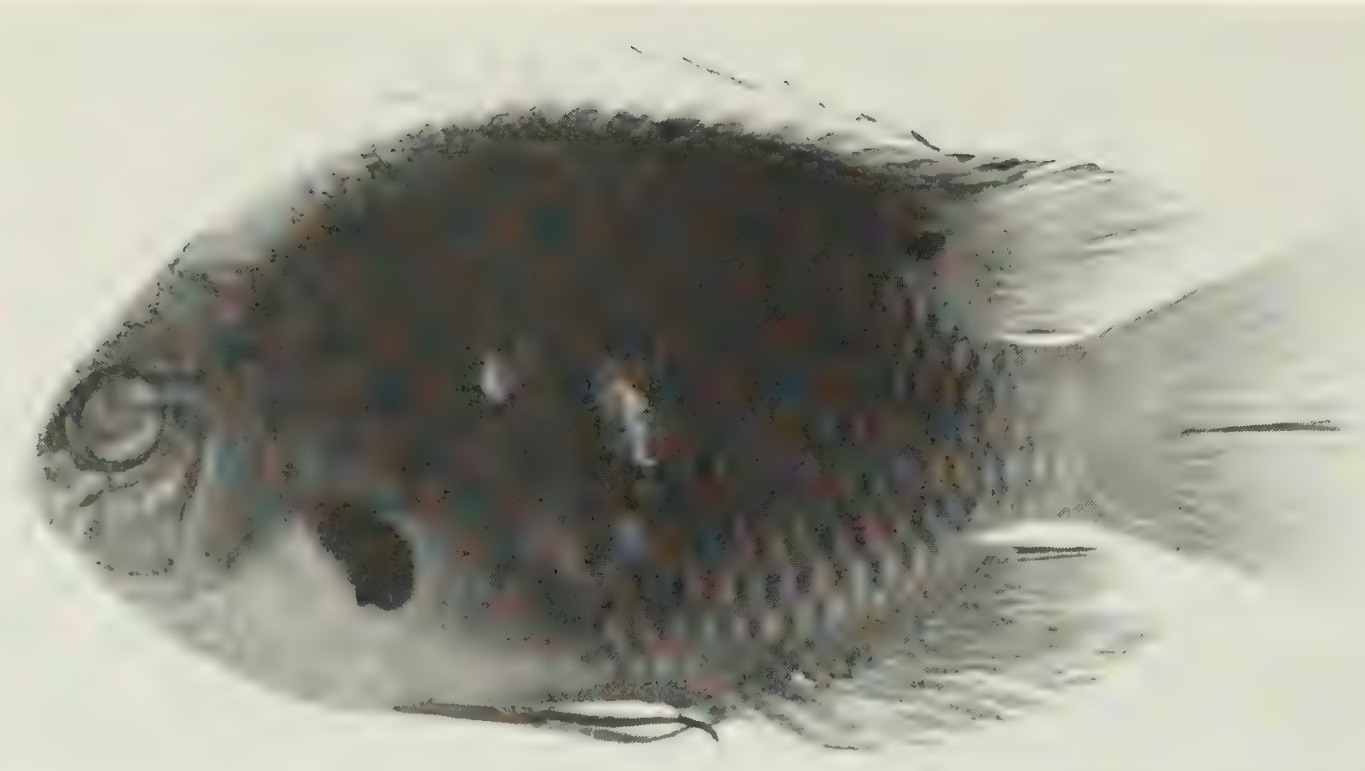

FIG. 278. Pomacentrus sp. 2, (preserved) $65 \mathrm{~mm} \mathrm{SL}$, Salomon. Photo by A. Strange.

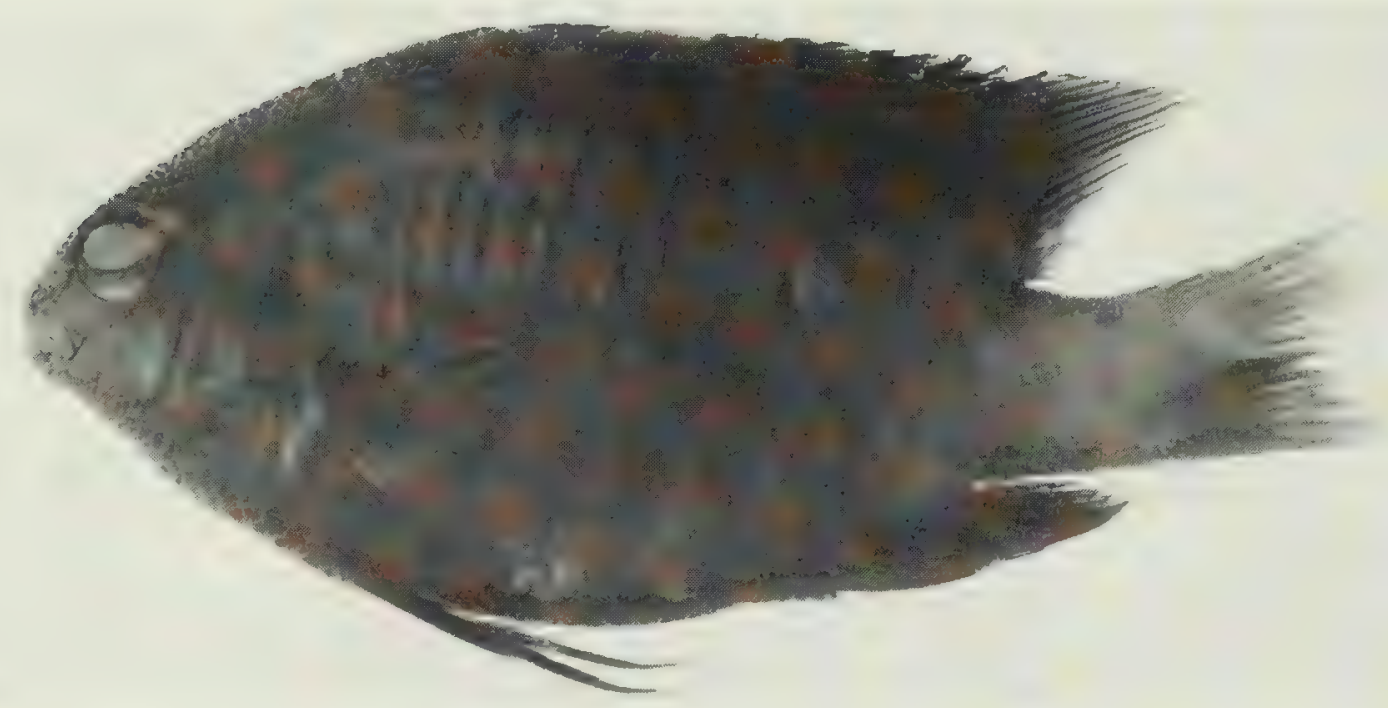

FIG. 279. Stegastes fasciolatus, (preserved) $73 \mathrm{~mm} \mathrm{SL}$, Salomon. Photo by A. Strange.

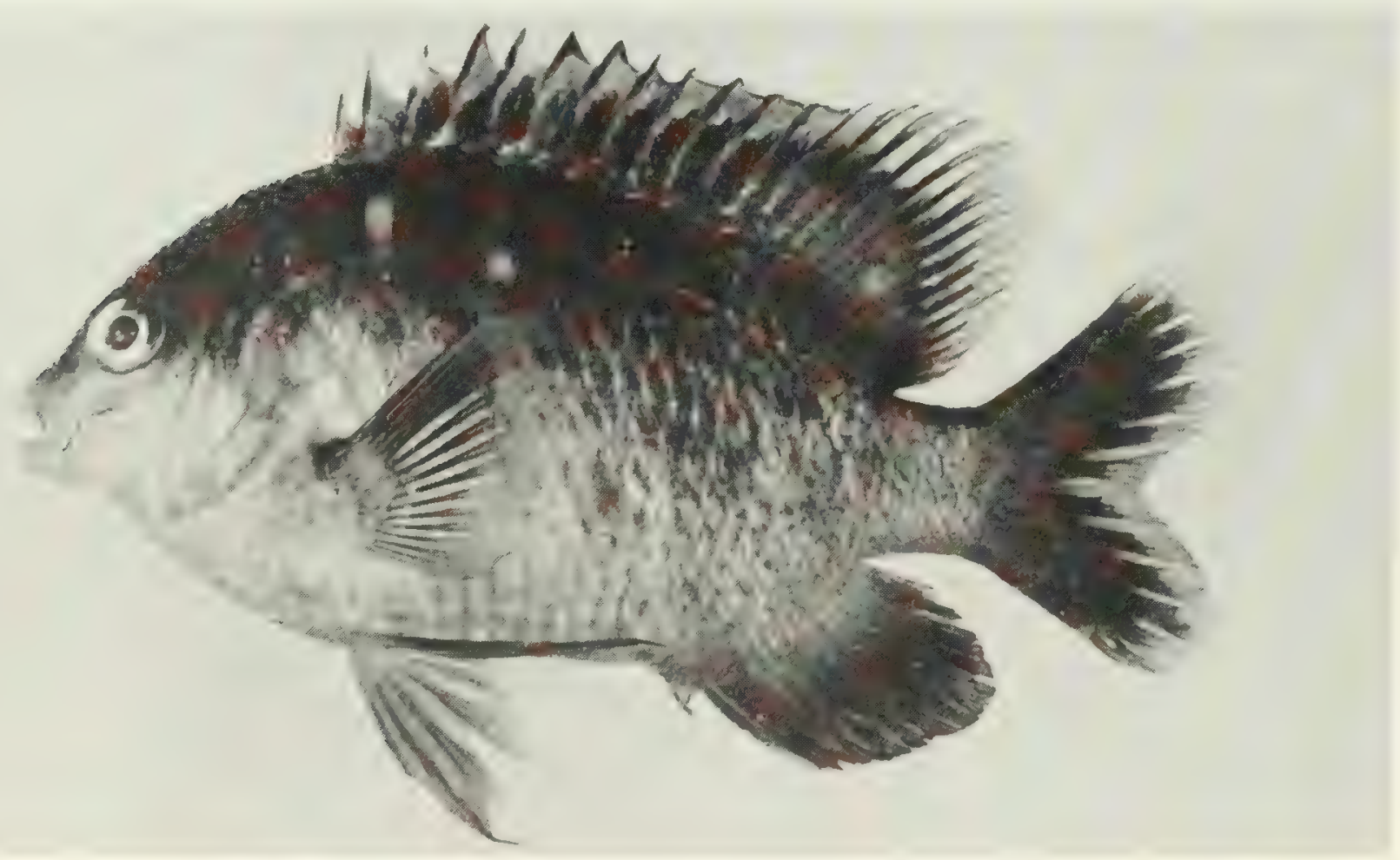

FIG. 280. Stegastes nigricans, $83 \mathrm{~mm} \mathrm{SL}$, Peros Banhos. 


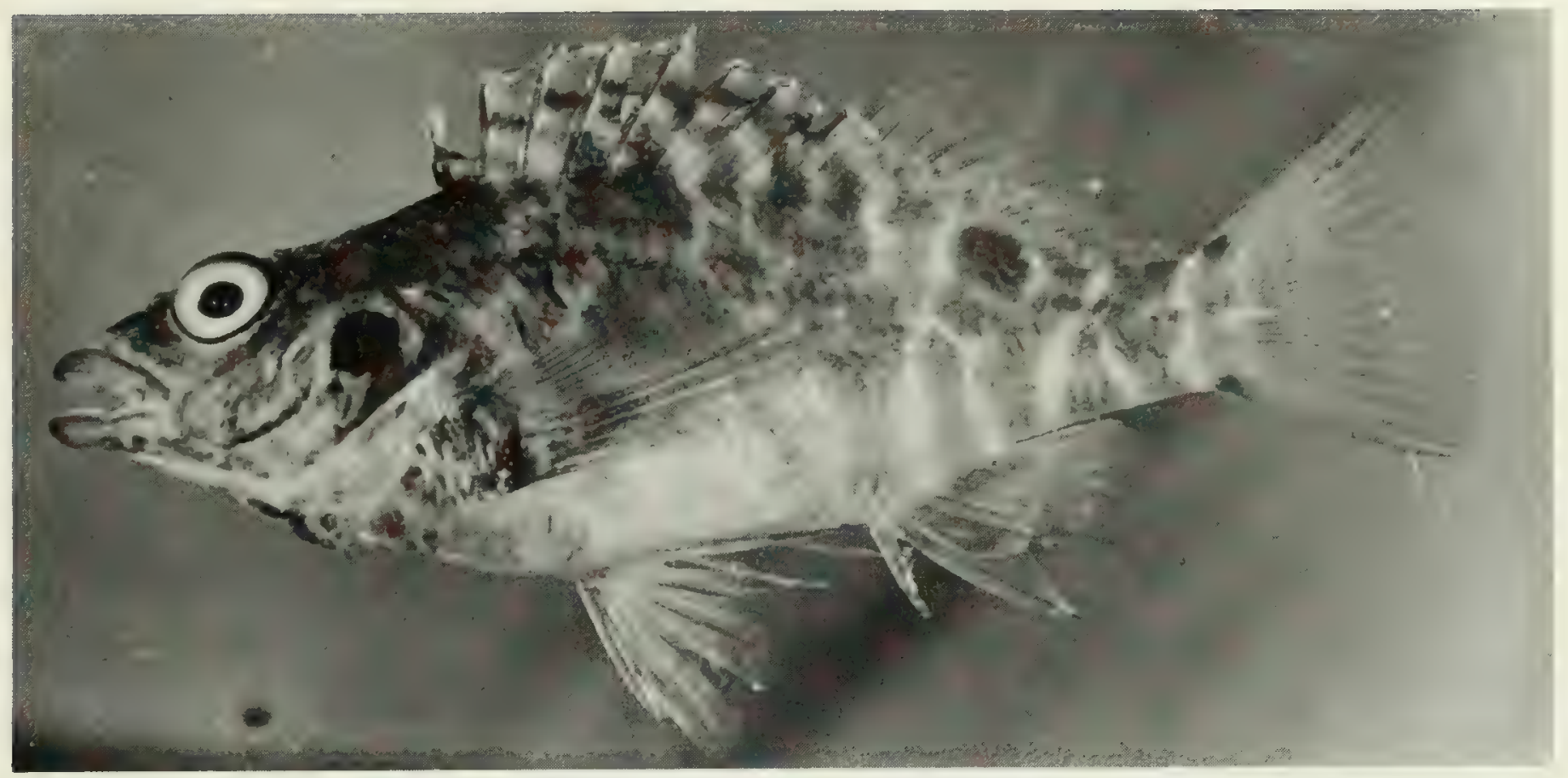

FIG. 281. Amblycirrhitus bimaculus, $53 \mathrm{~mm} \mathrm{SL}$, Peros Banhos.

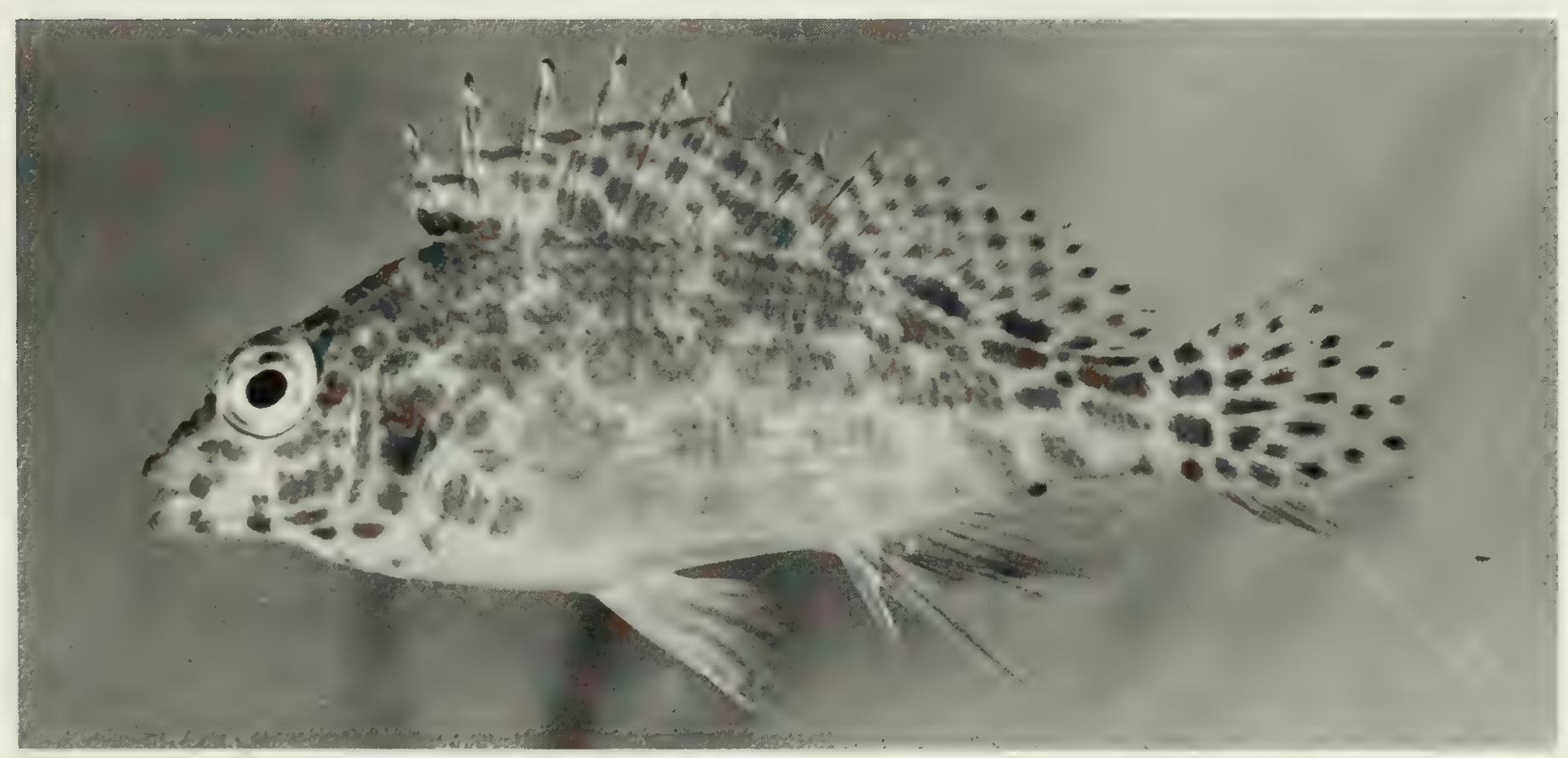

FIG. 282. Cirrhitichthys oxycephalus, $48 \mathrm{~mm} \mathrm{SL}$, Peros Banhos.

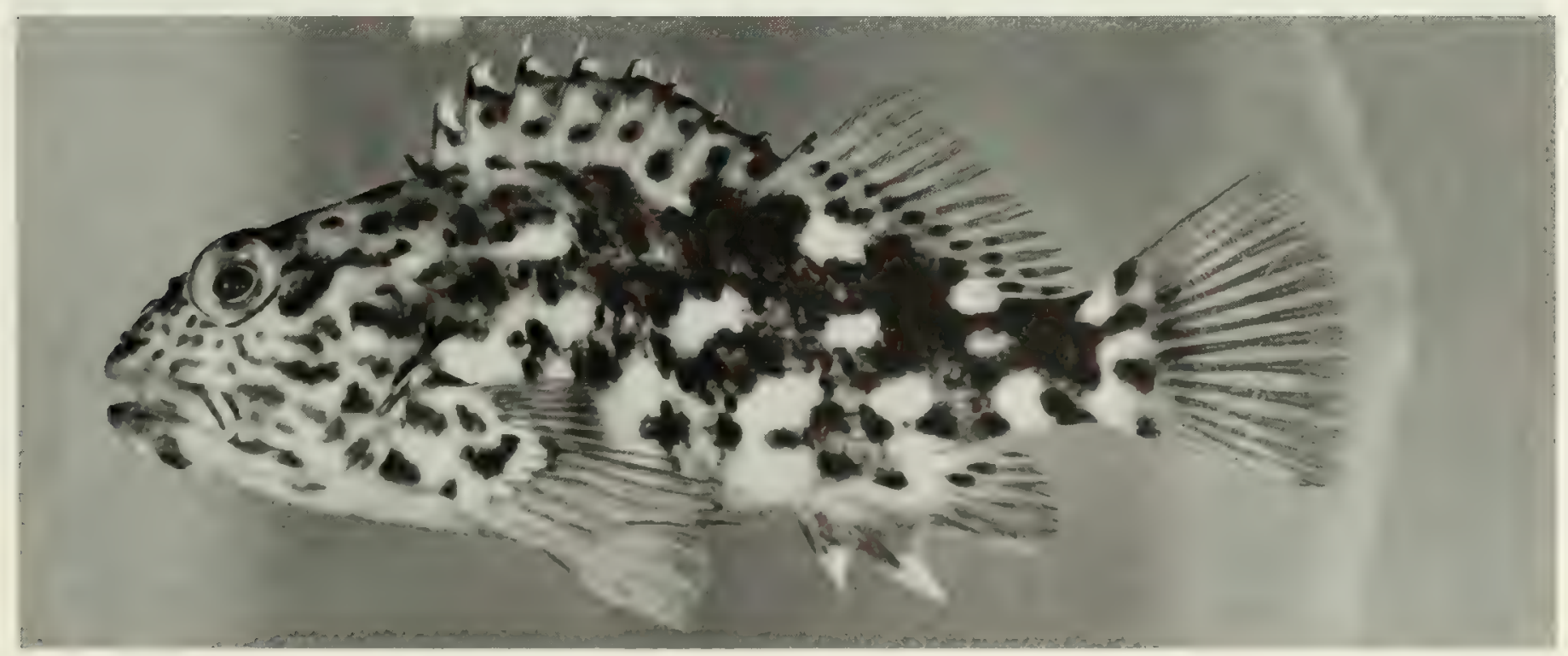

FIG. 283. Cirrhitus pinnulatus, $88 \mathrm{~mm} \mathrm{SL}$, Salomon. 


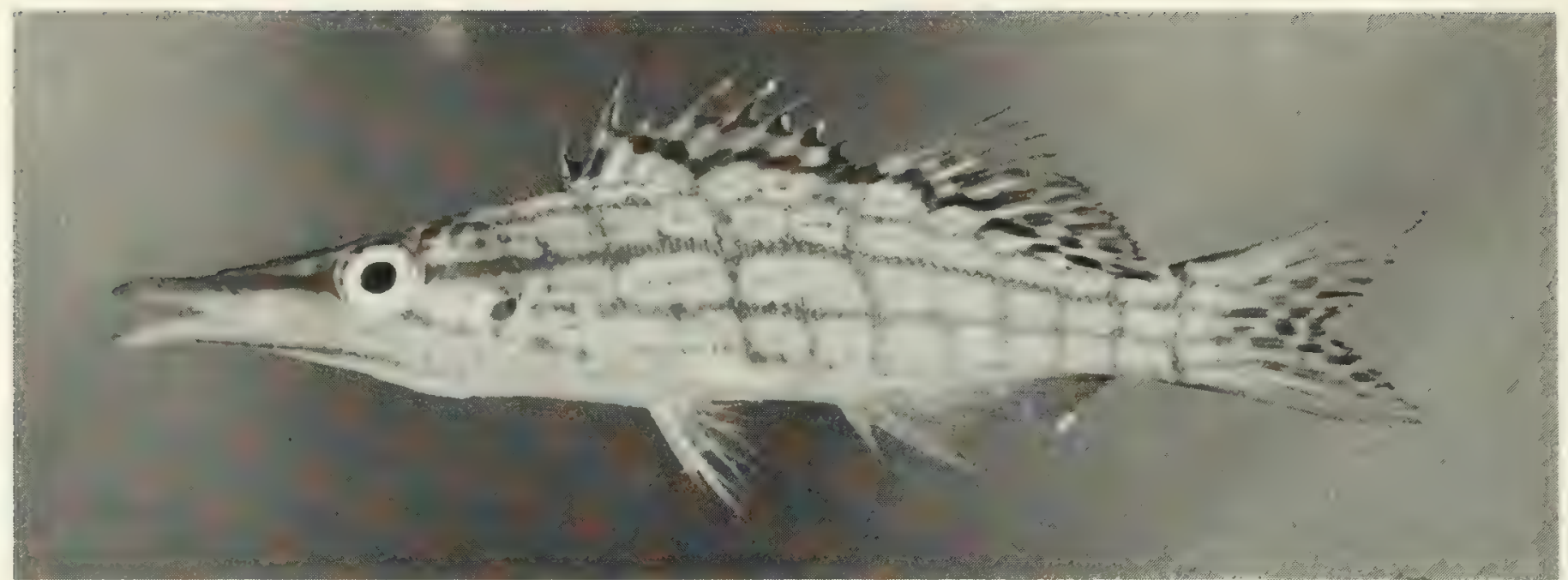

FIG. 284. Oxycirrhites typus, $44 \mathrm{~mm} \mathrm{SL}$, Salomon.

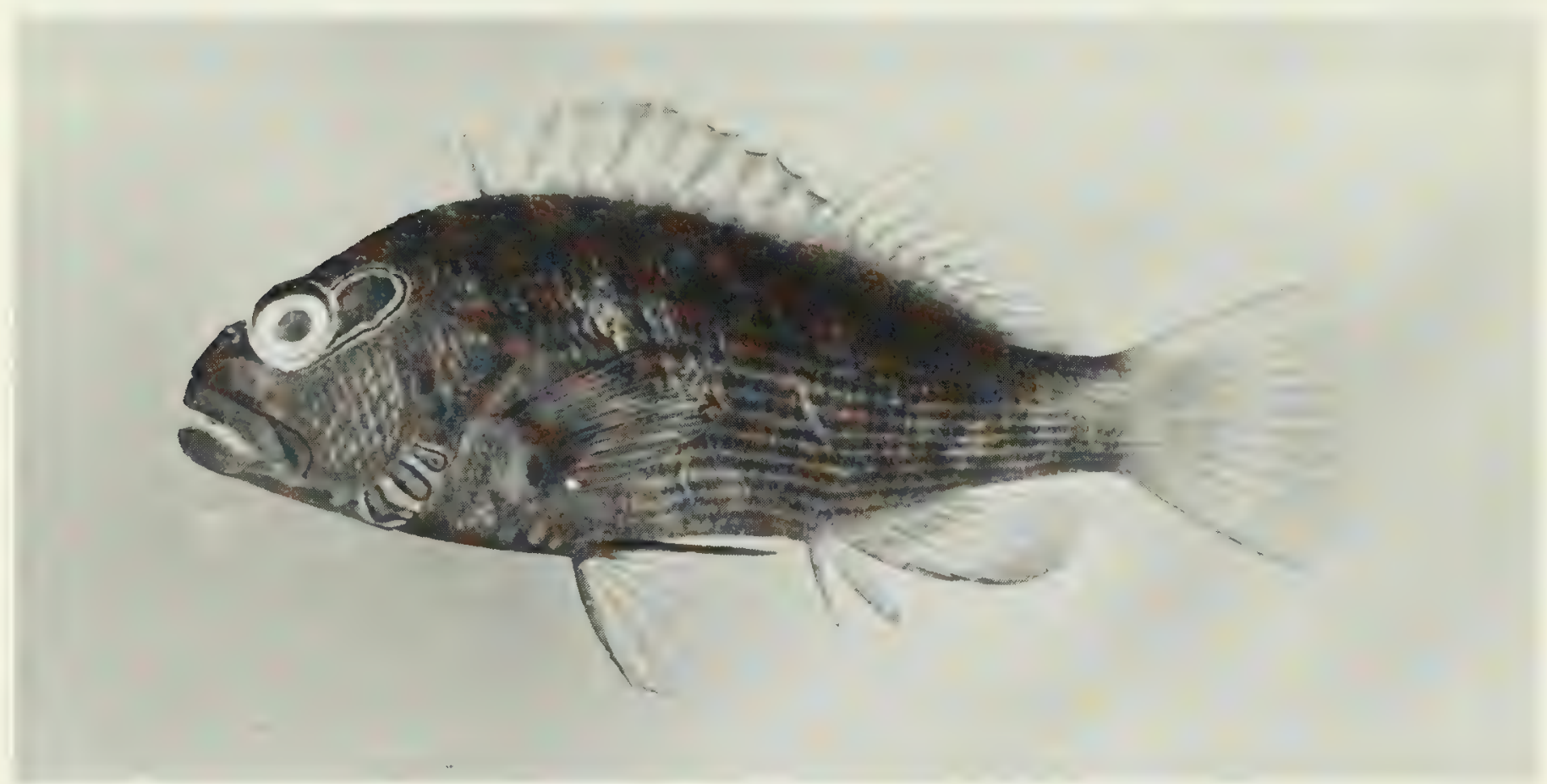

Fig. 285. Paracirrhites arcatus, $65 \mathrm{~mm} \mathrm{SL}$, Salomon.

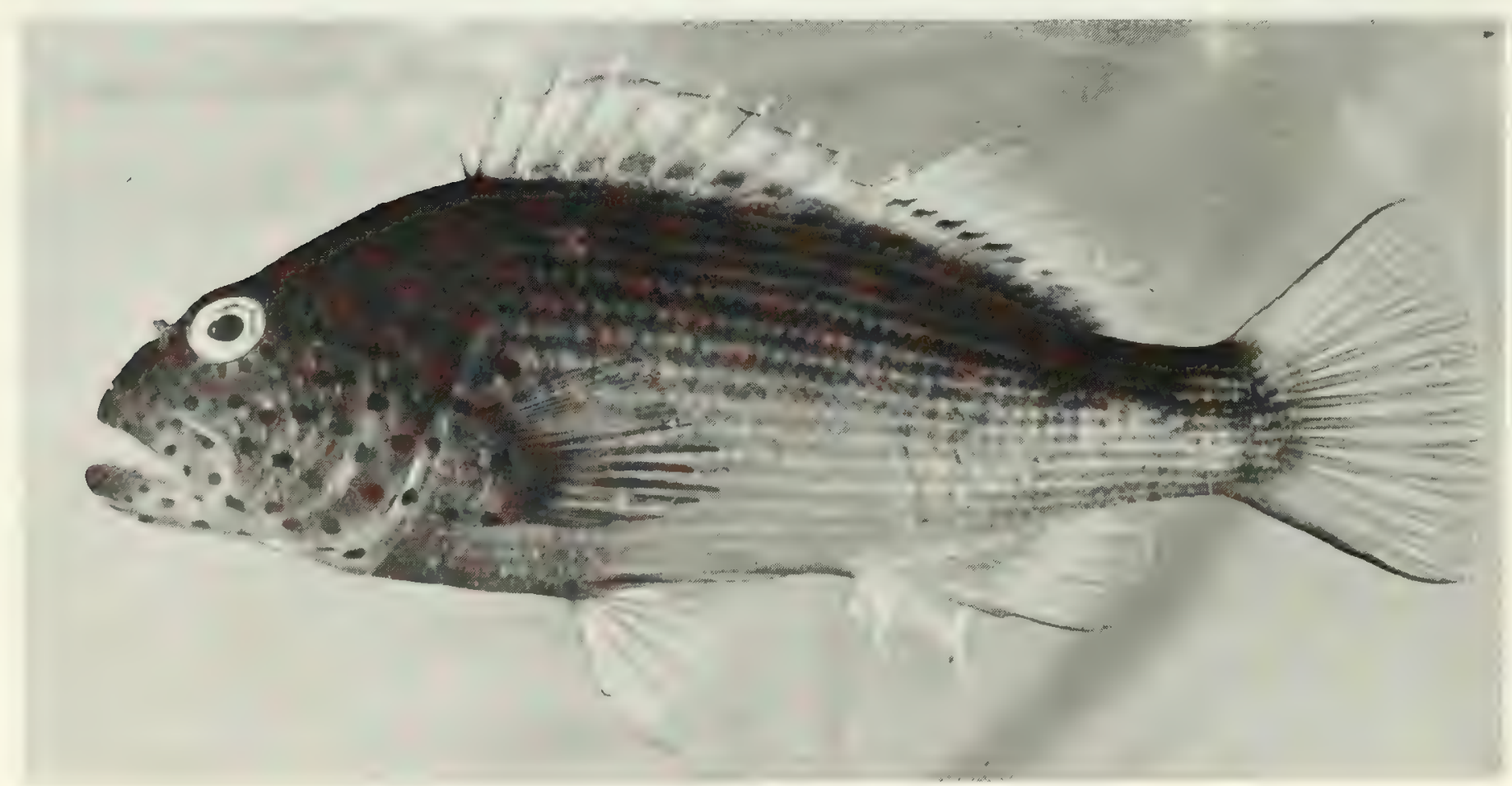

FIG. 286. Paracirrhites forsteri, $83 \mathrm{~mm} \mathrm{SL}$, Peros Banhos. 


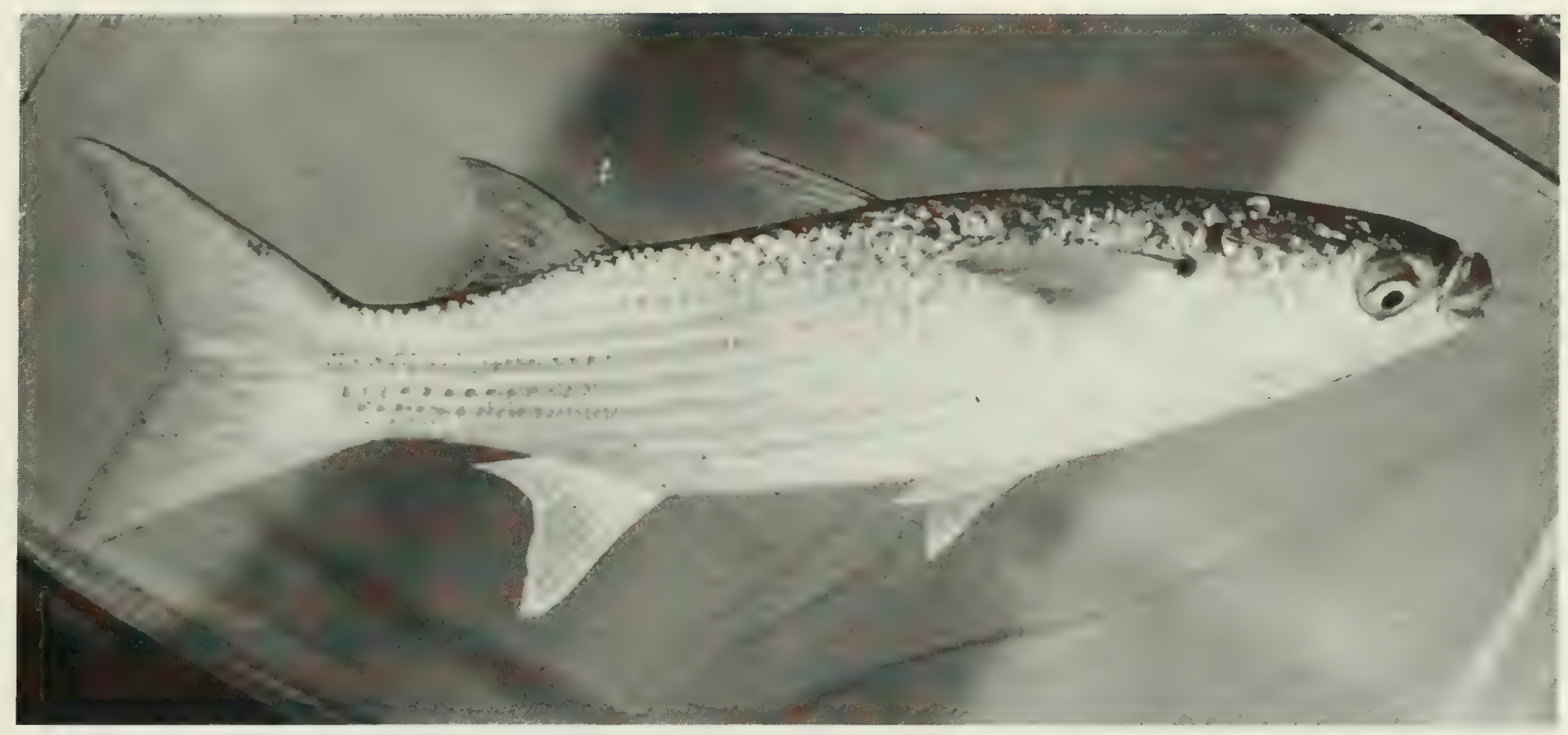

FIG. 287. Crenimugil crenilabis, $309 \mathrm{~mm}$ SL, Peros Banhos.

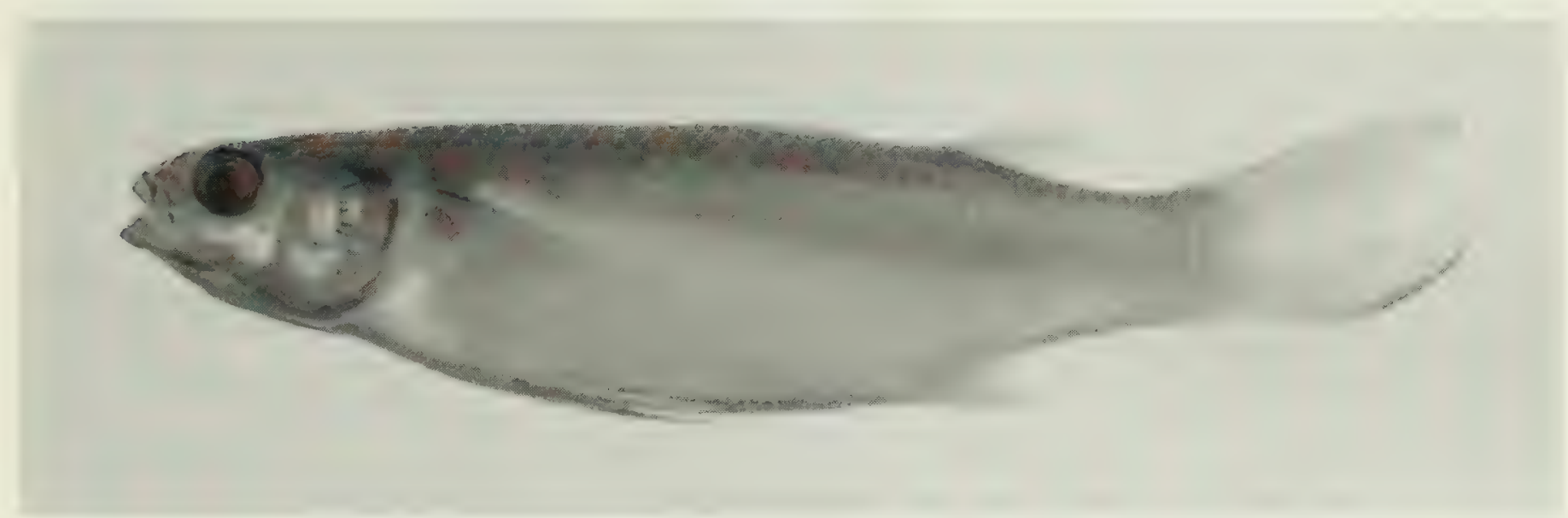

Fig. 288. Liza macrolepis, (preserved) $138 \mathrm{~mm} \mathrm{SL,} \mathrm{Diego} \mathrm{Garcia.} \mathrm{Photo} \mathrm{by} \mathrm{A.} \mathrm{Strange.}$

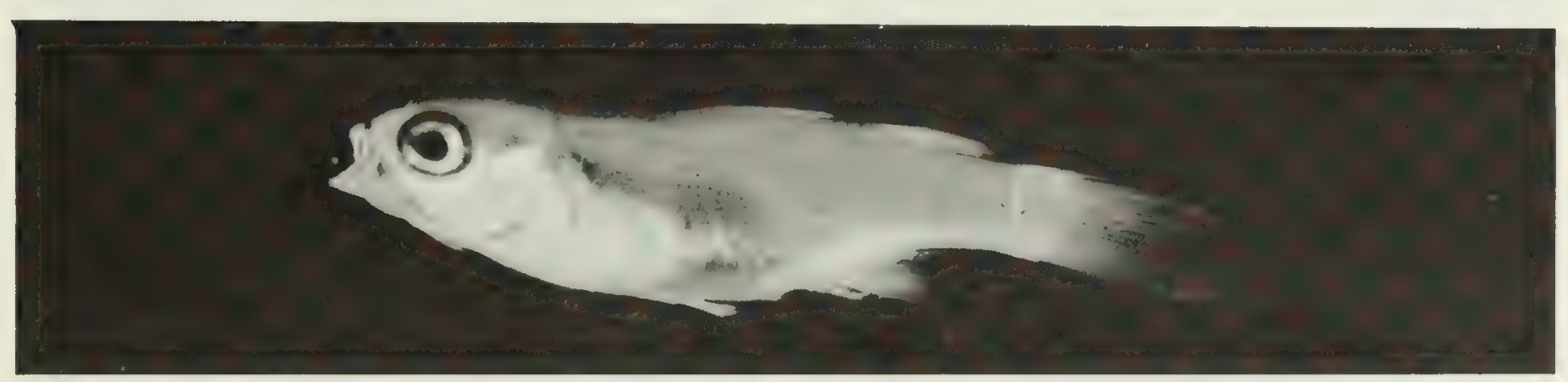

FIG. 289. ?Myxus elongatus, (preserved) $24 \mathrm{~mm} \mathrm{SL}$, Peros Banhos. Photo by A. Strange.

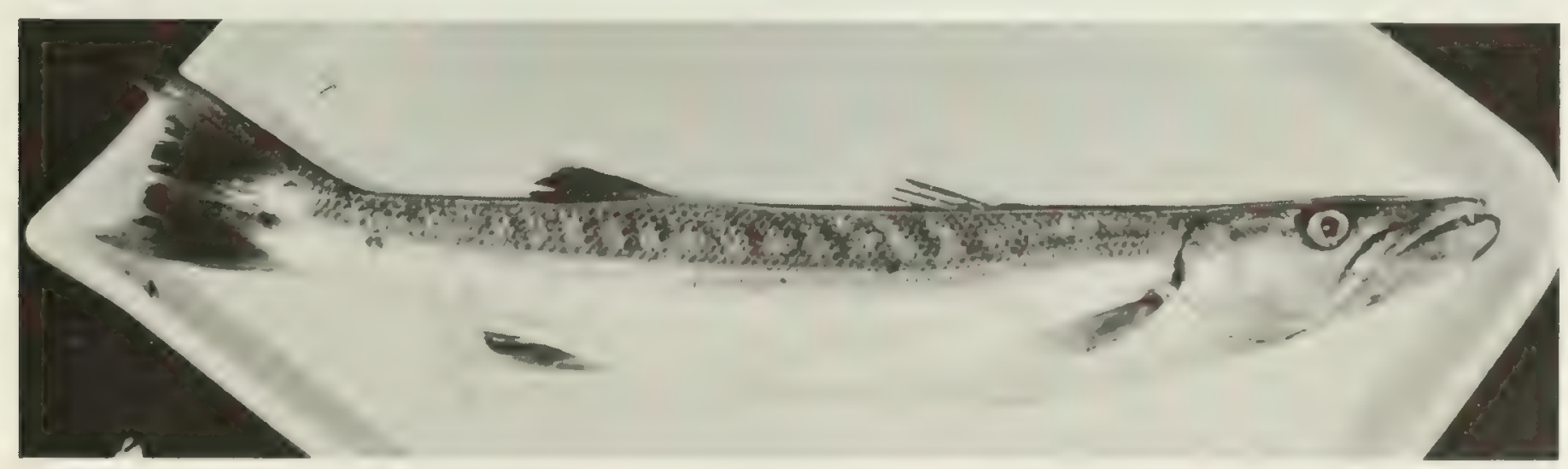

FIG. 290. Sphyraena barracuda, $616 \mathrm{~mm} \mathrm{SL,} \mathrm{Peros} \mathrm{Banhos.}$ 


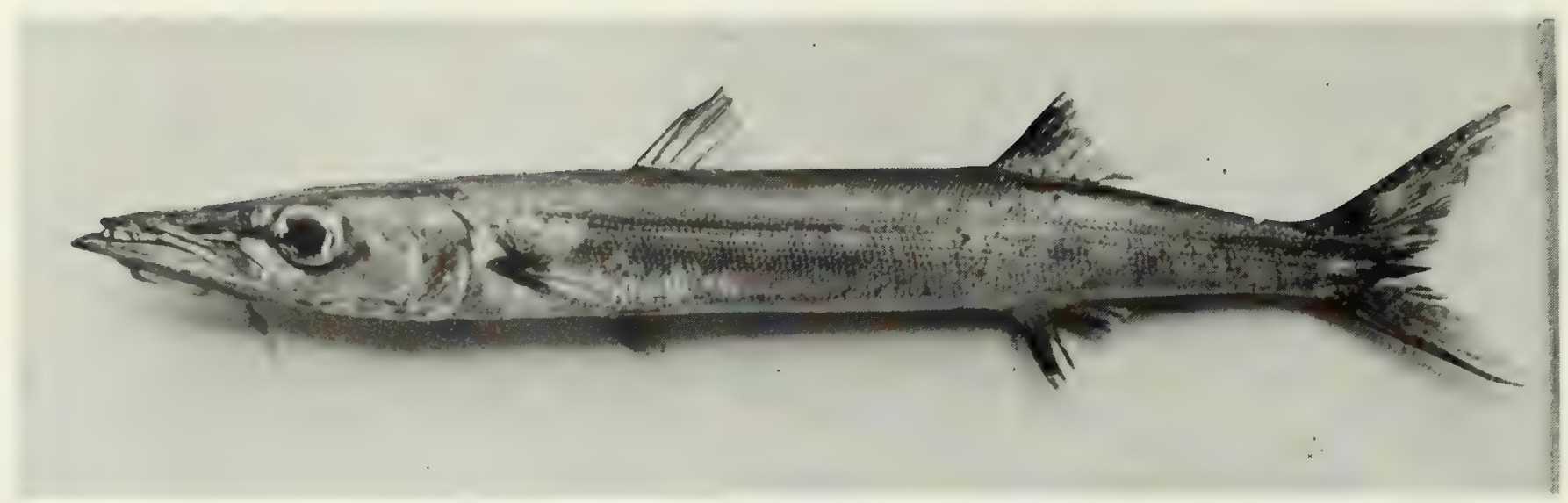

FIG. 291. Sphyraena forsteri, $433 \mathrm{~mm}$ SL, Peros Banhos.

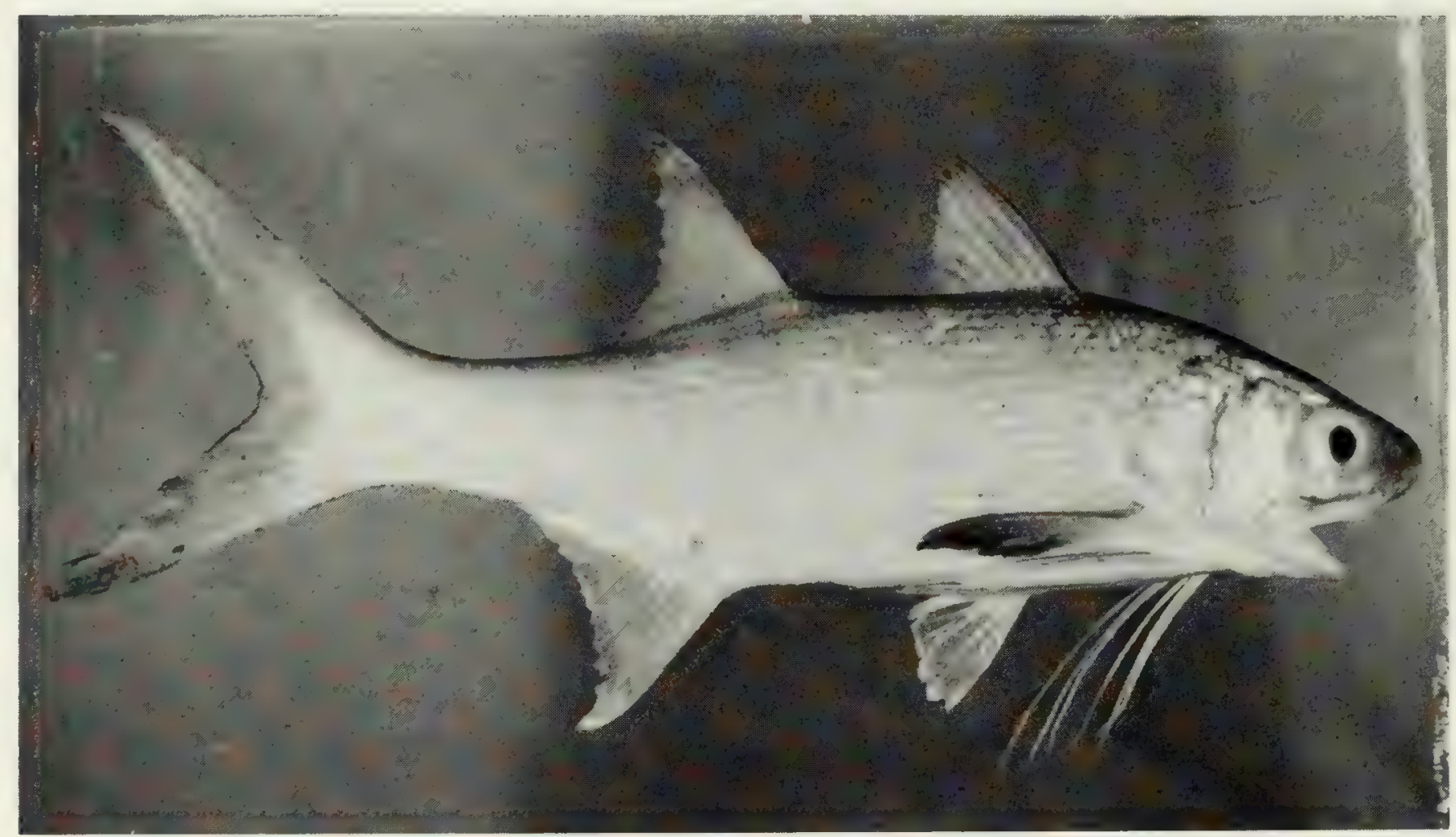

FIG. 292. Polydactylus sexfilis, $313 \mathrm{~mm}$ SL, Peros Banhos.

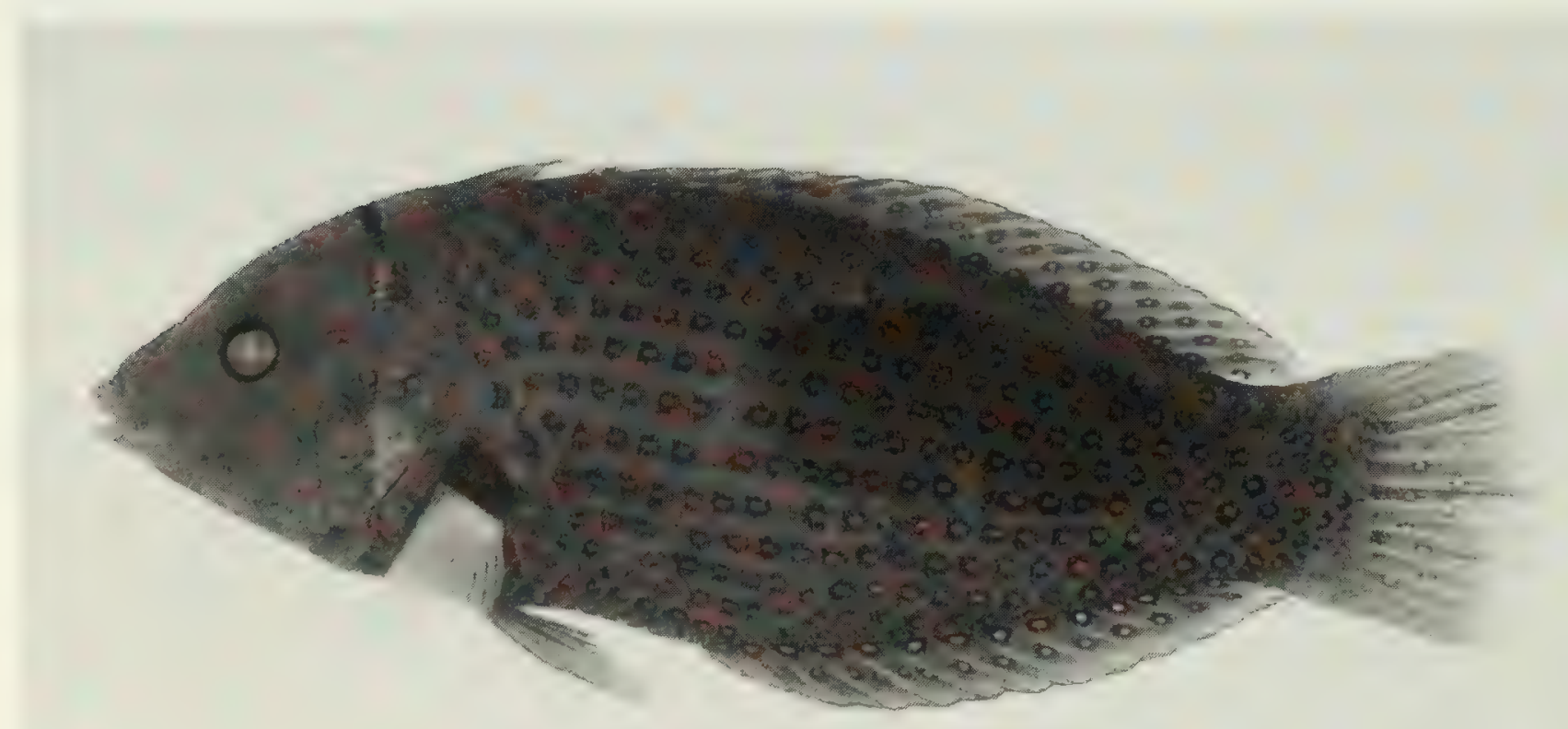

FIG. 293. Anampses caeruleopunctatus, (preserved) $127 \mathrm{~mm} \mathrm{SL}$, Diego Garcia. Photo by A. Strange. 


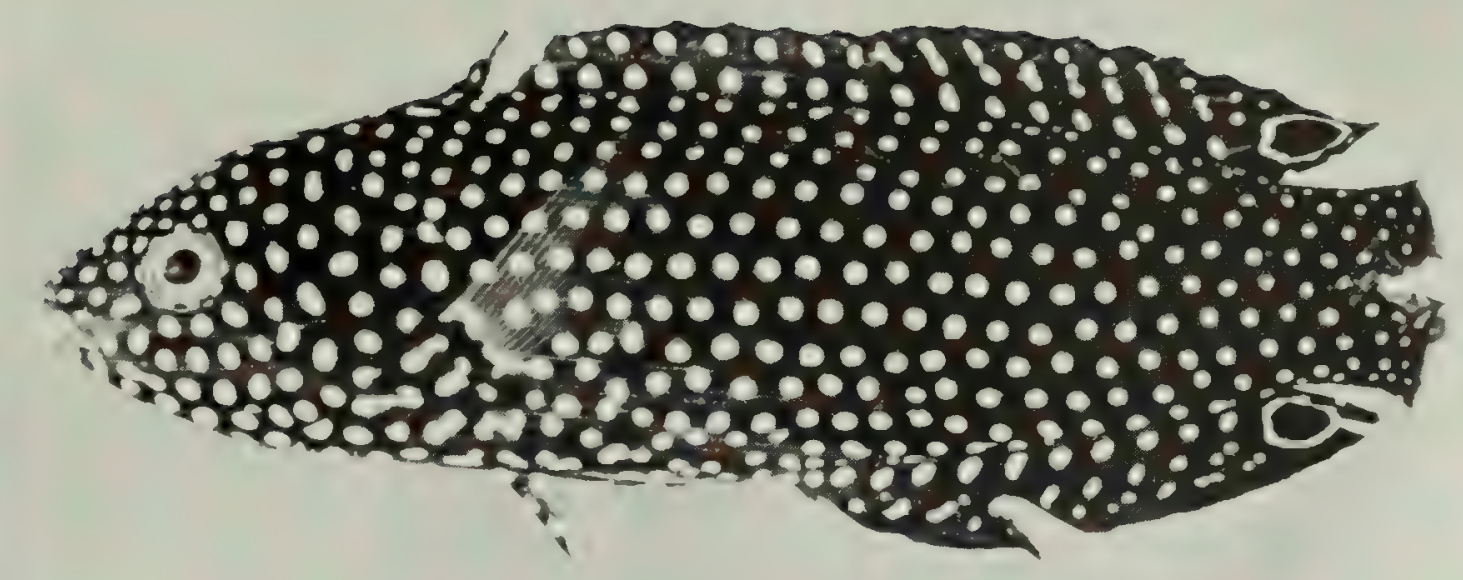

Fig. 294. Anampses meleagrides, 56 mm SL, Peros Banhos.

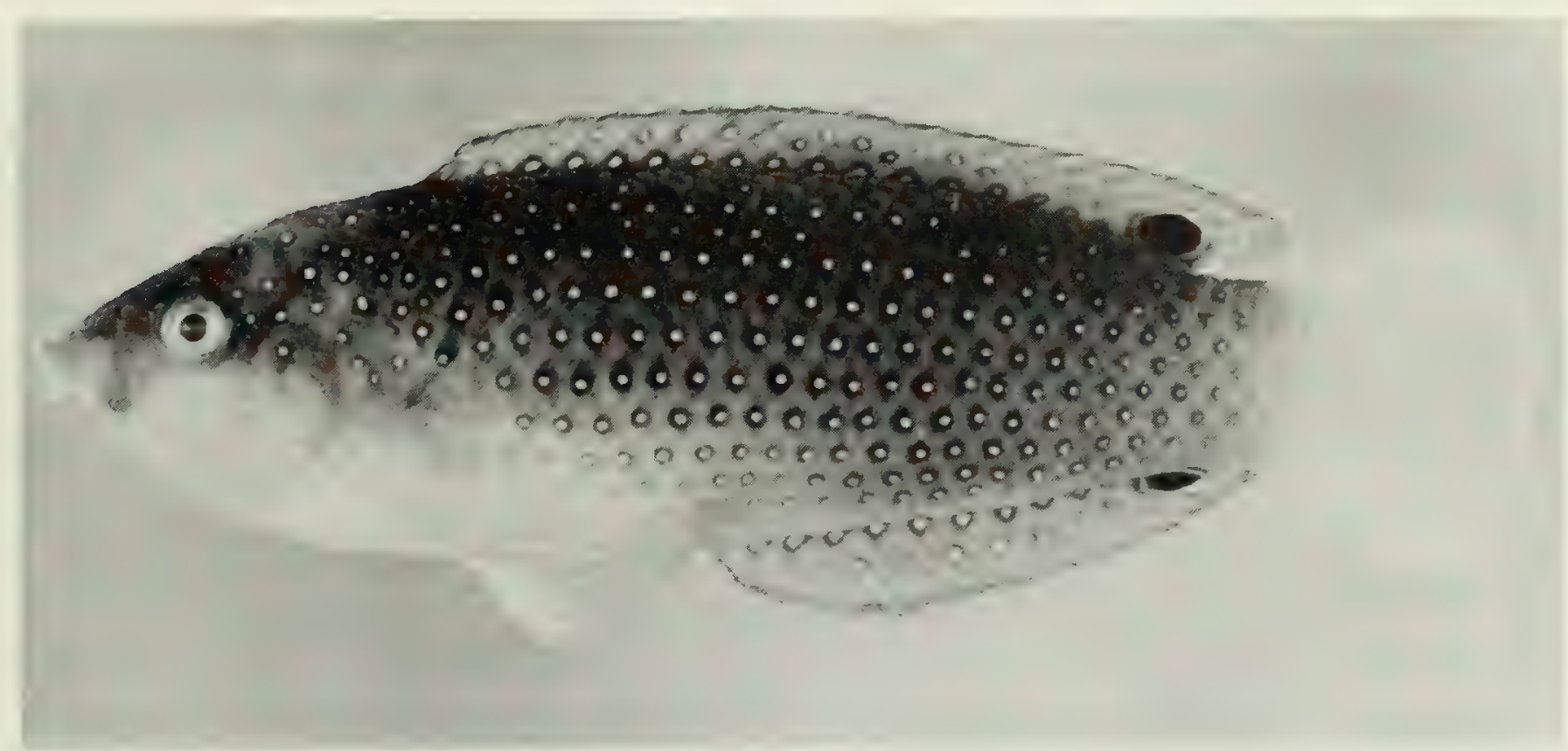

FIG. 295. Anampses twistii, $89 \mathrm{~mm} \mathrm{SL}$, Salomon.

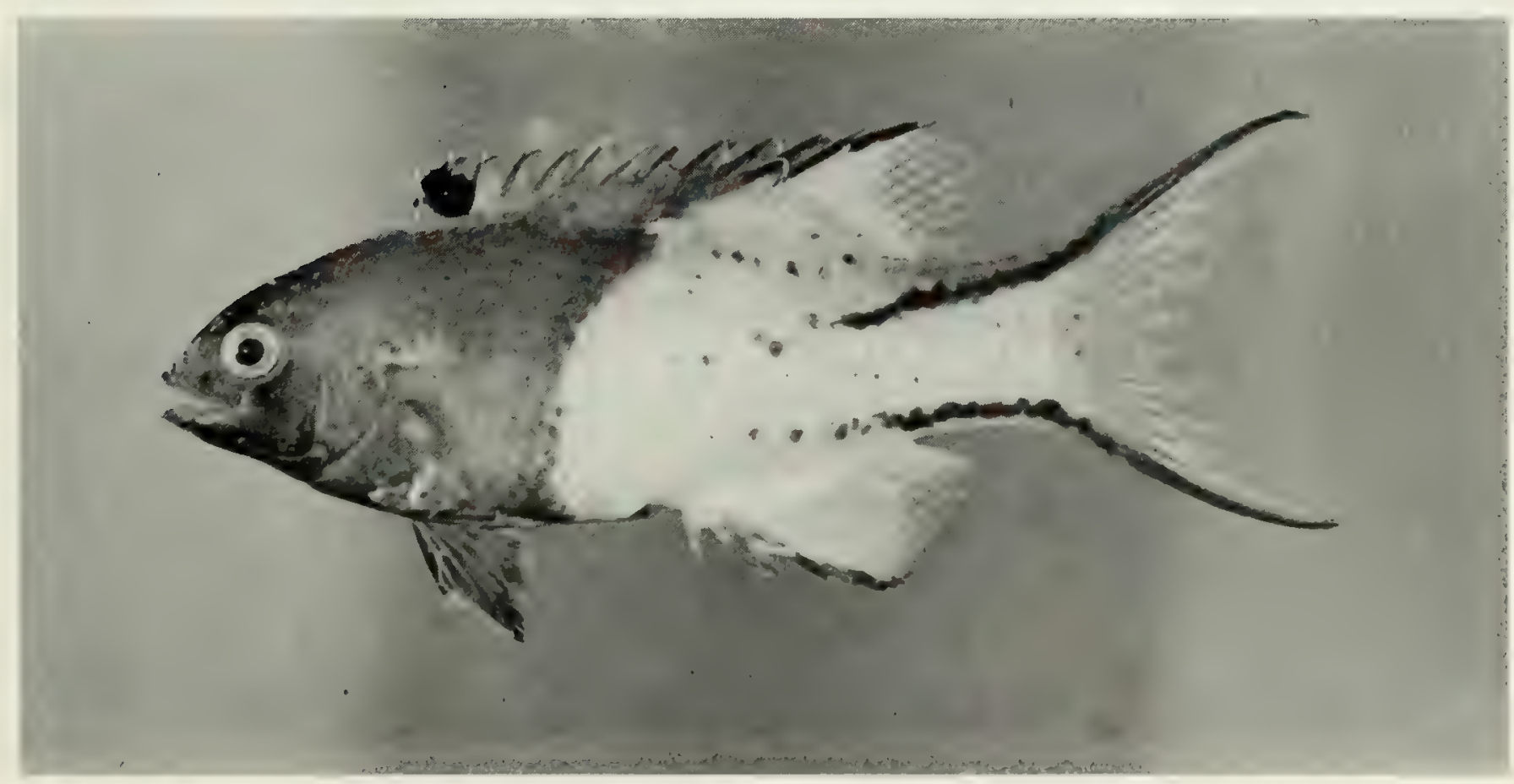

FIG. 296. Bodianus anthioides, $97 \mathrm{~mm} \mathrm{SL}$, Salomon. 


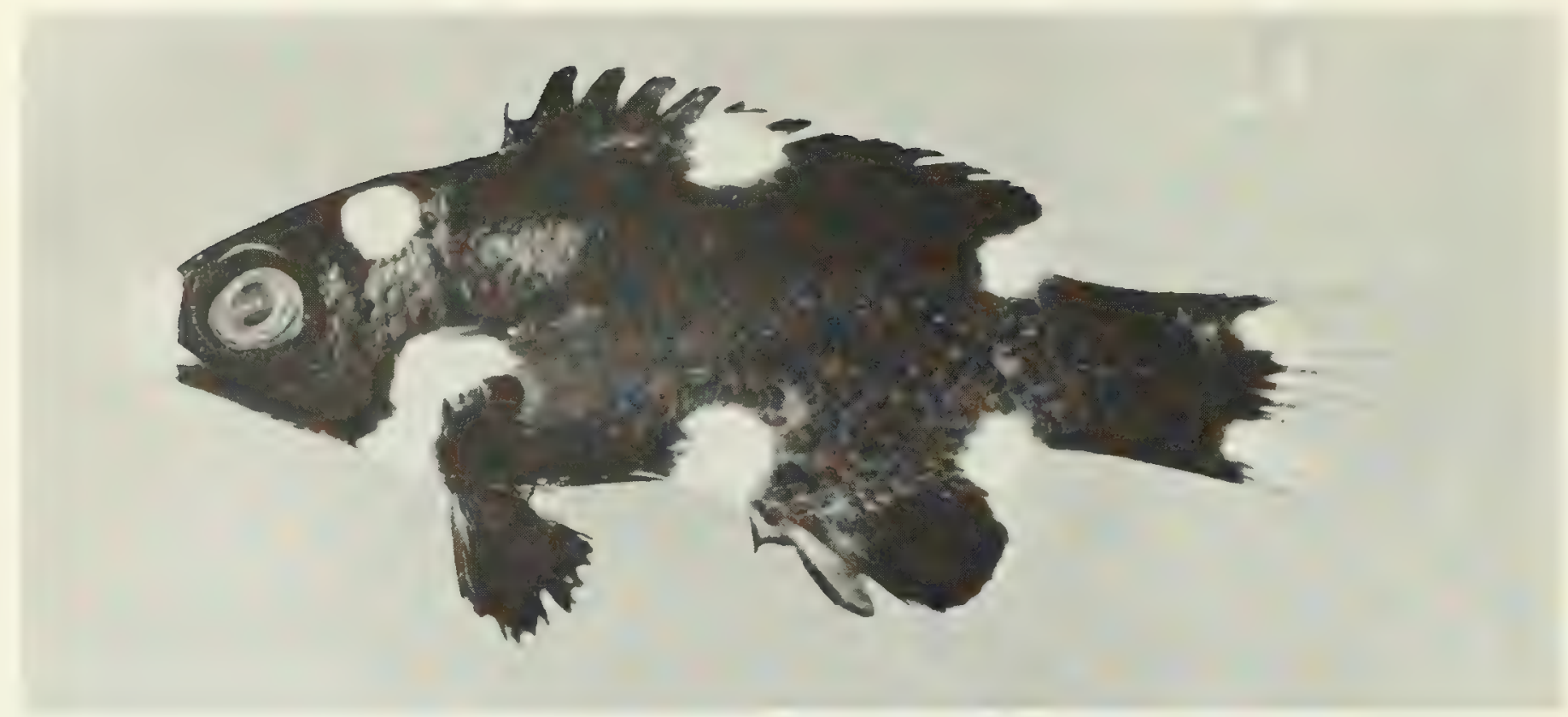

FIG. 297. Bodianus axillaris, $44 \mathrm{~mm}$ SL, Peros Banhos.

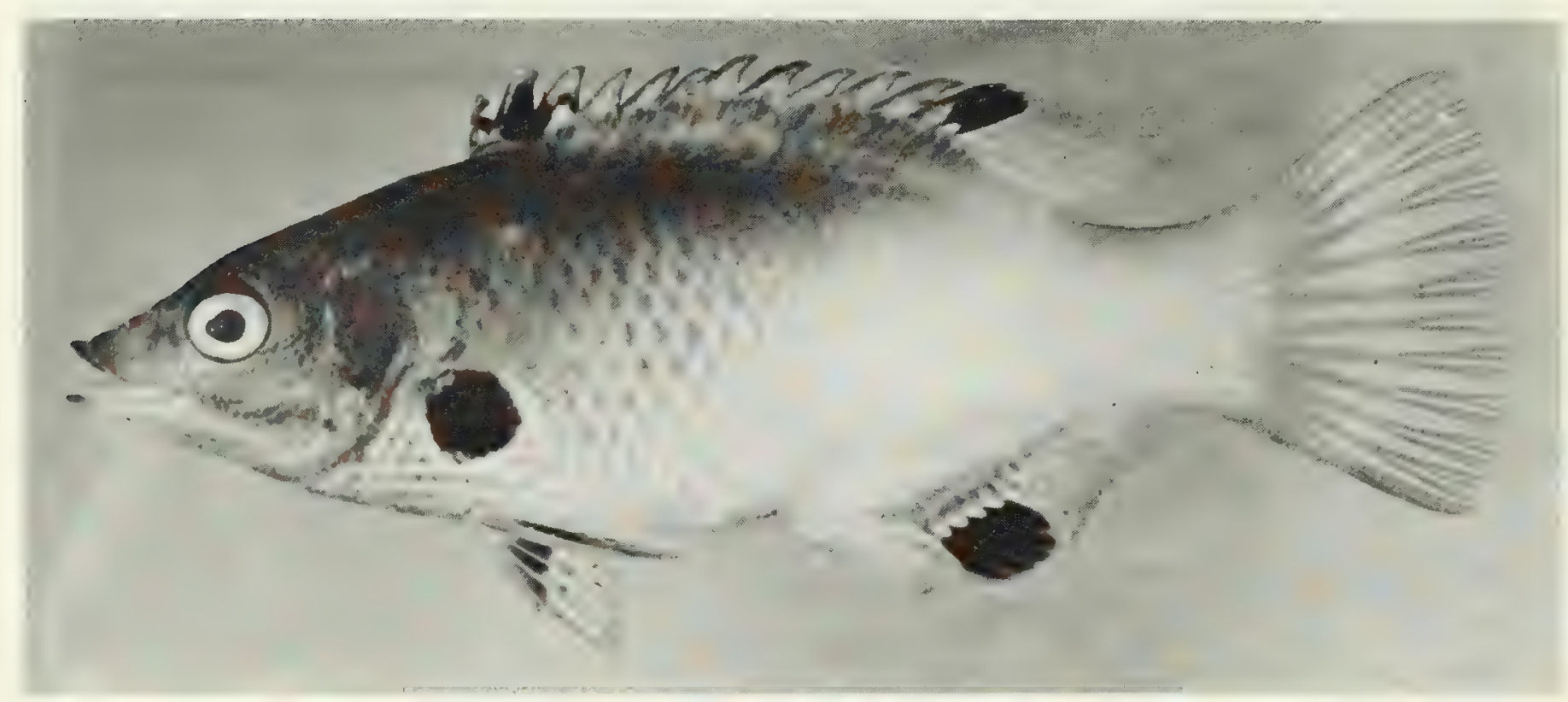

Fig. 298. Bodianus axillaris, $96 \mathrm{~mm} \mathrm{SL}$, Peros Banhos.

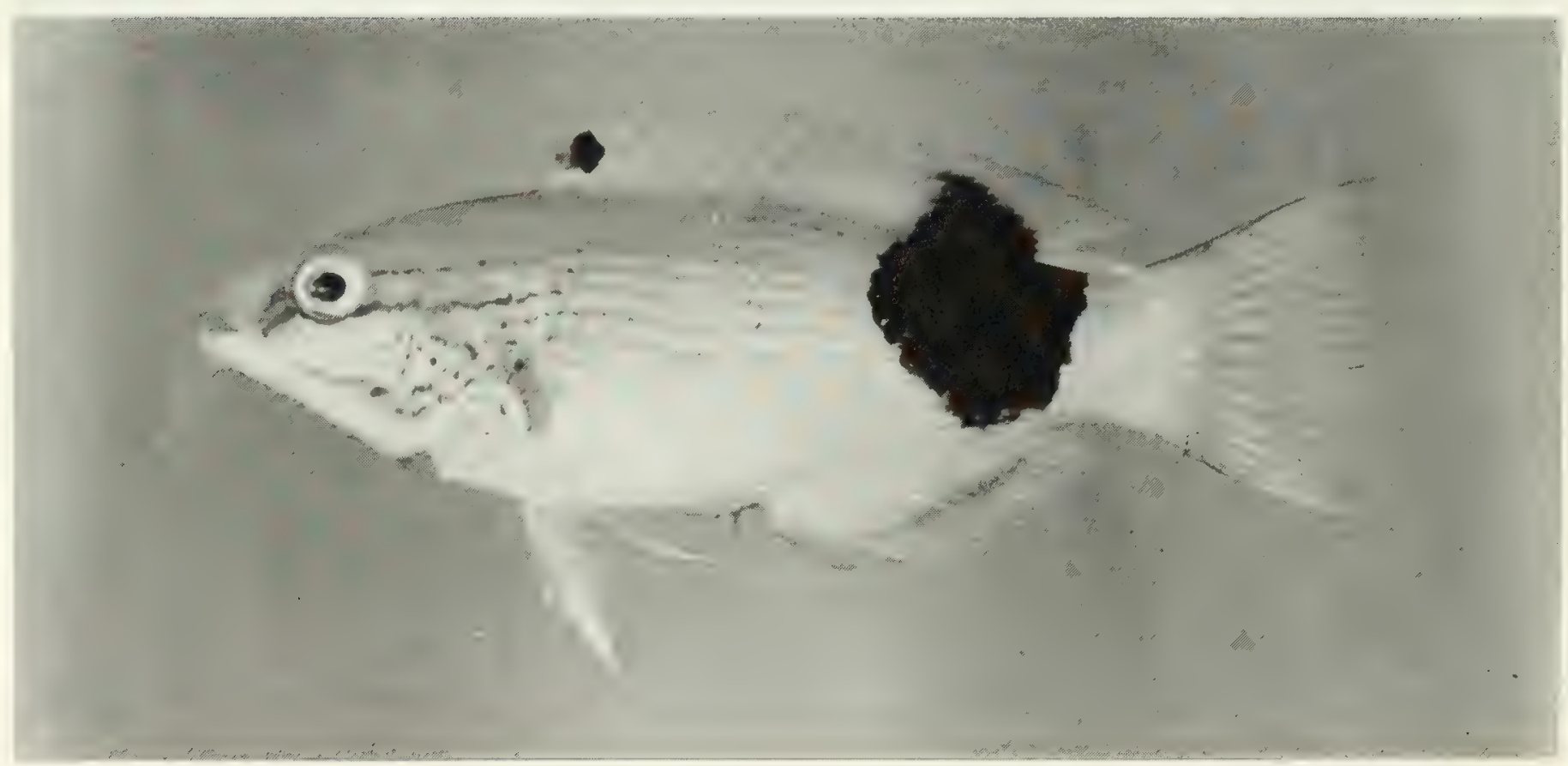

FIG. 299. Bodianus bilunulatus bilunulatus, $95 \mathrm{~mm} \mathrm{SL}$, Peros Banhos. 


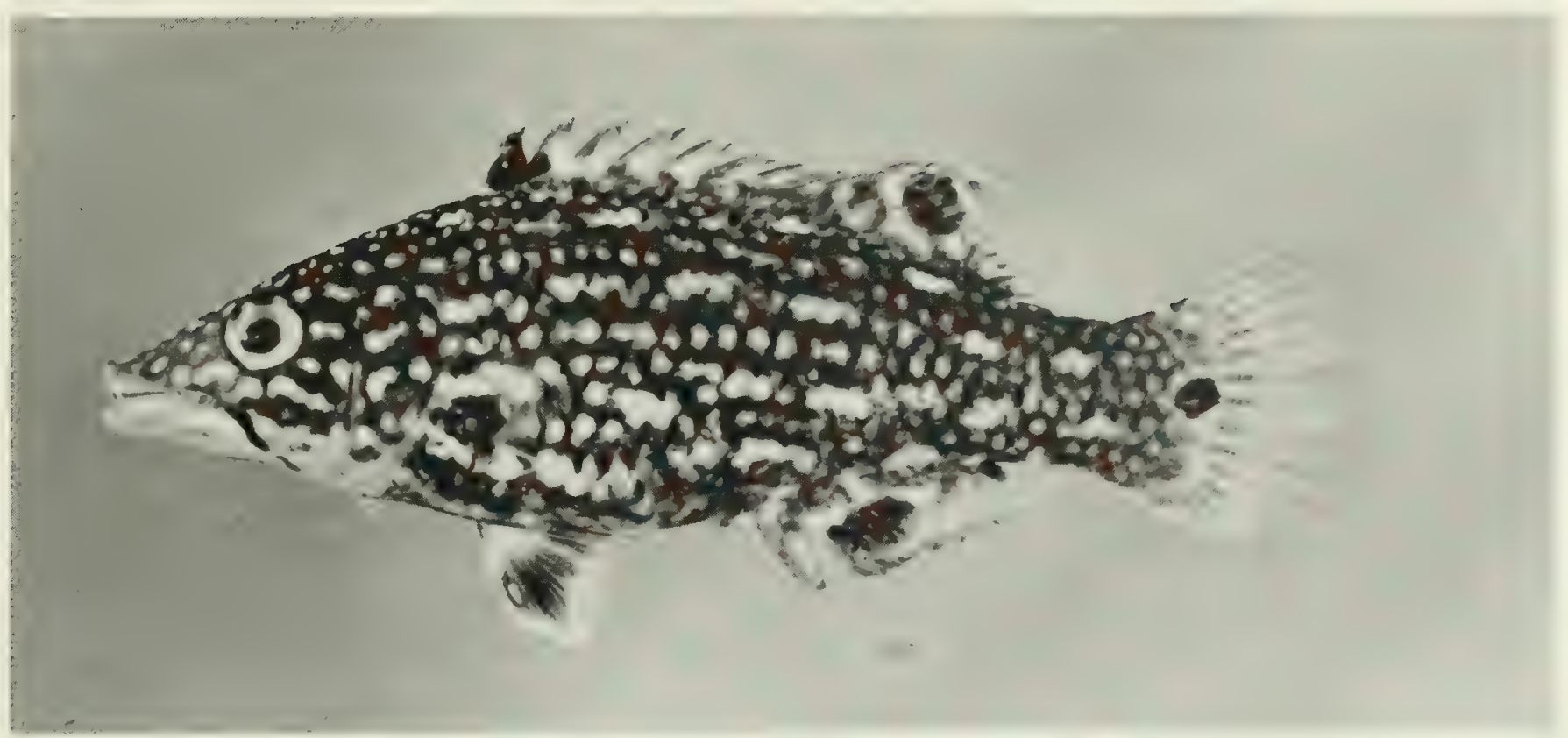

FIG. 300. Bodianus diana, $69 \mathrm{~mm}$ SL, Salomon.

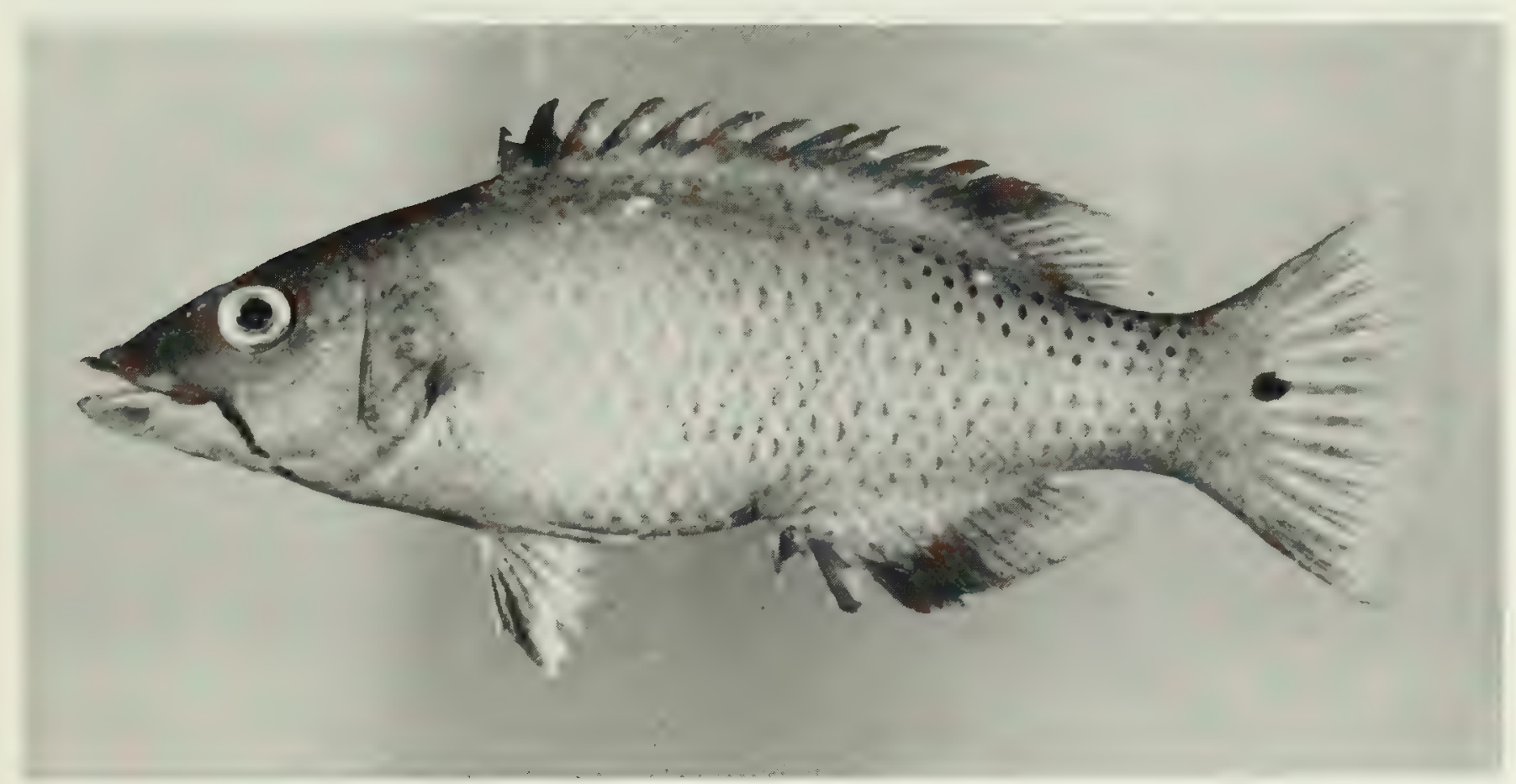

FIG. 301. Bodianus diana, $131 \mathrm{~mm}$ SL, Peros Banhos.

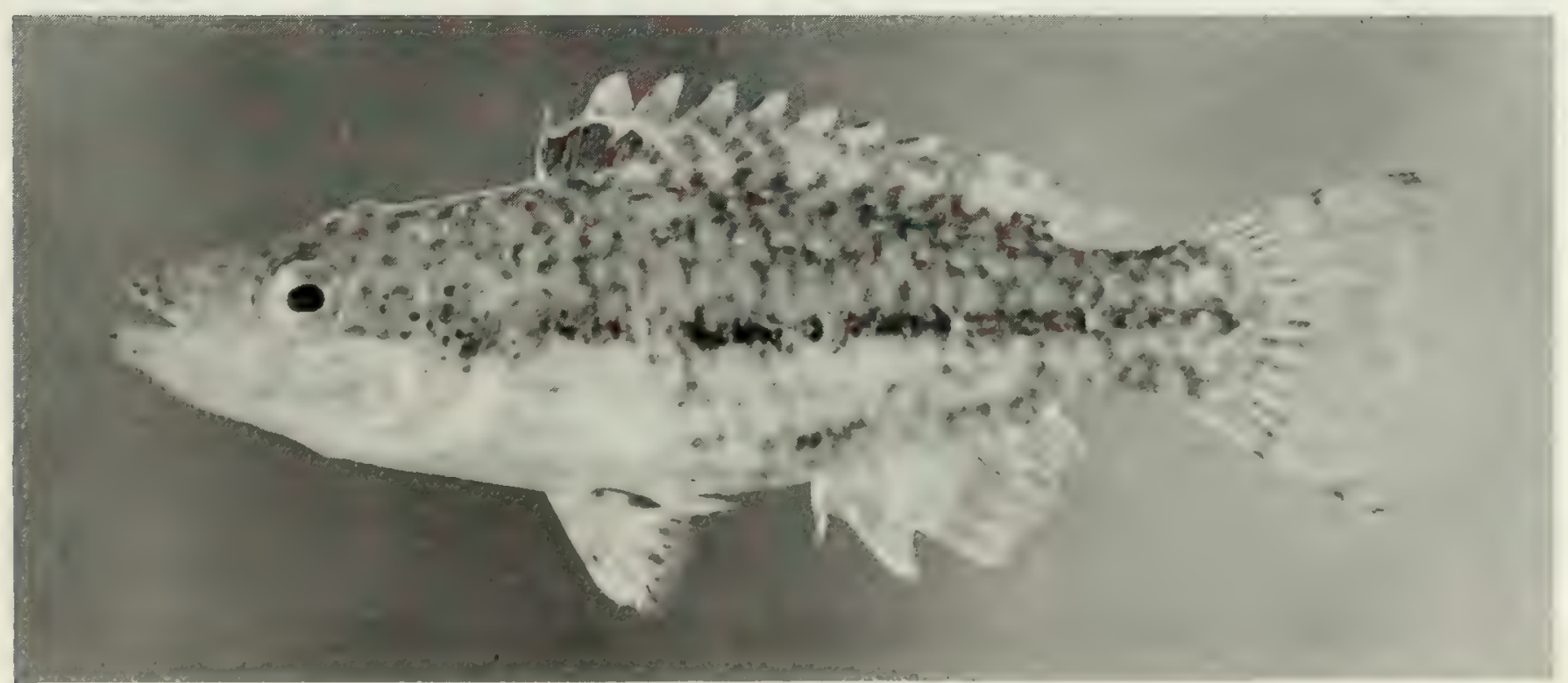

FIG. 302. Cheilinus arenatus, $56 \mathrm{~mm} \mathrm{SL}$, Salomon. 


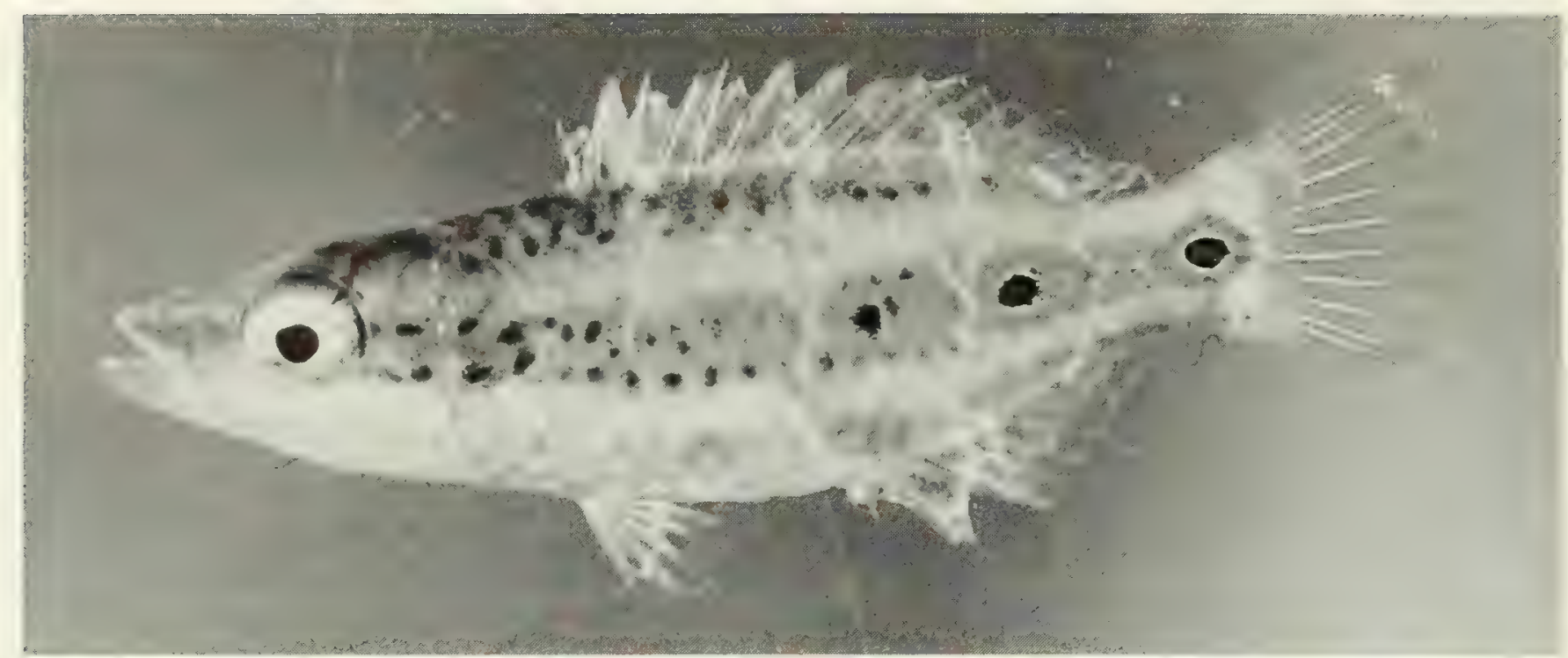

FIG. 303. Cheilinus digrammus, $22 \mathrm{~mm} \mathrm{SL}$, Peros Banhos.

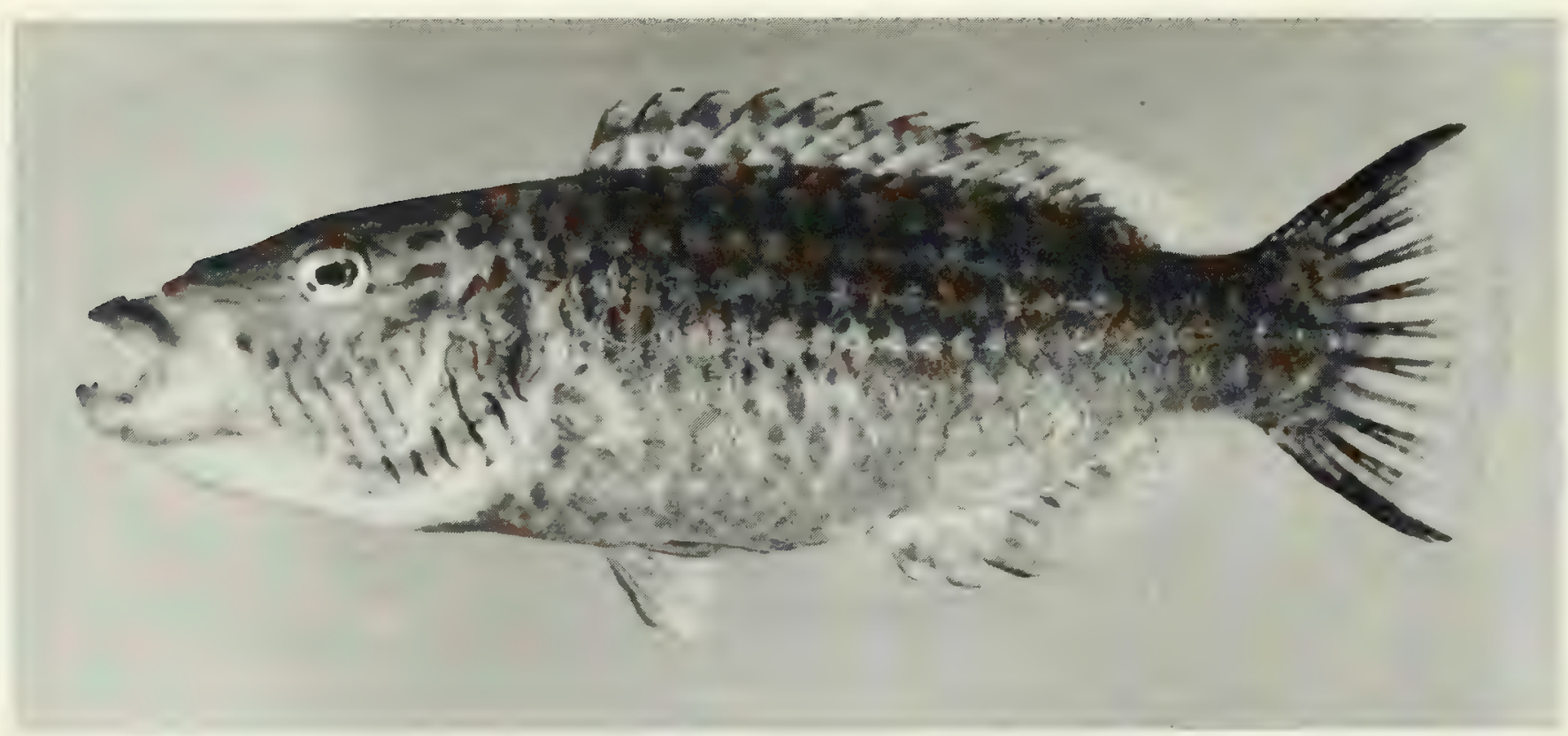

FIG. 304. Cheilinus digrammus, $157 \mathrm{~mm} \mathrm{SL}$, Peros Banhos.

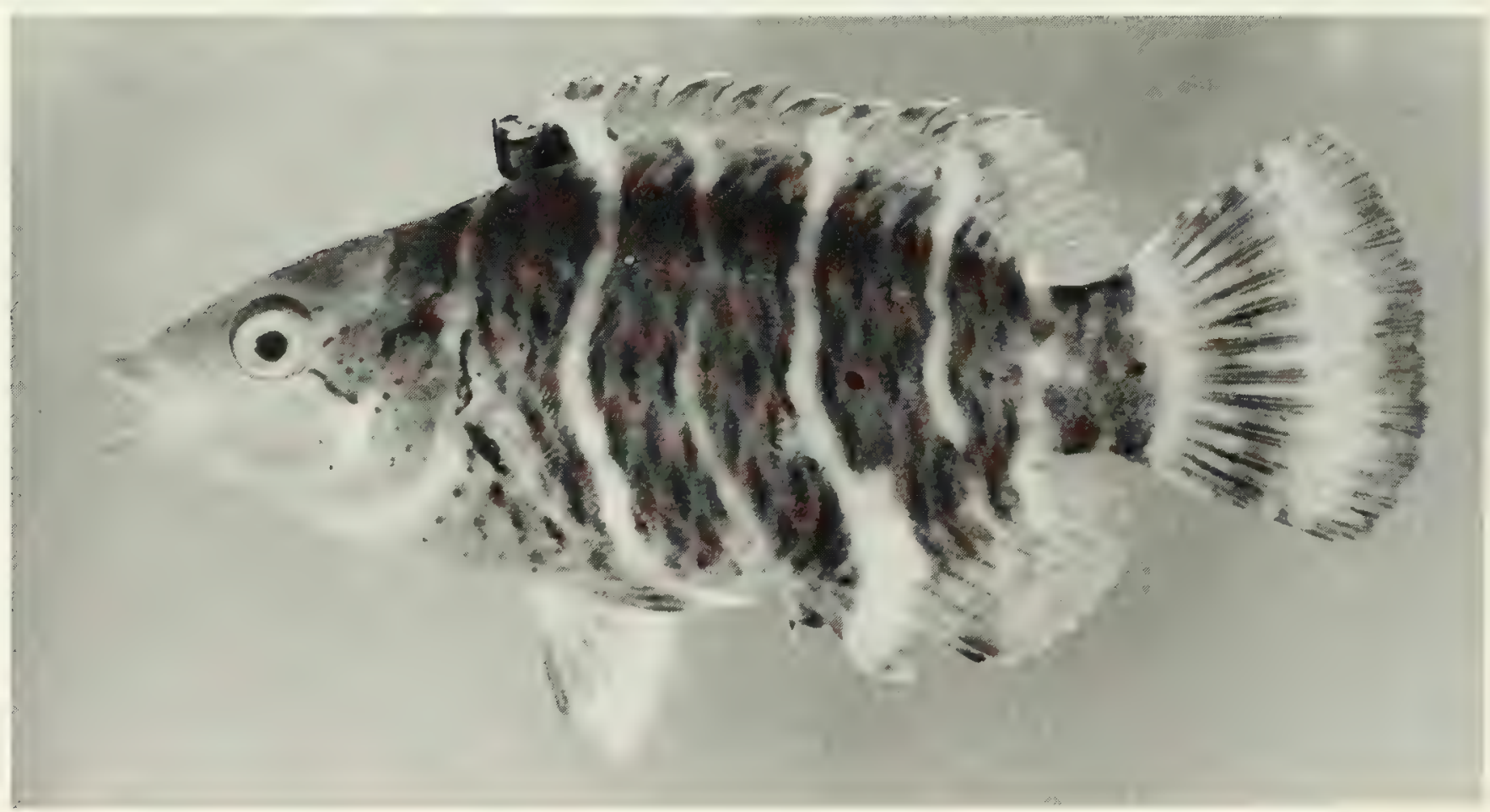

Fig. 305. Cheilinus fasciatus, $53 \mathrm{~mm} \mathrm{SL}$, Peros Banhos. 


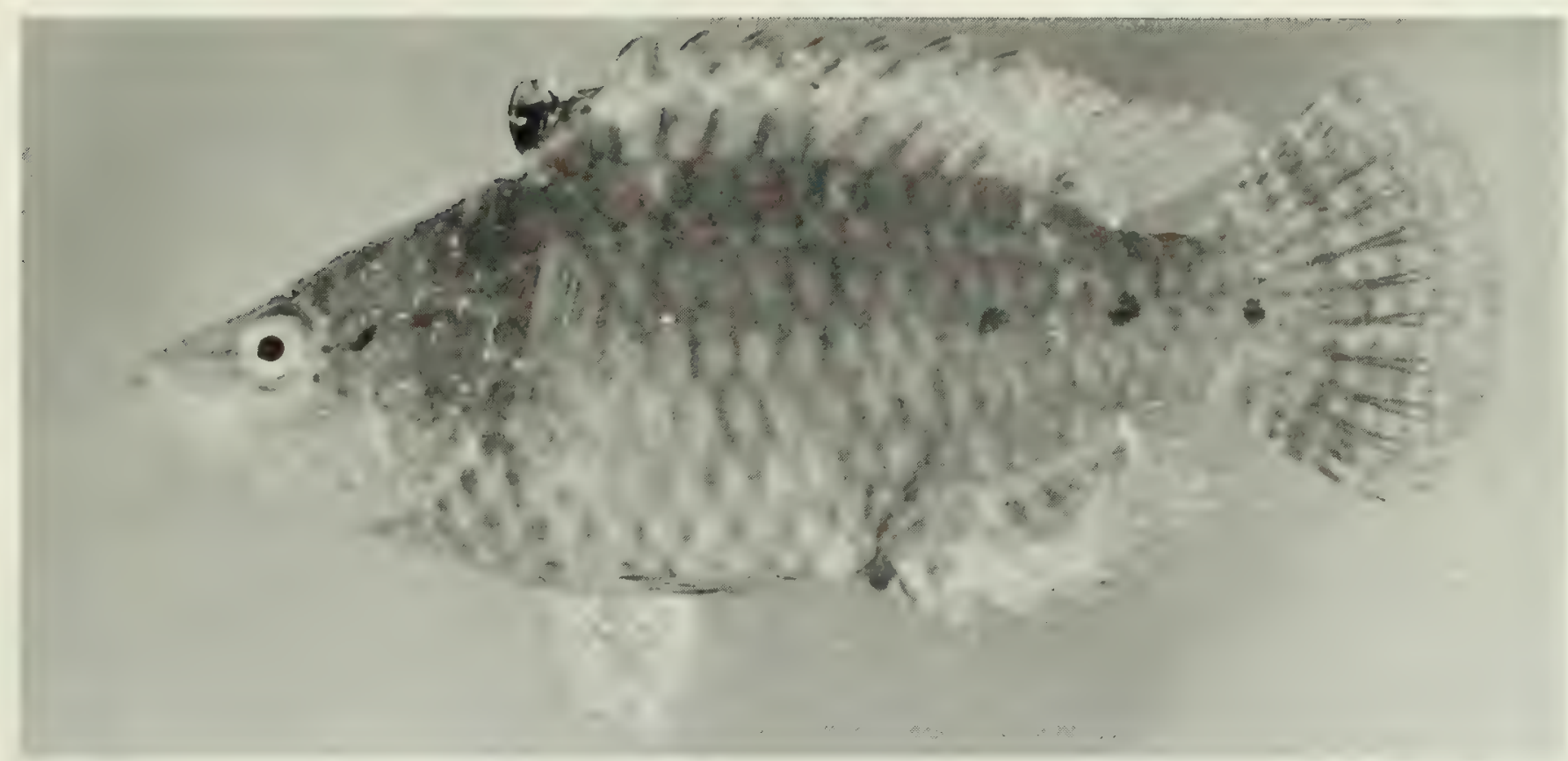

FIG. 306. Cheilinus oxycephalus, $62 \mathrm{~mm} \mathrm{SL}$, Peros Banhos.

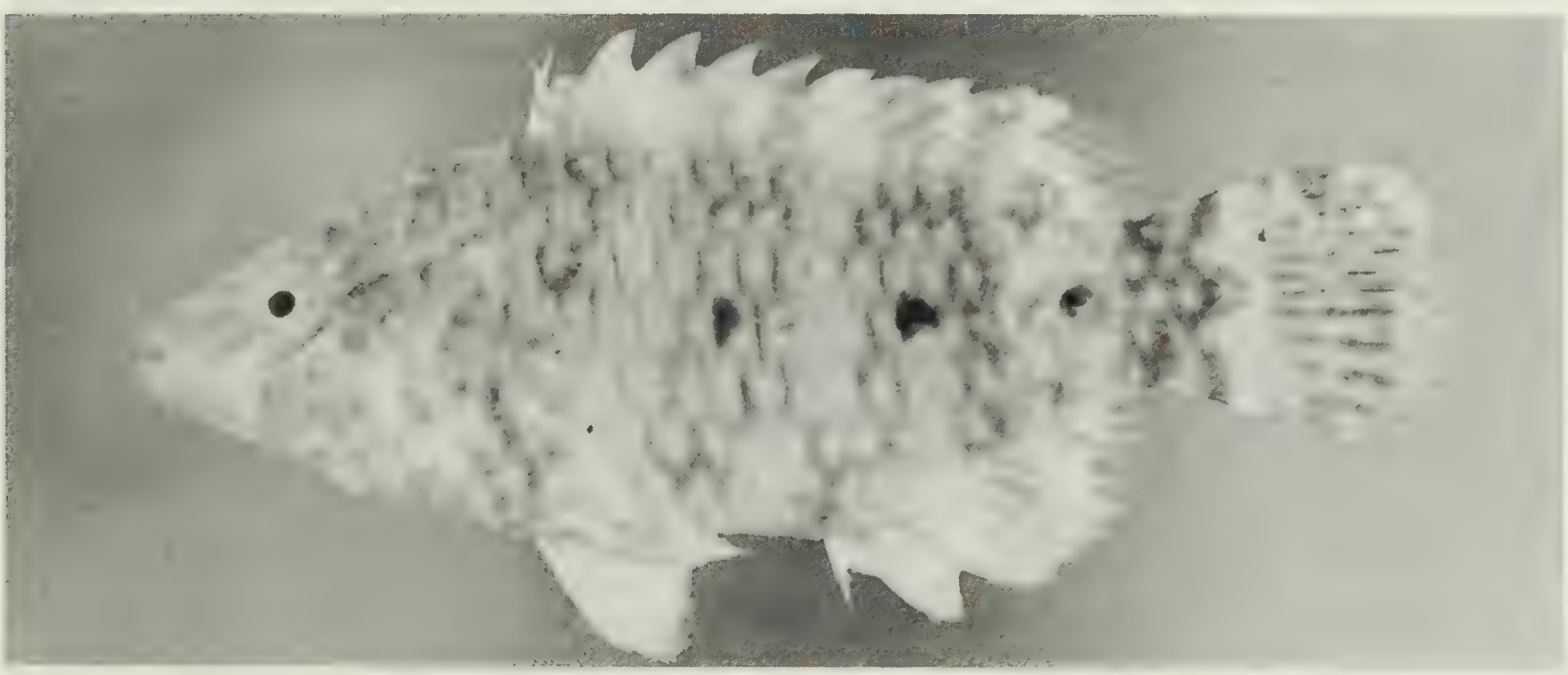

FIG. 307. Cheilinus trilobatus, $50 \mathrm{~mm}$ SL, Peros Banhos.

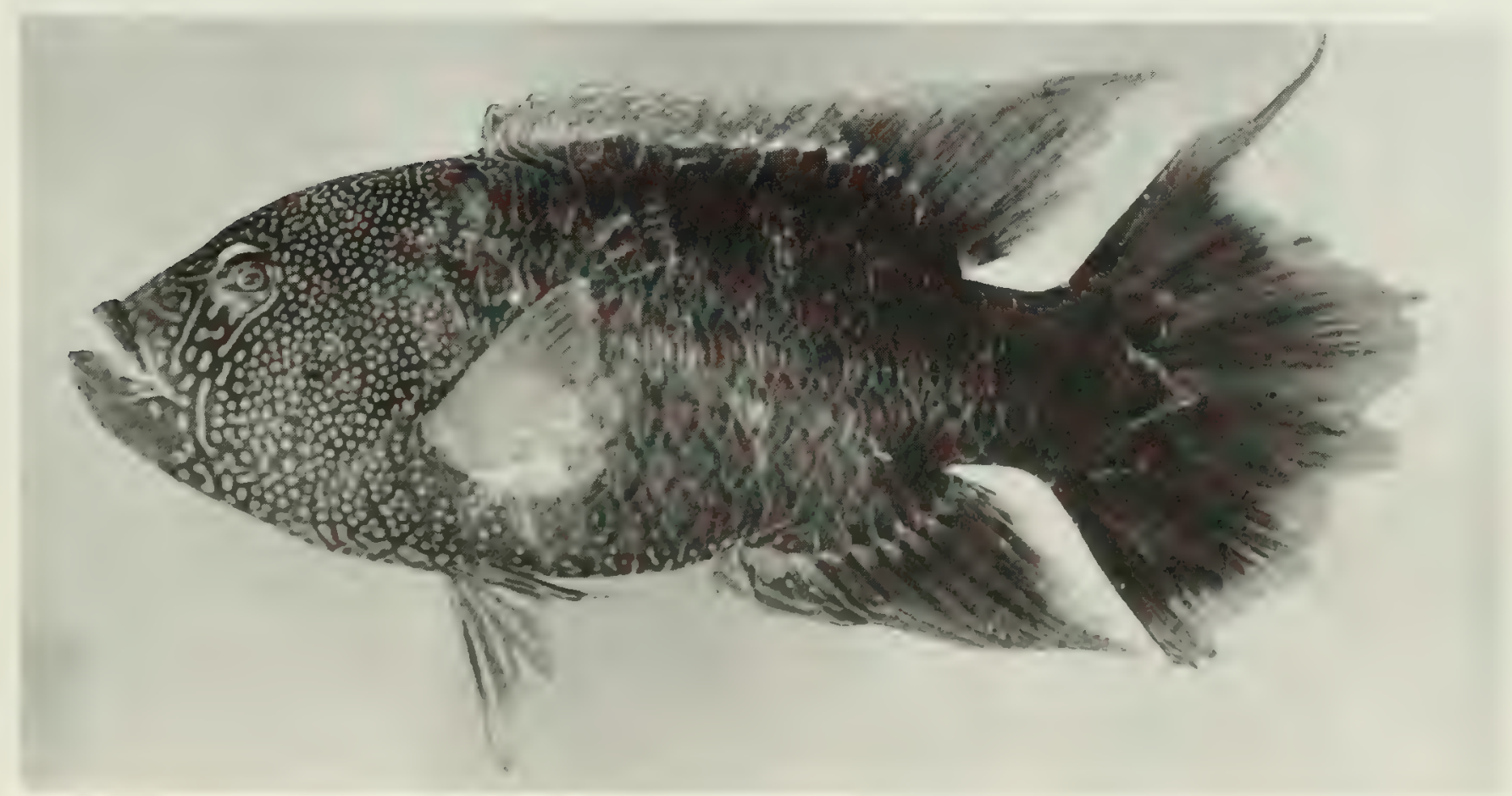

Fig. 308. Cheilinus trilobatus, $260 \mathrm{~mm} \mathrm{SL,} \mathrm{Peros} \mathrm{Banhos.}$ 


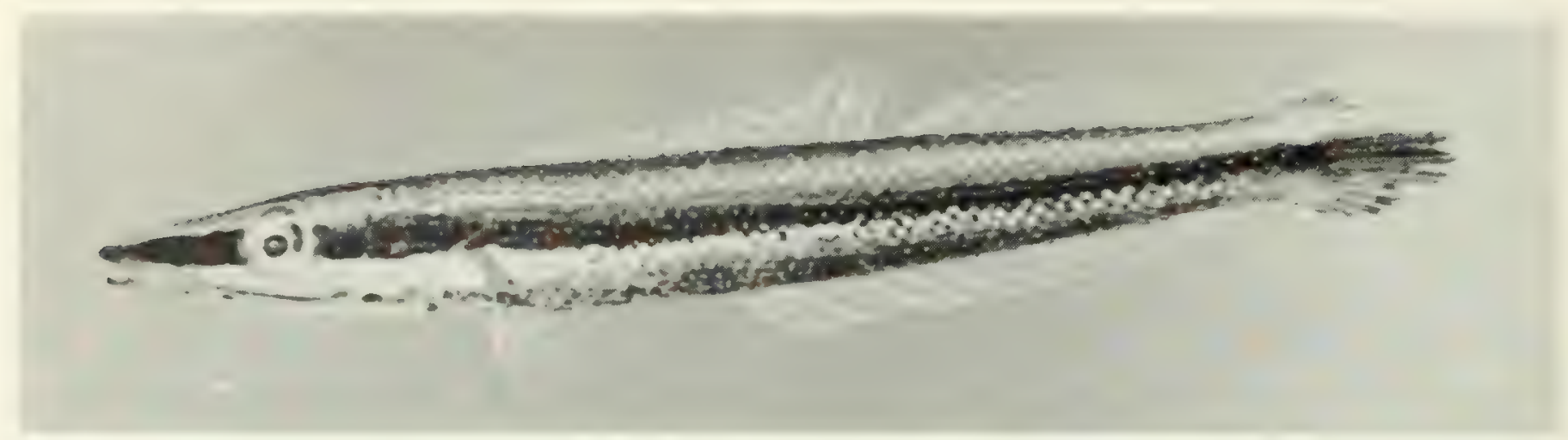

FIG. 309. Cheilo inermis, $43 \mathrm{~mm} \mathrm{SL}$, Peros Banhos.

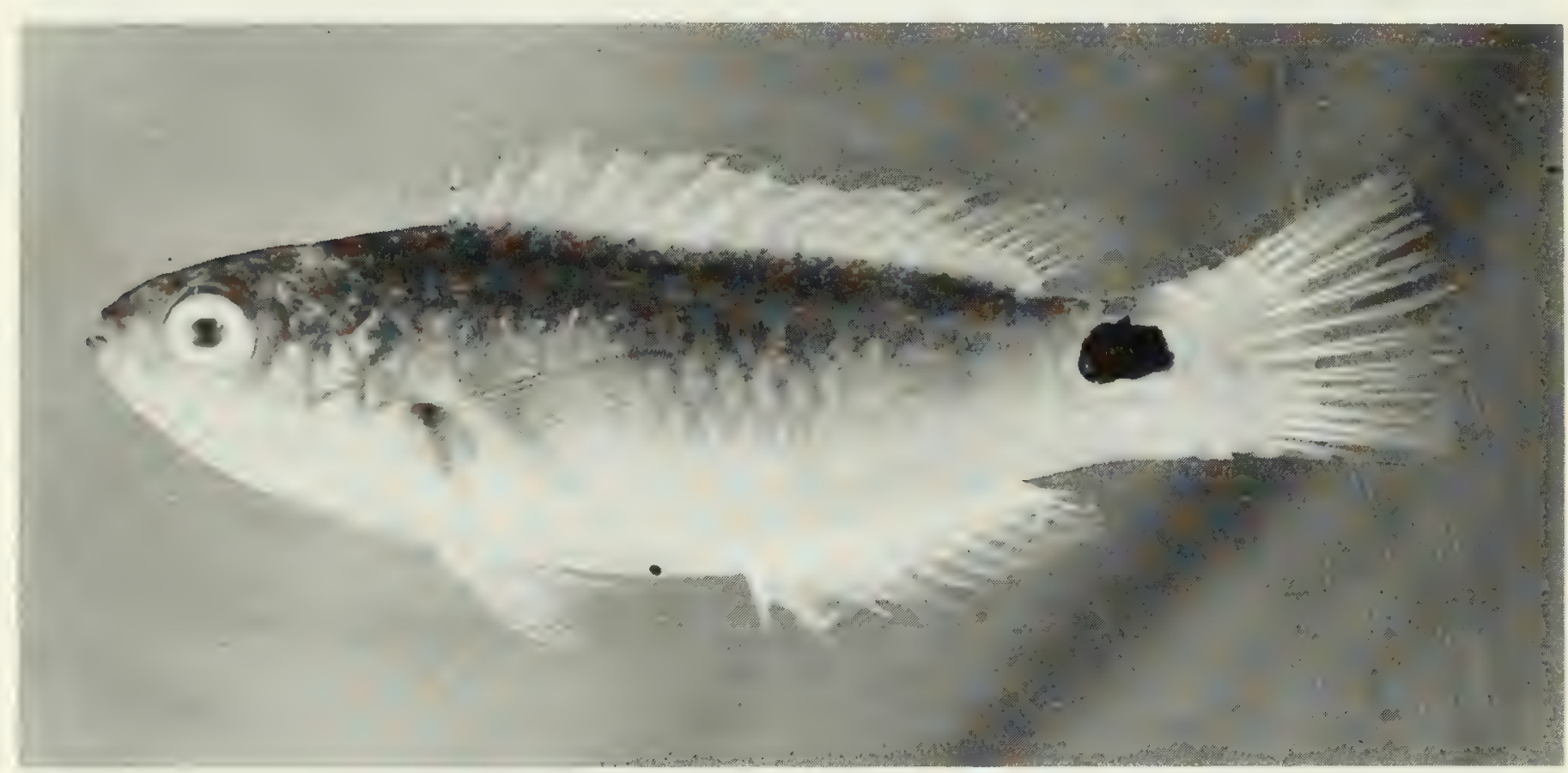

FIG. 310. Cirrhilabrus exquisitus, $46 \mathrm{~mm}$ SL, Peros Banhos.

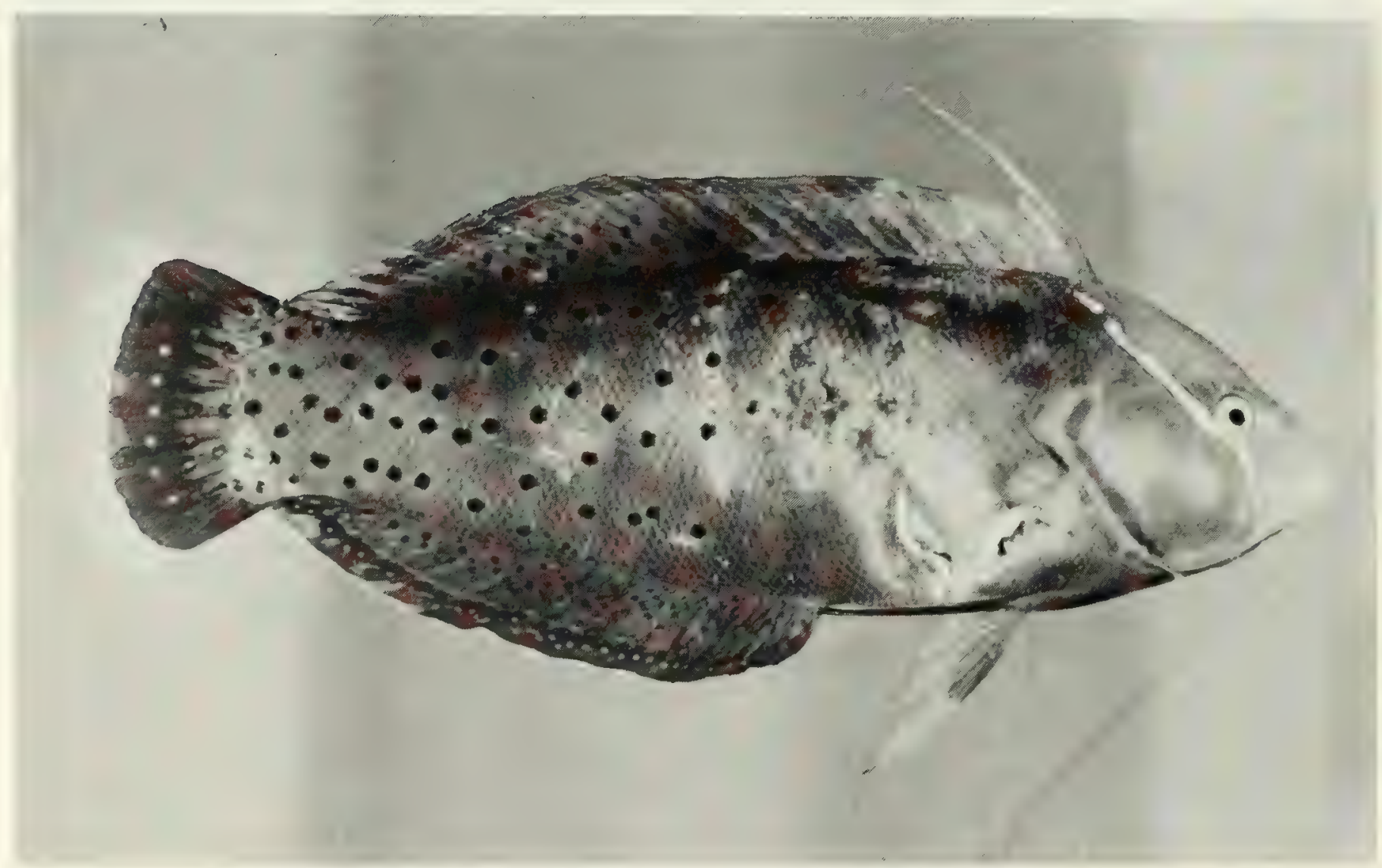

Fig. 311. Coris formosa, $206 \mathrm{~mm}$ SL, Peros Banhos. 


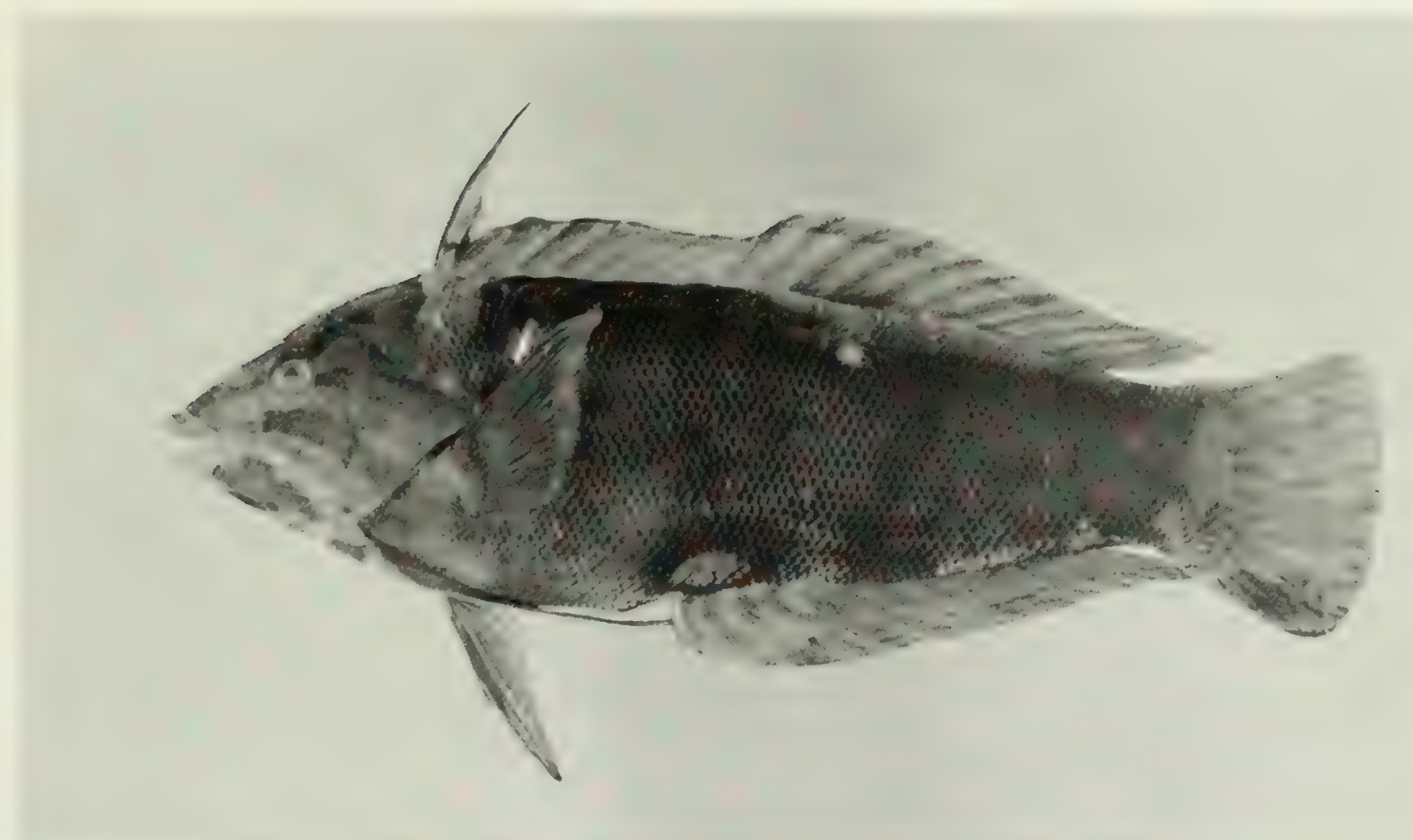

FIG. 312. Coris gaimard africana, $190 \mathrm{~mm}$ SL, Salomon.

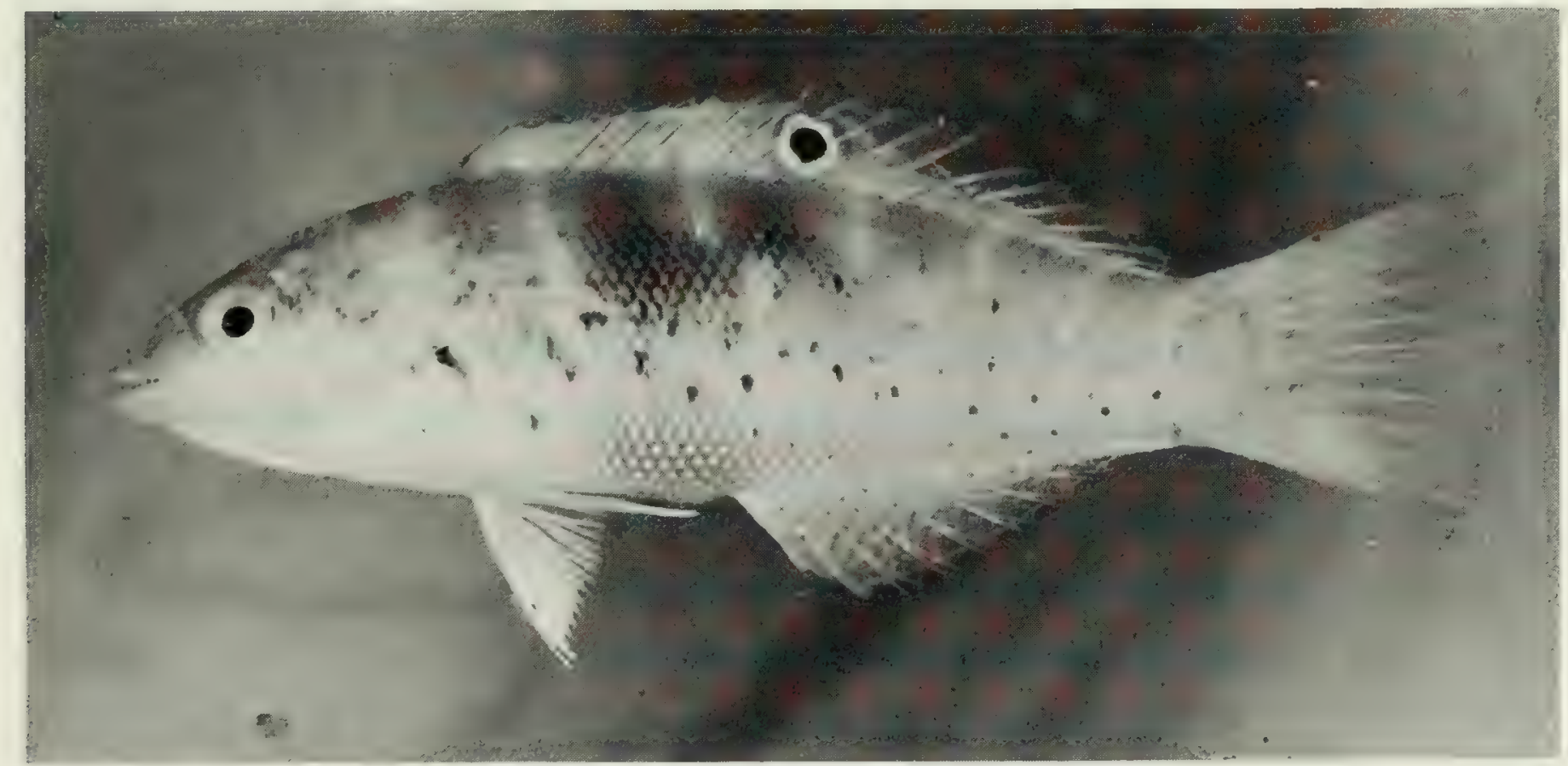

FIG. 313. Coris variegata, $67 \mathrm{~mm} \mathrm{SL}$, Peros Banhos.

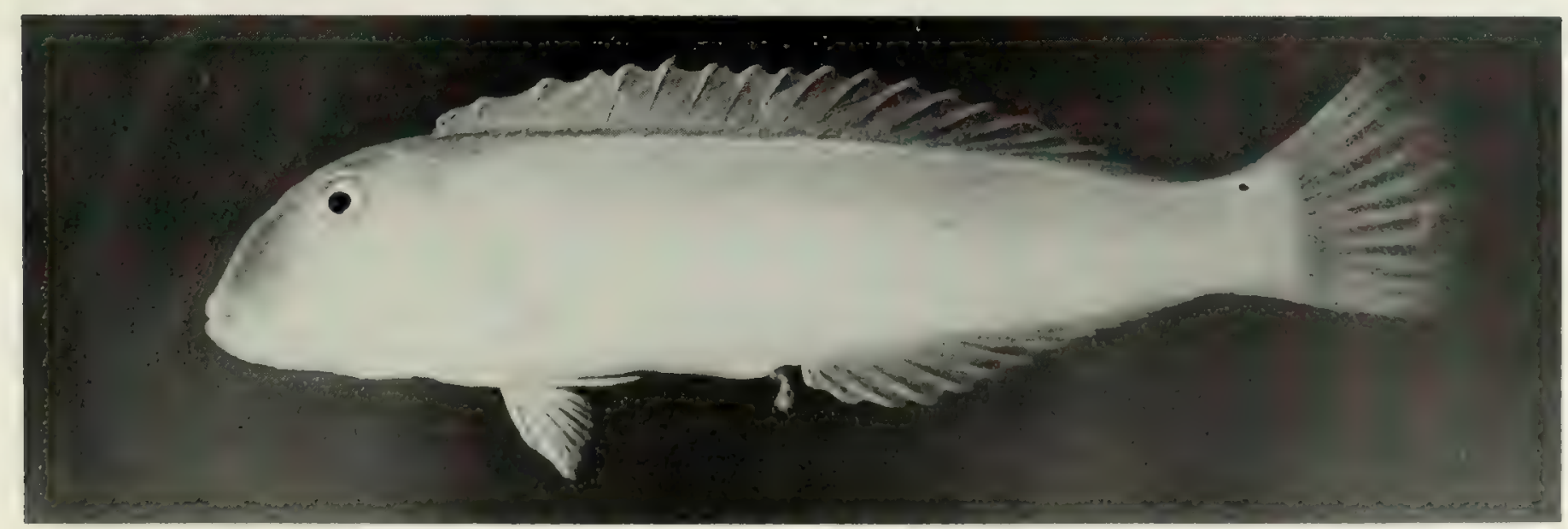

Fig. 314. Cymolutes lecluse, $65 \mathrm{~mm}$ SL, Peros Banhos. 


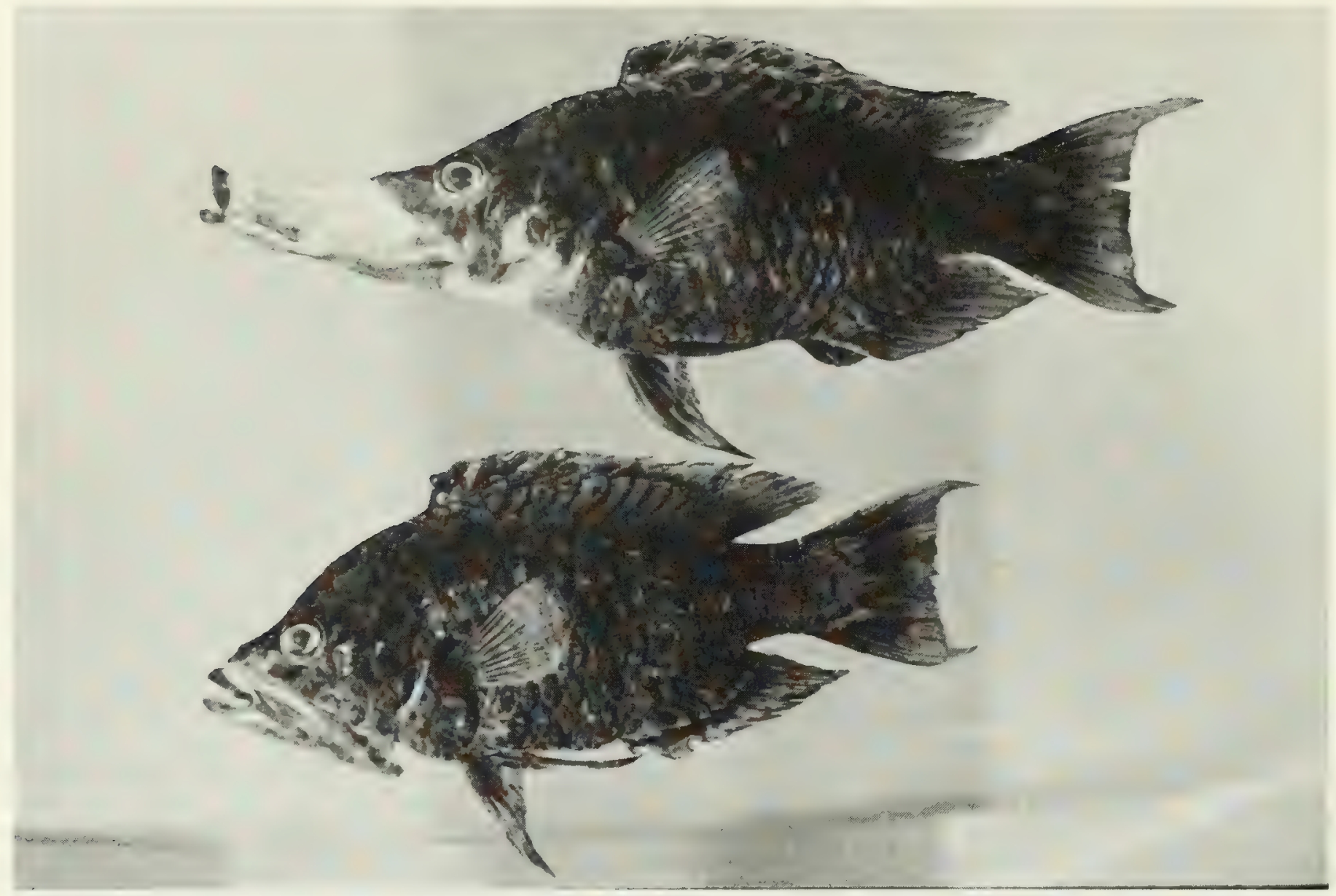

FIG. 315. Epibulus insidiator, $131 \mathrm{~mm} \mathrm{SL}$, Salomon.

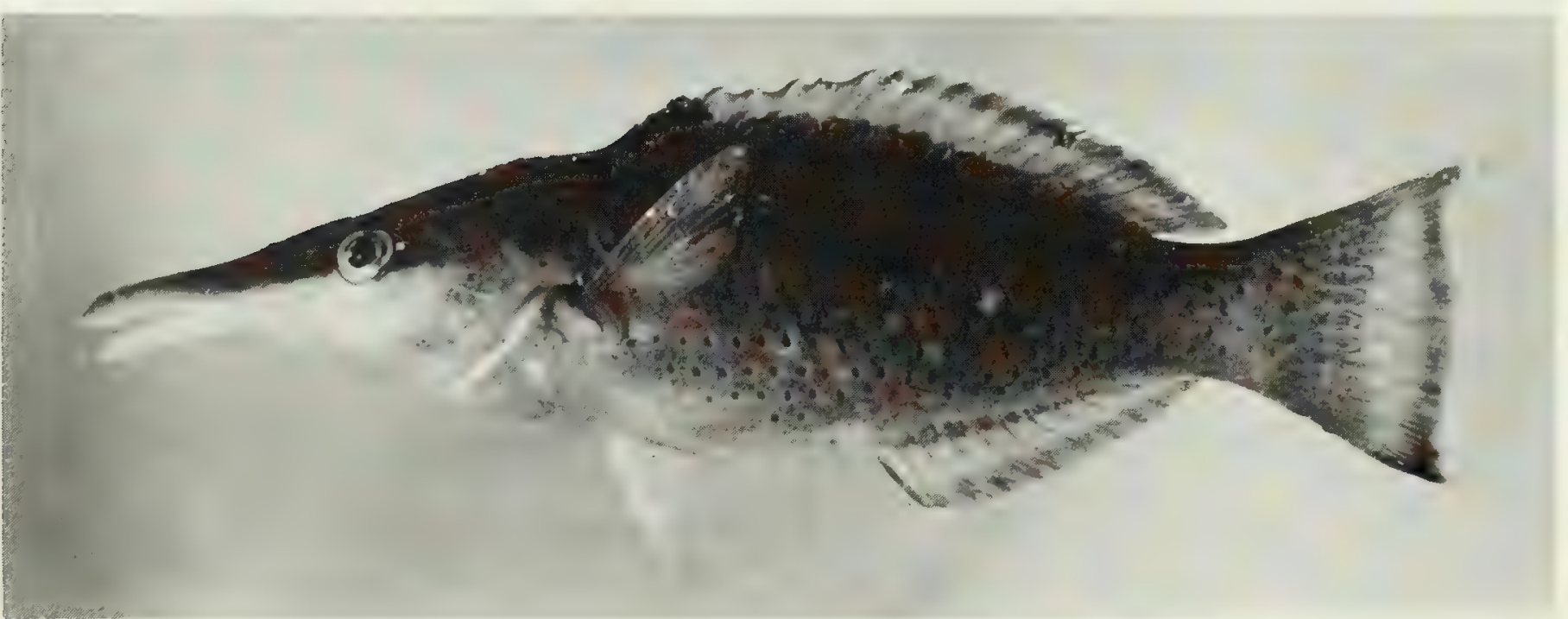

Fig. 316. Gomphosus coeruleus, $109 \mathrm{~mm} \mathrm{SL}$, Peros Banhos

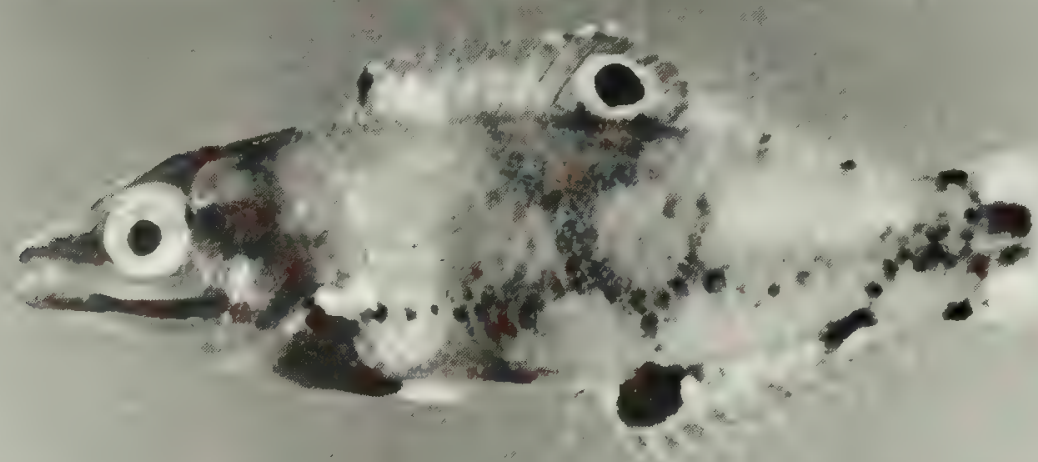

FIG. 317. Halichoeres hortulanus, $30 \mathrm{~mm}$ SL, Salomon 


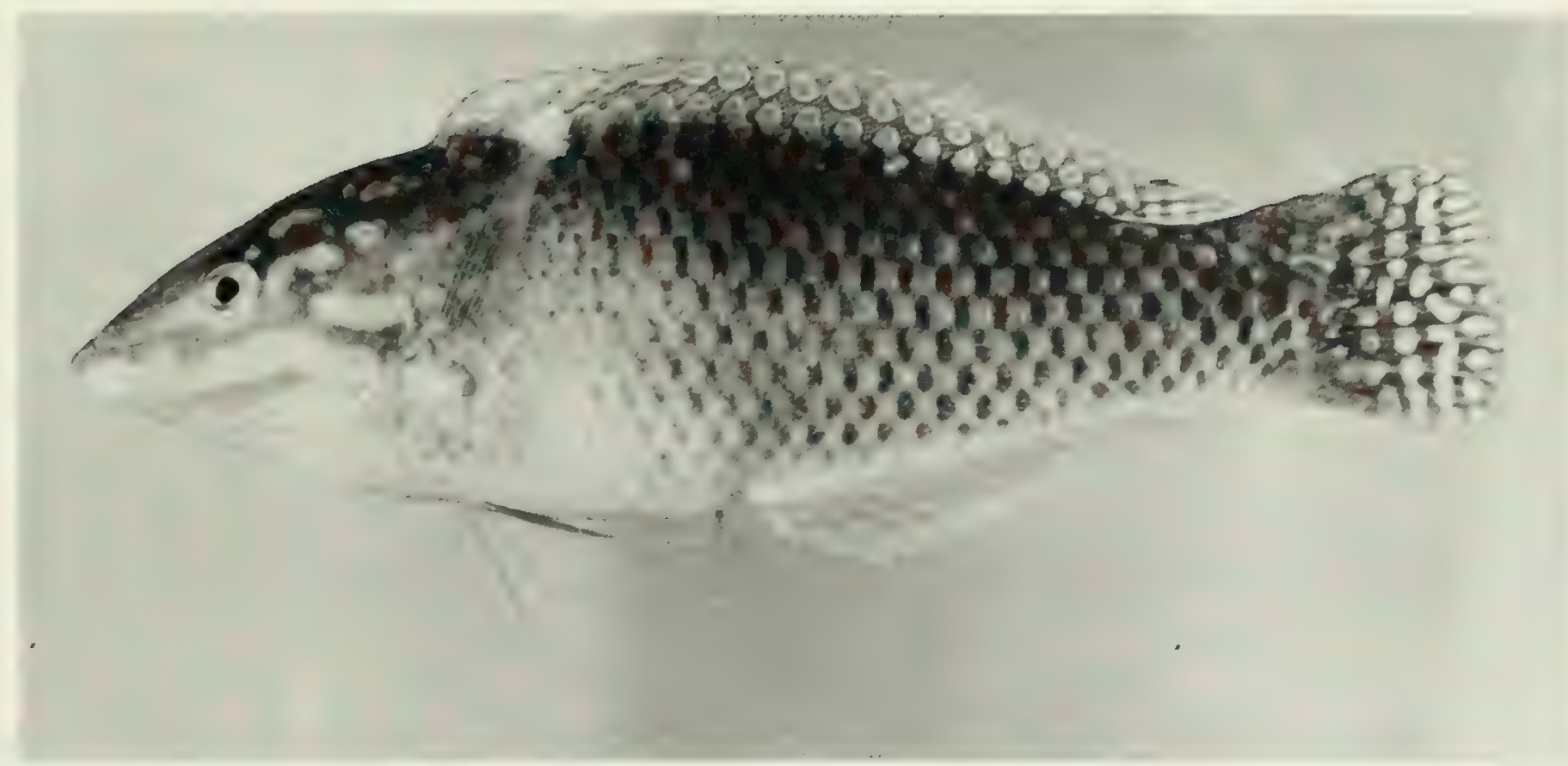

FIG. 318. Halichoeres hortulanus, $136 \mathrm{~mm} \mathrm{SL}$, Salomon.

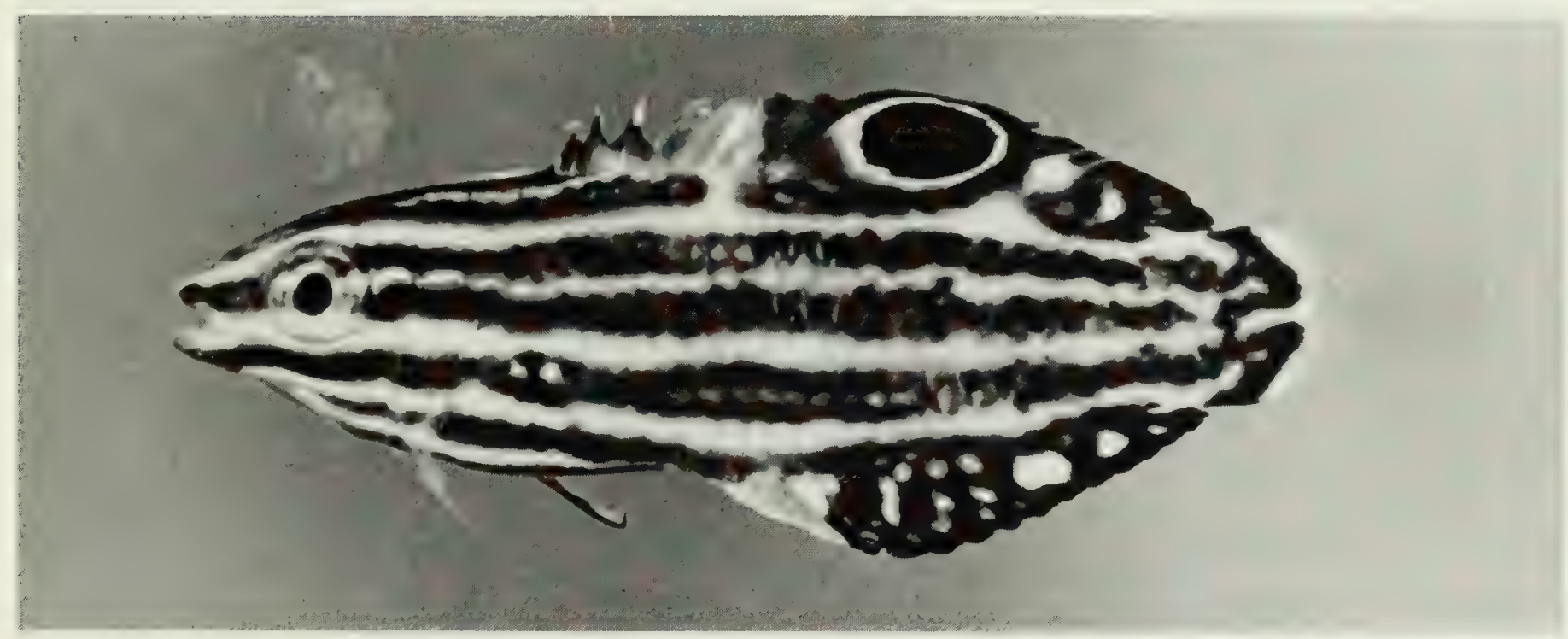

FIG. 319. Halichoeres marginatus, $19 \mathrm{~mm} \mathrm{SL}$, Peros Banhos.

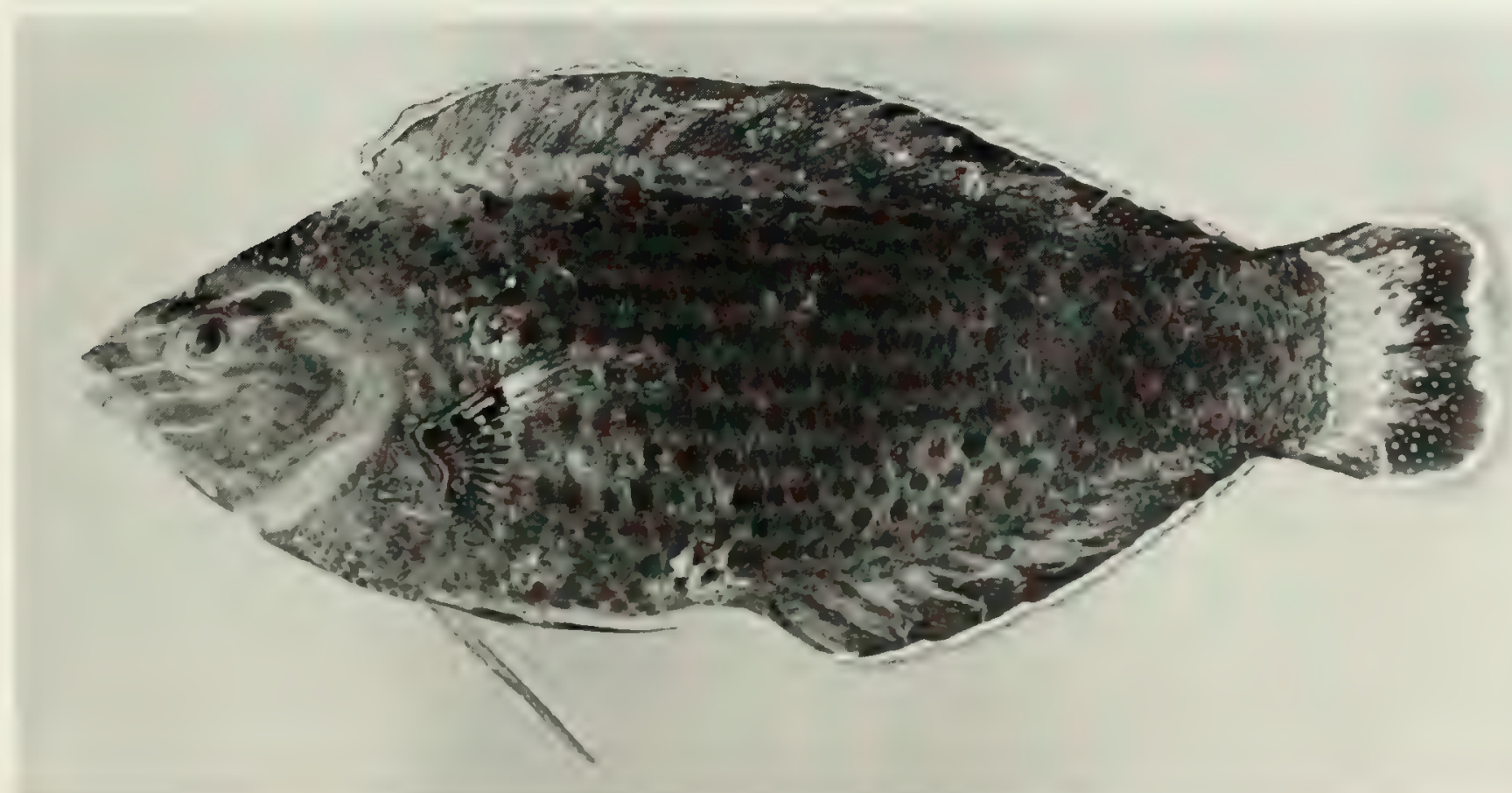

Fig. 320. Halichoeres marginatus, $91 \mathrm{~mm}$ SL, Salomon. 


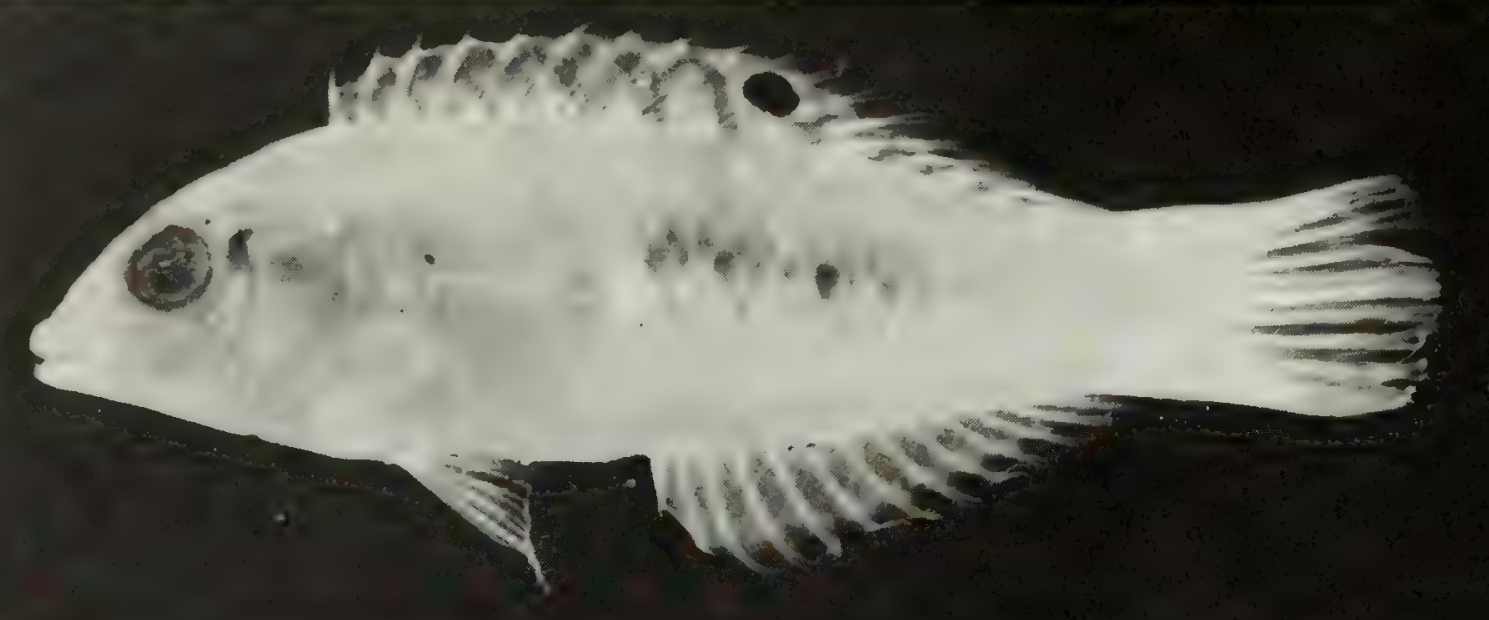

FIG. 321. Halichoeres nebulosus, (preserved) $49 \mathrm{~mm} \mathrm{SL}$, Eagle Island. Photo by A. Strange.

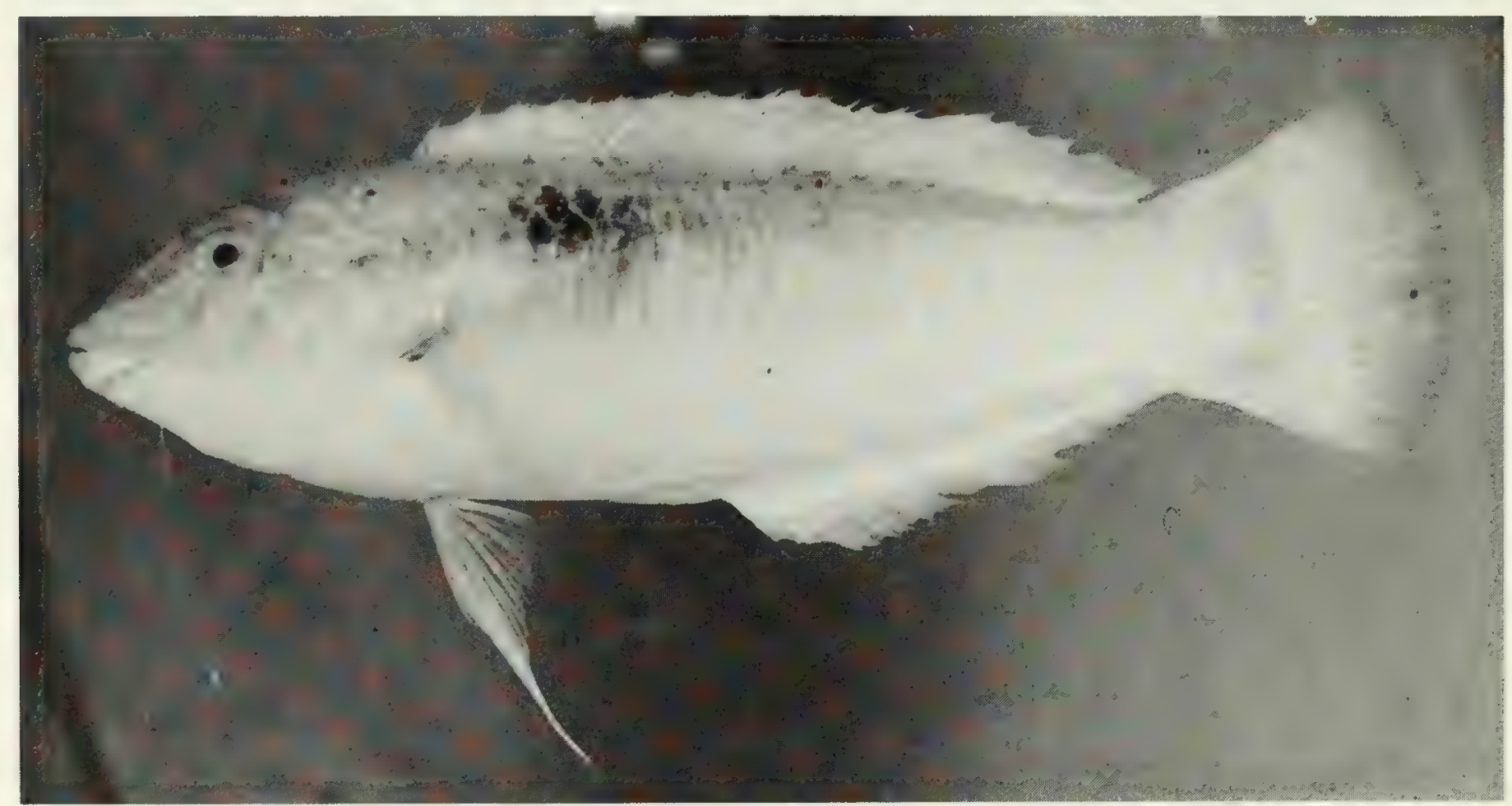

FIG. 322. Halichoeres scapularis, $110 \mathrm{~mm} \mathrm{SL}$, Peros Banhos.

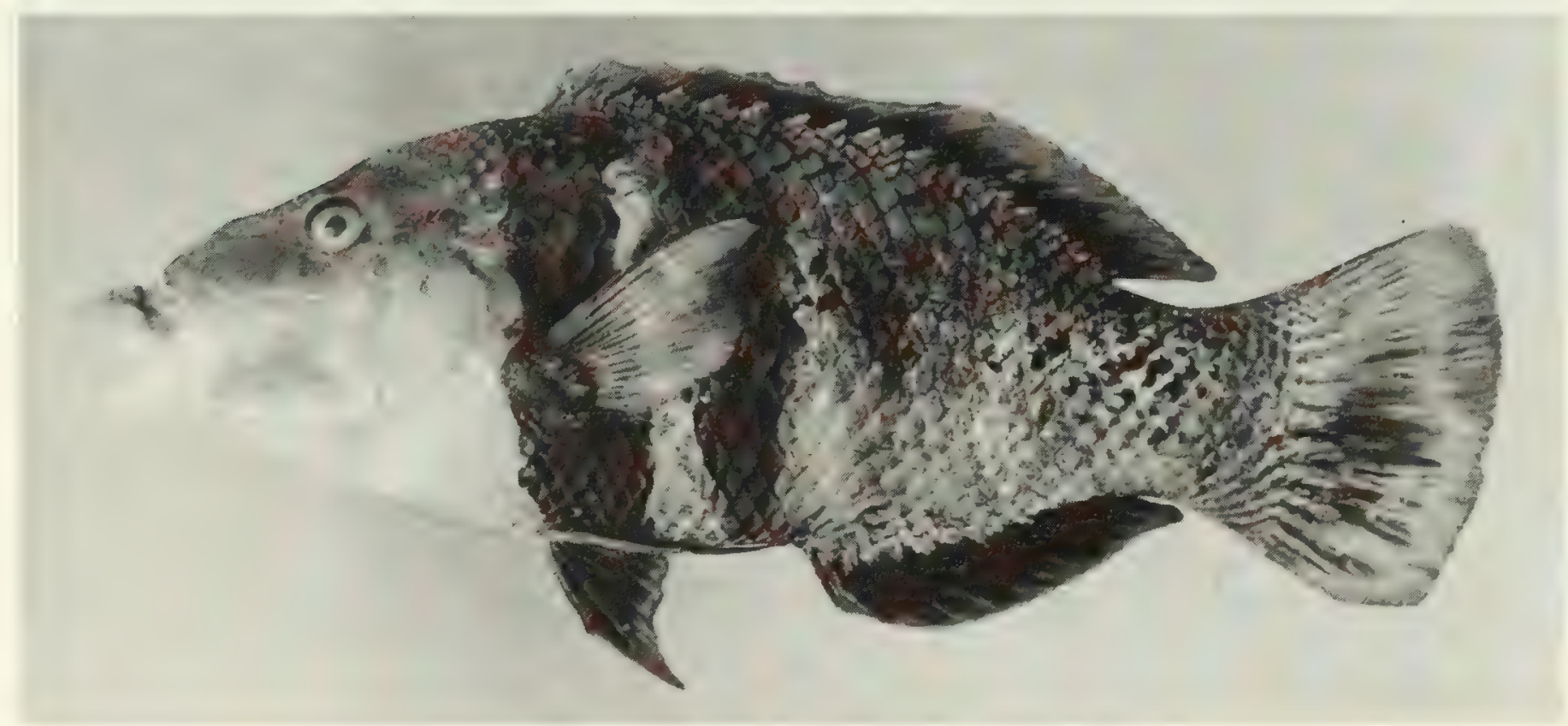

FIG. 323. Hemigymnus fasciatus, $202 \mathrm{~mm} \mathrm{SL,} \mathrm{Peros} \mathrm{Banhos.}$ 


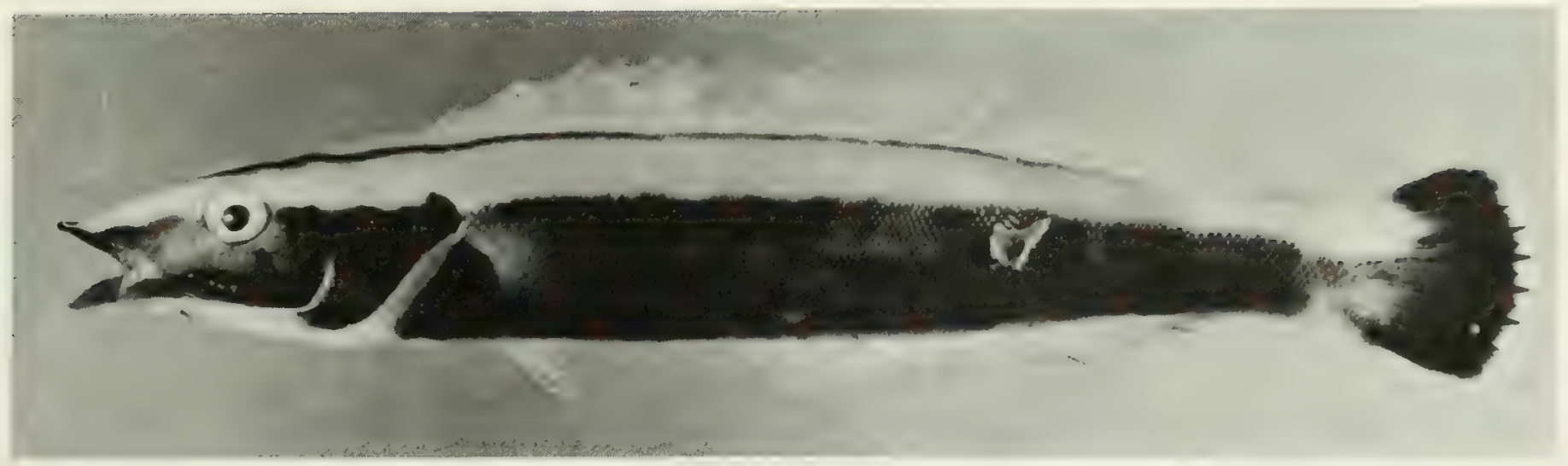

FIG. 324. Hologymnosus annulatus, $73 \mathrm{~mm}$ SL, Peros Banhos.

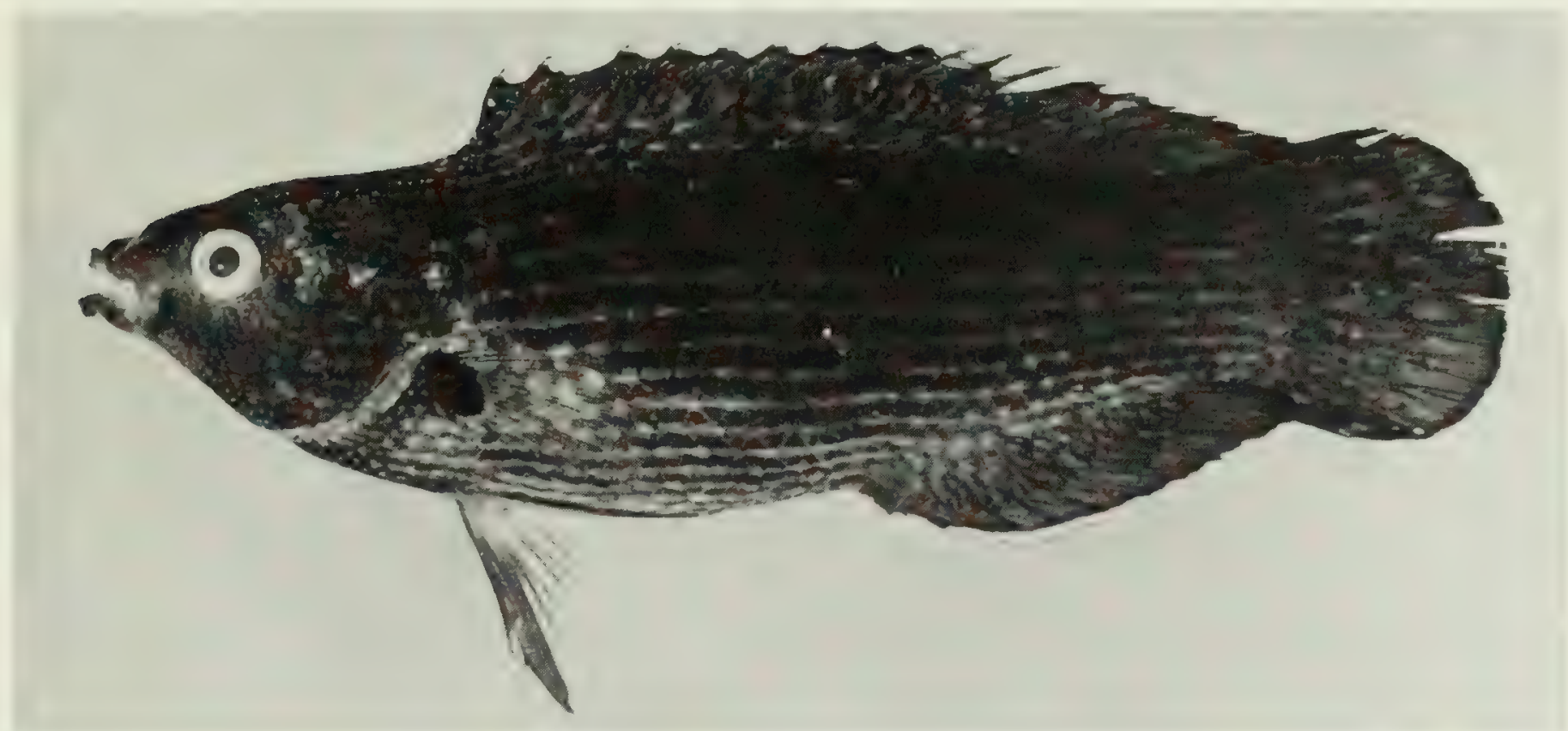

Fig. 325. Labrichthys unilineatus, $64 \mathrm{~mm} \mathrm{SL}$, Peros Banhos.

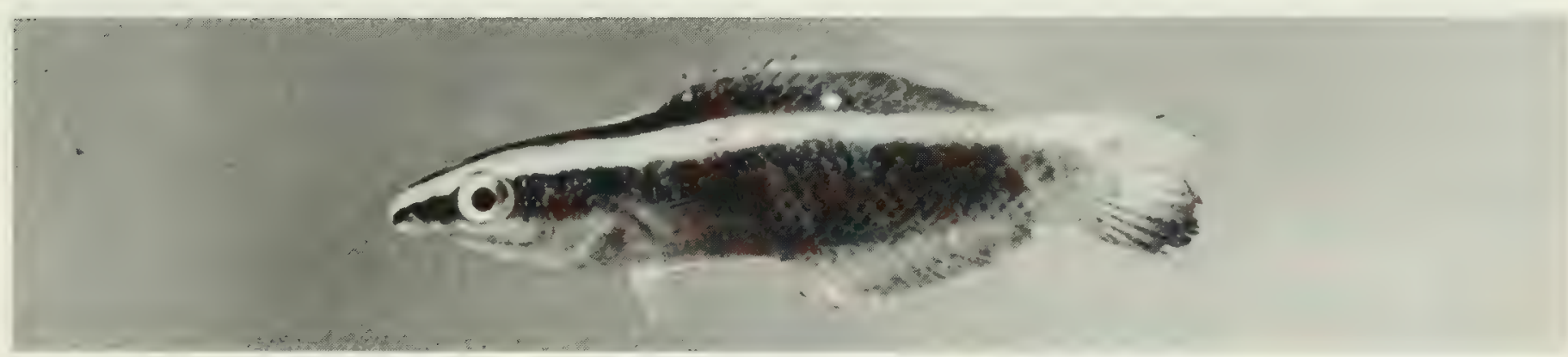

FIG. 326. Labroides bicolor, $25 \mathrm{~mm} \mathrm{SL}$, Salomon.

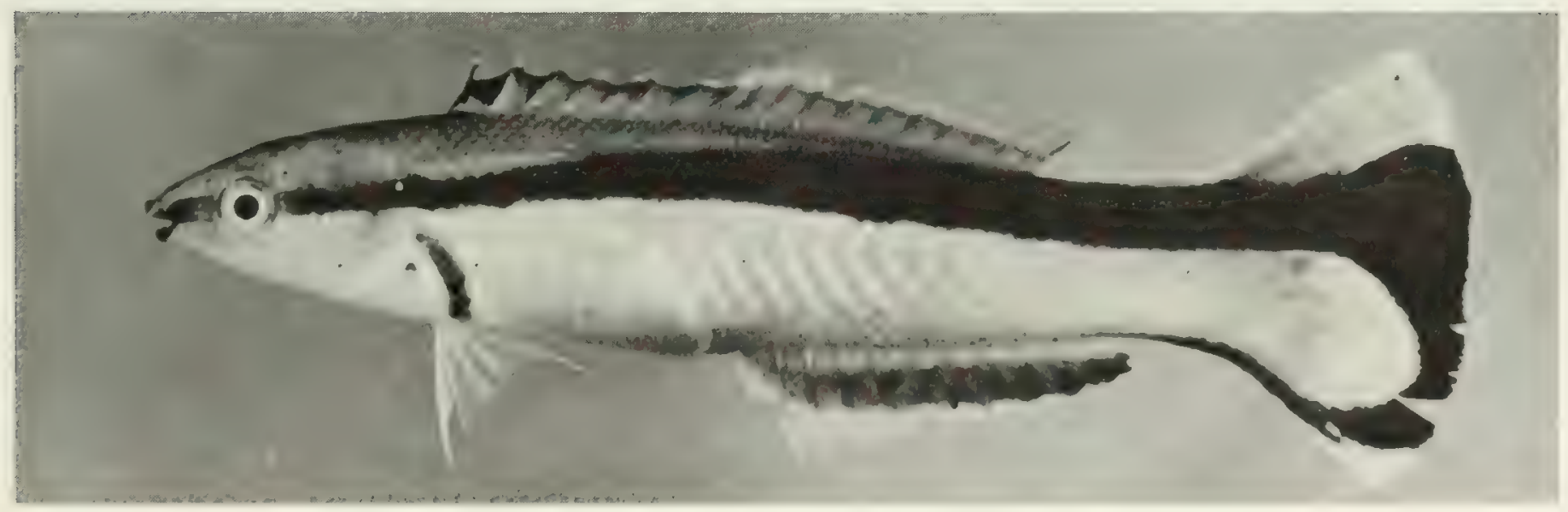

FiG. 327. Labroides dimidiatus, $55 \mathrm{~mm}$ SL, Peros Banhos. 


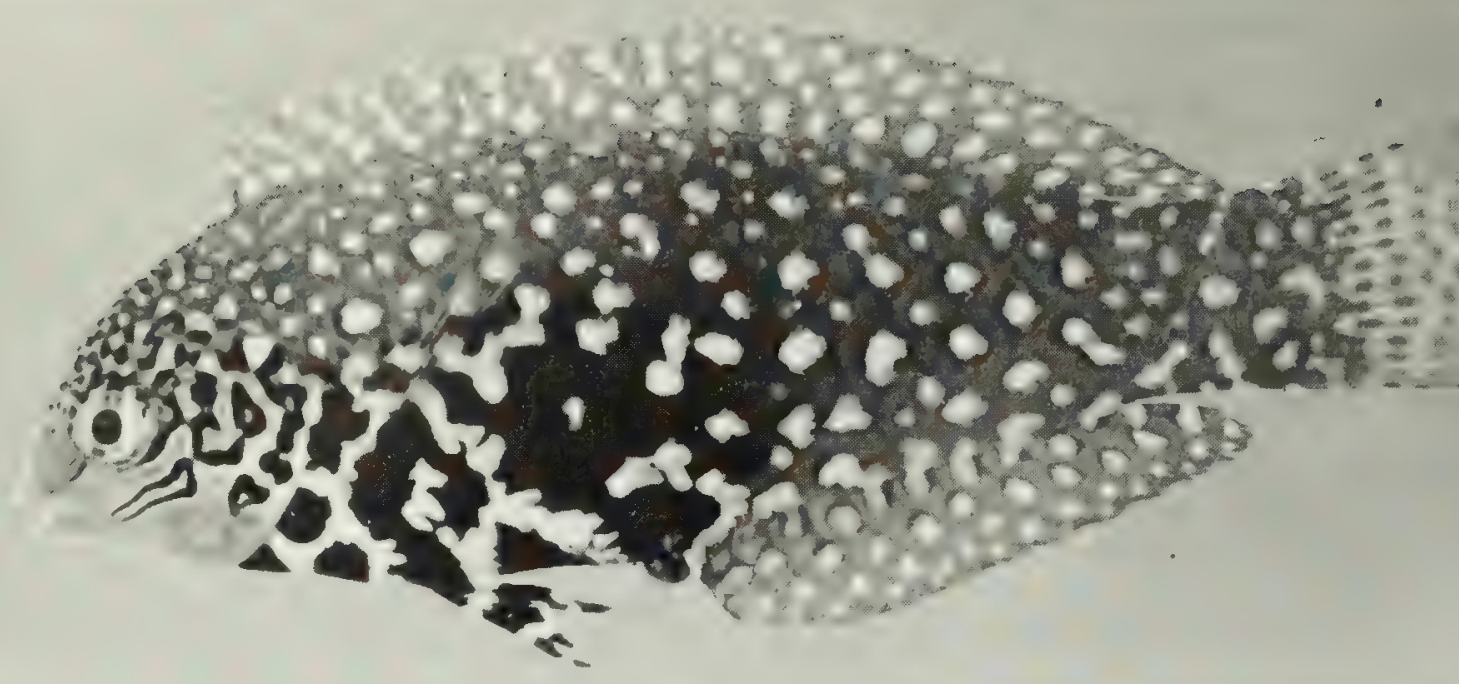

FIG. 328. Macropharyngodon bipartitus bipartitus, $58 \mathrm{~mm}$ SL female, Peros Banhos.

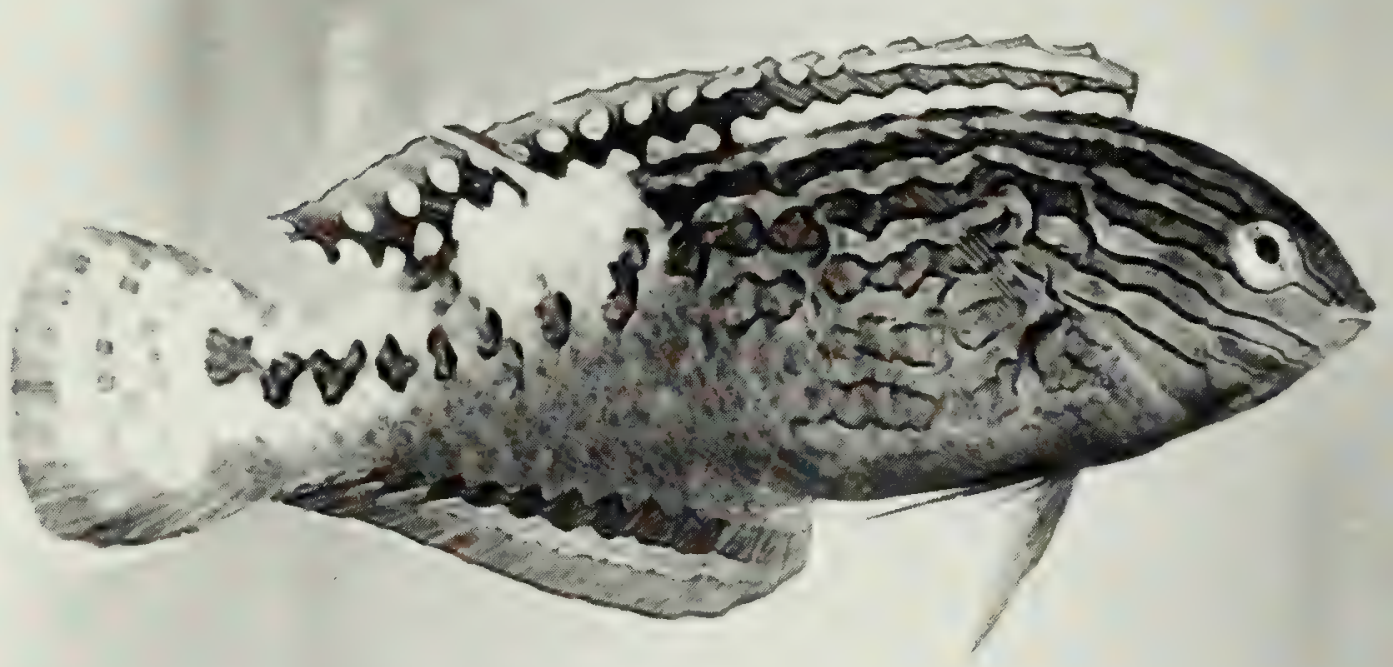

FIG. 329. Macropharyngodon bipartitus bipartitus, $75 \mathrm{~mm}$ SL male, Peros Banhos.

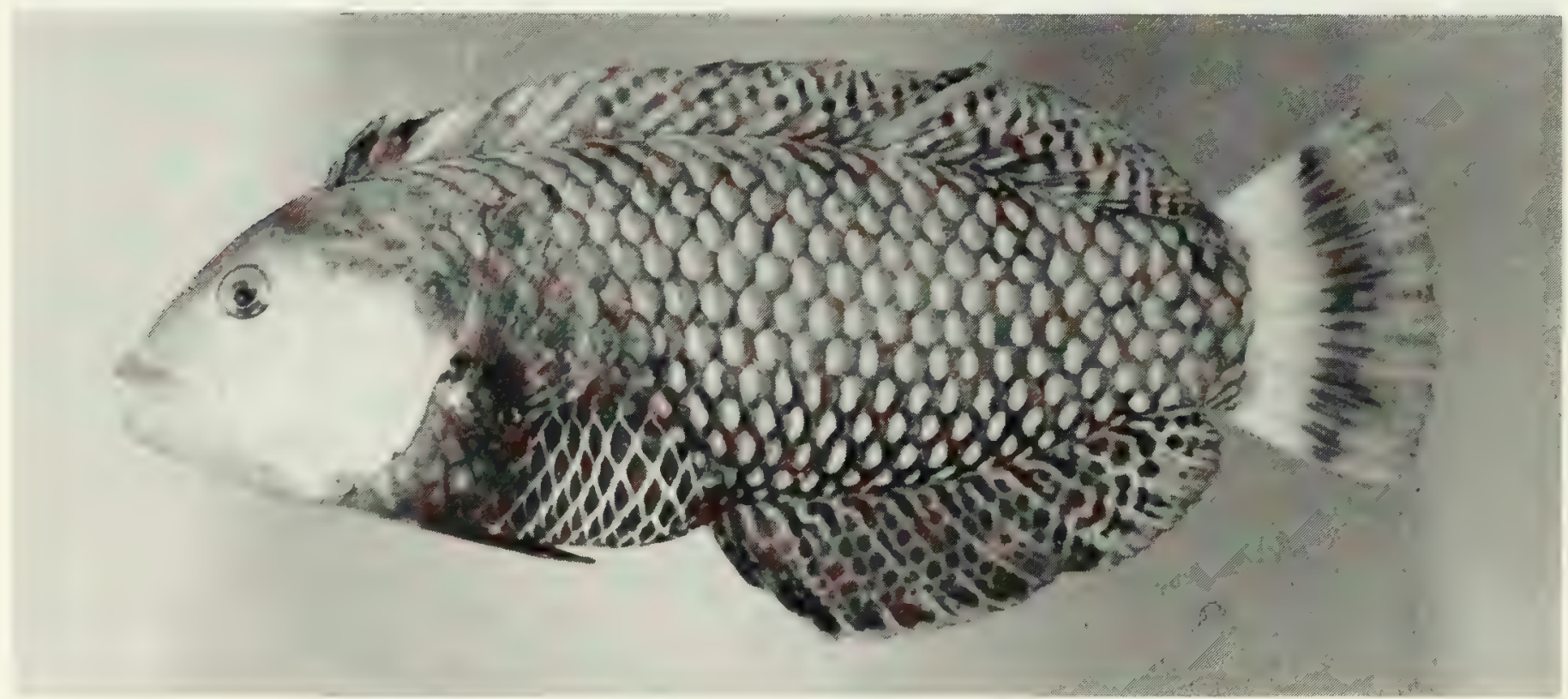

FIG. 330. Novaculichthys taeniourus, $177 \mathrm{~mm} \mathrm{SL}$, Peros Banhos. 


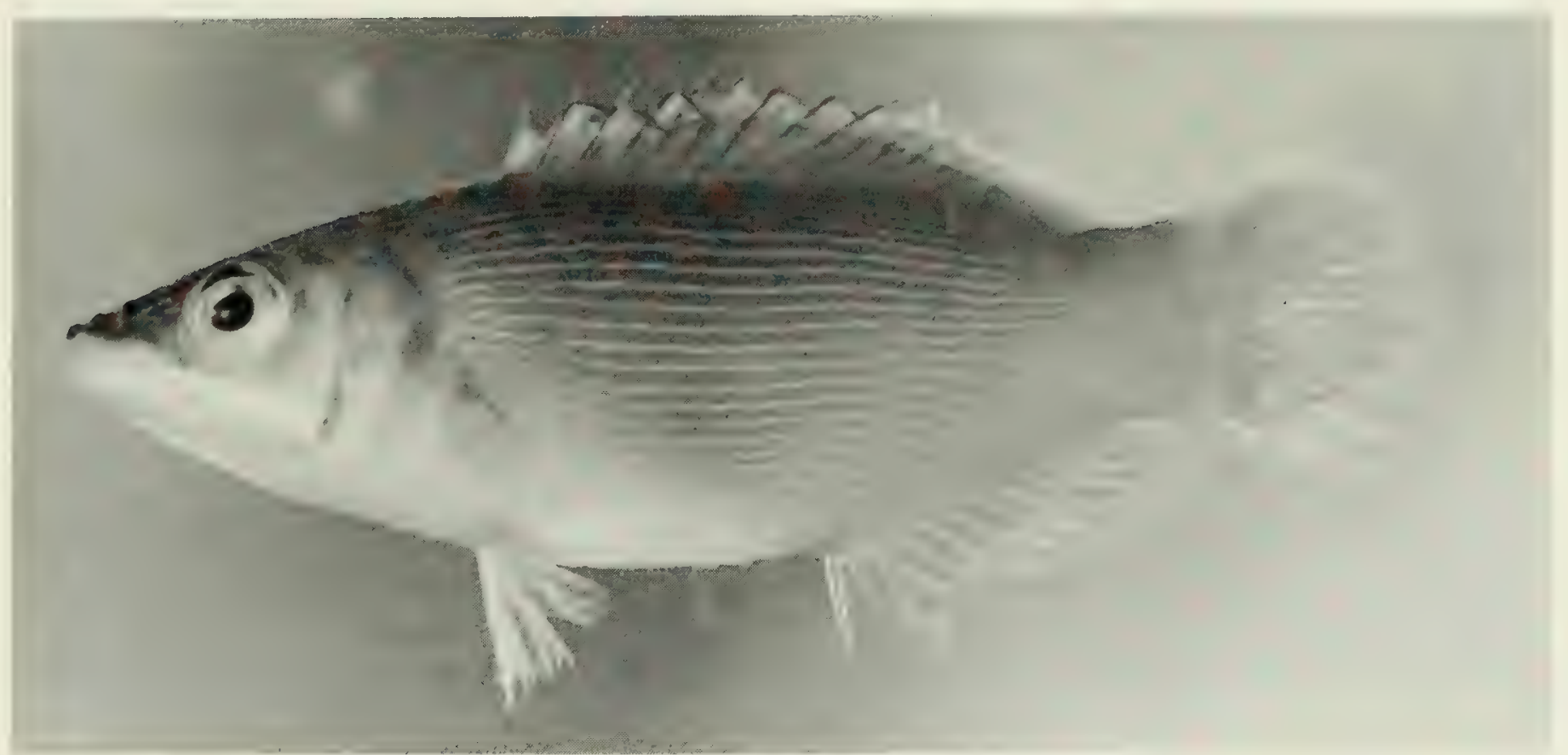

FIG. 331. Pseudocheilinus evanidus, $49 \mathrm{~mm} \mathrm{SL}$, Salomon.

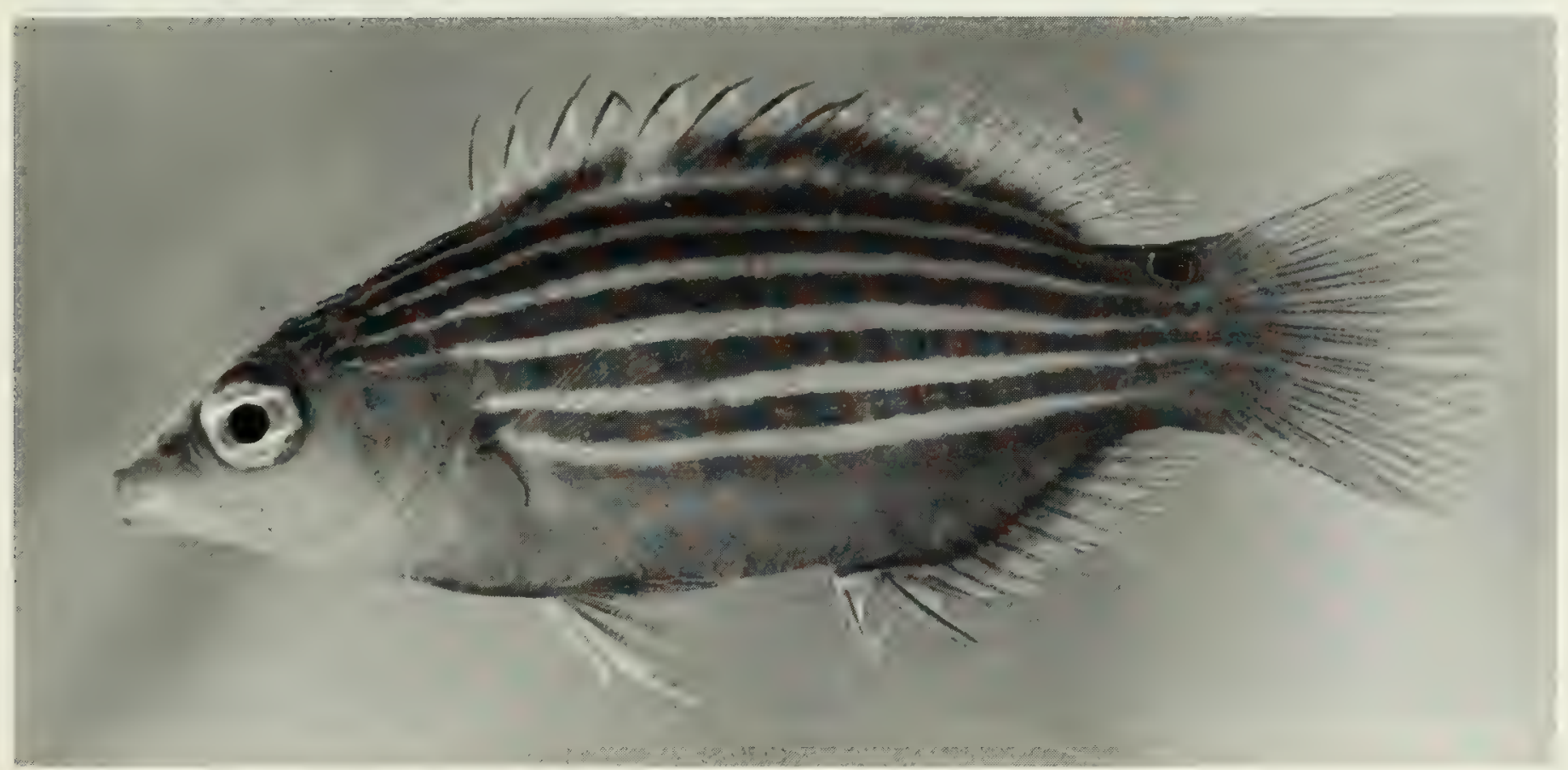

Fig. 332. Pseudocheilinus hexataenia, $39 \mathrm{~mm}$ SL, Peros Banhos.

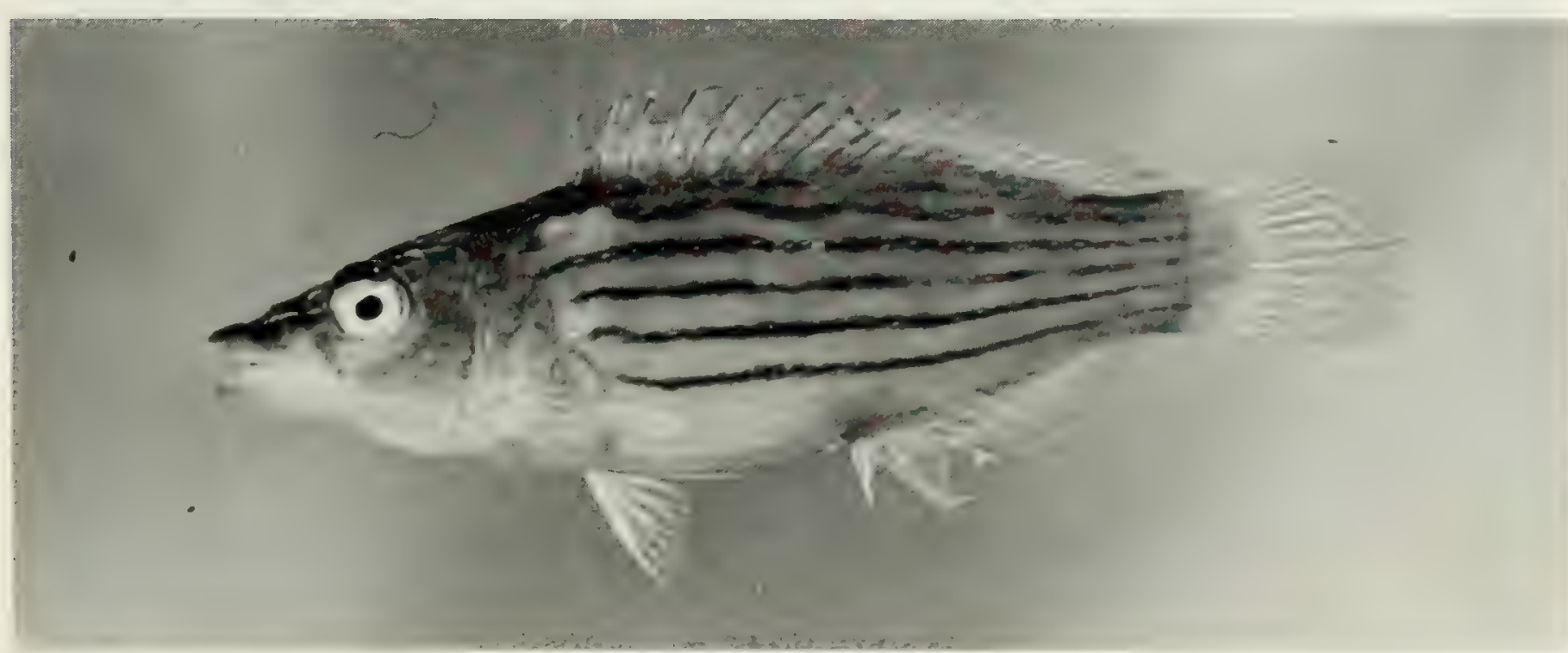

FIG. 333. Pseudocheilinus octotaenia, $44 \mathrm{~mm}$ SL, Salomon. 


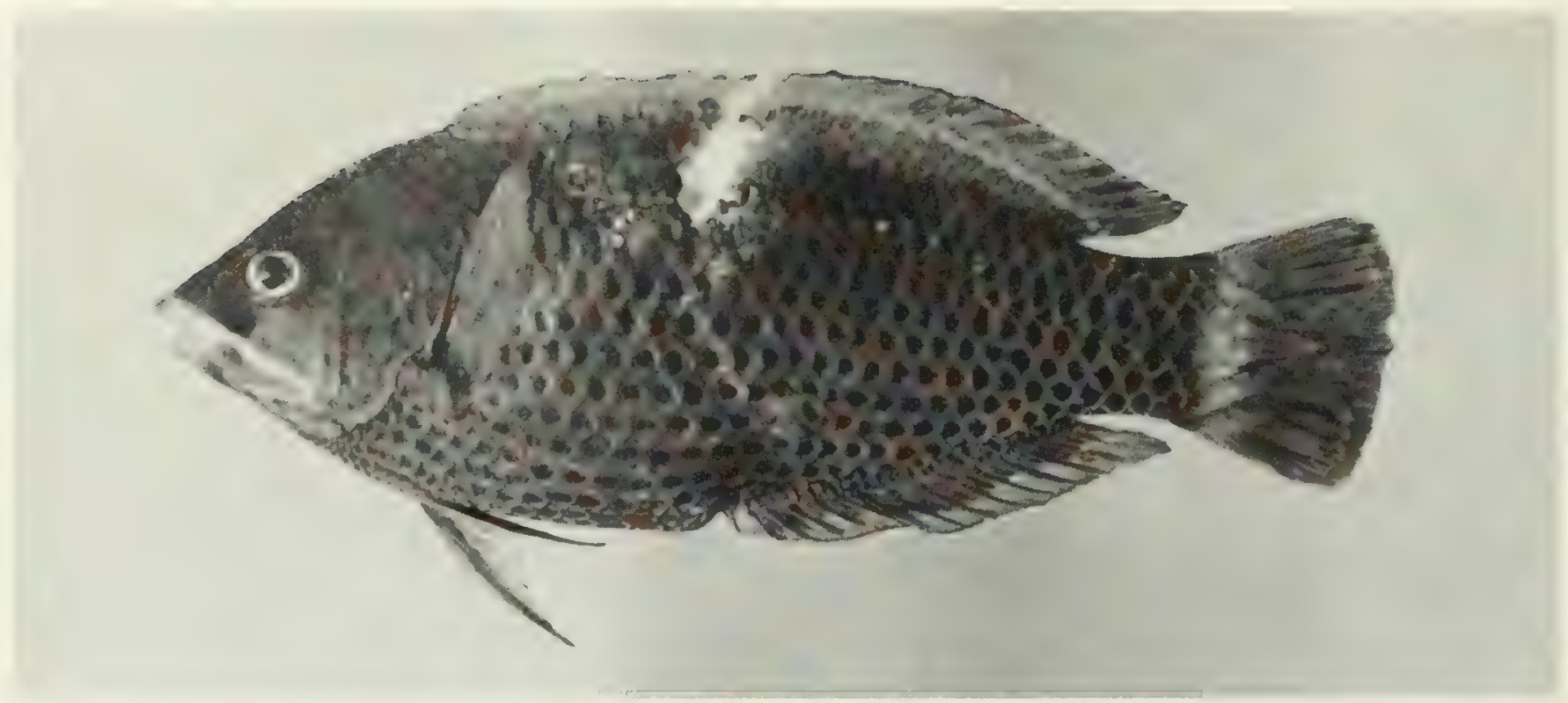

FIG. 334. Pseudodax moluccanus, $127 \mathrm{~mm}$ SL, Salomon.

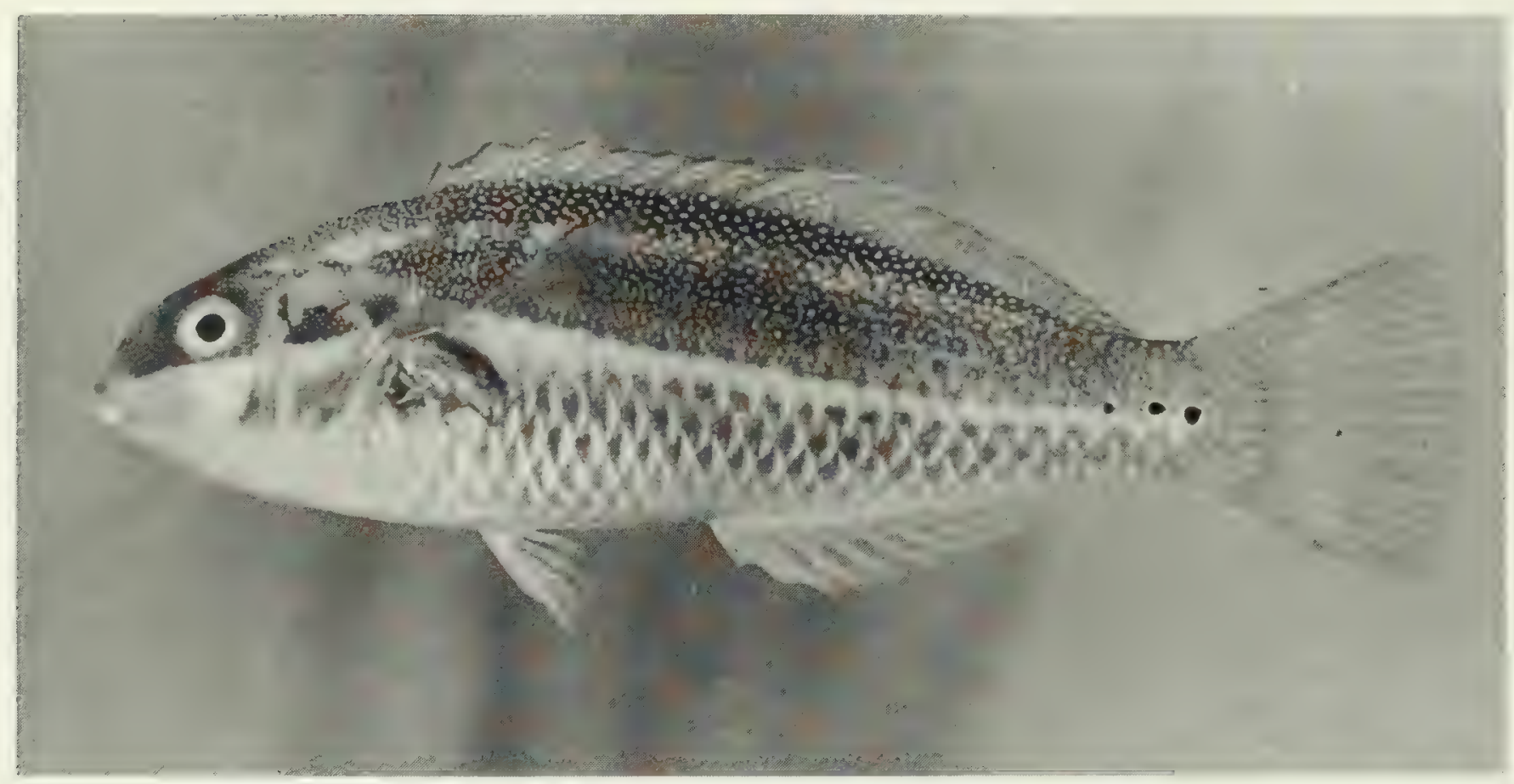

FiG. 335. Stethojulis albovittata, $59 \mathrm{~mm}$ SL, Peros Banhos.

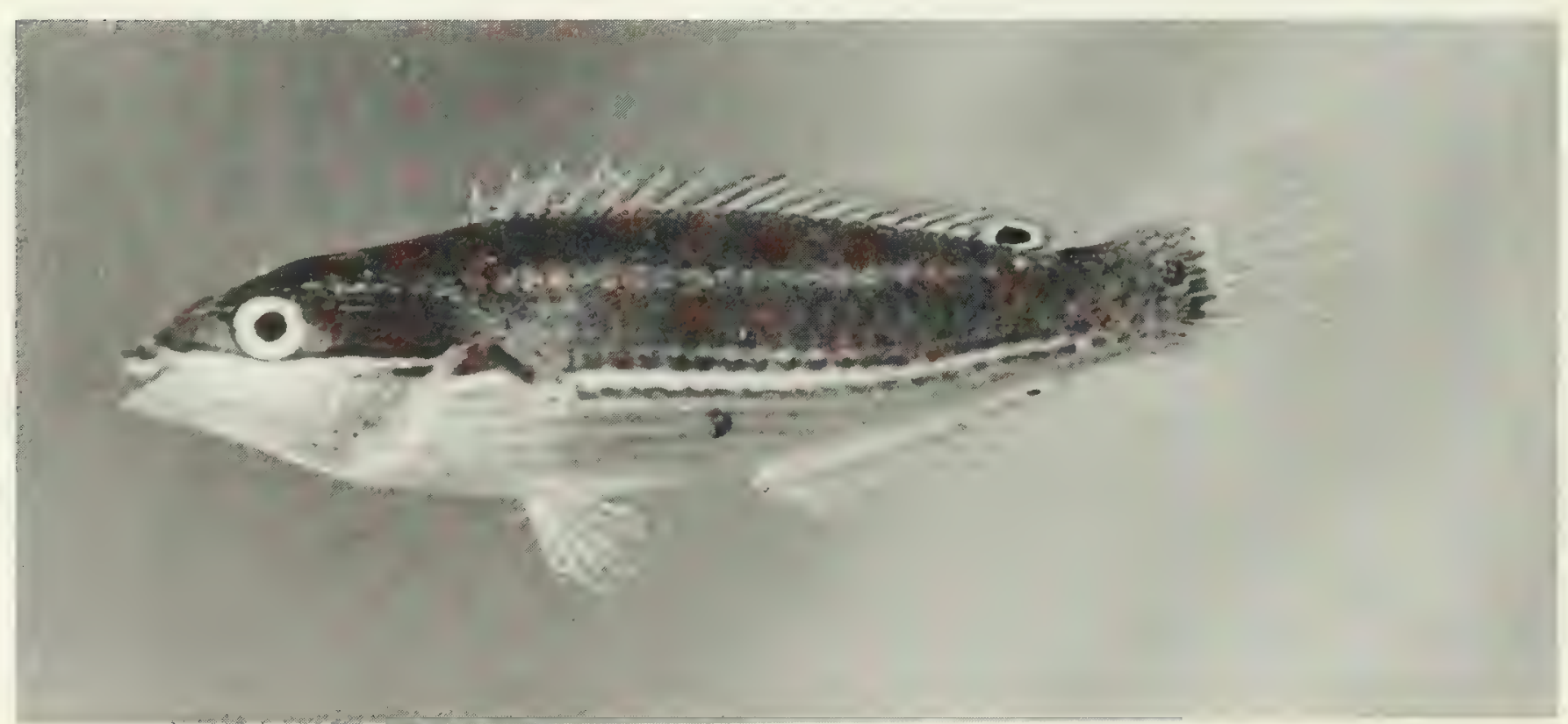

FIG. 336. Stethojulis strigiventer, $45 \mathrm{~mm} \mathrm{SL}$, Salomon. 


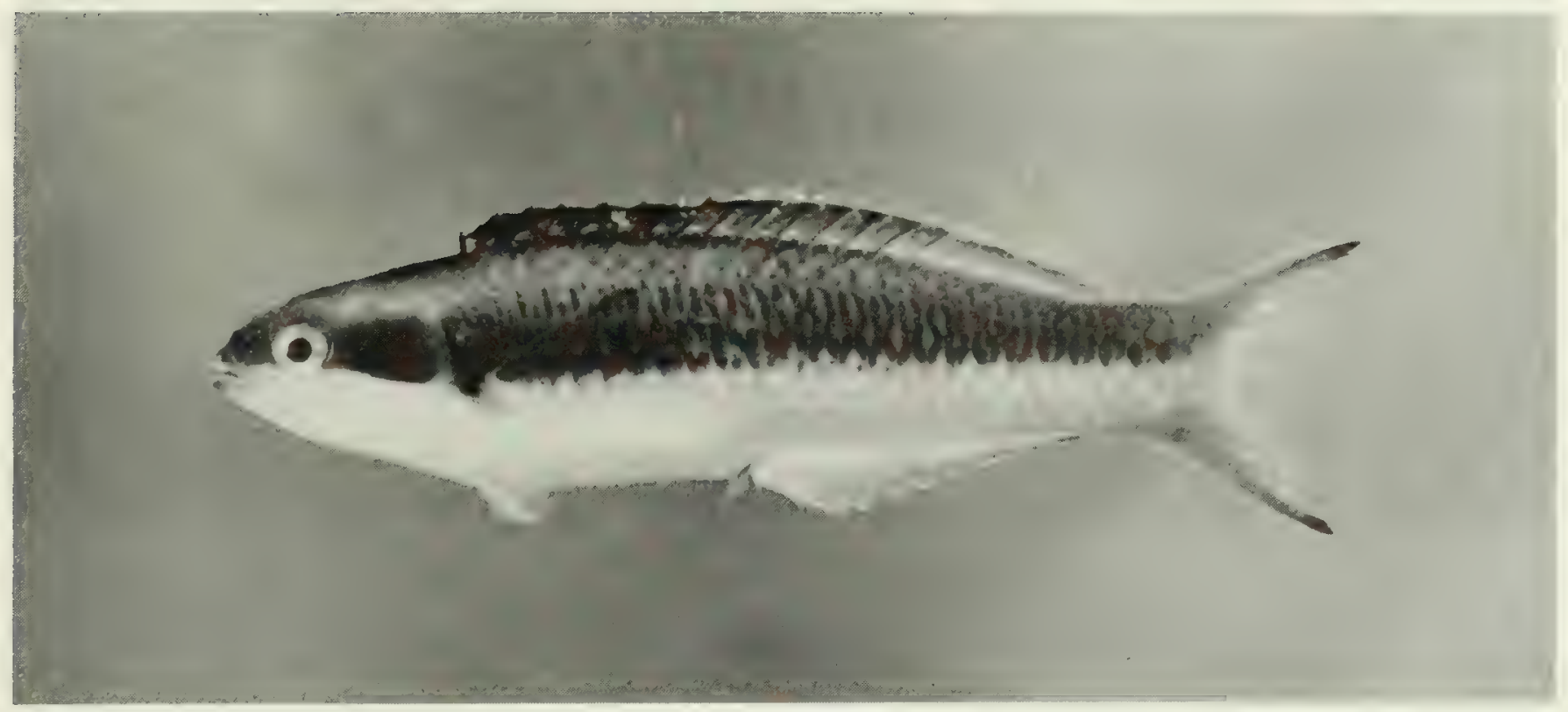

FIG. 337. Thalassoma amblycephalum, $60 \mathrm{~mm}$ SL, Salomon.

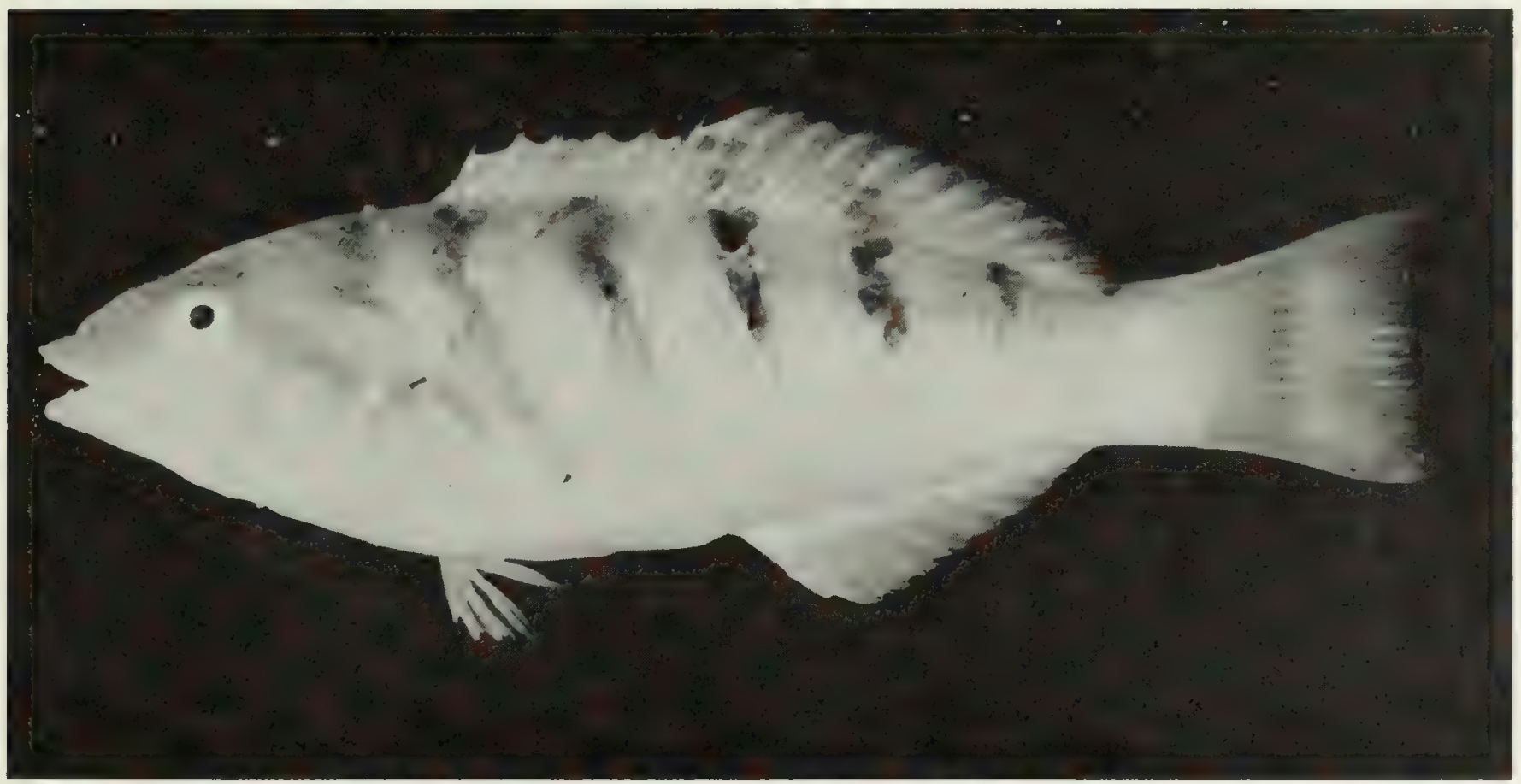

FIG. 338. Thalassoma hardwicki, 103 mm SL, Eagle Island.

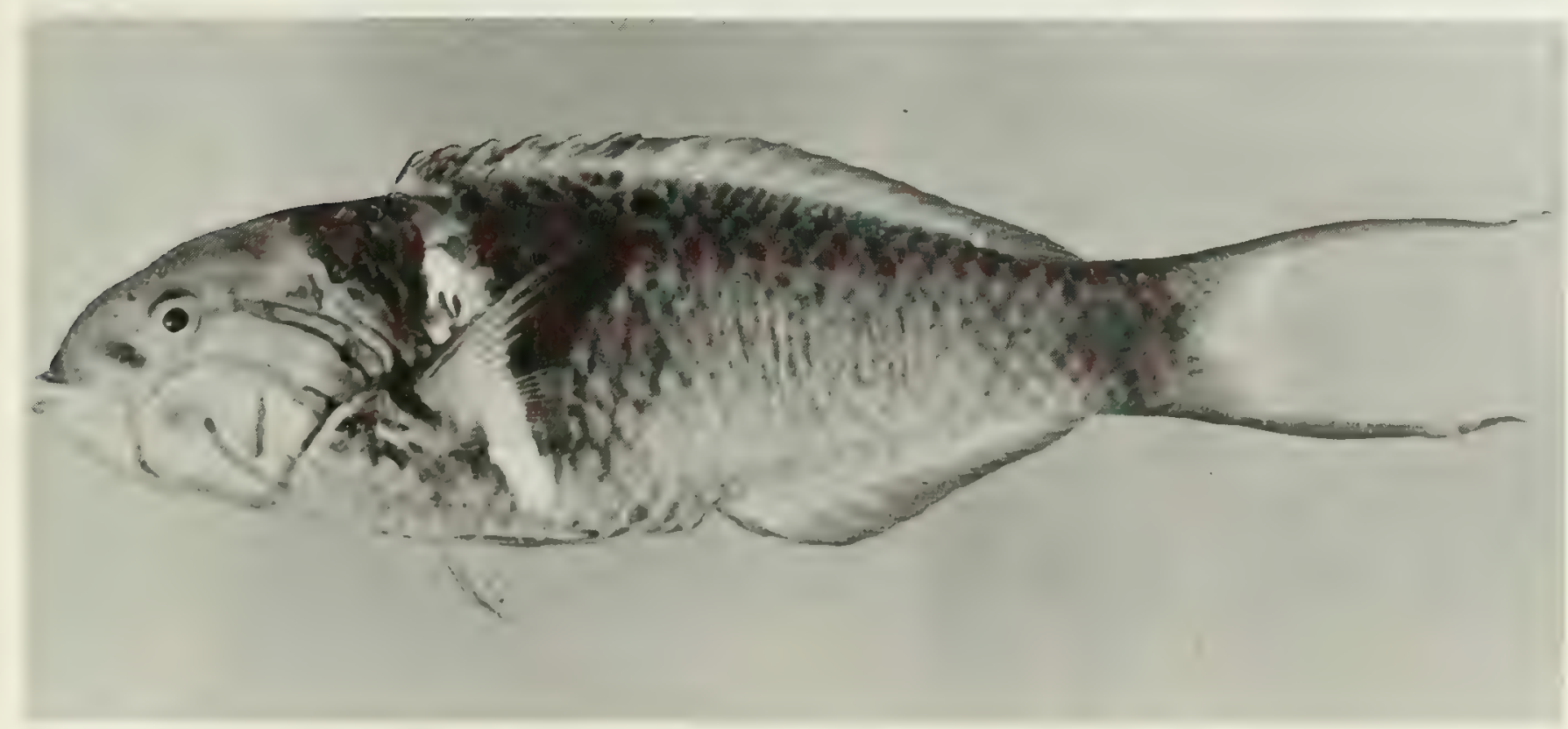

Fig. 339. Thalassoma hebraicum, $127 \mathrm{~mm} \mathrm{SL}$, Peros Banhos. 


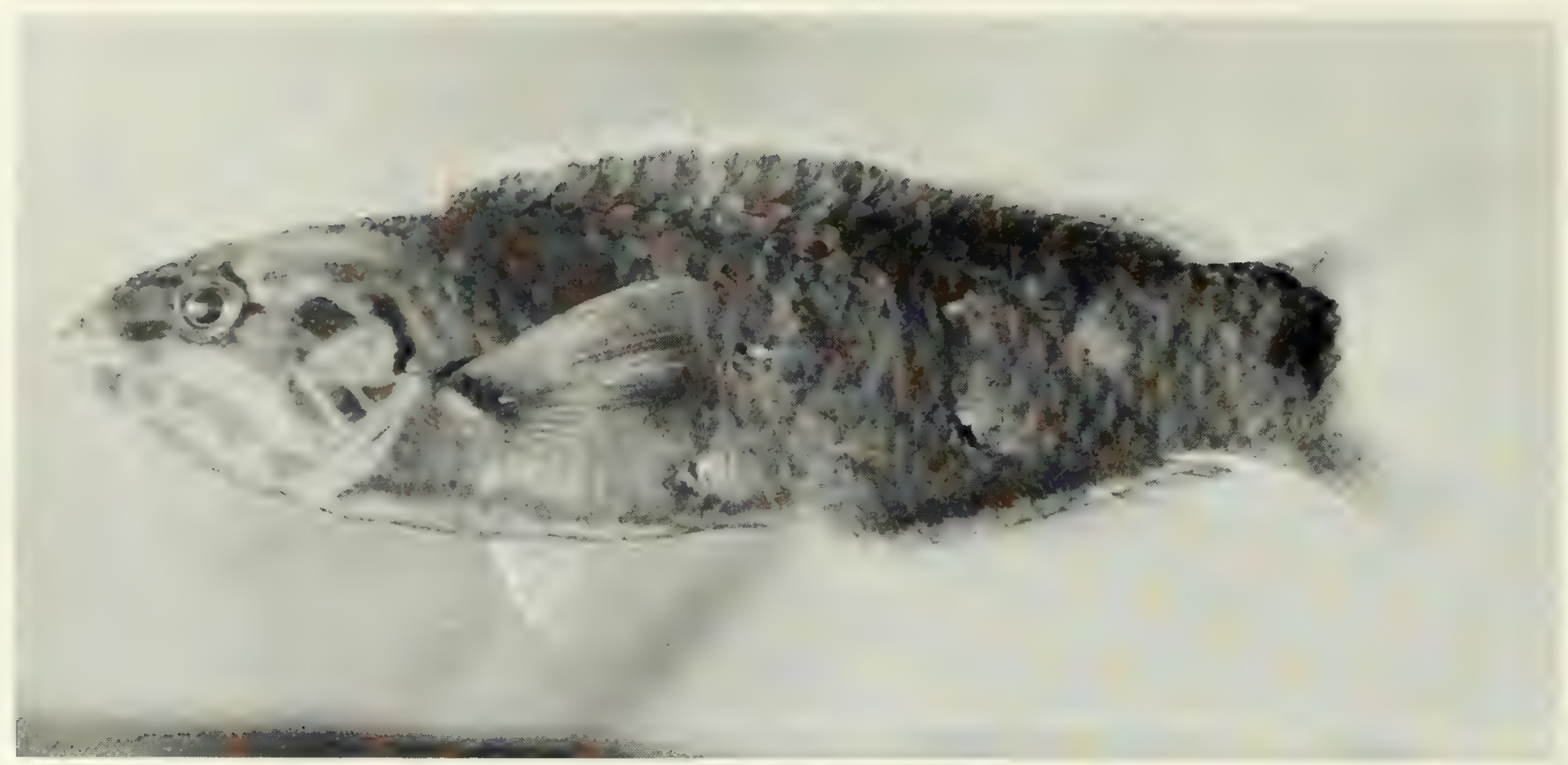

FIG. 340. Thalassoma lunare, $92 \mathrm{~mm} \mathrm{SL}$, Peros Banhos.

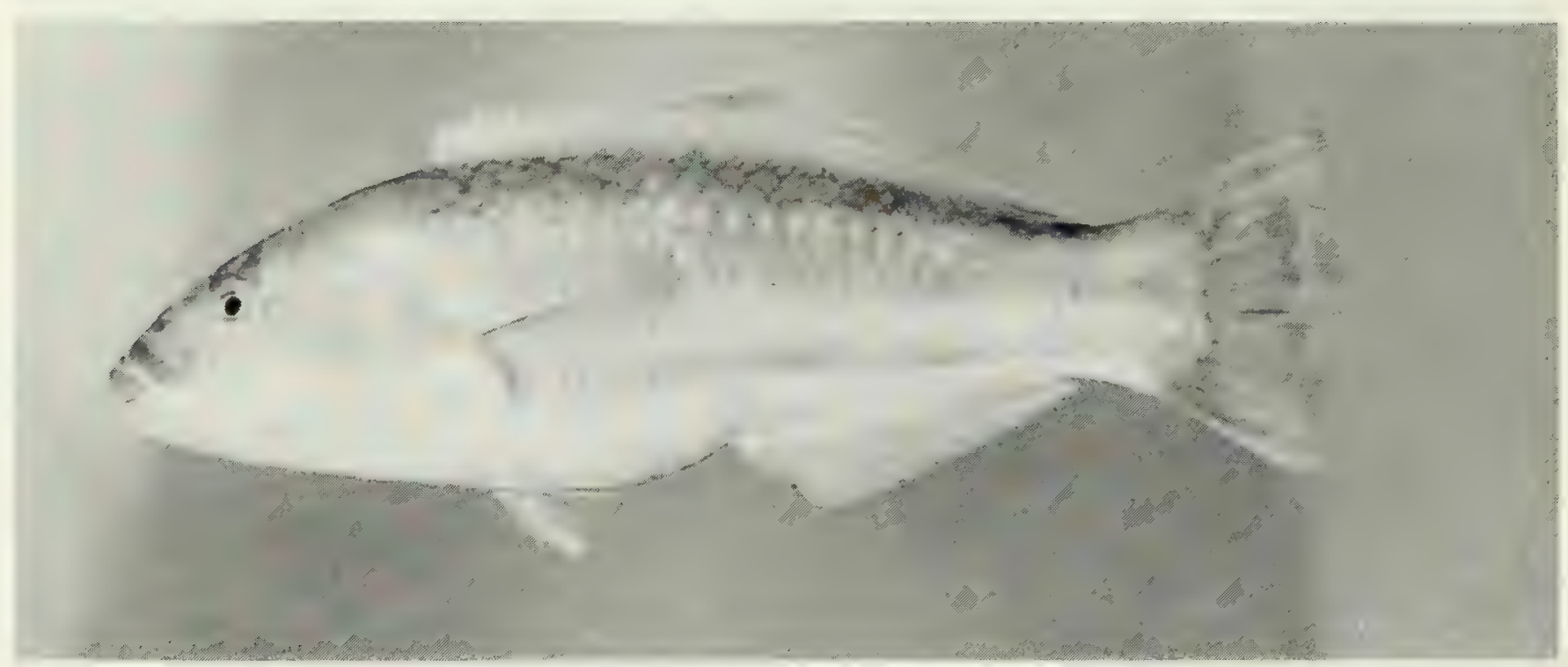

FIG. 341. Thalassoma purpureum, $174 \mathrm{~mm} \mathrm{SL,} \mathrm{Peros} \mathrm{Banhos.}$

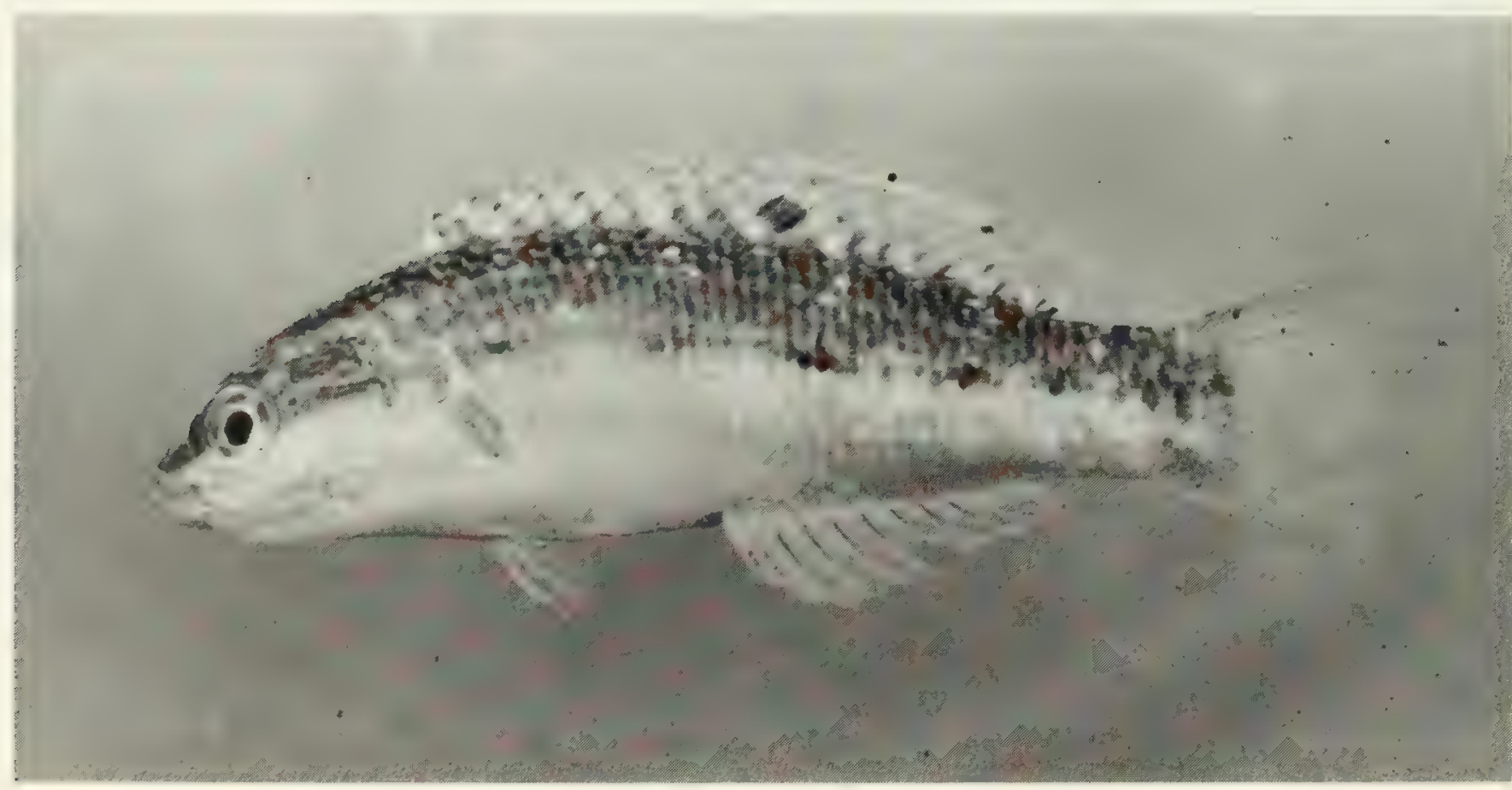

FIG. 342. Thalassoma quinquevittatum, $42 \mathrm{~mm}$ SL, Peros Banhos. 


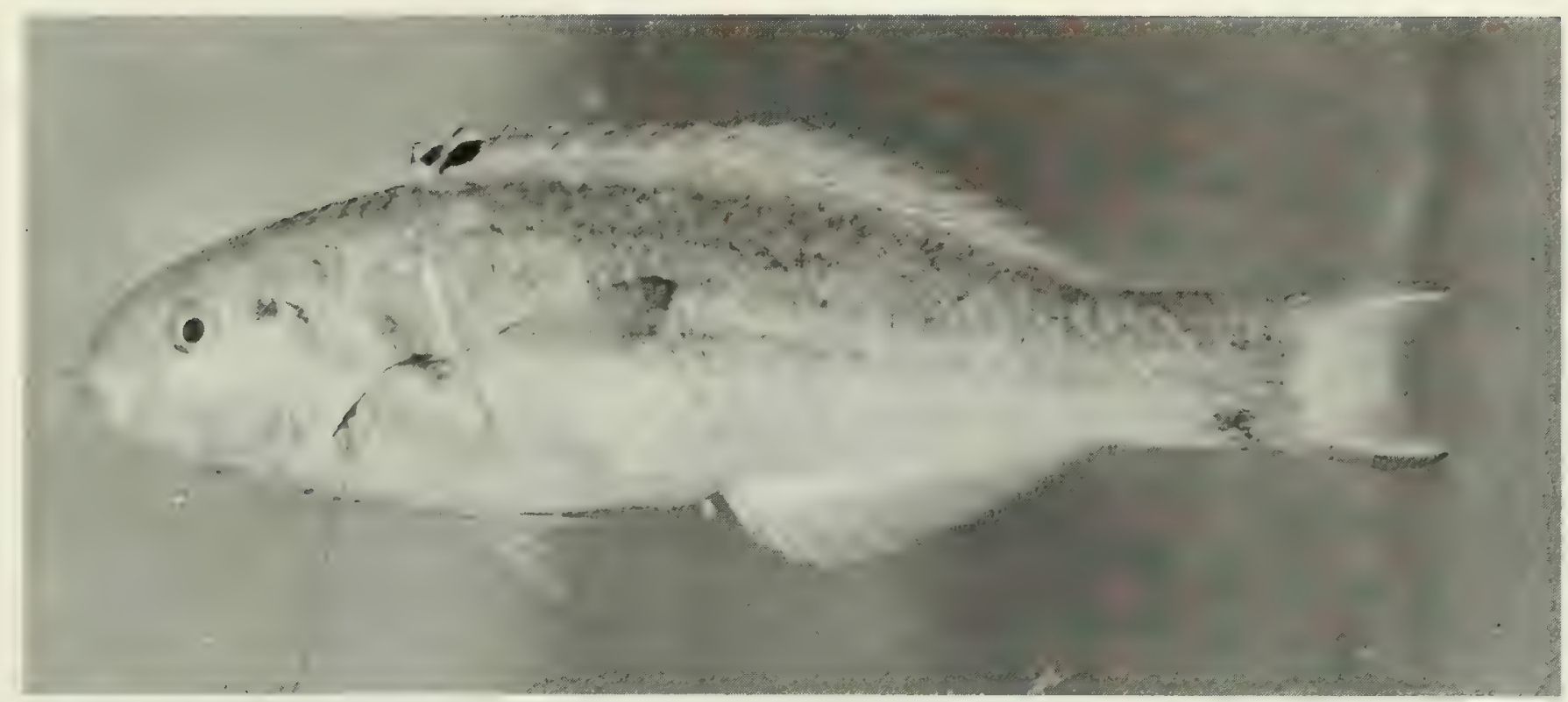

FIG. 343. Thalassoma quinquevittatum, $100 \mathrm{~mm} \mathrm{SL}$, Salomon.

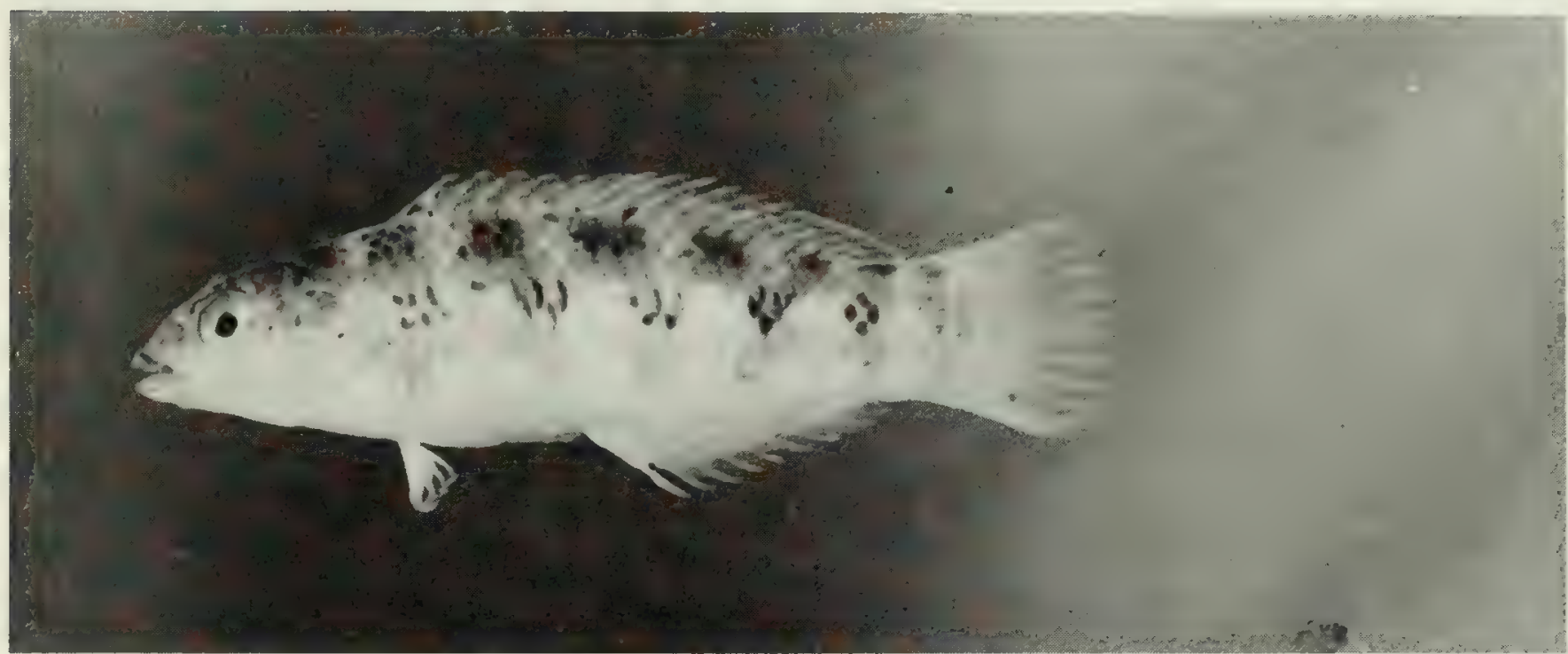

FIG. 344. Thalassoma trilobatum, $31 \mathrm{~mm} \mathrm{SL}$, Salomon.

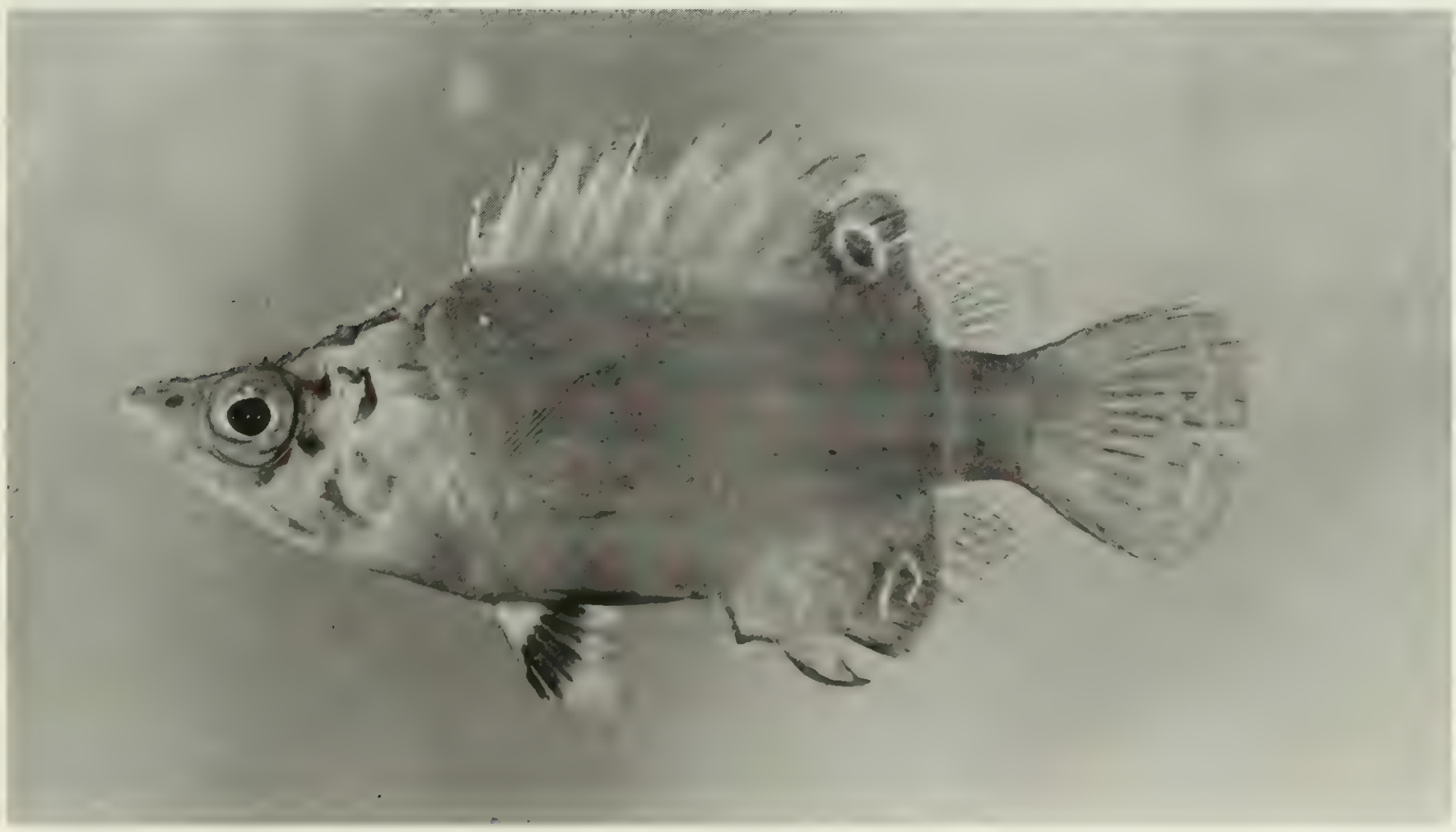

Fig. 345. Wetmorella nigropinnata, $39 \mathrm{~mm}$ SL, Peros Banhos. 


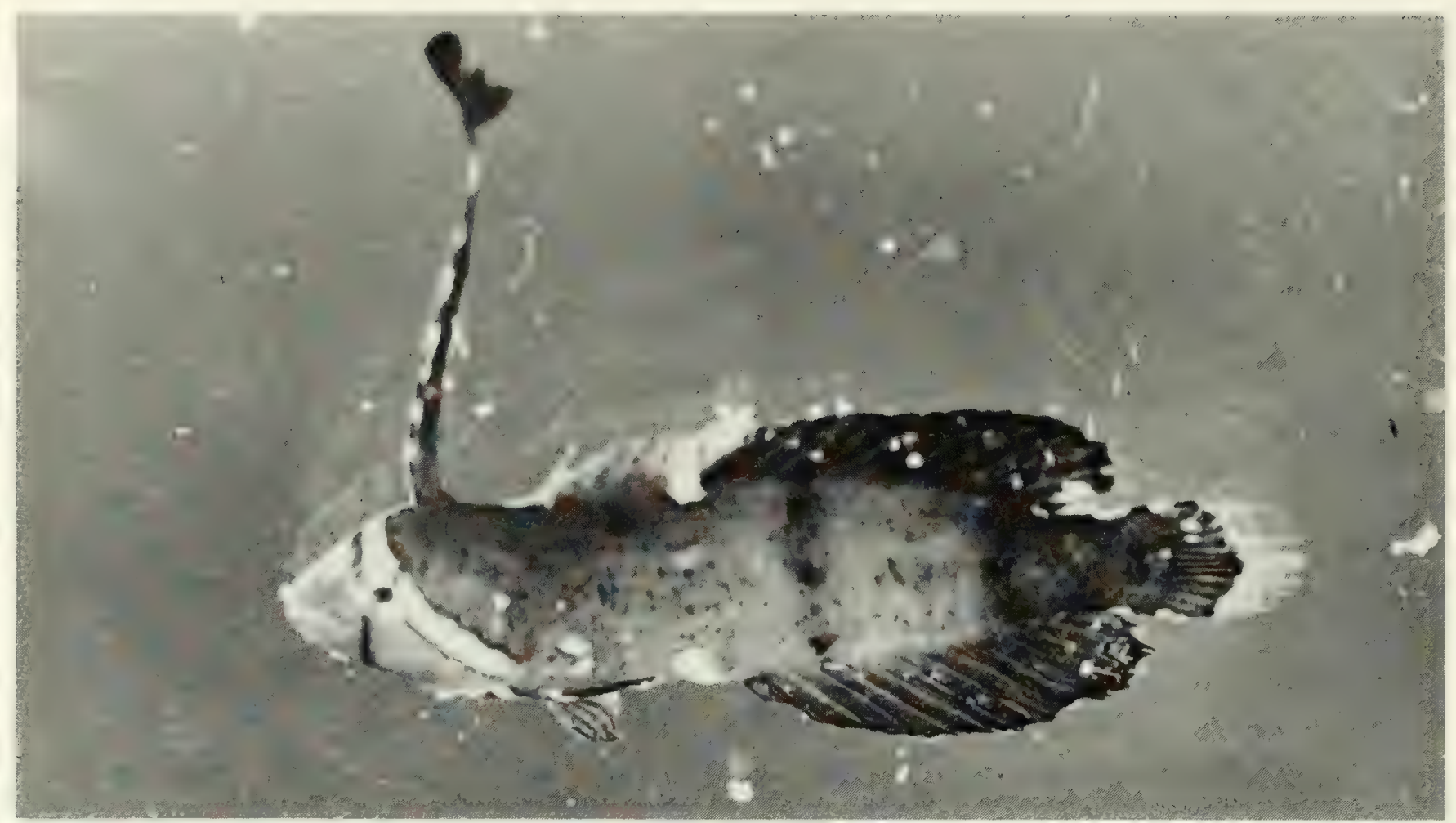

FIG. 346. Xyrichthys pavo, $16 \mathrm{~mm} \mathrm{SL}$, Peros Banhos.

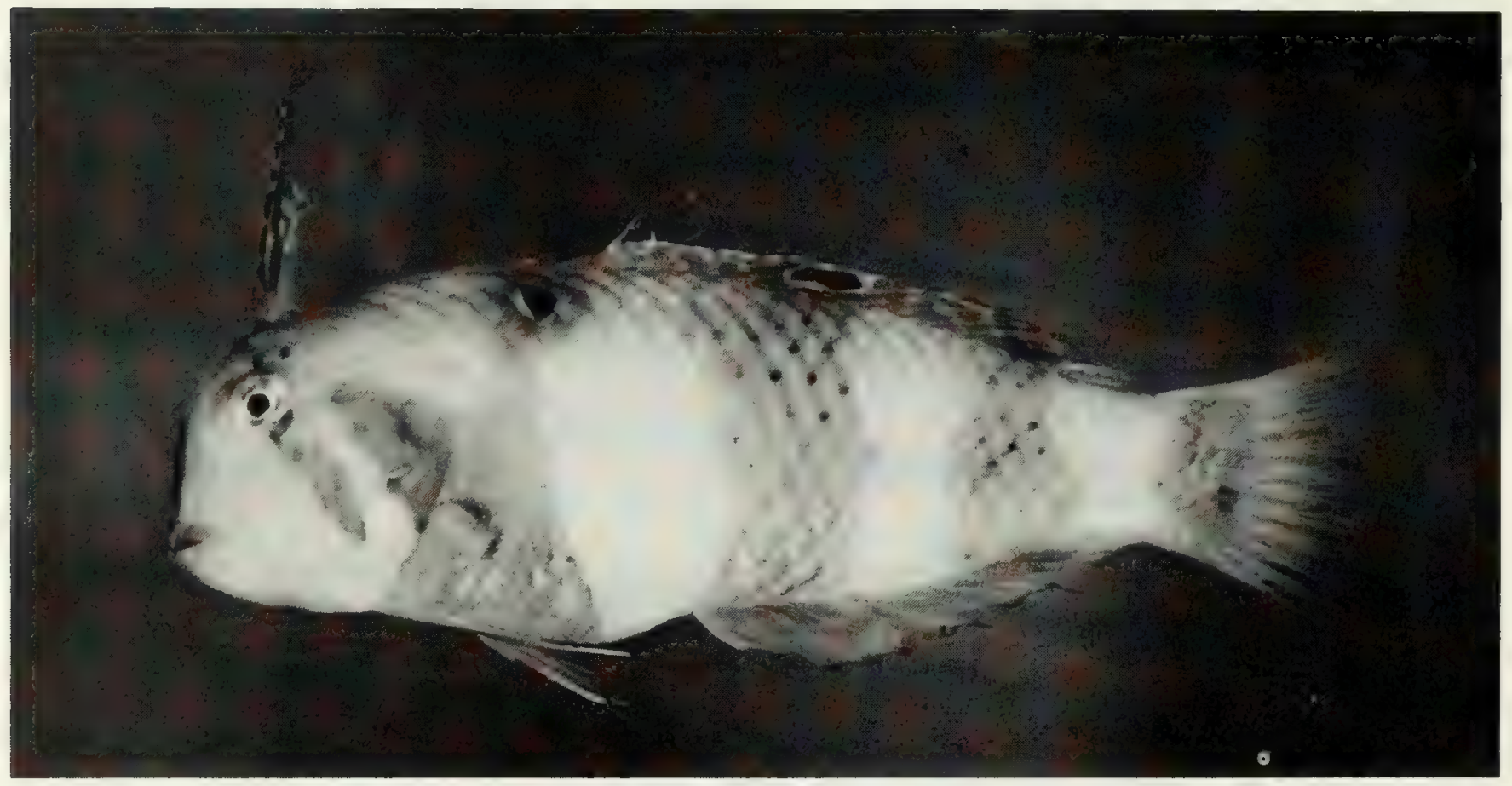

FIG. 347. Xyrichthys pavo, $102 \mathrm{~mm}$ SL, Peros Banhos.

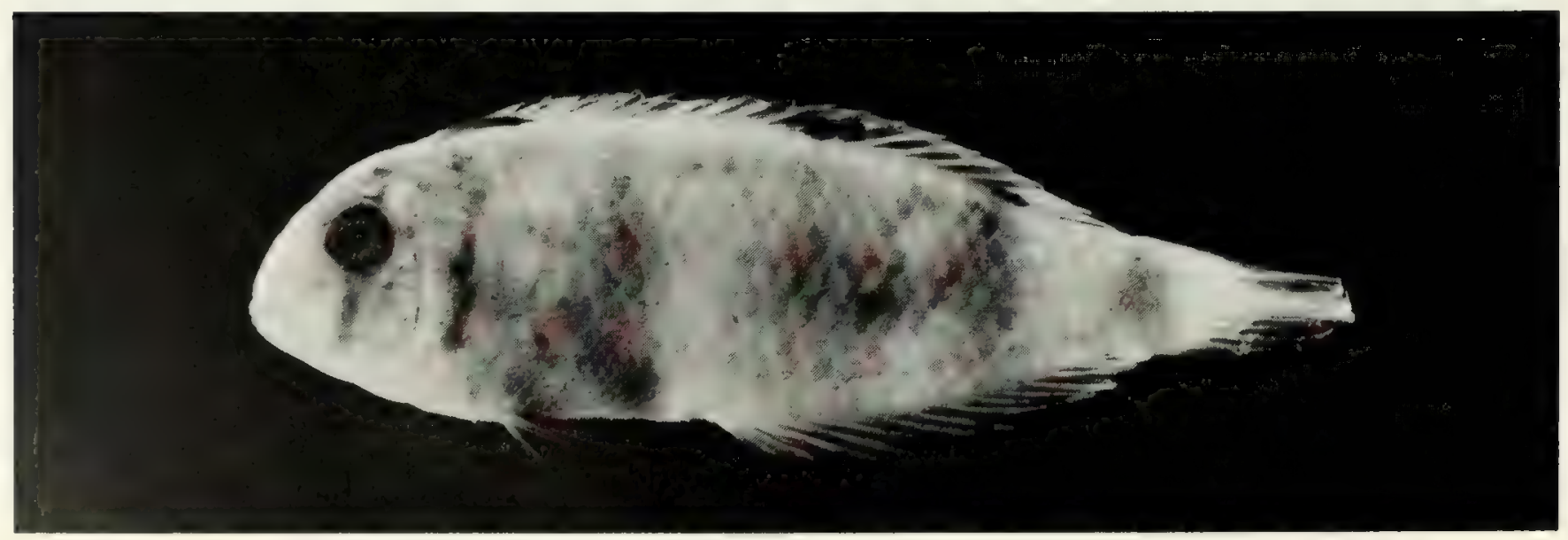

FIG. 348. Xyrichthys sp., (preserved) $38 \mathrm{~mm} \mathrm{SL,} \mathrm{Peros} \mathrm{Banhos.} \mathrm{Photo} \mathrm{by} \mathrm{A.} \mathrm{Strange.}$ 


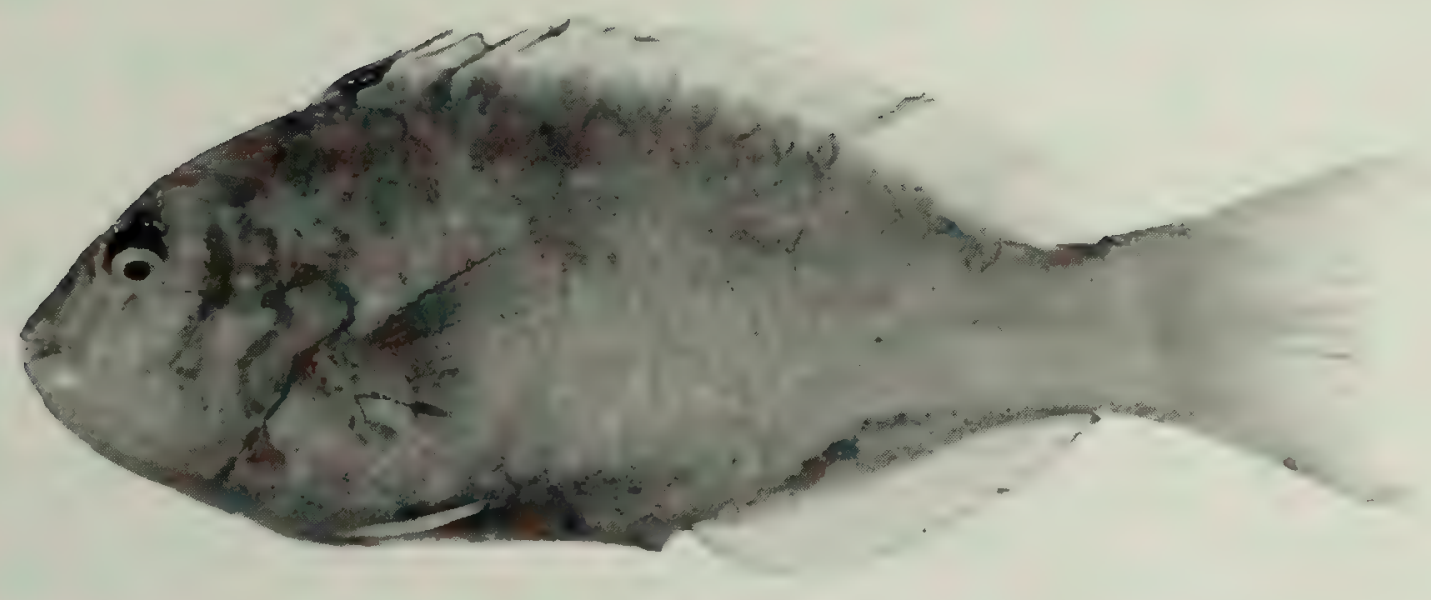

Fig. 349. Calotomus carolinus, (preserved) $190 \mathrm{~mm} \mathrm{SL}$, Eagle Island. Photo by A. Strange.

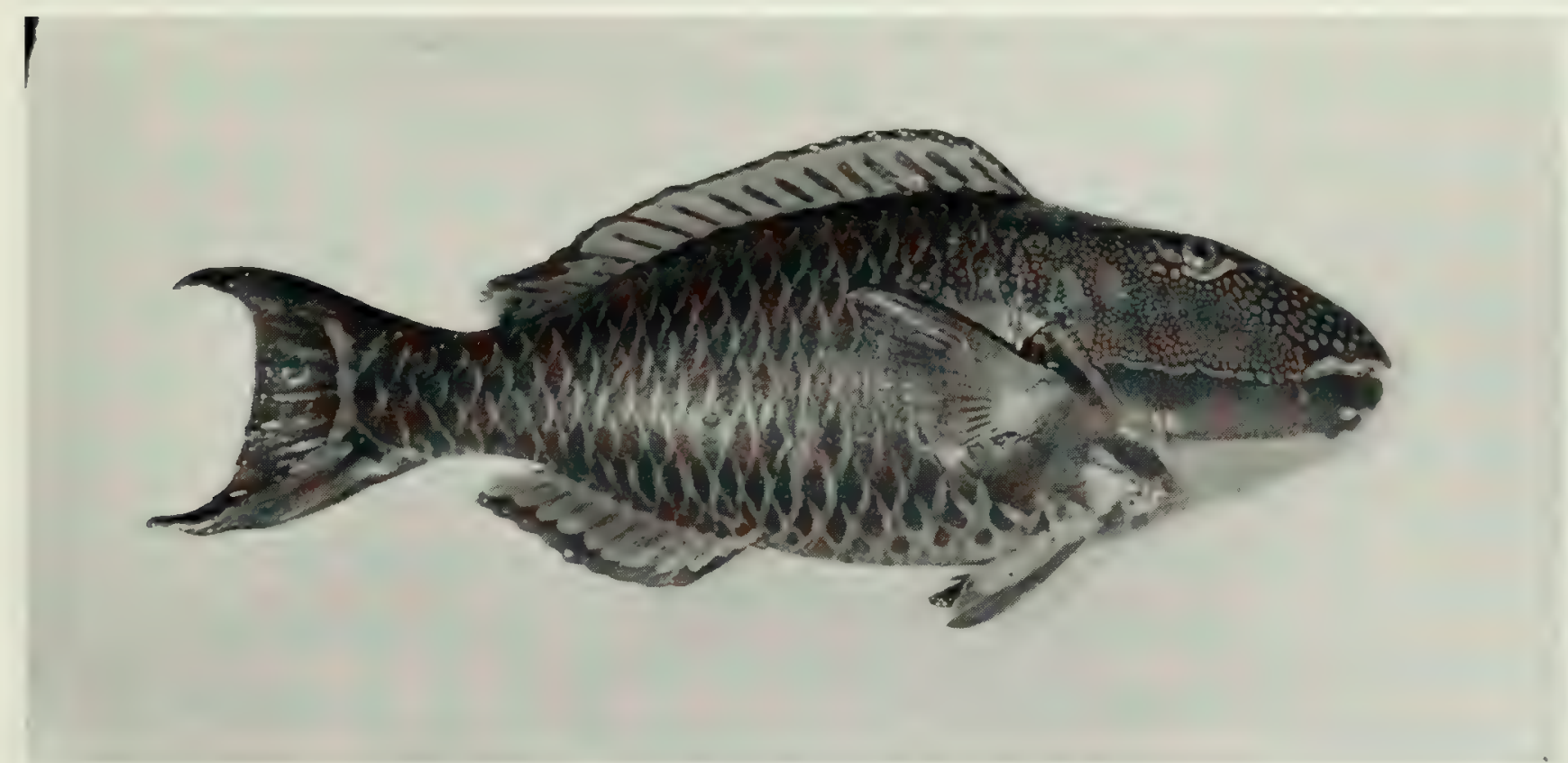

Fig. 350. Cetoscarus bicolor, $420 \mathrm{~mm} \mathrm{SL,} \mathrm{Salomon.}$

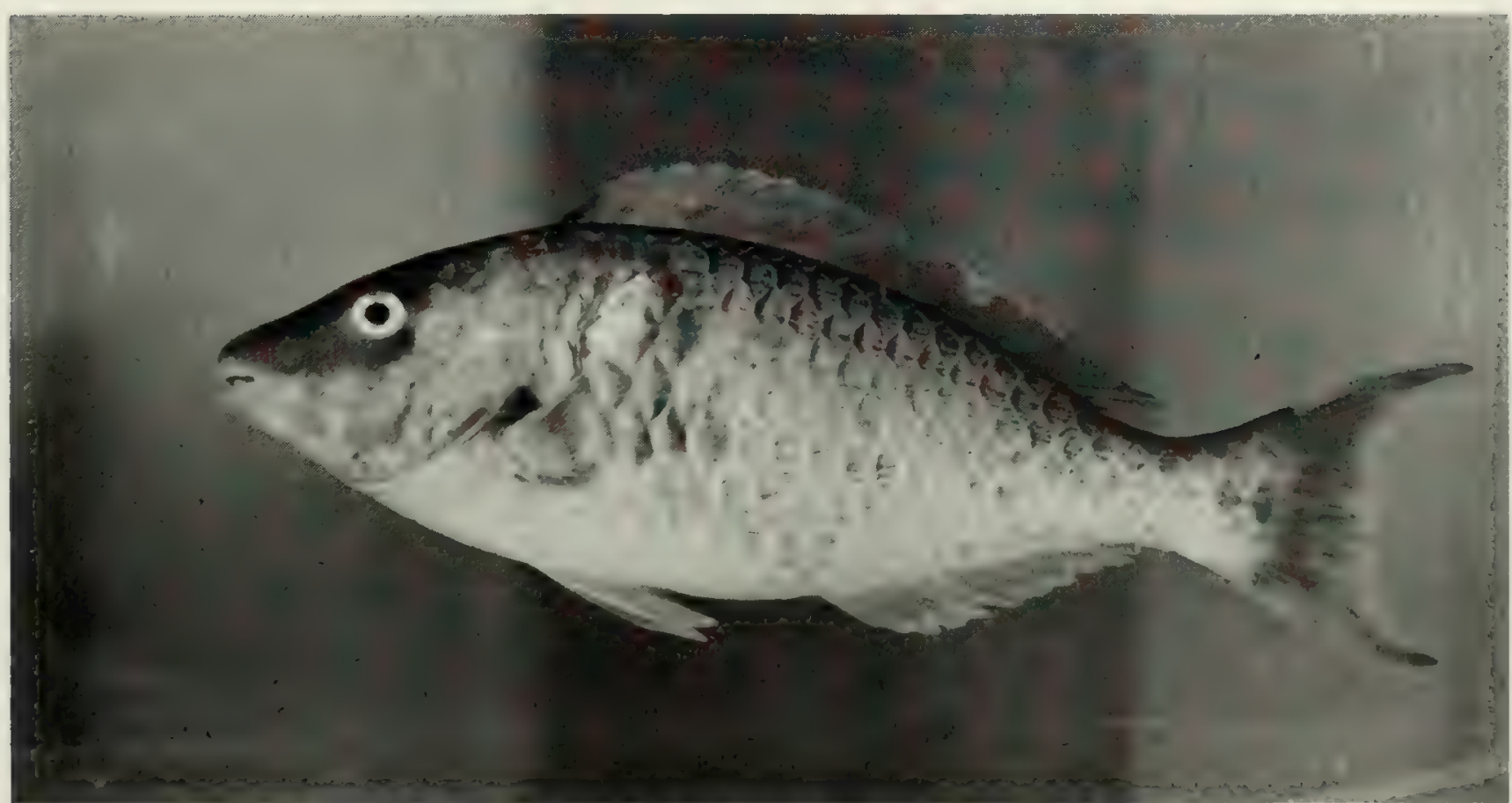

Fig. 351. Hipposcarus harid, $224 \mathrm{~mm} \mathrm{SL,} \mathrm{Salomon.}$ 


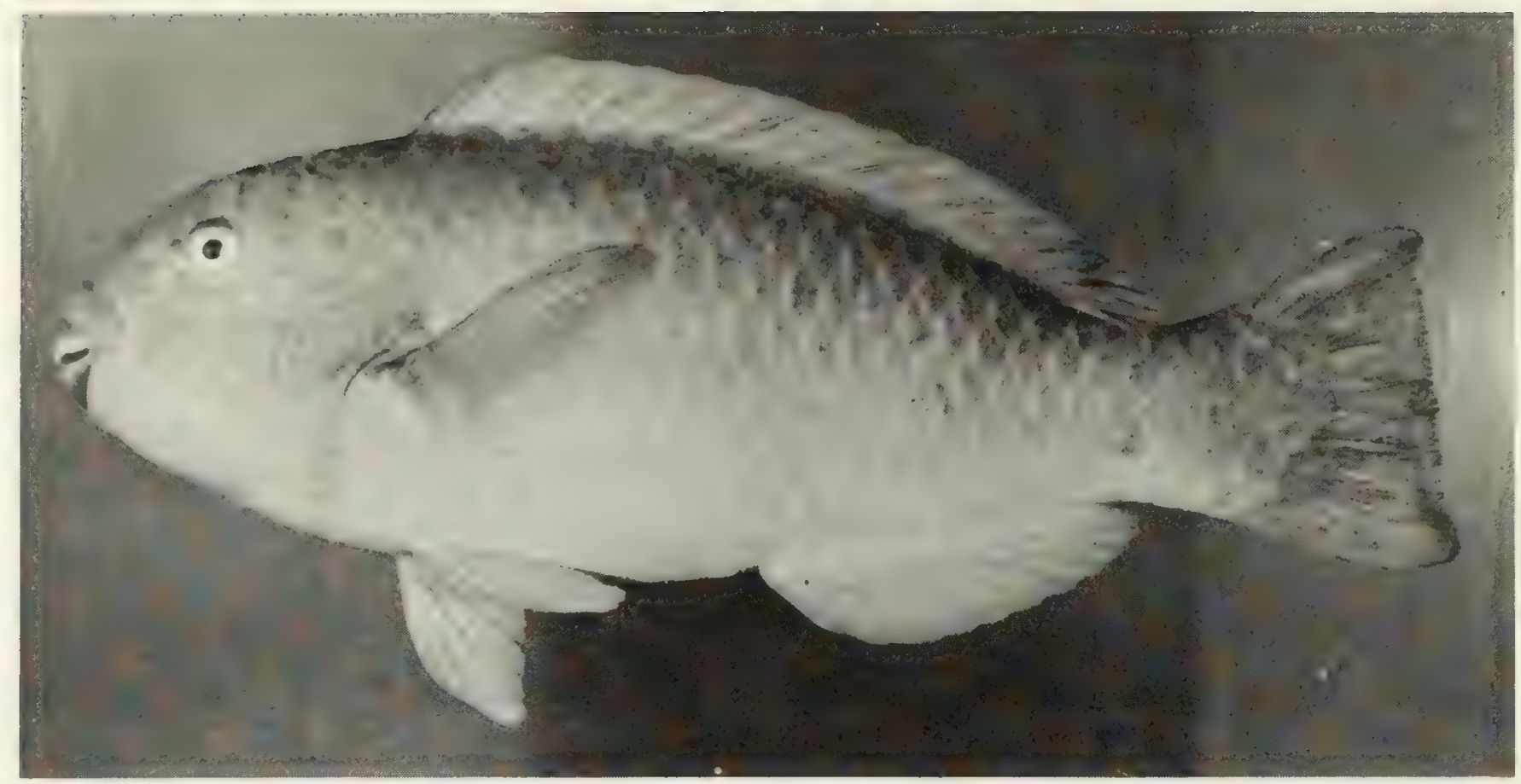

FIG. 352. Scarus enneacanthus, $255 \mathrm{~mm}$ SL, Salomon.

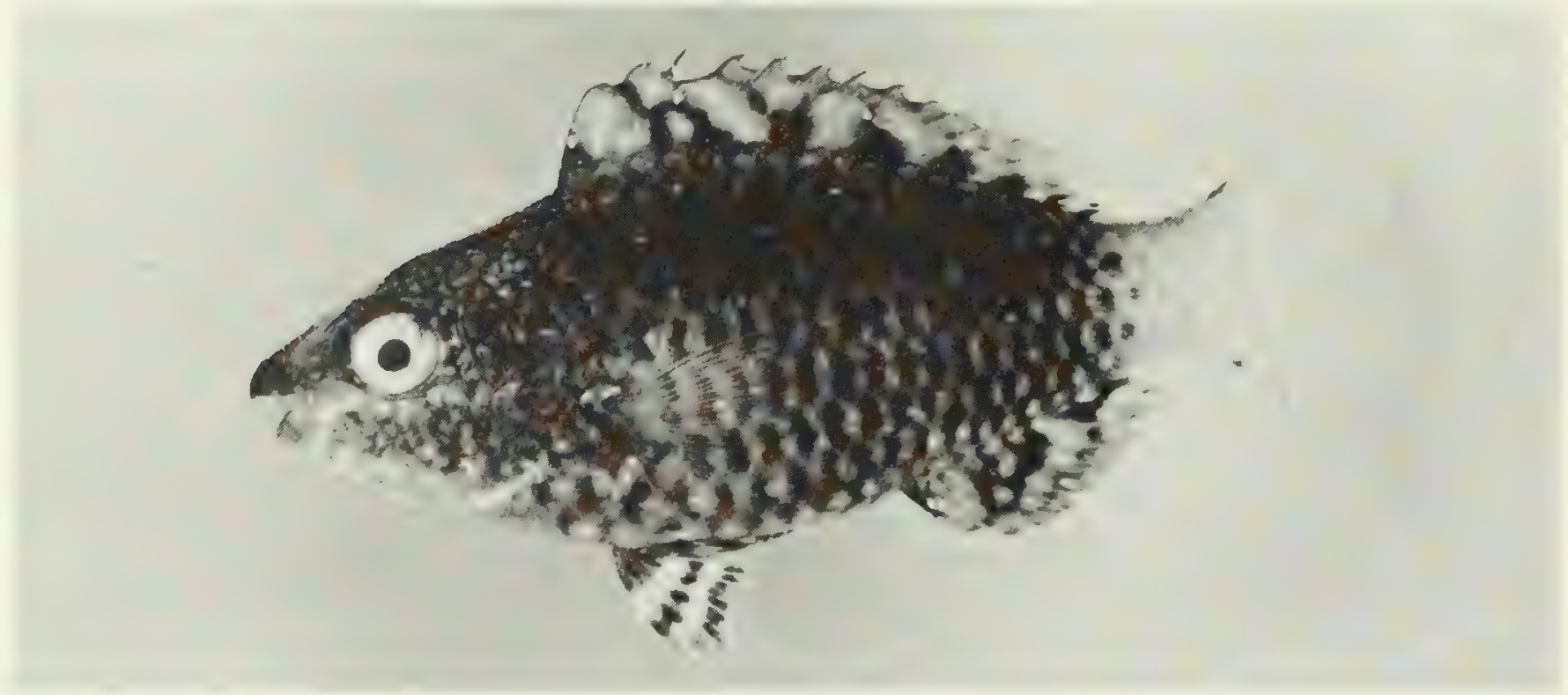

FIG. 353. Scarus falcipinnis, $48 \mathrm{~mm}$ SL, Salomon.

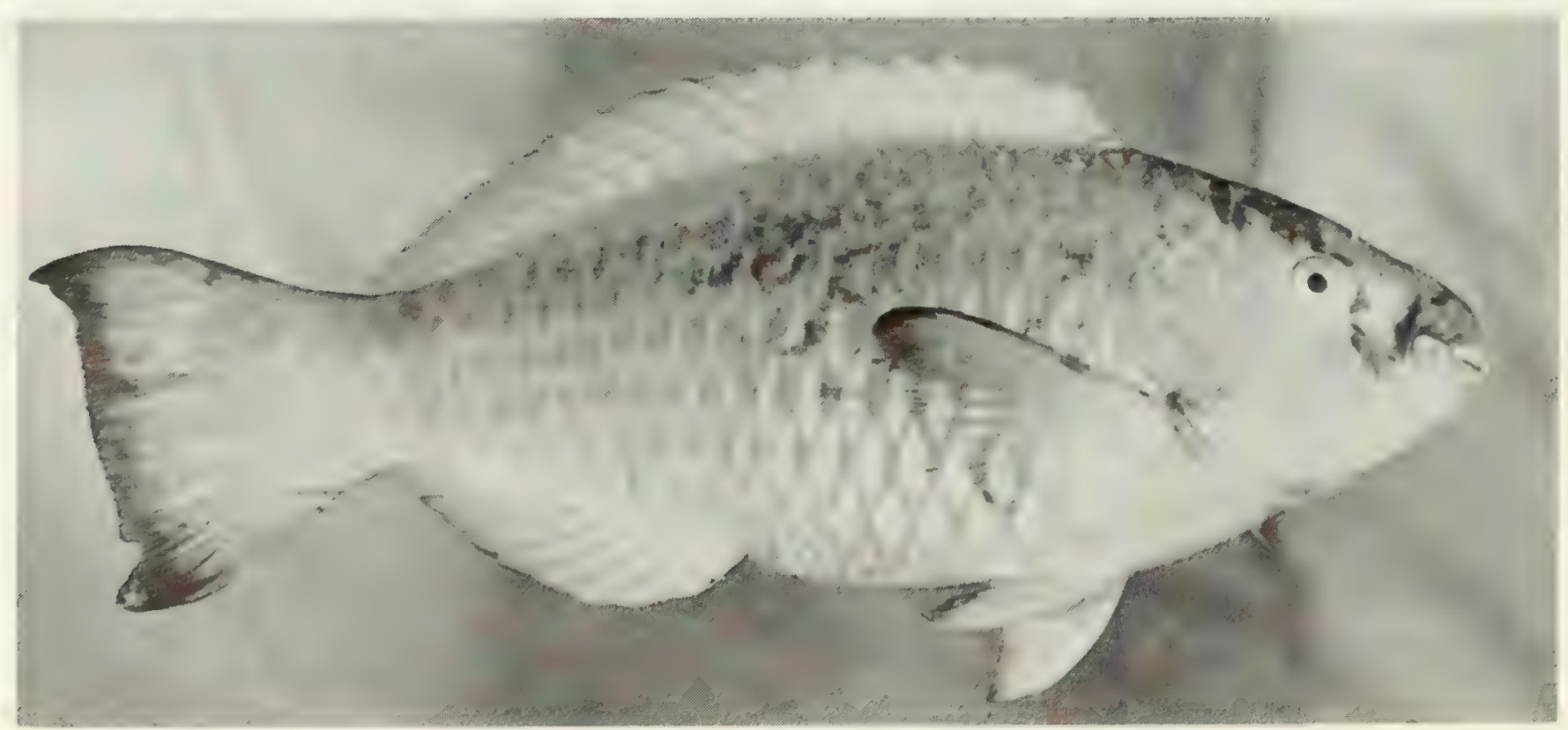

FIG. 354. Scarus frenatus, $270 \mathrm{~mm}$ SL, Peros Banhos. 


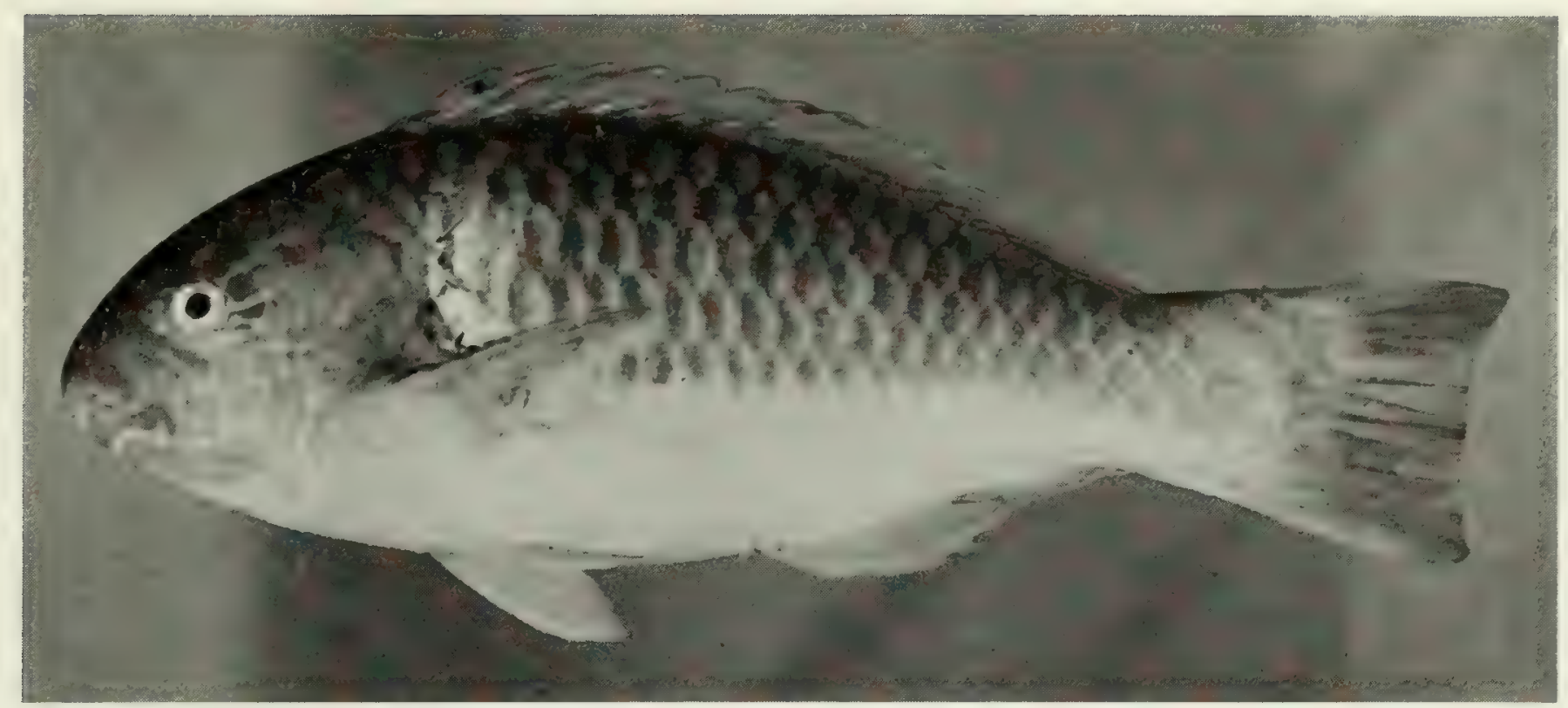

Fig. 355. Scarus ghobban, $190 \mathrm{~mm} \mathrm{SL}$, Peros Banhos.

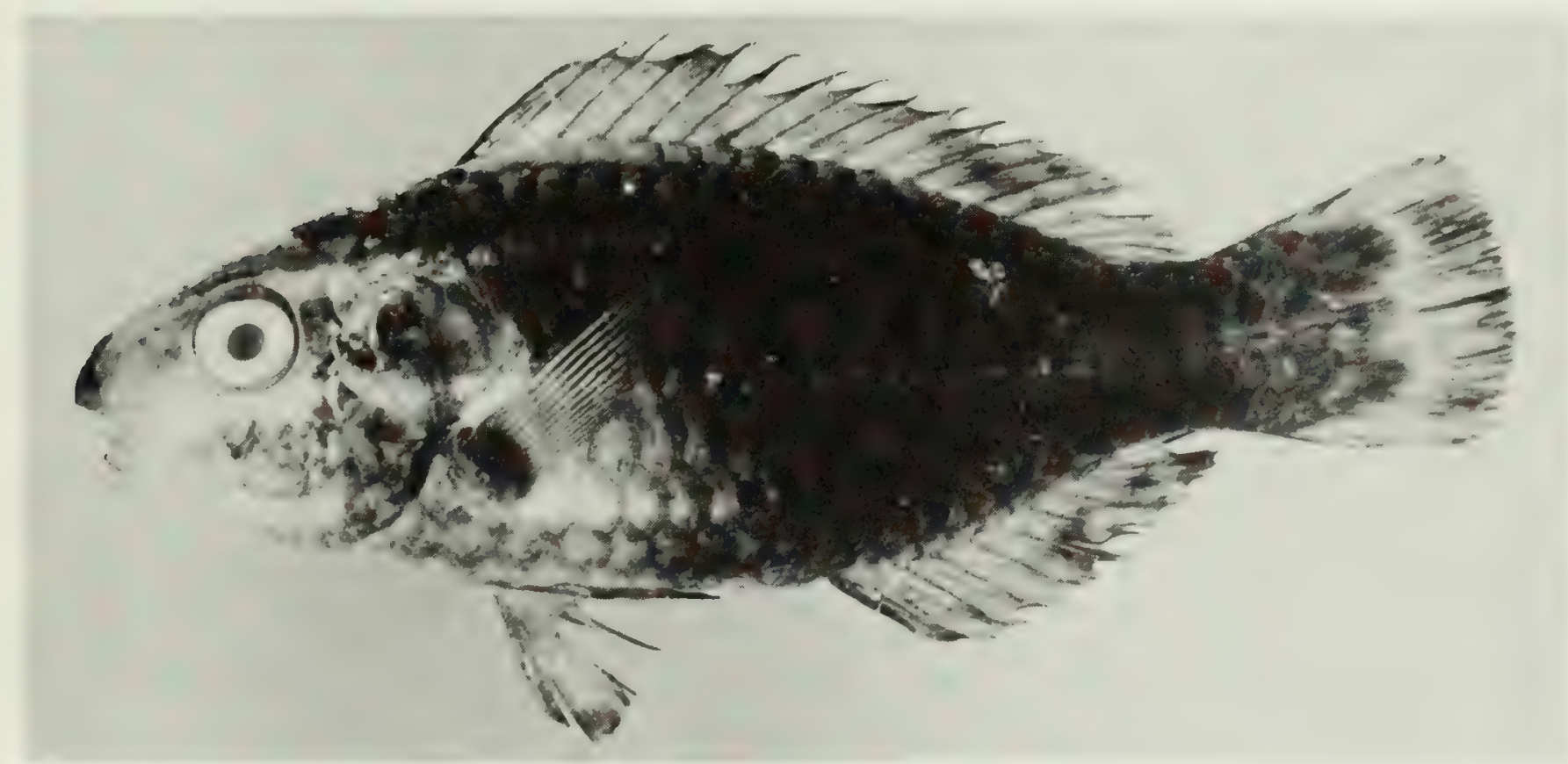

FIG. 356. Scarus gibbus, $47 \mathrm{~mm} \mathrm{SL}$, Salomon.

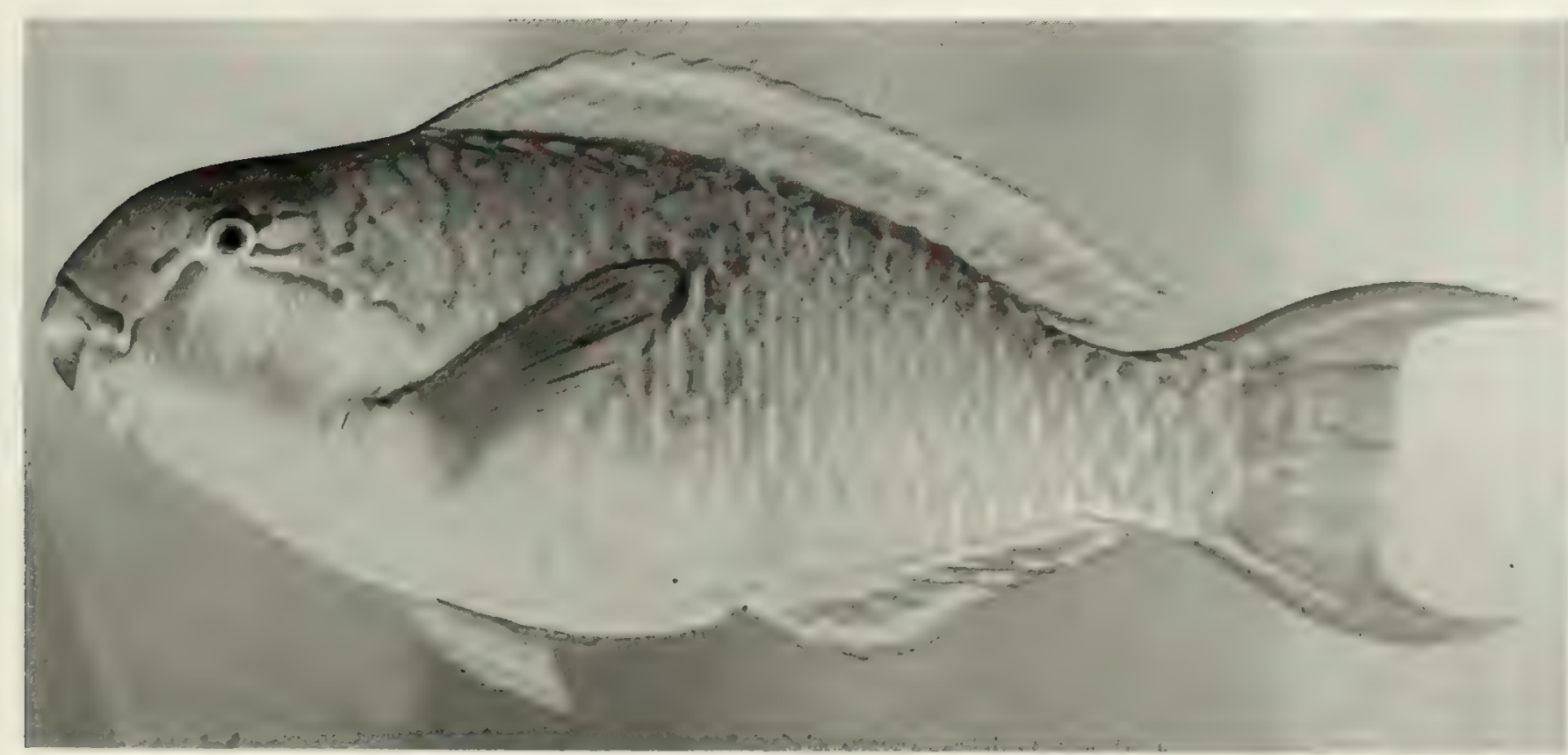

FIG. 357. Scarus gibbus, $270 \mathrm{~mm} \mathrm{SL}$, Peros Banhos. 


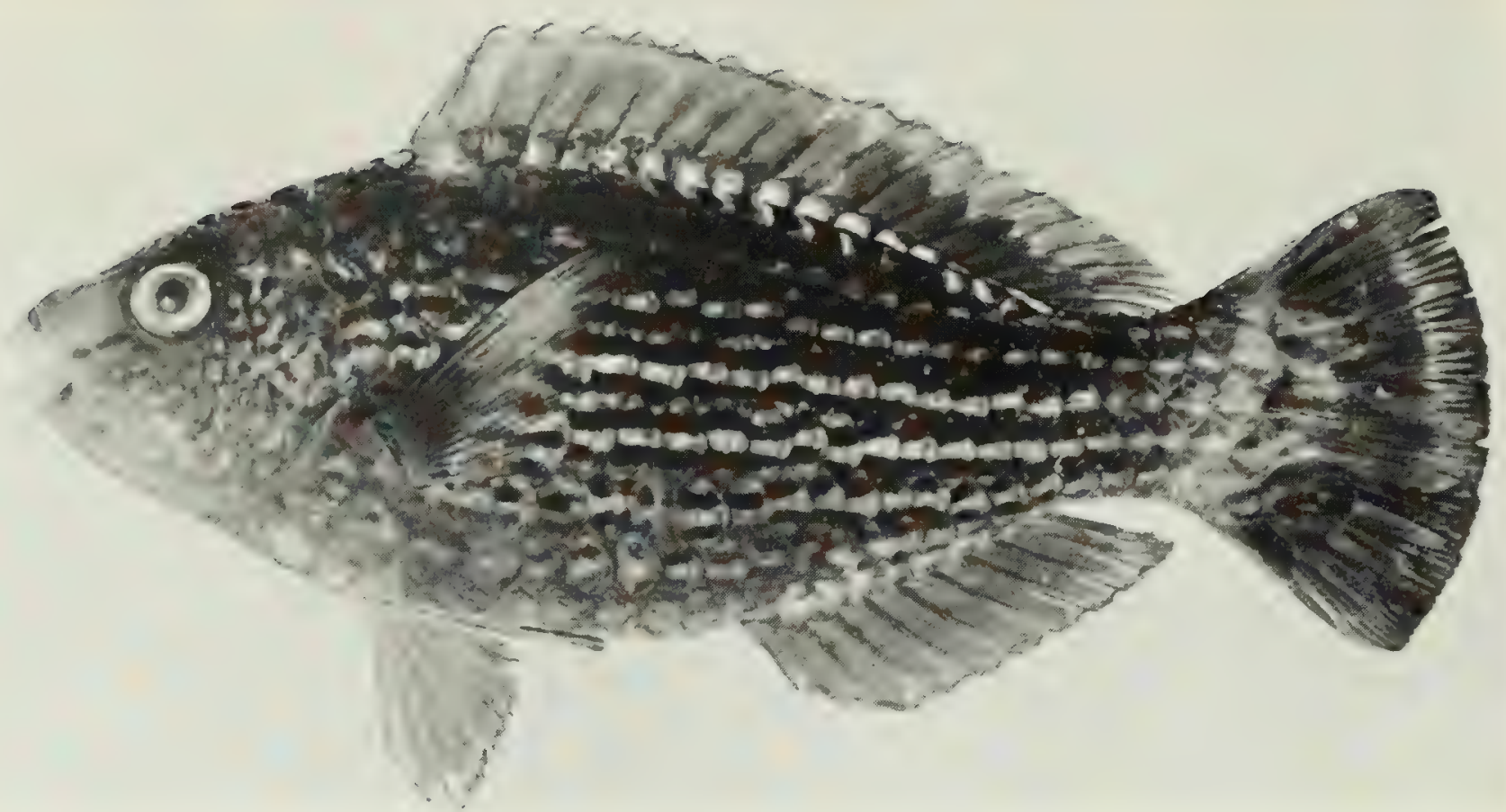

FIG. 358. Scarus niger, $108 \mathrm{~mm}$ SL, Peros Banhos.

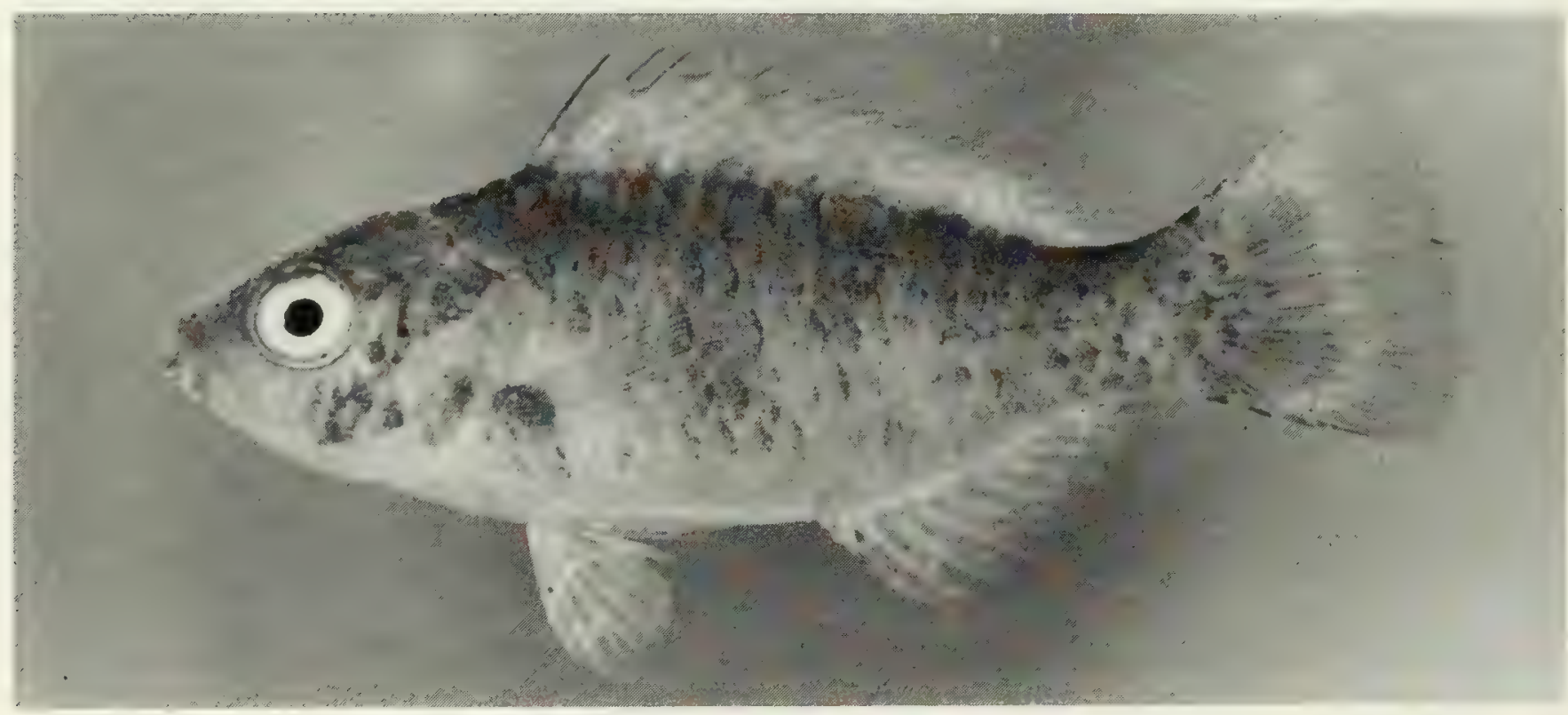

FIG. 359. Scarus psittacus, $39 \mathrm{~mm} \mathrm{SL}$, Peros Banhos.

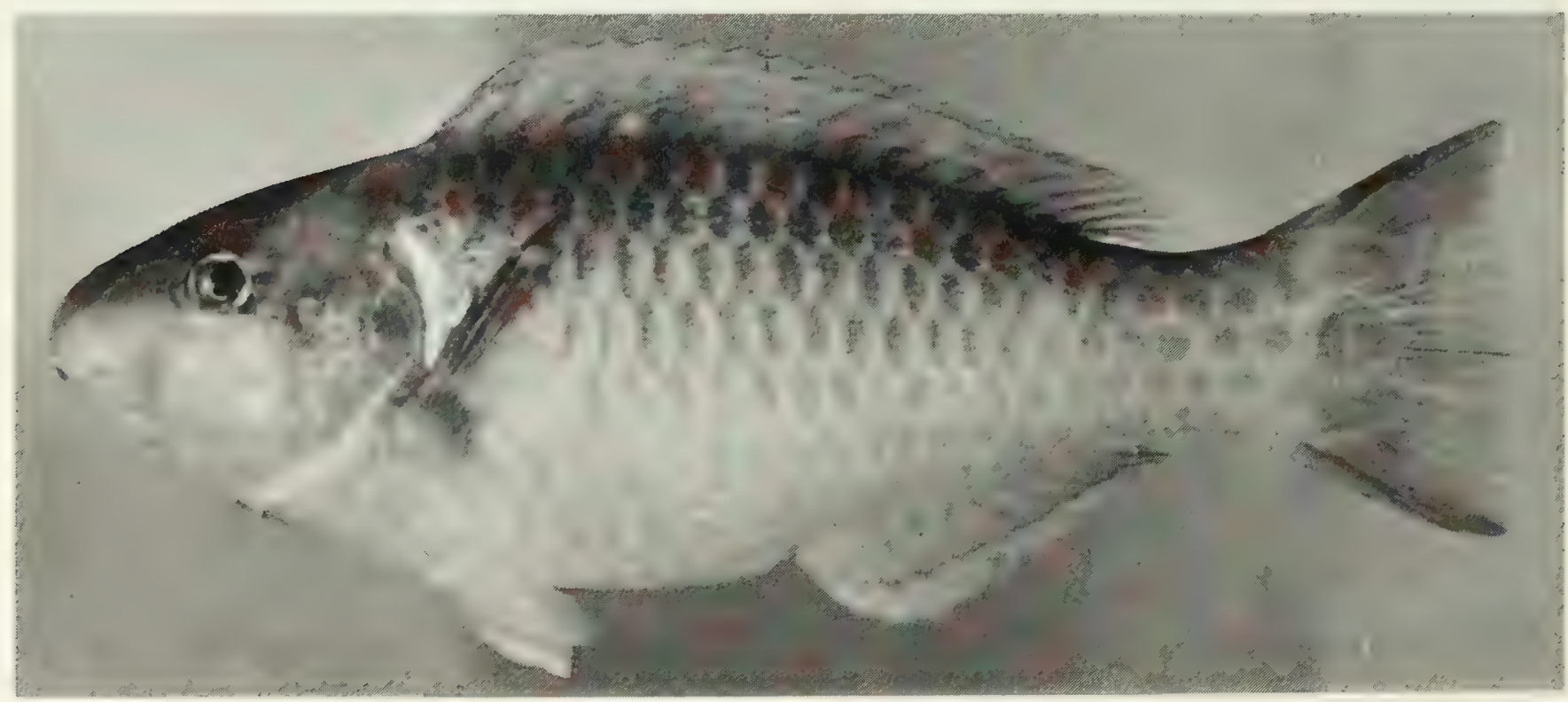

FIG. 360. Scarus psittacus, $125 \mathrm{~mm} \mathrm{SL}$, Salomon. 


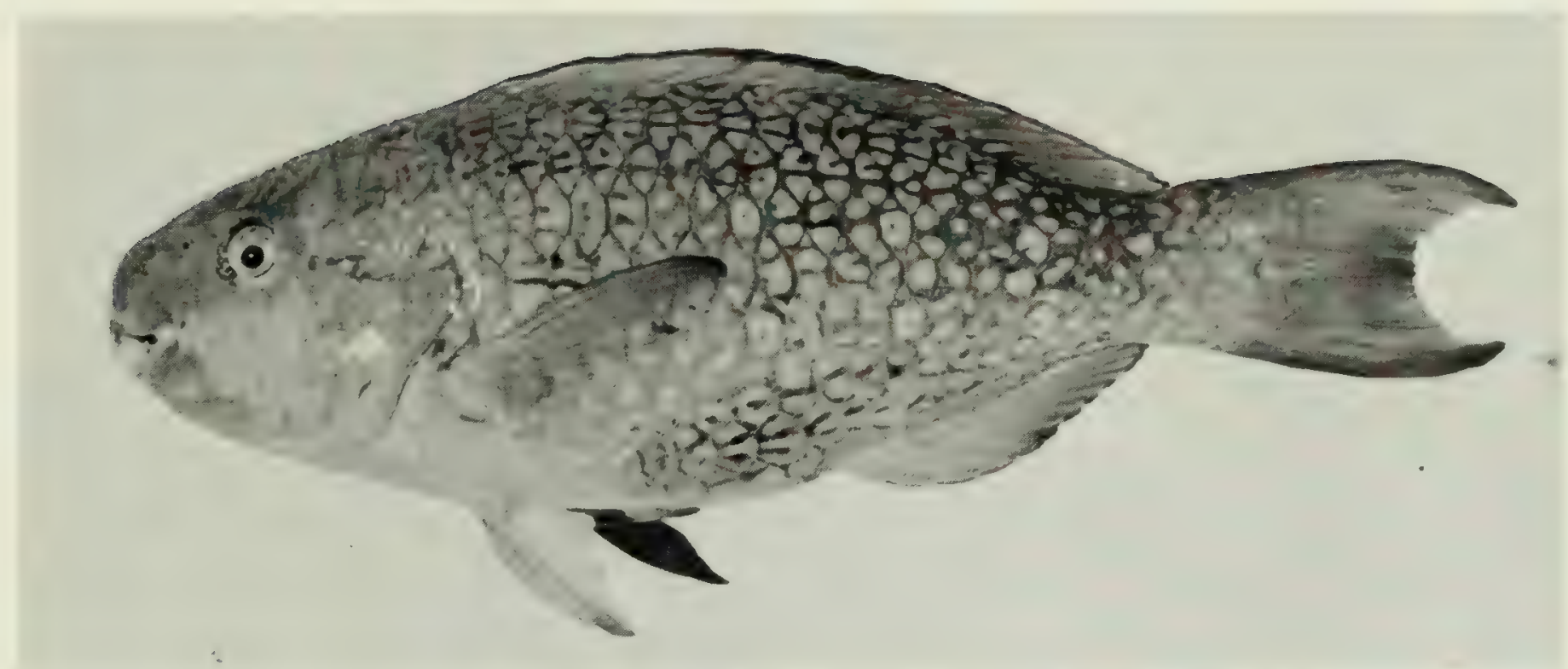

FIG. 361. Scarus rubroviolaceus, $340 \mathrm{~mm} \mathrm{SL}$, Eagle Island.

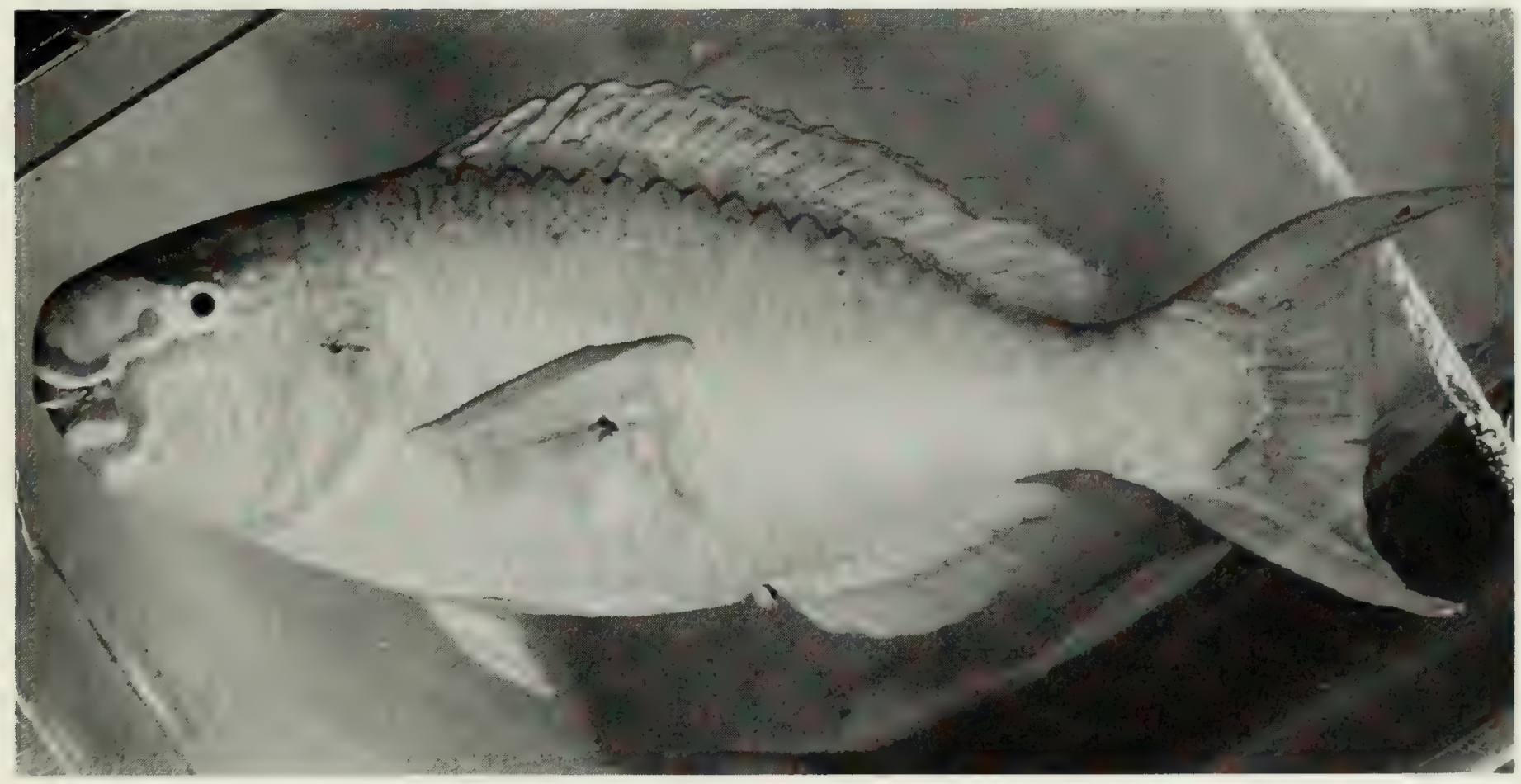

FIG. 362. Scarus rubroviolaceus, $350 \mathrm{~mm} \mathrm{SL}$, Peros Banhos.

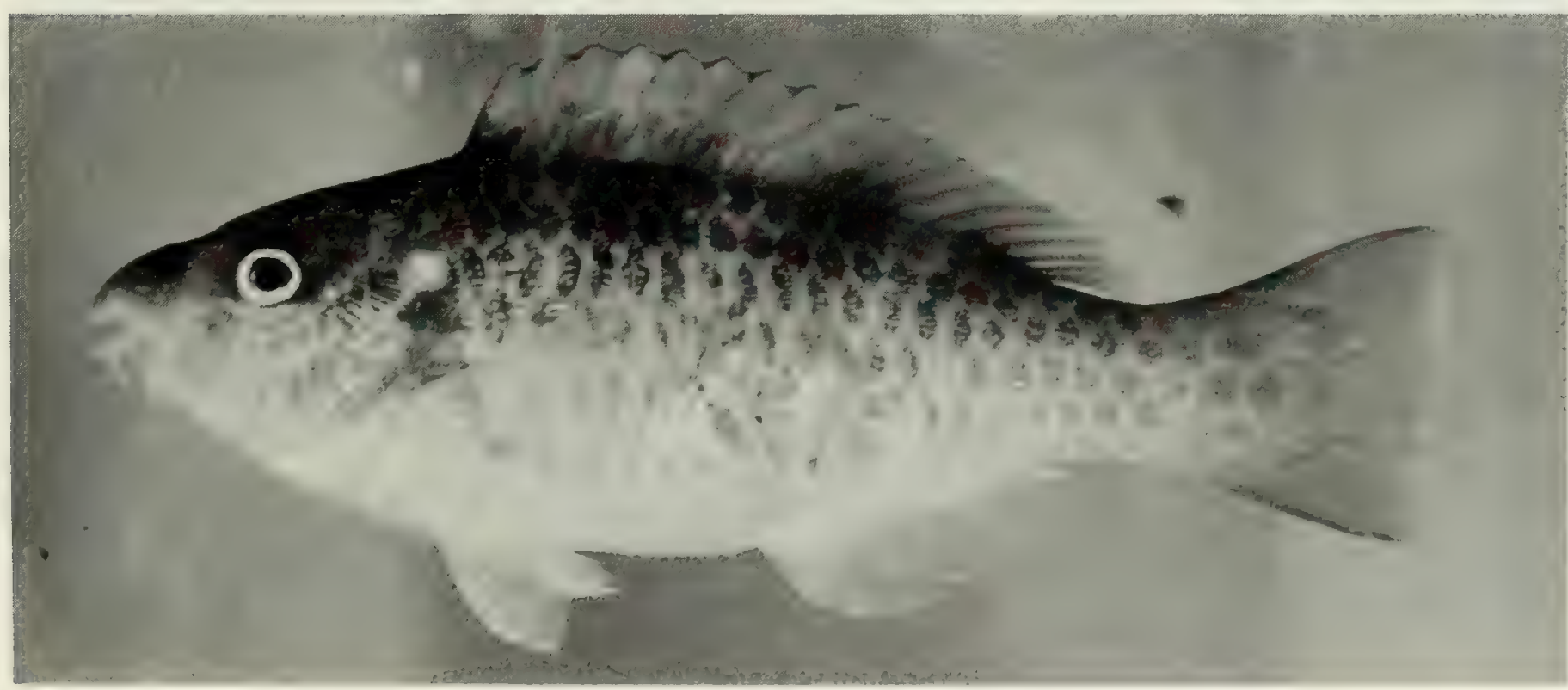

FIG. 363. Scarus scaber, $117 \mathrm{~mm} \mathrm{SL,} \mathrm{Salomon.}$ 


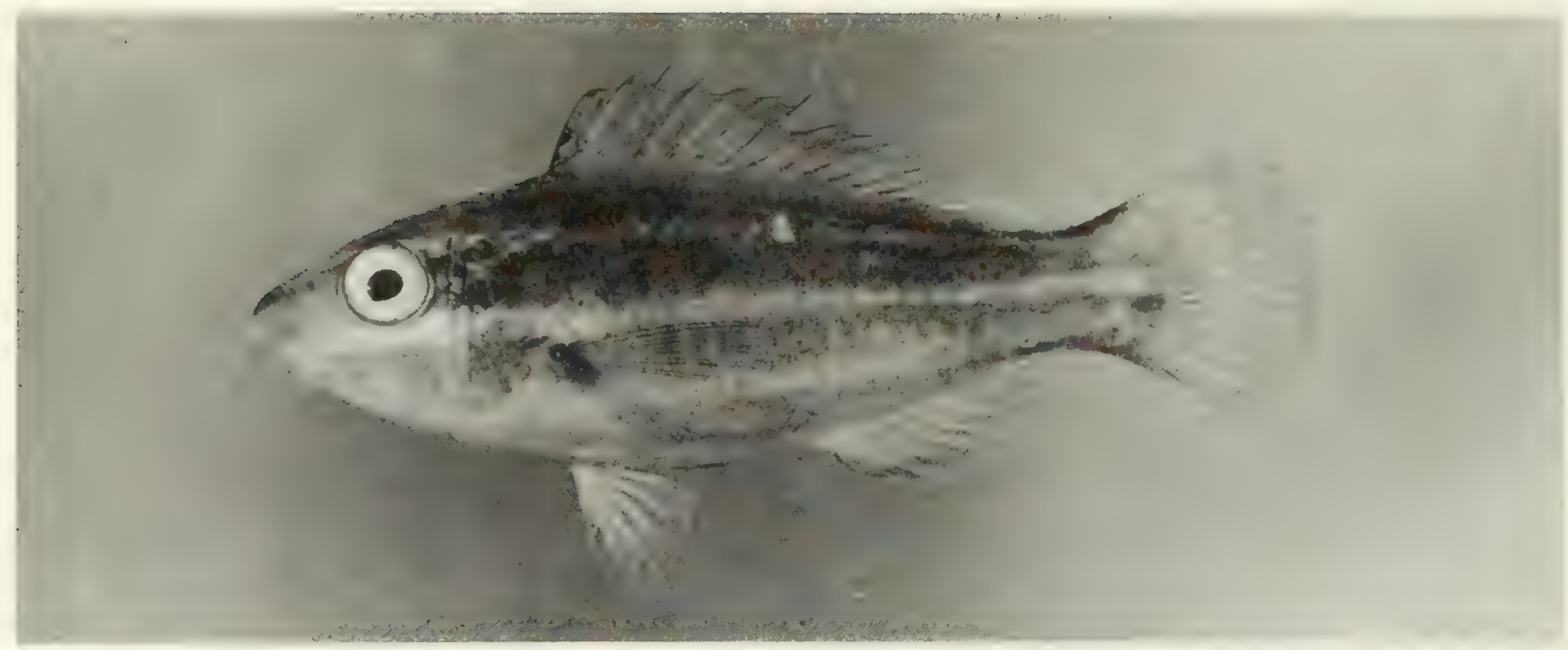

FIG. 364. Scarus sordidus, $35 \mathrm{~mm}$ SL, Salomon.

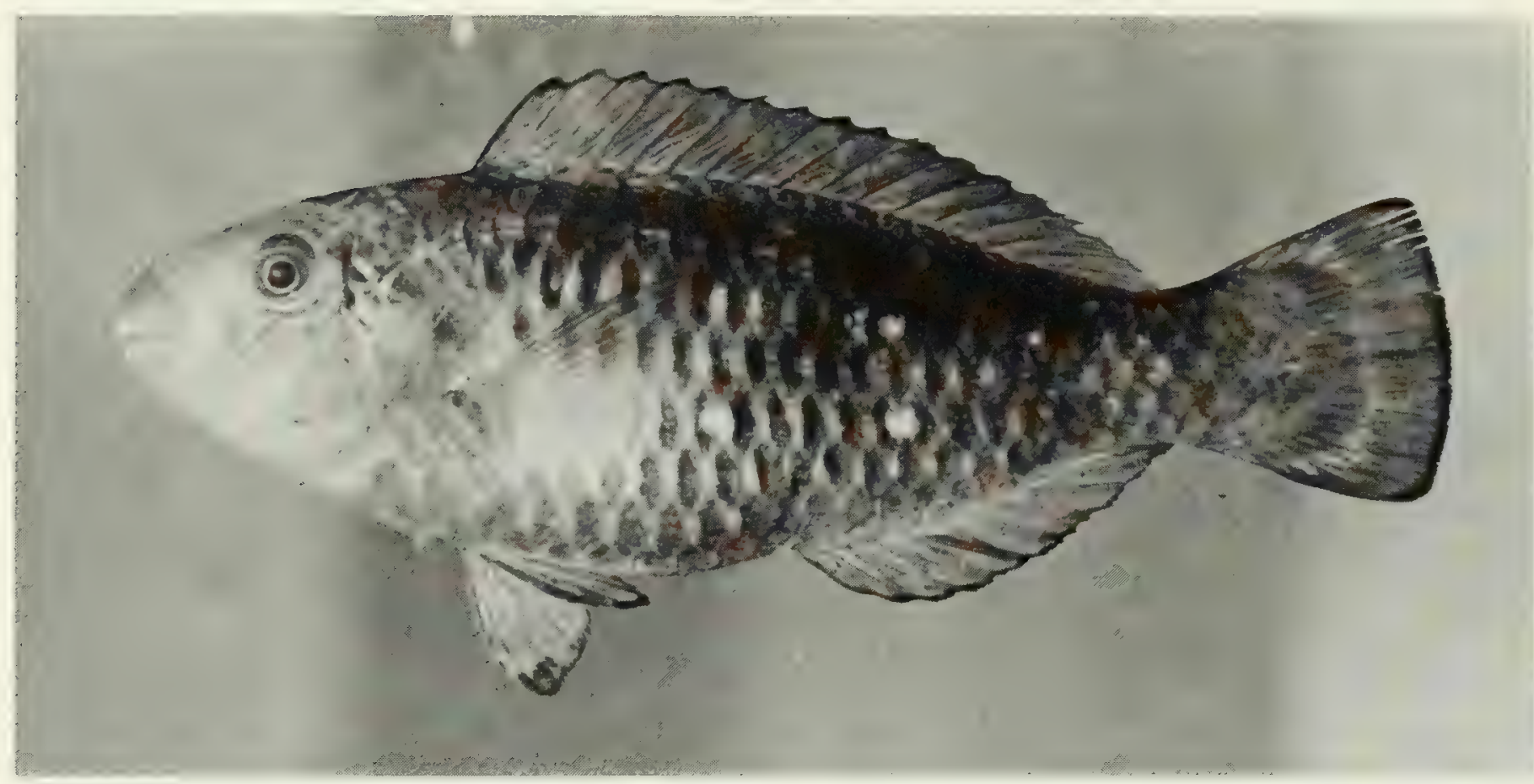

FIG. 365. Scarus sordidus, $111 \mathrm{~mm} \mathrm{SL}$, Salomon.

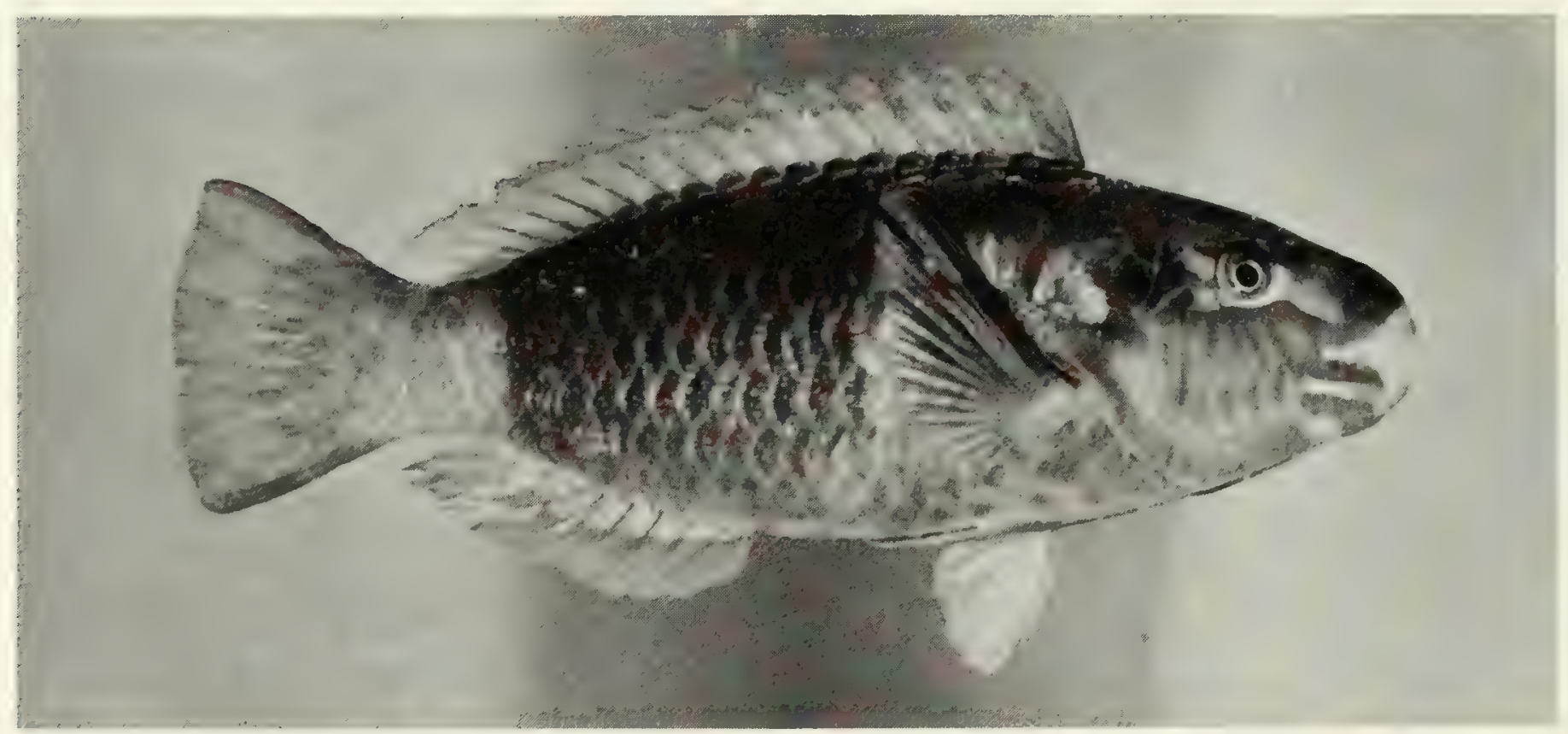

FIG. 366. Scarus sordidus, $155 \mathrm{~mm} \mathrm{SL}$, Salomon. 


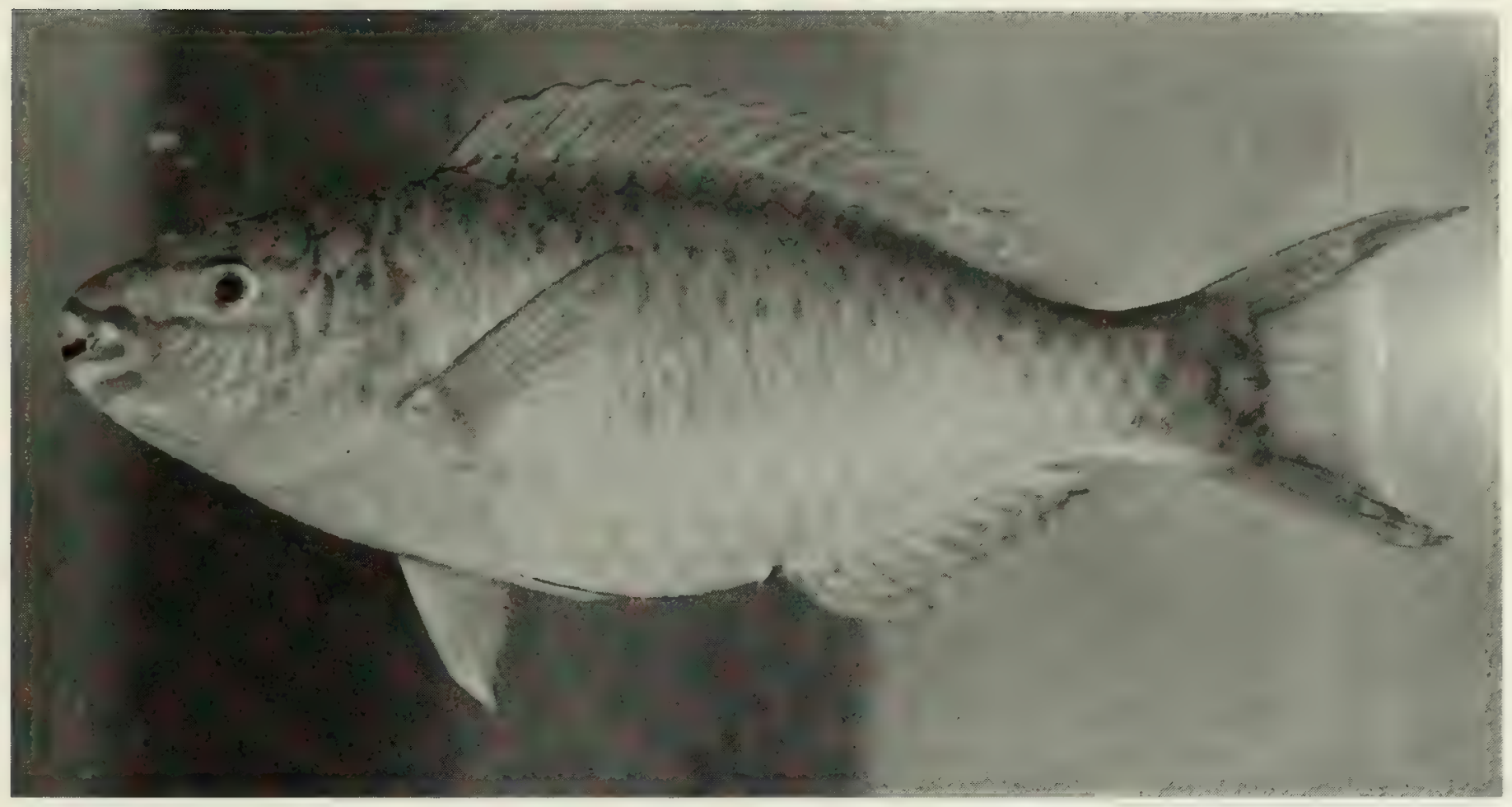

FIG. 367. Scarus tricolor, $206 \mathrm{~mm}$ SL, Salomon.

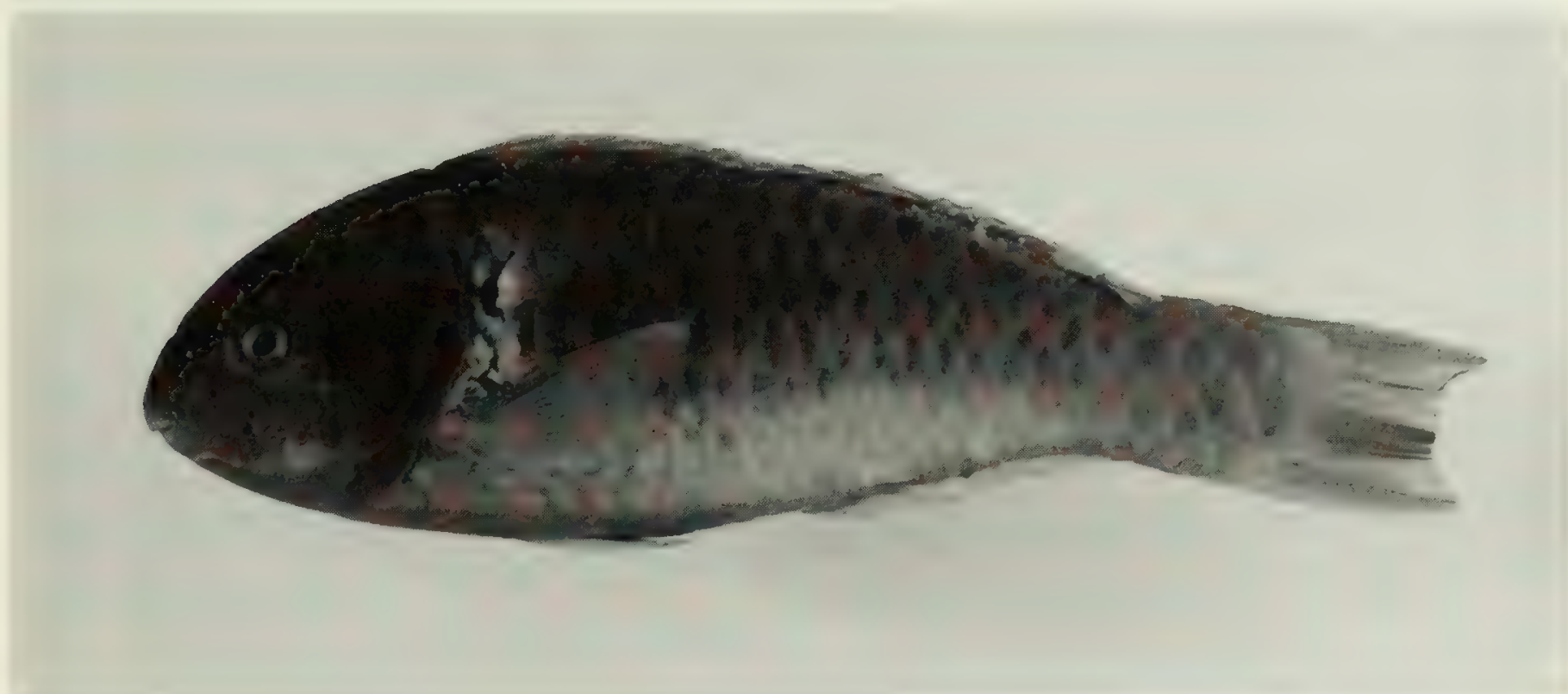

FIG. 368. Scarus sp., (preserved) $205 \mathrm{~mm} \mathrm{SL}$, Peros Banhos. Photo by A. Strange.

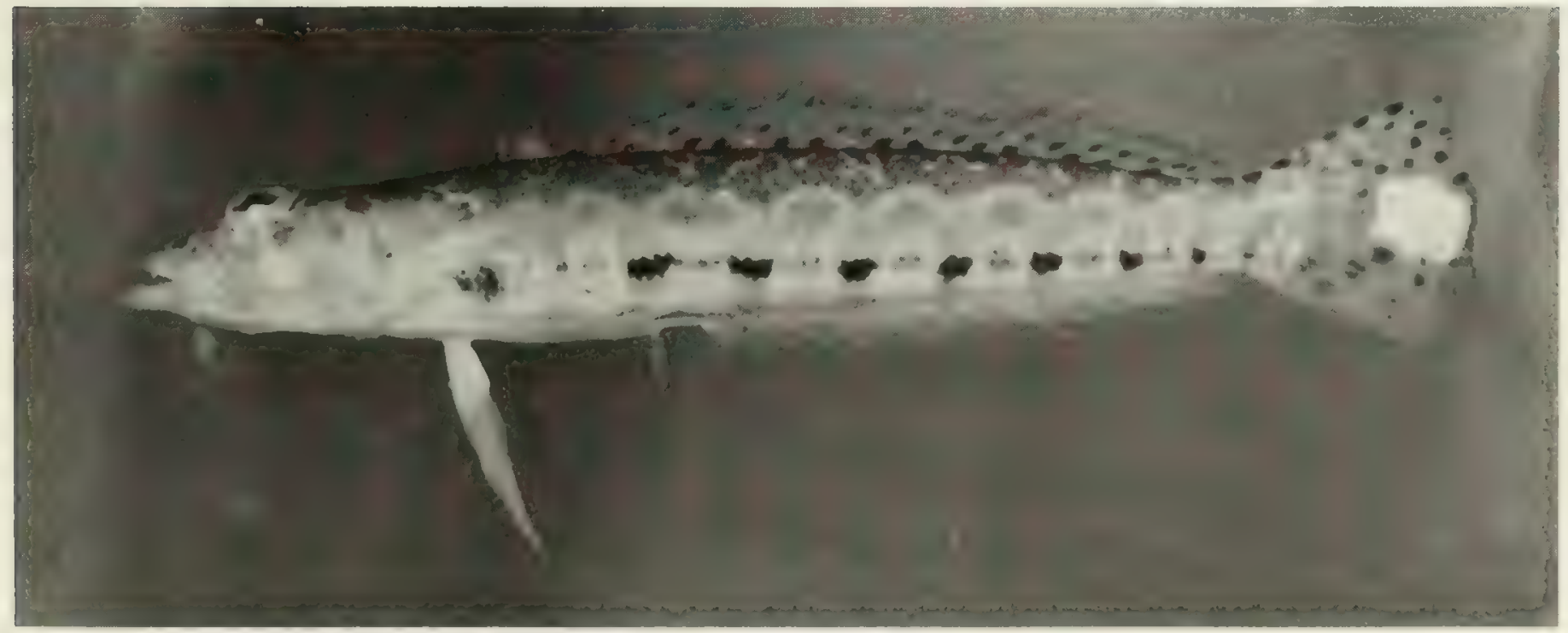

FIG. 369. Parapercis cephalopunctata, $100 \mathrm{~mm} \mathrm{SL,} \mathrm{Peros} \mathrm{Banhos.}$ 


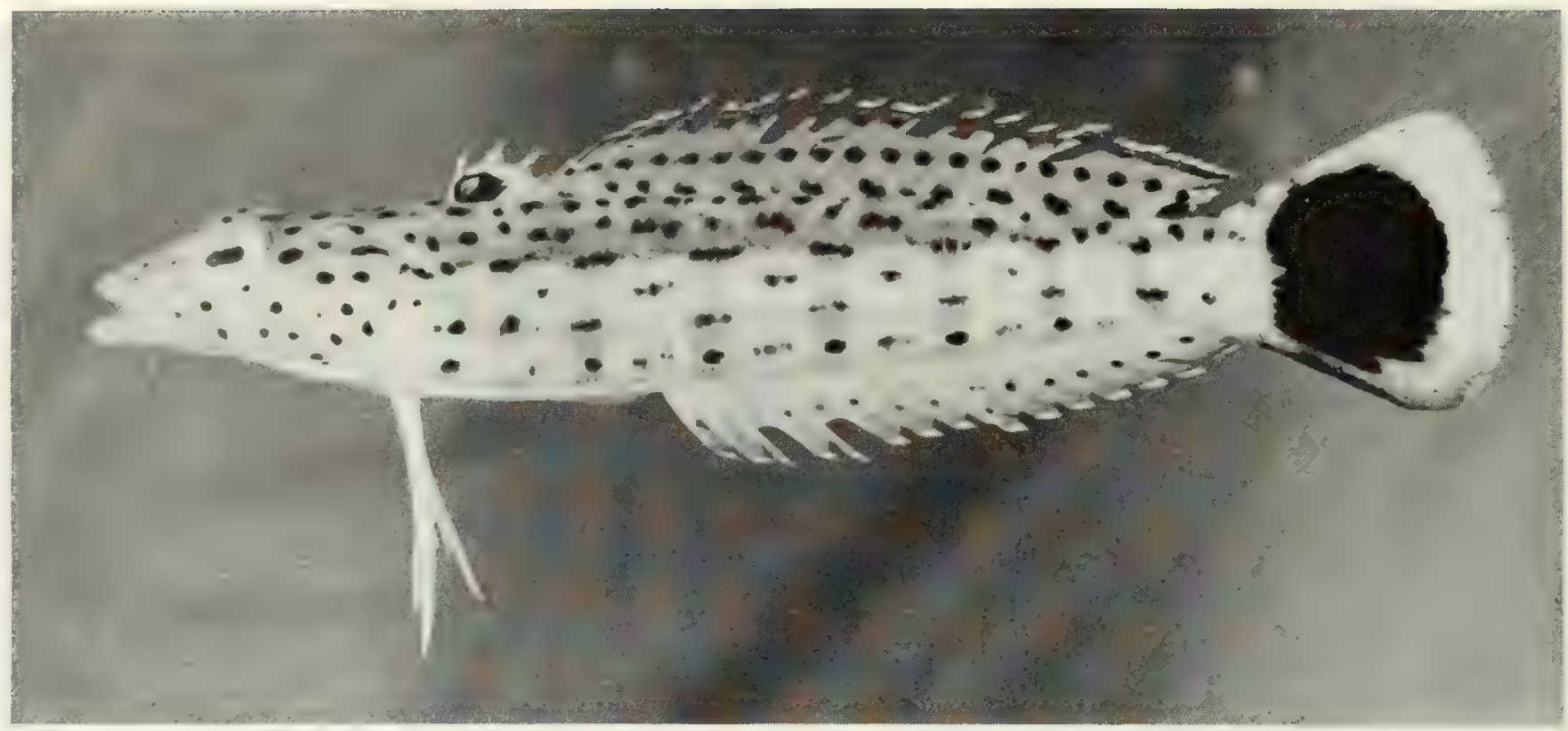

FIG. 370. Parapercis hexophthalma, $63 \mathrm{~mm}$ SL, Peros Banhos.

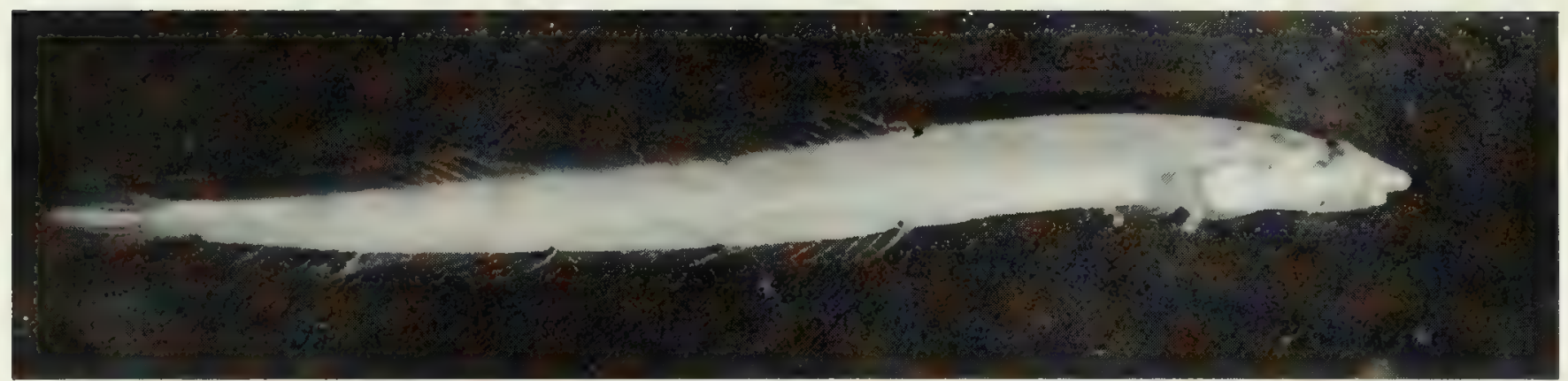

FIG. 371. Chalixodytes chameleontoculis, $31 \mathrm{~mm}$ SL, Peros Banhos.

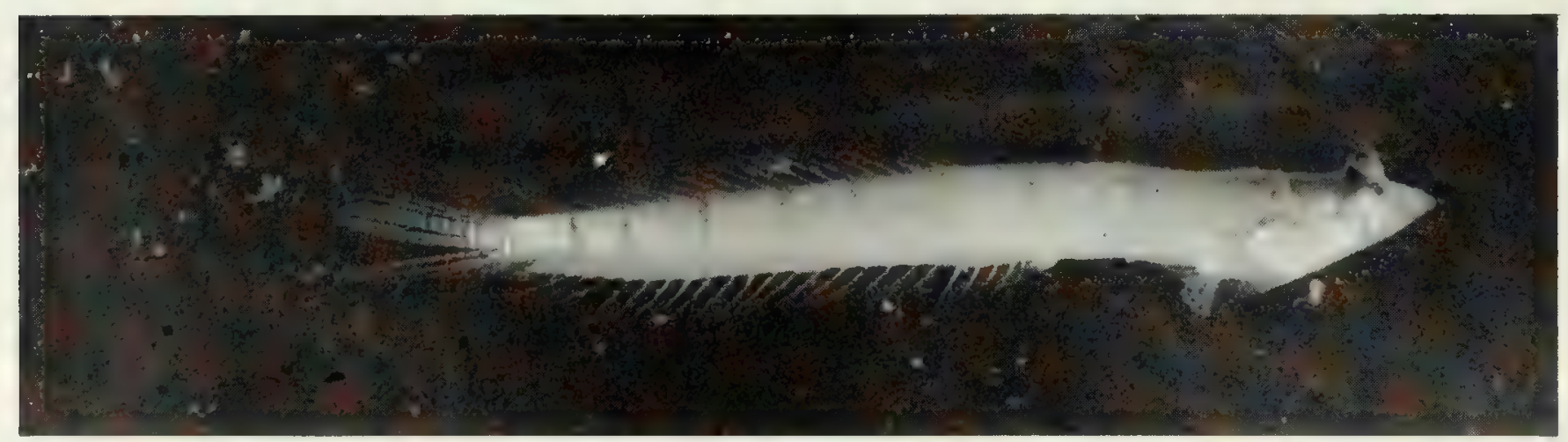

FIG. 372. Limnichthys nitidus, $17 \mathrm{~mm} \mathrm{SL}$, Peros Banhos.

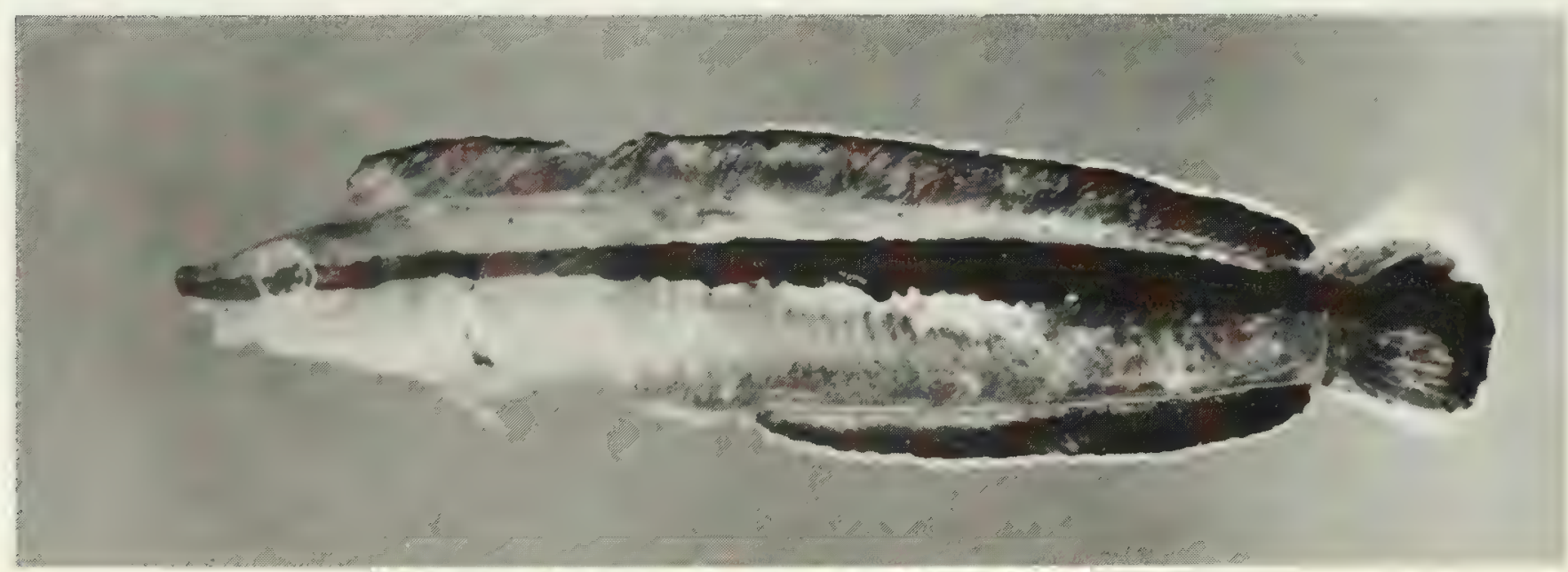

FIG. 373. Aspidontus taeniatus tractus, $79 \mathrm{~mm}$ SL, Peros Banhos. 


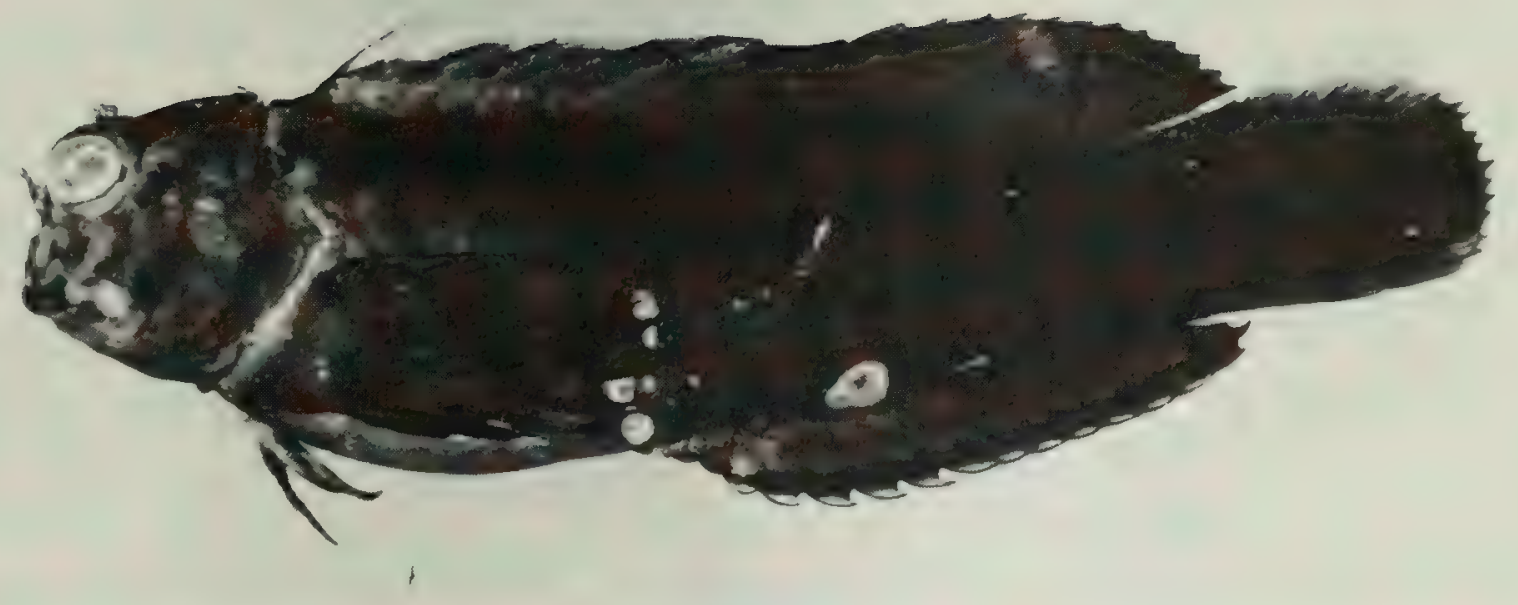

FIG. 374. Cirripectes castaneus, $61 \mathrm{~mm} \mathrm{SL,} \mathrm{Salomon.}$

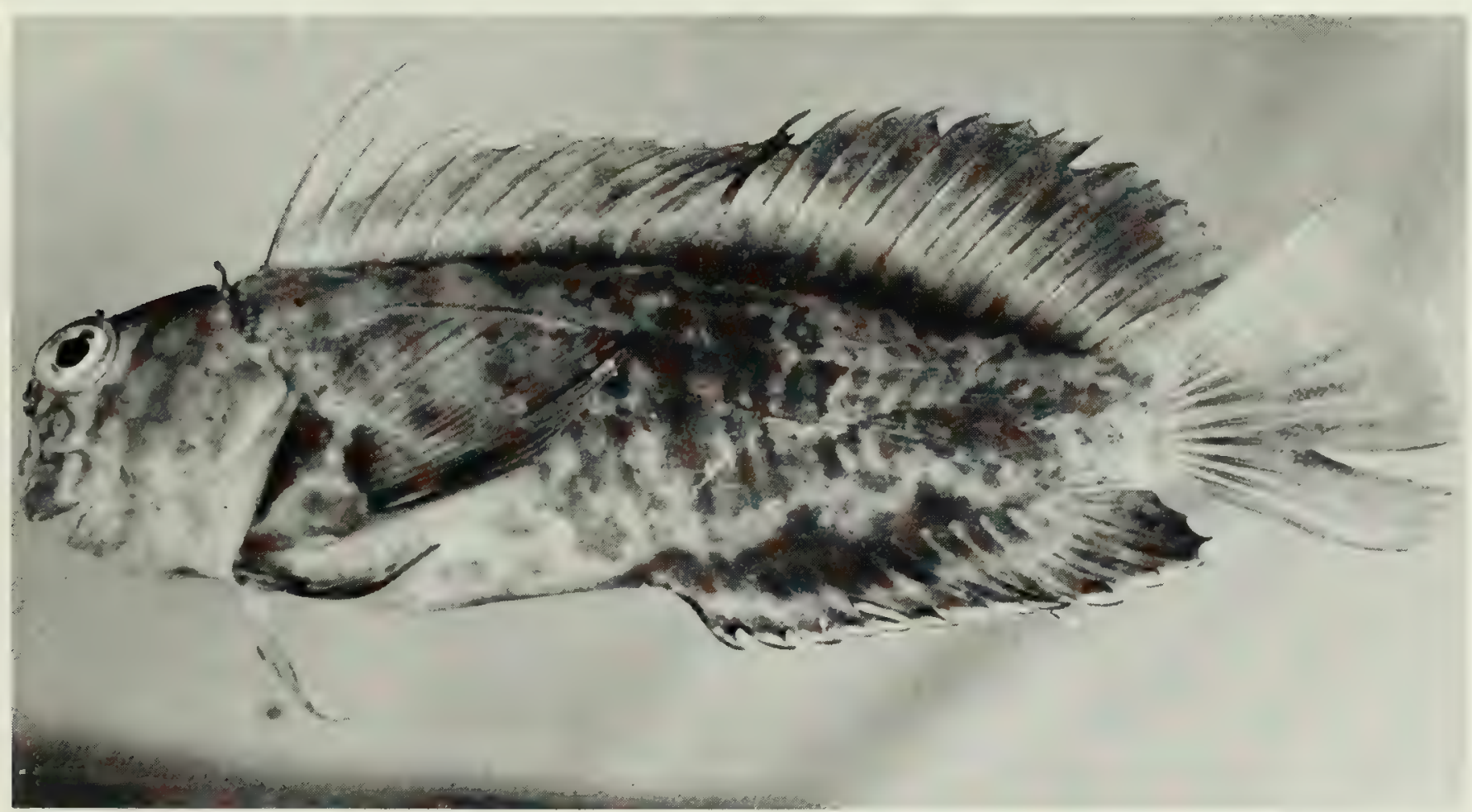

FIG. 375. Cirripectes castaneus, $48 \mathrm{~mm} \mathrm{SL}$, Peros Banhos.

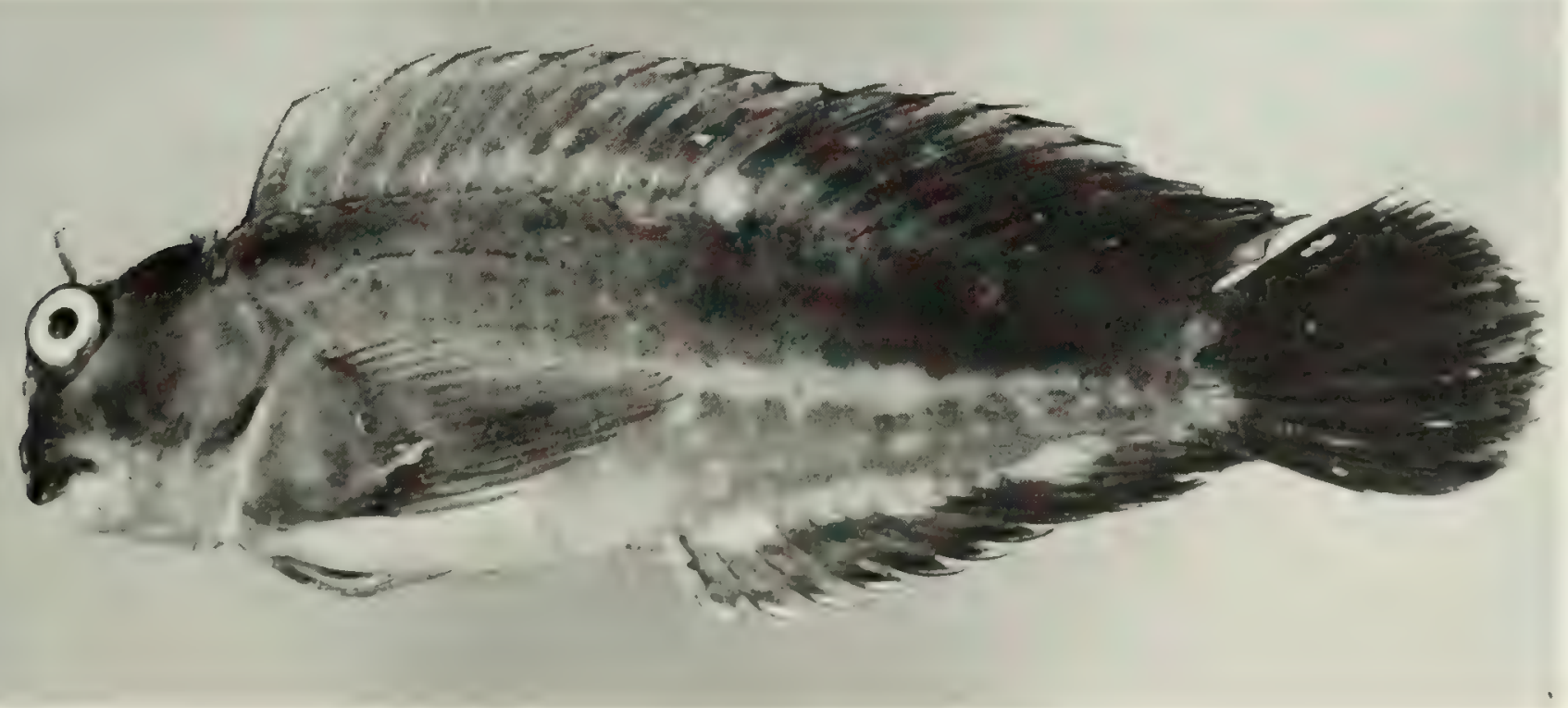

FIG. 376. Cirripectes perustus, $60 \mathrm{~mm} \mathrm{SL}$, Salomon 


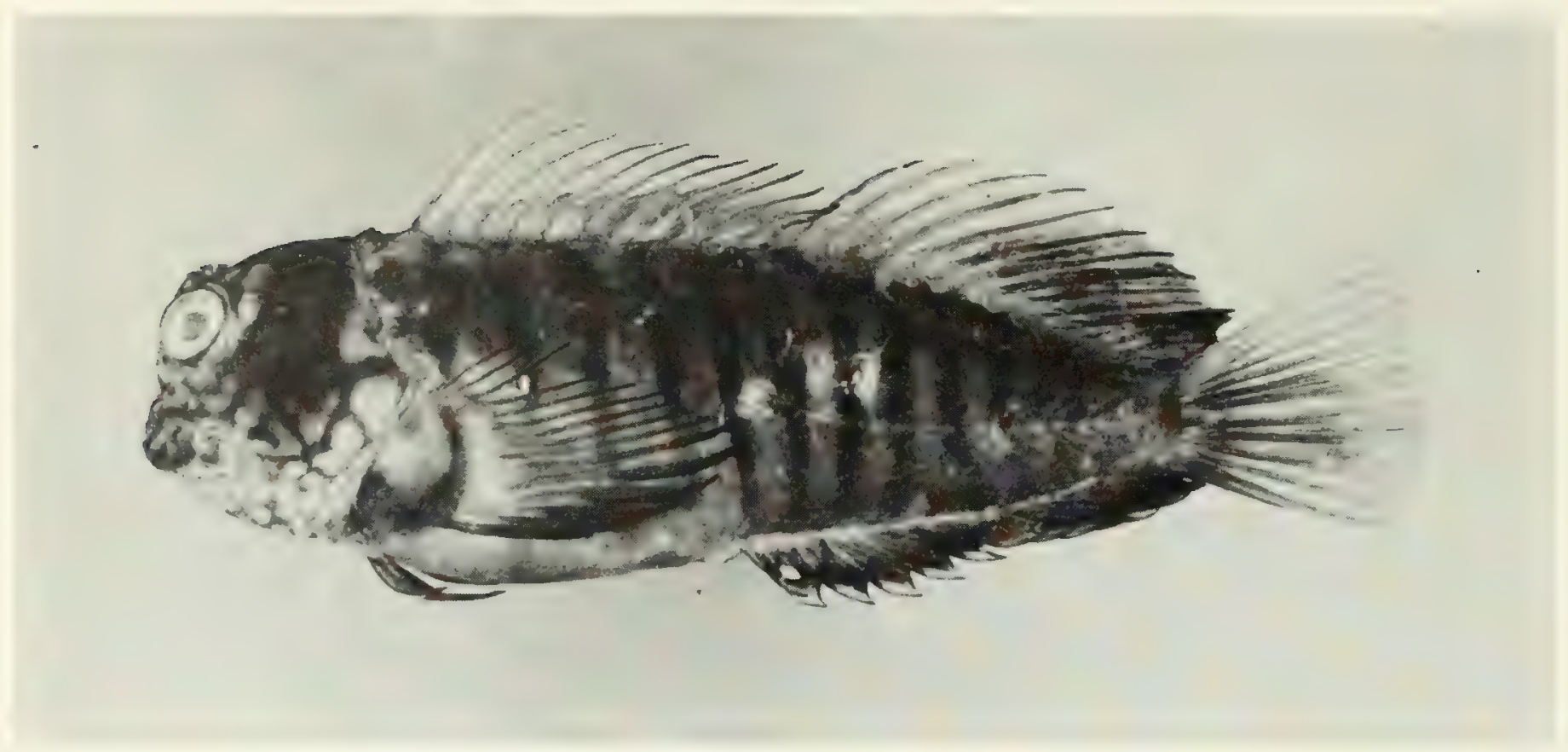

FIG. 377. Cirripectes polyzona, specimen missing, Salomon.

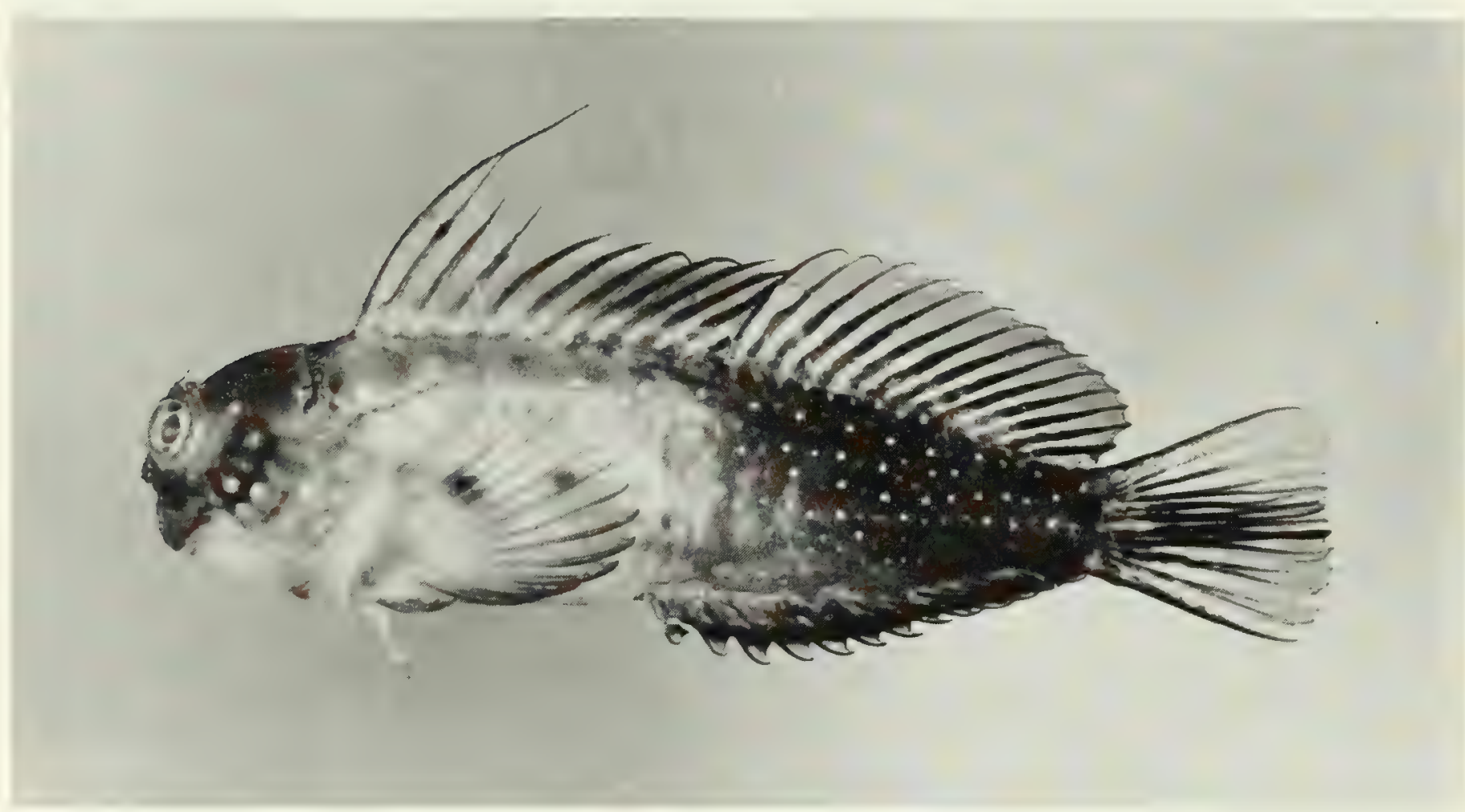

FIG. 378. Cirripectes quagga, $48 \mathrm{~mm}$ SL, Salomon.

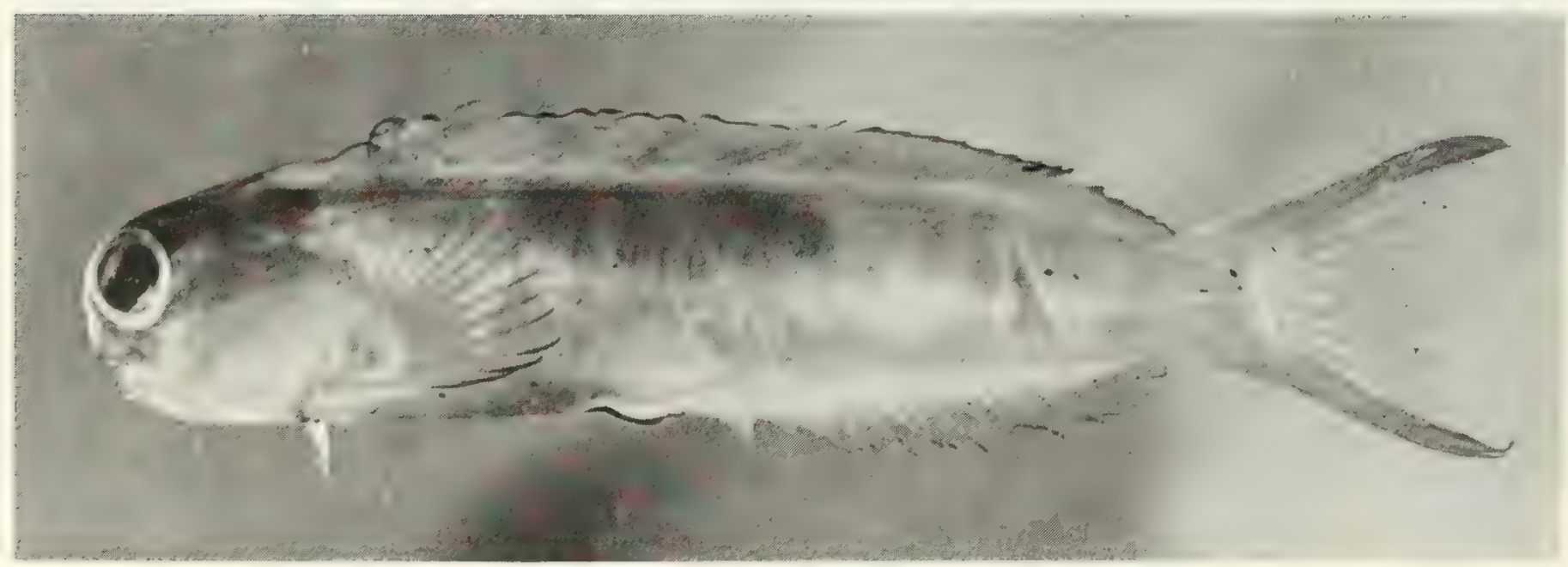

Fig. 379. Ecsenius midas, $52 \mathrm{~mm}$ SL, Peros Banhos. 


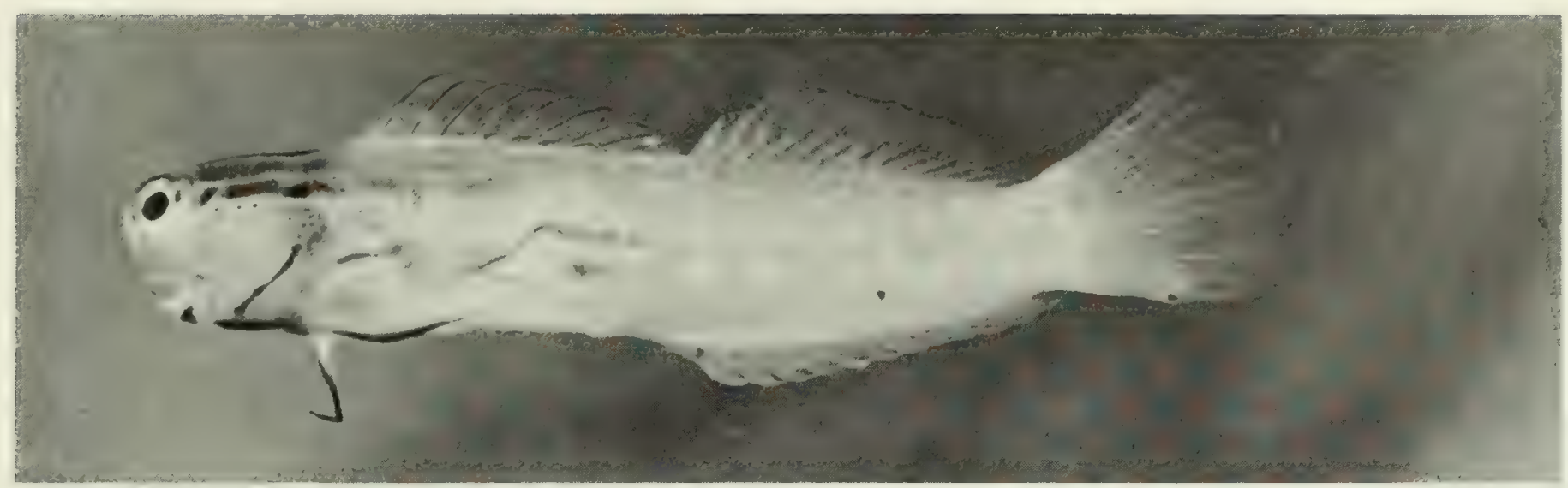

FIG. 380. Ecsenius nalolo, $34 \mathrm{~mm} \mathrm{SL}$, Peros Banhos.

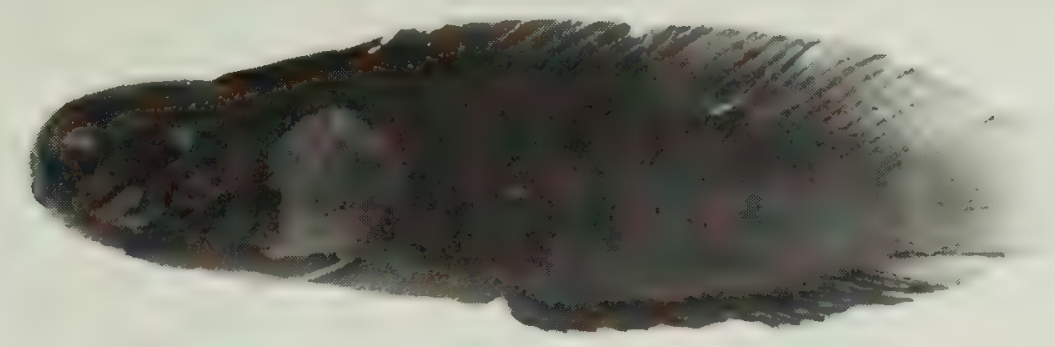

FIG. 381. Enchelyurus kraussi, (preserved) $26 \mathrm{~mm} \mathrm{SL}$, Eagle Island. Photo by A. Strange.

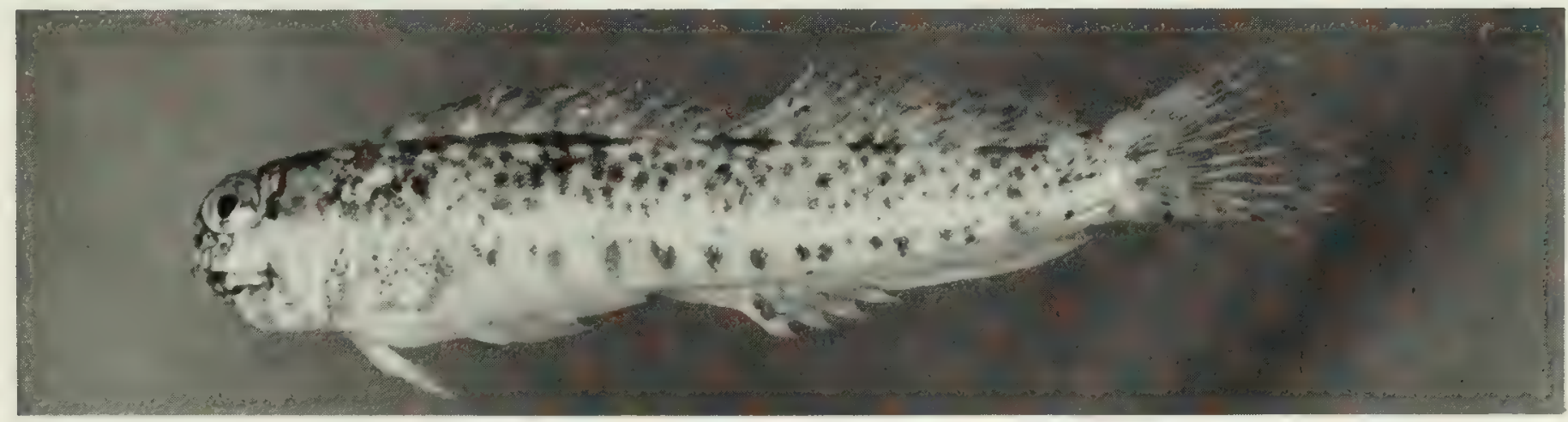

Fig. 382. Entomacrodus striatus, $30 \mathrm{~mm}$ SL, Peros Banhos.

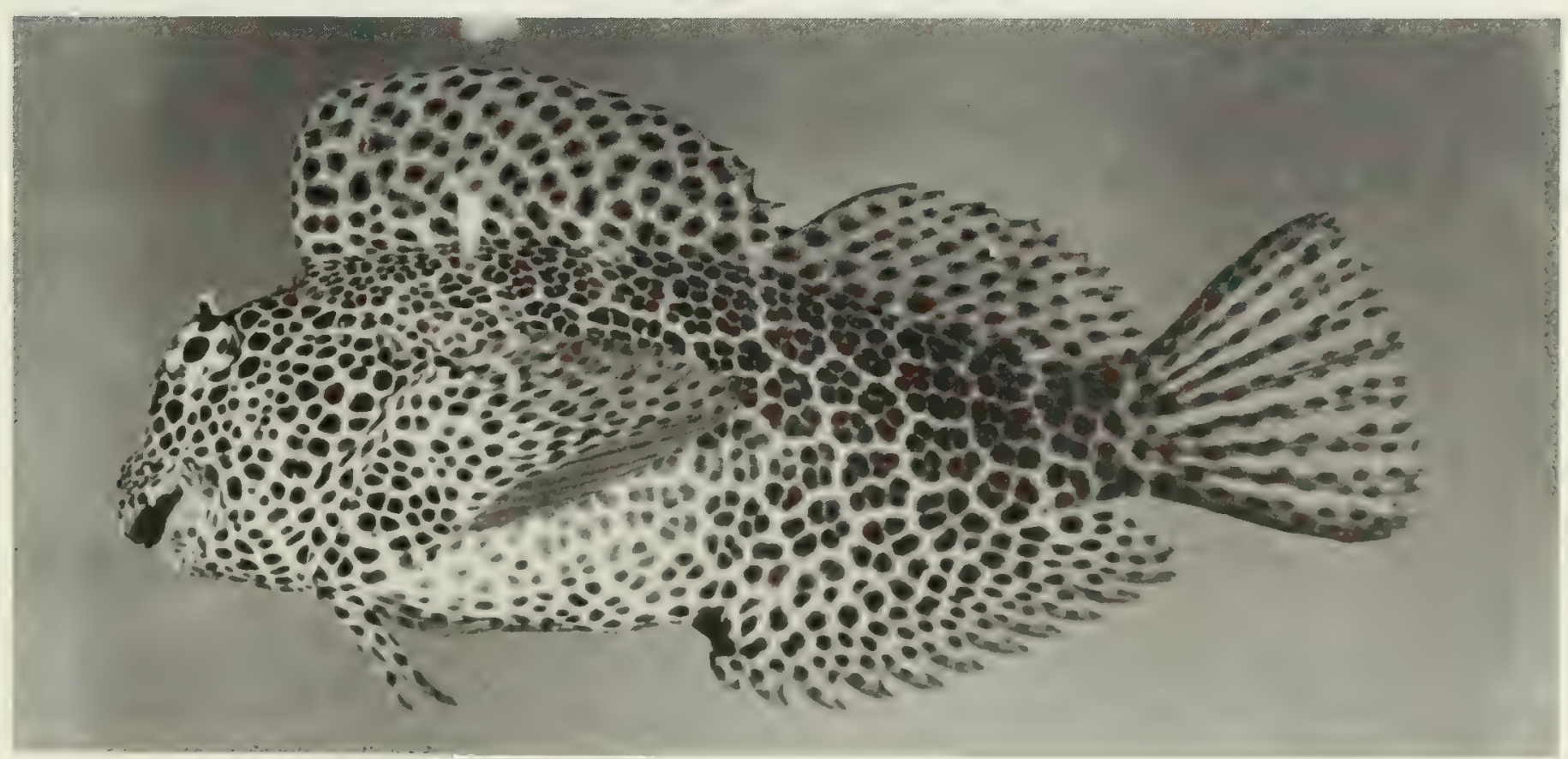

FIG. 383. Exallias brevis, $71 \mathrm{~mm} \mathrm{SL}$, Peros Banhos. 


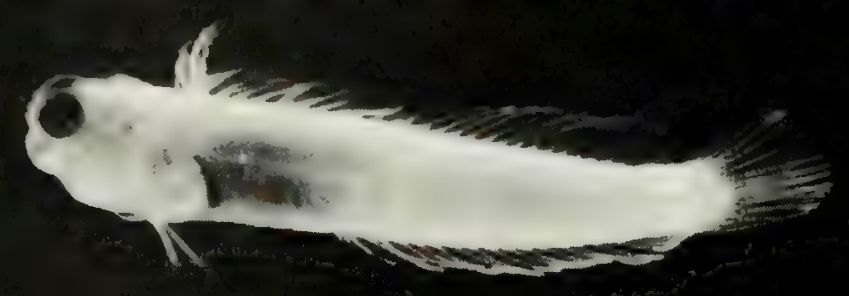

FIG. 384. Glyptoparus delicatulus, (preserved) $20 \mathrm{~mm} \mathrm{SL}$, Eagle Island. Photo by A. Strange.

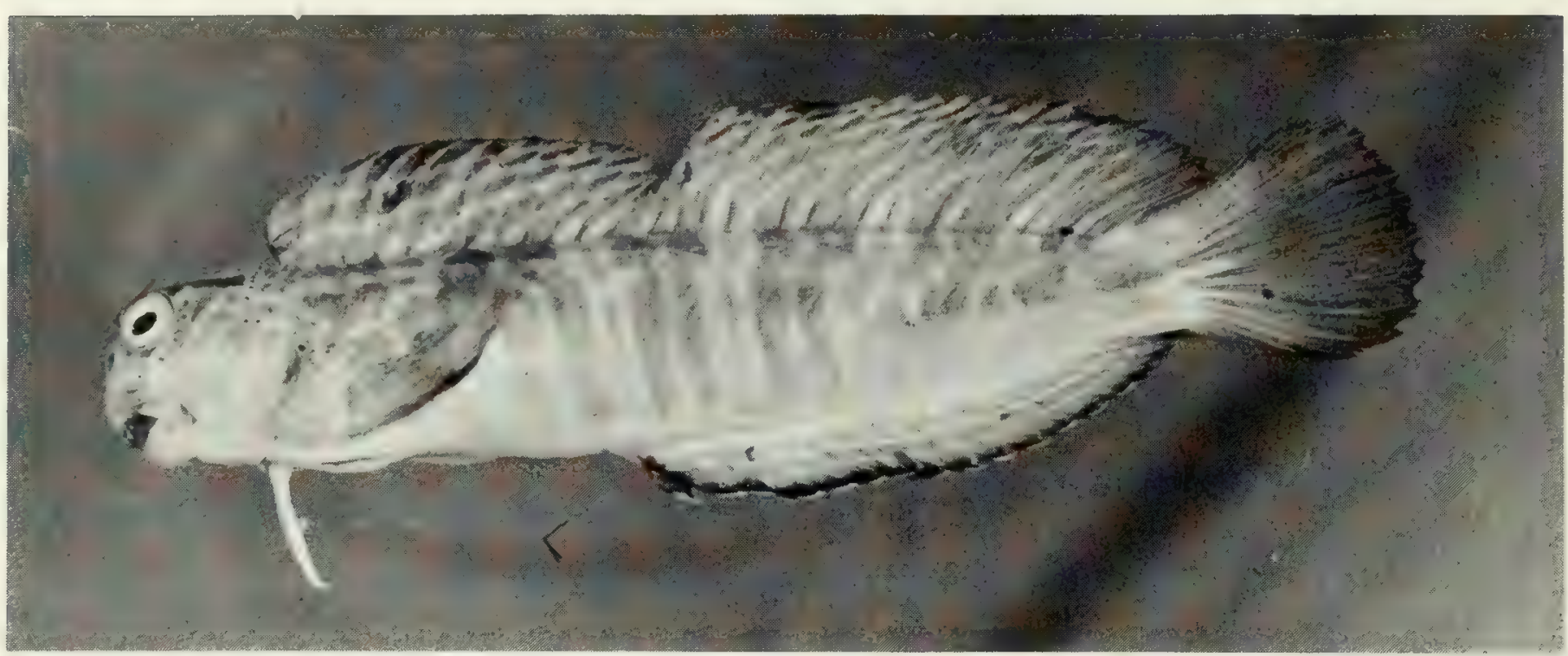

FIG. 385. Istiblennius edentulus, $65 \mathrm{~mm} \mathrm{SL}$, Peros Banhos.

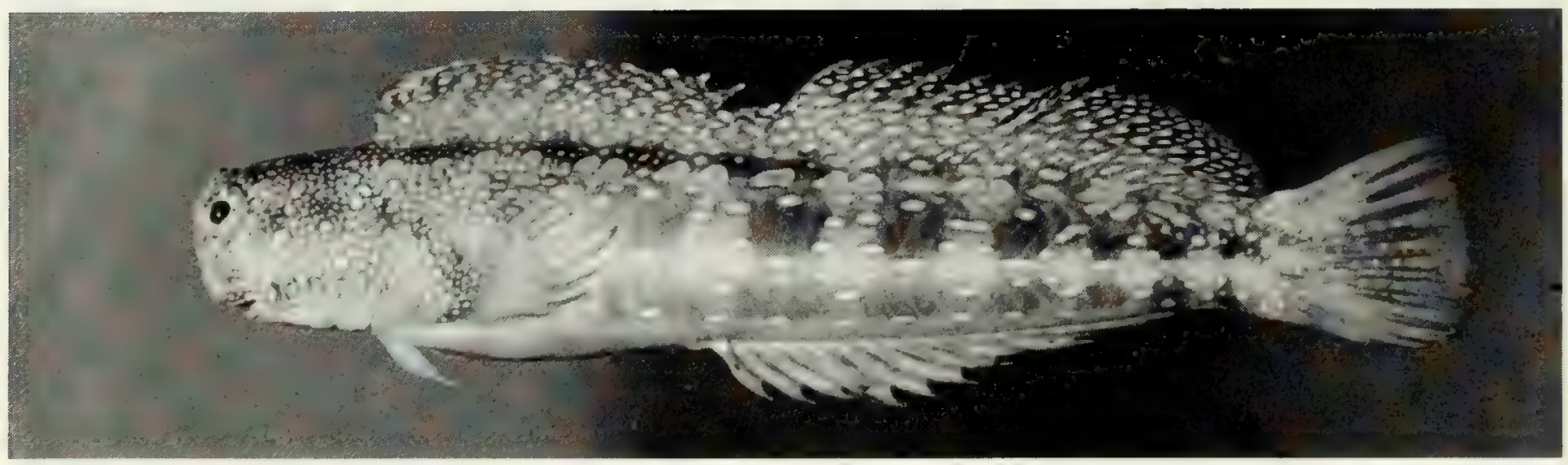

FIG. 386. Istiblennius gibbifrons, $75 \mathrm{~mm}$ SL, Salomon.

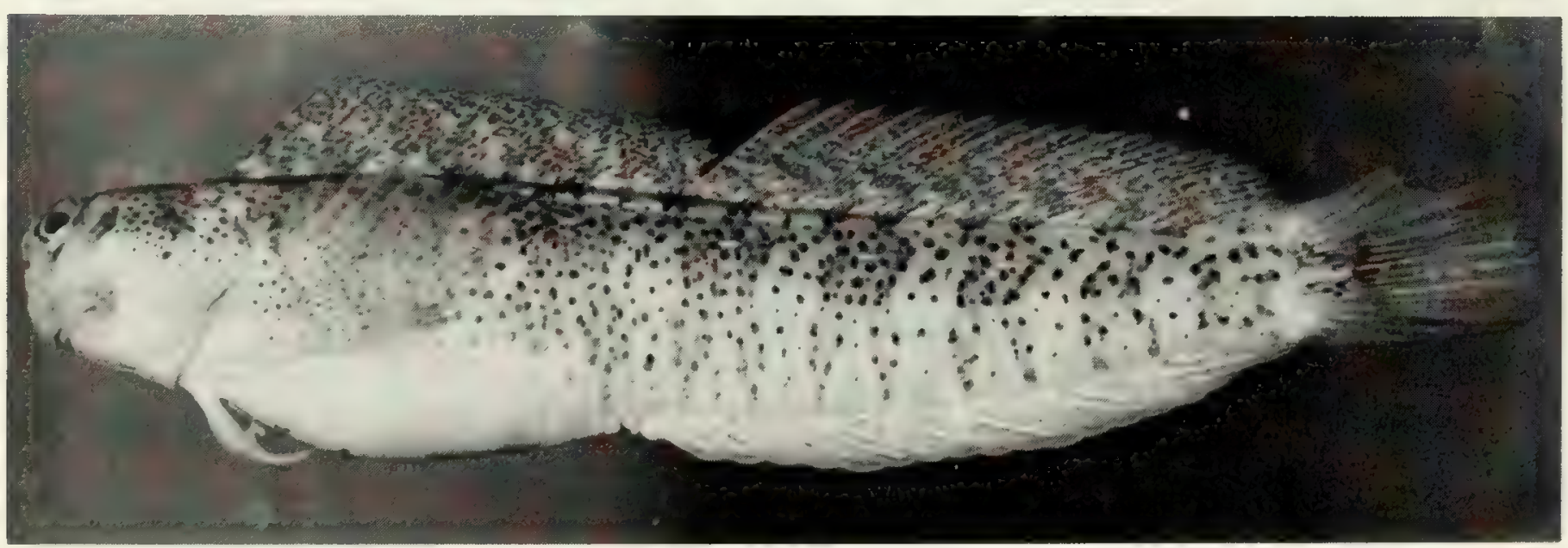

FIG. 387. Istiblennius periophthalmus, $91 \mathrm{~mm} \mathrm{SL}$, Salomon. 


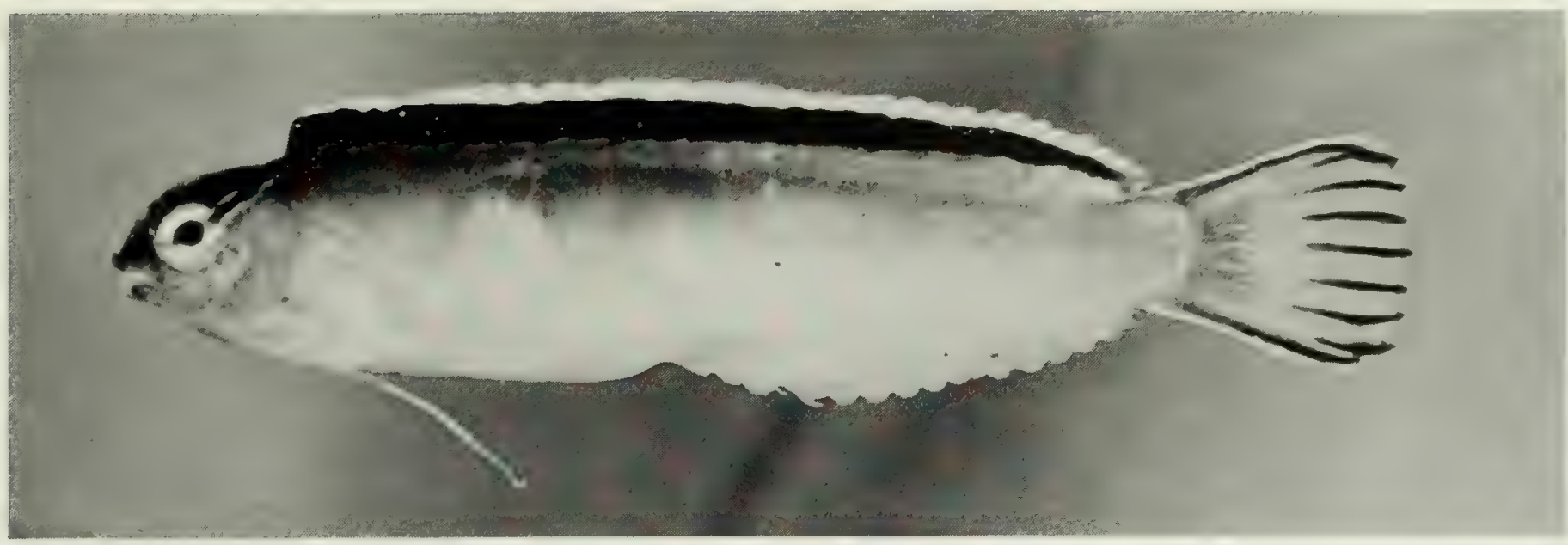

FIG. 388. Meiacanthus smithi, $56 \mathrm{~mm} \mathrm{SL}$, Peros Banhos.

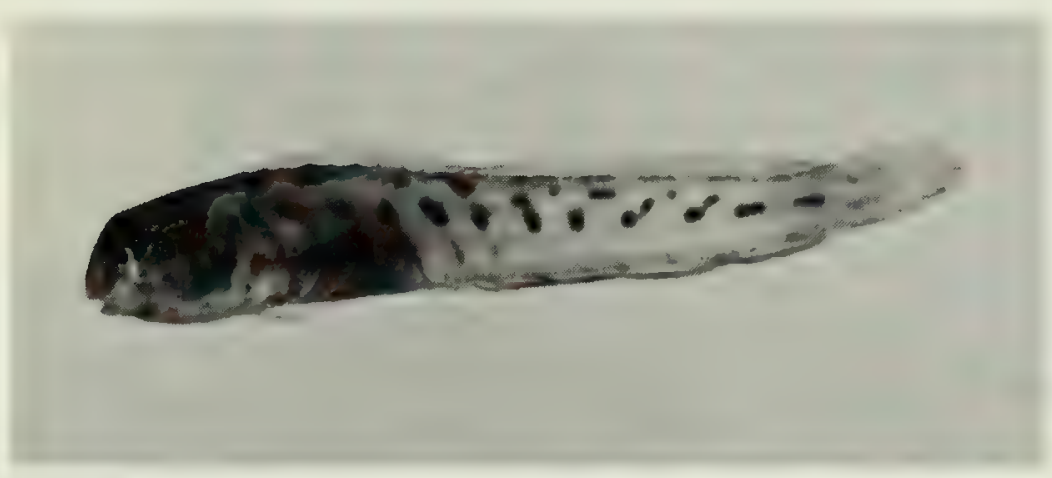

FIG. 389. Omobranchus elongatus, (preserved) $23 \mathrm{~mm} \mathrm{SL}$, Diego Garcia. Photo by M. Burridge-Smith.

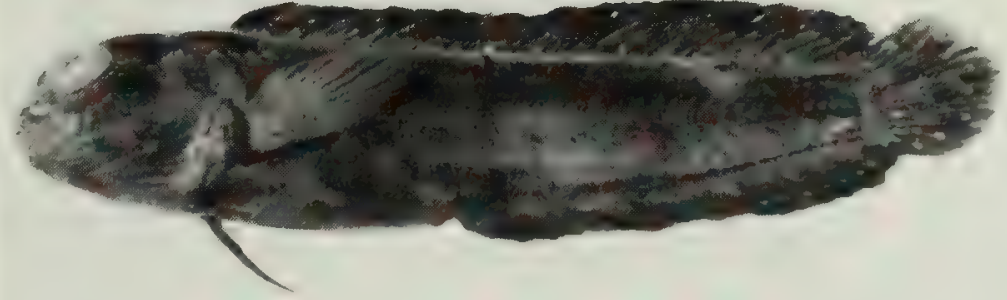

Fig. 390. Parenchelyurus hepburni, (preserved) $25 \mathrm{~mm}$ SL, Peros Banhos. Photo by A. Strange.

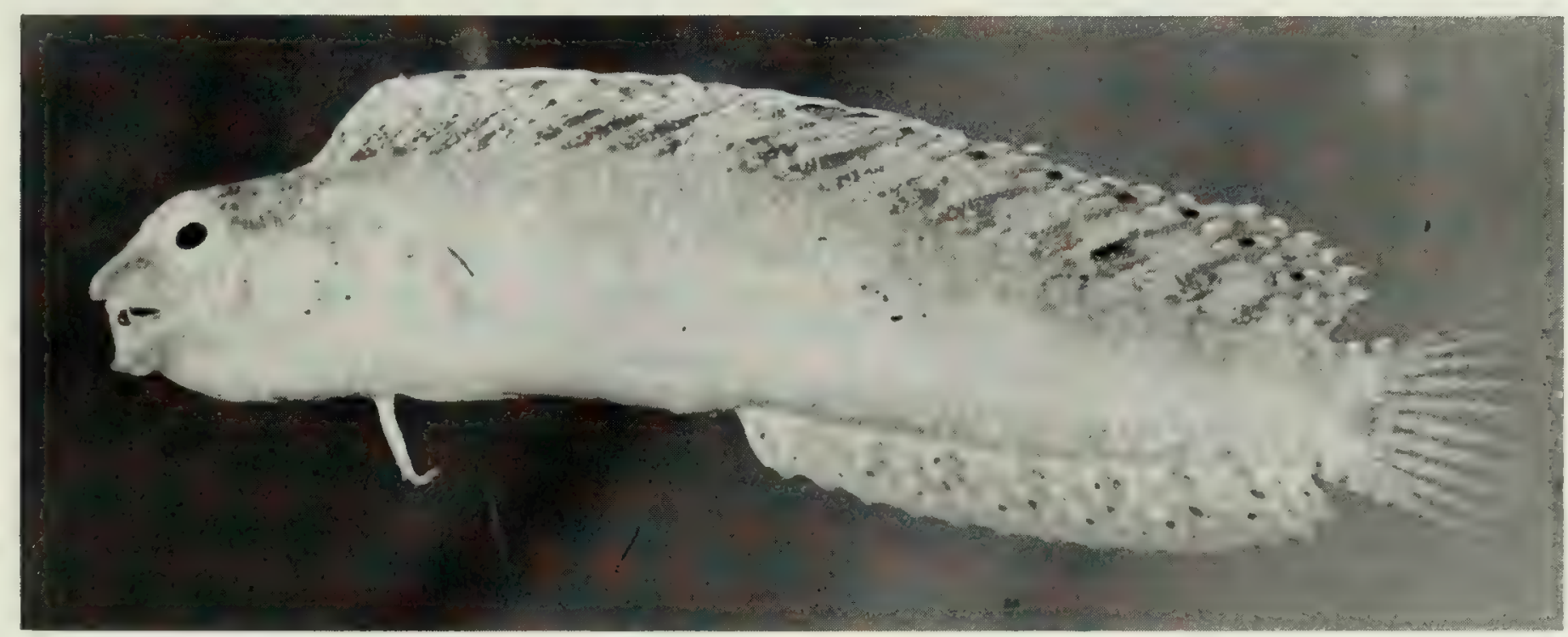

FIG. 391. Petroscirtes xestus, $47 \mathrm{~mm} \mathrm{SL}$, Peros Banhos.

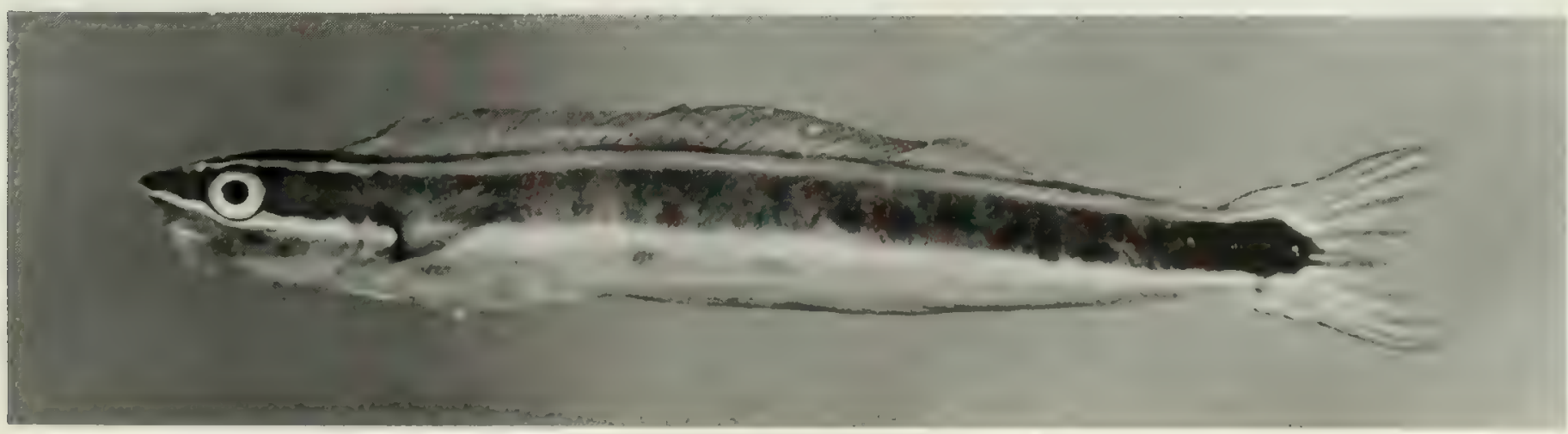

FIG. 392. Plagiotremus rhinorhynchos, $50 \mathrm{~mm}$ SL, Salomon. 


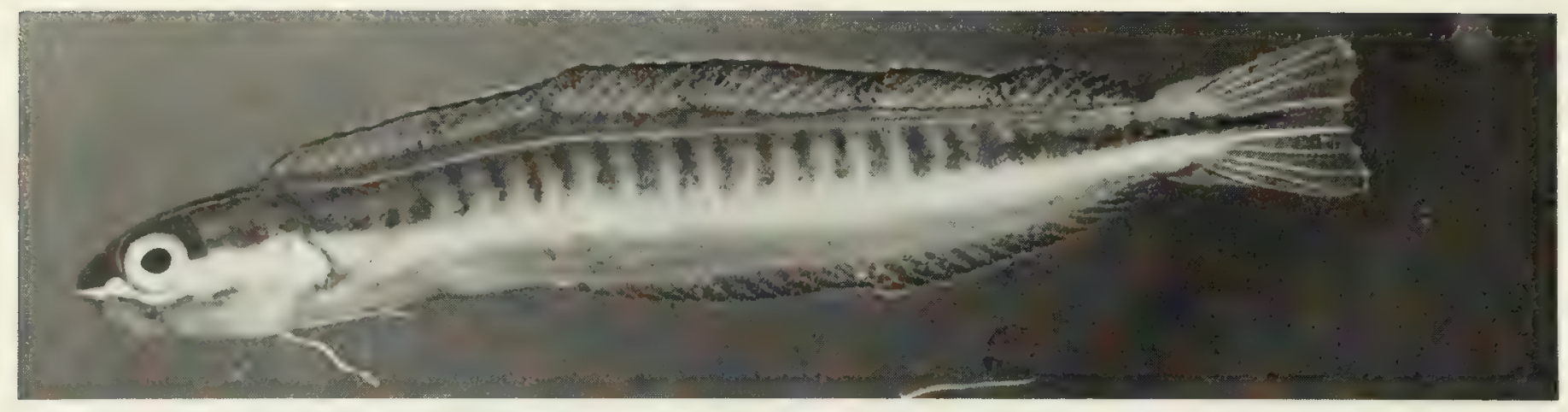

FIG. 393. Plagiotremus tapeinosoma, $39 \mathrm{~mm} \mathrm{SL,} \mathrm{Peros} \mathrm{Banhos.}$

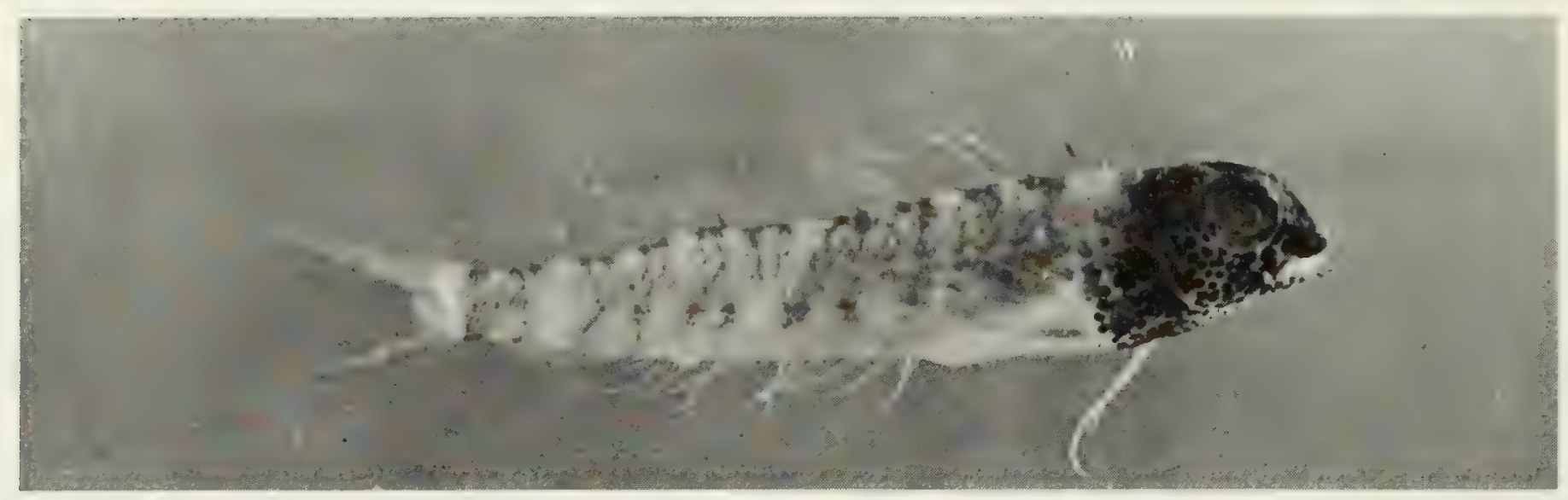

FIG. 394. Enneapterygius abeli, $17 \mathrm{~mm} \mathrm{SL,} \mathrm{Peros} \mathrm{Banhos.}$

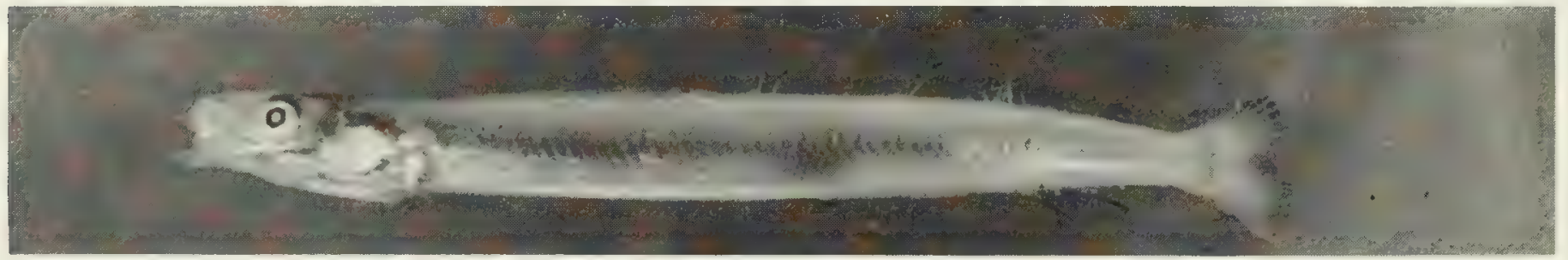

FIG. 395. ?Bleekeria renniei, $61 \mathrm{~mm}$ SL, Peros Banhos.

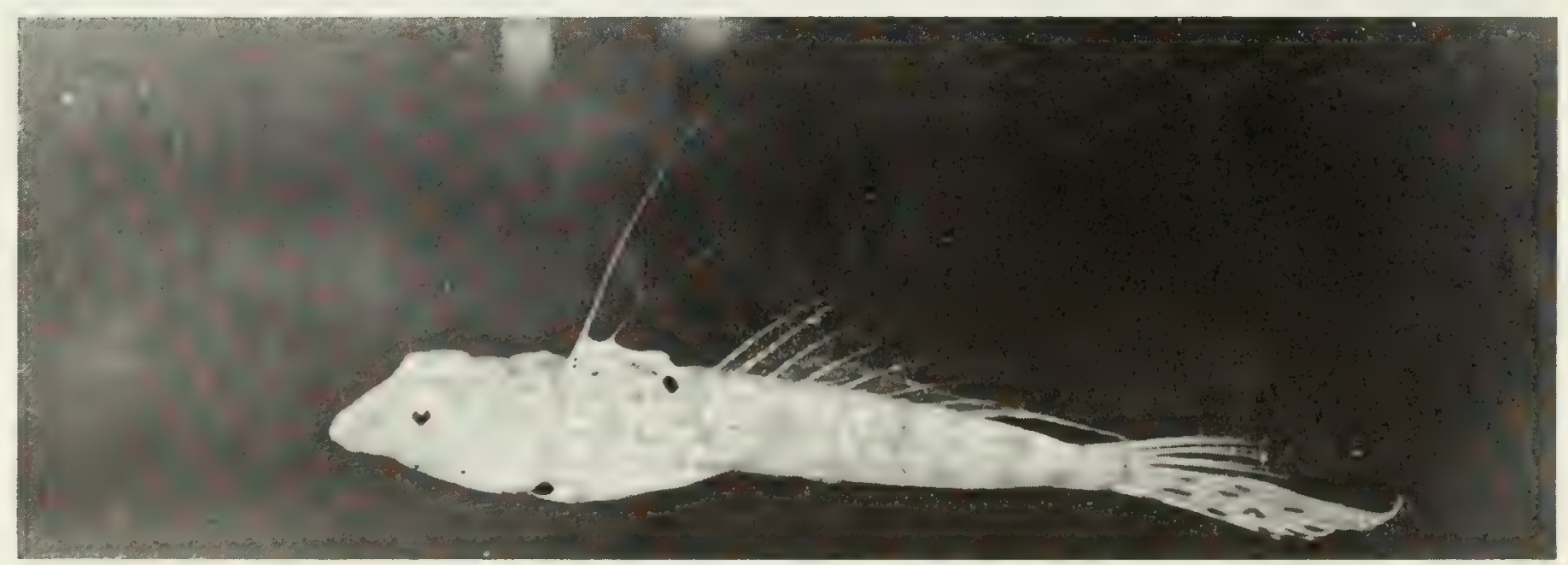

FIG. 396. Callionymus delicatulus, $29 \mathrm{~mm} \mathrm{SL}$, Peros Banhos.

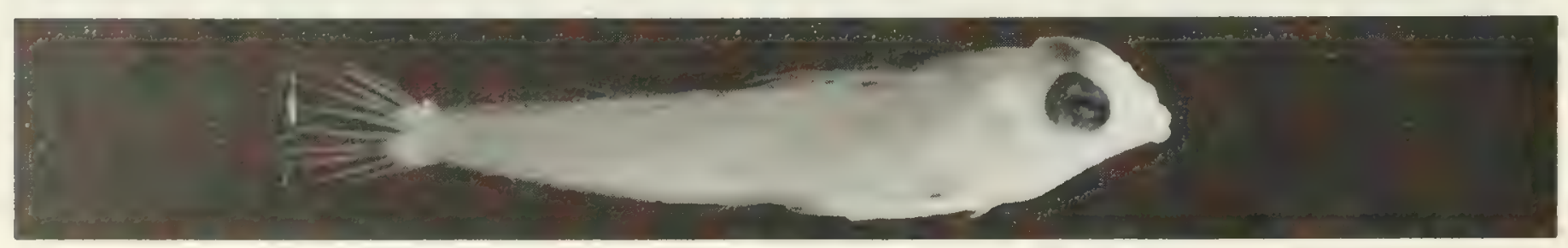

FIG. 397. Synchiropus minutulus, (preserved) $13 \mathrm{~mm} \mathrm{SL}$, Salomon. Photo by A. Strange. 


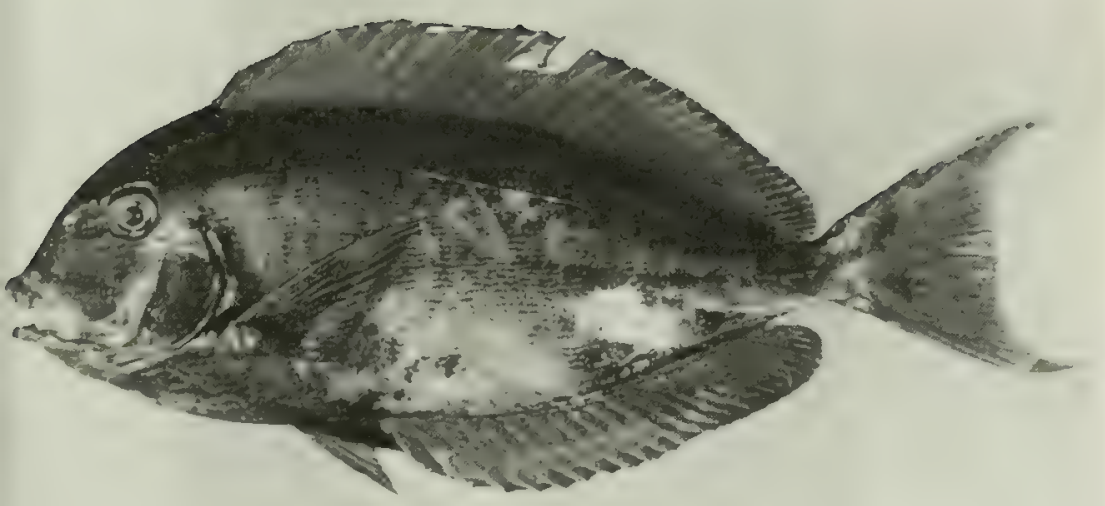

FIG. 398. Acanthurus bleekeri, $300 \mathrm{~mm}$ SL, Peros Banhos.

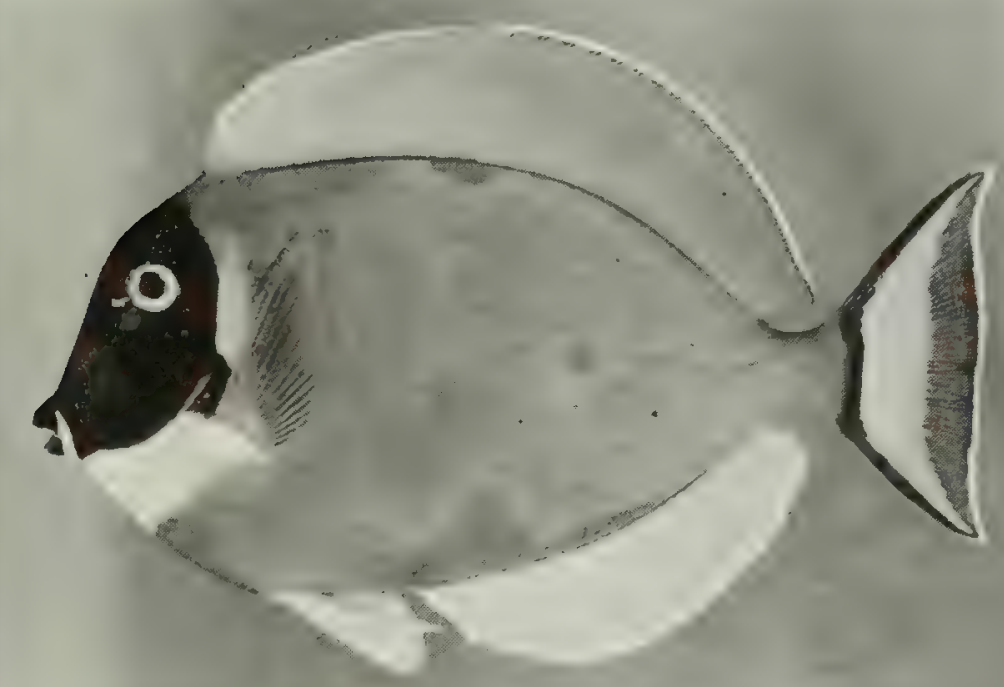

FIG. 400. Acanthurus leucosternon, $160 \mathrm{~mm}$ SL, Peros Banhos.

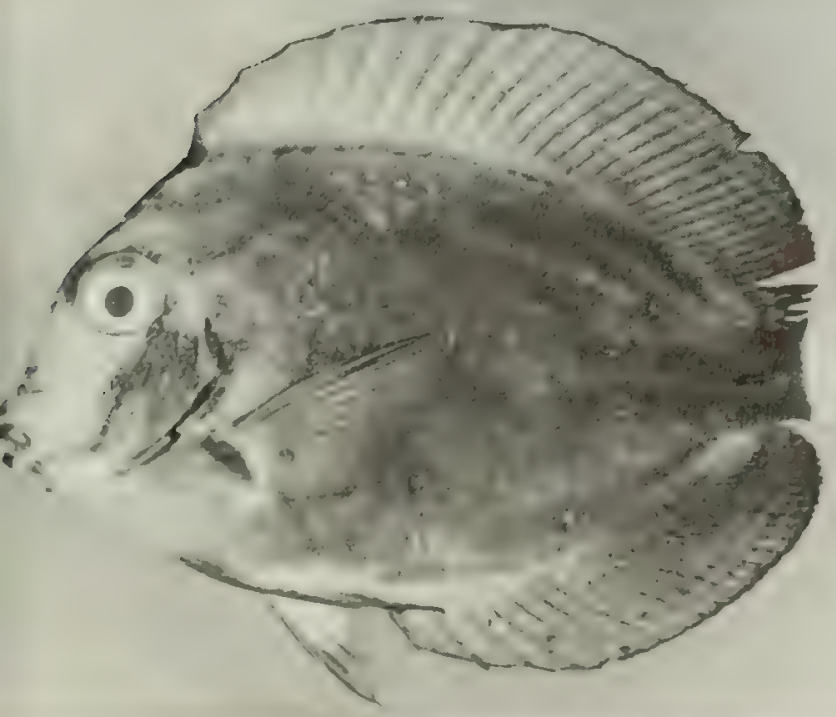

FIG. 402. Acanthurus mata, $30 \mathrm{~mm} \mathrm{SL,} \mathrm{Peros} \mathrm{Banhos.}$

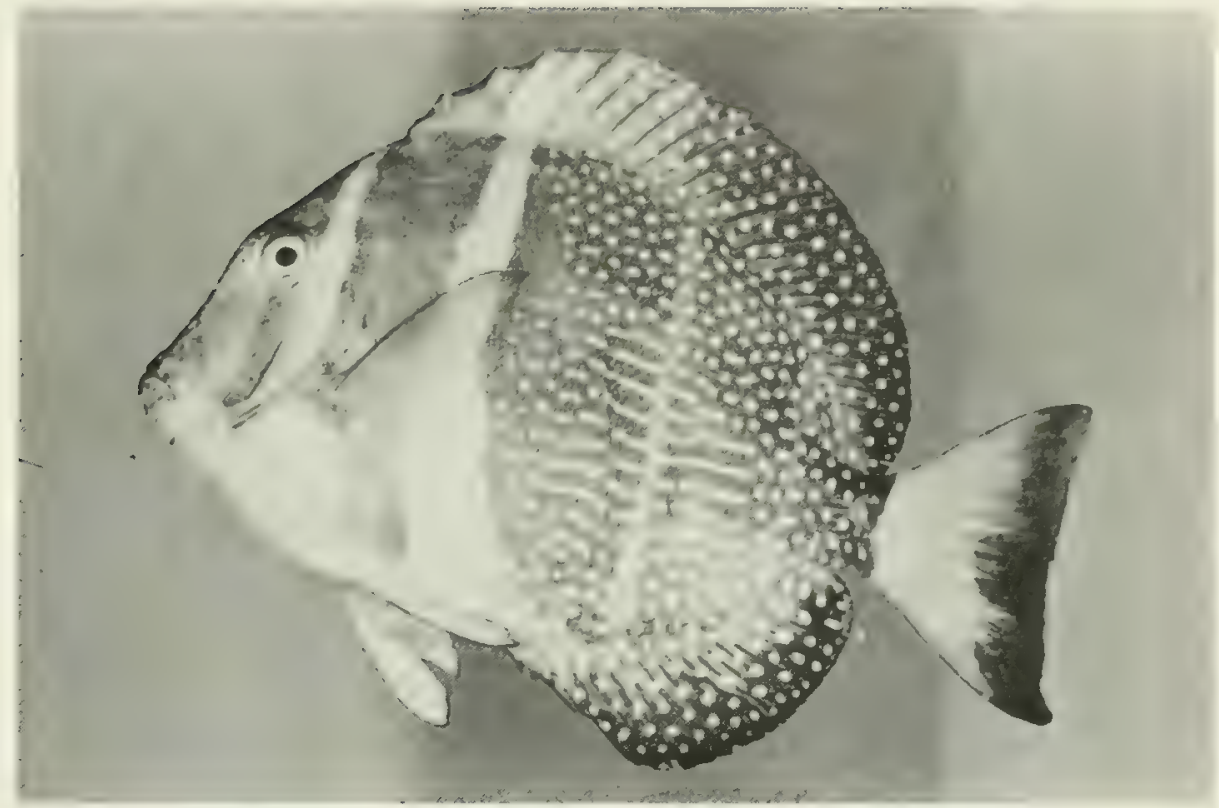

FIG. 399. Acanthurus guttatus, $173 \mathrm{~mm}$ SL, Salomon.

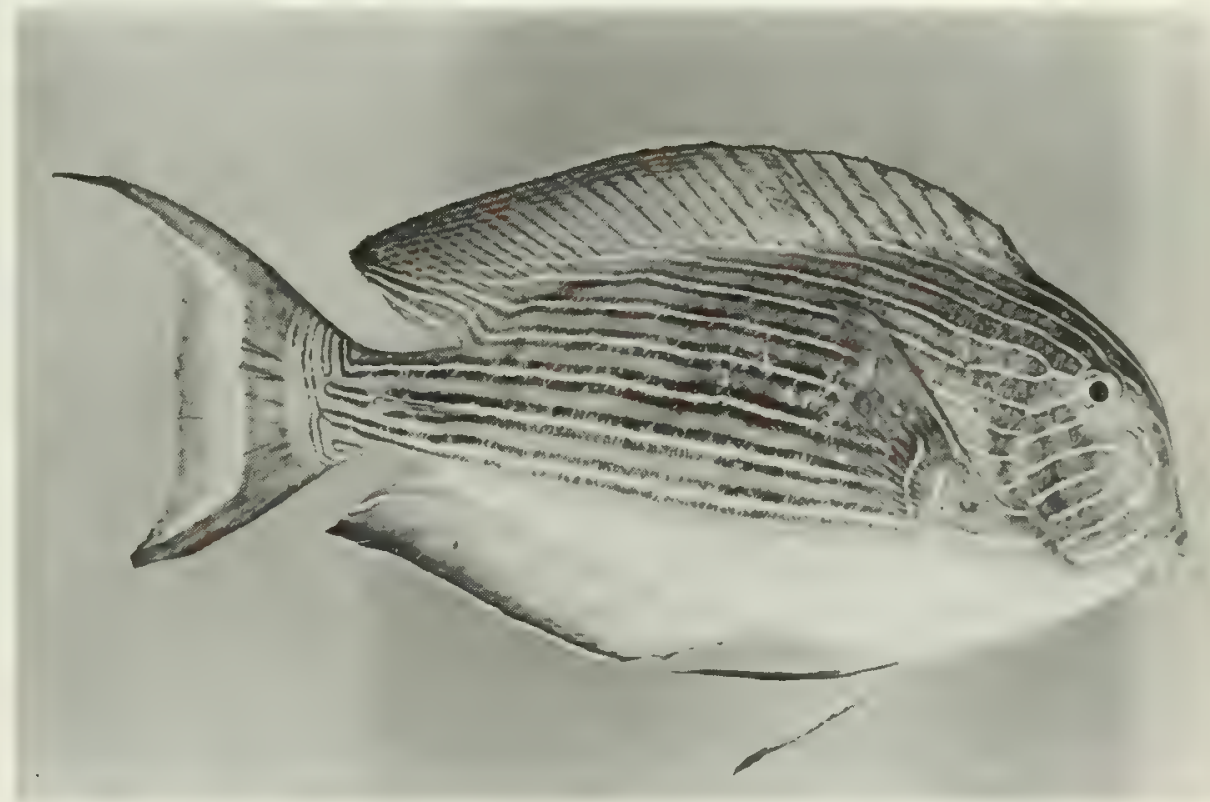

FIG. 401. Acanthurus lineatus, $198 \mathrm{~mm}$ SL, Peros Banhos.

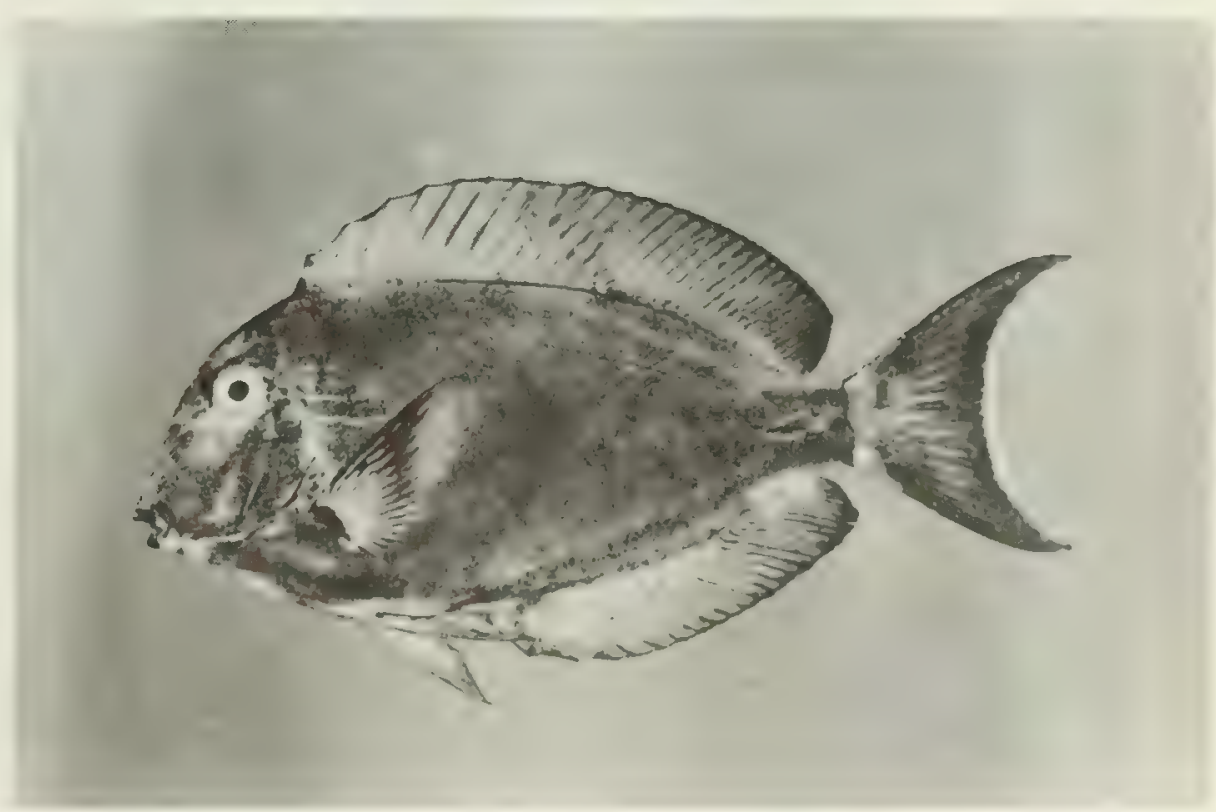

Fig. 403. Acanthurusnigricaudus, $122 \mathrm{~mm} \mathrm{SL}$, Peros Banhos. 


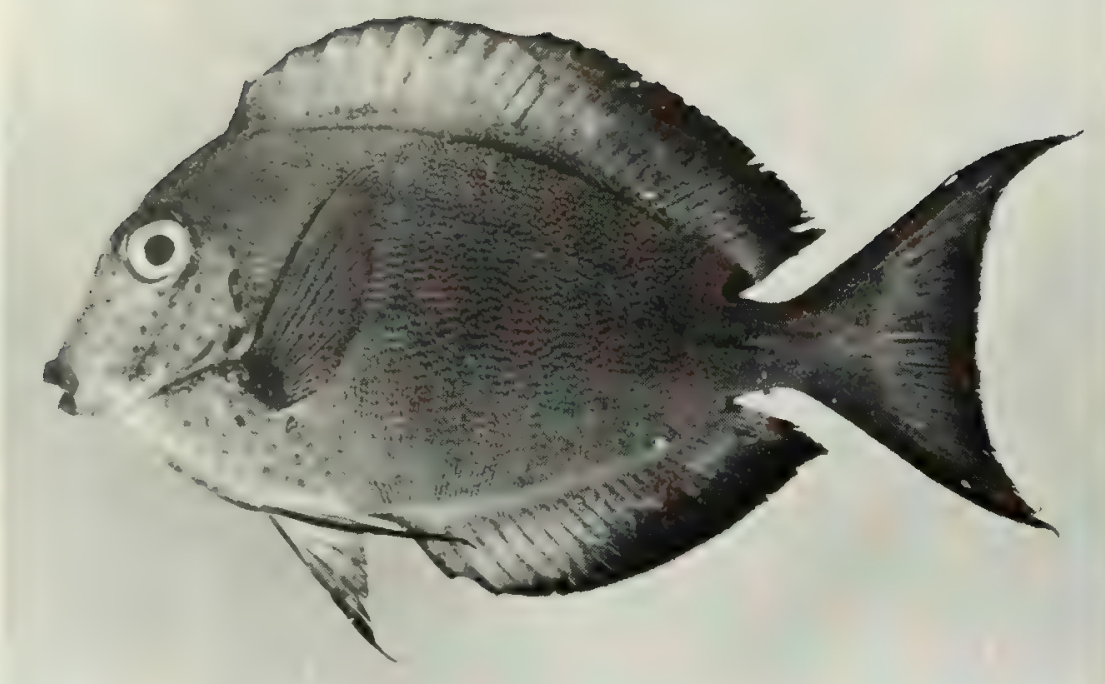

Fig. 404. Acanthurus nigrofuscus, $63 \mathrm{~mm} \mathrm{SL}$, Peros Banhos.

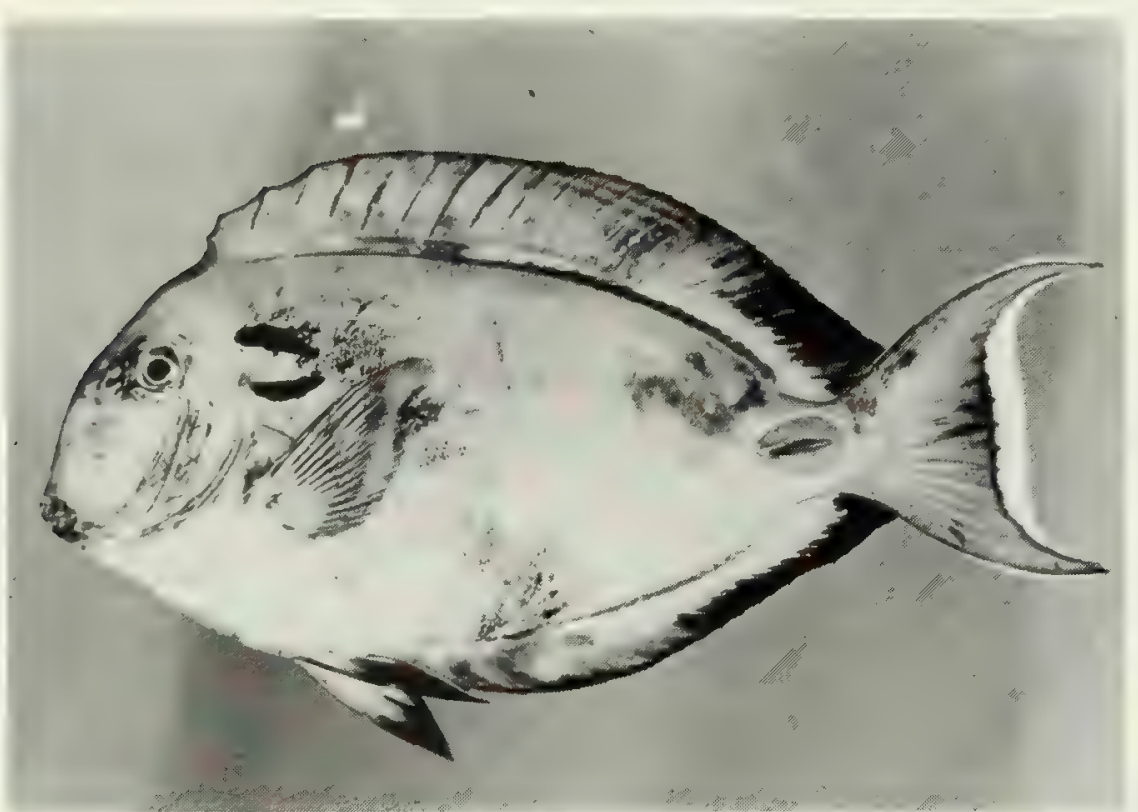

FIG. 406. Acanthurus tennenti, $148 \mathrm{~mm} \mathrm{SL}$, Peros Banhos.

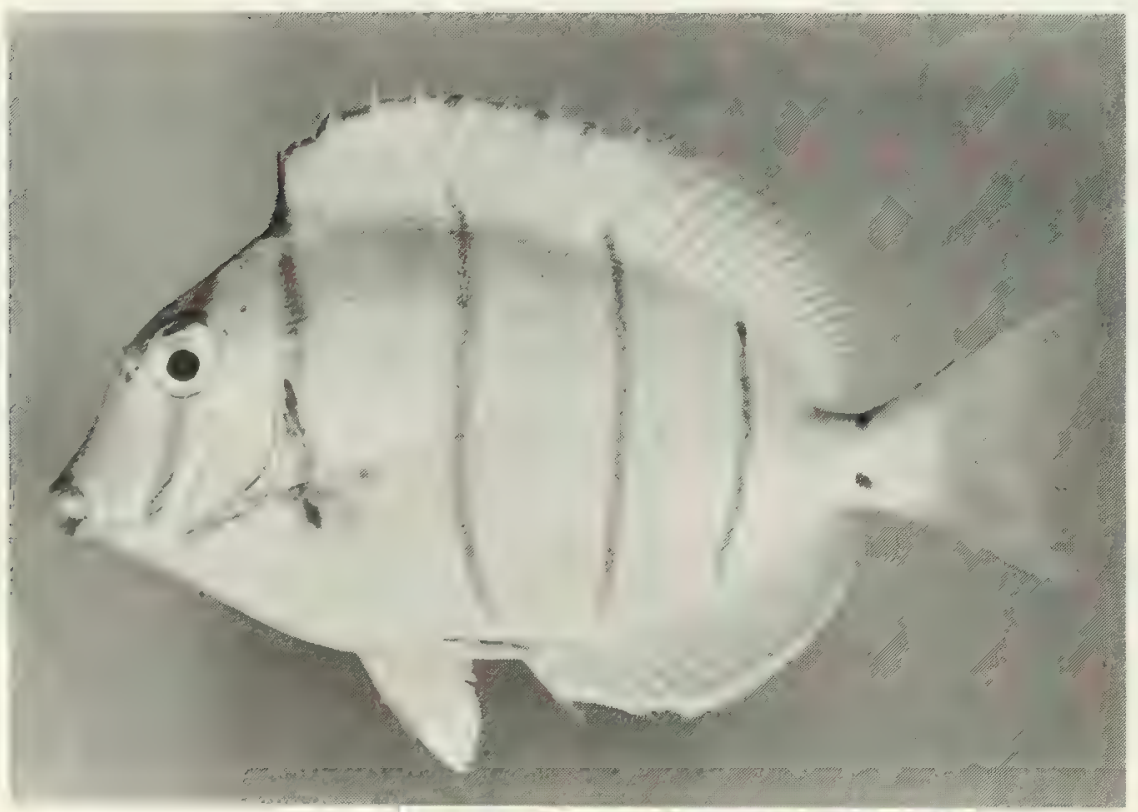

FIG. 408. Acanthurus triostegus, $87 \mathrm{~mm} \mathrm{SL}$, Peros Banhos.

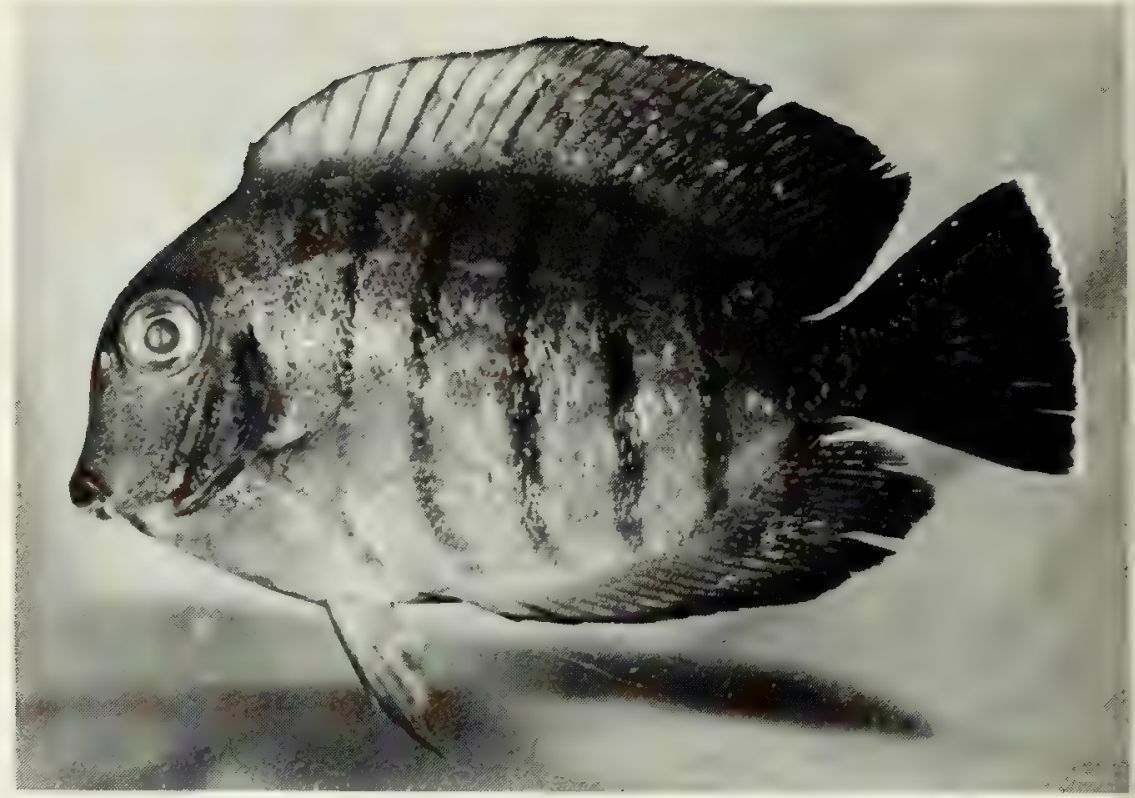

FIG. 405. Acanthurus pyroferus, $67 \mathrm{~mm} \mathrm{SL}$, Peros Banhos.

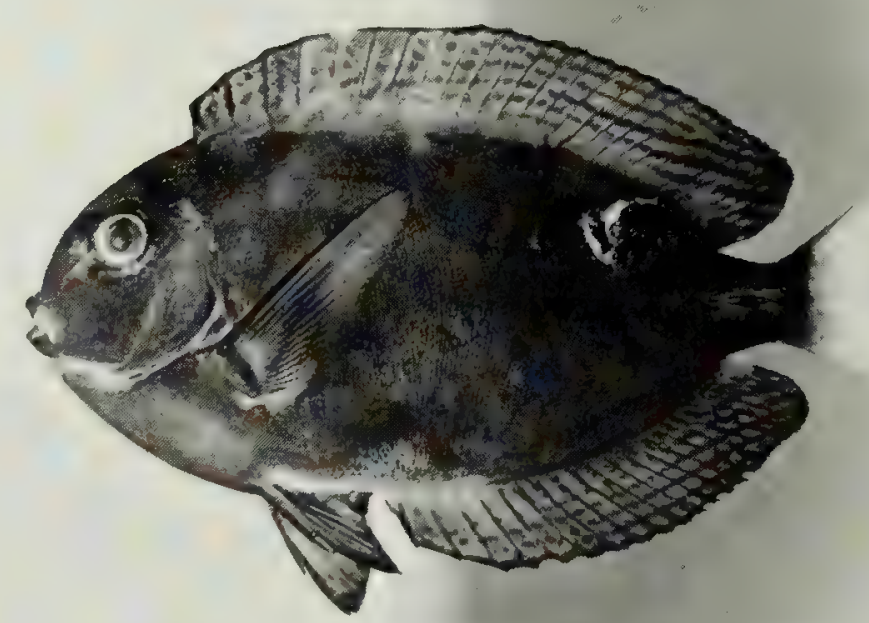

FIG. 407. Acanthurus thompsoni, $117 \mathrm{~mm} \mathrm{SL}$, Salomon.

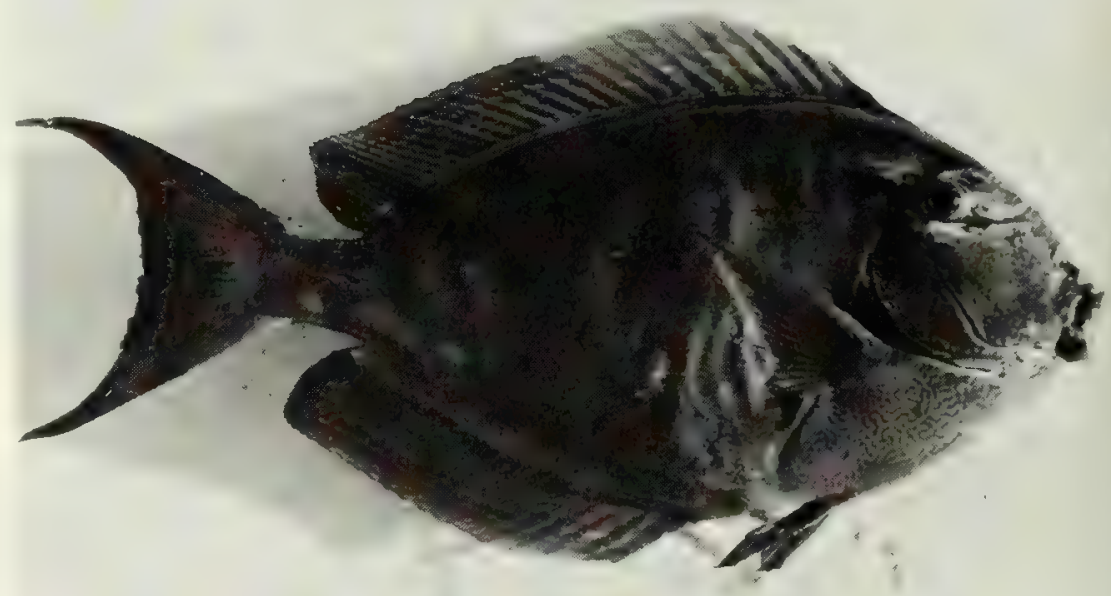

FIG. 409. Acanthurus xanthopterus, $421 \mathrm{~mm} \mathrm{SL}$, Eagle Island. 


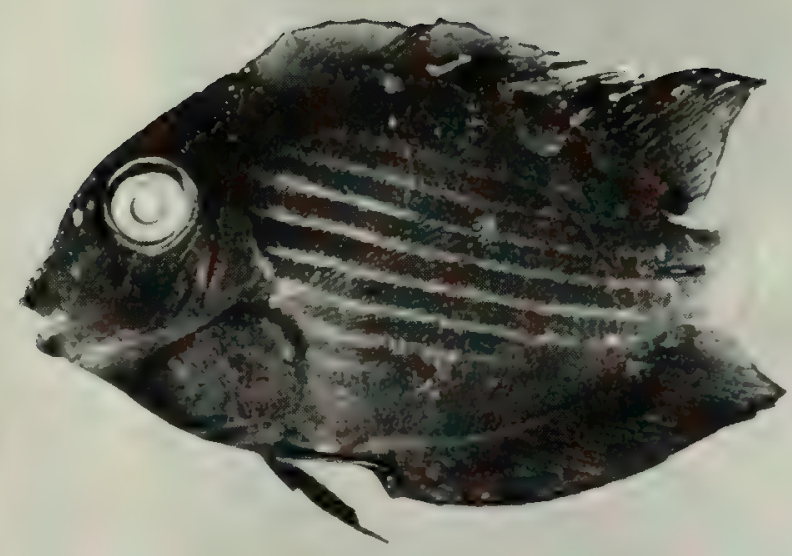

FIG. 410. Ctenochaetus striatus, $30 \mathrm{~mm} \mathrm{SL}$, Peros Banhos

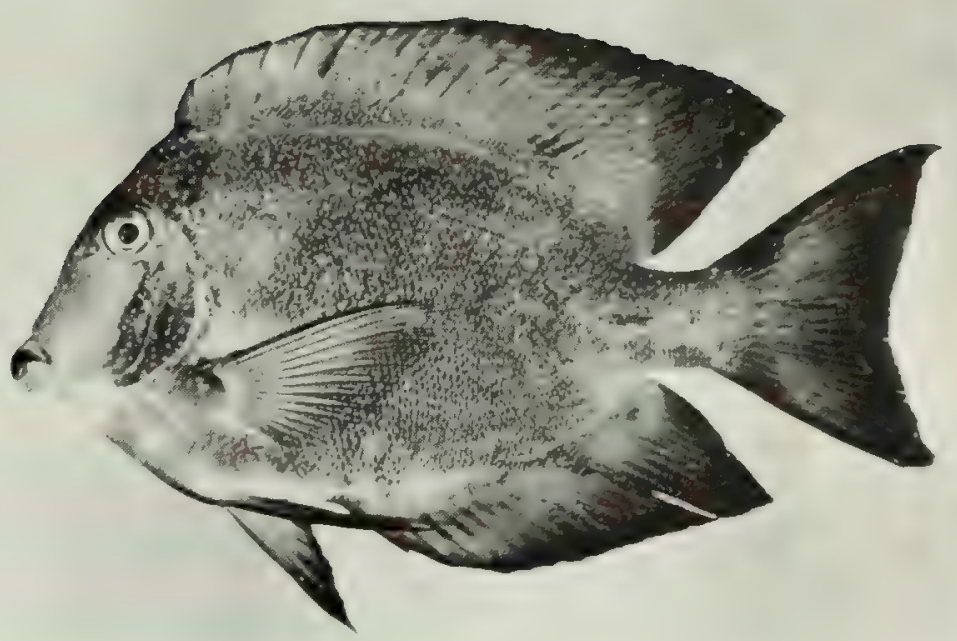

FIG. 411. Ctenochaetus strigosus, $101 \mathrm{~mm} \mathrm{SL}$, Peros Banhos

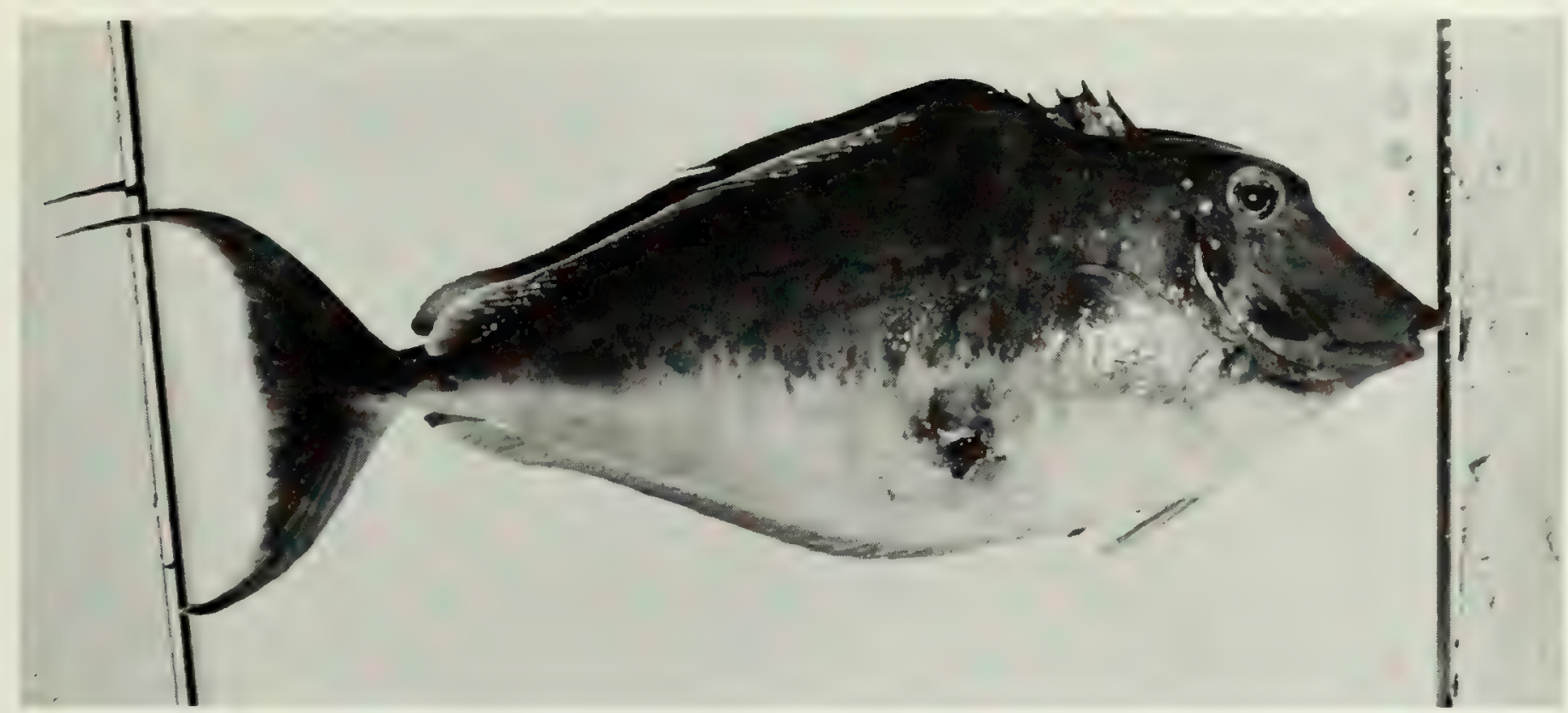

FIG. 412. Naso brachycentron, $464 \mathrm{~mm} \mathrm{SL}$, Eagle Island.

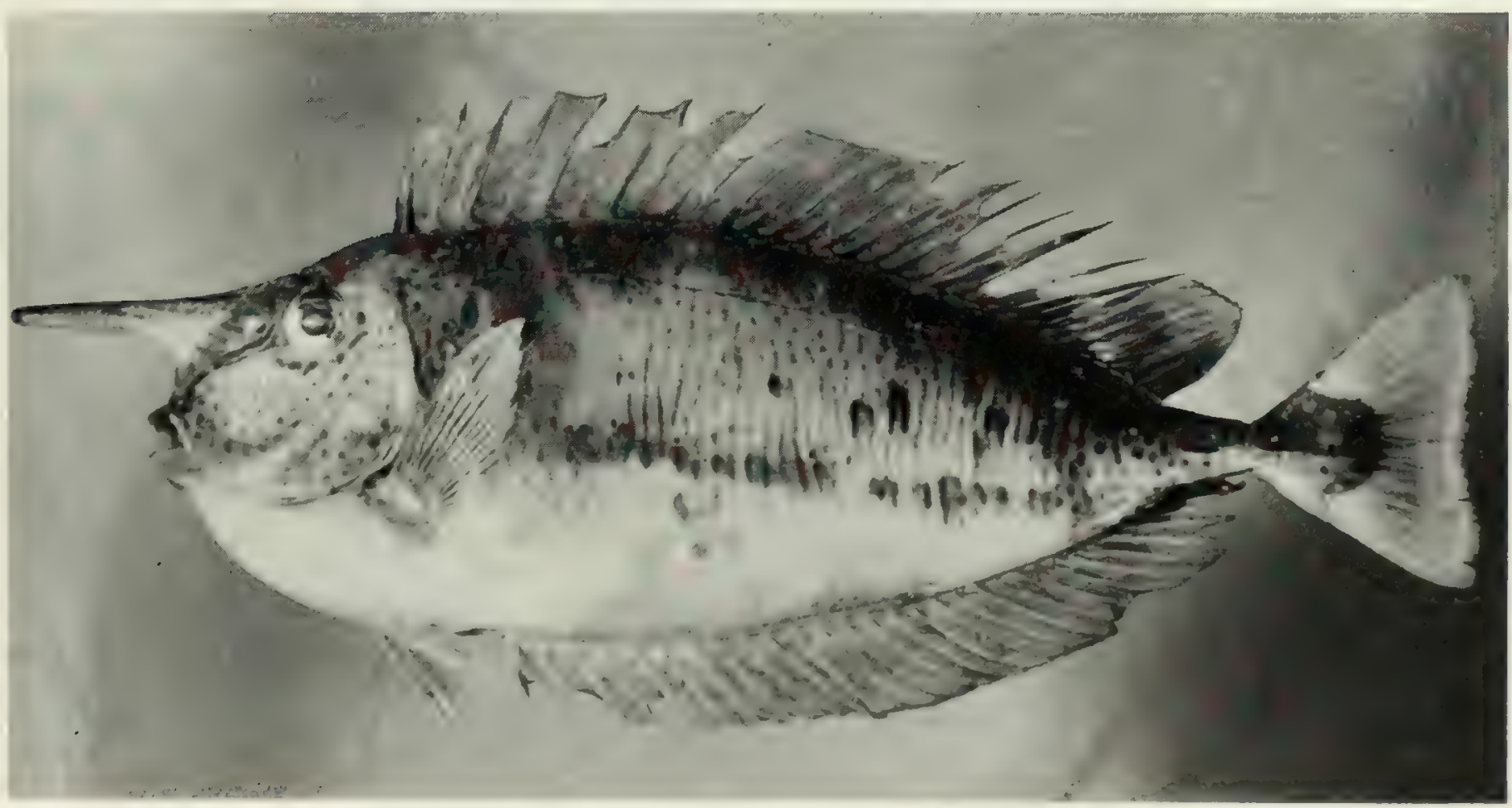

FIG. 413. Naso brevirostris, $277 \mathrm{~mm}$ SL, Peros Banhos. 


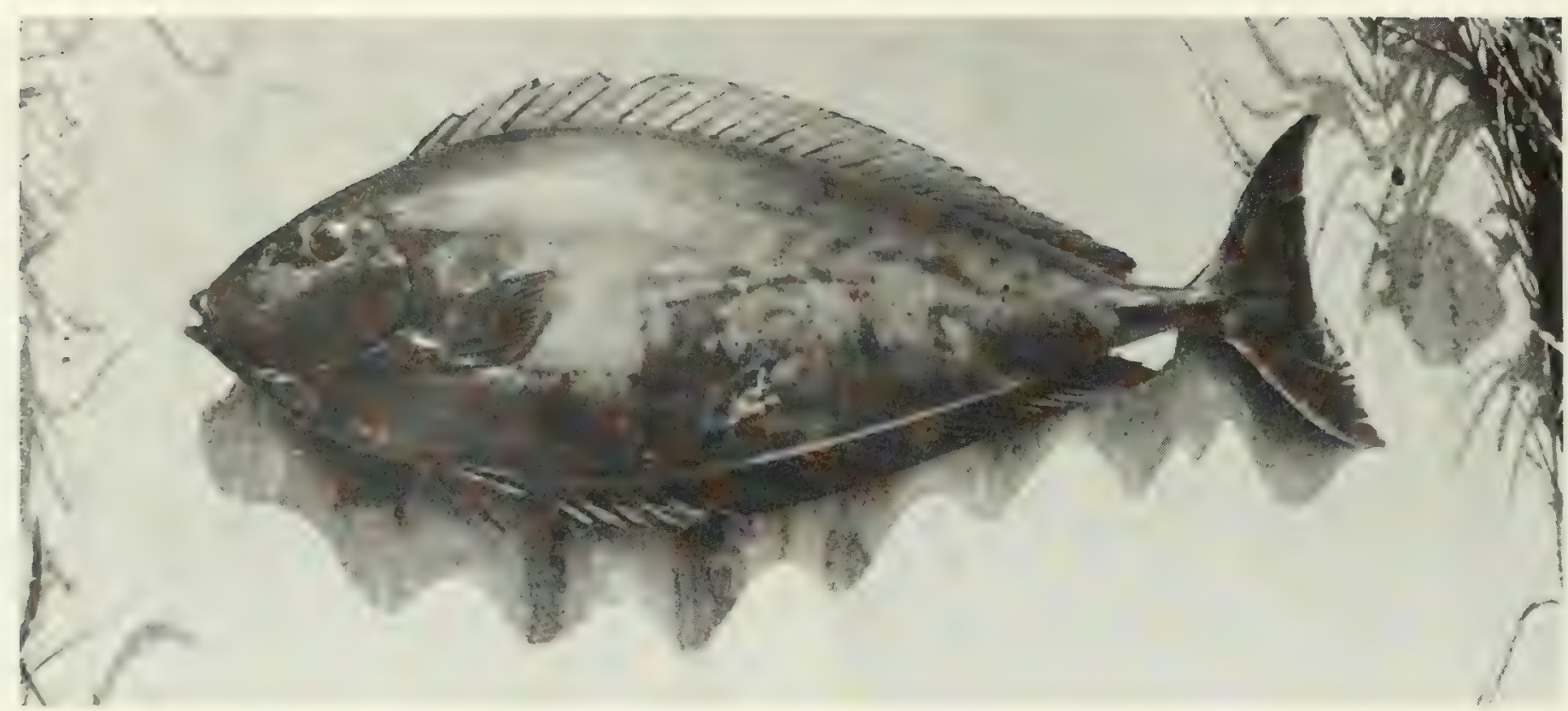

FIG. 414. Naso hexacanthus, $484 \mathrm{~mm} \mathrm{SL}$, Salomon.

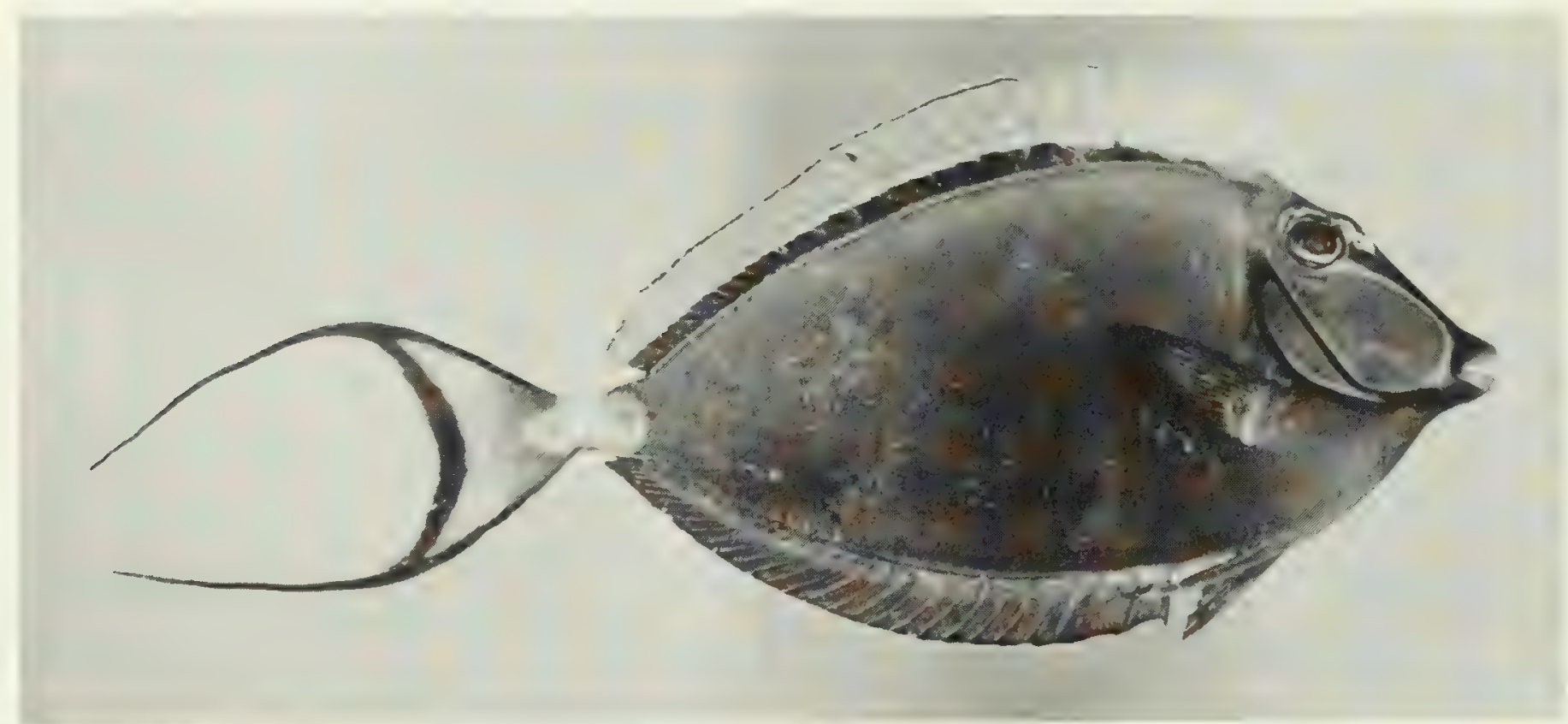

FIG. 415. Naso lituratus, $236 \mathrm{~mm}$ SL, Salomon.

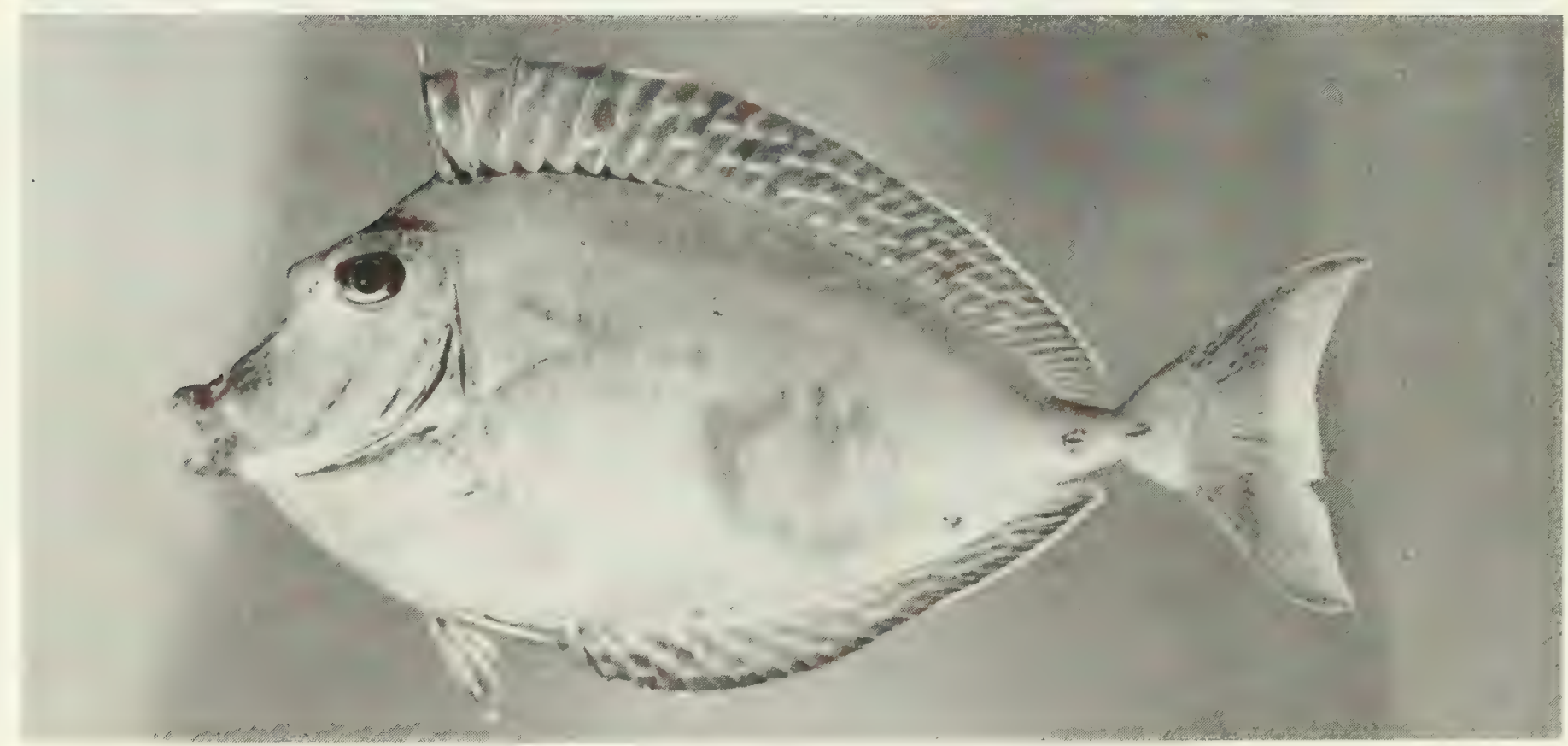

FIG. 416. Naso unicornis, $165 \mathrm{~mm}$ SL, Peros Banhos. 


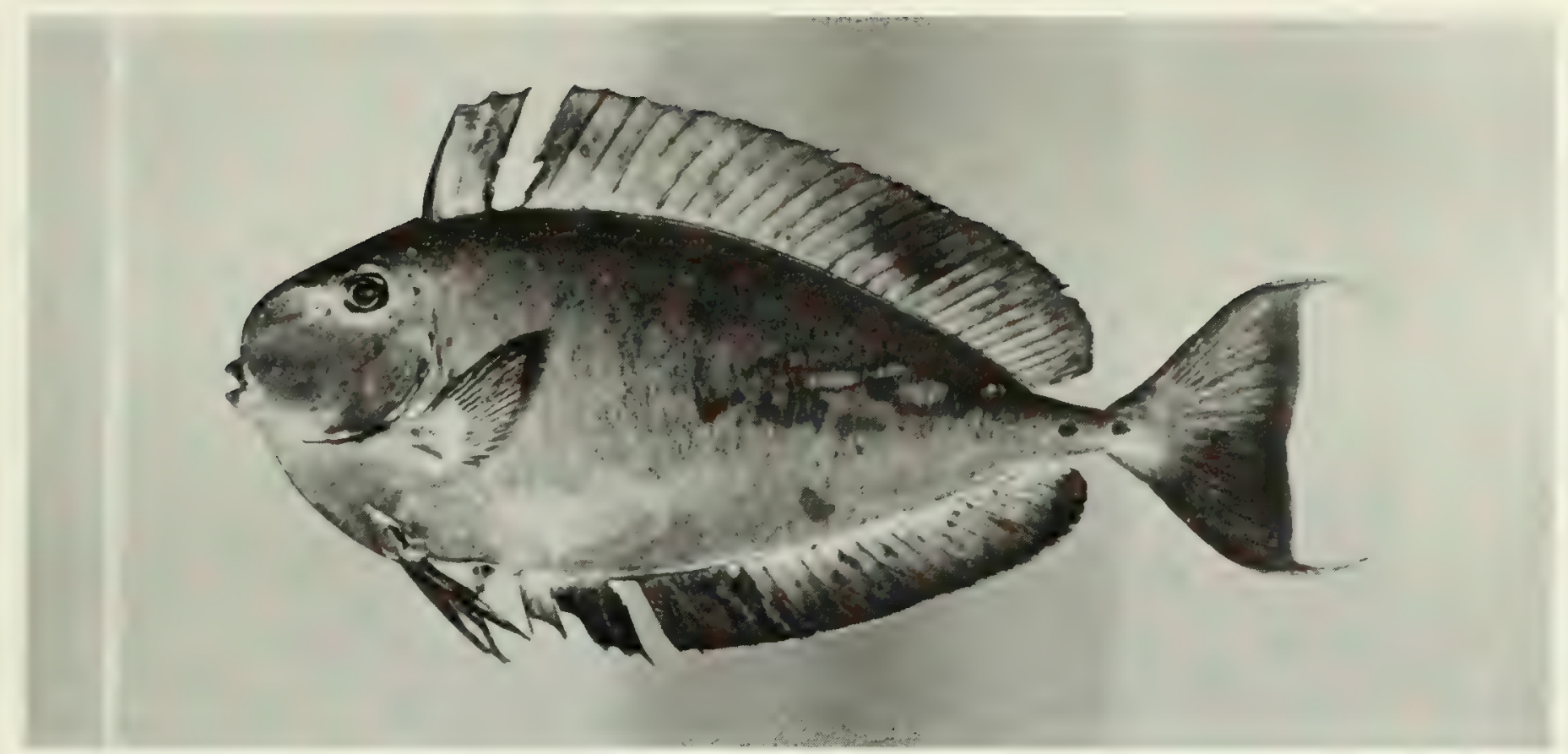

FIG. 417. Naso vlamingi, $255 \mathrm{~mm} \mathrm{SL}$, Salomon.

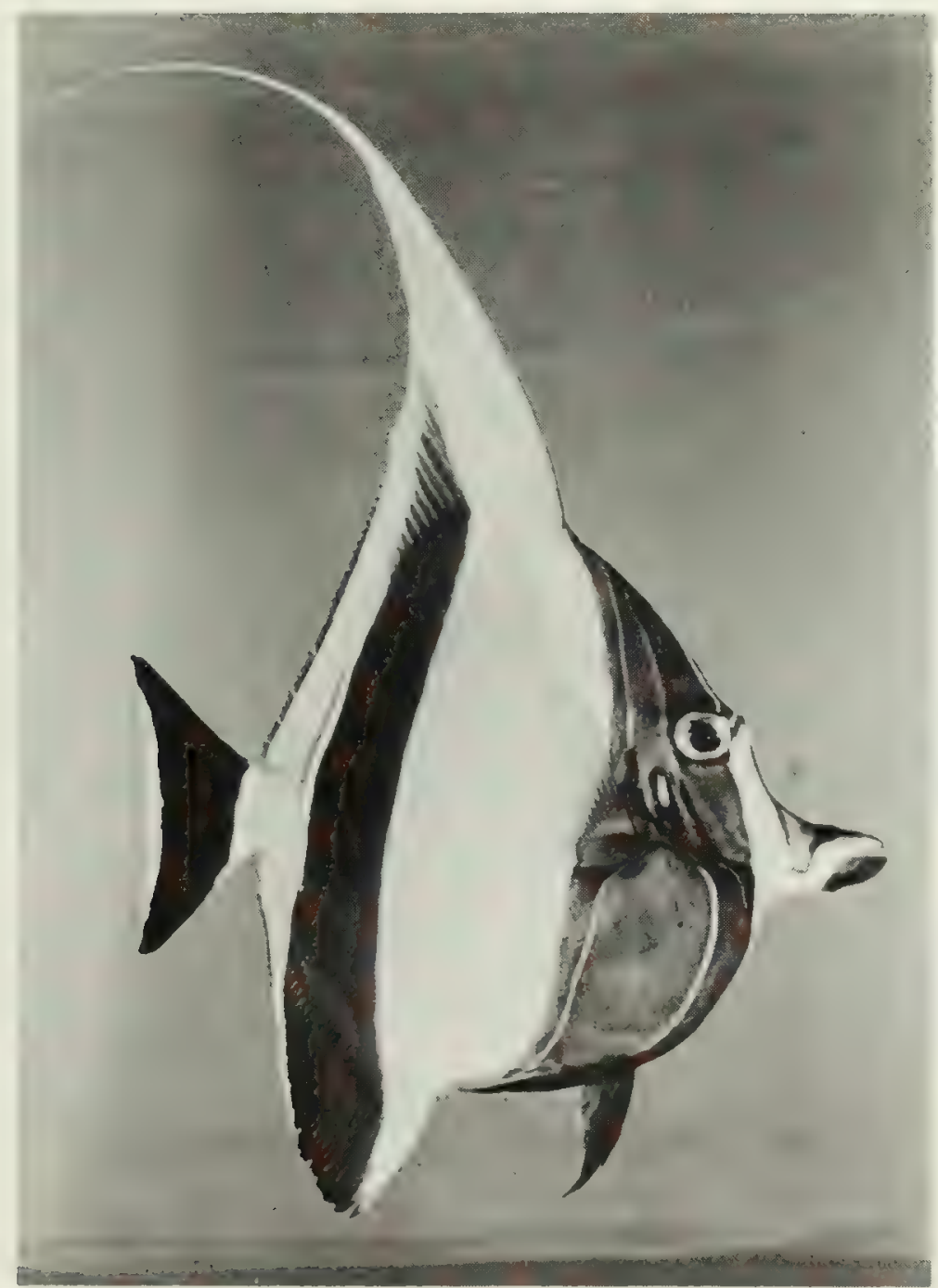

FIG. 418. Zanclus cornutus, $139 \mathrm{~mm}$ SL, Peros Banhos. 


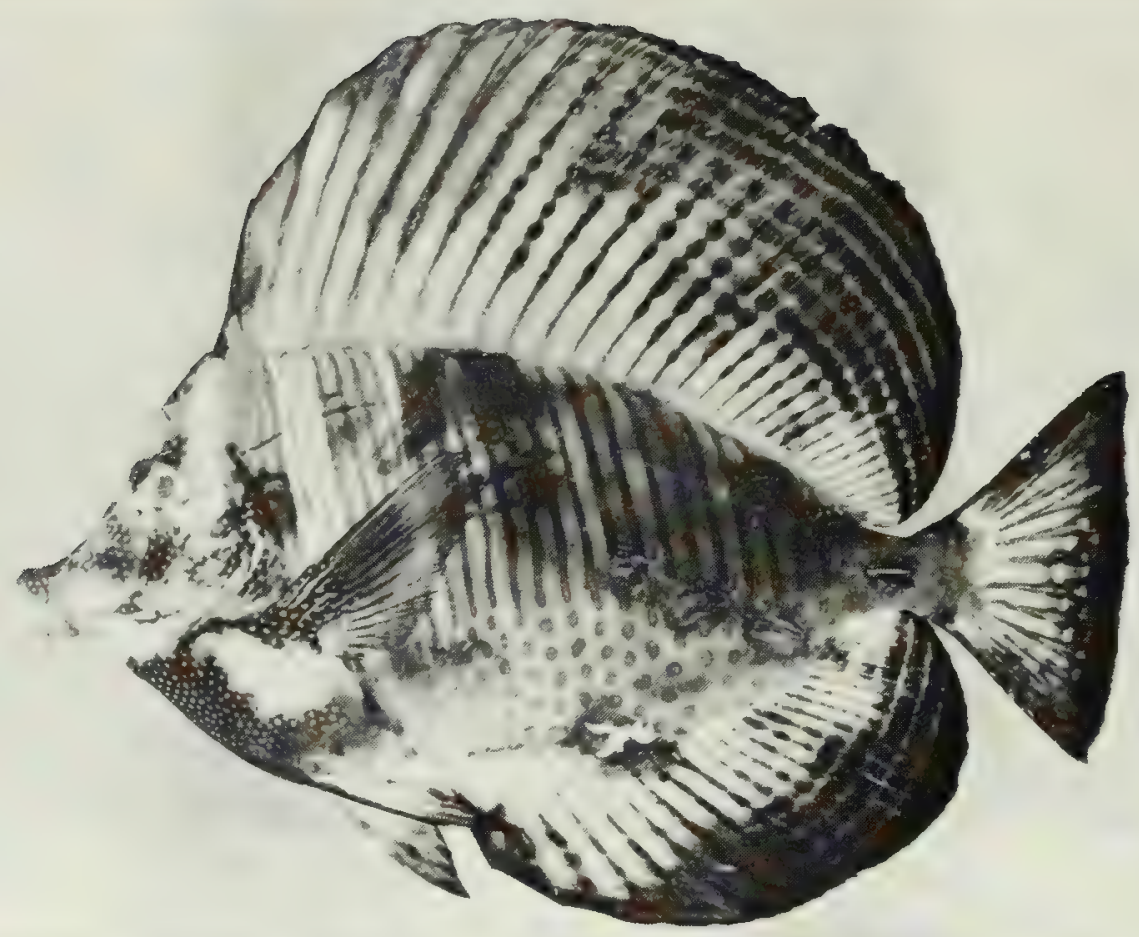

FIG. 419. Zebrasoma veliferum desjardinii, $200 \mathrm{~mm}$ SL, Peros Banhos.

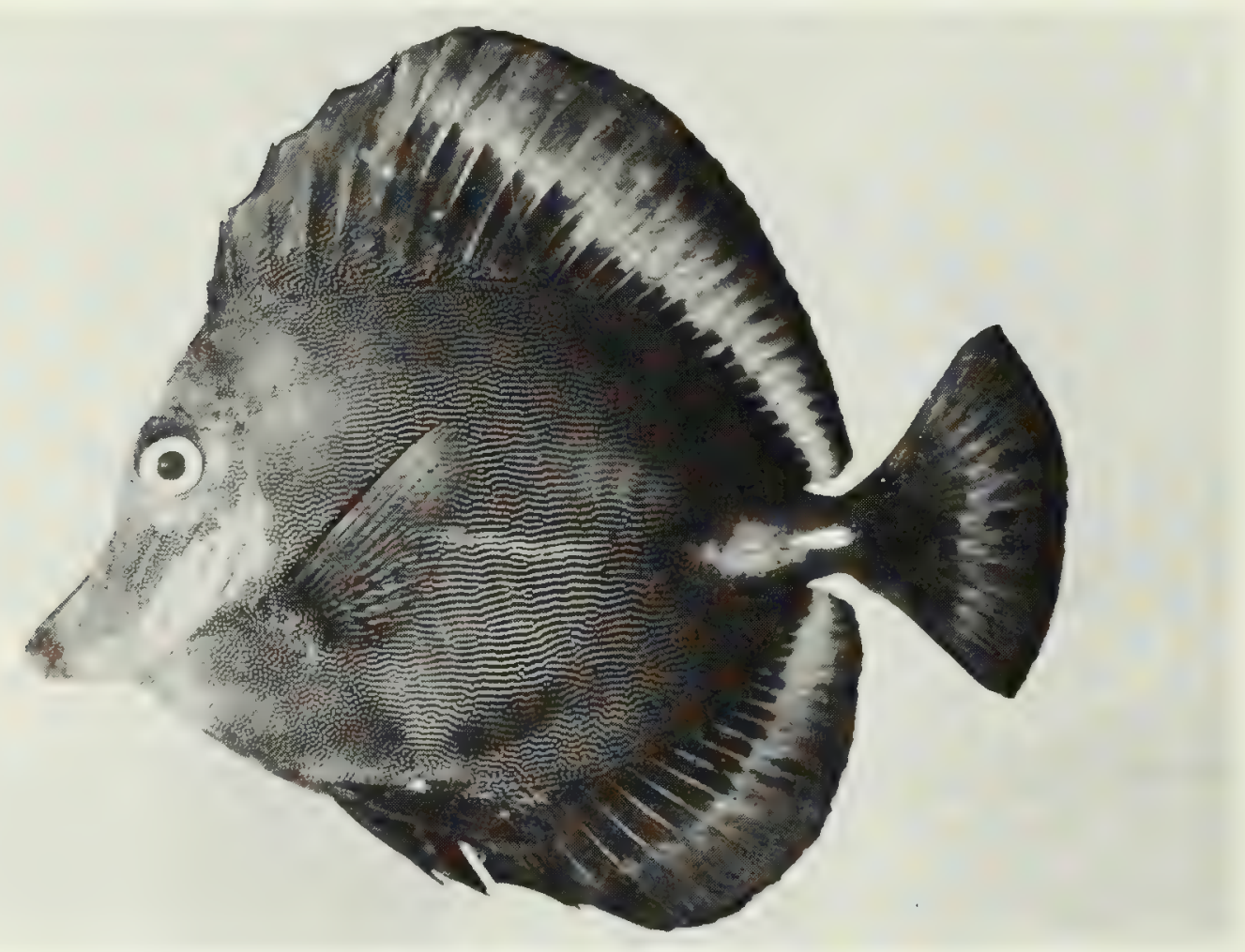

FIG. 420. Zebrasoma scopas, $114 \mathrm{~mm} \mathrm{SL}$, Peros Banhos. 


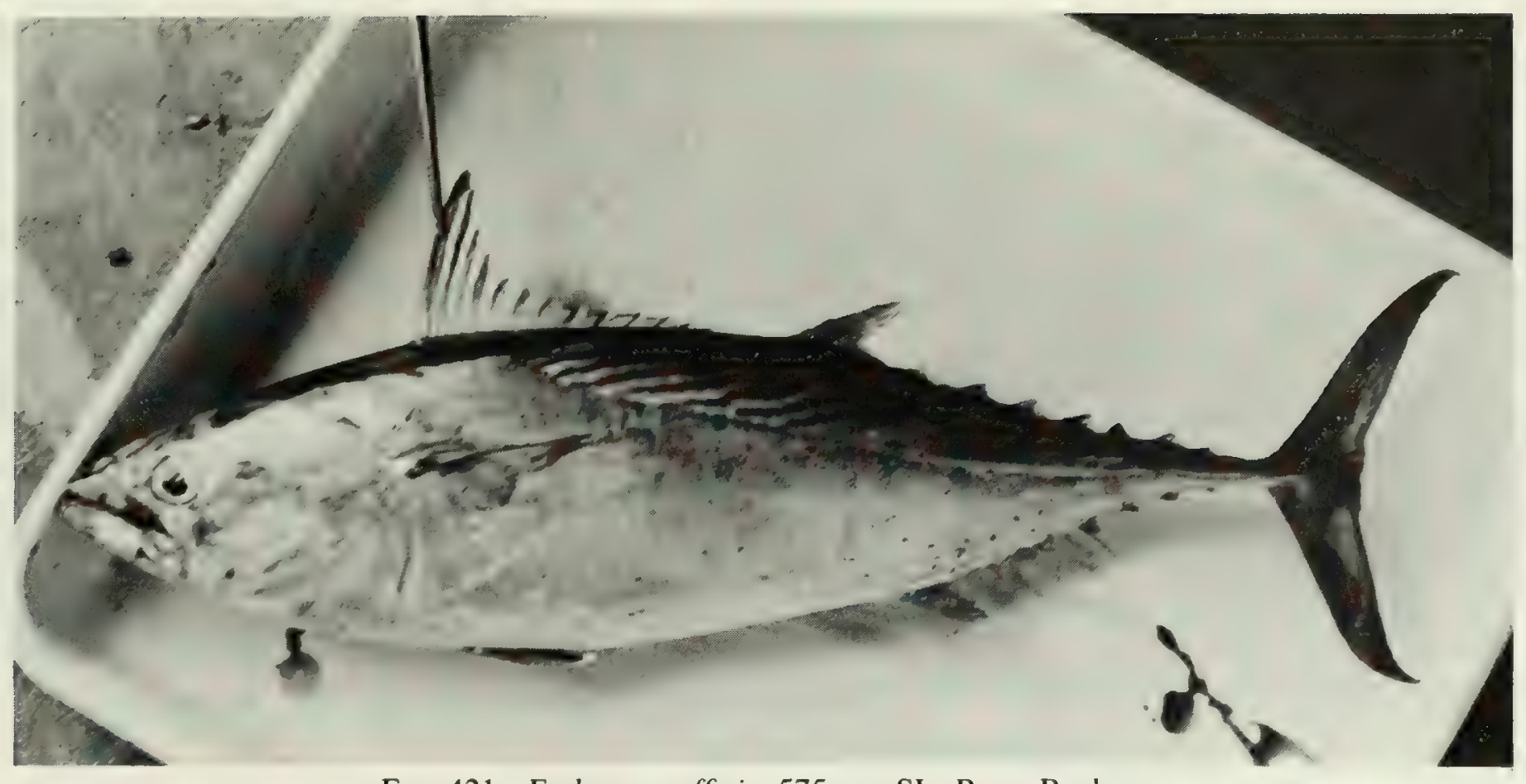

Fig. 421. Euthynnus affinis, $575 \mathrm{~mm} \mathrm{SL}$, Peros Banhos.

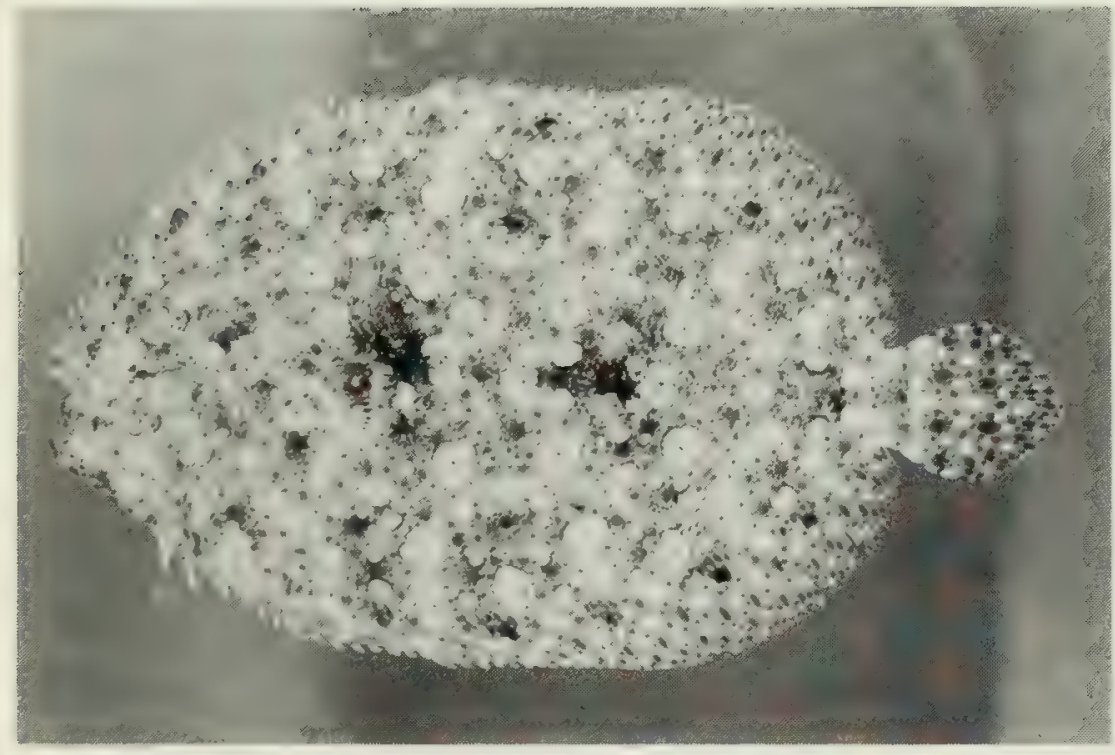

FIG. 422. Bothus mancus, $117 \mathrm{~mm} \mathrm{SL}$, Salomon.

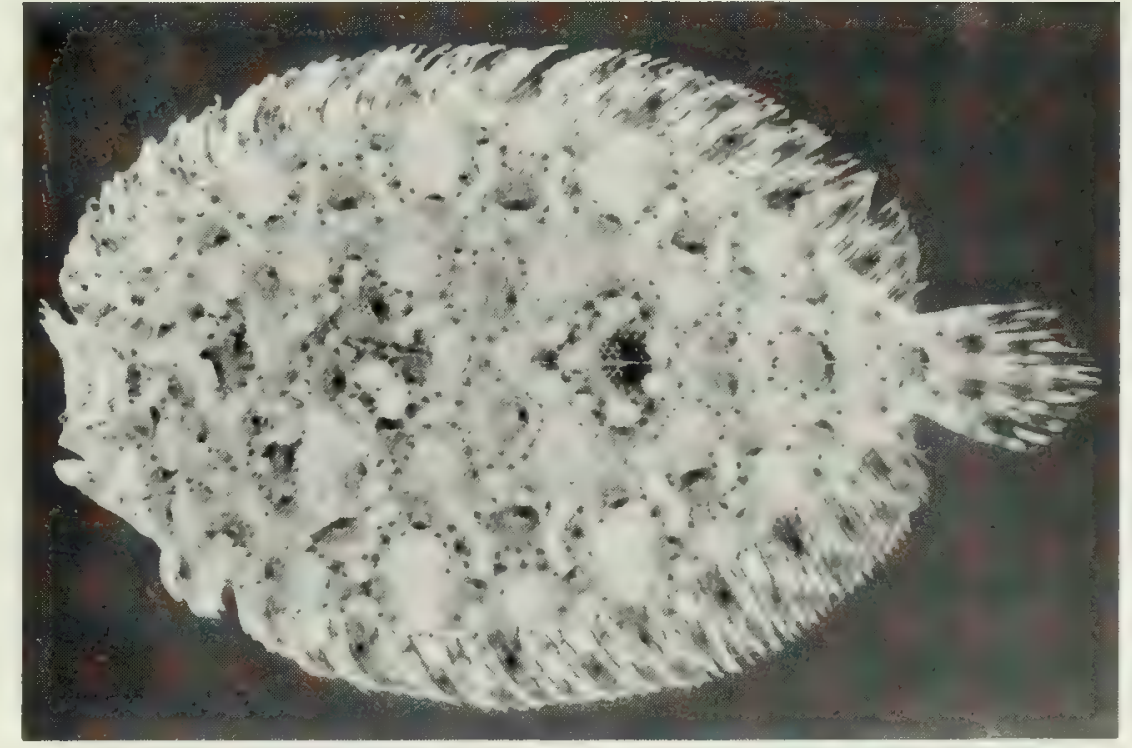

FIG. 423. Bothus pantherinus, $35 \mathrm{~mm} \mathrm{SL}$, Peros Banhos.

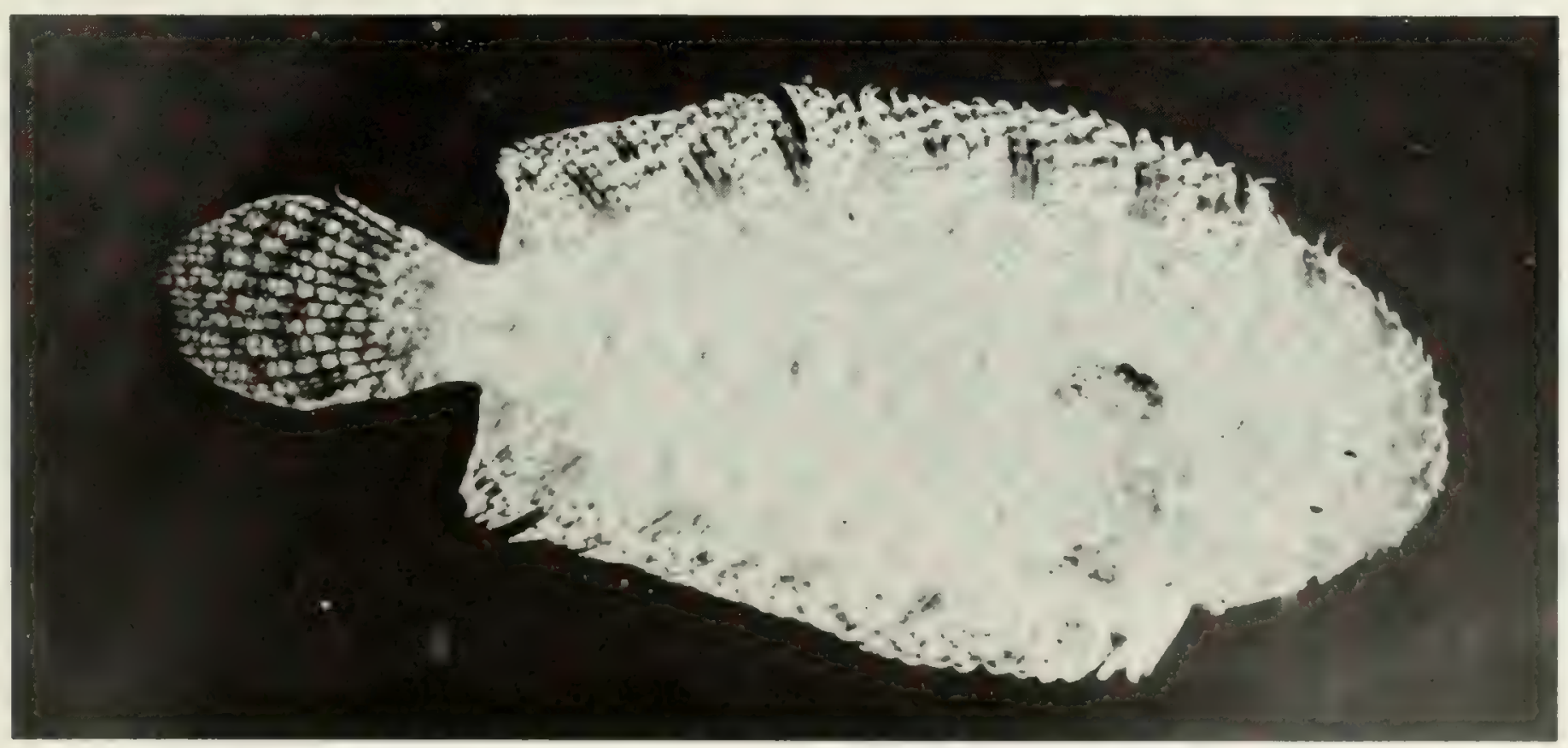

FiG. 424. Aseraggodes cyaneus, $34 \mathrm{~mm} \mathrm{SL}$, Peros Banhos. 


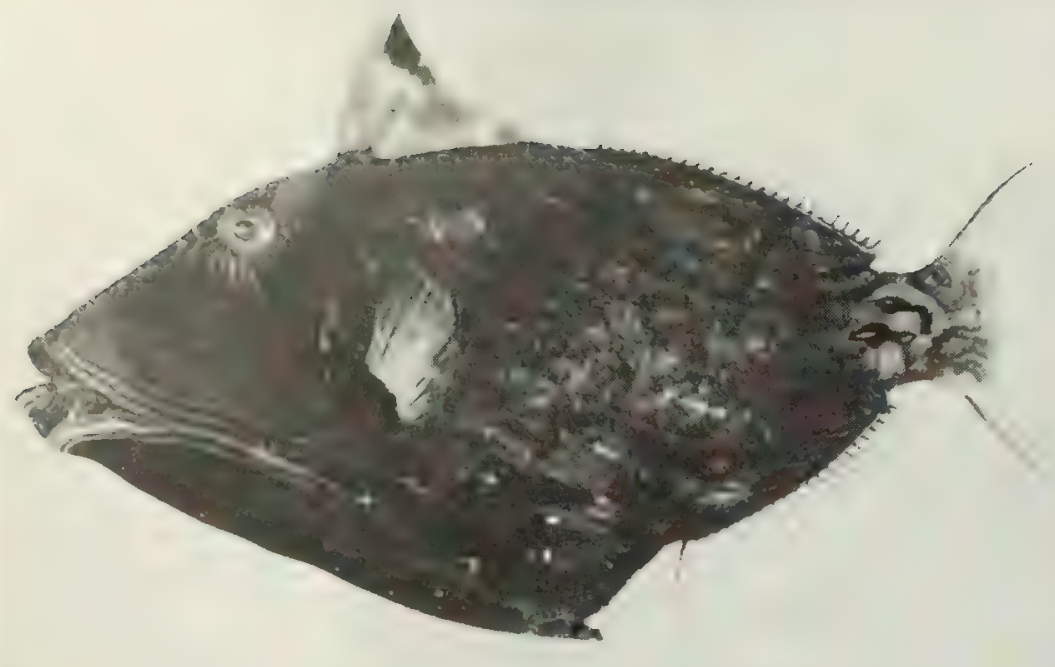

FIG. 425. Balistapus undulatus, $146 \mathrm{~mm}$ SL, Peros Banhos.

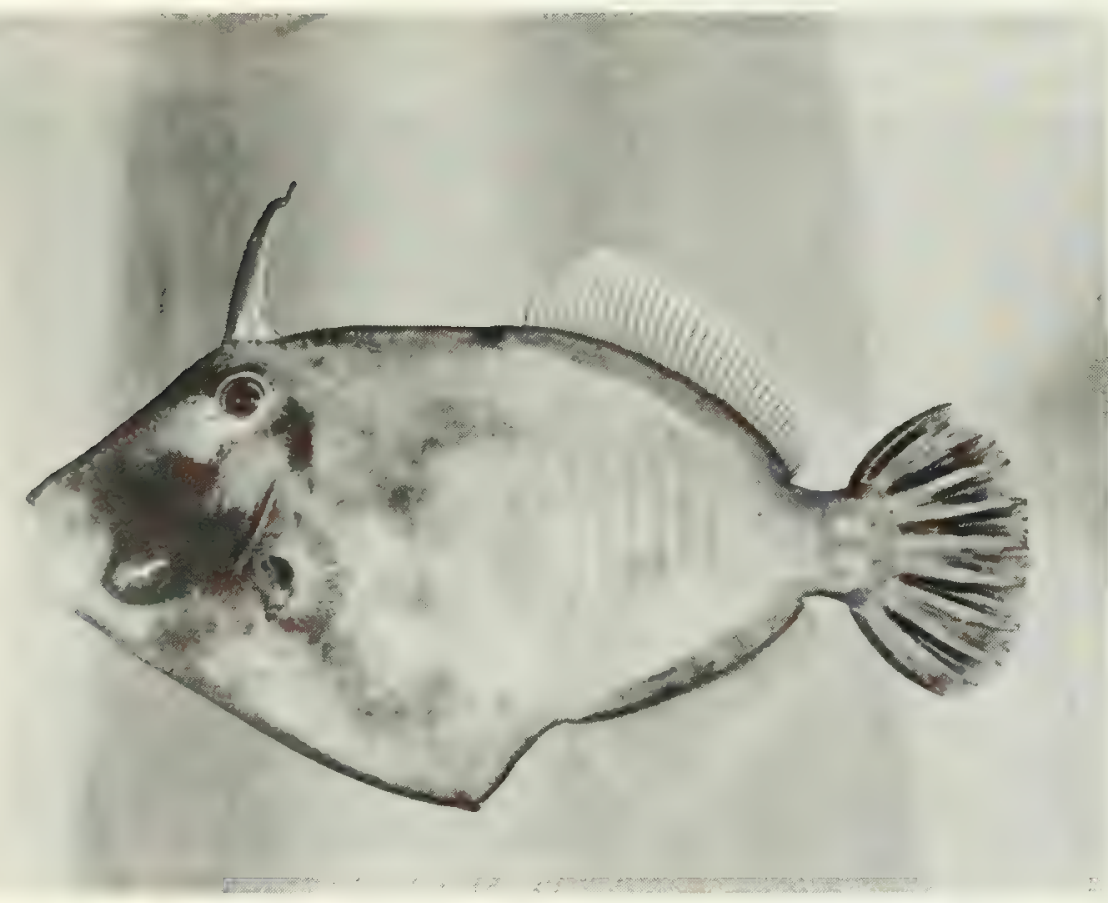

FIG. 427. Cantherhines dumerili, $219 \mathrm{~mm}$ SL, Peros Banhos.

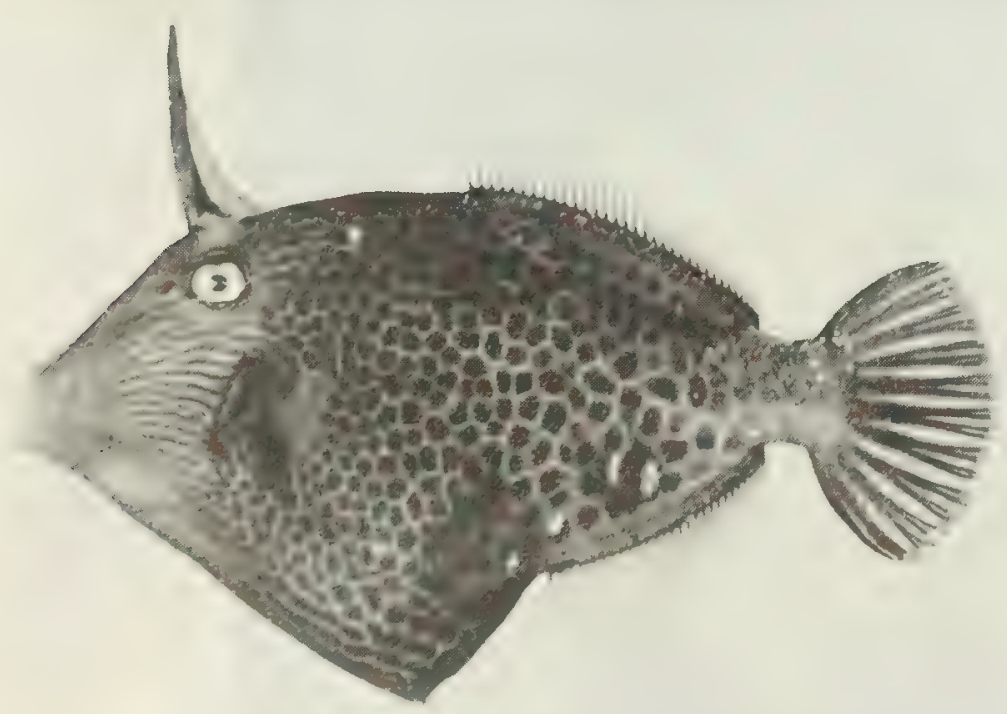

FIG. 429. Cantherhines pardalis, $133 \mathrm{~mm} \mathrm{SL}$, Peros Banhos.

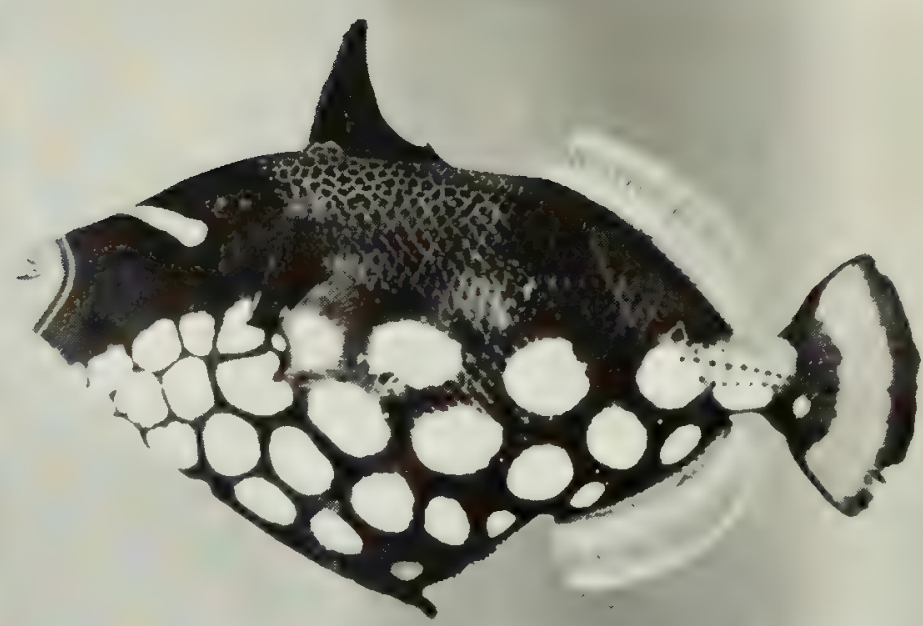

FIG. 426. Balistoides conspicillum, $183 \mathrm{~mm} \mathrm{SL}$, Salomon

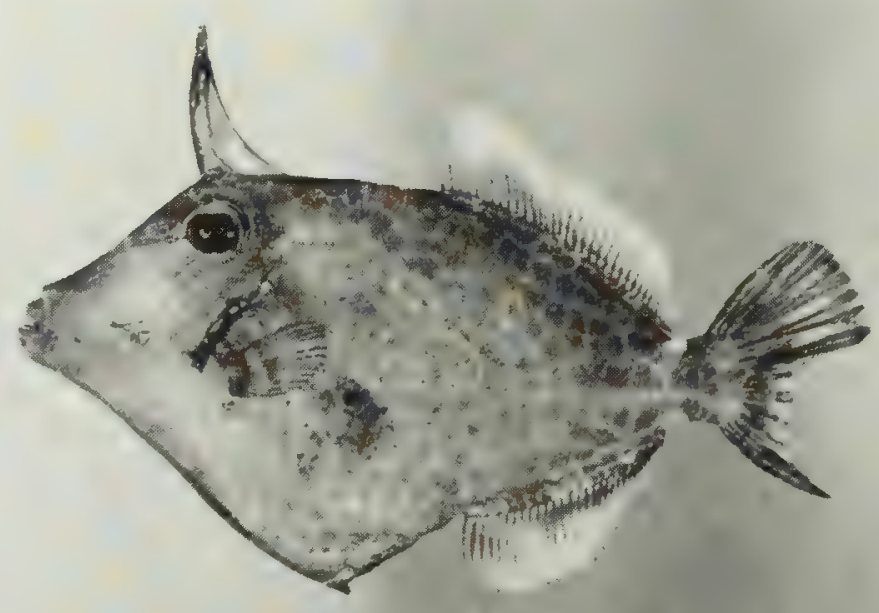

FIG. 428. Cantherhines fronticinctus, $98 \mathrm{~mm} \mathrm{SL}$, Peros Banhos.

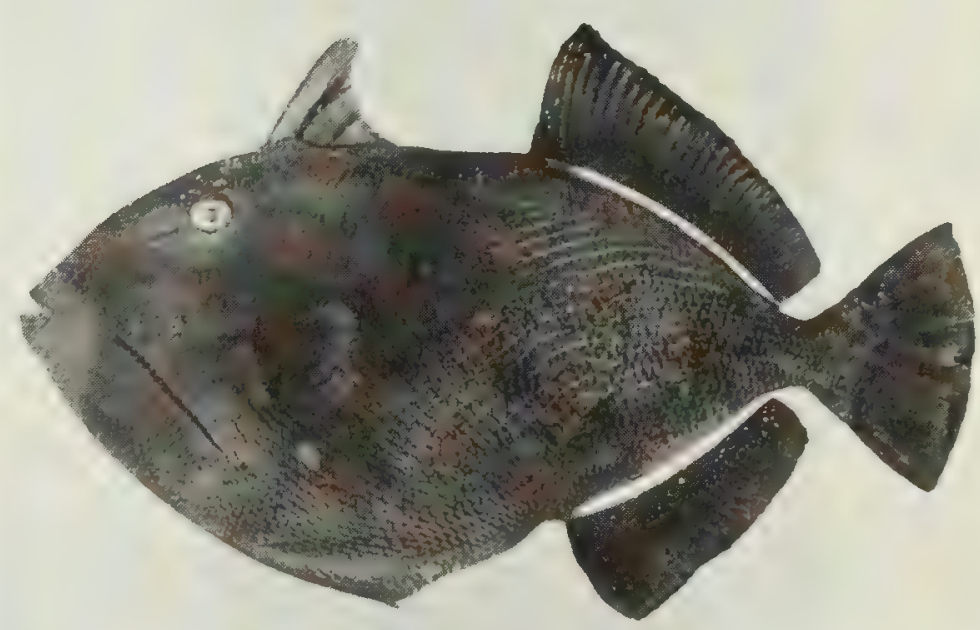

FIG. 430. Melichthys indicus, $190 \mathrm{~mm} \mathrm{SL}$, Salomon. 


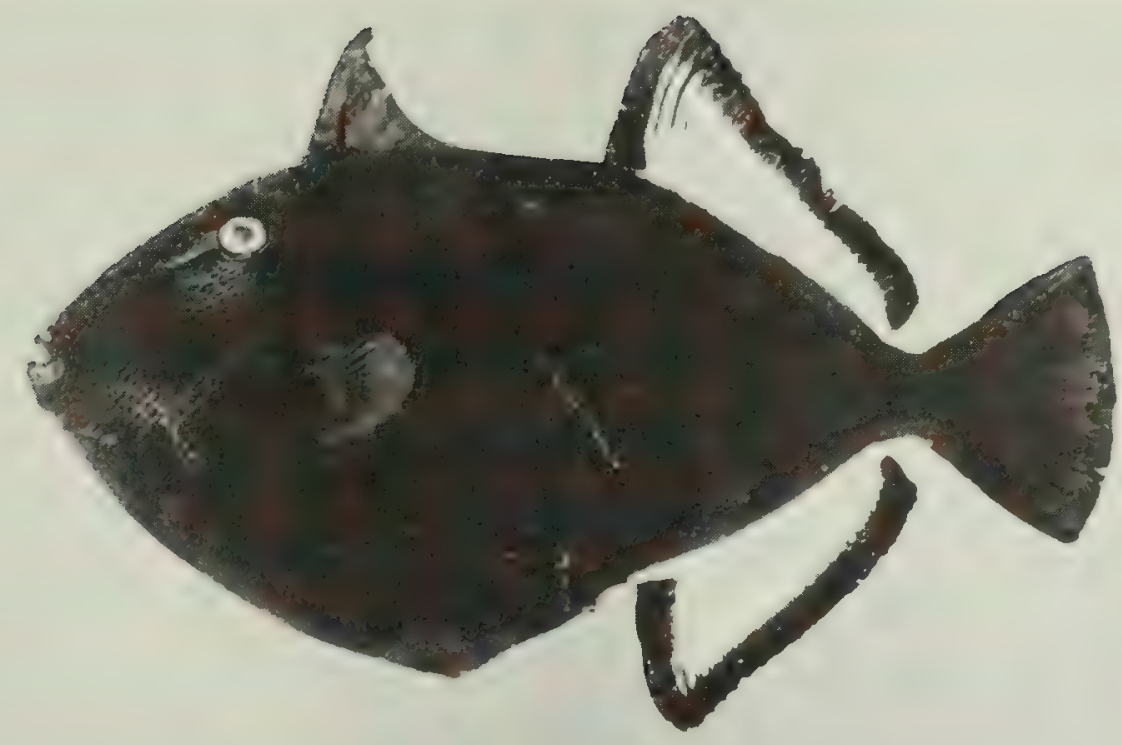

FIG. 431. Melichthys indicus, $170 \mathrm{~mm} \mathrm{SL}$, Salomon.

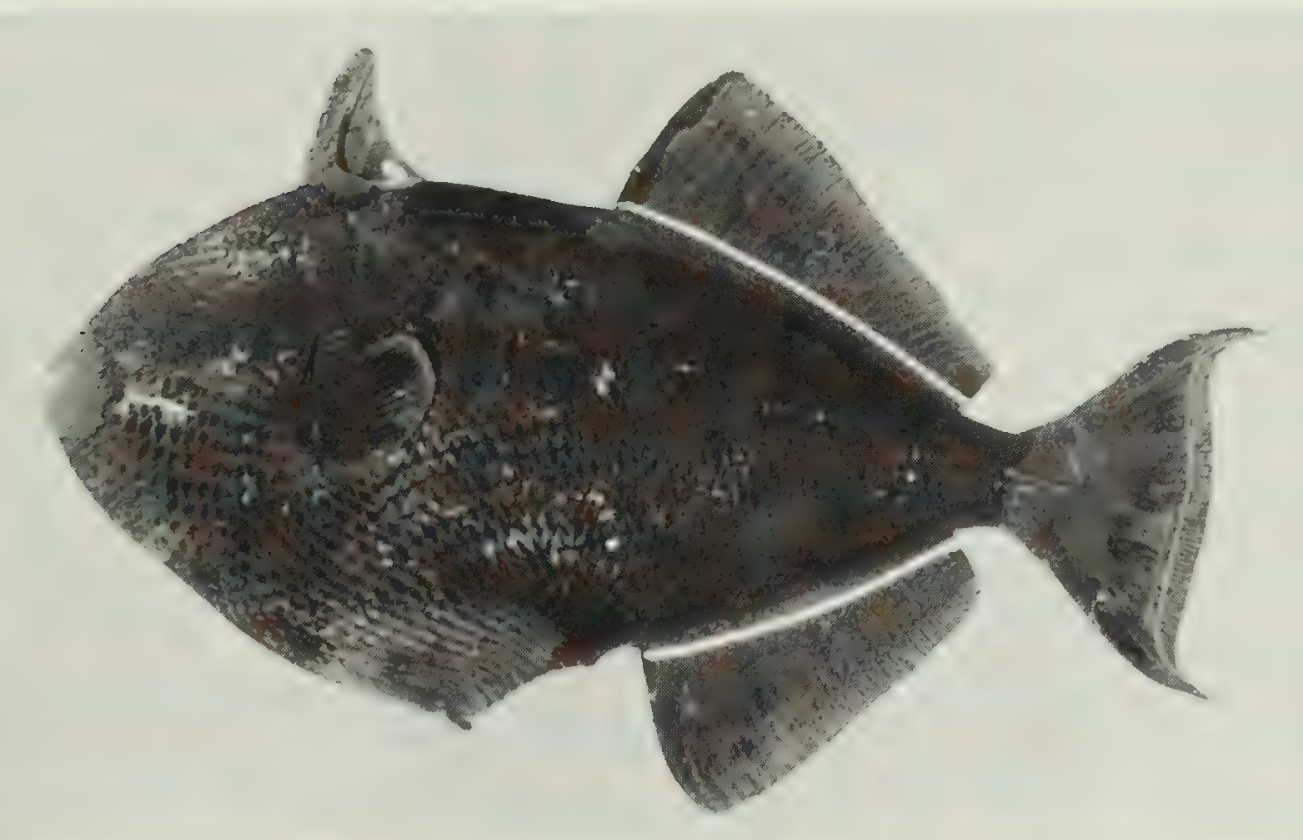

FIG. 432. Melichthys niger, $217 \mathrm{~mm} \mathrm{SL}$, Salomon.

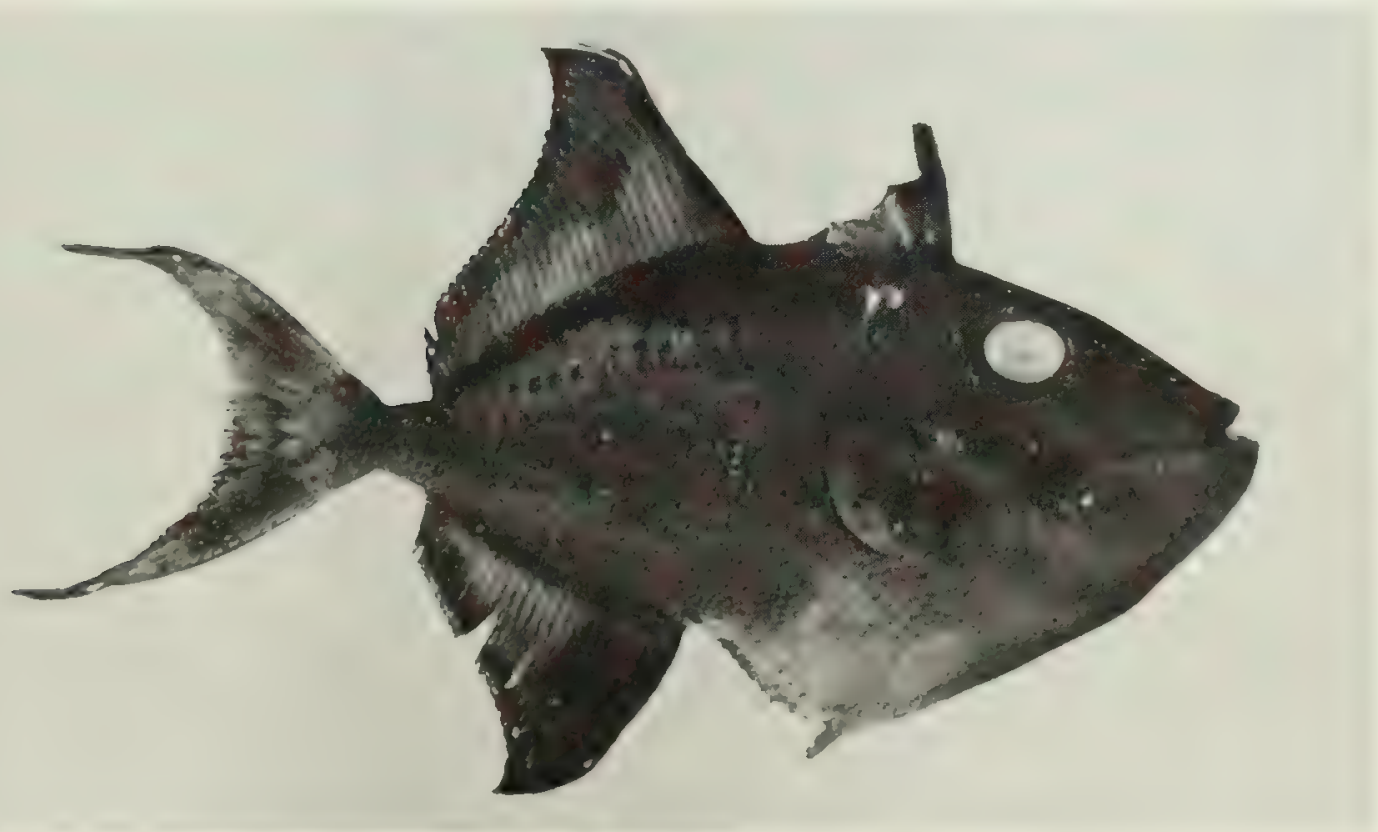

FIG. 433. Odonus niger, $71 \mathrm{~mm}$ SL, Peros Banhos. 


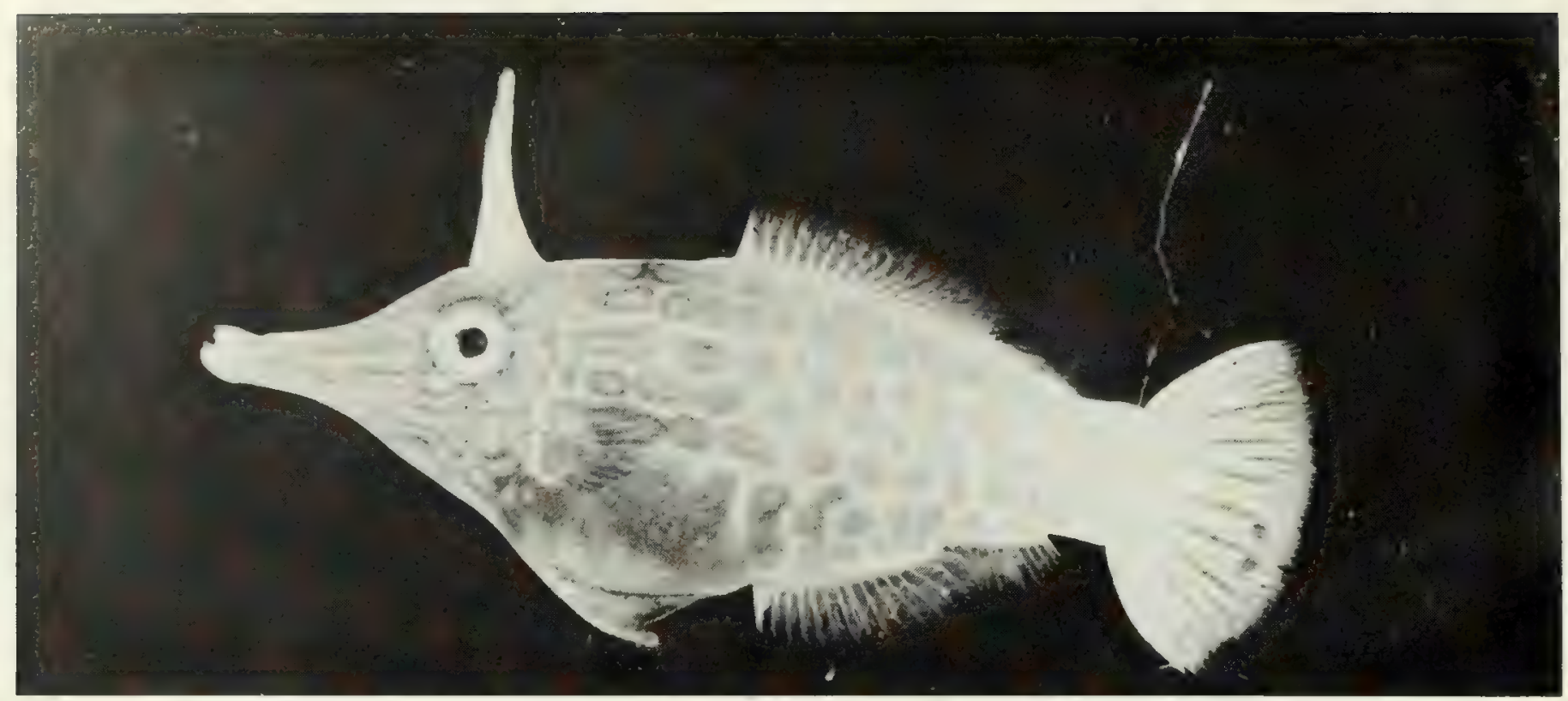

FIG. 434. Oxymonacanthus longirostris, $57 \mathrm{~mm} \mathrm{SL}$, Eagle Island.

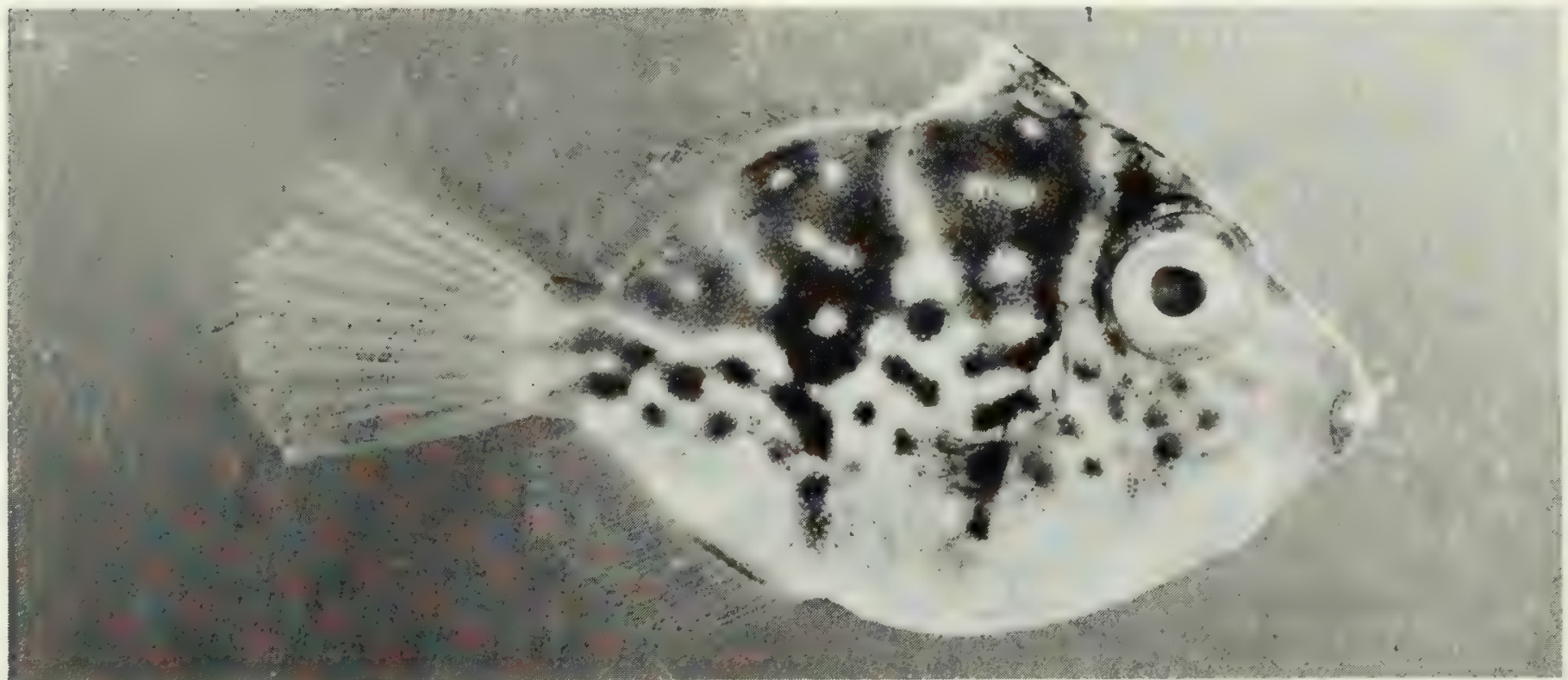

FIG. 435. Paraluteres prionurus, $16 \mathrm{~mm}$ SL, Peros Banhos.

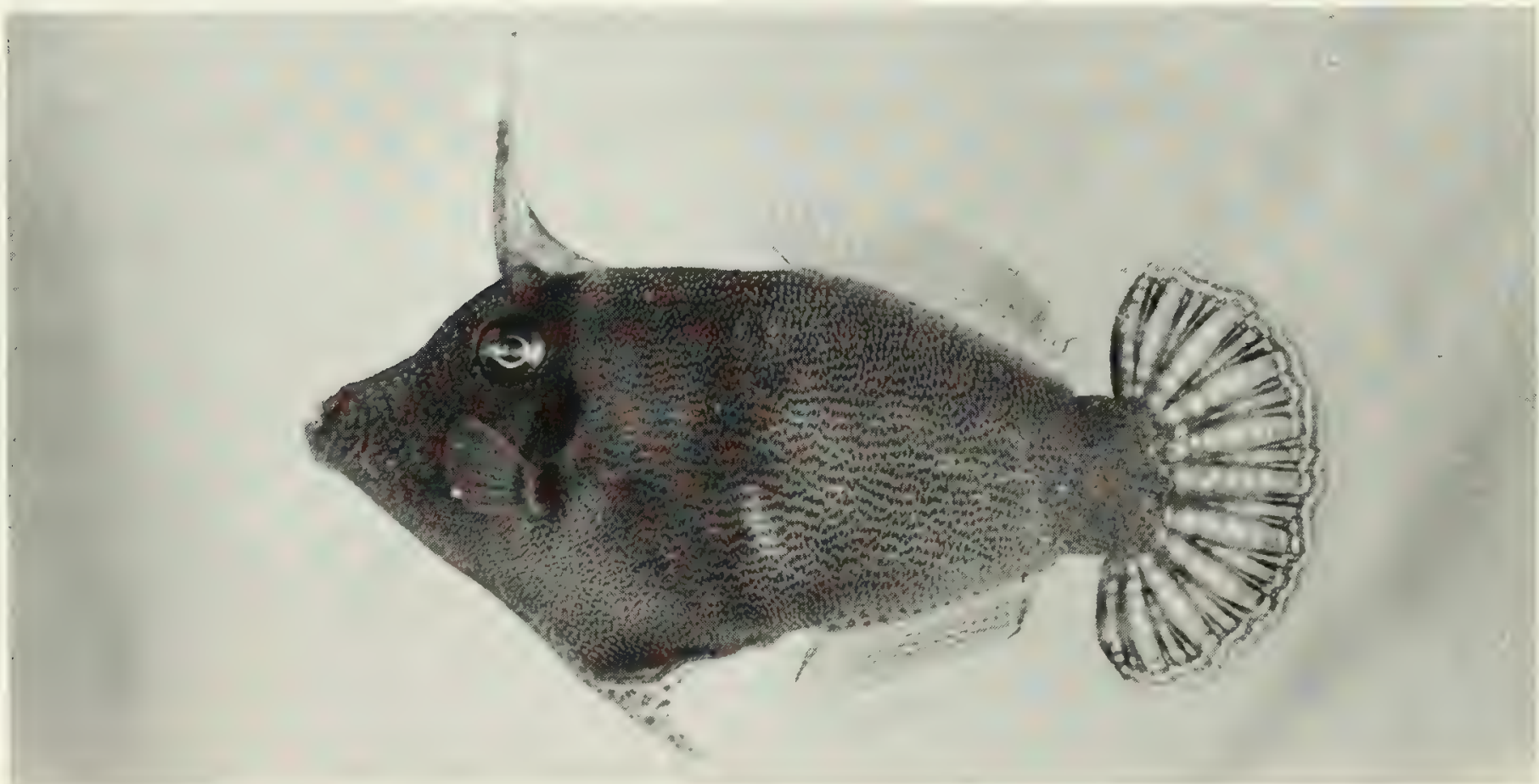

FIG. 436. Pervagor melanocephalus, $77 \mathrm{~mm}$ SL, Peros Banhos. 


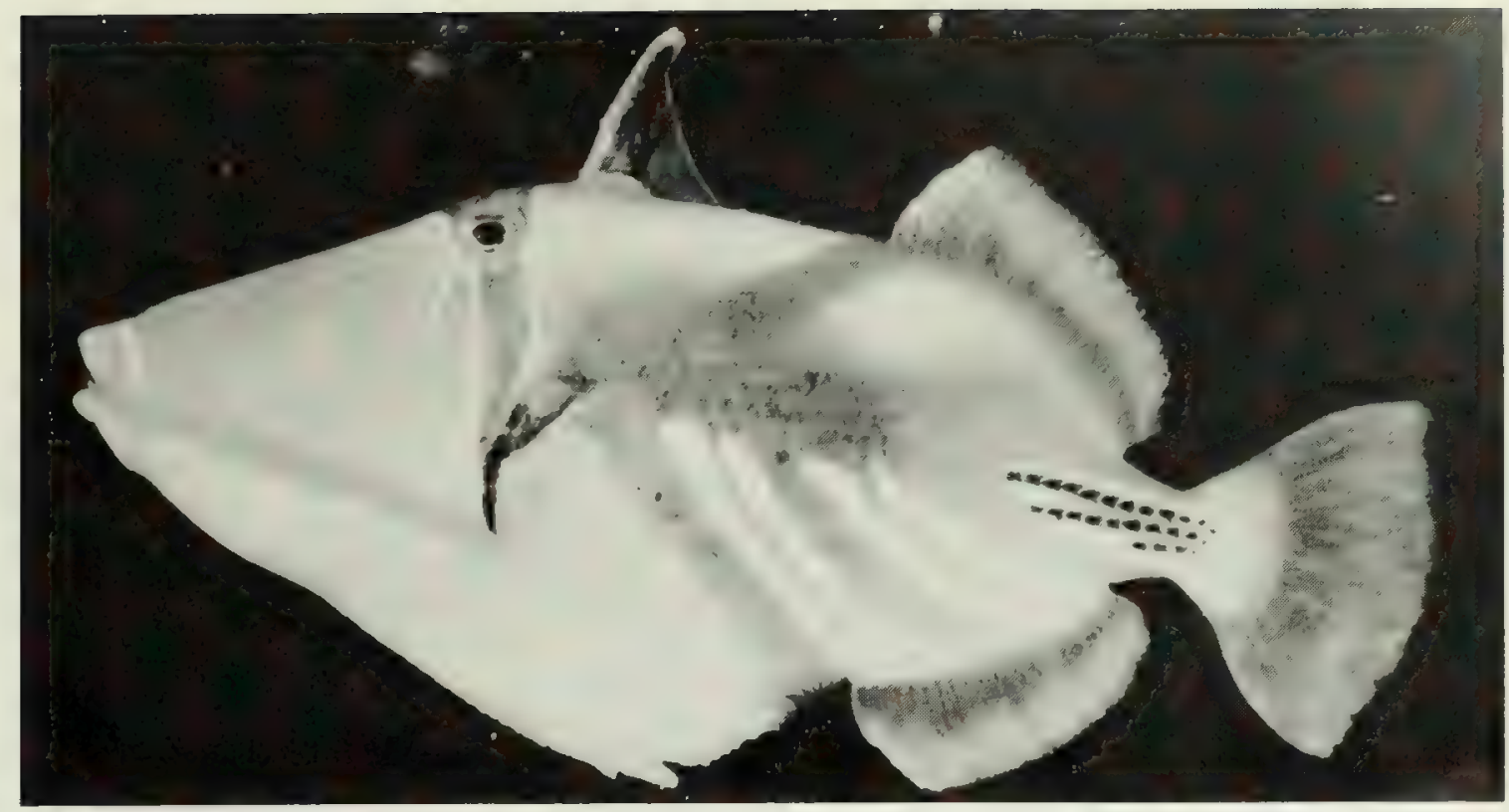

FIG. 437. Rhinecanthus aculeatus, $151 \mathrm{~mm} \mathrm{SL}$, Eagle Island.

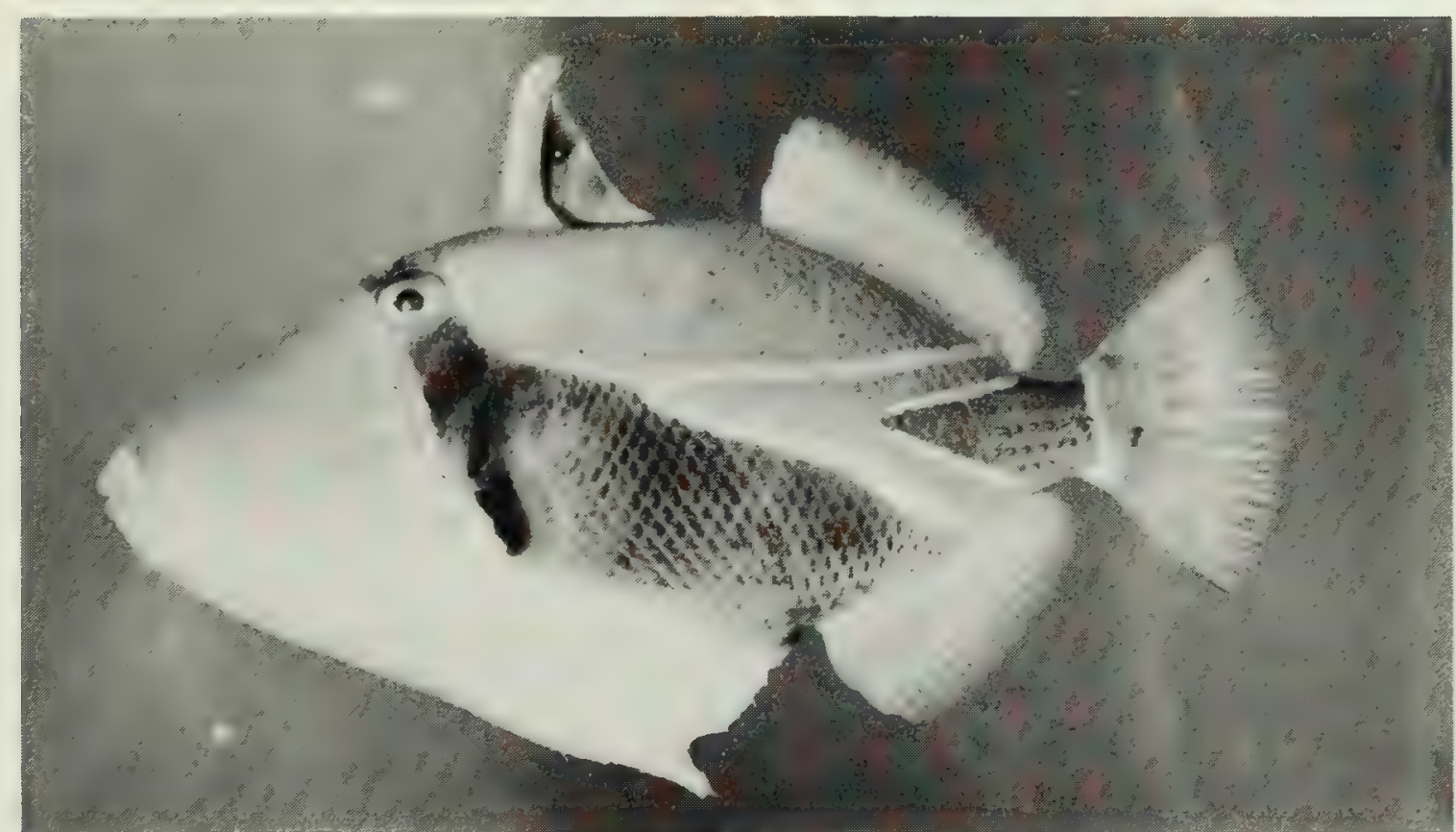

FIG. 438. Rhinecanthus rectangulus, $104 \mathrm{~mm} \mathrm{SL}$, Salomon.

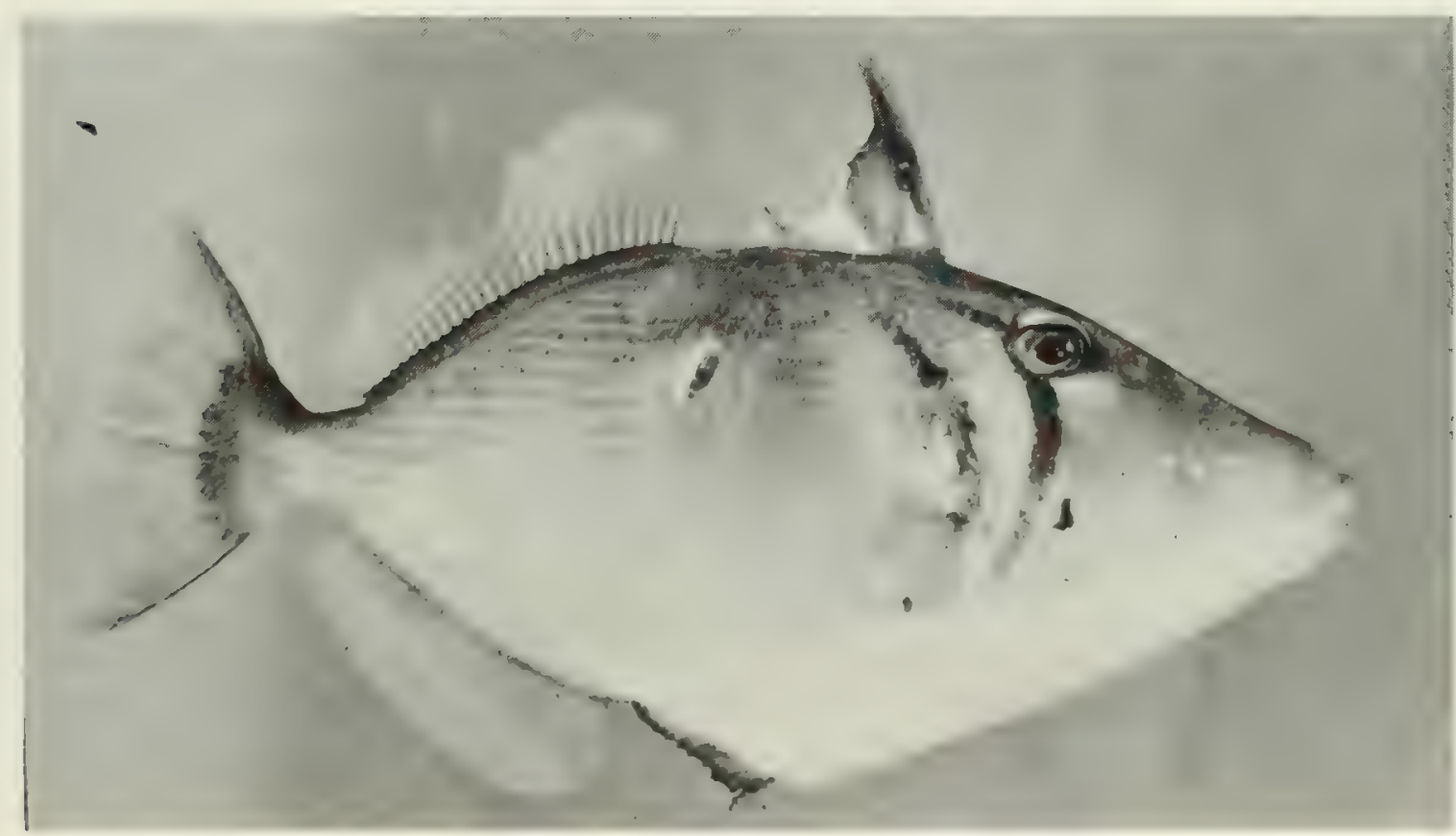

FIG. 439. Sufflamen bursa, $129 \mathrm{~mm} \mathrm{SL}$, Peros Banhos. 


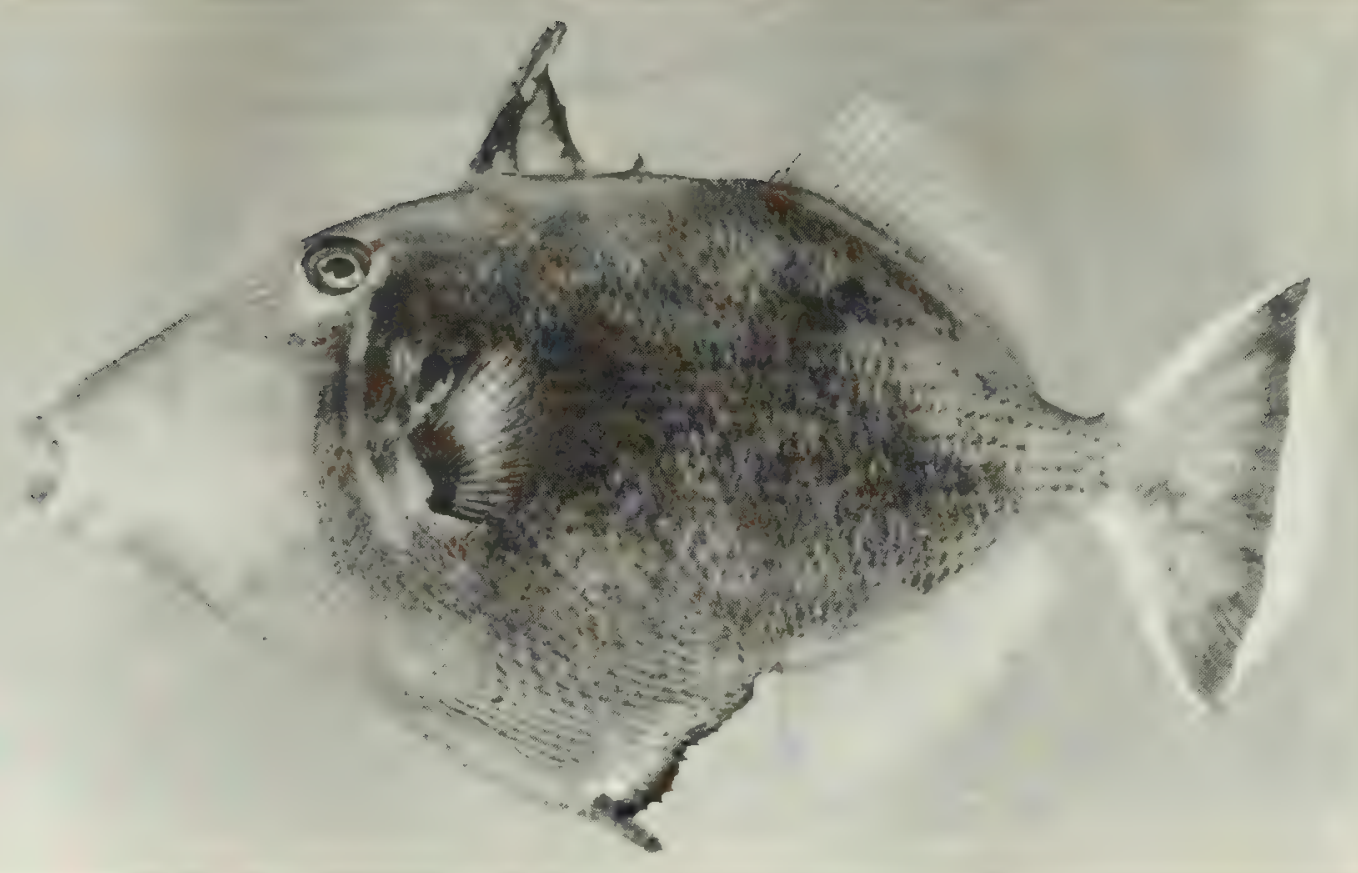

FIG. 440. Sufflamen chrysopterum, $134 \mathrm{~mm}$ SL, Peros Banhos.

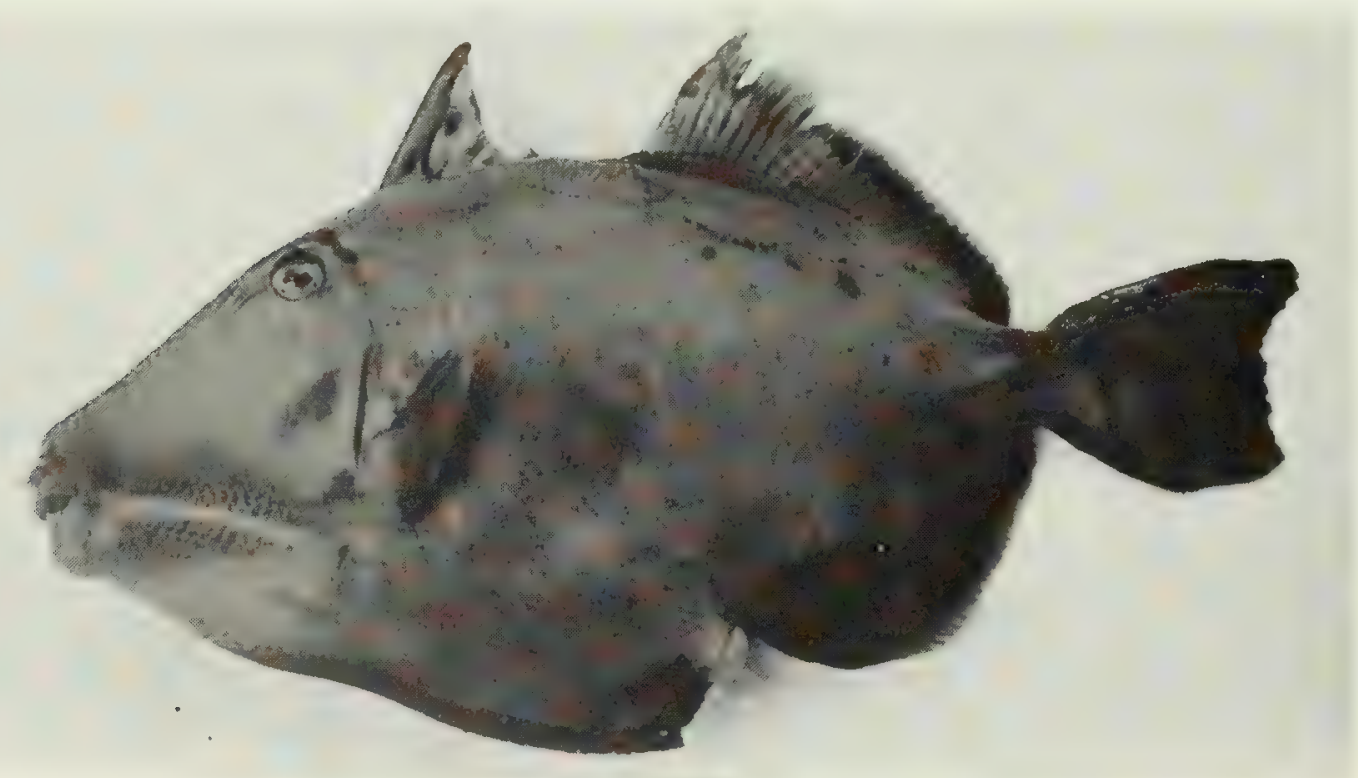

FIG. 441. Sufflamen fraenatum, $274 \mathrm{~mm} \mathrm{SL}$, Peros Banhos.

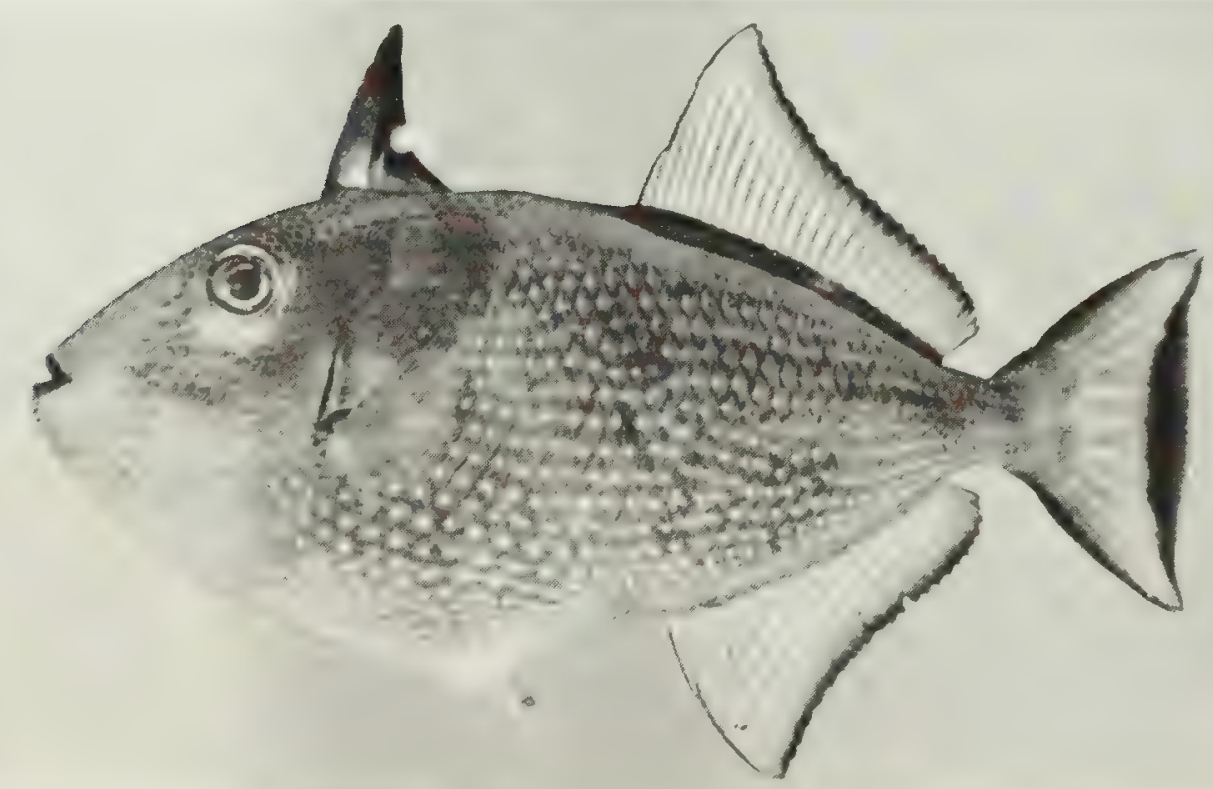

FIG. 442. Xanthichthys auromarginatus, $102 \mathrm{~mm}$ SL, Peros Banhos. 


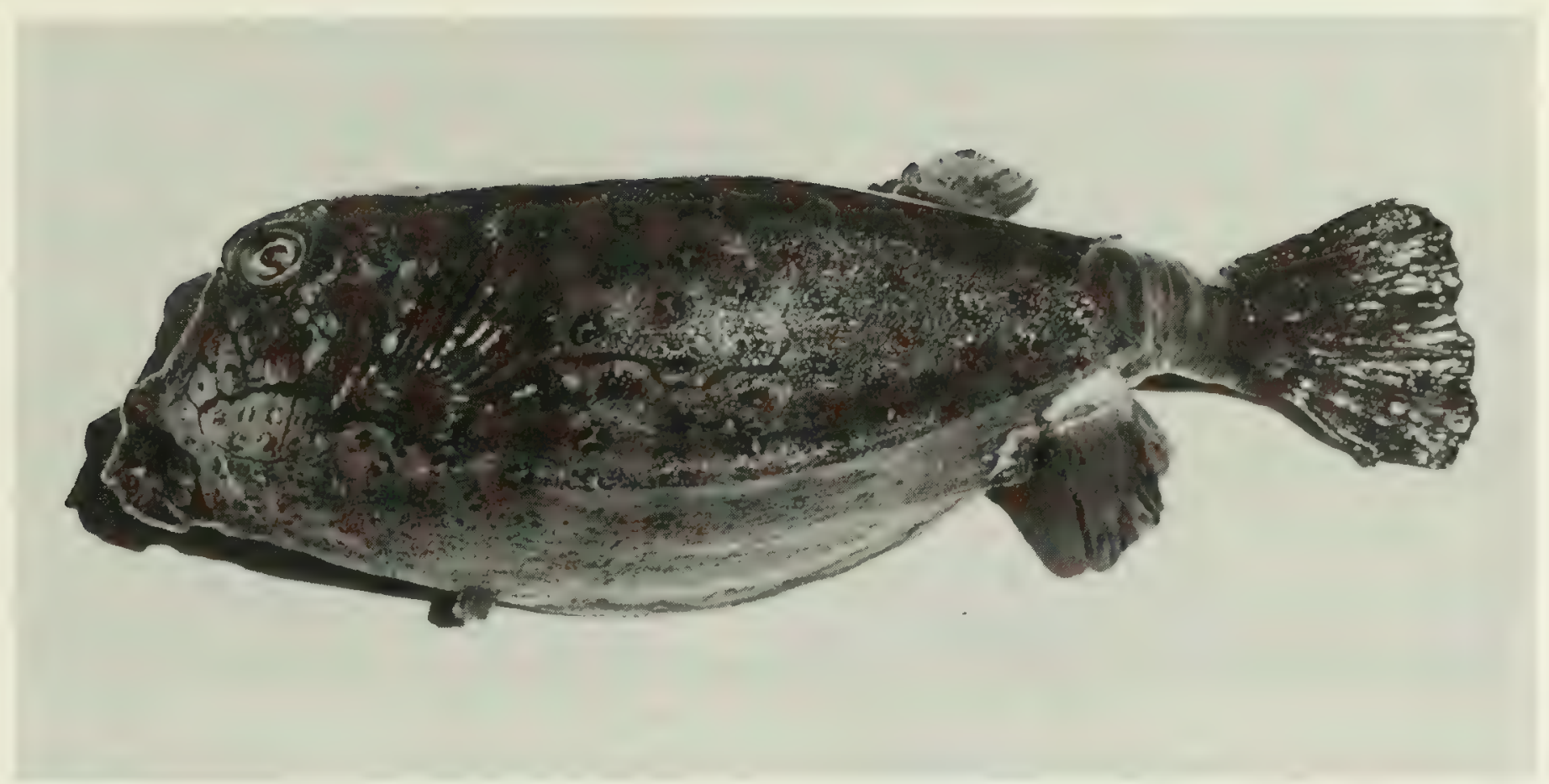

FIG. 443. Ostracion cubicus, $295 \mathrm{~mm}$ SL, Eagle Island.

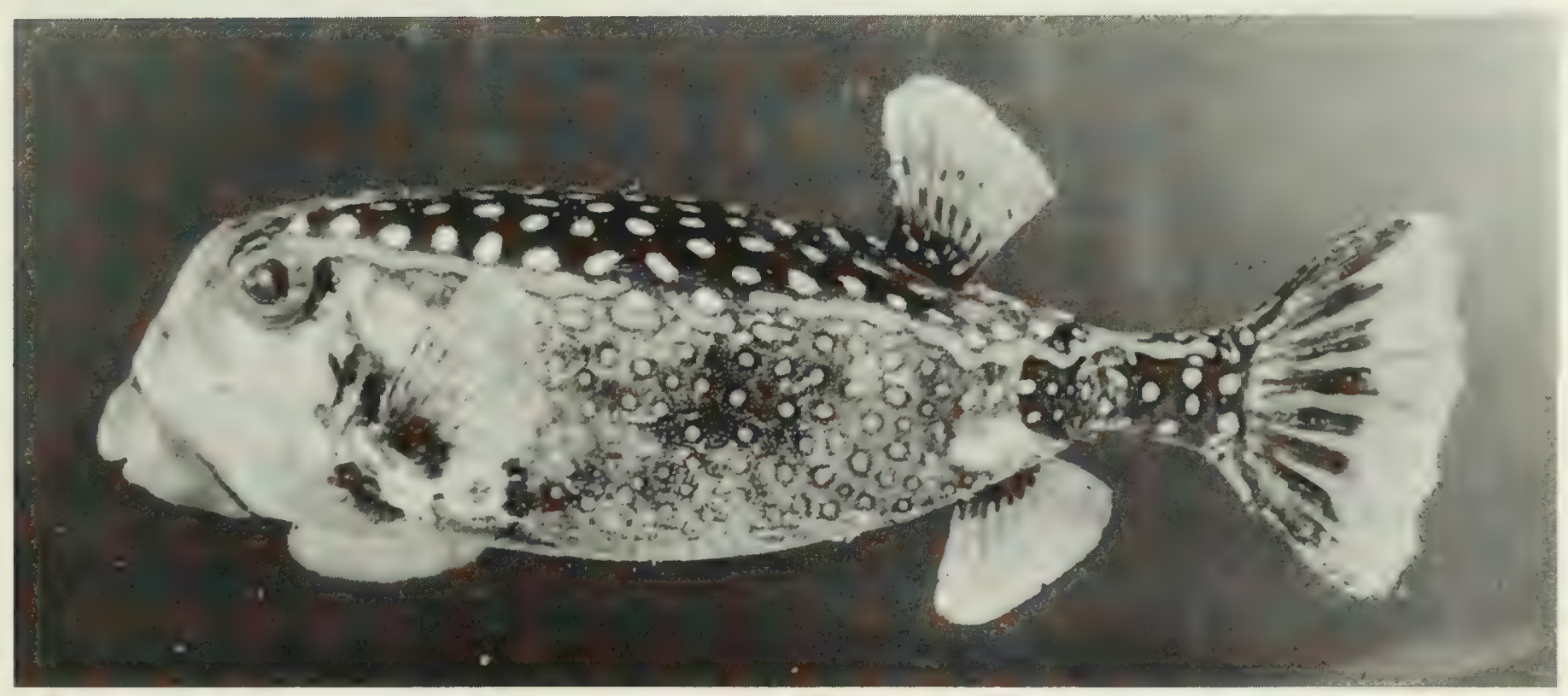

FIG. 444. Ostracion meleagris, $132 \mathrm{~mm} \mathrm{SL}$, Eagle Island.

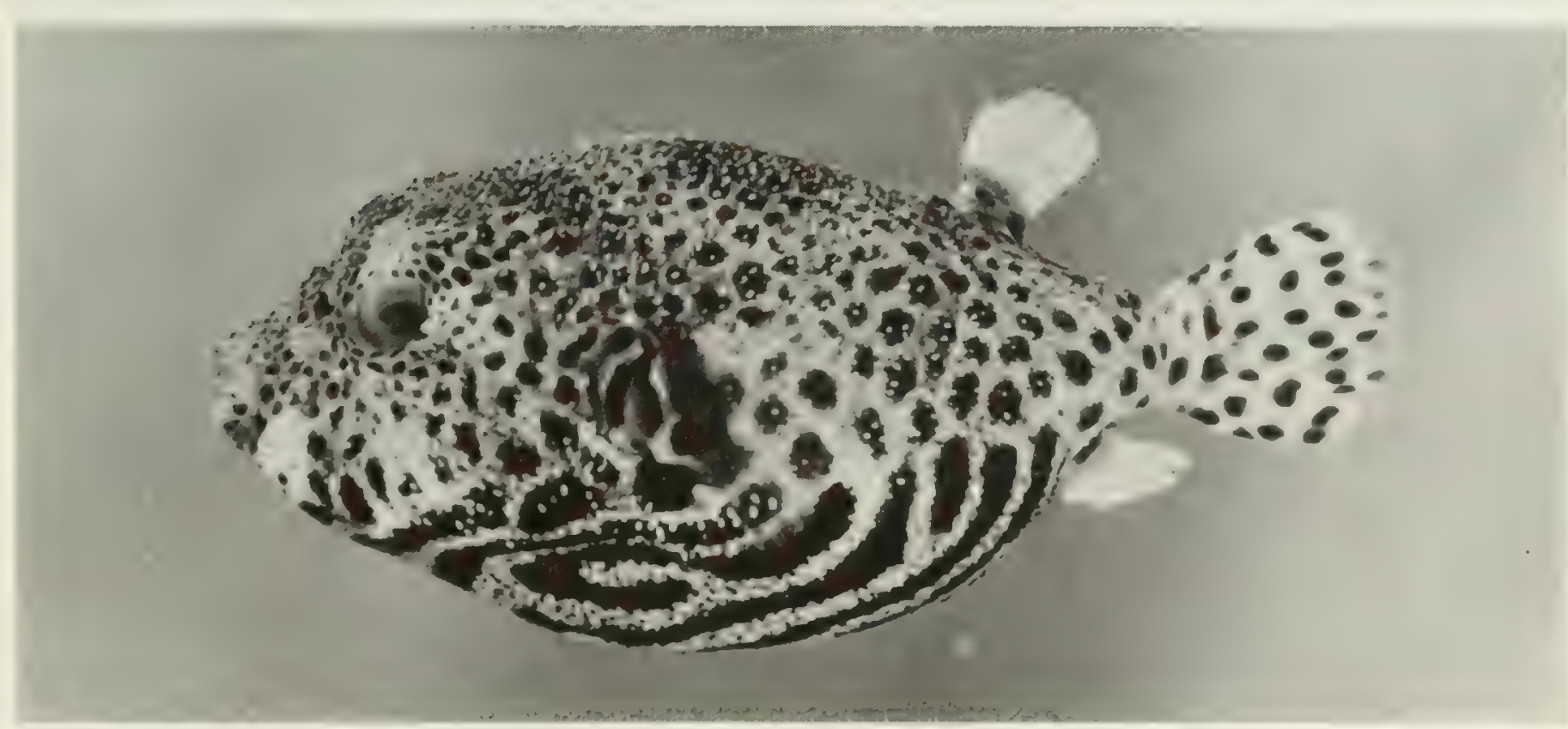

FIG. 445. Arothron aerostaticus, $46 \mathrm{~mm}$ SL, Salomon. 


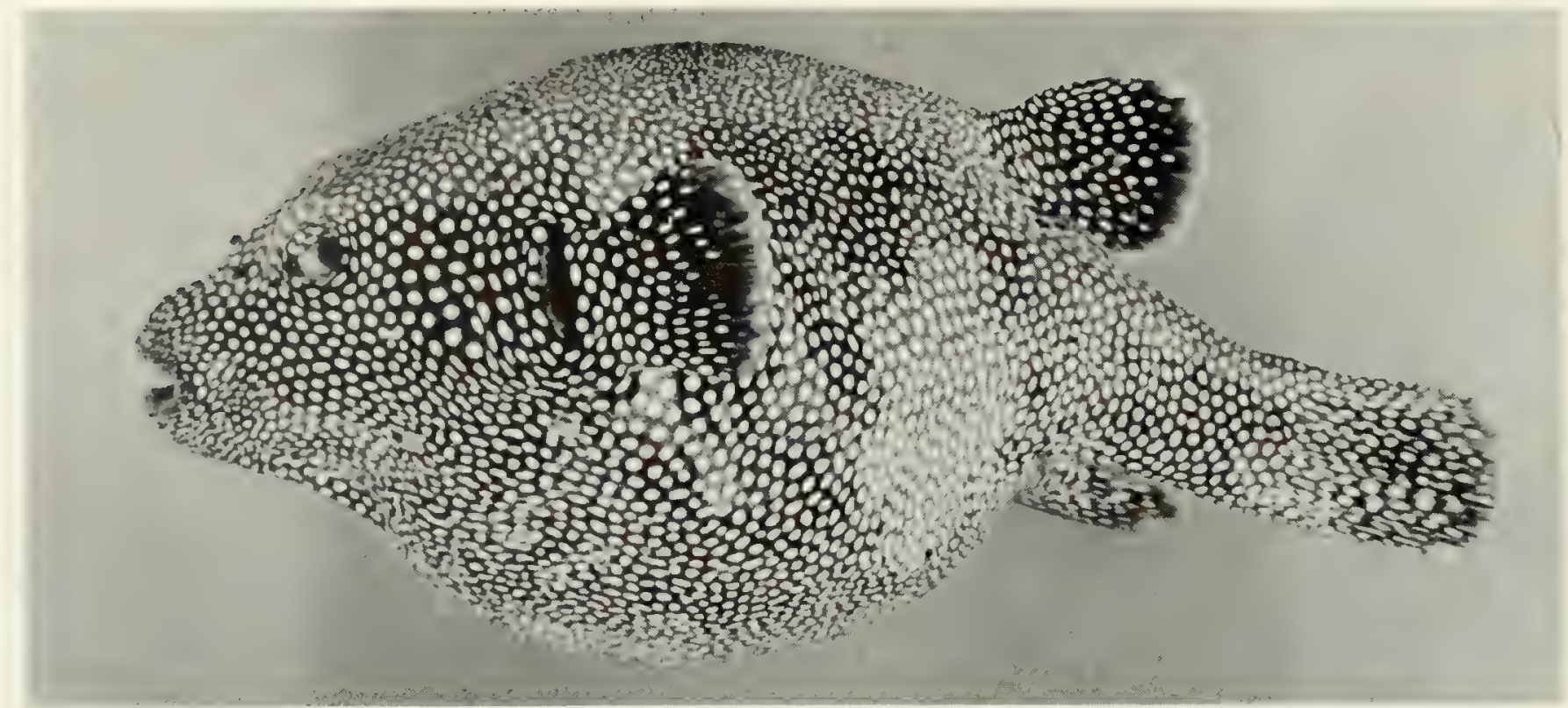

FIG. 446. Arothron meleagris, $209 \mathrm{~mm} \mathrm{SL}$, Peros Banhos.

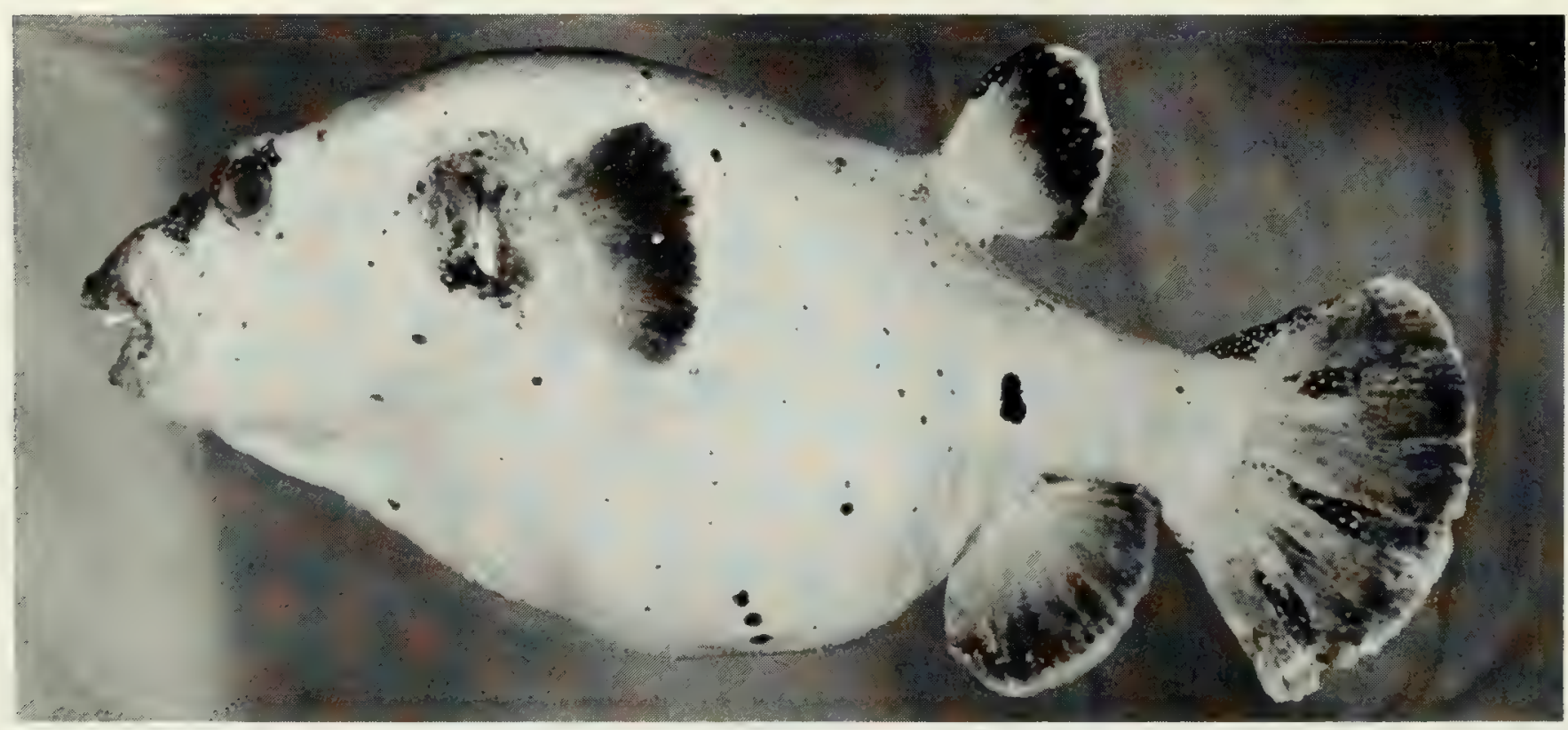

Fig. 447. Arothron meleagris, 243 mm SL, Peros Banhos.

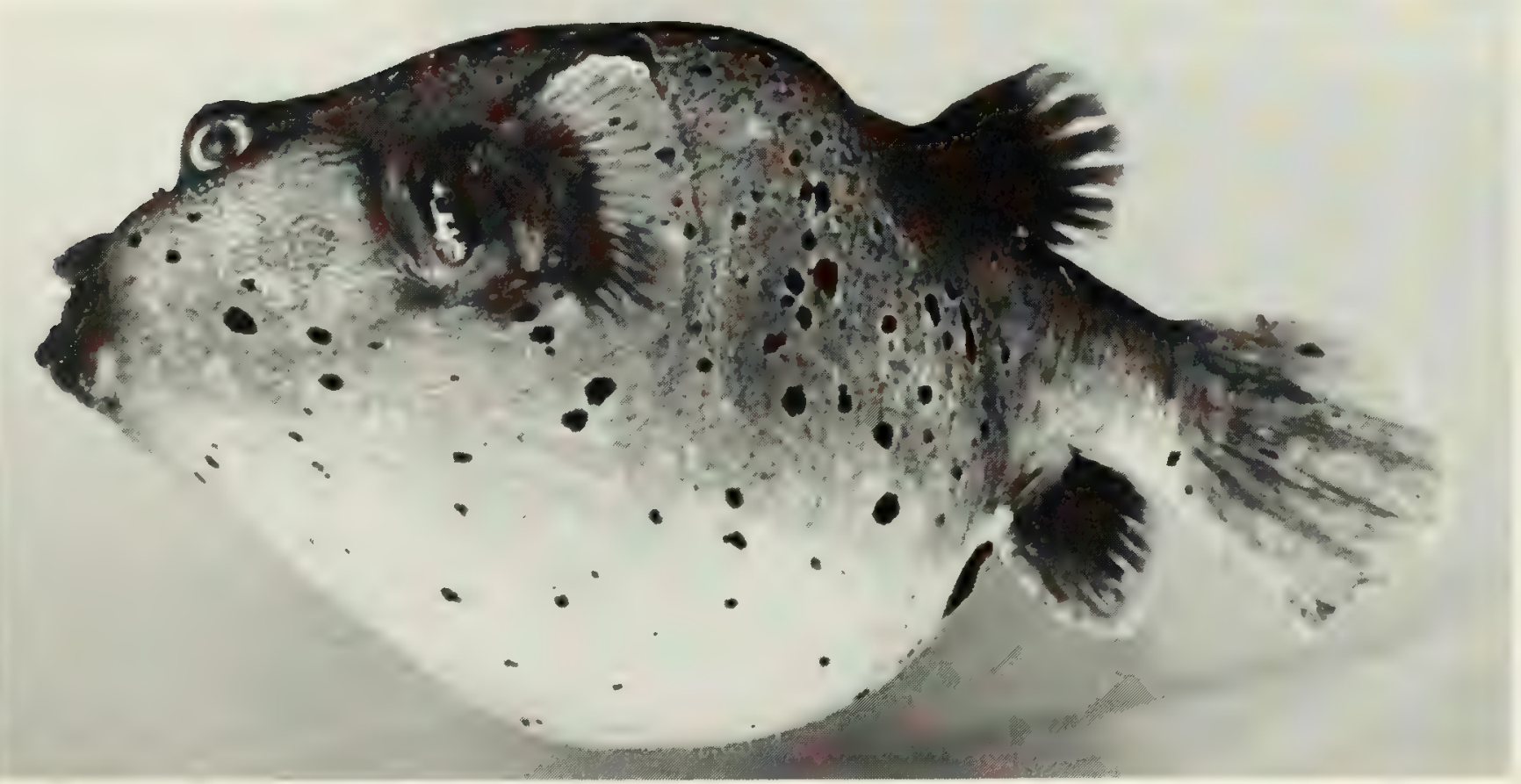

FIG. 448. Arothron nigropunctatus, $200 \mathrm{~mm}$ SL, Salomon. 


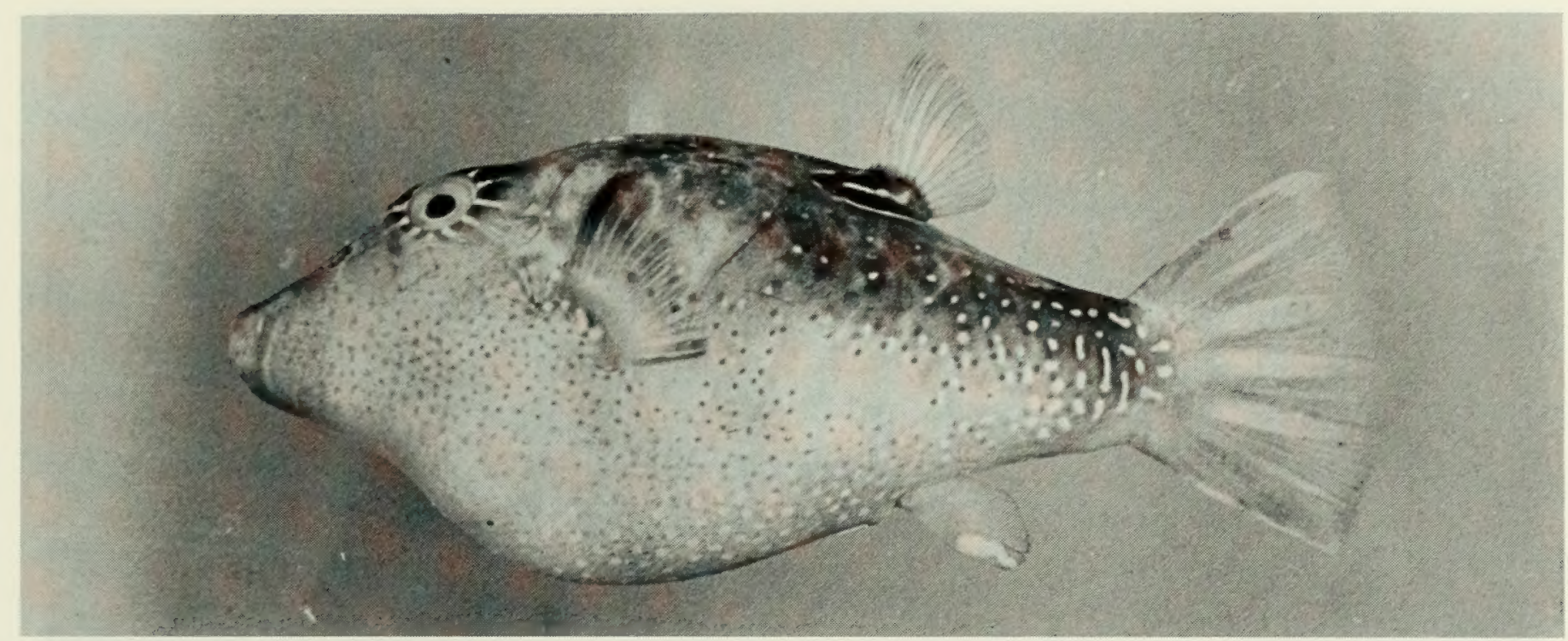

FIG. 449. Canthigaster bennetti, $63 \mathrm{~mm}$ SL, Peros Banhos.

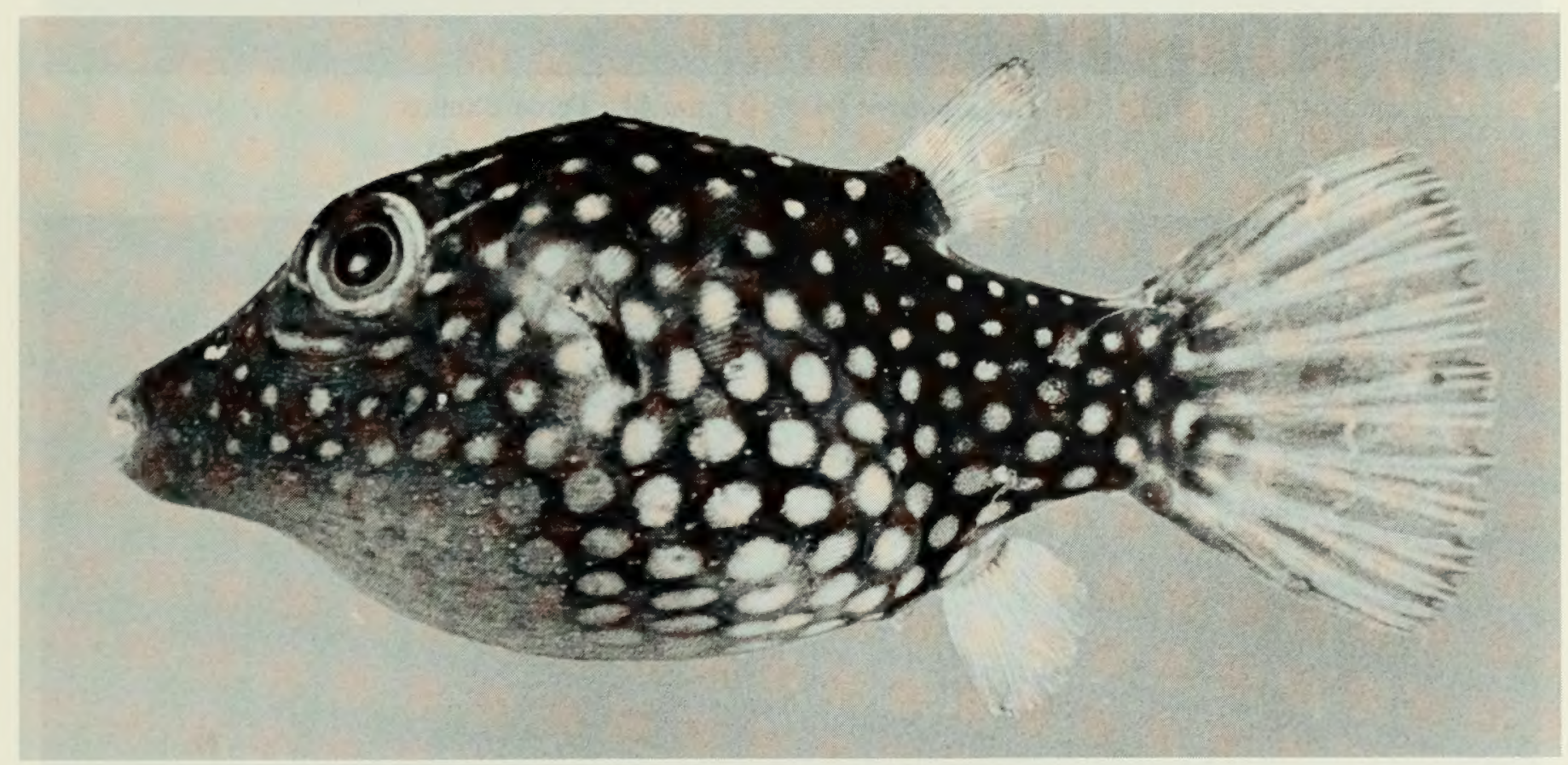

FIG. 450. Canthigaster janthinoptera, $25 \mathrm{~mm}$ SL, Peros Banhos.

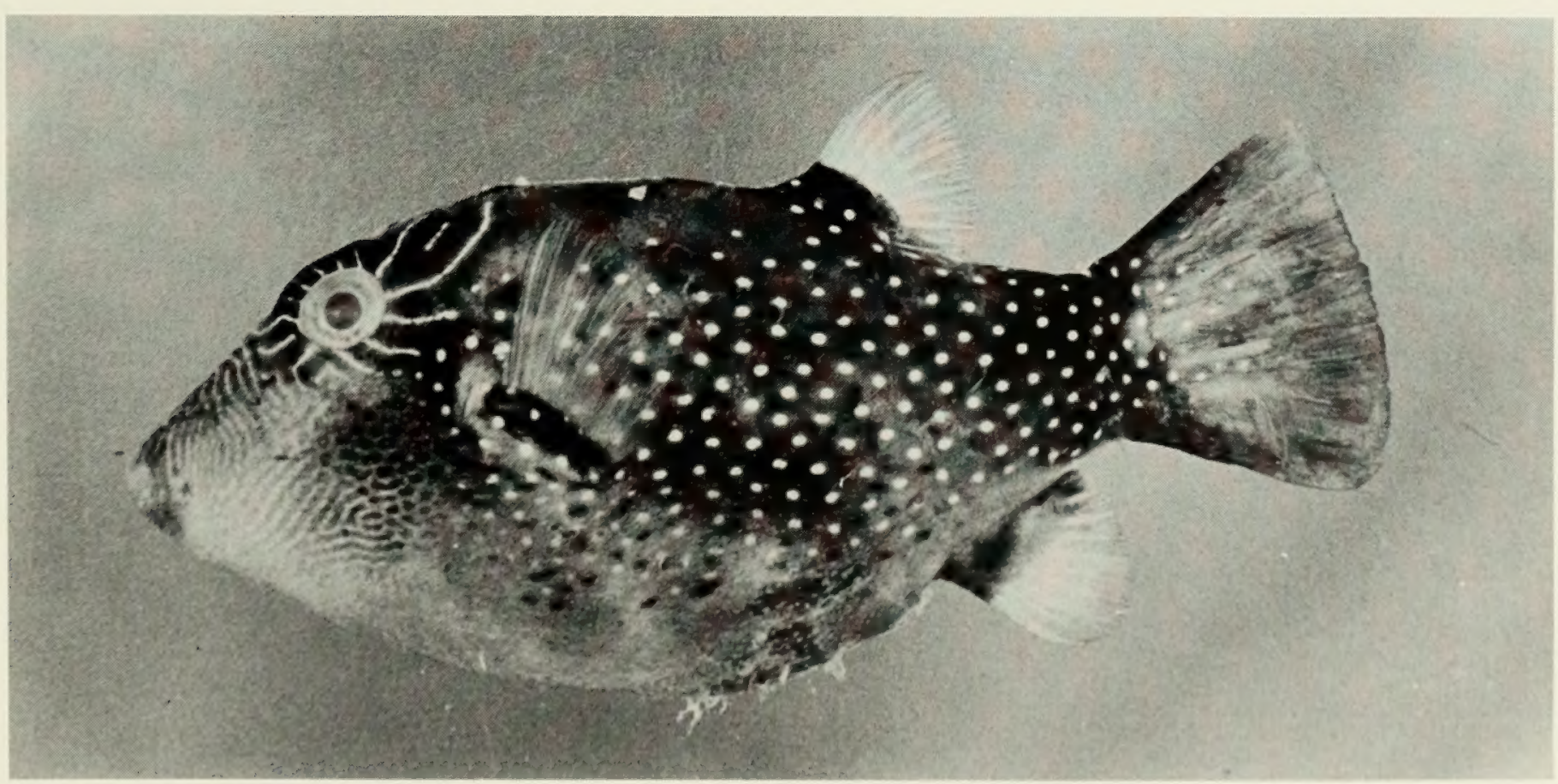

FIG. 451. Canthigaster natalensis, $67 \mathrm{~mm} \mathrm{SL}$, Salomon. 


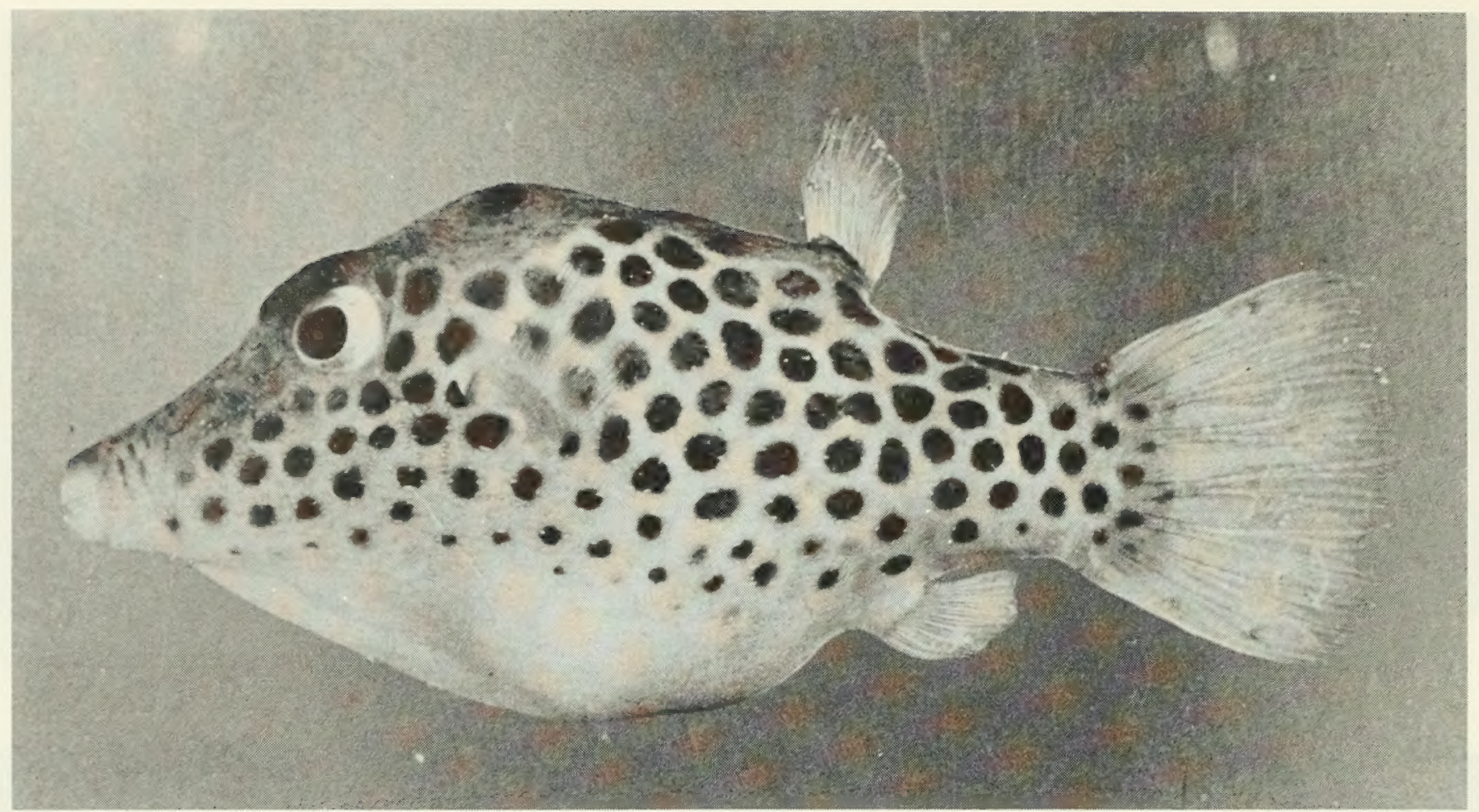

FIG. 452. Canthigaster tyleri, $37 \mathrm{~mm} \mathrm{SL}$, Peros Banhos.

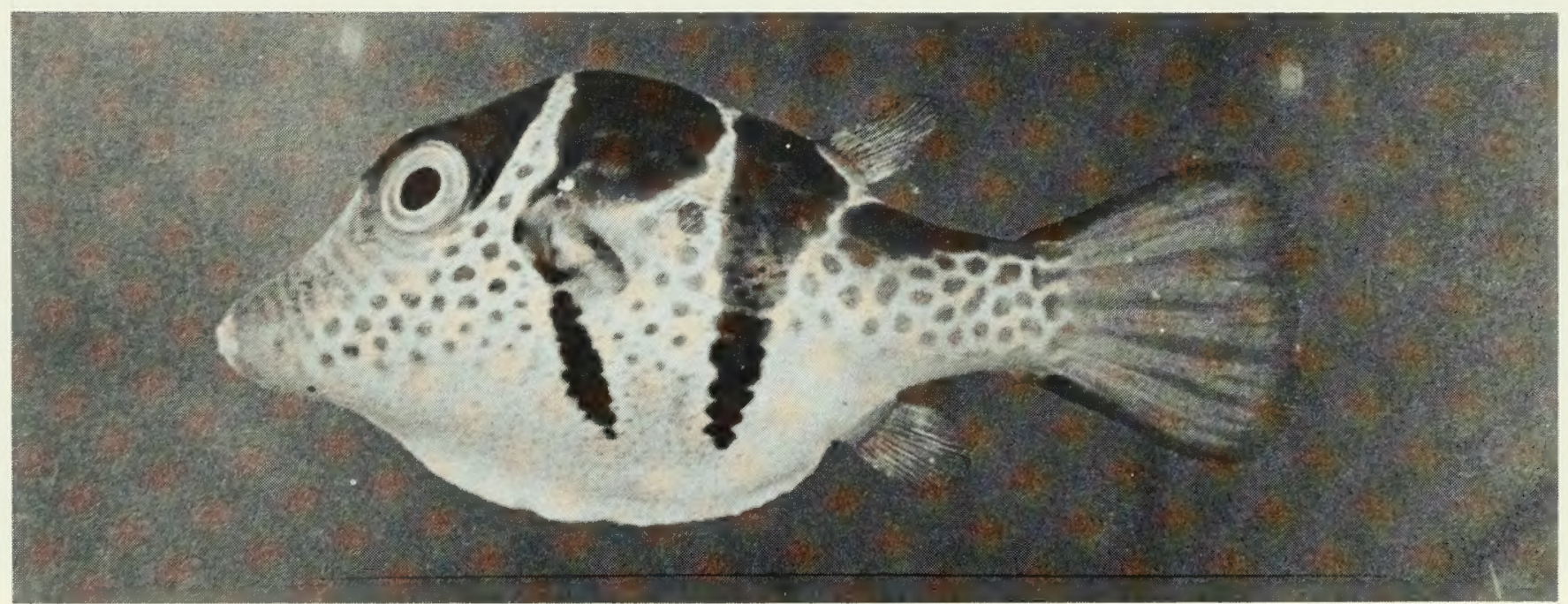

FIG. 453. Canthigaster valentini, $30 \mathrm{~mm}$ SL, Peros Banhos.

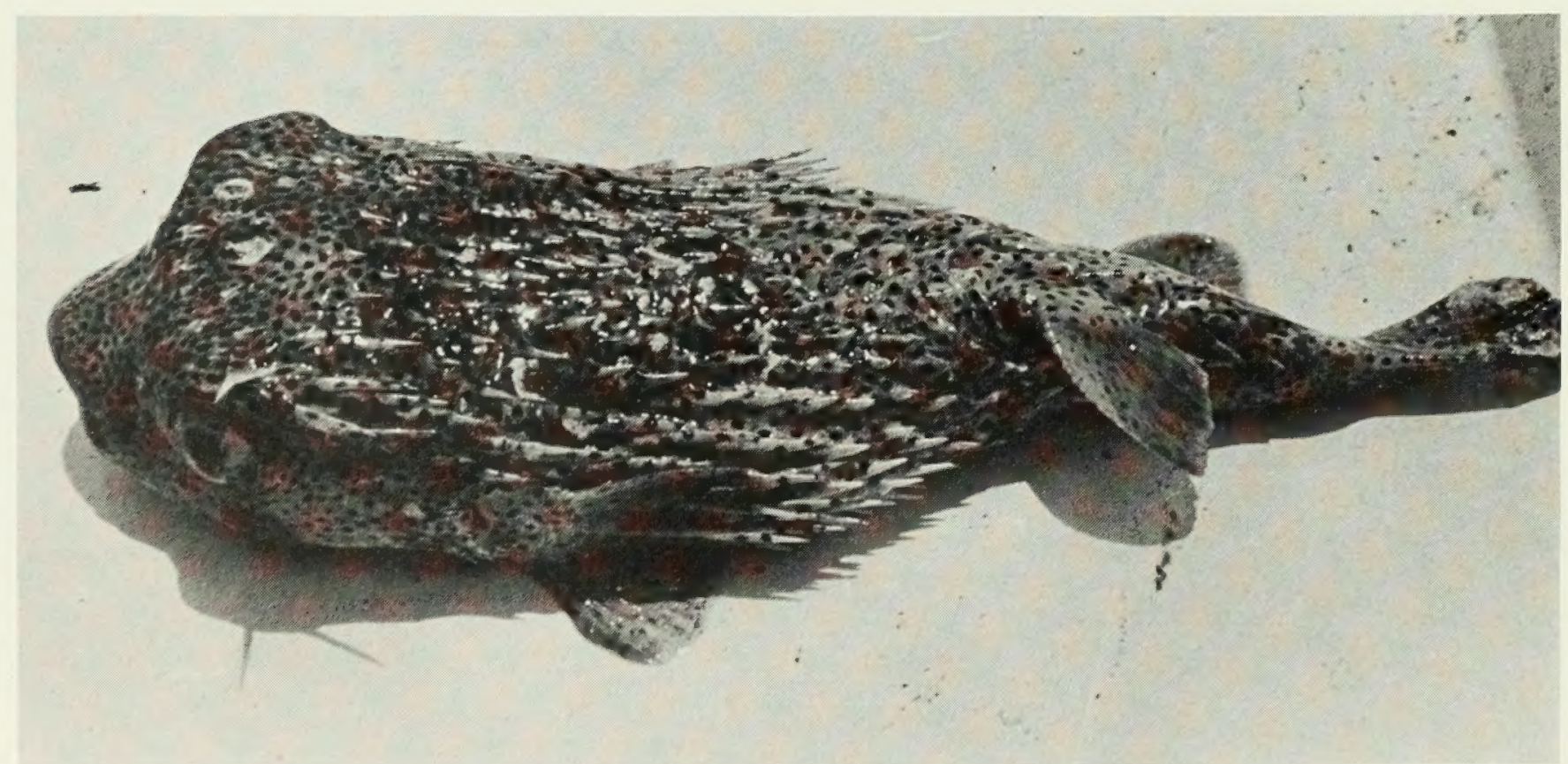

FIG. 454. Diodon hystrix, $365 \mathrm{~mm} \mathrm{SL}$, Eagle Island. 



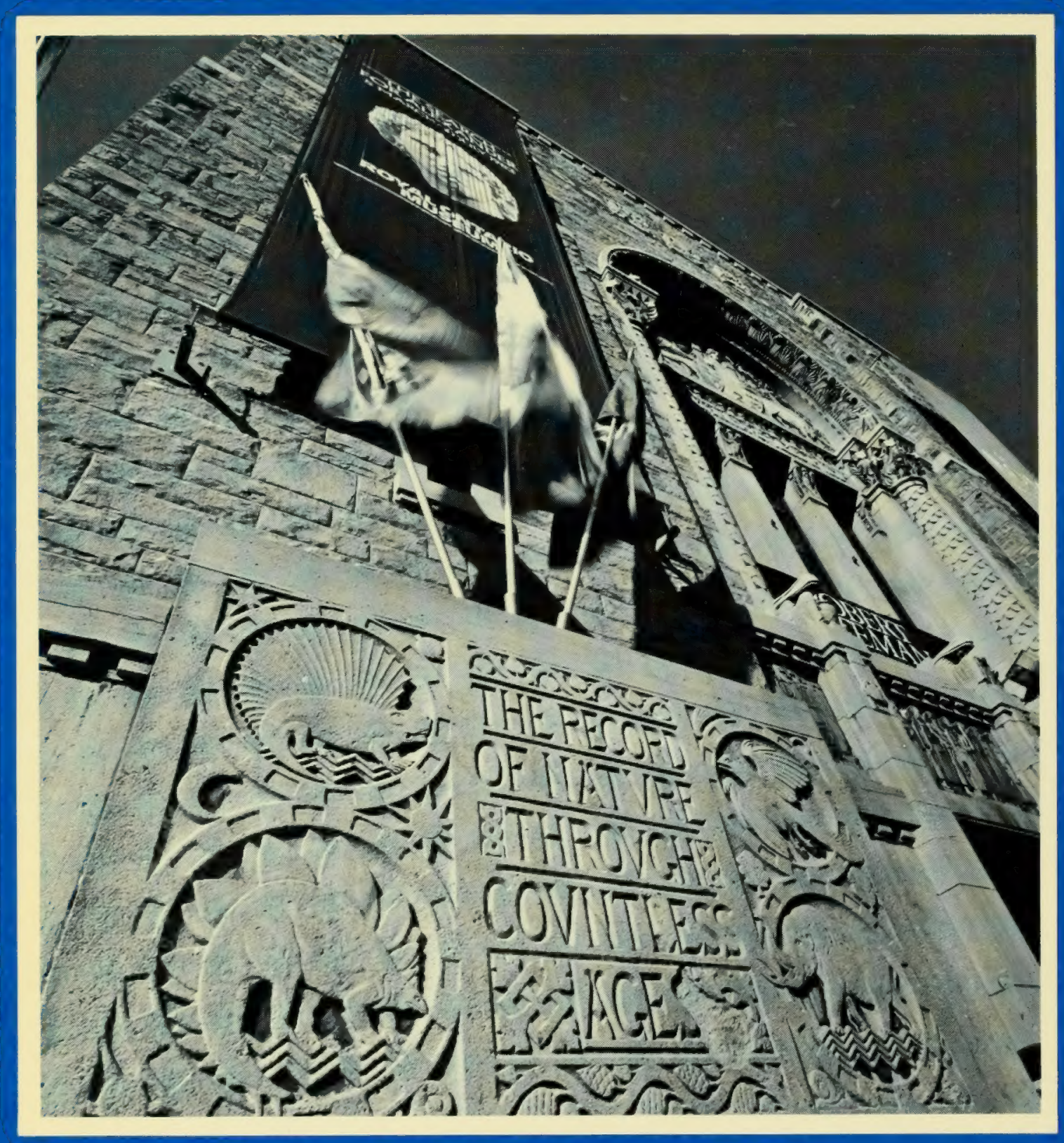

ISBN 0-88854-329-8

ISSN 0384-8159 